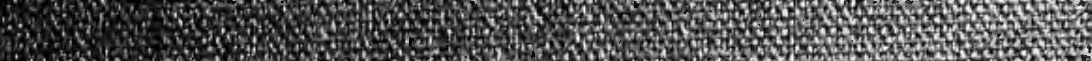

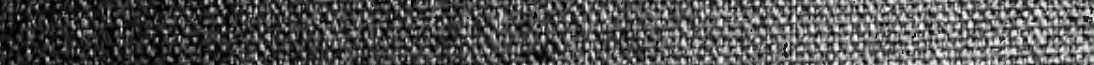

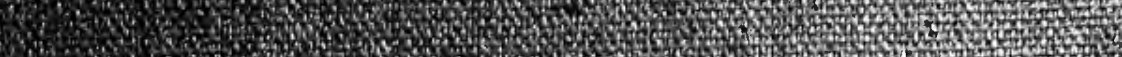

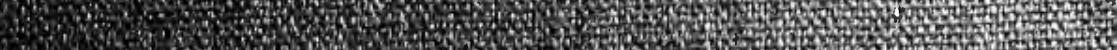
H.

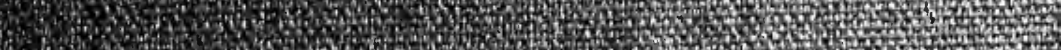

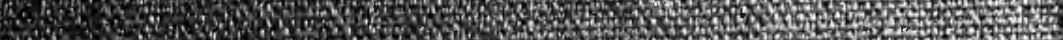

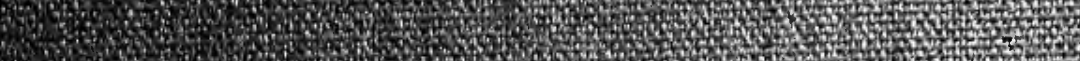
Non

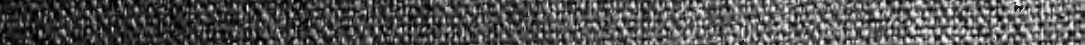
20. 20.

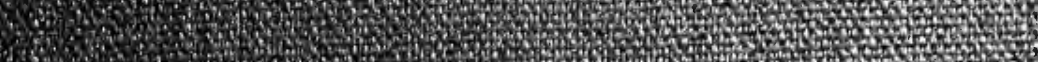

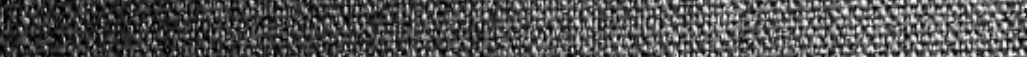

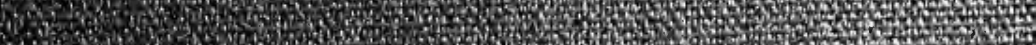

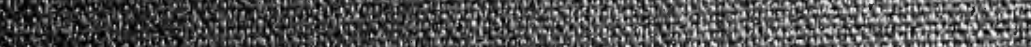

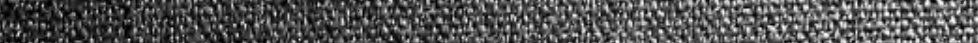
(1)

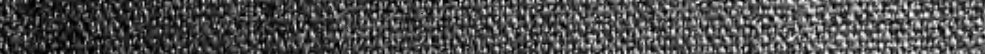
1.7. 60.7.

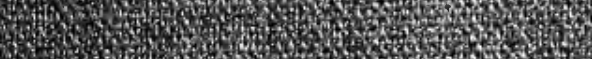

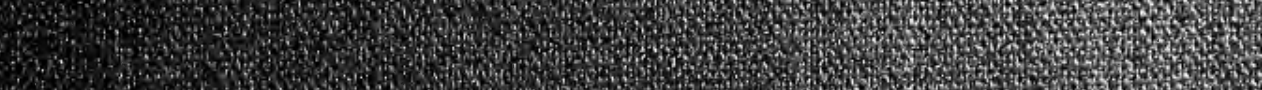
(2)

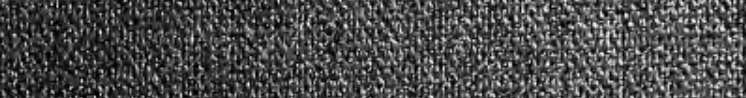
10.7. W Q

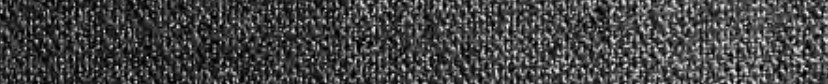
1.7. 7.7.7.

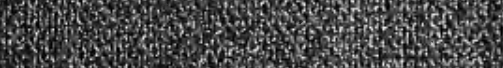
7.

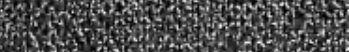
40.7. 7007 .

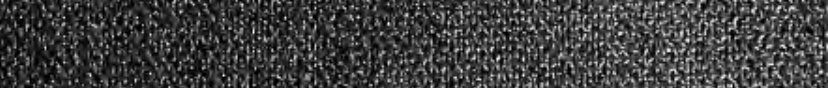
3.

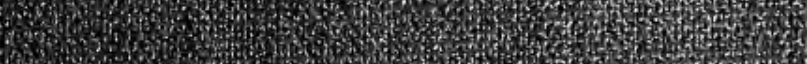

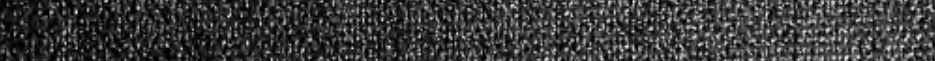

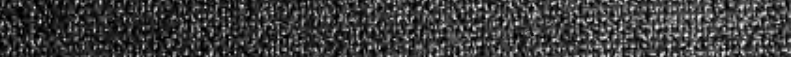

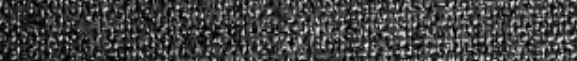

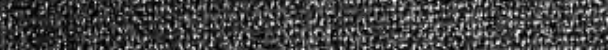
19.7.

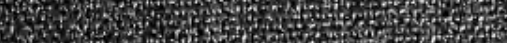
Wh.

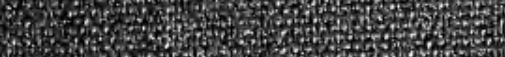

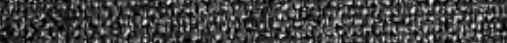
W. 2. 30 . W.

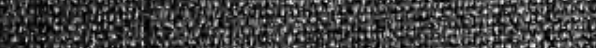
ace

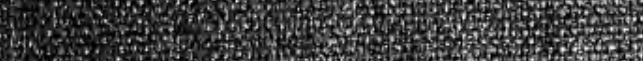

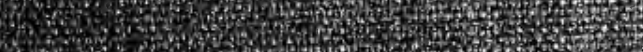





$=$ 





\title{
A TREATTSE
}

\author{
ON TITE I,A WV OF
}

\section{EXTRAORDINARY,}

\section{INDUSTRIAL AND INTERSTATE CONTRACTS}

BY

DARIUS H. PINGREY, IL. D.

Anthor of "The Law of Suretyship and Guaranty," etc., and Professor in the Illinois Wesleyan University College of Law.

ALBANY, N. Y.

MATTHEW BENDER AND COMPANY.

1905. 
Copyright, 1905.

BY DARIUS H. PINGREY.

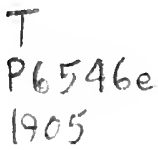




\section{PREF ACE.}

The advancement of material progress has developed contractual relations of vast and complicated nature. In treating of Extraordinary, Industrial and Interstate Contracts, it has been found necessary to investigate within circumscribed limits the police power of the State with reference to contracts, the prohibition by Congress of all contracts in restraint of interstate and foreign trade, whether reasonable or unreasonable, the contracts of industrial combinations, the violation of the obligation of contracts, contracts arising in the board of trade transactions, the contractual relations arising from trades unions and other relative rights. While the industrial combinations, such as corporate merger, pooling of railroad income and rebates have been considered, yet the right to contract by individuals has received due investigation.

Many works on contracts now before the public are classics, but they do not treat the subjects of contract of paramount importance to the welfare of the people. So, to meet this demand, among other things of vital interest, it has been the endeavor to present the industrial side of this all-important subject. In developing this work it was found that interstate contracts, of necessity, must be discussed; so it was deemed advisable to review concisely interstate contracts.

The author has also cited the leading articles on like questions found in the legal magazines, to illustrate the views of jurists on controverted points.

The author takes this opportunity to thank the profession, both lawyers and judges, for the cordial reception of his former works, and hopes that this treatise will be received in the same friendly spirit.

DARIUS H. PINGREY.

Bloomington, Ill., Feb. 1, 1905. 



\title{
TABLE OF CONTENTS.
}

\author{
PART I. \\ Freedon of Contract. \\ CHAPTER I. \\ Right to Contract.
}

Section. $1-4$

\section{CHAPTER II.}

Insane Persons.

Artiche I. Capacity to contract ................ $\mathbf{5 \cdot 2 0}$

II. Ratification and disaffirmance........... 21-25

\section{CHAPTER III.}

INFANTS.

ARTICLe I. Capacity to contract................. 26-50

II. Ratification of voiuable contract........... 51-56

III. Disaffirmance of voidable contracts......... 57-66

IV. Estoppel of infant by his deceit.......... 67-71

V. Guardian's right to contract........... $72-75$

\section{CHAPTER IV.}

Contracts Required to be in Writing-Statute of Frauds.

Article I. The statute-Sections four and seventeen....... 76-78

II. Contracts not within section four........... 79.82

III. Sufficiency of memorandm............. \$3-99

IV. Remedies on the contract.............. 100-116

V. Promises by executor and administrator....... 117-121

VI. Promise to answer for another's debt, default or

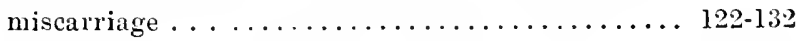

VII. Agreement not to be performed within a year..... 133-137

VIII. Agreement within section seventeen.......... 138-156

IX. Representations as to credit............. 157-160 


\section{PART II. \\ Contracts in Violation of Law. \\ CHAPTER V. \\ Agreements in Violation of tire Common Law.}

Article I. Illegal contracts

SECTION.

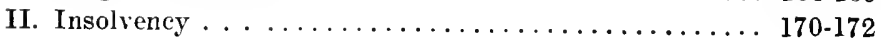

\section{CHAPTER VI.}

Agreement in Violation of Statute.

Article I. Violation in general. . . . . . . . . . . . . . .

II. Violation of Sunday laws.............. 180-195

III. Statutes regulating trade and professions....... 196-205

IV. Usurious contracts . . . . . . . 206.24.

CHAPTER VII.

Wagers and Gaming Contracts.

Article I. Wagers in general.................... 244-247

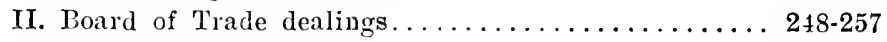

III. Rights under gambling contracts........... 258-265

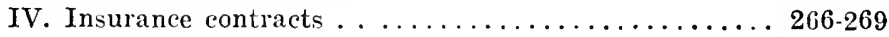

V. Lottery dealings . . . . . . . . . . . . 270-273

\section{PART III.}

\section{Contracts Against Public Policy.} CHAPTER VIII.

What is Public Policy.

Article I. The general doctrine............... 274-278

II. Contracts for oflice and for influencing official conduct, 279-287

\section{CHAPTER IX.}

\section{Limiting Liability for Negligence.}

Article I. Liability as to carriage............... 288-291

II. Limitation by notice on ticket............. 292-295

III. As to telegraph and telephone companies........ 296-298

IV. Limiting master's liability . . . . . . . 299.3.

CHAPTER X.

Obligations of Quasi-Public Corporations.

ArTICLE I. Disabling contracts of corporations owing a duty to

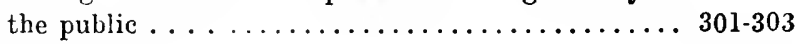

II. Discriminations . . . . . . . . . . . . . 304-308 


\section{TABLE OF CONTENTS.}

\section{CHAPTER XI.}

Restraint of Trade.

Section.

ARTrcLE I. Contracts in restraint of trade............ 309-315

II. Nature of the transactions............. 316-319

\section{CIIAPTER XII.}

Industrial Combinations.

Article I. Unlawful combinations and corporate trusts. . . . . . 320-322

II. Pooling and merger of railroad business........ 323327

III. As to patent rights.................. 328-329

IV. Parties in pari delicto.............. 330.332

\section{CHAPTER XIII.}

\section{Trades Unions.}

Artrcle I. General statement . . . . . . . . . . . . . . . .

II. Contractual relations . . . . . . . . . . . $335 \cdot 338$

\section{PART IV. \\ Operation of Contract. \\ CHAPTER XIV. \\ Contractual Relations.}

Article I. Contractual relations . . . . . . . . . . . . 339-351

II. Promise for the benefit of a third person....... $352-367$

III. Joint and several contracts............. 368-394

\section{CHAPTER XV. \\ Interstate Contracts.}

Article I. Law of the place of contract............. 395-407

II. Exceptions to the general rule............ 408.418

III. Enforcement of contract............. $419-422$

\section{CHAPTER XVI.}

Implied Contracts.

ARTTCLE I. By acts of the parties................ $423-429$

II. Paying another's debts................ 430-444

III. Recovering money for the use of another....... $445-456$

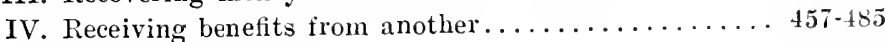

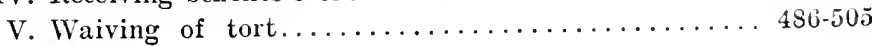




\section{CHAPTER XVII.}

Assignalests.

SeCtion.

Article I. Voluntary assignments ................ 506-514

II. Assignment of wages and salary.......... 515-517

III. Interests that may be assigned........... 518-527

\section{CIIAPTER TVIIT.}

IMPairaext of tile Obligation of Contracts and tile Righit to Contract.

Article I. The contract . . . . . . . . . . . . . . . . 528-533

II. Corporate charters and franchise........... 534-541

III. Police power of the State.............. $542-546$

IV. I'olice power and interstate commerce......... 5 5 7-554

V. Impairment of remedy................ 555-567

\section{PART V. \\ Termination of Contract. \\ CHAPTER XIX. \\ IMpossible Contracts.}

Article I. Discharge by impossibility of contract........ 568-579

II. Performance excused by act of God and public enemy .......................... 580-588

III. Non-performance of contract of personal service... 589-592

CHAPTER XX.

Rescission of Contract.

Abticle I. Right to rescind................... 593-601

II. Work and labor...................602-611

III. Rescission controlled by conditions subsequent....6 612-623

CHAPTER XXI.

Statute of Limitations

Article I. Discharge by lapse of time..............624-627

II. Application of statute . . . . . 628.6. 638

\section{CILAPTER XXII.}

Performance.

Artrcle I. Specific mode . . .................. 039-64l

II. Decision of arbiter, architect or engineer....... $64:-66$

III. Specific performance . . . . . . . . . . . $607-681$

CHAPTER XXIII.

Breacil and Discharge.

Article I. Measure of damages..................6.6.699

II. Composition with creditors............. 700-704

viii 


\section{PART I.}

FREEDOM OF CONTRACT. 



\section{IPARTI.}

\section{CHAPTER I.}

Right to Contract.

\section{ARTICLE I.}

Tine Basis of Ali Contracts of a Party Sui Juris.

Section I. The Power of the State Over the Right to Contract.

2. Regulating the Payment of Tages-Truck Systen.

3. Truck Laws in England.

4. Eight-Hour Jiln:

$\$$ I. The power of the State over the right to contract.Before a contract ean be formed, the parties must have the right to contract. For withont the liberty of contract, no contract can be made, and the attempt wonld be a mullity. Howerer, gencrally speaking, amomg the individual rights of the eitizen is that the liberty of contract; ret such liberty is not absolute or universal. The State may reatrain some individnals from all contracts, as well as all individuals from contracts. This is demonstrated by the denial of the right to contract for the purchase of lottery tickets; the State may deny the right to minors to assume any obligations except for the necessaries of existence; to the common carrice the power to make any contract releasing itself from negligence; and the State may restrain all 
engaged in any employment from any contract in the course of that employment which is against public policy. The possessinn of this power hy the State in no manner confliets with the proposition that every ditizen has a right freely to contract for the price of his lahor, services, or property. ${ }^{1}$ So a State cannot limit the rigluts of a citizen to eontract with reference to his property only when such limitation tends to promote the public good in sone way. Otherwise it is an unwarranted interference with his rights." Public policy requires that all persons of full age and of competent understanding shall be allowed the fullest liberty of contracting, and their contracts entered into freely and rohutarily shall be held saced and shall be enforced by the courts if necessary." This liberty to contract is subject to the following restrictions: 1 . The contract must be one which the law does not prohibit; 2 . the parties must be legally competent to contract; 3 . the contract must be in form, if the law requires it; 4 . the thing to be done must not be prohibited; 5 . the consideration must he legal and sufficient.

Whenever a law is unreasonable, arbitrary and oppressive, and interferes with the right to contract in a lawful manner, and prevents a person from entering into a lawful employment in a lawful manner, it is unconstitutional. No act is valid which unlawfully invades the privacy of the home withont due process of law, deprives the citizen of the full and profitable use of

1. Frisbie v. United States, 157 U. S. 160,15 Sup. Ct. 532. Sec, also, Woleott v. Frissell, 134 Mass. 1, 45 Am. Rep. 272; Leep v. Railroad Co., $5 \mathrm{~S}$ Ark. 407,25 S. IV. 75 , 23 I. R. A. 204, 41 Am. St. Rep. 109; State r. Coal Co., $36 \mathrm{WV}$. Va. S02, 15 S. R. 1000,17 L. R. A. 3S.5; Hancock v. Yaden, 121 Ind. 366, 23 N. E. 253,6 I. R. A. 576,16 Am. St. Rep. 396 ; State v. Brown, etc.,
Co., IS R. I. I6, 25 A. 246, 17 L. R. A. 856 ; Shaffer v. Mining Co., 55 Mcl. 74; Ritehie v. People, 155 11।. 98,40 N. F. 454,29 J. R. A. 79, 46 Am. St. Rep. 316: Kelleyville Coal Co. v. Harrier, 207 Ill. 624, 69 N. E. $92 \bar{\tau}, 99$ Am. St. Rep. 240.

2. Dennis $v$. Moses, is Wash. 537, 52 P. 333,40 L. R. A. 302.

3. Printing, ete., Kegistering Co. v. Sampson, L. R. 19, Eq. 462. 
his property, and of his riglit to labor at any lawful work when and where he pleases or infringes upon his rights of personal liberty. ${ }^{4}$

The provision of the Fourteenth Amendment to Federal Constitution, was intended to guarantee, not that every person shall have exactly the same privileges as every other person, regardless of differenec in conditions, and independent of proper and reasonable classification, lont that erery person shall be given the same rights and privileges under the same circumstances and conditions. But more ordinary classification cannot be justified; but where there is a reasonable distinetion between classes of citizens, the legislature has a right to recognize such classifieation, and to make different rules with respect to such classes, so long as it does not transgress those fundanental rights of life, liberty and the pursuit of happiness. ${ }^{5}$ Therefore, a State can make a distinction in favor of veteran volunteer firemen as against those not veterans, and give preferences in employing them to fill public office. Such preferment is justified by public policy. ${ }^{6}$ So the elassification of veterans of the civil war is not arbitrary. Political employment is not of the essence of civil rights of life, liberty or property. Such preference is based upon actual service to the State, which the State has the right to compensate. ${ }^{7}$

4. State v. Broadbelt, $59 \mathrm{Md}$. 565 ; Luman $\mathrm{v}$. Hitchens, $90 \mathrm{Md}$. 14, 44 A. 1051,46 L. T. A. 393 ; Bailey v. People, 190 Ill. 2S, $60 \mathrm{~N}$. E. 98,54 L. R. A. 538,83 Am. St. Rep. 116; Lawton v. Stecle, 152 U. S. 136, 14 S. Ct. 499 ; Ex parte Lee. 96 Cal. 354, 31 P. 245,24 L. R. A. 195, $31 \mathrm{Am}$. St. Rep. 21s; In re Hong Wal, S2 Fed: Rep. 623; Squire v. Tellier, 185 Mass. 18, 69 N. E. 312.
5. People v. Orange County Construction Co., 175 N. Y. 84,67 N. E. 129 .

6. People v. Folks, 85 N. Y. S. 1100.

7. Opinion of Justices, 160 Mass. 589, 44 N. E. 625, 34 L. R. A. 58. See Should There Be Freedom of Contract; 4 Columbia L. Review, 429. 


\section{\$2. Regulating the payment of wages - Truck system.-}

In many States laws have been enacted to protect the employes of corporations in payment of salaries in serip or in goors from the stores of the eorporations. But they have generally been held meonstitutional as restricting the right to enntract. It is held an encroachment upon the just liberty and rights of the workman and his employer, or those who may be disposed to employ him, for the legislature to interfere with the freedom of contract between them, as such interference hinders the one from working at what he thinks proper, and at the same time prevents the other from employing whom he chooses. ${ }^{1}$ Anel so a statute is unconstitutional which provides that no $\mathrm{cm}$ ployer shall impose a fine upon or withhold the wages or any part of the wages of a workman engaged in weaving for innperfections that may arise during the process of weaving. Because the right to employ weavers, and to make proper contracts with them, is protected by the constitution, and a statute which forbids the making of such contracts, or attempts to nullify them, or impair the obligations of them, violates the fundamental principles of right which are expressly recognized in the constitution. ${ }^{2}$

In some of the States it is held that the legislature has anthority to pass an act requiring the owners of mines to pay for

1. State v. Goodwill, $33 \mathrm{~W}$. Va. 179,10 S. E. 285,6 L. R. A. 621 , and note, $25 \mathrm{Am}$. St. Rep. 863 and note; State v. Loomis, $115 \mathrm{Mo}, 307$, $22 \mathrm{~S}$. W. 452,21 L. R. A. 789 and note; Godeluarles v. Wigeman, 113 Pa. St. 431, 6 A. 354; State v. Coal and Coke Co., 33 IV. Va. 188, $10 \mathrm{~S}$. E. $28 s, 6$ L. R. A. $359,25 \mathrm{Am}$. St. Rep. 891; Ramsey v. People, 142 Ill. 380,32 N. E. 364,17 L. R. A. 853; Braceville Coal Co. v. People,
147 III. 66,35 N. E. 62,22 L. R. A. 340, 37 Am. St. Rep. 200; Compare Hancoek v. Yaden, 121 Ind. 366, 23 N. E. 253,6 L. R. A. $57 \mathrm{~s}, 16 \mathrm{Am}$. St. Rep. 390 ; State v. Peel Splint Coal Co., 36 IV. Va. 802,15 S. E. 1000, 17 L. R. A. 385.

2. Commonwealth v. Perry, 155 Mass. 117,28 N. E. 1126, 14 L. R. A. 325 and note, 31 Am. St. Rep. 533. 
mining coal every two weeks in lawful money of the United States. $^{3}$ And so a law has been declared constitutional which prohibits a corporation or person to pay in serip or anything except in lawful money. ${ }^{4}$

If the charter is given with a reservation that the legislature may amend it, then the legislature may regulate the payment of wages by corporation, and forbid the paying of serip or compel the corporation to pay weekly, ${ }^{5}$ and to pay back salary when employe is dismissed, on day of dismissal. ${ }^{6}$ So it is held a statute is valid which requires payment of wages in money at the option of the employe. ${ }^{\top}$ In this case the court of Tennessee did not rest the case on the police power of the State, but upon appeal the United States Supreme Court sustains the statute as an execreise of the police power, which undonbtedly is the correct doctrine. And so a statute is valid which requires the weekly payment of wages ${ }^{8}$ and some courts hold that a statute is valid which requires the weighing of coal for the purpose of fixing wages, before it is screened $;^{3}$ but this doctrine is denied in other jurisdictions. ${ }^{10}$ This class of legislation is common, and its validity is attacked

3. Hancock v. Yaden, 121 Ind. 366,23 N. E. 253,6 L. R. A. 578 , $16 \mathrm{Am}$. St. Rep. 396. See, also, Shaffer v. Mining Co., 55 Md. 74; In re House Bill, 23 Colo. $504,48 \mathrm{P}$. 512.

4. State v. Peel Splint Coal Co., 36 W. Va. 802,15 S. E. 1000, 17 L. R. A. 385 .

5. State v. Brown, ete., Mfg. Co., 18 R. I. 16,25 A. 246,17 L. R. A. 856; Leep v. Railroad Co., 58 Ark. 407, 25 S. IV. 75, 23 L. R. A. 264, 41 Ain. St. Rep. 109.

6. St. Louis, etc., R. R. Co. v. Paul, 64 Ark. 83, 40 S. W. 705, 37
L. R. A. 504, 62 Am. St. Rep. 1154 and note.

7. Knoxville Iron Co. v. Harbison, 183 U. S. 13, $22 \mathrm{~S}$. Ct. I; Harbison v. Knoxville Iron Co., 103 Tenn. 421, 53 S. W. 955, 56 L. R. A. 316, 6 An. St. Rep. 682; Compare Kellyville Coal Co. v. Harrier, 207 III. 624,69 N. E. 927,99 Am. St. Rep. 240 .

8. In re House Bill, 163 Mass. 589, 40 N. E. 713,28 L. R. A. 344.

9. State v. Wilson, 61 Kan. 32, 64 P. 23,47 L. R. A. 71.

10. In re Preston, 63 Ohio St. 42S, 59 N. E. 101, 81 Am. St. Rep. 642. 
as in violation of the guarantee of equal protection. This legislation is illustrated loy the statutes fixing hours of labor, providing for the payment of wages in money only, and statutes controlling the mothor of fixing wages, as by requiring that where coal is mined by weight, it must be weighed before sereening. These are all statutes abridging the right of the citizen to make contracts, a right which is within the protection of the Fourteenth Amendment to the Federal Constitution. The liberty contemplated in this provision means not only the right of freedom from servitude, imprisonment or physical restraint, but also the right to use one's faculties in all lawful ways, to live and work where he chooses, to pursue any lawful calling or profession, to makc all proper contracts in relation thereto, and to enjoy the legitimate fruits thereof. And to control this right of liberty will be in violation of constitutional rights except under the police power of the State. ${ }^{11}$ But such statutes are sustained on other grounds, but incorrectly. ${ }^{12}$ The principle of these cases has been upheld by the United States Supreme Court as an exereise of the police power alone. Thus, where the police power is not applicable an attempt to fix the wages of employes on city contracts at the rate generally paid to employes in like vocations, is invalid. ${ }^{13}$ If the legislature undertalses to provide that persons following some lawful trade or profession shall not contract as they see fit, or in any other way make such use of their property as is permissible to others, this would transeend the limits of legislative power, unless the police power of the State is applicable. And this may explain

11. Sce Knoxvilic Iron Co. v. Harbison, 183 U. S. 13,22 S. Ct. I; Holden v. Hardy, 169 U. S. 366, is S. Ct. 383 .

12. Harbison v. Knoxville Iron Co., 103 Tenn. 421, 53 S. W. 734, 56 L. R. A. 3].6, 76 Am. St. Rep. 6s2; Hancock v. Yaden, 121 Ind. 366, 23
N. E. 553,6 L. R. A. 576,16 Am. St. Rep 346; Compare Kiellyrille Coal Co. v. Harrier, 207 Ill. 624,69 N. E. 927, 99 Am. St. Rep. 240.

13. People v. Coler, $166 \mathrm{~N} \mathrm{Y}, 1$, 59 N. E. 716,52 L. R. A. 814,82 Am. St. Rep. 605 and note. 
a secming confliet of authority in two cases, where one is controlled by the poliee power and the other not, which is often lost sight of, eren by judges. The decisions are in eonfusion and irreconcilable. So it is held that a statute compelling employers to make weekly paynent of wages is uneonstitutional, as infringing the right of private contract, and as depriving persons affected thereby of their property without due process of law. ${ }^{14}$ In the Indiana case, ${ }^{15}$ the judge, speaking of In re House Bill, ${ }^{16}$ says that the eonstitution of Massachusetts is more comprehensive than that found in the ennstitution of some of the other States, and the provision passed upon in supporting the view expressed is radically different and broader than the provision of the Indiana constitution. The court further says that the Rhode Island case $^{17}$ rests upon the theory that the statute was but an amendment to the charter of a corporation under the reserved power of the legislature to amend. And the case of Skinner v. Garnett ${ }^{1 \mathrm{~s}}$ is of little value on the point discussed because, (1) it involves the payment of wages monthly, and (2) because the decision turns on substantially the same grounds as the Rhode Island case.

The legislature cannot regulate rate of wages in eity contracts: (1) because it is an attempt to force a municipality to frame its contracts in the interest of individuals or classes, and thus to that extent, diverts its money to private purposes; (2) because it invades the rights of liberty and property by denying

14. Republic Iron, etc., Co. v. State, 160 Ind. 379,63 N. E. 1005 , C2 L. R. A. 136; Braceville Coal Co. v. People, 147 III. 66,35 N. E. 62 , 22 L. R. A. 340,37 Am. St. Rep. 206 ; Commonwealth v. Isenberg, 4 Pa. Dist. Rep. 579; San Antonia, etc. Co. v. Wilson (Tex. Civ. App.), 19 S. W. 910 ; Compare Skinner v. Garnett, 96 Fed. Rep. 738 .
15. Republic Iron, ete, Co. v. State, 160 Ind. 379 , 66 N. E. 1005 , 62 L. R. A. 136.

16. 163 Mlass. 589,40 N. E. 713, 28 L. R. A. 344.

17. State v. Brown Mfg. Co., is R. I. 17,25 A. 246,17 L. R. A. 856.

18. 96 Fed. Rep. 735 . 
to the municipality and to the employers of labor on city contracts the right to agree with their employes upon the measure of their compensation; (3) because it arbitrarily confiseates to the municipality all rights of property of the employers under their contract for their failure to comply with the terms of the statute. Such contracts entered into cannot be said to be voluntary and fall with the statute, if already made. ${ }^{19}$

It is held that the better rule is that a statute requiring the payment of wages in money is valid as an exercise of the police power..$^{20}$ But this is not the rule in Illinois and Missouri. The Illinois statute ${ }^{21}$ provides that no deduction shall be made in an employe's wages except by the payment of money or check without discount. This is so ordered to prevent the exercise of truck stores in paying wages by goods and the like. But the court holds that such a statute is unconstitutional as limiting the right to contract. ${ }^{22}$ It was not upheld as coming within the police power of the State.

The Missouri Supreme Comrt holds with the Illinois doctrine, that such a statute is a limit on the right to contract and, therefore, void. ${ }^{23}$ Many of the statutes have been held unconstitutional because of class legislation. When serip must be redeemed in cash, the rule in Illinois and Missouri, is that such statute is unconstitutional as limiting the right to contract. ${ }^{24}$

19. People v. Coler, 166 N. Y. 1, 59 N. E. 716,52 L. R. A. S14, S2 Am. St. Rep. 605 and note. See, also, People v. Coler, 166 N. Y. 144,59 N. E. 776.

20. Knoxville Iron Co. v. Harbison, 183 U. S. 13, 22 S. Ct. 1, 103 Tenn. 42 J, 58 S. IV. 734,56 I. R. A. 316, 76 Am. St. Rep. 682.

21. Hurd's 11l. St. (1901), p. 879, sees. 6, 7. See Kellyville Coal Co. v. Harries, 207 Ill. 624, $69 \mathrm{~N}$. E. 927,99 Am St. Rep. 240 .
22. Kellyville Coal Co. v. Harrier, 207 Ill. 624, 69 N. E. 927. See, also, Connelly v. Union Sewer Pipe Co., 184 U. S. 540, 22 S. Ct. 431.

23. State v. Missouri Tie and Lum. Co., 80 S. W. 933.

24. Kellyville Coal Co. v. Harrier, 207 Ill. 624, 69 N. E. 927, 99 Am. St. Rep. 440 ; State v. Missouri Tie and Lum. Co. (Mo.), 80 S. W. 933. 
Ch.

§ 3. Truck laws in England.- In England the truck laws are valid and, of course, not in aceord with the general doctrine in the United States. ${ }^{1}$

The old truck laws are snany and date from about the year $1464 .^{2}$ They were first applied to one branch of manufacture, and then, ats experience and the progress of mannfactures dictated, to others, until they embrace nearly the whole manufactures of England. They establish the obligation and produeed the eustom of uniformly paying the whole wages of laborers in the eurrent coin of the realm. All these laws have been consolidated. ${ }^{3}$

These acts were founded upon the principle that where tro classes of persons are dealing together and one class is, generally speaking, weaker than the other and liable to oppression, either from natural or accidental causes, the law should, as far as possible, redress the inequality by protecting the weak against the strong. On this prineiple rests the protection thrown around infants and persons of unsound or weak mind. But in the United States such inequality is not recognized as far as corporations and laborers are concerned.

And so in England a court refused to enforce a covenant between a mariner and his employer to the effect that the former should not be entitled to any part of his wages unless the ship should return to the last port of discharge, because the relative situation of the parties and the nature of the agreement, produced oppression on the weaker, and, therefore, the contract was not enforeeable in any court governed by the rules of natural justice. ${ }^{4}$

§ 4. Eight-hour law.-Class legislation is not constitutional. The right to contract in legitimate business is reeognized by the constitutional guaranties. Competent parties cannot be de-

1. Arcier v. James, 2 Best \& S. 73.

2. 4 Edw. IV.
3. $1 \& 2 \mathrm{Wm}$. IV, eh. 37 .

4. The Juliana, 2 Dod. 504. 
prived of the right to contract as they see fit in legitimate channels. Each citizen has the right to pursue his own advancenent and happiness in his own way, subject only to the restraint neessary to secure the sane right to all other's, as all are equal before the law. Every man has the right to use his porvers and faculties, and to adopt and pursue such a vocation as he may choose, suliject only to the restraint neeessary to seeure the common welfure. ${ }^{1}$ The right to contract necessarily includes the right to fix the price at which labor will be performed and the mode and time of payment. Each is an essential element of the right to contract, and whoever is restricted in either, as the same is enjoyed by the community at large, is deprived of liberty and property. ${ }^{2}$

Therefore, a law which provides that for all classes of mechanics, servants, and laborers, except farm or domestic laborers, a day's work shall not exceed eight hour's, and that for working any employe over eight hours the employer shall pay extra compensation, is unconstitutional because it descriminates against farm and domestic laborers and is special legislation, and denies the right to parties to contract with reference to compensation for services. ${ }^{3}$ And such law camot be upheld as a police regulation, because it docs not operate to promote the health, safety, or welfare of screicty. ${ }^{4}$

1. Frorer v. People, 141 Ill. 171, 31 N. E. 395,16 L. R. A. 492 and note; Commonwealth v. Perry, 155 Mass. 117,28 N. E. 1126,14 L. R. A. 325 ad note, 31 Am. St. Rep. 533; People v. Gillson, 109 N. Y. 389. 17 N. E. 343 ; Slaughter House Cases, 16 Wall. (U. S.) 26 ; Godelarles v. Wigeman, $113 \mathrm{~Pa}$. St. 431, 6 A. 354; State v. Goodwill, 33 W. Va. 179,10 S. E. 285,6 L. R. A. 621 and note, $25 \mathrm{Am}$. St. Rep. S63 and note; People v. Greut, 179 N. Y. 417 .

2. In re Jacobs, 98 N. X. 106;
Low v. Rees Printing Co., 41 Neb. 127, 59 N. W. 362, 24 L. R. A. 702, 43 Am. St. Rep. 670; People v. Coler, 166 N. Y. 1, 59 N. E. 716, 52 I. R. A. 814,82 Am. St. Rep. 605 and note.

3. Low v. Rees Printing Co., 41 Neb. 127, 59 N. IV. 362, 24 L. R. A. 702, 43 Am. St. Rep. 607; Ritchie v. People, 155 Ill. 98, 40 N. E. 454 , 29 L. R. A. 79, 46 Am. St. Rep. 315.

4. Millett v. Pcople, 117 Ill. 294, 7 N. E. 631, 57 Am. St. Rep. S69; Frorer v. People, 141 IlI. 171, 31 
The Utah Constitution provides that "cight lonrs shall constitute a day's work on all work or undertakings carricd on or aided by the State, comnty or municipal gorernments; and the legislature shall pass laws to provide for the health and safety of employes in factories, smelters and mines." Under this provision a statute providing that "the period of employment of workingmen in all underground mines shall be eight hours per day, except in case of emergeney, where life or property is in imminent danger," is valid and not opposed to the Federal Constitution; and the State statute may make it a misdemeanor to employ a person for a longer time. ${ }^{6}$ This is the doctrine also of the United States Supreme Court, which passed upon the validity of the Colorado statute, and held that the law was an exercise of the State's police power. Justice Brown said in his opinion that it was not the intention of the court to pass generally upon the constitutionality of eight-hour laws, but that in so far as State laws were enacted for the protection of the lives, the liealth or the morals of a community, they are ralid under the police power of the State; that there can be no doubt of the exceptional and unhealthful character of work in smelters or mines, because of bad air, high temperature and noxions gases, and hence the Colorado law was valid and constitutional. ${ }^{7}$

And so where the laborer is working for the State or a creation of a State, the legislature may prescribe the number of hours which shall constitute a day's labor. And a statute is

N. E. 395,16 L. R. A. 492 and note; State v. Loomis, 115 Mo. 307 , 22 S. W. 350,21 L. R. A. 789 and note; Ex parte Kuback, 85 Cal. 2$\rceil 4$, 24 P. 737,20 Am. St. Rep. 226, 9 I. R. A. 482; In re Jacobs, $98 \mathrm{~N}$. Y. 106 ; People v. Gillson, 109 N. Y. 3S9, 17 N. E. 343. 4 Am. St. Rep. 465; Ritchie v. People, 155 Ill. 9S, 40 N. F. 454,29 L. R. A. 79,46 Am. St. Rep. $31 \overline{5}$.
5. Utah Const., sec. 6 .

6. State v. Holden, 14 Utalı, 71 , 46 P. 756,37 L. R. A. 103.

7. Holden v. Hardy, 169 U. S. 366, is S. Ct. 383. See, also, In re Ten Hour Law (R. I.), 54 A. 600, 61 L. R. A. 612: Wenlam v. State (Neb.), 91 N. W. 421, 59 I. R. A. S25; Atkin v. Kansas, 191 U. S. 207, 24 S. Ct. 124. 
constitutional which declares that no one undertaking to perform work for the State or one of its municipalities shall permit or require an employe on such work to labor in excess of eight homrs each day, hecause the State is a guardian and trustee of the people, to prescribe conditions upon which it will permit work to be done. Regulations on this suluject suggest only considerations of public policy. No one is entitled, of absolute right and part of his liberty, to perform labor for the State; and no contractor for public work ean exense violation of his lawful agreenent with the State by doing that which the statute under which he procecds distinctly forbids him to do. ${ }^{8}$ But where the police power of the State and public policy do not control, such a statute to regulate the hours of private employment is nncoustitutional. ${ }^{9}$ But under the police power or where public policy control, such statutes are constitutional. ${ }^{10}$

In Atkins v. Kansas, ${ }^{11}$ a statute which makes it a criminal offense for a contractor for public work to permit or require an employee to labor thereon more than eight hours a day, is constitutional. Neither the constitutional guaranty of freedom to contract, nor the guaranty of the equal protection of the laws, is deemed to be violated by such a statute.

8. Atkin r. Kansas, 191 U. S. 207, 24 S. Ct. 124; Compare People v. Orange County Construction Co., 175 N. Y. S4, 67 N. E. 129 ; Cleveland v. Construction Co., 67 Ohio St. 197,65 N. E. 885,59 L. R. A. $775,93 \mathrm{Am}$. St. Rep. 670 ; Ex parte Kuback, 85 Cal. 29, 24 P. 737.

9. In re Eight Hours Bill, 21 Colo. 29, 39 P. 328; Fiske v. People, 188 I1I. 366,58 N. E. 985 ; 52 L. R. A. 274 ; In re Morgan, 26 Coln, $\frac{1}{15}$, 58 P. 107147 L. R. A. 52, 77 Am. St. Rep. 269; Street v. Varney
Electrical Supply Co., 160 Ind. 338, 66 N. E. 895, $98 \mathrm{Am}$. St. Rep. 325.

10. Commonwealth v. Hamilton Mfr.. Co., 120 Mass. 383; State v. Buchanan, 29 Wash. 602, 70 P. 52, 59 L. R. A. 342,92 Am. St. Rep. 939) Wenham v. State (Neb.), 91 N. W. 421, 58 L. R. A. 825; Holden v. IIardy, 169 U. S. 366, 18 S. Ct. 383 ; Compare Ritchie v. People, 155 Ill. 98, 46 Am. St. Rep. 315,40 N. E. 454,29 L. R. A. 79 ; State v. Legund (Md. Balt. Ct.), 35 Chi. L. News, 152.

11. 191 U. S. 207,24 S. Ct. 124. 
In New York a similar statute is held void, ${ }^{12}$ on the ground that the police power of the State does not extend to such interference with the employment of labor by independent contractors thongh they are engaged upon a public work. The New York court says that if the employes were working directly for the State, the State might regulate their hours and every other detail of their work, but the doctrine is stated, that the State has no greater right than a eitizen has to control the details of the work when let ont the performance thereof to a contractor, except so far as it reserves such right by the contract.

The United States Supreme Court holds differently, and says as the work is done for the State, or for one of its municipalities, the statute is ralid. It belongs to the State as the gnardian and trustce for its people, to control its affairs, to prescribe the conditions upon which it will permit public work to be done on its behalf, or on behalf of its mimicipalities. No court has authority to review the State's action in that respect. Regulations on this subject suggest only consideration of public policy. No contractor for public work can exeuse a riolation of his agreement with the State by doing that which the statute under which he proceeds distinctly and lawfully forbids him to do.

It seems that the highest conrt of any State can settle this question for its own jurisdiction. It the State does hold such a statute valid, the Federal court will not interfere, as it holds that the Federal constitution is not violated. But if the State court holds such a statute unconstitutional becanse it is not the proper exercise of the police power, then can this question reach the Federal court? And if such decision should rest upon a Federal question, and is consonant with the Federal right claimed as against the State, this would preclude the Federal court from interfering.

12. People v. Orange County N. E. 129 ; People v. Grout, 179 N. Road Const. Co., 175 N. Y. 84, 67 Y. 417. 


\section{CHAPTER II.}

\section{Insane Persons.}

\section{AR'TICLE I.}

\section{Capicity to Contract.}

Section 5. Insanity.

6. IVlat is Capacity to Contract.

7. Old Age, and Weakness of Mund as Incapacity.

8. Insane Delusior.

9. Void, Voidable, and Valid Contracts.

10. Restoration of Reason.

11. Necessaries.

12. After Inquisition and Finding of Lunacy.

13. Marriage-Insanity of Pasty.

14. Bills and Notes of Insane Persons.

15. l'artuership.

16. I.ife Insurance-No Suicide Clause in Policy.

17. Jife Insurance-Impulsive Insanity.

18. The Question of Right and Wrong-English Doctrine.

19. American Doctrine.

20. Die by Suicide, Sane or Insane.

§ 5. Insanity.- It is the umbroken current of opinion of both physician and court, running back for more than a century, that a person may be deranged, may be non compos mentis, or of moound mind, thongh not totally deprived of memory and understanding. To give a definition of insanity is impracticable, or to describe the different kinds of insanity, becanse the several varieties pass into each other imperceptibly and more frequently than insanity into a healthy and sound mind. All writers and jurists agree that an immovable delusion as to facts past or present is not merely a symptom of insanity, but is in fact insanity or the effect of an unsound mind. 
Insanity, exeept in case of idiots, who labor under a perpetual infirmity from their birth, implies a derangement in somo shape or form of the intellect.

As to whether a party is capalle of contracting is a question as to whetloe the mind is derangerl to such an extent as to disqualify the contractor from conducting himself with personal safety to hinself and others, and from managing and disposing of his own affair's and discharging his relative duties. ${ }^{1}$ Thus, the testamentary capacity of a party does not neessarily imply a mind wholly mimpaired. If the testator recollects the property he is to dispose of, the persons to whom he wishes to hequeath it, the manner in which he or she desires to dispose of it, and understands the business engaged in, this is sufficient eapaeity. The disposing mind or memory which the law declares is a test of testamentary capacity, is embraced in the one power to collect and retain the elements of business to be performed for a sufficient length of time to perceive and comprehend their relations to each other, ${ }^{2}$ and this test will apply to all business relations and the making of eontracts. ${ }^{3}$

The law recognizes all the grades and varieties of mental imbecility under the gencral head of insanity without troubling itself much about classification or exact definitions; in a legal sense mental ursoundness is insanity, and mental soundness is sanity.

1. MeElroy's Case, 6 Watts \& S. (Pa.) 451 .

2. Bulger v. Ross, $9 \mathrm{~s}$ Ala. 267, 12 so. 803 ; Hampton v. Westcott, 49 N. J. Eq. 522, 25 A. 254; Martin v. Thayer, $37 \mathrm{~W}$. Va. $38,16 \mathrm{~S}$. E. 489 ; Norton v. Paxtou, 110 Mo. 456, 19 S. W. S07; Greene v. Greene, 145 Ill. 264. 33 N. E. 941 ; Potter v. Jones, 20 Oreg. 239, 25 P.
1021, 12 L. R. A. 161 and note; shaver v. McCartlis, $110 \mathrm{~Pa}$. St. 339, 5 A. 614; Brown r. Mitchell, 75 Tex. 9, 12 S. W. 606; Bush v. Lisle. 89 Ky. 393. I2 S. W. 448; Spratt r. Spratt, 76 Mich. 3S4, 43 N. W. 627: Nicewander v. Nicewander, 151 Ill. 146.37 N. E. 698.

3. Davren v. White. $42 \mathrm{~N}$. J. Eq. 569, 7 A. 682 . 
$\S 6$. What is capacity to contract.- Whether a party is insane or in a condition of feeble or impaired mind at the date of the contract, so as to render it voidable, is a question difficult to answer. But if the contractor has memory and minil enough to reeollect the property he is to convey and the persons to whom he was to convey it, and the manner in which he wished it to be disposed of, and knows and understands the business he is engaged in, such person is, in contemplation of law, of sound mind, and his age or bodily infirmity will not vitiate the conveyance made by one possessing such capacity. ${ }^{1}$ But if the party cannot understand the nature and effeet of his contract on account of his idiocy, lunacy, monomania, or other diseases of the mind, he is non compos mentis. ${ }^{2}$ If the party is insane but has lucid intervals, a contract may be ratified during a lucid interval and become valid, though made when he was insane. ${ }^{3}$

While mere imbecility or weakness of mind in a grantor will not, in the absence of fraud, aroid his deed, insanity will do so if of such a character as to induce the conveyance, although such insanity may not amount to a complete dethronement of reason and understanding upon all subjects.

\section{\$ 7. Old age and weakness of mind as incapacity.- The} fact that a person's intellectual powers have been somewhat im-

1. Eaton v. Eaton, 37 N. J. L. 108, 18 Am. Rep. 710; Gould $\mathrm{r}$. Hull, 127 Ill. 523,20 N. E. 665 ; Somers v. Pumphrey, 24 Ind. 231 ; Dennett v. Dennett, 44 N. H. 531, 84 Am. Dec. 97 ; Hovey v. Chase, 52 Me. 316.

2. Burnham v. Kidwell, 113 Ill. 425; Merritt v. Gumaer. 2 Cow. (N. Y.) 552; Hale v. Brown, 11 Ala. 87; Ball v. Maunin, 3 Bligh, N. S. 1; Brown v. Brown, 108 Mass. 386; Boyce v. Smith, 9 Gratt.
( Va.) 704, 60 Am. Dec. 313; Perry r. Pearson, 135 Ill. 224, 25 N. E. 636.

3. Allis v. Billings, 6 Met. (Mass.) 415, $39 \mathrm{Am}$. Dec. 744 and note; Blakeley v. Blakeley, 33 N. J. Eq. 502; Gibson v. Loper, 6 Gray (Mass.) 279, 66 Am. Dec. 414.

4. Dewey v. Allgire, 37 Neb. 6 , 55 N. IV. 276, 40 An. St. Rep. 468; Hay v. Miller, 48 Neb. 156, $66 \mathrm{~N}$. IV. 1115. 
paired by age is not suftieient to invalidate his derel, if he still retains a foll compurehemsion of the meaning, design, and effect of his acts. ${ }^{1}$ The sole puestion is alwaye, hats the party sufficient intelligenee to understand lis contracts? ${ }^{2}$ As to the measure of calpacity, a party must have understanding enough to enable hins to comprehend in a reasonable mamer the mature of the business he is doing. ${ }^{3}$

Old age is not in itself sufficient evidence of incapacity to make a dect or willt or contract. Mere weakness of intellect does not incapacitate one from making a contract. ${ }^{5}$ There may be such imbecility of mind, from whatever canse, indneed to incapacitate to contract. It seems impossible to lay down a general rule of universal application. Each case must stand on its special circumstances. There are gradations and degrees of mental weakness, as there are of intellectual strength. The in-

1. Lindsey $v$ Lindsey, 50 IHl. 79 , 99 Am. Dec. 4S9; Davis r. Phillips, 85 Mich. 198, 48 N. W. 513 ; Cocke v. Montgomery, 75 Iowa, $259,39 \mathrm{~N}$. W. 386; White v. Farley, 81 Ala. 563,8 So. 215; Cain v. Warford, 33 Md. 23; Dewey v. Allgire, 37 Neb. 6,55 N. W. 276, 40 Am. St. Rep. 468; Maddox v. Simmons, 31 Ga. 528 .

2. Davis v. Phillips, 85 Mich. 198, 48 N. W. 513.

3. Lozear v. Shields, 23 N. J. Eq. 509 ; Hill v. Day, 34 N. J. Eq. 150; Day v. Seely, 17 Vt. 542; Gore v. Gibson, 13 Mees. \& Wal. 623; Stewart v. Flint, 59 Vt. 144, s A. 801; Peabody v. Kendall, 145 Ill. 519, 32 N. E. 674; Lynch v. Doran, 95 Mich. 395, 54 N. IV. S82: King v. Cummings, 60 Vt. 502, 11 A. 727 ; Trimbo $v$. Trimbo, 47 Minn. 389, 50
X. W. 350 ; Marshall v. Marshall, 75 Iowa, 132, 39 N. IV. 230; Jenesen v. Jenesen, 66 111. 259 ; Coleman v. Frazer, 3 Bush. (Ky.) 300; Crowe v. Peters, 63 Mo. 4:9.

4. Kerr v. Lunsford, 31 W. Va. 659, S S. E. 493,2 L. R. A. 668 and note; Buckey v. Buckey, 38 W. Va. 168, is S. E. 383 ; Collins v. Townley, 21 N. J. Eq., 353; Watson v. Watson, 2 B. Mon. (Ky.) 74; In re Snelling, 136 N. Y. 515,32 N. E. 1006 ; Bain v. Cline, 24 Oreg. 175, 41 Am. st. Rep. 851, 33 P. 542; Howell v. Taylor, 50 N. J. Eq. 428, 26 A. 566; Pooler v. Christman. 145 Ill. 405,34 N. E. 57.

5. 2 Kent's Com. 453; Farnam v. Brooks, 9 Pick. (Mass.) 220; Cram v. Cram, 33 Vt. 15; Curtis v. Brownell, 42 Mich. 165, $3 \mathrm{~N}$. W. 936. 
quiry in each ease, looking to all the ciremmstances, is, was the party led info the contract by unfair means, which amount to frand, deceit, imposition, or cireumvention $?^{6}$ If one is capable of taking eare of his own interests, makes a bad or losing contract, the law will not aid him mnless deceit has been practiced against himn." No degree of physicial or mental imbecility, which does not deprive the party of legal competeney to act, is of itself sufficient to avoid his contract. ${ }^{8}$ It must go so far as to clisable him from knowing and understanding the nature and effect of his act. ${ }^{9}$ His mind may be weak as compared with what it had been, the memory enfeebled, the understanding be weak, the character and demeanor eceentric, and he may not have the eapacity to transact all ordinary business of life, yet if he understands the nature of the act he does, recollects the property he is disposing of, and the person to whom he grants it, and how he desires to dispose of it, his act is valid. ${ }^{10}$ The presumption of capacity is always accepted at the time the deed was executed or contract made as to a person whose contract is brought in question. ${ }^{11}$

§. Insane delusion.- A party may be partially insane, or insane upon one subject and perfectly rational upon other subjects. In former times it was held that non compos mentis,

6. Simonton v. Bacon, 49 Miss. 52 ; Gartside v. Isherwood, 1 Bro. C. C. $560 ;$ Maun v. Betterley, $21 \mathrm{Vt}$. 326 ; Willis v. Jernegon, 2 Atk. 251; Stewart v. Lispenard, 26 Wend. (N. Y.) 254.

7. Miller v. Craig, 36 Ill. 109 ; Stone v. Wilbur, 83 Ill. 105; Aiwon v. Stout, 42 Pa. St. 114; Cain v. Warford, 33 Md. 23; Maddox v. Simmons, 31 Ga. 512; Van Alst v. Hunter, 5 Johns. Ch. 160.
8. Farnam v. Brooks, 9 Pick. (Mass.) 212, 19 Am. Dec. 353.

9. Mercer v. Kelso, 4 Gratt. (Va.) 106; Buckey v. Buckey, 38 IV. Va. 168,18 S. E. 383.

10. Nicholas v. Kershear, $20 \mathrm{~W}$. Va. 251; Kerr v. Lumsford, 31 W. Va. 662,8 S. E. 493.

11. Buswell on Ins., 159; Buckey v. Buckey, 38 W. Va. 168, 18 S. E. 383. 
meant that the party had wholly lost his muderstanding ; that the terms "non compos mentis," and of musound mind, are legal terms and import a total deprivation of sense. This doctrine has long sinee been repudiated. Every person is to be deemed of unsoumd mind who has lost his memory and understanding, by old age, sickness, or other accident, so as to render him incapable of transacting business or of managing his property. ${ }^{2}$

When an insane delusion is eonneeted with the transaction the contract is voidalle. Whenever the mind is so deranged that the testator, orantor, or contractor enters into a transaction under an insane delusion, so that he is incapable of doing business, the transaction is voidable. ${ }^{3}$ even if the delusion is the result of habitual drunkeness. ${ }^{4}$ If the insane delusion influenees the contractor's will in disposing of his property in a manner which he would not follow if he lad been sane, the contract, will, or deed will be roidable, ${ }^{5}$ though the actor may have been of sound mind in other respects. ${ }^{6}$ For it is well known that in many forms of insanity the capacity to transact business is entirely maffected, and in such ease the fact of insanity eannot be set up to aroid business transactions not affected by the insane delusion. ${ }^{\top}$

The belief in spiritual manifestations is not necessarily eri-

1. Beverley's Case, 4 Co. I23, Co. Litt. 24 ‘̆ 2 Bl. Com. 292.

2. In re Baker, 2 Johns. Ch. (N. Y.) 232; Perry v. Pearson, 135 Ill. 218,25 N. E. 636 ; Noel v. Karper, 53 Pa. St. 97.

3. Edge v. Edge, $3 s$ N. J. Eq. 211.

4. Menkins, v. Lightner, is IIl. 282; Bliss v. Railroad Co., 24 Vt. 424 .

5. Banks v. Goodfellow, L. R., 5 Q. B. 544; Ballantine v. Prondfoot. 62 Wis. 216 , 22 N. W. 392.
6. Lueas v. Parsons, 24 Ga. 640, $71 \mathrm{Am}$. Dec. 147; Cotton v. Ulnor, 45 Ala. 378, 6 An. Rep. 703; ('haney v. Bryan, 16 Leal (Tenn.), 63; Tawney v. Levs, 76 Pa. St. 106 ; Bond r. Bond, 7 Allen (Mass.) 1; Alston v. Boyd, 6 Iumph. (Tenn.) 504: Riggs v. Tract Soc.. 95 N. Y. 503 : Samuel v. Marshall, 3 Leigh. (Va.) $56 \pi$.

7. Searles v. Galbraith. 73 Ill. 269: West v. Russell, ts Mich. 74, 11 X. W. 812. 
dence of such an impaired mental condition as to show that those who hold such opinions are unfit to make a disposition of their property. ${ }^{8}$ So the fact that a testator is a spiritualist is not a suffieient ground for setting asisle his will. ${ }^{9}$ Extreme religions anxiety of a party is not a gronnd for setting aside his contract or will. ${ }^{10}$ Partial insanity in the form of monomania not connected with the subject of the contract, camnot invalidate the transaction. To avoid a contract, the insane delusion must be connected with it as a moring foree. ${ }^{11}$

\$. Void, voidable, and valid contracts. - The general rule is that transactions of insane persons are binding in law and equity until avoided. And althongh their transactions are in general not void, but only voidable, the conte will fully protect their interests and will allow them to set up their disability in avoidance of their transaction. ${ }^{1}$

A deed of conveyance of a person of insane mind, executed before an inquisition and finding in lunacy, if taken in good faith is roidable only and not roid, ${ }^{2}$ and this is the rule as to other contracts.

8. Lewis v. Arbuckle, 85 Iowa, 335,52 N. W. 237,16 L. R. A. 677 and note.

9. Otto v. Doty, 61 Iowa, 23, 15 N. W. $57 \mathrm{~s}$; Smith v. Will, 52 Wis. 543, 8 N. W. 616,9 N. W. 665. See, also, Burgess v. Pollock, 53 Iowa, 273, 5 N. W. 179, 36 Am. Rep. 218.

10. Chapin's Will Case, 32 Wis. 557; Weir's Will, 9 Dana (Ky.) 434.

11. Boyce v. Smith, 9 Gratt. (Va.) 704; Lewis v. Arbuckle, 85 Iowa, 335, $52 \mathrm{~N} . \mathrm{W} .237,16 \mathrm{~L} . \mathrm{R}$. A. 677 and note.

1. Mitehell v. Kingman, 5 Pick.
(Mlass.) 431; Seaver r. Phelps, 11 Piek. (Mass.) 304, 22 Am. Dec. 372.

2. Baldwin v. Golde, 88 Hun (N. Y.), 115, 34 N. Y. S. 587; Eaton v. Eaton, 37 N. J. L. 108, 15 Am. Rep. 716 ; 4 Kent's Com. 450; Elston v. Jasper, 45 Tex. 413; Pearsoll v. Cox, 71 Tex. 246, 9 S. W. 924, 10 Am. St. Rep. 740; Riggan v. Green, So N. Car. 236, 30 Am. Rep. 77; Hovey v. Chase, $52 \mathrm{Me}$ 304, $83 \mathrm{Am}$. Dee. 514; Alles v. Billings, of Met. (Mass.) 415, $39 \mathrm{Am}$. Dec. 744 and note: Gibben r. Maxwell, 34 Kan. 8, 7 P. 534, 55 An. Dec. 233; Boyer v. Berryman, 123 Ind. 451. 24 N. E. 
In England and in the T'nited States, when the common law prevailed, a feoffment of a lunatic or idiot, in jurom, was only voidable, and not void; because the solemnity and formalities of livery of seisin, together with the necestary participation of others in the act, and its notoriety, presuppose that the incapacity of that party was not apparent." In the United States livery of seivin has been abolished, and registration hat taken its place. So where a deel of bargain and sale of a lmatic, when executed witl all the formalities of law, and cluly registered, will, like a feoffment in person, be only voidable and not void.

But it is said that there is a distinction between the feoffment of a lunatic taking effect by livery of seisin and his deed of bargain and sale; that his surrender, or grant, is void $a b$ initio. ${ }^{4}$ It is held that a deed of a man who is non compos mentis, is legally ineffectual and inoperative to pass title to land; that it is not merely roidable, but absolutely void; that it cannot be a deed, it never having had any legal existence. ${ }^{5}$

And it is also held that a power of attorney of a lunatic, or of one non compos mentis, is roid. ${ }^{6}$

But this doctrine of a roid deed, if made by a lunatic, is not accepted only by a few courts and the weight of authority holds

249; Dennett v. Dennett, 44 N. H. 538 ; Blakely v. Blakely, 33 N. J. Eq. 508; Snowden v. Dulavey, 11 Pa. St. 525; Breckinridge r. Ormsby, i J. J. Narsh. (Ky.) 236, 19 Am. Dec. 71: Fitzgerald v. Reed, 9 S. M. (Miss.) 94: Allen v. Berryhill, 27 Iowa, 540; Riley v. Carter, 76 Id. 581,25 A. 667,19 L. R. A. 489 and note, 35 Am. St. Rep. 443: Jackson r. Gumear, 2 Cow. (N. Y.) 552; Key $r$ Davis, 1 Md. 32.

3. Thompson r. Jeach, Carthew,
4. 3 Salk. 300, 2 Vent. 198; Yates $v$. Boen, 2 Strange, 1104 ; Estate of Silver, 5 Rawle (Pa.) 371; Farley v. Parker, 6 Ore. 105, 25 Am. Rep. 504; Elder v. Schumacher, 18 Colo. 433, 33 P. 175; Rogers v. Blackwell, 49 Mich. 192, 13 N. W. 512 ; Van Dusen v. Sweet, 51 N. Y. 378.

5. Van Dusen v. Sreet, 51 N. Y. 378.

6. Dexter v. Hall, 15 Wall. (U. S.) 9 . 435. 
that such deed is only voidable. And as the conveyance laws of the United States take the place of the feoffment and livery of seisin, and which was voidable when made by an insane person, so a deed in the United States made by a lunatie should be voidable ouly and not void.

An insane man has not the power to convey an indefeasible title. This incapacity inheres in all titles transferred through him. The right of infants and insane alike to avoid their contracts is an absolute and paramount right superior to all equities of third persons, and may be exercised against a bona fide purchaser; his deed is voidable, not void, ${ }^{\top}$ and when not under guardianship, conveys the seisin. ${ }^{8}$ The insanity of one contracting party does not give to the other party the right to avoid the contract. ${ }^{9}$

There is an array of deeisions that hold that a deed given by a lunatic is void. It is generally held that after one has been judicially declared insane, any contract he assumes to make is absolutely void, and the presumption of the continuance of the insanity is conclusive as to all dealings with him montil it has been suspended. ${ }^{10}$ And so a deed executed by a lunatic is absolutely void, and if not taken in good faith and for a valuable consideration, will not be upheld in equity, even in favor of a mortgagee of the grantee. ${ }^{11}$ And so a note made by a lunatic with knowledge of his condition on the part of the payee is ab-

7. Hovey v. Hobson, 53 Me. 451, 80 Am. Dec. 705; Cook v. Parker, 5 Phila. (Pa.) 265; Ingraham v. Baldwin, 9 N. Y. 45; Arnold v. Richmond Iron Works, l Gray (Mass.) 434; Kates v. Woodson, 2 Dana (Ky.) 452; Burnham v. Kidwell, 113 111. 425; Keil v. Healey, 84 Ill. 104, 25 Am. Rep. 434; ScanIon v. Cable, 88 Ill. 291; Riley v. Carter, 76 Md. 581, 25 A. 667, 19 L. R. A. 489 and note, 35 Am. St.
Rep. 443 ; Boyer v. Berryman, 123 Ind. 451, 24 N. E. 249 ; Burke v. Allen, 29 N. H. 106, 61 Am. Dec. 642 .

8. Wait v. Maxwell, 5 Pick. (Mass.) 217, 16 Am. Dec. 391.

9. Atwell v. Jenkins, 163 Mass. 362, 40 N. E. 178, 28 L. R. A. 694 , 47 Am. St. Rep. 463.

10. Carter v. Beckwith, 128 N. Y. 312, 28 N. E. 582.

11. Goodyear v. Adams, 5 N. Y. 
solutely void, ${ }^{2}$ and this doctrine finds support in many cases. ${ }^{13}$ The other line of decisions which hold that a lunatices dealings, before inquest found, are only voilable, may possibly be reconciled on the gromul, that the contract was made in good faith, and withont knowledge, either actual or enstructive, on the part of the party contracting with the lunatic. This conflict of authority may be reconciled by the deternination of the question whether or not the contract is executed under conditions in which the law presumes sanity or insanity.

$\S$ Io. Restoration of reason.- $-\lambda$ fter a person has beell adjudged insane and sent to an asylum and then discharged as sane, any eontract entered into by him thereafter is valid without any adjudieation by the proper court that such person has been restored to reason. ${ }^{1}$ And so if a person has been adjudged insane, but no conservator has been appointed, and he still manages his business, no appearance of insanity, his contracts are valid, provided they are fair and reasonable, the other party having no notice of his insanity or of the court proceedings against him. ${ }^{2}$

And if the guardianship has been abandoned, though the party has not been restored to his rights by the proper court, his contract, if fair, will be enforced, provided his reason has been restored. ${ }^{3}$

Supp. 275, 119 N. Y. 650. See, also, Van Dusen v. Sweet, 51 N. Y. $4 ! 97$; Valentine v. Lunt, 115 N. Y. 497 , 22 N. E. 209 ; Riggs v. Society, 95 N. Y. 503.

12. Westerfield v. Jackson, 41 Hun (X. Y.) 645 .

13. Beavan v. MeDonnell, 9 Exch. 309: Gore v. Gibson, 13 Jees. \& W. 623 ; Johnson v. Stone, 35 Hun (N. Y.) 380,103 N. Y. 687;
Henry v. Fine, 23 Ark. 417; Lincoln v. Buckmaster, 15 Wall. (U. S.) 9 ; Refining Co. v. Medahon, 38 N. J. L. 537. See Contracts of Lunatics, 17 Law Quarterly Review, 147.

1. Topeka Water Supply Co. v. Root, 56 Kan. 187, 42 P. 715.

2. MeCormick r. Littler, 8.j Ill. 62, 28 Am. Rep. 610.

3. Elston Y. Jasper. 45 Tex. 403. 
But the burden of proving the restoration of reason and the termination or practical abandonment of the guardianship of one insane is upon him who seeks the enforeement of a contract against him who pleads insanity. ${ }^{4}$ And if the party was shown to be sane when he made the eontract, his subsequent insanity does not avoid it. ${ }^{5}$

§ I . Necessaries.-While an insane person cannot bind himself by express contract, ret the contracts created by law are binding on him. The law implies a contract on his part to pay for necessaries furnished him, and services rendered in good faith and under circumstances justifying their being furnished or rendered, and his estate will be bound for them. ${ }^{1} \mathrm{He}$ is liable for necessaries furnished his family, ${ }^{2}$ and even for luxuries furnished in good faith. ${ }^{3}$ If the party has been judged insane and a guardian appointed, he is still liable for necessaries, ${ }^{4}$ but if he is already sufficiently supplied with any necessaries, he should not be liable for a further supply of the same kind. ${ }^{5}$ But if necessarien arre furnished in good faith, and under circumstances justifying their being so furnished, the person furnishing may recover. The insane man stands in the same position as minors, and is liable for necessaries. And this

4. EIston v. Jasper, 45 Tex. 409. See, also, Searle v. Galbraith, 73 IIl. 269; MeGinnis r. Commonwealth, 74 Pa. St. 245. Compare Redden v. Baker, 86 Ind. 191; Kielne v. Wessell, 53 Mo. App. 667.

5. Sands v. Potter, 59 Ill. App. 206.

1. Williams v. Wentworth, 5 Beav. 325; Van Horn v. Hann, 39 N. J. L. 207 ; McCormick v. Littler, 85 Ill. 62, 2S Am. Rep. 610; Sceva v. True, 53 N. H. 627 ; Shaw v.
Thompson, 16 Pick. (Mass.) 198, 26 Am. Dec. 655; Searles v. Pipkin, 69 N. Car. 513.

2. Read v. Legard, 6 Exch. 636.

3. Kendall v. May, 10 Allen (Mass.) 59.

4. Reando v. Misplay, 90 Mo. 251, 2 S. W. 405, 59 Am. Rep. 13; MeCrellis v. Bartlett, 8 N. H. 569; Baxter v. Portsmouth, 5 Barn. \& Cr. 170.

5. Phillips on Lunaties, 17. 
rule is applicable though a guardian has been appointerl, as the law implies a promise to pay for necessaries. The estate of the insane is legally and equitably liable for necessaries furnished in good faith and under ciremustances justifying their being furmished, ${ }^{6}$ and when furnished to the insane man or his family and not to a third person. When another promise in writing to pay for necessarics for an insane person, or makes an original contract for them, the insane person's estate is not liable for the necessarics.

$\S$ I2. After inquisition and finding of lunacy.- - t common law an inquisition finding one a lunatic upon a writ of de lunatico inquircndo, was eridence of his lumacy as to all and any collateral proceedings; all his contracts thereafter were roid and not roidable. ${ }^{1}$.nd this rule has been adopted by many States, and all contracts of an insane person after finding of lunacy and the appointing of a guardian, are absolutely void. ${ }^{2}$ And under such a law in many States the appointment

6. Fruitt v. Anderson, 12 Ill. App. 421; La Rue v. Gilkyson, 4 Pa. St. 375, 45 Am. Dee. 700 ; Pearl v. McDowell, 3 J. J. Marsh. (Ky.) 658, 20 Am. Dec. 199; Sawyer v. Lufkin, 56 Me. 308.

7. Massachusetts General Hospital v. Fairbanks, 132 Mass. 414.

8. Massachusetts General Hospital v. Fairbanks, 129 Mass. 78, 37 Am. Rep. 303. See, also, Forester v. Fuller, 6 Mass. 5s, $4 \mathrm{Am}$. Dec. 87; Somes v. Bearer, l Pick. (Mass.) 314.

1. Wait v. Naxwell, 5 Pick. (Mass.) $217,16 \mathrm{Am}$. Dec. 391.

2. Copenrath v. Kienly, 83 Ind. 18; German Sar. and L. Asso. v.
DeLashmutt, 67 Fed. Rep. 399 ; Leonard v. Leonard, $14{ }^{\circ}$ Pick. (Mass.) 280; Mohr r. Tulip, 40 Wis. 66; New England, etc., Co. v. Spitler, 54 Kan. 560, 38 P. 799 ; Griswold v. Butler, 3 Comn. 227; Maloney v. Dewey, 127 Ill. 395, 19 N. E. S48, 11 Am. St. Rep. 131 ; Pearl v. MeDowell, 3 J. J. Marsh. (Kr.) 658, 20 Am. Dee. 199; White v. Pahmer, 4 Mass. 147; Ingraham v. Baldwin, 9 N. Y. 45; Wilcox v. Fitzhugh, 12 Barb. (N. Y.) 235; Compare Yanger $v$. Spinner. I licCarter (N. J.) 389; Lancaster Bank r. Wood, is Pa. St. 407, 21 Am. St. Rep. 24 and note. 
of a guardian is conclusive. ${ }^{3}$ This rule applies to drunkards who are ineapable of taking care of their property. ${ }^{4}$ Putting a party in control of a guardian, is in the nature of a commission on the writ de lunatico inquirendo." The assent of the gnardian to the lunitie's deed, does not validate it. ${ }^{6}$ After incuest and judgment of lnuacy, the disability of the ward is conclusive; and it is immaterial from what cause his insanity resulted, whether from old age, sickness, habitual drunkenness, or other causes whatever. ${ }^{7}$

So long as the guardianslip continues the decree is regarded as conclusive on the question of the ward's sanity, on the ground that the decree fixed the ward's status as to all the world, and because it might greatly embarrass the execution of his trust if the guardian could be compelled to try the question of his ward's sanity in every action for or against him. ${ }^{8}$ But when the guardianship has terminated, and a controversy has arisen between third parties, one of whom claims under a contract made with the ward after the termination of the guardianship, the reason ceases for holding the decree conclusive. ${ }^{9}$ And the discharge of a patient from a lunatic asylum may be regarded as evidence of recovery. ${ }^{10}$

3. Wadsworth v. Sherman, 14 Barb. (N. Y.) 169; Leonard v. Leonard, 14 Pick. (Mass.) 280; White v. Palmer, 4 Mass. 147 ; McDonald v. Morton, I Mass. 543.

4. Wadswortlı v. Sherman, 14 Barb. (N. Y.) 169.

5. Inhoff v. Witmer, $31 \mathrm{~Pa}$. St. 243; Ex parte Crammer, 12 Ves. 445; Barker's Case, 2 Johms. Ch. (N. Y.) 232; Gibson v. Jeyes, 6 Ves. 273; Ridgeway v. Darwin, $\mathrm{S}$ Ves. 65.

6. Griswold v. Butler, 3 Conn. 231. Sce, also, Huling v. Huling,
32 I1l. App. 521; Behrensmeyer v. Freitz, 135 Ill. 638, 26 N. E. 704; Hicks v. Chapman, 10 Allen (Mass.) 463.

7. Rannells v. Gerner, so Mo. 474.

8. White v. Palmer, 4 Mass. 147 ; Leonard v. Leonard, 14 Pick. (Mass.) 280; Legat v. Clark, 111 Mass. 308,310 .

9. Willworth v. Leonard, 156 Mass. 277, 31 N. E. 299.

10. Langdon v. People, 133 III. 382,24 N. E. 874. 
In some of the States, unter a statute, a court may sond a party to an insane asylum for treatment, and this dnes not disqualify him from making contracts. ${ }^{11}$ And though a party is under guardianship, he is still liable for neeessaries. ${ }^{12}$

\section{$\S$ r3. Marriage - Insanity of party.- The capacity to make} a legal marriage contract does not differ from any other contraet. If the capacity be such that the party is incapable of understanding the nature of the contract itself, and incapable from mental imbecility of taking eare of his or her own person or property, such an individual camnot dispose of his or her person and property by a matrimonial eontract any more than by any other contract. ${ }^{1}$ Hence, a marriage is void if, at the time it takes place, the husband had not sound mental eapaeity to enable him to understand the nature of the marriage contract and of the marital relations, and the understanding that he took upon himself duties, obligations and responsibilities of that relation. The rule of competeney does not require that he shall understand all the marital duties and obligations, but requires that he shall understand that he assumes them whatever they may be..$^{2}$ And the law is, in the absence of any statutory provisions to the contrary, that it is not required to go into court to annul a marriage which has no existence, but is absolutely void $a b$ initio, and its invalidity may be shown in a proceeding in any court whenever the question arises collaterally. ${ }^{3}$

11. Knox v. Haug, 48 Minn. 58, 50 N. W. 934.

12. Lilly v. Wagoner, 27 Ill. 395 ; MeCormiek v. Littler, 85 Ill. 62, 28 An. Rep. 610; Burnham v. Kidwell, 113 III. 425; Sawyer v. Lufkin, 56 Me. 308 ; Reando v. Misplay, 90 Mo. 251,2 S. IT. 405,15 Am. Rep. 13.

1. Kern v. Kern, 51 N. J. Eq.
574, 26 A. 837; Browning v. Reane, 2 Phillim. 70.

2. St. George v. Biddeford, 76 Me. 593; Atkinson v. Medford, 46 Me. 510; Cole v. Cole, 1 Sneed (Tenn.) 57; Unity v. Belgrade, 76 Me. 419; Middleboro v. Roehester, 12 Mass. 363.

3. Gathings v. Williams, 5 Ired. (x. Car.) 487; Schouler on Dom. 
The mere fact of insanity without more evidence is not sufficient ground to annul a marriage contract. ${ }^{4}$ In most of the States statutory provisions are made so that a judicial proceeding is neessary to anuul a marriage, and hence a roid mar riage cannot be attacked in a collateral proceeding. ${ }^{5}$

$\S$ I4. Bills and notes of insane persons.- When the payee of a promissory note has notice of the maker's insanity, he cannot recover on the note, though the consideration was for necessaries; but the amount may be collected from the estate. ${ }^{1}$ But where one in good faith takes a note signed by a person of whose incompetency to do business he has no notice, and in a transaction which is not likely to call his attention to it, he can recover on the note. ${ }^{2}$

In a suit by an indorser of a promissory note made by a lunatic, the latter may defend on the ground that the indorser

Rel. 24; Atkinson v. Medford, 46 Me. 510 .

4. Concord v. Rumsey, 45 N. H. 423.

5. State v. Setzer, 97 N. Car. 252, 1 S. E. 558, 2 Am. St. Rep. 290 ; Wiser v. Lockwood, $42 \mathrm{Vt}$. 720; Jenkins v. Jenkins, 2 Dana (Ky.) 102, 26 Am. Dec. 437; Waymeer v. Jetmore, 22 Ohio St. 291; Powell v. Powell, 18 Kan. 371, 26 Am. Rep. 774.

1. Milligan v. Pollard, 112 Ala. 465, 20 So. 620 ; Davis v. Tarver, 65 Ala. 98. See, also, McLain v. Davis, 77 Ind. 419; Seaver v. Phelps, 11 Pick. (Mass.) 304, 22 Am. Dec. 372.

2. Hosler v. Beard, 54 Ohio St. 398, 43 N. E. 1040, 35 L. R. A. 161 and note, $56 \mathrm{Am}$. St. Dec. 720 ;
Nace v. Boyer, 30 Pa. St. 99; Wilder v. Weakley, 34 Ind. 181; Henderson v. McGregor, 30 Wis. 78; Alexander v. Haskins, 68 Iowa, 73, 25 N. W. 935; Young v. Stevens, 48 N. H. 133, 97 Am. Dec. 592; Raggan v. Green, 80 N. Car. 236, 30 Am. Rep. 77 ; National Bank v. Moore, 78 Pa. St. 407, 21 Am. Rep. 24 and note; Mutual L. Ins. Co. v. Hunt, 79 N. Y. 54l; Shoulters v. Allen, 51 Mich. 529, 16 N. IV. 888; Leomis v. Spencer, 2 Paige (N. Y.) 153; Burnham v. Kidwell, 113 Ill. 425; Canfield v. Fairbanks, 63 Barb. (N. Y.) 461; Physio-Med. College v. Wilkinson, 108 Ind. 315,9 N. E. 376; Matthieson v. McMahon, 38 N. J. L. 536; Gibben v. Maxwell, 34 Kan. 8, 7 P. 584, 55 Am. Rep. 233 ; Behrens v. McKenzie, 23 Iowa, 
had knowledge of the maker's lumaey, or that the note was obtained by fratud or without proper consideration. ${ }^{3}$ And an aeconmodation indorser of a promissory note, who reenives no benefit therefrom either to himself or his estate, may defond against a bona fide holder on the ground that he was non compos mentis at the time of the indorsenent; and this though the holder at the time of the transfer to him had no knowledge of the indorser's insanity. ${ }^{4}$

\$ 15. Partnership.- Whether the insanity of a party dissolves a partnership of which he is a partner is not answered the same. In many States the insanity dissolves the partnership without any decree of conrt, as it is held to be a dissolution by operation of law; and as it is an event orer which the parties have no control, no notice of such a dissolution is necessary. Thus, the death, bankruptey or lunacy of one of the partners dissolves the contract. ${ }^{1}$ That is to say, an inquisition of lunacy against a member of a partnership dissolves ipso facto the partnership. ${ }^{2}$ But the rule is supported by the great weight of authority that the insanity of a partner does not, per se, dissolve a partnership, but may constitute a sufficient ground to justify a court of equity in deerecing its dissolution. This is the true doctrine and is applied by courts of equity with appropriate limitations and restrictions, for while curable, temporary insanity will be sufficient, upon inquisition, to sustain an adjudication of insanity in the proper court, the appointment of a conservator and commitment of the ward to an insane asylum,

333, 92 Am. Dec. 28; Seanlan v. tional Bank v. Sneed, 97 Tenn. 120, Coble, 85 111. 296. 36 S. W. 716,34 L. R. A. 274 and

3. Moore v. Hershey, $90 \mathrm{~Pa}$. St. 196.

4. Mirebach v. Bank, $97 \mathrm{~Pa}$. St. 543, $39 \mathrm{Am}$. Rep. 821; Vores v. Harshbayer, 11 Ind. App. 555, 39 N. E. 521; Compare Memphis Nanote, 56 Am. St. Rep. 788.

1. Griswold v. Waddington, 15 Johns. ( X. Y.) 57 .

2. Isler v. Baker, 6 Humph. (Tenn.) S5. See, also, Davis v. Lane, 10 N. H. 156. 
yet it will not authorize a court of chancery to decree dissolution of partnership if the malady be temporary only, with a fair prospect of reeovery within a reasonable time. ${ }^{3}$ When a partner is affected with insanity, the continuing partner may, if he thinks fit. make it a ground of dissolution, but generally in order to make it a sround of discolution le mast obtain a decree of court ; ${ }^{4}$ if it be a partnership at will, the sane partner may dissolve the partnership of his own volition. ${ }^{5}$

Insanity does not work a dissolution of partnership ipso facto. Courts of equity will, as between partner's, look to the effect produced upon the partnership relations and business, and refuse to dissolve the partnership and apply its assets unless the insanity materially affects the capacity of the partner to discharge the duties imposed by his contract relations. ${ }^{6}$ A decree of a court of chancery is necessary to a dissolution of partnership, notwithstanding there has been an adjudication declaring one partner a lunatic. ${ }^{\top}$

The better mle is that where, after one of the partners had been adjudged insane, but his insanity was considered only temporary and curable, and the continuing partner without objection, or notice to any one, still carried on the business precisely as before, the presumption is that he does not intend a dissolution of the firm, and, in the absence of evidence to the contrary, that he waits to determine whether the incapacity of

3. Story on Part. 297; Jones v. Noy, 2 Mylne \& K. 125; Doughty v. Doughty, 3 Hals. (N. J. Ch.) 227; Uberoth v. Bank, 9 Phila. (Pa.) 83.

4. Raymond v. Vaughn, 128 Ill. 256,21 N. E. 566,4 L. R. A. 440 , 15 Am. St. Rep. 112. See, also, Bagshaw v. Parker, 10 Beav. 532; Robertson v. Lockie, 15 Sim. 285; Pierce v. Cliamberlain, 2 Ves. Sr. 33.
5. Raymond v. Vaughı, $128 \mathrm{Ill}$. 256, 21 N. E. 556, 4 L. R. A. 440, 15 Am. St. Rep. 112. Sce, also, McElroy v. Lewis, 76 N. Y. 373 ; Carlton v. Cummings, 51 Ind. 478; Lawrence v. Robinson, 4 Colo. 567.

6. 3 Kent's Com. 58.

7. 2 Collier on Part., ch. 3 , sec. 3; Gow on Part., ch. 5, sec. 1. Compare Parson on Cont., 484. 
his partner will prove temporary mercly, and it becomes practicable for him to resmme husiness. ${ }^{8}$ In such case, as long as the sane partner continnes to carry on the business without taking steps to dissolve the partnership, there can be no dissolution, or he be excused from aftriwats alecounting for the profits actually derived by him from the husiness of the firm.?

An insane person cannot be adjudicated a bankrupt, but a partncrship, of which he is a partner can be, and the firm's property applied to the partnership debts. ${ }^{10}$

$\S$ r6. Life insurance - No suicide clause in policy.- In many life insurance policies a clause is inscrted that the insured shall not recover on the policy if he commits suicide. This question brings in the question of the sanity of the insured at the time of the suicide. The adjudged cases are conflicting.

It has been held that suicide will aroid a policy, although there are no conditions to that effect in the policy. ${ }^{1}$ Of course, if the insured obtained the insurance with the intent to commit suicide, while sane, this changes the rule and the policy will be void. ${ }^{2}$ This doctrine is qualified by stating that the

8. Raymond v. Vaughn, $128 \mathrm{Ill}$. 256, 121 N. E. 556, 4 L. R. A. 440 , 15 Am. St. Rep. 112; Jones v. Noy, 2 Mylne \& K. 125 ; Berch v. Frolick, 1 Phil. 172, 3 Kent's Com. 58; Pierce v. Chamberlain, 2 Ves. Sr. 33: Bagshaw v. Parker, 10 Beav. 532; Robertson v. Lockie, 15 Sim. 285; Uberoth v. Bank, 9 Phila. (Pa.) S3; Doughty v. Doughty, 3 Hals. (N. J. Ch.) 227.

9. Raymond v. Vaughn, 128 Ill. 256, 21 N. E. 556, 4 L. R. A. 440, 15 Am. St. Rep. 112;. Brown v. Richardson, 133 Mass. 293; Freeman v. Freeman, 136 Mass. 260; Perry on Trusts, 127, 128. See, also, Cook v. Collingridge, 1 Jac. 608; White v. Gardner, 37 Tex. 407 ; Chaney v. Smallwood. I Gill. (MId.) 367 ; Cranshay v. Collins, 15 Ves. 218.

10. In re Stein, 127 Fed. Rep. 29.

1. Hartman v. Ins. Co., $21 \mathrm{~Pa}$. St. 466 ; Horn v. Ins. Co., 30 L. J. Ch. 511, 4 L. T. N. S. 142; Supreme Comandery v. Ainsworth, 71 Ala. 436, 46 Am. Rep. 332. See, also, Hatch v. Ins. Co., 120 Mass. 550 , 21 Am. liep. 541 and note.

2. Smith v. Benefit Soc., 51 Hun (N. Y.) 57,4 N. Y. S. 531 ; Ritter 
suicide must be felonious and not accidental, and the party must not be insane. This qualified application will not allow the policy to be avoided when the condition exists. ${ }^{3}$ And if the insurance is for the benefit of another, suicide is no defense unless the policy provides for avoidance in case of suicide." When a policy is taken out by a person whose life is insured, and the policy is made payable to himself, his executors, administrators, or assigns, and provides for the payment of the sum stipulated if the insured took his life while sane, the policy is void as against public policy. ${ }^{5}$

\section{$\S$ I7. Life insurance - Impulsive insanity. - That form of} insanity called impulsive insanity, by which a person is irresistibly impelled to the commission of an act, is recognized by medical writers on this subject. ${ }^{6}$ It is sometimes accompanied by delusions, and sometimes exists without them. It is an impulse of a party of unsound mind. The cases are to be distinguished from those where persons in the possession of their reasoning faculties are impelled by passion, merely, in the same direction. These last are not insanity, and suicide committed under such conditions will avoid a policy with the suicide clause.

The true test lies in the word power. The policy is avoided, unless his mind is so impaired that he does not understand the consequences of his action, and that death would ensue. If he

v. Insurance Co., 169 U. S. 139, 18

S. Ct. 300.

3. Horn v. Ins. Ca., 30 L. J. Ch. 511,4 L. T. N. S. 142.

4. Darrow v. Family Fund Soc., 116 N. Y. 531, 22 N. E. 1093, 15 Am. St. Rep. 430 ; Kerr v. Benefit Asso., 39 Minn. 174, 39 N. W. 312 , 12 Am. St. Rep. 631 ; Fitch v. Ins. Co., 59 N. Y. 557,17 Am. Rep. 372; Morris v. Assurance Co., $183 \mathrm{~Pa}$. St. 563,39 A. 52.
5. Ritter v. Insurance Co., 169 U. S. 139, 18 S. Ct. 300.

6. Borradaile v. Hunter, $5 \mathrm{Man}$. \& Gr. 639; Dean v. Ins. Co., 4 Allen (Mass.) 96; Newton v. Ins. Co., 76 N. Y. 426, 32 Am. Rep. 335; Scheffer v. Ins. Co., 25 Minn. 534; American Life Ins. Co. v. Isett, $74 \mathrm{~Pa}$. St. 176; Manhattan Life Ins. Co. v. Broughton, 109 U. S. 121, 3 S. Ct. 131. 
exercises volition, is capable of forming an intention and with full knowledge that death will follow his action, his unind concurring in the act, he voluntarily destroys his own life, and the policy with a suicide clanse, becomes null and void. ${ }^{7}$

\section{$\S$ 18. The question of right and wrong - English doctrine.} - The English doctrine is that all the contract requires is, that the act of self-destruction shall be the voluntary and willful act of a man having at the time sufficient powers of mind and reason to understand the physical nature and consequences of such act of suicide, and having at the time a purpose and intention to cause his own death by that act, and the question whether at the time he was capable of understanding the moral nature and quality of his purpose, is not relevant to the inquiry further than as it might help to illustrate the extent of his capacity to understand the physical character of the act itself. ${ }^{1}$ That is, the terms of the condition include all acts of voluntary self-destruction; whether the party is a voluntary moral agent, is not in issue. ${ }^{2}$

The English judges refuse to apply to the act of the insured in causing his death the principles of legal and moral responsibility recognized in cases where the contract, the last will, or the alleged crime of such person may be in issue. This English rule has been adopted by four of the States. ${ }^{3}$

7. Weed v. Ins. Co., $70 \mathrm{~N}$. Y. 561.

1. Borradaile v. Hunter, 5 Man. \& Gr. 639; Bayley v. Alexander, cited in Biddle on Ins., 832.

2. Clift v. Schwabe, 3 C. B. 437 ; White v. Ins. Co., 38 L. J. Ch. 53; Dufaur v. Assurance Co., 25 Beav. 599 ; Stormont v. Assurance Co., 1 Fost. \& F. 22.
3. Mecham v. Ins. Co., 120 N. Y. 237, 24 N. E. 283 ; Weed v. Ins. Co., 70 N. Y. 561 ; Dean v. Ins. Co., 4 Allen (Mass.) 96; Cooper v. Ins. Co., 102 Mass. 227, 3 Am. Rep. 451 and note; Gay v. Ins. Co., 9 Blatch. C. C. 142; Nimick v. Ins. Co., 10 Am. L. Reg. N. S. 102. See, also. St. Louis Life Ins. Co. v. Graves, 6 Bush (Ky.) 26s; Knickerbocker L. Ins. Co. v. Peters, 42 Md. 414. 
$\$$ rg. American doctrine.- The American doctrine, when the poliey contains a suicide clanse, is that if the assured, being in possession of his ordinary reasoning faculties, from anger, pride, jealousy, or a desire to escape from the ills of life, intentionally takes his own life, the proviso attaches, and there can be no recovery. If the death is caused by the voluntary act of the insured, he knowing and intending that his death shall be the result of his act, but when his reasoning faculties are so far impaired that he is not able to understand the moral character, the general nature, consequences, and effeet of the act he is about to commit, which he has not the power to resist, such death is not within the contemplation of the parties to the contract, and the insurer is liable. ${ }^{1}$ It is the established doctrine of most of the American conrts that if one whose life is insured intentionally kills himself when his reasoning faculties are so impaired by insanity that he is unable to understand the moral character of his act, even if he does understand its plysical nature, consequence, and effect, it is not "suicide" or "selfdestruction," or "dying by his own hand," within the meaning of those words in a clause excepting risks out of the policy, and containing no further words expressly extending the exeeption to. such cases. $^{2}$

The clauses used are various in form, but are considered synonymously and mean the same thing, whether described by words of Saxon or of Latin origin, or partly of one and partly

1. Mutual Life Ins. Co. v. Terry, 15 Wall. (U. S.) 580. This case is distinguished in Ritter v. Ins. Co., 169 U. S. 139,18 S. Ct. 300.

2. Bigelow v. Ins. Co., 93 U. S. 284 ; Insurance Co. v. Rodel, 95 U. S. 232; Manhattan Ins. Co. v. Broughton, 109 U. S. 121, 3 S. Ct. 99 ; Connecticut Ins. Co. v. Lathrop, 111 U. S. 612, 4 S. Ct. 533; Acci- dent Ins. Co. v. Crandel, 120 U. S. 527, 7 S. Ct. 685; Connecticut Life Ins. Co. v. Akens, 150 U. S. 468, 14 S. Ct. 155; Supreme Commandery v. Ainsworth, 71 Ala. 436, 46 Am. Rep. 332; Life Asso. v. Waller, 57 Ga. 533; New Home L. Asso. v. Hagler, 29 Ill. App. 437; Scarth v. Ins. Co., 75 Iowa, 246, $39 \mathrm{~N}$. W. 658; Michigan Mut. L. Ins. Co. v. 
of the other." Itpon that part of the clanse which requires "proof that the same is the direst result of discase or of aceident oecurring without the voluntary aet of the insured," the word "prof" means, not the proof required as a preliminary to bringing suit on the policy, but the proof necessary to cetablish the liability of the insurer. And in making out such proof, the plaintiff is entitled to the benefit of the presumption that a sane man will not commit suieide, and of other rules of law established for the guidance of courts and juries in the investigation and determination of facts. ${ }^{4}$

$\S$ 20. "Die by suicide, sane or insane."-Formerly policies provided, generally, that they should be roid in case of death by "suicide," or "by one's own hand," without further qualifications. These terms are synonymous and convey the same idea. And in the United States such a condition refers to an act of criminal self-destruction, and does not apply to an insane person. ${ }^{1}$ So now insurance eompanies adopt a more specific condition as to liability in eases of death by suicide, and add in the suieide clause "die by suicide, sane or insane." This clause has been before the courts for construction, and it is generally held that the insurers are not liable if the insured designedly dies by his own hand, that is, if he commits the act inten-

Naugle, 130 Ind. 79,29 N. E. 393 ; Phillips v. Ins. Co., 26 La. Ann. 404, 21 Am. Rep. 549; Eastabrook v. Ins. Co., 54 Me. 224, 89 Am. Dec. 743; John Hancock L. Ins. Co. v. Moore, 34 Mich. 41 ; Scheffer v. Ins. Co., 25 Minn. 534; Schultz v. Ins. Co., 40 Ohio St. 217, 48 Am. Rep. 676 ; Connecticut Mut. L. Ins. Co. v. Groom, 86 Pa. St. 92, 27 Am. Rep. 689; Phadenhauer v. Ins. Co., 7 Heisk (Tenn.) 567, 19 Am. Rep. 623 and note; Mutual L. Ins. Co. v. Walden (Tex. Civ.) 26 S. WV. Rep. 1012.

3. Connecticut L. Ins. Co. v. Akens, 150 U. S. 468. $14 \mathrm{~s}$. Ct. 155.

4. Traveller's' Ins. Co. v. McKion. key, $12 \%$ U. S. 661, 667, 8 S. Ct. 1370; Home Ben. Asso. v. Sargent, 142 U. S. 691, 12 S. Ct. 332.

1. Scheffer v. Ins. Co., 25 Minn. 534; Eastabrook v. Ins. Co., 5t Me. 224, 89 Am. Dec. 743; Scarth v. Ins. Co., 75 Iowa, 346,39 N. W. 658. 
tionally with knowledge of its consequences, although unconscious of its criminal character. And the doctrinc of some of the States goes further and holds that the policy is void notwithstanding the self-destruction is accomplished at a time when the insured is wholly unconscious of the act. ${ }^{2}$

But it is held by some courts that the act of the insured must be voluntary and intentional, although he may at the time be incapable of discerning its moral quality. ${ }^{3}$ Of course where the death is accidental the death does not come within the clause. The clause was never intended to include death by accident, as by taking poison by mistake, the accidental discharge of a gun or pistol held in the hands of the insured. ${ }^{4}$ It generally means all suicidal acts, whether such are denominated as criminal, or such as arise from insanity, and as to the matter of proof, suicide itself and nothing more, is not sufficient to prove insanity. ${ }^{5}$

2. Streeter v. Life and Accident Soc., 65 Mich. 199, 31 N. W. 779; Salentine v. Ins. Co., 24 Fed. 159; Riley v. Ins. Co., 25 Fed. Rep. 315; Penfold v. Ins. Co., 85 N. Y. 317 , 39 Am. Rep. 660; Scarth v. Ins. Co., 75 Iowa, 346,39 N. W. 658; Billings v. Ins. Co., 64 Vt. 78, 24 A. 656,17 L. R. A. 89 and note, 33 Am. St. Rep. 913; DeGogorza v. Ins. Co., 65 N. Y. 232; Bigelow v. Ins. Co., 93 U. S. 284; Chapman v. Ins. Co., 6 Biss. C. C. 238; Dennis v. Ins. Co., 84 Cal. 570, 24 P. 120.

3. Sabin v. Nat. Union, 90 Mich. 177, 51 N. W. 202; Adkins v. Ins. Co., 70 Mo. 27, 35 Am. Rep. 410; Pierce v. Ins. Co., 34 Wis. 389; Suppiger v. Ins. Co., 20 Ill. App. 595 ; Mutual Ben. L. Ins. Co. v. Davies, 87 Ky. 54l, 9 S. W. 812; Northwestern Mut. L. Ins. Co. v. Hazelett, 105 Ind. 212, 4 N. E. 582, 55 Am. Rep. 192.

4. Michigan Mut. L. Ins. Co. v.
Naugle, 130 Ind. 79, 29 N. E. 393; Searth v. Ins. Co., 75 Iowa, 346, 39 N. W. 658 ; Billings v. Ins. Co., 64 Vt. 78,24 A. 656,17 L. R. A. 89 and note; Home Benefit Asso. v. Sargent, 142 U. S. 691, 12 S. Ct. 332; Pierce v. Ins. Co., 34 Wis. 389 ; Penfold v. Ins. Co., 85 N. Y. 317, 39 Am. Rep. 660; Northwestern Mut. L. Ins. Co. v. Hazelett, 105 Ind. 212, 4 N. E. 582, 55 Am. Rep. 192. See, also, Pollock v. Acci. Asso, 102 Pa. St. 230, 48 Am. Rep. 204.

5. Merritt v. Ins. Co., 55 Ga. 103; Mutual Benefit L. Ins. Co. v. Davies, 85 Ky. 54l, 9 S. W. 812; Blackstone v. Ins. Co., 74 Mich. $592,42 \mathrm{~N}$. W. 156 ; Weed v. Ins. Co., 70 N. Y. 561 ; Meacham v. Ins. Co., 120 N. Y. 237, 24 N. E. 283; Pendenlaaur v. Ins. Co., 7 Hiesk. (Tenn.) 567; linickerbocker Ins. Co. v. Peters, 42 Md. 414. 


\section{AR'TICLE II.}

\section{Ratification and Disaffirmance.}

Section 21. Affirmance and Avoidinee of Contracts.

22. Bona lide Purchaser from lnsane Person.

23. Return of Consilleration.

24. Bona Fide Grantee of the Grantee of the Lunatic-Rights of Third larties.

25. Relief in Equity.

§21. Affirmance and avoidance of contracts.- A deed made in proper form, executed and recorded, is equivalent to a feoffment with livery of seisin. ${ }^{1}$ Without the registry, where the delivery of the deed is accompanied by the surrender of the possession of the conveyed premises to the grantee, the effect would be the same, as to the conveyance by a man non compos mentis, as would result from a feoffment made by him. A deed of bargain and sale places the grantee upon the footing of a feoffment, as it passes the estate by the delivery of the land; such grants or deeds as take effect by delivery of the land being only voidable. ${ }^{2}$ Therefore, an insane man's deed is only roidabie and not roid, and may be ratified by him when he is of sane mind, whether the deed is recorded or not. ${ }^{3}$ So a person of full age, who has been insane may, after he has sufficiently recorered his reason to understand the character of his act, disaffirm his deed made by him while he was insane and incapable to contract, ${ }^{4}$ and he may proceed in a court of equity to rescind. ${ }^{5}$

1. Somes v. Brewer, 2 Piek. (Mass.) 197 ; Riley v. Carter, 76 Md. 581,25 A. 667,19 L. R. A. 489 and note, $37 \mathrm{Am}$. St. Rep. 443.

2. Somes v. Brewer, 2 Piek. (Mass.) 197.

3. Allis v. Billings, 6 Met. (Mass.) 415, $39 \mathrm{Am}$. Dee. 744 and note.

4. Tolson v. Garner, 15 Mo. 494 ; Farley v. Parker, 6 Oreg. 105, 25 Am. Rep. 504; Dexter v. Hall, 15
Wall. (U. S.) 20; Henry v. Fine, 23 Ark. 417 ; Betts v. Carroll, 6 Mo. App. 518; Schuff v. Rawson, 79 Ind. 458; Boyer v. Berryman, 123 Ind. 451,24 N. E. 249 ; Ashmead v. Reynolds, 127 Ind. $441, \mathbf{2} 6$ N. E. 80 ; Gibson v. Soper, 6 Gray (llass.) 279, 66 Am. Dec. 4l4; Burnham v. Kidwell, 113 Ill. 425; Tulner v. Rusk, 53 Md. 65.

5. Turner v. Rusk, 53 Md. 65. 
And an exchange of property made by a person of mind so iensane that the want of mental capacity is apparent to any one of ordinary prudence and observation eonversing with him, is roidable, and his guardian may reseind the deed. ${ }^{6}$ After the deatl of the insane person, his personal representatives or heirs may rescind. ${ }^{7}$ And this right to affirm or avoid is personal to the insane person and his legal representatives, and cannot be taken advantage of by the other party or by a third person. ${ }^{8}$ And ratification or avoidance may be by action, by express words or by suit. ${ }^{9} \quad \Lambda$ deed may be ratified by acts of acquiescence after the disability is removed; but the acts of confirmation to establish the deed, must show an intention to confirm it, and some courts say with knowledge of its eharacter and that it is voidable. ${ }^{10}$

In the absence of statutory provisions, a voidable deed may be ratified by long acquiescence, and by permitting the grantee to do acts by which his condition is changed, and which will prejudice him if the deed is set aside. The difference between a void and a voidable deed as defined in the law, is that the former eannot be ratified by aequiescence short of the statutory limitations, while the latter may be, by time and circumstance, within such limitations. ${ }^{11}$ Any distinct and decisive act of requisition as a valid and subsisting contract, is competent evi-

6. Allis v. Billings, 6 Met. (Mass.) 415, 39 Am. Dec. 744 and note; Halley v. Troester, 72 Mo. 73; Valpey v. Rea, 130 Mass. 384; McClain v. Davis, 77 Ind. 419.

7. Hovey v. Hobson, 53 Me. 451, $89 \mathrm{Am}$. Dec. 705 ; Schuif v. Rawson, 79 Ind. 458 ; Campbel] v. Kuhn, 45 Mich. 513, 8 N. 523, 40 Am. Rep. 479; Valpey v. Rea, 130 Míass. 384.

8. Allen v. Berryhill, 27 Iowa, 534, 1 Am. Rep. 309; Carrier v.
Sears, 4 Allen (Mass.) 336, 81 Am. Dec. 707 ; Compare Burke v. Allen, 29 N. H. 106, 61 Am. Dec. 642.

9. Ashmead v. Reynolds, 127 Ind. 441,26 N. E. 80 ; Gibson v. Soper, 6 Gray (Mass.) 283.

10. Eaton v. Eaton. 37 N. J. L. 108, 18 Am. Rep. 716; Tucker v. Moreland, 10 Pet. (U. S.) 64.

11. Eaton v. Eaton, 37 N. J. L. 108, 18 Am. Rep. 716. 
dence of ratification. A new delivery of a deer is not mentisite as it would be if the deed of an insane person wals void."

$\S 22$. Bona fide purchaser from insane person.- When the contract is executed it is held by many American courts, if not by a majority of them, that the insane party when of somel mind, niay aroid it, thongh it be fair and reasonable, and the other party acted in a bona fide numner, and the parties eamnot be placed in slatu quo. Because to say that an insane man, before he can aroid his deed, must put the grantee in statu quo, would be to say in effect in most cases that his deed shall not be avoided at all. The more insane the grantor was when the deed was made, the less likely will he be to retain the fruits of his bargain, so as to be able to make restitution. If he was so far demented as not to know or recollect what the bargain was, the difficulty will be still greater. This view of the case is certainly sound. ${ }^{1}$ Of course, all the courts agree where fraud is knowingly practiced upon the insane grantor that he may avoid without placing the grantee in statu quo.

In England, and by many of the American courts, it is held that where persons apparently of sound mind and not known to be otherwise, enter into a contract which is fair and bona fide,

12. Howe v. Howe, 99 Mass. 98. See, also, Campbell v. Kuhn, 45 Mich. 513, 8 N. 523, 40 Am. Rep. 479 ; Jones v. Evans, 7 Dana (Ky.) 96; Allis v. Billings, (; Met. (Mass.) 415, 39 Am. Dec. 744 and note; Gibson v. Soper, i Grily (Mass.) 279, 66 Am. Dec. 414.

1. Simonton v. Bacon, 49 Miss. 582 ; Brantley v. Wolf, 60 Miss. 420; Henry v. Fine, 23 Ark. 417; Gibson v. Soper, 6 Gray (Mass.) 279. 66 Am. Dee. 414; Ricketts v. Jolliff, 62 Miss. 440 ; Chew v. Bank, 14 Md. 315 ; Hovey v. Hobson. 53 Me. 453; Fitzgerald v. Reed, 9 Smedes \& M. (Miss.) 94; Crawford v. Scovell, 94 Pa. St. 48, 39 Am. Rep. 766 ; Somers v. Pumphrey, 24 1nd. 231; Flanders v. Davis, 19 N. H. 139; Chandler v. Simmons, 97 Mass. 508, 514, 93 Am. Dec. 117 and note; Brigham v. Fayer. weather, 144 Mass. 48, 10 N. E. 735 ; Rogers v. Blackwell, 49 Mieh. 19.2: Seaver v. Phelps, 11 Pick. (Mass.) 304, $22 \mathrm{Am}$. Dec. 372: Sullivan v. Flynn, 20 D. C. 396: Pearl v. MeDowell, 3 J. J. Marsh. (Ky.) 658, 20 Am. Dec. 199.

2. Schmidt v. Ittman, 46 La. Ann. Sss; Elder v. Sehumacher, 18 Colo. 433, 33 P. 175; Alexinder v. Haskins, 68 Iowa, 73,25 N. W. 93.5. 
and which is executed and completed, and the property, the subject-matter of the contract, camnot be restored so as to put the parties in statu quo, snch contract cannot be set aside either by the lunatic when he becomes sane or those who represent him. ${ }^{3}$ This doetrine is antagonistic to that held as to infants when avoiding their eontracts where they have not the power to restore the property received. The reason of this distinction is not based upon any solid foundation.

Some courts hold that if the insane party has received no benefit from the contract he can rescind, notwithstanding the good faith of the other party, but if he has received the ordinary benefits of such a contract, he is bound. ${ }^{4}$

$\S$ 23. Return of consideration.-As seen in the preceding section, the law in England and in many of the States, is an insane man on becoming sane cannot avoid his contracts unless he returns the consideration, thus putting the parties in statu quo, provided the other party acted in good faith.

But another line of authorities in the United States holds with much reason, that lunatics are not bound by their contracts no more than infants, though no fraud or imposition has been

3. Yanger v. Skinner, I MeCart. (N. J. Ch.) 389 ; Molton v. Camroux, 2 Exch. 487, 4 Exch. 17; Addison v. Dawson, 2 Vern. 678; Price v. Berrington, 3 Macn. \& G. 486; Myers v. Knabe, 51 Kans. 720, 33 P. 602; Eaton v. Eaton, 37 N. J. L. 108, 18 Am. Rep. 716; Reggan v. Green, 80 N. Car. 236, 30 Am. Rep. 77 ; Lancaster Co. Bank v. Moore, 78 Pa. St. 407, 21 Am. Rep. 24 and note; McCormick v. Littler, 85 Ill. 62; Mutual Life Ins. Co. v. Hunt, 79 N. Y. 541 ; Boyer v. Berryman, 123 Ind. 451, 24 N. E. 249 ; Gribben v. Maxwell, 34 Kans. 8, 55 Am. Rep. 233; Leavitt v. Files, 38 Kans. 26, 7 P. 584; Scanlon v. Cobb, 84
Ill. 104; Carr v. Halliday, 5 Ired. (N. Car.) 67 ; Young v. Stevens, 48 N. H. 136; Schaps v. Lehner, 54 Minn. 208, 55 N. W. 911; Shoulters v. Allen, 51 Mich. 529,16 N. W. 888; Abbott v. Creal, 56 Iowa, 175, 9 N. 115; Northwestern Ins. Co. v. Blankenship, 94 Ind. 535, $48 \mathrm{Am}$. Rep. 185; Asheraft v. De Armond, 44 Iowa, 229; Rusk v. Fenton, 14 Bush. (Ky.) 490, 29 Am. Rep. 413; Sewing Mach. Co. v. Barnard, 43 Mich. 379, 5 N. 411; Copenrath v. Kienly, 83 Ind. 18.

4. Van Patton v. Beals, 46 Iowa, 63; Lincoln v. Buckmaster, 32 Vt. 658. 
practiced upon them, even though the eonsideration cannot be returned. ${ }^{1}$

And so an insane person or his guardian may avoid a deed which was made while the grantor was insane, withont first restoring the consideration to the grantee, the deed not having been ratified. ${ }^{2}$ Aecordingly if the party wishes to avoid his contract, he need not restore the consideration of an exeentory eontract and the party has the notes which were given for the consideration, then, in that case, he must restore the notes upon disaffirmance of the contract. ${ }^{3}$ These cases place the acts of lunaties and infants upon the same ground as to ratification and avoidance, ${ }^{4}$ because the grants of infants and persons non compos mentis are parallel both in law and reason. ${ }^{5}$ And, hence, if the consideration was squandered during insanity, he can disaffirm his contract when restored to sanity and not return the consideration. ${ }^{*}$

$\S 24$. Bona fide grantee of the grantee of the lunatic Rights of third parties. - A grantee of the grantee of the insane party cannot demand the restoration of the consideration when the deed of the first grantor is disaffirmed. ${ }^{7}$ The last grantee must rely on the covenants of his deed for restitution, and it is not necessary that he shall be placed in statu quo by the first grantor when the deed is disaffirmed. It is said that the right of an insane person to avoid his contracts is an absolute and paramount right, superior to all equities of other

1. Chew v. Bank, 14 Md. 318; Hovey v. Hobson, 53 Me. 451, 89 Am. Dec. 705.

2. Gibson v. Soper, 6 Gray (Mass.), 279, 66 Am. Dec. 414; Arnold v. Richmond Iron Works, 1 Gray (Mass.), 434; Hovey v. Hobson, 53 Me. 451, 89 Am. Dec. 705.

3. Arnold v. Richmond 1 ron Works, l Gray (Mass.), 434.

4. Key v. Davis, 1 Md. 32.
5. Thompson v. Leach, 3 Mod. 310.

6. Rea v. Bishop, 41 Neb. 202, 59 N. IV. 555; Ricketts v. Jolliffe, 62 Miss. 440; Brigham v. Fayerweather, 144 Mass. 48, 10 N. E. 735: Crawford v. Scovell, $94 \mathrm{~Pa}$. St. 48, $39 \mathrm{Am}$. Rep. 766 ; Sullivan $\nabla$. Flynn, 20 D. C. 396.

7. Dewey v. Allgire. 37 Neb. 6. 55 N. W. 276, 40 Am. St. Rep. 468. 
persons, and may be exercised against bona fide purchasers from the grantec of the insane. ${ }^{8}$

And this rule applies to all third parties who cannot acquire a valid title to property though they purchase without notice of the infirmity of the party through whom they trace their title. ${ }^{9}$ Hence, an accommodation indorser who indorses when insane, is not liable on the note and can avoid it. ${ }^{10}$

But this rule is not accepted in North Carolina. In this State a purchaser for value and without notice from one who had acquired by fraudulent device a conveyance, regular in form and sufficient upon its face to pass title, obtains a good title, though the deed might have been adjudged void against the first grantor. ${ }^{11}$

The North Carolina court puts this decision upon the ground of fraud; that is, a deed taken from an insane man is a fraud, and while it may be avoided as to the first grantee, it cannot be avoided as to the grantee of the grantee who is a bona fide purchaser. But this reasoning is contrary to all other authority as to insane person's deeds and conveyance.

§ 25. Relief in equity.- A party dealing with an insane man in good faith cannot go into a court of equity for redress unless the infirmity of the former lunatic is made an instrument of frand; this is the general rule. So courts of equity in many States will not interfere to set aside the contracts of lunatics which have been executed, and where it is impracticable to restore the parties to their condition before the contract, unless the party contracting with the lunatic obtained an unjust ad-

8. Hovey v. Hobson, 53 Me. 451, 458, 89 Am. Dec. 705; Compare Odom v. Riddick, 104 N. Car. 515, 10 S. E. 609,7 L. R. A. 118,17 Am. St. Rep. 686.

9. Rogers v. Blackwell, 49 Mich. 192, 13 N. 512; Dewey v. Allgire, 37 Neb. 6, 55 N. IV. 276, 40 Am. St. Rep. 468; Hovey v. Hobson, 53 Me. 451, 89 Am. Dec. 705; Hull v.
Louth, 109 Ind. 315,10 N. E. 270 , 58 Am. Dec. 405.

10. Wirebach v. Bank, 97 Pa. St. 543, 39 Am. Rep. 821. See, also, Moore v. Hershey, 90 Pa. St. 196; MeClain v. Davis, 77 Ind. 419.

11. Odom v. Riddick, 104 N. Car. 515,10 S. E. 609,7 L. R. A. 118, 17 Am. St. Rep. 686. 
vantage in the contract, or knew of the infirmity, becanse it is impracticable of doing full justice nuder the circumstances, and the parties are left to their legal status." But in many States equity courts will aroid the contract whether the partics are plaeed in statu quo or not.

In England and in many of the States, courts of equity will not interfere to annul the contraets of hmatics, made with those who had no reason to believe them such at the time the contraets were made and have been fully executed, upon both sides, and the parties cannot be placed in statu quo. Under this doetrine a person of apparently somnd mind and not known to be otherwise, enters into a contract, which is fair and bona fide, and which is executed and completed, and the property, the subject-matter of the contract, has been paid for and fully enjoyed and cannot be restored, such contract cannot be set aside at law or in equity. ${ }^{3}$

Where the consideration of a deed is not the question at issue, and the grantor, a weak minded person, is misinformed as to the legal effect of the deed, it cannot be avoided in a court of law, but a court of equity will eorrect or reform the deed. ${ }^{*}$ Where the law will permit the insane person to avoid his contract, equity will set it aside at the suit of the grantor on attaining sanity, or at the suit of his guardian, executor, administrator, or heirs $;^{5}$ but a stranger cannot avoid an insane man's deed or contract. ${ }^{6}$

1. Elliot v. Ince, 7 DeG. M. \& G. 474 ; Price v. Berrington, 3 Macn. \& G. 498; Selby v. Jaekson, 6 Beav. 192 ; Niell v. Morley, 9 Ves. 478.

2. Segeson v. Leaky, 2 Atk. 4 r2.

3. Nolton v. Comroux, 2 Exch. $486,+$ Exch. I7; Yanger v. Skinner, I Nacarter (N. J. Ch.) 389.

4. Eaton v. Eaton, 37 N. J. L. 108, 18 Am. Rep. 716. See, also, Turner v. Rusk, 53 Md. 65; Long v. Fox, 100 Ill. 43; Riggan v. Green, 80 N. Car. 239.

5. Carew v. Johnston, 2 Sch. \& Lef. 280; Fecel v. Gumault, 32 La.

Am. 91; Kerwin v. Ins. Co., 25 Fed. Rep. 692; Miskey's Appeal, 107 Pa. St. 611; Hunt v. WVier, 4 Dana (Ky.) 34 7 ; Julge v. Stone, 44 N. H. 593; Burnham v. Kidwell, 113 Ill. 425; Gribben v. Maxwell, 34 Kan. 8, 7 P. 584, 55 Am. Rep. 233; Key v. Davis, 1 Md. 32; Campbell v. Kuhn, 45 Mich. 513, 8 N. 523, 40 Am. Rep. 475.

6. Ingraham v. Baldwin, $9 \mathrm{~N} . \mathrm{H}$. 45; Kilbce v. Myrick, 12 Fla. 4I9; Compare Valpey v. Rea, 130 Mass. 384. 


\section{CHAPTER III.}

\section{Infants.}

\section{ARTICLE I. \\ Capacity to Contract.}

SEction 26. Contracts are Voidable, Void or Valid.

27. Distinetion Between Infant's Contracts as Voidable and Void is not Sound.

28. Void Contracts of Infants.

29. Emancipation by Parents.

30. Valid Contracts-Legal Obligations.

31. Marriage by Infant.

32. Infant Wife.

33. Bastardy.

34. Notes Given for Torts.

35. Recognizance.

36. Enlistment in the Army.

37. Partition.

38. Shopping-Purchase of Goods.

39. Contract for Necessaries.

40. Things Necessary-Definition.

41. Things Not Necessary.

42. Repairs on Real Estate.

43. Things Necessary.

44. In Business.

45. When an Infant Lives at Home With His Father.

46. Cardinal Tenets.

47. Support of Family.

48. Payment of Minor's Debts by Another.

49. Value of the Article Sold.

50. Mixed Question of Law and Fact.

$\$ 26$. Contracts are voidable, void or valid.-At common law an infant is a person under twenty-one years of age. Under the statute women become of age at eighteen in Arkansas, California, Colorado, Idaho, Illinois, Iowa, Kansas, Minnesota, Mis- 
souri, Montana, Nebraska, Nevada, New Mexico Territory, North Dakota, Oklahoma Territory, Oregon (or as soon as married), Sonth Dakota, Texas (if married, otherwise twenty-one), Utah, Vermont, Washington, and Wiseonsin (if married, otherwise at twenty-one). The law of Oregon applies to Alaska District. In Alabama, Arkansas, Georgia, Kansas, Louisiana, Mississippi, and Texas, all minors under certain eircumstances may be declared by decree of court, of age, for the purpose of dealing with their property and the right to contract as adults, provided they are eapable of attending to their own business. ${ }^{1}$ But such statutory provisions can have no extra-territorial effect. $^{2}$

Under the general rule their contracts are voidable or valid. ${ }^{3}$ Still there are some older cases and a few modern that take the old decision and divide an infant's contracts into void, voidable and valid. ${ }^{4}$ That is, 1 , where the contract is prejudicial to the infant, it is void; 2 , where the contract is uncertain as to the benefit or prejudice it is voidable; 3 , where the contract is for the benefit of the infant, as for neeessaries, it is valid. ${ }^{\mathbf{5}}$ This rule, modified so as to declare that the contract necessarily prejudicial to the infant is void, has been adopted in some of

1. See Doles v. Hilton, 48 Ark. 305,3 S. W. 393 ; MeKaney $\mathbf{~}$. Cooper, 81 Ga. 679,8 S. E. 312 ; Succession of Gaines, 42 La. Ann. 699, 7 So. 788; Brown v. Wheelock, 75 Tex. 385, 12 S. W. 111, 841 ; Cox v. Johnson, 80 Ala. 22; Cooper v. Rhodes, 30 La. Ann. 533.

2. State v. Bunce, 65 Mo. 349.

3. Wharton on Cont., 36 ; Anson on Cont., 105; Addison on Cont., 295; Shipley v. Bunn, 125 Mo. 143, 28 S. W. 754 ; Pollock on Cont., 52; Lemmon v. Beeman, 45 Ohio St. 505, 15 N. E. 476; Thompson v. Strickland, 52 Miss. 574; Sparman v. Keim, 83 N. Y. 245; Skinner v. Plaisted, 43 N. H. 413 ; Allen v. Poole, 54 Miss. 323; Kendrick v.
Niesz, 17 Colo. 506, 30 P. 215; Scranton v. Stewart, 52 Ind. 68; Ill. Land, etc., Co. v. Bonner, 75 Ill. 315; Bozeman v. Browning, 31 Ark. 364; Mustard v. Wahlford, 15 Grat. (Va.) 329, 79 Am. Dec. 209; Patchin v. Cromack, $13 \mathrm{Vt} .330$; Flower v. Railroad Co. (1894), 2 Q. B. 65 ; Holmes v. Rice, 45 Mich. 142, $7 \mathrm{~N}$. 772 ; Weaver v. Jones, 24 Ala. 420; Irvine v. Irvine, 9 Wall. (U. S.) 617.

4. Robinson v. Coulter, 90 Tenn. 705, Is S. W. 250, 25 Am. St. Rep. 708; Robertson v. Weeks, 56 Me. 102; Green v. Willing, 59 Iowa, 679, 13 N. W. 761, 44 Am. Rep. 696.

5. Reare v. Boycott, 2 H. Bl. 511 . 
the earlier cases and in a few modern. But the great weight of authority repudiates the distinotion between void and voidable contracts, on account of their beneficial or prejudicial nature, and holds all to be voidable, ${ }^{6}$ except under a few conditions.

The privilege of infancy is given to protect the infant from his indiscretion and the imposition of adults. As a result he has the immunity from liability until such contracts are ratified by him on becoming of age. Upon arriving at age he is competent to ratify his contract made in infancy, whether beneficial or prejudicial. Being of full age, with full capacity, to contract, he has a right to ratify or avoid such contract; he has as much right to do that, as he has to make a new contract. A person sui juris is as strongly obligated by his contracts prejudicial as by those beneficial, and the same principle applies where a person sui juris ratifies and confims his contract made in infancy. This is the true doctrine, and the contrary is not supported by reason or by the weight of authority. In England many contracts of infants have been declared void by statute. The disability of infancy is not of the character of other non sui juris persons. An infant is compos mentis, has a sane mind, and, therefore, his disability is simply a privilege which he can exercise. In other words, he has the privilege of avoiding his contracts under most cireumstances. He is not disabled by an unsound mind, and his contracts should be held void only when such contracts, if made by persons sui juris, would also be void. His contracts are voidable. In other words he has the privilege of avoiding his contracts.

$\S 27$. Distinction between infant's contracts as voidable and void.-If the decisions are investigated it will be found that all

6. Lemmon v. Beeman, 45 Ohio St. 505,15 N. E. 476 ; Harner v. Dipple, 31 Ohio St. 72, 27 Am. Rep. 496.

7. $37 \& 38$ Vict., ch. 62 . As to the construction of 37 and 38 vict., c. 82, sec. 2, Infant's Relief Act of 1874, see Coxhead v. Mullis, 3 C. P. D. 439: Ditchman v. Worall, 5 C. P. D. 410 ; Dublin, etc., Railway Co. v. Black, 8 Exch. 181. 
simple, and nearly all sealed, contracts by infants, which are not founded upon an illegal consideration, are voidable and not void, and may be ratified by the infant on coming of age. Such contracts remain a legal substratum for future assent, or disaffirmance; and if, instead of avoiding, he confirms them, when he has legal capacity to make a contract, they are in all respects, like his contracts made after he is twenty-one. Of conrse in some cases he may make a valid contract, but all other simple contracts, executed or executory, and nearly all sealed contracts, are voidable or confirmable by him at his election, on arriving at majority. His rights are fully protected by conferring on him the power to aroid his contracts, or, in other words, by giving him immunity from liability until such contracts are ratified by him, after arriving at full age. ${ }^{1}$ Henee, his contracts of suretyship are merely voidable $;^{2}$ so also an account stated $;^{3}$ a conveyance by lease and release $;^{4}$ a deed $;^{5}$ a mortgage ;" a

1. Harner v. Dipple, 31 Ohio St. 72, 27 Am. Rep. 496,

2. Cole v. Pennoyer, 14 Ill. 158; Cummings v. Powell, S Tex. 80; Mustardv. Wahlford, 15 Grat. (Va.) 329, 76 Am. Dec. 209; Owen v. Long, 112 Mass. 103; Reed v. Lane, 61 Vt. 481, 17 A. 796; Patchin v. Cromack, 13 Vt. 330; Curtin v. Patton, 11 Serg. \& R. (Pa.) 305; Vaughn v. Dorr, 20 Ark. 600; Willianss v. Harrison, 11 S. Car. 412; Fetrow r. Wiseman, 40 Ind. 148; Scott v. Buchanan, 2 Humph. (Tenn.) 468; Fonda v. Van IIorne, 15 Wend. (N. Y.) 631; Williams v. Moore, 11 Mees. \& Wel. 256; Shropshire v. Burns, 46 Ala. 108; Harner v. Dipple, 31 Ohio St. 72,27 Am. Rep. 496.

3. Williams v. Moore, 11 Mces. \& Wel. 256.

4. Zouch v. Parsons, 3 Burr. 1794: Grifith v. Schwendenman, 27 Mo. 412.
5. Kendall v. Lawrence, 22 Pick. (Mass.) 540; Zouch v. Parsons, 3 Burr. 1794, 1805; Amer. Mort. Co. v. Wright, 101 Ala. 658, 14 So. 399 ; Sharp v. Robinson, 7 (i Ala. 343.

6. Salinas $r$. Bennett, 33 S. Car. 255; Barney v. Rutledge, 104 Mich. 289, 62 N. W. 369); Logan v. (Aardner, $136 \mathrm{~Pa}$. St. 58s, 30 A. 625, 20 Am. St. Rep. 939; French r. McAndrew, 61 Niss. 187; Henry v. loot, 33 N. Y. 526, 5.53: Keichen v. Lee, 11 Paige (N. X.), 107, 42 Am. Dee. 101; Robbins v. Eaton, 10 N. II. 561; Batger v. Phinney. 15 Mass. 359, \& Anı. Dec. 105; Callis v. Day". 38 Wis. 643: Dixon v. Merritt, 21 Minn. 196; Manning v. Johmson, 26 Ala. 446, 62 $\mathrm{Am}$. Dec. 732 and note; Irvine $r$. Irvine, 9 Wall. (U. S.) 617: Skimner $v$. Maxwell, 66 N. Car. 45. 
promissory note $;^{7}$ an indorsement of promissory note $;^{8}$ agreement to pay interest; ${ }^{9}$ honds with a penalty $;^{10}$ other bonds $;^{11}$ conveyances $;^{12}$ exehange of property $;^{13}$ eompromise ${ }^{14}$ stock contraets ${ }^{15}$ settlement of boundary between two premises ${ }^{16}$ agreements to render service $;^{17}$ appointment of agent $;^{18}$ gifts $;^{19}$ an appeal from a justice's decision $;^{20}$ judgments against him $;^{21}$ agreement to eonvey; ${ }^{22}$ his covenant to carry and deliver money $;^{23}$ his marriage settlement $;^{24}$ his partnership agreement. ${ }^{25}$

7. Boody v. MeKenney, 23 Me. 517 ; Minock v. Shortridge, 21 Mich. 304; State v. Plaisted, 43 N. H. 413; Baldwin v. Van Deusen, 37 N. Y. 487 ; Earle v. Reed, 10 Met. (Mass.) 389 ; Fetrow v. Wiseman, 40 Ind. 148.

8. Nightingale v. Withington, 15 Mass. 272; Frazier v. Massey, 14 Ind. 382; Briggs v. MeCabe, 27 Ind. $327,89 \mathrm{Am}$. Dec. 563; Willis v. Twombley, 13 Mass. 204.

9. Bradley v. Pratt, 23 Vt. 378; Compare Fisher v. Mowbray, 8 East, 330.

10. Karcher v. Green, 8 Houst. (Del.) 163; Weaver v. Jones, 24 Ala. 420; Mustard v. Wahlford, 15 Gratt. (Va.) 329, $76 \mathrm{Am}$. Dee. 209.

11. Conroe v. Birdsall, l John. Cas. (N. Y.) 127, 1 Am. Dec. 105; Blake v. Supervisors, 61 Barb. (N. Y.) 149 ; Patehin v. Cromaeh, 13 Vt. 330 .

12. Davis v. Dudley, 70 Me. 236 , 35 Am. Rep. 318; Allen v. Poole, 54 Miss. 323; Schatier v. Lorsette, 57 Ala. 14; Illinois Land Co. v. Bonner, 75 11l. 315; Tunison v. Chamblin, 88 Ill. 37s; Logan v. Gardner, 136 Pa. St. 588, 30 A. 625,20 Am. St. Rep. 939; French v. McAndrew, 61 Miss. 187.

13. Williams v. Brown, $34 \mathrm{Me}$. 594.
14. Baker v. Lovett, 6 Mass. 78, 4 Am. Dec. S8; Barnaby v. Barnaby, 1 Pick. (Mass.) 221; Ware v. Cartledge, 24 Ala. 622, 60 Am. Dee. 489.

15. Robinson v. Weeks, 56 Me. 102 ; Indianapolis Chair Co. v. Wilcox, 59 Ind. 42 !

16. Brown v. Caldwell, 10 Serg. \& R. (Pa.) 114, 13 Am. Dec. 660.

17. Clark v. Goddard, : Ala. 164, 84 Am. Dec. 777; Vent v. Ossood, 19 Pick. (Mass.) 572.

18. Voglesang v. Null, 67 Tex. 465,3 S. IV. 451 ; Ferguson v. Railroat Co., 73 Tex. 34t, 11 S. W. 347; Towle v. Dresser, 73 Me. 252 ; Compare Ware v. Cartledge, 24 Ala. 622, 60 Am. Dec. 489.

19. Person v. Chase, 37 Vt. 647, s8 Am. Dec. 630; Oxley v. Tryon, 25 Iowa, 95.

20. Robbins v. Cutler, $26 \mathrm{~N} . \mathrm{H}$. 173.

21. England v. Garner, $90 \mathrm{~N}$. Car. 197; Trapnall v. Bank, 18 Ark. 53.

22. Carrell v. Potter, 23 Mich. 377.

23. West v. Penny, 16 Ala. 186.

24. Whichcote v. Lyle, 28 Pa. St. 73 .

25. Jacques v. Sax, 39 Iowa, 367 ; Dunton v. Brown, 31 Mich. 182. 
$\S$ 28. Void contracts of infants. - The general foetrine has

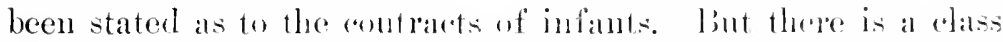
of contracts of infants which are held absolutely void. All contracts, it is said, which take offee the delivery of the infant himself are voilable and not void; it is only stech acts as lalke offect by the delivery of another for the infant that are alsolutely? void. ${ }^{1}$

So a minor's walrant to confess judgunent is absolntely void. ${ }^{2}$ And likewise jurisoliction camot be conferred npon a court by a warrant of attorney, executed hy a minor authorizing the entry of his appearance and confession of jumpunent. So an appointment of an attorney by an infant is absolutely void. ${ }^{3}$

So where a minor purchases property which is not a necessity and gives a judgment note, or a note with a warrant of attorner attached thereto, to confess judgment, the note is only voidable, but the warrant of attorney to confess the judgment is absolutely void. ${ }^{4}$ And it has also been held that a power of attorney to sell lands is voill." This is about the extent of roid contracts made by infints, and the doctrine of the old cases has been ignored and is no longer the law, and the practitioner should not be led astray. The decisions of to-day do not hold infants' contracts roid except those cases of the technical "warrant of attorner," to appear in court to bind the infant, and perhaps a "power of attorner."

A decision of the L'nited States Supreme Court has attracted a great deal of attention, ${ }^{6}$ which apparently holds that an infant's

1. Zouch v. Parsons, 3 Burr. 1794; Dexter v. Hall, 15 Wall. (U. S.) 9,25 .

2. Fuqua r. Sholem, 60 Ill. App. 140; Cole v. Pennoyer, 14 III. 158; Benmett $r$ Daris, 6 Cow. (N. Y.) 393; Knox v. Flack, 22 Pa. St. 337; Lawrence v. IcArter, 10 Ohio, 3s; Pyle v. Cravens, 4 Litt. (Ky.) 17; Tucker r. Morehead, 10 Pet. (U. S.) 58 .

3. Cole v. Pennoyer, 14 IIl. 158.
4. Fuqua v. Sholem, 60 Ill. App. 140; Compare Morton v. Steward, . Ill. App. 533.

5. Philpot v. Bingham, 55 Ala. 435: Compare Weaver v. Carpenter, 4. Iowa, 343; Armitage r. Widoe, (i) Mich. 124.

6. MacGreal $r$. Taylor, 167 U. S. 6ss, 17 S. Ct. 961. See, also, Morton v. Stewarl, 5 1ll. App. 533, as to the infant's rights, when note is in the hands of an innocent holder for value. 
contract is voidable only, unless it appears upon its face to be to his prejudice, in which ease it may be void. It is apparent that the reporter made a mistake in his head-notes. If the case is read with close attention, it will be found that no such doe trine was announced as incident to principles involved in the question under discussion. The justice, in his argument, ealled attention to some old eases that held sueh doctrine. And if the language can be construed as announeing such doctrine, it is certainly dictum, and, of course was not relative to the case under decision.

§ 29. Emancipation by parents.-Minor's may be emancipated from parental control by mutual consent. In common language, an infant is given his time by his parents, and then whatever he earus belongs to him, and not to his father, and if his father is dead, his mother cannot lay any valid claim to such ineome from his labor. But such emaneipation does not make him capable of contracting; it simply places lim outside of his parental eontrol, and he can avoid his contracts the same as if he had not been given his time. ${ }^{1}$ And so the question of the emaneipation of a minor at the time he executed a note, is irrelevant to the issue in a suit on the note, as it cannot affect his liability thereon. He can avoid such note notwithstanding his emancipation. $^{2}$ By emancipation the infant receives his wages, and the father has no right to demand them either from the employer or the child. Such an agreement may be inferred from circumstances. The emancipation is a relinquishment by the father of the right to the child's services, and an authorization to employers of the infant to pay him his wages as if of full age. It does not make the infant liable on his contracts as an adult. ${ }^{3}$

1. Mason v. Wright, 13 Met. (Mass.) 306.

2. Tyler v. Gallop, 68 Mich. 185, 35 N. W. 902, 13 Am. st. Rep. 336. See, also, Generaux v. Sibley, is R. I. 42,25 A. 345 .
3. Mason v. Wright, 13 Met. (Mass.) 306; Tyler v. Gallop, 68 Mich. 185, 35 N. W. 902, 13 Am. St. Rep. 336; Tayler v. Hill, 115 Cal. 143, 44 P. 336, 46 P. 922. 
Though the act of emancipation is not legal, ret a stranger cannot set up its illegality to defeat a minor's right to sue.

The marriage of an infaut with his parent's consent emaneipates lim; still if the infant's marriage be legal, even in defiance of the parent's consent, the child locomes emancipated, and the parent's right and control must yield to the new status of the child. ${ }^{5}$

\&3. Valid contracts - Legal obligations.- In infant is under legal obligations to provide for the support of his wife and children, and is answerable on his contracts for necessaries furnished them. ${ }^{6}$ And so if an infant's contract is in discharge of an obligation which he is by law, either general or statutory, bound to perform, it is valid. A contrary rule would only serve the purpose of fraud and injustice. ${ }^{\top}$ In infant may assign his property in compliance with the statute, and such assignment is valid, because he is bound by all actions which, by law, he is obliged to do $;^{8}$ thus, he must pay taxes levied on his land. ${ }^{9}$

$\S$ 3. Marriage by infant.- The statute designates the age of consent that an infant may marry. All marriage agreements made when the infant has arrived at the age of consent are

4. Munday v. Kaufman, 48 La. Ann. 591, 19 So. 753.

5. Aldrich v. Bennett, $63 \mathrm{~N}$. H. 415, 56 Am. Rep. 529; Commonwealth v. Graham, 157 Mass. 73, 31 N. E. 706,16 L. R. A. $57 \mathrm{~s}$ and note, 34 Am. St. Rep. 255; Sherburne v. Hartland. 37 Vt. 52s: Compare White v. Henry. 24 Me. 531.

6. Chapman $v$. Hughes, 61 Mis:. 339: Price v. Sanders, 60 Ind. 315: Gilley ง. Gilley, 79 Мe. 292, 9 A. 623, 1 Am. St. Rep. 307; Turner v. Frisby, 1 Strange. 168; Compare Kelly $\vee$ Davis, 49 N. 1I. 176, 6 Am. Rep. 486 and note.

7. People r. Moores at Denio (X.
Y.), 518, 47 Am. Dec. 272; Bavington v. Clarke, 2 Pen. \& IV. (Pa.) 115, $21 \mathrm{Am}$. Dec. 432; Stowers v. Hollis, $83 \mathrm{Ky} .544$.

8. People v. Mullin, 2.; Wend. (N. Y.) 698 ; United States v. Bainhidge, 1 Mason, C. C. S3; Winslow v. Anderson, 4 Mass. 3i. See, also, Elliott v. Horn, 10 Ala. $34 \mathrm{~S}, 44 \mathrm{Am}$. Dee. 488; Alexinder r. Wright, 20 Oliio St. 97 ; Nordholt $v$. Nordholt, 87 Cal. 552, 26 P. 599, $22 \mathrm{Am}$. St. liep. 268; Prouty v. Edgar, 6 Iowa, 353; Trader v. Jarvis, 23 W. Va. 100.

3. Horstmeyer v. Conners, 56 Mo. App. 115. 
valid ${ }^{1}$ but those made before the age of consent are voidable. And the better mle is that parties marrying befere the age of consent may disaffirm the contract during non-age and it is the: roid in toto." In some of the States a marriage eontract before age of comsent is declared roid; this is the law of $\Lambda$ rkansas, and Texas; and after judicial decree in New Mexico. In the following States marriages before age of consent are declared voidable, and may be amended on petition or suit from the date of the deeree: Arkansas, California, Indiana, Minnesota, Nevada, New York, Oregon, Vermont, West Virginia, and Wiseonsin; and such marriages may be anmulled by the injured party in Idaho, Iowa and Washington, and withont restrictions in Michigan. Marriage before age of consent may be declared void when the parties separate during non-age, and do not cohabit thereafter in the following States: Arizona Territory, Massachusetts, Michigan, North Carolina, and Virginia.

In Vermont the age of legal consent is the period of disability determined by the common law. ${ }^{3}$ In ITisconsin a marriage of parties incapable of consenting is roidable. ${ }^{4}$

\$32. Infant wife.- A married woman is incapable of performing any act of affirmance in any other mamner than in the mode provided ly statute for the converance of real estate. ${ }^{5}$ Hence, she cannot, after attaining the age of majority, affirm her deed while she was an infant feme covert by an instrument which is not executed in conformity to the statntes regulating the conveyance of land br married women. ${ }^{6}$

When the disabilities of infaney and eoverture concur at the time of the execution of a deed or mortgage, then the right to disaffirm continues mutil both disabilities are removed, without regard to the length of time which may elapse between the date

1. Frost v. Vaught, 37 Mich. 65 .

2. Tyler on Inf., 81.

3. Fisher v. Bernard, $65 \mathrm{Vt}$. 663, 27 A. 316.

4. State v. Cone, 86 Wis. $498,5 \pi$
N. W. 50; Compare Shafher v. State, 20 Ohio, 1.

5. Natherson v. Davis, ¿2 Cold. (Temm.) 443.

6. Walton v. Gaines, 94 Tenn. 420, 29 S. IV. 458. 
of the instrument and the freenge the grantor from these disabilities. but the disability of enerture dees mot prechule a married woman from affirming a covenant entered into hy her while single and an infint. ${ }^{\circ}$

§ 33. Bastardy.- An infant who is the putative father of an illegitimate child, may make a ralid contract to support such child when he acknowledges the paternity of it. Thus, an infant accused by the mother of a bastard child of being the father of such child, may admit his lialility and bind himself by contract to support the child.9 'The statute makes no distinction between adults and infants as to the liability for the support of illegitimate children. The eontract of a minor to pay for the support of particular illegitimate children is binding as being for necessities. ${ }^{10}$

$\S 34$. Notes given for torts. - Notes given in settlenient of torts by the infant are valid. The law makes infants liable for their torts. Hence, when an infant eleets to settle such liability by giving his note, so long as the ennsideration of the note is open to inquiry, he may be held liable upon the note to the same extent that he would be for an action brought upon the cause of action which formed the consideration of the note. ${ }^{1}$ Such contracts that are valid are none the less so, because in the form of a note or bill. ${ }^{2}$

7. Scott v. Bnehanan, 11 Humph. (Tenn.) 467; Dodd v. Bertlial, 4 Heisk. (Temn.) 609: Walton v. Gaines, 94 Tenn. 420, 29 S. W. 458.

8. In re Hodson's Settlement, (1894), 2 Ch. 421: Williams v. Knight (1894). 2 Ch. 421 ; Wilder v. Pigot, 2.2 Ch. Div. 263; Greenhill v. Ins. Co., 3 Reports, 674 .

9. Stowers v. llollis. 83 Ky. 544. 10. Swift v. Bennett, 10 Cush. (Mass.) 463; Turner v. Frisby, 1 Strange, 16s; Chapple r. Cooper, 13 Mees. \& Wel. 252; McCall v.
Parker, 13 Mlet. (Mans.) 372, 46 Am. Dec. 735; Bordentown v. Wallace, 50 N. J. L. 13, 11 A. 267; People v. Moores, 4 Denio (N. Y.) j1s, 47 An. Dec. 272 ; Gavin r. Burton. 8 Ind. 69.

1. Ray v. Tubbs, 50 Vt. $68 s, 28$ Am. Rep. 519.

2. Bradley v. Pratt, 23 Vt. 378 ; Stone v. Dennison, 13 Pick. (Mass.) 1. 23 Am. Rep. 6.5t; Earle v. Reed, 10 Met. (Milss.) 38i; Conn v. Coburn, 7 N. H. 368, $26 \mathrm{Am}$. Dec. 746 ; Elwell v. Martin, 32 Vt. 277. See 35 Cent. L. Jour., 203. 
$\S 35$. Recognizance.- In infant is capal)le of binding himself by any obligation which the law requires or anthorizes him to contract. ${ }^{1}$ IIence, a recognizance given by him is binding upon him. ${ }^{2}$ So his recognizance to appear in cont is binding "1pon him as if he was an adult. ${ }^{3}$ IJe is not only bound by his recognizance but by other bouls or obligations required by law. Whenerer he is bound by law to do an act or to bind himself by recognizance, his contraet is valid and he cannot avoid it. When he is to do that whieh the law binds him to do, he camnot avoid his contract and is bound as if of age. But lis bond whieh the law does not require him to give is voidable.

$\S 36$. Enlistment in the army.-- The statute of the United States provides for the enlistment of soldiers, and the age designated will be the age which will bind an enlisted soldier. The statute $^{6}$ anthorizes the enlistment of men above the age of sixteen years, and provides that no person under the age of twenty-one years shall be mustered into military service without the written consent of his parents or guardians. Under this statute, a contract of enlistment entered into by a minor, over sixteen years of age, without the consent or knowledge of his parents, cannot be avoided by the minor himself, but only by his parents, who may elaim the eustody of the minor before majority. ${ }^{7}$

§ 37. Partition.- Partition proceedings may be legal though one of the tenants in common is a minor. And a court of equity ean order land to be sold for partition among general tenants in common, some of whom are minor heirs. ${ }^{8}$ Infants en ventre sa

1. People v. Moores, 4 Denio (N. Y.) 518, 47 Am. Dec. 272.

2. Fagin v. Goggin, 12 R. I. 398.

3. State v. Weatherwax, 12 Kans. 463; Dial v. Wood, 9 Baxt. (Teun.) 296.

4. Tyler on Inf. \& Cov. 12:.

5. Karcher v. Green, 8 lioust. (Del.) 163.
6. U. S. Rev. Stat., sections 1116 , 1117.

7. In re Hearn, 32 Fed. Rep. 141; In re Davison, 21 Fed. Rep. 618; United States v. Gibbon, 24 Fed. Rep. 136; In re Morrissey, $137 \mathrm{U}$. S. 157,11 s. Ct. 57 .

8. Cocks v. Simmons, 57 Miss. 183; Wilson v. Duncan, 44 Miss. 612. 
mere are not bound by a decree of partition marle before they were born. ${ }^{9}$ So infant children are not bonnd by an allotnent or sale in partition made before they were borm." The doctrine is well settled that posthumous children inherit in the same manner as if they had been born in the lifetime of the ancestor and had survived him, and their interest camnot be divided by partition when they were not parties to the proceedings. ${ }^{11}$

And when the guardian and ward are tenants in common, the guardian cannot have the estate partitioned, mless the ward is actually represented in conrt by a guardian al litem." When voluntary partition is made, and not by decree of court, and some of the parties are infants, these infants after reaching majority, may affirm the partition by holding exchusive possession of their share and exercising ownership thereof. ${ }^{13}$

$\S 38$. Shopping - Purchase of goods. - It has been said that an infant's contracts when shopping cannot be avoided; that mere purchases at stores in the way of shopping, where the articles are received and the price paid, are irrevocable; that if an infant goes upon the street of a city shopping, he cannot afterwards retrace his steps, and receive back the money, even though he tenders the goods in return. ${ }^{1}$ But this statement is not sustained by the courts or text-writers. It is the miversal rule that all executory contracts which are voidable on the ground of infancy may be avoided during infancy by the infant as well as afterwards as when the minor promises to pay. So too all contracts respecting property which are executed by delivery of some article on payment of money, may be rescinded by the minor hefore and after the time of his coming of age. To this general rule are these three exceptions: 1, Contracts for neces-

9. Pearson v. Carlton, ls S. Car. 47; Gillespie v. Nabors, 59 Ala. 441, $31 \mathrm{Am}$. Riep. 20; Massie v. lliatt, 82 Ky. 314; Detrick v. Myatt, 19 Ill. 146, 6s Am. Dee. 584; Ścott v. Porter, 2 Lea (Temn.) 르.

10. Pearson v. Carlton, $18 \mathrm{s.} \mathrm{('ar.}$
11. Gillespie v. Nibbors, 59 Ala. 4t1, 31 Im. Rep. 20.

12. Roodhouse v. lioolhouse, 132 111. 362,24 N. E. 55 .

13. Whittemore v. Cope, 11 Utah, $: 34,40$ l'. 256.

1. Bishop on Cont. 921. 47. 
saries; 2, contracts, not mequal, to effect what the infant is compellable in chancery to do, as making partition, releasing a mortgage, and the like: 3, contracts under which the infant has so enjoyed or arailed himself of the consideration, that the parties cannot be restored to their original situation. ${ }^{2}$

Hence, it is held by some courts where the infant does not enjoy the bencfit of the purchases, he can recover the purchasemoney on restoring the thing purchased, but if he has enjoyed the benefit of the purchase and had the use of it, the money cannot be recorered. ${ }^{3}$

\$ 39. Contract for necessaries.-An infant's contract fon necessaries is valid. But what are necessaries, is not easily answered.

The social standing of the infant and his environment have something to do with the kind of necessaries suitable to him. Necessaries generally refer to supplies which are personal, either for the body, as food, clothing, lodging, or those necessaries for the proper cultivation of the mind, as suitable instruction, and the purchase of text-books. ${ }^{4}$

The English doctrine is applicable in some respect to the American, though not wholly, on account of easte in the English society. It is held in England that an infant may bind himself to pay for necessary meat, lrink, apparel, necessary medicine, and good teaching, whereby he may profit himself afterwards. ${ }^{5}$ So regimentals furnished to an infant who was a member of a volunteer corps are necessaries. ${ }^{6}$ That is necessary which is

2. Reeve's Dom. Rel. pp. 227, 254: Chitty on Cont. p. 222 ; Leake on Cont. 553; 2 Kent's Com. 240.

3. Corpe r. Overton, 10 Bing. 252; Riley v. Mallory, 33 Conn. 201; Medbury v. Watrous, $T$ Hill (N. Y.) 110; overruling MeCoy v. Hoffman, s Cow. (N. Y.) 178, 184, 18 Am. Dec. 432 and note.

4. Tupper r. Cadwell, 12 Met. (Mass.) 559, 46 Am. Dec. 704;
Freeman v. Bridger, 4 Jones L. (N. Car.) 1, 67 Am. Dee. 258; McCarty v. Carter, 49 Ill. 53, 95 Am. Dec. 572: West v. Greggs, 1 Grant (Pa.). 53; Hassard v. Rowe, 11 Barb. (N. I.) 22: Putnam v. Ritchie, 6 Paige (N. Y.) 390 .

5. Co. Litt. 172a.

6. Coates v. Wilson, 5 Esp. 152. 
bona fide purchased for une and not for ormanent, and which consorts with the condition and rank in life in whichl the party 1110yes. ${ }^{\top}$

\$ 40. Things necessary-Definition.-Things nesessary are those without which an indivichal camnot reasonably exist, snch as food, rainent, lodging, and medicine; so the proper entivation of the mind is a necessary, such as a common school education, and instruction in art w trade, or intellectual, moral on religious information. The assistance and attendanee of servants may be necessary. The infant's elothes may be fine or coarse, according to his social standing; and his edneation may vary according to the position he is to fill; the medicine will depend on his illness; and a servant in livery may be allowed to a rich infant, if such attendance is commonly appropriate in his social condition. But articles of mere luxury are always excluded, though luxurious articles of utility are in some cases allowed. But eontraet for charitable assistance to other's camnot be allowed to be binding, beeause they do not relate to the infant's own personal advantage. ${ }^{1}$

Necessaries for an infant's wife are neeessaries for him.' Necessaries for a livery servant of an officer in the army are necessaries. ${ }^{3}$ And an infant widow is bound by her eontract for the furnishing of the funeral of her husband, who has left no property. ${ }^{4}$

The meaning of the term "necessaries" camnot be defined by a general rule applieable to all eases. The question is a mixed one of law and fact, to be determined in each ease from the peenliar fancts and circmustances of such ease. ${ }^{5}$

7. Peters v. Fleming, 6 Nees. \& Wel. 42 .

1. Chapple v. Cooper, 13 Mees. \& Wel. 252. See, also. Ryder v. Wombwell, I. R. 3 Exch. 95; Price v. Sanders, 100 Ind. 310. 168.
3. Hand v. Slanes, $s$ Term. R. 578.

4. Chapple v. Cooper, 13 Mees. \& 11. 2.2.

5. Englebert v. Troxell, 40 Neb. 19.5, 5 S N. W. 852, 42 Am. St. Rep. (65: Cobbey v. Buehanan, ts Neb. 391,67 N. W. 176. 
§ I. Things not necessary.-As the rule stands necessaries which an infant may be compelled to pay for, if he has agreed to, are supplies, which are personal, either for the body, as food, clothing or lodging or those necessaries for the proper cultivation of the mind, as suitable instruction and the purchase of textbooks. Under this rule a dwelling house is not necessary and an infant may aroid a bond and mortgage given for the erection of it. ${ }^{2} \Lambda$ bicycle is not a necessity $;^{2}$ nor an unnecessary supply of clothing $;^{3}$ nor professional education $;^{4}$ nor things for mere ornament $;^{5}$ nor tobacco, prima facie $;^{6}$ nor is a horse, ${ }^{7}$ except when an infant is directed to use one by his physician, ${ }^{8}$ or in order to take a trip on business and not for pleasure. ${ }^{9}$ The quality and quantity of the things furnished must be taken into consideration, because if the infant has a sufficient supply they will be mnecessary, and if they are not suitable they are equally unnecessary. ${ }^{10}$ Necessaries do not "include horses, saddles, bridles, liquors, pistols, powder, whips, and fiddles." 11 A pair of solitaires and a goblet are not necessaries $;^{12}$ nor kid gloves,

1. Allen v. Lardner, 78 Hun (N. Y.), 603, 29 N. Y. S. 213.

2. Pyne v. Wood, 145 Mass. 558, 14 N. E. 775. See, also, Merriam v. Cunninglam, 11 Cush. (Mass.) 40 ; Leonard v. Stott, 108 Mass. 46.

3. Johnson v. Lines, 6 Watts \& S. (Pa.) 80, 40 Am. Dec. 542.

4. Turner v. Gaither, $83 \mathrm{~N}$. Car. 357, 35 Am. Rep. 574.

5. McKenua v. Merry, 61 Ill. 179.

C. Bryant v. Richardson, $12 \mathrm{Jur}$. (N. S.) 300 L. R. 3 Exch. 93n.

7. Wharton v. Mackenzie, $5 \mathrm{Ad}$. \& El. 606 ; House v. Alexander, 105 Ind. 109, 4 N. E. 891, 55 Am. Rep. 189; Howard v. Simpkins, 70 Ga. 322 ; Miller v. Smith, 26 Minn. 248, 37 An. Rep. 407.
8. Hart v. Prater, I Jurist, 623; Harrison v. Fane, 1 Man. \& G. 556.

9. Breed v. Judd, 1 Gray (Mass.) 455. See, also, MeKenna v. Merry, 61 Ill. 177.

10. Nicholson v. Spencer, $11 \mathrm{Ga}$. 610; Nicholson v. IVilborn, 13 Ga. 467 ; Perrin v. Wilson, 10 Mo. 451; Davis v. Caldwell, 12 Cush. (Mass.) 512; Johnson v. Lines, 6 IVatts \& S. (Pa.) 80, 40 Am. Dec. 542; Horstman v. Connors, 56 Mo. App. 115.

11. Price v. Sanders, 60 Ind. 310 . See, also, Harrison v. Fane, 1 Man. \& G. 556 ; Glover v. Ott, 1 McCord (S. Car.) 572.

12. Ryder v. Wombell, L. R. 4 Exch. 32. 
cologne, cravats, and firldle strings, ${ }^{13}$ nor buggy ${ }^{14}$ nor stock on a farm. ${ }^{15}$

\$ 42. Repairs on real estate.- "Necessaries," within the technieal meaning of the word, embraces such things as are necessary for the support or confort of the minor or for his personal use, taking into account his condition and circumstances in life. ${ }^{16}$

So repairs on real estate are clearly not within this definition, and, hence, an infant is not liable for such repairs either on his own contract or on the contract of his guardian or parent, even though the repairs are necessary to prevent immediate and serious injury to the property. ${ }^{1 i}$

$\S$ 43. Things necessary.- Whatever is reasonably needed for the infant's support is necessary, as food and lodging ${ }^{1}$ a nurse in sickness $;^{2}$ attorney's fees in a necessary suit ${ }^{3}$ dentist's services $;^{4}$ common sehool education $;^{5}$ board of infant while attending school, ${ }^{6}$ and an infant who has purchased an unnecessary article of personal property, may rescind the contract and recover the money paid. ${ }^{7}$ A college education, under certain

13. Lefils v. Sugg, 15 Ark. 137.

14. Howard $v$. Simpkins, 70 Ga. 322; Rice v. Boyer, 108 Ind. 472, 9 N. E. $420,5 \mathrm{~S}$ Am. Rep. 53.

15. Decell v. Lewenthal, 57 Miss. 331, 34 Am. Rep. 449; Compare Mahoney v. Evans, 51 Pa. St. 80.

16. Price v. Sanders, $60 \mathrm{Ind}$. 310. 314; Cobbey v. Buchanan, 4s Neb. $391,67 \mathrm{~N}$. W. 176; Englebert v. Troxell, 40 Neb. 195, 58 N. IV. 8.52, 42 Am. St. Rep. 665.

17. Tupper v. Cadwell, 1:2 Met. (Mass.) 559, 46 Am. Dec. 704; Phillips v. Llogd, 1s R. I. 99, 25 A. 906. See, also, West v. Gregg, 1 Grant (Pa.) 53; Wallis v. Bardwell, 126 Mass. 366.
1. Barnes v. Barnes, 50 Conn. 572.

2. Werner's Appeal, $91 \mathrm{~Pa}$. St. 222.

3. Crafts v. Carr (R. I.), 60 L. R. A. 12S; Englebert v. Troxell, 40 Neb. 951, 58 N. W. 852, 42 Am. St. Rep. 665; Askey v. Williams, 74 Tex. 294; Epperson v. Nugent, 57 Mirs. 45, 34 Am. Rep. 434; Barker ๖. Hibbard, 54 న. H. 539, 20 Am. Rep. 160; Compare Phelps v. Worcester, 11 N. H. 51.

4. Strong v. Foote, 42 Conn. 203.

5. Nidleburg College v. Chandler, 16 Vt. 686.

6. Kilgore v. Rich, 83 Me. 305 , 22 A. 176,23 Am. st. Rep. 780.

7. Shurtleff $v$. Millard, 12 R. I. 
circumstances, may be necessary, as when an infant wishes to become a professor. ${ }^{8}$ But generally a professional education is not necessary. ${ }^{9}$ But in determining what is necessary the infant's station in life must be considered. ${ }^{10}$

$\S$ 44. In business.-- The law does not throw any protection around an infant in business not applicable when out of business, and does not encourage persons to engage in business during non-age. The policy of the law is to keep infants from engaging in business until they have reached full age, and so articles purchased for business purposes, whether that of farming or commerce, are not deemed necessaries. And this is so though the infant enters business in order to support himself. ${ }^{1}$ So a horse purchased by an infant who is engaged in farming is not a necessary. ${ }^{2}$ And a bicycle bought to ride to and from business is not a necessary. ${ }^{3}$

272, 34 Am. Rep. 640; Robinson v. Weeks, 56 Me. 102, 104; Sparman v. Keim, 83 N. Y. 245; Looper v. Allport, 10 Daly (N. Y.) 352; Carpenter v. Carpenter, 45 Ind. 142 ; Ayers v. Burns, 87 Ind. 245, 44 Am. Rep. 759; Honse v. Alexander, 105 Ind. 109, 4 N. E. 891, 55 Am. Rep. 189; Wharton on Cont. 47. Compare. Parson .on Cont. 322, whieh states the rule incorrectly, with no authority to sustain the statement.

8. Pickering v. Gunning, W. Jones, 182; Middlebury College v. Chandler, 16 Vt. 686.

9. Bouchell v. Clary, 3 Brev. (S. Car.) 194; Turner v. Gaither, 83 N. Car. 357.

10. Mekenna v. Merry, 61 11!. 177 ; Squier v. Hydliff, 9 Mieh. 274; Jordan v. Coffield, 70 N. Car. 110 ; Breed v. Judd, 1 Gray (Mass.) 455; Wilhelm v. Hardman, 13 Md. 144;
Chapple v. Cooper, 13 Mees. \& Wel. 252.

1. Lowe v. Griffith, 1 Scott, 458; Latt v. Booth, 3 Car. \& Kir. 292; Mason v. Wright, 13 Met. (Mass.) 306 ; House v. Alexander, 105 Ind. 109, 4 N. E. 891, 55 Am. Rep. 189; Merriam v. Cunningham, 11 Cush. (Mass.) 40; Pyne v. Wood, 145 Mass. 558, 14 N. E. 775; Paul v. Smith, 41 Mo. App. 275; State v. Howard, 88 N. Car. 680; Dilk v. Keighley, 2 Lsp. 480; Wood v. Losey, 50 Mieh. 475; Decell v. Lewenthal, 57 Miss. 331, 34 Am. Rep. 449; Grace v. ILale, 2 Humph. (Tenn.) 28; Whittingham v. Hill, Cro. Jae. 494; Priee v. Sanders, 60 Ind. 310 .

2. House v. Alexander, 105 Ind. 109, 4 N. E. 891,55 Am. Rep. 189.

3. Pyne v. Wood, 145 Mass. 558, 14 N. E. 775 . See, also, Ryan v. Smith, 165 Mass. 303,43 N. E. 109. 
$\S 45$. When an infant lives at home with his father.- In infant when residing at home and under the care of his father and supported by him, is not liable even for neressarties. If he were, the father would be deprived of his right to determine what the character of that support should be ${ }^{1}$ he is not liable for the necessaries furnished him, merely because his father is poor and mable to pay for them. ${ }^{2}$ When necessary professional services are rendered to a minor residing in the house with his father, the legal inference is that the father is the person liable therefor. The poverty of the father is not sufficient to render a minor liable for necessaries furnished the infaut. To make the father liable for the minor's necessaries, there must be a refusal of the father to furnish them.. Where an infant has been deserted by the father, or driven away from home, either by command or by eruel treatment, then the infant carries with him the credit and authority of the father for necessaries. The obligation of the father to support the child is and always has been recognized, in some way and in some degree, in all eivilized countries.

$\S 46$. Cardinal tenets. - The true rule is that those things, and those only, are properly to be deemed necessaries which pertain to the becoming and suitable maintenance, support, clothing, health, education, and appearance of the infant according to his condition and rank in life, the employment or pursuit in which he is engaged, and the circumstances under which he may be placed as to profession or position.

Under this doctrine the property of an infant is not subject to a mechanic's lien for material purchased by him during his

1. Angel v. MeLellan, 16 Mass. 28, 8 Am. Nec. 118; Wailing v. Toll, 9 Johns. (N. Y.) 141; 'Bainbridge v. Pickering, $2 \mathrm{~W}$. B1. 1325; Trainer v. Trumbull, 141 Mlass. $530,6 \mathrm{~N}$. E. 761 ; Decell v. Lewenthal, 57 Miss.
331, 34 Am. Rep. 449; Elrod v. Myers, 2 Ilead (Tenn.) 33; Perrin v. Wilson, 10 Mo. 451.

2. Hoyt v. Casey, 114 Mass. 397 , 19 Am. Rep. 3 iı.

3. Hoyt v. Casey. 114 Mass. 397 , 399, 19 Am. Rep. 371. 
infancy, ${ }^{1}$ though the repairs on the house were necessary to prevent immediate and serious injury to it. ${ }^{2}$ So a contract for insurance on his property against loss or damage by fire is not a contract for necessaries which will bind an infant. ${ }^{3}$ So if a party, at the request of the guardian, pays off a mortgage on the infant's land, he cannot recover from the infant, as such payment was not for necessaries $;^{4}$ nor need a minor pay a bond and mortgage given to secure the payment for the erection of a house on his land. ${ }^{5}$

$\S$ 47. Support of family.- By the common law a father, if of sufficient ability, is as much bound to support and provide for his infant children, in sickness and in health, as a husband is bound by the same law to support and provide for his wife. ${ }^{6}$ But a minor, who voluntarily abandons his father's house, without any fault of the latter, carries with him no credit on his father's account even for necessaries. ${ }^{\top}$

The father is entitled by law to the services and earnings of his minor children. This right is founded upon the obligation which the law imposes upon him to nurture, support and educate them during infancy and early youth, and it continues until their maturity, when the law determines that they are capable of providing for themselves. ${ }^{8}$

1. Bloomer v. Nolan, 36 Neb. 51 , 53 N. W. 1039, 38 Am. St. Rep. 690.

2. Phillips v. Lloyd, Is K. I. 99, 25 A. 909; Tupper v. Cadwell, 12 Met. (Mass.) 559, 46 Am. Dec. 704; Wallis v. Bardwell, 126 Mass. 366.

3. New Hampshire F. Ins. Co. v. Noyes, 32 N. H. 345.

4. Bicknell v. Bicknell, 111 Mass. 265. See, also, Phelps v. Worcester, 11 N. H. 51 ; MeCarty v. Carter, 49 Ill. 53, 95 Am. Dec. 572; Putnam v. Ritchie, 6 Paige (N. Y.) 390 ; Magee v. Welsh, 18 Cal. 155. 5. Allen v. Jordner, $78 \mathrm{Hun}$ (N.
Y.) 603 ; Wornock v. Loar, 11 S. W. 438, 11 Ky. L. R. 6.

6. Reynolds v. Sweetser, 15 Gray (Mass.) 80; Hall v. Weir, 1 Allen (Mass.) 261 ; Camerlin v. Palmer Co., 10 Allen (Mlass.) 539.

7. Weeks v. Merrow, 40 Me. 1.5l; Angel v. MeLellan, 16 Mass. 27; White v. Henry, 24 Me. 533; Gilley v. Gilley, 79 Me. 292, 1 Am. St. Rep. 307 ; Price v. Sanders, 60 Ind. 315; Chapman v. Hughes, 61 Miss. 339.

8. Furman v. Van Sise, $56 \mathrm{~N}$. Y. 435, 439, 444, 446, 15 Am. Rep. 441; Van Valkenburgh v. Watson, 13 
In Vermont and New Hampshire it is held that a parent is under no legal obligation, independent of statutory provision, to maintain his minor child, and that in the absence of any contract on the part of the father, he camnot be held except under the pauper laws of those States which provide such laws. ${ }^{9}$ But this is against the great weight of authority and is not supported by the rules of society or the doctrine of publicists.

\section{$\S 48$. Payment of minor's debts by another.- If an infant} procures another to pay a bill for necessaries for him, that payment is regarded as furnishing of necessaries, in which a suit may be maintained against the infant for the reasonable value, to him on the amount so paid, ${ }^{1}$ as money paid for an infant for necessaries is recoverable from him. ${ }^{2}$ And where a person lends money to an infant to pay a debt incurred for necessaries, and the debt is so actually paid, he will stand in equity in the place of the original creditor, and the minor will be liable to him. ${ }^{3}$ The money loaned must be applied to the payment of the debt for necessaries in order to make the infant liable. ${ }^{4}$

$\S 49$. Value of the articles sold.- An infant may bind himself to pay for necessaries he obtains, as much as they are reasonably worth, but not what he may foolishly have agreed to pay for them. ${ }^{5}$ If he has made an express promise to pay, or has

Johns. (N. Y.) 480, 7 Am. Dec. 395 ; Garland v. Dover, 19 Me. 441 ; Benson v. Remington, 2 Mass. 113; Dawes v. Howard, 4 Mass. 98; Nightingale v. Withington, 15 Mass. 274, 18 Am. Dec. 101; State v. Smith, (; Me. 462, 464, 20 Am. Dee. 324 and note; Dennis v. Clark, 2 Cush. (Mass.) 352, 353.

9. Gordon v. Potter, 17 rt. 34 s: Kelley v. Davis, 49 N. H. 187, 6 Am. Rep. 499.

1. Kilgore v. Rich, 83 \е. 305, 22 A. 176,23 Am. St. Rep. 780;
Genereux v. Sibley, 18 R. I. 43, 25 A. 345 .

2. Swift v. Bennett, 10 Cush. (Mass.) 436; Randall v. Sweet, 1 Denio (N. Y.) 460 ; Robinson v. Weeks, 56 Mre. 102: Conn r. Coburn. 7 N. H. 368, 26 Am. Dec. 746.

3. Harris v. Lee, 1 P. 1 m. 482 ; Darby v. Boncher, l Salk, 279: Clark v. Teslie, 5 Esp. 28; Price v. Sanders, tio Ind. 310; Beeler v. Young, 1 Bibl) (Ky.) 5.2.

4. Randall v. Swcet, 1 Denio (N. Y.) 460 .

5. Tocto v. Smith, 41 N. II. 346. 
given a note in payment for necessaries, the real value will be inquired into, and he will be held only for that anomnt." An infant who is already well provided for in respect to board, clothing, and other articles suitable to his condition, cannot be held responsible if any one supplies other board, elothing, and the like, although such person did not know that the infant was already supplied.'

The question whether the infant made an express promise to pay is not important. He may be held on a promise implied by law, from the necessity of lis situation.s

$\S 50$. Mixed question of law and fact.- What are necessaries is a mixed question of law and fact. The better rule is that whether the articles are of those classes for which an infant shall be bound to pay, is a matter of law to be determined by the court; if they fall under those general descriptions, then, whether they were actually necessary and snitable to the condition and estate of the infant, and of reasonable prices, must, regularly, be left to the jury as a matter of fact. ${ }^{9}$ It must also be noted that the articles furnisher, to come within the class of necessaries, must not only be of the kind which are suitable to the infant's situation in life, lut must be actually needed by him, by reason of his failure to have the requisite supplies. If

6. Earle v. Reed, 10 Mret. (Mass.) 387 ; Barnes v. Barnes, 50 Conn. 5i:; Guthrie v. Morris, 2.2 Ark. 411 ; Bradley v. Pratt, 23 Vt. 378 ; Askey v. Williams, 74 Tex. 294, 11 S. W. 1101,5 L. R. A. 576 and note; ('ompare Morton v. Stewart, 5 Ill. App. 533: Ayers v. Burns, 87 Ind. 245, 44 Am. Rep. 759; Gregory v. Lee. 64 Conn. 407,30 A. 53, 25 L. R. A. 618 .

7. Angel v. MeClellan, 16 Masi. 28, $8 \mathrm{Am}$. Dee. 118; Swift v. Bennett, 10 Cush. (Mass.) 436; Barnes v. Toye, 13 Q. B. Div. 410 ; Trainer v. Trumbull, 141 Mass. 527, 530, 6 N. E. 761 .
3. Gregory r. Lee, 64 Conn. 407 , 30 A. 53,25 L. R. A. 618 ; Hyman v. Cain, 3 Jones (N. Car.), 111; Richardson v. Strong, 13 Ired. (N. Car.) 106, 55 Am. Dee. 430; Epperson v. Nugent, 57 Miss. 45, 47, 34 Am. Rep. 434; Gay v. Ballou, 4 Wend. (N. Y.) 403, 21 Am. Dec. 158; Buekinhamshire v. Drury, 2 Eden, 60, 72; Clarke v. Leslie, 5 Esp. 28.

9. Cobbey v. Buchanan, 48 Neb. 391,67 N. W. 176 ; Englebert v. Troxell, 40 Neb. 195, 58 N. IV. 852 , 42 Am. St. Rep. 665; Beeler v. Young, l l3ibb. (Ky.) 5l!; Decell v. Lewenthal, 57 Miss. 331. 
the infant is already supplied he cannot be held for other supplies ${ }^{10}$ It is incumbent on the party furnishing supplies to satisfy himself by due inquiry that the articles furnished the infant are actually suitable in quantity and in quality. ${ }^{11}$ The jury shonld decile whether the articles are suitable to the estate and condition of the infant. ${ }^{12}$

\section{ARTICLE II.}

\section{Ratification of Voidable Contract.}

Sectiox51. Necessity of Ratification.

52. How Ratified.

53. What is a Ratification.

54. Ratification Upon Condition.

55. Time to liatify.

5i. Silence as a Ratilication.

$\S 5$ I. Necessity of ratification. - A difference exists between an executed and an executory contract. In the former case the contract is binding until it is avoided. In the latter it is without binding force until it is confirmed. If an infant is sued on his executory contract before or after becoming of age, if he has not affirmed it since his majority, the infancy is a perfect defense. ${ }^{13}$ But after ratification the contract is binding ab initio. ${ }^{14}$ Thereafter the contract subsists between the parties and is valid

10. Decell v. Lewenthal, 57 Miss. 331, 34 Am. Rep. 449; Daris v. Caldwell, I2 Cush. (Mass.) 513 ; Nicholson v. Spencer, 11 Ga. 607.

11. Hands v. Slaney, s Term li. 578 ; Peters v. Fleming, 6 Mees. \& IVel. 42.

12. McKemna v. Merry, $61 \mathrm{Ill}$. $17 \overline{7}$; Jordan v. Coffield, 70 Ga. 110.

13. Neal v. Berry, S6 Me. 193,29 A. 987; Tobey v. IVood, 123 Mass. 8S, 25 Am. Rep. 27 and note;
Edgerly v. Shaw, 25 N. H. 514, 57 Am. Dec. 349 ; Petrow v. Wiseman, 40 Ind. 14S; Hale v. Gerrish, $8 \mathrm{~N}$, H. 374; Savage v. Lichlyter, 59 Ark. 1, 26 S. W. I2; Carrell v. Potter, 23 Mich. 379; Bush v. Linthieum, 59 Md. 344 .

14. Ward v. Anderson, 111 N. Car. 115,15 s. E. 333 ; Kincaid v. Kincaid, Sé Hun (N. Y.), 14I. $32 \mathrm{~N}$. Y. S. 476; Hall v. Jones, 21 Md. 439. 
and cannot then be avoided by the party who has reached the age of twenty-one years. ${ }^{15}$

$\S 52$. How ratified.- The cases are not in accord as to what constitutes a ratification of a voidable contract. Of course the contract imposes no liability on him until ratified after full age. Some authorities hold that such a ratification must have all the elements of a new contract except a new consideration. The debt is regarded as standing on the same footing as a debt that has been destroyed by a discharge in bankruptcy, and not as one barred by the statute of limitations. ${ }^{1}$

But the better rule is that the contracts of infants are only suspended during minority, and may be ratified upon the same principle and for the same reasons as a debt barred by the statute of limitations may be revived. Hence, under this rule, a new promise, clear and precise, equivalent to a new contract, is not essential; but any words or acts by the infant, after becoming of age, that clearly recognize the existence of the contract as a binding obligation, will constitute a ratification. ${ }^{2}$ So an express promise to pay is not the only method of ratification; but any declaration or act which satisfies the court that the liability or contract duty is still binding and intended to be complied with, if voluntarily done, or entered into, completely neutralizes the defense of infancy; and it is not necessary to a binding ratification that the party songht to be charged knew, at the time the promise was made, or act done, that he had the right to avoid the contract. All men are presumed to know the law, and no one will be heard to plead ignorance of it. ${ }^{3}$

15. Hastings v. Dollarhide, $2+\mathrm{Cal}$. 195; Houlton v. Manteuffel, 51 Minn. 185, 53 X. W. 541 ; Curry v. Płow Co., 55 Ill. App. 82.

1. Tibiets v. Gerrish, $25 \mathrm{~N}$. H. 41, 57 An. Dec. 307; Metson v. Roath, 12 Conu. 550; Edmunds v. Mister, 58 Miss. 765: Turner v. Gaither, 83 N. Car. 357, $35 \mathrm{Am}$. Rep. 574.
2. Henry v. Root, 33 N. Y. 526; Ameriean Mort. Co. v. Wright, 101 Ala. 658, 14 So. 399 ; In re Hodson's Settlement (1894), 2 Ch. 421.

3. Ameriean Mort. Co. v. Wright, 101 Ara. 658, 14 So. 399; Morse v. Wheelel, 4 Allen (Mass.) 570 ; Bestor v. Hickey (N. J.), 41 A. 555 ; Compare Hatch v. Hateh, $60 \mathrm{Vt}$. 160, 13 A. 791 ; Kendrick v. Niesz, 
The method of ratification is regulated by statute in some jurisdictions, which must be followed; and, howerer ratified, the ratification once made camnot be repudiated. ${ }^{4}$

It has been held by some courts, against the great weight of authority, that the promise of the adult to bind himself by a contract made in infancy must not only be roluntary and explicit, but must be made with knowledge that he is not legally liable unless the promise is made. The claim for the necessity of such knowledge first appeared in a dictum of a nisi prius court. $^{5}$ This unsound doctrine was exposed and orerthrown by a Massachusetts deeision, ${ }^{6}$ and strange to say, the sane court affirmed the doctrine of the erroneous dictum, in a brief and hasty opinion. ${ }^{7}$

The promise affects only the liability, and has no effect unless there is an existing eontract. When that is established through the acts of the infant, the liability must be proved, and is limited by the pronise of the adult. ${ }^{8}$ It is immaterial whether the promise is treated as a waiver, or ratification, or a new contract, and it is not necessary that the adult knows that he is not legally liable. The action nust be brought on the original contract. The validity of the adult's promise depends on his ability to affirm his infant contract, and the fact that he does not know that he is not legally liable has no effect; he is morally liable, and his promise makes him legally liable for the original contract.

$\S 53$. What is a ratification. - Where an infant executes a purchase-money mortgage to secure the purchase-money for land conveyed to him by deed, he cannot, after he comes of age, affirm the deed and at the same time disaffirm the nortgage ${ }^{1}$ because

17 Colo. 506, 30 P. 245; Dolph v. Hand, 156 Pa. St. 91; 27 A. 114, $36 \mathrm{Am}$. St. Rep. 25; Edwards v. Carter, Appeal Cases (IS93), 360. 82.

4. Curry v. Plow Co., 55 IIl. App.

5. Harmer v. hllling, 5 Esp. 102.
6. Morse v. Wheeler, 4 Allen (Mass.) 570.

r. Owen v. Long, II2 Mass. 403.

3. Edgerley v. Shaw, $25 \mathrm{~N}$. H. 514, $57 \mathrm{Am}$. Dec. 349.

1. Kendrick v. Baker, 159 Pa. St. 146, 27 A. 114. See, also, Amer. 
the deed and mortgage is one transaction, and the one cannot be ratified or avoided without producing the same effect on the other. ${ }^{2}$ So a deed of trust is ratified by acceptance, by the party at majority, of part of the proceeds. ${ }^{3}$ A prior mortgage may be ratified by the party after becoming of age, by a recital in a subsequent mortgage that the latter is given subject to the former. ${ }^{4}$ Keeping a house erected on an infant's land, after his coming to maturity, is not a ratification for materials furnished to erect the loouse. ${ }^{5}$ An offer by an infant after coming of age to affirm a conveyance by him, if the grantee will pay balance of purchase-money which is refused, is no ratification $;{ }^{6}$ and if he agrees to ratify upon a condition, the eondition must arise before he will be bound. ${ }^{7}$ Receiving part of the purchase-money of his land, after becoming of age, is a ratification of the sale $;^{8}$ taking up an old deed and giving a new one in affirmanee of it, avoids the old deed ab initio. ${ }^{9}$

$\S 54$. Ratification upon condition.- A contract may be ratified or qualified upon condition. ${ }^{10}$ So in an aetion on such a contract, such a conditional ratification will not avoid the defense of infancy unless there is proof of the happening of the conditions amnexed thereto. ${ }^{11} \quad \mathrm{As}$ an adult may wholly avoid the contract made during infancy, he may avoid it in part or may undertake a conditional performance of it. ${ }^{12}$ Thus, a note given

Free L. Co. v. Dykes, 111 Ala. 178, 18 So. 292, 56 Am. St. liep. 38.

2. Necker v. Koehn, 21 Neb. 559, 59 Am. Rep. 849; skmner v. Maxwell, 66 N. Car. 45.

3. Darraugh v. Blackford, $84 \mathrm{Va}$. 509,5 S. E. 542; Treadway v. Veasey, 97 Ga. 329, 22 S. E. 915.

4. Warr v. Anderson, 111 N. Car. 115, 15 S. E. 933.

5. Bloomer v. Nolan, 36 Neb. 51, 53 N. IV. 1039, 38 Am. St. Rep. 690. See, also, Allen v. Lardner, 78 Hun (N. Y.), 603, 29 N. Y. S. 213.
6. Craig v. Van Bebber, 100 Mo. 584, 13 S. IV. 906, 18 Am. St. Rep. 569 and note.

7. Peacock v. Binder, 57 N. J. L. 374,31 A. 215.

8. Smith v. Gray, 116 N. Car. 311,21 S. F. 196.

9. Cox v. MeGowan, 116 N. Car. 131,21 S. E. 108.

10. Peacock v. Binder, 57 N.J.L. 374.31 A. 215.

1 1. Peacock v. Binder, 57 N. J. L. 374,31 A. 215.

12. Thompson v. Lay, 4 Pick. (Mlass.) 47; Proctor v. Sears, 4 
in infancy may be ratified upon condition by the adult upon condition of his financial ability to pay it or some part of it. ${ }^{13}$

§5. Time to ratify.- It is provided by some States that a ratification shall be made within a specified time br the party coming of age. But where the statute does not control, a reasonable time should be allowed to ratify or avoid, and if not avoided, the contract should be declared valid. Such neglect to ratify, it is generally held, may be regarded as equivalent to an act of aftirmance, and as amounting in fact and in law as a ratification. ${ }^{14}$ What is a reasonable time will depend upon circum stances of each particular case, and may be, either for the court or for the jury to determine. ${ }^{15}$

$\S 56$. Silence as a ratification. - Some courts hold that no passive acquiescence, though long continued, will ratify a contract. ${ }^{1}$ A ratification may be inferred by acts of the infant and circumstances, after the infant has attained majority, which are inconsistent with an intention to disaffirm ; as receiving rent on a lease, receiving a part of the purchase-money, or conveying a part of the land received in consideration of a deed. ${ }^{2}$ The

Allen (Mass.) 95; Eversen v. Car, penter, 17 Wend. (N. Y.) 419.

13. Peacock v. Binder, 57 N. J. L. 374,31 A. 215.

14. Dolph v. Hand, 156 Pa. St. 91, 27 A. 114, 36 Am. St. Rep. 25; IVallace v. Lewis, 4 Harr. (Del.) 75 ; Zoebisch v. Rauch, $133 \mathrm{~Pa}$. St. 532, 19 A. 415; Goodnow v. Empire Lumber Co., 31 Minn. 468, 47 Am. Rep. 798; Scott v. Buchanan, 11 Humph. (Tenn.) 46s; Houlton v. Manteuffel, 51 Minn. 185, $53 \mathrm{~N} . \mathrm{IT}^{\top}$ 541 ; Terrell v. Wentworth, 32 Fla. 255, 13 So. 429, 37 Am. St. Rep. 94.

15. Bingham v. Barley, 5.5 Tex. 281, 40 Am. Rep. S01; O’Brien v.
Goslin, 20 Neb. 347 ; Thompson v. Strickland, 52 Miss. 574.

1. Davis v. Dudley, 70 Me. 236, $35 \mathrm{Am}$. Rep. 318; IVallace v. Latham, 52 Miss. 291; Eureka v. Edwards, $7 l$ Ala. 248, 46 Am. Rep. 314; Hill v. Nelums, 86 Ala. 442, 5 So. 796; Cresinger v. Welch, 15 Olıio, 193; Drake v. Ramsey, 5 Ohio, 251; Ferguson v. Bell, 17 Mo. 347 ; Bostwiek v. Atkins, 3 N. Y. 53; Irvine v. Irvine, 9 Wall. (U. S.) 617 ; Huth v. Carondelet, etc., Co., 56 Mo. 202, 209.

2. Tlromas v. Pullis, 56 Mo. 219 ; Sims v. Everbardt, 102 U. S. 312; Gillespie r. Bailey, 12 W. Va. 70, 29) Am. Rep. 445; Lacy v. Pixler, 
better rule is, especially where the rights of third parties have intervened, an unreasonahle delay to avoid the contract on coming of age, should be considered an affirmation of the contract. ${ }^{3}$

\section{ARTICLE III.}

\section{Disaffirmance of Voidable Contracts.}

Secrion 57. Avoidance.

58. May Disafiim Contracts Pertaining to Personalty Before Majority.

59. What is a Reasonable Time to Disaffirm.

60. In Case of Partnership Contracts.

61. Rights of Third Persons.

62. Contracts for Service.

63. Contracts Beneficial to Infants.

64. Return of Consideration.

65. How Affirmed or Disaffirmed.

66. Who May Avoid.

\$57. Avoidance- - All contracts of an infant, except those for necessaries and those binding on him by law, are voidable by him at his election, made within a reasonable time after becoming of age. ${ }^{1}$ Deeds made by a minor are not void, but only voidable. Their validity does not depend upon a ratification after the minor attains majority, but to avoid them he must by some act, clear and unmistakable in its character, disaffirm them. ${ }^{2}$ And so where an infant, after attaining majority, expressly revokes and disaffirms a deed made by him during minority, it may be disregarded, and the rights of the parties

120 Mo. 383, 25 S. W. 206 ; Donovan v. IVard, 100 Mich. 601, $59 \mathrm{~N}$. W. 254; Tyler v. Gallop, 6s Mich. 187,35 N. W. 902.

3. Langdon v. Clayson, i5 Mieh. $20 x, 42$ N. IV. 805; Lacy v. Pixler, 120 Mo. 383. 25 S. W. 206; Dolph v. Hand, 156 Pa. St. 91, 27 A. 114, 36 Am. St. Rep. 25.
1. Gregory v. Lee, 64 Conn. 407 , 30 A. 53; Englebert v. Troxell, 40 Neb. 195, 58 N. W. 852, 42 Am. St. Rep. 665.

2. Tunison v. Chamblin, ss $\mathrm{nl}$. 378; Irvine v. Irvine, 9 Wall. (U. S.) 617 ; Dixon v. Merritt, 21 Minn. 196. 
will be determined the same as if the deed had never been made. ${ }^{3}$

The right to disaffirm a contract of personal liability is absolute, and does not depend upon any other consideration than the obligations of that contract, ${ }^{4}$ and relates back to the time of contract $;^{5}$ such disaffirmance is final and the contract cannot be affirmed thereafter. ${ }^{6}$

And where an infant buys of another infant, and avoids the contract, the other may avoid the implied contract to return the purchase-money, so that there can be no recovery on the contract. Where, at the time one infant avoids a contract of purchase from another infant and the latter has spent the purchasemoney, he, also, having avoided his contract, is not liable for conversion. If an infant gets property by fraud, a different question then presents itself. ${ }^{s}$ Thus, where an infant procures the intoxication of a man and then tortiously receives possession of the man's cow, the man on coming to his senses may avoid the contract and bring trover against the infant where he has sold the cow and spent the money, upon the ground that the cow had been tortiously taken from him under a fraudulent contract. ${ }^{9}$

Formerly it was held that an infant, after the sale of his land, might enter and take the rents and profits until his majority, when he could affirm or disaffirm his sale. ${ }^{10}$ But that cannot be the law. In the first place he wonld not be allowed to enter the premises in possession of his grantee, and therefore could not

3. Mette v. Feltgen, 148 Ill. 357, 36 N. E. 81.

4. Leacox v. Griffith, 76 Iowa, 89, 40 న. W. 109.

5. French v. McAndrew, 61 Miss. 187; Rice v. Boyer, los Ind. 472, 9 N. E. 420 , $5 \mathrm{~S}$ Am. Rep. 53.

6. MeCarty v. Woodstock Iron Co., 92 Ala. 463, S So. 417; Ihley v. Padgett, 27 S. Car. 300,3 S. E. 468 .

7. Drude v. Curtis, 183 Mass. 317,67 N. E. 317. See, also, Slay- ton v. Barry, 175 Mass. $513,56 \mathrm{~N}$. E. 574, 49 L. R. A. 560, $7 \mathrm{~s} \mathrm{Am.} \mathrm{St.}$ Rep. 510, and cases cited; Carr v. Clough, 26 N. H. 280, 59 Am. Dec. 345 .

8. Walker v. Daris, I Gray (Mass.) 506.

9. Thurston v. Blanchard, 23 Pick. (Mass.) 18, 33 Am. Dec. 700.

10. Cummings v. Powell, $s$ Tex. su; Harrod v. Myers, 21 Ark. 592, $76 \mathrm{Am}$. Dec. 409. 
take the rents and profits. The must wait until he is of age. ${ }^{11}$ The deed of an infant is by no means inoperative, and transmits title with all of its incidents. ${ }^{12}$

The privilege of infaney is not always personal to the infant; and contracts, grants or deeds by a matter in writing, and which take effect by the delivery of his hands, are voidable not only by himself during his life time, but also by his heirs, or those who have his estate, after his decease; and his heirs may exercise the same right of disaffirmance within the same time that the infant himself might if living. ${ }^{13}$

The right to disaffirm the sale on eoming of age, is not lost by the sale of the land by the infant's grantee to an innocent purchaser. $^{14}$

An infant may be the subject of a petition in bankruptcy, if the debts from which discharge is sought, cannot be disaffirned by him on coming of age. ${ }^{15}$ But other cases hold that an infant eamnot be adjudged a bankrupt in either voluntary or involuntary proceedings $;^{16}$ but in these cases the debts from which release was sought could be disaffirmed, and it was intimated that a petition for discharge would be granted if the liability had been for necessaries. In England the question whether debts for necessaries will support a petition in bankruptey is an open one. $^{17}$

\section{$\$ 58$. May disaffirm contracts pertaining to personalty be-} fore majority. - While there is not entire harmony in the decisions upon the question whether a minor can avoid all his

11. Shipley r. Bumn, 125 Mo. 445,28 S. W. 754.

12. Irrine v. Irvine, 9 Wall. (U. S.) 617; Worcester v. Eaton, 13 Mass. 371.

13. Land and Loan Co. v. Bonner, 75 IlI. 315; Breckenridge v. Ormsby, 1 J. J. Marsh. (Ky.) 248; Austin v. Seminary, 8 Met. (Mass.) 203; Compare Jackson v. Burchin, 14 Johns. (N. Y.) 137.
14. Searcy v. Hunter, 81 Tex. 644, 17 S. W. 372,26 Am. St. Rep. 837.

15. In re Penzansky, 8 Am. B. R. 99.

16. In re Eidenmiller, 110 Fed. Rep. 594; In re Dugend, 100 Fed. Rep. 274 .

17. In re Saltykoff, 1 Q. B. 415. 
executory contracts, before he attains majority, he may avoid those relating to personal property in his minority. ${ }^{1}$ Executed contracts relating to land cannot be avoided until the infant comes of age. He may take possession of the land sold by him during infancy and enjoy the profits, and then upon attaining his majority may disaffirm the sale. ${ }^{2}$ But this is not the rule in all States. In Missouri a deed of a minor passes his estate in the land conveyed, subject only to be defeated by a disaffirmance by him. During infancy he camot disaffirm his deed, nor can he enter upon the land sold by him and enjoy its profit. $^{3}$

$\S 59$. What is a reasonable time to disaffirm. - Many of the States have answered this question by statutory provisions. But when not so answered, it is generally held that the time must be reasonable in respect to the special circumstances of each case. ${ }^{4}$ And if the voidable contract is not rescinded within a reasonable time after attaining majority, by the party who has come of age, when third parties' rights intervene, he will then be barred from aroiding it. ${ }^{5}$ But there are a few courts that hold that the infant on coming of age has a period equal to that

1. Bool v. Mix, 17 Wend. (N. Y.) 119, $31 \mathrm{Am}$. Dec. 285; Stafford v. Roof, 9 Cow. (N. Y.) 626; Chapin v. Shafer, 49 N. Y. 407; Sparman v. Keim, 83 N. Y. 245; Beardsley v. Hotchkiss, 96 N. Y. 201; Petric v. Williams, 68 Hun (N. Y.), 589, 23 N. Y. S. 237; State v. Plaisted, 43 N. H. 413; Adams v. Beall, 67 Md. 53, 8 A. 664, 1 Am. St. Rep. 379; Towle v. Dresser, 73 Me. 252; Rice v. Boyer, 108 Ind. 472, 9 N. E. 420, 58 Am. Rep. 53; Riley v. Mallory, 33 Conn. 207.

2. Baker v. Kennett, 54 Mo. 88 ; Welch v. Bunce, 83 Ind. 38\%; Shirk v. Shultz, 113 Ind. 571,15 N. E. 121 ; Stafford v. Roof, 9 Cow. (N. Y.) 626 ; Chandler v. Simmons, 97
Mass. 508, 93 Am. Dec. 117 and note.

3. Shipley v. Bunn, 125 Mo. 445, $2 S$ S. W. 754; Craig v. Van Bebber, 100 Mo. 584, 13 S. IV. 906, 1s Am. St. Rep. 569 and note; Harris v. Ross, 86 Mo. S9, 56 Am. Rep. 4l1; Peterson v. Laik, 24 Mo. 541, 69 Am. Dec. 441.

4. Amey v. Cockey. 73 MId. 297 , 20 A. 1071.

5. Ward v. Laverty, 19 Neb. 429 , 27 N. W. 393; Thormachlen v. Kaeppel, 86 Wis. $37 \mathrm{~S}, 57 \mathrm{~N}$. W. 29S: Dolph v. Hand, $156 \mathrm{~Pa}$. St. 91, 27 A. 174, 36 Am. St. Rep. 25; Goodnow v. Empire Lum. Co.. 31 Minn. 468, is N. 2\$3, 47 Am. Rep. 798. 
of the statute of limitations, in which to avoid his contract, and an acquiescence for a shorter period will not aftirm it. ${ }^{6}$

The better rule is that what is a reasomable time depends upon the circumstances of each particular case, and may be either for the comrt or for the jury to determine. ${ }^{\top}$ If the infant upon attaining his majority desires to repudiate his contract he must do so within a reasonable time; and he must be treated as knowing the contents of a deed whether he knew them or not, and if his repudiation is not made within a reasonable time, he is bound by the deed. ${ }^{8}$

$\$ 6$ o. In case of partnership contracts. - Where an infant enters into a partnership and continues until he attains majority, and then continues in the partnership, he will be liable for the debts of the firm. But he will not be liable personally for debts not affirmed, when they were made in his infancy as a member of the partnership. ${ }^{1}$ Where money is paid by a minor in consideration of being admitted as a partner, and does become and remain a partner for a given time, he ought not to be allowed to recover back the money thus paid unless he was induced to enter into the partnership by fraudulent representations of the other partners. ${ }^{2}$

An infant having entered into a partnership cannot repudiate his contract so as to escape the consequences of partnership which do not involve personal liability for claims against the firm or costs incident to the legal settlement of its affairs. Such partnership must be dissolved as any other, and partnership assets must be assignable to partnership creditors. ${ }^{3}$ And it is held that a min-

6. Prouty v. Wiley, 28 Mich. 164; Drake v. Ramsey, 5 Ohio, 251: Lacy v. Pixler, 120 Mo. 383, $25 \mathrm{~S}$. IV. 206; Richardson v. Pate, 93 Ind. 432 .

7. Goodnow v. Empire Lum. Co., 31 Minn. 468, 18 N. IV. 283, 47 Am. Rep. 798; O'Dell v. Rogers, 44 IVis. 136; Bingham v. Bailey, 55 Tex. 281, 40 An. Rep, 801.
8. Ewards v. Carter, Appeal Cases (1893), 360.

1. Bush v. Lintlicum, $59 \mathrm{Md}$. 345; Tobey v. Wood, 123 Mass. 88, $25 \mathrm{Am}$. Rep. 27 and note.

2. Adrms v. Beall, 67 Md. 53. 8 A. 664. 1 Am. St. Rep. 379; Ex parte Taylor, 8 DeG. Mac. \& Gor. 254.

3. Armitage r. Widoe, 26 Mich. 
or may avoid a personal liability by disaffirming a contract made by the firm of which he was a member without disaffirming the contract of partnership. ${ }^{4}$ But an infant coming of age, or before, may disaffirm the partnership agreement and also the debts of the firm so far as his personal liability is concerned. ${ }^{5}$ As to the creditors of the firm, his only immunity is, he cannot be held personally liable for the firm debts. ${ }^{6}$ He may thus throw the liability for the whole debts on his partners, and make such partners solely responsible, but the assets of the firm must be devoted to the satisfaction of the contracts by which they have been procured. Having placed the whole liability on the other partners, and having extricated himself by avoiding his contract, from all liability personally, it would be unjust to allow him to share in the assets of the firm as against the partnership creditors. ${ }^{7}$

$\S 6$ r. Rights of third persons. - Third persons are also bound by the avoidance of an infant's contract. So a bona fide purchaser from the rendee of an infant does not take title against the right of the minor at majority to disaffirm. ${ }^{8}$ When a voidable contract of an infant is disaffirmed by him it is made void $a b$ initio by relation and the parties remitted to the same situation as if the contract had not been made. If the contract is one of sale by the infant he becomes revested with his title to the property and may demand and recover it, not only of his vendee but of any other person who may have it in possession. The

124; Kitchen v. Lee, 11 Paige (N. Y.) 107, $42 \mathrm{Am}$. Dec. 101; Moley v. Brine, 120 Mass. 324; Furlong v. Bartlett, 21 Pick. (Mass.) 401. See, also, Shirk v. Shultz, 113 Ind. 571,19 N. E. 12.

4. Nehlhop v. Rae, 90 Iowa, 30, 57 N. W. 650 ; Compare Salinas v. Bennett, 33 S. Car. 285, 11 S. E. 968; Niller v. Sims, 2 Hill (S. Car.) 479 .

5. Mason v. Wright, 13 Met.
(Mass.) 306; Folds v. Allardt, 35 Mimn. 4S8, 29 N. W. 201 ; Todd v. Clapp, 118 Mass. 495.

6. Yates v. Lyon, 61 N. Y. 344 ; Pelletier v. Couture, 1ts Mass. 269, 19 N. E. 400,1 L. R. A. 863 and note.

7. Pelletier v. Couture, 148 Mass. 269,19 N. E. 400,1 L. R. A. $\$ 63$ and note.

8. Searey v. Hunter, S1 Tex. 614 , 17 S. W. 372, 26 Am. St. Rep. 837. 
right of an infant to aroid his eontract is an absolute and paramount right, superior to all equities of other persons, and may therefore be exercised against purchaser's from his rendee. ${ }^{9} \mathrm{He}$ who deals with an infant deals at his peril and subject to those rights of the infant to disaffirm and avoid the contract. This is the case even though he deal in ignorance of the infancy and on the fraudulent representation that he is of full age. ${ }^{10}$

§62. Contracts for service.- An infant can avoid his contract for service and recover a quantum meruit as if no contract had been made. So where an infant has performed labor on a special contract, which he afterwards abandons, he may recover for his services as if no such contract had been made. This is the true rule of law, and the parties are left to their legal rights and remedies just as if no contract had ever been made. ${ }^{1}$ The express contract to work a certain time does not control. ${ }^{2}$

However, where an infant seeks to avoid his contract and recover what his services are reasonably worth, the employer may set off against the ralue of the infant's services, the reasonable value of what the infant has received on account of such services. $^{3}$ Thus, when a minor repudiates his contract to work for two years, after working five months, and being paid by the month, he can recover no more than his equitable dues. What

9. Jenkins v. Jenkins, 12 Iowa, 195; Leacox v. Griffith, 76 Iowa, 89,40 N. W. 109 ; Myers v. Sanders, 7 Dana (Ky.) 506, 521 ; Hill v. Anderson, 5 Sinedes \& M. (Miss.) 216 ; Downing v. Stone, 47 Mo. App. 144; Miles v. Longerman, 24 Ind. 385.

10. Stack v. Cavanaugh, 67 N. H. 149. 30 A. 350 ; Conroe v. Birdsall, 1 Johns. Cas. 127, 1 Am. Dec. 105; Winkle v. Ketcham, 3 Caine's Cas. 323: Mustard v. Wohlford, 15 Grat. (Va.) 340.

1. Thompson v. Marshall, 50 Mo. App. 145; Vent v. Osgood. 19 Pick. (Mass.) 572; Vehne v. Pinkham, 60 Me. 142. See, also, Harrison v.
Burnes, 84 Iowa, 446, 50 N. W. 41.

2. Whitmarsh v. Hall, 3 Denio (N. Y.), 375; Robinson v. Weeks, it Me. 102 ; Dorecher v. Continental Mills, 58 Me. 217, 4 Am. Rep. 286; liay v. Haines, 52 Ill. 485; Price v. Furnam, 27 Vt. 268, 65 Am. Rep. 194.

3. Breed v. Judd, 1 Gray (Mass.) 45.5: Gaffney v. Hayden, 110 Mass. 137, 14 Am. Rep. 580; Hoxie v. Lincoln, 25 Vt. 206 ; Squier v. Hydliff, 9 Mich. 274; Spicer v. Earl, 41 Mich. 191, $32 \mathrm{Am}$. Rep. 152; Hall v. Butterfield, 59 N. H. 354, 47 Am. Rep. 209. 
he received is deducted from the value of the work done. ${ }^{4}$ The employer may set up a counter-claim for board and other necessaries furnished even to the extinction of the infant's claim ${ }^{5}$ but the employer cannot set up any damages for breach of the contraet. ${ }^{6}$ If the articles furnished are not necessaries, then the infant may repudiate the contract and recover for his serviees, and the employer cannot set off the amount thus paid the infant. $^{7}$

\$ 63. Contracts beneficial to infants. - Where the personal contract of an infant is fair and reasonable, and free from any fraid, overreaching, or mudue influence by the adult, and has been partly or wholly executed on both sides, so that the infant has enjoyed the benefit of it, but has parted with what he has received, or the benefits receired are of such a nature that he cannot restore them, he eannot recover back what he has paid; this is the rule held by the English and many American decisions. ${ }^{1}$ In Holmes v. Blagg, ${ }^{2}$ it was erroneously held that the infant could never recover back money voluntarily paid. This was obiter of the chief justice. It has been said that Corpe $v$. Overton, ${ }^{3}$ has overruled this case, but such is not the fact. Corpe v. Overton held that the infant might recover back what he had voluntarily paid, but on the ground that the contract in that ease remained wholly exeeutory on the part of the other party, and hence the infant had nerer enjoyed its benefits. And this

4. Hagerty v. Nashua Lock Co., 62 N. H. 576; Ray v. Haines, 52 Ill. 485; Spicer v. Earl, 41 Mich. 191; Gaffney v. Hayden, 110 Mass. 137.

5. Hoxie v. Lincoln, 25 Vt. 206 ; Roundy v. Thatcher, 49 .N. H. 526; Meredith v. Crawford, 34 Ind. 399.

6. Dorecher v. Continental Mills, 58 Me. 217, 4 Am. Rep. 286; Whitmarsh v. Hall, 3 Den. (N. Y.) 375 .

7. Morse v. Ely, 154 Mass. 458, 28 N. E. 577, 26 Am. St. Rep. 263.
1. Holmes v. Blagg, 8 Taunt. 508; Valentine v. Canali, 24 Q. B. Div. 166; Riley v. Mallor, 33 Conn. 206 ; Adams v. Beall, 67 Md. 53; 8 A. 664,1 Am. St. Rep. 379; Breed v. Judd, 1 Gray (Mass.) 455; Johnson v. Ins. Co., $56 \mathrm{Mlinn} .365,57 \mathrm{~N}$. IV. 934,59 N. IV. 992,26 L. R. A. 187, 45 Am. St. Rep. 473 and note; Compare. Chicago, etc., Asso. v. Hunt, 127 Ill. 278,20 N. E. 55.

2. 8 Taunt. 508.

3. 10 Bing. 252. 
doctrine of the text has been accepted by able writers. ${ }^{4}$ This doctrine does not apply to real property contracts. But, if the contract involved the element of actual frand or bad faith, the infant may recover all he paid or parted with; but if reasonable and fair, except that what the infant paid was in excess of the value of what he received, he may recover the excess, ${ }^{5}$ and the contract must be one which is deemed beneficial to the infant by law.

The majority of the American decisions have modified the rule thus given, and others have repudiated it in toto. They hold that although the contract was in all respects fair and reasonable, and the infant had enjoyed the benefits of it, yet if the infant had spent the money received, or if the benefits of it were of such a nature that they could not be restored, still he might recover back what he had paid. The courts seem to want to protect the infant from the improvidence incident to his youth and inexperience, ${ }^{6}$ But the late decision of the American courts are not uniform, and no definite rule can be stated. Every one who assumes to contract with an infant should be held to the utmost good faith and fair dealing. The disparity between the infant and the adult is such as to raise a presumption against the fairness of the contract, and to cast upon the adult party the burden of proving that it was a fair and reasonable one, and free from any fraud, undue influence, or overreaching. ${ }^{7}$ So an infant will be bound by a stipulation in his fire insurance policy, which provides that no suit shall be brought for the recovery of any lose,

4. See Chitty on Cont., p. 222; Leake on Cont., p. 553; 2 Kent's Com. 240; Reeve's Dom. Rel. chs. 2 and 3 ; Parsons states the law too broad, by omitting the qualification "and enjoys the benefit of it." Parsons on Cont., p. 322. The Illinois decision accords with Parsons' statement, Chicago, etc. Asso. v. Hunt, 127 IIl. 278,20 N. E. 55.

5. Johnson v. Ins. Co., 56 Minn. 375,57 N. W. 934, 59 N. W. 992, 26 L. R. A. 187,45 Am. St. Rep. 473 and note.
6. Bloomer v. Nolan, 36 Neb. 5l, 53 N. W. 1039, 38 Am. St. Rep. 690; Reynolds v. MeCurry, 100 Ill. 356, 39 Am. Dec. 39; Hawes v. Railroad Co., 64 Iowa, 315, 20 N. IV. 717 ; Englebert v. Troxell, 40 Neb. 195, $5 \mathrm{~S}$ N. W. 852, 42 Am. St. Rep. 665.

7. Johnson v. Ins. Co., 56 Minn. 365,57 N. W. 934,59 N. W. 992, 26 L. R. A. 187,45 Am. St. Rep. 473 and note; Charles v. Hastedt, 51 N. J. Eq. 171, 26 A. 564. 
unless commenced within twelve months after the destruction by fire of his building. Such a stipulation is entirely fair and equitable and will hold the minor. ${ }^{8}$

\$64. Return of consideration.- The authorities agree that if the infant had in specie what he received under the contract, he must restore it, as condition of recovering what he parted with. The disagreement in the authorities is in cases where the infant cannot restore the benefits he has received; where he has expended them, or they are of such a character that they cannot be restored.

The weight of authority is that when the infant's contracts are not for necessaries, he may aroid them at his election, and it is not necessary in order to do so to return the consideration received, to put the other party in statu quo, whether he has been benefited or not $;^{1}$ that if the infant has wasted or squandered the consideration or property during infancy, he can repudiate the contract without making a tender, ${ }^{2}$ But if he has the consideration in possession the other party may recover it. ${ }^{3}$

8. Mead. v. Phoenix Ins. Co. Brantly v. Wolf, 60 Miss. 420; (Kan.), 64 L. R. A. 79.

1. Fox v. Drewry, 62 Ark. 316, 35 S. W. 533; Chandler v. Simmons, 97 Mass. 508, 93 Am. Dec. 117 and note; Morse v. Ely, 154 Mass. 459, 28 N. E. 577, $26 \mathrm{Am}$. St. Rep. 263; Boody v. McKenney, 23 Me. 517; Price v. Furman, 27 Vt. 268, 65 Am. Dec. 194; Dube v. Beauding, 150 Mass. 448, 23 N. E. 222, 15 Am. St. Rep. 228; Snell v. Harris, 51 Ark. 294, 11 S. IV. 104.

2. Green v. Green, 69 N. Y. 553, 25 Am. Rep. 233: Chandler v. Simmons, 97 Mass. 508, $93 \mathrm{Am}$. Dec. 117 and note; Reynolds v. MeCurry, 100 Ill. 346; Brandon v. Brown, 106 Ill. 519; Crary v. Van Bebber, 100 Mo. 5\$4, 13 S. W. 106, 18 Am. St. Rep. 569 and note; Harvey v. Briggs, 68 Miss. 60,8 So. 274; Englebert v. Troxell, 40 Neb. 195, 58 N. W. 842, 42 Am. St. Rep. 665; Bloomer v. Nolan, 36 Neb. 51, 53 N. IV. 103, 38 Am. St. Rep. 690; Hawes v. Railroad Co., 6t Iowa, 315, 20 N. IV. 71 ; ; Carpenter v. Carpenter, 45 Ind. 142; Beddinger v. Wheaton, 27 Grat. (Va.) 857; Dawson v. Holmes, 30 Minn. 107, 14 N. W. 462 ; Gillespie v. Bailey, 12 W. Va. 7,29 Am. Rep. 445; Lacy v. Pixler, 120 Mo. 383, 25 S. IV. 206; Shirk v. Shultz, 113 Ind. 571,15 N. E. 12; Lemmon v. Beeman, 45 Ohio St. 505,15 N. E. 476 ; Young v. Railroad Co., 42 W. Va. 112,24 S. E. 615; Brawner v. Franklin, 4 Gill. (Md.) 463; Gibson r. Soper, 6 Gray (Mass.) 282, 66 Am. Dec. 414.

3. Badger v. Phinney, 15 Mass. 
In Texas it is indispensable to the disaffirmance by the infant on coming of age, that the consideration money for the property should be returned; that snch is the law of Spain and applied to Texas when it belonged to Mexico. ${ }^{4}$

The general rule is that the restoration of the consideration, even when he has it, is not a condition precedent to his right to avoid the contract. After disaffirmance, the infant is regarded as loolding the consideration, when he has it, in trust for the other party, who may recover it in any appropriate proceeding. ${ }^{5}$ And when the money is horrowed on a mortgage upon disaffirmance of the mortgage, a decree of sale may be entered upon foreclosure and the proceeds applied as follows:

1. Payment to the mortgagee, with interest, the sums paid by the mortgagee in discharge of the prior liens and the taxes upon the property. 2. Payment to the mortgagor or infant an amount equal to the value of the premises mortgaged at the institution of the suit to foreclose, less such prior liens and taxes, without interest on that amomnt, and without taking into consideration the value of the improvements placed on the lands. 3. Payment to the mortgagee such of the proceeds of sale as may remain, not exceeding the balance due on the loan, with interest.

If the property does not lring enough to pay the debt due the mortgagee, under the conditions stated, he will be without remedy for the deficiency. ${ }^{6}$

359, S An. Hec. 105; MacGreal v. Taylor, 167 U. S. 688,17 S. Ct. 961 ; Mustard v. Wohlford, 15 Grat. (Va.) 329, 76 Am. Rep. 209.

4. Cummings v. Powell, 8 Tex. 93; Kilgore v. Jordan, 17 Tex. 35 ; Stuart v. Baker. 17 Tex. 421 ; Bingham v. Barley, 55 Tex. 2S1, 40 Am. Rep. 801 .

5. Assoriation v. IJerman, 33 Md. 128; Cressinger v. Welch, 15 Ohio, 156; Badger v. Phinney, 15 Mass. 359, 45 Am. Dec. 565; Chandler v. Simmons, 97 Mass. 508, 93 Am. Dec. 117 and note; Tucker v.
Moreland, 10 Pet. (U. S.) 58; MacGreal v. Taylor, 167 U. S. 688,17 s. Ct. 961 .

6. MacGreal v. Taylor, 167 U. S. 6S8, 17 S. Ct. 961. See, also, Lynd v. McGregor, 13 Allen (Mass.) 182, $90 \mathrm{Am}$. Dec. 18s; Dellinger v. Foltz, 93 Va. 729, 25 s. E. 998; Darraugh v. Blackford, 84 Va. 509, 5 S. E. 542; Wilson v. Branch, 77 Va. 65, 46 Am. Rep. 709: Mustard v. Wohlford, 15 Grat. (Va.) $329,76 \mathrm{Am}$ Dec. 209; Bedinger v. Wharton, $2 \tau$ Grat. (Va.) 857 . 
$\S 65$. How affirmed or disaffirmed. - The general rule is that such contract may be affirmed hy mequivocally recognizing its continuing existence and binding force. So it may be aroided by some distinct and positive act, leaving no room for doubt as to the intention. It may be effected by notice of disaffirmance by snit, plea, or entry upon the land, or other unequirocal act or dissent, or of confirmation as the case may be. So a contract of purchase of land may be disaffirmed by the infant after attaining his majority by acts manifesting distinct and unequivocally an election and intention to disaffirm, by an act of distinct and positive dissent whatever may be its form or expression. ${ }^{1}$ A tenler is onl material and essential as a condition to the right of either party to sue and recorer in equity. ${ }^{2}$

It is at the election of the infant, after attaining majority, in cases of real contracts, to affirm or disaffirm the contract. Something must be done which expresses the purpose of the grantor to abide by the conveyance; mere acquiescence or passiveness will not have the effect, unless the rendee, with the knowledge of the grantor, is making expenditures on the property as he would not make, unless absolute owner. ${ }^{3}$

A mortgage made during infancy may be affirmed by a conreyance after majority to a third person subject to the mortgage. But such a deed which does not refer to the mortgage is rather a disaffirmance. ${ }^{4}$ Entry will avoid the deed; but entry is not necessary in most of the States to avoid the deed. ${ }^{5} \mathrm{~A}$ voidable deed may be confirmed by a recital in a subsequent deed, with a design to ratify. ${ }^{6}$ A clanse in a will directing the payment of all just debts does not impose on the executor liability for the testator's note made during infancy. ${ }^{7}$

1. Drake v. Ramsey, 5 Ohio, 251.

2. Tunison v. Chamblin, 88 Ill. 378; Singer Mach. Co. v. Lamb, 81 Mo. 22; MeCarty v. Woodstock Iron Co., 92 Ala. 463 , 8 So. 417.

3. Wheaton. v. .East, 5 Yerg. (Tenn.) 41, 62, 26 Am. Dec. 251; Allen v. Poole, 54 Miss. 323.

4. Allen v. Poole, 54 Miss. 323;
Boston Bank v. Chamberlin, 15 Mass. 220 .

5. See. Pingrey's Real Prop., $1: 85$.

6. Phillips v. Green, 5 Mon. (Ky.) 344.

7. Smith v. Mayo, 9 Mass. 62,6 Am. Dec. 28. See, also, Upshaw v. Gibson, 53 Miss. 341; Compare Mer- 
A new promise, positive and precise, is not now essential; but a ratification of what was done during minority, is sufficient to make the contract obligatory. All that is necessary is that the infant, after attaining his majority, shall expressly agree to ratify his contract by words, oral or in writing, or by acts which import a recognition and a confirmation of his promise. ${ }^{8}$

So if an infant, after attaining majority, retains the property purchased by him during minority, for his own use, or sells or otherwise disposes of it, such detention, use or disposition, which can be conscientiously done only on the assumption that the contract of sale was a valid one, and by it the property became his own, is evidence of an intention to affirm the contract, from which a ratification may be inferred, when he purchases land and goes into possession and continues in possession after his majority, for he thereby affirms the purchase and ratifies the contract of sale. ${ }^{9}$ A suit to enforce a contract is an affirmance of it. $^{10}$ If he brings suit for the purchase-money, after becoming of age, this is a disaffirmance of his contract. ${ }^{11}$ Executing a warranty deed to a third party is a disaffirmance of his deed. ${ }^{\mathbf{1 2}}$

$\S 66$. Who may avoid.- Infancy is a personal privilege, and can only be set up by the party himself and not by the other party to avoid contracts and set aside titles made by him, ${ }^{1}$

chants' Fire Ins. Co. v. Grant, 2 Edw. (N. Y.) 544.

8. Whitney v. Dutch, 14 Mass. 460, 7 Am. Dec. 229 and note; Hartley v. Wharton, 11 Adol. \& El. 934; Harris v. Wall, 1 Exch. 122; Goodsell, v. Myers, 3 Wend. (N. Y.) 479; Delano v. Blake, 11 Wend. (N. Y.) 85, 26 Am. Dec. 617.

9. Henry v. Root, 33 N. Y. 526 ; Boyden v. Boyden, 9 Met. (Mass.) 519; Hubbard v. Cummings, 1 Me. 11; Boody v. McKenney, 23 Me. 517: Robbins v. Eaton, 10 N. H. 561 ; Ellis v. Alford, 64 Miss. 8, 1
So. 155; Buchanan v. Hubbard, 119 Ind. 187, 21 N. E. 538; Callis v. Day, 38 Wis. 643.

10. Ferguson v. Bell, 17 Mo. 347; Morrill v. Aden, 19 Vt. 505; Compare Kendrick v. Niesz, 17 Colo. 506, 30 P. 245.

11. Stack v. Cavanaugh, $67 \mathrm{~N}$. H. 149,30 A. 350 .

12. Scott v. Brown, 106 Ala. 604,17 So. 731 .

1. Alsworth v. Cordtz, 31 Miss. 32: Hartness v. Thompson, 5 Johns. (N. Y.) 100; Baldwin v. Rosier, 48 Fed. Rep. 810. 
and his personal representatives. ${ }^{2}$ An infant's contract cannot be aroided by other partics in collateral proceedings. ${ }^{3}$ And as the privilege is for the benefit of the infant, it passes to his heirs or personal representatives." Privies in blood may take advantage of this privilege, but it does not pass to privies of estate merely with the infant. ${ }^{5}$ A lease executed by an infant cannot be avoided by the lessce by scting up the disability of the lessor. ${ }^{6}$

An individual creditor eannot attach property conreyed by a debtor while a minor, the conveyance of which such debtor might have disaffirmed, and thus arail himself of the infant's privilege. $^{7}$ Voidable acts by an infant, or matters of record

2. Patterson v. Lippincott, $47 \mathrm{~N}$. J. L. 457, 1 A. 516, 54 Am. Rep. 178; Towle v. Dresser, 73 Me. 252; Hastings v. Dollarhide, 24 Cal. 195; Davies v. Turton, 13 Wis. 185; Putnam v. Hill, 32 Vt. 85 ; Monaghan v. Ins. Co., 53 Mich. 238, 18 N. 797 ; Parsons v. Hill, S Mo. 135; Person v. Chase, 37 Vt. 650 ; Smith v. Mayo, 9 Mass. 62, 6 Am. Dec. 28; Breckenridge v. Ormsby, 1 J. J. Marsh. (Ky.) 236, 248, 19 Am. Dec. 71.

3. Winchester v. Thayer, 129 Mass. 129; Doane v. Covel, 56 Me. 527 ; Holmes v. Rice, 45 Mich. 142, 7 N. 712; Sparman v. Keim, 83 N. Y. 245; Chapin v. Shafer, 49 N. Y. 407 ; Walsh v. Powers, 43 N. Y. 23, 3 Am. Rep. 654; Henry v. Root, 33 N. Y. 526, 536, 443 ; Emerson v. Carpenter, 17 Wend. (N. Y.) 419; Taft v. Sergeant, $1 \overline{8}$ Barb. (N. Y.) 320; Berdsley v. Hofchkiss, $96 \mathrm{~N}$. Y. 201; Harris v. Ross, 112 Ind. 314, 13 N. E. S73; Hooper r. Payne, 94 Ala. 223, 10 So. 431; Dentler v. O'Brien, 56 Ark. 49, 19 S. W. 111 ; Keane v. Boycott, 2 H. Bl. 511.
4. Dinsmore v. Webber, 59 Me. 103 ; Persons v. Chase, 37 Vt. 650; ITilson v. Porter, 13 La. Ann. 407; Nolte v. Libbert, 34 Ind. 163 ; Parsons v. Hill, 8 Mo. 135; Bozeman v. Browning, 31 Ark. 364; Veal v. fortson, 57 Tex. 482; Harris v. Loss, 86 Mo. 89, 50 Am. Rep. 411; Nharp v. Robertson, 76 Ala. 343 ; Harvey v. Briggs, 68 Miss. 60, 8 So. 27,10 L. R. A. 82 ; Searcy v. Hunter, 81 Tex. 644,17 S. IT. 373,26 Am. St. Rep. 837; Illinois L. \& Loan Co. v. Ponner, 75 111. 315.

5. Harris v. Ross, 112 Jnd. 314, 13 N. E. 873; Shrock v. Cowl, 83 Ind. 243; Gillenwaters v. Campbell, 142 Ind. 529, 41 N. E. 1041 ; Price ฯ. Jenuings, 62 Ind. 111; Singer Mach. Co. v. Lamb, Sl Mo. 221; Compare Beeler v. Bullett, 3 A. K. Mars. (Ky.) 280, $13 \mathrm{Am}$. Dec. 161; Taekson v. Burchim, $1+$ Johns. (N. Y.) 124; Walton $v$. Gaines, 94 Tenn. 420, 29 S. WV. 458.

6. Field v. Herrick, 101 Ill. 110.

7. Kingman v. Perkins, 105 Mass. 111; Kendall v. Lawrence, 22 Pick. (Mass.) 540; MeCarty v. Murray, 3 Gray (Mass.) 578. 
done or suffered by him, can be avoided by none but himself or his privies in blond, and not hy privies in estate; and this right of avoidance is not assignable. ${ }^{8}$ And hence an assignee in insolvency cammot avoid a nortgage on real estate given by an infant, and not ratified or disaffimed by lim after attaining his majority. ${ }^{9}$

The fact that the infant may rescind without returning the consideration when he has squandered it, and has received no benefit from the contract, indicates the right is strictly a personal pririlege, and that, as the rule permitting him thus to aroid his contract is established solely for his protection, so he alone also can have the benefit of it, and this privilege will not pass to his assignee in insolvency.

But an absolute gift of articles of chattels made by an infant can be revoked or avoided by him or by his administrator, ${ }^{10}$ because the administrator is a personal representative of the deceased infant. But a person of full age contracting with an infant is bound absolutely although the infant has a right to avoid the contract. ${ }^{11}$ A holder of an infant's note must demand payment in order to hold the endorser. ${ }^{12}$

8. Austin v. Charlestown Seminary, 8 Met. (Mass.) 196, 203, 41 Am. Dee. 497 ; Wettingham's Case, 8 Co. $42 \mathrm{~b}, 43 \mathrm{a}$.

9. Mansficld v. Gordon, 144 Mass. 168,10 N. E. 773.

10. Person v. Chase, $37 \mathrm{Vt} .647$, 88 Am. Dec. 630; Hussey v. Jewett, 9 Mass. 100 ; Jefford v. Ringgold, 6 Ala. 544; Parsons v. Hill, 8 Mo. 135.

11. Holt v. Clarencieux, Strange,
937 ; Field v. Herrick, 101 Ill. 110; Johnson v. Rockwell, 12 Ind. 76; Cammon v. Olsburg, I A. K. Marsh. (Ky.) 76, 10 Am. Dec. 709; Monaghan v. Ins. Co., 53 Mich. 238, 18 N. W. 797 ; Bruce v. Warwick, 6 Taunt. 118; Thompson v. Hamilton, 12 Pick. (Mass.) 425, 23 Am. Dec. 619.

12. Wyman v. Adams, 12 Cush. (Mass.) 210 . 


\section{ARTICLE IV.}

Estoppel of Infant by His Deceit.

Section 67. Misrepresentation as to Age.

68. Tort Growing Out of Contract Relations.

69. Actions Ex Delicto

70. In Equity.

71. Actions to Avoid Contracts.

\$67. Misrepresentations as to age.- It is the general rule at common law that simple misrepresentations by the infant, whereby the impression is conveyed that he is of age will not estop him from avoiding his contract. ${ }^{1}$

But if a tort arises from a breach of contract, although there may have been false representations or concealment respecting the subject-matter of it, the infant cannot be charged for this breach of his promise or contract by a change of the form of action. But if the tort is subsequent to the contract, and not a mere breach of it, but a distinct, willful, and positive wrong of itself, then, although it may be counected with a contract, the infant is liable. So an infant is liable for deceit in falsely representing himself to be of age, and thereby inducing a party

1. Cobbey v. Buchanan, 48 Neb. 391, 67 N. W. 176; Alt v. Grafl, 65 Minn. 141, 68 N. W. 9; Wieland v. Kobick, 110 Ill. 16, 51 Am. Rep. 676 ; Stack v. Cavanaugh, 67 N. H. 149, 30 A. 350; Lockman v. Wood, 25 Cal. 147 ; Conrad v. Lane, 26 Minn. 386, 4 N. 695; Studwell v. Snapter, 54 N. I. 249 ; Sims v. Everhardt, 10: U. S. 300 ; Whitcomb v. Joslyn, $51 \mathrm{Vt}$. 79, $31 \mathrm{Am}$. Rep. 678; Barnes v. Toye, 13 Q. B. Div. 410; Johnson v. Lines, 6 Watts \& S. (Pa.) 80, $40 \mathrm{Am}$. Dec. 542; Monumental Asso. v. Herman, 33 Md. 15̄1; Sewell v. Sewell, 92
Ky. 500, 18 S. W. 162, 36 Am. St. Rep. 60:; Nash v. Jewett, 61 Vt. 501, 18 A. 97, 4 L. R. A. 561 and note; $15 \mathrm{Am}$. St. Rep. 931 ; Merriam v. Cunningham, 11 Cush. (Mass.) 40; Gilson v. Spear, 38 Vt. 311, 89 Am. Dec. 659; Brown v. McCune. 5 Sand. (N. X.) 224, 228; Curtin v. Patten, 11 Serg. \& R. (Pa.) 305; Burlett v. Williams, 30 Fed. Rep. 607; Burley v. Russell, 10 N. H. 184, 34 Am. Dec. 146 ; MeKaney v. Cooper, 81 Ga. 679, 8 S. E. 312 ; Eaton v. Hiil, 50 N. 11. 235. 9 Am. Rep. 189; Selinell v. Chicago, 38 Ill. 383,87 Am. Dec. 364 . 
to sell him goods on credit, and afterwards avoiding his promise to pay by pleading infancy. ${ }^{2}$ So an infant who represents himself to be of age as an inducement to one to purchase land, will be estopped by such fraudulent representation from having a court of equity cancel his deed. ${ }^{3}$ That is, the representation made by the infant must be frandulent and be believed and relied on and aeted upon by the other party; then the infant is estopped from avoiding his contract. ${ }^{4}$

\$ 68. Tort growing out of contract relations. - So the majority of the decisions holds that if the wrong grows ont of eontract relations, and the real injury ennsists in the non-performance of the contract into which the party wronged has entered with an infant, the law will not permit the former to enforce the contract indirectly by counting on the infant's neglect to perform it, or omission of duty under it as a tort. ${ }^{5}$ So, as held by some courts, an infant is not liable for the value of the property obtained by means of misrepresentations. ${ }^{6}$

The doctrine that an infant is not estopped by the misrepresentation that he is of age, when such misrepresentations are not fraudulent per se, is based upon the principle that one under the disability of infancy has no power to remove the disability by such representation, when he does not commit a fraud. ${ }^{7}$

2. Fitts v. Hall, 9 N. H. 44I; I'rescott v. Norris, 32 N. H. 103.

3. Ryan v. Growney, 125 Mo. 474 , 28 S. W. 1S9; Schmitheimer v. Eiseman, 7 Bush. (hy.) 298; Patterson v. Lawrence, 90 111. 174, 32 Am. Rep. 22; Adams v. Fite, 3 Baxt. (Tem.) 69; Carpenter v. Carpenter, 25 N. J. Eq. 194; Ferguson r. Bobo. 54 Miss. 121; Hayes 511 ; Orerton v. Banister, 3 Har. 511 ; Orerton r. Banister, 3 Hose, 503; Campbell v. Riugeley. 13 Tict. Law R. (Austral.) 701.

4. Baker r. Stone, 136 Mass. 405 ; Cobbey v. Buchanan, 48 Neb. 391,
67 N. W. Rep. 176; Pemberton Build. L. Asso. v. Adams, $53 \mathrm{~N}$. J. Eq. 25S, 31 A. 280. The civil law makes the minor responsible for misrepresentations as to Mis age. Kilgore v. Jordan, 17 Tex. 341: Carpenter v. Pridgen, 40 Tex. 32.

5. Cooley on Torts, 106, 107; Adlison on Cont. 1314.

6. Howlett v. Haswell, 4 Camp. 118; Studwell v. Shapter, 54 N. Y. 249; Vasse v. Smith, 6 Cranch (U. S.), 226; Green v. Greenbank, 2 Marsh. 485, 4 Kng. Com. L. 375.

7. Carpenter r. Carpenter, 45 
So an infant is not liable for injury to property in his possession under contract of sale, if it is cansed solely by his ignorance or want of skill. ${ }^{s} \mathrm{Nor}$ is an infant liable for negligence in the performance of a contract for threshing grain, as a consequence of which there was a fire causing much loss. ${ }^{9}$

In England, misrepresentations as to his age or other matters, by which he obtains a contract, are insufficient to make an infant liable, for the reason that this would be really an enforcement of the contract, and that the deception is a part of the contract. Massachusetts and Maryland hare adopted the English rule. But the great weight of authority in the United States is contrary, and the infant is liable for such contract, and is estopped to set up his infancy. In Iowa, Kansas, Utah, and Washington, the infant is estopped to disaffirm his contracts where on account of misrepresentations as to his majority, or from his having engaged in business as an adult, and the other party had good reasons to believe him capable of contracting.

As to estoppel of an infant there are two classes of cases: 1. Where, in an action on a contract induced by the frandulent misrepresentations that he was of age, and he sets up infancy as a defence. 2. Where he has given a deed of property, or executed a release for money due him, and then seeks to recover the property, or compel a second payment, upon the ground that he has elected to disaffirm his deed or contract of sale, or release, upon reaching his majority. Under the first class the weight of authority is, he is not estopped to avoid his contract, because es toppel would have the effect of validating the contract, against the policy of the law. Is to the second class, the weight of authority in the United States is that he is estopped.

An infant's misrepresentations as to the property which he

Ind. 142; Sims v. Everhardt, 102 U. S. 300 ; Whitcomb v. Joslyn, 51 Vt. 79, 31 Am. Rep. 67s; Wieland v. Koblick, 100 Ill. 16; Conrad v. Lane, 26 Minn. 359, 4 N. 695, 37 Am. Rep. 412 and note.
8. Stack v. Cavauaugh, 67 N. H. 149,30 A. 350 .

9. Lowery r. Cate, 108 Tenn. 5t, 64 S. W. 1068, 57 L. R. A. 673 and note reviewing the American and English cases, 91 Am. St. Rep. 744 . 
sclls are regarled as part of the contract, for which he cannot be held liable. For injuries which an infant does to property in his hands as hailee, he is held not to be responsible, if the damages are occasioned simply by negligence, but if he damages the property by intentional wrong, he is held in most of the States liable, notwithstanding any stipulation to the contrary. For refusal to deliver goods which he has in his possession, he is liable. In contracts other than bailments the distinction between mere negligence and deliberate wrongs is applied.

$\$ 69$. Actions ex delicto. - So if the infant frandulently and falsely represents that he is of full age, he is liable, by the weight of authority, in an action ex delicto for the injury resulting from his tort. This result does not involve a riolation of the principle that an infant is not liable where the consequences would be an indirect enforcement of the contract, for the recovery is not upon the contract, as that is treated as of no effect; nor is he made to pay the contract price of the goods purchased by him, as he is only held to answer for the actual loss caused by fraud; he is guilty of a frand by false pretenses, for which he is to answer under the criminal laws. ${ }^{1}$ This doctrine concedes the power of the infant to avoid his contract, but affirms that he must answer for his positive fraud. ${ }^{2}$

Under the civil law, if a minor represents himself to be of age, and from his person he appears to be so, he will be bound by any contract, made with him, ${ }^{3}$ and this is the law, by statute, in Iowa, ${ }^{4}$ Kansas, ${ }^{5}$ Utah and Washington.

Infants are liable for frauls and torts to the same extent as adults, and where actions ex delicto are brought to make them

1. Neff v. Landis, 110 Pa. St. 204, 1 A. 177, 56 Am. Rep. 260.

2. Rice v. Boyer, 108 Ind. 472. 9 N. E. 420, 58 Am. Rep. 53; IVallace v. Morss, 5 Hill (N. Y.), 391 ; Manning v. Johnson, 26 Ala. 446, 62 Am. Dee. 732 and note; Badger v. Plinney, 15 Mass. 359,8 Am. Dec. 105.
3. Kilgore v. Jordan, 17 Tex. 341 .

4. Iowa Code, 2239; Childs v. Dobbins, 55 Iowa, 20̄, 7 N. 496 ; Jaques v. Sax, 39 Iowa, 367; Prouty v. Edgar, 6 Iowa, 353.

5. Comp. L. el. 67 , sec. 3 ; Dillon v. Burnham, 43 Kans. 77, $22 \mathrm{P}$. 1016 . 
answerable therefor, they cannot escape the consequences of their acts, by reason of the fact that the tort or fraud was connected with a contract, unless it constituted the consideration of it. Whenever it does constitute the basis of the contract, as in an action for a breach of a fraudulent warranty, it cannot be changed into a tort in order to charge the infant in trover or case by a change in the form of the action. ${ }^{6}$ But where goods are obtained by a minor upon the false affirmation that he was of age, the fraud vitiates the contract, and no title will rest in the infant, and he may be treated as having unlawfully converted them, and may be sued in trover or replevin. ${ }^{7}$

In some of the cases it is held that by a positive and willful tort in case of bailment, the bailment is determined and the remedy must be by action of trespass or trover, and that ease will not lie $;^{8}$ because the action on the case necessarily supposes the defendant or infant to have a right to the possession of the property, under the contract of hiring or other bailment, at the time the injury was committed, and by declaring in case the adult affirms the existence of the contract, and the plea of infancy will be a good defense to such action. ${ }^{9}$ This doctrine is assailable. If a wrong has been done to the property bailed of such nature that an action on the case would ordinarily lie, and at the same time an infant would be liable for it in any form of action, no reason exists for holding that case would not lie against the infant. In bringing an action on the case setting out such a positive and willful tort as is wholly inconsistent with the contract of bailment, and amounts to a disaffirmance of it, it may fairly be inferred that the plaintiff elects to consider

6. In re King, 3 DeG. \& J. 63 ; Ferguson v. Bobo, 54 Miss. 121; Rice v. Boyer, 108 Ind. 472,9 N. E. 420, 58 Am. Rep. 53. See, also, Humphrey v. Douglass, $10 \mathrm{Vt}$. 71, $33 \mathrm{Am}$. Dec. 177 and note; Lewis v. Littlefield, 15 Me. 233; Wallace v. Morss, 5 Hill (N. Y.), 391 ; Walker v. Davis, 1 Gray (Mass.) 506; Hower v. Thwing, 3 Pick. (Mass.)
492; Oliver v. MeClellan, 21 Ala. 675.

7. Badger v. Phinney, 15 Mass. 359,8 Am. Dec. 105; Story on Cont. 107, 111.

8. Campbell v. Stakes, 2 Wend. (N. Y.) 137, 19 Am. Dec. 561.

9. Jennings v. Rundall, 8 Term R. 335; Green v. Greenbank, 2 Marsh. 485, 4 Eng. C. Law, 375. 
the bailment at an end, and this applies to an action on the case for a tort which disaffirms the contract, the same as to trespass or trover; the latter is indeed but a subdivision of actions upon the case. Therefore, case should lie against an infant for a positive and willful tort of such a nature that, upon general principle of pleading, case is a proper remedy. ${ }^{10}$

If and infant receives goods on a contract, and disposes of the property without right, he is liable in trover. ${ }^{11}$

An infant bailee of a horse is not liable for treating him negligently or riding him immoderately, but is liable if he goes to a different place, or beats the animal to death $;^{12}$ or if he has hired a horse, and willfuly and intentionally injures the animal, trespass will lie against him, or if he does any willful or positive act which amounts to a disaffirmance of the contract; but if he neglects to use him with ordinary eare, or to return him at the time agreed upon, he is not liable. ${ }^{13}$

In a civil suit for seduction under a promise of marriage, the infant seducer cannot set up his infancy as a defense, for the seduction is a tort irrespective of the promise. ${ }^{14}$ There is no enforcement of a promise where an infant who has been guilty of a positive frand is made to answer for the actual loss his wrong has caused to one who has dealt with him in good faith and has exercised due diligence. This does not apply to executory contracts which an infant refuses to perform, for, in such case, the action would be on the promise, and the only recovery that could be had would be for the breach of contract; but it will apply where an infant, on the faith of his false and fraudulent representations, obtains property from another and then repudiates his contract. Any other rule would generally suffer an infant of discretion, guilty of fraud, to escape loss, although

10. Eaton v. Hill, 50 N. H. 235 , 9 Am. Rep. 3.89.

11. Vasse v. Smith, 6 Cranch (U. S.) 231 ; Campbell v. Stakes, 2 Wend. (N. Y.) 137, 19 Am. Dee. 561 ; Mill 3 v. Graham, 1 Bos. \& P. N. R. 140.
12. 2 Greenl. on Ev. 368 .

13. Campbell v. Stakes, 2 IVend. (N. Y.) 137, 19 Am. Dee. 561; Towne v. Wiley, $23 \mathrm{Vt}$. 359, $56 \mathrm{Am}$. Dec. 85.

14. Becker v. Mason, 93 Mich. 336, 33 N. IV. 361 . 
his frand had enabled him to secure and make way with the property of one who had trusted in good faith to his representations, and had exercised due care and dilegence. ${ }^{15}$

$\S 70$. In equity.- In law it is conclusirely presumed that a person within the age of twenty-one years is unfitted for business, and that every contract into which he enters is to his disadvantage, and that he is incapable of fraudulent acts which will estop him from interposing the shield of infancy against the enforcement, ${ }^{1}$ but he is certainly liable in an action $e x$ delicto for the injury resulting from his tort, ${ }^{2}$ provided the in. fant has arrived at such years of discretion that fraud may fairly be imputed to him. ${ }^{3}$

In equity this rigid rule of non-estoppel has its exceptions. Equity regards the circumstances surrounding the transaction, the appearance of the minor, his intelligence, the character of his representations, the advantage he has gained by the fraudulent representations, and the disadvantage to which the person deceived has been put by them, in determining whether the infant should be permitted to invoke successfully the plea of infancy. ${ }^{4}$ Therefore, whenever an infant, who has arrived at the years of discretion, by direct participation, or by silence when he was called upon to speak, has entrapped a party, ignorance of his title or of his minority, into purchasing his property of another, he will be estopped in a court of equity from setting up such title. ${ }^{5}$

In the code States, a court cannot deny substantial justice

15. Badger v. Phinney, 15 Mass. 359, 8 Am. Dec. 105; Mustard v. Wohlford, 15 Gratt. (Va.) 3:9, 76 Am. Dec. 209; Vasse v. Smith, 6 Cranch (U. S.), 226.

1. Johnson v. Pie, l Lev. 169; Price v. Hewett, 8 Exch. 146; Liverpool, etc. Asso. v. Fairhurst, 8 Exch. 422; Gilson v. Spear, 38 Vt. 311, 88 Am. Dec. 659: Homer v. Thwing, 3 Pick. (Mass.) 492; Curtin v. Patten, 11 Serg. \& R.
(Pa.) 305 ; Jennings v. Rundell, 8 Term R. 335.

2. Rice v. Boyer, 108 Ind. 472, 9 N. E. 420, 58 Am. Rep. 53; 2 Kent's Com. 241; Vasse v. Smith, 6 Cranch (U. ১.), 226.

3. Watts v. Creswell, 9 Vin. Abr. 415, 3 Eq. Cas. Abr. 515.

4. Hayes v. Parker, 41 N. J. Eq. $630,631,7$ A. 511 .

5. Ferguson v. Bobo, 54 Miss. 121; Curry v. Plow Co., 55 Ill. 
becanse the complaint states a cause of action in a peculiar form, for the court is bound to render such a judgment as yields justice to those who invoke its aid, irrespective of mere forms, in all cases where the substantial facts are stated, and are such as entitle the party to the general relief sought. It will not. inquire whether the proceeding which asks its aid is at law or in equity, but it will render justice to those who ask it in the method prescrilued by the Code of Civil Procedure.

$\S 7$ r. Actions to avoid contracts. - In law, if the infant attaining majority, avoids his contracts, he must restore the consideration, or so much of it as he has, on demand. If the entract is excented, then in asserting his claim he must become the actor, and so going into count for equity he must do equity as a condition on which relief will be decreed him. This is the difference between asking and resisting relief, and he must tender the consideration or so much as he has. ${ }^{1}$ If the suit be at law, the tender of the consideration need not be made as a condition precedent of recovering property he had disposed of. If the suit be in equity that he brings, and if the money or consideration be in esse, and in his possession, or in him from whom the right to sue is derived, the bill, to be sufficient, must tender, or offer to produce or pay as the case may be. But if the quandam infant has, during minority, squandered or used the consideration, then no teuder need be made. ${ }^{2}$

App. 82; 2 Pom. Eq. 945; Ex parte Unity, ete., Asso., 3 DeG. \& J. 63; Charles v. Hastedt, 51 N. J. Eq. 171, 26 A. 564; Bradshaw v. Van Winkle, 133 Ind. 134, 32 N. E. 877 ; Lacy v. Pixler, 120 Mo. 383, 25 S. W. 206 ; Evans v. Morgan, 69 Miss. 328, 12 So. 270; Thormachlen v. Kaeppel, 86 Wis. 378,56 N. W. 1089 ; Pemberton Build. \& I. Asso. v. Adams, 53 N. J. Eq. 258, 31 A. 280 ; United States, ete., Investment Co. v. Harris, 142 Ind. 226, 40 N. E. 1072,41 N. E. 451 ; Stack v. Cavanaugh, 67 N. H. 149, 30 A. $3 \tilde{0}$; Johnson v. Ins. Co., 56 Minn. 365,57 N. W. 930,59 N. W. 992, 26 L. R. A. 18, 45 Am. St. Rep. 473 and note.

1. Smith v. Evans, 5 Humph. (Tenn.) 70; Bartholomew v. Finnemore, 17 Barb. (N. Y.) 428; Hillyer v. Bennett, 3 Edw. (N. Y.) 222; Mustard v. Wohlford, 15 Gratt. (Va.) 329, 76 Am. Dec. 209 ; Bedinger v. Whorton, 27 Gratt. (Va.) 857.

2. Eureka Co. v. Edwards, 71 
Hence, where an infant has executed a deed to lands sold by him, and receired and consumed the purchase-money during his infancy, a bill averring this fact, filed by one claiming the land under a deed executed by the infant, after he had attained majority, to have the first deed canceled as a cloud upon his title, need not tender back the purchase-money received by the infant. $^{3}$ And the fact that the last purchaser had notice of the first deed given by the infant is immaterial, because the disaffirmance of the first deed destroyed all claims, both legal and equitable, and left him no pretense or any equity to assert against the later purchaser ${ }^{4}$ the second grantee in such case stands in the shoes of his grantor and can set up the right of the latter to avoid his deed after coming of age. ${ }^{5}$

\section{ARTICLE V.}

\section{Guardian's Right to Contract for His Ward.}

Section 72. Guardian's Right to Contract for His Ward.

73. Guardian's Capacity to Contract for Ward.

74. Guardian's Title to the Ward's Property.

75. Personal Liability of the Guardian.

$\S 72$. Guardian's right to contract for his ward.- A guardian has no authority whatever to bind either the person or the estate of his ward by contract. For any reasonable expenditure made by a guardian, out of his own means, for the benefit of

Ala. 248, 76 Am. Rep. 314; Goodman v. Winter, 64 Ala. 410, 38 Am. Rep. 13; Badger v. Phinney, 15 Mass. 359, 8 Am. Dec. 105; Price v. Furman, 27 Vt. 268, $65 \mathrm{Am}$. Dec. 194; Green v. Green, 69 N. Y. 553, 25 Am. Rep. 233; Phillips v. Green, 5 T. B. Mon. (Ky.) 344; Roberts v. Wiggin, 1 N. H. 73, 8 Am. Dec. 38; Walsh v. Young, 110 Mass. 396 ; Dill v. Bowen, 54 Ind. 204;
Mustard v. Wohlford, 15 Gratt. (Va.) 329, 76 Am. Dec. 209; Bartlett v. Drake, 100 Mass. 174, il Am. Rep. 101.

3. Eureka Co. v. Edwards, 71 Ala. 248 .

4. Eureka Co. v. Edwards, 71 Ala. 248, 46 Am. Rep. 314.

5. Mustard v. Wohlford, 15 Gratt. (Va.) 329, 76 Am. Dec. 209. 
his ward, he is entitled to be reimbursed out of the ward's estate, but this is the limit of the ward's liability, in law or equity. The guardian has no authority or capacity to impose contract obligations on his ward. What he does for his ward must be done under the conrt of competent jurisdietion. ${ }^{6}$ IIence, a guardian has no power to bind either the person or the estate of his ward by contract, ${ }^{7}$ even when made in his capacity as guardian. ${ }^{s}$

At common law a guardian was regarded as a trustee, clothed with such powers and rights as were necessary for the discharge of the trust imposed upon him, and he was held accountable for the faithful diseharge of his duties. At the present time a guardian's duties are prescribed by statute, which must be consulted in each State to know his duties and rights. He is under the probate court which approves or disapproves his transactions in dealing with the ward; and with this court he makes his final settlement and is discharged when his accounts are satisfactory.

$\S 73$. Guardian's capacity to contract for ward.-The guardian cannot bind the person or the estate of his ward by a contract made by himself. Such contracts bind him personally, and a recovery for breach of it must be had in an action against him. ${ }^{1}$ But a guardian may be anthorized, by a court of competent jurisdiction, to make a contract for his ward, but, in such case, he does not exercise a power belonging to his office, but an extraordinary power granted to him for a special purpose. ${ }^{2}$

6. White v. Joyce, 158 U. S. 128 , 15 S. Ct. 788; Schouler on Dom. Rel. 342-344. Compare Barnum v. Frost, 17 Gratt. (Va.) 398.

7. Reading v. Wilson, 38 N. J. Eq. 446.

8. Phelps v. Worcester, $11 \mathrm{~N}$. H. 51 ; Tenney v. Evans, 14 N. H. 343 , 40 Am. Dec. 194; McGarock v. Whitford, 45 Miss. 452; St. Joseph's Academy v. Augustine, 55
Ala. 493; Dalton v. Jones, 51 Miss. 585 ; Cheney v. Roodhouse, 135 Ill. 265, 25 N. E. 1019; Kingsbury v. Powers, 131 Ill. 188, 22 N. E. 479.

1. Hicks v. Clsapman, 10 Allen (Mass.), 463; Bicknell v. Bicknell, 111 Mass. 265; Wallis v. Bardwell, 126 Mass. 366.

2. Reaäing v. Wilsnn, 38 N. J. Eq. 446. 
Withont the authority of court, a contract by a guardian for the support and care of his ward binds the guardian personally, and not the ward. ${ }^{3}$ And so admissions of a guardian ad litem are not binding upon the infant if not supported by proof, and a decree based thereon will not conclude him. ${ }^{4}$

§ 74. Guardian's title to the ward's property.-The title of the property remains in the ward. The guardian has only a naked power, not coupled with an interest. The debts of the ward remain his debts, and can be recovered by suit against him, not by suit against the guardian $;^{1}$ but such suit may be defended by the guardian in behalf of the ward.

It is the guardian's duty to see that his ward is maintained and educated in a manner suitable to his means, and if, in the performance of this duty, it becomes necessary for him to enter into contracts, such contracts impose no duty on the ward and do not bind his estate, but bind the guardian personally and alone. For any reasonable expenditure made by a guardian, out of his own means, for the benefit of the ward, the court will allow him reimbursement out of the ward's estate, but this is the limit of the ward's liability, in equity or at law. ${ }^{2}$

\section{$\S 75$. Personal liability of the guardian.- A guardian can-} not, by his own contract, bind the person or estate of his ward; but if he promises on a sufficient consideration to pay the debt of his ward, he is personally bound by it, although he expressly promises as guardian. And a guardian who has discharged a debt of his ward, may lawfully indemnify himself ont of the ward's estate; or if he be discharged from his guardianship, he may have an action against the ward, for money

3. Rollins v. Marsh, 128 Mass. 116.

4. White v. Joyce, 158 U. S. 128 , 15 S. Ct. 788.

1. Brown v. Chase, 4 Mass. 436 ; Simons v. Almy, 100 Mass. 239.

2. Schouler on Dom. Rel. 342-
344; Rollins v. Marsh, 128 Mass. 116; Reading v. Wilson, 38 N. J. Eq. 446; Compare Barnum v. Frost, 17 Gratt. (Va.) 398; Jacobia v. Terry, 92 Mich. $275,52 \mathrm{~N}$. W. 629. 
paid for his use. ${ }^{1}$ But he cannot maintain an action against his ward for moncy advanced or services rendered as guardian of the ward until he has settled his guardianship with the court, ${ }^{2}$ for an infant is liable to his guardian solely on a decree of the proper court on the adjustment of his guardian account. ${ }^{3}$

It is competent for a ward when he becomes of age to ratify and affirm a sale made by the guardian where it is invalid for a want of compliance with some statute requisite, or to avoid it within a reasonable time. ${ }^{4}$

1. Sperry v. Fanning, S0 $\mathrm{Ill}$. 371.

3. Smith v. Philbrick, 2 N. H. 395.
3. Phelps v. Worcester, $11 \mathrm{~N}$. H. 51.

4. Tracy v. Roberts, 88 Me. 310 , 34 A. 68,5 I Am. St. Rep. 394. 


\section{CHAPTER IV.}

\section{Contract Required to be in Writing - Statute of Frands.}

\section{ARTICLE I.}

The Statute - Sections Four and Seventeen.

Section 76. When Enacted.

77. Section Four.

is. Section Seventeen.

$\S 76$. When enacted. - In 1676 , an act was passed, entitled, "An Aet for Prevention of Frauds and Perjuries." 1 It had for its object the "prevention of fraudulent practices, which are commonly endearored to be upheld by perjury and subordination of perjury." The anthor, it is thought, was Lord Nottingham, though it has been ascribed to Lord Hale.

The statutes of most of the States follow this enactment. Two sections affect the form of simple contracts-the fourth and the serenteenth. The State statutes are not exactly alike in all particulars, and, therefore, must be consulted to see the correct meaning.

"The Statute of Frands," as it is commonly called, has made a great change in the form of contracts. Before its enactment nearly every contract could be orally made, with the same effect as by writing.

The requirement of writing to hold a party upon a representation as to the character, credit and the like, of a third person, was enacted since the original English statute."

1. 29 Car. 2 , с. 3 . It took effect after the 24 th day of June, $167 \%$. As to the modification of this statute in England, see 7 Will. 4, and 1 Vict., c. 26, sec. 2; 42 and 43
Vict., (. 59, sec. $2 ; 44$ and 45 Vict., e. 59 , see. 3.

2. 9 Geo. IV, c. 14, sec. v, commonly called Lord 'Tenterden's Act. 
\$7. Section four.- The fourth section is as follows: "No action shall be brought whereby to charge any executor or administrator, upon any special promise, to answer damages out of his orn estate; or whereby to charge the defendant, upon any special promise, to answer for the debt, default, or miscarriage of another person; or to charge any person upon any agreement made upon consideration of marriage; or upon any contract or sale of lands, tenements, or hereditaments, or any interest in or concerning them; or upon any agreement that is not to be performed within the space of one year from the making thereof; unless the agreement upon which such action shall be brought, or some memorandum or note thereof, shall be in writing, and signed by the party to be charged therewith, or some other person thereunto by him lawfully authorized."

$\S 78$. Section seventeen.- Section seventeen is as follows: "No contract for the sale of any goods, wares, and merchandise, for the price of ten pounds sterling or upwards, shall be allowed to be good; except the buyer shall accept part of the goods so sold, and actually receive the same, or give something in earnest to bind the bargain, or in part of payment, or that some note or memorandum in writing of the said bargain be made, and signed by the parties to be charged by such contract or their agents thereunto lawfully authorized." 


\section{ARTICLE II.}

\section{Contracts Not Witimn Section Four.}

Section 79. Contracts Created by Law.

80. Executed Contracts.

81. Modification of Written Contraets Required by the Statute.

8.. Executed on One Side.

$\S 79$. Contracts created by law.- Where the law raises a promise, it is not within the statute. ${ }^{1}$ And so where land is conveyed by deed poll, and the grantee enters under the deed, certain duties being reserved to be performed, as no action lies against the grantec on the deed, the grantor may maintain assumpsit for the non-performance of the duties reserved; and the promise, being ereated by law, is not within the statute, ${ }^{2}$ which applies only to contracts made in fact. So a suit can be brought on an implied contract to refund money which, in consequence of the vendor's misrepresentation in the sale of land, the grantee paid him in excess of the contract price. ${ }^{3}$

The statute of frauds applies only to common law agreements where the consideration is the subject of mutual agreements between the parties, and not to instruments created under and derived from other obligations from special statutes, without the acceptance or assent of the parties for whose ultimate benefit they were giren. ${ }^{4}$ So where a statute requires an undertaking to be entered into by securities in order to give a right of appeal, an instrument containing the requisite stipulation is valid, although it does not express the consideration, and is not under seal..$^{5}$

1. Jackson v. Benson, 11 Johns. (N. Y.) 91,6 Am. Dec. 355 ; Jackson v. Seelye, 16 Johns. (N. Y.) 197, 8 Am. Dec. 306; Hills v. EIliott, 12 Mass. 26, 7 Am. Dec. 26.

2. Goodwin v. Gilbert, 9 Mass. 510.

3. Arnold v. Garst, 16 R. I. 4,
11 A. 167. See, also, Sage v. Wilcox, (i) Conn. 8\%.

4. Thompson v. Blanchard, $3 \mathrm{~N}$. Y. 335 .

5. Doolittle v. Dinny, 31 N. Y. 350. See, also, Smith v. Bradley, 1 Root (Conn.), 150. 
\$ 80. Executed contracts. - A parol contract may be voidable by the statute of frauds; but when such a contract has been fully executed and performed, it is no longer within the statute as between the parties who have already received its benefits. ${ }^{1}$ So when the terms of an instrument, required to be in writing under the statute of frauds, are afterwards modified by parol, and as so modified have been fully carried out, the obligation is discharged. $^{2}$

The statute provides that " no action shall be brought whereby to charge" another on a parol contract; so when it has been exccuted there is no occasion for an action, and the contract is valid. ${ }^{3}$

The statute applies to executory contracts therein indicated. If the contract is an original and personal contract, the statute does not apply. Thus, an oral executory contract of insurance, when not controlled by statute, is valid, as it is an original contract, and the statute of frauds has no application. ${ }^{4}$ For such contract is not made to answer for the debt, default, or miscarriage of another, but is an original contract between the insurance company, represented generally by an agent, and the party to be insured. ${ }^{5}$

\$ $8 \mathrm{I}$. Modification of written contracts required by the statute. - While written contracts, which would have been law-

1. MeClellan v. Sanford, 26 Wis. 595; Niland v. Murphy, 73 Wis. 326, 41 N. IV. 335; Pereaux v. Simon, 79 Wis. 392; Hagelin v. Wacks, 61 Minn. 214, $63 \mathrm{~N}$. IV. 624; Gardner v. Gardner, 106 Mich. 18, 63 N. W. 988; Wilson v. Fuller, 58 Minn. 349, 59 N. IV. 988; Ball v. Stover, 82 Hun (N. Y.), 460, 31 N. Y. S. 781 ; Largerfelt v. MeKie, 100 Ala. 430, 14 So. 281; Swanzey v. Moore, 22 Ill. 63, 74 Am. Dec. 134; King v. Bushnell, 121 Ill. 656, 13 N. E. 245; Webster v. Le Compte, 74 Md. 249,22 A. 232; Harris v. Harper, 48 Kan.
418, 29 P. 697; Showalter v. McDonell, 83 Tex. 158, 18 S. W. 491; stone v. Dennison, 13 Pick. (Mass.) 1, 23 Am. Dec. 654 .

2. Doherty v. Doe, 18 Colo, 456 , 33 P. 65.

3. Bolton v. Tomlin, 5 Ad. \& E. S56; Slatter v. Meek, 35 Ala. 528; Newman r. Nellis, 97 N. Y. 285.

4. Croft v. Ins. Co., 40 WV. Va. 508, 21 S. E. 854,52 Am. St. Rep. 902 ; Ins. Co. v. Colt, 20 Wall. (U. S.) 560 .

5. Nat. Fire Ins. Co. v. Rowe (Ky.) 49 S. W. Rep. 425, 20 Ky. L. R. 1473. 
ful if unwritten, may be modified by parol subsequently in many cases, yet this cannot he done where the law requires the agrecment to be in writing. ${ }^{1}$ So parol evidence camnot be received to show a subsequent verbal agreement to change any of the terms, as no part of the contract ean rest in parol. ${ }^{2}$ In cases within the statute of frauds, an action cannot be maintained upon the contract not in writing; but in a controversy between parties to a written contract, an executed parol agreement to waive a particular provision in the contract may be shown ${ }^{3}$ this is the general rule, though there are exceptions.

If by part performance the contract is taken ont of the statute, and is then valid, a subsequent verbal modification of it, with respect to the manner of performance, is not within the statute. ${ }^{*}$ In such case there is no change in the terms of the original contract, but only the substitution, with respect to a single item of one mode of performance for another. ${ }^{5}$

\$ 82. Executed on one side. - It is the prevailing doctrine that the statute of frauds does not extend to actions for payment upon contracts which have been wholly executed within one year by one of the parties thereto. ${ }^{6}$ This is the English rule and has been followed in Alabama, Arkansas, Georgia, Illinois, Indiana, Maine, Maryland, Missouri, Ohio, Rhode Island, South Carolina, and Wisconsin. ${ }^{7}$ The earliest and latest de-

1. Goss v. Nugent, 5 Barn. \& Cr. 58; Stowell v. Robinson, 3 Bing. (N. C.) 928; Stead v. Dawber, 10 Ad. \& El. 57; Marshall v. Lymu, 6 Mees. \& Wels. 109: Blood v. Goodrich, 9 Wend. (N. Y.) 68, $24 \mathrm{Am}$. Dee. 121 and note.

2. Abell v. Munson, 18 Mich. 306, $100 \mathrm{Am}$. Dee. 165 . and note. See, also, Rucker v. Harrington, 52 Mo. App. 481.

3. Lee r. Hawks, 68 Miss. 669 , 9 So. 828,13 L. R. A. 633 and note. 4. Blanchard v. Trim, 38 N. Y. 225; Organ v. Stewart, 60 N. Y.
419; Cummings v. Arnold, 3 Met. (Mass.) 486, 37 Am. Dec. 155; Packer v. Steward, 34 Vt. 127.

5. Goss v. Nugent, 2 Nev. \& Man. 28.

6. Donellan v. Read, 3 Barm. \& Ad. 889 ; South v. Strawbridge, 2 C. B. S0s; Cherry v. Hening, 4 Exch. 631; Si..ith v. Neale, 2 C. B., C. S. 67; Miles v. Altord Estate Co., 54 L. J. Eq. 1035, 1040.

7. Rake r. Pope, 7 Nla. 161; Pledger v. Garrison, 42 Ark. 246; Johnson v. Watson, I Ga. 34S; Curtis v. Sage, 35 Ill. 22; Haigh v. 
cisions in New Mampshire follow the English rule. ${ }^{8}$ But the contrary doctrine is held in Massachusetts, New York, and Vermont. ${ }^{9}$

The first doctrine holds that the statute does not extend to contracts which are wholly executed on one side, or which may be execnted by one side within a year, but only to contracts which, as a whole, are not to be executed within a year; because the words "not to be performed," mean not to be performed on either side within a year. And, inasmuch as the contract is not executory except as to the matter of payment, or recovery back of the consideration, as to which a clear right of action exists, such cases are not within the mischief which the statute is designed to prevent, and, therefore, not to be construed as within the operation of the statute. This is the weight of authority. ${ }^{10}$

The minority of courts hold that performance by one party is not performance of the agreement, and that, in any view, the part of the contract sued upon comes within the statute, for which the part performed is only the consideration. ${ }^{11}$

Blythe, 20 Ind. 24; Holbiook v. Almstrong, 10 Me. 31; Ellicott v. Turner, 4 Md. 476; Suggett v. Cason, 26 Mo. 221 ; Randall v. Turner, 17 Ohio St. 262; Durfee v. O'Brien, 16 R. I. 213, 14 A. 857; Compton v. Martin, 5 Rich. (S. Car.) 14; MeClellan v. Sanford, 26 Wis. 596 .

8. Blanding v. Sargent, 33 N. H. 239, 66 Am. Dec. 720; Emery v.
Smith, 46 N. H. 15l; Perl-ins v. Clay, 54 N. H. 518.

9. Marcy v. Marcy, 9 Allen (Mass.), 8; Lockwood v. Barnes, 3 Hill (N. Y.), 128, 38 Am. Dec. 620 and note; Broadwell v. Getman. 2 Denio (N. Y.), 87; Kellogg v. Clark, 23 Hun (N. Y.), 393 ; Piereo v. Paine, 28 Vt. 34 .

10. Durfee v. O'Brien, 16 R. I, 213,14 A. 857.

11. Pierce v. Paine, 28 Vt. 34. 


\section{ARTICIE III.}

\section{Suffictexcy of Memorandum.}

Section 83. What is a Valid Memorandum.

84. Delivery of Note or Memorandum.

8.5. Letcrs, Telegrams, and Other Papers.

86. Widlence of Contract.

87. Sale by Auctionees or Broker-Suffieieney of Memorandum.

8s. Description of Parties.

S9. Evidene to dimtify Parties.

90. Parol Evidence to Identify Agent or Principal.

9l. Terms of the Memorandum.

92. Description of Subject-Matter.

93. Consideration.

94. For Vilue Received.

95. Scal-Consideration.

96. Guaranty-Consideration.

97. Signature.

98. Mutuality of Agreement.

99. Signature by Agent.

$\S 83$. What is a valid memorandum.- A contract itself, and the memorandum which is necessary to its validity under the statute of frauds, are in their nature, distinct. The statute presupposes a contract by parol. ${ }^{1}$ The memorandum may be made at one time and the note or memorandum of it at a subsequent time. The contract may be proved by parol, and the memorandum may be supplied by documents and letters written at various times, if they all appear to have relation to it, and if coupled together, they contain by statement or reference all the essential parts of the bargain, signed by the party to be charged or his agent. ${ }^{2}$

When the memorandum of a sale of land contains the essential terms of the contract, the price to be paid and the date of the payment, all expressed with such certainty as that they may

1. Marsh v. Hyde, 3 Gray macher. 9 Allen (Mass.), 412; (Mass.), 333.

Townsend v. Kennedy, 6 S. Dak.

2. Williams v. Bacon, 2 Gray $47,60 \mathrm{~N}$. W. 164.

(Mass.), 38 $i$; Lerned v. Wanne- 
be understood from the writing itself, which was signed by the purchaser, it is sufficient. ${ }^{3}$

A stipulation not self-explanatory may be explained by other testimony, written or oral. ${ }^{4}$

The memorandum must contain in substance the complete agreement in terms sufficiently lucid to be understood, ${ }^{5}$ and an oral acceptance of a written contract is sufficient, which may be proved by parol evidence. ${ }^{6}$ And such eridence may be admitted as is admissible in interpreting ordinary contracts. ${ }^{7}$

$A$ rote of an authorized committee of a city, electing their clerk city engineer for a year from a subsequent date, duly recorded and signed by him as clerk, is a sufficient memorandum. ${ }^{8}$ And a vote of a town council signed by its clerk, the town council having been made previonsly the agent of the town by vote in town meeting, is sufficient. ${ }^{9}$

Entries by the party on his own or his agent's books are sufficient $;^{10}$ and also entries in the records of a corporation $;^{11}$ and recitals in a will to answer for the debts of a son. ${ }^{12}$

In general, the memorandum must state the whole contract with reasonable certainty so that the names of the parties thereto and the substance thereof may be made to appear from the writing itself, without recourse to parol evidence. ${ }^{13}$

3. Reynolds v. Kirk, 105 Ala. 446, 17 So. 95 .

4. Willis v. Hammond, 41 S. Car. 153, 19 ऽ. E. 310 .

5. Reid v. Kenworthy, 25 Kans. 701; Newbery v. Wall, 65 N. Y. 484; Whalen v. Sullivan, 102 Mass. 20 t; Smith v. Jones, 66 Ga. 338, 42 Am. Rep. 72.

6. Lee v. Cherry, 85 Tenn. 707 , 4 S. W. 835,4 Am. St. Rep. 800.

7. Beckwith v. Talbot, 95 U. S. 289 ; White v. Core, 20 W. Va. 272.

8. Chase v. Lowell, 7 Gray (Mass.), 33. See, also, Grimes v. Hamilton County, $3 \overrightarrow{7}$ Iowa, 290; Johnson v. Church, 11 Allen (Mass.), 123.
9. Marden v. Champlin, 17 R. I. 423, 22 A. 938; Compare Wilhelm v. Fagan, 90 Mich. 6,50 N. W. 1072.

10. Clason v. Bailey, 14 Johns. (N. Y.) 484; Coddington v. Goddard, 16 Gray (Mass.), 436; Johnson v. Dodgson, 2 Mees. \& IVels. 653 .

11. Tufts v. Plymouth, etc., Co., 14 Allen (Mass.), 407.

12. In re Hoyle, 41 Weekly Rep. 81.

13. Cheever v. Schall, 87 Hun (N. Y.), 32,33 N. Y. S. 751 ; Mentz v. Newmiller, 122 N. Y. $491,25 \mathrm{~N}$. E. 1044,11 L. R. A. 97 and note, 19 Am. St. Rep. 514. 
\$ 84. Delivery of note or memorandum.- The statute itzelf is entirely silent on the question of delivery of the note or memorandum of the bargain, and its literal requirements are fulfilled by the existence of the note or momorandum of the bargain, signed by the party to be charged thereby. The statute deals exchsively with the existence and not with the enstorly of the paper; that is, when the memorandmm is evidenee of an existing contract previonsly made by the parties, so delivery of it, in the sense in which that word is used in respect to deeds, is necessary, for the writing is not the substantive act or thing itself, as is a deed, but only the means by which the substantive act - the making of the contract - is shown to have been done $;^{2}$ the acceptance being unconditional, it is not material that it is never delivered to the party making the written offer or to any one for him. ${ }^{3}$

$A$ deed must be delivered when used as a memorandum of an agreement to sell in fact, ${ }^{4}$ or in escrow. ${ }^{5}$

Where an agreement is to be delivered before it becomes binding, it does not take effect until such delivery, and is not, therefore, a sufficient menorandum under the statute. ${ }^{6}$

§ 85. Letters, telegrams and other papers.-- In determining whether there is a written proof of a contract, all the paper's must be considered. Where no one paper alone, which is form-

1. Drury v. Young, is Mld. 546, $42 \mathrm{Am}$. Rep. 343 and note.

2. Townsend v. Hargraves, 118 Mass. $3 \cdot \overline{2} \overline{5}$.

3. Alford v. Wilson, $95 \mathrm{Ky}$. 506, 26 S. W. 539.

4. Swain v. Burnett, s9 Cal. 564, 26 P. 1093; Wier r. Batlorf. 24 Neb. 83,38 ‥ W. 22; lay $v$ Laeasse, 85 Me. 242, 27 A. 124; Callaman v. Chapin. 158 Mass. 113, 32 工. E. 941 .

5. Cannon v. Handies, 72 Cal. 133, 13 P. 315; Johnston v. Jones,
Si Ala. 286, 4 So. 748 ; Compare Dncett v. Wolf, 81 Mich. 311, 45 N. W. S:9.

6. Parker v. Parker, I Gray (Mass.), 409: Cagger v. Jansing. 43 X. Y. 550: Campbell v. Thomas, 42 Mis. 437, $24 \mathrm{Am}$. Rip. 427; Popp v. Swanke. 6s Wis. 364,31 X. W. 916: Weir v. Batdorf, 24 Neb. S3. 38 X. W. 2.2; Conner $r$. Baldwin, 16 Minn. 172: Johnson $\mathrm{v}$. Brook, 31 Miss. 17, 60 .m. Dee. 547 : Callanan v. Chapin, los Mass. 113, 32 N. E. 194. 
ally signed, purports to express the terms of the contract, all the letters that have passed between the parties must be considered in order to see what the contract actually was as shown by the writings. ${ }^{1}$ And if the letters of offer and acceptance contain all the terms agreed on between the parties, the complete contract thus arrived at cannot be affected by subsequent negotiations. ${ }^{2}$

A telegram is a sufficient memorandum to charge the sender. ${ }^{3}$

It is the general rule that two or more papers which have been executed as parts of one transaction may be read and construed together, in order to ascertain the scope and effect of the transaction, and whether it is within the statute of frauds. ${ }^{4}$ Nor are all the paper's required to be signed by the party sought to be charged, provided those not thus signed are referred to in those which are signed. But the connection between such documents must appear from the signed memoranda, and cannot be established by parol evidence. ${ }^{5}$

The courts have gone very far in construing referential words so as to comnect several documents and collect the terms of the contract out of them. A correspondence through letters or telegrams, or both, if they show clearly what the contract was, is sufficient under the statute. A meromandum of agreement is sufficient, and it may be found in one or more papers, some or

1. Hussey v. Horne-Payne, 4 App. Cas. 311 ; Bristoe, etc., Co. v. Maggs, 44 Ch. Div. 616; Bellamy v. Debenham, 45 Ch. Div. 481 ; Williams v. Smith, 161 Mass. 248, 37 N. E. 455 .

2. Singleton v. Hill, 91 Vis. 51, 64 N. W. 588, 51 Am. St. Rep. S68; Bellamy v. Debenham, $45 \mathrm{Ch}$. Div. 481 ; Pitcher v. Lowe, 95 Ga. 423, 22 S. E. 678; Calverley v. Worth. 59 Ill. App. 553.

3. Trevor v. Wood, 36 N. Y. 307 , $93 \mathrm{Am}$. Dec. $51 \mathrm{l}$ and note ; Little v. Dougherty, 11 Colo. 103, 17 P. 292 ; Whaley v. Hinchman, 22 Mo.
App. 483; MeElroy v. Buck, 35 Mich. 434.

4. Townsend v. Kennedy, $6 \mathrm{~S}$. Dak. 47,60 N. W. 164; Lee v. Mahoney, 9 Iowa, 348; Myers v. Munson, 65 Iowa, 425, 21 N. W. 759; Beckwith v. Talbot, 95 U. S. 289; Alson v. Sharpless, 53 Minn. 91, 55 N. W. 125; Salmon Falls Manuf. Co. v. Goddard, 14 How. (U. S.) 446, 456; American Oak Leather Co. v. Porter, 94 Iowa, 117, 62 N. W. 658 .

5. Boydell v. Drummond, 11 East, 142; Coles v. Trecothic, 9 Ves. 250 ; Ridgeway v. Wharton, 6 
all of which nuay be telegrans ; ${ }^{6}$ but such doeuments must show clearly what the contract is, and are so connected with rach other that they may fairly be said to constitute one paper relating to the contract. ${ }^{\text {? }}$

Filing a bill in chancery by a party who has not signed tho contract, takes the case out of the statute of frauds. ${ }^{8}$

The signature of the telegram-form amounts to and operates as a signature of the contract contained in the contract, and is valid under the statute of frauds. ${ }^{9}$ And it is believed that the use of the sender's telegraphic sobriquet, in lieu of his own or his firm's name, would make no difference, and would be valid under the statute of frauds. The question is, whether a telegram is or is not a sufficient memorandum within the statute; the courts universally say it is.

$\S 86$. Evidence of contract.- It is the general rule that the evidence necessary to take a contract out of the statute of frands must be furnished by the writings, parol evidence not being admissible to supply evidence found in them. ${ }^{10}$ The memorandum required by the statute must show, either on its face or by reference to some other writing, the contract between the

H. L. Cas. 237 ; Blair v. Snodgrass, 1 Sneed (Tenn.), 1; Fowler Elevator Co. v. Cottrell, 38 Neb. 512, 57 N. W. 19; Boardman v. Spooner, 13 Allen (Mass.), 353, 90 Am. Dec. 196; Carter v. Shorter, 57 Ala. 256; Brown v. Whipple, 58 N. H. 229 ; North v. Mendel, 73 Ga. 400; 54 Am. Rep. 879; Ridgeway v. Ingram, 50 Ind. 145, 19 Am. Rep. 706 ; Johnson v. Buck, 35 N. J. L. 338, 10 Am. Rep. 243; Thayer v. Luce, 22 Ohio St. 62; Tice r. Freeman, 30 Minn. 389 , 15 N. 674.

6. Breckenridge v. Crocker, 78 Cal. 534. 21 P. 179: Ryan v. United States, 136 U. S. 63, 10 S. Ct. 913.

7. Elbert v. Gas Co., 97 Cal. 244, 32 P. 9; Ryan v. United
States, 136 U. S. 68,10 S. Ct. 913 ; Beckwith v. Talbot, 95 U. s. 289 , 29:; Ridgeway v. Wharton, $6 \mathrm{H}$. L. Cas. 238; Coles v. Trecothie, 9 Ves. 234, 250; Cave r. Hastings, 7 Q. B. D. 125, 128; Long v. Millar, 4 C. P. D. 450.

8. Peevey v. Haughton, 72 Miss. 915, 1\% So. 378, 18 So. 35\%, 4S Am. St. Rep. 592 .

9. Godwin v. Francis, 22 L. T. Rep. 338, I. R. 5 C. P. 295 ; McBlain v. Cross, 25 L. T. Rep. S04.

10. Watt v. Cranberry Co., 63 Iowa, 730, 18 N. 898; Vaughn $v$. Smith, 58 Iowa, 558, T2 N. 604; Compare Salmon Falls Manuf. Co. v. Goddard, 14 How. (U. S.) 446 . 456. 
parties, so that it can be understood without having recourse to farol proof ${ }^{11}$ and it must contain the essential elements of the contract, including the consideration, ${ }^{12}$ except in some States the consideration need not be expressed. ${ }^{13}$

The relation to each other of the documents relied on to satisfy the requirements of the statute must appear on their face and cannot be established by parol evidence. ${ }^{14}$

\section{$\S 87$. Sale by auctioneer or broker - Sufficiency of memo-} randum. - An anctioneer is to be ordinarily treated as agent of both seller and purchaser of either real or personal property sold by him, and a memorandum of the sale signed by him is a sufficient written memorial of the contract to bind both parties. ${ }^{1}$ But the memorandum of a sale of land must show who the vendor is. ${ }^{2}$ The auctioneer's authority to sign cannot be delegated to others; ${ }^{3}$ though he may authorize another to make the ontery and the swinging of the hammer. ${ }^{4}$ The signing of the memrandum by the auctioneer must be at the time of the sale, and cannot be made at a future time. ${ }^{5}$ These rules apply to a broker. ${ }^{6}$

If the vendor is the anctioneer, the rules applicable to an

11. Parkhurst v. Van Cortland, 1 Johns. Ch. (N. Y.) 273; Williams v. Morris, 95 U. S. 444; Hale v. Hale, 90 Va. 728,19 S. E. 739.

12. Grafton v. Cummings, $99 \mathrm{U}$. S. 100 .

13. Hale v. Hale, 90 Va. 728,19 S. E. 739 .

14. Fowler Elevator Co. v. Cottrell, 38 Neb. 512, 57 N. IV. 19.

1. Nioore v. Taylor, 81 Md. 644, 32 A. 320,33 A. 886 ; Bent v. Cobb, 9 Gray (Mass.), 397, 69 Am. Dec. 295 ; MeBrazer v. Cohn, 92 Ку. 479, 18 S. W. 123; Gill v. Hewitt, 7 Bush. (Ky.) 10, Sims v. Landray (1894), 2 Ch. 318.

2. Mentz v. Newmiller, $122 \mathrm{~N}$.
Y. 491, 25 N. E. 1044, 11 L. R. A. 97 and note, 19 Am. St. Rep. 514, Osullivan r. Overton, 56 Conn. 102,14 A. 300.

3. Stone v. State, 12 Mo. 400; Commonwealth v. Hamden, 19 Pick. (Mass.) $48 \%$.

4. Commonwealth v. Hamden, 19 Pick. (Miass.) 482.

5. Gill v. Bicknell, 2 Cush. (Mass.) 355; Horton v. MeCarty, 53 Me. 394; Bawber v. Savage, 52 Wis. 110, 8 N. 609, 38 Am. Rep. 723 ; Jelks v. Barrett, 52 Miss. 515; Gwathney v. Cason, 74 N. Car. 5, 21 Am. Rep. 484.

6. Rucker v. Cammeyer, 1 Esp. 105 . 
auctioneer do not apply. ${ }^{7}$ And so where the auctioneer departs before making a sale, and the vendor sells to a bidder, the clerk of the sale is not the agent of the purchaser, so that he can bind him by a memorandum. ${ }^{8}$

Del credere is where the agent or factor, in consideration of an increase of commission, absolutely engages to pay to his principal the price of the goods which he sells for his consignor.' Such a contract is original contract, and absolute agreement that the price for which the goods were sold, or the debt created by the sale of the goods, shall be paid to the principal when the credit given on the sale shall have expired. ${ }^{10}$

The principal transfers a right in his orn name to collect the debts and hold the money, accounting only for the net proceeds; but this does not come under the statute of frauds. ${ }^{11}$ Some English cases ${ }^{12}$ and a few American cases hold that the factor's liability is as a surety merely, and his contract of guaranty comes within the statute. But the great weight of American authority is to the effect that one who sells under such a commission is liable absolutely and originally to the principal, or consignor, and, hence, the contract does not come within the statute of frauds. ${ }^{13}$

\$ 88. Description of parties. - It is essential to the validity of an agreement or memorandum thereof, that it shall contain the names of both parties to the agrcement. It is not necessary,

7. Bent v. Cobb, 9 Gray (Mass.), 397,69 Am. Dec. 295.

8. Wyckoff v. Mickle (N. J.), 20 At. Rep. 214.

9. Nat. Cordage Co. v. Sims, 44 Neb. 148, 62 N. W. 514.

10. Bradley v. Richardson, 23 Vt. 720; Swan v. Nesmith, 7 Pick. (Mass.) 220, 19 Am. Dec. 282; Bullowa v.Orga, 57 N. J. Eq. 428, 41 A. 494; Courturier v. Hastie, 8 Exch. 40 ; Wolff $v$. Kappel, 5 Hill (N. Y.), 458; Osborne v. Baker, 34 Minn. 307,25 N. IV. 606 ; Seeman v. In- man, 6 Mo. App. 384; Wickham v. Wickham, 2 Kay \& J. 4is; Grover v. Dubois, l T. R. 112; Bize v. Dickanson, 1 T. R. 285 .

11. Sherwood v. Stone, 14 N. Y. 267.

12. Morris v. Cleasby, 4 Maul. \& Sel. 566; Peele v. Northcote, 7 Taunt. 478 .

13. Balderston v. Rubber Co., 18 R. I. 338,27 A. 507,49 Am. St. Rep. 772 ; Lewis v. Brehm, 33 Md. 112. 
however, that both parties shall sign it; all that is required is that it shall be signed by the party to be charged. ${ }^{1}$ So a memorandum in the sale of real estate which does not contain the name of the purchaser or any description of him whatever is insufficient within the statute. ${ }^{2}$ So a memorandum of the sale of goods, which does not designate the seller and the buyer, is insufficient. ${ }^{3}$ The parties must be described with reasonable certainty. "The ratio decidendi is that the language of the statute cannot be satisfied unless the existence of a bargain or contract appears, evidenced in writing, and a bargain or contract cannot so appear unless the parties to it are specified therein nominally or by a description or reference. ${ }^{5}$

\section{§ 89. Evidence to identify parties. - It is essential that the} memorandum shall show the parties. It is true that they need not be named. It is sufficient if they are described, and in that case, parol evidence is admissible to apply the description and identify the persons meant. ${ }^{6}$ In the absence of description, parol evidence is not admissible to describe the parties intended. ${ }^{7}$

1. Williams v. Lake, 2 El. \& El. 349; Sherbourne v. Shaw, I N. H. 157, 8 Am. Dec. 47; Nichols v. Johnson, 10 Conn. 192; Osborn v. Phelps, $1 \overline{9}$ Conn. 63, 48 Am. Dec. 133; Bailey v. Ogden, 3 Johns, (N. Y.) 399,3 Ám. Dec. 509 .

2. Carrick v. Mincke, 1 Mo. App. Rep. 67 ; Lewis v. Wood, 153 Mass. 321, 26 N. E. 862,11 L. R. A. 143.

3. Frank v. Eltringham, 65 Miss. 281, 3 So. 655; Bailey v. Ogden, 3 Johns. (N. Y.) 399, 3 Am. Dec. 509 ; Compare Thornton v. Kelly, 11 R. I. 498.

4. Champion v. Plummer, I Bos. \& Pul. (N. C.) 25.; Williams v. Byrnes, 1 Moore, P. C., N. S. 154 ; MeGovern v. Hern, 153 Mass. 308, 26 N. E. 861,10 J. R. A. 875 , 25 Am. St. Rep. 632; Grafton v.
Cummings, 99 Ư. S. 100; Lincoln v. Preserving Co., 132 Mass. 129; Vandenburgh v. Spooner, L. R. 1 Exch. 316; Fessenden v. Mussey, 11 Cush. (Mass.) 127; Coddingham v. Goddard, 16 Gray (Mass.), 436, 444 ; McConneil v. Brillhart, 17 Ill. 354, $65 \mathrm{Am}$. Dec. 661 and note; McElroy v. Seery, 61 Md. 389, 48 Am. Rep. 110; Coombs v. Wilkes (1S93), 3 Ch. 77; Sherburne v. Shaw, 1 N. H. 157, 8 Am. Dec. 47; Watt v. Cranberry Co., 63 Iowa, 730,18 N. 898 .

5. Williams v. Byrnes, 1 Moore, P. C., N. S. $154,195$.

6. Jones v. Dow, 142 Mass. 130, 140, 7 N. E. 839 ; Catling v. King, 5 Ch. D. 660 ; Rossiter v. Miller, 3 App. Cas. 1124, 1141, 5 Ch. D. 648. 7. Sale v. Lambert, 18 Eq. 1; 
And the mere reference to a person selling as vendor is no description. ${ }^{8}$

A signature is valid and binding, though made with the initials of the party only, as parol eridence is admissible to explain and apply them. ${ }^{9}$ And parol evidence is competent to show who the principal is, when a factor has used a fictitious name in selling goods. ${ }^{10}$ The parties must either be named or deseribed in the memorandum in order to bind them; if not named but described, then parol evidence may be admitted to identify them.

$\S$ go. Parol evidence to identify agent or principal. - It is no objection to the sufficiency of a memorandum that the seller therein named is but an agent or the real owner; and on proof of the ageney the latter may sue or be sued on the contract made by his agent. ${ }^{11}$ So it is a sufficient compliance with the statute that the contract to eonvey land be signed by one who is proved or admitted to have been authorized to execute it by the party to be charged therewith, although the agent signed his own name instead of that of his principal, and the authority of the agent may be shown by parol. ${ }^{12}$ But such agent camot show by parol that he is not the principal to the contract. ${ }^{13} A$ subscrip-

Jones v. Dow, 142 Mass. 130, 140; Violett v. Powell, 10 B. Mon. (Ky.) 347, 52 Am. Dec. 548; Thornton v. Kelly, 11 R. I. 498; Lerned v. Johns, 9 Allen (Mass.), 419. 665 .

8. Catling v. King, 5 Ch. D. 660 ,

9. Phillimore v. Barry , l Camp. 513; Salmon Falls Manuf. Co. v. Goddard, 14 How. (U. S.) 446; Samborn v. Flagler, 9 Allen (Mass.), 474; Palmer v. Stephens, 1 Denio (N. Y.), 471.

10. Bibb r. Allen, 149 C. S. $4 \$ 1$. 13 S. Ct. 950; Compare Newcomb r. Clark, l Denio (N. Y.), 226; Minard $v$. Mead, 7 Wend. (N. Y.) 68.
11. Gowen v. Klous, 101 Mass. 449.

12. Hargrave v. Adcock, $111 \mathrm{~N}$. Car. 166, 16 S. E. 16; Hippes v. Grithin, 89 Ill. 134, 3̄1 Am. Dec. 71 ; Mantz v. Maguire, 52 Mo. App. 136; Williams v. Bacon, 2 Gray (Matss.). 387; Sanborn v. Flagler, 9 Allen (Mass.), 47 ; Trueman $r$. Loler, 11 Adol. \& El. 589. See, also, Wilson v. Hunter, 7 Taunt. 275; Cox v. Painter, 6 Ad. \& El. 491. Compare Repetti v. Maisak, 6 Nackey (D. C.), 360; Crampet v. Bells. 39 Minn. 272, 39 N. W. 495.

13. Higgins v. Senior, 8 Mces. \& Wels. 834; Waring v. Mason, 18 Wend. ( Y. Y.) 425. 
tion by an agent of the party to be charged is sufficient under the statute, though the name or existence of a principal does not appear upon the instrument. ${ }^{14}$ On the same principle a partner may, by his individual signature, bind the firm if the contract is within the scope of the business of the firm, which may be shown by extrinsic evidence. ${ }^{15}$

$\S 9$. Terms of the memorandum.- In order to satisfy the statute of frauds, the memorandum must contain the substantial terms of the agreement, expressed with such certainty that they may be understood without resort to parol evidence. ${ }^{1}$

No particular form is required so long as it states the terms with reasonable certainty. ${ }^{2}$ Under the statute of frauds, if the subject-matter of the contract is within the statute, and the contract or memorandum is defective in some one or more of the essentials required by the statute, parol evidence cannot be received to supply the defects, for this would do the very thing prohibited by the statute. ${ }^{3}$ And if the memorandum refers to additional terms agreed on between the contracting parties, its terms not being evidenced by writing but left in parol, it is insufficient. ${ }^{4}$ And so if the time for delivery of goods be fixed in

14. Dykers v. Townsend, 24 N. I. 57.

15. Soames v. Spencer, l Dowl. \& R. 32; Higgins v. Senior, 8 Mees. \& Wels. 834; Williams v. Bacon, 2 Gray (Mass.), 387, 393.

1. Messmore v. Cunnington, 78 Mich. 623, 44 N. W. 145; Smith v. Shell, 82 Mo. 215, 52 Am. Rep. 365; North v. Mendel, 73 Ga. 400, 54 Am. Rep. 879 ; Fry v. Platt, 32 Kan. 62, 3 P. 781 ; Williams v. Robinson, 73 Me. 186, $40 \mathrm{Am}$. Rep. 352; Lee v. Hills, 66 Ind. 474: Banks v. Manuf. Co., 20 Fed. Rep. 667; Williams v. Morris, 95 U. S. 414; Grafton v. Cummings, $99 \mathrm{U}$. s. 100 ; Ringer v. Holtzclaw, 112 Mo. 519, 20 S. W. 800.

2. Atwood v. Cobb, 16 Pick. (Mass.) 230, 26 Am. Dec. 657 and note; Gordon v. Avery, 102 N. Car. 532,9 S. E. 486 ; Peck v. Vandemark, 99 N. Y. 29,1 N. E. 41.

3. Musselman v. Stover, $31 \mathrm{~Pa}$ St. 205; Gloss v. Hurlbert, 10 ! Mass. 24, 3 Am. Rep. 418; Mould ing v. Prussing, 70 Ill. 151; Osborn v. Phelps, 19 Conn. 63, 48 Am. Dec. 133 ; Ringer v. Holtzclaw, 112 Mo. 519,20 S. W. 800, overruling O'Neil v. Cram, 67 Mo. 250, and Lash v. Parlin, 7s Mlo. 391.

4. Lester v. Heídt, 86 Ga. 226, 12 S. E. 214, 10 L. R. A. $10 \overline{8}$. 
the verbal agreement of sale, such time must be incorporated in the memorand $1 m .^{5}$ So the agreement for the sale of land, not specifying the purchase price, nor the time or times of payment, is not sufficient. ${ }^{6}$ When not made unnecessary by the statute, the price must be stated in the memorandum of sale, ${ }^{7}$ unless an adequate price has leen paid, ${ }^{8}$ or such is not required by statute. ${ }^{9}$

Parol eridence is not adnissible to prove any substantial requirement of the memorandum. ${ }^{10}$ But the agreement required by the statute may sufficiently appear in a receipt signed by the defendant. $^{11}$

\section{$\S$ 92. Description of subject-matter.- The description of} the subject-matter must be such as to be easily understood, so as to identify the property. ${ }^{1} A$ description of the sale of real estate is sufficient which gives the owner's name, the street and number of the lot; the omission of the name of the city or town in which the lot is located, is not material ; but if the owner's name had not been given, the memorandum would have been insufficient. $^{3}$

Where the description of the land is defective, but is suffciently full for easy identification, the memorandum is sufficient. ${ }^{4}$

5. Kreith v. Myer, 61 Md. $55 \mathrm{~s}$.

6. Webster $r$ Brown, 67 Mich. 328, 34 N. W. 676 ; Gault v. Stormout, 51 Mich. 636, 17 N. 214; McElroy v. Buck, 35 Mich. 434. See, also, Elliott v. Barrett, 144 Mass. 256,10 N. E. 820 .

7. Phelps v. Stillings, 60 N. H. 505; Phillips v. Adams, 70 Ala. 373; Ide v. Stanton, 15 Vt. 68 .

8. Sayward v. Gardner, 5 IVash. 247, 31 P. 761,33 P. 389.

9. Hale v. Hale, 90 Va. 728, 19 S. E. 739 .

10. Oppenheim v. Waterbury, S6 Hun (N. Y.), 122, 33 N. Y. S.
183; Weil r. Willard, 55 Mo. App. 376 ; Boyd v. Paul, 125 Mo. 9, 28 S. W. 171 .

I1. Lewis $v$ Reichey, $27 \mathrm{~N}$. J. Eq. 240; Jones v. Tye, $93 \mathrm{Ky} .390$, 20 S. W. 358.

1. Beekman v. Fletcher, 48 Mich. $555,12 \mathrm{~N} .35$; Whelan r. Sullivan, 102 Mars. 204; Ellis r. Railroad Cu., T Colo. Apr. 350, 43 r'. 457.

2. Price v. McKay, 53 X. J. Eq. 58s, 32 A. 130.

3. Rose v. Allen, 45 Kans. 231, 25 P. 570,10 1. R. A. 835.

4. Ellis v. Deadman, 4 Bibb (Ky.), 467; Hanly v. Blackford, 
If the subject-matter cannot be identified by the terms of the memorandum, it is insufficient. ${ }^{5}$ Where two tracks of land answer the description, the memorandum is insufficient as parol testimony cannot be admitted to identify the land. ${ }^{6}$ But when the memorandum identifies and furnishes the means of finding the land, it is sufficient. ${ }^{7}$

An agreement in writing for the eonveyance of land, which does not, either in itself or by reference to any other writing, contain the means of identification of the boundaries, is within the statute, and is therefore insufficient. ${ }^{8}$

$\S$ 93. Consideration.-The statnte of frauds in the various States are not alike as to whether the consideration must be expressed in the memorandum. Many of the statutes set forth that the consideration of a promise, contract or agreement need not set forth or be expressed in the writing signed by the party to be eharged therewith. ${ }^{9}$ This is the law in Illinois, Indiana, Kentucky, Maine, Massachusetts, Michigan, Nebraska, New Jersey, Virginia, and West Virginia.

1 Dana (Ky.), 1, 25 Am. Dec. 114; Anderson v. Perkins, 94 Ky. 207, 21 S. W. 1035; Mellon v. Dawson, 123 Pa. St. 298, 16 A. 431; Cassitt v. Hobbs, 56 Ill. 231; Dougherty v. Chestnutt, 86 Tenn. 1, 5 S. WV. 444; Oliver v. Hunting, 44 Ch. D. 205; Humber v. Brisbane, 25 S. Car. 506; Breckenridge v. Crocker, 78 Cal. 529, 21 P. 179; Quinn v. Champagne, 38 Minn. $322,37 \mathrm{~N}$. W. 451 .

5. Weil v. Willard, 55 Mo. App. 376 ; Doherty v. Hill, 114 Mass. 465,11 N. E. 581 ; Taylor v. Allen, 40 Mrinn. 433, 42 ․ TV. 292; Lowe v. Harris, 112 N. Car. 472,17 S. E. 539, 22 L. R. A. 379 and note; Brockway r. Frost, 40 Minn. 155, 41 N. W. 4l1; Repetti v. Maisak, 6 Mackey (D. C.), $\overline{3} 66$.

6. Jones v. Tye, $93 \mathrm{Ky}$ 390, 20
S. W. 388 ; Doherty v. Hill, 144 Mass. 465,11 N. E. 581.

7. Eggleston v. Wagnor, 46 Mich. 610,10 N. 37 ; Robison v. Hornbaker, 3 N. J. Eq. 60; White v. Hermann, 51 Ill. 243, 99 Am. Dec. 543 ; Lento v. Clarke, 22 Fla. 515, 1 So. 149 ; Phillips v. Swank, 120 Pa. St. 76,13 A. 712,6 Am. St. Rep. 691; Frances v. Barry, 69 Mich. 311,37 N. W. 353.

8. Atwood v. Cobb, 16 Pick. (Mass.) 227, 26 Am. Dec. 657 and note; Morton v. Dean, 13 Met. (Mass.) 385; Hurley v. Brown, 98 Mass. 545; Whelan v. Sullivan, 102 Mass. 204; White v. Breen, 106 Ala. 759, 19 So. 59; Lingeman v. Shirk, 15 Ind. App. 432, 43 N. E. 33.

9. Hayes v. Jackson, 159 Mass. 451, 34 N. E. 683; Compare Grace 
It has been held in England that the promise is not binding under the statute unless the consideration which forms part of the agreement be also stated in writing. ${ }^{10}$

But the old English doetrine ${ }^{11}$ has been changed by statute, ${ }^{12}$ because it was found in practice that it led to many unjust and merely technical defonees to actions upon guarantics. In some of the States it has been held unnecessary to state the consideration, even when there is no provision that it need not be inserted in the memorandum, although the consideration was executory. ${ }^{13}$

$\S 94$. For value received.- It has been repeatedly held that the words "for value received" sufficiently comply with the statute which requires the consideration to be expressed. "Hence, the words "for value received" are a sufficient statement of the consideration in a written guaranty of the payment of a bond and mortgage to constitute a valid contract under the statute. The former rule in New York, that contracts of guaranty are void under the statute unless their consideration was expressed upon the face of the instrument itself, ${ }^{3}$ has been modified, and

v. Denison, 114 Mass. 16. See, also, Siemens v. Siemens, 65 Minn. 194, 60 Am. St. Rep. 430 and note; Straight v. Wright, 60 Minn. 515, 63 N. W. 103.

10. Wain v. Walter's, 5 East, 10 ; Deutsch v. Bond, 46 Md. 164; Buckley v. Beardsley, 5 N. J. L. 572, 8 Am. Dee. 620; Taylor v. Pratt, 3 Wis. 674; Eilison v. Jackson Water Co., 12 Cal. 542; Thompson v. Blanchard, 3 N. Y. 335; Hargraves $v$. Cooke, 15 Ga. 321.

11. Wain r. Walters, 5 East, 10.

12. 19 and 20 Vict. e. 9 -, sec. 3 : In re Eyre, 13 Reports, 670.

?3. Camp v. Moreman. st Ky. 635, 2 S. W. 179; Violett $v$. Patton, 5 Cranch (U. S.), 142; Ellis v. Bray, 79 Mo. 227; Thornburg v. Masten, s8 N. Car. 293.
1. Day v. Elmore, 4 Wis. 214; Watson v. McLarin, 19 Wend. (N. Y.) 557 ; Miller v. Cook, 23 N. Y. 495; Osborne v. Baker, 34 Minn. 307, 25 N. IV. 606, 57 Am. Rep. 55; Brooks v. Morgan, l Har. (Del.) 123; Whitney v. Stearns, $16 \mathrm{Me}$. 394: Johnson v. Wadswortl, 24 Oreg. 494, 34 P. 13; Smith v. Northrup, 80 Hun (N. Y.), 65, 29 X. I. S. 851; Drake v. Seaman. 97 N. Y. 230 ; Emerson v. Aultman, (j) Md. 125 .

2. Smith v. Northrup, so Hun (X. Y.), 65, 29 N. Y. S. 851.

3. Union Bank v. Coster, $3 \mathrm{~N}$. Y. $211.53 \mathrm{Am}$. Dee. 280 and note; Newromb r. Clark, 1 Denio (N. \.), 226 . 
where the nature of the consideration is fairly inferable from the contract, it will satisfy the requirements of the statute. ${ }^{4}$ And this is the law in other States. It is sufficient if, from the writing it appears with reasonable clearness what the consideration is. ${ }^{5}$

$\$ 95$. Seal - Consideration. - A seal is a sufficient expression of the consideration, when the statute of frands requires an agreement or memorandum for sale of lands to express a consideration. ${ }^{6}$ An instrument under seal is held not void under the statute, although no consideration is in terms stated therein, upon the ground that the seal imports consideration. ${ }^{7} \mathrm{~A}$ covenant under seal is not within the statute requiring agreements to be in writing expressing the consideration. ${ }^{8}$

§ 96. Guaranty - Consideration. - In many of the States, as Alabama, Minnesota, Nevada, and Oregon, a consideration expressed is necessary. That is, the consideration must appear with reasonable clearness. ${ }^{1}$ So a guaranty of a note, under such doctrine, written by a third person on the note before delivery, need not express a consideration, since the guaranty requires no other consideration than that which the note or its face implies to have passed between the original parties, but it is otherwise if the guaranty is written after the note has been delivered and taken effect as a contract. ${ }^{2}$

Where the nature of the consideration for the guarantor's undertaking is fairly inferable from the written provision of

4. Smith $v$. Northrup, S0 Hun (N. Y.), 65, 29 N. Y. S. 581 ; Gates v. Mcliee, 13 N. Y. 232, 64 Am. Dec. 545; Church v. Brown, $21 \mathrm{~N}$. Y. 315; Douglass v. Howland, 24 Wend. (N. Y.) 35.

5. Straight v. Wight, 60 Minn. 515, 63 N. W. 105; Hayes v. Jackson, 159 Mass. 451,34 N. E. 683.

6. Johnston v. Wadsworth, 24 : Oreg. 494. 34 l'. 13; Douglass v.
Howland, 24 Wend. (N. Y.) 45; Barnum v. Childs, 3 Super. Ct. (N. I.) 58 .

7. Mckenzie v. Farrell, 4 Bosw. (N. Y.) 207.

8. Smith v. Northrup, 80 Hun (N. Y.), 65, 29 N. Y. S. 851.

1. Straight v. Wight, 60 Minn. 515,63 N. W. 105.

2. Moses v. Lawrence Co. Bank, 149 U. S. 298,13 S. Ct. 900. 
guaranty, it is snflicient ninder the statute. ${ }^{3}$ When the entract is merely one of guaranty, it is manifestly within the terms of the statute, and the contract must be in writing. Ind there must be a principal debtor, and the promise must be made to the creditor to whom the principal debtor has alrealy or is thereafter to become liable. The guarantor must agree to pay if the debtor does not, and the promise must be in writing. ${ }^{4}$ Ilowever, in some jurisdictions, it is held to be a presumption of law, that if any contract, beneficial to the guarantor, is the object sought to be obtained by his promise, he must be understood to intend an original undertaking which is not within the statute. ${ }^{5}$ So the promise to pay the debt of an infant, made upon a suffcient consideration, is a promise to pay the debt of another and must be in writing to be enforeeable; the doctrine that there was no debt because the prineipal debtor was a minor, cannot prevail. ${ }^{6}$ However, some courts hold that in case of a guaranty of a person's contract who is incapacitated to contract, the guarantor is not liable. Because, so soon as the incompetent principal sets up his inability to make the contract, the debt cannot be collected either from him or of his guarantor; that the party guarantied something that did not exist and hence he is not liable. ${ }^{7}$ But under this rule the guarantor would become liable on an original undertaking, and he is therefore liable as on any other debt he may contract $;^{8}$ and the rule applied to the guaranty of an ultra vires contract. It is void and eannot be en-

3. Smith v. Northrup, 80 Hun (N. Y.), 65, 29 N. Y. S. 851 . See, also, Ryde v. Curtis, 8 Dowl. \& R. 62; Kennaway v. Trelevan, 5 Mees. \& Wel. 493; Newbury v. Armstrong, 6 Bing. 201; Hutton v. Padgeti, 26 MId. 228.

4. Elder v. Warfield, 7 H. \& J. (IId.) 391; Birkmyr v. Darnell, Salk. 2т; Spear v. Bank, 156 Ill. 555,41 N. E. 164.

5. Westmoreland v. Porter, 75
Ala. 452; Chapline v. Atkinson, 45 Ark. 67, 55 Am. Rep. 531; Lerch v. Gallup, 67 Cal. 595, \& P. 322.

6. Dexter v. Blanchard, 11 Met. (Mass.) 365; Davis v. Statts, 43 Ind. 103, $13 \mathrm{Am}$. Rep. 382.

7. King v. Summit, 73 1nd. 312 , 38 Am. Rep. 145; Smith r. Hyde, 19 Vt. 54.

8. Harris r. Huntbach, 1 Burr, 373. 
forced against the corporation, but the original promise of the guarantor can he enforeced against lim. ${ }^{9}$

The general rule is that an oral promise by one person to indemmify another for becoming a guarantor for a third person is not within the statute, and need not be in writing, for the assumption of the responsibility is a sufficient consideration for the promise. ${ }^{10}$ But there is another line of cases that hold that an indemnity contract is within the statute and must be in writing, because whenever there is a liability in existence, a performance of which by the debtor will put an end to liability upon special promise, the special promise amounts to a promise to pay the debt of another and must be regarded as collateral to it, and therefore it comes under the statute. ${ }^{11}$

\$97. Signature.- The contract must be signed by the party to be charged therewith, or some other person thereunto by him lawfully anthorized. ${ }^{1}$ To be clearly in the handwriting of the party to be charged is not sufficient." And the unsigned memorandum of an auctioneer uncomnected by annexation or reference with any writing duly anthenticated by the signature of the party sought to be charged or his duly authorized agent, is not a part of the memorandum required by the statute. ${ }^{3}$

While the writing must be signed, it is not always necessary

9. Drake v. Flewellen, 33 Ala. 106.

10. Jones v. Bacon, 145 N. Y. 446, 40 N. E. 216 ; Rose v. Wallenberg, 31 Oreg. 260, 44 P. 382; Guild v. Conrad (1894), 2 Q. B. 885 ; IVildes v. Dudlow, 19 Eq. 198; Pingrey on Suretyship and Guar. 382 ; Resseter v. Waterman, 151 IIl. 109,37 N. E. 875 .

11. May v. Williams, 61 Miss. 125, $48 \mathrm{Am}$. Rep. 80; Bissig v. Brit. ton, 59 Mlo. 204, $2 \overline{1} \mathrm{Am}$. Riep. 379; Farrell v. Maxwell, 28 Ohio St. 383, $22 \mathrm{Am}$. Rep. 393; Nugent $\mathrm{v}$. Wolfe, $111 \mathrm{~Pa}$. St. 471,4 A. 15.
1. Brown v. Whipple, 58 N. H. 229; Thiebaud v. Furniture Co., 143 Ind. 340,42 N. E. 741 ; Sanborn v. Sauborn, 7 Gray (Mass.), 142: Washington Ice Co. v. Webster, 62 Me. 341, 16 Anı. Rep. 462; Guthrie v. Auderson, 47 Kan. 383, 28 P. 164; McElroy v. Seery, 61 Mrl. 389, 48 Am. Rep. 110.

2. Champlin v. Parish, 11 Paige (N. Y.), 405; Selby v. Selby, 3 Merv. 2.

3. Rafierty v. Lougee, $63 \mathrm{~N}$. H. 54; O'Donnell v. Leaman, 43 Me. 158, 69 Am. Dee. 54; Horton v. McCarty, 53 Me. 394; Brown v. IVhip- 
that the party's name shall appear at the end of the contract, unless he must sulbseribe it. ${ }^{4}$

$\S 98$. Mutuality of agreement.- Whether the agreement nust be signed by both parties, in order to bind them, is a disputed question. The cases are incapable of being reconcilerl. A large and respectable class holds that a contract which the statute of frands declares shall not be valid unless in writing and signed by the party to be charged therewith, need only be signed by the party defendant in the suit, and that it is no objection to maintaining such suit and recovering upon the contract that the other party did not sign and was not bound by the terms. ${ }^{1}$ Another and equally prominent class of cases holds that unless the party bringing the action is bound by the contract neither is bound because of the want of mutuality. ${ }^{2}$

ple, 58 N. II. 229; Giurdels v. Kiluke, 36 Neb. 493, 54 N. W. 834 ; Moore v. Chenault, 29 S. IV. 140, 16 Ky. L. Rep. 531; Durham, ete., Improvement Co. v. Guthrie, $116 \mathrm{~N}$. Car. 381, 21 S. E. 952 ; Howell r. Shewell, 96 Ga. 454, 23 S. E. 310 , 51 Am. St. Rep. 148.

4. New England, etc.. Co. $v$. Worsted Co., 165 Mass. 328. 43 $\mathrm{X}$ E. $112,52 \mathrm{Am}$. St. Rep. 516 ; Tourret r. Cripps. 45 L. J. Ch. N. S. 567.

1. Smith's Appeal, 69 Pal. St. 480; Tripp v. Bishop, 56 Pa. St. 428; Perkins v. Hadsell, 50 IIl. 217; Old Colony Railroad Co. v. Evans. (Gray (Mass.), 31, 66 Am. Dec. 391: Williams v. Robinson, 73 Me. 186, $40 \mathrm{Am}$. Rep. 35\%; Love v. Welch, 97 X. Car. 200, 2 S. E. 24; Durham, atc., Improvement Co. v. Guthrie, 116 Y. Car. 381, 21 S. E. 952 ; Jones v. Daris, 48 N. J. Eq., 493, 21 A. 1035 ; Cavanangh v. Casselman, s8 Cal. 543, 26 P. 515;
Hougres r. Kowing, 亏5 Conn. 12, 18 A. 979,7 «. R. A. $8 \tau$; Justice v. Lange, 42 N. Y. 493; Morin v. Martz, 13 Minn. 191; Oliver v. Ins. Co., S2 Ala. 417, 2 So. 445 ; Gartrell v. Stafford, 12 Neb. 545, $11 \mathrm{~N}$. 732, 11 Am. Rep. 167; Reuss v. Pieksley, L. R. 1 Exch. 342; Cunningham v. Williams, 43 Mo. App. 629 ; Anderson v. Harold. 10 Ohio, 399 ; Douglass r. Spear's, 2 Nott. \& McC. (S. Car.) 207, 10 Am. Dec. 588; Shirley v. Shirley, 7 Blackt. (Ind.) 452; Smith v. Neale, 2 C. B., N. S. 67; Clason v. Bailey, 14 Jonhs. (N. X.) 4Ss: Parton v. Crofts. 16 C. B.. X. S. 11: Farwell r. Lowther. 18 Ill. 252; Cheney v. Cook. T Wis. 413; Tassault v. Edwards, 43 Cal. 458.

2. Lees v. Whiteomb, 3 Craig \& P. 289: Srkes v. Dixon. ! Ad. \& El. 693: Krohn v. Bautz, 65 Ind. 277; Stiles v. MeClellan, 6 rolo. s?: Wilkinson r. Teavenrich, 5s Mich. 574, 26 X. W. 139. 5.5 Am. Rep. 708; 
It is a general principle in the law of contracts, but not without exceptions, that an agreement entered into between parties competent to contract, in order to be binding, must be mutual; and this is especially so when the consideration consists of mutual promises. In such cases, if it appears that the one party never was bound on his part to do the act which forms the consideration for the promise of the other, the agreement is void for want of mutuality. ${ }^{3}$

The weight of authority is that the statute of frauds is satisfied by the signature to the contract of the party sought to be charged only, whether the suit to enforce it be at law or in equity, and whether it relates to the sale of real or personal estate. ${ }^{4}$

$\S 99$. Signature by agent.- The party to be charged may authorize a signing of the nemorandum by his agent. ${ }^{5}$ But if the agent goes beyond his anthority, his signing is invalid. ${ }^{6}$ In the absence of a statutory provision to the contrary, the authority of an agent to sign the memorandum nay be rerbal. ${ }^{7}$ In some States, contracts relating to land require that the agent's au-

Corbett v. Gaslight Co., 6 Oreg. 405 , 25 Am. Rep. 541 and note; Thomas v. Trustees, 3 A. K. Marsh. (Ky.) 295, 13 An. Dec. 165.

3. Hoplinins r. Logan, j Nees. \& Wel. 241; Dorsey v. I'ackwood, 12 How. (U. S.) 126; Ewins v. Gordon, 49 N. II. 444; Hoddesdon Gats Co. v. Haselwood, 6 C. B., N. S. 239 ; Souch v. Strawbridge, 2 C. B. 808; Callis v. Bothamly, 7 Wkly. 87; Sykes v. Dixon, 9 Ad. \& El. 693 ; Lester v. Jewett, 12 Barb. (N. Y.) 502 ; Utica, ete., R. R. Co. v. Brinckerhoff, 21 Wend. (N. Y.) 139, 34 Ann. Dee. 220.

4. Clason v. Bailey, 14 Johns. (N. Y.) 184; MeCrea v. Purmont,
16 Wend. (N. Y.) 460,30 Am. Dee. 103 and note; Richardson v. Green, 23 N.J. Eq. 3336 ; Old Colony R. R. Co. v. Evans, (; Gray (Măss.), 33, (6i) Am. Dee. 394; Sutherland v. Briggs, l Hare, 34; Hodges v. Kowing, 58 Comn. 12, 18 A. 979.

5. Hefiron v. Arnsly, 61 Mich. 505,28 N. IV. 672.

6. Henderson v. Beard, 51 Ark. 483, 11 s. W. 706.

7. Roehl v. Haumesser, 114 Ind. 311, 15 N. T. 345; Kennedy v. Eblen, 31 W. Ta. 540, 8 S. E. 398; Watson v. Sherman, $8 \bar{s}$ Ill. 263; Moore v. Taylor, SI Md. 644, 32 A. 320,33 A. 886 . 
thority must be in writing. ${ }^{8}$ The agent must be some third party who has no interest in the subject-matter. ${ }^{9}$

When an agent has the power to make a contract for the sale of land, but no power to make a deed, and makes a deed, the instrument is roid as a deed, the deed is good in equity as a contract to convey, and if a party enters upon the land under such an instrument, he is, in equity entitled to retain possession. ${ }^{10}$

\section{ARTICLE IV. \\ Remedies on the Contract.}

Sectros 100. No Action to Be Brought.

101. Void and Voidable.

102. Perfornance in Part-At Law.

103. Part Performance-In Equity.

104. What is Part Performance.

105. Possession of Land and Improvements.

106. Parol Gift of Real Estate.

107. Specific Performance of Agreement.

108. Personal Services and Conveyance of Personal Property.

109. Recovery of Money Paid.

110. Services Rendered or Benefits Received.

111. Use and Occupation.

112. Defense.

113. Who Nay Take Advantage of the Statute of Frauds.

114. Waiver of Statute in Action for Breach of Contract.

115. Conflict of Laws.

116. Conflict of Laws-Statute of Frauds.

$\S$ roo. No action to be brought. - The statute provides that "no action shall be brought whereby to charge" another on an unwritten contract. ${ }^{1}$

8. Lasher v. Gardner, 124 Ill. 441,16 N. E. 919; Kozel v. Dearlove, 144 111. 23, 32 న. E. 542, 36 Am. St. Rep. 416; Pratt v. Butcher, 112 Cal. 634, 44 P. 1060; Hall v. Wallace, Ss Cal. 434, 26 P. 360; Gerhart v. Peck, 42 Mo. App. 644; Williams v. Mershon, 57 N. J. L. 242, 30 A. 619.

9. Bent r. Cobb, 9 Gray (Mass.), 397, 69 Am. Dec. 295.
10. Groff v. Ramsey, 19 Minn. 44; Thomas v. Joslin, 30 Minn. 38s, 15 N. 675 ; Baum r. Dubois, 43 Pa. st. 260; Horrow v. Higgins, వ! Ala. 4.45; Ledbetter v. Walker, 31 Ala. 175; Worrall v. Munn, $5 \mathrm{~N}$. Y. 229, $55 \mathrm{Am}$. Dec. 330 and note; Long v. Hartwell, $3 \overline{4}$ N. J. I. 116 ; Lobdell v. Mason, 71 Miss. 937, 15 So. 44.

1. Montgomery v. Edwards, $4^{R}$ 
The statute of frands affects the remedy only, and, as generally held, not the validity of the contract. ${ }^{2}$ Hence, when the contract has been executed, and if it wonld have been good before the statute of frands, it cannot be said to be void. ${ }^{3}$ And when one has done a thing which he need not have done because his promise was oral, he may have his action against the other for the consideration orally promised, the statute not forbidding. ${ }^{4}$

$\S$ ror. Void and voidable.-In Alabama, California, Michigan, Nevada, New York, Oregon, Virginia, and Wisconsin, the statute does not follow the English, but declares that the contract shall be void unless in writing. This would seem to make the contract absolutely void unless in writing; however it is not clear what these statutes do mean. It is said that such statute makes the contract voidable but not void; that no action shall be maintained to charge one upon it, but for all other purposes it is good. ${ }^{5}$ So an oral contract for the sale of land is not utterly void. ${ }^{6}$ And it is doubtful whether such a statute was intended to embrace land in other States, over which the legislature had no jurisdiction. ${ }^{7}$ Provided the promisee, waiving his right to the land itself, should treat the contract as personal, bringing

Vt. 151, 14 Am. Rep. 618; Fowler v. Burget, 16 Ind. 341.

2. Townsend v. Hargraves, 118 Mass. 325; Leroux v. Brown, $12 \mathrm{C}$. B. 801; Carrington v. Roots, 2 Mees. \& Wel. 248; Reade v. Lamb, 6 Exch. 130; Browning v. Parker, 17 R. I. 183, 20 A. 835 ; Webster v. Le Compte, 74 Md. 289, 22 A. 234; Newton v. Bronson, 13 N. Y. 587, 67 Am. Dec. 89 and note.

3. Bolton v. T'omlin, 5 Ad. \& El. 856; Slatter v. Meek, 35 Ala. 528; snaw r. Woodeock, 7 Barn. \& $\mathrm{Cr}$. 73; Newman v. Nellis, 97 N. Y. 285.

4. Sims v. MeEwan, 27 Ala. 184;
Adams v. Honness, 62 Barb. (N. Y.) 326 ; Tinkler v. Swaynie, 71 Ind. 562 .

5. Leroux v. Brown, 12 C. B. 801; Maddison v. Alderson, 8 App. Cas. 467, 488; Cooper v. Hornsly, 71 Ala. 62; Crane v. Gough, $4 \mathrm{Md}$. 316.

6. Coughlin v. Knowles, 7 Met. (Mass.) 57, 39 Am. Dec. 759; Wetherbee v. Potter, 99 Mass. 361; Sims. v. Hutchins, 8 Sm. \& Mar. (Miss.) 331 ; Galway v. Shields, 66 Mo. 313, 27 Am. Rep. 351.

7. Sce Gibson v. Ins. Co., 77 Fed. Rep. 561. 
an action at law for damages for its breach, the lex celebrationis should govern, whether the action is begun in the courts of the situs, of the locus celebrationis, or of a third State. ${ }^{8}$ When the promisee has waived all claim to the land, and treats the contract as personal, the same should apply as in other personal contracts. ${ }^{9}$

$\S$ 102. Performance in part - At law.- In a court of law part performance of a rerbal contract does not take a case out of the statute of frands. ${ }^{1}$ At law part performance of a parol agreement for the sale of land will not exempt it from the operation of the statute; and the payment of the purchase-money is not such a performance as will induce a decree for specific performance. ${ }^{2}$ And if the contract is void at law, the rendee is entitled to recover back anything he may have paid to the rendor on account of such purchase. ${ }^{3}$ But if the contract is not void, he will not be allowed to recover back what he has paid, where the vendor is willing to perform his part. ${ }^{4}$ In Iowa and Alabama ${ }^{6}$ the statute provides that certain acts of part performance shall take the contract out of the statute of frauds.

Marriage, coupled with possession, is sufficient to compel per-

8. Minor's Conf. L. p. 417 , and cases cited; Story's Conf. L. 372d; Whar. Conf. L. $276 a$.

9. See Polson v. Stewart, 167 Mass. 211,45 N. E. 737,36 L. R. A. 771,57 Am. St. Rep. 452; Miller v. Wilson, 146 Ill. 523,34 N. E. 1111, 37 Am. St. Rep. 186; Wolf v. Burke, 18 Colo. 264, 32 P. 427, 19 L. R. A. 792 and note.

1. Chicago Attach. Co. v. Singer Machine Co., 142 Ill. 171,31 N. E. 438, 15 L. R. A. 754 and note; Fleming v. Carter, 70 Ill. 286; Durand v. Curtis, 57 N. Y. 7 ; Pierce v. Estate, 28 Vt. 34 ; Henry $v$. Wells, 49 Ark. 4S5, 3 S. W. 637;
Brown v. Pollard, 89 Va. 696, 17 S. E. 6 .

2. Anthony v. Leftwich, 3 Rand. (va.) 255; Dunsmore v. Lyle, 87 Va. 393,12 S. E. 610.

3. Brown v. Pollard, 89 Va. 696 , 17 S. E. 6.

4. Galway v. Shields, 66 Mo. 313, $27 \mathrm{Am}$. Rep. 351; Hawley v. Moody, 24 Vt. 605; Coughım v. Ǩnowles, 7 Met. (Mass.) 57, 39 Am. Dee. 759; Sims v. Hutehins, $8 \mathrm{Sm}$. \& M. (Miss.) 331 .

5. Price v. Lien, 84 Iowa, 590,51 N. W. 52 .

6. Louisville, ete., R. R. Co. v. Philyaw, 94 Ala. 463, 10 So. 83. 
formance. ${ }^{7}$ So where a father verbally promises, in contemplation of his danghter's marriage, to give her a house, and she and her husband took possession, the possession and marriage took the promise ont of the statute $;^{8}$ but marriage alone is not suffcient. $^{9}$

Where the statute does not declare otherwise, payment of the consideration alone does not take a parol gift out of the operation of the statute of frauds. ${ }^{10}$

Delivery of possession, coupled with the making of valuable improvements or the payment of the purchase price, is sufficient to compel specific performance. ${ }^{11}$ And in general delivery of possession alone having reference to the contract is all that is required $;^{12}$ becanse, if the contract was avoided, the vendee in possession would be liable as a trespasser. ${ }^{13}$

$\S$ 103. Part performance - In equity.- The doctrine that part performance of a contract will make valid a contract invalid by the statute of frands, is exclusively a creature of equity and applies only to contracts relating to lands. ${ }^{1}$ So where one of the parties to a contract roid by the statute of frauds, avails himself of its invaliclity, and unconscientiously appropriates what he has acquired indirect, equity will compel restitution, and it constitutes no objection to the claim that the opposite party may secure the same practical benefit, through the process of restitution, which would have resulted from the observ-

7. Gregory v. Mighell, is Ves. 328.

8. Ungley v. Ungley, L. R. Ch. Div. 76 .

9. Brown v. Conger, 5 Hun ( $\mathrm{N}$. Y.), 625 .

10. Gorham v. Dodge, 122 Ill. 528, 14 N. E. 44: Lanz v. Mclaughlin, 14 Minn. 72; Waton v. Whitaker, 18 Conǹ. פ2.ّ; Glass v. Hulbert. 102 Mass. 24. In Iowa the arreptance of the purchase price makes the contraet binding.
11. Holfman v. Felt, 39 Cal. 109; Glass v. Hulbert, 102 Mass. 24, 3 Am. Rep. 418; Moss v. Culver, 64 Pa. St. 414, 3 Am. Rep. 601.

12. Danforth v. Lancy, 28 Ala. 274; Tilton v. Tilton, 9 N. H. 386.

13. Laton v. Whitaker, 18 Conn. 222; 44 Am. Dec. 486.

1. McElroy v. Ludhm, 32 N. J. Eq. 828; Brittain r. Rossiter. 11 Q. B. D. 123 . 
ance of the roid agreement. The part performance must he such that the party will be put into a situation which is a frand upon him unless the agreement is fully performed. ${ }^{2}$ And the mere fact that the purchase price of real estate was paid by one person and the eonveyance thereof made to another, does not raise any use or trust in favor of the former, but the title vests in the latter. But this does not prevent the operation of any agreement that was good in law or equity in part performance of which the deed was given, and the power of a court of equity to compel the specific performance of a verbal agreement in cases of part performance is not thereby abridged. ${ }^{3}$

This principle rests upon equitable estoppel, that the vendor has so dealt with the purchaser in receiving the value or a part of the purchase-money or in contracting for its payment, and in putting the vendor in actual possession of the land in part execution of the contract of sale that it would be a frand on the vendor's part to repudiate the contract and stop short of the complete execution. ${ }^{4}$

When a party obtains title to real estate upon a verbal agreement to transfer in payment of the same to the grantor other property, real or personal, the statute does not apply and equity will enforce the agreement, since it would be a fraud on the part of the grantee to refuse. Such an agreement is not executory, but completely executed on the part of the grantor, and the purchaser alone is in default. ${ }^{5}$

$\S$ I04. What is part preformance.- Acts of part performance to take a parol contract out of the statute of frauds, must

2. Kincaid $\vee$. Kincaid, 85 Hun (N. Y.), 141, 32 K. Y. S. 476 ; Wheeler v. Reynolds, 66 N. Y. 231 ; Farwell v. Johnston, 34 Mich. 342.

3. Kincaid v. Kineaid, S5 Hum (X. Y.), 141. 32 N. Y. S. 476 : Snith v. Smith, 125 N. Y. 224, 20 N. א. $259 ;$ Murkley v. Whitney, 140 X. Y. $5 \div 6.35$ N. E. 930 .

4. Milley v. Lorentz, $39 \mathrm{~W}$. Va. 160. 19 ‥ E. 391 ; Clinan v. Cook.
1 Sch. \& Lf. 433 ; Gallagher v. Gallagher, 31 W. Va. 9. 5 S. E. 297; Wright r. Pucket, 22 Gratt. (Va.) 370: Harrison v. Harrison, 36 IV. Ta. 5.86, 15 S. E. 87; Trammell v. Craddlock, 100 Ala. 266, 13 So. 911.

5. Sprague r. Cochran, 144 N. Y. 104,38 N. E. 1000: Roherge $v$. Winne, 144 N. Y. 709,39 N. E. 631: Newman v. Nellis, 97 N. Y. 285. 
be of such unequivocal nature as of themselves to be evidence of the existence of an agreement; thus, where, under parol agreement to sell land, the purchaser is put in possession, and makes valuable improvements. ${ }^{1}$ Payment or part payment of the purchase-money is not sufficient to take the contract out of the statute. $^{2}$

An act of part performance, to take a case out of the statute of frauds, must be sufficient of itself, without any other information or evidence, to satisfy the court, from the circumstances it has created and the relation it has formed, that they are only consistent with the assumption of the existence of a contract the terms of which equity requires, if possible, to be ascertained and enforced.

This is so because the defendant in a suit founded on such part performance is really "charged" upon the equities resulting from the acts done in execution of the contract, and not, within the meaning of the statute, upon the contract itself. Hence, until such acts are shown as of themselves imply the existence of some contract, parol evidence to show the terms of the contract relied on is inadmissible. ${ }^{3}$

The act of performance as could be done with no other view or design than to perform the agreement. ${ }^{4}$ The principle of the cases is that the act must be of such nature that, if stated, it would of itself infer the existence of some agreement and then parol evidence is admitted to show what the agreement is. ${ }^{5}$

1. Hale v. Hale, 90 Va. 728,19 S. E. 739 ; Maddison v. Alderson, 8 App. Cas. 479,7 Q. B. D. 174.

2. Cooley v. Lobdell, 82 Hun (N. Y.), 98, 31 N. Y. S. 202; Brown v. Pollard, 89 Va. 696, 17 S. E. 6; Glass v. Hulbert, 102 Mass. 28, 3 Am. Rep. 418; Boulder Valley, etc., Co. v. Farnham, 12 Mont. 1, 29 P. 277 ; Maxfield v. West, 6 Utah, 327 , 23 P. 754; Gorham v. Dodge, 122 Ill. 528, 14 N. E. 44; Goddard v. Danaha, 42 Kan. 754, 22 P. 708; Horn v. Luddington, 32 Wis. 73;
Kinyon v. Young, 44 Mich. 339, 6 N. 835 ; Nibert v. Bazhurst, $47 \mathrm{~N}$. J. Eq. 201, 20 A. 252; Forrester v. Flores; 64 CaI. 24, 28 P. 107; Townsend v. Vanderwerker, $20 \mathrm{D}$. C. 197 .

3. Dale v. Hamilton, 5 Hare, 381; Maddison v. Alderson, 8 App. Cas. 467; Hale v. Hale, 90 Va. 728, 19 S. E. 739.

4. Gunter v. Halsey, Amb. 586.

5. Frome v. Dawson, 14 Ves. 387 ; Phillips v. Thompson, 1 Johns. Ch. (N. Y.) 131. 
$\S$ 105. Possession of land and improvements. - Possession must be taken under the verbal contract. It is not enough that the possession was taken. It must be taken under the rerbal contract pursuant to the provisions, in order to take the contract out of the statute, ${ }^{1}$ when the consideration has been paid, ${ }^{2}$ or valuable improvements have been made on the land in the purchaser's possession. ${ }^{3}$ And a party having possession, who buys and then makes valuable improvements, will be protected, because this is such a part performance as to take the contract out of the statute. ${ }^{4}$ Mere possession alone is not sufficient $;^{6}$ it must be under the contract, payment of consideration and generally improvements must be made. ${ }^{6}$

1. Boozer v. Trague, $27 \mathrm{~S}$. Car. 34 , 3 S. E. 551 ; Tunison v. Bradford, 49 N. J. Eq. 10, 2.2 A. 1073; Foster v. Maginnis, 89 Cal. 264, 26 P. 8:2 ; Clark v. Clark, 122 1ll. 383, 13 N. E. 553 ; Ridgway v. Ridgway, 69 MId. 242, 1! A. 659; Judy v. Gilbert, 77 Ind. 96, 40 Am. Rep. 289 and note; Waymire v. Waymire, 141 Ind. 164,40 N. E. 523.

2. Martin v. Patterson, $27 \mathrm{~S}$. Car. 621, 2 S. E. 859; Carney v. Carney, 95 ㄱo. $35 \overline{3}, 8$ s. IV. 729 ; Bechtel v. Cone, 52 Md. 698; Gould v. Banking Co., 136 1ll. 60, 26 N. E. 497; Jameson v. Dimock, 95 Pa. St. 52; Lipp v. Hunt, 25 Neb. 91, 41 N. W. 143; Compare Bradley v. Owsley, 74 Tex. 69, 11 S. W. 1052.

3. Smith v. Smith, 125 N. Y. 224, 26 N. E. 259 ; Freeman v. Freeman, 43 N. Y. 34, 3 Am. Rep. 657; Hale v. Hale, 90 Va. 728,19 S. E. 739 ; Mudgett v. Clay, 5 Wash. 103, 31 P. 424; Brown v. Sutton, 129 U. S. 238, 9 S. Ct. 273; Potter v. Jacobs, 111 Mass. 32; Cutsinger $r$. Ballard, 115 Ind. 93, 17 N. E. 206; Evans v. Miller, 38 Minn. 245, 36
N. W. 640; Barnett v. Forney, 82 Va. 269; Hunter v. Mills, $29 \mathrm{~S}$. Car. 72, 6 S. E. 907 ; Noulton v. Harris, 94 Cal. 420, 29 P. 706 ; Hunkins v. Hunkins, 65 N. H. 95 , 18 A. 665 ; Melvhinne r. Martin, 77 Wis. 182, 46 N. W. 18; Morrison v. Herrick, 130 Ill. $631,22 \mathrm{~N}$. E. 537 .

4. Peck v. Stanfield, 12 Wash. 101, 40 Pae. 635.

5. Dongan v. Blocker, 24 Pa. St. 28 ; Glass v. Hulbert, 102 Mass. 32, 3 Am. Rep. 418; Miller v. Ball, 64 N. Y. 292; Hibber $\bar{t}$ v. Aylatt, 52 Tex. 530; Compare Kennemore v. Kennemore, 26 S. Car. 251, 1 S. E. 881.

6. Townsend v. Vanderwerker, 160 U. S. 171,16 S. Ct. 258; Wells v. Stradling, 3 Ves. Jr. 37s; Mundy v. Joliffe, 5 Mr. \& Cr. 167; Morgan v. Battle, 95 Ga. 603,22 S. E. 6S9; Delevan v. Wright, 110 Mich. 143, 67 X. W. 110; Moumin v. Trainer, 63 Minn. 230, 65 N. IV. 444: Stult v. Sweesy, 48 Teb. 767, 67 N. W. 748 . 
\$ 106. Parol gift of real estate. $-A$ parol gift of real estate and a parol promise to convey the same is valid and enforcible in equity, where the donee has entered into possession of the property and made permanent improvements thereon, on the faith of the donor's promise, ${ }^{1}$ and this, although when specific performance by the donee is clained, the rental valne of the property for the time it has been occupied by the latter would be more than the amount expended by him. ${ }^{2}$ Because the courts of equity, in decreeing specific performance of verbal agreements where there has been part performance, do so for the purpose of preventing a party from escaping engagements he has entered into through the statute of frands, after the other party to the contract has expended his money, or otherwise acted in execution of the agreement. ${ }^{3}$ Expenditures made upon permanent improrements upon land with the knowledge of the owner, induced by his promise, made to the party making the expenditure, to give the land to such party, constitnte in equity a consideration for the promise. ${ }^{4}$ Whether delivery of possession of the land is sufficient to take a parol gift of land out of the statute of frauds, is a question of some difficulty. Some of the courts hold that a valuable consideration must also pass. ${ }^{5}$ If a parol gift is clearly proven and possession is given, it should be specifically enforced. ${ }^{6}$

\section{$\S$ 107. Specific performance of agreement.-Many courts} hold that where an agreement has been executed, or is partly performed by the plaintiff, and the acts done place him in a position which is a fraud upon him unless the agreement is

1. Lobdell v. Lobdell, 46 N. X. 327, 7 Am. Rep. 341; Crosbie v. McDonald, 13 Tes. 148; Freeman v. Freeman, 43 N. Y. 34, 3 Am. Rep. 657; Schroeder v. Wauzor, 36 Hun (N. Y.), 425; Ogsbury v. Ogsbury, 115 N. Y. 290,22 N. E. 219.

2. Young v. Overbaugh, $145 \mathrm{~N}$. Y. 158,39 N. E. $71 \hat{z}$.

3. Young v. Glendenning, 6
Watts (Pa.), 510; Schuey v. Schaefer, 130 Pa. St. 23, 18 A. 544, 549 ; Seary v. Drake, 62 N. H. 393.

$\Delta$. Freeman v. Freeman, 43 N. Y. 34, 3 Am. Rep. 657.

5. Stewart v. Stewart, 3 Watts (Pa.), 253.

C. Freeman v. Freeman, 43 N. Y. 34, 3 Am. Rep. 657; Manley v. Howlett, 55 Ca1. 9.. 
executed, equity will not permit the defendant to protect himself from exeeuting his part of the agreement by pleading that the contract was not in writing. ${ }^{1}$ So in the sale of land when all the requisites have been complied with, a deed will be decreed to the vendee. Thus, when the contract fully described the boundaries, the precise amount of the consideration, possession actually delivered by the vendor and taken by the vondee, a deed will be decreed to be made by vendor to rendee. ${ }^{2}$ But it has been held by some courts that a written contract cannot be decrced, as it is not such a fraud as will take the contract out of the statute. ${ }^{3}$ But generally specific performance of a contract will be deereed when the contract is ralid, unobjectionable in character, and capable of being enforecd. ${ }^{4}$

\section{$\S$ ro8. Personal services and conveyance of personal prop-} erty.- The equity of part performance to entitle plaintiff to specific execution of a contract within the statute, does not extend to contracts within the fifth clause of the fourth section of the statute, when such contracts, not being evidence in writing, relate to personal service, or the subject-matter of them is the sale and delivery of mere personal chattels. ${ }^{5}$ So for labor and service performed under a contract which is void under the statute, a recovery may be had by declaring a quantum meruit. ${ }^{6}$ And where a person pays money, renders service or conveys property under an agreement within the statute, which the other

1. Dean v. Anderson, 24 N. J. Eq. 496; Walker v. Barney, 3 Madd. 247 ; Herman v. Hodges, L. R. 16 Eq. 18; Humble's Case, 11 Irish Ch. 132; McClintock v. Laing, 22 Mich. 212; Lavrence v. Lawrence, $42 \mathrm{~N}$. H. 109; Equitable Gas Light Co. v. Manuf. Co., 63 Md. 285; Graft v. Loueks, 138 Pa. St. 453, 21 A. 203; McDorald v. Youngbluth, 46 Fed. Rep. 830 .

2. Graft v. Loucks, $138 \mathrm{~Pa}$. St. 453, 21 A. 203.

3. Jackson v. Myers, 120 Ind.
504, 2.2 N. E. 90,23 N. L. 86 ; Feeney $v$. Howard, 79 Cal. 525, 21 P. 984, 12 An. St. Rep. 162.

4. Hoover $x$ Buck (Va.), $21 \mathrm{~S}$. E. 474; Grubb v. Sharkey, 90 Va. 831,20 S. E. 784.

5. Equitable Gas Light Co. v. Manuf. Co., 63 Md. 285; Brittain v. Rossiter, 12 Q. B. D. 123 ; Maddison v. Alderson, $S$ App. Cas. 474 , 490 .

6. Patten v. Hicks, 43 Cal. 509; Whipple r. Parker, $2 \overline{4}$ Mlich. 369. 
party refuses to perform, an action will lie by such person against the party refusing, to recover the money paid or the value of the services rendered or the property conveyed. ${ }^{7}$

And so a parol agreement to devise and bequeath real and personal property as compensation for a nephew's services is within the statute of frands as to the real estate, and, being inadmissible, fails wholly; but it may be shown in evidence to rebut the presumption that the services were rendered gratuitously, and the nephew may recorer quantum meruit.

$\S$ Iog. Recovery of rnoney paid.-If a contract is invalid because it is oral, and the vendor has received a purchase-money, and then refuses to eomply with the contract, he may be compelled to repay the purchase-price. ${ }^{1}$ But the purehaser must be willing to consummate the bargain, or he cannot recover. ${ }^{2} \mathrm{It}$ is when the rendor repudiates the contract invalid under the statute, that the vendce may recover back the amount he has paid. $^{3}$

$\S$ IIo. Services rendered or benefits received. - When the contract is invalid under the statute and one party has accepted its benefit or received the consideration, an action

7. Sherburne v. Fuller, 5 Mass. 133, 138; Gillet v. Maymard, 5 Johns. (N. Y.) 85, 4 Am. Dec. 329; King v. Brown, 2 Hill (N. Y.), 485; Day v. Railroad Co., 51 N. Y. 583 ; Richards v. Allen, 17 Me. 296 ; O'Grady v. O'Grady, 162 Mass. 290, 38 N. E. 196; Dix v. Marey, 116 Mass. 416.

8. Ellis v. Cary, 74 Wis. 177,42 N. W. 252, 17 Am. St. liep. 120; Freeman v. Foss, 145 Mass. 361, 14 N. E. 141,1 Am. St. Rep. 467; Wallace v. Long. 105 Ind. $522,5 \mathrm{~N}$. E. $666,55 \mathrm{Am}$. Rep. 222; Schwab v. Picrro, $43 \mathrm{Minn} .520,523,46 \mathrm{~N}$. W. 711 : Estate of Kessler, S7 Wis.
660, 59 N. W. 129, 41 Am. St. Rep. 74 .

1. Herrick v. Newell, 49 Minn. 149, 51 N. W. 819; Taylor v. Read, 19 Minn. 372; Schroeder v. Loeber, 75 Md. 195, 23 A. 579, 24 A. 226; Welch v. Darling, 59 Vt. 136, 7 A. 547 .

2. Brockhausen v. Bowes, 50111. App. 98; Dulin v. Príce, 124 Ill. 70, 16 N. E. 242.

3. Wilkie v. Womble, 90 N. Car. 254; Durham, etc., Improvement Co. v. Guthrie, 116 N. Car. 381, 21 S. E. 952 ; Bacon v. M[eChrystal, 10 Utah, 200, 37 P. 563 . 
may be maintained against him for the benefit thus conferred, and the money, property, or value thus accepted and appropriated by hinl; not, however, upon the contract, but upon the appropriate common counts in assumpsit, and upon the duty, promise, or obligation springing from the property, money, or benefit thus conferred by the plaintiff, and received and appropriated by the defendant. ${ }^{1}$

The statute inclurles every agreement by which one promises to sell an existing interest in land upon a consideration either good or valuable. Hence, a contract to convey land in consideration of labor or service to be rendered, is within the statute. ${ }^{2}$ But when the contract is repudiated by the vendor a quantum meruit will lie for the value of the services. ${ }^{3}$

$\S$ III. Use and occupation.- Though a contract for the use of property is invalid by the statute of frauds, its covenants are still ralid so long as the use continues. ${ }^{4}$ The fact that a party has been let into possession of the premises under a verbal contract and occupies them for a time and pays rent pursuant to a verbal contract, does not take the case out of the statute, and there can be, therefore, no recovery under the contract, and the only remedy of the lessor is under quantum meruit for use and occupation. ${ }^{5}$

1. Whipple v. Parker, 29 Mich. 374; Pierce v. Paine, 28 vt. 34 ; Emery v. Smith, 46 N. H. 151; Cadman v. Markle, 76 Nich. 448; 43 N. W. 315,5 L. R. A. 707 and note.

2. Dowling v. Melienny, 12f Mass. 478; Baxter v. Kitch, 37 Ind. 554; Burlingame v. Burlingame, 7 Conn. 92; Helm v. Logain, 4 Bibb (Ky.), 7S; Jock r. McKee, 9 Pa. St. 235; Sprague v. Ilaines, 68 Tex. 215, 4 S. WV. 37 I.

3. King v. Brown, 2 Ilill (N. Y.), 485; Stevens v. Lee, 70 Tex. 279. 8 S. W. 40 ; Wonsettler v. Lee,
40 Kans. 367, 19 P. 862; Koch v. Williams, 82 Wis. 186, 52 N. W. 257; Thomas v. Hatch, 53 Wis. 296,10 N. 393 ; Miller v. Eldredge, 1:6 Ind. 461,27 N. E. 132.

4. Hermann v. Curiel (N. Y.), 3 App. Div. 5ll, 38 N. Y. S. 343 ; Steele v. Asso., 57 Minn. 18, $58 \mathrm{~N}$. IV. 685; Zachry v. Nolan, 66 Fed. Rep. 467.

5. Marr v. Ray, 151 1ll. 340,37 X. E. 1029,26 L. R. A. 399 and note; Clicago Attachment Co. v. Sewing Machine Co., 142 Ill. 171, 31 N. E. 438; Smallwood v. Shepparls (1895), 2 Q. B. 627. 
The English rule is that a parol lease in contravention of the statute, under which possession is taken creates a tenancy at will, and payment of rent thereunder converts it into a tenancy from month to month or year to year as the period may be indicated by the payment. ${ }^{6}$

In many of the States the English rule prevails while in others the only tenancy created under such circumstances is one from year to year, the contract controlling the rights and obligations of the parties in all particulars except as to duration. ${ }^{7}$

§II2. Defense.-A verbal contract within the condemnation of the statute, as for the sale of land, cannot be enforced in any way either directly or indirectly, and cannot be made a ground of demand or a ground of defense. ${ }^{1}$ The party may plead the statute in bar of a collateral action, based on the contract, as well as of a direct action on the contract itself. ${ }^{2}$ Thus, if a party in express terms makes a verbal contract to serve for five years, it camnot be enforced against him by the other party. And if after serving a portion of the time he should refuse to carry out his contract, and bring suit to recover the value of the services rendered, the verbal contract will not avail the employer as a defense. It camnot be set up as a contract at all; the breach of it will impose no liability which the law can enforce; the obligation to perform cannot be maintained in an action at law. ${ }^{3}$ 3.

6. Clayton v. Blakey, 8 Term R.

7. Koplitz v. Gustavus, 48 Wis. 48, 3 N. 754 ; Morehead v. Wotlyus, 5 B. Mon. (Ky.) 228; Dunn v. Rothernel, 112 Pa. St. 272, 3 A. 800; Laughran v. Smith, 75 N. Y. 205 ; Morrill v. Mackman, 24 Mich. 279, 9 Am. Rep. 124; Evans v. Winona Lumber Co., 30 Mınn. 515, 16 N. 404 ; Cody v. Quarterman, 12 Ga. 386; Drake v. Newton. 23 N. J. L. 111; Warner v. Hale, 65 Ill. 395: Wheeter $r$. Frankenthal, 78

III. 124; Creighton v. Sanders, 89 III. 543; Brownell v. Welch, 91 III. 523 .

1. MeGinnis v. Fernandes, 126 111. 228, 19 N. E. 44; Wheeler v. Frankenthal, 78 Ill. 124; Leavitt v. Stern, 159 Ill. 526,42 N. E. 869.

2. Banks v. Crossland, L. R. 10 Q. B. 97, 100; Carrington v. Roots, 2 Mees. \& Wel. 248; Reade v. Lamb, 6 Exch. 130; Comes v. Lawson, 16 Conn. 246.

3. Baker v. Lauterbach, $68 \mathrm{Md}$. $6 \div, 11 \therefore 703$. 
The contraet cannot be available as a contract at all, unless an action can be brought upon it. What is done under the contract may admit of apology or excuse, as where a eontract hy parol, the party is put into possession, that possession may be set up as an exeuse for trespass alleged to have been eommitted by him.

The agreement may be arailable in answer to a trespass by setting up a license; not setting up the eontract itself as a contract, but only showing matter of exeuse for the trespass.

$\S$ Ir3. Who may take advantage of the statute of frauds.The statute of frauds is a defense personal to the party to the contract. ${ }^{5}$ So the benefit of the statute of frauds cannot be claimed by one not a party to the contraet who is not sought to be eharged. ${ }^{6}$ Many eases illustrate the doctrine that a third person cannot make the statute available to overthrow a transaction between other persons. It concerns the remedy alone. and the modern law is well settled that in the absence of a statutory provision to the contrary, the effect of the statute of frauds, is not to render the agreement void, but simply to provent its enforcement by parties and to refeuse damages for its breach. $^{8}$

\section{$\S$ II4. Waiver of statute in action for breach of contract.-} It is generally held that contracts within the statute of frauds are not void but voidable; hence, a party to be charged may waire the statnte and the contract thereby becomes binding

4. Carrington v. Roots, 2 Mees. \& Wel. 24 S.

5. Carpenter v. Davis, 72 Ill. 14; King v. Bushnell, 121 H1l. 656, 13 N. E. 245; Cahill v. Bigelow, 18 Pick. (Mass.) 369.

6. St. Louis, etc. Railroad Co. v. Clark, 121 Mo. 169, 25 S. W. 19:, 906, 26 L. R. A. 751 and note; Cooper v. Hornsby, 71 Ala. 62; Houser v. Lamont, $55 \mathrm{~Pa}$. St. 311 ,
93 Am. Dec. 755; Dock Co. v. linzie, 49 Ill. 289; Wright v. Jones, 105 Ind. 17,4 N. E. 281; Savage v. Lee, 101 Ind. 514; Ames v. Jackson, 115 Mass. 508.

7. Jackson v. Stanfield, 137 Ind. 592,36 N. E. 345,37 N. E. 14,23 L. R. A. 588 .

8. Jackson v. Stanfield, 137 Ind. 592,36 N. E. 345,37 N. E. 14,23 L. R. A. 588 . 
upon him. ${ }^{1}$ So when a contract within the statute of frauds is proved by parol evidence withont objection or exception, the right to invoke the statute is waived, and cannot afterwards be insisted upon. ${ }^{2}$ And the statute of frauds as a defense must be pleaded or it will be considered as waived though shown by the eridence. $^{3}$

$\S$ II5. Conflict of laws. - Where a contract is entered into in one State to be performed in another, there are two loci contractus, the lex loci celebrationis and lex loci solutionis, and the law of the former governs the interpretation, nature, and validity of the contract, that of the latter its performance. A contract may be valid by the law of both places, and yet fail practically, if the lex fori does not permit its enforcement. ${ }^{4}$

This is a rule of personal contracts, though it is at variance with many dicta and decisions, but is well supported on authority. ${ }^{5}$ And some cases hold that a contract made in good faith in one State to be performed in another, will be upheld if if conforms to the law of either State. Because, in making such

1. Aultman v. Booth, 95 Mo. 383, 8 S. W. 742; McGowen v. West, 7 Mo. 570, 38 Ans. Dec. 468; Sneed .v. Bradley, 4 Sneed (Tenn.), 304, $70 \mathrm{Am}$. Dec. 250; Brakefield v. Anderson, 87 Tenn. 206, 10 S. IV. 360; Montgomery v. Edwards, 46 Vt. 151, 14 Am. Rep. 618.

2. Nunez v. Morgan, 77 Cal. 427, 19 P. 753; Donald v. Homestead Asso., 51 Cal. 210; McClure v. Otrich, 118 Ill. 320,8 N. E. 784 ; Wells v. Monihan, 129 N. Y. 161, 29 N. E. 232.

3. Espalla v. Wilson, 86 Ala. 487, 5 So. 867 ; Jonas v. Fields, 83 Ala. 445. 3 So. 895 ; Barrett r. McAllister, 33 W. Va. 738, 11 S. E. 230 ; Compare Fontaine v. Bush, 40 Minn. 141, 41 N. W. 465, 12 Am. St. Rep. 722; Harris v. Frank, 81
Cal. 280, 22 A. 856; Barnlardt v. Walls, 29 Mo. App. 206 ; Senmes v. Worthington, 38 Md. 29s; Popp v. Siwanke, 68 Wis. 364,31 N. W. 916; Hogan v. Easterday, 58 Ill. App. 45 ; Hurt v. Ford, 142 Mo. '283, 44 S. IV. Rep. 228.

4. Leroux v. Brown, 12 C. B. 801; Emery v. Burbank, 163 Mass. $3 \div$ ช. 39 N. E. 1026, 47 Am. St. Rep. 456.

5. Cooper v. Waldegrave, 2 Beav. 282; Vidal r. Thompson, 11 Mart. (La.) 23; Dacosta v. Davis, $24 \mathrm{~N}$. J. L. 319 ; Aymar v. Slieldon, 12 Wend. (N. Y.) 439, 27 Am. Dec. 137 and note; Clapman v. Robertson, 6 Paige (N. Y.), 627, 31 Am. Dec. 264 and note; Bain v. Railway, 3 H. I. I; Story on Conit. of $\mathbf{L}$. $23 \%$. 
contracts the parties may have in view either the law of the State where the eontralet is maile or the law of the State where it is to be performed; henee, if made in good faith withont any design to evale the law, it ought to be allowed and enfored aecording to its presumable intent, ut res magis valeat quam pereat, that the thing maly rather have effect than be destroyed."

If the contract is roid because not in writing, the question is determined by the lex loci celebralionis. If the question is not one of validity but whether an action can be brought on it, the lex juri governs. ${ }^{\mathrm{s}}$

The statute of frauds is somewhat different in the several States. In some it is provided that "no action shall be brought" on a contract unless it is in writing, and others that such contract shall be "void" unless it is in writing. In such case a contract made under the first would not be void, and if suit was brought on it in the second case, it would be enforced, because the oral contraet is not void by the lex celebrationis and is not against the statute of the lex fori, or in other words the statute would not apply in either case. ${ }^{9}$ If the lex celebrationis provides that no action shall be brought unless in writing, while the lex for $i$ does not require it to be in writing, then the lex for does not raise the question of the impairment of the obligation of the contract. The matter is one pertaining to the remedy to be controlled by the lex for i, which will enforce the obligation to a greater extent than would the lex celebrationis. ${ }^{10}$

6. Bolton v. Street, 3 Cold. (Tenn.) 31; Fisher v. Otis, 3 Chand. (Wis.) 83 ; Depau v. Humphreys, 8 Mart. (1a.) N. S. 1; Cromwell v. County, 96 U. S. 51.

7. Miller v. Wilson, 146 Ill. 523, 34 N. E. 1111, 37 Am. St. Rep. 186; Wilson v. Mills Co., 150 N. Y. 314 , 44 N. E. 959, 55 Am. St. Rep. 680; Sullivan v. Sullivan, 70 Mich. 583, 38 N. W. 472.

8. Hall v. Cordell, 142 U. S. 116 , 12 S. Ct. 15t; Wolf v. Burke, 18 Colo. 264, 32 P. 427,19 L. R. A.
192 and note; Compare Baxter Bank v. Talbot, 154 Mass. 213, 28 N. E. 163,13 J. R. A. 97 and note.

9. Wolf v. Burke, is Colo. 264, 32 P. 427,19 \&. R. A. 792 and note.

10. Downer v. Chesbrough, 30 ('un. $\therefore 9,+$ in. Hep. 29 ; Wolf v. Burke, 18 Colo. 264, 32 P. 427, 19 L. R. A. 702 and note; Compare Cochrane v. Wald, 5 Ind. App. 89. 29 Y. E. 79.5, 31 N. E. 581.51 . Im. St. Rep. 229. 
$\S$ Ir6. Conflict of laws - Statute of frauds. - It has been held that a contract, valid by the laws of the place where it is made, although not in writing, will not be cnforced in the courts of a country where the statute of frauds prevails, unless it is put in writing. ${ }^{2}$ But where the law of the forum and that of the place of the execution of the contract coincide, it will be enforced, although required to be in writing by the law of the place of performance, ${ }^{2}$ because the form of the contract is regulated by the law of the place of its celebration, and the evidence of it by that of the forum. ${ }^{3}$

As to the requisites of a valid contract, the morle of authentication, the forms and ceremonies required and as to every thing which is necessary to perfect or consummate the contract, the lex loci contractus governs, though with respect to conveyances, or other contracts relating to real estate, the statutory regulations of the place where such estate is situate, must be observed. ${ }^{4}$

Accordingly a parol agreement made in Illinois to lease real estate in that State for the term of a year, to begin at some definite time in the future, falls within the provisions of the Illinois statute of frauds, and a suit to enforce the same camnot be maintained in Indiana though the agreement is not repugnant to any provision of the statute of frauds in the latter State. ${ }^{5}$

1. Leroux v. Brown, 12 C. B. 801; Compare Gibson v. Holland, L. R. 1 C. P. 1.

2. Scudder v. Bank, 91 U. S. 406.

3. Pritchard v. Norton, 106 U. S. 124,1 S. Ct. 102 .

4. Baltimore, etc., R. R. Co. v. Gienn, 28 Md. 287, 92 Am. Dec. 688 ; Fox v. Matthews, 33 Miss. 433; Wilcox, etc., Co. v. Green, 72
N. Y. 117, 28 Am. Rep. 116; Hallgarten v. Oldham, 135 Mass. 1, 46 Am. Rep. 433; Gross v. Jordan, 83 Ne. 380,22 A. 250 ; Butters v. Glass, 31 U. C. Q. B. 379.

5. Cochran v. Ward, 5 Ind. App. 89, 29 N. E. 795,31 N. E. 581,51 Am. St. Rep. 229. See, also, Anderson v. May, 10 Heisk. (Tenn.) 84. 


\section{ARTICLE Y.}

Promises iy Exectitors and Amministrators.

Sectron 117. Statutory Provisions.

118. Application of this Clanse.

119. Forbearance.

120. The Special Promise.

121. Original Consideration.

\& I 7. Statutory provisions.-. The fourth section of the statute of frauds declares that "no action shall be brought whereby to charge any executor or administrator, upon any special promise, to answer damages out of his own estate . . . unless the agreement upon which such action shall be brought, or some memorandum or note thereof, shall be in writing, and signed by the party to be charged therewith, or some other person thereunto by him lawfully authorized." So to make an executor or administrator personally liable for the debt of the decedent, his pronise to pay it must be in writing.

$\S$ Ir8. Application of this clause.- This clause of the statute does not apply to original undertakings by the exeeutor or administrator. ${ }^{1}$ The statute only applies to promises to answer for debts or liabilities of the decedent; where an executor or administrator has assets of the estate, a promise by him, to pay a debt due by the person he represents, is not within the statute. $^{2}$ But the possession of assets is not, of itself, sufficient to charge him personally, as such promise, without a new consideration. $^{3}$

\& IIg. Forbearance.- Although the mere possession of assets by an executor or administrator will not be a good consider-

1. 'Taylor v. Mygatt, 26 Com. 184; Stebbins v. Smith, 4 Pick. (Mass.) 97 ; Williams v. Davis, 18 Wis. 184; In re Hummel's Estate, 55 Minn. 315,56 N. W. 1064.
2. Stebbins $v$ Suith, 4 Pick. (Mass.) 97 ; Pratt v. Humphrey, 22 Conn. 317.

3. Pratt v. Humphrey, 22 Conn. 317 . 
ation to charge him personally on such promise, a new ennsideration, such as forbearance to procecd against the estate he represents, is sufficient for the purpose, although he has no assets ${ }^{1}$ and the same doctrine will apply as to forbearance in collecting legacies. ${ }^{2}$ Thus, the pronise of an executor to pay five thousand dollars to one of the testator's heirs-at-law, who received nothing under the will, in consideration that he would forbear further opposition to the probate of the will, claimed to have been made as it was through undue influence, is not within the statute; and such forbearance is a sufficient consideration. ${ }^{3}$

\& I20. The special promise.- The special promise referred to in this section of the statute is any actual promise made by an executor or administrator to answer damages out of his own estate. The promise must be to answer damages out of his own estate.

This phraseology clearly implies an obligation, duty, or liability on the part of the testator's estate for which the executor promises to pay damages out of his own estate. The statute was enacted to prevent executors or administrators from being fraudulently held for the debts or liabilities of the estates which they were called upon to administer. "To answer damages" is equivalent "to pay debts of the decedent."

To be bound personally the executor's promise must show the intent as when lie adds "executor," or in case of administrator, he adds "administrator" to lis signature.

1. Ramn v. Hughes, 7 Term R. $346 n$; Parish v. Wilson, Peake, 73; Barber v. Fox, 2 Saund. 136; Philpot v. Briant, 4 Bing. 717 ; Treford v. Holmes, Hutton, 108; Palnier's Case, Hutton, 52; Porter v. Bille, 1 Freem. 125; Jones v. Ashburnham, 4 kast, 455 .

2. Davis v. Reyner, 2 Lev. 3; Bellows v. Sowles, 57 Vt. 164, 52 Am. Rep. 118.
3. Bellows v. Sowles, 57 Vt. 164 , 52 Am. Rep. 118.

4. Browne's Stat. of Frauds, p. $150 ; 2$ Redfield on IVills, p. 290 et seq.; Harrington v. Rich, 6 Vt. 666.

5. Treadwell v. Herndon, $4 \mathbf{l}$ Miss. 38; Lockwood v. Gilson, 12 Ohio St. 526; Winter v. Hite, 3 Iowa, 142; Stoudenmeier v. Williamson, 29 Ala. 558. See, alco, Childs v. Monins, 2 Brod. \& B. 460. 
§ I2I. Original consideration.- When the contract is founded upon a new and listinct consideration moving between the parties, the undertaking is original and independent, and not within the statute. ${ }^{1}$ It is a principle of law well sustained by authority, that when the principal or inmmediate object of the promisor is not to pay the debt of another, but to subserve some purpose of his own, the promise is original and independent, and not within the statute. ${ }^{2}$ The consideration must not only be sufficient to support the promise, but of such a nature as to take the promise ont of the statute; and that requisite is to be found in the fact that it operates to the advantage of the promisor, and places him under a pecuniary obligation to the promisce, entirely independent of the original debt. ${ }^{3}$

The statute by its terms operates on cases where there is a primary or original debt or obligation upon which is based a collateral promise of another person, to answer for such primary or original debt or obligation. If there be in fact no such primary debt or obligation, or the same is extinguished and discharged or if the promise be not to answer for such primary debt or obligation, or if it be a primary or direct promise for a sufficient consideration, the statute does not apply or require a promise to be in writing; because the statute contemplates the mere promise of one person to be responsible for another and cannot be interpreted as a cover and shield against the actual obligation of the defendant himself. If the third person makes an entire but substantial and independent contract with the creditor to perform, or some service, this may be enforced though not in writing, as it is not collateral. ${ }^{4}$ The object of a collateral promise is to promote the interest of another; the ob-

1. Templeton v. Bascom, $33 \mathrm{Vt}$. 132; Cross v. Richardson, 30 Y.t. 641; Forth v. Stanton; I Saund. 201, n. 1 .

2. Emerson v. Slater, 22 How. (U. S.) 28. See, also, Lampson v. Hobart, as Vt. 697; Cross v. Richardson, $30 \mathrm{Vt}$. 641.

3. Cross v. Richardson, $30 \mathrm{Vt}$.
641. See, also, Bellows v. Sowles, 57 Vt. 164, 52 Am. Rep. 118.

4. Ieoman v. Mueller, 33 Mo. App. 343; Gale v. Harp, 64 Ark. 462,43 S. IV. 144; Crawford v. Edison, 45 Olio St. 239, 13 N. E. S0; Clifford v. Lubring, 69 Ill. 401 ; llagadore v. Stronach, 81 Mich. 50, $45 \mathrm{~N}$. W. 650 ; Hitzgerald v. Mor- 
ject of an original promise is to promote the interest of the party making the promise. The former is within the operation of the statute, the latter is not affected by it. When the promisor is himself to receive the benefit for which the promise is exchanged, it is not usually material whether the original debtor remains liable or not. ${ }^{5}$

\section{ARTICLE VI.}

Promise to Answer for Anotiner's Debt, Default, or Miscaritage.

Secrrox 122. To Bind a Third Person for the Debt of Another.

123. Promise-To Whom Made.

124. When the Promise is Within the Statute.

125. Original Promise.

126. Evidence to Place Liability.

127. Promise to Pay Debt on llis Own Behalf.

128. Benefit Accruing to Promisor.

129. Indemnity.

130. Release of Original Debtor-Novation.

131. Receipt of Property Out of Which to Pay the Dcbt.

132. Contractor Abandoning Work.

$\S$ I22. To bind a third person for the debt of another.-To bind one person for the debt or default of another, there must not only be a promise or memorandum in writing, but such promise must be made on good consideration. The statute does not vary the rule of common law, as to what constitutes a valid and binding promise; to every such promise, whether oral or written, there must be a good consideration. A promise

rissey, 14 Neb. 19S, 15 N. 233; 72 N. W. 213; Compare Ellison v. Joung v. French, 35 Wis. 111: Jackson, 12 Cal. 542; Noyes v. Lemmon v. Box, 20 Tex. 329; Humphreys, 11 Gratt. (Va.) 635; Bayles v. Wallace, 56 Hun, 428, 10 Ware v. Stephenson, 10 Leach, 155; N. Y. S. 191 ; Jolly v. Walker, 26 Puckett v. Bates, 4 Ala. 390.

Ala. 680; Killbride v. Moss, 113 Cal. 432, 45 P. S12, 54 Am. St. Rep. 361: Jearn v. Lpstil. 52 Neb. 271 ,

5. Calkins v. Chandler, 36 Mich. :24, 24 Am. Rep. 593. 
withont consideration is had by the common law as nudum pactum; a promise on good consideration, withont writing, if for the debt of another, is had by the statute. T'o bind one, therefore, for the debt or default of another, both must concur; first, a promise on good consideration, and secondly, evidence thereof in writing. It is not enough therefore that a sufficient legal consideration for a promise is proved, if the olject of the promise is the payment of the deht of another for his account, and not with a view to any benefit to the promisor.

This liability may be incurred as to a tort as well as to a contract. ${ }^{1}$ The question is said to be, is the promise one to answer for the debt, default, or niscarriage of another, for which that other continues liable; if so it must be in writing to be valid. ${ }^{2}$ But where one orally contracts a debt of his own, the payment of which has the effect of payment of another's debt, the statute does apply: ${ }^{3}$

1. There must be either a present or prospective liability of a third person for which the promisor agrees to answer in order to come within the statute. 2. The liability of the original debtor must continue. 3. The promise must be made to the creditor. 4. When the promisor does not become a surety or guarantor, and the promise is to subserve some purpose of his own, and his promise is merely incidental, it is not within the statute. 5. There must be three parties: (a) A creditor, (b) his debtor, and (c) a person who guarantees to the former the latter's debt.

A party who becomes responsible for goods sold to another, and if the goods are supplied entirely on the credit of the promisor, so the third party is not liable at all, then the promise to pay is not within the statute; but whenever the third party would become liable, the contract must be in writing. ${ }^{4}$ Where

1. Kirkham v. Morter, 2 Barn. \& Ald. 613 .

2. Bloom v. MeGratl, 53 Miss. 249 ; Richardson v. Robbins, 124 Mass. 105; Laidlou v. Hateh, 75 11l. 11; Krutz v. Stewart, 54 Ind. 178.
3. Hartley v. Varner, Ss Ill. 561; Cahill v. Bigelow, 18 Pick. (Mass.) 369 ; Morrison v. Baker, 81 N. Car. 76 ; MeLendon v. Frost, 57 Ga. 448; Webb v. Lumber Co., 101 Ala. 630, 14 So. 407.

4. Tance $r$. Pearce, 101 Ind. 
a third party would become liable for the property so sold to another, it is collateral, and the fact that the creditor relied chiefly upon the promise will make no difference. If the eredit is given to a third party instead of the promisor, then it is within the statute, if such is the contract where one agrees to pay the debt of another. ${ }^{5}$ If the credit is given to the person to whom the goods are delivered, the promise of a third person to pay for them, though made at the same time, is a promise to pay the debt of another, and is within the statute. ${ }^{6}$ And when the sale of goods is upon joint credit, the promise of two, though the property is purchased for and delivered to but one, the legal effect as between them and the vendor, is a sale to the two jointly. Such promise is an original one, and, therefore, not within the statute. $^{7}$

So the promise to answer for the torts of another comes within the statute of frands, and, therefore, must be in writing. Thus, where a party has converted the goods of another, an oral promise to answer for such tort by a third person is void. ${ }^{8}$ So, where a hirer of a horse rides it to death, an oral promise by a third person to pay the damages to the owner is not binding, as it comes within the statute of frauds, under the words "miscarriage" and "default." 9

$\S$ I23. Promise to whom made.- To bring a promise within the statute it must be made to the person entitled to enforce the

595; Walker v. Hill, 119 Mass. 249; Sutherland v. Carter, 52 Mich. $151,471,17$ N. 780,18 N. 223 ; Grant v. Wolf, 34 Minn. $32,24 \mathrm{~N}$. W. 2S9; West v. O'Harra, 55 Wis. 645,13 N. 894.

5. Welch v. Marvin, 36 Mich. 59; Radcliff v. Poundstone, 23 W. Va. 724; Wills v. Ross, 77 Ind. 1; Cahill v. Bigelow, 1s Pick. (Mass.) 369 ; Bugbee v. Kendrickson, 130 Mass. 437; Cole v. Hutchinson, 34 Minn. 410, 24 N. W. 289; Cowdin v. Cottgetren, 55 N. Y. 650 .
6. Hetfield v. Down, 27 N. J. L. 440 .

7. Stone v. Walker, 13 Gray (Mass.), 612; Gibbs v. Blanchard, 12 Mich. 292, 86 Am. Dec. 52; Boyce v. Murphy, 91 Ind. 1, 46 Am. Rep. 567; Rottman v. Fix, 25 Mo. App. 571.

8. Turner v. Hubbell, 2 Day (Conn.), 457, 2 Am. Dec. 115.

9. Kirkham v. Morter, 2 P. \& Ald. 613, distinguishing Reed v. Nash, 1 Wilson, 305. 
liability assumed by the promisor $;^{1}$ for a promise not made to the person entitled to enforce the liability assumed by the promisor is not within the statute. ${ }^{2}$

An English case, Green v. Cresswell, ${ }^{3}$ holds an opposite doctrine, but can no longer be regarded as the law in England as appears from several later cases. ${ }^{4}$

The promise must be to the creditor, and not to the debtor. So if one upon a sufficient consideration arranges with the debtor to pay his debt, but not with the ereditor, this is valid though not in writing. ${ }^{5}$

Where the purpose of a person who agrees to pay the debt of another is to gain some advantage or promote some intercst or design of his own, and not to become a mere guarantor or surety for another's debt, and the promise is made on a sufficient consideration, it will be valid, although not in writing. ${ }^{6}$

$\S$ I24. When the promise is within the statute.- In order that the promise may be held to be within the statute, it is essential that there is to be a binding and substantial obligation or liability to the promisee to which the promise is collateral. The party for whom the promise has been made must be liable

1. Tighe v. Morrison, $116 \mathrm{~N} . \mathbf{Y}$. 263, 22 N. E. 164,5 L. R. A. 617 and note.

2. Smith v. Sayward, 5 Me. 504 ; Jones v. Shorter, 1 Ga. 294, 44 Am. Dee. 649; Aldrich v. Ames, 9 Gray (Mass.), 76 ; Cripps v. Hartnall, 4 Best \& S. 414, 10 Jur., N. S. 200 ; Reader v. Kingham, 13 C. B., N. S. 344 ; Thomas v. Cook, 8 Barn. \& Cress. 72s; Harrison v. Sawtel, 10 Johns. (X. I.) 242, 6 Am. Dee. 337; Barry v. Ransom, 12 N. Y. 462; Mallory v. Gillett, 21 N. Y. 412 ; Sanders v. Gillespie, 59 N. Y. 250, 252; MeCraith v. Bank, 104 N. Y. 414, 10 N. E. S62; Compare Kingsley v. Balcome, 4 Barb. (N. Y.) 131.
3. 10 Ad. \& El. 453.

4. Fitzgeral v. Dressler, 6 C. B., N. S. 374; Reader v. Kingham, 13 C. B., N. S. 344 ; Batson v. King, 4 Hurl. \& N. 739 ; Cripps v. Hartnall, 4 Best \& S. 414; Wildes v. Dudlow, L. R. 19 Eq. Cas. 198.

5. Center v. MeQuesten, 18 Kan. 476 ; Eastwood v. Kenyon, 11 Ad. \& El. 438 .

6. Ames v. Foster, 106 Mass. 400, 8 Am. Rep. 343 ; Nelson v. Boynton, 3 Met. (Mass.) 396, 37 Am. Dec. 148; Fullman v. Adams, $37 \mathrm{Vt}$. 391 ; Clapp v. Webb, 52 Wis. 63s, 9 N. 796; Fitzgerald v. Morrissey, 14 Neb. 19S, 15 N. 233; Cliflord v. Luluring, 69 Ill. 401. 
to the party to whom it is made. ${ }^{1}$ For unless it appears that some person other than the promisor has incurred an actual liability with respect to the subject-matter of the promise, the agreement is not within the statute, although the third person may be under an imperfect or merely moral obligation to respond. ${ }^{2}$

For if the other party be not liable to answer, it cannot be said that the undertaking of the promisor is one to answer for the former's debt or default, and therefore within the statute. There being no liability on the other party to the promisee, the promisor would have nothing to answer for, and his promise, therefore, will necessarily he an original and independent undertaking and not a collateral one. ${ }^{3}$

An oral acceptance of an order in existence is not within the statute, because acceptor simply agrees to pay his own debt to those persons to whom his creditors request him to pay. ${ }^{4}$ And a promise to pay for services already rendered is not valid as to such services, because not in writing. ${ }^{5}$ A verbal acceptance of a bill of exchange in existence or other order for the payment of money is not within the statute. ${ }^{6}$ Unless forbidden

1. Hargreaves v. Parsons, 13 Mees. \& Wels. 561; Resseter v. Waterman, 151 Ill. 169, 37 N. E. 875; Eastwood v. Kenyon, 11 Ad. \& El. 438; Westfall v. Parsons, 16 Barb. (N. Y.) 645 ; Prebble v. Baldwin, 6 Cush. (Mass.) 549; Pratt v. Humphrey, 22 Conn. 317; Alger v. Scoville, 1 Gray (Mass.), 391; Baker v. Bucklin, 2 Denio (N. Y.), 45, $43 \mathrm{Am}$. Dec. 726 and note; Perkins v. Littlefield, 5 Allen (Mass.), 370; Tighe v. Morrison, 116 N. Y. 263,22 N. E. 164,5 L. R. A. 617 and note.

2. Downey v. Hincliman, 25 Ind. 453; Read v. Nash, 1 Wilson, 305; Smith v. Mayo, 1 Allen (Mass.), 160; Tighe v. Morrison, 116 N. Y. 263,22 N. E. 164,5 L. R. A. 617 and note.
3. Resseter v. Waterman, $151 \mathrm{Ill}$. 169, 37 N. E. 875 .

4. Lavell v. Frost, 16 Mont. 93, 40 P. 146.

5. Malone r. Ice Co., 88 Wis. $\mathbf{5 4 2 ,}$ 60 P. 999.

6. Short v. Blount, 99 N. Car. 49; Bruner v. Nisbett, 31 Ill. App. 517; Neuman v. Schroeder, 71 Tex. 81, 8 S. W. 632. See, also, Martyn v. Arnold, 36 Fla. 446, 18 So. 91; Magnon v. Clay, ] A. K. Marsh. (Ky.) 189; Chase v. Trafford, 116 Mass. 529; Strickland v. Hamlin, 87 Me. 81, 32 A. 732; Harbele v. O’Day, 61 Mo. App. 390 ; Bixby v. Church, 28 Oreg. 242, 42 P. 613; Putnam Machine Co. v. Cann, 173 Pa. St. 392, 34 A. 67; Spear v. Bank, 156 Ill. 555, 41 N. E. 164; Amont v. Christofferson, 57 Minn. 
by statute, it is the rule of general law, that a promise to accept an existing bill is an acceptance thereof, whether the promise be in writing or by parol. ${ }^{7}$ But an agreement to accept drafts and orders to be drawn must be in writing where the drawee has no funds of the drawer to disburse. ${ }^{8}$

$\S$ 125. Original promise.- The sale of goods to one at the request and on the sole credit of another, renders the promise to pay an original promise and takes the ease out of the statute. ${ }^{1}$

Where the leading object of the promisor is to subserve some interest or purpose of his own, notwithstanding the effect is to pay or discharge the debt of another, the promise is not within the statute and need not be in writing. ${ }^{2}$

Where the credit is given entirely to one party and the sale of goods is in fact to that party, though they are delivered to and used by another party, the statute does not apply; and in such case the oral promise of the first party is not an agreement to answer for the debt of another, but an original promise, upon which a cause of action may be alleged and proved without a writing. ${ }^{3}$ But if the person for whose use the goods are fur-

234, 59 N. IV. 304; Collins v. Stanfield, 139 Ind. 184, 38 N. E. 1091; Lesserrich v. Pettit, 91 Iowa, 609, 60 N. WV. 192; Brown v. Bank, 88 Tex. 265, 31 S. IV. 285, 33 L. R. A. 359 and note; Fain v. Turner, 96 Ky. 631, 29 S. IV. 628 .

7. Scudder v. Bank, 91 U. S. 406; Wynne v. Raikes, 5 East, 514; How v. Loring, 24 Pick. (Mass.) 254; Bank v. Arclier, 11 Mees. \& W. 383 .

8. Upham v. Clute, lo5 Mich. 350,63 N. IV. 317 .

1. Collins v. Stanfield, 139 Ind. 184, 38 N. E. 1091; Lessenick v. Pettit, 91 Iowa, 609, 60 N. IV. 192 ; Nesbit v. Works, 22 Ner. 260, 38 P. 670; Hartley v. Varner, 88 Ill. 561; Barras v. Coal Co., 38 Neb.
311,56 N. IV. 890 ; Morris v. Osterhout, 55 Mich. 262, 21 N. IV. 339 ; Calahan v. IVard, 45 Kan. 545, 26 P. 53; Baldwin v. Hiers, 73 Ga. 739; Clark v. Jones, 87 Ala. 474, 6 So. 352; Lance v. Pearce, 101 Ind. $59 \bar{s}$.

2. Hind v. Holship, 2 Watts. (Pa.) 104, 26 Am. Dec. 107; Willis v. Cutter, 61 N. H. 405; Clifford v. Luhring, 69 Ill. 401 ; Leonard v. Vredenberg, 8 Johns. (N. Y.) 28; Greene v. Burton, 59 vt. 423; Lemmon v. Box, 20 Tex. 329 ; Katzmyer v. Ennis, 27 N. J. L. 376 ; Emerson v. Slater, 22 How. (U. S.) 43 ; Fitzgerald v. Morrisser, 14 Neb. 198, 15 N. 233.

3. Mackey v. Smith, 21 Oreg. 39S, 28 P. 974; Boston v. Farr, 148 
nished be at all liable, any promise by a third person to pay for them must be in writing, as such an agreement is within the statute. $^{4}$

$\S$ I26. Evidence to place liability.-Book accounts, though competent, are not conclusive that the vendor relied upon the party charged to pay for them, but such evidence is opened to explanation by showing as a matter of fact to whom the credit was given. It is for the jury to judge upon all the evidence, to whom the credit was given, and whether the agreement of the defendants is original or collateral. ${ }^{1}$ Charges made on books are evidence, but may be explained, and is for the jury to say to whom credit was given. ${ }^{2}$

$\S$ 127. Promisor to pay debt on his own behalf.- The question often arises whether a party who promises to pay the debt of the person who first owed and still owes it, for a consideration passing to that person, is to be regarded as promising to

Pa. St. 220, 23 A. 901; Greene v. Burton, 59 Vt. 423; Nelson v. Boynton, 3 Mlet. (Mass.) 396, $37 \mathrm{Am}$. Dee. 148; Higgins v. Hallock, 60 Hun (N. Y.), 125, 14 N. Y. S. 550; Meyer v. Graffin, 31 Md. 350, 100 Am. Dec. 66; Peyson v. Conniff, 32 Neb. 269, 49 N. W. 340; Ellis v. Murray, 77 Ga. 542; Grant v. Wolf, 34 Minn. 32, 24 N. W. 289.

4. Wallace v. Wortham, 25 Miss. 119, 57 Am. Dec. 197; Andre v. Bodman, 13 Md. 241, 71 Am. Dec. 28; Whittemore v. Wentworth, 76 Me. 20; Willard v. Bosshard, 68 Wis. 545, 32 N. W. 538; Gump v. Halberstadt, 15 Oreg. 356, $15 \mathrm{P}$. 467 ; Packer v. Benton, 35 Conn. 343, 95 Am. Dee. 246 and note; Cole v. Hutehinson, 34 Minn. 410, 26 N. W. 319 ; Studley v. Borth, 54 Mich. 6, 19 N. 568; Morrissey v. Kinsey, 16 Neb. 11, 19 N. 454;
Langdon v. Richardson, 58 Iowa, 610,12 N. 622; Harris v. Frank, 81 Cal. 280, 22 P. 856; Chappel v. Barkley, 90 Mieh. 35, 51 N. W. 614; Bice v. Building Asso., 96 Mich. 24, 55 N. W. 382 ; Beubow v. Soothsmith, 76 Iowa, 154, 40 N.W. 693; Dougherty v. Bash, $167 \mathrm{~Pa}$. St. 429,31 A. 729 ; Walker v. Irwin, 94 Iowa, 448, 62 N. W. 785; Howell v. Field, 70 Ga. 592; Teeters v. Lamborn, 43 Ohio St. 144, 1 N. E. 513 .

1. Walker v. Richards, 41 N. H. 391 ; l3arrett v. McHugh, 128 Mass. 165.

2. Larsen v. Jensen, 53 Mieh. 427, 19 N. 130; Burphalter v. Farmer, 5 Kans. 477; Champion v. Doty, 31 Wis. J00; Maurin v. Fogelbeyer, 37 Minn. 23, $32 \mathrm{~N}$. IV. S5S, $5 \mathrm{Am}$. St. Rep. 814; Hazen v. Bearden, 4 Sneed ('I'enn.), 50. 
pay on his own behalf or on the original debtor's behalf. In such ease, if the debt is payable on his own behalf the promise may be rerbal. If not, then it must be in writing. ${ }^{3}$

Thus, when by the release of property from a lien, the promisor is to pay the debt so as to enable him to apply the property to his own benefit, the release inures to his own advantage, and it is evident that a promise to pay the debt in order to obtain the release may be regarded as made on his own behalf, and not on behalf of the original debtor, and any possible advantage to the latter is merely incidental and is not the thing bargained for. That promise is, therefore, in no proper sense a promise to answer for ancthing but for the promisor's own responsibility, and need not be in writing. And so when a person sells a claim and guarantees its payment, the guaranty is collateral to his own contract, and is not intended for the debtor's advantage.

$\S$ I28. Benefit accruing to promisor.- The promise of one person, though in form to answer for the debt of another, if founded upon a new and sufficient consideration, moring from the creditor and promisee to the promisor, and beneficial to the latter, is not within the statute of frauds, and need not be in writing. ${ }^{1}$ A consideration to support a promise not in writing to pay the debt of another must be of a peculiar eharacter, and must operate to the adrantage of the promisor, plaeing him under a peeuniary obligation to the promisee independent of

3. Corkins v. Collins, 16 Mich. 478.

4. Leonard v. Vredenburg, 8 Johns. (N. Y.) 29, 5 Am. Dec. 317 and note; Nelson v. Boynton, 3 Met. (Jass.) 396, $37 \mathrm{Am}$. Dec. 148; Mallory r. Gillett. 21 N. Y. 412; White r. Rintoul, 105 N. Y. 22, 15 N. E. 318 ; Calkins v. Chandler, 36 Mich. 320, 24 Am. Rep. 593; Bice v. Building Asso. 96 Mich. 24, 55 N. W. 382; MeLaughlin v. Austin, 104 Mich. 4S9, 62 N. W. 719. See, also, Fain v. Turner, $93 \mathrm{Ky} .634$,
29 S. W. 628; Green v. Hadfield, s9 Wis. 138, 61 N. W. 310 ; lieyes r. Maynard, 65 Vt. 667,27 A. 319.

3. Mallory v. Gillett, 21 N. Y. 412: Cornell v. Electric Co., 61 Ill. spp. 325; Brownell r. Harsh, 29 Ohio st. 631; Bailey v. Marshall, 1it Pa. St. 602, 3t A. 326; Tan Doren v. Tjader, 1 Nev. lls; Fisk v. Reser, 19 Colo. 88, 34 P. 572; Calkins r. Chandler, 36 Mich. 320 , 2t Am. Rep. 593; Clapp v. Webb, 52 Wis. 638, 9 N. 796; Lamb v. Tucker, 42 Iowa, 118; Hawkes v. 
the original debt, and which obligation is to be discharged by the payment of that debt. ${ }^{2}$

In suclı case the debt has become that of the new party promising; his promise is not to pay the debt of another, but his own; as between him and the primary debtor the latter has become practically a surety entitled to require the payment to be made by the transferee. The consideration of the primary debt, by the transfer of the money or property into which that consideration had been in effect nierged, may be said to have been shifted over to the new promisor, who thereby becomes under a duty of payment as obvious as if such original consideration had passed directly to him. ${ }^{3}$ So, if a person guaranties a debt in consideration of a release of a lien, or forbearance to file it, the guaranty need not be in writing as held by many courts $;^{4}$ but if the liability of the debtor continues, the agreement comes within the statute as generally held by the cases. ${ }^{5}$

Phillips, 7 Gray (Mass.), 284; Lincoln v. Kinzey, $5 \mathrm{I}$ Ill. 435; Haydeu v. Weldon, 43 N. J. L. 128, 39 Am. Rep. 551 and note; Fitzgerald v. Morrissey, 14 Neb. 198, 15 N. 324 ; Perkins v. Catlin, 11 Conn. 230; Fuller v. Scott, S Kans. 25 ; Bateman v. Butler, 124 Ind. 223, 24 N. E. 989 ; Schafer v. Bark, 59 Pa. St. 148, 93 Am. Dec. 323; Nichols v. Allen, 23 Minn. 542; Schneider v. S'chiffman, 20 Mo. 571; Mathews v. Seaver, 34 Neb. 592,52 N. W. 283; Garvey v. Crouch, 35 S. W. 273,18 Ky. L. R. 84; Muller v. Riviere, 59 Tex. 640, 46 Am. Rep. 291; Williams v. Leper, 3 Burr. 1886; Joseph v. Snith, 39 Neb. 259, 57 N. W. 1002, 42 Am. St. Rep. 571.

2. Ackley v. r'almenter, 98 N. Y. 425, 56 Am. Rep. 693; Cross v. Richardson, $30 \mathrm{Vt}$. 641; McKenzie v. Bank, 9 Wash. 442, 37 P. 668, 3 Am. St. Rep. 844; Rushing Reduction Co. v. Hilliard, 92 Ga. 555, 17
S. E. 848 ; Irenson v. Caldwell, 3 Wyo. 465, 2 P. 23 s.

3. First National Bank v. Chalmers, 144 N. Y. 432,39 N. E. 331.

4. Smith v. Bank, $110 \mathrm{~Pa}$. St. 508, 1 A. 760; Wells v. Brown, 118 Mass. 138; Scott v. White, 71 Ill. 287; Power v. Raukin, 114 Ill. 52, 29 N. E. 185 ; Crawford v. King, 54 Ind. 6; Wooten v. Wilcox, 87 Ga. 474; Rogers v. Hardware Co., 24 Neb. 653, 39 N. W. 844; Prime v. Koehler, 77 N. Y. 91; Shook v. Vanmeter, 22 Wis. 507.

5. Warner v. Willoughby, 60 Conn. 468, 22 A. 1014, 25 Am. St. Rep. 243; Curtis v. Brown, 5 Cush. (Mass.) 488; Stewart v. Jerome, 71 Mich. 201, 38 N. W. 895, 15 Am. St. Rep. 43 ; Bunneman v. Wagner, 16 Oreg. 433, 18 P. 841, 8 Am. St. Rep. 306; Clark v. James, 85 Ala. 127, 4 So. 771; Simpson v. Harris, 21 Nev. 353, 13 P. 1009. 
$A$ holder of a note who verbally guaranties it in order to sell it, is liable on such guaranty. ${ }^{6}$ And the guaranty of the solveney of a party by an agent who sells his principal's goods, is not within the statute. ${ }^{7}$

The statute of frauds in relation to the liability of an assignor of a promissory note, is not applicable to eases where a guaranty accompanies the assignment. ${ }^{8}$ The assignor owes the assignee, and that particular mode of paying him is adopted. He guarantees, in substance, his own clebt. Though the debt of a third person is ineidentally guaranteed, it is not necessary that the contract shall be in writing.

129. Indemnity.- In some States where the promise is one of indemnity and not of guarantee, it need not be in writing. ${ }^{1}$ Where one person induces another to enter into an engagement by a promise to indemnify him against liability, that is not an agreement within the statute, and, therefore, is not required to be in writing. ${ }^{2}$ But it is otherwise in other States

6. Darst v. Bates, 95 Ill. 493 ; Milks v. Rich, 80 N. Y. 269, 36 Am. Rep. 615.

7. Sherwood v. Stone, 14 N. Y. 267; Swan v. Nesmith, 7 Pick. (Nass.) 220, 19 Am. Dec. 282; Couturier v. Hastie, 5 H. L. Cas. 673 .

8. Darst v. Bates, 95 Ill. 493; Smith v. Finch, 2 Scam. (Ill.) 321.

9. Darst v. Bates, 69 Ill. 493 ; Wilson v. Hentges, 29 Minn. 102, 12 N. 151; Cardell v. McNell, 21 N. Y. 330; Melone v. Keener, $44 \mathrm{~Pa}$. St. 107; Barker v. S'cudder, 56 Mo. 272; Beaty v. Grim, 18 Ind. 131; Thoman v. Dodge, 8 Mich. 50; Wyman v. Goodrich, 26 Wis. 21 ; Compare Dows v. Sweet, l 20 Mass. 322, 127 Mass. 364, 134 Mass. 140, 45 Am. Rep. 310; Harsinger v. Newman, 83 Ind. 124, 43 Am. Rep. 64.
1. Commercial F. Ins. Co. v. Morris, 105 Ala. 49818 So. 762; Guild r. Conrad (1894), 2 Q. B. 885; Thomas v. Cook, 8 Barn. \& Cr. i28; Hidelity, etc., Co. v. Lawlor, (54 Minn. 144, 66 N. W. 143; Wildes v. Dudlow, L. R. 19 Eq. 198.

2. Wildes v. Dudlow, L. R. 19 Eq. 198; Hargreaves v. Parsons, 13 Mees. \& Wels. 56I; Aldrich v. Ames, 9 Gray (Mass.), 76 ; Dunn v. West, 5 B. Mon. (Ky.) 376 ; Mills v. Brown, 11 lowa, 314 ; Holmes v. Knights, 10 N. H. 175; Harrison v. Sawtel, 10 Johns. (N. Y.) 242, 6 Am. Dec. 337; Sauborn v. Merrill, $\$ 1$ Me. 46 ; Blount v. Hawkins, 19 Ala. 100; Flemm v. Whitmore, 23 Mo. 430; Stark v. Raney, Is Cal. 622; Marcy v. Crawford, 16 Conn. 549, 41 Am. Dec. 158; Bohannon v. Jones, 30 Ga. 48s; Soule v. Albee, 31 Vt. 142; Lerch v. Gallop, 67 
where the promise to indemnify the promisee against any loss he may sustain by reason of the default or miscarriage of a person muler liability to him; in this case the promise is within the statute ${ }^{3}$ but a mere indemmity is not. ${ }^{4}$

The law will not enforce, it seems, an express agreement to indemnify bail by the principal, as it would be against public policy. ${ }^{5}$ So, where the principal has deposited money to indemnify the bail, and is exonerated, he camnot recorer it, as the contract was illegal and the courts will not interfere. ${ }^{6}$ However, a third party may indemnify the bail, which they may recover, as it is not an illegal contract. ${ }^{7}$ And such contract of indemnity by a third party need not be in writing, as the bail is not given for the purpose of answering for the debt of another as in a eivil action, so the statute does not apply. ${ }^{8}$ In some States indemnity to bail is allowed by statute, then it is a valid contract. ${ }^{9}$

Cal. 595; Keesling v. Frazier, 119 Ind. 155,21 N. H. 552 ; Simith v. Delaney, 6t Conn. 264, 29 A. 416 , 42 Am. St. Rep. 181 and note; Barry v. Ransom, 12 N. Y. 462; Anderson v. Spencer, 7๖ Ind. 315, 37 Am. Rep. 162 .

3. Clements' Appeal, 5:2 Conm. 464; Nugent v. Wolfe, $111 \mathrm{~Pa}$. St. 471,4 A. 15, 56 Аm. liep. 291 ; Cheesman v. Wiggins, 12: Ind. 352, 23 N. W. 945 ; Haster v. White, 12 Ohio St. 2l9; Walberton v. Davis, $85 \mathrm{Va} .64,6$ S. E. 619,17 Am. St. Rep. 56; Mallony v. Gillett, $21 \mathrm{~N}$. Y. 412; Ferrell v. Maxwell, 28 Ohio st. 383, 22 Am. Rep. 393; Bissig v. Briton, 59 Mo. 204, 21 Am. Rep. 379; Green v. Cresswell, 10 Ad. \& El. 453; May v. Williams, 61 Miss. 125, 48 Am. Rep. S0; Demeritt v. Hickford, 58 N. H. 523 ; Anderson v. Spence, 72 Ind. 315, 37 Am. Rep. 162; Draughan v. Bunting, 9 Ired. (N. Car.) 10; Simpson v. Nanee, 1 Speal. (S. Car.) 4;
Compare Lerch v. Gallop, $67 \mathrm{Cal}$. 595, , $\mathrm{P} .322$.

4. George v. Hoskins, $30 \mathrm{~S}$. IV. 406, $17 \mathrm{Ky}$. L. R. 63; Jones v. Baeon, 145 N. Y. 446,40 N. I. 216 ; Boyer v. Soules, 105 Mich. 31, 62 N. IV. 1000; Croft v. Ins. Co., 40 W. Va. 508, 21 S. E. 854, 52 Am. st. Rep. 902; Minich v. Huff, 41 Neb. $516,5 !$ N. W. 795.

5. Jones r. Orehard, 16 C. B. 614; Harp v. Osgood, 2 Hill (N. Y.), 375 .

6. Dunkin v. Ilodge, 46 Ala. 523; Herman v. Jeuchner, 15 Q. B. Div. 561.

7. People v. Ingersoll, $14 \mathrm{Abb}$. Pr. N. S. 23; Stevens v. Hay, 61 I11. 399: Harp v. Osgood, 2 Hill (N. Y.), 216 .

8. Cripps v. Hartnoll, 4 B. \& S. 414; Anderson v. Speneer, 27 Ind. 315 .

9. Maloney v. Nelson, 158 N. Y. 351,53 N. E. 31; Simpson v. Robert, 35 Ga. 180. 
Where no authority is griven by statute to take money in place of bail, a deposit of money so taken is illegal and camot ho recovered back, ${ }^{10}$ but it shonld be paid into the comnty treasury just as if collected on a reoognizance."1

$\$$ r30. Release of original debtor - Novation. - Where the verbal promise to accept an order is in effort a promion to disburse funds by the drawee for the purpose, or where the aceeptance is conditional on having funds of the drawee on land, such verbal promise is cnforcable. But where there is no agreement to disburse funds belonging to the drawer by the drawee, the case comes within the statute, and an agreement to aceept drafts and orders must be in writing."

In agreement for a full consideration to pay the debt of another, where the original debtor is released and a new promisor is accepted as the sole debtor, is not within the statute. ${ }^{3}$ So, a promise whereby a debtor agrees to pay his debt to a third person to whom his ereditor is indebted, is not within the statute, being a contract of novation. ${ }^{4}$ And so when the contract is not collateral but a substituted contract, it is not within the statute. ${ }^{5}$

\section{$\S$ I3I. Receipt of property out of which to pay the debt.-} Where a person being under no legal obligation to do so, transfers a elaim to another upon the oral condition that the assignee will, out of the moness collected therefrom, pay the indebtedness of the assignor to a third person, and the assignment is acepted upon that condition, the promise is not voidable under the stat-

10. Smart v. Casoll, 50 Ill. 105; Reinhard v. Columbus, 49 Ohio St. 257,31 N. 1. 35 ; Butler v. Foster, 14. 11a. 323 .

11. Rock Island v. Mercer County, 24 Ill. 35 .

1. Sturges v. Bank, 75 Ill. 595 ; Hughes v. Fisher, 10 Colo. 383,15 P. 702 ; Comstock v. Norton, 36 Mielı. 277. See, also, Gleason v. Fitzgerald, 105 Mich. 516,63 N. IV. 512 .
2. Upham v. Clute. 105 Mich. $350,63 \mathrm{~N} . \mathrm{W}, 317$.

3. Lindley v. Simpson, 45 Ill. App. 648.

4. Wilson v. Voss, 54 Mo. App. 221 ; Trudeau v. Poutre, 165 Mass. 81, 42 N. E. 508.

5. Wood v. Corcoran, 1 Allen (Mass.), 405; Furbish v. Goodnow, 98 Mass. 296; Eden v. Chaffee, 160 Mass. 225, 35 N. E. 675; Lord v. Davis. 3 Allen (Mass.), 131. 
ute, and the assignee, upon the collection of the claim by him, becomes liable to such third person in the amount of such indebtedness. ${ }^{1}$ And so the statute does not apply where the defendant after having received moneys from plaintiff's debtor with which to pay the debt, retains it. Having received and retained the money the debt becomes his own. ${ }^{2}$ If the receiver takes the property for such purpose and promises the debtor to pay such debt, the promise need not be in writing. ${ }^{3}$ Thus, where lumber was sold to $A$ on the credit of $B$, and $A$ pays $B$ therefor, a promise by $B$ to the vendor to pay him for the lumber will be in the nature of an original contract to pay the debt of a third party, founded upon a sufficient consideration, and not within the statute. ${ }^{4}$

The property must be placed in the hands of a third party unconditionally, and the third party must take it for that purpose. If the third party has the option to pay the debt out of his own property, and not out of the debtor's, then the promise to pay the creditor comes within the statute and must be in writing. ${ }^{5}$ So where the assignee arranges to pay the assignor's debt after he has reduced or converted the property into cash, a verbal promise to the debtor's creditor before such conversion into money, to pay the debt is void, as it comes within the statute. $^{6}$

When the money is in the hands of the promisor no written contract is required. Thus, where a party agrees to pay board for workmen, and has the money for that purpose, an oral contract is sufficient. ${ }^{7}$

\section{§ 132. Contractor abandoning work - Agreement with his} workmen to finish. - It is held that where a contractor aban-

1. Wills v. Bank, 23 Nev. 59,42 P. 490 ; Watson v. Perrigo, $87 \mathrm{Me}$. 202, 32 A. 876; Phelps v. Rowe, 75 Hun (N. Y.), 414, 27 N. Y. S. 89.

2. Hamill v. Hall, 4 Colo. App. 290, 35 P. 927.

3. Wait v. Wait, 28 vt. 350 ; Dock v. Boyd, 93 Pa. St. 92.
4. Watkins v. Sands, 4 IIl. App. 207.

5. Ackley v. Parmenter, 98 N. Y. 425, 50 Am. Rep. 693; Sliaaber v. Bushong, 105 Pa. St. 514.

6. Belknap v. Bender, 75 N. Y. 446, 31 Am. Rep. 476.

7. Chicago, etc., Coal Co. v. Liddell, 69 I1l. 639. 
dons his work in erecting a building, the owner may be held on a verbal agreement marle with the workmen to go on and complete the work. ${ }^{1}$ But other cases hold that such contract with the workmen is within the statute and, therefore, must be in writing." The general rule is this: Where the leading object of the undertaking is to promote some objects of the owner, his promise to pay is not within the statute, although its effect is to release or suspend the debt of another. Thus, where a party had employed a contractor to build a house, who fails on account of financial inability to pay his workmen and material men, and the owner who will be benefited by the performance of the contract, in order to make performance possible, promises to pay for the labor and materials, if the laborers and materialmen will go on; such a promise is to answer for the debt of another, yet it is not a contract of surety, and need not be in writing. Such a promise is original, and not within the statute. ${ }^{3}$ Because the leading object is to promote some interest of his own, and so the promise is not within the statute, although the effect is to release or suspend the debt of another. ${ }^{4}$ The distinction is between a promise, the object of which is to promote the interest of another, and one in which the object is to promote the interest of the party making the promise. The former is within the statute; the latter is not affected by it. But where the promisor is himself to reeeive the benefit for which the promise is exchanged, it is not usually material whether the original debtor remains liable or not $;^{5}$ this is the general rule, but there are cases which hold that the statute applies in spite

1. Buchanan v. Moran, 62 Conn. 83, 25 A. 396; Crawford v. Edison, 45 Ohio St. 239,13 N. E. S0; Ycomans v. Mueller, 33 Mo. App. 343.

2. Farnham r. Davis, 79 Me. 282, 9 A. 725 ; Greene v. Latham, 2 Colo. App. 416, 31 P. 233.

3. Nelson v. Boynton, 3 Met. (Mass.) 396, 37 Am. Dec. 148; Hall v. Alfred, 105 Ky. 664, 49 S. W. 444.
4. Clifford v. Luhring, 69 Ill. 401; Walker v. Hill, 110 Mass. $249,14 \mathrm{Am}$. Rep. 598; Merriman v. MeManus, $10^{2}$ Pa. St. $10^{2}$; Kelley v. Schupp, 60 Wis. $76,15 \mathrm{~N}$. 725; Crawford v. Edisou, 45 Ohio st. 239,13 N. E. 80; Emerson v. slater, 22 How. (U. S.) 43.

5. Calkins v. Chandler, 36 Mich. 324; Jefierson v. Slagle, $66 \mathrm{~Pa}$. St. 202. 
of the benefit obtained, if the original liability is allowed to remain. ${ }^{6}$

\section{ARTICLE VII.}

Agreenent Not to Be Perforied Witimin a Year.

Secrion 133. What Contracts are Within the Statute.

134. Contracts Not Within the Statute.

135. One Year from the Making Thereof.

136. P'arol Lease of Land for a Year.

137. Part Performance Within a Year-Performance on One Side.

§ I33. What contracts are within the statute.-The English statute of frauds provides that no action shall be brought in any agreement that is not to be performed within the space of one year from the making thereof. This statute includes only snch contracts as either by their express terms, or by a fair reasonable construction of all their provisions, cannot possibly, under any circumstances, be performed within a year from the making thereof. ${ }^{2}$ To be void under the statute, the contract must be one not to be performed within one year from the making thereof. ${ }^{3}$

The doctrine established by the adjudications of this country, is that, in order to bring a case within the operation of the statute, there must be an express and specific stipnlation in the contract that it is not to be performed within the year, or it must appear therefrom that it was not the intention of the parties that the agrecment should be performed within that period, that is there must be a negation of the right to perform within the year. ${ }^{4}$

6. Morrissey v. Kinsey, $16 \mathrm{Neb.}$ 17, 19 N. 454; Sext v. Geise, 80 Ga. 698, 6 S. E. 174; Wihhelm v. Voss, 118 Mich. 106, 76 N. W. 308.

1. 29 Car. II, ch. 3, see. 4 .

2. Kansas City, etc., R. R. Co. v. Conlee, 43 Neb. 121, 61 N. IV. 111; Bulloek v. Turnpike Co., 85
Ky. 184, 3 S. W. 129; Durham v. Hiatt, 127 Ind. 514, 26 N. E. 401.

3. Powder River Live Stoek Co. v. Lamb, 38 Neb. $339,56 \mathrm{~N}$. W. 1019.

4. Treat v. Hiles, 68 IVis. 344 , 32 N. IV. 517, 60 Am. Rep. 858; Baker v. Lauterbach, 68 Md. 64, 11 A. 703; Aiken v. Nogle, 47 Kans. 
$\S$ I34. Contracts not within the statute.-1. The first elass of cases not within the statute is where no term of years is alluded to, hut the time of performance is either wholly indefinite, or depends upon some future eontingency or event which may or may not happen within a year. Although such event does not oceur until a year, the promise is clearly not within the statute. Thus to marry in or within three years, ${ }^{1}$ or within four years $;^{2}$ or to do something on the marriage or death of a person without further specifications of time $;^{3}$ or upon the happening of any other event which may happen at any time. ${ }^{4}$

It is well settled that an oral agreement, which according to the express understanding or contemplation of the parties may or may not be performed within a year, is not within the statute. ${ }^{5}$ Thus, the agreement to support a child until a certain age at which the child will arrive after several years, is not within the statute,'because it depends upon a contingeney of the child's life, and if the child should die within one year, the contract would be fully performed. ${ }^{6}$

2. The same general principles apply to promises to continue

96, 27 P. 825; Durham v. Hiatt, 127 Ind. 514, Kent v. Kent, $62 \mathrm{~N}$. Y. 560, 20 Am. Rep. 502; Barton v. Gray, 57 Mich. 622, 24 N. W. 638; Horner v. Frazier, 65 Md. 1; Smalley v. Greene, 52 Iowa, 241, 3 N. 78, 35 Am. Rep. 267 and note; Powder River Live Stock Co. v. Lamb, 38 Neb. 339, 56 N. IV. 1019; Worley v. Sipe, 111 Ind. 238, 12 N. E. 385 ; Raynor v. Drew, $72 \mathrm{Cal}$. 307 , 18 P. 82 ; Meflin v. Milton, 69 Ala. 354; Sarles v. Sharlow, 5 Dak. 100, 37 N. IV. 748 ; Gonzoles v. Chartier, 63 Tex. 36; Farwell v. Tilson, 76 Me. 228; Blair Town Lat. Co. v. IValker, 39 Iowa, 411.

1. Paris v. Strong, 51 Ind. 341.

2. Lawrence v. Cook, 56 Mc. 187 , 96 Am. Dec. 443.

3. Kent v. Kent, 65 N. Y. 560.

4. MePherson v. Cox, 96 U. S.
404; Cole v. Singerly, 60 Md. 34s; Clark v. Pendleton, 20 Conn. 495; Thomas v. Armstrong, 86 Va. 323 , 10 S. E. 6; McConahey v. Grifly, 82 Iowa, 564, 48 N. W. 983.

5. Doyle v. Dixon, 97 Mass. 208, $93 \mathrm{Am}$. Dec. 80 and note; Bartlett v. Mystic River Corp., 151 Mass. 433, 24 N. E. 780 ; Faine v. Turner, 96 Ky. 634, 29 S. IV. 628; Sweet v. Lumber Co., 56 Ark. 629, $20 \mathrm{~S}$. IV. 514; Jones v. Pouch, 41 Ohio St. 146.

6. Peter v. WVestborough, 19 Pick. (Mass.) 211; MeClellan v. Sanford, 26 Wis. 595; Curtis v. Sage, 35 Ill. 22; Berry v. Doremus, 30 N. J. I. 403: Haugh v. Blythe, 20 Ind. 24; Smalley v. Greene, 52 Iowa, 241, 3 N. 78,35 Am. Rep. 267 and note; Blanding v. Sargent, 33 ․ H. 239, 66 Am. Dec. 720 . 
to pay or to do something until some future event or contingency, either distinctly expressed or necessarily implied, shall occur. ${ }^{7}$ Thus, the promise to support a child so long as the party thinks proper $;$ to employ a person so long as he may be disabled by an injury ; a contract by an actress to aid in performing a play so long as it continues a success $;^{10}$ to pay a party a certain amount so long as he shall maintain and educate children properly. ${ }^{11}$ So contracts that may be terminated at any time on notice, and contracts to perform acts so long as the other party may need such work. ${ }^{12}$

3. The same doctrine applies when a party contracts not to do something, as never to carry on some particular business; because it is a personal engagement and stipulates nothing beyond the promisor's life, and imposes no duties upon his legal representatives. The fact of abstaining from the business of the promisor until his death would be a full performance of the contract, and that event might occur within a year. ${ }^{13}$

4. Another class of cases are those in which the contract prorides a certain number of years as the extreme limit of its continuance, and also expressly contains an alternative, or contingency on which it may sooner terminate. If this contingency may happen within a year the contract is not within the statute. ${ }^{14}$

5. Another class of cases not within the statute are contracts

7. Dant v. Head, 90 Ky. 255, 13 S. W. 1073, 29 Am. St. Rep. 369; Heath v. Heath, 31 Wis. 223 ; McGregor v. McGregor, L. R. 21 Q. B. 424.

8. Souch v. Strawbridge, 2 C. B. 808 .

9. East Tennessee, etc., R. R. Co. v. Staub, 7 Lea (Tenn.), 397. See. also, Hutchinson v. Hutchinson, 46 Me. 154; Stowers v. Hollis, $83 \mathrm{Ky}$. 544 ; Atchison, etc., R. R. Co. v. English, 38 Kan. 110, 17 P. 811.

10. Haines v. Tliompson, $19 \mathrm{~N}$. Y. Supp. 184.

11. Knowlman v. Bluett, L. R.
9 Ex. 1, 309. See, also, Arkansas, etc., R. R. Co. v. Whitby, 54 Ark. 199,15 S. W. 465,11 L. R. A. 621 and note.

12. Blake v. Voight, $134 \mathrm{~N}$. Y. 69,31 N. E. 256,30 Am. St. Rep. 622; Walker v. Railroad Co., 26 S. Car. 80, 1 S. E. 366.

13. Foster v. McO'Blennis, 18 Mo. 88; Lyon v. King, 11 Met. (Mass.) 411, 45 Am. Dec. 219; Doyle v. Dixon, 97 Mass. 208; Richardson v. Pierce, 7 R. I. 330. See, also, Jordan v. Miller, 75 Va. 442.

14. Seddon v. Rosenbaum, 85 
for personal service. Thus, a contract for a reasonable time or from month to month comes within this class though the service extends through several years before settlement. ${ }^{15}$ But a contract for a year's service to begin on some future day beyond the next is within the statute $;^{16}$ and this is so provided the intervening day is Sunday. ${ }^{17}$ If the service is entered into on the day of the contract it is valid. ${ }^{18}$ A contract of service which may be completed within a year is not within the statute. ${ }^{19}$

$\S$ I35. One year from the making thereof.- It appears that the plurase "from the making thereof" is omitted in some of the tatutes of frauds. In such case, a lease for a term not longer than one year may be made to begin in the future by verbal contract, and will he held to be binding under the statute. ${ }^{1}$ And other courts arrive at the same conclusion by construction of the statute. Thus, in Texas, clause 4 of the statute reads: "Upon any contract for the sale of real estate, or the lease thereof for a longer term than one year." Clause 5 reads: "Upon any agreement which is not to be performed within the

Va. 928, 9 S. E. 326,3 L. R. A. 337 and note; Hodges v. Manuf. Co., 9 R. 1. 482 ; Roberts v. Rock Bottom Co., 7 Met. (Mass.) 46.

15. Kiene v. Snaeffing, 33 Neb. 22, 49 N. W. 773; Niagara Fire Ins. Co. v. Greene, 77 Ind. 590; Cole v. Singerly, 60 Md. 348; Aiken r. Nogle, 47 Kan. 96, 27 P. 825; Dickson v. Frisbee, 52 Ala. 165, 23 Am. Rep. 565; Brittain v. Rossiter, 11 Q. B. Div. 123.

16. Bracegirdle v. Heald, 1 Barn. \& Ald. 727 ; MeElroy v. Ludlum, 32 N. J. Eq. 828; Shumate v. Farlow, 125 Ind. 359,25 N. E. 432 ; Lee v. Hill, 87 Va. 497, $12 \mathrm{~S}$. E. 1052, 26 Am. St. Rep. 666.

17. Brittain v. Kossiter, 11 Q. B. Div. 123. See, also, Billington v. Cahill, 51 Hun (N. Y.), 132, 4 ‥ Y. S. 660 .
18. Cox v. Brewing Co., 53 Hun (N. Y.), 634, 6 N. Y. S. 84; Aiken v. Nogle, 47 Kans. 96.

19. Vocke v. Peters, 5s Ill. App. 338; Louisville, etc., R. R. Co. v. Offutt (Ky.), 36 S. IV. 181, 1s Ky. L. R. 303; Baltimore Breweries Co. v. Callahan, 82 Md. 106, 33 A. 460; Carter White Lead Co. v. Kivlin, 47 Neb. 409, 66 N. W. 536 ; Harrington v. Railroad Co., 60 Mo. App. 223. See, also, Butler v. Shehan, 61 Ill. App. 561; Hughes v. Frum, 41 W. Va. 445,23 S. E. 604; Frain v. Turner, $96 \mathrm{Ky} .634$, 29 S. W. 628 ; Weatherford, ete., R. R. Co. v. Wood, 88 Tex. 191, $32 \mathrm{~S}$. IV. 878,28 L. R. A. 526 .

1. Becar $r$. Flues, 64 N. Y. 518 ; Young v. Dake, 5 N. Y. 468; Sears v. Smith, 3 Colo. 287. 
space of one year from the making thereof." The court says in construing these clauses that clause 5 would prohibit a verbal agreement for the lease of real estate for one year, to begin in future, if it were not that clanse 4 provides specially a rule to govern such leases. The rule of construction is, that a special prorision in a statute will control a general provision which wonld otherwise include that mentioned in the particular provision. Hence, a lease for a term not longer than one year may be made to commence in the future by verbal contract, and is valid under the statute. ${ }^{2}$

The Texas court says that there is a marked difference in the language of clauses 4 and 5 of the article. The fifth prohibits the enforcements of contracts which are not to be performed "within one year from the making thereof," limiting both the time of commencement and continuance; while the fourth clause prohibits the enforcement of leases of real estate "for a longer term than one year," limiting and fixing only the time of duration. "If the legislature had intended that leases should be limited to one year from the time of making, then it was useless to mention them in clause 4 , for they would have been embraced in clause $5 . " 3$

But this interpretation is not accepted by all the courts, and it is held that a parol lease for a year, to commence at a future day, is within the clause of the statute and must be in writing to be valid; ${ }^{4}$ but a part performance may take it out of the statute. $^{5}$

2. Bateman v. Maddox, 86 Tex. 546, 26 S. IV. 51. See, also, Sobey v. Brisbee, 20 Iowa, 105; Anderson v. May, 10 Heisk. (Tenn.) 90; Eaton v. Whitaker, 18 Conn. 230; Huffman v. Starks, 31 Ind. 474; Whiting v. Ohlert, 52 Mieh. 462, 18 N. 219, 50 Am. Rep. 265; MeCroy v. Toney, 66 Miss. 233, 5 So. 392, 2 L. R. A. 847.

3. Bateman v. Maddox, 86 Tex. 546, 554, 26 S. W. 51.

4. Wheeser v. Frankenthal, 78 Ill. 124; White v. Levy, 93 Ala.
484, 9 So. 164; Cook v. Redman, 45 Mo. App. 397; White v. Holland, 17 Oreg. 3, 3 P. 5/3; Jellett v. Rhode, 43 Minn. $166,45 \mathrm{~N}$. W. 13; Greenwood v. Strather, $91 \mathrm{Ky}$. 482, 16 S. W. 138; Alt v. Lohnas, 19 Ill. 576 ; Wolf v. Dozer, 22 Kan. 436; Atwood v. Norton, 31 Ga. 507.

5. People's Pure Ice Co. v. Trumbull, 70 F'ed. Rep. 166; Rhodes Furniture Co. v. IVeedon, 10s Ala. 252, 19 So. 31 s. 
§36. Parol lease of land for a year.- A tenant by parol for a single year, has not, at common law, nor save by express valid stipulation, or custom of the country, or estoppel in pais a right to an outgoing erop. ${ }^{6}$ But this is otherwise in P'enn.sylvania, New Jersey, and Delaware.' The fact that the usual crop of the country cannot come to maturity in a year, does not raise by inplication a right to hold over. ${ }^{8}$. ind the right to enter and reap a erop of wheat after the expiration of a parol lease of land is an interest in land. ${ }^{9}$ Hence, a parol lease of land for one year, coupled with a rerbal agreement that the tenant may sow the land to wheat, will not give him the right to enter after the expiration of the year, and harrest the wheat. ${ }^{10}$

\section{\$ 37 . Part performance within a year - Performance on} one side.-The general rule in England and in many of the United States is that an agreement does not fall within the statute, prorided one party can, according to the contract, perform and does perform within a year. ${ }^{1}$ But other courts hold that the contract is still within the statute whenever the other party's promise is not to be performed within the year. ${ }^{2}$ And

6. Wigglesworth v. Dallison, I Doug. 201; Caldecatt v. Smythies, 7 Car. \& P. sos; Bain v. Clark, 10 Jolns. (N. Y.) 424; Reeder v. Silyre, 70 N. Y. 180, 26 Am. Rep. 567.

7. Gordon v. Little, 8 Serg. \& R. (I'a.) 533, $11 \mathrm{Am}$. Dec. 432; Stutz v. Diekey, 5 Binn. (Pa.) 285, 6 Am. Dee. 411 ; Demi v. Bossler, 1 Pa. 224; Van Doren v. Everett, 2 South. (N. J.) 460, 8 Am. Dec. 615; 'Templeman v. Biddle, 1 Harr. (1)el.) 52:2.

8. Reeder v. Sayre, 70 N. Y. 180, 26 Am. Rep. 567.

9. Carney v. Mosher, 97 Mich. 554, 56 N. W. y35.

10. Carney v. Mosher, 97 Mich. 554, 56 N. W. 935.
1. Bracegirdle v. Heald, 1 Barn. \& Ald. 722 ; Donellan v. Read, 3 Barn. \& Ad. 899 ; Worden v. Sharp, 56 Ill. 104; Halbrook v. Armstrong, 10 Me. 31; Horner v. Frazier, 65 Md. 1; Washburn v. Dasch, 68 Wis. 436,32 N. W. 5jl, 60 Am. Rep. S73; Smock v. Smock, 37 Mo. App. 56 ; Winters v. Cherry, is Mo. 344; Kendall v. Gaxnead, 55 Neb. 403,75 N. W. S52; Blanding v. Salgent 33 X. H. 239, 66 Am. Dec. 720; Berry r. Doremus, $30 \mathrm{~N}$. J. L. 399: Piper v. Foster, 121 Ind. 407,23 X. E. 269; Smalley v. Greene, 52 Towa, $241,3 \times$. 75,35 Am. Rep. $26 \%$ and note; Durfee v. OBrien, 16 R. $1.213,14$ A. 857.

2. Pierce v. Paine, 28 Vt. 34 ; Marey v. Marey, 9 Allen (Mass.), 
so a part performance by one of the parties will not take the agreement out of the statute. ${ }^{3}$

In Boytell v. Drummond, ${ }^{4}$ it was held that an agreement is within the statute, if its performance is to be commenced on both sides within a year. In 1832, in Donellan v. Read, ${ }^{5}$ it was decided that the statute refers only to agreements to be performed on either side within a year. But this decision was doubted in another case, ${ }^{6}$ but followed in Cherry v. Heming. ${ }^{7}$ In 1886 the doctrine of Donellan v. Read was disapproved, but was considered to be too finely established to be overruled. ${ }^{8}$

8; Lane v. Shackford, 5 N. H. 130; Broadwell v. Getman, 2 Denio ( $N$. Y.), si; Whipple v. Parker, 29 Mich. 369; Montague v. Garnett, 3 Bush (Ky.) 297; Wilson v. Ray, 13 Ind. 1.

3. Shumate v. Farlow, 125 Ind. 359, 25 N. E. 432 ; Osborne v. Kimball, 41 Kan. 187, 21 P. 163; Compare Washburn v. Dasch, 68 Wis. 436, 32 N. W. 551, 60 Am. Rep. 873.

4. 11 East, 142.

5. 3 Barn. \& Adol. 899.

6. Sonch v. Strawbridge, 2 Man. G. \& S. 808 .

7. 4 Exch. 631.
8. Miles v. Estate Co., $32 \mathrm{Ch}$. D. 266. See, also, Rake v. Pope, 7 Ala. 161; Johnson v. Watson, 1 Kelly (Ga.) 348; Bates v. Moore, 2 Bailey (S. Car.), 614; Perkins v. Clay, 54 N. H. 518; Curtis v. Sage, 35 111. 22; Grace v. Lynch, 80 Wis. 166,49 N. W. 751 ; Dant v. Head, 90 Ky. 255, 13 S. W. 1073, 29 Am. St. Rep. 369; Seddon v. Rosenbaum, 85 Va. 928, 9 S. E. 326,3 L. R. A. 337 and note; Atchison, etc., Railroad Co. v. English, $38 \mathrm{Kan} .110,16$ P. 82; Compare IVarner v. Railway Co., 54 Fed. Rep. 922, 4 C. C. A. 673. 


\section{ARTICLE VIII.}

\section{Agreenients Witinin Section Seventeen.}

SECtion 138. Application of Statute.

139. Executed and Executory Contracts.

140. Taking liack Chattels After Sale.

1+1. Price.

142. Amount of Sale.

143. Sale of Several Articles.

144. Goods, Wares, and Merehandise.

145. Delivery and Aceeptance.

146. Contracts for Work and Labor.

147. What is an Acceptance-When Question for Jury.

148. Goods Delivered Subjeet to Examination-Acceptance.

149. Intention.

150. Property in Possension of Third Person.

15l. Acts which Amomt to an Acceptance.

152. Designation of Carrier by Vendee-Delivery of Goods.

153. Eamest and Part Payment.

154. When Part Payment Must be Made.

155. What Constitutes Part Payment.

156. In What Property Part Payment may be Made.

$\S$ I38. Application of statute.- The seventeenth section of the statute of frauds, ${ }^{1}$ declares all contracts for the sale of goods, wares, and merchandise for the price of ten pounds and upwards to be invalid unless part of the goods be accepted, or part of the price be paid, or something be given in earnest to bind the bargain, or some note or memorandum in writing be signed by the party to be charged. This section governs all sales of goods, as at auction or at private sale. ${ }^{2}$

In Illinois this section has never been enacted, and hence no cases from this State can be cited as to its application and interpretation.

It is generally held in England ${ }^{3}$ and the United States that

1. 29 Car. $\mathrm{H}$, el. 3 .

2. Kenworthy v. Schofield, 2 Barn. \& Cr. 945; Davis v. Rowell, 2 Pick. (Mass.) 6f, 13 Am. Dee. 398 and note; Singstack r. IIarding, 4 Har. \& J. (Md.) 186, 7 Am. Dee. 669.

3. Pollock on Cont. 605; Anson on Cont. 67. 
the contracts not in accord with the provisions are not void but only not enforceable by suit, as in case of verbal contracts within section fourth. ${ }^{4}$ The later enunciations of the English and American courts hold that upon principle contracts not made in compliance with this section are not void but voidable. ${ }^{5}$ For any case to be within this section the contract must be for the sale of goods, wares, and merchandise, of a price or value in the statute specified.

\& I39. Executed and executory contracts. - The seventeenth section extends to executed as well as to executory contract, ${ }^{6}$ and no sale is valid except when the statute has been complied witl. ${ }^{7}$ At an early time in England, it was held that this section did not include executory contracts ${ }^{8}$ so it was enacted" that it should apply "notwithstanding the goods may be intended to be delivered at some future time, or may not at the time of such contract be actually made, procured, or provided, or fit or ready for delivery, or some act may be requisite for the making or completing thereof, or rendering the same fit for delivery."

However, before this statute was passed the doetrine had been changed and executed and executory contracts were held to be within the statute. ${ }^{10}$ This is the American doctrine. ${ }^{11}$ Hence a

4. Townsend v. Hargraves, 118 Mass. 325 ; Compare Houghtaling v. Ball, 20 Mo. 563; Alderton v. Bucboz, 3 Mich. 322; Daniel v. Frazer, 40 Miss. 507; Head v. Goodwin, 37 Me. 181.

5. Madditon v. Alderson, 8 App. Cas. 467,488 ; Bira v. Mumree, 60 Me. 337, 22 Ans. Rep. 57I; Harman v. Reeve, is C. B. 587; Townsend v. Hargraves, 118 Mass. 325, 334.

6. Benmett v. Hull, 10 Johns. (N. Y.) 364; Rondeau v. Wyatt, 2 H. Bl. 63; Cooper v. Elston, 7 Term R. 14; Edwards v. Railroad Co., 4S Me. 373; Hight v. Ripley, 19 Me. 137.
7. Buxton v. Bedell, 3 East, 303; Marsh v. Hyde, 3 Gray (Mass.), 331 ; Alexander v. Comber, 1 H. Bl. 20.

8. Clayton v. Andrews, 4 Burr. 2101; Towers v. Osborne, I Strange, 506.

9. 9 Geo. IV, e. 14 , sec. 7 .

10. Corbett v. Watson, 5 Barn. \& Ald. 613; Cooper v. Elston, 7 Term R. 14; Rondeau v. IVyatt, 2 H. Bl. 63 .

11. Crookshank v. Burrell, 18 Johns. (N. Y.) 58, 9 Am. Dec. 187 and note; Cason v. Cheely, 6 Ga. 554; Benmett v. Hull, 10 Johns. 
contract by a ralload company to take all the wood that a person would put on its line of its roarl during the season at the price it had paid him before for wood, or more if the wood was better, is within the statute. ${ }^{12}$ Ind an executory contract for the sale of chattels is within the statute, although it also embraces some other agreement to which the statute is not applicalle. ${ }^{13}$

§ 140. Taking back chattels after sale. - Executed contracts of sale, with a promise by the vendor of chattels, that in ease they do not suit the vendee or do not possess certain specified qualities the vendor will repay to the vendee the purchase-price upon their return, do not make such promise an independent contract $;{ }^{1}$ it is an entire contract, and the promise to take back the property and repay the purehase-price is not void under the statute. $^{2}$

And when ar: agent, by an oral contract, sells and delivers the goods of a diselosed principal, his personal oral warranty of quality is not a contract, independent of the contract of sale, but is a part of it, and one consideration is sufficient to support the sale and warranty. ${ }^{3}$

$\S$ I4I. Price.- The price is an essential element in a contract of sale, and a memorandum which does not state the price

(‥ Y.) 364; Edwards v. Railroad Co., 48 Me. 379; Naterman v. Meigs, 4 Cush. (Mass.) 497; Jackson v. Covert, 5 Wend. (N. Y.) 139; Lamb v. Crafts, 12 Met. (Mlass.) 353; Sawyer v. Wire, 36 Ala. 676 ; Franklin v. Long, 7 Gill \& J. (Md.) 407; Newman v. Morris, 4 Harr. \& Me. (Md.) 42l.

12. Elwards v. Railroad Co., 48 Me. 379. See, also, Watermin v. Meigs, 4 Cush. (Mlass.) 499.

13. Hanson v. Marsh, 40 Minn. 1, 40 N. IV. 841 ; Harman v. lieeve, 18 C. B. 587 ; Irvine v. Stone, 6 Cush. (Mass.) 508 .
1. Thornton v. Wymn, l: Wheat. (U. S.) 183; Towers v. Barnett, 1 'Term R. 133.

2. Wooster v. Sage, 67 N. Y. 67 ; Williams v. Burgess, 10 Ac. \& E. 499 ; Fitzpatrick v. Woolrutl, 96 N. I. 561 ; Johnston v. L'rask, 116 N. I. 136,22 N. E. 377,5 L. R. A. 630, 15 Am. St. Rep. 394; White ๖. Knapp, ti Barb. (X. L.) 549 ; Fay v. Wheeler, 44 Vt. 292; Dickinson v. Dickinson, 29 Conn. 600.

3. Johnston $\mathrm{r}$. Trask, $116 \mathrm{~N}$. Y. 136. .2. ․ E. 375.5 L. R. A. 630 , 15 Am. St. Rep. 394. 
- except in cases where no price being stipulated, it is left to be measured by the rule of reasonable or market value - is insufficient to satisfy the statute, and the contract is by the terms of the statute roid. ${ }^{4}$

Where the parties fix no price, the case is within or without the statute according to the finding of the jury. ${ }^{5}$ It will be presumed in the absence of a specified consideration for the sale, that there was a promise to pay a reasonable price, provided there be no verbal agreement as to the price.

$\S$ r42. Amount of sale. - Most of the statutes fix the amount of sale which brings it within the statute; if not within the statute it is governed by the common law. In England the amount of sale is ten pounds. In Massachusetts, Oregon, Indiana, Wisconsin, and New York, it is fifty dollars. In Arkansas, Maine, Missouri, and New Jersey it is thirty dollars. In New Hampshire it is thirty-three dollars. In Vermont, forty dollars. In California and Idaho, two hundred dollars. In Florida and Iowa no amount is fixed. ${ }^{6}$

$\S$ I43. Sale of several articles. - When several articles are sole separately and independently, one of which reaches the amount fixed by statute, the statute does not apply; but if they are all included in the same transaction and the price is equal to or exceeds the amount of the statute, then it applies, ${ }^{1}$ and the combined price of all the articles transferred in the one transaction, is compared with the amount in the statute. ${ }^{2}$

4. Elmore v. Kingscott, 5 Barn. \& Cr. 583; Acebal v. Levy, 10 Bing. 376 ; Goodman v. Griffiths, 1 Hurl. \& N. 574; Ide v. Stanton, 15 Vt. 685, 40 Am. Dec. 698; Waterman v. Meigs, 4 Cush. (Mass.) 497; Ascroft v. Butterworth, 136 Mass. 511 ; Stone v. Browning, $68 \mathrm{~N}$. Y. 598, 604; James v. Muir, 33 Mich. 223.

5. Harmon v. Reeve, 18 C. B
6. See Mass. Gen. Stat. c. 105, sec. 5; Snith v. Smith, 8 Blackf. (Ind.) 208; Dykers v. Townsend, 24 N. Y. 57; Buckman v. Nash, 12 Me. 474; Carman v. Smick, 3 Green (N. J.), 252.

1. Baldey v. Parker, 2 Barn. \& Cr. 37 .

2. Gilman v. Hill, 36 N. H. 311 ; Jenness v. Wendell, 51 N. H. 63; 12 Am. Rep. 48. 587. 
$\S$ 144. Goods, wares and merchandise.- What are goods, wares, and merchandise, is a question not easily answered. In fact the courts are in conflict as to this subject, and cannot be reconeiled. Thus, it is said that shares of stock are but choses in action, and not within the statute. This is the English holding at the present time. ${ }^{1}$ And this is the decision of many of the American courts. ${ }^{2}$ Some of the courts of this country have taken a different view of the question, and hold choses in action to be included within the meaning of the statute $;^{3}$ so is a sale of book accounts, of land serip. ${ }^{5}$

In California, Minnesota, Montana, Nebraska, Nevada, New York, North Dakota, South Dakota, Utah, Wisconsin, and Wroming, the words "things in action" have been substituted in the statute; and in Connecticut, Florida, Mississippi, and Oregon the words "personal property" have been added to the statute. These additions must be taken into consideration in reading decisions of these States.

§ 4 4. Delivery and acceptance.- There must be both a delivery and an acceptance; and both of the parties must partake in the same act. A delivery alone by the vendor is not sufficient to take the contract out of the statute; there must also be a receipt and acceptance of the thing sold by the vendee, to have that effect. ${ }^{6}$ And a vendor eannot sell that which does not be-

1. Benjamin on Sales, 90, 91 ; Humble v. Mitchell, 11 Adol. \& El. 205.

2. Webb v. Railroad Co., 77 Md. 92, 39 Am. St. Rep. 396 ; Clark v. Burnham, 2 story, C. C. 15 ; Whittemore v. Gibbs, 24 N. H. 484 ; Vawter v. Griftin, 40 Ind. 593.

3. Greenwood v. Law, $55 \mathrm{~N}$. J. L. 168,26 A. 134,19 L. R. A. 688 ; Baldwin v. Williams, 3 Met. (Mass.) 365; North v. Forest, 15 Conn. 400; Pray v. Mitchell, 60 Me. 430; Tisdale v. Harris, 20 Pick.
(Mass.) 9 ; Boardman v. Cutter, l2s Mass. 388; Hinchman v. Lincoln, 124 U. S. 38,8 S. Ct. 369 ; Bernhardt v. Walls, 29 Mo. App. 206.

4. Smith v. Bouck. 33 Wis. 19; Walker v. Supple, 54 Ga. 178.

5. Somerby v. Buntin, 118 Mass. 279 ; Blakeney v. Goode, 30 Ohio St. 350 ; Compare Jones v. Reynolds, 120 N. Y. 213,24 N. E. 379.

6. Powder River Live Stock Co. v. Lamb, 38 Neb. 339, 56 N. IV. 1019; Simmons Hardware Co. v. 
long to him and not in his possession. Thus, a sale by a tenant of al crop raised on the leased premises, and no delivery made, he having abandoned the premises, is roid. After the abandomment by the tenant, the possessory right in whatever was upon the premises reverter to the owner of the land, and there was no possession in the tenant at the time of the proposed sale.' It may be a question for the jury whether there has been such an acceptance and receipt of the chattels as to take the contract out of the statute.

Acceptance and delivery need not be simultancons, but either may take place before the other $;^{9}$ and delivery may be subsequent to the agreement. ${ }^{10}$ In most States a delivery on Sunday is void, but the goods may be accepted subsequently, when the sale will be valid. ${ }^{11}$ And surrender of a farm and tools to a vendee, makes the sale of the tools valid. ${ }^{12}$

$\S$ I46. Contracts for work and labor.-When work and labor are to be bestowed by the vendor upon the article sold before it is to be delivered some courts hold that the contract is not within the statute. ${ }^{1}$ That is where a mechanic furnishes articles, it is generally held that an oral bargain for the making of the thing is good. ${ }^{2}$ But where a manufacturer produces the

Mullen, 33 Minn. 195, 22 N. 294; Caulkins v. Hellman, 47 N. Y. 449, 7 Am. Rep. 461: Hx parte Parker, 11 Neb. 309, 9 N. 33; Smith v. Brennan, 62 Mich. 349, $28 \mathrm{~N}$. W. 892, 4 Am. St. Rep. S67; Fontaine v. Bush, $40 \mathrm{Minn} .1+1,41 \mathrm{~N}$. W. 465, 12 Am. St. Rep. 722; Shaw Lumber Co. v. Manville, 4 Idaho, 369, 39 P. 559; Crosby Hardware Co. v. Tester. 90 Wis. 412,03 N. W. 1057 .

7. Maclary v. Turner, 9 Houst. (Del.) 281, 32 A. 325 .

8. Becker v. Holm, 89 Wis. 86 , 61 N. W. 307.

9. Amson v. Dreher, 35 Wis. 616; Cross v. O'Dommell, 44 N. Y.
601, 4 Am. Rep. 7.21; Vietor v. Stroock, 15 Daly (N. Y.), 329, 5 N. Y. S. 659,7 N. Y. S. 959.

10. Ortloff v. Klitzke, 43 Minn. 154, 44 N. IV. 1085; MeCarthy v. Nash, 14 Mimn. 95; Gaslin v. Pinney, 24 Minn. 32.2.

11. Sehmidt v. Thomas, 75 Wis. 529, 44 N. W. 791.

12. Wilkinson v. Wilkinson, 61 Vt. 409,47 A. 795.

1. Niehelberger v. McCaulev, 5 Hari. \& J. (Md.) 2l3, 9 Am. Dec. 514; Rentch v. Long, $27 \mathrm{Md}$. 188; Bagley v. Walker, 78 Md. 239, 27 A. 1033.

2. Parsons v. Loucks, 48 N. Y. 17, S Am. Rep. 517; Crookshank v. 
goods in the usual eourse of his business, the contract is one of sale and not for the bestowal of work and labor. ${ }^{3} \quad A$ contract for the sale of the whole of a erop for a certain year, to be delivered at a certain price, as soon as it ean be gathered and prepared for market, is within the statute. ${ }^{4}$

To make the case one for work and labor, the contract should contemplate or require some change in the condition, business, or cireumstances of the rendor. ${ }^{5}$

In some States a distinction is made between ehattels in existence and goods to be manufactured. When the goods are in existence, then it is a contract of sale; if to be manufactnred then a contract of work and labor. ${ }^{6} \quad$ It is held that if the thing sold exists at the time in solido, the mere fact that the seller is to do something to put it in a marketable condition does not take the contract ont of the operation of the statute.

\section{$\S$ I47. What is an acceptance - When question for jury.-} Ordinarily the question of acceptance is one of fact. However if the uncontroverted facts are such as cannot afford any ground for finding an acceptance, or where, thongh the court may admit that there is a seintilla of evidence tending to show

Burell, 18 Johns. (N. Y.) 58, 9 Am. Dec. 1si and note; Alien v. Jarvis, 20 Conn. 3S; Meincke v. Falk, j5 Wis. $42 \pi, 13$ N. 545,42 Alil. Rep. 722 .

S. Pratt v. Miller, 109 Mo. is, 18 S. II. 965,32 Am. St. Rep. 656; Godklard r. Binney, 115 Mass. 450.

4. Cason v. Cheely, 6 Ga. 554; Mighell v. Dougherty, 86 Iowa, 480 , 53 ․ 11. 402,15 L. R. A. 755,41 Am. St. Rep. 5ll. See, also, Spencer v. Cone, 11 Met. ('Mass.) 283; Lamb v. Crafts, 12 Mct. (Mass.) 353; Prescott v. Locke, 51 N. H. 94, 12 Am. Rep. 55; Atwater v. Hough, 29 Conn. 508; Finney v. Apgar, 31 N. J. L. 266; Edwards v. Railroad Co., 48 Me. 379, 54 Me.
105: Sawyer v. Ware, 36 Ala. 675; bivel Muhlinbrink, 1 Rich. L. (s. Car.) 199, 44 Am. Dec. 247 .

5. OXeil v. Mlining Co., 3 Nev. 141: Goddard v. Bimey. 115 Mass. 450, 15 Am. Rep. 112; Finney v. A pgar, 31 N. J. L. 267 : Prescott v. Locke. 51 N. H. 4t, 12 Am. Rep. 55; Crocketc v. Seribner, $64 \mathrm{Me}$. 447: Mixer v. Howarth, 21 Pick. (Mass.) 205, 32 Am. Dec. 256.

6. Higgins v. Murray, $73 \mathrm{~N}$. Y. 252; Pawelski v. Hargreave, $47 \mathrm{~N}$. J. L. 334, 54 Am. Rep. 162 and note; Pitkin v. Noyes, 48 N. H. 294, 2 Am. Rep. 218.

7. Downes v. Ross, 23 Wend. (N. Y.) 270; Cooke v. Millard, 5 Lans. (N. Y.) 246 . 
an acceptance, the court could still feel bound to set aside a verdict finding an aceptance on the evirlenec, it is the duty of the cont to withhold the case from the jury. ${ }^{8}$ But otherwise the question of acceptance is one of fact for the jury upon all the evidence. ${ }^{9}$

$\S$ I48. Goods delivered subject to examination - Acceptance.- Performance of the vendor of his part of a verbal contract is not sufficient to give it validity, where the buyer does not perform his part. ${ }^{1}$ So, where goods are sold subject to examination under a verbal contract, so long as the vendee can, without self-contradiction, declare that the goods are not to be taken in fulfillment of the contract, he has not accepted them. And it is immaterial whether his refusal to take them be reasonable or not. ${ }^{2}$

To constitute an acceptance, it is requisite that the purchaser shall have made the examination and pronounced it satisfactory, or shall have dealt with the goods, or done some unequivocal act, evincing his intent to accept them unconditionally as his own. And although the refusal to accept be unreasonable, without an acceptance the contract is not valid. ${ }^{3}$

In general when the vendee takes upon himself to exercise a dominion over the property, and deals with it in a manner inconsistent with the rights of property or the title being in the vendor, that is evidence of its acceptance. ${ }^{4}$ When the contract is for the purchase of articles to be selected by the vendor from a large number of similar articles, to set aside for the buyer, there is no sale until the buyer has examined and accepted them. ${ }^{5}$

8. Denny v. Williams, 5 Allen (Mass.), 5; Howard v. Borden, 13 Allen (Mass.), 299; Stone v. Browning, 68 N. Y. 598 .

9. Garfield v. Paris, 96 U. S. 557.

1. Stone v. Browning, 51 N. Y. 211, 68 N. Y. 598 ; Caulkins v. Hellman, 47 N. Y. 449, 7 Am. Rep. 461.

2. Stone v. Browning, 68 N. Y.
598; Hewes v. Jordan, 39 Md. 472; Knight v. Mann, 118 Mass. 143.

3. Stone v. Browning, $68 \mathrm{~N}$. Y. 598.

4. Morton v. Tibbett, 15 Q. B. 428.

5. Cusack v. Robinson, 1 Smith \& B. 299; Bog Lead Mining Co. v. Montague, 10 C. B., N. S. 481; 
$\S$ I49. Intention.-To constitute an acceptance the rendee must deal with the paper in such a manner as to evidence his acknowledgment of the contract. The property must be completely transferred, which includes both delivery by the vendor and acceptance by the vendee. There must be a delivery of the goods by the vendor with an intention of vesting the right of possession in the vendee, and there must be an actual receiving and acceptance by the latter with the intention of taking possession as owner. ${ }^{1}$ The intention of the parties at the time as to the delivery must prevail, even if there be something yet to be done to complete it."

\section{$\S \mathrm{r} 50$. Property in possession of a third person.- Many} cases hold that the delivery is complete between the parties, everything else being done, upon receipt of the order for the delivery of the property when in the keeping of another person and in another place. ${ }^{3}$ And when the possession is obtained from the third person by frand of the vendee, it may be treated by the vendor as a delivery to complete the sale at his option. ${ }^{4}$

It is the fact of delivery under and in pursuance of the agree-

Coombs v. Railroad Co., 3 Hurls. \& Nor. 510; Knight v. Mamn. 118 Mass. 143; New England, etc., Co. v. Worsted Co., 165 Mass. 328, 43 N. E. 112, 52 Am. St. Rep. 516; The Elgie Cotton Cases, 22 Wall. (U. S.) 180; Hateh v. Oil Co., $100 \mathrm{U}$. S. 124; Morrison v. vingley, $63 \mathrm{Me}$. 553 ; Bailey v. Smitn, 43 N. H. 141; Halderman v. Duncan, 5l Pa. St. 66; Hahn v. Frederrcks, $3 v$ Mich. 223, 18 Am. Rep. 119; Woods v. McGee, 7 Ohio, 467; Browning v. Hamilton, 42 Ala. 484; Commercial Nat. Bank v. Gillette, 90 Ind. 268, 46 Am. Rep. 222; Ferguson v. Bank, 14 Bush. (Ky.) 555, 29 Am. Rep. 4ls; Baldwin v. McKay, 41 Miss. 358; Upham v. Dodd, 24 Ark. 545; Courtright v. Leonard,
11 lowa, 32; McLaughlin v. Piatt, 27 Call. 451.

I. Stone v. Browning, $51 \mathrm{~N}$. Y. 211: Gilman v. Hill, 36 N. H. 311 ; Rerlington v. Roberts, $25 \mathrm{Vt}$. 686; Galvin v. Kenneth, 21 Oreg. 184, 24 P'. 1039 .

2. Sewell v. Eaton, $d$ Wis. 490 , 70 Am. Dec. 47l; Fleteher v. Ingram, 46 Wis. 191,50 N. WV. 424 ; Kirby v. Johnson, 22 Mo. 354; Henline v. Hall, 4 Ind. 189; Gough v. Ldelen, 5 Gill (Ald.), 10l; Foster v. Ropes, 111 Mlass. 10.

3. Ranney v. Higby, 4 Wis. 154; Magee v. Billingsly, 3 Ala. 679.

4. Weed v. Page, 7 Wis. 503; Somers v. MeLaughlin, 57 Wis. 358 , 15 N. 442. 
ment of sale, not the time when the delivery is made, that the statute renders essential to the proof of a valid contract; so that a delivery at a future day is sufficient if made in pursuance of the contract. ${ }^{5}$ And upon the same principle, the place of delivery can make no difference. ${ }^{6}$ And so when an order is made to deliver the property at a designated place, and it is delivered at such place, it is sufficient, and the acceptance is complete when the bargain was made.

$\S$ I5I. Acts which amount to an acceptance.-Any unequivocal act or acts on the part of the vendee which amount to an assertion of ownership of the property is sufficient to take the sale ont of the statute. Acts of ownership consistent with the intent to keep the property are often sufficient and sometimes conclusive evidence of acceptance. ${ }^{8}$ The act or acts relied upon as constituting a receipt and acceptance must establish the relation between the parties of vendor and vendee. ${ }^{9}$ The acceptance and receipt contemplated by the statute and as adjudged by the cases, must always be governed by the circumstances surrounding the transaction, as to whether there has been such acceptance and receipt. ${ }^{10}$ Whether the buyer has accepted, depends upon the fact and circumstances of each separate transaction. ${ }^{11}$

In the earlier decisions, slight acts were considered as suffciently evidencing acceptance and receipt, but the later cases are much more strict, evincing a determination by the courts to give full effect to the design and spirit as well as the letter of the statute. ${ }^{12}$

5. Marsh v. Hyde, 3 Gray (Mass.), 331; Townsend v. Hargraves, 118 Mass. 336.

6. Somers v. McLaughlin, $57 \mathrm{Wis}$. 358, 15 N. 442.

7. Cusack v. Robinson, I Best \& S. 299; Victor v. Stroock, 15 Daly (N. Y.), 329, 5 N. Y. S. 659, 7 N. Y. S. 959 .

8. Vincent v. Germond, 11 Johns.
(N. Y.) 283; Gray v. Davis, $10 \mathrm{~N}$. 1. 285 .

9. Reneick v. Sandford, 120 Mass. 309.

10. Galvin v. Kenneth, 21 Oreg. 184, 27 P. 1039.

11. Jones v. Bank, 29 Md. 287, 96 Am. Dec. 533.

12. Clarke v. Marriott, 9 Gill (Md.), 335; Jones v. Bank, 29 Md. 287, 96 Am. Dec. 533. 
All the cases agree that the receipt and acceptance of goods to satisfy the terms of the statute must be proved by clear and mequivocal acts on the part of the buyer. ${ }^{13}$ Mere delivery is not sufficient; there must be actual acceptance by the buyer by dealing with the goods as owner. ${ }^{14}$ In general terms the rule is: The clear and unequivocal acts, showing an acceptance, or from which an acceptance may be inferred, must relate to some dealing with the property itself by the buyer or his authorized agent after the delivery of the whole or part of it. ${ }^{15}$

\section{$\S$ I52. Designation of carrier by vendee - Delivery of} goods.- The mere designation of a carrier by the vendee, and delivery of the goods to, and receipt of them by him as carrier, do not make such acceptance and receipt as the statute requires. ${ }^{1}$

The authorities hold, with no conflict, that the acceptance and receipt which the statute requires, may be made by an agent of the buyer empowered for that purpose; but the weight of authority both in England and America is, that the agency to accept and receive cannot be inferred from the mere fact that the buyer has designated a particular vessel or person as carrier of goods. In an early case, ${ }^{2}$ where goods ordered verbally were shipped by the seller by a certain vessel according to the customary dealings between the parties, it was held, the buyer must be considered as having constituted the master of the vessel as his agent to accept and receive the goods. In another

13. Davis v. Eastman, 1 Allen (Mass.), 422; Denny v. IVilliams, 5 Allen (Mass.), 1; Johnson v. Cuttle, 105 Mass. 447, 7 Am. Rep. 545 .

14. Phillips v. Bislolli, 2 Barn. \& Cr. 511 .

15. Currie v. Anderson, 2 El. \& El. 592; Snow v. Warner, 10 Jet. (Mass.) 132, 43 Am. Dec. 417; Marsh v. Hyde, 3 Gray (Mass.), 331; Ullmann v. Barnard, 7 Gray (Mass.), 554; Ross v. Welch, 11 Gray (Mass.), 235; Morton v. Tib- bett, 15 Q. B. 42S; Chaplin v. Rogers, l East, 192; Blenkinsop v. Clayton, 7 Taunt. 497. See, also, Spear v. Bach, S2 Wis. 19-2, $52 \mathrm{~N}$. W. 97 .

1. Jones v. Bank, 29 Md. 287,96 Am. Dec. 533; Frostburg Mining Co. v. Glass Co., 9 Cush. (Mass.) 115 ; Bushel v. Wheeler, 15 Q. B. 442; Coombs v. Railroad Co., 3 Hur. \& Nor. 510; Cusack v. Robinson, 1 Best \& S. 299.

2. Hart v. Sattley, 3 Camp. 528. 
case, ${ }^{3}$ it was held, that the same result followed from the goods being delivered to a carrier designated by the buyer for that purpose. The first of these cases has been expressly overruled, and the doctrine asserted by both entirely overthrown by all the subsequent adjudications. ${ }^{4}$

§ I53. Earnest and part payment.-The idea of "earnest," in connection with contracts, was borrowed from the civil law. ${ }^{5}$ But it secms that the statute of frauds distinguishes between "earnest," and "part payment," either of whieh, if given by the vendee, will make a verbal contract valid. ${ }^{6}$ But as used in the statute, it amounts to nothing else than part payment. ${ }^{7}$

"Earnest" is not generally used in modern statutes, as it was suited to times when the people were illiterate, before the introduction of writing. ${ }^{8}$

$\S$ I54. When part payment must be made.-In New York ${ }^{1}$ and $\mathrm{W}$ isconsin ${ }^{2}$ the statute requires that the part payment shall be made "at the time" of the agreement. So when the agreement is void for want of "earnest" under these statutes, it cannot be made valid by a mere payment or tender of even the entire purehase-money afterwards. For that purpose there

3. Dawes v. Peck, S Term R. 330.

4. Hanson v. Armitage, 5 Barn. \& Ald. 557; Astey v. Emery, 4 Maule \& S. 262; Acebat v. Levy, 10 Bing. 376; Norman v. Phillips, 14 Mees. \& Wel. 277; Farina v. Howe, 16 Mees. \& Wel. 119; Coombs v. Railroad Co., 3 Hurls. \& Nor. 510; Hunt v. Hecht, 8 Exch. 814; Bushel v. Wheeler, 15 Q. B. 442; Hart v. Bush, 1 E1., B. \& E. 494; Cusack v. Robinson, 1 Best \& S. 299 ; Nicholson v. Bower, 1 El. \& El. 172; Meredith v. Meigh, 2 El. \& B. 363; Currie v. Anderson, 2 El. \& El. 591.

5. Guterbock's Bracton, 145;
Howe v. Smith, 27 Ch. Div. 89, 101, 102.

6. 29 Car. 11, c. 3 , sec. 17 .

7. 2 Bl. Com. 447; Pordage v. Cole, 1 Saund. 319b; Langfort v. Tiler, I Salk. 113; Morton v. Tibbett, 15 Q. B. 428; Walker v. Nussey, 16 Mees. \& IVel. 302; Howe v. Hayward, 108 Mass. 54, 11 Am. Rep. 306; Bissell v. Balcom, 39 N. 1. 275 .

8. 2 Kent's Com. 495n.

1. Jackson v. Tupper, 101 N. Y. 515 ; Hallenback v. Cockran, 20 Hun (N. Y.), 416.

2. Kerkhof v. Atlas Paper Co., 68 Wis. 674, 32 N. W. 766. 
must be a delivery and aeceptance of the property as well; or there nust be a distinct renewal of or assent to the terms of the original agreement so as to make the payment apply to a present and not to a past agreement of sale. ${ }^{3}$ the New York eourt holds that one after payment reaffirms or restates the terms of the contract, and that such payment is then made at the time of the contraet, and not afterwards. ${ }^{4}$

The clause requiring payment of part of the purehase-price at the time of the contract does not oecur in the other statutes of the various States, so it may be made at any time before an action on the contract. ${ }^{5}$

$\S$ I55. What constitutes part payment.- To constitute part payment the money must be actually paid. A rerbal stipulation to give and to receive something in earnest to bind the bargain or in part payment is as much within the statute as is the agreement or contract taken as a whole; a note or memorandum in relation to give something in earnest to bind the bargain, or in part payment, which is insufficient of itself to take the contract out of the statute, is also insuffieient to make the eontract binding upon either party. ${ }^{6}$ A promise to pay is not sufficient, nor is an aceepted tender of payment sufficient. ${ }^{7}$

$\S$ I56. In what property part payment may be made.- It is competent for parties to designate by their contraet how and in what payment may be made. It may be made in property or in service. Whatever the parties agree shall constitute payment will be regarded by the eourt as payment provided the thing agreed upon is of some value. ${ }^{1}$ So payment in articles of prop-

3. Bates v. Chesbro, 32 Wis. 594 ; Kerkhof v. Atlas Paper Co., 68 Wis. 674, 32 N. IV. 766 ; Crosby Hardwood Co. v. Trester, 90 Wis. 412,63 N. W. 1057.

4. Hunter v. Wetsell, 57 N. Y. 375,84 N. Y. 549, 15 Am. Rep. 508.
5. Thompson v. Alger, 12 Met. (Mass.) 128 .

6. Edgerton v. Hodge, $4 \mathrm{I}$ Vt. 676.

7. Arteher v. Zeb, 5 Hill (N. Y.), 200, 205; Walrath v. Ingles, 64 Barb. (N. Y.) 265.

1. Kuhns v. Gates, 92 Ind. 66; Tilford v. Roberts, 8 Ind. 254. 
erty will bind the bargain and prevent the operation of the statute. ${ }^{2}$ All that is necessary that the payment be made in something of value, even if "it be but a penny." 3 So giving the vendor a eredit on an existing debt in favor of the vendee is part payment, ${ }^{4}$ or paying the vendor's debt to a third party is sufficient. $^{5}$

\section{ARTICLE IX.}

\section{Representations as to Credit.}

SeCtion 157. Statutory Provisions.

158. When the Statute Applies.

159. Sufficiency of Writing.

160. Parol Evidence.

$\S$ I57. Statutory provisions.-The statute generally provides that no action shall be brought to charge one upon the representation as to the eredit or trade of another person, unless such representation is in writing and signed by the person to be charged. The various statutes are substantially the same. This statute is intended to reach cases where the plaintiff has dealt with and given eredit to the person favorably mentioned, and done so on the faith on the assurances. It does not apply to conspiracies or frands where representations are made to enable the party making the representation to profit by it. ${ }^{1}$

$\S \mathbf{5 8}$. When the statute applies.-Oral representation as to the credit or ability of another person must be in writing in order to be binding on the party making the representation. A

2. Sharp v. Carroll, 66 Wis. 62 , 27 N. W. 832; Dow v. Warthen, 37 Vt. 108; Bach v. Owen, 5 Term R. 409; Phillips v. Ocmulgee Mills, 55 Ga. 633; Hunter v. Wetsell, 84 N. Y. 549, 38 Am. Rep. 544; Combs v. Bateman, 10 Barb. (N. Y.) 573.

3. Shep. Touch. 224. Sce, also, Langfort v. Tiler, 1 Salk. 113;
Artcher v. Zeh, 5 Hill (N. Y.), 200. 4. Norwegian Plow Co. v. Hawthorn, 71 Wis. $529,37 \mathrm{~N}$. W. 825.

5. Catterill v. Stevens, 10 Wis. 366.

1. Hess v. Culver, 77 Mich. 598, 43 N. W. 994,6 L. R. A. 498 and note, 18 Am. St. Rep. 421 ; Clark v. Hurd, 79 Mich. 130, 44 N. W. 343. 
representation by an officer of a corporation with reference to its financial standing or means, is made with reference to the credit or ability of another person, and to support an action must be in writing $;^{1}$ oral statements of an officer of a corporation that it owns certain specific property, if made eoneerning its credit, ability, or trade, are within the statute. ${ }^{2}$ And the representation by one that he is the owner of certain corporate stock, and that the corporation is paying large dividends, which representations were made for his own benefit to induce another to purchase his stock, are not actionable. ${ }^{3}$ This statute applies to cases where the representations are made for the purpose of obtaining a credit for a person in relation to whom the words are spoken. ${ }^{4}$ And it is immaterial that the party making the representation has an additional purpose of obtaining an indirect benefit to himself from the transaction. ${ }^{5}$ And a case is not serered from the operation of the statute by the fact that the defendant also, at the same time misrepresented his own financial standing, and made certain personal promises that he has not kept. ${ }^{6}$

$\S$ I59. Sufficiency of writing.- The writing must be clear and explicit without ambiguous phrases. ${ }^{7}$ That a representation has been made in writing somewhere, and at some time to some person by a person sought to be charged, is not sufficient. It must be made to the person seeking to charge the defendant. ${ }^{8}$ The writing must be direct and elear as to whom is to be bound. Thus, where a notice is signed by defendants as directors, no

1. Kimball v. Comstock, 14 Gray (Mass.), 508; Wells v. Prince, 15 Gray (Mass.), 562; Mann v. Blanchard, 2 Allen (Mass.), 386; McKinney v. Whiting, 8 Allen (Mass.), 207.

2. Humnewell v. Duxbury. 157 Mass. 1, 31 N. E. 700.

3. Hubard v. Jong, 105 Mich. 442,63 N. W. 644.

4. Hunter v. Randall, $62 \mathrm{Me}$. 423, 16 Am. Rep. 490.
5. Mann v. Blanchard, 2 Allen (Mass.), 386 ; Brown v. Kimball Co., 84 Me. 280, 24 A. 1007.

6. Brown v. Kimball Co., 84 Me. 280, 24 A. 1007. See 34 Central L. Jour. 115.

7. Russell v. Clarke, 7 Cranch (U. S.), 69.

8. Grant v. Naylor, 4 Cranch (U. S.), 224. 
recovery can be had from them individually even if the notice was sufficiently represented in writing.9.

$\S$ r6o. Parol evidence.- Such representation in writing cannot be aided by evidence of additional verbal representations. ${ }^{1}$ Where the statute requires a writing, the writing not under seal is the evidence of the agreement and cannot be varied by verbal additions. ${ }^{2}$ The parties have reduced their meaning to writing under the statute and cannot adduce evidence in contradiction or alteration of it. The contract binds them, and the writing is conclusive. ${ }^{3}$

9. First Nat. Bank v. Sowles, 46 Fed. Rep. 731 .

1. First Nat. Bank v. Sowles, 46 Fed. Rep. 731 .

2. Wake v. Harrop, 6 Hurl. \& N.
768; Compare Grant v. Nayor, 4 Cranch (U. S.), 224.

3. Wake r. Harrop, 6 Hurl. \& N. 668. 


\section{PART II.}

\section{CONTRACTS IN VIOLATION OF LAW.}





\section{PAR'TI.}

CHAPTER V.

Agreements in Violation of the Common Law.

\section{ARTICLE I.}

\section{Illegal Contracts.}

Section 161. Illegal Contracts Cannot be Enforced.

162. Agreement to Defraud Others-Bueket Shops.

163. Agreement to Buy Shares at a Fictitious Premium.

164. Libel.

165. Auction Sales-By, Birlling.

166. Auetion Sales-English Doctrine.

167. Stipulation not to Bill.

168. By Bidding-When Legill.

169. The Purehase of Property on Joint Aecount.

$\$$ I6r. Illegal contracts cannot be enforced.-Ex turpi causa non oritur actio - no action arises out of an immoral consideration. This maxim is founded in good sense, and expresses a clear and well-recognized principle, which is not confined to indictments. No court will enforee an illegal contract or allow itself to be made the instrument of enforeing obligations alleged to arise out of a contract or transaction which is illegal, if the illegality is duly brought to the notice of the court, and if the person involing the aid of the court is himself implicated in the illegality. It matters not whether the defendant has pleaded the illegality or whether he has not. If the evidence adduced by the plaintiff proves the illegality the court ought not to assist him. ${ }^{1}$ If the plaintiff cannot maintain his cause of

1. Holman v. Johnson, Cowp. 343. See, also, Pearce r. Brooks, L. R. 1 Exch. 213. 
action without showing, as a part of such cause of action, that he has been guilty of illegality, then the court will not assist him in his cause of action, where the illegality is pleaded, ${ }^{2}$ or where it is not pleaded, but the fraud is apparent. ${ }^{3}$

\section{$\S$ I62. Agreement to defraud others-Bucket shops.-If} two or more persons agree to cheat and defrand others by means of deceit and fraud, each is indictable for a criminal conspiracy at common law. Thus, it is a criminal conspiracy for two or more to agree by false rumors to endeavor to raise the price of the public funds on a particular day. ${ }^{4}$ And so an agreement by two or more to cheat and defraud by means of false pretenses those who might buy shares in a company is an indictable offense. ${ }^{5}$ When the plaintiff cannot present his case to a jury without necessarily disclosing the unlawful purpose, he cannot sustain his action because of its illegality. ${ }^{6}$

This principle of law applies especially to bucket shops to be found in all large cities. $A$ bucket shop is a brokerage office where orders are never execnted and the funds of customers are fraudulently appropriated. A bucket shop generally has an extensive suite of rooms fitted up with all the paraphernalia of a stock exchange house. Operators appear to be receiving dispatches over private wires, and many clerks are busy posting quotations on the bulletin boards. But the private wires do not go outside the building, but lead only to a basement room where dispatches are sent and the fraud directed. All the business is done on a one or two point margin, no customer being allowed to put up more than five points.

So, if persons buy stock on a one-point margin the manager of the office gives the signal for a fictitious quotation of one

2. 'Taylor v. Chester, L. R. 4 Q. B. 309 .

3. Begbie v. Phosphate Serrage Co., L. R. 10 Q. B. 4 I.

4. Rex. v. Berenger, 3 Maule \& S. 67.

5. Reg. v. Aspinall, 1 Q. B.
D. 730,2 Q. B. D. 48 . See, also, Reg. v. Hudson, Bell, C. C. 263; Allen v. Rescons, 2 Lev. 174.

6. Simpson v. Bloss, 7 Taunt. 246; Jones v. Yates, 9 Barn. \& Cr. 501 ; Fivaz v. Nichalls, 2 C. B. 501. 
point lower, which wipes out the contingent and the office buckets the proceeds, which sometimes amount to $\$ 10,000$ or $\$ 15,000$ in a single stock.

In cases where fictitious quotations are not possible, the more wealthy bucket shop men club together and depress values on the regular stock exchange to a point where their customers' margins become exhausted. In this way the bucket shop always wins, except in a continuously rising stock market, when the concerns are sometimes forced to the wall. The public as a rule only buys for an advance and never sells short. All such transactions are fraudulent and void.

\section{$\S$ 163. Agreement to buy shares at a fictitious premium.-} An agreement between two or more to purchase shares in a company in order to induce persons who might thereafter purchase shares in such company to believe, contrary to fact, that there was a bona fide market for its shares, and that the shares were at a real premium, is an illegal transaction and may be made the subject of an indictment for conspiracy, and no action can be maintained in respect of such agreement or purchase of shares. ${ }^{1}$ And so there can be an indictment for conspiracy by false rumors to raise the price of government funds with intent to injure those who should purchase. Because a public mischief is stated as the object of this conspiracy, the conspiracy is by false rumors to raise the price of the public funds and securities, and the crime lies in the fact of conspiracy and combination to effect that purpose, and will be complete, although it be not pursued to its consequences, or the parties have not been able to carry it into effect. ${ }^{2}$ Such contract strikes at the price of a rendible commodity in the market, and if it gives it a fictitious price, by means of false rumors, it is a fraud leveled against the public, for it is agaiust all such as may possibly have anything to do with the funds on that particular day. It is a perpetration

1. Scott v. Brown (1892), 2 Q. B. 724 .
2. Rex $v$ Berenger, 3 Matule \& S. $6 \%$. 
of a fraud on the public. ${ }^{3}$ Whatever contract is contrary to positive law cannot be enforced."

§64. Libel.- In agreement contemplating a publication of a libel is illegal. Hence, no action will lie to recover compensation for printing and publishing a libelous book, or for breach of such contract, or any agreement to indemnify against liability for publishing it. ${ }^{5}$ This is so because the whole contract is tainted with illegality, and neither party is bound to perform. ${ }^{6}$

To render the contract unlawful, it should appear that there was an intention on the part of the author and publisher to write and publish libelous matter, or that the author proposed, with the knowledge and acquiescence of the publisher, to write libelous matter, or that the contract on its face provided for or promoted an illegal act; if this is not the nature of the contract then it is valid. ${ }^{7}$

If a publisher denounces a fraud, it is no libel. Thus, where a healer endearors to cure an absent patient by telepathic methods, a newspaper has a right to warn the public of such practice as a fraud, and cannot be held for damages. ${ }^{8}$

3. Materne v. Horwitz, $101 \mathrm{~N}$. Y. 469; Jerome v. Bigelow, t6 Ill. 452, 16 Am. Rep. 597.

4. Woostock Iron Co. v. Extension Co., 129 U. S. 643, 9 S. Ct. 402; McCall v. Capehart, 20 Ala. 521; Gray v. Reynolds, 65 Iowa, 461, 21 N. W. 777, $54 \mathrm{Am}$. Rep. 16; Thomas v. Caulkett, 57 Mich. 392, 24 N. IV. 154.

5. Shackell v. Rosier, 2 Bing. N. C. 634 ; Colburn v. Patmore, 1 Cromp. M. \& R. 73; Gale v. Leckie, 2 Stack. 107 ; Clay v. Yates, 1 Hurl. \& N. 73; Arnold v. Clifford, 2 Sumner, C. C. 238. See, also, Bradlaugh v. Newdegate, 11 Q. B. D. 1, 12 ; Babcock v. Terry, 97 Mass. 482.

6. Robinson v. Green, 3 Met. (Mass.) 159, 161 ; Perkins v. Cummings, 2 Gray (Mass.), 258; Wood- ruff v. Wentworth, 133 Mass. 309; Bishop v. Palmer, 146 Mass. 469, 16 N. E. 299,4 Am. St. Rep. 339; Lound v. Grimwade, 39 Ch. D. 605, 613.

7. Fletcher v. Harcat, Hutton, 55 ; Battersey's Case, Winch, 48; Betts v. Gibbins, 2 Ad. \& El. 57; Jewett Pub. Co. v. Butler, 159 Mass. 517, 34 N. E. 108, 22 L. R. A. 253; Adamson v. Jarvis, 4 Bing. 66 ; Waugh v. Morris, L. R. 8, Q. B. 202 ; Pearce v. Brooks, L. R. 1 Exch. 213; Cannan v. Bryce, 3 Barn. \& Ald. 179; Graves v. Johnson, 156 Mass. 211, 30 N. E. 818, 15 L. R. A. 834 and note, 32 Am. St. Rep. 446 and note.

8. Weltmer v. Bishop, 171 Mo. 110,71 s. W. 167. 
\$ 165 . Auction sales-By-bidding.- There is some diversity in the decisions, as to the circumstances under which by-bidding will invalidate a sale at auction. But when the sale is advertised or stated to be without reserve, the secret employment by the seller of puffers or by-bidders renders the sale voidable by the buyer. ${ }^{1}$ 'The offer at auction withont reserve is an implied guaranty that the property is to be sold to the highest bidder, and each bidder has the right to assume that all previous bids are genuine. If the buyer succeeds in proving his allegation of the seller's fraud by employing by-bidders, the seller cannot maintain his action against him, and he is entitled to recover back the deposit paid to the auctioneer. ${ }^{2}$

Any agreement entered into for the purpose of preventing competition at an auction sale is unlawful and void. ${ }^{3}$ If two or more persons in actual competition intend bidding for an acticle, agree that one shall abstain from bidding and the profits shall be divided, the courts will not enforce such a bargain."

$\S$ r66. Auction sales-English doctrine. - In England the doctrine is strongly expressed that all secret arrangements calculated to mislead and deceive purchasers or vendors are invalid, as the strict observance of good faith and fair dealing is es-

1. Phippen $v$. Stickney, 3 Met. 384; Towle v. Leavitt, 23 N. H. 360, 55 Am. Dec. 195; Veazie v. Williams, 8 How. (U. S.) I34; Thornett v. Haines, 15 Mees. \& Wel. 367; Ray v. Mackin, 100 Ill. 246; Gardner, v. Morse, 25 Me. 140; Wooten v. Hinkle, 20 Mo. 290.

2. Thornett v. Haines, 15 Mees. \& Wel. 367; Curtis v. Aspinwall, II4 Mass. 187, 19 Am. Rep. 332.

3. Goldman v. Oppenheim, 118 Ind. 95, 20 N. E. 635 ; Atcheson v. Mallon, 43 N. Y. 147, 3 Am. Rep. 678; Bresbane v. Adams, J N. Y. 129; Hunter v. P'feiffer, 108 Ind. 197, 9 N. E. 124; Smitl v. Greenlee, 2 Dev. (N. Car.) 729 ; Mc-
Minn v. Phipps, 3 Sneed (Tenn.), 196; Small v. Jones, 6 Watts \& S. (Pa.) 128, 40 Am. Dec. 546; Jones v. Fulcord, 5 Tex. 512, 55 Am. Dec. 743 ; Barton v. Benson, $126 \mathrm{~Pa}$. St. 431,17 A. 642,12 Am. St. Rep. 883.

4. Lloyd v. Malone, 23 Ill. 43, $74 \mathrm{Am}$. Dec. 179 and note; Doolin r. Ward, 6 Johns. (N. Y.) 194 ; Jenkins v. Frink, 30 Cal. 586, 89 Am. Dec. 134; Gibbs v. Smith, 115 Mass. 592; Gardiner v. Morse, 25 Me. 140 ; Baggott v. Sawyer, 25 S. Car. 405; Wooten v. Hinkle, 20 Mo. 290; Compare Galton v. Emuss, 1 Collyer, 243. 
sential to the validity of such sales. ${ }^{1}$ Hence, this doctrine applics where the owner of the cstate, that was offered for sale at auction, employed puffers to bid at the auction; as this was fraud upon the bidders, and was sufficient to avoid the sale. ${ }^{2}$ But this doctrine was questioned by some of the English decisions. $^{3}$ But the more recent cases countenance the early doctrine of the English courts. ${ }^{4}$

$\S$ r67. Stipulation not to bid. - In the American courts, there is some diversity of views upon this subject. It is held that contracts by which one party stipulates not to bid against another at an auction sale, or an agreement by one to bid for the benefit of himself and the other party, cannot be enforced in a court of law. The doctrine is based upon the ground that such a contract is nudum pactum, being without consideration, and that it is against public policy and fraud upon the vendor. ${ }^{5}$

$\S$ I68. By-bidding - When legal. - It seems that the employment of a bidder by the owner will or will not be fraud, according to the circumstances of the case, as they tend to show innocence of intention or fraudulent design. ${ }^{6}$ So by-bidding may be allowed in auction sales, if it be bona fide, and for the sole purpose of preventing a sacrifice of the property offered for sale. While the general doctrine is that a sale may be avoided when made to one in behalf of an association of bidders

1. Beckwell v. Christie, Cowp. 395. See, also, Crowder v. Austin, 2 Car. \& P. 208; Wheeler v. Collier, 1 Mood. \& Malk. 123; Fuller v. Abrahams, 3 Brod. \& Bing. 116, 6 Moore, 316 . 642.

2. Howard v. Castle, 6 Term R.

3. Connelly v. Parsons, 3 Ves. 625 ; Smith v. Clark, 12 Ves. 477.

4. Crowder v. Austin, 2 Car. \& P. 208; Wheeler v. Collier, l Mood. \& Malk. 123; Fuller v. Abrahams, 3 Brod. \& Bing. 116, 6 Moore, 316.
5. Jones v. Caswell, 3 Johns. Cas. (N. Y.) 29; Doolin v. Ward, 6 Johns. (N. Y.) 194; Wilbur v. How, 8 Johns. (N. Y.) 444; Thompson v. Davies, 13 Johns (N. Y.) 112; Piatt v. Oliver, I McLean, C. C. 295 ; Gulick v. Ward, 5 Halst. (N. J.) 87, 18 Am. Dec. 389.

6. 2 Kent's Com. 529.

7. Wolfe v. Luyster, I Hall (N. Y.), 146; Jenkins v. Hogg, 2 Cost. (S. Car.) 821. 
designed to stifle competition, yet this rule does not apply to an association of bidder's formed for honest and proper purposes. ${ }^{8}$

$\S$ I69. The purchase of property on joint account. - The mere fact that an arrangement is entered into by parties having an interest in property about to be sold at public judicial or other sale with honest motives for the purpose of preserving their interests is not invalid, though it may incidentally restrict competition upon such sale. ${ }^{1}$ Parties may unite to purchase property on their joint account when the combination is honest and bona fide. ${ }^{2}$ If the arrangement is entered into for no fraudulent purpose, but for mutual convenience of the parties, as with a view of enabling them to become purchasers, each being desirous of purchasing a part of the property offered for sale, and not an entire lot, or is induced by any other reasonable and homest purpose, such agreement will be ralid and binding. ${ }^{3}$

\section{ARTICLE II.}

\section{INSOLNENCY.}

Section 170. Assignment for Beriefit of Creditors.

171. Composition Agreenent-Insolvencs.

172. Secret Preferences.

$\S$ r70. Assignment for benefit of cređitors.-A debtor may make an assignment for the benefit of his creditors where the statute does not provide for such proceedings. The solvency of

8. Smith v. Greenlee, 2 Dev. (N. Car.) 126, 18 Am. Dec. 564; Phippen r. Stickney, 3 Met. (Mass.) 384.

1. Marie v. Garrison, $83 \mathrm{~N}$. Y. 14; Kearney v. Taylor, 15 How. (U. S.) 496; Wicker v. Hoppoch, 6 Wall. (U. S.) 529 ; Smith v. Ulman, 58 Md. 183, 42 Am. Rep. 329 ; Gibbs v. Smith, 115 Mass. 592.
2. Plippen v. Stickney, 3 Met. (Mass.) 385; Garrett v. Moss, 20 111. 54!).

3. Smull v. Jones, 1 Witts \& S. (Pa.) 128; Gibbs v. Smith, 115 Mass. 592; Jenkins v. Frink, 30 Cal. 5sti. 89 Am. Dec. 134; Switzer v. Skiles, 3 Gil. (Ill.) 529 ; Garrett v. Moss. 20 Ill. 549,44 Am. Dec. 723 . 
a debtor, in his own estimation or in fact, does not invalidate his assigmment of all or any portion of his property for the payment of his debts. But an intention to hinder or delay his creditors is fraudulent and avoids the assignment. ${ }^{1}$ Nor can insolvent debtor exercise his right of giving preferences among creditors by assignment, so as to secure himself the future control of the assigned property or of its proceeds. ${ }^{2}$ Because the reservation by the assignor of any benefit to himself, in addition to the payment of his debts, is a fraud upon his creditors, which will make the instrument void. ${ }^{3}$ And so giving preference to certain creditors, upon condition that they should accept the sums received under the assignment in satisfaction of their entire debts, is the reservation of such a benefit, and makes the assignment fraudulent. ${ }^{4}$

The fraudulent character of an assignment does not depend on the assignor's opinion that what he does is not fraud in law.

$\S$ I 7r. Composition agreement-Insolvency.-A composition agreement is an exception to the rule that payment of part of a liquidated debt is not satisfaction for the whole. It is excepted because there is a consideration to each creditor for his agreement to accept less than his claim in full payment. The composition is an agreement, not merely between the debtor and each creditor, but also between the several creditors. The engagement of each creditor to accept less than his claim is the consideration to each of the others for his engagement. So, any separate agreement by

1. Ogden v. Peters, 21 N. Y. 23, 78 Am. Dec. 122; Place v. Langworthy, 13 Wis. 629, $80 \mathrm{Am}$. Dec. 758. 68.

2. Haydock v. Coope, 53 N. Y.

3. Blacklock v. Dobie, 1 C. P. Div. 265; Grover v. Wakeman, 11 Wend. (N. Y.) 190, 25 Am. Dec. 624 and note; Young v. Hail, 6 Lea (Tenn.) 175; Knight v.
Packer, 12 N. J. Eq. 214, 72 Am. Dec. 388 .

4. Grover v. Wakeman, 11 Wend. (N. Y.) 190, 25 Am. Dec. 624 and note; Wakeman v. Grover, 4 Paige (N. Y.) 23.

5. Hubbard v. McNaughton, 43 Mich. 220, 5 N. 293, 38 Am. Rep. 176. Sec, also, Price v. Haynes, 37 Mich. 487; Smith v. Mitchell, 12 Mich. 180. 
which one of the creditor's seeures to himself benefits not conferred on the others, and which agreement is not diselosed to them before they sign the composition agreement, is a fraud upon them. Such separate agreement is void as to all the parties.

There is a class of eases which holds that even where the sceret agreement is fully performed by payment of the money, or transfer of the property stipulated, the debtor may, upon the theory of coercion exercised over him by the ereditor, recover it back from the areditor." The creditor who has entered into the secret agreenent can take no advantage from it, but he will lose the benefit of the eomposition, which becomes void. ${ }^{3}$

But courts of great influence hold that the secret agreement only is roid and that the eomposition agreement is valid, ${ }^{4}$ but they are in the minority.

\section{$\S$ r72. Secret preferences. - As has been stated a composition} agreement is an agreement, as well between the ereditors themselves as between the ereditors and their debtor, by which each agrees with the others to reeeive the sum fixed by the agreement in satisfaction of his debt; and the rule that a secret pref-

1. Howden v. Haigh, 11 Adol. \& E. 1033; Atkinson v. Denby, 7 Hurl. \& N. 933; Case v. Gerrish, 15 Pick. (Mass.) 49; Ramsdell v. Edgarton, 8 Met. (Mass.) 227, 41 Am. Dec. 503; Harvey v. Hunt, 119 Mass. 279; Fay v. Fay, 121 Mass. 561; Wiggin v. Bush, 12 Johns. (N. Y.) 305; Lawrence v. Clark, 36 N. Y. 128; Continental Bank, v. McGeoch, 92 Wis. 286, 66 N. W. 606; Newell v. Higgins, 55 Minn. 82, 56 N. W. 577; Patterson v. Boelım, 4 Pa. St. 507; Powers' Dry Goods Co. v. Harlin, 68 Minn. 193, 71 N. W. 16, 64 Am. St. Rep. 460; Lee v. Sellens, $81 \mathrm{~Pa}$. St. 473; Brown v. Nealey, 161 Mass. 1, 36 N. E. 464 .
2. Atkinson v. Denby, 7 Hurl. \& N. 933 ; Smitl v. Cuff, 6 Moore \& S. 160 ; Knight v. Hunt, 5 Bing. 429 ; Darlinger v. Earle, 82 N. Y. 393.

3. Clark v White, 12 Pet. (U. S.) 178; Mullalien v. Hodgson, 16 Q. B. 689; Cobleigh v. Pierce, 32 Vt. 78s; O'shea v. Lead Co., 42 Mo. 397, 97 Anı. Dee. 332; Kullman v. Greenebaum, 92 Cal. 403, 23 P. 674, 27 Am. St. Rep. 150; Hefter v. Cahn, 73 Ill. 296; Huckins v. Ilunt, 138 Mass. 366 .

4. Hanover Bank v. Blake, 142 N. Y. 404,37 N. E. 519,27 L. R. A. 33 and note, $40 \mathrm{Am}$. St. Rep. 607 ; Cheveront v. Textor, 53 Mid. 295. 
erence of one or more creditors over others invalidates the composition agreement does not rest solely upon the participation of the debtor in the frand and the diminution of his actual assets; but such preferenee, though made by another than the debtor, violates the principle of equity and the mutual confidence as between ereditors upon which the agreement is based. ${ }^{1}$

If the debtor knows of such seeret payments by his friends, he is not immocent of the imposition practiced upon the other creditors. $^{2}$ Because if the composition provides for a pro rata payment to all the creditors, a seeret agreement, by which a friend of the debtor undertakes to pay to one of the creditors more than his pro rata share, to induce him to unite in the composition, is as much a fraud upon the other creditors as if the agreement was directly between the debtor and such creditor. ${ }^{3}$

The creditor cannot sue for the stipulated composition if accompanied by a secret agreement by the debtor to give an additional benefit, even though the additional benefit was not afterwards available; the whole is an entire agreement, and the fraud vitiates the whole. ${ }^{4}$ The principle being, not that a party is not to be permitted to recover more than others, but that every secret bargain is a frand on the creditors and is void when it is made, and, being executory, eannot be enforced even against a fraudulent party; and where a part is fraudulent, the bargain, being an entire thing, is altogether frandulent and void. ${ }^{5}$

The debtor is a particeps criminis, and, as well as the creditor, a party to a fraud on the creditors, and he cannot be allowed to enforce this part of the same fraudulent executory agreement. ${ }^{6}$ There are cases where a particeps criminis has been al-

1. O'Shea v. Lead Co., 42 Mo. 397, 97 Am. Dec. 332; Bank v. Hoeber, 8s Mo. 37, 57 Am. Rep. 359 and note; O'Brien v. Greenebaum, 92 Cal. 104, 28 P. 214; Kullman v. Greenebaum, 92 Cal. 403, 28 P. 674, 27 Am. St. Rep. 150.

2. Kullman v. Greenebaum, 92 Cal. 403, 28 P. 674, 27 Am. St. Rep. 150 .
3. Solinger v. Earle, 82 N. Y. 393.

4. Howden r. Haigh, 11 Ad. \& El. 1033; Hanover National Bank v. Blake, 142 N. Y. 404, 37 N. E. 519,19 L. R. A. 33 and note, 40 An. St. Rep. 67 .

5. Higgins v. Pitt, 4 Excl. 372.

6. Iliggins v. Pitt, 4 Exch. 312. 
lowed to recorer back money paid as the consideration for an illegal act, where, though guilty, he is not in pari delicto; as a bankrupt who has paid money to obtain his certifieate, or a borrower, the premium of usury. ${ }^{7}$ In such cases, the law considers that he is oppressed, and advantage taken of his situation, and that he is entitled to be restored to the benefit he has lost by the oppressive act of his creditor.

7. Smith จ. Bromley, 2 Doug. $696 \mathrm{n}$. 


\section{CHAPTER VI.}

\section{Agreements in Violation of Statutes.}

\section{ARTICLE I.}

\section{Violations in General.}

Section 173. Contracts Made in Violation of Statute-Scalping Contracts.

174. Peonage Contracts.

175. Prohibition and Penalty.

176. Malum Prohibitum and Malum in Se.

177. Penalty Imposed for Administrative Purposes.

178. Acts Impliediy Prohibited.

179. What Cannot be Done by Direct Means Cannot be done by Indirect Action.

\section{$\S$ I73. Contracts made in violation of statute - Scalping} tickets. - The general rule of law is, that a contract made in violation of a statute is roid; and that when a plaintiff cannot establish his cause of action without relying upon an illegal contract, he cannot recover. ${ }^{1}$ There can be no civil right where there can be no legal remedy; and there can be no legal remedy for that which is itself illegal. ${ }^{2}$ There are some exceptions to this general rule, and these exceptions are based upon a supposed intent of the legislature. The true test is that while as a

1. Winchester Electric Light Co. v. Veal, 143 Ind. 681,42 N. E. 914 ; Penn v. Bornman, 102 Ill. 523; Wright v. Gardner, $98 \mathrm{Ky} .454,33$ S. IV. 622,35 S. IV. 116 ; Alexander v. O'Donnell, 12 Kan. 608; Leonard v. Pool, 114 N. Y. 371,21 N. E. 707, 4 L. R. A. 728, 11 Am. Rep. 667; Gunter v. Leckey, 30 Ala. 591; State v. Wilson, 113 Ind. 501, 15
N. E. 598 ; Kennedy v. Cochrane, 65 Me. 594 ; Bank v. Uwens, 2 Pet. (U. S.) 527, 539; Ryan v. Potwin, 62 Ill. App. 134; Pangburn v. Westlake, 36 Iowa, 546, 549; Harris v. Runnels, 12 How. (U. S.) 79, 84; Case v. Johnson, 91 Ind. 477.

2. Bank v. Owens, 2 Pet. (U. S.) 527. 
general rule, a penalty implies a prohibition, yet the courts will always look to the language of the statute, the subject-matter of it, the wrong or evil which it secks to remedy or prevent, and the purpose sought to be accomplished in its enactment; and if, from all these, it is manifest that it was not intended to imply a prohibition or to render the prohibited act void, the eourts will so hold, and construe the statute accorlingly. ${ }^{3}$ So, statutes prohibiting the sale of railroad and steamboat tickets except by lawfully authorized agents are constitutional. ${ }^{4}$ It is held, however, in New York, that such statutes are not constitutional. ${ }^{5}$ In the New York case the Appellate Division held that the act was constitutional. On appeal the judgment was reversed by a divided court. The court held that a duly constituted agent of one railroad company had authority to sell tickets of other carriers. It may be that the various acts of the States contain no provision susceptible of the construction upon which the majority judges of the Court of Appeals have based the conclusions.

$\S$ I74. Peonage contracts.-Peonage means a system of compulsory labor or service in discharge of contracts, debts, or obligations. The law of Congress of 1867 is violated by such compulsion. This act was aimed more especially at the condition of peonage then existing in the territory of $\mathrm{New}$ Mexico, which had derived this institution from Mexico and through

3. Pangburn v. Westlake, 36 Lowa, 546; Miller v. Anmon, 145 U. s. $421,12 \mathrm{~S}$. Ct. 884 ; Cope v. Rowlands, 2 Mees. \& Wel. 149; Arken v. Blaisdell, 41 Vt. 655 ; Lester v. Howard, 33 Md. 558, 3 Am. Rep. 211; Buekman v. Bergholtz, 37 N. J. L. 437 ; Barton v..Mruir, L. R. 6 P. C. 134.

4. Fay v. State, 63 Ind. 552; State v. Corbet, 57 Minn. 345, 59 N. W. 317,24 L. R. A. 498, 30 Am. St. Rep. 234 ; Burdick v. People, 149 Ill. 600,36 N. E. 952,24 L. R. A. 152 and note; Jannin v. State, 42
Tex. Cr. App. 631, 5 I S. IV. 1126, 62 S. IV. 419,53 L. K. A. 349,96 Am. St. Rep. S2l and note; Commonwealth v. Wilson, 14 Phil. 3S4; Railroad Co. v. McConnell (Tenn.), 82 Fed. Rep. 65; State v. Bernheim, 19 Mont. 512, 49 P. 441 ; Commonwealth v. Keary, $198 \mathrm{~Pa}$. St. 500, 48 A. 472. These statutes are known as "Ticket scalping Statutes."

5. People v. Warden, $157 \mathrm{~N}$. Y. 116,51 N. E. 1006, 43 L. R. A. 264, 68 Am. St. Rep. 763 . 
Mexico from Spain. 'The terms of this act reaches any system of this kind in the Inited States. This aet is constitutional by virtue of the thirteenth amendment; the statute applies to any ease of illewal sale, holding in imprisonment, and labor of eitizens to work out a debt or contract."

I75. Prohibition and penalty.-Before the general rule can be applied in any case of a statute prohibiting or enjoining things to be done, with a prohibition and a penalty, or a penalty only for doing a thing which it forbids, the statute must be exanined as a whole, to find out whether or not the inakers of it meant that a contract in contravention of it should be void, or that it was not to be so. It is true that a statute, containing a prohibition and a penalty, makes the act which it punishes unlawful, and the same may be implied from a penalty without a prohibition; but it does not follow that the unlawfulness of the act was meant by the legislature to avoid a contract made in contravention of it. When the statute is silent, and contains nothing from which the contrary can be properly inferred, a contract in contravention of it is void. ${ }^{1}$

If a statute prohibits a contract in the sense of making it unlawful for any one to enter into it, such a contract, if made, is wholly void, and connot be enforced. Whether a statute forbidding an act to be done, or enjoining the mode of doing it, is prohibitory, so as to make any contract in violation of it absolutely void, or whether it is directory in its purpose, and does not necessarily invalidate the contract, is a difficult question.

There is a large class of eases, both in this country and in England, in which statutes have enacted, in substance, that goods should only be sold in certain measures, or in a certain manner, or after being inspected and branded by public officers; and contracts of sale which do not meet the requirements of such statutes are void, as the intention of the legislature to make

6. The Peonage Cases, 123 Fed. Rep. 671. See, The Peonage Cases, 4 Columbia L. Review, 279; What Constitutes a Condition of Peon- age Repugnant to the Federal Constitution, 57 Cent. L. Jour. 441.

1. Harris v. Runnels, 12 How. (U. S.) 79 ; Miller v. Ammon. 145 U. S. 421,12 S. Ct. 884 . 
them roid is inferred. ${ }^{2}$ It has been held that contracts made in violation of the provisions of statutes are not void, upon the ground that the statutes are intended merely to be directory to the officers or persons to whom they are addressed, and not to the conditions precedent to the ralidity of contracts made in reference to them. Thus, the revised statutes of the United States respecting national banks provide that a bank shall not lend to any onc person, corporation, or firm a sum exceeding ome-tenth part of the capital stock actually paid in, and that national banks shall not take real estate as collateral security except for debts previonsly contracted; and it is held that contracts made in contravention of the statute are not void. ${ }^{3}$ And so where the officers of a sarings bank invest its funds in a manner forbidden by statute, such illegal action of the officers does not impair the validity of the instrument. ${ }^{4}$

Each statute must be judged as a whole, regard being had not only to its language, but to the objects and purposes for which it was enacted. If the statute does not declare a contract made in violation of it to be void, and if it is not necessary to hold the contract roid in order to accomplish the purposes of the statute, the inference is that it was intended to be directory, and not prohibitory of the contract. ${ }^{5}$ But the statute is roid if it riolates the constitutional guaranty of liberty. Thus, a statute forbidding an employer to discharge an employe because he is a member of a labor organization, is void. ${ }^{6}$

2. Miller v. Post, 1 Allen (Mass.), 434 ; Sawyer v. Smith, 109 Mass. 2:20; Kleckley v. Leyden, 63 Ga. 215: MeCommell v. Kitchens, 20 S. Cir. 430, 47 Am. Rep. 845; Doe $v$. Burnham, 31 N. H. 426; Durgin v. Dyer, 6s Me. 143; IIallett $v$. Norion, 14 Johns. (X. Y.) 273 ; Bowditch v. Ins. Co.. 141 Mass. 292, 4 N. k. 798, 55 Am. Rep. 474.

3. Gold Mining Co. v. Bank, 96 U. S. 640; National Bank r. Matthews, 98 U. \$. 621 ; National Bank v. Whitney, 103 U. S. 99; Reynolds v. Bank, 112 U. S. 405,5 S. Ct. 213.

4. Holden v. Upton, 134 Mass. 177.

5. Cope $\dot{r}$. Rowlands, 2 Mees. \& II. 149; Smith v. Mawhood, 12 Mees. \& Wel. 452; Taylor v. Gas and Coke Co., 10 Exch. 293; Ruckman v. Bergholz, 37 N. J. L. 437.

6. Zilmer v. Kreutzberg. 114 Wis. 530, 90 N. W. 1098, $5 \mathrm{~s}$ L. R. A. 748,91 Am. St. Rep. 934. 
$\S 176$. Malum prohibitum and malum in se.- It is asserted by some that there is a distinction between malum prohibitum and malum in se-between things intrinsically and morally wrong, and things which are made so merely by legislation. That is, the inference is this: When an aet is merely malum prohibitum, it may conseientionsly be done, provided only the party be willing to incur the penalty; it is optional with the party to do or to refrain from doing the act in question, and the alternative is presented him by the legislature to abstain from the act, or to do it and pay the penalty. But this reasoning is not correct.

So far as regards the effect of a statute upon a matter prohibited under a penalty, there is no distinction between mala prohibita and mala in se. ${ }^{1}$ Where the act is prohibited by the statute, the contract is void at its inception, and it is immaterial whether the act of the party was malum in se or merely malum prohibitum. $^{2}$ The distinction in some of the old cases between malum in se and malum prohibitum has long since been repudiated both in this country and in England. ${ }^{3}$ Where a contract is malum in se, thus involving moral turpitude or violating some principle of public policy, the courts will in no case interfere to relieve either party from any of its consequences. ${ }^{4}$ But where the contract is merely malum prohibitum, the court will interfere if the guilt rests chiefly upon one, although both have participated in the illegal act, as equity requires it to the more immocent party. ${ }^{5}$ The question to settle is whether the parties are in pari delicto as well as particeps criminis; if so the courts will give no relief ${ }^{6}$ if the parties are only in pari delicto the more innocent may be relieved; but neither will be relieved where they are also particeps criminis. ${ }^{7}$

1. Lewis v. Welch, $14 \mathrm{~N}$. H. 294.

2. Pucket v. Alexander, $102 \mathrm{~N}$. Car. 95,8 S. E. 767 ; Penn v. Bornman, 102 Ill. 523; White v. Buss, 3 Cush. (Mass.) 448.

3. Cannon v. Brice, 3 Barn. \& Ald. 179; Auhert v. Maze, 2 Bos. \& Pul. 371 .
4. Bank v. Owens, 2 Pet. (U. S.) 539 ; White v. Buss, 3 Cush. (Mass) 448.

5. Beusley v. Bigold, 5 Barn. \& Ald. 335 .

6. Tracy v. Talmage, 14 N. Y. 162: Irwin v. Curie, 171 N. Y. 409, 64 N. E. 161,58 L. R. A. 830.

7. Jaques v. Golightly, 2 W. Black, 1073. 


\section{$\S$ 177. Penalty imposed for administrative purposes.--}

Where the object of the law is merely to protect the revenue, and not to protect the public, the imposition of a penalty will not amount to a prohibition of the contract. The iniposition of the defined penalty shows that the legislature did not intend that the contract should be wholly void, as this would be imposing an added penalty. ${ }^{9}$ So the provisions of the internal revenue laws of the Lnited States, prohibiting persons from carrying on the business of wholesale dealers in merchandise until they pay the special tax therein provided, do not invalidate sales made by persons who fail to comply with the statute, or prevent them from recovering the price of the goods sold. ${ }^{10}$ So where a usurious contract is made, a penalty being inflicted for taking usury, the act of making such a contract is illegal, but the contract is not roid.

$\S$ I78. Acts impliedly prohibited.-It is held by some of the eases that whenerer a statute imposes a penalty for any act or omission, it impliedly prohibits it. Thus, a contract for the sale of chattels entered into in contravention of the terms and policy of the statute, cannot be enforced; and it is immaterial whether the sale is expressly prohibited or penalty imposed therefor; the imposition of a penalty in such case implies a prohibition. ${ }^{1}$ And it is held that it is not necessary that the act

8. Holman v. Johnson, Cowp. 341; Johnson v. Hudson, 11 East, 180; Brown r. Dunean, 10 Barn. \& Cr. 98; Hodgson v. Temple, 5 Taunt. 181; Wethwell v. Jones, 3 Barn. \& Ald. 221; Larned v. Andrews, 106 Mass. 435, 8 Am. Rep. 346 ; Baliey v. Harris, 12 Q. B. 905; Bisbee v. McAllen,' 39 Mim. 143, 39 N. W. 299 ; Aiken v. Blaisdell, 41 Vt. 655; Smith r. Mawhood, 14 Mees. \& Wel. 452; Compare Cope $v$. Rowlands, 2 Mees. \& W. 149; Territt v. Bartlett, 21 Vt. 184.

9. Merrill v. McIntire, 13 Gray (Mass.), 157.
10. Larned v. Andrews, 106 Mass. $43 \tilde{5}, 8$ Am. Rep. 34ti; Aiken v. Blaisdell, 41 Vt. 655; Bowditcl v. Ins. Co., 141 Mass. 292, 4 X. E. 79S, 55 Am. Rep. tit. See, also, Mandlebaum v. Gregorich, $17 \mathrm{Ner}$. 87, 2s P. 121, 45 An. Liep. 433; Rather v. Bank, 92 Pa. St. 393; Jolnnson v. Hulings, 103 l'al. St. 498, 49 Am. Rep. 131.

1. Cundell v. Dawson, 4 C. B. 376 ; Miller v. l'ost, 1 Allen (Mass.), 434; Libbey v. Downey, 5 Allen (Mass.), 299 ; Durgin v. Dyer, is Me. 143 . 
should be prohibited in express terms, but that a prohibition may be implied from the imposition of a penalty, as, it is claimed, a penalty implies a prohibition, though there are no prohibitory words in the statute. ${ }^{2}$

The weight of authority is, that a contract founded on an act prohibited by statute is void, and that it makes no difference whether the prohibition is expressed or is to be implicd from the imposition of a penalty. But whether a prohibition is to be implied from the imposition of a penalty is a question of legislative intent, to be ascertained by an examination of the various provisions of the statute in question, and where there are any terms in the statute which indicate that the legislature did not intend to avoid a contract made in contravention of it, such a contract may be enforced. ${ }^{3}$ And where the statute forbids a contract, but provides that, if made, it shall not be void, then the courts will enforce it. ${ }^{4}$ The omission of a penalty, or a failure of the penal clause, will not prevent the court from giving effect to an express prohibition $;^{5}$ therefore, the general rule that a marriage, valid where consummated, is valid everywhere, does not apply, where the parties, living in the same State, and subject to an absolute statutory provision against their marriage, on grounds of good morals and public policy, leave the State of their domicil, and enter another where their

2. Pray v. Burbank, 10 N. H. 377 ; Law v. Hodgson, 11 East, 300 ; Kileckley v. Leyden, 63 Ga. 216; Johnston v. McConnell, 65 Ga. 129; Dillon v. Allen, 46 lowa, 299, 26 Am. Rep. 145; Woods v. Armstrong, 54 Ala. 150, 25 Am. Rep. 671 and note; O'Donnell v. Sweeney, 5 Ala. 468, 39 Am. Dec. 336; Hallett v. Novion, 14 Johns. (N.Y.) 273 ; Doe v. Burnham, 31 N. H. 426 ; Cope v. Rowlands, 2 Mees. \& Wel. 149 ; Bacon v. Lee, 4 Iowa, 490; McConnell v. Kitchens, $20 \mathrm{~S}$. Car. 430, 47 Am. Rep. 845; Brown v. Duncan, 10 Barn. \& Cr. 93.
3. Harris v. Runnels, 12 How. (U. S.) 79 ; Niemeyer v. Wright, 75 Va. 239, 40 Am. Rep. 720; Penn v. Bornman, 102 Ill. 523; Hunt v. Knickerbocker, 5 Johns. (N. Y.) 327 ; Bensley v. Bignohl, 5 Barn. \& Ald. 335; Griffith v. Wells, 3 Denio (N. Y.), 226; Siedenbender v. Charles, 4 Serg. \& R. (Pa.) 150; Lewis v. Welch, 14 N. H. 294; Springfield Bank v. Merrick, 14 Mass. 322.

4. Lewis v. Bright, 4 El. \& Bl. 917.

5. Sussex Peerage Case, 11 Clark \& F. 85, 148, 149. 
tmiarriage is not prohibited, and are there married, for the express purpose of erading the laws of their own State. ${ }^{6}$

$\S$ I79. What cannot be done by direct means cannot be done by indirect action.- The law will not permit the accomplishment, by indirect means, of what it prohibits directly. ${ }^{1}$ No contract between parties to do a thing prohibited by law will be enforeed by the courts. ${ }^{2}$ When the restrictive policy of a law alone is in contemplation, it is a universal rule that it is unlawful to contract to do that which it is unlawful to do. ${ }^{3}$

6. Appeal of Morehours-Stull's Estate, 153 Pa. St. 6.5. 39 A. 16. 39 L. L. A. 589, 63 Am. St. Rep. 76 ; Brook v. Brook, II. L. Cas. 212; Williams v. Oates, 5 Ired. L. (N. Car.) 535; Penngar v. State, 87 Tem. 244, 10 S. IV. 305,2 L. R. A. 703 and note, $10 \mathrm{Am}$. St. Rep. 648; Marshall v. Marshall, 2 Hun (N. Y.), 23s; Compare Van Voorhis v. Brintnal, 86 N. Y. 18, 40 Am. Rep. 505; Putnam v. Putnam, 8 Piek. (Mass.) 433; Medway v. Needham, 16 Mass. I57, 8 Am. Dec. 131 and note.
1. Booth v. Bank, 7 Cl. \& F. 540 ; In re Macleay, L. L. 20 Eq. 186, 189; Wells v. People, 71 111. 532.

2. Dillon v. Allen, 46 Iowa, 299 , 20 Am. Rep. 145; Hathaway v. Moran, 44 Me. 67; Cook v. Phillip, 56 N. Y. 310; Cope v. Rowlands, 2 Mees. \& Wel. 149, 2 Gale, 231; Bemis v. Beeker, 1 Kans. 226 ; Edwards County v. Jennings, 89 Tex. 618, 35 S. IV. 1053.

3. Bank v. Owens, 2 Pet. (U. S.) 527. 


\section{ARTICLE II.}

\section{Violation of Sunday Laws.}

Section 180. Contracts Marle on Sunday at Common Law.

181. Constitutionality of Sunday Laws.

182. As to Interstate Commerce.

183. Prohibited Contracts.

184. Contracts not Prohibited by Statute.

185. Negotiations on Sunday-Contracts Completed on Monday. 1S6. Contracts Within the Statute.

187. Ordinary Calling.

18s. Work of Necessity.

189. Working on sunday to Prevent Loss on Week Day.

190. Works of Charity.

191. Traveling on Sunday.

192. Ratification.

193. Third Persons.

194. Contracts Dated on Sunday.

195. Executed on Sunday.

$\S$ I8o. Contracts made on Sunday at common law.- The common law made no distinction between Sunday and any other day of the week. ${ }^{1}$ The common law never considered those contracts as roid which were made on Sunday. ${ }^{2}$

The English statute ${ }^{3}$ prohibits only work of one's ordinary calling; and, hence the English cases carefully distinguish between contracts which are and are not of the "ordinary calling " of the parties. The former, if made on Sunday, are void; the latter not. So, contracts, not within the prohibition, have

1. Swann v. Swann, 21 Fed. Rep. 299 ; Said v. Stromberg, 55 Mo. App. 538.

2. Comyns v. Boyer, Cro. Eliz. 485; Rex v. Brotherton, 1 Strange, 702; King v. Whitnash, 7 Barn. \& Cr. 596; Bloxsome v. Williams, 3 Barn. \& Cr. 232; Bloom v. Richards, 2 Ohio St. 387 , 15 Am. Dec. 557; More v. Clymer,
12 Mo. App. 11; Hellams v. Abbercombie, 15 S. Car. 110, 40 Am. Rep. 684; Brown v. Browning, 15 R. I. 422, 7 A. 403, 2 Am. St. Rep. 908; Richmond v. Moore, 107 Ill. 429,47 Am. Rep. 445; Eden v. People, 161 Ill. 296,43 N. E. 1108,32 L. R. A. 659,52 Am. St. Rep. 365.

3. 29 Car. II, ch. 7 , sec. I. 
alway's been held valid in England. ${ }^{4}$ By the English decisions, such contracts, when not within the pohilition of the statute, are not deened rontra bonos mores, "r in any other way invalid.

The English statute has been generally followed in this country, prohiliting work of me's ordinary calling on Sunday. But the observance of this day is not requirerl from all citizens. Believers in the Sabbatarian faith and the Jews are allowed to labor in their respective rocations on Sunday, and in ecrtain places to open stores and earry on mechanical trades. ${ }^{6}$

$\S$ I8I. Constitutionality of Sunday laws.--Sunday laws are constitutional. It is not the object of such laws to compel the observance of Sunday, as a religious institution, because it is the Christian Sahbath, to be kept holy under the ordinances of the Christian religion; if it was, it would violate the provisions of the Federal and the State Constitutions. It would then violate equally the religious liberty of the Christian, the Jew and the infictel, none of whom can be compelled by law to comply with any merely religious observance, whether it accords with his faith and conscience or not. Such is the general doctrine of the courts. ${ }^{1}$

The laws make no reference to Sunday as a religious day, and the exceptions generally made to the general prohibition

4. Drury v. Defontaine, 1 Taunt. 131; King v. Whitmash, 7 Barn. \& Cr. 794; Fennell v. Ridder, 5 Barn. \& Cr. fot; hex v. Brotherton, 1 strange, 70:2.

5. 29 Car. II, eh. 7, sec. 1.

6. Martin v. Goldstein, $39 \mathrm{~N}$. I. S. 254 ; Judefind v. State, 78 Ml. j]0, „๖ A. $40 j, 22$ L. R. A. 721 and note.

1. State v. Powell, j8 Ohio St. 324,50 N. E. 900,41 L. R. A. 854; Judefind v. State, $7 \mathrm{~S}$ Md. 510 , $2 S$ A. 405,22 L. R. A. 721 and note; State v. Bott, 3 La. Ann. 663; State v. Baum, 33 La. Ann. 985; Corporation v. Minden, 36 La. Ann.
913; State v. Judge, 39 La. Ann. 132, I So. 43\%; State v. Oliourk, 35 Nelr. 614, 53 N. W. 591, 17 L. R. A. 830 and note; State v. Fernandez, 39 La. Ann. 53s, 2- So. 233; Commonwealth v. Has, $1: 2$ liass. 40; Commonwealth v. specht, 8 Pa. St. 312, 49 Am. Dec. 5ls; Commonwealth $v$. Nesbrt, 34 Pa. St. 39s; HIudson v. Geary, 4 R. I. 485 ; State v. Railroad Co., $15 \mathrm{IV}$. Va. 362, 36 Am. Rep. S03; Charleston v. Benjamin, 2 Strob. (S. Car.) 50S, 49 Am. Dec. 605 and note; Johns $r$ state, 78 Ind. 332, 41 Am. Kep. 577 and note; Bold v. Slate, 3 Tex. App. 683. 
show that they are not designed to enforce the Christian idea of the Sabbath, or to apply the rules of any religions sect to the observance of Smday. Such statutes are to be judged precisely as if they had selected for a day of rest any day of the week other tham Sunday. And the validity of the statute is not to be questioned becanse, in the exercise of a wise discretion, it has chosen that day which the majority of the citizens of the State, under the sanction of their religious faith, already observe as a day of rest. ${ }^{2}$

It is essentially a civil regulation, providing for a fixed period of rest in the business, the ordinary vocations and the amusements of the people. Some one day must be seleeted for that purpose, and even if the day thus selected is chosen becanse a great majority of the people celebrate it as of peenliar sanetity, the legislative authority to provide for its observance is derived from its general authority to regulate the business of the commmity and to provide for its moral and physical welfare. The act imposes upon no one any religious ceremony or attendance upon any form of worship, and any one who deems another day more suitable for rest or worship, may devote that day to the religious observance which he deems suitable or appropriate. That one who conseientiously observes the seventh day of the week may also be compelled to abstain from business of the kind expressly forlidden on Sunday; this is not oceasioned by any subordination of his religion, but because as a member of the community he must submit to the rules which are made by lawful authority to regulate and govern the business of the people. ${ }^{3}$ Under this view, Sunday laws do not conflict with constitutional law.

2. State v. Judge, 39 La. Ann. 132, 1 So. 437.

3. Frolickstein v. Mobile, 40 Ala. 725; Gabel v. Houston, 29 Tex. 33.; Scales v. State, 47 Ark. 476, 1 S. W. 769, 58 Am. Rep. 768 and note; Bloom v. Richards, 2 Ohio St. 387; Specht v. Commonwealth, 8 Pa. St. 312, 49 Am. Dec. 518; Commonwealth v. Has, 122
Mass. 40; Ex parte Andrews, 18 Cal. 678; Ex parte Newman, 9 Cal. 502; State v. Railroad Co., 24 IV. Va. 783, 49 Am. Rep. 290; State v. Ambs, 20 Mo. 214; Mayor v. Linck, 12 Lea (Tenn.), 499; Hennington v. State, $90 \mathrm{Ga}$. 396, 17 S. E. 1009,163 U. S. 299,16 S. Ct. 1086. See Sunday Laws-3 Canadian L. Review, 77, 215. 
\$ I82. As to inierstate commerce.- I statute making it nnlawful to run freight trains on Sunday is not in conflict with the United States Coustitution, and is not directed against interstate commerce. Such statute places the business of transporting freight in the same category as all other secular business. Such a law, although in a limited degree affecting interstate commerce, is not for that reason a needless intrusion upon the domain of Federal juriscliction, nor strictly a reculation of interstate commeree, but considered in its own nature is an ordinary police regulation designed to seenre the well-being and to promote the general welfare of the people within the State by which it was established and, therefore, not invalid by force alone of the constitution of the United States. ${ }^{1}$ Lottery tickets are subject of traffic, and, therefore, of commerce, and the regulation of the carriage of such tickets, at least by independent carliers, is a regulation of commerce among the several States, and lience Congress may prohibit the carriage of such tickets from State to State. The power of Congress to regulate interstate commeree comprises the right to enact a law prohibiting the citizen from entering into such private contracts which directly and substantially, and not merely indirectly, or remotely, regulate to a greater or less degree the commerce among the States. Hence, Congress may prohibit the carriage of lottery tickets from one State to another where they are to be sold. ${ }^{2}$ This rule does not curtail one's liberty as recognized by the supreme laws of the land, because he should not be allowed to introduce into commerce among the States an element that will confessedly be injurious to public morals. The liberty protected by the Constitution embraces the right to be free in the enjoyment of one's faculties, and to enter into all contracts that may be proper. ${ }^{3}$

Lottery companies are not engaged in interstate commerce, and are, therefore, subject to control by the State; lottery tick-

1. Hennington v. Georgia, $163321,23 \mathrm{~S}$. Ct. 321 , 26 Nat. Cor. U. S. 299,16 S. Ct. 1086 . Rep. 76.

2. Champion v. Ames, 158 U. S. 3. Allgeyer v. Louisiana, 165 U. S. $57 \mathrm{~s}, 17$ S. Ct. 427 . 
ets when sent beyond the State are subjects of interstate commerce and, therefore, within the control of commerce. And transportation for others as an independent business, is commerce, irrespective of the purpose to sell or retain the goods which the owner may entertain. ${ }^{4}$ Yet a party who merely ships goods subject to interstate commerce does not thereby necessarily become engaged in interstate commerce. ${ }^{5}$ But an agent, engaged in soliciting, not selling, passage on an interstate road in another State, is engaged in interstate commerce. ${ }^{6}$ Cab service contracted for by railroad companies in transporting passengers from one station to another, may not be interstate commerce. If the cab service is separately contracted for, though the commerce clanse would cover the entire journey where there is one through contract, yet where there are separate contracts, some to be performed entirely within the State and some involving the crossing of State lines, this clause extends only to the latter. So where the Pennsylvania railroad had established a cab service in New York City for the sole use of passengers in getting to and from its ferry station before or after its passage across New Jersey line, this service was not interstate commerce. ${ }^{7}$ But such service could be included in interstate commerce by selling through tickets, with a coupon to special points within New York City, making the cab service a part of one through contract. Of course, a party is not an interstate passenger merely because he has a through ticket, for it is necessary, to accomplish this, that he engages in one through trip. Thus, a passenger having a ticket from St. Louis to Chicago, who exercises a privilege of stopping off at Bloomington, could not be said to be an interstate passenger when subsequently resuming his journey between Bloomington and Chicago. But the mere fact of a change of vehicle will not prevent a cab service between stations from being within the

4. Hanley v. Kansas City, etc. R. R., 187 U. S. 67,23 S. Ct. 314.

5. Kidd v. Pearson, 128 U. S. 1, 9 S. Ct. 6.
6. McCall v. California, $136 \mathrm{U}$. S. 104, 10 S. Ct. 881 .

7. New York ex rel. Pennsylvania R. R. Co. v. Knox, 192 U. S. 21. 
term of interstate commeres. But where there are several contracts, some to be performed within the State and others without, the interstate commerce clause extends only to those extending across State lines. ${ }^{9}$

\$ 183. Prohibited contracts. - The doctrine that contracts niade on Sunday are roid depends alone upon statutory enactments, but the statutes vary in the scveral States. Where the statute expressly prohibits the execution of contracts on Sumday, all contracts made on that day are absolutely roid, and incapable of ratification, any dealings between the parties upon the basis of such contracts will, so far as completed, be treater as the voluntary acts of the partics which cannot be disturbed, and so far as not completed, must be dealt with as if no contract had erer been made. ${ }^{10}$

$\S$ I 84 . Contracts not prohibited by statute.-While contracts growing out of the violation of statutes are void and will not be enforced by the courts, other business contracts are left as at common law, and as the common law makes no distinction between Sunday and any other day, as to the making of contracts, and all other acts, not of a judicial nature, contracts other than those prohibited by statute are valid though made on Sunday. ${ }^{11}$

8. Rhodes v. Iowa, 170 U. S. Merriam v. Stearns, 10 Cush. 412, 18 S. Ct. 664 .

9. New York ex rel. Pennsylvania R. R. Co. r. Knox, 192 U. S. 21.

10. Gennett v. Wuestner, $53 \mathrm{~N}$. J. Eq. 302, 31 A. 609 ; Burns v. Moore, 76 Ala. 339, 52 Am. Rep. 332 ; Watts v. Van Ness, 1 Hill (N. Y.), 76 Calhoun v. Phillips, 87 Ga. 482, 13 S. E. 593 ; Barnhard v. Lupping, 32 Mo. 341 : Pike v. King, 16 Iowa, 49; Clough v Goggins, 40 Iowa, 325; Love v. Wells, 25 Ind 503, $87 \mathrm{Am}$. Dec. 375; Pattee v. Greely, 13 Met. (Mass.) 284;

(Mass.) 25i; Slade v. Arnold, 14 B. Mon. (Ky.) 287; Morgan v. Bailey, 59 Ga. 683; Towle v. Larrabee, 26 Me. 464; Lyon v. Strong, 6 Vt. 219; Smith v. Railroad Co., 83 Wis. 271,50 N. W. 497,53 N. IV. 555 ; Nibert v. Baghurst, 47 N. J. Eq. 201, 20 A. 252; Whitmore v. Montgomery, $165 \mathrm{~Pa}$. St. 253. 30 A. 1016 .

11. Roberts v. Barnes, 127 Mo. 405, 30 S. W. 113, 4s Am. St. Rep. 640; Kaufman r. IIamm, 30 Mo. 387; More v. Clymer, 12 Mo. App. 11; Glover v. Cheatham, 19 Mo. 
The estalnlished doctrine is that the law will not lend its aid to enforce a contract made in violation of a statute, nor set aside such a contract when it has been fully executed by the parties. ${ }^{12}$ 'The entering of judgument ly eonfession on a judgment note does not make the contract to pay, of which the note is evidence, an executed contract. The agreement for entering judgment only is executed. ${ }^{13}$

\section{$\S$ I85. Negotiations on Sunday-Contracts completed on} Monday.-A contract may be good though the negotiations were had on Sundas, but was completed on Monday. Hence, a policy of insurance dated and delivered on Monday is not a Sunday contract, although the property was examined on Sunday and the terms established. ${ }^{1}$

The date of a written contract within the meaning of the statutes is not necessarily the day of its delivery. It can have no efficiency or binding force until the act of delivery is performed, and if not delivered until Monday or other secular day, it is valid. ${ }^{2}$

So a note and trust deed executed on Sunday but not delivered until Monday are valid. ${ }^{3}$ So a promissory note executed

App. 650; Bloom v. Richards, 2 Ohio st. 387; Boynton v. Page, 13 Wend. (N. Y.) 425; Johnson v. Brown, 13 Kans. 529; Horacek v. Keebler, 5 Nebr. 355; Hellams v. Abbercombie, 15 S. Car. 110, 40 Am. Rep. 684; Moore v. Murdock, 26 Cal. 514.

12. Whitmire v. Montgomery, 165 Pa. St. 253, 30 A. 1016.

13. Whitmire v. Montgomery, 165 Pa. St. 253, 30 A. 1016.

1. Wooliver v. Ins. Co., 104 Mich. 132, 62 N. IV. 162. Sce, also, Lovejoy v. Whipple, is Vt. 379, 46 Am. Dee. 157; King v. Fleming, 72 11l. 21, 22 Am. Rep. 131; Fritsch v. Heislem, 40 Mo. 556; Evert v. Kleimenhagen, 6 S. Dak. 221, 60
N. W. 851; Taylor v. Young, 61 . Wis. 314, 21 N. 408; Tyler v. Waddington, 58 Conn. 375, 20 A. 335; Melinues $v$. Estes, 81 lowa, 749, 46 N. W. 987; Bradley v. Rea, 103 Mass. 188, 4 Am. Rep. 524; Bryan v. Booze, 55 Ga. 438; Gibbs, etc. Manuf. Co. v. Brucker, 111 U. S. 597,4 S. Ct. 572 .

2. King v. Fleming, 72 Ill. 21, 22 Am. Rep. 131; Butler v. Lee, 11 Ala. 885, $46 \mathrm{Am}$. Dee. 250; Clough v. Davis, 9 N. H. 500 ; Burns v. Moore, 76 Ala. 339, 52 Am. Rep. 332 ; Uhler v. Applegate, $26 \mathrm{~Pa}$. St. 140: Stackpole v. Symonds, $23 \mathrm{~N}$. H. 229; Mosely v. Vanhooser, 6 lea (Tenm.), 286, 40 Am. Rep. 37. 3. Roberts v. Barnes, 127 Mo. 
on Sunday is not on that account void, ${ }^{4}$ provided it is delivered on Monday." And a sale of goods negotiated on Sunday, hut delivered on a seenlar day is ralid, ${ }^{6}$ but if delivered on Sunday and the price paid on the following Monday, the sale is roid. ${ }^{7}$ And a Sundiy anthorization to deliver a contract made on that day, on the following Monday, is void." But in Michigan the mere delivery of a note executed on a secular day does not avoid the note. ${ }^{9}$

$\$$ I86. Contracts within the statute - Return of consideration.- A contract which requires the doing of an act prohibited by law is void. There is a difference in the decisions on the question whether a contract, void merely because it was made on Sunday, may be ratified on a secular day, so as to become valid; but there is no conflict of decisions on the proposition that a contract, void because it stipulates for doing what the law prohibits, is incapable of being ratified. Thus, in Minnesota, the issuing, publishing, and circulating a newspaper on Sunday is unlawful. ${ }^{2}$

When the contract is void because made on Sunday, the payment of money or the performance of any service cannot be enforced as between the parties. Hence, the endorsement as well as making and delivery of a promissory note, is an act within the statute prohibiting secular business on Sunday. ${ }^{2}$ An en-

405, 30 S. IV. 113, 48 Am. St. Rep.

640; Kaufman v. Hamm, 30 Mo.

387. See, also, Foster v. Wooten, 67 Miss. 540, 7 So. 501 ; Compare Hanchett v. Jordan, 43 Minn. 149, $45 \mathrm{~N} . \mathrm{IV} .61 \%$.

4. More v. Clymer, 12 Mo. App. 11 ; Glover v. Cheatham, 19 Mo. App. 656 .

5. Beman v. Wessels, 53 Mich. 549,19 N. 179; Wilson v. Winter, 6 Fed. Rep. 16; Bell v. Mahin, 69 Iowa, 408, 29 N. IV. 331 ; Schwab v. Rigby, 38 Minn. 395, 38 N. W. 101: Hill v. Dunham, 7 Gray
(Mass.), 543; Hilton v. Hougliton, 35 Me. 143; Lovejoy v. Whipple, Is Vt. 379, $46 \mathrm{Am}$. Dec. 157.

6. Barks v. Werts, 13 Ind. 203.

7. Grant v. McGrath, 56 Conn. 333,15 A. 370 .

8. Davis v. Barger, 57 Ind. 54.

9. Steere v. Trebilcock, 108 Mich. 464, 66 N. IV. 342.

1. Hand v. Pub. Co., 41 Minn. ISS, 42 N. W. S72. See, also, Smith v. Wilcox, 24 N. Y. 353,82 Anr. Dec. 302.

2. Benson v. Drake, 55 Me. 555. 
dorsement creates a new contract; it affects the liability of the maker as well as the contract to which it is subsidiary. ${ }^{3} \mathrm{~A}$ notice to a tenant that after the expiration of his existing contract, he will be charged an increase of rent, is of no avail, if such notice is given on Sunday, and the tenant simply remains in possession after his term, because this does not raise any contract to pay such increased rent. ${ }^{4}$ In Missouri athletic sports are not prohibited. ${ }^{5}$

A bond void because executed on Sunday may still be used in evidence as an admission of liability. ${ }^{6}$ And so an acknowledgment or new promise made on Sunday may be used in evidence for the purpose of removing the bar of the statute of limitations. ${ }^{7}$

Selling tickets to theatre for performance, on Sunday, is laboring on Sunday and is prohibited. ${ }^{8}$ In Maine a party rescinding Sunday contract must return consideration. ${ }^{9}$

$\S 187$. Ordinary calling.-In some of the States the statute prohibits persons from doing any work, business, or labor "of his ordinary calling." Under this statute a party may contract to labor or do work not in his ordinary calling, and the contract will be valid. ${ }^{10}$ And so making a mortgage may be outside of the party's ordinary calling, ${ }^{11}$ or a promissory note. ${ }^{12}$ Such statutes do

3. First Nat. Bank v. Kingsley, 84 Me. 111,24 A. 794.

4. Cannon v. Ryan, 49 N. J. Eq. 314, 23 A. 285.

5. St. Louis Agricultural, etc. Asso. v. Delano, 108 Mo. 217, 18 S. W. 101 .

6. Lea v. Hopkins, 7 Pa. St. 492.

7. Thomas v. Hunter, 29 Md. 406 ; Compare Baumgardner v. Taylor, 28 Ala. 687.

8. Quarles v. State, 55 Ark. 10, 17 S. W. 269, 14 L. R. A. 192 and note.

9. Berry v. Clary, 77 Me. 482, l A. 360; Wentworth v. Woodside, 79 Me. 156, 8 A. 763 ; First Nat.
Bank v. Kingsley, 84 Me. 111, 24 A. 794; Wheelden v. Lyford, 84 Мe. 114, 24 A. 793.

10. Drury v. Defountaine, I Taunt. 131; Merritt v. Earle, 31 Barb. (N. Y.) 38; Moore v. Murdock, 26 Cal. 514; Mills v. Williams, 16 S. Car. 593; Kaufman v. Hamm, 30 Mo. 387; Allen v. Gardiner, 7 R. I. 22; Ames v. Kyle, 2 Yerg. (Tenn.) 31, 24 Am. Dec. 463 .

11. Hellams v. Abbercrombie, 15 S. Car. 110, 40 Am. Rep. 684.

12. Sanders v. Johnson, 29 Ga. 526. 
not apply to all persons, but to such only as have some ordinary calling; but every species of labor, hminess, or work, whether public or private, in the ordinary calling of a tradesnan, artifieer, workman, laborer, or other person, is within the prohibition of the statute. And so al release by a creditor to an as-igner. under a voluntary assignment, and delivered on Sunday is not void, not being labor, business, or work of the ordinary calling of either of the parties to it. ${ }^{14}$ Where the statute prohibits the exposure of merchandise for sale on Sumday, it extends to public sales only, and not to private sales. ${ }^{15}$ If the statute requires business liouses to be closed on Sunday, the command must be obeyed. ${ }^{16}$

$\S \mathrm{r} 88$. Work of necessity.- The word necessity as used in the various statutes, is not susceptible of an accurate and entirely comprehensive definition. Each case must be decided according to the ciremustances, and it is, therefore, more a question of fact than of law whether the labor done in a particular case is to be deemed of necessity or not. An absolute and physieal necessity is not meant or required. ${ }^{1}$ Work, to prevent a great waste of property, has always been held to be within the exception of such statutes. The necessity for the work to be done must be real and urgent, and must not have been the result of negligence or indolence on the part of the person doing the labor. ${ }^{2}$ Works of necessity are not limited to the preservation of life, health, or property from impending danger. The neeessity may grow out of, or be incident to, the general course of business, or even be an exigency of a particular trade or business, and ret be within the exemption of the statute. Hence, the danger of navigation being closed may make it lawful to load a ves-

13. Smith v. Sparrow, 4 Bing. 84 ; Bloxsome v. Williams, 3 Barn. \& Cr. 232.

14. Allen v. Gardiner, 7 R. I. 22.

15. Boynton v. Page, 13 Wend. (N. Y.) 425; Batsford v. Every, 44 Barb. (N. Y.) 618 .
16. State $v$. Gelpi, 48 La. Amm. 520,19 So. 755 .

1. Johnson v. People. 42 П1l. App. 594: Shipley v. State, 61 Ark. 216, 32 S. W. 459,33 S. W. 107.

2. Parmalee v. Wilks, 22 Barb. (N. Y.) 539; Whitcomb v. Gilman, 35 Vt. 297. 
sel on Sunday, if there is no other time to do so. ${ }^{3}$ The sailing of vessels engaged in commerce, and even their lading and unlading, are classed among works of necessity which are excepted from the operation of such statute. And this is confirmed by the usage of all nations, so far at least as it concerns commencing a royage on Sunday. ${ }^{4}$ And running passenger trains is a work of necessity $;^{5}$ and so is running excursion trains. ${ }^{6}$ But it is said that running a freight train is not a work of necessity, ${ }^{7}$ however, this may be doubted. ${ }^{8}$

Under some of the statutes the work of a barber is a necessity. ${ }^{9}$ The following are works of necessity: Repairing defects in a highway $;^{10}$ reaping a field of grain $;^{11}$ shoeing horse used in carrying mail ${ }^{12}$ telegram from husband to wife explaining his absence $;^{13}$ telegram informing child of his father's death $;^{14}$ telegram to physician $;^{15}$ repairing railroad tracks, ${ }^{16}$ giving a bail bond $;^{17}$ contract of indemnity from an absconding debtor $;^{18}$ and whatever must be done to preserve life and health. ${ }^{19}$

3. McGatrick v. Wasson, 4 Ohio St. 566 .

4. Philadelphia, etc. R. R. Co. v. Tow Boat Co., 23 How. (U. S.) 209.

5. Commonwealth v. Railroad Co., $80 \mathrm{Ky}$. 291, 44 Am. Rep. 475.

6. Louisville, etc. R. R. Co. v. Commonwealth, 30 S. W. 878,17 Ky. L. J. 223.

7. Heard v. State, $92 \mathrm{Ga} .477,17$ S. E. 857 .

8. Philadelphia, etc. R. R. Co. v. Lehman, $56 \mathrm{Md} .209$.

9. State v. Krech, 10 Wash. 166, 38 P. 1001; People v. Havnor, 149 N. Y. 195,43 N. E. 541,31 I. R. A. $689,52 \mathrm{Am}$. St. Rep. 707 ; Ungericht v. State, 119 Ind. 379; 21 N. E. 1082; Stone v. Graves, 145 Mass. 353, 13 N. E. 906, 12 Am. St. Rep. 419; Compare Phillips v. Innis, 4 Cl. \& F. 234; Eden v. People, 161 Ill. 296, 43 N. E. 1108 ,
32 L. R. A. 659, 52 Am. St. Rep. 365 .

10. Flagg v. Inhabitants, 4 Cush. (Mass.) 243.

11. Johnson v. People, 42 Ill. App. 594.

12. Nelson v. State, 25 Tex. App. 599, 8 S. W. 927.

13. Burnett v. Telegraph Co., 39 Mo. App. 599.

14. Western Union Telegraph Co. v. Wilson, 93 Ala. 32 , 9 So. 414 , 70 Am. Rep. 523.

15. Western Union Tel. Co. v. Griffin, 1 Ind. App. 46, 27 N. E. 113.

16. Yonoski v. State, 79 Ind. 393, 41 Am. Rep. 614.

17. Hammons v. State, 59 Ala. 164, 31 Am. Rep. 13 and note.

18. Hooper v. Edwards, 18 Ala. 280.

19. Aldrich v. Blackstone, 128 Mass. 148; Smith v. Watson, 14 Vt. 332 ; Stewart v. Davis, 31 Ark. 
But a telegram respecting ordinary business is not a work of charity $;^{20}$ sale of tobacco is not a necessity $;^{21}$ nor gathering seaweed. ${ }^{22}$

In Illinois, ${ }^{23}$ Missouri, ${ }^{24}$ and California ${ }^{25}$ the law is held unconstitutional which makes it unlawful for barbers to do business on Sunday. But in New York such law is upheld as a police power. ${ }^{26}$

\section{$\S$ I89. Working on Sunday to prevent loss on week day.-} Doing work on Sunday in order to prevent loss on a week day, is not a work of necessity. Thus, the clearing out of a wheel-pit on Sunday, for the purpose of preventing the stoppage on a week day, of mills which employ many hands, is not a work of necessity or charity. ${ }^{27}$ Where the only reason for doing the work on Sunday, is because the party is doing a large business, employing many hands, and the work would obviate the necessity of stopping the machinery on a week day, the statutory prohibition is violated and it is not a work of necessity. ${ }^{28}$ This does not make it a work of necessity or charity. ${ }^{29}$

518, 25 Am. Rep. 576; Philadelphia, etc., R. R. Co. v. Lehman, 56 Md. 209, 226, 40 Am. Rep. 415 and note.

20. Western Union Tel. Co. v. Yopst, 118 Ind. 48, 20 N. E. 222, 3 L. R. A. 224 and note.

21. State v. Ohmer, 34 Mo. App. 115.

22. Commonwealth v. Sampson, 97 Mass. 407 .

23. Eden v. People, 161 11l. 296, 43 N. E. 1108,32 L. R. A. 659,52 Am. St. Rep. 365 .

24. State v. Grameman, 132 Mo. 326, 33 S. IV. 784 .

25. Ex parte Jentzsch, $112 \mathrm{Cal}$. 468, 44 P. 803, 32 L. I. A. 664.

26. People v. Havnor, 149 N. Y. 195,43 N. E. 541,31 L. R. A. 689 , 52 Am. St. Rep. 707. S'ee. also, People v. Butting, 35 N. Y. Supp.
19 ; State v. Krech, 10 Wash. 166, 38 P. 1001; Hugerecht c. State, 119 Ind. 379,21 N. E. I082, 12 Am. St. Rep. 419 ; Stone v. Graves, 145 Mass. 353,13 N. E. 906.

27. McGrath v. Merwin, 112 Mass. 467, 17 Am. Rep. 119. S'ee, also, Commonwealth v. Sampson, 97 Mass. 407; Commonwealtl v. Josselyn, 97 Mass. 411; Hamilton v. Austin, 62 N. H. 575, 13 Am. St. Rep. 607; Compare Hennersdorf v. State, 25 Tex. App. 597, s S. IV. 926.

28. Williams $v$. Hastings, $58 \mathrm{~N}$. H. 373; Hamilton v. Austin, $62 \mathrm{~N}$. H. 575 .

29. Commonwealth v. Sampson, 97 Mass. 407; Commonwealth v. Josselyn, 97 Mass. 41I; McGrath v. Merwin, 112 Mass. 467, 17 Am. Rep. 119. 
$\$$ rgo. Works of charity.- If work is done in the canse of charity it comes within the exception. ${ }^{30}$ Thus, the subseription to al church made on Sunday to liquidate the indebtedness on a church contracted in the erection of a building to be used as a place of worship is not labor, but is a work of charity, and is valid and binding. ${ }^{31}$ 'The purpose for which it was taken falls within the definition placed upon the word charity by the courts. $^{32}$

$\S$ I9r. Traveling on Sunday.-- Some statutes prohibit travel on Sunday, except for necessity or charity. But all traveling on Sunday is not unlawful. One may lawfully travel on Sunday for exereise in the open air. ${ }^{33}$ So one may go after a domestic and bring her home on Sunday, as such is a work of necessity. ${ }^{34}$ Hiring a carriage on Sunday is illegal $;^{35}$ but traveling on Sunday may be justified on the ground of necessity or as a deed of charity. ${ }^{36}$ This subject does not come directly under contracts and cannot be further treated.

$\S$ I92. Ratification.- Many courts hold that a contract void because made on Sunday, may be ratified on a secular day; that contracts on Sunday are distinguished from other illegal contracts to secure an immoral end, or for an immoral consideration,--being illegal only as to time, not tainted with any general corluption, they may be affirmed afterwards. If the party seeking redress has received anything he must restore it. If he declines restitution or compensation, this affirms the contract. ${ }^{1}$

30. Stewart v. Davis, 31 Ark. 518 , 25 Am. Rep. 570.

31. Bryan v. Watson, 127 Ind. 42, 26 N. E. 637, 11 L. R. A. 63.

32. Doyle v. Lynn, 118 Mass. 195. 19 Am. Rep. 431; Allen v. Duffie, 43 Mich. 1, 4 N. 427, 38 Am. Rep. 159 and note; Dale v. Knepp, 98 Pa. St. 389, 42 Am. Rep. 624. 34 .
34. Crosman v. Lynn, 121 Mass. 301.

35. Tillock v. Webb, 56 Me. 100 ; Compare Buck v. Biddeford, 82 Me. 433, 19 A. 912.

36. Buck v. Biddeford, 82 Me. 433, 19 A. 912. See, also, Horton v. Tramway Co., 66 Conn. 272, 33 A. 914.

1. Adams v. Gay, 19 Vt. 358; Sargeant v. Butts, 21 Vt. 99; Sum- 
But the better rule is that a contract made on Sunday in riolation of a statute is absolutely void, and no subsequent ratification will sustain an action upon it. ${ }^{2}$ Such a contract has no legal force or obligation. This illegal contract eannot be ratified, beeause its want of validity does not depend in any degree upon the party's choice. The law annuls it, and there can be no subject of ratification. The party might make a new contract; but any arrangement or agreement between the parties on any secular day, whether direct or express, or implied from their dealings with each other's property, wonld be a new and independent trimsaction. It is not accurate to speak of ratification by a party of something which the law forbids, and which is made void, not from any want of his full consent, but in spite of it. $^{3}$ Ratification is to impart validity to an original agreement. Such act creates no new obligation; it merely extends the continuance of, or legalizes, one already in existence. The maxim of the law is: "Omnis ratihabitio retro trahitur, et mandato priori aequiparatur" - - every subsequent ratification has a retrospective effect, and is equivalent to a prior command. Henee, there can be no such thing in law, strictly speaking, as a

ner v. Jones, 24 Vt. 317; Banks v. Werts, 13 Ind. 203; Sayles v. IVellman, 10 R. I. 46.5; Haacke v. Literary Club, 76 Md. 429, 25 A. 422; Hopkins v. Stefan, 77 Wis. 45,45 N. IV. 676 ; Evansville v. Morris, 87 Ind. $269,14 \mathrm{Am}$. Rep. 763: Kulns v. Gates, 92 Ind. 66; Halrison v. Colton, 31 lowa, 16; 'lucker v. West, 29 Ark. 356; Smith v. Case, 2 Oreg. 190; Wilsom v. Milligan, 75 Mo. 41; Russe!l v. Murdock, 79 lowa, 101, 44 N. W. 237, 18 Am. St. Rep. 348 ; Melchoir v. MeCarty, 31 Wis. 256, 11 Am. Rep. 605; Campbell v. Young. 9 Bush. (Ky.), 245; Van lloven v. Irish, 10 Fed. Rep. 13.

2. Day v. MeAllister, 15 Gray (Mass.), 433: Fim v. Donahue, 35 Conn. 216; Pope v. Linn. 50 Me. 83; Ladd $v$. Rogers, 11 Nlen
(Mass.), 209; Bradley v. Rea, 14 Allen (Mass.), 20; Meriwether $v$. Smith, 44 Ga. 541; Butler v. Lee, 11 Ala. 885, 46 Am. Dee. 230; Ramey v. Capps, 22 Ala. 288; Allen v. Deming, 14 N. H. 133, 40 Am. Dec. 170 ; Wintield v. Dodge, 45 Mich. 355, 7 N. 966, 40 Am. Rep. 476; Grant v. McGrath, 56 Conn. 333, 15 A. 370; Plaisted v. Palmer, 63 Me. 576 ; Kountz v. Price, 40 Miss. 341 ; Compare Winchell v. Carey, 115 Mass. 560, 15 An. Rep. 1.51 ; Gennert v. Wuestner, 53 N.J. Fq. 302,31 A. 609; Nibert v. Boghurst, 47 N. J. Eq. 201,20 A. 25:2; Ryno v. Darby, 20 N. J. Eq. 231; Reeves v. Butcher, 31 N. J. L. 225; Cannon v. liyan, 49 N. J. L. 314,8 1. 293.

3. Stebbins $v$ Peck, 8 Gray (Mass.), 553. 
ratification of a transaction which, at the time of its performance, was prohibited by statute. The parties cannot legalize that which the law has declared illegal. It is competent to them to impart a new efficacy to a voidable act, but they have no power to give life to an act which, from reasons of public policy, has been ordained by the legislature, to be absolutely void. ${ }^{4}$ But a new contract, express or implied, may be made on the same subject, as though nothing had been done on Sunday. ${ }^{5}$

§ 193. Third persons.- Dating of a contract on a week day, when it is really executed on Sunday, does not render it valid. But, in favor of an innocent party, an indorsee, assignee, or other innocent party, if he bona fide and for a valuable consideration acquires his interest on a week day, the contract will be good. So a maker of a note executed on Sunday has no equity existing as to a payee or bona fide assignee after maturity. It is only against the person in equal fault that the maker can be allowed to allege his own turpitude. ${ }^{1}$

There is no reason why a note should be avoided in the hands of the payee, who was not aware of its invalidity, and has not himself participated in any violation of the statute prohibiting labor and business on Sunday. ${ }^{2}$ So an innocent indorsee is not affected by the circumstance of a note dated on a week day, which was in reality executed on Sunday. ${ }^{3}$ A party to a contract, who has not himself violated the law, is not precluded

4. See Watts v. Van Ness, l Hill (N. Y.), 76; Merriam v. Stearns, 10 Cush. (Mass.) 257; Reeves v. Butcher, 31 N. J. I. 224.

5. Bradley v. Rea, 103 Mass. 188, 4 Am. Rep. 524; Pope v. Linn, 50 Me. 83; Finn v. Donahue, 35 Com. 216; Pate v. Wright, 30 Ind. 476, 95 Am. Dec. 705; Butler v. Lee, 11 Ala. S85, 46 Am. Dee. 230: Rainey v. Capps, 22 Ala. 288; Williams v. Paul, f Bing. 653; Simpson v. Nicholls, 3 Mees. \& Wel. 240; Van Ioven $v$. Irish, 3 McCrary, C.
C. 443 ; Rosenblatt v. Townsley, 73 Mo. 536 .

1. Leightmens $v$. Kadetska, 58 Iowa, $676,12 \mathrm{~N} .736,42 \mathrm{Am}$. Rep. 129 ; Johns v. Bailey, 45 Iowa, 241.

2. Ray v. Cattell, 12 B. Mon. (Kiy.) 532; Dahoney v. Dahoney, 7 Bush (Ky.), 217; Hilton v. Houghton, 35 Me. 143; Commonwealth v. Kendig, 2 Pa. St. 448; Lovejoy v. Whipple, 18 vt. 379, 46 Am. Dec. 157.

3. Trieder v. Bank, 31 Ark. 128; lleise v. Bumpass, 40 Ark. 545. 
from enforcing such contract, and that the acceptance of a bond on a secular day, which was signed on the Sabbath, is not a violation of the law." And if sone steps are taken toward the execution of a contract on Sunday, but is not fully consunmated until a secular day, such contract is not in contravention of the statute. ${ }^{5}$ And the fact that a bond for costs was signed on Sunday, but delivered to the court on a week day, does not render it void. ${ }^{6}$

\& 194. Contracts dated on Sunday.- Because a contract is dated on Sunday does not make it a Sunday contract. Hence, making and delivering on a secular day, of a promissory note dated and to take effect on a subsequent Sunday, is not work prohibited by the statute, for the observance of the Sabbath. ${ }^{7}$ So, where a land contraet was delivered on a week day, the mere fact that it was dated as if made on Sunday is not material, and it is valid. ${ }^{s}$ If the contract is entered into on a week day, and dated to be performed on Sunday, it is still valid, ${ }^{9}$ unless something prohibited by the statute is to be done. ${ }^{10}$

$\S$ I95. Executed on Sunday.-A contract made and concluded on Sunday cannot he enforced by action in some States. ${ }^{1}$ Hence, a loan of money made on Sunday cannot be recovered back. $^{2}$ And so a party to whom property has been delivered

4. Evansville v. Morris, 87 Ind. 269, 44 Am. Rep. 763.

5. Beitemman's Appeal, $55 \mathrm{~Pa}$. St. 183; Merrill v. Downs, $41 \mathrm{~N}$. H. 72; State v. Young, 23 Minn. 551 ; Prather v. Harlan, 6 Bush (N. Y.), 185 .

6. Hall v. Parker, 37 Mich. 590, 26 Am. Rep. 540. See, also, Hilton v. Houghton, $3 \pi$ Me. 143.

7. Stacy v. Kemp, 97 Mass. 166.

8. Lamore v. Frisbie, 42 Mich. 186, 3 N. 910 .

9. Aldridge v. Bank, 17 Ala. 45 : Lamore v. Frisbie, 12 Mich. 186, 3
N. 910 ; Stacy v. Kemp, 97 Mass. 166.

10. Smith v. Wilcox, 24 N. Y. 353, 82 Am. Dec. 302.

1. Pike v. King, 16 Iowa, 49; Greene v. Godfrey, 44 Me. 25; Kinney v. MeDermott, 55 Iowa, 674. 8 N. 656,39 Anı. Rep. 191; Finn v Donahue, 35 Conn. 216; Compare Tucker v. Nowrey, 12 Mich. 378; Brazee v. Bryant, 50 Mich. 136. 15 N. 49 ; Smith v. Betn, 15 N. II. 575.

2. Finn v. Donahue, 35 Conn. 216. 
under a contract made on Sunday may maintain replevin therefor, if retaken from his possession without his consent by the other party. ${ }^{3}$

Where both parties to a contract have failed to comply with the law, neither party can invoke the aid of the law to repudiate it. ${ }^{4}$

Money paid on Sunday and retained afterwards discharges the debt. ${ }^{5}$ So, payments made on Sunday and not returned, but allowed on a final accounting, will not avoid the contract on which they were received, as one made in violation of the Sunday laws. ${ }^{6}$

However the cases are in conflict as to executed contracts. Executory contracts cannot be cntorced when illegal because made on Sunday. And it has been held that an executed contract made by an agent having full power, is binding on his principal, though it was made on Sunday, and is within the scope of the agent's authority. Hence, the mere fact that an agent, in the course of exercising a delegated anthority, himself violates a prohibitive statute, does not liberate or discharge the principal from the obligation of the contract, if the contract be one within the scope of his authority. Thus, where an agent, with full power. trades his principal's horse on Sunday, and the contract is executed, the principal cannot sustain an action of replevin to regain the horse, which was delivered to the defendant by the agent. ${ }^{7}$

3. Kinney v. MeDermot, 55 Iowa, 674, 8 N. 656, 39 Am. Rep. 191. See, also, Smith v. Bean, 15 N. H. 577; Pattee v. Greely, 13 Met. (Mass.) 284.

4. Greene v. Godfrey, 44 Me. 25.
5. Johnson v. Willis, 7 Gray (Mass.), 164 .

6. Lamore v. Frisbie, 42 Mich. 186, 3 N. 910 .

7. Ricards v. Ricards (Md.), 56 At. Rep. 397 . 


\section{ARTICLE III.}

Statutes Regulatixg Thane and Professions.

Section 19). Contracts Prohibited by Statute.

197. Sealing of Weights and Measures.

19s. Bickers-Peddlers.

199. Lawyers.

200. L'hysicians.

201. Sdiool Teachers.

20:. Articles of Commerce-Sales Without Inspection.

203. Ninors-Prohibited Work.

204. Contract Valid in Part and Void in Part.

205. Sale of intoxicants Without a License.

$\S$ 196. Contracts prohibited by statute.- It is familiar law, both in England and America, that a contract prohibited, either expressly or impliedly, by statute, is illegal and cannot be enforced. ${ }^{1}$ Where a contract is made in a manner prohibited by a statute passed for the protection of a buyer, no action can be maintained upon it; and where the statute directs the mode in which the contract shall be male, not following the directions is equivalent to disobeying a prohibition. And, if the statute imposes a penalty upon the act done, this will make the contract void in like manner as if it were in terms prohibited, because a penalty implies a prohibition. ${ }^{2}$ However, when the statute enacts as one of the means of raising a revenue, that those engaged in a particular occupation shall take out a license and pay a certain sum for it, or be subject to the payment of a greater sum, by way of penalty, for neglecting to do so, the only consequence that follows the neglect or omission is the liability

1. Perkins v. Watkins, 2 Baxt. ('Temn.) 187; Holt v. Green, 73 Par. St. 198; Dillon v. Allen; 46 lowa, 299. 26 Am. Rep. 145; McConnell v. Kitchens, 20 S. Car. 430, 47 Am. Rep. 845; Wood v. Armstrong. 54 Ala. 150, $25 \mathrm{Am}$. Rep. $67 \mathrm{l}$ and note: Johnson v. Hulings, 103 Pa. St. 49 S, 49 Am. Rep. 131.
2. Law v. Hodgson, 11 East, 300 ; Bartlett v. Viner. Carth. 252: Little v. Poole, 9 Barn. \& Cr. 192; Foster v. Taylor, 5 Barn. \& Adol. SsT: Cuudell v. Dawson, 4 C. B. 376: Wheeler v. Russell, 17 Mass. 258: Allen v. Hawks, 13 Pick. (Mass.) 82: Pattee v. Greely, 13 Met. (Mass.) 284. 
to the penalty, ${ }^{3}$ for the penalty is imposed only for the purpose of securing the payment of the anount required for the taking out of the license. ${ }^{4}$

But where the object of requiring that a license shall be obtained is to limit the pursuit of certain eallings to those who are declared duly qualified by the granting to them of a license, then the penalty implies a prohibition against engaging in that pursuit, unless a license is procured $;^{5}$ or where, for the purpose of securing a more effectual compliance with the requirement of a revenue law, it is enacted that no one shall engage in or carry on a particular oceupation, until he shall have obtained a license as provided for in the act, it is an express prohibition. ${ }^{6}$

\section{$\S$ 197. Sealing of weights and measures.- Statutes are en-} acted which have in view the prevention of fraud or imposition. In such ease, though there be nothing but a penalty imposed for violation, such contracts are void. Thus, a statute for selling and disposing of goods, wares and merchandise by unsealed and unproved seales or measures, implies a prohibition; and such sales being made in violation of law, no recovery can be had for the price. ${ }^{7}$ Hence, no action lies to recover the price of milk sold by the can, at wholesale, in can not sealed ac-

3. Johnson v. Hodgson, 11 East, 300 ; Foster v. Taylor, 5 Barn. \& Cr. 898; Witherall v. Jones, 3 Barn. \& Cr. 221; Brown v. Duncan, 10 Barn. \& Cr. 93.

4. Griffith v. Wells, 3 Denio (N. Y.), 227 .

5. Bartlett v. Viner, Carth. 252; De Begius v. Armistead, 10 Bing. 107 ; Foster v. Taylor, 5 Barn. \& Ad. 887 .

6. Bartlett v. Viner, Carth. 252; Mitchell v. Smith, 4 Dal. (U. S.) 269; Griflith v. Wells, 3 Denio ( $\mathrm{N}$. Y.), 226; Smith v. Mawhood, 14 Mees. \& Wel. 463; Banking Co. v. Rantenberg, 103 Ill. 460, 42 Am.
Rep. 26; Penn. v. Bowman, 102 Ill. 523 ; Downing v. Ringer, 7 Mo. 585 ; IVilliams v. Cheney, 3 Gray (Mass.), 222; Jones v. Smith, 3 Gray (Mass.), 500; Hustis v. Pickands, 27 Ill. App. 270.

7. Griffith v. Wells, 3 Denio (N. Y.), 226; Lewis v. Welch, 14 N. H. 294 ; Brackettv. Hoyt, 29 N. H. 264 ; Sinith v. Arnold, 106 Mass. 269; Woods v. Arunstrong, 54 Ala. 150, $25 \mathrm{Am}$. Rep. 671 and note; Ingersoll v. Randall, 14 Minn. 304; Bis. bee v. McAllen, 39 Minn. 143, 39 N. W. 299 ; Finch v. Barclay, 87 Ga. 393,13 S. E. 566. 
cording to statute, although the sealer refused to seal them fur the statute price. ${ }^{8}$

$\S$ 198. Brokers-Peddlers. - Where a statute or ordinance enacts a penalty for the carrying of a particular business without a license, no action can be maintained for services performed by one who violates the statute or ordinance in performing them. Thus, where it is unlawful to exercise within the city the business of a real estate broker without a license, a per son so engaged in negotiating the sale or exchange of real property, in violation of such ordinance, can recover no commission for his services, ${ }^{1}$ though the sale is valid. ${ }^{2}$ So, a broker who has purchased mining stock for a third party, in violation of an ordinance, without a license, cannot maintain an action for commissions. ${ }^{3}$

But a party not a broker may sell real estate without a license and collect a commission. ${ }^{4}$

In South Carolian it is said that one of the leading canons of construction in cases of this kind, is the test whether or not the license or exaction is a police regulation, or a tax assessment for the security and collection of the revenue. If the former, the calling itself is invalid, unless the requirement is complied with; but, if it is a tax for revenue, then the act done is valid. The law does not operate on the business or ealling, and affect that, but on the person, and punishes him with penalty or otherwise. ${ }^{5}$ Hence, the fact that a broker has not paid the license

8. Miller v. Post, 1 Allen (Mass.), 434: Ritchie v. Boynton, 114 Mass. 431. See, also, Eaton v. Kegan, 114 Mass. 433; Bisbee v. MeAllen, 39 Miun. 143, 39 N. W. 299 ; Finch v. Barclay, 87 Ga. 393, 13 S. E. 566.

1. Richardson v. Brix, 94 Iowa, 626,63 N. IV. 225; Buckley v. Humanson, 50 Minn. 195, 52 N. W. 385, 36 Am. St. Rep. 637; Hustis v. Pickands, 27 11l. App. 270 ; John- son v. Huling, $103 \mathrm{~Pa}$. St. 501 ; Holt v. Green, 73 Pa. St. 198, 13 Am. St. Rep. 737; Stevenson v. Ewing, 87 Tenn. 46, 9 S. IV. 30.

2. Murray v. Bond, 167 IIl. 368 , 47 N. E. 717,59 Am. St. Rep. 297.

3. Hustis v. Pickards, 27 Ill. App. 270.

4. O'Neill v. Sinclair, 153 Ill. 525, 39 N. 1:. 124.

5. McComell v. Kitchens, $20 \mathrm{~S}$. Car. 436: In re Jager, 29 S. Car. 
tax required by an ordinance is no defense against an action brought by him to recover compensation on a sale duly made. ${ }^{6}$

No action lies for serviee rendered in peddling goods for another without license in violation of law. ${ }^{7}$ Nor ean a special act of the legislature exempt honorably discharged soldiers from paying a license to peddle. This is so, as the Fourteenth Amendment to the Federal Constitution forbids such diserimination, ${ }^{7}$ beeause all persons subject to sueh legislation shall be treated alike under like cireumstances and conditions, both in the privileges conferred and liabilities im posed. ${ }^{8}$ So any statute which provides that a license to peddle shall not apply to veterans of the civil war is void, because it is a discrimination, having no conneetion with the duties of the eitizens as taxpayers, and their excmptions of the tax therein required of others exercising the same ealling is favoritism, and a denial of the equal protection of the laws. ${ }^{9}$ A State may require a license fee from persons in one occupation, and not from those in another, provided no discrimination is made between those of the same elass; but when such diserimination exists, it impairs that equal right which all can claim in the enforcement of the laws. To diseriminate between citizens by denying to one class the privilege of transacting business without complying with conditions and exactions not required of others, when the ground of elassification is wholly arbitrary, is a denial of the equal protection of the law.

445, 7 S. E. 605 ; Fairly v. Wappoo Mills, 44 S. Car. 227, 22 S. E. 108, 29 L. R. A. 215.

6. Fairly v. Wappoo Mills, 44 S. Car. 227,22 S. E. 108,29 L. R. A. 215.

7. Stewartson v. Lathop, 12 Gray (Mass.), 52. See, also, Banks v. MeCosker, 82 Md. 518, 34 A. 539, 51 Am. St. Rep. 478; Commonwealth v. Newhall, 164 Mass. 338. 41 N. E. 647; State v. Shedroi (Vt.), 54 At. Rep. 1081.
8. Magoun v. Bank, 170 U. S. 283, 18 S. Ct. 594, 42 L. Ed. 1037.

9. State v Garbroski, 111 Iowa, 496,82 N. W. 959,56 L. R. A. 570 , $82 \mathrm{Am}$. St. Rep. 524; State v. Harrington, 68 Vt. 623,35 A. 515, 34 L. R. A. 100 ; State v. Cadigan, 73 Vt. 245, 50 A. 1079, 57 L. R. A. 666, 87 Am. St. Rep. 714. See, also, In re Keymer, 148 N. Y. 219,42 N. E. 667,35 L. R. A. 447 ; Brown v. Russell, 166 Mass. 14, 43 N. E. 1005, 53 Am. St. Rep. 357 and note, 32 L. R. A. 253. 
In passing an ordinance, a city must not establish an exorbitant license fee for peddling and selling goods. So, a license fee of ten dollar's a day imposed on itincrant merchants is invalid, because it is mreasonably burdensone, in general restraint of trace and prohibitory of business. ${ }^{10}$ So, a fee of two humdred and fifty dollars a month, or twenty-five dollars a day, imposed on a transient merchant is void. ${ }^{11}$ In general, when a clear case is presented, showing that the ordinance imposes a fee which is mnreasonable or oppressive, the courts will not enfore it, the fee being an mauthorized restraint of trade. ${ }^{12}$

\$ 199. Lawyers.-Under the same principle, a lawyer who has not obtained a license, as required by the internal revenue law act of the United States Congress, cannot recover for professional services rendered since the passage of the act, and before it was repealed. ${ }^{1}$ And, in general, an unlicensed attorney cannot recover compensation for professional services. ${ }^{2}$ But a law firm, one of which has been duly licensed, may recover in a joint action for services rendered by the firm, when there is no prohibitory statute which controls. ${ }^{3}$ And in Virginia it is held that lawyers practicing their profession without paying the license tax prescribed, are subject to the penalty, but their clients on that account cannot refuse to pay them their fees for professional service. ${ }^{4}$ It must be remembered that if a law requiring a license declares in terms that the act or calling is un-

Ro. Carralton v. Bazzett, 159 Ill. 284, 42 N. E. 837,31 L. R. A. 522.

11. Othemway v. Zekind, 95 lowa, 622,64 N. W. 646,29 L. R. A. 734. 58 Am. St. Rep. 447.

12. Springfield $\checkmark$. Jacobs, 101 Aío. App. 339, 73 S. W. 1097; Tugman v. Chicago, 78 Ill. 405: Caldwell v. Alton, 33 11l. 416, 85 Am. Dee. 282 and note; Morse v. West Port. 110 Mo. 502, 19 S. W. 881; Gratiot v. Railway Co., 116 Mo. 450, 21 S. W. 1094, 16 L. R. A. 189; La Mar v. Weidman, 57 Mo. App.
507 ; Hannibal v. Telephone Co., 31 Mo. App. 23.

1. Hall $v$. Bishop, 3 Daly (N. Y.), 109. See, also, Holshue $v$. Morgan, 170 Pa. St. 217. 32 A. 623.

2. Hillson v. Browne, 3 Colo. 304 ; Anies v. Gilman, 10 Met. (Mass.) 243; Ex parte Fellows, 2 Seam. (IIl.) 369; Hughes v. Dougherty, 62 Ill. App. 464.

3. Harland v. Lilienthal, $53 \mathrm{~N}$. Y. 440 .

4. Yates v. Robertson, $80 \mathrm{Va}$. 475 . 
lawful unless the law is complied with, then the act or calling is prohibited, and a contract made under it cannot be sued on. If, however, there is no express and specific prohibition, then it is necessary to construe the act or ordinance and see whether the intent is to prohibit. ${ }^{5}$

$\S 200$. Physicians. - The application of the law is made as to physicians who undertake to practice the profession of medicine without a license required by statute; and where the law prohibits the act, the physician can recover no compensation for his services if he has not procured the license, ${ }^{1}$ though it appears that he may recover upon an implied contract for services rendered after such license is procured. ${ }^{2}$ The physician must comply with the statute when prohibitory, or he cannot collect for his services. ${ }^{3}$

This is upon the principle that where a statute has for its manifest purpose, the promotion of some object of public policy, and prohibits the carrying on of a profession, occupation, trade or business, except in compliance with the statute, a contract made in violation of such statute cannot be enforced. ${ }^{4}$

5. Harris v. Runnels, 12 How. (U. S.) 84 .

1. Haworth v. Montgomery, 91 Tenn. 16, 18 S. W. 399; Orr v. Meek, 111 Ind. 40, 11 N. E. 787 ; Cooper v. Griffin, 13 Ind. App. 212, 40 N. E. 710 ; Eastman v. State, 109 Ind. 278,10 N. E. 97, 58 Am. Rep. 400 ; Coyle v. Campbell, 10 Ga. 570.

2. Gardner v. Tatum, 81 Cal. 370,22 P. 880.

3. Adams v. Stewart, 5 Har. (Del.) 144; Holmes v. Halde, 74 Me. 28, 43 Am. Rep. 567; Puckett v. Alexander, 102 N. Car. 95, 8 S. E. 767, 3 L. R. A. 43; Bailey v. Mogg, 4 Denio (N. Y.), 60; Davidson v. BohIman, 37 Mo. App. 576; Eastman v. State, 109 Ind. $27 \mathrm{~S}, 10 \mathrm{~N}$. E. 97,58 Am. Rep. 400 ; Cooper v. Criffin, 13 Ind. App. 212, 40 N. E.
710; Richardson v. Dorman, 28 Ala. 679; Jordan v. Dayton, 4 Ohio, 295; Underwood v. Scott, 43 Kans. 714, 23 P. 942; Dow v. Haley, 30 N. J. L. 354 ; Bibber v. Simpson, 59 Me. 181; Downs v. Minchew, 30 Ala. 86; Gaither v. Lindsey (Tex.), 83 S. W. 225.

4. Haworth v. Montgomery, 91 Tenn. 16, 18 S. W. 399; Compare Aiken v. Blaisdell, $41 \mathrm{Vt}$. 655, 666. See, also, People v. Arendt, 60 Ill. App. 89; Paquin v. State Board, 19 R. I. 365,33 A. 870 , Boucher v. State Board, 19 R. I. 361, 33 A. 878; McCurry v. Gibson, 108 Ala. 451, 18 So. 806, 54 Am. St. Rep. 177; State v. Bonlam, 96 Iowa, 252, 65 N. W. 154; Maxwell v. Swigart, 48 Neb. 789, 67 N. IV. 789 ; 
But a physician does not come under the rule of a common carrier or innkeeper, and, therefore, may refuse to attend any person who calls him, even if the usual fee is tendered. ${ }^{5}$

$\S$ 20I. School teachers.- So, a school teacher is entitled to no compensation for services, if he has not a certificate as preseribed by law. ${ }^{6}$ So, where a teacher is enployed who has no certificate to teach, the contract of hiring is void, and is not susceptible of subsequent ratification. ${ }^{7}$ But a teacher is entitled to compensation for services rendered in good faith under a license prima facie correct, notwithstanding irregularity in issuing it by the proper officer. ${ }^{8}$

\section{$\S$ 202. Articles of commerce-Sales without inspection.-} Articles of commerce, such as fertilizers, are generally sold under restrictions, and the statute must be followed in order to make a valid sale. Thus, a contract for the sale of a fertilizer not labeled, as required by statute, is void, although such sale is not expressly prohibited. Because the penalty fixed for selling without complying with the statute, implies a prohibition, it being manifest that the statute was enacted for the purpose of protecting the public against the fraudulent sale of goods, not for the purpose of raising revenue. ${ }^{9}$ And so, where a merchant sells fertilizers without complying with the statute and takes a note for the purchase-money, he cannot maintain an action on the note. ${ }^{10}$ So, where articles of commerce are subject to inspection before they can be sold, a contract of sale is void if made

Harrison v. State, 102 Ala. 170, 15 So. 563; O'Connor v. State, 46 Neb. 157,64 N. W. 719 ; State v. Smith, 60 Mo. App. 283.

5. Hurley v. Eddenfield, 156 Ind. 416,59 N. E. Rep. 1058, 53 L. R. A. 135, 83 Am. St. Rep. 198.

6. Jemness $v$. School Dist., 12 Minn. 448; Sinnott v. Colombet, 107 Cal. 187, 40 P. 329; Ryan v. School
Dist., 27 Minn. 433; Board v. Wagaman (Md.), $3 \tilde{5}$ At. Rep. 85.

7. Wells v. People, 71 Ill. 532.

8. Hill v. Swinney, 72 Miss. 248 , 16 So. 497 . See, also, Keller v. Hewitt, 109 Cal. 146, 41 P. 871.

9. Vanmeter v. Spurrier, $94 \mathrm{Ky}$. 22, 21 S. W. 337 ; Brown v. Adair, 104 Ala. 652, 16 So. 439.

10. McConnell v. Kitchen. $20 \mathrm{~S}$. Car. 430, 47 Am. Rep. 845. 
before the inspection provided by statute, and if the article proves worthless, this is wholly immaterial. And in Georgia there can be no recovery, even of the contract comes into the hands of a bona fide holder. ${ }^{11}$

These cases are decided on the principle that a contract void which a statute prohibits under penalty is void although the statute does not expressly so provide. ${ }^{12}$ And a subsequent repeal of the statute without any saving clause as to penalties already incurred, will not validate the contract void under the law in existence when the contract was made. ${ }^{13}$

\section{$\S$ 203. Minors-Prohibited work.-A father cannot bring an} action to collect the wages of his minor child where the work is prohibited by statute. So, where a parent hires his son out to work in a factory, which is forbidden by statute, he cannot collect for the minor's wages. Because when he begins an action for the compensation, he is suing for an act in violation of the statute, for having done a forbidden thing. ${ }^{1}$ Such statute is intended for the good of the minor, and also for the good of the public. And so the law will not help a man to recover pay for doing what the law says shall not be done. ${ }^{2}$

And so an employer who puts a child, under the age specified by law, to work on a printing press, where the minor is injured, the employer is liable civilly for damages, on account of his violation of law, and the question of negligence of the child is for the jury. ${ }^{3}$ The employer having violated the law, he cannot call upon the law to help him escape the liability or injury. It is only justice that he restores the minor's injury by a money

11. Johnson v. McConnell, 65 Ga. 129; Conley v. Blalock, 71 Ga. 161.

12. Woods v. Armstrong, 54 Ala. 150. $25 \mathrm{Am}$. Rep. 671 and note; O'Donnell v. Sweeney, 5 Ala. 468, 39 Am. Dec. 336. See, also, Pacitic Guano Co. v. Mullen, 66 Ala. 582; Campbell v. Segars, 81 Ala. 259, 20 So. 668 .
13. Woods v. Armstrong, 54 Ala. 150, 25 Am. Rep. 671 and note.

1. Birkett v. Chatterton, 13 R. I. $299,43 \mathrm{Am}$. Rep. 30 .

2. Peck v. Burr, 10 N. Y. 294; Levy v. Yates, 8 Ad. \& El. 129; Gallini v. Laborie, 5 T. R. 242.

3. Marino v. Lalımaier, $28 \mathrm{~N}$. Y. L. Jour. 2139, 173 N. Y. 530, 66 N. E. 572,61 L. R. A. 807. 
compensation. Whether the employment of a minor in violation of the child labor law, is negligence per se by the employer or only evidence of negligence is a question not answered alike by the courts. Many hold the violation of such law is negligence perse, when the minor is injured in the cmployment, and others that it is evidence of negligence. This last rule is the New York doctrine. ${ }^{*}$ The true rule slould be that whenever it is elear from the interpretation of the statute that the exact consequences against which it was intended to provide have actually ensued from its violation, the act is negligence per se; but if the injury is merely collateral, the breach is evidence of negligence of the employer. ${ }^{5}$ The object of the statute is to fix the age limit below which it is neither safe nor proper to employ a child. It shows that a child below the age limit is not eapable of exercising due care around machinery, and any such employment is a dangerous and wrongful act. The employer should be liable for all the direct consequenees, that is, all the natural and probable consequences. ${ }^{6}$

$\S 204$. Contract valid in part and void in part.- As a general rule, where a promise is made for one entire consideration, a part of which is fraudulent, immoral, or unlawful, and there has been no apportionment made, or means of apportionment furnished by the parties themselves, it is well settled that no action will lie upon the promise. If the bad part of the consideration is not severable from the good, the whole promise fails. ${ }^{?}$

When it appears that the consideration was made up of several distinct transactions, some of which are entirely honest and

4. Marino v. Lahmaier. $173 \mathrm{~N}$. Y. 530,66 N. F. 572,61 L. R. A. s07.

5. Hays v. Railroad Co., 111 U. S. 228,4 S. Ct. 369 .

6. Stone v. Railroad Co., 171 Mass. 544, 51 N. E. 1.

7. Robinson v. Green, 3 Met. (Mass.) 159; Rand v. Mather, 11
Cush. (Mass.) 1, 59 Am. Dee. 131 ; Woodruff $v$. Wentworth, 133 Mass. 309 ; Clark v. Ricker, 14 N. H. 44; Woodruff v. Himman, 11 Vt. 592, 34 Am. Dec. 712; Pickenny v. Railway Co., 3 C. P. 235; Harrington v. Dock Co., 3 Q. B. D. 549 ; Bishop v. Palmer, 146 Mass. 469, 16 N. E. 299, 4 Am. St. Rep. 339. 
fair, and the valid consideration can be separated with certainty and ease from the vicions, then it may be held good for so much as is free from the taint of illegality. ${ }^{8}$

$\S 205$. Sale of intoxicants without a license.- Statutes are enacted to regulate the sale of intoxicating liquors. These regulations are intended to protect the public against the consequence which may be expected to follow from allowing all persons, at their pleasure, to deal in strong liquors. And although the statute only inflicts a penalty for selling withont a license, the contract is illegal, and no action will lie to enforce it. ${ }^{1}$ Such statutes look beyond the question of revenue, and have in view the protection of the public health or morals, or the prevention of frands by the seller, and such contracts cannot be enforced. ${ }^{2}$

And, in an action upon an account stated, the defendant may plead and prove that the whole claim was founded in an illegal transaction $;^{3}$ such as the sale of intoxicating liquors in violation of law. ${ }^{4}$

But the mere knowledge by the vendor that liquor is to be resold in violation of the statute, without participation in the illegality, will not vitiate the sales he makes to the intermediate dealers. ${ }^{5}$ But if the vendor designedly contributes to the scheme,

8. Carleton v. Woods, $28 \mathrm{~N}$. H. 290 ; Feldman v. Gamble, $26 \mathrm{~N}$. J. Eq. 494; Scott v. Gilmore, 3 Taunt. 226; Cotten v. MeKenzie, 57 Miss. 418; Shurman v. Thompson, 11 Ad. \& E. 1027; Sawyer v. Smith, 109 Mass. 220; Eaton v. Kegan, 114 Mass. 433; Allen v. Pearce, 84 Ga. 606, 10 S. E. 1015.

1. Knowlton v. Dorety, $87 \mathrm{Me}$. 518, 33 A. 18, 47 Am. St. Rep. 349 ; Storz v. Finkelstein, 46 Neb. 577, 65 N. W. 195, 30 L. R. A. 644; Woodford v. Hamilton, 139 Ind. 481, 39 N. E. 47 ; Gipps Brewing Co. v. De France, 91 Iowa, 108, 58 N. W. 1087, 28 L. R. A. 386; Holden v. Brooks, 66 N. H. 184, 20 A.
247 ; Griffith v. Wells, 3 Denio ( $N$. Y.), 226. See, also, Springfield Bank v. Merrick, 14 Mass. 322.

2. Law v. Hodgson, 2 Camp. 147 ; Brown v. Duncan, 10 Barn. \& $\mathrm{Cr}$. 93; Foster v. Taylor, 3 Nev. \& Man. 244; Little v. Poole. 9 Barn. \& Cr. 192; Wheeler v. Russell, 17 Mass. 258.

3. Thomas v. Hawkes, 8 Mees. \& Wel. 140; Cocking v. Ward, 1 C. B. 858, 870; Kennedy v. Brown, 13 C. B. N. S. 677 ; Rundlett v. Weber, 3 Gray (Mass.), 263.

4. Dunbar v. Johnson, 108 Mass. 519.

5. Tatum v. Kelly, 25 Ark. 209. 
or is to derive a benefit from it, or if there is unity of purpose between him and the party to be supplied, he is affected with the latter's criminality, and the contract is void. ${ }^{6}$ All sales without a license are prohibited and are illegal. Such statutes are not for the mere purpose of revenue, but for the regulation of the sale of intoxicants, and where no license has been procured, the vendor cannot collect the price from the vendee. ${ }^{\text {? }}$

And so the owner of a building, who wilfully suffers it to be used for the illegal sale of intoxicating liquors, cannot recover for the use and occupation of the same for the period during which he suffers it to be so illegally used. ${ }^{8}$

A party may sell intoxicating liquors in another State, if not against the statute of that State, and collect the price $;^{9}$ but if it be against the statute of the latter State and a contract of that State, it will be illegal. ${ }^{10}$

6. Fisher v. Lord, 63 N. H. 514 , 3 A. 927 ; Foster v. Thurston, 11 Cush. (Mass.) 322 ; Riley v. Jordan, 122 Mass. 231; O'Bryan v. Fitzgerald, 48 Ark. 48,3 S. W. 527.

7. Territt v. Bartlett, 21 Vt. 184 ; Vannoy v. Patton, 5 B. Mon. (Ky.) 248; Cobb v. Billings, 23 Me. 470; Lewis v. Welch, 14 N. H. 294 ; Soloman v. Dreschier, 4 Minn. 278; Melchoir v. McCarthy, 31 IVis. 252, 11 Am. Rep. 605; Bach v. Smith, 2 Wash. Ter. 145; Bancroft v. Dumas,
21 Vt. 456; Boutwell v. Foster, 24 Vt. 485.

8. Mitchell v. Scott, 62 N. H. 596. See, also, Bliss v. Brainard, 41 N. H. 256; Allen v. Deming, 14 N. H. 133, 40 Am. Dec. 179; Lewis v. Welch, 14 N. H. 294.

9. Holden v. Brooks, 66 N. H. 184, 20 A. 247.

10. Gipps Brewing Co. v. De France, 91 Iowa, 108, 58 N. IV. 1087, 28 L. R. A. 386, 51 Am. St. Rep. 329. 


\section{AR'TICLE IV. \\ Usurious Contracts.}

SECTION 206. Definition.

207. Statutory Provisions.

208. Intent is Essential to Constitute Usury.

209. Lending and Borrowing Money.

210. Legal Interest-Commission.

211. Agent of the Party Loaning.

212. Discount of Accommodation Paper.

213. Taking Personal Property as Interest.

214. Cash and Credit.

215. In Purchase Price of Land.

216. Bonus for Consideration of Making the Loan.

217. Antedating a Note-Interest Payable in Advance.

218. Hiring or Renting Securities.

219. Building and Loan Association.

220. Building Associations Must Keep Within the Statute.

221. Premiums and Exchange.

222. Compound Interest.

223. Statutory Provisions.

224. Interest Coupons.

225. Recovering Back Usurious Interest.

226. Computation of Interest-Compounding.

227. Taxes and Expenses.

228. Commission and Discount.

229. Attorney's Fees.

230. Sale of Security-Innocent Purchaser.

231. Absolute Sale with Agreement to Repurchase.

232. National Banks.

233. Mistake in Taking Interest.

234. Renewal Notes and Mortgages.

235. Contracts Having an Independent Existence.

236. Evidence-Suffieiency.

237. Who May Plead Usury.

238. Waiver of Usury.

239. Burden of Proof.

240. Place of Payment of Interest-Conflict of Laws.

241. Payment may be Controlled by Contract.

242. Computation of Interest-At Stated Periods.

243. The Law of Another State Must be Pleaded.

\& 206. Definition.-Usury is the excess over the legal rate charged to a borrower for the use of money. Originally, the 
word was applied to all interest reserved for the use of money; and in the early ages taking such interest was not allowed. ${ }^{1}$ To constitute usury there must be: 1 . A loan, expressed or implied; 2. An understanding between the parties that the money shall be returned; 3 . That a greater rate of interest than is allowed by law shall be paid or agreed to be paid; 4 . A corrupt intent to take more than the legal rate for the use of the sum loaned. ${ }^{2}$ Money paid above the legal rate for the forbearance of an existing debt is usury. ${ }^{3}$

$\S 207$. Statutory provisions. - The statutory provisions as to the law of usury are frequently changed and modified. Some of the States have no usury laws, and there is no uniformity in the laws of the other States in this regard. In many of the States there is a forfeiture of the usury above the statutory rate; and in other States all usurious contracts are void. In few of the States it is a misdemeanor to take usury. ${ }^{4}$

$\S$ 208. Intent is essential to constitute usury.- To charge one with usury he must know of and be a party to the intent to riolate the law against usury. ${ }^{5}$ While intent is essential to constitute usury, yet the intent must be deduced from, and determined by, the facts. The voluntary taking and reserving a greater interest or compensation for a loan than that allowed by law is per se usurious. So the offense is not ordered dismissed by a want of intent to violate the statute or by giving the transaction another name than that of a loan. ${ }^{6}$

1. Bouvier's L. Dict.

2. Miller v. Ins. Co., 118 N. Car. 612, 24 S. E. 484,54 Am. St. Rep. 741 ; Balfour v. Davis, 14 Oreg. 47 ; Roe v. Kiser, 62 Ark. 92, 34 S. W. 534, 54 Am. St. Rep. 2s8; Tyler on Usury, 110; McGuire v. Campbell, 58 Ill. App $\rightarrow$ S.

3. Hathaway v. Hagan, 59 vt. 75, 8 A. 678; Bang v. Windmill Co., 96 Tenn. 361, 34 S. WV. 516; Chase v. Whitten, 62 Minn. $498,65 \mathrm{~S}$. IV.
S4; Compare Omaha Loan and Trust Co. v. Hanson, 46 Neb. 870, 65 N. W. 1058. See What Law Governs Usurious Contracts.-17 Harv. L. Review, 568.

4. Pingrey on Mortg. 770.

5. Jackson v. Travis, 42 Minn. 438,44 N. IV. 316 ; Garvin v. Lenton, 62 Ark. 370,35 S. W. 430.

6. Cooper v. Nock, 27 Ill. 301 ; Kelley v. Lewis, 4 W. Va. 456 ; Culver v. Pullman, 59 Hun (N. Y.), 
Because interest has been calculated and included in the mortgage debt in excess of the strict legal right, does not make a usurious contract $;^{7}$ and an agreement for the highest rate of interest, payable semi-annually or quarterly, is not usurious, ${ }^{8}$ nor is taking the highest rate in advance for a whole year. ${ }^{9}$

An agreement by a borrower upon mortgage to allow the lender to retain part of the land mortgaged after being repaid principal and interest of the loan, if it is part of the mortgage transactions, is usurious, and will not be enforced. ${ }^{10}$ But the mortgagor may agree to pay the taxes, which may be included with the interest, and the agreement will not be usurious. ${ }^{11}$

$\S$ 209. Lending and borrowing of money.- Where the transaction is not the loaning of money, the question of usury cannot arise. ${ }^{12}$ But if the transaction be really a borrowing and loaning of money at an unlawful rate of interest, no ingenuity can give it a form that will shicld it against impeachment and judicial investigation. ${ }^{13}$ If the parties understand that more

615, 12 N. Y. S. 663 ; Fiedler v. Darrin, 50 N. Y. 437 ; Steele v. Andrews, 19 N. J. Eq. 409; Scruggs v. Mort. Co., 54 Ark. 566, 16 S. W. 563 ; Duvall v. Bank, 7 Gill \& J. (Md.) 44; Childers v. Deane, 4 Rand. (Va.) 406.

7. Spencer v. Ayrault, 10 N. Y. 202.

8. Goodrich v. Reynolds, 31 Ill. 490, 83 Am. Dec. 240; Meyer v. Muscatine, 1 Wall. (U. S.) 384; Mowry v. Bishop, 5 Paige (N. Y.), 98.

9. Telford v. Garrels, 132 П11. 550, 24 N. E. 373 ; Tholen v. Duffy, 7 Iians. 405; Fowler v. Trust Co., 141 U. S. $381,408,411,12$ S. Ct. 8 ; Mitchell v. Lyman, 77 Ill. 525; Brown v. Mortg. Co., 110 Ill. 235; Hoyt v. Pawtucket Inst., 110 Ill. 390. 390; Vahlberg v. Keaton, 51 Ark. 534,11 S. W. 878,4 I. R. A. 462,14
Am. St. Rep. 73; English v. Smock, 34 Ind. 115, 7 Am. Rep. 215; Newell v. Bank, 12 Bush. (Ky.) 57 ; Polen v. Palmer, 53 Ill. App. 223; Bank v. Cook, 60 Ark. 2S3, 30 S. W. 35, 29 L. R. A. 761 and note, 46 Am. St. Rep. 171 and note; Parker v. Cousins, 2 Gratt. (Va.) 372, 44 Am. Dec. 388.

10. Gleason v. Burke, 20 N. J. Eq. 300. See, also, Lombard v. Gregory, S1 Iowa, 569, 47 N. IV. 298; Succession of Latchford, 42 La. Ann. 529, 7 So. 628; Southall v. Farish, 85 Va. 403; Keagy v. Trout, 85 Va390, 7 S. E. 534 .

11. Dutton v. Aurora, 114 Ill. 138, 28 N. E. 461 ; Compare Hodgdon v. Davis, 6 Dak. 21,50 N. W. 478.

12. Struthers v. Drexel, 122 U. S. 487,7 S. Ct. 1293.

13. Gaither v. Clarke, $67 \mathrm{Md} .18$, 9 A. 632,10 A. 309 . 
than legal interest is taken, no contrivance can cover it, and the real nature of the transaction will be considered; but if no loaning and borrowing of money is made, the transaction will not be usurious as there can be no basis for usury. ${ }^{14}$

\$2ro. Legal interest-Commission.-A loaner of money may receive the legal rate of interest and also a commission for the care and management and sale of property shipped him. Thus a contract between a commission merchant and a dealer in produce, by which the former agrees to advance money at the legal rate of interest to enable the dealer to purchase or carry his produce, and is also to receive a percentage upon the money advanced as a commission for the care, management and sale of the property, is not per se usurious $;^{15}$ the onus is upon the party seeking to impeach the transaction to show a guilty intent and that the contract was to cover usury. ${ }^{16}$ Such question may be submitted to the jury, as such contract is not per se and of necessity usurious; but it does not follow that every contract, usual and customary in its terms, is in all cases to be submitted to a jury with liberty to find it usurious and void upon mere conjecture or caprice, and without evidence to impeach it, merely because the contract may be made a cover for usury, and under sone circumstances may be invalid for that reason. ${ }^{17}$

$\S 2$ II. Agent of the party loaning.- If the agent of the party loaning the money takes commission without the knowledge and consent of the loaner, this is not usury. But if the

14. Hartranft v. Uthlinger, $115 \mathrm{~Pa}$. St. 270, \& A. 244; Drury v. Wolfe, 34 11l. App. 23, 134 Ill. $294,25 \mathrm{~N}$. E. 626 ; Tyson v. Rickard, 3 Har. \& J. (Md.) 109, 5 Am. Dec. 424; Swayne v. Riddle, $37 \mathrm{IV}$. Va. 291, 16 S. F. 512.

15. Elliott $v$. Sugg, 115 N. Car. 236, 20 S. E. 450; Cockle v. Flack, 93 U. S. 3.t4; Norwood v. Faulkner, 22 S. Car. 367. 53 Am. Rep. 717 ; Woolsey v. Jones, 87 Ala. S8, 4 So.
190 ; Blackburn v. Hares, 59 Ark. 366, 27 S. W. 240 .

16. Matthews $v$. Coe, $70 \mathrm{~N}$. Y. 239. 26; Am. Rep. 583; Thomas v. Murray, 32 N. Y. 605: Booth v. Sweery, 4 Seld. (X. Y.) 280 : Smith v. Marvin, 27 N. Y. 137.

17. Cockle v. Flaek, 93 U.S. 344.

1. George v. Security C., 109 Ala. 548, 20 So. 331; Fowler v. Trust Co., 141 U. S. 385, 12 S. Ct. 8; Call v. Palmer, 116 U. S. 98, 6 S. 
loaner instructs his agent to take a commission, or knows it and the rate of interest is full legal rate, then such transaction is usurions. ${ }^{2}$ And if the agent included the commission in the principal of a note, and takes full legal rate of interest besides, then the transaction is usurious though the loaner did not know of the agent's commission. ${ }^{3}$

\section{$\$ 2$ I2. Discount of accommodation paper. - It is commonly} held that where a promissory note has been fairly made, and there is no usury between the original parties, so that the payee has acquired a legal right to sue the maker thereon, he may then dispose of it at any rate of discount from its face, and the purchaser will have a right to enforee its full payment against the maker. ${ }^{4}$ In respect to an aceommodation note sold or negotiated at a greater rate of discount than legal interest, the authorities are not uniform. One class of eases holds that the purchaser of such note from the payee, being the first party paying anything for it, is therefore the first owner, and that, as the payee before the sale of the note had not acquired a legal right to sue the aceommodation maker, the purchaser must pay the full face of the note, or the transaction will be usurious; that, as between the maker and the payee, the note is without consideration and void in the hands of the payee, and beeomes valid only upon being negotiated to a bona fide purchaser, and hence a party who buys an aceommodation note before it has been used

Ct. 301 ; Whaley v. Mort. Co., 74 Fed. Rep. 73, 20 C. C. A. 306, 42 U. S. App. 90; Ditmas v. Sackett, $92 \operatorname{Hun}$ (N. Y.), 381,36 N. Y. S. 690.

2. Fowler v. Trust Co., 141 U. S. 385,12 S. Ct. S; Whaley v. Mortg. Co., 74 Fed. Rep. 73, 20 C. C. A. 306,42 U. S. App. 90 .

3. Stephens v. Olson, 62 Minn. 295, $6+$ N. W. 898 ; Cronin v. Olson, 60 Minn. 534, 63 N. W. 108.

4. Robinson v. Smith, 62 Minn. 62, 64 N. W. 90 ; Lynchberg Nat.
Bank v. Scott, 91 Va. 652, 22 S. E. 487,29 L. R. A. 827,50 Am. St. Rep. 860 ; May v. Campbell, 7 Humph. (Temn.) 450; Salt Marsh v. Bank, 17 Ala. 761; French v. Grindle, 15 Me. 163; Nichols v. Fearson, 7 Pet. (U. S.) 103; Mun v. Commission Co., 15 Johns. (N. Y.) 43; Jackson v. Travis, 42 Minn. 438, 44 N. W. 316 ; Claflin v. Boorum, 122 N. Y. 385,25 N. E. 360 ; Rodecker v. Littauer, 59 Fed. Rep. 857, 8 C. C. A. 320,19 U. S. App. 455 . 
for any business purpose stands in the same situation, in respect to the defense of usury, as if he were the payee named thercin, and this though he had no knowledge that the note was accommodation paper, and supposing it to be business paper." But the better rule is that the defense of usury cannot be set up against the purchaser of an accommodation note, taken at a greater rate of discount than legal interest, mless such purchaser has knowledge of the character of the paper. ${ }^{6}$ So, where one buys an accommodation note of the payee, not knowing that it was accommodation paper, but supposing that it was already a valid subsisting security in the hands of the payce, the transaction is not usurious, though a greater discount was allowed than legal rate. ${ }^{7}$

\$213. Taking personal property as interest.-Usury can taint a contract where personal property is taken as interest, instead of money. So where a lender receives money or other valuable thing, in any greater sum or value for a loan than the legal rate, which he accepts as interest, it will render the contract usurious. ${ }^{1}$ And this is so whether the property is taken for the purpose of evading the usury law or not. ${ }^{2}$

§ 2I4. Cash and credit.-A party may take a less amount for property where cash is paid than when he sells on credit, and this will not amount to usury. Hence, when a note is given for

5. Williams v. Banks, Il Md. 198; Corcoran v. Bowers, 6 Ohio St. 19; Sylvester v. Swain, 3 Allen (Mlass), 134; Clark v. Sisson, 22 N. Y. 312; Carlisle v. IJill, $16 \mathrm{Alal}$ 398; llolmes r. Willians, 10 Paige (N. Y.), 326, $40 \mathrm{Am}$. Dece. 250 and note; Powell $r$. Waters, 17 Johns. (N. Y.) 176 .

6. Sherman v. Blackman, 24 III. 347 ; Otto v. Durege, 14 Wis. 571 ; Gaul v. Willis, 26 Pa. St. 257; Ramsay v. Clark, 4 Humph. (Tenn.) $244,40 \mathrm{Am}$. Dec. 645: Whitwarth v. Adams, 5 Rand. (Va.) 333;
Jackson v. Fassitt, 33 Barb. (N. Y.) 645: Nidaletown Bank r. Jerome, Is Conn. 48s; Humphrey v. Clark, 27 Conn. 38I; Dickerman v. Day, 31 Iowa, 444, $7 \mathrm{Am}$. Rep. 156; Holmes r. Bank, 53 Minn. 350, 55 N. 11.555 .

7. Holmes v. Bink, 53 Minn. 350. 55 N. W. 555.

1. Silpl $r$ Cobb, 60 Ark. 367.30 S. W. 349 .

2. Cummins v. Wire, 2 Halst. Ch. (N. J.) 73; Low v. Prichard, 36 Vt. 183; Voorhis v. Staed, 63 IIo. $А$ p. 370 . 
the price of goods purchased on a credit, and the rate is more than legal interest, but this method was adopted solely as a means of expressing a difference between cash and credit price of the goods, there is no usury. ${ }^{1}$ If what is called interest, or what is aimed at on the basis of a certain rate of interest, is in fact a part of the purchase-money or price of the article, as, for instance, land, and not a mere cover for a loan or for the forbearance of money, it is not usurious, but is as really a part of the purchase-price for the land as is the prnicipal sum. ${ }^{2}$ It is neither a present loan, nor is it a forbearance in respect to some debt previously existing, but is a part of the contract price of the thing sold. ${ }^{3}$

$\S 2$ I5. In purchase price of land.-A stipulation in a note for the purchase-money of land calling for more than legal rate is usurious. ${ }^{4}$ But, in the purchase of, if the vendee agrees to pay as part of the purchase price, a rate of interest on the deferred payments in excess of the legal rate, the contract is not usurious. $^{5}$ And so, where there is an advance in the cash price of land, because credit was given, this is not usury, the advance being part of the consideration, and the vendee executing his notes for the same. ${ }^{6}$ This was a sale of land, where the vendor was willing to sell for so much at a cash valuation, or for so much on credit.

\section{$\S 2$ I6. Bonus for consideration of making the loan.- $A$} bonus paid by the borrower to the lender of money for making a

1. First Nat. Bank v. Mann, 94 Tenn. 17, 27 S. W. 1015, 27 L. R. A. 561 and note, $45 \mathrm{Am}$. St. Rep. 696; Cutler v. Wright, 22 N. Y. 427.

2. Swayne v. Riddle, 37 W. Va. 291,16 S. E. 512.

3. Hogg v. Ruffner, 1 Black (U. S.), 115; Crawford v. Johnson, 11 Ind. 258. See, also, Primley v. Shirk. 60 Ill. App. 312; Saxe v. Womack, 64 Minn. 162, $66 \mathrm{~N}$. W. 269 ; Hawley v. Kountze, 6 App. Div. 217,39 N. Y. S. 897 .
4. People's Bank v. Jackson, 43 S. Car. 86,20 S. E. 786,27 L. R. A. 569 and note, 49 Am. St. Rep. 823.

5. Reger จ. O'Neal, 33 W. Va. 159, 10 S. E. 375,6 L. R. A. 427 ; Dykes v. Bottoms, 101 Ala. 390, 13 So. 582; Swayne v. Riddle, 37 W. Va. 291,16 S. E. 512.

6. Dykes v. Bottoms, 101 Ala. 390, 13 So. 582. See. also, Jackson v. Morris, 29 S. W. $435,16 \mathrm{Ky}$. L. R. 684 . 
loan may make the transaction usurions. And the bonus, in computing, for the purpose of determining whether the loan is usurious, is to be deducted as of the kate when it is payable. If payable at the time of the loan, it is to be deducted from the prineipal as of the date of the loan, and the remainder, or what the borrower receives and retains, is to be taken as the basis for computation. ${ }^{1}$ So where part of the money loaned is withheld, the borrower paying interest from the time the transaction took place, it is usurv, if it resulted in paying more than legal interest. $^{2}$

But the mere fact that a note is given for an amount in excess of that actually due does not render the note usurious. ${ }^{3}$ And an agreement to pay a per cent. quarterly or otherwise for the extension of time for the payment of a loan in addition to the legal rate of interest thereon, is usurious notwithstanding the increased interest is called "bank commission." " But where there is no time set for payment, a deduction of a greater rate than the legal interest is not usurious. ${ }^{5}$ And when it is not a loan a deduction is not usurious. ${ }^{6}$

In general, if the lender exacts a bonus for loaning the money, besides taking the full legal rate, it is usury. ${ }^{7}$

But a bonus paid by a borrower to his own agent for procuring a loan is no part of the sum paid for the loan, and is not usury, notwithstanding the lender takes full legal interest. ${ }^{8}$

\section{$\S 217$. Antedating a note-Interest payable in advance.-} No device to cover up usury will avail. Thus, when parties con-

1. Phelps v. Montgomery, 60 Minn. 303, 62 N. IV. 260 ; Smith v. Parsons, 55 Minn. 520, 57 N. IV. 311; Anderson v. Smith 108 Mich. 69,65 N. IV. 615.

2. East River Bank v. Hoyt, 29 How. Pr. 290, 32 N. Y. 119.

3. Minneapolis Harvest Works $v$. Kaessner, 41 Neb. 716, 60 N. W. 8.

4. Bowdoin v. Hammond, $79 \mathrm{Md}$. 173, 28 A. 769 .

5. Philadelphia v. Kelly, $166 \mathrm{~Pa}$.
6. Meaker v. Fiero, 14.j N. Y. 165, 39 N. 1. 714.

7. Hewitt v. Dement, 57 Ill. 510 ; Walter v. Foutz, 52 MId. 147; Fanning v. Dumham, 5 Johns. Ch. (N. Y.) 122; Harris v. Wicks, 28 Wis. 198; Stack v. Sperry, 6 Lea (Tenn.).411, 40 Am. Rep. 47; Rowland v. Bull, 5 13. Mon. (Ky.) 146 .

8. Goodwin v. Bishop, 145 Ill. 421,34 N. E. 47 : Dryfus v. Burnes, 53 Fed. Rep. 410. 
tract for a loan of money at the highest rate of interest, and the note is made to bear interest from date and is dated at a time prior to that when the money is paid to the borrower, as a device to cover usury, the transaction is tainted with usury. ${ }^{1}$ But where the loan is transacted through the mails, and a reasonable time transpires between the date of the execution of the papers and their final acceptance, there is no usury because the borrower did not have the money at the date of the papers. ${ }^{2}$ And if the delay is caused by the borrower's own negligence, the contract is not usurious because the money is not paid at the date of the contract. ${ }^{3}$

The mere payment of interest in advance is not necessarily usurious $;^{4}$ but an arrangement to pay interest in advance may be such as to be usurious. ${ }^{5}$

$\S 218$. Hiring or renting securities.-A contract by which a party lends United States bonds, and the borrower agrees to pay over to the owner the interest paid the government thereon, and a per cent. in addition, is not usurious. Such a contract is merely one of renting or hiring, and is as legitimate as will be the hiring of a horse or renting of a house, with the agreement that the party may pledge or sell, but at the same time undertaking, with security, the return of the property in kind to the original owner, or account for its value. ${ }^{6}$

$\S 2$ 19. Building and loan association.-A building and loan association is an organization created for the purpose of accumulating a fund by monthly subseription or savings of its members, to assist in building or purchasing for themselves real estate by loaning to them the requisite money from the funds of the society upon good security. Nearly every State in the

1. Vail v. Van Doren, 45 Neb. 450, 63 N. W. 787.

2. Daley v. Investment Co., 43 Minn. 517, 45 N. W. 1106.

3. Rose v. Munford, 36 Neb. 148, 54 N. W. 129.

4. Warren Deposit Bank v. Robinson, 35 S. W. 275, 18 Ky. L. R. 78 .

5. Hiller v. Ellis, 72 Miss. 701, 18 So. 95, 4I L. R. A. 707 and note.

6. Marshall v. Rice, 85 Tenn. 502, 3 S. W. 177. 
Union has a general statute relating to the incorporation of such associations, which statutes generally differ in some degree. But these associations are not generally subject to the usury laws by reason of exeess of preminms contracted to be paid by their members to them, or loans to them, over the rate of interest permitted by law. ${ }^{2}$ But to entitle mutual building and loan associations to the benefit of this exemption from the usury laws, they must conduct their business in good faith, and loan their funds only to bona fide members. They cannot loan their funds to strangers, upon usurions terms; otherwise they would become simply associations of legalized usurers, availing themselves of the privileges and exemptions of the statute, intended only for strictly mutual building and loan associations. The sale of stock may be a mere cover for usury. ${ }^{2}$ And when they are so conducted that the borrower's contract requires of him only lawful interest, it is not usury. ${ }^{3}$

Usury camnot exist between the parties bearing one to another the intimate relation existing between members of a building and loan association. ${ }^{4}$ Such loans are not rendered usurious by a premium which cach borrower agrees to pay for the loan since such premium is neither a prepayment of interest nor a deduction of money belonging to the member, but merely represents the agreed discount of the future dividends of his share of stock. ${ }^{5}$

When there is actual usury in the transaction, the association is responsible like other parties. ${ }^{6}$

1. Hawkins v. Association, 96 Ga. 206, 22 S. E. 711 ; Goodrich v. Association, 96 Ga. 803, 22 S. E. 585 ; Central Build. \& Loan Asso. v. Lanıson, 60 Minn. $422,62 \mathrm{~N}$. IV. 544. See, also, Hensel v. Association, 85 Tex. 215, 20 S. W. 116 ; International Build. \& Loan Asso. v. Abbott, 85 Tex. 220,20 S. W. 118 ; Reeve $v$. Association, 56 Ark. 335,19 S. W. 917,18 L. R. A. 129 and note; Suceession of Latehford, 42 La. Ann. 529, 7 So. 628 .
2. City Joan Co. v. Cheney, 61 Minn. 83, 63 N. W. 250.

3. Natches Build. \& Loan Asso. v. Shields, 7 I Miss. 63, 15 So. 743. See, also. Granite State Provident Association v. Monk (N. J.), 30 At. Rep. Si2.

4. Conservative Build. \& Loan Asso. r. Cady, 55 Ill. App. 469.

5. Sullivan v. Association, 70 Miss. 94, l2 So. 590; Red liank Mut. Build. \& Loan Asso. v. Patterson, 27 N. J. Eq. 223.

6. Henderson Build. \& Loan Asso. 
$\S 220$. Building associations must keep within the statute.A corporation which nuakes its loans to members in the approved form of building association loans, but whose aims and nature do not bring its property within the statute as a building association, is not allowed to enforce reservations lawfully permitted to such institutions. ${ }^{7}$ And, hence, the transaction between a quasi building and loan association and its borrowing stockholder is simply a loan, and is usurious, where he is liable, under certain circumstances, to pay more than the amount loaned and legal interest. ${ }^{8}$

$\S 22$ I. Premiums and exchange.- The sale of securities at a premium cannot subject the party to an action to recover back the premium on the ground of usury; whether the premium was computed in the contract of sale at a certain percentage in excess of the legal rate for the time past, or stated at a gross sum, or as compound, is immaterial. ${ }^{1}$ The payment of exchange is not usury, unless it appears that this allowance was a mere device on the part of the mortgagee to evade the usury laws. ${ }^{2}$ And paying premium on gold in buying an exchange to pay a mortgage held in a foreign country, where gold is the basis of currency, is not usurious. ${ }^{3}$

\$22. Compound interest.- The law, as a general rule, will not allow the recovery of compound interest. There are two exceptions to this rule: 1 . In relation to interest bearing coupons attached to the principal note or other securities for the payment of money. Such coupons, when payable to bearer, have,

v. Johnson, 88 Ky. 191, 10 S. WV. 87, 3 L. R. A. 289 and note; Burlington Mut.L. Asso. v. Heider, 55 Iowa, 424,5 N. 518, 7 N. 686; City Loan Asso. v. Gallagher, 25 Ohio St. 208. See, also, Southern Building \& Loan Asso. v. Harris, 98 Ky. 41, 32 S. W. 261 ; United States, etc. Co. v. Scott, $98 \mathrm{Ky} .695,34$ S. W. 235.

7. Williams v. Association, 45 Md. 546; Jarrett v. Cope, $68 \mathrm{~Pa}$.
St. 67 ; Kupfert v. Association, 30 Pa. St. 465; Rhoads v. Association, 82 Pa. St. 180.

8. Meroney v. Association, 116 N. Car. 882, 21 S. E. 924, 41 Am. st. Rep. 841.

1. Culver v. Bigelow, 43 Vt. 249.

2. Williams v. Hance, 7 Paige (N. Y.), 581.

3. Oliver v. Shoemaker, 35 Mich. 464. 
by mercantile usuage, legal effect of promissory notes. The interest of such eoupons is not componnded indefinitely. 2. In case the interest has become dne and remains mpaid, the debtor may then agree to have the accrued interest added to the principal and it beeones interest bearing. ${ }^{1}$ When the borrower has compounded the interest a promise by him to pay such eompound interest is valid if supported by a consideration. ${ }^{2}$ But many comrts hold that the arlding of the interest every year to the principal, is usury. ${ }^{3}$

$\$ 223$. Statutory Provisions.- The statutes of many States control as to compounding interest, and must be consulted. In Arkansas, when a payment falls short of paying the interest due at the time of making such payment, the balance of interest must not be added to the prineipal." In California the interest, by written agreement, if not paid when due, may be added to the principal ; ${ }^{5}$ in Louisiana it is otherwise. ${ }^{6}$ In Idaho compound interest is not allowed to be contraeted for in the original agreement. ${ }^{7}$ Interest cannot be componmded in Minnesota. ${ }^{8}$

$\S$ 224. Interest coupons.- Money loaners now generally take notes with coupons attached for the payment of a specified sum at certain periods, and if not paid at the time stated, the amount stated in the coupon draws interest from the date of its matmity. ${ }^{9}$ Such coupons are in effect promissory notes and draw

1. Bowman v. Neely, 151 III. 37 , 37 N. E. 840 ; Leonard v. Williams, 23 Ill. 37T; Stickney v. Moore, 108 Ala. 590, 19 So. 76. See, also, Gross v. Cofley, 111 Ala. 468, 20 So. 428; Stewart v. Petree, $55 \mathrm{~N}$. Y. 621, 14 Am. Rep. 352; Crider v. Association, 89 Tex. 597, 35 S. W. 1047; Scott v. Salflord, 37.Ga. 384; Columbia County v, King, 13 Fla. 251; Hill v. Meeker, 23 Conn. 592; Lewis Invest. Co. v. Boyd, 48 Neb. 604, 67 N. W. 456.

2. Tillotsson $v$. Nye, ss Hun (N. Y.), 101, 34 N. Y. S. 606; Young r. Hill, 67 N. Y. 162, 23 Am. Rep. 99.

3. Waring v. Cunlift, 1 Ves. Jr. 9!); Chambers $v$. Goldwin, 9 Ves. 254; Thornbill v. Evans, 2 Atk. 330 ; Leith v. Irwin, 1 Myl. \& K. 277 .

4. Dig. of Stat. 1884, sec. 4738.

5. Civil Code, 1885, sec. 1919.

6. Rev. Code, 1870, art. 1939.

7. Rev. Stat. 1887 , sec. 1265 .

8. Laws of 1879 , ch. 66 .

9. Columbia County v. King, 13 Fla. 451; Gelpcke v. Dubuque, 1 IVall. (U. S.) 175, 206; Harper v. 
interest after maturity. ${ }^{10}$ Hence, overdue coupons bear interest after maturity at the lawful rate of interest, and taking such interest is not usury. ${ }^{11}$ However, interest upon interest, as represented by coupons, must be allowed or refused, as may be required by the statute of the State. ${ }^{12}$

§225. Recovering back usurious interest.-- In many States, money paid as usurious interest is allowed to be recovered back on the theory that the law regards the payment as made under duress. ${ }^{1}$ But the general rule is that money voluntarily paid, with full knowledge of all the material facts, cannot be recovered back, even though made upon illegal consideration, which the law will not enforce. ${ }^{2}$ In Illinois an agreement after interest is due to make it a principal sum does not render the transaction usurious $;^{3}$ but in a usurious contract the debtor is entitled to have all payments on account of usury, applied in diminution of the principal unpaid. ${ }^{4}$

\section{$\S 226$. Computation of interest-Compounding.-Taking the} legal rate of interest in advance is not usury. ${ }^{5}$ But where the

Ely, 70 Ill. 581; Hollingsworth v. Detroit, 3 MeLean, C. C. 472. See, also, Bowman v. Neely, 151 Ill. 37, 37 N. E. 840 .

10. Miller v. Railroad Co., 40 Vt. 399, 94 Am. Dec. 413; Gelpcke v. Dubuque, 1 Vall. (U. S.) 175; Hollingsworth v. Detroit, 3 MeLean, C. C. 472; Mercer County v. Hubbard, 45 Ill. 139; Johnson v. Stark County, 24 Ill. 75; Bennson v. Savage, 130 Ill. 352,22 N. E. 838 .

11. United States Mortg. Co. v. Sperry, 138 U. S. 313, 11 S. Ct. 321.

12. Ohio v. Frank, 103 U. S. 697 ; Phinney v. Baldwin, 16 Ill. 108, 61 Am. Dec. 62; Chicago v. Allcock, 86 Ill. 384; United States Mort. Co. v. Sperry, 138 U. S. 313 , 11 S. Ct.
321 ; Stickney v. Moore, 108 Ala. 599, 9 So. 76.

1. Albany v. Abbott, 61 N. H. 158.

2. Caldwell v. Wentworth, $14 \mathrm{~N}$. H. 431 .

3. Haworth v. Huling, 87 Ill. 23; Gilmore v. Bissell, 124 III. 488, 17 N. E. 758; Drury v. Wolfe, 134 Ill. 294, 25 N. E. 626; Thayer v. Star Mining Co., 105 Ill. 540; McGovern v. Ins. Co., 109 IIl. 151; Bowman v. Neely, 151 Ill. 37,37 N. E. 840.

4. Fowler v. Trnst Co., 141 U. S. 3S4, 40S, 411, 12 S. Ct. 8.

5. Bank v. Cook, 63 Ark. 288,46 Am. St. Rep. 171 and note, $30 \mathrm{~S}$. W. 35, 29 L. R. A. 761 and note; Polen v. Palmer, 53 Ill. App. 223; Hoyt v. Pawtucket Inst., 110 Ill. 390 ; Bloomer v. MeInerney, 30 Hun (N. 
acerned annual interest is added to the principal and then on that anomnt the interest is paid in advance, that is 11 sury. ${ }^{6}$ But the adding in to the principal the overdue interest, and giving a note for the whole anount, withont taking interest in advance upon the whole, is not usury $;^{i}$ but this matter is sometimes regulated by statute, which must be consulted.

\$227. Taxes and expenses.- An agreement to pay taxes on the mortgaged debt in addition to the highest logal rate is not usurious. So, the payment by the borrower, in addition to full legal interest, of the costs of drawing the mortgage and examining the title to the security does not constitute usury. ${ }^{9}$ "Where a note has been withheld or antedated in order to evade the usury law, this is nsury..$^{10}$ But if the completion of the contract had been caused by the delay of the mail, then it would not be usury. ${ }^{11}$

\section{$\S 228$. Commission and discount.- An agent of the borrower} may take a commission for loaning money, from the borrower, where the loaner is not interested, the legal rate of interest being the highest allowed ${ }^{1}$ hut an executor cannot be such an

Y.). 201; Mitehell v. Lyman, 77 Ill. 525 .

6. First Nat. Bank v. Davis, 108 IIl. 633 .

7. MeGovern v. Ins. Co., 109 Ill. 151.

8. Banks v. McClellan, $24 \mathrm{Md}$. 62, 87 Am. Dec. 594.

9. Kidder v. Vandersloot, $114 \mathrm{Ill}$. 133, 28 N. F. 460; Ammondson v. Ryan, 111 Ill. 506; Ellenbogen v. Griffey, 55 Ark. 268, 18 S. W. 126; Daley v. Association, 43 Minn. 517. 45 N. W. 1100 ; Dayton v. Moore, 30 N. J. Eq. 543.

10. Barr v. Chureh (N. J.), 10 At. Rep. 2si; Vail v. VanDoren. 45 Neb. 450. 63 N. W. 787.

11. Daly v. Invest. Co., 43 Minn. 517,45 N. W. 1100.
1. Dreyer v. Goldy, 62 Ill. App. 347; Stansell v. Trust Co., $96 \mathrm{Ga}$. 207, 22 S. E. 898; New kngland Mort. Co. v. Baxley, 44 S. Car. Sl, 21 S. E. 444; Gray v. Van Blarcom, 29 N. J. Eq. 454; Spring v. Reed, 28 N. J. Eq. 345; Van Wyek v. Watters, 81 N. Y. 352; Guggenheimer v. Grieszler, 81 N. Y. 293; Rogers r. Buckingham, 33 Conn. 81; Eslava v. Crampton, 61 Ala. 50-; Phillips r. Roberts, 90 Ill. 952: New England Mort. Co. v. Gay, 33 led. Rep. 636: Estevez v. Purds, 66 N. Y. 4t6: Whaley v. Mort. Co. 74 Fed. Rep. 73,20 C. C. A. 306,42 U. S. App. 90; Jordan v. Humphrey, 31 Minn. 495, is N. 450 ; Board v. Millword, 51 Ark. 548, 11 s. W. S8: Pass v. Security Co., 
agent." Whan the agent has the general oversight of his prineipal's money, and loans it withont any special anthority, and in such smms and at such times as he pleases, and is only restricted as to the least anomnt of interest to be taken, if the agent exacts usury upon his loans by taking full legal rate of interest and also a commission, the principal is affected and the transaction is usurious. ${ }^{3}$

An agent generally may loan noney and take commission where there is no arrangement to this effeet between the agent and the lender." But when the prineipal ratifies the agent's usurious eontraet, then the prineipal beeomes affeeted with the usury and must abide the consequences. ${ }^{5}$

Even the lender himself may charge for extra services and expenses rendered or incurred by him in good faith, for to constitute usury, the charge must be for the loan or forbearance. ${ }^{6}$

$\$ 229$. Attorney's fees.- Gencrally a stipulation in a mortgage or a note for the payment of attorney's fees in addition to

66 Miss. 365, 6 So. 239; Hughes v. Griswold, 82 Ga. 299, 9 S. E. 1092; Telford v. Garrells, 132 Ill. 550, 24 N. E. 573; Ginn v. Securnty Co., 92 Ala. 135, 8 So. 385; Davis v. Sloman, 27 Neb. 877,44 N. W. 41 ; Weems v. Mort. Co., 86 Ga. 760, 13 S. E. S9.

2. Landis v. Saxton, 89 Mo. 275. 1 S. W. 359 .

3. Payne r. Newcomb, 100 Ill. 611; Fowler v. Trust Co., $141 \mathrm{U}$. S. 381, 12 S. Ct. S; Banks v. Flint. 54 Ark. 40, 14 S. W. 709,16 S. WV. 477. 10 L. R. 1. 459 and note: Hall r. Mandlin, 58 Minn. 137, 59 N. W. 985, 49 Am. St. Rep. 492: Horkan v. Nesbit, 58 Minn. 287, 60 N. IV. 132; Bliven v. Iydecker, I30 N. Y. 102,28 N. E. 625; Kenmitt $v$. Adamson, 44 Minn. 121. 46 N. TV. 327 ; Stein v. Swenson, 41 Minn. 218, 46 N. NT. 360 .
4. Hoyt r. Pawtucket Inst., 110 111. 390, 398; Telford v. Garrells, 132 Ill. $550,5.54,24$ N. E. 573; Sanford v. Kane, 132 Ill. 199, 205, 24 X. E. 414,8 i.. R. A. $724,23 \mathrm{Am}$. St. Rep. 602 ; Ginn v. Security Co., 92 Ala. 135. 8 So. 38s; May v. Flint, 54 Ark. 573, 16 S. W. 575; Veems v. Mort. Co., S6 Ga. 760, 13 s.. 1.. 89 .

5. Bliven v. Lydecker. 130 N. Y. 102,28 N. W. 025 ; Hyatt v. Clark, 118 ․ Y. 563. 23 N. E. 89; Hoyt v. Thompron. 19 X. Y. 207.

6. Dayton v. Moore, 30 X. J. Eq. 543; Ntlanta Min. Co. v. Gwyer, 48 Gar. 9; Horton v. Thurber, 85 N. Y. 550; Matthews v. Coe, 70 N. Y. 239; Ammondson v. Rivan, 111 Ill. 506: De Forest v. Strong, 8 Comn. 513; Compare Jackson v. May. 28 11]. App. 305. 
legal interest, in ease the holder is compelled to sue, does not render the mortange or note usurions, ${ }^{1}$ provided the fee is reasonable. ${ }^{2}$ Attorney's fees are not allowed in all the States. Kentucky, Ohio, Michigan, and North Carolina hold that the stipulation in a mortgage for attorney's fees is void as against public policy. ${ }^{3}$ It is generally held reasmable attorney's fees may bo provided for in case the mortgagee has to foreclose the mortgage. Such a contract of itself does not make the contract nsurious. But the statute cannot be avoided by any shift or device which may be resorted to by the parties, in order to cover up a usurious contract." But a provision in a mortgage for the "expenses of the sale" does not include attorney's fees. ${ }^{6}$

\section{\$230. Sale of security-Innocent purchaser.- As a general} rule a mortgage nnce issued may be sold withont affecting an innocent purchaser in any of the consequences of taking usurions interest. ${ }^{7}$ The morthagee may sell the mortgage at a discount before taken, if it he not a plan to eover up usurr. ${ }^{8}$ And

1. Williams r. Flowers, 90 Ala. 136, 7 So. 439, 24 Am. St. Rep. 772; Fowler v. Trust Co., 141 U. S. 384 , $408,411,12$ S. Ct. 1, 7, 8; Siegel v. Drumm, 21 La. Ann. 8; Weatlerly v. Smith, 30 Iowa, 131, 6 Am. Rep. 663; Hunter v. Linn, 61 Ala. 492; Billingsbey v. Dean, 11 Ind. 331; Huling $v$. Drexell, 7 Watts (Pa.), 126; American Freehold Land-Mortg. Co. v. Whaley, 63 Ferl. Rep. 743 ; Mumford v. Tolan, 5t Ill. App. 471; Smith v. Silvers, 32 Ind. 321: National Bank $v$. Danforth, s0 Ga. 55, 7 S. E. 546: Barton v. Bank, 122 111. 352. $13 \mathrm{~N}$. E. 503 .

2. Hunter v. Linn, 61 AIa. 492; Clawson v. Munson, 5.5 IIl, 399.

3. Thomasson v. Townsent. 10 Bush (lig.), 114, 19 Am. licp. is: Dow r. Uplike. 11 Neb. 95: Rilling v. Thompson, 12 Bush (Ky.), 210 : State $r$ Taylor. 10 Ohio, 378 ; Tins- ley $v$. Harkins, 111 N. Car. 346, 16 S. E. 325, 32 Am. St. Rep. 801 ; Vin Marter v. McMillan, 39 Nich. 30\%; Leavans r. Bank, 50 Ohio St. 591. 3 t N. E. 1089; Williams v. lich, $114 \mathrm{~N}$. Car. 235.

\&. Parton v. Bank, 122 Ill. 352, 13 X. I. 503; 'Lelford v. Garrels, 132 Ill. 550, 24 N. E. 573; Clawson r. Munson, 55 Ill. 394; MeIntyre v. Yates, 104 Ill. 491; Haldeman v. Ins. Co., 120 11I. 390, 11 N. E. 520.

5. Leonard v. Patton, 106 Ill. 99, 104.

6. Thomas v, Jones, 84 Ala. 302 , 4 Sio. 270 .

7. Jockson $r$ Travis, 42 Minn. 438, 44 X. W. 316 ; Sickles r. Flanagan, 79 X. Y. 2024: Smith v. Cross, 90 N. Y. 549 ; Dunham v. Cudlipp, 94 X. Y. 129; Nlix v. Ins. Co., 11 Ind. 117 .

8. Armstrong r. Freeman, 9 Neb. 11,2 N. 353 . 
a corporation mayy sell its bonds at a discount and not violate

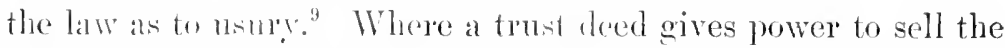
property for any amomut that may he due on the second note, a trustee sale is not rendered inralid by the existence of usury in the loan, when the smm for which the land is sold is less than the anomint dne after deducting the nsurions interest. ${ }^{10}$

A purchaser under a junior mortgage has the right to remove the lien of the prior usurious nortgage by discharging only so much of the debt secured therely as the law recognizes as valid; and this right is not defeated by a conveyance subsequently made by the mortgagor to the prior mortgagee. ${ }^{11}$

But to he an imnocent purchaser, he must take the note or seenrity in the regular conrse of busines. ${ }^{12}$

$\S 23$ I. Absolute sale with agreement to repurchase.Usury cannot he covered up by a pretended sale of land with a lease back to the rendor. ${ }^{1}$ So when land is sold and the transaction is apparently a conditional sale, it will not be sustained as such unless it clearly appears that it is not a scheme to cover usury. ${ }^{2}$

In Georgia, all titles to property made as a part of a usurious contract are void. So when a deed is infected with usury it is void as title. And if void as title, it cannot have effect as an equitable mortgage, becanse unless title passes an equitable mortgage is not created by the conveyance of the land. ${ }^{3}$

9. Traders' Nat. Bank v. Woodlawn Manuf. Co., 96 N. Car. 298, 3 S. E. 363 .

10. Ammondson v. Ryan, $111 \mathrm{Ill}$. 506.

11. Maloney v. Echart, 81 Tex. 281,16 S. W. 1030.

12. Freden v. Richards, 61 Minn. 490, 63 N. W. 1081; Stephens v. Olson, 62 Minn. 295, 64 N. IV. 898.

1. Gaither v. Clark, $67 \mathrm{Md} .18$, 8 A. 740 ; Grand United Order v.
Merklin, 65 Md. 579, 5 A. 544 ; Morrison v. Markham, 78 Ga. 161, 1 S. E. 425 .

2. Gleason v. Burke, 20 N. J. Eq. 300 .

3. McLaren v. Clark, 80 Ga. 423 , 7 S. E. 230 : Broach v. Smith, 75 Ga. 159; Morrison v. Markliam, 78 Ga. 161, 1 S. E. 425: Baggett v. Truloek, 77 Ga. 369, 3 S. E. 162; Pope v. Marshall, $78 \mathrm{Ga} .635,4 \mathrm{~S}$. E. 116 . 
\$232. National banks.- - It is the general law that national banks may reserve and receive whatever interest is allowed by the law of the State regulating the matter. ${ }^{1}$ So, natioual banks may take as high a rate of interest as is allowed either to individuals or banks of issue in the various States of their organization. $^{2}$ In all the States where there is a statute fixing the rate of interest, the only limitations upon these rights must be found in the State statutes. ${ }^{3}$ But the penalty prescribed by the national bank statute for usurious discounting paper by national banks, is exclusive, and that imposed by State statute cannot be applied and enforced. ${ }^{4}$ The national banking law ${ }^{5}$ provides that the party paying usurious interest to a national bank may recover twice the amount of interest paid; but this rule does not apply to discounting negotiable papers. The action to recover twice the amount of the usury must be commenced within two years. The bank may apply the usurious interest on the principal of the note muless the maker has applied it on the interest, ${ }^{6}$ and the usnry is retained in the debt, no matter how many renewals have been made, and the debt may recover twice the amount of all the interest paid. ${ }^{7}$ And jurisdiction is rested in the State as well as in the federal court. ${ }^{8}$

1. La Dow v. Bank, 51 Ohio St. 234,37 N. E. 11; Wiley v. Starbuck, 44 Ind. 298, 15 Am. Rep. 235 ; Newell v. Bank, 12 Bush (Ky.), 57 ; Rockwell v. Bank, 4 Colo. App. 562, 36 P. 905 .

2. National Bank v. Bruhn, 64 Tex. 571, 53 Am. Rep. 771; Hinds v. Marmolejo, 60 Cal. 229; Farmers' Nat. Gold Bank v. Stover, 60 Cal. 387 ; Guild v. Bank, 4 S. Dak. 566. 57 N. W. 499.

3. liockwell v. Bank; 4 Colo. App. 562, 36 P. 905.

4. Barnet v. Bank, 98 U. S. 555 ; Stephens v. Bank, 111 U. S. 197, 4 S. Ct. 336, 337; Bank v. Dearing,
91 C. S. 29; Bank v. Pratt, 115 Mass. 539, 15 Am. Rep. 138; Bank v. Garlinghouse, 22 Ohio St. 492, 10 Am. Rep. 751 ; Davis v. Randall, 115 Mass. 547; Higley v. Bank, 26 Ohio St. 75, 20 Am. Rep. 759 : Florence R. R., etc., Co. v. Bank, 106 Ala. 364, 17 So. 720 .

5. Rev. Stat. U. S. section 5198.

6. Brown v. Nat. Bank, 169 U. S. $416,420,18$ S. Ct. 390 .

7. Colgin v. Bank, 16 Tex. App. 346, 40 s. W. 634: Citizens Nat. Bank v. Donnell (1904), 25 S. Ct. 49.

8. Endres v. Bank, 66 Minn. 257, 68 N. W. 1092. 
$\S$ 233. Mistake in taking interest.- - Where illegal interest is taken by mistake, it is not usury. Thus, where interest upon a loan was computed at a usurious rate and included in the prineipal of a promissory note, which by its terms bore interest only from maturity, if it appears that illegal interest was taken by mistake, the contract is not nsmions;' because there was no intent in making and receiving a note to provide for the payment of the illegal rate of interest. ${ }^{10}$

\section{$\S 234$. Renewal notes and mortgages.- Every renewal note} given for a usurious loan of money is subject to the defense of usury between the original parties and purehasers with notice. ${ }^{1}$ And where a new note is given at the maturity of an old one and inchudes interest on the loan to date at a nsurions rate, the renewal note is tainted with nsury though the original note was not usurious. ${ }^{2}$ And so a mortgage which is given to secure a pre-existing deht, which is tained with usury, will be vitiated by the original indelitedness." If a party takes a renewal mortgage without knowledge of the taint of usury in the original, he will be protecterl. ${ }^{4}$ Put it is not usury for one to loan money to a debtor who nees it in paying his usurious debt to his creditor. ${ }^{5}$

9. Brown v. Bauk, 86 Iowa, 527, 53 N. W. 410 ; Garvin v. Linton, 62 Ark. 370,35 S. W. $430,37 \mathrm{~s} . \mathrm{W}$. 569 .

10. Tyler on Usury, 103; Lloyd v. Scott, 4 Pet. (U. S.) 20.5 ; MeElpatrick r. llieks, $21 \mathrm{~Pa}$. St. 402 ; Price v. Campbell, 2 Call (Va.), 110, 1 Am. Dec. 535; Smythe v. Allen, 67 Miss. 146, 6 So. 627; Bearee v. Barstow, 9 Mass. 45, 6 Am. Dee. 25; Bevier v. Covell. 87 N. Y. 50; Tyson v. Riehard, 3 Har. \& J. (Md.) 109, 5 Am. Dee. 424; Gibson v. Stearns, 3 N. H. 185; MeFarland v. Pank, 4 Ark. 44, 37 Am. Dee. 761 ; Henry v. Sanson, 2

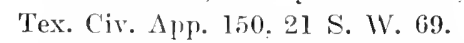

1. McDonald $r$. Anfdengarter, 41 Neb. 40,59 N. W. 762 ; Exeter Nat.
Bank v. Orehard, 39 Neb. 485, 58 N. IV. 144.

2. Melonald v. Beer, 42 Neb. 437, 60 N. IT. 868; Parsons v. Babroek, 40 Neb. I19, 58 N. IV. 726.

3. Bell v. Lent, 24 Wend. (N. Y.) 230: Berry v. Thompson, 17 Johns. (N. Y.) 436; Viekery v. Dickson, 35 Barb. (N. Y.) 96. See, also, MeCraney v. Alden. 46 Barb. (N. Y.) 272; Cope v. Wheeler, 41 N. Y. 303: Exley v. Berryhill, 37 slinn. 182, 33 N. W. 567 .

4. Kilner v. O'Brien, $14 \mathrm{Hun} \mathrm{(N.}$ Y.), 414; Sherwood $v$. Archer, 10 Hun (N. Y.), 73; Jenkins v. Lewis, 25 Kans. 479; Coon v. Spicer, 65 N. Car. 401.

5. Wilson r. Harver, 4 Jans. (N. Y.) 507. Fion, also. Ham ․ De- 
And notes given to a third party for money to be applied in payment of other notes which are usurious are not themselves usurious, ${ }^{6}$ provided it is not a guise to cover up usury. ${ }^{7}$

\section{$\S$ 235. Contracts having an independent existence.-} Where one of several and independent loans is usurious, the taint does not adhere to the others, though all were between the same parties at the same time, and secured by the same mortgage. ${ }^{\mathrm{s}}$

If a usurious agreement is independent of the loan and mortgage, and not a condition of the loan, and eapable of being sustained without referenee to them, either as a sale on consideration or as a gift, it may be enforeed. ${ }^{9}$ And a valid mortgage is not affected by a subsequent usurious agreement. ${ }^{10}$

Obligations and securities having an independent existence, and free from usury, are not affeeted by the statute, although the subject of a contract tainted with nsury. A ralid and subsisting debt is not destrored because included in a security or made the subject of a prohibited contraet. Although formally satisfied and diseharged, and the security surrendered, it may be revived and enforced in case the new security is aroided. ${ }^{11}$

$\S 236$. Evidence-Sufficiency.- A fair preponderance of evidence is only necessary to establish the fact of usury. ${ }^{12}$ But the lan presumes that the loan was not usurious, and proof that a

kate: (N. J.), 20 At. Rep. 65T; Hendrickann v. Godsey, 54 Ark. 155, 15 S. II. 113: Trible v. Nichols, 53 Ark. 271,13 S. W. 796, 22 Am. St. Rep. 190.

6. Vaught v. Rider, 83 Va. 659, 3 S. E. 293, 5 Am. St. Rep. 285 ; Cottrel] v. Southwick, 71 Iowa, 50, 32 N. Wr. 2.2: Trimble v. Thorson, 80 fowa, 246, 45 N. W. 74:; Brown v. Bank, 86 Iowa, 527,53 N. IV. 410.

7. Luckens r. Hazlett, 37 Minn. 4t1. Sice, also, Cim v. Post, 41 W. Va. 397,23 s. E. 613.

8. Jackson v. Mas, 28 I11. App. 305: Crimpen v. Heermance, 9 Paige (X. Y.), 211.

9. Gleason v. Burke, $20 \mathrm{~N} . J$. \&.q. 300 .

10. Allison v. Sehmitz. 3l Hun (N. I.), 106.

11. Patterson v. Birlsall, 64 N. Y. 294, 21 Am. Rep. 609; Smith v. Hollister, 14 N. J. Eq. 153.

12. Phelps $v$ Montgomery 60 Minn. 303, 62 N. IV. 260. 
bonus or commission in addition to the highest legal rate of interest anthorized has been exacted by an agent of the principal dees not raise a presumption of nsury. ${ }^{13}$ But where a contract is tainted with usury on its face, it will take clear proof to show that nsury was not intended. ${ }^{14}$

$\S 237$. Who may plead usury.-- One class of decisions holds that the plea of usury as a defense is personal to him from whom the usury has been exacted, his privies in blood, estate or contract, ${ }^{1}$ so a subsequent purchaser camnot set it up. ${ }^{2}$ So, one not a party to the contract camnot attack it on account of usury. ${ }^{3}$ But where several persons purchase a track of land and give their joint note and mortgage for the purchase-money, and then one of them buys the whole interest of the others, he may plead usury to the whole note, and is not limited in his plea to onethird of it, he being lialile for the whole debt. ${ }^{4}$

If one loans money at usurious rates and the borrower pays the usury agreed upon, and the lender deposits the money so received in the hank, the bank cannot set up the fact that the money was obtained through usury, in defense of a suit to recover the deposits. ${ }^{5}$

Another line of decisions holds that not only the party who

13. Greenfield v. Monaghan, 85 Lowa, 211. 52 N. W. 193: Barthell v. Jensen, 86 Iowa, $736,53 \mathrm{~N}$. W. 124.

14. Henry v. MeAllister. 93 Ga. 667,20 S. E. 66.

1. Holladay v. Holladay, 13 Oreg. 523, 11 P. 260, 12 P. 821; Phillips v. Ogle, 21 D. C. 199; Hill v. Taylor, 125 Mo. 331, 28 S. W. 599: People's Bank v. Jackson, 43 S. Car. 86, 20 S. E. 786, 49 Am. St. Rep. 823: Moses v. Association, 100 Ala. 465, 14 So. 412; Fenno v. Sayre, 3 Ala. 458; Porter v. Banking Co., 40 Neb. 274, 58 N. W. 721; Chapins v. Mathol, 91 Hun, 565. 36 N. Y. S. 835.
2. Ready v. Huebner, 46 IVis. 692, 1 N. W. 344, 32 Am. Rep. 749; Darst v. Bates, 95 Ill. 493; Sellers v. Botsford, 11 Mich. 59; Butts v. Broughton, 72 Ala. 294; Union Nat. Bank v. Bank, 122 Ill. 510, 14 N. E. 859 ; Lamoile County Nat. Bank v. Bingham, 50 Vt. 105, 28 Ain. Rep. 490 and note; Cheney v. Dunlap, 27 Neb. 401, 43 N. W. 178.

3. Hill v. Taylor, 125 Mo. 331, 28 S. WV. 599.

4. People's Bank v. Jackson, 43 S. Car. 86,20 S. H. 786,49 Am. St. Rep. 823.

5. Porter v. Banking Co., 43 Neb. 274, 5S N. W. 721. 
makes a usurious contract, but any person who is seized of his estate and vested with his rights, where he has assmued the payment of the debt, may interpose the defense of nsury, although a mere stranger cannot. ${ }^{6}$ Under this chass of cases a jurlgment creditor of a mortgagor may plead usury. ${ }^{\top}$ So any one in legal privity under this doctrine with a mortgagon nay sot up this defense. $^{\mathrm{s}}$

The law in force at the time of bringing the suit will continue in force as to the relief afforded by it. ${ }^{9}$ One who voluntarily pays unlawful interest upon a usurious eontract cannot recover it back by suit. ${ }^{10}$

$\S 238$. Waiver of usury.- The general rule is that for one to avail himself of the plea of usury he must set it up, or he will be considered to have waived it. A mortgagor may waive usury, and he and those in privity with him cannot avail themselves of this defense; as where he sells the land subject to the mortgage, the purchaser cannot set up nsury in the mortgage note as a defence. ${ }^{11}$ So, a mortgagor is estopped to set up usury when he sells his equity of redemption subjeet to the nortgage, which grantee assumes as part payment, and such estoppel binds grantee. ${ }^{12}$ And a mortgagor who has eonveyed the mortgaged land to the mortgagee, in consideration of a release from personal liability on the mortgaged debt cannot afterward attack

6. Westerfield v. Bried, 26 N. J. Eq. 357; Mason v. Lord, 40 N. Y. 476; Pearsall v. Kingsland, $3 \mathrm{Edw}$. (N. Y.) 195 .

7. Stein v. Swensen, 44 Minn. 218, 46 N. W. 360 ; Carow v. Kelly, 59 Barb. (N. Y.) 239 ; Thompson v. Van Veehten, 27 N. Y. 568; Gunnison v. Gregg, 20 N. H. 100; Spengler v. Snapp, 5 Leigh (Va.), 478; Chaffe v. Wilson, 59 Miss. 42; Greene v. Tyler, 39 Pa. St. 361; Compare Powell v. Hunt, 11 Iowa. 430 ; Gaither v. Clarke, 67 Md. 18, 8 A. 740 .
8. Shufelt v. Shufelt, 9 Paige (N. Y.), 137, 37 Am. Dec. 381; Stein v. Swensen, 44 Minn. 218, 46 N. W. 360.

9. Edmunds v. Bruee, 88 Va. 1007,14 S. E. 840.

10. Kirkpatriek v. Smith, 55 Mo. 389, Rinson v. Hays, 39 Mo. 445.

11. Stiger v. Burt, 111 Ill. 328; Log-Cabin Permanent Build. Asso. v. Gross, $71 \mathrm{Md} .456,18 \mathrm{~A} .896$; Fulford v. Keerl, $7 \mathrm{l}$ Md. 397, $18 \mathrm{~A}$. 663.

12. Essley v. Sloan, 116 Ill. 391, 6 N. E. 449. 
the mortgage on the ground of usury, since the conveyance constitutes a voluntary payment of the entire debt. ${ }^{13}$

$\$ 239$. Burden of proof.- The burden of proof is on the party alleging; ${ }^{14}$ he must establish nsury by a elear preponderance of the evidence. ${ }^{15}$ In a mortgage for purchase-money, the fact that the sum seeured is greater than that named in the consideration of the eonveyance to the mortgagor, with interest, is no evidenee of usury. ${ }^{16}$ Under the Illinois statute, a mortagor in defending may avail himself of the defense of nsury before tender of the amomint legally due.."

\section{$\S 240$. Place of payment of interest - Conflict of laws.-} Where the rate of interest in the State in whieh the contract is made, and in the State in which it is to be performed, differ, the parties may contract for the rate at either place. ${ }^{1}$ The rights of parties to a contract are to he judged of by that law which they intended, or, rather, by which they may justly be presumed to have bound themselves. ${ }^{2}$

The law of the comntry where the contract is made governs as to the nature, the obligation, and the interpretation of it, ${ }^{3}$

13. Mlason v. Pierce, 142 In, 331 , 31 N. H. 503.

14. Puterbaugh v. Farrell, 73 Ill. 213: Kilılhol\% v. Wolff, 103 ill. 362.

15. Phelps v. Montgomery, 60 Minn. 303, 62 N. W. 260: Hotel Co. v. Wade, 97 U. S. 13; Conover v. Van Mater, 18 N. J. Eq. 481; New England Mort. Sec. Co. v. Gay, 33 Fed. Rep. 636.

16. Vesey v. Ackington, $16 \mathrm{~N}$. H. 479.

17. Clark v. Finlon, 90 Ill. 245 ; Tooke v. Newman, 75 111. 215.

1. Nickles v. Asso., 93 Va. 380, 25 S. E. 8; Aimstead v. Blythe (Miss.), 20 So. 298; Hill v. Mortg.
Co., 99 Ga. S7, 24 S. E. S48; Underwood v. Mortg. Co:, 97 Ga. 238, 24 S. E. 847; Craven v. Bates, 96 Car. 78, 23 S. E. 202: Martin v. Johnson, 84 Ga. 48I, 20 S. E. 1082; Osborne v. Bank, 175 Pa. St. 494, 34 A. 858; Mott v. Rowland, 85 Mieh. 561,48 N.W. 638; Smith v. Parsons, 55 Minn. 520,37 N. W. 311 ; Hubbell $r$. Ins. Co., 95 Temm. 585, 32 S. W. 965 ; Wittkowski v. Harris, 64 Fed. Rep. 712.

2. Lloyd v. Giubert. 6 Best \& s. 100: Central Trust Co. v. Burtoll, 74 Wis. $329,43 \mathrm{~N} . \mathrm{W} .1+1$.

3. Peninsular, etr. C $(1$. v. Shand, 3 Moore, P. C. N. S. 272, 290. 
unless the contracting parties clearly appear to have har some other law in view. ${ }^{4}$

Where a proposition to loan money was accepted by the lender in another State where he resided and where the contract was, by its terms to be performed, the contract is governed by the laws of that State." Loans made in other States may be at the rate of interest allowed by the State where the contract or loan is made, althongh such rate is in excess of that fixed by the law of the loaner's residence. ${ }^{6}$ But a note void in the State where it was executed, for usury, cannot be enforced in another State though it would not have been usurious if made in the latter State. $^{7}$

$\S 24$ r. Payment may be controlled by contract.- The parties may contract where the parnent of the rnte secured shall he made. Thus, the parties may agree that the 'ebts shall be paid in a State other than where the contract is liade, and in such case the place where the contract is to be fulfilled will govern, as to the legal effect of the contract. ${ }^{1}$ In case of a mortgage, if the mortgagee resides in the State where the lanrl lies, and the mortgagor in another State, if no place of payment is named, then the law of the mortgagee's State will govern. ${ }^{2}$ The parties

4. Cox v. United Stites, 6 Pet. (U. S.) 172 ; Sendder v. Bank, 91 U. S. 406 ; Pritchard v. Norton, 106 U. S. 124, 1 S. Ct. 102; Lamar v. Mieou, 114 U. S. 21s. 5 S. Ct. 85T; Watts v. Camors, 115 U. S. 353, 362, 6 S. Ct. 91; Liverpool Steam Co. r. Ins. Co.. 129 U. ১. $397,453$. 9 S. Ct. 480 .

5. Bank r. Gibson, 60 Ark. 269 , 30 ‥ W. 39. Sce, also, United States Mort. Co. v. Nprery. 138 U. S. 313, 11 S. Ct. 321: Newman v. Kershaw, 10 Wia. 333; Mills v. Wilson, S Pa. St. Ils; Cope v. Wheeler, 41 K. Y. 303; Dobbin v. Hewitt, 19 La. Ann. 513; Cubbedge v. Napier, 6으 Ala. 518.
6. Sheldon v. Hactun, $91 \mathrm{~N}$. Y. 124: Tilı!en v. Blair, 21 Wall. (U. S.) 241: Sculder v. Bank, $91 \mathrm{U}$. S. 406. 412: Pratt $r$ Adams, 7 Paige (N. Y.), 615: Wayne County Salvings Bank v. Low, 81 N. Y. 566, 37 Am. Rep. 533.

7. MeGarry v. Nieklin, 110 Ala. 559, 17 So. $726,55 \mathrm{Am}$. St. Rep. 40 and note.

1. Slacim r. Pomery, 6 Cranch (U. S.) 221: Duncan v. Heln., 22 Lil. Ann. His: Fitch v. Remer, 1 Flippen, C. C. 15.

2. Mills v. Wilson, ss Par. St. l1s; Pingrey on Mort. 796. 
may stipulate for interest in either State, so long as it be not a plan to cover up a usurious transaction. ${ }^{3}$ But if made payable in another State to cover up usury, the debt will be declared usurious. ${ }^{4}$

When the contract does not control, in determining what law governs the true inquiry is as to the intention of the parties. The fact that the contract would not be held invalid by the laws of the State where the land lies where the mortgagor resides, and where the money is intended to be used, furnishes ground for the presumption that the law there will govern as intended by the parties. ${ }^{5}$ So, a loan made in New Hampshire, upon land in the State, may be made payable in New York, and at a higher rate than allowed by the New Hampshire law. ${ }^{6}$

In respect to mortgages the law of the place of contract, or of the place of performance, determines the question of usury irrespective of the place where the land is situated. ${ }^{7}$ Contracts are to be governed by the law of the place of performance, and, if the interest allowed at the place of performance is higher than that permitted at the place of contract, the parties may stipulate for the higher interest without incurring the penalty of usury. And so, if the rate of interest be higher at the place of contract than at the place of performance, the parties may lawfully contract in that case also for the highest rate. These rules, however, are subject to the qualification that the parties act in good faith, and that

3. Townsend v. Riley, $46 \mathrm{~N}$. H. 300 ; Peck v. Mayo, 14 Vt. 33, 38, 39 Am. Dec. 205; Martin v. Johnson, 84 Ga. 481,10 S. E. 1092 ; Mott v. Rowland, 85 Mich. 56, 48 N. IV. 638; Smith v. Parsons, 55 Minn. 520, 57 N. W. 311: Wittkowski v. Harris, 64 Fed. Rep. 712.

4. Cope v. Wheeler, 41 N. Y. 303 ; Williams v. Fitzhugh, $37 \mathrm{~N}$. Y. 444; Lockwood v. Mitchell, 7 nhio St. 387.
5. Newman v. Kershaw, 10 Wis. 333; Richards v. Bank, 12 Wis. 697 ; Vlict v. Camp, 13 Wis. 208; Chapman v. Robertson, 6 Paige (N. N.) , 627, 31 Am. Dec. 264 and note.

6. 'lownsend v. Riley, 46 N. H. 300.

7. Campion v. Kille, 14 N. J. Eq. 229; DeWolf v. Johnson, 10 Wheat. (U. S.) 367 ; Cotheal v. Blydenburgh, l Halst. (N. J.) 17 , 631; Dolman v. Cook, 14 N. J. Eq. 56. 
the form of the transaction is not adopted to disguise its real character. ${ }^{8}$

$\$ 242$. Computation of interest-At stated periocis.-- Where the paynents are in installnents with interest at certain times, the interest begins from the naking of the contract, and the interest fall due on the specified intervals. ${ }^{9}$ In case of a mortgage, if it provides that the whole debt shall fall due if the interest is not paid when due, the mortgagee can enfurce the payment of the interest alone or the whole debt at his election. ${ }^{10}$ When no payments have been made on the mortgage, the interest must be computed from the date of the note until the rentition of the decree. It must not then be componnied. ${ }^{11}$

A settlement and parment of a debt, with compound interest, where there has been contract to pay interest at stated periods, or to pay interest in that manner, is a usurious transaction. ${ }^{12}$

$\S 243$. The law of another State must be pleaded.- In setting up the usnry law of another State as a defense, it must be averred and proved as a matter of fact. ${ }^{1}$ The defense of usury not having been made, the court should not declare a contract made in another State usurious, although upon its face it bears a rate of interest in excess of that allowed by the law of the State where the suit is brought. ${ }^{2}$

The manner of enforeing the remedy is not binding upon the

8. Gelpeke v. Dubuque, 1 Wall. (U. S.) 175, 206; Hollingsworth v. Detroit, 3 MeLean, C. C. 472 ; Dunlap v. Wiseman, 2 Disney (Ohio), 398. See, also, Clark v. Iowa City, 20 Wall. (U. S.) 583; Genoa v. Woodneff, 92 U. S. 502; Amy v. Dubuque, 98 U. S. 470, 473.

9. Conners v. Holland, 113 Mass. 50: Hastings v. Wiswall, \& Mass. 45.5 .

10. Waples v. Jones. 62 Mo. 440.

11. Barker r. Bank, 80 Ill. 96.
12. Ward v. Bandon, 1 Heisk. (Tenn.) 490.

1. Camp v. Randall, 81 Ala. 240 . 2 So. 287: Klinck v. Price, $4 \mathrm{~W}$. Va. 4, 6 Am. Rep. 268; Campion v. Kille, 14 N. J. Eq. 229; Hosford v. Nichols, 1 Paige, (N. Y.), 220; Dolman v. Cook, 14 N. J. Eq. 56; Antrews v. Torrey, 14 N. J. Eq. 355, 27 Am. Dec. 63.

2. Reiff $r$. Bakken, 36 Minn. 333. 3 I N. W. 348. 
courts of other States. ${ }^{3}$ And when the court can use his discretion, he may refuse to allow the statute of another State, as to the contract, to be set up, where he is of the opinion that such statute is unconscionable. ${ }^{4}$ The defendant should file such a plea as the law of the foreign State prescribes. ${ }^{5}$

3. Matthews v. Wason, 6 Fed. Rep. 461. See, also, Wheelock v. Lee, 64 N. Y. 242; Bissell v. Kel$\log g, 65$ N. Y. 432.

4. Corning $\mathrm{r}$. Lutlum, 28 N. J. Liq. 398.

5. Bowman v. Miller, 25 Gratt. (Va.) 331, 18 Am. Rep. 686. 


\section{CHAPTER VII. \\ Wagers and Gaming Contracts.}

\section{ARTICLE I.}

\section{Wagers in General.}

ŚEction 244. Wagers-Definition.

245. Liability of Wagers at Common Law.

246. In the United States.

24. Statutory Provisions.

$\S$ 244. Wagers-Definition.-A wager is a bet; a contract by which two or more parties agree that a certain sum of money, or other thing, shall be paid or delivered to one of them on the happening or not happening of an uncertain event. ${ }^{1}$ Or it is a promise to pay money or to deliver property upon the determination or ascertainment of an meertain event or fact, the consideration for the promise heing either a present parment or transfer by the other party, or a promise to do so upon the event or fact being determined or aseertained in a partienlar way. $^{2}$ Or it is a contract conditional upon an erent in which the parties have no interest except that which thes create by wager. ${ }^{3}$ But Leake's definition is not broad enough, because parties may make a wager on matter in which they are interested. ${ }^{4}$

It may be defined as an agreement between parties, differing as to an meertain fact $:^{5}$ or a forecast of a futme erent, that on the trancpiring of what will disclose the truth, a designated

1. Bouvier's I. Dict.

4. Anson on Cont. 173.

2. Hampden v. Walsh, 1 Q. B.

5. Goole v. Elliott, 3 Term $R$. Div. 189.

693: Pugh v. Jenkins, 1 Q. B. 631.

3. Lrake on Cont. 377 . 
sum of money or other thing shall be transferred from one who is found to be in the wrong to the other who is ascertained to be in the right." If from the terms of the engagement one of the parties may gain but camnot lose and the other may lose but cannot gain, and there must be either a gain by the one or a loss by the other according to the happening of the contingency, it is a gaming contract. Thus, a merchant who gives to a designated class of customers an opportunity to secure by means of a nickel-slot machine any article of value additional to that for which such customers have paid, is a gaming device, and against the statute as to gaming. ${ }^{7}$

$\$ 245$. Liability of wagers at common law.- Wagers or wagering contracts upon indifferent subjects are valid at common law. ${ }^{1}$ But all wagers which tended to a breach of the peace, or to injure the feelings, character, or interests of third persons, or which are against the principles of morality, or of sound policy, were void at common law. ${ }^{2}$

In England it is held that contracts, although wagers, are not void at common law, and that the statute has not made them illegal but only non-enforceable. ${ }^{3}$ But, in the United States, all wagering contracts are held to be illegal and void as against public policy. ${ }^{4}$

6. Bishop on Cont. 530 .

7. Meyer v. State, 112 Ga. 20 , 37 S. E. 96,51 L. R. A. 496,81 Am. St. Rep. 17. This was a slot machine used by a cigar merchant.

1. Goode v. Elliott, 3 Term Rep. 693; Jones v. Randall, 1 Cowp. 37; Da Costa v. Jones, 2 Cowp. 734; Bunn v. Riker, 4 Johns. (N. Y.) 427, 4 Am. Dec. 292; Bernard v. Taylor, 23 Oreg. 416, 39 P. 968, 37 Ans. St. Rep. 693 and note, 18 L. R. A. 859 and note.

2. 4 Kent's Com. 466: Greenhood's Pub. Pol. 226; Goode v. El- liott, 3 Term R. 693; Da Costa v. Jones, 2 Cowp. 734.

3. Thacker v. Hardy, 4 Q. B. Div. 685, 8 and 9 Vict. c. 109 , sec. 18: Fitch v. Jones, 5 El. \& B. 238.

4. Dickson v. Thomas, $97 \mathrm{~Pa}$. St. 278; Gergory v. Wendell, 40 Mich. 432: Lyon v. Culbertson, 83 Ill. 33, 25 Am. Rep. 349 ; Melchert v. Telegraph Co., 3 MeCreary, C. C. 527 ; Barnard v. Backhaus, 52 Wis. 593, 6 N. 252, 9 N. 595; Kingsbury v. Kirwan, 77 N. Y. 612; Story v. Soloman, 71 N. Y. 420; Love v. Harvey, 114 Mass. 80; Irwin v. IVilliar, 110 U. S. 499,4 S. Ct. 160. 
$\$ 246$. In the Unnited States.- The law is interpreted differently in many of the United States ats to the legality, at common law, of wagering entulats. Hele wagering contracts are roid by the common law, and contracts which are roid at common law, because they are against public policy, like contracts which are prohibited liy statute, are illegal as well as void. They are prohibited hy law becanse they are comsidered ricions, and it is not necessary to impose a penalty in order to render them

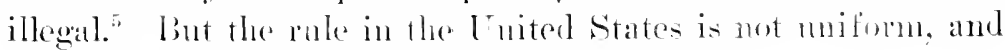
in some States Waloers have heom enforcest."

$\$ 247$. Statutory provisions. - The States have enacted laws making all gambling contracts either roid, or both illegal and roid. By the English statute it is cuacted that any sum or value exceeding $£ 100$ lost in playing at ans game, or in betting on the players, shall not be recoverable, and that any contract or security given for the same shall be roid. Inotler statute provides that secmrities for money lost in playing at games, or betting on the players, or knowingly adranced for such purposes, shall be roid, and that the loser of $£ 10$ or more, after paring it, may recover it back. A later statute, ${ }^{3}$ repealed the act of Inne so far as regarded the aroidance of securities as specified in that act, and provides that they shall thenceforth be taken to have been given originally upon an illegal consideration. Another statute ${ }^{4}$ enacts that all contracts, whether by parol or in

5. Bishop v. Palmer, 146 Mass. 469, 16 N. F. 299, 4 Am. St. Rep. 339: Gibbs v. Gas Co., 130 U. S. 396. 9 S. Ct. 553: Harvey v. Merritt, 150 Mass. 1, 22 N. E. 49. 5 L. R. A. 200 and note, $15 \mathrm{Am}$. St. Rep. 159 ; Love v. Harrey. 114 Mass. 80; West v. Holmes, 26 Vt. 530; EIdred v. Malloy, 2 Colo. 320, 25 Am. Rep. 752; Wheeler v. Spencer, 15 Conn. 28: Bernard v. Taỵlor, 23 Oreg. 416, 39 P. 968, 18 T. R. A. 889 and note, 39 Am. St. Rep. 693 and note: Stoddard v. Martin. I R. I. I, 19 Am. Dec. 643: Lucas v. Harper, 24 Ohio St. 328; Edgall v.
MeLaughlin, 6 Whart. (Pa.) 176; Rice v. Gist, 1 Strob. (S. Car.) 82; Wilkinson v. Towsles, 16 Minn. 299, 10 Am. Dec. 139.

6. Cothran v. Ellis, 125 Ill. 496, 16 N. E. 646; Campbell v. Richardson, 10 Johms. ( N. Y.) 406; Dewees r. Miller. 5 IIarr. (Del.) 347; Trenton Ins. Co. v. Tohnson. 24 N. J. L. 576: Kirkland v. Randen. 8 Tex. 10, 58 Am. Dec. 94; .Tohnson r. Russell, 3i Cal. 6r0.

1. 16 Car. 11, cl. 7 .

2. 9 Anne. ch. 14.

3. 5 and $6 \mathrm{Wm}$. IV, ch. 41 .

4. 8 and 9 Vict., ch. 109. 
writing, by way of gaming or wagering, shall be null and void, and that no suit shall be brought or maintained in any court of law or equity for recorering any sum of money or valuable thing which shall have been deposited in the hands of any person to abide the event on which any wager shall have been made, provided that this statute shall not be deemed to apply to any subscription or contribution, or agreement to subscribe or contribute, for or towards any plates, prizes, or sum of money to be awarded to the winner or winners of any lawful game, sport, pastime, or exercise. This act repeals the statute of 16 Charles and Anne, but has no effect on the act of 5 and 6 William, as to securities. The statutes of the varions States differ considerably and must be consulted in many cases to know what the law is. But all of them bear considerable resemblance to the English.

\section{ARTICIE II.}

\section{Board of Trade Dealings.}

Section 248. Dealing in Futures-When Valid.

249. Options-Futures-Margins.

250. Corners in Grain on Board of Trade.

251. Brokers.

252. Designation of Transaction by the Parties.

253. Construction of Gambling Laws.

254. Intent-Deal in Futures.

255. Selling Commodities not in Existence.

256. Parol Evidence.

257. Rights of Innocent Holder of Note Given on Option Contract.

$\S 24.8$. Dealing in futures-When valid.-Stock exchanges were created because the business requirements made them necessary. Without them those that have products to sell and those that wished to buy would have to spend their time in seeking customers. They are labor-saving concerns, logical, inevitable, and absolutely required for the expansion of trade and commerce of the civilized world. They are necessary to the business world as improved machinery to the manufacturing and farming operations. They are legitimate institutions. 
Their misuse by gamblers does not condemn them. Every invention of man for the amelioration of the race may be diverted, in some particulars, from legitimate channels. All, or nearly all, of the great accumulations of property in the hands of capitalists were obtained in speculation, sometimes legal, sometimes illegal. To assert that the gambling element dominates the stock or produce exchange, is erroncous and far from the facts. Legitimate speculation even in staple products which everybody uses is sometimes burdensome and the States and Congress have enacted laws to regulate such manipulation. These laws will be treated in their proper places in this chapter.

It is well scttled that purchases or sales of commodities of any kind for future delivery are valid when not against a statute, although the seller may not own the commodity at the time the contract is made, and will have no other means of performing than by going into market and making the requisite purchase when the time for delivery arrives. ${ }^{1}$ Marginal contracts which are void by statute, have no reference to transactions between commission merchants, their customers and patrons. ${ }^{2}$ And the mere purchase of stocks on a margin is not necessarily a gambling contract. ${ }^{3}$

Stocks may be bought on credit, just as flour or sugar or any other commodity, and the credit may be for the whole price or for a part of it, and with security or without it. "Margin" is security, nothing more, and the only difference between stocks and other commodities is that as stocks are more commonly made the article of gambling speculation than some other things, and courts are disposed to look more closely into stock transactions to ascertain their true character. If they are real purchases and sales, they are not gambling though they are done partly or wholly on credit. ${ }^{4}$

1. Western Union Telegraph Co. v. Littlejohn, 72 Miss. 1025, 18 So. 418; Warren v. Scanlon. 59 Ill. App. 13s; Hatch v. Douglas, 48 Conn. 116, 40 Am. Rep. 154.
2. Connor v. Black, 119 Mo. 126, 24 S. W. 184.

3. Peters v. Grim, 149 Pa. St. 163, 24 A. 192, 34 Am. St. Rep. 599.

4. IIopkins v. O'Kane, $169 \mathrm{~Pa}$. St. 478,32 A. 429. 
The law against the sale of stocks on margin does not prevent any legitimate transfer of stock, whother through the ageney of a broker or otherwise, nor any legitimate and bona fide pledge of stoek rertificates as security for borrowed money, whether borrowed for the purpose of paying for the stock or any other purpose; and where such is not only the form, but the snbstanee of the eontract, the inhibition of the statute does not apply. ${ }^{5}$

249. Options-Futures-Miargins. - A contract whereby one of the parties is to have the option to buy or sell at a future time a eertain commorlity, on the understanding of both that there is to be no delivery of the eommodity, the party losing to pay to the other the difference in the market price simply, is by common law, as well as by statutes, in nearly all the States, a gaubling contract, or wager upon the future price of the commodity, and is, therefore, void. ${ }^{1}$

If, in a formal contract for the purchase and sale of commodities to be delivered in the future at a fixed price, it is aetually agreed that the commodities shall not be delivered and the price paid, but that, when the appointed time for performance arrives, a settlement shall be made by a payment in money of the differenee between the enntract price and the market price of the commodities at that time, this is a wagering contract. But if it is agreed that the contract shall be performed aceord-

5. Sheehy v. Shinn, 103 Cal. 325, 37 P. 397; Seales v. State (Tex.), 81 S. W. 947.

1. Board of Trade v. Kinsey Co., 121 Fed. Rep. 670; Peterson v. Gurrell, 62 Ill. App. 163; Cover v. Smith, 82 Md. 586, 34 A. 465 ; Connor v. Black, 132 Mo. 150, $33 \mathrm{~S}$. W. 783; Walker v. Johnson, 59 Ill. App. 448: Pearce v. Rice, 142 U. S. 28, 12 S. Ct. 130 ; Jrwine v. Williar, 110 U. S. 499, 505, 4 S. Ct. 501 ; Embrey v. Jemison, 131 U. S. 336. 9 S. Ct. 776 ; Bigelow v. Benedict,
70 N. Y. 202, 26 Am. Rep. 573; Kahn v. Walton, 46 Ohio St. 195 , 20 N. E. 203: Lester v. Buel, 49 Ohio St. 240, 30 N. E. 821,34 Am. St. Rep. 556; Harvey v. Merrill, 150 Mass. 1, 22 N. E. 48, 52 L. R. A. 200, 15 Am. St. Rep. 159; Gregory v. Wandell, 39 Mich. 337, 33 Am. Rep. 390 ; Cockrell v. Thompson. 85 Mo. 510: Rumsey v. Berry, 65 Me. 570; Burt v. Mever, 71 Md. 467,18 A. 746 ; Stewart v. Schall, 65 Md. 289, 4 A. 399. 
ing to its terms if either party requires it, and either party shall have a right to require it, the contract is not a wagering contract because one or both parties intend, when the tine for performance arrives, not to require performance, but to substitute therefor a settlenent by the payment of the difference between the contract price and the market price at that time.

To constitute a wagering contract, it is sufficient, whatever may be the form of the contract, that both parties understand and intend that one party shall not be bound to deliver the commodity and the other to receive it and pay the price, but that the settlement shatl be made by the payment of the difference in prices. ${ }^{2}$

In general, where a person contracts with another to purchase stock for him with the muderstanding that the stock shall not be delivered and that the only difference in the market price shall be paid or received, the transaction is a wager on future market price and is roid under the statute. ${ }^{3}$ But a future sale and delivery of a commodity at a fixed price, with a bona fide intention to fulfill the requirement of the agreement, is valid and not a wagering contract. ${ }^{4}$ But a statute invalidating contracts giv-

2. Junn v. Bell. 8.5 Tenn. 581. 4 S. IV. 4l: Pearce v. Foot. 113 Ill. 2.05. 55 Am. Rep. 414; Flagg v. Gilpin. 17 R. I. 10. 19 A. 1084; Mohr v. Miesen, 47 Minn. 22s, 49 N. W. S62: Lawt on v. Bletch, 83 Ga. 663, 10 S. F. 353; Kirkpatrick ऽ. Bonsall, 72 Pa. St. 155; Maxton v. Groen, 75 Pa. St. 160; Fveringham v. Meighan. 5.5 Wis. 354, 13 N. 269; Lowry v. Dillman, 59 Wis. 197, 18 N. 14; Cothran v. Ellis, 125 I11. 496, 16 N. E. 648; Shaw v, Clark, 49 Mich. 384, 13 \. 78ti. 43 Am. Rep. 474; Bullard v. Smith, 139 Mass. 49.2. 2 N. E. 86; Harvey v. Merrill, 150 Mass. 1. 22 N. L. 49. 5 I. R. A. 200 and note, 15 Am. St. Rep. 59; Whitesides v. Hunt, 97 Ind. 191, $49 \mathrm{Am}$. Rep. 44; Crawford v. Spenser, 92 Mo. 498, $4 \mathrm{~S}$.
IV. 113. 1 Am. St. Rep. 145 and note; White $v$. Barber, 123 C. .'. 392,8 S. Ct. 221 ; Tomblin $r$. ('allen, 69) Iowa, 229, 28 N. W. 573; Pickering v. Cease, 79 Ill. 32S: IIcGrew v. Produce Exchange, 8.5 Tenn. 572, 4 S. W. 38, 4 Am. St. Rep. 771; Lyon v. Culbertson, 8:3 Ill. 33, 25 An. Rep. 349; Johnson v. Kaune, 21 No. App. 22.

3. Standard Mill Co. v. Flower, 46 La. Amm. 315, 15 So. 16; West v. Wright. 86 Hum, 43t, 33 N. Y. S. ses: Kingsbury v. Kirwan 77 X. $\mathrm{Y}$. 612: Story v. Saloman, 71 N. $Y$. 420 ; Sichreiner $v$ Orr, 55 Mo. App. 406: Cover v. Smith, S2 Md. 586, 34 A. 465; Conner v. Black, $132 \mathrm{Mo}$ 150, 33 s. W. 783.

4. Cleves v. Jamison, 182 U. S. 461,21 S. Ct. S45. 
ing an option to sell or buy, at a future time any commodity, whether delivery is contemplated or not, is not in violation of any constitutional provision. ${ }^{5}$ This is on the ground that if, by taking all the circumstances that attend the pursuit of a particular vocation, the State thinks that certain admitted evils cannot be successfully reached unless that calling be actually prohibited, the courts cannot interfere, unless an unmistakable infringement of right secured by the fundamental law. Such statute must be deemed a valid law, and as such must be enforced, though it infringes to a degree upon the property right of citizens, as it prevents option contracts which are wagering. A calling may not in itself be immoral, and yet the tendency of what is generally or ordinarily or often done in pursuing that calling may be towards that which is admittedly immoral or pernicious. The object of this legislation is to suppress absolutely gambling in future sales, and to this extent private rights must be deemed secondary to the public good.

A contract which on its face is one of sale with a provision for future delivery, being valid, the burden of proving that it is invalid, as being a mere cover for the settlement of difference rests with the party making the assertion. ${ }^{6}$ And the defendant may introduce the charter of a stock exchange to show that it makes only actual sales, and has no right to deal in futures. ${ }^{7}$

$\S 250$. Corners in grain on board of trade. - Contracts to corner the market in relation to grain or other commodity are made void by statute or are void because against public policy. ${ }^{\mathbf{1}}$ And also a loan for making a corner is void. ${ }^{2}$ A combination of several parties to enhance the price of grain by making large purchases and preventing a fair selling thereof, whereby an

5. Booth v. Illinois, 184 U. S. 425, 22 S. Ct. 425,186 Ill. 43,57 N. E. 798,50 L. R. A. 762,78 Am. St. Rep. 229 and note.

6. Clews v. Jamison, 182 U. S. 461,21 S. Ct. 845 .
7. Scales v. State (Tex.), $81 \mathrm{~S}$. W. 947 .

1. Craft v. MeConoughy, $79 \mathrm{Ill}$. 346, 22 Am. Rep. 171; Samuels v. Oliver, 130 Ill. 73,22 N. E. 499.

2. Raymond v. Leavitt, 46 Mich. 447,9 N. 525. 
immense lot of grain is put into the hands of a firm in the combine, and thus forcing up the price of grain in the market, is contrary to public policy and no party to the agreement can maintain an action for services growing out of the transaction. ${ }^{3}$

Legitimate dealing on the board of trade is as valid as other sales and purchases of grain and such contracts will be enforced by the courts. And where, in a contract, the term "market price" is used, parties will be conclusively held to have had in contemplation an honest market price, and not any fictitious or corner price which might possibly occur upon the market or exchange involved; or the average market price of the lawful market on the board of trade. ${ }^{4}$

$\S 25$ r. Brokers. - A broker may negotiate a wagering contract without being privy to the illegal intent of the principal parties to it which renders it void, and in such ease, being innocent of any violation of law, and not suing to enforce an unlawful contract, has a meritorious ground for the recovery of compensation for services advanced. But when the broker is privy to the unlawful design of the parties, and brings them together for the purpose of entering into an illegal agreement, he is particeps criminis, and cannot recover for services rendered or losses incurred by himself on behalf of either in forwarding the transaction. ${ }^{5}$

The weight of authority in the United States is that brokers who knowingly make contracts that are void and illegal as against public policy, and advance money on account of them at

3. Foss v. Cummings, 149 Ill. 353, 36 N. E. 553.

4. Waite v. Paud (Chi. Super. Ct.), 25 Nat. Cor. Rep. 118, 37 Chi. Leg. News, 25.

5. Embrey v. Jemison, 131 U. S. 336, 9 S. Ct. 776 ; Harvey v. Merrill, 150 Mass. 1, 22 N. E. 41 J, 5 L. R. A. 200 and note, 15 Am. St. Rep. 159. See, also, Kahn v. Walton, 46 Ohio St. 195, 20 N. E. 203; Cothran v. Ellis, 125 Ill. 496, 16
N. E. 646 ; Fareira v. Gabell, 89 Pa. St. 89; Crawford v. Spencer, 92 Mo. 498, 4 S. WV. 713, 1 Am. St. Rep. 745 and note; Lowry v. Dillman, 59 Wis. 197,18 N. 4; Whitesides v. Hunt, 97 Ind. 191, 49 Am. Rep. 441 ; First Nat. Bank v. Packing Co., 66 Iowa, 41, 23 N. W. 255; Rumsey v. Berry, 65 Me. 570; DeMary v. Bartenshaw, 131 Mich. 326,91 N. IV. 647. 
the request of their principals, camnot recover either the money advanesed or their commissions."

And where the purchase or sale of a commodity is adopted as a morle to dingnise a wager mpon the manket price of the commodity at a future time, the fact that one of the parties assumes to make the purchase, or sale, as a commission merchant only, will not alter the relation in which they stand as parties to the wager. Each is in law particeps criminis. ${ }^{7}$

\section{$\$ 252$. Designation of transaction by the parties.-The} designation given to the transactions by the parties themselves is not conclusively determinative of their character or of their legallity. ${ }^{1}$ Whether a transaction or a series of transactions between a broker and his customer for the purchase of stocks that are not immediately delivered, or of which an immediate delivery is not contemplated, is in contravention of the statute, is a question to be determined in each particular case, and the circumstances under which the transaction is had, and the conduct of the parties in reference thereto, will have great influence in determining this fact. ${ }^{2}$ It is not the purpose of the statute to interfere with legitimate husiness, or to make void all time contracts for the purchase of shares in incorporated companies. ${ }^{3}$

\$253. Construction of gambling laws.- The court will take judicial knowledge that the object of these statutes was to strike

6. Embrey v. Jemison, 131 U. S. 336,9 S. Ct. 776; Harvey v. Merrill, 150 Nass. 1, 22 N. E. 419. 5 L. R. A. 200 and note; $15 \mathrm{Am}$. St. Rep. 159.

7. Lester v. Buel, 49 Ohio St. 240, 39 N. E. 821,34 Am. St. Rep. 556; Kaln v. Walton, 46 Ohio St. 195. 20 N. E. 203; Pearee v. Foot. 113 Tll. 228: Conners v. Black, 119 No. 126, 24 S. W. 184; Dows v. Glaspel, 4 N. Dak. 257,60 N. W. 60; Pope v. Hanke, 155 Ill. 617, 40 N. E. 839,28 L. R. A. 568.
1. Kullman v. Simmes, 104 Cal. 595, 35 P. 362.

2. Kullman v. Simmes, 104 Cal. 595, 38 P. 362.

3. Cashman v. Root, 89 Cal. 373 , 26 P. 883,12 L. R. A. 511, 23 Am. St. Rep. 482 . See, also, Hatch v. Donglas, 48 Conn. 116, 40 Am. Rep. 154: Peters v. Grim, 149 Pa. St. 163, 24 A. 192, 34 Am. St. Rep. 599: Scales v. State (Tex.), 81 S. W. 947 . 
down a species of gambling in commundities, wherein parties are wont to contract for the purchaso of eommodities to be delivered at a future day, mpon the speconlation that they womld advance in price suflieiently to meet their agreements or pur-

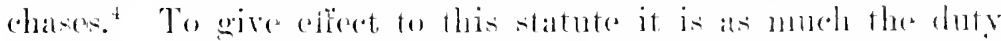
of the courts to see that it is not evaded as that it is not directly rishated." But there is no warrant for comstruines the statmte with any mucasonable strictness. It should be construed justly, to the end that the logishative intention may he acomplished. Legitimate lansactions on the board of trade are of the ntmost importance in commerce. Such contracts, whether for immediate or future delivery, are valid in law, and reeeive its sanction and all the support that can be given then. It is against gambling contracts that the law applies, and no subtle construction ansht to be andopted to defeal the end of justice.

$\$ 254$. Intent-Deal in futures. - Where the transaetions for the delivery and sale of commodities in the future are not made with the intention that any commodity shall be receired or delivered, but that the understanding that eaeh transaetion shall be settled by the payment of the differenee between the eontract price and the market price at the time fixed, they are mere wagers or gambling contrats and are void. ${ }^{1}$ This intention may be established not merely by the assertion of the parties but by all the attending eireumstances of the transactions $;^{2}$ and is

4. Cashman v. Root, 89 Cal. 373 , 20 P. 883, 12 L. R. A. 511, 23 Am. St. Rep. 482.

5. Sheeliy v. Shinn, 103 Cal. 325 , 37 P. 393.

6. Pearce v. Foote, 113 Ill. 228, 239. 5.5 Am. Rep. 414.

1. Jamison v. Wallice, 167 Ill. 388, 47 N. E. 762,59 Am. St. Rep. 302; Schneider v. Turner, 130111. 2S, 22 N. E. 497,6 L. R. A. 164 and note; Cothran v. Ellis, 125 Ill. 196. 16 N. E. 646; Pope v. Hanke, 155
Ill. 617, 40 N. E. 839, 28 L. R. A. 568 ; Barnard v. Backhaus, 52 Wis. 593, 6 N. 252, 9 N. 595; Crawford v. Spencer, 92 Mo. $498,4 \mathrm{~S}$. II. 713 , 1 Am. St. Rep. 745 and note; First Nat. Bank v. Packing Co., 66 Iowa, 41, 23 N. IT. 255.

2. Crawford v. Spencer, 92 Mo. 498, 4 S. W. 713,1 Am. St. Rep. 745 and note; Pope v. Hanke, 155 Ill. 617,40 N. E. 839,28 L. R. A. 568. 
a question for the jury, to be determined by the circumstances of all the evidence. ${ }^{3}$

In regard to option contracts, they are valid and enforceable. If it is not the intention in making a contract, that any property shall be delivered or paid for, but that the fictitious sale shall be settled on differences, the contract is void. But if it is the bona fide intention of the seller to deliver, or the buyer to pay, and the option consists merely in the right of delivery within a given time, the contract is valid, and the putting up of margins to cover losses which may accrue from the fluctuations of prices is legitimate and proper, ${ }^{4}$ while this is the law, yet several States have passed laws making all option contracts invalid as gambling contracts and, therefore, void. These statutes are constitutional and are given their full force by the courts. $^{5}$

$\S 255$. Selling commodities not in existence.- At one time it was held that when the vendor had neither the commodities, nor entertained any contract to buy them, at the time of the sale, nor had any reasonable expectation of receiving them by consignment, but intended to go into the market and buy the articles he engaged to deliver, no action could be maintained on such contract. That doctrine has been changed by the au-

3. Hill v. Johnson, 38 Mo. App. 383 ; Pope v. Hanke, 155 Ill. 617, 40 N. E. 839,28 L. R. A. 568.

4. Bigelow v. Benedict, $79 \mathrm{~N}$. Y. 202 ; Kirkpatrick v. Bonsal, $72 \mathrm{~Pa}$. St. 155; Hanna v. Ingram, 93 Ala. 482, 9 So. 621; Pieronnet v. Lull, 10 Neb. 45,6 N. 759 ; Lester v. Buel, 49 Ohio St. 249,30 N. E. 821,34 Am. St. Rep. 556; Godman v. Meixel, 65 Ind. 32 ; Clewes v. Jamison, 182 U. S. 461,21 S. Ct. 845.

5. Booth v. Illinois, 184 U. S. 425,21 S. Ct. 845,186 I1l. 43, 50 L. R. A. 762, 78 Am. St. Rep. 229 and note, 57 N. E. 79 ; Schneider v. Turner, 130 Ill. 28,21 N. E. 497,6
I. R. A. 164 and note; Fichter v. Frank, 41 Fed. Rep. 859; Osgood v. Bender, 75 Iowa, 550,39 N. W. 887,1 L. R. A. 655 and note, 82 Iowa, 171,47 N. W. 100; Schlee v. Guckenkeimer, 179 Ill. 593, $54 \mathrm{~N}$. E. 302 ; Minnesota Lumber Co. v. Coal Co., 160 Ill. 85, 43 N. E. 774; Preston v. Smith, 156 Ill. 359, 40 N. E. 949, 31 L. R. A. 529 ; Burnett v. Baxter, 64 Ill. App. 544; Corcoran v. Coal Co., 138 Ill. 390, 28 N. E. 759 ; People v. Booth, 186 Ill. 43,57 N. E. 798,50 L. R. A. 762 , 184 U. S. 425,21 S. Ct. 485, 78 Am. St. Rep. 229 and note. 
thorities of to-day, and now the vendor may contract for the sale of an article not in his possession, and such rule is entirely in aceordance with public policy. ${ }^{1}$ If this was not the rule, the mercantile business of the present day could no longer be suecessfully carried on if merchants and dealers were unable to purchase that which as to them had no actual or potential existence. A dealer has a clear right to sell and agree to deliver at some future time that which he then has not, but expects to go into the market and buy; and it is equally clear that the parties may mutually agree that there need not be a present delivery of the eommodities, but that such delivery may take place at some other time. ${ }^{2}$ But there is a difference, and a distinction must be made between a contract where there is a bona fide intent to fulfill the agreements according to their terms, and those where the difference in the market price is to be paid. If the parties agree at the time of making the contract that no title to any property shall pass or any delivery be made, or when, from the nature of the contract, it must be apparent that the intent of the parties was such that at some future specified time the party losing should pay to the other the difference between the selling price at that time and the time of making the contract, it will be a contract which the law refuses to enforce, for the reason that it is clearly a wager upon the price of the eommodity, at some future day. ${ }^{3}$

1. Bryan v. Lewis, Ry. \& Moody, 386, a; Walcott v. Heath, is Ill. 433 ; Rumsey v. Berry, 65 Me. 570 ; Ashton v. Dakin, 4 Hurl. \& N. 867; Cole v. Milmine, 88 Ill. 349; Logan v. Musie, 81 Ill. 415; Gregory v. Wendell, 39 Mich. 337, 33 Am. Rep. 390 ; Bona's Appeal, 55 Pa. St. 294; Noyes v. Spaulding, $27 \mathrm{Vt}$. 420; Hibblewhite v. McNlorine, 5 Mees. \& Wel. 462; Kingsbury v. Kirwin, 43 N. Y. Super. 45l; Pixley v. Boynton, 79 I1l. 351.

2. Gregory v. Wendell, 39 Mich. 337, 33 Am. Rep. 340.
3. Whitesides v. Hunt. 97 Ind. 191, 49 Am. Rep. 441; Grizwood v. Blane, 11 C. B. 526; Yerkes v. Saloman, 11 Hun (N. Y.), 471; Cameron v. Durkheim, 55 N. Y. 425; Story v. Salomon, 71 N. Y. 420; Pickering v. Cease, 79 Ill. 328; Iyon v. Culbertson, 83 Ill. 33. 25 Am. Rep. 349 ; Bigelow v. Benedict, 70 N. Y. 202, 26 Am. Rep. 573; Maxton v. Gheen, 75 Pa. St. 166; Peabody r. Speyers, 56 N. Y. 230; Williams v. Tiedemann, 6 Mo. App. 299 ; Sampson v. Shaw, 101 Mass. 145. 3 Am. Rep. 327 ; Kirkpatrick 
$\S$ 256. Parol evidence-Charter of corporation.- Parol evidence is admissible between the parties when the contract was made; that the commodity should not be delivered but that only the difference in the market price should be paid or reeeived. ${ }^{4}$ And so the intention that none of the commodity in question shonld be delivered may be shown by parol evidence, and that the difference in the market price should be adjusted between the parties. ${ }^{5}$ And a charter of a stock exchange may be offered in evidence to show what powers the exchanges have in selling commodities, and that only actual sales are made. ${ }^{6}$

\section{$\S 257$. Rights of innocent holder of note given on option} contract.- The general rule is that illegality of consideration, even though such consideration grows out of an act prohibited by statute, camnot be set up against the bona fide assignee of a note, unless the statute expressly, or by necessary implication, declares the note to be void. ${ }^{1}$ That such notes are void between the parties does not admit of discussion. ${ }^{2}$

Some of the expressions in the text-books are to the effect that, where a statute expressly declares the contract or transaction which forms the consideration of the note or bill illegal, it is void in the hands of a bona fide holder for value; but the

v. Bonsall, 72 Pa. St. 155: Rudolf v. Winters, 7 Nebr. 125; Bartlett v. Smith, 13 Fed. Rep. 263; Barnard v. Backhaus, 52 IVis. 593, 6 N. 252,9 N. 595 ; Seales v. State (Tex.), 81 S. IV. 947.

4. West v. Wright, 86 Hun, 436 , 33 N. Y. S. 898 ; Watte v. Wiekersham, 27 Neb. 457, 43 N. Wr. 259; Sprague v. Warren, 26 Nebr. 326, 41 N. W. 1113,3 L. R. A. 679 and note; Boyd v. Hanson, 41 Fed. Rep. 174.

5. Dwight v. Badgley, 60 Hun (N. Y.), 144, 14 N. Y. S. 498; Gaw v. Bennett, 153 Pa. St. 247, 25 A. 414, 34 Am. St. Rep. 699; Hentz v. Jewell, 20 Fed. Rep. 592.
6. Scales v. State (Tex.). $81 \mathrm{~S}$. IV. 947 .

1. Pope v. Hanke, 155 Ill. 617, 40 N. E. 839,28 L. R. A. 568; Daniel on Neg. Inst. 197, 808, 3 Kent's Com. 79, 80; Thacker v. Hardy, 4 Q. B. Div. 685; Cunningham v. Bank, 71 Ga. 490; Lully v. Morgan, 21 D. C. 88; Grizewood v. Blane, 11 C. B. 526. See, also, Lyons v. Hodgen, $90 \mathrm{Ky} .280,13 \mathrm{~S}$. IV. 1076 ; Compare Shaw v. Clark, 49 Mich. 384, 13 N. 786, 43 Am. Rep. 474; Third Nat. Bank v. Harrison, 10 Fed. Rep. 243.

2. Bride v. Clark, 161 Mass. 130, 36 N. E. 745. 
weight of authority sustains the position llat, while such note or bill is roid al lectreen the parties to it, it is not roid as against the holder for value without notice muless the statute also declares the note or bill itself to be void. ${ }^{3}$ Illegality is not the circunstance which aroids negotiable securities in the hands of a bona fide holder, because, in the absonce of exprese declaration by the legislatme that the securities shall he wirl, it will la no defense against a bona fide holder, without notice of the illegality. To hold such notes void, in the absence of statutory provisions dectaring them void, would be materially to ohatruet, the circulation of negotiable instruments, and thereby serionsly embarrass mereantile transactions. They are only voirl in the hamels of an immocent party for value, when the statute declares them roid. ${ }^{5}$

\section{ARTICLE III. \\ Rigits Under Gambing Contracts.}

Section 258. Law of the Place-Gambling Contracts.

259. Recovering Back the Money Lost.

260. Constitutionality of Statute to Recover Back Money Lost in Wagering Contracts.

261. Action to Recover Back Money Lost in Gambling Contract.

262. Offering a Reward or Premium.

263. Entrance Fee-Competitors in Horse Racing.

264. Bookmaking and Pool Selling.

265. Difference Between Wager and Preminm or Reward.

$\S 258$. Law of the place-Gambling contracts.- A contract that is ralid in one State will be enforced in another State, unless it is against good morals, or is repugnant to the policy or positive institutions and laws of such State. ${ }^{1}$ The nature, valid-

3. Daniel Neg. Inst. S08; Eagle v. Koln, 84 Ill. 292; Chit. on Bills, 115. 116.

4. Pope v. Hanke, 155 III. 617, 40 N. E. 839,28 L. R. A. 568.

5. Traders Bank v. Alsop. 64 Iowa, 97, 9 N. 863; Barnhard $v$.
Backlaus, 52 Wis. 593, 6 N. 252, 9 N. 595; Pope v. Hanke, 155 Ill. 617. See, also. Vallett v. Parker, 6) Wend. (N. Y.) 61 \%.

1. Phinney v. Baldwin, $16 \mathrm{Ill}$. 108, 61 Am. Dec. 62; Numford v. Canty, 50 Ill. 370, 99 Am. Dec. 525. 
ity, and interpretation of contracts must be governed by the laws of the country where made or where they are to be performed. ${ }^{2}$

But the law of any State has no force or validity proprio vigore beyond the territorial limits of the State. Whatever extraterritorial validity it may have is owing to the comity which prevails between different States or nations. That comity does not require that such law should be executed when it is against the public policy of the State where the remedy is sought, or in violation of its own laws. ${ }^{3}$ Hence, the validity of a note in the hands of an innocent holder in the State where the contract was made, does not require the enforcement of such note by the courts of another State, in which the statute makes such notes void eren in the hands of a bona fide holder. ${ }^{4}$

If the transactions out of which an alleged debt arose occurred in a State, and are within the statute prohibiting gambling and both parties are citizens of such State, a court of equity of this State will restrain the creditor from proceeding against the debtor in another State to which the creditor has resorted to evade the laws of the State where the contract was made. $^{5}$

$\S 259$. Recovering back the money lost.- The right of action to recover back money paid in pursuance of a wagering contract depends wholly upon the statute; no remedy being allowed at common law. ${ }^{6}$ The party having knowingly partici-

2. Evans v. Anderson, 78 Ill. 558; Austedt v. Sutter, 30 Ill. 164; Yeatman v. Cullen, 5 Blackf. (Ind.) 280; Woodruff v. Hill, 116 Mass. 310 .

3. Mumford v. Canty, 50 Ill. 370 ; Faulknor v. Hyman, 142 Mass. 53,6 N. E. 846 ; Hill v. Spear, 50 N. H. 253, 9 Am. Rep. 205; Fisher v. Lord, 63 N. H. 514, 3 A. 927.

4. Pope v. Hanke, 155 Ill. 617,40 N. E. 839,28 L. R. A. 568.

5. Miller v. Gittings, $85 \mathrm{Md}$. 601,
37 A. 372,37 L. R. A. 654, 60 Am. St. Rep. 352. See, also, Bushby v. Wunday, 5 Madd. 297 ; Portarlington v. Soulby, 3 Mylne \& K. 104 ; Keyser v. Rice, 47 Md. 203, 28 Am. Rep. 448; Cole v. Cunningham, 133 U. S. 107, 10 S. Ct. 241; Densmore v. Neuesheimer, 32 Hun (N. Y.), 204 ; Don v. Lippman, 5 Cl. \& F. 8 ; Liverpool Marine Credit Co. v. Hunter, 3 Ch. App. 486.

6. Weyburn v. White, 22 Barb. (N. Y.) 82. 
pated in an illegal transaction, the common law will leave him without remedy in case of loss. ${ }^{7}$

But in most of the States a statute has been passed giving the loser the right to recover back the money lost in a wagering contract.

$\$ 260$. Constitutionality of statute to recover back money lost in wagering contract.-The acts relative to wagering contracts in securities and commorlities are constitutional, ${ }^{\mathrm{s}}$ on the principle that the laws aiming at the suppression of gambling contracts are for the public good. Neither is the objection tenable that the statute is unconstitutional because it makes certain conduct prima facie evidence of the existence of certain facts. ${ }^{9}$

$\S 26 \mathrm{I}$. Action to recover back money lost in gambling contracts. - An action for money had and received, which has been lost in gambling contracts, is an action on contract. ${ }^{10}$ And demand for the money lost before commeneing action is not necessary in order to maintain suit for the recovery of money lost in gaming. ${ }^{11}$

$\S 262$. Offering a reward or premium. - The mere trotting or racing of horses, when done in a proper manner and not in the public streets or highways, is not an illegal act at common law; and it is well settled that betting on the result of a horse race is not illegal at common law. ${ }^{12}$ The mere racing or trotting of

7. Crawford v. Spencer, 92 Mo. 498, 4 S. IV. 713, 1 Am. St. Rep. 745 and note; Irwin v. Williar, 110 U. S. 499,4 S. Ct. 160 ; Embrey v. Jemison, 131 U. S. 336, 9 S. Ct. 776 ; Phelps v. Holderness, 56 Ark. 300,19 S. W. 921 ; Dows v. Glaspel, 4 N. Dak. 25l, 60 N. W. 60.

8. Crandell v. White, 164 Mass. 54, 41 N. E. 204.

9. Holmes v. Hunt, 122 Mass. 505, 23 Am. Rep. 381.
10. Crandell v. White, 164 Mass. 54, 21 N. E. 204.

11. Johnson v. MICGregor, 55 Ill. App. 530.

12. See Da Costa v. Jones, Cowp. 729; Goode v. Elliott, 3 Term R. 693; McAllester v. Haden, 2 Camp. 43S; Blaston v. Pye, 2 Wils. 309; Gibbons v. Gouverneur, 1 Denio ( $N$. Y.), 170; Van Valkenburgh v. Torrey, 7 Cow. (N. Y.) 252; Bunn v. Riker, 4 Johns. (N. Y.) 426, 4 
horses, when eonducted in a proper place and in a proper manner, is not an illegal act. Offering a reward or premium to the successful competitor in such a race or trot is therefore just as lawful as the offering a reward for competing in any other lawful business: ${ }^{13}$ but in some states such reward is prohibited in certain cases. ${ }^{14}$

$\$ 263$. Entrance fee-Competitors in horse racing.-The fact that the parties competing for the reward or preminm offered are required to pay something in the way of an entrance fee before they are allowed to compete does not make the transaction a betting or gaming transaction. All competitors for preminus in agrieultural societies are required to pay an entrance fee, and these entrance fees go to make up the premiums offered to the competitors. ${ }^{1}$ It is only when it is shown that the offering a reward or premium to the competitors is a mere subterfuge for bettting and gaming on a horse-race or an uncertain event, that it comes within the law prohibiting betting and gaming. ${ }^{2}$ Thus, if two men owning trotting horses should contribute equally or otherwise a sum of money, and put it into the hands of some other person for the purpose of offering it as a premium or reward to them only, and to the owner of the horse that should win the race, such a transaction will come under the rule that prohibits betting on a horse or other race. ${ }^{3}$

$\S 264$. Bookmaking and pool selling.- That bookmaking and pool-selling are each betting upon the horse-race or particular event upon which they are made or sold, is not questioned. In

Am. Dec. 292; Campbell v. Ricl-ardson, 10 Johns. (N. Y.) 406.

13. Porter v. Day, $7 \mathrm{I}$ Wis. 296,37 N. IV. 259; Harris v. White, $81 \mathrm{~N}$. Y. 532; Misner v. Knapp, 13 Org. 135, 9 P. 65, 57 Am. Rep. 6; Delier v. Agri. Society, 57 Iowa, 481, 10 N. 872 ; Alvord v. Smith, 63 Ind. 58.

14. Bronson Agri. \& B. Asso. v. Ramsdell, 24 Mich. 441.
1. People v. Fallon, 4 App. Div. 82,39 N. Y. S. 865; Biegler v. Trust Co., 62 Ill. App. 560; Ballard v. Brown, 67 Vt. 586, 32 A. 485; Porter v. Day, 71 Wis. 296, 37 N. W. 259.

2. Gibbons v. Gonverneur, 1 Denio (N. Y.), 170.

3. Gibbons v. Gouverneur, 1 Denio (N. Y.), 170. 
the first, the betting is with the book-makers; in the second, the betting is among the purchasers of the pool, the paying a commission to the seller. ${ }^{1}$ In Illinois the proviso of the act against book-making and pool selling, that its provisions shall not apply to the actual enclosure of fair or race-track association, confers no such right to carry on book-making and pool-selling within such enclosure. ${ }^{2}$

\section{$\S 265$. Difference between wager and premium or reward.-} A bet or wager is ordinarily an agreement between two or more persons that a sum of money or some valuable thing, in contributing which all agreeing take part, shall become the property of one or more of them on the happening in the future of an event at the present uncertain, and the stake is the money or thing thus put upon the chance. There is in a wager this element that does not enter into a premium or reward, that each party to the wager gets a chance of gain from others, and takes a risk of his own to them. I premium is ordinarily some valuable thing, offered by a person for the doing of something by others, into the competition of which he does not enter. $\mathrm{He}$ has no chance of gaining the thing offered; and if he abides by this offer, that he must loose it and give it orer to some of those contending for it is reasonably certain. ${ }^{3}$

This is the difference, when a premimn or prize is offered in good faith to the winner in a competitive contest, which contest is not unlawful in itself, the transaction is a lawful one, and the person offering the prize or premium will be held liable in the law to make good his offer to the winner. ${ }^{4}$

1. James v. State, 63 Mr. 242 ; Commonwealth r. Simonds, $79 \mathrm{Ky}$. 618.

2. Swigart v. People, 154 Ill. 284, 40 N. E. 432 ; Chicago v. Brownell, 146 Ill. 64,34 N. E. 595. See, also,
State v. Falk, 66 Conn. 250, 33 A. 913.

3. Harris v. White, 81 N. Y. 532.

4. Porter r. Day, il IVis. 296, 37 N. W. 259. 


\section{AR'TICLE IY.}

\section{Insurance Contracts.}

Sector 266. Wagering Contrats of Insurance.

26i. Assignment of Policy.

268. Limiting Amount of Debt in Insurance.

269. Benevolent Associations.

$\S 256$. Wagering contracts of insurance.-At common law, wagering contracts of insurance were valid, and no insurable interest was necessary to make eontraet valid. ${ }^{1}$ But in the United States, irrespective of statute, contracts of insurance with a person who has no insurable interest in the property or life are mere wagering contracts, and are void. ${ }^{2}$ In order to take the case ont of the objection of being a wager policy, it is necessary to show that the insured has some interest in the life of the cestui que vie; so that the real purpose is not a wager, but to secure such advantage, supposed to depend on the life of another. Whatever may be the nature of such interest, and whatever the amount insured, it can work no injury to the insurers, because the premium is proportioned to the amount; and whether the insurance be to a large or small amount, the premium is computed to be a precise equivalent for the risk taken. $^{3}$ Wagering contracts of insurance have been repudiated generally in the United States. ${ }^{4}$

1. New York Life Ins. Co. v Rosenheim, 56 Mo. App. 27; Dean v. Dicker, 2 Stra. 1250; Kemp v. Vigne, 1 Term R. 304; Trenton Ins. Co. v. Johnnson, 24 N. J. L. 576 ; Buehanan v. Ins. Co., 6 Cow. (N. Y.) 318; Clendening v. Chureh, 3 Caines (N. Y.). I41; Lord v. Dall, 12 Mass. 115, 117,7 Am. Dee. 38 and note; Dalby v. Life Assur. Co., 15 C. B. 365.

2. Loomis v. Ins. Co., 6 Gray (Mass.), 396; Lord v. Dall, I2 Mass. 115. $7 \mathrm{Am}$. Dee. 38 and note;
Stevens v. Warren, 101 Mass. 565; Beseh v. Ins. Co., 28 Ind. 64; Sweeney v. Ins. Co., 20 Pa. St. 337; Fowler v. Ins. Co., 26 N. Y. 422; Crotty v. Ins. Co., I44 U. S. 621 , I2 s. Ct. 749 .

3. Loomis v. Ins. Co., 6 Gray (Mass.), 396 ; Ky. L. \& C. Ins. Co. v. Hamilton, 63 Fed. Rep. 93, 11 (.) C. A. 42,22 U. S. App. 386 .

4. Cammack v. Lewis, I7 Wall. (U. S.) 612; Crotty v. Ins. Co., 144 U. S. 621,12 S. Ct. 749 . 
$\$ 267$. Assignment of policy.-It is gencrally held that where a policy is valid at its inception, it may he assigned to one not having an interest in the life of the insured, where not used to cover up a wagering contract. 'The rule gathered from the decisions is that where one takes ont a policy upon his own life as an honest and bonu fide transaction, and the anomut insured is made payable to a person having no interest in the life, or where such polieg is assigned to one laving no interest in the life, the bencficiary in the one case and the assignee in the other may hold and enforce the policy if it was valid in its inception, and the policy was not procured or the assigmment made as a contrivance to cireumvent the law against betting, gambling and wagering policies. ${ }^{2}$ But there is respectable opposition to this doetrine, and it is held that the assignment of a policy to a party not having an insurable interest is as objectionable as the taking out of the poliey in his name, and such poliey is then void. $^{3}$

$\S 268$. Limiting amount of debt in the insurance.- In case of a creditor and debtor, the policy camnot be limited to the amount of the debt. If it was otherwise the creditor wonld be compelled to lose whatever sums he might be required to pay in effecting the insurance and paving preminums. The bene-

1. Nye $v$ Graind Lodge, 9 Ind. App. 131: Classey v. Ins. Co., 84 Hun (N. Y.), 350,32 N. Y. S. 335 ; Olmstead v. Tieyes, 85 N. I. 593 ; Honston v. Merrifield, 51 Ind. 24. 19 Am. Rep. 722 ; St. John v. Ins. Co., 13 N. Y. 31, 64 Am. Dec. 529: Valton v. Ins. Co., 20 N. Y. 32 : Mutual Life Ins. Co. v. Allen, 138 Mass. 24, 52 Am. Rop. 245; Eckel v. Renne, 41 Olio St. 232; Martin v. Stubbins, 126 Ill. 387 , is N. E. 657. 9 Am. St. Rep. 6:0: Fitzgerald v. Ins. Co., 56 Conn. 116, 13 A. 673 , 17 A. 411, 7 Am. liep. 28s: Clark v. Allen, 11 R. I. 430; Ritter v. Smith, 70 M[d. 260, 16 A. 890 ; Ash- liy v. Asluler, 3 Sim. 149: Bursinger v. Bank, 67 Wis. 75, $30 \mathrm{~N}$. II. $290,5 \mathrm{~S}$ Am. Rep. 848 and note; Murphy $\checkmark$. Reell, 64 Miss. 614, $1 \mathrm{~S}$. 11. 761 .

2. Olmstead r. Keyes, 85 N. Y. 593 ; Classey v. Ins. Co.. 84 Hum ( N. Y.), 350, 32 N. Y. S. 335.

3. Warnock v. Davis, 104 U. S. 402: Cammack v. Lewis, 15 Wall. (U. S.) 643; Missouri Valley L. Ins. Co. v. Sturges, 18 Kim. 93, 26 Am. Rep. 671; Bosye r. Adams, 81 Ky. 368: Franklin L. Ins. Co. v. llazzard, 41 lnd. I2I; Crotty v. 1ns. Co.. 144 U. S. 621, 12 S. Ct. 749. 
ficiary takes the chances of all future contingencies. ${ }^{1}$ In Pennsylavania ererlitors insured their debtor, a healthy man of fortytwo years of age, in the sum of $\$ 3,000$, to protect a debt of about $\$ 100$. The expectancy of life of the insured was twenty-six years, and the assessment and annual dues during such time would have, together with the interest, amounted to $\$ 4,336$, and the court held that it was not a gambling transaction and that a recovery for the full amomt of the policy could be sustained. ${ }^{2}$ And so where the assignee pays $\$ 300$ for the assignment of a policy for $\$ 2,000$, and agrees to pay the dues and assessments on the policy, in the absence of proof of any age or expectancy of life of the insured, the court cannot say, as a matter of law, that the sale or assignment was tainted with the vice of gambling, such question usually being one of fact. ${ }^{3}$

$\S 269$. Benevolent associations. - In the ordinary life insurance, the beneficiary named in the policy acquires an interest in the policy, but in benevolent associations, the beneficiary acquires no vested interest until the death of the insured. ${ }^{4}$ In benevolent associations, if any person is designated as a beneficiary who does not come within the classes named, the designation is invalid. 5 The association can only pay the fund to the persons designated in its constitution and by-laws, or the statute creating it. And if it should promise to pay to some other person the promise is roid $;^{6}$ so wagering contracts cannot be created in this kind of insurance.

1. Arnick v. Butler, 111 Ind. 578, 12 N. E. 518, 60 Am. Rep. 722 and note.

2. Uhrich v. Reinachl, $143 \mathrm{~Pa}$. St. 238, 22 A. 862,13 L. R. A. 433 and note, 24 Am. St. Rep. 534.

3. Nye v. Grand Lodge, 9 Ind. App. 131, 36 N. E. 429.

4. Holland v. Taylor, 111 Ind. 121, 12 N. E. 116: Masonic Mut. Ben. Soc. v. Burkhart, 110 Ind. 189 , 10 N. E. 79,11 N. E. 449.
5. Daniels $\because$ Pratt, 143 Mass. 216, 10 N. E. 166; Rindge v. Aid Soc., 146 Mass. 286,15 N. E. 628.

6. Britton v. Royal Arcanum, 46 N. J. Eq. 102, 18 A. 675, 19 Am. St. Rep. 376 ; Knights v. Nairn, 60 Mich. 44,26 N. IV. 826 ; Michigan Mut. Ben. Asso. v. Rolfe, 70 Mich. I 46, 42 N. W. 1094; Sanger v. Rothschild, 123 N. T. 577,26 N. E. 3. 


\section{AR'TICLE $Y$.}

\section{LOTTERT Dealings.}

Secriox 270. Lattery-Definition - Trading stamps.

27 . (iratuitous Distribution of P'roperty by Lot or Chance.

272 . Sale of Lottery Tickets.

273. Lottery company Chartered by the Lewi-lature.

\section{$\$$ 270. Lottery - Definition - Trading stamps. - 1 lottery} is a scheme by which, on one's paying money or some other thing of value, he obtains the contingent right to have something of greater value, if on appeal to chance, by lot or otherwise, under the direction of the manager of the scheme, it should decide in his faror.' Or it is a transaction where a pecuniary consideration is paid, and it is to be determined by lot or chance, according to some schenie held out to the public, what and how much he who pars the noney is to receive for it. ${ }^{2}$

The term lottery has no technical meaning. The statutes generally declare a lottery to be a scheme for the distribution of property by chance among persons who have paid or agreed to pay a valuable consideration for the chance, whether called a lottery, rafle, or gift enterprise or by some other name." Every lottery has the characteristies of a wager or bet, although every bet is not a lottery. The courts have shown a general disposition to bring within the term lottery erery species of gaming, involving a distribution of prizes by lot or chance, and which comes within the mischief to be remedied." Any scheme for the distribution of prizes, by lot or chance, by which one, on paying money to another, obtains a token, which entitles him to reccive a larger value or nothing, as some formula or chance may determine, is a lottery. ${ }^{5}$ But a guessing contest where one

1. Cross v. People, is Colo. 321. 32 P. 821, 38 Am. St. Rep. 292.

2. Hull v. Ruggles, 56 N. Y. 424 : Barelay v. Pearson (1893), 2 Ch. 154.

3. State v. Moren. 48 Minn. 555. 51 N. II. 618.
4. Yellow stme Kit v. State. 88 Ala. 196, T So. 338, T L. R. A. 559 and note, 16 Am. St. liep. 38 and note.

5. State v. Boneil, 42 La. Ann. 1110. 8 So. 300,21 Am. St. Rep. 413; Dumn v. People, 40 Ill. 465; 
pays money to guess on the number of rotes that will be east for a candidate or any other guessing of the number of things and the like is not a caming transaction or lottery. And if the party paying to gness has any right to recover the money paid, it is on the gronul that the contest is illegal at conmon law or against public poliey. ${ }^{6}$

The law prohibiting the use of trading stamps is unconstitutional. Such law does not eome within the police power of the State. The use of trading stamps is not injurions to the public. And if such use does seriously interfere with the business of others, this will not make it an illegal act. Hence such statute is not the ralid exercise of the legishative power and is, therefore, unconstitutional. ${ }^{7}$ Such a scheme is not a gift enterprise, because it is not a distribution of article; by chance, ${ }^{8}$ as is done in a gift enterprise. ${ }^{9}$

However, the courts are not in harmony as to the legality of prohibition of the use of trading stamps. So it has been held that giving trading stamps is not a lottery or gift enterprise in the ordinary sense, yet it is within the terms of the prohibition of gift enterprises under the act of Congress of 1873, and therefore the issuing of trading stamps to customers is illegal. ${ }^{10}$ In Rhode Island a statute which prohibits the merchant from giving to the purchaser, as part of the same transaction, a stamp, coupon, or other device, which would entitle him to receive from a third person some article, well-defined article, in addition to the one sold, is an unwarranted interference with personal liberty guaranteed by the State and the Federal Constitu-

Commonwealth v. Sheriff, 10 Phil. (Pa.) 203; Holman v. State, 2 Tex. App. 610; Chavannah v. State, 49 Ala. 396 ; Commonwealth v. Wright, 137 Mass. 250, 50 Am. Rep. 306; Hull v. Ruggles, 65 Barb. (N. Y.) 432 ; State v. Clarke, 33 N. H. 329 , $66 \mathrm{Am}$. Dec. 723; State r. Bryant, 74 N. Car. 207; Randle v. State, 42 Tex. 580.

6. Stevens v. Cincin. Enquirer Co.. Court Inlex, Noy. 8, 1902.
7. Young v. Commonwealth (Va.), 45 S. E. 327 ; State v. Dalton, 22 R. I. 77,46 A. 234,84 Am. Rep. 818 .

8. State v. Shugart, 138 Ala. 86, 35 So. 28.

9. Lolman v. State, 81 Ind. 17 ; Marseve v. Anderson, 106 Mass. 422 ; State v. Shugart. 138 Ala. 86, 35 So. 28.

10. Lansburg v. Dist. Col., 11 App. I. C. 512. 
tion. ${ }^{11}$ So a statute is unconstitutional so far as it prohibits a corporation trom issuing trading stamps and selling the same to merchants for distribution to their customers, to be exchanged for articles of fixed value at the option of the holder of the stamp. ${ }^{12}$

A statute making it a misdemeanor to issne trading stamps muless they bear upon their face the amount for which they can he redeemed in ash, is unconstitutional.

In Massachusetts a statute prohibiting the use of stamps is limited to the use of such stamp in a way that involves some chance: in such case the issuing of stamps is illegal. ${ }^{13}$ In Maryland a statute making it mularul to issue trading stamps which are not releemable out of ans artieles that are certain and known to the purchaser at the time of his purchase is ralid though a provision of it prohibiting the redemption at any other place than that of the purchase is invalid. ${ }^{14}$ In ease there is no statute plohiliting the issue of trading stamps, their use is not a lotterr or gift enterprise and there is nothing illegal in such use. ${ }^{15}$

27I. Gratuitous distribution of property by lot or chance. - The gratuitous distribution of money or property ly lot has never prevailed to such an extent as to require police regulation at the hands of the State. The history of lotteries both in England and in the Tnited States shows that they have been schemes for the distribution of money or property by lot in which chances were sold for money, either directly or through some cunning device. The element of a valuable consideration, parted with, directly or indirectly. by the purchaser of the

11. State v. Dalton, 2.2 R. 1. 77 . 46 A. 234,48 L. R. A. 7.5. St Am. St. Rep. 818 .

12. People v. Dycker. i2 App. Dir. 309, 76 N. Y. s. 111.

13. Commonwealth r. Sisson. 178 Mass. 578, 60 N. E. 385.

14. State v. Hawkins. is Md. 133, 11 A. 8.50, 93 An. Si. liep. 328.
15. State v. Shligart, 138 Ala. 86,35 tho. 28 . Sice, also, Winston v. Beeson (X. Car.), 4TS. F. 4.5 . ree Whether the Giving of Traling Stamp is Subject to Prohihitory Legislation, 57 Cent. L. Jour. 421. The Latest Development of the Interstate c'ommerce Lower-The Lottery Tickets Case-l Mich. I. Review, 115. 
chance, must enter into the transaction in order to constitute a lottery. ${ }^{16}$ And so acts that declare that 10 person sliall give away anything to a purchaser of goods, wares or merchandise, as an inducement to make the purchase, are invalid. Because such regulation of trade is unlawful, as it is not for the welfare of the poople, but oppression and hurdensome to the people. ${ }^{17}$

There is no law which prolnibits the gratuitons distribution of one's property by lot or chance. If the distribution is a pure gift or bounty, and not in name or pretense merely, which is designed to evade the law-if it is entirely unsupported by any valuable consideration moving from the taker-there is nothing in this mode of conferring it which is violative of the policy of the statute condemning lotteries, or gaming.. ${ }^{\text {is }}$

$\S 272$. Sale of lottery tickets. - It is made illegal to sell lottery tickets. So a principal cannot recover money received by his alleged agent from the sale of lottery tickets delivered to the latter by the former under an agreement that he shall account for the proceeds." And so where the proprietor of a "guessing contest." has received the money paid for guessing, he cannot be compelled to pay it to the winner. ${ }^{2}$ So, where clubs of forty persons each are formed by a merchant-tailor for the disposition of suits of elothing, each of the stipulated value of $\$ 40$,

16. State v. Munford, 73 Mo. 747 ; Hull v. Ruggles, 56 N. Y. 424; Thomas v. People, 59 Ill. 160 ; Dumn v. People, 40 Ill. 465; United States v. Olney, I Deady, D. C. 461 ; Bell v. State, 5 Snced (Temn.), 507 ; Buckalew v. State, 62 Ala. 334, 34t Am. Rep. 22; Governor v. Art Union, 7 N. Y. 228; Yellow Stone Kit v. State, 88 A'a. 196, 7 So. 338, 7 L. R. A. 559 and note, 16 Am. St. Rep. 38 and note; Long v. State, 74 Md. 565, 22 A. 4, 12 L. R. A. 425 , 28 Am. St. Rep. 268.

17. People v. Gillson, 109 N. Y. 389, 17 N. E. 343, 4 An. St. Rep. 465 ; In re Jacobs, 98 N. Y. 98, 56 Am. Rep. 636 and note; Butchers' Union Co. v. Creseent City Co.. 111
U. S. 746, 4 S. Ct. 652; Toledo, etc., Co. v. Jacksonville, 67 Ill. 46; Long v. State, 74 Md. 565, 22 A. 4, 12 L. R. A. 425, 28 Am. St. Rep. 268.

18. United States $\nabla$. Olney, I Deady, D. C. 461,1 Abb. C. C. 275 ; Ehrgatt v. Mayor, 95 N. Y. 264, 48 Am. Rep. 622; Commonwealth v. Thacher, 97 Mass. 583, 93 Am. Dec. 125; Cross v. People, 18 Colo. 221, 32 P. 821,36 Am. St. Rep. 292.

1. Mexican International Banking Co. v. Lichtenstein, 10 Utah, 338, 37 P. 574; Udall v. Metcalf, 5 N. H. 396 .

2. Barelay v. Pearson (1893), 2 Ch. 154. 
by lot, under nominal contracts of purchase, the price to bo paid in weekly installments of $\$ 1$ each, such payments entitling the holders of tiekets to participate in weekly drawings by lot, with the chance of securing goods of the value of $\$ 40$ at any drawing, without further additional payments than the weekly installments paid, the transaction is a lottery and illegal. ${ }^{3}$ So, sending lottery tickets from one State to another to be sold or used is interstate commerce, ean he regulated by Congress. Therefore, Congress can prohibit the carriage of lottery tickets from one State to another. ${ }^{4}$ And an anti-policy law will be upheld which makes the possession by any person, other than an officer, of any paper or document representing a chance or interest in a game, eommonly called "policy," presumptive evidence of wrongful possession. ${ }^{5}$

\section{$\S 273$. Lottery company chartered by the Legislature.-} The legislature cannot, by chartering a lottery company, defeat the will of the people of the State authoritatively expressed in relation to the continuance of such business in their midst. Because lotteries are a species of gambling and wrong in their influence, the right to suppress them is govermmental, to be exercised at all times by those in power, at their discretion. An one, therefore, who accepts a lottery charter does so with the implied understanding that the people, in their sorereign capacity and through their properly constituted agencies, may resume it at any time when the public good shall require, whether it be paid for or not. All that one ean get by such eharter is a suspension of certain governmental rights in his favor subject to withdrawal at will. He has, in legal effect, nothing more than a license to enjoy the privilege on the terms named for the specified time, unless it be sooner abrogated by the sovereign power of the State. ${ }^{1}$

3. State v. Moren, 48 Minn. 55.5, 51 N. II. 618 .

4. Champion v. Ames, 188 U. S. 321, 23 S. Ct. 321,26 Nat. Cor. Rep. 76.

5. Adams v. New York, 192 U.
S. 585; People v. Adams, 176 N. Y. 351, 68 N. E. 636,98 Am. St. Rep. 675 and note.

1. Stone v. Mississippi, 101 U.S. 814: Douglas v. Kentucky, 168 U. S. 488,18 S. Ct. 199. 



\section{PART II.}

CONTRACTS AGAINST PUBLIC POLICY.

(283) 



\section{PART III.}

\section{CHAPTER VIII.}

What is Public Policy.

\section{ARTICLE I. \\ The General Doctrine.}

Section 274. Public Policy-How Determined.

275. Defense of Public Policy.

276. Stipulation that False Representations Shan not Avoid tns Contract.

277. Contracts for Welfare of Children.

278. Contracts Payable in Gold Coin.

§ 274. Public policy-How determined.-The public policy of nations must be determined by its constitution, laws, and judicial decisions. ${ }^{1}$ And as a nation advances in civilization, public policy may mean more than at the inception of government. Take the subject of lotteries as an example. Formerly in many States lotteries were legitimate and the sale of tickets was sanctioned. Schools and colleges were established by funds received from the traffic of lottery tiekets. Now such eoneerns are prohibited by all the States.

At the beginning of the last century the Federal government ran a lottery and the drawings were supervised by Washington and Adams. Even religious bodies entered into lottery schemes to build their churches. This traffic has fallen within the police power of the nation, and Congress, acting for the nation, has declared a previonsly" lawful business unlawful, and prohibits

1. United States v. Freight Asso., v. Girard, 2 How. (C.S.) 127, 197; 166 U. S. 290, 17 S. Ct. 546; Vidal Swann r. Swann, 21 Fed. Rep. 299. 
it for all time. All this is because the needs of our government demand it; and this prohibition cannot be overestimated.

But it must be understood that the rules which say a given contract is void, as being against public policy, must not be extended arbitrarily, because, if there is one thing which, more than another, public policy requires, it is that men of full age and competent understanding shall have the utmost liberty to contract, and that their contracts when entered into freely and voluntarily shall be held valid, and shall be enforced by courts of justice. ${ }^{2}$

The common law will not permit individuals to obligate themselves by a contract, either to do or not to do anything, when the thing to be done or omitted is in any' degree clearly injurious to the public $;^{3}$ and a contract is not void as against public policy unless it is injurious to the interest of the public or contravenes some established interest of society. ${ }^{4}$

Public policy, in the administration of the law by the courts, is essentially different from what may be public policy in the view of the legislature. With the legislature it may be, and often is, nothing more than expediency. The public policy which dictates the enactment of a law is determined by the wisdom of the legislature. ${ }^{5}$ But in the absence of any statute forbidding the making of certain contracts, a court can find a contract void because it has a tendency to injure the public, or is against the public good. To be void it must be inconsistent with sound policy and good morals as to the consideration or thing to be done. ${ }^{6}$

Where the transaction is nothing more or less than the acceptance by the party of a bribe to perform his duties in a manner

2. Printing Numerical Registering Co. v. Sampson, L. R. 19 Eq. Cas. 462, 465; Hulse v. Machine Co., 65 Fed. Rep. 864 , 13 C. C. A. 180, 25 U. S. App. 239; In re Garcelon, 104 Cal. 590, 38 P. 413, 32 I. R. A. 595 and note.

3. Chappel v. Brockway, 21 Went. ( Y. Y.) 159.
4. Peterson v. Christensen, 26 Minn. 377,4 N. 623.

5. Enders v. Enders, $164 \mathrm{~Pa}$. St. 266, 30 A. 129,27 L. R. A. 56 and note, 44 Am. St. Rep. 598.

6. Trist v. Child, 21 Wall. (U. S.) 448 . 
desired by the person who gives the bribe, it is void as against public policy. ${ }^{7}$ But a doubtful matter of public policy is not sufficient to invalidate a contract. An agreement is not void on this ground unless it expressly and unquestionably contravenes public policy, and is manifestly injurious to the interest of the State ${ }^{8}$ if it is then it is void. ${ }^{9}$ But if a contract is valid when made, it is not affected by a change in the public policy of the State. ${ }^{10}$

The public policy of the government is to be found in its statutes, and when they have not directly spoken, then in the decisions of the courts and the constant practice of the government officials; but when the law-making power speaks on a particular sulject, orer which it has constitutional powers public policy in such a case is what the statute enacts. And a contract or combination made in violation of a law is void, whaterer may have been theretofore decided by the courts to have been the public policy of the country on the subject. ${ }^{11}$ And a contract which endeavors to modify the statute of limitations is void, because it is against public policy. ${ }^{12}$ And an agreement that an attorney shall have part of the alimony awarded his client is roid as it contravenes public polier, and is also nonassignable. ${ }^{13}$

In the Lottery Case $^{14}$ the Trnited States Supreme Court held that the traffic in lottery tickets contravenes public policy. If Congress has power to declare a traffic prejudicial to the public morals and, therefore, unlawful, it has the power to declare a

7. Harrington v. Dock Co., 3 Q. B. Div. 549 ; West v. Camden, 135 U. S. 507, 10 S. Ct. 832; Fuller v. Dawe, 18 Pick. (Mass.) 472; Lum v. MeEwen, 56 Minn. $278,57 \mathrm{~N}$. IV. 662 ; Smith v. Humphrey, 88 Me. 345.

8. MeCandless $v$. Steel Co., 152 Pa. St. 139, 25 A. 579; Vocke v. Peters, 58 111. App. 338.

9. Meridian Water Co. v. Sehulhorr (Miss.), 17 So. 167.

10. Stephens v. Railroad Co., 109
Cal. 86,41 P. 783,29 I. R. A. 751 , 50 Am. St. Rep. 17.

11. United States v. Freight Asso., 166 U. S. 290, 17 S. Ct. 540.

12. Miller v. Ins. Co., 54 Neb. 121, 74 N. W. 416, 69 Am. St. Rep. 709 .

13. Lynde $v$ Lỵnde, $64 \mathrm{~N}$. J. Eq. 736, 52 A. 694, 97 Am. St. Rep. 692.

14. Champion r. Ames, $188 \mathrm{U}$. S. 321,23 S. Ct. 321 . 
traftic prejudicial to public interests and, therefore, illegal, by reason of oppression of the consumer by combinations which stifle competition. If Congress has power to condemn interstate traffic becanse it is immoral and prejudicial to public interests, it also has the power to declare it prejudicial for any other purpose, such as the interstate transportation of all commodities, the product of combinations. The Lottery Case is confined only to such traffic as public policy condemns as immoral or prejudicial to health, and left undecided the question whether such prohibition would be justified if the business wore not inherently immoral or unwholesome but prejudicial to the public welfare by reason of economic consideration, such as the stifling of competition.

So, contracts against the morals of the people are void. At common law the keeping of a house of prostitution is an indictable offense. Such places are regarded with so much disfavor, that not only the keeper of the house, but also a landlord, knowingly leasing the same for the purpose of bawdry, is held to be guilty of a criminal offense when the house is actually put to immoral use. ${ }^{15}$ So, where a lessor of the premises knows or ought to know that they will be used for unlawful purposes, the lease is void, and the obligation of the lessee to pay will not be enforced by the court. ${ }^{16}$ An agreement which contravenes any statute for the protection of public morals is void. ${ }^{17}$

So, an agreement in consideration of future illicit cohabitation between man and woman is void, and past cohabitation does not form an adequate consideration not under seal, even if it

15. Commonwealth v. Harrington, 3 Pick. (Mass.) 26; Dougherty v. Seymour, 16 Colo. 289,26 P. 823. See, also, Niver v. Best, 10 Barb. (N. Y.) 369 ; Pearce v. Brooks, L. R. 1 Exch. 213; Shankel v. Moflatt, 53 Ill. App. 382; Smith v. White, L. R. 1 Eq. 626 .

16. Ernst v. Crosby, 140 N. Y. 364,35 N. E. 603; Compare Hul- bard v. Moore, 24 La. Ann. 591; Lyman v. Townshend, 24 La. Ann. 625, 13 Am. Rep. 128; Mahood v. Teazle, 26 La. Ann. 108, 21 Am. Rep. 546; Sampson v. Townshend, 25 La. Ann. 78.

17. Ritchie v. Smith, 6 C. B. 462; Cowan v. Milbourn, L. R. 2 Exch. 230; Compare O'Brien v. Prictenbach, 1 Hilt. (N. Y.) 304. 
does when made under seal $;^{18}$ and it is immaterial whether the contract is by parol or under seal, if it be for further intercourse; if under seal the illegality of the consideration will aroid the contract; so no contract can be made for futme illicit cohabitation. ${ }^{19}$

\section{$\S 275$. Defense of public policy - Waving the statute of} limitations - Marriage brokerage.-The defense of public policy does not proceed so much upon the idea of relief to an innocent party as protection to the public by withholding legal remedies from the party contemplating or practicing an imposition. It would be a strange rule of law which would extend relief to a particeps criminis, and withhold relief from an innocent party who seeks to avail himself of its protection when the imposition is discovered. ${ }^{1}$ But a person who has derived benefit from a contract which is void as against public policy is not estopped thereby' to defend against such contract when it is sought to be enforced against him. ${ }^{2}$

In some States a party may waive the statute of limitations at the time he signs a note, and such action is not against public policy. ${ }^{3}$

The doctrine is that murriage brokerage contracts are roid in this country and in England. The interference by one upon an agreement to receive a moneyed or valuable consideration to in-

18. Wallace v. Rappleye, $103 \mathrm{Ill}$. 229 ; Trovinger v. McBurney, 5 Cow. (N. Y.) 253; Gray v. Mathias, 5 Ves. 286.

19. Dreeman v. Douglass, 102 Ill. 341, 40 Am. Rep. 595; Hanks v. Nagles, 54 Cal. 51, 35 Am. Rep. 67 and note; Baldy v. Stratton, 11 Pa. St. 316; Walker v. Gregory, 36 Ala. 180; Massey v. Wallace, $32 \mathrm{~S}$. Car. 149, 10 S. E. 937 ; De Sobry v. De Laistre, 2 Har. \& J. (MIl.) 191, 3 Am. Dee. 535.

1. Cowan v. Mlilbourn, I Exch. 230; Spotswood v. Barrow, 5 Exch.
110; Holman v. Johnson, Cowp. 34 ; Chureh v. Proetor, 66 Fed. Rep. 240,13 C. A. A. 426,33 U. S. App. 1.

2. Brown v. Bank, 137 Ind. 655, 37 N. E. 158, 24 L. R. A. 206; Hutehinson v. Weldin, 114 Ind. 80, 15 N. E. 804; Wheeler v. Whceler, 5 Lans. (N. Y.) 355; Snyder v. Willey, 33 Mich. 483.

3. State Trust Co. v. Shellon, 68 Vt. 259, 35 A. 17i; Bridges v. Stephens, 132 Mo. 524, 34 S. IV. 5.55. 
duce or bring about a marriage between others has always been held roid." Hence, a contract made by an aged man with bis grandson, that if the latter will aid the grandfather in inducing a young lady to marry him, the grandfather will deliver to the graudson a note he holds against him, is against public policy and is void. ${ }^{5}$

Contracts made with "matrimonial bureans" are illegal; and while such contracts are illegal, yet the courts will aid a party who has patronized such a business by relieving him or her from all contracts made, and will grant restitution of any money paid or property transferred, on the principle that he is not equally guilty. ${ }^{6}$ Where a party carries on a business of promoting marriage, the natural tendency of such a business is immoral and it would be so clearly the policy of the law to suppress it, and public interest would be so greatly promoted by its suppression, that the courts will not hesitate to aid the party who has patronized such a business by relieving him or her from all contracts made, and grant restitution of any money paid or property transferred. In that way only could the policy of the law be enforced and public interest promoted. ${ }^{7}$ The question of this kind must always be whether the parties are equally guilty. Cases may arise where the court would be justified in holding as a matter of law that neither party had any remedy, as where there is an agreement between two, having for its purpose the marriage of one to a third party, in which case the parties would be clearly in pari delicto. So if two parties enter into a partnership to carry on negotiations for the promotion of marriage, neither party would have relief in court. ${ }^{8}$

4. Johnson v. Hunt, $81 \mathrm{Ky} .321$; Hall v. Potter, 3 Lev. 411 ; Keat. v. Allen, 2 Vern. 588.

5. Johnson v. Hunt, $81 \mathrm{Ky} .321$.

6. Duval v. Wellman, $12+\mathrm{N}$. Y. 156,26 N. E. 343 ; Smith v. Bruning, 2 Vern. 392; Goldsmith v. Bruning, 1 Eq. Cas. Abr. 89; Taylor v. Bowers, 1 Q. B. D. 291.

7. Duval v. Wellman, 124 N. Y. 156,26 N. E. 243 .
8. Duval v. Wellman, 124 N. Y. 156, 26 N. E. 343 ; Kearley v. Thomson, 24 Q. B. D. 742, criticizing Taylor v. Bowers, 1 Q. B. D. 291, where it is held that if money is paid for an illegal purpose the person who has paid the money may recover it back before the illegal purpose is completed. Compare Glanville v. Jennings, 3 Rep. in Ch. 31. 
But the courts make a distinction as to the party paying money or other property, to a matrimonial broker, and hold that the customer is not equally guilty with the broker, and hence, the customer may recover back the money paid. ${ }^{9}$

\section{$\$ 276$. Stipulation that false representations shall not avoid} the contract. - A stipulation in a contract that false representations used in procuring it shall not affect its validity, is itself invalid and has no effect whatever. ${ }^{1}$ So, where one party to a contract has perpetrated a fraud upon the other by means of which the other was induced to enter into the contract, the latter cannot be precluded from seeking redress by a provision in the contract purporting to grant to the former immunity against the consequences of any fraud. ${ }^{2}$ No authority can be found that a party who had perpetrated a fraud upon another, may, nevertheless, contract with him in the very instrument by means of which it was perpetrated, for immunity against its consequences. Public policy and morality are both ignored if such an agreement can be given effect in a court of justice. Such a clause of immunity from fraudulent representations cannot be separated from the transaction in which it originated. It is tainted with the same vice and must share the same condemnation. This doctrine is sound and supported by analogy, and must be sustained. ${ }^{3}$

The clause cannot be given any greater effect than if it had been written upon a separate piece of paper after the execution of the contract and signed by the partics. It cannot operate by way of estoppel for the reason that the statements were false to the party's knowledge, who made them. A mere device of

9. Duval v. Wellman, $124 \mathrm{~N}$. Y. 156, 26 N. E. 343.

1. Hofflin v. Moss, 67 Fed. Rep. 440,14 C. C. A. 459,32 U. S. App. 200.

2. Bridger v. Goldsmith, $143 \mathrm{~N}$. Y. 424,38 N. E. 458 .

3. Smyth v. Munroe, 84 N. Y. 361 ; Steel v. Smelting Co., 106 U. S. 447,1 S. Ct. 389 ; Wilcox v.
Howell, 44 N. Y. 39S; Shapley v. Abbott, 42 N. Y. 443, 1 Am. Rep. 548; Hutchins v. Hebbard, $34 \mathrm{~N}$. Y. 24; Universal Fashion Co. v. Spencer, 64 Hun (N. Y.), 293, 19 N. Y. S. 62 ; Kneetle v. Neweomb, 22 N. Y. 249, is Am. Dec. 156; Bell v. Leggatt, 8 N. Y. $176,59 \mathrm{Am}$. Dec. 476 ; Sedgwick v. Stanton, 14 N. Y. 289. 
a guilty party to a contract intended to shield himself from the results of his own fraud, practiced upon the other party, cannot be set up as an equitable estoppel. ${ }^{4}$

\section{$\S 277$. Contracts for welfare of children.- A contract of a} parent, by which he bargains away for a consideration the custody of his child to a stranger, he attempting to relieve himself from all parental obligations, and place the burden on another, who accepts it, withont natural affection or moral obligation to prompt to the performance of parental duty, but only because of a bargain, is void, as against public policy. Such a contract would be a mere sale of the child for money. ${ }^{5}$ But where parental solicitude and affection are not extinguished, and where the welfare of the child is intended to be promoted, a contract by parents in reduced circumstances and grand-parents of good character and ample means, that the grandparents shall bring up the child, is not against public policy. ${ }^{6}$ And it has been decided that contracts of the parents are not against public policy, although made with strangers to the blood; because of the special facts, and on the ground that the contract was for the welfare of the child. ${ }^{?}$

$\$ 278$. Contracts payable in gold coin.-Contracts made payable in gold coin of the United States are not against public policy and are valid. ${ }^{1}$

No transaction of commerce or business, or obligation for

4. Bridger v. Goldsmith, $143 \mathrm{~N}$. Y. 424. 38 N. E. 458.

5. Chapsky v. Wood, 26 Kans. 650, 40 Am. Rep. 321 and note; State v. Clover, 16 N. J. L. 419 ; Johnson v. Terry, 34 Conn. 259.

6. Enders v. Enders, $164 \mathrm{~Pa}$. St. 266, 30 A. 129, 27 L. R. A. 56 and note, 44 Am. St. Rep. 598.

7. Van Dyne v. Vreeland, 11 N. J. Eq. 371; Hill v. Gomme, 1 Beav. 541. See, also, Bently v. Terry, 59 Ga. 555, 27 Am. Rep. 399.
1. Brown v. Rodes, 7 Wall. (U. S.) 229 ; Trebilcock v. Wilson, 12 Wall. (U. S.) 687 ; Belford v. Woodward, 158 Ill. 122, 41 N. E. 1092, 29 L. R. A. 593 and note. See, also, Judson v. Bessemer, 87 Ala. 240, 6 So. 267,4 L. R. A. 742; Dennis v. Moses, 18 Wash. 537, 52 P. 333; Farson v. Louisville, $97 \mathrm{~K} v$. 119 , 30 S. W. 17 ; Blanck v. Sadlier, 153 N. Y. 551,47 N. E. 920 ; Murphy v. San Luis Obispo, 119 Cal. 624, 51 P. 1085, 39 L. R. A. 444. 
the payment of money that is not immoral in its character and which is not, in its manifest purpose, detrimental to the peace, good order and general interest of socicty, can be declared or held to be invalid because enforced or made payable in gold coin or currency when that is established or recognized by the government. ${ }^{2}$

And any alets by State authority impairing or lessening the validity or negotiability of obligations thus made payable in gold coin are violative of the laws and constituton of the United States. ${ }^{3}$

The agreement to pay eoin is as much of the consideration as the agreement to pay at all, and the presumption is that an ample equivalent has been received for the promise. The parties are competent to contract, the contract is not against public police, it is not prohibited by law, it is payable in a lawful kind of moner, and is a lawful contract. ${ }^{4}$

Contracts to pay gold coin are simply engagements for the delivery of a specific conmodity, or to deliver a certain weight of standard gold, to be ascertained by a count of coins, each of which is certified to contain a definite proportion of that weight. It is not distinguishable in principle from a contract to deliver an equal weight of bullion of equal fineness. ${ }^{5}$

Under the doctrine of the courts Congress will have no anthority to legislate against such contracts, for such contracts are an engagement for the delivery of a specific commodity. Congress cannot interfere with and assume to regulate the husiness dealings of eitizens except under some power $\mathrm{cx}$ pressly granted by the Federal constitution. ${ }^{6}$ Neither can the

2. Woodruff $\vee$ Mississippi, 162 U. S. 291,16 S. Ct. 820 ; Wallace v. Eldridge, 27 Cal. 498; Carpenter v. Atherton, 25 Cal. 564; Harding v. Cowing, 2S Cal. 213; Julliard v. Greenman, 110 U. S. 421,4 S. Ct. 122; Hagar v. Reclanation Dist., 111 U. S. 701, 4 S. Ct. 663 ; Belford v. Woodward, 158 Ill. 122, 41 N. E. 1097, 29 L. R. A. 593 and note;
Skinner v. Sinta Rosil, 107 Cal. 464 , 40 P. Tt2.

3. Woodruff v. Mississippi, 162 U. S. 291,16 S. Ct. S20.

4. Carpenter v. Atherton, 25 Cal. 564 .

5. Brown v. Rodes, 7 Wall. (U. S.) 229,250 .

6. Brown v. Rodes, 7 Wall. (U. S.) 229 . 
State legislate to regulate such contracts, as such legislation would be in violation of the Federal constitution. ${ }^{\text {? }}$

There are State decisions, rendered before the United States Supreme Court decision, which hold that a contract payable in gold may be discharged by payment of any legal tender money of the same nominal value. ${ }^{8}$ But the weight of authority is that the contract must be paid in gold when so stipulated, as shown by cases already cited. If a party insists upon payment of gold coin as stipulated in his contract, if the State court decides against him, he can appeal to the United States Supreme Court, because such judgment is a denial of a right, privilege, and immunity claimed under the constitution and statutes of the United States $;^{9}$ hence, the final arbiter is the United States Supreme Court, which has decided that such contracts must be paid in gold. Contracts payable in gold coin or other money are valid and not against public policy. To prohibit such contracts is also an unwarranted interference with liberty of contract which is protected alike by State and Federal constitutions. ${ }^{10}$

7. Woodruff v. Mississippi, 162 U. S. 291,16 S. Ct. 820 .

8. Gallious v. Pierce, 18 La. Ann. 10; Frothingham v. Morse, $45 \mathrm{~N}$. H. 545; Henderson v. McPike, 35 Mo. 255; Appel v. Waltman, 38 Mo. 194; Riley v. Sharp, 1 Bush. (Ky.), 348; Laughlin v. Harvey, $52 \mathrm{~Pa}$. St. 9; Brown v. Weleh, 26 Ind. 116 ; Buchegger v. Schultz, 13 Mich. 420 ; Mervine v. Sailer, 5 Phila.
(Pa.) 422; Bank v. Burton, 27 Ind. 426.

9. Bronson v. Rodes, 7 Wall. (U. S.) 229 ; Trebilcock v. Wilson, 12 Wall. (U. S.) 687; Butler v. Horwitz, 7 Wall. (U. S.) 258; Bronsan v. Kimpton, 8 Wall. (U. S.) 444 ; Woodruff v. Mississippi, 162 U. S. 293, 16 S. Ct. 820.

10. Allgeyer v. Louisiana, 165 U. S. 578,17 S. Ct. 27. 


\section{ARTICLE IT.}

Contracts for Office and for Tnituencixg Officht, Conduct.

SFCtion 279. Sale of Offices.

280. Influeneing Appointment to Office.

281. Compensation by Private Person.

28:. Controlling the Regular Administration of Justice.

283. Assigmment of Unearned Compensation.

284. Contracts to Proenre Legislation-Lobbying Contraets.

285. Compensation for Professional Services.

286. Use of Improper Influence.

287. Contract for Securing a Pardon.

$\S 279$. Sale of offices. - All bargains made or given for the purchase or sale of any office whatever, is void as against public policy. Such agreements are void at common law, as well as by statute. And contracts to procure appointment to office ${ }^{1}$ are void or to resign office in another's favor. ${ }^{2}$ Public offices are public trusts, and should be conferred solely upon consideration of ability, integrity, fidelity and fitness for the position. Agreements for compensation to procure these tend directly and necessarily to lower the character of the appointments to the great detriment of the public. Therefore, all such agreements of whatever nature have always been held roid as contrary to public policy. ${ }^{3}$

The services performed by an officer are paid for by salaries and fees, presumed to be adjusted at the point of adequate remuneration only. Any premium paid to obtain office interferes with the adjustment and tempts to speculation, orercharges and

1. Meacham v. Dow, 32 Vt. 721 ; Gracone v. Wroughton, 11 Exch. 146; Bobertson v. Robinson, 65 Ala. 610, 39 Am. Rep. 17; Stout v. Ennis, 28 Kans. 706; Engle v. Chipman, 51 Mich. 524, 16 N. 886 ; Card v. Hope, 2 Barn. \& Cr. 661.

2. Eddy v. Capron, 4 R. I. 394 , 67 Am. Dee. 541.
3. Meguire v. Corwine, 101 U. S. 108 ; Tool Co. v. Norris, 2 Wall. (U. S.) 45; Gray v. Hook, 4 N. Y. 449; Gaston v. Drake, 14 Ner. 175, 33 Am. Rep. 548; Filson v. Himes, 5 Pa. St. 452, 47 Am. Dee. 422; Liness v. Hesing, 14 Ill. 113; Basket v. Moss, 115 N. Car. 448, 20 S. E. 733, 44 Am. St. Rep. 463. 
frauds in the effort to restore the balance thus disturbed. ${ }^{4}$ And an agrecment whereby an officer agrees to accept a different compensation than that provided by statute for his official acts, or whereby he agrees not to avail himself of the statutory method of enforcing collection of fees, is contrary to public policy and void. ${ }^{5}$

$\S 280$. Influencing appointment to office.-A contract is contrary to public policy and void whereby one by his influence appoints another to office, the latter agreeing as compensation to share the fees with the former. ${ }^{6}$ So an agreement by an applicant for the appointment of deputy sheriff, to pay the sheriff a portion of the fees received by him as an officer, is void.?

Where, therefore, a deputy sheriff, upon his appointment, gave to the sheriff a bond with sureties, conditioned for the payment by him to the sheriff of one-third of all the fees received by him, both in civil and criminal cases, the bond is void and no action can be maintained on it to recover the proportion specified of fees received by the deputy as peace officer. ${ }^{8}$

Not only an agreement by one to pay to another, a public officer, an amount equal to the emoluments of the unexpired term of his office, in consideration of his resignation and his influence to secure the appointment of the former to the office, is roid, and likewise an agreement to compensate any one for, or to pay the expenses of anyone in, attempting to seeure the appointment; ${ }^{9}$ and a mortgage to secure such an agreement is void. ${ }^{10}$

4. Eddy v. Capron, 4 R. I. 394 . 67 Am. Dec. 541.

5. Peters v. Davenport, 104 Iowa, 625, 74 N. W. 6 .

6. Meguire v. Corwine, 101 U. S. 108. See, also, Marshall v. Railroad Co., 16 How. (U. S.) 314; Tool Co. v. Norris, 2 Wall. (U. S.) 45; Trist v. Child, 21 Wall. (U. S.) 44; Cappell v. Hall, 7 Wall. (U. S.) 542 ; Deyoe v. Woodworth, $144 \mathrm{~N}$. Y. $448 ; 29$ N. E. 375 .
7. Deyoe v. Woodworth, 144 N. I. 448,29 N. E. 375 ; White v. Cook, 51 IV. Va. 201, 41 S. E. 410, 57 L. R. A. 417, 90 Am. St. Rep. 775 .

8. Deyoe v. Woodworth, 144 N. Y. 448,29 N. E. 375.

9. Basket v. Moss, 115 N. Car. 448, 20 S. E. 733,44 Am. St. Rep. 463.

10. Basket v. Moss, 115 N. Car. 
Closely allied to this class of cases are those engaging an editor to use his paper to advance the interest of a candidate. Thus, a contract by which an editor or proprietor of a newspaper agrees to use the influence of his paper to secure a candidate's nomination to a political office is void as against public policy. ${ }^{11}$

The invalidity of such contracts designed to control the freedom of election, results from the principles of the common law, and so those relating to cancuses cannot be made an exception on the ground that such meetings are not recognized by the statute. To secure a free and exact expression of the sovereign will, there must be a proper selection of candidates, as well as an honest election. If the choice of delegates and the action of the nominating convention are improperly determined, the election ballots will fail to express the real judgment of the voters.

$\$ 28 \mathrm{r}$. Compensation by private person.- An agreement by a private person to pay a public officer for doing his duty is void as against public poliey, it is otherwise as to matters not in the scope of the officer's public duties. ${ }^{1}$ But the agreement to pay for such services must be special in order to bind. ${ }^{2}$ And an agreement by a constable with an execution creditor to charge less than his legal fees for lerring an exeention and conducting a sale thereunder, is not contrary to pullic policy. ${ }^{3}$ But a contract for the allowance and payment of a greater compensation to a public officer than that fixed by law for his services is void. ${ }^{4}$

4ts, 20 S. F. 733. 44 Am. St. Rep. 463.

11. Livingston v. Page, $74 \mathrm{Vt}$. 356,52 A. 965,59 L. R. A. 336,93 Am. St. Rep. 901 and note; Liness v. Hessing, 44 Ill. 113, $92 \mathrm{Am}$. Dee. 153.

1. McCandless v. Steel Co., 152 Pa. St. 139,25 A. 579.
2. Wirner v. Grace, 14 Minn. 4Si; Trundler v. Riley, 17 B. Mon. (Ky.) 396; England v. Davidson, 11 Adol. \& E. 85t, 39 Eng. Com. L. 254; McCandless v. Steel Co., 152 Pa. St. 139, 25 A. 579.

3. Bloom r. Hiızard, 104 Cal. 310, 37 P. 103i.

4. Fawcett $r$. Woodbury County, 55 Iowa, 154, 7 N. 483; Faweett v. 


\section{$\S 282$. Controlling the regular administration of justice.-} All agreements for pecuniary consideration to control the regular administration of justice are void as against public policy, regardless of the good faith of the parties, and withont reference to the question as to whether improper means are contemplated or used in their execution. ${ }^{1}$ And, hence, a justice of the peace before whom an affidavit is filed charging a person with a crime, although his powers are merely those of an examining court, cannot enter into a valid contract with the prosecuting witness to arrest the accused for a pecuniary consideration, when the recompense is contingent upon the amount of property that may be recovered. ${ }^{2}$ All agreements relating to proceedings in the courts, which may involve anything inconsistent with the full and impartial course of justice therein, are void, though not open to the charge of actual corruption. ${ }^{3}$

So, where a candidate for judge, in order to secure his election, pledges himself, if elected, to perform the duties of such office for a sum less than one-half the fees allowed by law, and voters are thereby induced to vote for such candidate, and he thus receives a majority of the votes cast for such office at such election, his election, secured by these means, is invalid as against public policy. ${ }^{4}$

Eberly, 58 Iowa, 544, 12 N. 580; Moore v. Mahaska County, 61 Iowa, 177, 16 N. 79; Farley v. Platt, 105 Mich. 635, 63 N. W. 521 ; Griffin v. Clay County, 63 Iowa, 413, $19 \mathrm{~N}$. 329 ; Adams County v. Hunter, 78 Iowa, 328, 43 N. W. 208, 6 L. R. A. 615; Kick v. Merry, 23 Mo. 72; Wilcoxson v. Andrews, 66 Mich. 553, 33 N. W. 533; Neustadt v. Hall, 58 Ill. 172; Gilmore v. Lewis, 12 Ohio, 281; Brown v. Bank, 137 Ind. 655,37 N. E. 158, 24 I. R. A. 206 ; Mitchell v. Vance, 5 T. B. Mon. (Ky.) 528, 17 Am. Dec. 96; Pool v. Boston, 5 Cush. (Mass.) 219;
Stamper v. Temple, 6 Humph. (Tenn.) 113, 44 Am. Dec. 296.

1. Brown v. Bank, 137 Ind. 655, 37 N. E. 158, 24 L. R. A. 206 ; Tool Co. v. Norris, 2 Wall. (U. S.) 45 , 56 ; State v. Johnson, 52 Ind. 197; Oscanyan v. Arms Co., 103 U. S. 261; Clipfinger v. Hepbaugh, 5 Watts \& S. (Pa.) 315, 40 Am. Dec. 519 and note.

2. Brown v. Bank, 137 Ind. 655 , 37 N. E. 158, 24 L. R. A. 206.

3. Elkhart County v. Crary, 98 Ind. 238, 240, 242, 49 Am. Rep. 746.

4. State v. Collier, 72 Mo. 13,37 Am. Rep. 417 and note. 


\section{$\S 283$. Assignment of unearned compensation by officer.-}

It is contrary to public policy for a public oflicer to assign or give a lien upon his unearned compensation which is given by law, whether such compensation be salary or fees. Any such assignment or lien is void. ${ }^{1}$ And this is the law in England without exception. ${ }^{2}$

There is no distinction in principle between the assignment of unearued fees and the assignment of unearned salary. A salary is a fixed sum for a given time, and there can be no doubt as to the amount to which the assignee would be entitled. In case of fees to be paid by a county or State, the officials would be required to go into a settlement of the question of amount, with many different persons in some instances, which would confuse and embarrass the public business. So, if there can be any difference, the reason is stronger for holding such assignment of fees void than for holding a like assignment of a salary to be invalid. ${ }^{3}$

There are cases which are sometimes referred to as announcing a different rule. ${ }^{4}$ But in these cases the point of public policy was not considered by the court in any of them; the question involved in them was regarded as relating to the sufficiency of the interest of the assignor in the future unearned

1. National Bank v. Fink, 86 Tex. 303, 24 S. W. 256, 40 Am. St. Rep. 833 ; Bliss v. Lawrence, 58 N. Y. 442, 17 Am. Rep. 273 ; Bangs v. Dunn, 66 Cal. 74, 4 P. 963 ; Schloss v. Hewlett, 81 Ala. 266, 1 So. 263 ; Bowen Nat. Bank v. Wilson, 122 N. Y. 478,25 N. E. 855 , 19 Am. St. Rep. 507 ; Field v. Chipley, 79 Ky. 260, 42 Am. Rep. 215 and note; Schwenk v. Wyckoff, 46 N. J. Eq. 560, 20 A. 259, 9 L. R. A. 221 ; Webb v. Mccauley, 4 Bush. (Ky.) 10; Bell v. MeVicker, 8 Mo. App. 202; State v. Williamson, 118 MTo. 146, 23 S. W. 1054, 40 Am. St. Rep. 358 .

2. Flarity v. Odlum, 3 Term $R$.
681; Baurick v. Read, I H. Bl. 627; Arbuckle v. Cowtan, 3 Bos. \& Pul. 328 ; Wells v. Foster, 8 Mees. \& Wcls. 149; Hill v. Paul, S Cl. \& Fin. 307 ; Palmer v. Bates, 2 Brod. \& Bing. 673; Liverpool v. Wright, 28 L. J., N. S. Ch. 871; Davis v. Marlborough, 1 Swanst. 79; Stone v. Lidderdale, 2 Anst. 533; Lidderdale v. Montrose, 4 Term R. 248 .

3. Bliss v. Lawrence, $5 \mathrm{~s} \mathrm{N.} \mathrm{Y.}$ 442, 17 Am. Rep. 273.

4. Brackett v. Blake, $\tau$ Met. (Mass.) 335, 41 Am. Dec. 442 and note; Marshall v. Quinn, I Gray (Mass.), 105, 6l Am. Dec. 414; Macomber v. Dane, 2 Allen (Mass.), 541 . 
salary to distinguish the cause from those of attempted assignment of mere expectations, such as those of an expectant heir. In the case of Marshall v. Quinn, ${ }^{5}$ the matter in dispute was neither fees nor salary of a public officer, but was for the price of work done for a city. In Brackett v. Blake, ${ }^{6}$ the question of public policy was not considered. In Macomber $\nabla$. Dane, ${ }^{7}$ an officer had assigned his salary, but the only question considered was as to whether or not it was assignable on account of its being a mere possibility. Public policy was not discussed nor mentioned in the case.

A few cases announce a different rule from the weight of authority. In People v. Dayton ${ }^{8}$ it was held that the assignment of unearned fees does not fall within the rule sustained by the courts as to salaries. But this doctrine was overruled in a later case. $^{9}$ In State v. Hastings, ${ }^{10}$ it seems to announce a contrary rule, hut as in that case the order for the unearned salary, with authority to collect the same, had been transferred to an innocent purchaser, the ease turned principally on estoppel. The question as to whether or not the assignment of the unearned salary was against public policy, was not raised or discussed.

The reason of the rule is that public serrice may not be so good and efficient when the unearned salary has been assigned as when it has not been, and that the public service is protected by protecting those engaged in the performance of public duties; and this, not upon the ground of their private and undivided interests, but that of the necessity of securing the efficiency of the public service by seeing to it that the funds provided for its maintenance should be received by those who are to perform the work at such periods as the law has appointed for their payment. $^{11}$ Or, as the English case holds that emoluments of this sort are granted for the dignity of the State for the decent sup-
5. 1 Gray (Mass.), 105, 61 Am.
122 N. Y. 478,25 N. E. S55, 9 L. Dec. 414 .
6. 7 Met. (Mass.) 335 .
R. A. $706,19 \mathrm{Am}$. St. Rep. 507.
7. 2 Allen (Mass.), 541.
10. 15 Wis. 75 .
8. 50 How. Pr. (N. Y.) 143.
11. Bliss v. Lawrence, $58 \mathrm{~N}$. Y.
9. Bowery Nat. Bank v. Wilson, 442, 7 Am. Rep. 273; Peters v. Dav- enport, 104 Iowa, 625, 74 N. W. 6. 
port of those persons who are engaged in the service of it. It would, therefore, be highly impolitie to permit them to be assigned; for persons who ane liable to be called out in the service of their combry ought not to be taken from a state of porerty. ${ }^{12}$ Dignity of oflice, in the sense that the ter'm is nsed in the English cases, does not exist in this conntry; hut there should be a dignity attending every office, in the sense that a proper and independent discharge of its duties inspires respect for the officer and for the office.

It is easy to see how great abuses would follow if such transfers were permitted. Not only would there exist a constant temptation to anticipate future earnings under the stress of present financial pressure, at usurious rates of discount, but when completed, one of the strongest incentives to industrions exertion - the expectation of pecuniary reward in the near future - would be gone. ${ }^{13}$

\section{$\S 284$. Contracts to procure legislation - Lobbying con-} tracts.-Contracts, which have for their subject-matter any interference with the creation of laws or their due enforcement, are against public policy and, therefore, void. ${ }^{1}$ It is enough that such is the tendency of the contract, that it is contrary to sound morality and public policy, leading necessarily, in the hands of designing and corrupt men, to improper tampering with law makers, and the use of an extraneous secret inflnence, over an important branch of the gorernment. It may not corrupt at all, but if it corrupts or attempts to corrupt some. or if it deceives or tends to deceive or mislead some, that is sufficient to stamp its character with the seal of reprobation before

12. Flarity v. OdIum. 2 T. Rep. 681.

13. Sehloss v. Hewlett. 81 Ala. 290, l So. 263; In re Worthington, 141 N. Y. 9. 35 N. E. 929 . By act of Congress of Feb. 28. 1853, any pledge, mortgage, sale, assignment. or transfer of any right, elaim or interest in a pension is void. See,
Wells y Foster. \& Mees. \& IV. 149; Loser v. Board. 92 Mich. 633, 52 N. W. 956.

1. Ormerod v. Dearman. $100 \mathrm{~Pa}$ St. 561.45 Am. Rep. 391 : Spalding v. Ewing, 149 Pa. St. 375,24 A. 219. 15 L. R. A. 727,34 Am. St. Rep. 60s; Frost v. Belmont, 6 Allen (Mass.), 152; Weed v. Black, 2 
the courts. ${ }^{2}$ If a party is employed to render lobby service in procuring the legislation desired by another party, then he cannot recover for his services. ${ }^{3}$ And a promise to pay a contingent fee on the passage of a bill is roid $;^{4}$ but if the contract is not a lobbying contract it will be upheld. ${ }^{5}$

In general, a contract to procure or endeavor to procure the passage of an act of the legislature by any illegal method, or by using personal influence, with the members, is void, as against public policy. ${ }^{6}$ The weight of authority is, that a contract for a consideration to use personal influence or other secret methods, not necessarily wrong in themselves, is against public policy and, therefore, void. ${ }^{7}$ And in all these cases where services are rendered for a contingent fee the contract is void

MacArthur, D. C. 268 ; McBratney v. Chandler, 22 Kans. 692, 31 Am. Rep. 213; Cook v. Shipman, 24 Ill. 614 ; Harris v. Roof, 10 Barb. (N. Y.) 489; Rose v. Truax, 21 Barb. (N. Y.) 361 .

2. Trist v. Child, 21 Wall. (U. S.) 441 ; Clipfinger v. Hepbaugh, 5 Watts \& S. (Pa.) 315, 40 Am. Dec. 519 and note; Bryan v. Reynolds, 5 Miss. 200, 68 Am. Dec. 55; Wood v. MeCann, 6 Dana (Ky.), 366; Hatzfield v. Golden, 7 Watts (Pa.), 152, $32 \mathrm{Am}$. Dec. 750; Bowman v. Coffroth, 59 Pa. St. 19; Marshall v. Railroad Co., 16 How. (U. S.) 314; Powers v. Skinner, 34 Vt. 274, s0 Am. Dec. 677; Coquillard v. Bearss, 21 Ind. 479, 83 Am. Dee. 362 ; Howell v. Fountain, 3 Ga. 176; Mills v. Mills, 40 N. Y. 543, $100 \mathrm{Am}$. Dec. 535.

3. Chippewa, etc. R. R. Co. v. Railroad Co., 75 Wis. $248,44 \mathrm{~N}$. W. 17,6 L. R. A. 601 ; Frost v. BeImont, 6 Allen (Mass.), 152; Harris v. Roof, 10 Barb. (N. Y.) 489 ; Sedgwick r. Stanton, 14 N. Y. 289.

4. Wood v. McCann, 6 Dana (liy.), 366; Spalding v. Ewing, 149 Pa. St. 375,24 A. 219, 15 L. R. A. 727, 34 Am. St. Rep. 608; Compare Bryan v. Reynolds, 5 Wis. 200, 68 Am. Dec. 55 ; Workman v. Campbell, 46 Mo. 305; Denison v. Crawford, 48 Iowa, 211; Burbridge v. Fockler, 2 MeAr. D. C. 407 . See, also, Tool Co. v. Norris, 2 Wall. (U. S.) 48, 56 ; Oscanyan v. Arms Co., 103 U. S. 261; Woodstock Iron Co. v. Extension Co., 129 U. S. 643,9 S. Ct. 402 .

5. Houlton v. Nichol, 93 Wis. 393, 67 N. W. 715, 33 L. R. A. 166, 57 Am. St. Rep. 928.

6. Burney v. Ludling, 47 La. Ann. 73, 17 So. 877; Frost v. Belmont, 6 Allen (Mass.), 15̄ ; Houlton v. Dunn, 60 Minn. 26, 61 N. W. 898, 30 L. R. A. 737 and note, 51 Am. St. Rep. 493.

7. Trist v. Child, 21 Wall. (U. S.) 441; Spalding v. Ewing, 149 Pa. St. 375, 24 A. 219,15 L. R. A. 727, 34 Am. St. Rep. 608; MreBratney v. Chandler, 22 Kan. 692, 31 Am. Rep. 213; Sweeney v. McLeod, 15 Oreg. 339, 15 P. 275 ; Powers v. 
irrespective of the meins nsed. ${ }^{8}$ But all professional contracts for preparing and arguing a case before a legislative body or its committee are valid. ${ }^{9}$ And contracts which contemplate, not the influencing of the legislature, but only meeting the eonditions of legislative action, are generally valid. Thus, a contract to use personal influence to obtain the consent of property holders necessary to enable a eity council to pass an ordinance authorizing the construction of an elevated railway is valid. ${ }^{10}$ So, also, where a city agrees to pass a certain ordinance on the consent of a certain number of taxpayers, a contract by which the mayor of the eity was employed to procure the number is valid. ${ }^{11}$ So where one with large experience in regard to public lands, is engaged to conduct the business of procuring certain lands, the contract is valid. ${ }^{12}$ And so the distribution of circulars for the purpose of influencing legislation is a ralid consideration for a contract. ${ }^{13}$

$\$ 285$. Compensation for professional services. - An attorney may claim compensation for purely professional services performed in connection with legislation in which his client has an interest. ${ }^{14}$ Within this category are included drafting the petition to set forth the claim, attending to the taking of

Skinner, 34 Vt. 274, S0 Am. Dec. 677 .

8. Marshall v. Railroad Co., 16 How. (U. S.) 314; Burmudez Asphalt Co. v. Critchfield, 62 Ill. App. 224; Chippewa Valley R. R. Co. v. Railroad Co., 75 Wis. 224, $44 \mathrm{~N}$. W. 17,6 L. R. A. 601 ; Irood v. MeCann, 6 Dana (Ky.), 366; Coquillard v. Bearss, 22 Ind. 479.

9. Chesebrough v. Conover, 140 N. Y. 382,35 N. E. 633 ; Strathman v. Gorla, 14 Mo. App. 1 ; Wildey v. Collier, 7 MId. 273, 61 Am. Dec. 346; Trist r. Child, உ1 Wall. (U. S.) 441; Yates $v$. Robertson, 80 Va. 475; Miles v. Thorne, 38 Cal. 335, 90 Am. Dec. 384 and note;
Russell v. Burton, 66 Barb. (N. Y.) 539.

10. Union El. R. R. Co. v. Nixon, 199 Ill. 235,65 N. E. 314.

11. Bridgeford $v$. Tuscumbia, 16 Fed. Rep. 910.

12. Houlton v. Nichol, 93 Wis. 393,67 N. IV. 715,33 L. R. A. 166, 57 Am. St. Riep. 92s.

13. Kansas, etc. R. R. Co. v. MeCoy. 8 Kan. 359.

14. Spalding v. Ewing, $149 \mathrm{~Pa}$. St. $375,2+$ A. 219,15 L. R. A. 727 , $34 \mathrm{Am}$. St. Rep. 608; Bryan v. Reynolds, 15 Wis. 200, 68 Am. Dec. 57. 
testimony, collecting facts, preparing arguments, and submitting them, orally or in writing, to a committee or other proper authority, and other services of like character. All these things are intended to reach only the reason of those sought to be influenced. They rest on the same principle of ethics as professional services rendered in a court of justice, and are no more exceptional. But such services are separated by a broad line of demarcation from personal solicitations, and other means and appliances, tending to corrupt the lawmakers. ${ }^{15}$

It is the right of every party interested in any proposed legislation to employ, and agree to pay, an agent to draft a bill, and fairly and openly to explain it to a legislative committee or any member of the legislature, and ask to have it introduced; and a contract with an agent which does not call for more, and services under it which does not go further, are not against public policy. ${ }^{16}$

\$286. Use of improper influence.- If a contract is legal, it will not be made illegal by the misconduct on the part of the plaintiff in carrying it out. ${ }^{1}$ If the contract is legal, the fact that the plaintiff did things against public policy, if it be a fact, can be considered only as bearing by way of illustration upon the question whether the tendency of the contract necessarily was to induce the doing of such things. ${ }^{2}$ If the only service on the part of the plaintiff promised by him, or contemplated by either party at the time, were legitimate services, the contract is valid. ${ }^{3}$ But a contract contemplating the use of secret influence with

15. Trist v. Child, 21 Wall. (U. S.) 441. See, also, Tool Co. v. Norris, 2 Wall. (U. S.) 48, 56; Oscanyan v. Arms Co., 103 U. S. 261; Woodstock Iron Co. v. Extension Co., 129 U. S. 643, 9 S. Ct. 402 .

16. Chesebrough v. Conover, 140 N. Y. 382,35 N. E. 633.

1. Howden v. Simpson, 10 Ad. \& El. 793, 818, 819, 2 Per. \& Dav. 714, 740, 9 Cl. \& Fin. 61, 68.
2. Powers v. Skinner, 34 Vt. 274 , $284,80 \mathrm{Am}$. Dec. 677 .

3. Fuller v. Davis, 18 Pick. (Mass.) 472, 480; Trist v. Child, 21 Wall. (U. S.) 441, 450; Marshall v. R. R. Co., 16 How. (U. S.) 314, 335; Lyon v. Mitchell, $36 \mathrm{~N}$. Y. 235, 241, 93 Am. Dec. 502; Barry v. Capen, 151 Mass. 99, 23 N. E. 735,6 L. R. A. 808 . 
public officers is void as against public policy." So, a contract to bribe or corruptly influence officers of a foreign government will not be enforced in the courts of the United States, not from any consideration of that gorernment or any regard for its policy, but from the inherent viciousness of the transaction, its repugnancy to our morality and the pernicious effect which its enforcement by our courts would have upon our people. ${ }^{5}$

Contracts to influence legislative action are void as against public policy. ${ }^{6}$

$\S 287$. Contract for securing a pardon.- It is generally held that a contract for services in securing a pardon of one convicted of crime is not illegal, if the employment of improper methods is not contemplated. ${ }^{1}$ The presumption of law is in favor of the legality of contracts, and, the object sought to be acomplished being lawful, unless it affirmatively and distinctly appears that it was contemplated that means were to be resorted to for its accomplishment which the law will not sanction, the courts cannot declare the contract void. So, there can be nothing unlawful or opposed to public policy in simply employing a party to secure a pardon by proper means. ${ }^{2}$

4. Hutchen v. Gibson, I Bush. (Ky.) 270; Murray v. Wakefield, 9 Mo. App. 591; Ormerod v. Dearman, 100 Pa. St. 561, 45 Am. Rep. 391 ; Wright v. Rindskoff, 43 Wis. 344 ; Rhodes v. Neal, 64 Ga. 704, 37 Am. Rep. 93; Wildey v. Collier, 7 Md. 273, 61 Am. Dee. 346.

5. Watson v. Murray, 23 N. J. Eq. 257; Hope v. Hope, 8 DeG. M. \& G. 731 .

6. Bermudez Asphalt Paving Co. v. Critchfield, 62 IIl. App: 221 ; Barber Asphalt Paving Co. v. Botsford, 56 Kans. 532, 44 P. 3; Harrington v. Crawford, 61 Mo. App. 221; Honaker v. Board, 42 W. Va. 170,
24 S. E. 544, 32 L. R. A. 413, 57 Am. St. Rep. 847.

1. Moyer v. Cantieny, 41 Minn. 242, 42 N. W. 1060. See, also, Timothy v. Wright, 8 Gray (Mass.), 522, Rau v. Boyle, 5 Bush (Ky.), 253.

2. Chadwick v. Knox, 31 N. H. 226, 64 Am. Dec. 329; Formby v. Pryor, 15 Ga. 258; Brewsen v. Engler, 49 N. Y. Super. Ct. 172; Compare Hainey v. Lewis, 54 Iowa, 301, 6 N. 495, 37 Am. Rep. 202 and note; Kribben v. Haycraft, 26 Mo. 396; Hatzfield v. Gulden, 7 Watts (Pa.), 152, 32 Am. Dec. 750. 
CHAPTER IX.

Limiting Liability Por Negligence.

\title{
ARTICLE I.
}

\section{Liability as to Carriage.}

\author{
Section 288. Common Carriers-Railroad Companies. \\ 289. Express Companies. \\ 290. Liability Limited Beyond Its Own Line of Carriage. \\ 291. Limiting Liability as to Losses Occurring not from Its Own \\ Negligence.
}

$\S 288$. Common carriers. - A common carrier cannot as a general rule divest itself of liability, either by special contract or notice, where damages or loss results from its own negligence, fraud, or misfeasance. ${ }^{1}$ A common carrier cannot lawfully stipulate for exemption from responsibility when such exemp-

1. Jones v. Railroad Co., 125 Mo. 666, 28 S. W. 883,26 L. R. A. 718 , 46 Am. St. Rep. 514; Union Pac. R. R. Co. v. Rainey, 19 Colo. 225, 34 P. 986; Transportation Co. v. Cornforth, 3 Colo. 280, 25 Am. Rep. 757; Sager v. Railroad Co., $31 \mathrm{Me}$. 228, 50 Am. Dec. 659; Rallman v. Express Co., 3 Kans. 211 ; Pratt v. Railroad Co., 102 Mass. 557 ; Farnham v. Railroad Co., 55 Pa. St. 58 ; Indianapolis R. R. Co. v. Allen, 31 Ind. 394; Berry v. Cooper, 28 Ga. 543; Railroad Co. v. Stevens, 95 U. S. 655 ; Rose v. Railroad Co., 39 Iowa, 246; Annas v. Railroad Co., 67 Wis. 46, 30 N. W. 282, 58 Am. Rep. 848; Jacobus v. Railroad Co.,
20 Minn. 125, 18 Am. Rep. 360; Missouri Pac. Railroad Co. v. Iney, 71 Tex. 409, 9 S. W. 346, 10 Am. St. Rep. 758; Willis v. Railroad Co., 65 Me. 489; Flinn v. Railroad Co., 1 Houst. (Del.) 469; Railroad Co. v. Curran, 19 Ohio St. 1, 2 Am. Rep. 362; Railroad Co. v. Hopkins, 41 Ala. 486, 94 Am. Dec. 607; Railroad Co. v. Wynu, $\$ \overrightarrow{8}$ Tenn. 330, 14 S. W. 311; Moslin v. Railroad Co., 14 W. Va. 180, 35 Am. Rep. 748; Vaughn v. Railroad Co., 62 Mo. App. 461 ; Maxwell v. Railroad Co., 48 La. Ann. 382, 19 So. 287; Springs v. Railroad Co., 46 S. Car. 104, 24 S. E. 166; Railroad Co. v. Sayers, 26 Gratt. (Va.) 328; Orendorff v. 


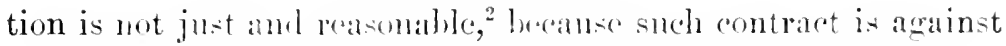
public polier and is therefore roid. ${ }^{3}$

A railroad compuny, in the carriage of gormls, is subject to the liability of a common carrier, and must answer for all losses not occasioned by the alet of hod or the pullic eneny, and cannot by special contract limit or relieve itself from this liability. ${ }^{4}$ common carrier ma! make special rontracts of carriage with customers, and thus relicre itself of many of the responsibilities imposed by law, but it cammot eontract against the consequenees of its own negligene. . And it cannot limit its liability in any respect by such special contract, where the shipper is not afforded an opportunity to contract for the services required of the carrier by law withont restrictions. ${ }^{6}$ But where a carrier, receiving merchandise to be shipped and to collect on delivery, stipulates that its liability, while holding it for collection shall be that of a warehouscman, sucls an agreement is valid if there is nothing to show that it is mreasonable; and the carrier will not be liable for the destruction, by a mob, of the merchandise so held, without negligence on its part. ${ }^{7}$ An express stipulation

Express Co., 3 Bush. (Ky.) 194, 26 Am. Dec. 207; Taylor v. Railroad Co., 39 Ark. 148; Express Co. r. Moon, 39 Miss. 822; Fonseka r. Steamship Co., 153 Mass. 553, 27 N. E. 665,12 L. R. A. 340 and note, 25 Am. St. Rep. 660; Hoadley v. Transportation Co., 115 Mass. 304, 15 Am. Rep. 106.

2. New York Cent. R. R. Co. v. Lockwood, 17 Wall. (U. S.) 357; Railroad Co. v. Stevens, 90 U. S. 655.

3. Pennsylvania Railroad Co. v. Henderson, 51 Pa. St. 315; Armstrong v. Express Co.. 15: Pit. St. 640, 28 A. 448; Louisville R. R. Co. v. Dies, 91 Tenn. 177, 18 S. W. 206, 30 Am. St. Rep. 87l; Pacific Express Co. v. Wallace, 60 Ark. 100, 29 S. IV. 32 ; Railroad Co. v. Cravens, 57 Ark. 112,20 S. W. 803,18
L. R. A. 527 and note, 39 Am. St. Rep. 230 and note; St. Joseph, etc. R. R. Co. v. Palmer, 38 Neb. 463, 56 N. W. 957, 22 L. R. A. 335.

s. St. Joseph, et.e., R. R. Co. v. Palner, 38 Neb. 463, 56 N. W. 957, 22 L. R. A. 33 J.

5. Pacific Express Co. v. Wallace, 60 Ark. 100, 29 S. IV. 32; Grace v. Alams, 100 Mass. 505, 1 Am. Rep. 13I; Hoadley v. Trinsportation Co., 115 Mass. 304, 15 Am. Rep. 106 .

6. Railroad Co. v. Cravens, 57 Ark. 112, 20 S. W. 803, is L. R. A. $5 \cdot 27$ and notc, 35 Am. St. Rep. 230 and note.

7. Pacific Express Co. v. Wallace, 60 Ark. 100, 29 S. IV. 32. See, also, Constable v. Steamship Co., 154 U. S. 51, 14 S. Ct. 1062. 
by any common earrice for hire in a contract of carriage that he shall be exempt from liability caused by his own or his servants' negligence is void as against public policy. ${ }^{8}$ But in England, New Jersey and New York a common carrier may stipulate against his own negligence, and the contract will be upheld. ${ }^{9}$

In the absence of Federal legislation, the validity of a stipulation of a common carrier who does an interstate business, will be determined by the common law. ${ }^{10}$ Contracts are often made by railroad companies, with the next of kin against liability for negligence to the employee, where the railroad company is released from all damages that may accrue to the employee by reason of the railroad negligence. Generally such contracts are void as against public policy. ${ }^{11}$ But other cases hold that such contracts are not against public policy, ${ }^{12}$ though this doctrine is against the weight of authority. The employee may stipulate that, if injured through the fault of the railroad company, he will then elect whether to accept certain benefits by

8. Express Co. v. Caldwell, 21 Wall. (U. S.) 264; Chicago, etc. R. R. Co. v. Davis, 159 Ill. 53, 42 N. E. 382,50 Am. St. Rep. 143; Atchinson, etc. R. R. Co. v. Lawler, 40 Neb. 356, 5S N. W. 968 ; Black v. Transportation Co., 55 Wis. 319 , 13 N. 244, 42 Am. Rep. 713; Liverpool, ete., Steamship Co. v. Ins. Co., 129 U. S. 397,9 S. Ct. 480 ; McFadden v. Railroad Co., 92 Mo. 343, 4 S. IV. 681, 1 Am. St. Rep. 721; Grogan v. Express Co., $114 \mathrm{~Pa}$. St. 523, 7 A. 134, 60 Am. Rep. 360; Burk v. Railroad Co., 150 Pa. St. 170, 24 A. 341, 30 Am. St. Rep. 805; Lindsley v. Railroad Co., 36 Minn. 539, 33 N. W. 7,1 Am. St. Rep. 692 ; Hull v. Railroad Co., 41 Minn. 510, 41 N. W. 936, 5 L. R. A. 587, 16 Am. St. Rep. 722 ; Boehl v. Railroad Co., 44 Minn. 191, 46 N. W. 333 ; Abrams v. Railroad Co., 87
Wis. 485,58 N. W. 780, 4 Am. St. Rep. 55.

9. Peck v. Railroad Co., $10 \mathrm{H}$. L. Cas. 473; McConeley v. Railroad Co., L. R. 8 Q. B. 57; Kenney v. Railroad Co., 125 N. Y. 422, 26 N. E. 626 ; Mynard v. Railroad Co., 71 N. Y. 180, 27 Am. Rep. 28; Nicholas v. Railroad Co., 89 N. Y. 370 ; Kinney v. Railroad Co., 32 N. J. L. 409, 90 Am. Dec. 675.

10. Davis v. Railroad Co., 93 Wis. 470,67 N. W. 16, 1132, 33 L. R. A. 654, 51 Am. St. Rep. 935.

11. Tarbell v. Railroad Co., 73 Vt. 347,51 A. 6,56 L. R. A. 656,87 Am. St. Rep. 734.

12. Griffiths v. Dudley, 9 Q. B. D. 357 ; Railroad Co. v. Bishop, 50 Ga. 465; International, etc. Railroad Co. v. Hinzie, 82 Tex. 623, 18 S. IV. 672 . 
means of a relief fund ereated by the company alone or with other companics, and that he will not clain double compensation. ${ }^{13}$

Of course the wencral pule is that a common carrier cannot stipulate against its own carclessness to aroid damages to its custoners, but this doctrine does not hold and is not anplicable to special contracts. Thus, a railroad compluny is not liable under a special contract, whereby the company was released and discharged from all liability for loss or damages to cireus property. Where a railroad company makes a special contract with the owners of a circus company to laul their special cars, the railroad company is not a common carrier under such circumstances and its special contract against damages, from its orn negligence, is valid. ${ }^{14}$ In such a case the railroad company is not required as a common carricr to take a circus train of this kind on a special schedule, and therefore the contract is not compulsory, and the circus proprietors must stand by their contract exempting the railroad company from damages caused by the company's own negligence; the company was not a common carrier as to the circus cars, and the special contract was valid. ${ }^{15}$

$\$ 289$. Express companies. - As stated in the preceding section an express company or other common carrier cannot, by special contract relieve itsclf from consequences of its own negligence. ${ }^{1}$ The express company has the right to demand from the consignor such information as will enable it to decide on the

13. Pittsburg, ete. Railroad Co. v. Moore, 152 Ind. 345,53 N. E. 290, 44 L. R. A. 638 ; Johnson v. Railroad Co., 163 Pa. St. 127, 29 A. 854 ; N. Y. Cent. R. R. v. Lockwood, 17 Wall. (U. S.) $35 \% .21 \mathrm{~J}$. Ed. 627.

14. Wilson v. Railroad Co., 129 Fed. Rep. 774; Chicago, ete. Railroad Co. v. Wallace, 66 Fed. Rep.
506,14 C. C. A. 257.24 U. S. App. 589, 30 L. R. A. 161 and note.

15. Wilson v. Railroad Co., 129 Fed. Rep. 774.

1. Armstrong v. Express Co., 159 Pa. St. 640, 28 A. 148; Express (o. v. Caldwell, 21 Wall. (U. S.) 264; Pacific Express Co. v. Wallace, 60 Ark. 100, 29 S. W. 32; Durgin v. Express Co., 66 N. H. $277,20 \mathrm{~A}$. 328, 9 L. R. A. 453. 
proper compensation to charge for the risk, and the degree of care to bestow in discharging its trust; and a limitation of its liability not to exceed fifty dollars unless the value of the goods or package forwarded is truly stated, is reasonable and consistent with public policy $;^{2}$ but this limitation must be brought home to the knowledge of the consignor. ${ }^{3}$

A distinction is to be made between the effect of this notice by a carrier by which it is sought to discharge the carrier from duties which the law has annexed to his employment and those designed simply to insure good faith and fair dealing of his employer. In the former, notice withont assent to the attempted restriction, is incfiectual, while in the latter, actual notice alone will be sufficient. ${ }^{4}$

An express company cannot by special contract limit its liability for negligence or misconduct. ${ }^{5}$

\section{$\S 290$. Limiting liability beyond its own line of carriage.-} At common law the carrier is not liable for loss, in the absence of special contract, beyond the point at which it is to deliver the goods to a connecting line. But when the contract of the shipper is with the carrier first receiving the goods, that such carrier should deliver the goods at their destination, even though it contemplated doing so, through intermediate carriers, then it assumes the liability of such character for every part of the route. ${ }^{1}$

But where a carrier receives goods marked for a particular designation beyond its terminus of its line, and does not ex-

2. Oppenheimer v. Express Co., 69 Ill. 62,18 Am. Rep. 596.

3. Oppenheimer v. Express Co., 69 Ill. 62, 18 Am. Rep. 596.

4, Orange County Bank v. Brown, 9 Wend. (N. Y.) 115, 24 Am. Dec. 129 ; Farmer's' Bank r. Transportation Co., 23 Vt. 186, 56 Am. Dec. 68; Western Transportation Co. v. Newhall, 24 Ill. 466, 76 Am. Dec. 760 and note.
5. Armstrong v. Express Co., 159 Pa. St. 640, 28 A. 148; Southern Express Co. v. Hunnieutt, 54 Miss. 566. 28 Am. Rep. 385; Boscowitz v. Express Co., 93 Ill. 523, 34 Am. Rep. 191: Bank v. Express Co., 93 U. S. 174; Muser v. Express Co., 74 Mo. 538 .

1. St. Joseph, etc., R. R. Co. v. Palmer, 38 Neb. 463, 56 N. IV. 957, 22 L. R. A. 335. 
pressly undertake to deliver them at the point designated, the implied contract is only to transport over its own line, and forward, according to the usual course of busincss, from its terminus. ${ }^{2}$

The prevailing rule in this country is that a common carrier receiving goods to be transported over several lines, including his own, is not responsible for negligence of other carriers in the route beyoud his own line, unless he has specially contracted to transport the property to its destination: and that receiving goods marked for a place beyong its own terminus roes not import an undertaking to carry to the destination named. ${ }^{3}$

It is held in Illinois that a stipulation in a bill of lading that the carrier will not be liable beyond its own line, does not bind the shipper unless he has had notice of it: that is he must read it. ${ }^{4}$

The first earrier occupies the relation of a mere forwarder of the goods from the terminus of its carriage. Such relation does not have the effect of making its stipulations for exemptions inure to the benefit of the comncting carrier, nor can it for any purpose, bind the shipper or the owner of the goods. ${ }^{5}$

2. Mulligan v. Railioal ('o.. : ;t; Iowa, 181, 14 Am. Rep. 514; Rome, etc. R. R. Co. v. Sullivan, 25 Ga. 228; McMillan v. Railroad Co., 16 Mich. 920; Smith v. Express Co., 108 Mich. 572, 66 N. W. 479; Farmers, etc., Bank v. Transportation Co., 23 Vt. 186, 56 Am. Dec. 68; Hood v. Railroad Co., 22 Conn. 1, 502; Keller v. Railroad Co., $174 \mathrm{~Pa}$.

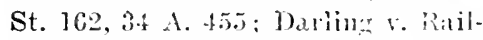
road Co., 11 Allen (Mass.), 295; Root v. Railroad Co., 45 N. Y. 524; United States Express Co. v. Rush, 24 Ind. 403; Ortt v. Ralilum Co., 36 Minn. 396, 31 N. W. 519.

3. Lawrence v. Railroad ( $0 . .15$ Minn. 313; McEacherman v. Railroad Co., 101 Mich. $26+t, 59 \mathrm{~N}$. W.
612; Burroughs r. Railroad Co., 100 Mass. 26; Hadd v. Express Co., 52 Vt. $335,36 \mathrm{Am}$. Rep. 757 and note; Root v. Railroad Co., 45 N. Y. 524 ; Crawford v. Railroad Co., 51 Miss. 222, $24 \mathrm{Am}$. Rep. 626; Grindle v. Express Co., 67 Me. 317, 24 Am. Rep. 31 ; Knight v. Railroad Co.. 13 R. I. 572, 43 Am. Rep. 46; Durbar r. Railroad Co., 36 s. Car. $110,15 \mathrm{~s}$. F. $357,31 \mathrm{Am}$. St. Rep. 860 .

4. Chicago, etc. R. R. Co. v. simon, 160 Ill. 648,43 ‥ E. 396.

5. Babcock v. Railroad Co., 49 N. Y. 491 ; Camden, etc. R. R. Co. v. Forsyth, $61 \mathrm{~Pa}$. St. 81. See, also, Union State Bank v. Railroad Co. (Xeb.), 59 L. R. A. 939. 
$\S 291$. Limiting liability as to losses occurring not from its own negligence.-A common carrier may limit its liability from losses or injuries occurring from other causes than its own negligence, as from accident, and for which it would not be liable as an insurer. ${ }^{1}$ And so a stipulation in a bill of lading exempting a carrier from liability for loss by fire, which does not happen through the negligence of the carrier, is reasonable and will be sustained. ${ }^{2}$ In Nebraska, a common carrier cannot limit its common law liability by special contract, and this applies to interstate shipments. ${ }^{3}$ Generally a common carrier cannot contract to relieve itself from its own negligence. In case an excursion ticket is sold for less than the full rate, as a condition that the passenger will assume all risks from accidents, he can then hold the carrier responsible for injuries caused to him by its negligence, but this fact he must affirmatively show. ${ }^{4}$ In the transportation of mail by a railroad company, if a registered package is lost, the company is not liable to the owner of the package, even if the loss was caused by the negligence of its servants. ${ }^{5}$

1. Chicago, etc. R. R. Co. v. Davis, 159 Ill. 53, 42 N. E. 382,50 Am. St. Rep. 143; Davis v. Railroad Co., 66 Vt. 290, 29 A. 313.

2. Davis v. Railroad Co., $66 \mathrm{Vt}$. 290, 29 A. 313,44 Am. St. Rep. 852.

3. St. Joseph, etc. R. R. Co. v.
Palmer, 38 Neb. 463, 56 N. W. 957, 22 L. R. A. 335.

4. Crary v. Railroad Co., $203 \mathrm{~Pa}$. St. 525, 53 A. 363,59 L. R. A. 815 , 93 Am. St. Rep. 778.

5. Boston Ins. Co. v. Railroad Co., 118 Iowa, 423, 92 N. W. 88. 59 L. R. A. 796. 


\section{AR'TICLE II. \\ Limitation by Notice on 'Ticket.}

Section 292. Limitation on Tickets-Mlileage.

293. Tickets as a Contract-limitations.

294. Coupon Tirket of Carrier-lights of comnecting lines.

295. Free Passes.

\$292. Limitation on tickets - Mileage.- Where a common carrier cannot limit its liability by any notice on tickets sold, it cannot, after sclling a return ticket, exact as a condition of return on the ticket, that the passenger shall sign it before a given agent who shall stamp it, though the ticket was sold at a reduced price, and recites such condition on its face. ${ }^{1}$

A carrier, in the abscnce of statute to the contrary, may restrict the use of the ticket to the use of the original purchaser. The words "not transferable," printed on the ticket, will have that effect, and a third party can acquire no right by virtue of such a ticket. ${ }^{2}$ But if a third party, without attempting to conceal his identity, presents a non-transferable ticket issued to another, and his claim is recognized by the conductor, he is entitled to the rights of a passenger. ${ }^{3}$

After a non-transferable ticket has been used by a third party, it may be forfeited in the hands of the owner, if the use by another was known to him and by his consent or negligence."

A mileage book is a contract between the railroad company and passenger, and the conductor has a right to detach coupons from any part of the book. ${ }^{5}$ Some railroad companies issue mileage coupons not to be used except when the company has no ticket office at the station where the passenger enters the

1. Phillips v. Banking Co., 93 Ga. 856,20 S. E. 247. See, also, Solan v. Railroad Co., 95 Iowa, 260 , 63 N. W. 692. 28 l. R. A. 718,58 Am. St. Rep. 430.

2. Way v. Railroad Co., 64 Iowa, 48, 19 N. 828, 52 Am. Rep. 431 and note; Cody v. Railroad Co., 4 Saw. C. C. 114 .

3. Robstelli v. Railroad Co., 33 Fel. Rep. 796.

4. Frederick v. Railroad Co., 53 IId. 201.

5. Waton $r$ MeIntire. 88 Me. 578 , 34 i. 528. 
train. In such case, if the ticket agent at the place of taking the train, has no exchange tickets, the holder of the mileage ticket can offer his conpon, which is complying with his contract, and the conductor has no right to expel him from the train. ${ }^{6}$ And so a passenger who buys a round-trip ticked good only on the day of sale, has a right to return that day on the only train running, though it is not scheduled to stop at his station. $^{7}$

$\S$ 293. Ticket as a contract - Limitations. - Under the earlier decisions, and some late decisions, it is held that a railroad ticket is merely a receipt or token of evidencing the paynent of the passage money, and showing that the purchaser has paid the toll enabling him to ride from one place to another. ${ }^{1}$ But by most courts a ticket is now held to be a contract between the purchaser and the railroad company. ${ }^{2}$ The purchaser of a ticket does not ordinarily enter into any special negotiations by which the carrier undertakes to carry him, for the custom established by the carrier and those doing business with him has fixed the terms upon which he may be carried; and if he accepts a ticket limiting the time within which he may use it for passage, or designating the train upon which he may use it for passage, or designating the train upon which it shall be used, he is bound thereby. The carrier may offer a ticket good upon

6. Pennsylvania R. R. Co. v. Lenhart, 120 Fed. Rep. 61,35 Ch. L. News, 181, 56 C. C. A. 467 ; N. Y. and Erie R. R. Co. v. Winter, 143 U. S. 60, 12 S. Ct. 356 ; Pittsburg, etc. R. R. Co. v. Russ, 57 Fed. Rep. 822, 6 C. C. A. 597,18 U. S. App. 279 ; Northern Pac. R. R. Co. v. Pauson, 70 Fed. Rep. 585, 30 L. R. A. 730,17 C. C. A. 287,44 U. S. App. 178.

7. Illinois Cent. R. R. Co. v. Harris, 81 Miss. 208, 32 So. 309,59 L. R. A. 742, 95 Am. St. Rep. 466.

1. Hubbard r. Railrond Co., 15
N. Y. 455 ; Dietrich v. Railroad Co., 71 Pa. St. 432, 10 Am. Rep. 711 ; Chicago, etc., R. R. Co. v. Dumser, 161 Ill. 190, 43 N. E. 698; Railroad Co. v. Bartram, 11 Ohio St. 457; Burdick v. People, 149 Iil. 600; Chicago, etc., R. R. Co. v. Mulford, 162 I1l. $522 ; 44$ N. E. 861,35 L. R. A. 599 .

2. Sleeper v. Railroad Co., 100 Pa. St. 259, 45 Am. Rep. 380; New York, etc., R. R. Co. v. Bennett, 50 Fed. Rep. 496,1 C. C. A. 544,6 U. S. App. 95; Railroad Co. v. Fitzgerald, 47 Ind. 79. 
certain trains within a specified time, and to be used only by the person purchasing it, and upon such terms as are embraced therein.

When a passenger knowingly accepts a ticket containing limitations, and imposing upon him certain duties to make it available for passage, he is bound thereby. ${ }^{3}$

As between the passenger and the conductor, the face of the ticket is conclusive evidence of the passenger's right to ride."

There is a conflict upon the question of the rights and duties of the conductor and passenger respectively, when an authorized agent sells a passenger a ticket different from what he asked and pay for, and one which does not entitle liim to the passage desired. One line of authorities holds that the conductor cannot be expected to listen to explanations, and the passenger should either pay his fare or walk quictly from the car, and then sue for breach of the contract; but should he attempt to remain on the train without paying fare, and is expelled, no recovery can be had. ${ }^{5}$

But the better doctrine is that the conductor under such circumstances has no right to expel the passenger, and if he does so, the company is liable in damages therefor. ${ }^{6}$ And condi-

3. Callaway v. Mallett, 15 Ind. App. 366,44 N. E. 198, 57 Am. St. Rep. 238.

4. Bradshaw v. Railroad Co., 135 Mass. 407, 46 Am. Rep. 481 and note; MeKay r. Railroad Co., 34 W. Va. 65. 9 L. R. A. 132 and note, 11 S. E. 737, 26 Am. St. Rep. 913; Townsend v. Railroad Co., 56 N. Y. 295, 15 Am. Rep. 419; Boyland v. Railroad Co., 132 U. S. 146,10 S. Ct. 50.

5. Railroad Co. v. Tinatta, 21 Ill. 188, $14 \mathrm{Am}$. Dee. 96: Rose v. Railroad Co., 106 N. Car. 168, 11 S. E. 526; Peaboly v. Railroad Co., 21 Oreg. 121, 26 P. 1053, 12 I. R. A. 823 and note; Mckay v. Railroad Co., $34 \mathrm{~W}$. Va. 65, $11 \mathrm{~S}$. E.
737, 9 L. R. A. 132 and note, 26 Am. Rep. 913; Sheldon v. Railroad Co., 29 Ohio St. 214; Townsend v. Railroad Co., 56 N. Y. 295,5 Am. Rep. 419 ; Frederick v. Railroad Co., 37 Mich. 342, 26 Am. Rep. 531.

6. Murdock v. Railroad Co., 137 Mass. 293, 50 Am. Rep. 307; Phila., W. and B. Railroad Co. v. Rice, $c 4$ Md. 63. 21 A. 97 ; Bradhliaw v. Railroal (o., 135 Mass. 407, 46 Am. Rep. 181 and note; Head $v$. Railroad Co., 7 Ga. 358, 3 S. E. 621. $11 \mathrm{Am}$. St. Rep. 434; Railroad v. Fix, ss Ind. $381,45 \mathrm{Am}$. Rep. 464 ; Pa. Railroad Co. v. Bray, 125 Ind. 229, 2.) X. E. 439 : Railroad Co. v. Martino, 2 Tex. Cir. App. 634. 
tions printed on the back of a passenger's ticket, exempting a carrier from liability for loss or damages to baggage under certain circumstances or beyond a specified amount, are not binding on the passenger, if not signed or seen by him, nor referred to in the contract on the face of the ticket, nor otherwise brought to his attention. ${ }^{7}$ This rule also applies to bills of lading. ${ }^{8}$ The question of notice must be submitted to the jury as a question of fact. ${ }^{9}$

\section{$\S 294$. Coupon tickets of carriers - Rights of connecting} lines.-Railroad companies generally sell tickets with coupons for carriage over connecting lines. But the selling company does not guarantee that the other carriers will honor such coupons and is not responsible in case the connecting line refuses to accept such coupon, as the selling company is only an agent; the selling company does not impliedly contract that such tickets will be recognized and honored by such connecting lines, but merely that it is the agent of such lines and has authority to issue such tickets. " And so, a ticket issued with coupons "good for one first-class passage" for an entire journey does not constitute a contract by the selling company to transport the holder over the connecting lines, so as to make it liable for failure of the connecting lines to honor the coupons. ${ }^{2}$

7. The Majestic, 17 U. S. 597. See, also, Richardson v. Rountree (1894), App. Cas. 217; Henderson v. Stevenson, L. R. 2 H. L. 470.

8. Railroad Co. v. Navigation, 16 Wall. (U. S.) 318.

9. Malone v. Railroad Co., 12 Gray (Mass.), 388, 74 Am. Dec. 598. See, also, Brown v. Railroad Co., 11 Cush. (Mass.) 97; Transportation Co. v. Thielbar, $86 \mathrm{Ill}$. 71; Rawson v. Railroad Co., 48 N. Y. 212, 8 Am. Rep. 543; Wilson v. Railroad Co., 21 Gratt. (Va.) 654.

1. Chicago, etc., R. R. Co. v. Mulford, 162 Ill. 522, 44 N. E. 861, 35 I. R. A. 599; 2 Redfield on
Railways, 185; Chicago, etc., R. R. Co. v. Dumser, 161 Ill. 190, $43 \mathrm{~N}$. E. 698 ; Pennsylvania Railroad Co. v. Connell, 112 I1l. 295, 54 Am. Rep. 238 and note.

2. Chicago, etc., R. R. Co. v. Mulford, 162 Ill. 522,44 N. E. 861,35 L. R. A. 599. See, also, Knight v. Railroad Co., 56 Me. 235; Furstenheim v. Railroad Co., 9 Heisk. (Tenn.) 238; Mosher v. Railroad Co., 127 U. S. 390,8 S. Ct. 324 ; Hood v. Railroad Co., 22 Conn. 1; Young v. Railroad Co., $115 \mathrm{~Pa}$. St. 112, 7 A. 741 ; Lundy v. Railroad Co., 66 Cal. 191; 4 P. 1193, 56 Am. Rep. 100. 
§295. Free passes.- In many juriselictions one who aceepts and uses a free pass, as a pure gratuity, on condition that he will assmme all risk of personal injury, numst he decmed to have accepted it on that condition whether he reads it or not. Such a contract, exempting a carricr from liability, is not prohibited by any rule of public policr, and is effectual to exonerate the carrier from liability for the negligence of his servants. ${ }^{1}$ Under this dictrine where a party accepts a pass, he does so on the conditions fully expressed therein, whether he actually reads them or not. ${ }^{2}$

In England a common carrier has practically unlimited power to provide by contract against liability for negligence, ${ }^{3}$ even gross negligence. In New York and New Jersey a carrier may contract with free passengers against liablity for all degrees of negligence, provided the exemption is in clear and unmistakable terms. ${ }^{5}$ And some courts seek to distinguish the different degrees of negligence and concede the right to make such exemptions as to a free passenger, in all cases of ordinary negligence, but decline to extend the doctrine to cases of gross negligence.

1. Northern Pac. R. R. Co. r. Adams, 187 U. S. 643, 192 U. S. 440; Muldoon v. Railroad Co., 10 Wasl. 311, 38 P. 995, 45 Am. Rep. 787 ; Rogers v. Steamboat Co., 86 Me. 261,29 A. 1069,25 L. R. A. 491; Quimby v. Railroad Co., 150 Mass. 366,23 N. E. 205.

2. Fonseea v. Steamboat Co., 153 Mass. 553, 27 N. E. 665, 12 L. R. A. 340 and note, $25 \mathrm{Am}$. St. Rep. 660 ; Rogers v. Steambont Co., S6 Me.261,29 A. 1065, 25 L. R. A. 491 ; Compare Gulf, ete. R. R. Co. v. McGowan, 65 Tex. 640; Jacobus v. Railroad Co., 20 Minn. 125. $15 \mathrm{Am}$. Rep. 360 ; Mobile, etc. R. R. Co. v. Hopkins, 51 Ala. 486; Rose v. Railroad Co., 39 Iowa, 246; Louisville, etc., R. R. Co. v. Faylor, 126 Ind. 126, 25 N. L. $\$ 69$; Railroad Co. v. Stevens, 95 U. S. 655.
3. McCawley v. Railway Co., L. R. 8 Q. B. 57 ; Peck v. Railway, 10 H. L. Cas. 473.

4. Gallin v. Railway Co., L. R. 10 Q. B. 212. See, also, Alexander v. Railway Co., 33 Upp. Can. Q. B. 474.

5. Kenney v. Railroad Co., 125 N. Y. 422,26 N. E. 626: Wells v. Railroad Co., 24 N. Y. 1S1; Poncher v. Railroad Co., 49 N. Y. 263,10 Am. Rep. 364; Maynard v. Railroad Co., 71 N. Y. 150. 27 Am. Rep. 2S; Maguire r. Dinsmore, 56 N. Y. 168 ; Nichols v. Railroad Co., S9 $\mathrm{N}$. I. 370; Kinney v. Railroad Co., 32 N. J. L. 409.34 N. J. L. 513.90 Am. Dec. 675, 3 Am. Rep. 265. See, also, Railroad Co. r. Bishop, 50 Ga. 465.

G. Illinois Central Railroad Co. v. Read, 37 Ill. 484, S7 Am. Dec. 
And others refuse to give effect to any stipulation absolving the carricr from liability for any degree of negligence. ${ }^{7}$

In connecticut, Massachusetts and Maine, such special contracts relieving the carrier from liability to free passengers, are not forbidden by any principle of public policy. ${ }^{8}$ These cases seem to be clearly in harmony with the principles of justice and common right. In what manner the public welfare or the safety of human life is involved, or any of the cherished interests of the law are invalid by allowing a party to ride on a pass at his own risk, does not clearly and satisfactorily appear.

It is held, in case of free passengers, that since the carrier is not bound to transport them, it may impose such terms, short of willful negligence or injury, as it chooses, as a condition of carrying them. ${ }^{9}$ But, in the absence of any special contract or stipulation, the carrier is bound to exercise the same degree of care toward a free passenger as toward a passenger for hire. ${ }^{10}$

260 ; Railroad Co. v. Míndy, 21 Ind. 48, 83 Am. Dec. 339; Annas v. Railroad Co., 67 IVis. $46,30 \mathrm{~N}$. W. 282, 58 Am. Rep. 848 .

7. Railroad Co. v. Henderson, 51 Pa. St. 315; Railroad Co. v. Curran, 19 Ohio St. 1, 2 Am. Rep. 362; Jacobus v. Railroad Co., 20 Minn. 125, 18 Am. Rep. 360; Gulf, etc., R. R. Co. v. MeGowan, 65 Tex. 640 ; St. Louis, ete. R. R. Co. v. Nelson, 20 Tex. Civ. App. 536, 49 S. W. 710. See, also, N. Y. Cent. R. R. Co. v. Lockwood, 17 Wall. (U. S.) 357 .

8. Griswold v. Railroad Co., 53 Conn. 371, 4 A. 261, 55 Am. Rep. 115; Quimby v. Railroad Co., 150 Mass. 365,23 N. E. 205,5 L. R. A. 846 ; Rogers v. Steamboat Co., 86 Mie. 261, 29 A. 1069, 25 L. R. A. 491.

9. Quimby v. Railroad Co., 150 Mass. 365,23 N. E. 205, 5 L. R. A. 846 ; Rogers v. Steamboat Co., 86 Me. 261,29 A. 1069,25 L. R. A.
491; Griswold v. Railroad Co., 53 Comm. 371, 4 A. 261, 55 Am. Rep. 115.

10. Quimby v. Railroad Co., 150 Mass. 365, 23 N. E. 205; Griswold v. Railroad Co., 53 Comm. 371, 4 A. 261 ; Rogers v. Steamboat Co., 86 Me. 261, 29 A. 1069,25 L. R. A. 491; Rose v. Railroad Co., 39 Iowa, 246; Railroad Co. v. Mieche, 83 Ill. 428; Pittsburgh, etc., R. R. Co. v. Caldwell, 74 Pa. St. 421; Blair v. Railroad Co., 66 N. Y. 313, 23 Am. Rep. 55; Gulf, etc., R. R. Co. v. McGowan, 65 Tex. 640; Gillenevatu v. Railroad Co., 5 Ind. 339, 61 Am. Dec. 101; Siegrist v. Arnat, 10 Mo. App. 197; Todd v. Railroad Co., 3. Allen (Mass.), 18, 80 Am. Dec. 49 ; Files v. Railroad Co., 149 Mass. 204, 21 N. E. 311, 14 Am. St. Rep. 411; Perkins v. Railroad Co., 24 N. Y. 196, 82 Am. Dec. 282 and note; Jacobus v. Railroad Co., 20 Minn. 125, 18 Am. Rep. 360. 
So, if a passenger insists upon riding, or is required by the nature of lis oempation to ride, in a place not provided for passengers, it has been held that the carrier properly may say to him that he must take the risk, however, arising. ${ }^{11}$

If a person can show that the pass had been issued to him under conditions sufficient to make his earriage one for hire in any legal sense, it is competent for him to show that his attention lad not been cnlled to the stipulation exonerating the carrier from liability, and that he had never seen it or given his assent to it; this is the law of many States. ${ }^{12}$ But as heretofore stated, if the passenger is not one for hire, it is of no consequence whether or not he knows of and had assented to the assumption of the risk of aceident imposed by the stipulation. And so when a party accepts a free pass and avails himself of the privileges set forth, he is bound by the conditions. ${ }^{13}$ If the pass is issued as part of the eonsideration of a contract of which it is collateral, then the passenger ean recover for the accident caused by the railroad's negligence. ${ }^{14}$ And if the passenger rides on the special invitation of the president of the railroad without any stipulation or condition whaterer, then the company will be liable for the aceident caused by its own negligence. ${ }^{15}$ In general, when one aceepts a gratuity qualified by conditions, he is estopped to repudiate the condition and at the same time accept the privileges conferred. This rule is in conformity with the moral sense which justly holds those who aceept gratuities and acts of hospitality to perform the condition on which such gratuities are bestowed. Under such conditions the common

11. Hosmer r. Railioad Co., 156 Mass. 50631 N. E. 652 ; Robertson v. Railroad Co., 156 Mass. 525, 31 N. E. 650; Bates v. Railroad Co., 147 Mass. 255, 17 N. E. 633. See, also, Doyle v. Railroad Co., 160 Mass. 492,44 N. E. 611,33 L. R. A. 844, 55 Am. St. Rep. 417.

12. The Majestic, 166 U. S. 375, 17 s. Ct. 597 .

13. Quimby v. Railroad Co., 150
MIass. 365,23 N. L. 205,5 L. R. A. 846; Griswold v. Railroad Co., 53 Conn. 371,4 A. 261, 55 Am. Rep. i15; Muldoon v. Railroad Co., 10 Wash. 311,38 P. 995, 45 Am. St. Rep. $78 i$; Ill. Cent. R. R. Co. v. Read, 37 Ill. 486, 87 Am. Dec. 260.

14. N. Y. Cent. Railroad Co. v. Iockwood, 17 Wall. (U. S.) 357.

15. Railroad Co. v. Derny, 14 How. U. S.) 468. 
carrier becomes, or holds the position of, a gratuitous bailee. A common carrier is one that pursues the public employment of conveying goods or passenger's for hire; so if a passenger is not carried for hire and assumes all responsibility of the carriage, he cannot recover for injuries caused by the railroad company. ${ }^{16}$

The courts are not agreed on this question of riding on a free pass, as to the liability of the common carrier for his negligence. Some of the courts hold that a stipulation of a passenger riding on a free pass to assume the risk is void as against public policy, and this doctrine cannot be changed by a decision of the Federal Supreme Court, as the question is not one of Federal nature, so a decision of that court is in no sense binding on the State courts. However, the weight of authority is with that court. $^{17}$

\section{ARTICLE III.}

\section{As to Telegraph and Telephone Companies.}

Section 296. Telegraph Companies.

297. Limiting Liability for Mistake in Sending Message.

298. Telephone Companies.

§ 296. Telegraph companies.- Telegraph companies resemble common carrires, in that they are instruments of commerce; and in that they exercise a public employment, and are therefore bound to serve all customers alike, without discrimination. They have a duty to the public, to receive, to the extent of their capacity, all messages clearly and intelligently written, and to transmit them upon reasonable terms. But they are not common carriers; their duties are different, and are performed in different ways; and they are not subject to the same liabilities. ${ }^{1}$

16. Duncan v. Railroad Co., 113 Fed. Rep. 508; Boering v. Railroad Co., 20 D. C. App. 500; affirmed by U. S. S. Ct, 37 Chi. Legal News, 33.

17. Muldoon v. Railroad Co., 7 Wash. 528, 36 P. 422. See, 22 L. R. A. 794 and note, 38 Am. St. Rep. 901. See "Stipulations Against
Liability for Negligence in Gratuitous Passes."-56 Cent. L. Jour. 204.

1. Express Co. v. Caldwell, 21 Wall. (U. S.) 264, 269, 270; Telegraph Co. v. Texas, 1 Am. Electl. Cas. 373,105 U. S. $460,464$. 
Like conmon carriers, they cannot contract with their employers for excmption from liability for the consequenees of their own negligenee. But they mar, hy such contracts, or by their rules and regulations brought to the knowledge of their employers, limit the measure of their responsibility to a reasonable extent. Whether their rules are reasonable or unreasonable must be determined with reference to public policy, precisely as in the case of a carrier. ${ }^{2}$

It was sald in one case that it is no louger an open question that telephone and telegraph companies are subject to the rules gorerning conmon carriers and others engaged in like employment. ${ }^{3}$ But that case has regard, as is evident from the contract, and from the reference to another case, ${ }^{4}$ to those rules only which require persons or corporations exercising public employment to serve all alike, without discrimination, and which make them subject to legislative regulations $;^{5}$ but they are not common carriers. ${ }^{6}$ Some decisions hold that a telegraph company is a common carrier, ${ }^{7}$ and that it cannot make a valid contract against its own negligence. ${ }^{8}$

\section{$\S 297$. Limiting liability for mistake in sending message.-} A stipulation by a telegraph company and the sender of a message, that the company shall not be liable for mistakes in the

2. Express Co. v. Caldwell, 21 Wall. (U. S.) 264.

3. Delaware \& Atlantic Telephone Co. v. Telegraph Co., 4 Am. Electl. Cas. 579, 50 Fed. Rep. 677,2 C. C. A. 1,13 U. S. App. $30,105$.

4. Budd v. New York, 143 U. S. 517, 12 S. Ct. 468.

5. Primrose v. Telegraph Co., 5 Am. Electl. Cas. 809,154 U. S. 1 , 22, 14 S. Ct. 1098.

6. Express Co. v. Caldwell, 2l Wall. (U. S.) 264, 269, 270; Telegraph Co. v. Texas, 1 Am. Eleetl. Cas. 373,105 U. S. 460,
464; Primrose v. Telegraph Co., 5 Am. Electl. Cas. 809, 154 U. S. 1, 14 S. Ct. 1098.

7. Western Union Tel. Co. v. Call Pub. Co., 5 Am. Electl. Cas. 673, 44 Neb. 326, 62 N. W. 506, 27 L. R. A. 622,48 Am. St. Rep. 724 .

8. Brown $v$. Tel. Co., 111 N. Car. 187, 4 Am. Electl. Cas. 774, 16 S. E. 179,17 L. R. A. 648 , 32 Am. St. Rep. 793; Gillis v. Tel. Co., 2 Am. Electl. Cas. 841, 61 Vt. 461, 17 A. 736, 4 L. R. A. 611 and note, $15 \mathrm{Am}$. St. Rep. 917. 
transmission or delivery of a message, beyond the sum received for sending it, unless the sender orders it to be repeated by being telegraphed back to the originating office for comparison, and pays half that sum in addition, is reasonable and valid. This is the settled law in many of the States and in England. ${ }^{1}$ As is generally held a telegraph company has a clear right to protect itself against extraordinary risks and liability by such rules and regulations as may be required for the purpose. But it cannot, by rules and regulations of its own making, protect itself against liability for the consequence of its own willful conduct, or gross negligence, or any conduct inconsistent with good faith. It is bound to use due deligence, but not to use extraordinary care and precaution. But by no device can it avoid liability for fraud, for willful wrong, or for the gross negligence which, if it does not intend to occasion injury, is reckless of consequences. and transcends the bound of right with full knowledge that mischief may ensue. ${ }^{2}$

1. Jarboe v. Telegraph Co., 63 Mo. App. 226; Kiley v. Telegraph Co., 2 Am. Electl. Cas. 650, 109 N. Y. 231, 235, 237, $16 \mathrm{~N}$. E. 75; Primrose v. Telegraph Co., 5 Am. Electl. Cas. 809, 154 U. S. 1, 14 S. Ct. 1098; Western Union Tel. Co. v. Blanchard, I Am. Electl. Cas. 404, 68 Ga. 299, 45 Am. Rep. 480 and note; Hart v. Telegraph Co., 1 Am. Electl. Cas. 734, 66 Cal. 579, 6 P. 631, 56 Am. Rep. 119 and note; Wann v. Telegraph Co., 37 Mo. 472, 90 Am. Dec. 395; Breeze v. Telegraph Co., 48 N. Y. 132, 8 Am. Rep. 5\%0; Grinnell v. Telegraph Co., 1 Am. Electl. Cas. 70, 113 Mass. 299, 18 Am. Rep. 485; Camp v. Telegraph Co., 1 Met. (Ky.) 164 , $17 \mathrm{Am}$. Dec. 461 and note; Western Union Tel. Co. v. Carew, 15 Mich. 525; McAndrew v. Telegraph Co.,
17 C. B. 3 ; Baxter v. Telegraph Co., 37 Up. Can. Q. B. 470; Compare Western Union Tel. Co. v. Crawford, 110 Ala. 460, 23 So. 111.

2. Passmore v. Telegraph Co., 1 Am. Electl. Cas. 168, 9 Phil. (Pa.) 90, 78 Pa. St. 238; Birney v. Telegraph Co., 18 Md. 341, 358, 81 Am. Dec. 697 and note; United States Tel. Co. v. Gildersleve, 29 Md. 232, 96 Am. Dec. 519; Western Union Tel. Co. v. Stevenson, 3 Am. Electl. Cas. 764, 128 Pa. St. 442, 18 A. 441, 5 L. R. A. 515, 15 Am. St. Rep. 687; Ellis v. Telegraph Co., 13 Allen (Mass.), 226; Redpath v. Telegraph Co., 1 Am. Electl. Cas. 40, 112 Mass. 71, 17 Am. Rep. 69; Grinnell v. Telegraph Co., 1 Am. Electl. Cas. 70, 113 Mass. 299, 18 Am. Rep. 485; Clement v. Telesraph Co., 1 Am. Electl. Cas. 671, 
There are cases in which such regulations have been considered to be wholly void. Many of them, however, upon examination, appear to have been decilled by considerations which do not apply the doctrine already discussed. Some of them were actions brought not by the sender, but hy the receiver of the message, who had no notice of the printed conditions until after he received it, and could not, therefore, have agreed to them in advance." Others were cases or night messages, in which the whole provision as to repeating was omitted, and a sweeping and comprehensive provision substituter, by which in effect, all liability beyond the price paid was avoidable."

And when the telegraph company does not undertake to restrict its liability by express stipulation, the sender may recover damages. ${ }^{6}$

In some of the States the decisions are controlled by statutes. Thus, in Indiana telegraph companies are made liable by statute for special damages by failure or negligence of their operators or servants, in sending messages. ${ }^{6}$

But there are decisions, not controlled by statute, which hold that a stipulation that the sender of a message, if he would hold the company liable in damages beyond the sums paid, must have it repeated and pay half that sum in addition, is roid as against public policy. ${ }^{7}$ These cases hold that it is against public policy to permit telegraph companies to secure exemptions from

137 Mass. 463; Dixon v. Telegraph Co., 6 Am. Eleetl. Cas. 803, 3 App. Div. 60, 38 N. Y. S. 1056.

3. New York, ete., Tel. Co. v. Dryburg. 35 Pa. St. 298, 78 Am. Dec. 338; Harris v. Telegraph Co., 9 Pbila. (Pa.) 88: De La Grange v. Telegraph Co., 25 La. Ann. 383.

4. True r. Telegraph Co.. to Me. 9, 18, $11 \mathrm{Am}$. Rep. 156 and note: Bartlett v. Telegraph Co., l Am. Electl. Cals. 45, 62 Me. 209, 215, 16 Am. Rep. 437 : Candee v. Telegraph Co., 1 Am. Electl. Cas. 99, 34 Wis. 471, 476, 17 Am. Rep. 452; Hibbard v. Telegraph Co., 1 Am. Eleetl. Cas.
62, 33 Wis. 55s, 564, 14 Am. Rep. 775 .

5. Rittenhouse v. Telegraph Co., 1 Daly (N. Y.). 47. 4. 4 N. Y. 263; Turner v. Telegraph Co., l Am. Electl. Cas. 208, 41 Iowa, 4.5, 20 Am. Rep. 605.

6. Western Union Tel. Co. v. Meek, $1 \mathrm{Am}$. Electl. Cas. 135, 49 Ind. 53: Western L'nion Tel. Co. v. Fenton, 1 Am. Electl. Cas. 198, 52 Ind. 1.

7. Tyler v. Telegraph Co., $1 \mathrm{Am}$. Electl. Cas. 14, 60 Ill. $421,14 \mathrm{Am}$. Rep. 38, $7+$ Ill. 168, $24 \mathrm{Am}$. Dec. 279 and note; Ayer v. 
the consequences of their own gross negligence by contract. So, notwithstanding any special conditions which may be contained in a contract between the company and the sender of a message restricting liability of the company in case of an inaccurate transmission of the message, the company will still be liable for a mistake happening by its own fault. ${ }^{8}$ Some hold that this fault may be a defective instrument or carlessness or unskillfulness of its operators, and not for mistakes occasioned by uncontrollable canses $;^{9}$ that plaintiff, in order to recover damages, must show that the mistake was cansed by the fault of the company, and that it might have been avoided if the company's instruments had been good ones and if its agents had possessed the requisite skill and exercised proper care and diligence in respect to the transmission and receipt of the message in question. ${ }^{10}$

In Illinois the mere fact that a condition is printed in a tele-

Telegraph Co., 2 Am. Electl. 1 Am. Electl. Cas. 14, 60 Ill. Cas. 601, 79 Me. 493, 10 A. 493, 1 Am. St. Rep. 353; Telegraph Co. v. Griswold, 37 Ohio St. 301, 41 Am. Rep. 500; Western Union Tel. Co. v. Crall, 2 Am. Electl. Cas. 575, 38 Kan. 679, 17 P. 309, 5 Am. St. Rep. 795; Western Un. Tel. Co. v. Howell, 2 Am. Electl. Cas. 581, 38 Kan. 685, 17 P. 313; Brown v. Cable Co., 4 Am. Electl. Cas. 774, 111 N. Car. 187,16 S. E. 179,17 L. R. A. 648,32 Am. Rep. 793; Western Union Tel. Co. v. Cook, 5 Am. Electl. Cas. 799, 61 Fed. Rep. 624, 9 C. C. A. 680,15 U. S. App. 445 ; Western Union Tel. Co. v. Linn, 87 Tex. 7, 26 S. WV. 490 , 47 Am. St. Rep. 58; Gillis v. Telegraph Co., 2 Am. Electl. Cas. 841,61 Vt. 461, 17 A. 734, 4 L. R. A. 611 and note, 15 Am. St. Rep. 917. See, also, Gray on Communications by Tel. 51; Thompson on Elect. 235, 236.

8. Tyler v. Telegraph Co., 421, 14 Am. Rep. 38, 74 Ill. 168, 24 Am. Rep. 279 and note.

9. Tyler v. Telegraph Co.. 1 Am. Electl. Cas. 14, 60 Ill. 421, 14 Am. Rep. 38.

10. Sweatland v. Telegraph Co., 27 Iowa, 433, 1 Am. Rep. 285. As to damages for breach to transmit message, see Western Union Tel. Co. v. Hall, 2 Am. Electl. Cas. 868, 124 U. S. 444,8 S. Ct. 577 ; Hadley v. Baxendale, 9 Exch. 345; Howard v. Stillwell Co., 139 U. S. $199,206,207,11$ S. Ct. 500 ; Sanders v. Stuart, 1 C. P. D. 326, 328, 45 L. Journ., N. S., C. P. 682, 684; United States Tel. Co. v. Gildersleve, 29 Md. 232, 251, 96 Am. Dec. 519 ; Baldwin v. Telegraph Co., 45 N. Y. 744, 749, 750, 752, 6 Am. Rep. 165; Tyler v. Telegraph Co., 1 Am. Electl. Cas. 14, 60 Ill. 434, 14 Am. Rep. 38; Postal. Tel. Co. v. Lathrop, 3 Am. Electl. Cas. 630,131 Ill. $575,585,23$ N. E. 583, 
graph blank, does not charge the sender of a mesaage with notice thereof. ${ }^{11}$

$\S$ 298. Telephone companies. - The same rule applies to telephone companies as to telegraph companies. Such rules and regulations as a telephone company adopts must be reasonable and must not have the effect of relieving the company of its duties and obliagtions which it owes to its patrons by means of its public character. ${ }^{1}$ A telephone company has the right to adopt reasonable rules and regulations; but a rule that it will not be responsible for the negligence of messenger sent from its station, who must of necessity be of its selection and under its control, and that such messengers shall be deemed the agent of the patrons at whose instance they are sent, is roid as aaginst public policy, on the ground that a telephone company cannot limit its liability, for negligence of its serrants. ${ }^{2}$ Some decisions hold that a telephone company is a common carrier. ${ }^{3}$ Whenerer such companies are held to be common carriers the court will apply the same rule with respect to liability for negligence that it applies in cases of other common carriers.

7 L. R. A. 474, 19 Am. St. Rep. 55; Candee v. Telegraph Co., 1 Am. Electl. Cas. 99, 34 Wis. 471,479 , Telegraph Co., 1 Am. Electl. Cas. 141, 2l Minn. 155; Mackay v. Telegraph Co., 16 Nev. 222; Danicl v. Telegraph Co., 1 Am. Electl. Cas. 650, 61 Tex. 452, 48 Am. Rep. 305; Cannon v. Telegraph Co., $2 \mathrm{Am}$. Electl. Cas. 699, 100 N. Car. 300; 6 S. E. 731,6 Am. St. Rep. 390; Western Union Tel. Co. v. Wilson, 4 Am. Electl. Cás. 664, 32 Fla. 527,14 S. E. 1, 22 L. R. A. 434, $37 \mathrm{Am}$. St. Rep. 125; Abeles v. Telegraph Co., 37 Mo. App. 554; Kinghorne v. Telegraph Co., $18 \mathrm{Up}$. Can., Q. B. 60, 69; Primrose v. Telegraph Co., 5 Am. Electl. Cas. 809,154 U. S. $1,1 \pm$ S. Ct. 1098.
11. Western Union Tel. Co. v. Lyon, 60 Ill. App. 122. See "Liability of Telegraph Companies for Negligence in the Transmssion and Delay of Messages."-10 Va. L. Register, 392.

1. Central Union Telephone Co. v. State, 2 Am. Flectl. Cas. 27, 118 Ind. 194, 19 N. E. $604,10 \mathrm{Am}$. St. Rep. 114 and note.

2. Central Union Telephone Co. v. Swoveland, $6 \mathrm{Am}$. Electl. Cas. 679, 14 lnd. App. 341,42 N. E.

3. Gwynne v. Tel. Co., 61 S. Car. 83,39 S. E. $25 \overline{7}, 55$ L. R. A. 130 , $85 \mathrm{Am}$. st. Rep. 870 ; Nebraska Tel. Co. v. State, $7 \mathrm{Am}$. Electl. Cis. 860 , 1035 .

55 Neb. 627,76 N. IV. 171, 45 L. R. A. 113. 


\section{ARTICLE IV.}

\section{Limiting Master's Litability.}

SECrion 299. Limiting Master's Liability to Servant.

300. Limiting Master's Liability to Servant-Servant Receiving Benefits from Association.

§ 299. Limiting master's liability to servant.- No man may contract contrary to law, or contrary to public policy or good morals, and this is true of merchants, lawyers, doctors, of buyers and sellers, bailors and bailees, and of master and servants. And the liability of railroad companies and other carriers for injuries to their servants caused by the carelessness of those who are superior in authority and control over them, is placed chiefly upon consideration of public policy $;^{1}$ and it is not competent for a railroad company to stipulate with its employes at the time, and as a part of their contract of employment, that such liability shall not attach to it. ${ }^{2}$ A rule which imposes upon an employee to look after and be responsible for his own safety, contravenes the law itself, which fixes the liability of railroads for negligence causing injury or death to their employees, ${ }^{3}$ and is opposed to public policy. ${ }^{4}$

And in general, a contract whereby a party stipulates for his exemption from liability for the consequences of his own negligence, is against public policy and void, and this is so independ-

1. Little Miami R. R. Co. v. Stevens, L0 Ohio, 415; Railroad Co. v. Spangler, 44 Ohio St. 471,8 N. E. 467, 58 Am. Rep. 833 and note.

2. Railroad Co. v. Spangler, 44 Ohio st. 471,8 N. E. 467 ; Raesner v. Hermann, 8 Fed. Rep. 782; Kansas Pac. I. R. Co. v. Peavey, 29 Kans. 169, 44 Am. Rep. 630 and note; Louisville, etc., R. R. Co. v. Orr, 91 Ala. 548, 8 So. 360 ; Hissong v. Railroad Co., 91 Ala. 514, 8 So. 776 ; Riclmond, etc., R. R. Co. v. Jones, 92 Ala. 218, 9 So. 276 ; Com- pare Western, etc., R. R. Co. v. Bislrop, 50 Ga. 465; Western, ete., R. R. Co. v. Strong, 52 Ga. 461; Hendricks v. Railroad Co., 52 Ga. 467; Grifiths v. Dudley, L. R. 9 Q. B. Div. 357 .

3. Louisvalle, etc., R. R. Co. v. Orr, 91 Ala. 548, 8 So. 360.

4. Hissong v. Railroad Co., 91 Ala. 514, 8 So. 776; Richmond, ete., R. R. Co. v. Jones, 92 Ala. 218, 9 So. 276 ; Railroad Co. v. Spangler, 44 Ohio St. 471,8 N. E. 467,58 Am. Rep. 833 and note. 
ently of statute." ( ommmon carriers ammot by contratet rexempt themselves from responsibility for their own or their servants' negligence in the earriage of goods and passengers for him : and the prineiple which vitiates a stipulation for exrmption from liability for one's wwn negligence, is not eonfinerl to the contracts of carriers as such; it applies miversally. ${ }^{6}$

The Georgia doctrine holds that such eontracts are valid so far as they do not waive any eriminal neglect of the master or his prineipal agents; but when the contract contravenes public policy it will be voil. ${ }^{7}$

\section{$\S$ 30o. Limiting master's liability to servant - Servant re-} ceiving benefits from association.-Where the corporation has contributed to the funds of a relief association composed of its employees, an agreement by a member of the association that the acceptance of beuefits from the relief fund for injury or death shall operate as a release of all claim for damages against the corporation or master, is not contrary to public policy, and does not violate the rule that a common carrier, or other master, cannot make a valid contract against his own negligence.

In cases of injury through the master's negligence there is no waiver of any right of action that the person injured may thereafter be entitled to. It is not the signing of the contract, but the acceptance of benefits after the accident that constitutes the release. The serrant is not stipulating for the future, but settling for the past; he is not agreeing to exempt the master from liability for negligence, but accepting compensation for an injury already caused thereby. ${ }^{1}$ The substantial feature of the contract which distinguishes it from those held void as against

5. Johnson v. Railroad Co., 86 Va. 975,11 S. E. 829.

6. Cooley on Torts, 68i ; Raesner r. Hermamn, 10 Biss. C. C. 486; Railway Co. v. Spangler, 44 Ohio St. 471,8 N. E. 467,58 Am. Rep. 833 and note: Johnson v. Railroad Co., 86 Va. 975,11 S. E. 829 .

7. Western, ete. R. R. Co. $v$. Bishop. 50 Ga. 465.
1. Eckman v. Railroad Co., 169 111. 312,48 N. E. 496,38 L. R. A. 750 ; Johnson v. Railroad Co., 163 Pa. St. 127, 29 A. 854 ; State v. Railroad Co., 36 Fed. Rep. 655; Owens v. Railroad Co., 35 Fed. Rep. 715, 1 L. R. A. 75 and note; Chicago, ete. Railroal Co. v. Bell, 44 Neb. 44, 62 N. W. 314; Fuller v. Relief Asso., 67 Md. 433, 10 A. 237 ; 
public policy is that the servant retains whatever right of action he may have until after knowledge of all the facts, and an opportunity to make his choice betwcen the sure benefit of the association or the chances of litigation. Having accepted the former he cannot justly ask the latter in addition. ${ }^{2}$

The acceptance of such relief fund by the servant operates as a release of such servant's elaim against the master for damages because of injury under the following eonstruction of such contract: 1. Such contract of a servant does not lack consideration to support it. 2. The promise made by the servant or employee to the relief association of the master is available to the latter as a cause of action or defense. 3. Such contract is not contrary to public policy. 4. The effect of such contract is not to make the master exonerate himself by contract from liability for the negligence of himself or servants. 5. The cmployee does not waive his right of action against the master, in case he should be injured by the master's negligence, by the exceution of the contract. 6 . It is not the execution of the contract that estops the injured servant, but his acceptance of payment from the relief association on account of the injury after his cause of action against the master on account thereof arises. ${ }^{3}$ And if the relief association has no money to pay the injured servant, then he may sue the company and recover, notwithstanding he has accepted benefits as a member of such association organized by the company, under an agreement that he thereby relinquishes his right of action. ${ }^{4}$

Ringle v. Railroad Co., 164 Pa. St. 529, 44 Am. St. Rep. 628 and note; Kinney v. Railroad Co., 35 W. Va. 385 ; 14 S. E. 8,15 L. R. A. 142 and note; Spetz v. Railroad Co., 75 Md. 308, 23 A. 307.

2. Johnson v. Railroad Co., 163 Pa. St. 127, 29 A. 854; Lease v. Railroad Co., 10 Ind. App. 47, 37 N. E. 423; O'Neil v. Iron Co., 63 Mich. 690,30 N. W. 688 .
3. Chicago, etc. Railroad Co. v. Bell, 44 Neb. 44, 62 N. W. 314; Martin v. Railroad Co., 41 Fed. Rep. 125. See, also, Otis v. Railroad Co., 71 Fed. Rep. 136; Clements v. Railroad Co. (1894), 2 Q. B. 482; Vickers v. Railroad Co., 71 Fed. Rep. 139; Shaver v. Railroad Co., 71 Fed. Rep. 931.

4. Chicago, et.c. R. R. Co. v. Miller, 76 Fed. Rep. 439, 22 C. C. A. 264, 40 U. S. App. 448. 


\section{CHAPTER X.}

\section{Obligations of Quasi-Public Corporations.}

\section{ARTICLE I.}

\section{Disabling Contracts of Corporations Owing a Duty to time Public.}

Sectios 301. Private Contract of Quasi-Public Corporations.

302. Lociting Right of Way and Stations of Railroads.

303. Use of Franchise.

$\S 30$. Private contracts of quasi corporations.- The general rule that contracts in partial restraint of trade are not inralid, does not apply to corporations in a public business, in which the public are interested. Such contracts cannot be allowed. Any private contract by them which is injurious or prejudicial to the public interest is void on the ground of public policy. ${ }^{1}$ And so a contract by which a company renders itself incapable of performing its duties to the public or attempts to absolve itself from its dutics, withont the consent of the State, violates its charter and is forbidden by public policy. ${ }^{2}$ And so a contract which obliges one of the parties to do an act in violation of law, or restricts the free exercise of discretion rested by law in a public or municipal officer in reference to a trust reposed in him, or which contemplates such violation of law or discharge of the free exercise of a public dutr, is a nullity. ${ }^{3}$

1. Burney v. Ludeling, 47 Lat. Ann. 73, 16 So. 507; Chicago Gas light Co. v. Coke Co.. 12 T Ill. 530, $13 \mathrm{~N}$. E. 169; Hays v. Railroad Co., 61 Ill. 422; Thomas v. Railroad Co., 101 U. S. 71. 83.

2. Thomas v. Railroad Co., 101
U. S. 71, 83; Ashbury Railway, etc. Co. v. Riche, I. R. 7 H. L. 653.

3. Mayor v. Bowman, 39 Miss. 671. See, also, Jerret v. Bartlett, 21 Vt. 184: Wooten v. Miller, 7 Sm. \& Mr. (Miss.) 385. 
So, a board of education has no right to stipulate in a contract for improvement that none but union labor shall be employed by the contractor." Such a stipulation is an infringement of the constitutional rights of citizens. Even the State, through its legislature could not enact such a provision. ${ }^{5}$

\section{$\$ 302$. Locating right of way and stations of railroads. -} It is generally held that a railway company cannot bind itself with an individual to locate and maintain stations at particular points or not to locate and maintain them at other points. The company must be left free to establish and reestablish whenever the public welfare or wants of the public may require. The power to locate stations is, from its nature, a continuing one. ${ }^{1}$ So a contract materially limiting a railroad's power to locate and relocate its depots, is against public policy and, therefore, void. $^{2}$

So a contract in which an officer or other person supposed to be influential with a railway company, for a consideration promised him, agrees to secure the location of station, depot or railway at a particular place, is void. ${ }^{3}$ Another class of cases, which restrict the doctrine of the general rule holds, that where an

4. Adams v. Brennan, $177 \mathrm{Ill}$. 194, 52 N. E. 314,60 Am. St. Rep. 222, 42 L. R. A. 718.

5. People v. Live Stock Exchange, 170 Ill. 556,48 N. E. 1062,30 L. R. A. 373, 62 Am. St. Rep. 404; Holden v. Alton, 179 Ill. 318, 53 N. E. 556 .

1. Mobile, etc. R. R. Co. v. People, 132 Ill. 559, 24 N. E. 645, 22 Am. St. Rep. 556 .

2. Fuller v. Dame, 18 Pick. (Mass.) 472; Burney v. Ludeling, 47 La. Amn. 73, 16 So. 507; St. Joseph, ete. R. R. Co. v. Ryan, 11 Kan. 602, 15 Am. Rep. 357; Pacific R. R. Co. v. Seeley, 45 Mo. 212, 100 An. Dec. 369; Currie v. Railroad Co., 61 Miss. 725; Florida, ete. R. R. Co. v. State, 31 Fla. 482 , 13 So. 103, 20 L. R. A. 419, 34 Am. St. Rep. 30 ; Woodstock Iron Co. v. Railroad Co., 129 U. S. 642, 9 S. Ct. 402; Williamson v. Railroad Co., 53 Iowa, 126, 4 N. 870, 36 Am. Rep. 206 and note: Marsh v. Railroad Co., 64 Ill. 414, 16 Am. Rep. 564 ; Holladay v. Patterson, 5 Oreg. 182; Linder v. Carpenter, 62 Ill. 309 ; St. Louis, etc. R. R. Co. v. Mathews, 71 Ill. 592, 104 Ill. 257; Bester v. Wathen, 60 Ill. 138; People v. Railroad Co., 130 Ill. 175, 22 N. E. 857.

3. Fuller v. Dame, 18 Pick. (Mass.) 472; Bester v. Wathen, 60 Ill. 138; Linder v. Carpenter, 62 Ill. 309 . 
agreement has been made, between an individual and railway corporation, for the location of a station or depot at a particular place, in consideration of a donation of money or property to the corporation, without any restrietion or prohibition against any other location, it is ralid." And, hence, an agreement to pay a railway company a stipulated sum, in consideration that it wonld locite its ronte at a particular place, is valid, and not against public policy. ${ }^{5}$ So a conditional subseription of stock is valid. ${ }^{6}$ And so a vohuntary grant to a railroad, on condition that it would locate its route and establish a depot at a certain place, is not against public policy. ${ }^{7}$ According to these cases where there is no restriction or prohibition against any other location, such contracts are not void as against public policy. ${ }^{8}$ All the cases agree that those contracts which stipulate for location of stations or depots at particular places, and which prohibit the location of others within preseribed limits, are void, ${ }^{9}$ because railroad companies can make no contract which shall prohibit it from serving the public as the future demands of business or concentration of population may require. ${ }^{10}$

4. Louisville, etc. R. R. Co. v. Sumner, 106 Ind. 55, 5 N. E. 404, 55 Am. Rep. 719.

5. Cumberland R. R. Co. v. Baab, 9 Watts (Pa.), 458, 36 Am. Dee. 132; First Nat. Bank v. Hendrie, 49 Iowa, 402, 31 Am. Rep. 153; Swartout v. Railroad Co., 24 Mich. 389 ; Harris v. Roberts, 12 Nebr. 631, 2l N. 89, 41 Am. Rep. 779; International R. R. Co. v. Dawson, 62 Tex. 260.

6. New Albany, etc. R. R. Co. v. MeCormick, 10 Ind. 499, $71 \mathrm{Am}$. Dee. 337 ; Jewett v. Railroad Co., 10 Ind. 539.

7. McClure v. Railroad Co., 9 Kans. 373. See, also, Watterson v. Railroad Co., 74 Pa. St. 208;
Galveston, etc. R. R. Co. v. Pfeuffer, 56 Tex. 66.

8. Louisville, etc. R. R. Co. v. Sumner, 106 Ind. 55, 5 N. E. 404 , 55 Am. Rep. 719.

- 9. Williamson v. Railroad Co., 53 Iowa, 126, 4 N. 870, 36 Am. Rep. 206 and note; St. Louis, etc. R. R. Co. v. Mathews, 104 Ill. 257, 22 An. Rep. I22, 71 Ill. 592; St. Joseph, etc. R. R. Co. v. Ryan, 11 Kan.602,15 Am. Rep. 357. See, also, Fuller v. Dame, 18 Pick. (Mass.) 472 ; Bester v. Wathen, 60 Ill. 138.

10. Lonisville, etc. R. R. Co. v. Sumner, 106 Ind. 55,5 N. F. 404, 55 Am. Rep. 719; Williamson $\nabla$. Railroad Co., 53 Iowa, 126, $4 \mathrm{~N}$. 870, 36 Am. Rep. 206 and note. 
$\S 303$. Use of franchises. - Where a corporation like a railroad company has granted to it by charter a franchise intended in large measure to be exercised for the public good, the due performance of those functions being the consideration of the public grant; and any contract which disables the corporation from performing those functions, which undertakes without the consent of the State to transfer to others the rights and powers conferred by the charter and to relieve the grantee of the burden which it imposes, is a violation of the contract with the State and is roid as against public policy. ${ }^{1}$

A contract of a carrier, whether an individual or a corporation, not to cary passengers or goods over a particular route may be reasomable and valid. ${ }^{2}$ But a contract by which a corporation, chartered to perform the duties of a common carrier, or any other duties to the public, agrees that it will not perform those duties at all, anywhere, for ninety-nine years, is clearly unreasonable and void. ${ }^{3}$ When the corporation abandons its duty to the public in making contracts, such contracts are void."

The supplying of illuminating gas is a business of a public nature to meet a public necessity. It is not a business like that of an ordinary corporation engaged in the manufacture of articles that may be furnished by individual effort, and are controlled in making contracts by their charters. ${ }^{5}$

1. Thomas v. Railroad Co., 101 U. S. 71, 83; Pickard v. Car Co., 117 U. S. 34,6 S. Ct. 635; York, ete. R. R. Co. v. Winans, 17 How. (U. S.) 30,39 .

2. Peirce v. Fuller, 8 Mass. 223; Palmer v. Stebbins, 3 Pick. (Mass.) 188, 15 Am. Dec. 204; Leslie v. Lorillard, 110 N. Y. 519, 18 N. E. 363,1 L. R. A. 456 and note.

3. Oregon Steam Nav. Co. v. Winsor, 20 Wall. (U. S.) 64; Gibbs v. Gas Co., 130 U. S. 408, 410, 9 S. Ct. 553.
4. Central Trans. Co. v. Car Co., 139 U. S. 24,11 S. Ct. 478.

5. New Orleans Gas Co. v. Louisiana Light Co., 115 U. S. 650, 6 S. Ct. 252; Louisville Gas Co. v. Citizens' Gas Co., 115 U. S. 683, 6 S. Ct. 265; Shepard v. Gas Light Co., 6 Wis. 539, 70 Am. Dec. 479 and note; Chicago Gas Light and Coke Co. v. Coke Co., 121 Ill. 530, $13 \mathrm{~N}$. E. 169,2 Am. St. Rep. 124; St. Louis v. Gas Light Co., 70 Mo. 69. See, also, State v. Railroad Co., 29 Conn. 538; Pefers v. Ryland, 20 Pa. St. 497, 59 Am. Dec. 746. 


\section{ARTICLE II.}

\section{Discriminations.}

Section 304. Suppressing Competition.

305. Combination of (uasi-1'ublic Corporations.

306. Discrimination by Carriers.

307. Telephone and Telegraph Companies.

308. Exclusive Privileges.

$\S$ 304. Suppressing competition. - While it is justly urged that those rules which say that a given contract is against public policy, should not be arbitrarily extended so as to interfere with the freedom of contract, ${ }^{1}$ yet in the instance of business of such character that it presumably cannot be restrained to any extent whatever without prejudice to the public interest, courts decline to enforce or sustain contracts imposing restraint, however partial, because in contravention of public policy. ${ }^{2}$ A railway company cannot lease or buy a competing line in order to suppress competition. ${ }^{3}$ Any combination or agreement, the object of which is to destroy or interfere with free competition in any line of business is roid, whether or not in the particular instance it has its desired effect. ${ }^{4}$ When the provisions of agreements in restraint of competition tend beyond measures for self-protection and threaten the public good in a distinctly appreciablo manner, they should not be sustained. The apprehension of danger to the public interests, however, should rest on evident grounds, and courts should refrain from the exercise of their equitable powers in interfering with and restraining the con-

1. Printing and Registering Co. v. Sampson, L. R. 19 Eq. Cas. 462.

2. West Virginia Trans. Co. v. Pipe Line Co., 22 IV. Va. 600, 46 Am. Rep. 527; Chicago Gas Light and Coke Co. v. Coke Co., $121 \mathrm{Ill}$. 530, 13 N. E. 169, 2 Am. St. Rep. 124; Western Union Tel. Co. v.
Telegraph Co., 65 Ga. 160, 38 Am. Rep. 781 and note.

3. Thomas v. Raillroad Co., 101 U. S. 71 ; Gulf, etc. R. R. Co. v. Morris, 67 Tex. 692, 4 S. IV. 156.

4. Anderson v. Jett, S9 Ky. 375, 12 S. W. 670,6 L. R. A. 390. 
duet of the affairs of individuals or of corporations, unless their conduct, in some tangible form, threatens the welfare of the public. ${ }^{5}$

To the extent that the eontract prevents the vendor from carrying on the particular business, it deprives the community of any benefit it might derive from his entering the eompetition. But the business is open to all others and there is little danger that the public will suffer harm from lack of persons to engage in a profitable industry. Such contracts do not create monopolies. They confer no special or exclusive privilege. ${ }^{6}$

If the restriction is only commensurable with the fair proteetion of the business sold, the contract is reasonable, valid and enforceable. It is only where the restriction can be of no avail to the vendee and unnecessarily hampers the vendor that it becomes oppressive and void. ${ }^{?}$

All contracts, in which the public are interested, which tend to prevent eompetition, whenever a statute or known rule of law requires competition, are void. ${ }^{8}$ A party has a right to solicit business, and may, even maliciously solieit eustomers from another so long as he does not induce the customers to violate their contracts with another. ${ }^{9}$

\section{$\S 305$. Combinations of quasi-public corporations.-Com-} binations among those engaged in business impressed with a

5. Diamond Match Co. v. Roeber, 106 N. Y. 473,13 N. E. 419,60 Am. Rep. 464; Leslie v. Lorillard, 110 N. Y. 519,18 N. E. 363,1 L. R. A. 456 and note.

6. Diamond Match Co. v. Roeber, 106 N. Y. 473,13 N. E. 419,60 Am. Rep. 464.

7. Fowle v. Park, 131 U. S. 88, 9 S. Ct. 658; Ellerman v. Stock Yards Co., 49 N. J. Eq. 217, 23 A. 287; Long v. Towl, 42 Mo. 545; Tode v. Gross, 127 N. Y. 480, 28 N. E. 469,13 L. R. A. 652 and note; 24 Am. St. Rep. 475; Oakes v. Water
Co., 143 N. Y. 430,38 N. E. 461 , 26 L. R. A. 544 and note.

8. Chicago v. Rumoff, 45 Ill. 90, 92 Am. Dec. 196; People v. Trust Co., 130 Ill. 268, 22 N. E. 798, 8 L. R. A. 497 , and note; 17 Am. St. Rep. 319 ; Foss v. Cummings, 149 IIl. 353,36 N. E. 553; Fishburn v. Chicago, 171 Ill. 338,49 N. E. 532, 39 L. R. A. 482,63 Am. St. Rep. 236.

9. West Virginia Trans. Co. v. Standard Oil Co., 50 W. Va. 611, 40 S. E. 472,56 L. R. A. 804,88 Am. St. Rep. 895 . 
public or quasi-public character, which are manifestly prejudicial to the public interest caunot be mpheld.'

A corporation cannot disable itself by eontract from the performance of pullic duties which it has undertaken, and thereby make public anecommodation or envenience subservient to its private interests. ${ }^{2}$. And a combination between two or more railroad companies owning competing lines, by which one line is to be discontinued or leased to the other, is roid as against public policy. ${ }^{3}$ And a statute may prohibit mergers of competing quasi-public corporations. So an ordinance of a city requiring the giving of transfers, where one street railway controls another, either by owning or leasing, or operating it, to passengers riding on either line, is valid. ${ }^{4}$

$\S 306$. Discrimination by carriers. - Persons having a public duty to perform are bound to exercise such office for the equal benefit of all, and, therefore, to permit a common carrier to charge various prices according to the person with whom he deals for the same services, is to riolate his duty to the public. If he exacts different rates for the carriage of goods of the same kind between the same point, he violates the principles of public policy. ${ }^{5}$ In the United States, the stat-

1. Woodstock Iron Co. v. Extension Co., 129 U. S. 643,9 S. Ct. 402 ; Trist v. Child, 21 Wall. (U. S.) 441 ; Irwin $v$. Williar, $110 \mathrm{U}$. S. 499,4 S. Ct. 160 ; Arnat v. Coal Co., 68 N. Y. 558, 23 Am. Rep. 190; Central Salt Co. v. Guthrie, 35 Ohio St. 666 ; Woodruff v. Berry, 40 Ark. 25l, 261; Craft v. MeConoughy, 79 Ill. $346,22 \mathrm{Am}$. Rep. 171; Hooker v. Vandewater, 4 Denio (N. Y.), 349, 47 Am. Dec. 258; Stanton v. Allen, 5 Denio (N. Y.), 434, 49 Am. Dec. 282.

2. Gibbs v. Gas Co., 130 U. S. 396, 9 S. Ct. 553.

3. Thomas v. Railroad Co., 101 U. S. 71,83 .
4. Chicago Union Traction Co. v. Chicago, 199 Ill. 579, 65 N. E. 470; Compare San Diego Gas Co. $\checkmark$. Frame, 137 Cal. 4t1, 70 P. 295 ; Atchison, etc. R. R. Co. r. Cockran, 43 Kan. 225, 23 P. 151, 7 L. R. A. 414, 19 Am. St. Rep. 129.

5. Messenger v. Riallroal Co., $36 ;$ N. J. L. 407, 13 Anl. Rep. 457: Indianapolis, ete. R. R. Co. r. Ervin. 118 IIl. 250, s N. E. S62, 59 Am. Rep. 369 ; United States lixpress (o. v. Backman, 28 Ohio St. 144; New England Express Co. v. Railroad Co., 57 Me. 188, 2 Am. Rep. 31; MeDuffee v. Railroad Co., 52 N. H. 430, 13 Am. Rep. 72; Sinford v. Railroad Co., 24 Pa. St. 378, 64 
utes prohibiting discrimination are merely declaratory of the common law. ${ }^{6}$

$\S 307$. Telegraph and telephone companies. - The term "telegraph" includes any apparatus or adjustment of instruments for transmitting messages or other communications by means of electric currents and signals, and hence, it includes the telephone. ${ }^{1}$ The telegraph and telephone both being instruments in constant use in conducting the commerce, and the affairs, both public and private, of the country, their operation therefore, in doing a general businese, is a public employment, and the instruments and appliances used are properly devoted to public use, and in which the public have an interest. And such being the case, the owner of the property thus devoted to public use, must submit to have that use and employment regarded by public authority for the common good. ${ }^{2}$ Such companies cannot refuse to perform impartially the functions that they have assumed to discharge, no more than a railway company, as a common carrier, can rightfully refuse to perform its duty to the public; they have no power to discriminate, and while offering to serve some, refuse to serve others; they must serve all alike, upon compliance with their reasonable rules and regulations. ${ }^{3}$

$\S$ 308. Exclusive privileges.- Contracts made by corporations owing a duty to the public which foster monopolies are

Am. Dec. 667; Audexried v. Railroad Co., 63 Pa. St. 370, 8 Am. Rep. 195 ; Scofield v. Railroad Co., 43 Ohio St. 571, 3 N. E. 917, 54 Am. Rep. 846 and note.

6. Sinking Fund Cases, 99 U. S. 719 ; Messenger v. Railroad Co., 36 N. J. L. 407, 13 Am. Rep. 457; Hayes v. Railroad Co., 12 Fed. Rep. 309 ; Vincent v. Railroad Co., 49 Ill. 33 ; McCay v. Railroad Co., 13 Fed. Rep. 3 ; Chicago, etc. R. R. Co. v. People, 56 Ill. 365, \& Am. Rep. 690 .
1. Attorney Gen. v. Telephone Co., 6 Q. B. Div. 244.

2. Munn v. Illincis, 94 U. S. 113; Hockett v. State, 105 Ind. 250, 5 N. E. 202, 55 Am. Rep. 201.

3. Chesapeake, etc. Co. v. Teleg. Co., 66 Md. 399, 7 A. 809, 59 Am. Rep. 167 and note. See, also, Shephard v. Gas Light Co., 6 Wis. 526; Gas Light Co. v. Colliday, 25 Md. 1; People v. Gas Light Co., 45 Barb. (N. Y.) 136. 
void, such as giving exclusive privilegres. Such contracts made and entered into, eripple and prevent competition, and are not favored by the law; they are against public policy, because they tend to create monopolies, and are in general restraint of trade. ${ }^{1}$

Hence, eontracts between a railroad and a telegraph company, vesting in the latter exclusive riglt to use or ocenpy the right of way of the former, for the creetion of telegraph poles and other purposes in connection with their business of sending messages by telegraph, are void as in general restraint of trade, and tending to create a monopoly, thus being against public policy. ${ }^{2}$ But it has been held in Illinois that a second telegraph company could not use the telegraph poles of the first company though given that privilege by the railroad company. ${ }^{3}$

A ferry company may limit its operations to a single place, and limit it to one railroad company, so long as the ferry company furnishes all the facilities that the public interest requires, as this is no general restraint of trade. ${ }^{4}$

1. Oregon Steam Nav. Co. v. Winsor, 20 Wall. (U. S.) 66, 68; Western Union Tel. Co. v. Telegraph Co., 5 Nev. 103.

2. Western Union Tel. Co. v. Telegraph Co., 65 Ga. 160, 38 Am.

Rep. 781 and note.
3. Western Union Tel. Co. v. Railroad Co., s6 Ill. 246, 29 Am. Rep. 28.

4. Wiggins Ferry Co. v. Railroad Co., 73 Mo. 389, 39 Am. Rep. 519. 


\title{
CHAPTER XI.
}

\author{
Restraint of Trade.
}

\section{ARTTCLE I.}

Contracts in Restraint of Trane.

Section 309. Contracts in Restraint of Trade.

310. Unreasonable Restraint.

311. English Doctrine as to Limitations of Time and SpaceReasonableness.

312. American Doctrine as to Limitation of Time and Space.

313. Test of Reasonableness.

314. The Latest Statement of the Test of Reasonableness.

315. Injuring the Trade of Another.

$\S 309$. Contracts in restraint of trade-As preliminary to the discussion of this subject, it may be well to speak of the modern combination, and industrial and largely commercial enterprise. This modern combination is created solely to control trade and commerce in certain articles of production and substitute a more or less perfect monopoly in the place of a more or less free competition. Combination as an economic agent is taking the place of competition. The producers are combining; transportation companies are merging; laborers and employers have distinct unions, and competition seems to be losing its place in commerce. The principle of uniting is carried still further and there are combinations of combinations. And the great combinations of to-day are the creation of competing producers who were themselves combinations of still other producers. The individualistic civilization which has made the Republic great is losing its place, and individuals now dare not take the initiative and rely upon themselves in the commercial world. The economic virtue of our industrial system which has made the 
nation great is being supplanted lyy combinations and monopoly. These combinations are rapidly driving out of busines' the small trader and the small producer. These combinations are changing the commereial methods of our people and having great effects upon our commercial laws. And a jurisprudence of commercial restriction must take the place of jurisprudence of commercial competition. But treating the subject in its ordinary conception, irrespective of modern combinations, the leading decision of Mitchel v. Reynolds, ${ }^{1}$ is the foundation of the rule in relation to the invalidity of contracts in restraint of trade; but as it was made under a condition of things, and a state of society, different from those which now prevail, the rule laid down is not regarded as inflexible, and has been considerably modified. Public welfare is first considered, and if it be not involved, and the restraint upon one party is not greater than protection to the other party requires, the contract may be sustained. The question is whether, under the particular circumstances of the case and the nature of the particular contract involved in it, the contract is or is not umreasonable. ${ }^{2}$ Cases must be judged according to their circumstances, and can only be rightly judged when the reason and grounds of the rule arc carefully considered.

There are two principal grounds on which the doctrine is founded that a contract in restrain of trade is roid as against public policy: 1. The injurs to the pullic by being deprived of the restricted party's industry. 2. The injury to the party himself by being precluded from pursuing his occupation, and thus being prevented from supporting himself and his family. It is evident that both these evils oceur when the contract is general, not to pursue one's trade at all, or not to pursue it in the entire realm or country. The country suffers the loss in hoth eases: and the party is deprived of lis occupation, or is obliged to expatriate himself in order to follow it. ${ }^{3}$ And a contract in re-

1. 1 P. Wm. 181; Dier's Case, Year Bcok, 2 Hen. V, fol. 5, p. 26.

2. Rousillon v. Rousillon. $14 \mathrm{Ch}$.
D. 351 ; Leather Cloth Co. v. Lorsont, 9 Eq. 345 .

3. Oregron Steam Nar. Co. v. Winsor, 20 Wall. (U. S.) 64, 6s; 
straint of trade must be bascd on a sufficient consideration. ${ }^{4}$ It may be unlimited as to time, but limited as to space; it may be unlimited as to space, but limited as to time; or it may be unlimited both as to time and space.

§ 310. Unreasonable restraint.- In Alger v. Thacher, ${ }^{1}$ it is laid down that the unreasonableness of contracts in restrain of trade and business is very apparent from several obvious considerations. Among these are such contracts which injure the parties making them, because they diminish their means of procuring livelihood and a competency for their families; they tempt improvident persons, for the sake of present gain, to deprive themselves of the power to make future acquisitions, and they expose such persons to imposition and oppression; they tend to deprive the public of the services of men in the employments and capacities in which they may' be most useful to the community as well as to themselves; they discourage industry and enterprise, and diminish the products of ingenuity and skill; they prevent competition and enhance prices; they expose the public to all the evils of monopoly. "All this is especially applicable to wealthy companies and large corporations, who have the means, unless restrained by law, to exclude rivalry, monopolize business, and engross the market. Against evils like this, wisc laws protect individuals and the public by declaring all such contracts void."

In Oregon Steam Nav. Co. v. Winsor, ${ }^{2}$ it was said that the two principal grounds on which the doctrine is founded is (1)

Trenton Petteries Co. v. Oliphant, 56 N. J. Eq. 680,39 A. 923.

4. Chapin v. Brown, 83 Iowa, 156, 48 N. W. 1074, 12 L. R. A. 428, 32 Am. St. Rep. 297; Urmston v. Whitleley, $62 \mathrm{~L}$. Times, 455 ; Collins v. Loche, 4 App. Cas. 674; Smalley v. Greene, 52 Iowa, 241, 3 N. 78, 35 Am. Rep. 267 and note; Shober, ete. Co. v. Kertney, 107 Ill. 344 ; Burekhardt v. Burckhardt, 36 Ohio St. 261.
1. 19 Pick. (Mass.) 51, 31 Am. Dec. 119.

2. 20 Wall. (U. S.) 64. See, also, Allgeyer v. Louisiana, $165 \mathrm{U}$. S. 578,17 S. Ct. 427 ; United States v. Coal Dealers' Asso., 85 Fed. Rep. 252; United States $v$. Pipe and Steel Co., 85 Fel. Rep. 271, 46 L. R. A. 122,29 C. C. A. 141,54 U. S. App. 723. 
the injury to the public ly being doprived of the restricted party's industry; $(\cdot 2)$ the injury to the party himself being precluded from pursuing his occupation, and thus being prevented from supporting himself and his family.

\section{$\S 3$ II. English doctrine as to limitation of time and space} - Reasonableness. - The doctrine as to restraint of trade is founded upon public policy, and has undergone considerable change since Mitchel v. Reynolds, ${ }^{1}$ as is shown by Davies $v$. Davies. $^{2}$

The result of the English authorities down to the present time on this question of a covenant in restraint of trade appears to be as follows: Where the restraint is general, that is, without qualification, it is held as being unreasonable and contrary to public police; where it is partial, that is, subject to some qualification either as to time or space, then the question is whether it is reasonable, and, if reasonable, it is good in law. In considering the question of reasonableness, the points to which the attention of the court is specially directed are the limits of time and of space and the protection required for the trade of the corenantee, this latter point involving the examination of the nature and extent of the trade. The reasonableness depends on all the circumstances, which must be duly weighed in each case. If the restraint is greater than can possibly be required for the protection of the business of the covenantee the covenant is unreasonable and roid. ${ }^{3}$

The circumstances which may be legitimately inquired into on this question of reasonableness include the general circum. stances under which the trade is carried on at the time when the corenant is entered into. The improvements in the means of communication which have taken place in recent times by reason of railways, steamships, postal facilities, the telegraph, and the telephone, are within the scope of the inquiry, and bear

1. P. Wm. 181 .

2. $36 \mathrm{Ch}$. Div. $3 \nsim 9$.

3. Hitcheock v. Coper, 6 Adol. \& E. 438, 453; Ward v. Byrne. 5 Mees.
\& Wel. 54s. 561: Rousillon v. Rousillon. 14 ('h. 1). 363: Badische Anilin Und Soda Fabrik v. Schott, (18!2), 3 Ch. 447. 
particularly on the question of space; they are relevant more or less in proportion to the greater or lesser area within which the trade songlit to be protected is carried on and to the varying nature of the trade itself. Such matter's, of course, have little or no relerancy to a small local business, but they are relevant in reference to the large trade of a merchant and a widely-extended news-collecting agency, or to any other trade covering a great portion of the globe. What might in former ages have been considered an unreasonable restriction would not necessarily be so held in the altered circmmstances of the present time. And so a covenant unlimited as to space may, under the cireumstances be reasonable. ${ }^{4}$

\section{\$312. American doctrine as to limitation of time and space.} - It may be that the American decisions have not gone so far as the English, but the old law has been a great deal modified in some jurisdictions in view of modern methods of doing business. ${ }^{1}$ And an agreement by which one binds himself not to exercise his trade or profession is not roid simply because the agreement covers the whole territory of the State. Such an agreement cannot be enforced if unreasonable, and it is unreasonable if its restrictions extend beyond what is apparently necessary for the protection of the one in whose favor it is made. ${ }^{2}$

4. Maxim Nordenfelt Guns and Ammunition Co. v. Nordenfelt (1893), 1 Ch. 630, App. Cas. (1894) 535 .

1. Uregon Steam Nav. Co. v. Winsor, 20 Wall. (U. S.) 164; Fowle v. Park, 131 U. S. s8, 9 S. Ct. 658; Ellerman v. Stock Yards Co., 49 N. J. Eq. 217, 2:) A. 237 ; Western Wooden Ware Asso. v. Starkey, 84 Mich. 76,47 N. W. 604, 11 L. R. A. 503 and note, 22 Am. St. Rep. 686; Matthews v. Associated Press, 136 N. Y. 333, 32 N. E. 981, 32 Am. St. Rep. 741 ; Oliver v. Gilmore, 52 Fed. Rep. 562; Diamond Match Co. v. Roeber, 106 N. Y. 473,13 N. E. 419, 60 Am. Rep. 464; Whitney v. s'layton, 40 Me. 2.-t; Gamewell Fire Alarm Tel. Co. v. Crane, 160 Mass. 50,35 N. E. 98,22 I. R. A. 673 and uote, 39 Am. St. Rep. 458.

2. Herreshoff v. Boutineau, $17 \mathrm{R}$. I. 3, 19 A. 712,8 L. R. A. 469 and note, $33 \mathrm{Am}$. St. Rep. 850 ; Pierce v. Fuller, 8 Mass. 223, 226, 5 Am. Dec. 102; Gilman v. Daught, 13 Gray (Mass.), 356, 74 Am. Dec. 634; Anceer v. Webber, 14 Allen (Mass.), 211, 92 Am. Dec. 748 and note; Handforth v. Jackson, 150 Mass. 149, 22 N. E. 634; Bishop v. 
All the English cases which assert the loctrine that all entracts in general restraint of trade are void, wore and where the contract before the court was limited or partial. The same is generally true of the American cases.. ${ }^{3}$ If the agreenent is reasonable it will be upheld. Thus, a covenant in a deed not to sell intoxicating liquors on the prenises in less quantities than five gallons is reasonable ${ }^{4}$ and so is a eontract not to manufacture ochre in a certain county $;^{5}$ or not to carry on a tracling business on certain prenises $;^{6}$ or to sell salul from eretain premises by the rendee $:^{7}$ or not to sell a particular line of goods in a certain town ${ }^{8}$ or not to sell to any person in a certain town or State except the promisee. ${ }^{9}$

The tendency of the courts in the Enited States is to follow the late Engligh decisions, which hold that an agreement not to exereise a trade or profession is not roid simply beeause it is not limited as to space, provided it be reasonable. ${ }^{10}$

Palmer, 146 Nias. 469,16 ‥ E. 294, $4 \mathrm{Am}$. St. Rep. 339; Thomas v. Miles, 3 Ohio St. 274; Trenton Potteries Co. v. Oliphant, $56 \mathrm{~N}$. J. Eq. 608, 39 A. 923; Western Dist. Warehouse Co. v. Hobson. $96 \mathrm{Ky}$. 550, 29 S. W. 308; Peltz r. Eichele, 62 Mo. 171; Berlin Machine Works v. Perry, 71 Wis. 495,35 X. W. 82 , 5 Am. St. Rep. 236; Sutton v. Head, $86 \mathrm{Ky} .156,5 \mathrm{~S} . \mathrm{W} .410,9 \mathrm{Am}$. St. Rep. 274; Warfield v. Booth, 33 Md. 63; Goorman v. Henderson. 58 Ga. 567 .

3. Diamond Match Co. v. Roeber, 106 N. Y. 473,13 N. E. 419,60 Am. Rep. 464.

4. Sutton v. Head. $86 \mathrm{Ky}, 156,5$ S. WV. 410, 9 Am. St. Rep. 274.

5. Smith's Appeal, 113 Pa. St. 579, 6 A. $25 \mathrm{I}$.

6. Morris v. Mamuf. Co., S3 Ala. 565. 3 So. 639 .

7. Hodge v. Sloan, 107 N. 5. 244. 17 N. E. 335,1 Am. St. Rep. S1f.
8. Chark v. ('rosby, 37 Vt. 188 .

9. Newell v. Meyendorf, !) Mont. 254, 23 l'. 333, $18 \mathrm{Am}$. rit. Rep. 739 ; Keith v. Optical Co., 48 Ark. 1ss, 2 S. W. 77 ; Roller v. Ott, 14 Kan. 609.

10. Herreshoff $v$ Boutineau, 17 R. 1. 3, 19 A. 712,8 L. R. A. 469 and note, 33 Am. St. Rep. 850 ; Diamond Match Co. v. Roeber, $106 \mathrm{~N}$. Y. 473,13 N. E. 419,60 Am. Rep. 464; Ellerman v. Stock Yards Co., 49 N. J. Eq. 217, 23 A. 287; National B. Co. v. Hospital Co.. 45 Minn. 272,47 N. W. 806, II L. R. A. 437 and note: O.kilale Manuf. Co. v. Garst, is li. 1. 4S4, $28 \mathrm{~A}$. 973, 49 Am. St. Rep. 784; Carter v. Alling, 43 Fed. Rep. 20s; Oregon Steam Nav. Co. v. Winsor, 20 Wall. (U. S.) 64: Beal v. Cliase, 31 Mich. 490 ; Eisel v. llayes, 141 Ind. 41,40 N. E. 119 ; Martin v. Murphy, 129 Ind. 464. 2S X. E. 1118; IIurson v. Gaum, 59 111. App. 66; Gregory v. 
§ 3I3. Test of reasonableness. - Any agreement in restraint of trade of one of the parties to a contract is void, as being against public policy, unless founded upon a valuable consideration and limited, as regards time, space, and the extent of the trade, to what is reasonable under the circumstances of the case, for the reason that such contract tends to deprive the public of the services of parties in the employment and capacities in which they are most useful, and that it tends to expose the public to the evil of monopoly. ${ }^{1}$

It is essential, in order not to be unreasonable, that the restraint imposed must not be larger than is plainly required for the protection of the party with whom the contract is made, and whether it is reasonable in a given case is a question, not of fact, but of law for the court. ${ }^{2}$

The question is whether the restraint is such only as to afford a fair protection to the interests of the party, in favor of whom it is given and not so large as to interfere with the interests of the public. Whatever restraint is larger than the necessary

Spicker, 110 Cal. 150, 42 P. 576, 52 Am. St. Rep. 70; Neal v. Hines, 145 Ind. 32, 43 N. E. 946; Davis v. Brown, 98 Ky. 475, 32 S. W. 614, 36 S. W. 534; Meyer v. Estes, 164 Mass. 457,41 N. E. 683,32 L. R. A. 28:3; Smith v. Brown, 164 Mass. 584,42 N. E. 131; Cowan v. Fairbrother, 118 N. Car. 406,24 S. E. 212,32 L. R. A. 829 and note, 54 Am. St. Rep. 733; Western Dist. Warehouse Co. v. Hobson, 96 Ky. 550, 29 S. IV. 308; Consumers Oil Co. v. Nunemaker, 142 Ind. 560, 41 N. E. 1048, 51 Am. St. Rep. 192; Lufkin Rule Co. v. Fringeli, 57 Ohio, 596, $49 \mathrm{~N}$. E. 1030. 41 L. R. A. 185, 63 Am. St. Rep. 736.

1. Kellog̣n v. Larkin, 3 Pin. (Wis.) 123, $56 \mathrm{Am}$. Dec. 164; Laubenheimer $v$ Mann, 17 Wis. 542; Alger v. Thacher, 19 Pick. (Mass.) 5l. 31 Am. Dec. 119; Bishop v. Palmer, 146 Mass. 469, 473, $16 \mathrm{~N}$. E. 299,4 Am. St. Rep. 339 ; Oregon Steam Nav. Co. v. Winsor, 20 Wall. (U. S.) 66, 67; Gibbs v. Gas Co., 130 U. S. 396,9 S. Ct. 553 ; Lange v. Werk, 2 Ohio St. 59; Gamwell Fire A. Tel. Co. v. Crane, 100 Mass. 50, 35 N. E. 98, 22 L. R. A. 073 and note, $39 \mathrm{Am}$. St. Rep. 458; Richards v. Seating Co., 87 Wis. 503, 58 N. W. 787; More v. Bennett, $140 \mathrm{Ill}$. 69, 29 N. E. 888,15 L. R. A. 361,33 Am. St. Rep. 216; Standard Cotton Oil Co. v. Adoue, 83 Tex. 650, 19 S. W. 274,15 L. R. A. 598,29 Am. St. Rep. 690 ; Emery v. Ohio Co., 47 Ohio St. 320,24 N. E. 660,21 Am. St. Rep. 819.

2. Pollock on Contracts, 366 368; Washburn v. Dosch, 68 Wis. 440, 32 N. W. 551, 60 Am. Rep. 873. 
protection of the party ean be of no henefit to either. It ean only be oppressive; and if oppressive, it is, in law, unreasonable. ${ }^{3}$

The common law recognizes that there are reasonable combinations and umreasonable combinations-that is to say, some promote and some prejudice public interests. The United States Supreme Court has interpreted the Ferleral law ${ }^{4}$ as a declaration of public policy that all restraints of interstate trade is unreasonable.

\section{$\S 3$ I4. The latest statement of the test of reasonableness.-}

All restraints upon trade are bad as being in violation of public poliey, mnless they are actually and not unreasonably for the protection of parties dealing legally with some subject-matter of contract. ${ }^{1}$ A limited restraint may be good, provided the restraint is reasonable and such as was required for the protection of parties with whom the corenant is entered into. ${ }^{2}$

In olden times all restraints of trading were considered prima facie void. An exception was introduced when the agreement to restrain from trading was only from trading in a particular place and upon reasonable consideration, leaving still invalid agreements to restrain trading at all. Such general restraint was then considered to be of no benefit even to the corenantee himself; but in the present civilization it may be said that

3. Horner $v$ Graves, 7 Bing. 735, 743.

4. Act of Congress, July 2, 1890 . eh. $647 ; 26$ Stat. 209.

1. Leather Cloth Co. v. Lor'sont. L. R. 9 Eq. 354; Rousillon v. Rousillon, 14 Ch. Div. 351.

2. Davies v. Davies, 36 Ch. Dir. 359 ; Leslie v. Lorillard, $110 \mathrm{~N}$. Y. 519 , 18 N. E. 636 , l I. R. A. 456 and note; Diamond Natch Co. v. Roeber, 106 N. Y. 473,13 N. F. 419. 60 Am. Rep. 464; Herreshotr v. Boutineau, 17 R. I. 3,19 A. 712 , 9 L. R. A. 469 and note, 33 Am. St.
Rep. 850 ; National Ben. Co. v. Hospital Co., 45 Minn. 272,47 N. W. s06, 11 L. R. A. 437 and note; Gibbs v. Gas Co., 130 U. S. 409, 9 S. Ct. 5.53; Nordenfelt v. Maxim Nordenfelt Guns and Ammunition Co., App. Cases (1894), 535; Eisel v. IIayes. 14l Ind. 41, 40 N. E. 119 ; Martin $v$. Murphy, 129 Ind. 464, 28 x. L. 418: Brown v. Kling, 101 Cal. 295. 35 P. 995; Fuller v. Hope, 16.3 Pa. St. 62, 29 A. 779; Trenton Potteries Co. v. Oliphint. 56 N. J. Eq. 680, 39 A. 923. 
science and invention have almost annihilated both time and space. Consequently there should no longer exist any cast-iron rule making roid any agreement not to carry on a trade anywhere. The generality of time or space must always be a most important factor in the consideration of reasonableness, though not per se a decisive test. Hence, a patentee and manufacturer of guns and ammmition for purposes of war may covenant with a company to which his patents and business had been transferred that he will not for twenty-five years engage except on behalf of the company either directly or indirectly in the business of a manufacturer of guns or ammunition. Such a covenant though unrestricted as to space was not, having regard to the nature of the business and the limited number of the customers, wider than was necessary for the protection of the company, nor injurious to the public interests of the country; it is, therefore, valid and may be enforced. ${ }^{3}$ The test of reasonableness is the test of validity of contracts of this kind. ${ }^{4}$

Some courts have formulated arbitrar rules. Thus, in Illinois the court says in relation to space that trade and business is not affected by State lines, and a contract may be good in restraint of truke which embraces, within reasonable limits, parts of different States, but an agreement which applies to the whole State is roid, and cannot be enforced. ${ }^{5}$ The reason of this rule is stated to be that it is against public policy of the State that its citizens should not have the privilege of pursuing their lawful occupation at some place in the State, and not be compelled to leave the State to engage in their business and to support their family. The doctrine of a New York case ${ }^{6}$ is more reasonable, which holds that the question, what is a general restraint of trade, does not depend on State lines; that they are

3. Nordenfelt v. Maxim Nordenfelt Guns and Ammunition Co., App. Cas. (1894) 535, (1893) l Ch. 630 .

4. Oakdale Manuf. Co. v. Garst. 18 R. I. 484,28 A. 973,23 L. R. A. 639, 49 Am. St. Rep. 784.
5. Union Strawboard Co. v. Bonfield, 193 Ill. 420, 61 N. E. 1038, 86 Am. St. Rep. 346. See, also, Chappel v. Brockway, 21 Wend. (N. Y.) 157 , an obiter dictum on this point.

6. Diamond Match Co. v. Roeber, 106 N. Y. 473,13 N. E. 419,60 Am. Rep. 464. 
not the hommlaries of trade and commeree and that a restraint is not necessurily general which enbraces an entire State. So, in Illinois an alsolute covenant to refrain from trate within the State where the contract is malle, is necessarily fatal to its validity. In New York such contrilet is not necessarily void, because whit is a general restrinint of trade does not depend upon State lines. The Illinois rule is arbitrary, and such a construction shonll not be on sucli contract as will make it a general restraint of trade when on its face it is only partial.

$\S 315$. Injuring the trade of another.- One's motives in exercising an alsolute right cannot be questioned; but when the right is correlative, it must be exercised with due regard to the rights of others; hence, one who exercises such a right for the sole purpose of injuring another is liable for the injury inflicted. This is illustrated in cases involving the liability of an employer to a third person for injury to trade caused by the employer threatening to discharge his workmen if they continued to trade with such person. Thus, an employer is relieved from liability where he acted for the purpose of securing the trade for himself. ${ }^{1}$ Here the employer was seeking to build up his trade and the doctrine announced is correct. But in another case the court relieved the employer from liability on the ground that he had a right to discharge his employees. ${ }^{2}$

The question whether an act which injures another is rendered actionable solely for the reason that it was done in malice, is not answered the same way by the different courts. So it has been held that a merchant is not liable to an action for damages by sending a circular to the retail trade, offering to sell, at a reduced price, a small quantity of a manufacturer's goods for the purpose of injuring and depressing the price of the goods on the market. ${ }^{3}$ But in another case an agreement among

1. Robinson v. Texas Pine Land Asso. (Tex. Civ. App.), 40 S. W. Rep. 843.

2. Payne v. Western, etc., Co., 13

Lea (Tenn.), 507, 49 Am. Rep. 666.
3. Passaic Print Works v. Dry Goods Co., 1S1 U. S. 617, 21 S. Ct. 922, 62 L. R. A. 673 and note. 
several independent newspaper publishers to compel a fourth person engaged in like business, either to reduce his rates for advertising or lose customers, is a malicious conspiracy to injure such publisher's business, and the parties are liable. ${ }^{4}$

\section{ARTICLE II.}

Nature of tile Transaction.

DECTION 316. Construetion of Contract.

317. Dealing with Exclusive T'ersons.

318. Sale of Secret Process.

319. Sale of Good-Will of a Business.

$\S 3$ I6. Construction of the contract. - The meaning of a contract of this character, however, is not to be found solely from a consideration of its expressed terms. Courts look to all the circumstances surrounding the parties, and attendant upon the transaction, and from a consideration of these circumstances in connection with the expressions of the undertaking, they will first construe the contract, and then proceed to pass upon its reasonableness as thus construed. So where the parties are engaged in a certain business, in and covering a certain territory, which could easily be covered by them, and were dealing in competition with each other, one party may sell to the other; and if the space is not expressed, the contract will be construed so as to include and cover the territory of their previous competition; so it will become specific as to space and time, and the character of the dealing to be restrained, and will, therefore, he reasonable and valid. ${ }^{5}$ And the mere fact that the

4. Durner v. Huegin, 110 Wis. 189,85 N. W. 1046,62 L. R. A. 700 and note; Huegin v. Wisconsin (U. S. S. Ct.), 37 Chi. Legal News, 108, opinion filed Nov. 7, 1904, affirming the Wisconsin decision.

5. Noore, ete. Hardware Co. v.
Hardware Co., 87 Ala. 206, 6 So. 41, 13 An. St. Rep. 23 and note; Hubbard v. Miller, 27 Mich. 15; Curtis v. Gokey, 68 N. Y. 300 ; Warfield v. Booth, 33 MId. 63; Dethlifs v. Tomsen, 7 Daly (N. Y.), 354; Beal v. Chase, 31 Mich. 490 ; Morse 
duration of the restrietion as to time is indefinite or perpetnal, will not of itself avoid the contract if it he limited as to place and is reasonable and proper in other resperts. ${ }^{6}$

$\S$ 317. Dealing with exclusive persons. $-\Lambda$ party may contract to deal exelusively with one persom. A vendor may bind himself to manufacture and sell exelusively to one person. ${ }^{1}$ So, also, a vendee may agree to buy exelusirely from one person. ${ }^{2}$ An agreement to work as a servant or agent for another exclusively for a certain period is valid. ${ }^{3}$ And contracts may be valid which provide for exelusive dealing with a particular person. ${ }^{4}$ This rule applies where there is no diserimination and no contravention of constitutional rights; otherwise it is illogal. Thus, a board of erncation has no right in making contracts for pullie improvements, to eompel the eontractor to employ only union labor. Such contract tends to create a monopoly in bidding for work, and in selecting members of certain soeieties. Such provision in a contract would limit competition by preventing contractors from employing any except certain persons, and by excluding all others engaged in the same work, and is therefore illegal and roid $;^{5}$ snch an agreement is in rio-

Machine Co. v. Morse, 103 Mass. 73, 4 Am. Rep. 513; Oregon Steam Nav. Co. v. Winsor, 20 Wall. (U. S.) 64. See, also, Mollyneaux v. Wittenberg, 39 Neb. 547, $5 \mathrm{~s} \mathrm{N.} \mathrm{W.}$ 205 ; Fuller v. Hope, $163 \mathrm{~Pa}$. St. 62,29 A. 779.

6. Hitcheoek v. Coper, 6 Adol. \& El. 447 ; Bumn v. Gny, 4 East, 190; Mallen v. May, 11 Mees. \& Wels. 652; Pierce v. Woolward, 6 Pick. (Mass.) 206; Cook v. Johnson, 47 Conn. 178.

1. Donnell v. Bennett, 22 Ch. D. 835; Central S. R. Co. v. Cushman, 143 Mass. 353,9 N. I. 629; Arnot v. Pittston, ete., Co., 68 N. Y. 558 , 23 Am. Rep. 190.
2. Brown v. Rounsavell, is Ill. 589; Thornton v. Sherratt, 8 Taunt. 529: Catt v. Tourle, I. R. 4 Ch. App. 654; Morris v. Colman, 18 Ves. 437 .

3. Hartley v. Cummings, 5 C. 13. 247: Pilkington v. Scott, 15 Mees. \& Wel. 65i; De Franciseo v. Barnum, 43 Ch. Div. 174.

4. George v. East Temn. C. Co., 15 Lea (Tenn.), 455, 54 Am. Rep. 425 ; Clay v. Powell, 85 Ala. 538, 5 So. 330, $7 \mathrm{Am}$. St. Rep. 70 ; Roller v. Ott, 14 Kans. 609: Keith v. Herschberg Co., 4 S Ark. 139, 2 S. II. 77 .

5. Adams v. Breman, 177 Ill. 194. 52 N. E. 314, 69 Am. St. Rep. 222. 42 L. R. A. 718. 
lation of conmon right, and tends to create a monopoly and is void. ${ }^{6}$

$\S 3$ I8. Sale of secret process. $-\Lambda$ party has the right to sell his business, including as an essential part thereof the secret process, and, in order to place the purchaser in the same position that the vendor occupied, to promise to divulge the secret to him alone and keep it from anyone else. Having the right to make the promise, the vendor has the right to make it good to the rendee to protect him by covenants with proper safeguards against the consequences of any violation. Such covenant is not in general restraint of trade, but is a reasonable measure of mutual protection to the parties, as it enables the one to sell at the highest price and the other to get what he paid for. It imposes no restriction upon either that is not beneficial to the other by enhancing the price to the seller or protecting the purehaser. ${ }^{7}$ It is very elear that such an agreement is not opposed to public policy, even if the restriction was unlimited as to both time and territory. ${ }^{8}$ Restraint of trade is not applicable to a business which is a secret, and not known to the public, because the public has no right in a secret. ${ }^{9}$

§ 319. Sale of good-will of a business.-A sale of the goodwill simply, and no more, implies no obligation on the part of the vendor not to engage in the same business at another place in the same locality. ${ }^{1}$ But it appears that if the sale of the

6. Holden v. Alton, 179 Ill. 318, 53 N. E. 556.

7. Tode v. Grass, 127 N. Y. 480 , 23 N. E. 469,13 L. R. A. 652 and note, 24 Am. St. Rep. 475.

8. Diamond Match Co. v. Roeber, 106 N. Y. 473,13 N. E. 19,60 Am. Rep. 464; Hodge v. Sloan, $107 \mathrm{~N}$. Y. 244, 17 N. E. 335, 1 Am. St. Rep. 816; Leslie v. Lorillard, $110 \mathrm{~N}$. Y. 519, 18 N. E. 363,1 L. R. A. 456 and note; Watertown Thermometer
Co. v. Pool, 51 Hun (N. Y.), 107, 4 N. Y. S. 861.

9. Taylor v. Blanchard, 13 Allen (Mass.), 370, 90 Am. Dec. 203; Vickery v. Welch, 19 Pick. (Mass.) 523 ; Peabody v. Norfolk, 98 Mass. 452, 96 Am. Dec. 664; Leather Cloth Co. v. Lorsont, 9 Eq. 345; Morse Mach. Co. v. Morse, 103 Mass. 73, 4 Am. Rep. 513.

1. Moreau v. Edwards, 2 Tenn. Ch. 347; Porter v. Gorman, 65 Ga. 
good-will is within eertain linits, which is the legitimats sulsject matter of the contraet, it arpore with it the implionl rovenant, as in othere sales, that the vendor will not de anything to disturb or injure the ventere in the enjoyment of that which he purchased. ${ }^{2}$

$A$ contract by a phrsician for the sale of his practice and good-will in a specified town is not void as against public policy. ${ }^{3}$ If the agreement is not to engage in the same business for a time certain, the vendor may, on the expiration of the time, enter into the same business and solicit his former patrons. ${ }^{4}$ If the sale is compulsory he may again enter the business and solicit his former trade. . Ifter selling the good-will and business, the rendor is not prohibited from hiring to a party in the same business and in the same town." The sale of the good-will of a school does not obligate the vendor to use personal efforts to influence the attendance of pupils. i

1I; Bergamini v. Bastian, 35 La. Ann. 60, 48 Am. Rep. 216 and note; Bassett v. Pereival, 5 Allen (Mass.), 345 .

2. Wwight v. Hamilton, 113 Mass. I75; Munsey v. Butterfield, 133 Mass. 492; Angier v. Webber, 14 Allen (Mass.), 211, 92 Am. Dee. 748 and note; Rauft v. Reimers, 200 Ill. 386.65 N. E. 720,60 L. R. A. 291.

3. Dwight $v$. Hamilton, 113 Mass. 175; Cole v. Edwards, 93 Iowa, 477. 61 N. W. 940, 60 L. R. A. 291 ; Gilman v. Dwight, 13 Gray (Mass.), 356, 74 Am. Dee. 634; Atkyns $v$. Kinnier, 4 Exeh. 776; Hoyt v. Holly, 39 Com. 326, 12 Am. Rep. 390. See, also, Powers v. Stout, 67
Iowa, 341, $25 \mathrm{~N} . \mathrm{W} .273$; Haldeman v. Simonton, 55 lowa, 144, $7 \mathrm{~N}$. 493 ; Smalley $v$. Greene, 52 Iowa, 241,3 N. 78,35 Am. Rep. 267 and note: Hedge v. Lowe, 47 Iowa, 137; French v. Parker, 16 li. I. 219, 14 A. S70, 27 Am. St. Rep. 733; Bunn v. Guy, 4 East, 190 ; Compare Mandeville $v$. IIarman, $42 \mathrm{~N}$. .. Eq. 185, 7 A. 37.

4. Llanna v. Andrews, 50 Iowa, 462.

5. Walker v. Mattraw, $19 \mathrm{Ch}, \mathrm{D}$. 355.

6. Grimm v. Warner, 45 Iowa, 106.

7. McCord v. Williams. 15 Norris (Pa.), $7 \mathrm{~S}$. 


\section{CHAPTER XII.}

\section{Industrial Combinations.}

\section{AR'TICLE I.}

Unlawful Combinations and Corporate Trusts.

Section 320. Monopoly-Contracts in Restraint of Trade.

321. Restraint, General or Partial.

322. Legal Combinations.

$\S$ 320. Monopoly - Contracts in restraint of trade.-At common law a contract calling for a reasonable restraint of trade will be upheld. It is only the unreasonable restraint of trade that receives the condemnation of the law, whereby monopolies are created. Monopolies may be divided into three classes: 1. All sources of supply may be put in the hands of one company, so no other source of supply is available. Such a monopoly is absolute, and can sell its products at any price limited to the necessities of commerce. 2. The monopoly may have the best and most economical source of supply, but competition still be possible, when competition can be suppressed by selling so low by the monopoly that competition is impossible. 3. The monopoly may use its general control of the market to require all parties to buy from it alone under penalty of being denied further supplies. This method is generally practiced by the monopoly.

Monopolies are as old as human history. They were forbidden by the laws of Greece and Rome; they are prohibited by the common law. During a part of Queen Elizabeth's reign they were not forbidden. They became so exorbitant in their prices that they became intolerant and most pernicious in their consequences, and were regulated. Parliament chartered the 
East India Company in order to build up an empire in the East, but it became so oppressive that it was overthrown as a matter of necessity. Many thousands of monopolies exist in the United States. The gigantic combinations are anthorized to buy up the stock of any other corporation, so they may gain control of any industry. Before the time of gigantic industrial and commercial combinations, there was indiridualistic initiative, and self-reliance produced rivalry that created the keenest interest and kept all the faculties in continual activity. The original colonies grew under this system into one of the wealthiest nations in christendom. The wealth thus created by rears of struggle and competition has been utilized by the combinations, thus crushing a system of competition which has accomiplished the greatest commercial success known to history, proving the old maxim that competition is the life of trade. Thesc industrial and commercial combinations, some times called trusts, are taking the place of competition and business rivalry, without trying to protect the legal rights of the individual; but now the law must protect the citizen from the danger of the destruction of his means of livelihood. At the present time many avenues of individual success are practically closed to men of moderate fortunes, and are sealed against young men of ability and energy. This great accumulation of capital is a menace to the very foundation of the republic. Such vast and arbitrary combinations will forever retard the equal distribution of wealth. The unbroken experience of ages has clearly established the fact that competition is the system conducive to the best interest of a people. In all of the States where the common law prevails, contracts greatly in restraint of trade, and monopolies of all kinds are illegal; and though some States have chartered corporations with powers "to do all things that a natural person can do," yet such corporations cannot create a monopoly, for a natural person is forbidden to do that without violating the law. Some of the States faror these combination and derive a considerable revenue from the grant of unlimited charters. 
The common law and statutory law have been applied to suppress these monopolies in many of the States, and how well their application has remedied the evils will now be considered.

When a combination is formed among parties which create a monopoly by restricting competition and controlling the price of an article of commerce, the contract is roid at common law and against public policy. ${ }^{1}$ IIence, where a number of persons enter into an agreement the object of which is purely and simply to silence and stifle competition among themselves, the agreement is in restraint of trade, and void as against public policy. ${ }^{2}$ Thus, a combination among brewers to prevent competition among themselves in the sale of beer is illegal. ${ }^{3}$

Combinations of this character are illegal. ${ }^{4}$ Thus, where a contract is entered into by the grain dealers of a town, which on its face indicates that they had formed a partnership for the

1. United States v. Feight Asso., 166 U. S. 290,17 S. Ct. 540 ; Cummings v. Stone Co., 164 N. Y. 401,58 N. E. 523,52 L. R. A. 262 , 79 Am. St. Rep. 655; Emery v. Candle Co., 47 Ohio St. 320, 24 N. E. 660, 21 Am. St. Rep. 819; Salt Co. v. Guthrie, 35 Ohio St. 666; Pittsburg Carbon Co. v. McMillin, 119 N. Y. 346,23 N. E. 530, 7 L. R. A. 46; Richardson v. Buhl, 77 Mich. 632, 43 N. W. 110, 6 L. R. A. 457 and note; Santa Clara, etc., Co. v. Hayes, to Cal. 387, is P. 391, 9 Am. St. Rep. 211; Pacifie Factor Co. v. Adler, 90 Cal. 110, 27 P. 36, 25 Am. St. Rep. 102; Stewart v. Mallon, 43 N. Y. 149, 3 Am. Rep. 678; Clancey v. Salt Manuf. Co., 62 Barb. (N. Y.) 407; Cohen v. Envelope Co., 166 N. Y. 292, 59 N. E. 006 .

2. Nester v. Brewing Co., $161 \mathrm{~Pa}$. St. 473, 29 A. 102, 24 L. R. A. 247, 41 Am. St. Rep. 894 ; People v. Milk Exchange, 145 N. Y. 267, 39 N. E. 1062,27 L. R. A. 437,45 Am. St.
Rep. 609 ; Judd v. Harrington, 139 N. Y. 105,34 N. L. 90 ; People v. Sheldon, 139 N. Y. 251, 34 N. E. 785, 23 L. R. A. 221,36 Am. St. Rep. 609; Merz Capsule Co. v. Capsule Co., 67 Fed. Rep. 414; Ford v. Milk Shippers Asso., 155 Ill. 166, 29 N. L. 651,27 L. R. A. 298 ; State v. Standard Oil Co., 49 Ohio St. 137,30 N. E. 270,15 L. R. A. 145, 34 Am. St. Rep. 541; Bishop v. American Preserve Co., 157 IHl. 284, 41 N. E. 765,48 Am. St. Rep. 317.

3. Nester v. Brewing Co., 161 Pa. St. 473,29 A. 102,24 L. R. A. 247, 41 Am. St. Rep. 894.

4. State v. Distillery Co., 99 Neb. 700, 46 N. IV. 155; State v. Standard Oil Co., 49 Ohio St. 137,30 N. E. 270,15 L. R. A. 145, 34 Am. St. Rep. 541 ; Distilling and Cattle Feeding Co. v. People, 156 Ill. 448, 41 N. E. 188, 47 Am. St. Rep. 200 ; People v. Gas Trust Co., 130 Ill. 268, 22 N. E. 798, 17 Am. St. Rep. 319. 
purpose of dealing in grain, but the true object of which was to form a secret combination which shomld stifle all rompetition and enable the parties to control prices, it is roid on the ground of public policy.5 'The common law forbids the organization of such combinations, composed of numerous corporations and firms. They are dangerous to the peace and good order of society, and they arrogate to themselves the exereise of powers destructive of the right of free competition in the markets of the country, and, by their aggregate power and influence, imperil the free and pure administration of justice.

The right of a railroad company to charge reasonable rates does not include the right to enter into a combination with competing roads to maintain reasonable rates. ${ }^{7}$ So the legislature mar give a corporation the same powers to regulate trade within its park that is generally granted mumicipal corporations to regulate trade within their limits. And the power to regulate a useful trade does not authorize its prohibition or the creation of a monopoly. ${ }^{8}$

$\S 32$ r. Restraint, general or partial. - If it appears that such a combination is injurious to the public, the courts will not stop to inquire as to the degree of injury inflicted, nor whether the restraint be geneeral or partial, nor will they consider the form and declare purpose of the combination. ${ }^{1}$ The test ques-

5. Crafts v. MeConoughy, 79 Ill. 346. 22 Am. Rep. 171; India Ruhber Co. v. Koch, 14 La. Ann. 168.

6. Richardson v. Buhl, 77 Mich. 632, 43 N. W. 1102,6 L. R. A. 407 and note; Emery v. Candle Co., 47 Ohio St. 320,24 N. E. $660,21 \mathrm{Am}$. St. Rep. S19; State v. Nebraska Distilling Co., 29 Neb. 700, $46 \mathrm{~N}$. W. 155; National Harrow Co. v. Quick, 67 Fed. Rep. 130; Bishop v. American Preserves Co., 157 Ill. 2S4, 41 N. E. 765, 48 Am. St. Rep. 317 .

7. United States v. Freight Asso.. 166 U. S. 290,17 S. Ct. 540.
8. Thousind Island Park Asso. v. Tucker, 173 N. Y. 203, 65 N. E. $97 \overline{5}$, reversing 59 App. Div. $62 \pi, 69$ N. I. S. 1149.

1. 'lexas Standard Oil Co. $v$. Adoue, 83 Tex. 650, I9 S. 11.274 , 15 J. R. A. 50S. 29 Am. St. Rep. 690; Raymond v. Leavitt, 46 Mich. 447, 9 N. 525, 41 Am. Rep. 170; Clark v. Needham, 125 Mich. S4, 93 ‥ W. 1027, 51 L. R. A. 785,84 Am. St. Rep. 559: Nester v. Browing Co.. 161 Pa. St. 473, 29 A. 102. 24 L. R. A. 247, 41 Am. St. Rep. 894. 
tion, in erery case coming under this head, is whether or not a contract in restraint of trade exists which is injurious to the public interests. If injurious, it is void as against public policy. Courts will not stop to inquire as to the degree of injury inflicted. It is enough to know that the natural tendency of such contracts is injurions. The application of the rule does not depend upon the number of those who may be implicated, nor the extent of space included, in the combination; but upon the existence of injury to the public. One combination, consisting of but part of those engaged in a given branch of trade, may amount to a practical monopoly, while another, less extensive in its scope, may, as well, bring disaster in its train. The difference lies only in degree, but equally forbids the aid of courts. $^{2}$ The true test is the effect upon public interests.

And when the notice of the character of the combination is in the channel of an assignee's title, he is not innocent of participation in, or knowledge of, the illegality of the combination, and must be treated as having taken subject to the disabilities of his assignor. ${ }^{3}$

Where the combination is against public policy and void, the law will not attempt to adjust differences which arise out of the transactions which it condemns, even though the proceeds or profits of the unlawful combination may be in the hands of the parties to it. ${ }^{4}$ If a State passes anti-trust laws, they must not improperly discriminate. Thus, where a statute discriminates in favor of agricultural products or live stock in the hands of the producer or raiser, it is unconstitutional as in

2. More v. Bennett, 140 Ill. 69, 29 N. E. 888,15 L. R. A. 361,33 An. St. Rep. 216. See, also, Hooker v. Vandewater, 4 Denio (N. Y.), 349, 47 Am. Dec. 258; Hilton v. Eckerley, 6 El. \& B1. 66 ; Salt Co. v. Guthrie, 35 Ohio St. 666; Morris Run Coal Co. v. Coal Co., $68 \mathrm{~Pa}$. St. 173, \& Am. Rep. 159.

3. Chamberlain v. Barnes, 26 Barb. (N. Y.) 160; Riddle v. Hall, 99 Pa. St. 116; Nester v. Brewing
Co., 161 Pa. St. 473, 29 A. 102, 24 L. R. A. 247, 41 Am. St. Rep. 894.

4. Brooks v. Martin, 2 Wall. (U. S.) 70 ; Norton v. Blinn, 39 Ohio St. 145; Armstrong v. Toler, 11 Wheat. (U. S.) 258; Snell v. Dwight, 120 Mass. 16; Cummings v. Foss, 40 Ill. App. 523. See, also, MeMullan v. Hoffman, 69 Fed. Rep. 509 ; Atlas Nat. Bank v. Holm, 71 Fed. 489 ; Kine v. Turner, 27 Oreg. 350, 14 P. 664. 
conflict with the Fourteenth Amendment. ${ }^{5}$ So where an antitrust statute exempts agrieulturalists and live stock raisers, it is void. ${ }^{6}$

$\S$ 322. Legal combinations.- In the eases in which eombinations have been upheld by the eourts, it was apparent from the contracts themselves that they did not tend to ereate a monopoly or put an end to competition. ${ }^{1}$ If the combination is not made to control prices or ereate a monopoly, it is not against public poliey. ${ }^{2}$ It does not follow that every combination in trade, eren though such eombination may have the cffect to diminish the number of competitions, is therefore, illegal. Monopolies are liable to be oppressive, and hence, are deemed to be hostile to the publie good. But combinations for mutual advantage which do not amount to a monopoly and leave the field of competition open to others are neither within the reason nor the operation of the rule. Hence, where sereral companies engaged in the manufacture of an article consolidate as a corporation, for the purpose of stopping competition among them, and agree that none of them shall engage in the business for a certain time, such arrangement is not invalid as creating a monopoly. ${ }^{3}$ It has been held in Missouri that the Associated Press is not a monopoly within the prohibition of the statute, and it can make exclusive contract. ${ }^{4}$ But the Illinois court

5. Connally v. Union Sewer Pipe Co., 184 U. S. 541,22 S. Ct. 431 , overruling, in effect, Price v. People, 193 Ill. 114,61 N. E. 544,55 L. R. A. 588 .

6. People v. Foundry Co.. $201 \mathrm{Ill}$. 236, 86 Am. St. Rep. 306 and note, 66 N. E. 349.

1. Shrainka v. Sehoringhau-en, 8 Mo. App. 522; Ontario Salt Co. v. Salt Co., 18 Grant's Ch. 540; San Diego Water Works v. Flume Co., 108 Cal. 549, 41 P. 495, 29 L. R. A. 839 ; Collins v. Locke, L. R. 4 App. Cas. 674; Central Shade Roller Co. v. Cushman, 143 Mass.
353, 9 X. E. 629; Swam r. Swann, 21 Fed. Rep. 301 ; Gompers v. Rochester, 56 Pa. St. 194; Smith's Appeal, 113 Pa. St. 549, 6 A. 251,57 Am. Rep. 483 and note; Raub $v$. Van Horn, 133 Pa. St. 573, 19 A. 704.

2. Marsh v. Russell, 66 N. Y. 2ss.

3. Oakdale Manuf. Co. v. Garst, 1S R. I. 484, 28 A. 973,23 L. R. A. 639,47 Am. St. Rep. $7 S 4$. See, also, Central Shade Roller Co. r. Cushman, 143 Mass. 355,9 N. E. 629.

4. Star Publishing Co. v. Associated Press, 159 Mo. 410, S1 Am. 
holds that the Associated Press must serve all newspapers alike in furnishing news; and a by-law disciplining its members who dealt with news agencies contrary to the prohibition, creates a monopoly of the news, and is contrary to the public policy of the State of Illinois, and hence void. ${ }^{5}$

The Associated Press, in the Missouri case, claimed that it was in form a corporation, but essentially it was only a cooperative society based on agreement among its members to gather the news; that it was not engaged in news-gathering as a commercial enterprise, and that it carried on its business without any effort of profit-making, and that its laws binding its members by exlcusive contracts were not in contravention of any State or United States law. The Missouri court upheld the legality of the Association's by-laws and the Illinois court declared them void.

\section{ARTICLE II.}

\section{Pooling and Merger of Ratlroad Business.}

Section 323. Corporate Trusts.

324. Pooling Railroad Business.

325. Rebates to Shippers.

326. Monopoly in Interstate and International Trade.

327. Corporate Trusts and Labor.

\section{$\S 323$. Corporate trusts - Industrial and commercial com-} binations. - Competition in trade has been the basis of our civilization. But competition is coming to an end. The socalled corporate trusts are absorbing the small owners and producers of commercial products. It is estimated that the United States Steel Corporation is a creation of a dozen producers absorbed, which were themselves combinations of other producers. The Amalgamated Copper Company has property once belonging to nearly a thousand mining claims, each one

St. Rep. 368, 60 S. W. 91,51 L. R. A. 151 .

5. Inter-Oeean Publishing Co. v.
Associated Press, 184 Ill. 438, 56 N. E. 822,48 L. R. A. 568, 75 Am. St. Rep. 184. 
owner by a half a dozen miners. The drpartment strme haw absorbed humbleds of business enterprises of merehants, butehers, shoe-dealers, and the like. The Standard Oil Company has absorbed, by contract and other ways, the business of ten thousand corporations and merchants fhroughout the Cnited States. The great railway combinations are made up by the combination of hundreds of smaller lines. This process of eombining of combinations is going on, amel the cont is not in sight, and competition will no longer be an element that shall conduce to the builling up of our commerce. If the Northern Pacific Railroad Company and the Great Northern Railroad Company had been permitted to merge their interests, then all the railroads of the mation conld have pooled their issmes, and combined into one great transportation company on the perfection of whose manipulations the welfare of the nation might depend. Competition must be restored, even if the State has to enter the field. Whether the State should, under the right of eminent domain, take the railroads and the coal lands, is a question of great importance. The United States carries the mail at a reasonable cost. Some cities furnish gas and water to citizens at reasonable rates. But it is better for the individual to live under conditions where he ean take the initiatice and become self-reliant and prosperous. But if this condition cannot longer exist under the laws, the State must enter the contest, a master which can be governed by the citizens.

The great question now is to suppress the modern gigantic commereial and industrial combinations, which are ehanging the commercial jurisprudence of the United States, and driving out of business the small trader and the small producer.

The States and the United States have passed laws prohibiting these combinations, but so long as the combination returns a good profit, the combinations will endearor to keep ahead of the legislature. The law, so far as settled, will now be discussed, though some decisions are in conflict.

A combination eannot legalize its actions by incorporation of its members into one corporate trust, becanse the incorpor- 
ation of an organization formed to monopolize a business, and the transfer to the corporate trust of the property of the varions members, do not purge the combination of its illegality. ${ }^{1}$ So where a corporate trust has for its object a virtual monopoly of the business of producing petrolcum, and of manufacturing, refining and dealing in it and all its products, throughout the entire country, and by which it might not merely control the production, but the price at pleasure, it is an unlawful organization, and such agreement is not only ultra vires, but is contrary to the policy of the State, and is void. ${ }^{2}$ And so a corporation organized for the purpose of controlling the manufacture and sale of friction matches, and by means of which all competition was stifled and opposition crushed, and the whole business of the country in that line engrossed by the corporation, is a menance to the public, its object and direct tendency being to prevent fair competition and to control prices. ${ }^{3}$

Until 1885 Congress made little or no attempt to regulate interstate commerce. The railway monopoly was left to the State to suppress. Then in 1890 it passed the Sherman AntiTrust Act, ${ }^{4}$ which made a radical prohibition of all combinations in restraint of trade, whether reasonable or unreasonable. ${ }^{5}$ This act has been the subject of judicial interpretation from that time until the present. The famous Sugar Trust case ${ }^{6}$

1. Distilling and Cattle Feeding Co. v. People, 156 IIl. 448, 41 N. E. 188, 47 Am. St. Rep. 200; State v. Nebraska Distilling Co., 29 Neb. 700, 46 N. W. 155.

2. State v. Standard Oil Co., 49 Ohio St. 137, 30 N. E. 279,15 L. R. A. 145, 34 Am. St. Rep. 54l. See, also, People v. Sugar Refining Co., 121 N. Y. 582,24 N. E. 834,9 L. R. A. 33 and note, 18 Am. St. Rep. 843.

3. Richardson v. Buhl, 77 Mich. 632, 43 N. W. 1102, 6 L. R. A. 457 and note. See, also, People v. Gas Trust Co., 130 Ill. 268, 22 N. E. 788, 8 L. R. A. 497 and note, 17
Am. St. Rep. 319; People v. Milk Exchange Co., 145 N. Y. 267, 39 N. E. 1062,27 L. R. A. 437,45 Am. St. Rep. 609 ; Ford v. Milk Shippers Asso., 155 Ill. 166, 39 N. E. 651, 27 L. R. A. 298 ; Merz Capsule Co. v. Capsule Co., 67 Fed. Rep. 414; Judd v. Harrington, 139 N. Y. 105 ; People v. Sheldon, 139 N. Y. 251, 34 N. E. 785, 23 L. R. A. 221, 36 Am. St. Rep. 690.

4. Act of Congress, July 2, 1890, 26 Stat. 209.

5. United States v. Freight Asso., 166 U. S. 290, 17 S. Ct. 540.

6. United States v. Knight Co., 156 U. S. 1, 15 S. Ct. 249. 
holds that a combination to purchase refineries throughout the United States is not a restraint of commeree, becanse the products of the refineries thus purchased night never enter into the channels of interstate trade. The anthority of this case was, in effect, modified by the Addyston l'ipe Company, ${ }^{7}$ where a combination of pipe manufacturers songht to monopolize their industry, and for that purpose allotted certain territory in different States to constituent companies wherein each of which had the exchnsive right, under certain conditions, to sell. The court said, that though the manufacture of pipe was not commerce, yet the allotment of interstate territory for the sale of pipe was a direct restraint of interstate commerce and therefore the combination was illegal. This decision seems to conflict with the Sugar Trust case as to what is interstate commerce.

A distinction exists between interstate and intrastate commerce. The former is regulated by Congress, the latter by the State. So commerce carried on within a State cannot be regulated by Congress. ${ }^{8}$ Whenever a corporation of a State is absorbed by a foreign corporate trust, it ceases to be a domestic corporation, and the trust owning it is a foreign corporation, which must be subject to the same restrictions and duties as domestic corporations, and has no greater power, if admitted by conity into a State. ${ }^{9}$ So where a corporate trust absorbs different corporations in different States, it and the corporations absorbed become foreign to the State other than its situs, and can be controlled by the State as to conditions of entry into the State, and acceptance of imposed restrictions. A corporation as an entity, may not be able to create a corporate trust or combination with itself, but its individual stockholders may,

7. Addyston Pipe and Steel Co. v. United States, 175 U. S. 211,20 S. Ct. 96. See " $\Lambda$ Remedy for the Trust Evil."-12 Yale L. Journal, 117 ; "The Power of Congress Over Combinations Aflecting Interstate Commerce."-17 Harv. Law Review, 83; "Combinations in Restraint of Interstate Commerce Under the
Anti-Trust Aet."-54 Cent. L. Jour. 349 .

8. Adyston Pipe and Steel Co. v. United States, 175 U. S. 211,20 S. Ct. 96.

9. Harding v. Am. Glucose Co., 182 Ill. 551.55 N. E. 577,74 Am. St. Rep. 189 and note. 
in controlling it, together with it, create such trust or combination that will make it, with them, alike guilty, and the combination is illegal. ${ }^{10}$ Wherever there is a combination to suppress competition, to fix the price of commodities and limit their production, and to restrain trade, it is a monopoly and can be controlled. And a corporate trust is created where a majority of the stockholders, in competing companies, consolidate their interests by conveying their property to a corporation, organized for the purpose of taking their property, when the necessary consequence of the combination is to control prices, limit production or suppress competition in such a way as to create a monopoly. ${ }^{11}$

Congress has endeavored to suppress interstate monopolies. But when one reads the opinions of the United States Supreme Court in United States v. Knight Co. ${ }^{12}$ and Addyston Pipe and Steel Co. ${ }^{13}$ he will agree that the law does not meet all the difficulties of the situation, for there is a seeming if not a real conflict in the two decisions. Whether the Sherman act ${ }^{14}$ has exhausted the powers of Congress, is a question of which there may be difference of opinion. It is certain that the anti-trust act does not apply to contracts in restraint of trade, which in a mere incidental way or in some remote manner comes into relation with or between the source of interstate traffic. ${ }^{15}$ There is a distinction between the aggregation of properties by purchase when the seller no longer retains any interest therein, and a combination of owners and properties under one management where each owner's interest is continued in the operation. The first would not be in violation of the anti-trust law; the second undoubtedly would be. But where the transaction

10. Ford v. Milk Shippers Asso., 155 Ill. 166, 39 N. E. 651, 27 L. R. A. 298; National Lead Co. v. Paint Store, 2 Mo. App. 723.

11. Harding v. Am. Glucose Co., 182 Ill. 551,55 N. E. 577,74 Am. St. Rep. 189 and note.

12. 156 U. S. 1, 15 S. Ct. 249.

13. 175 U. S. 211,20 S. Ct. 96.
14. 26 U. S. Stat. 209 , Act of July 2, 1890; Compare United States v. Knight Co., 156 U. S. 1, 15 S. Ct. 249; Hopkins v. United States, 171 U. S. 578,19 S. Ct. 40 ; Anderson v. United States, $171 \mathrm{U}$. S. 604,19 S. Ct. 50.

15. United States v. Knight Co., 156 U. s. 1, 15 S. Ct. 249. 
is of a mixed character, the sellor acepting part cash and part stock in payment it is not settled as to whother surh amblimation is in violation of the anti-trust act. If the seller parts with his whole interest and agrees not to muter into the husiness within the territory ocmpied by the combination, such agreement at common law is not void. ${ }^{16}$

$\S 324$. Pooling railroad business. - In agreement between railroad companies, by the terms of which all their roads are to be operated, as to through traffic, as if operated by one division of such traffic, and, where this is not done, for a division of the gross earnings thereof, the ohvions purpose being to suppress or limit competition, and to establish rates without regard to their reasonableness, is contrary to public policy and void. ${ }^{1} \mathrm{~A}$ railroad company is a quasi-public corporation, and owes certain duties to the public, among which are the duties to afford reasonable facilities for the transportation of persons and property, and to charge only reasonable rates for such service. Any contract by which it disables itself from performing these duties, or which makes it to its interest not to perform them or removes all incentive to their performance, is contrary to public policy and roid; and, the obvious purpose of this eontract being to suppress or limit competition among the contracting parties in respect to the traffic covered by the contract, and to establish rates withont regard to the question of their reasonableness, it is contrary to public policy, and void. ${ }^{2}$ So a contract entered into between competing common carriers for the establishment and maintenance of freight rates, forming what is known as a "pool," being a combination for no other purpose

16. Davis v. Booth (U. S. C. C. A.), 37 Chicago L. News, 112, decided July 6, 1904.

1. Clicicago, etc., R. R. v. Wabash, ete., R. R., 61 led. 993.

2. Gibbs v. Gas Co., 130 U. S. 396, 9 S. Ct. 553; Morris Rum Conl Co. v. Coal Co., 68 Pa. St. 173, 8 Am. Rep. 159; Cleveland, ete., Rail- road Co. v. Closser, 126 lnd. 345, 20 ‥ E. 159 , 9 L. K. A. 754 and note, 2.2 An. St. Rep. 593; West Virginia Trans. Co. $\checkmark$. Pipe Line Co., 22 W. Va. $600,46 \mathrm{Am}$. Rep. 5.27: Woodstock 1ron Co. v. Extension Co., 129 L. S. 643, 9 $\mathrm{s}$. Ct. 402: Aruot r. Cual Co., is X. Y. $55 \mathrm{~s}, 23 \mathrm{Am}$. Rep. 190. 
than that of stifling competition, and providing means to accomplish that purpose, is illegal. Such a combination being void, ${ }^{3}$ any one of the associated carriers has a right to provide by special contract for a special rate to a shipper, and such contract will be upheld when no element of partiality, oppression, or improper faroritism entered into the contract. ${ }^{4}$ But competing and non-connecting railroads are not authorized by the commerce act ${ }^{5}$ to make an agreement of maintenance of rates and the curbing of competition. All combinations in restraint of trade or commerce are prohibited by the commerce act, whether they are in form of trusts or merger of corporations or in any other form whatever. ${ }^{6}$ These cases show that the doctrine of unlimited competition applies to railroads; that they cannot merge their lines and interests in order to keep prices within certain prescribed limits; that the prohibition of railroad companies merging and thus secure unlimited competition will produce the greatest good to the public and be no unreasonable injury to the railroads.

In the Northern Securitics Company Case, ${ }^{7}$ the company was formed as an attempt to distinguish between an unincorporated pool and a so-called holding company. It was argued that a cor-

3. Hunter v. Pfeifer, los Ind. 197, 9 N. E. 124; Atcheson v. Mallon, 43 N. Y. 147, 3 Am. Rep. 67s; United States v. Freight Asso., 166 U. S. 290,17 S. Ct. 540 ; Gibbs v. Smith, 115 Mass. 592; Hannah v. Fife, 27 Mich. 172; People v. Sugar Refining Co., 22 Abb. N. Cas. 317, 121 N. Y. 582, 18 Am. St. Rep. 843; Cleveland, etc., R. R. Co. v. Closser, 126 Ind. 348,26 N. E. 159, 9 L. R. A. 754 and note, 22 Am. St. Rep. 593.

4. Cleveland R. R. Co. v. Closser, 126 Ind. 348,26 N. E. 159,9 L. R. A. 754 and note, 22 Am. St. Rep. 593.

5. Act of July 2, 1890, 26 U. S. S. at Large, 209.
6. United States v. Freight Asso., 166 U. S. 290,17 S. Ct. 540 ; United States v. Northern Securities Co., 120 Fed. Rep. 729; Northern Securities Co. v. United States, 36 Chi. L. News, 255, 191 U. S. 555, 24 S. Ct. 119, 4 S I. Ed. 299.

7. United States v. Northern Securities Co., 120 Fed. Rep. 729. See, also, United States v. Joint Traffic Asso., 171 U. S. 505, 19 S. Ct. 125; Hopkins v. United States, 171 U. S. 578, 19 S. Ct. 40; Anderson v. United States, 171 U. S. 604,19 S. Ct. 50; Addyston Pipe and Steel Co. v. United States, 175 U. S. 211 , 20 S. Ct. 96 ; Montague v. Lowry, 193 U. S. 175 . 
poration, as an individual, conld own a majority of tho stork of two competing lines, and that such ownership of stork liel uot constitute such a direct and necessary relation to commerce als to subject it to Federal anthority. The Lnited States ('irenit Court held in this ease that consolidation of parallel and competing lines cannot be effeeted by the mere transfer of their stoek to a new eorporation. Therefore the morer was illewal and in conflict with interstate commerce. The question arises whether their prohibition of sueh combinations is an unwise interference with the right to contraet; whether Congress shonld so modify the Federal law as to permit the judiciary to determine whether a given restraint of trade is reasonable, and if so, then to uphold the traffic.

The combinations or mergers hereafter to be made in the light of the Northern Securities ease will be combinations that do not conflict with the law. The owners of the stoek of one railroad company may buy the stock of a competing line, and then there ean be no competition. The law cannot make two parallel lines compete where the dividends go into the same treasury, any more than it can make two merchants compete after the owner of the one store has bought out the other. This principle is illustrated in the Sugar Trust Combination which was held invalid by the courts of New York. Then the different owners of the constituent elements combined all the properties into one corporation and the anti-trust law has no application. ${ }^{8}$

The decisions of the Ohio ${ }^{9}$ Court and the New York ${ }^{10}$ court make all of the trusts, namely, combinations or partnerships of corporations, illegal. This had the effect to dissolve the two trusts. But the legislatures of these two States passed enabling acts, permitting competing eorporations to combine under one management, that is, corporations may be formed to own and

8. See Park v. Druggists Asso., 175 N. Y. 1,67 N. E. 136,62 L. R. A. 632,96 Am. St. Rep. 578 and note.

9. State v. Standard Oil Co., 49
Ohio St. 137,30 ․ E. 279, 15 L. R. A. 145,34 Am. St. Rep. 541 .

10. People v. Sugar Refining Co., 121 N. Y. 582,24 N. E. 834,9 L. R. A. 33 and note, 18 Am. St. Rep. 843. 
hold the stock of other corporations without limit. In this way the stockholders of any number of corporations are enabled to turn their certificates of shares over to such a stockholding corporation and receive in exchange the stock certificates of such corporation, which in that way becomes the one owner and controller of all such corporations. This method is, in effect, the same as that by which several corporations were formerly put in control of the same set of outside trustees in order to be under one management, which was condemned as illegal. The courts condemned in the States of Ohio and New York the trusts, namely, all combinations or partnerships of competing corporations, and then the legislature passed enabling acts for such combinations to form and exist. The courts destroyed and the legislature reconstructed and revived. It is by the acts of the legislatures of Ohio and of New York that the Standard Oil Company and the Sugar Refining Company exist.

Another phase of this subject of merger was passed upon by the United States Supreme Court in The Northern Securities Co. v. United States, ${ }^{11}$ where there was a combination or partnership of two interstate railroad companies, the Great Northern Railroad Company and the Northern Pacific Railroad Company. The companies had combined by a majority of the shareholders, to turn orer their stock to the Northern Securities Company, a business corporation formed in New Jersey for the sole purpose of owning and controlling the stocks and securities of other corporations, their share certificates being exchanged for share certificates in such business corporation. The court held this merger illegal under the anti-trust law ${ }^{12}$ of Congress, because any combination which destroys or restricts free competition among those engaged in interstate commerce is illegal. And it does not change the rule as to sucl commerce whether the combination is effected by the acts of the stockholders of the

11. 36 Chicago Leg. News, 255, 191 U. S. 555 , 193 U. S. 197.

12. 26 U. S. St. at Large, 209. See "The Northern Securities Company."-11 Yale L. Jour. 387, 3
Columbia L. Review, 168, 305, 315, 13 Yale L. Journal, 57, 17 Harv. L. Review, 474, 533, 52 Am. L. Register, 358. 
several miting corporations or whether it rosults ly the stockholding eorporation acpuiring a majority of the stock of such corporations gradually and as best it may, by stock purehasing in open market, or otherwise.

But suppose the Northern Securities Company had not been formed by the stockhollers of the two railroad companies, but by others, and its directors had conceived and carried out the scheme of getting control of the stock of the two companies by purchase for cash, and thus changing them from competiturs to allies, would the court hold different? The question whether the combination of several competing corporations under one stockholding corporation, without any preconceived and workedout scheme by their shareholders, would be illegal remains to be decided. This phase of the case opens up a rast field for carefully devised statutes and conservative court decisions.

§325. Rebates to shipper.-Common carriers may, within the limits of fairness and impartiality, consult their own interests. ${ }^{13}$ So a contract giving a special rate to a shipper, and providing for a drawback, is not in itself illegal and void. To have that effect other elements must enter into the contract. but when such elements are present in such form, as to make the discrimination mujust or oppressive, the contract will be illegal. Discrimination withont partialiț is inoffensive: partiality exists only in cases where advantages are equal, and one party is unduly favored at the expense of another who stands upon an equal footing. And whether a common carrier acts inpartially or not depends upon the circumstances of the particular case. Mere discrimination will not invalidate a contract. If a common carrier makes a special contract to repas part of the sum received from the shipper, he must perform his part of the contract, unless he overthrows the presumption of fairness and

13. Louisville, etc. R. R. Co. v. Flanagan, 113 Ind. 488,14 N. E. 370, 3 Am. St. Rep. 6it; Chicago. etc., R. R. Co. v. Iowa, 94 U. S.
155; Easton v. Railroad Co., 32 Fol. Rep. Sat: Nicholson v. Railroad Co., 7 C. B., N. S. 755. 
right by countervailing facts. The shipper's right to recover rests upon the contract providing for a rebate. ${ }^{14}$

\section{$\S 326$. Monopoly in interstate and international trade.-} Congress passed an act declaring all contracts void in the form of trust or otherwise in restraint of trade or commerce among the States, or with foreign nations. ${ }^{1}$

The regulation of commerce applies to the subjects of commerce and not to matters of internal police. Contracts to buy, sell, or exchange goods to be transported among the several States, the transportation and its instrumentalities, and articles bought, sold or exchanged for the purpose of such transit among the States, or put in the way of transit, may be regulated, because they form part of interstate commerce. The fact that an article is manufactured for export to another State does not of itself make it an article of interstate commerce, and the intent of the manufacturer does not determine the time when the article or product passes from the control of the State and belongs to commerce. ${ }^{2}$ When a combination is made for private gain in the manufacture of a commodity, but not through the control of interstate or foreign commerce, the statute does not apply. And it does not follow that an attempt to monopolize, or the actual monopoly of, a manufacturer is an attempt,

14. Bayles v. Railroad Co., 13 Colo. 181, 22 P. 341; Erie and Pacific Despatch Co. v. Cecil, 112 Ill. 185; Root v. Railroad Co., 114 N. Y. 300,21 N. E. 408,4 L. R. A. 33 and note, 11 Am. St. Rep. 643 and note; Spofford v. Railroad Co., 128 Mass. 326 ; Fitchburg R. R. Co. v. Gage, 12 Gray (Mass.), 393 ; Christie v. Railroad Co., 94 Mo. 453, 6 S. W. 656; Stewart v. Railroad Co., 38 N. J. L. 505; Union Pacific R. R. Co. v. United States, 117 U. S. 355,6 S. Ct. 772; Johnson v. Railroad Co., 16 Fla. 623, 26 Am. Rep. 731; Ragan v. Aiken, 9 Lea
(Tenn.), 609, 42 Am. Rep. 684; Hersh v. Railroad Co., $74 \mathrm{~Pa}$. St. 181; McDuffee v. Railroad Co., 52 N. H. 430, 13 Am. Rep. 72; Garton v. Railway Co., 1 Best \& S. 112; Great Western Railway Co. v. Sutton, L. R. 4 H. L. 226; Boxendale v. Railway Co., 5 C. B., N. S. 336 ; Ransome v. Railway Co., I C. B., N. S. 437 .

1. Act of July 2, 1890, ch. 647, 26 Stat. 209.

2. Coe v. Errol, 116 U. S. 517, 525, 6 S. Ct. 475; Kidd v. Pearson, 128 U. S. $20,21,22,9$ S. Ct. 6. 
whether executory or consummated, to monnpolize anmmerce, even though, in order to dispose of the product, the instrumentality of eommeree is necessarily invokerl. Hence, when the American Sugar Refining Company, a corporation existing under the laws of the State of New Jerser, being in control of a large majority of the mamufactories of refined sugar in the United States, acquired, through the purchase of stock in four Philadelphia refineries, such disposition over those manufactories throughout the United States as gave it a practical monopoly of the business, it ereated a monopoly in the mannfacture of a necessary of life, which could not be suppressed under the statute, ${ }^{3}$ to protect trade and commerce against unlawful restraint and monopolies; and the acquisition of the Philadelphia refineries by a New Jersey corporation, and the business of sugar refining in Pemnsylvania, bear no direct relation to commerce among the States or with foreign nations."

The monopoly and restraint denounced by the statute are a monopoly in interstate and international trade or commerce, and not a monopoly in the manufacture of a necessary of life; thus, this trust act does not apply to a company engaged in one State in the refining of sugar, where such industry bears no distinct relation to commerce between the States or with foreign nations. $^{5}$

But agreement as to rates by competing railroads for the transportation of articles of commerce between the States do come within and are condemned by this act. The act includes every contract, combination in the form of trust, or otherwise, or conspiracy in restraint of trade or commerce, among the sereral States, or with foreign nations. Hence, an agreement by railroads for the purpose of mutual protection by establishing and maintaining reasonable rates, rules and regulations on all freight traffic, both through and local, is void, as it puts a re-

3. Act of July 2, 1890, (h. 647, 26 Stat. 209.

4. United States r. Knight Co..
156 U. S. 1,15 S. Ct. 249, Harlan, J., dissenting.

5. United States $v$. Knight Co., I.j6 L. S. 1. 15 S. Ct. 249. 
straint 11 ron commeree as described in the trust act; ${ }^{6}$ therefore pooling arrangements by railroarts are forbidden. ${ }^{7}$ So a contract or combination which imposes any restraint, reasonable or unreasonable, upon interstate commerce is unlawful; and it is immaterial whether or not the restraint is a fair and reasonable one or whether it has actually resulted in increasing the price of the commodity dealt in. ${ }^{8}$ Where the main object of the parties in making the contract is merely to restrain competition, and enlance and maintain prices, the contract is void. ${ }^{9}$

The object of the Sherman Anti-Trust Aet $^{10}$ was to protect trade and commerce against unlawful restraint and monopolies. To accomplish that object Congress declared certain contracts illegal. That act, in effect, prohibits the doing of certain things, and its prohibitory clanses have been sustained in several cases as valid under the power of Congress to regulate interstate commerce. $^{11}$

Most great combinations from which the people have anything to fear are engaged in some way in interstate commerce. The Constitution of the United States gives Congress jurisdiction to regulate commerce among the States. But Congress cannot say that a particular article is subject to interstate commeree when it is not, so as to exclude judicial inquiry. While Congress has power to regulate interstate commerce, it has no power to select the subjects and instrumentalities. which it intends shall thereafter enter into commerce between the States. In all the cases up to the present time, the United States Supreme Court has held that the scope of the term com-

6. United States v. Freight Asso., 166 U. S. 290,17 S. Ct. 540.

7. United States v. Freight Asso., 166 U. S. 290,17 S. Ct. 540.

8. United States v. Coal Dealers' Asso., 85 Fed. Rep. 252; United States v. Freight Asso., 166 U. S. 290, 17 S. Ct. 540.

9. United States v. Pipe and Steel Co.. 85 Fed. Rep. 271, 46 T. R. A. 122,175 U. S. 211,20 s. Ct. 96 .
10. Act of July 2, 1890, ch. 647 , 26 Stat. 209.

11. United States v. Freight Asso., 166 U. S. 290, 17 S. Ct. 540; United States v. Traffic Asso., 171 U. S. 505, 19 S. Ct. 25; Addyston Pipe and Steel Co. v. United States, 175 U. S. 211,20 S. Ct. 96 ; United States v. Northern Securities Co., 120 Fed. Rep. 721, 191 U. S. 555, 193 U. S. 197, 24 S. Ct. 119. 
merce, as used in the constitution, is to be retermined ly the court and not by Congress. ${ }^{12}$

$\S$ 327. Corporate trusts and labor.- In antagonism exists between industrial combinations and labor. In the begimning trusts were not cordial to labor. In the Sugar 'Trust agreenent one of the principal provisions was to furnish protection against combinations of labor, and the attitude of labor against trusts was apparently hostile. The method of guarding against the advance of labor combinations, as set forth in the Sugar Trust agreement, was to be ablo to close a refinery in which a striko occurred without embarrassing the production, as all of tho other refineries in the trust would continue. But this method was soon met by the extension of the labor organization to all the refineries, and therefore labor confederacies were completed to meet the combination of capital. So, one organization confronted the other. ${ }^{1}$

12. Champion v. Ames, $18 s$ U. S. $321,23 \mathrm{~S}$. Ct. 321 . As to the application of the Act of Congress of 1893, in enforcing the anti-trust and interstate commerce laws, see, Inter- state Commerce Commission v. Baird, 194 U. S. 25.

1. See "Labor Competition and the Law."-19 Law Quarterly Review, 37. 


\section{ARTICLE III.}

\section{As to Patent Rights.}

Section 328. Rights of Patentee.

329. Owner of Different Patent Rights in Single Article.

$\S 328$. Rights of patentee.- $\Lambda$ patentee may not only neglect and refuse to make the patented article, but he may refuse to permit anyone else to do so, on any terms; he may also sell to another the right itself, or agree with him that he will permit no one else to use it; and to make the agreement binding such other person need not agree to make the patented article or sell it, and such a contract is not void as in restraint of trade. ${ }^{1}$

Considerations which might obtain, if the agreement were in regard to other articles, cannot be of any weight in the decision of a question arising upon an agreement as to patented articles. It is the purpose of a patent to give the inventor a monopoly, which is anthorized by the government; and, hence, an agreement by a patentee to allow an association and its members the exclusive use and sale of inventions patented by him, is valid. $^{2}$

The very essence of a patent is monopoly, and the law recognizes this in every way. The argument that the public is injured by a course of dealing in patents is founded on the assumption that it has rights in such property, a notion utterly repugnant to the true nature of the monopoly. No case can be found which recognizes such a public right, and the attempt to apply to this the rules which forbid a restraint of trade is without precedent. $^{3}$ And it is not against public policy for a party to contract not to contest the validity of a patent right. ${ }^{4}$

1. Good v. Deland, 121 N. Y. 1, 24 N. E. 15.

2. Good v. Deland, 121 N. Y. 1, 24 N. E. 15. See, also, Kinsman v. Parkhurst, 18 How. (U. S.) 289; Billings v. Ames, 32 Mo. 265; Costar v. Brush, 25 Wend. (N. Y.)

628; Morse Machine Co. v. Morse, 103 Mass. 73, 4 Am. Rep. 513.

3. Morse Machine Co. v. Morse, 103 Mass. 73, 4 Am. Rep. 513.

4. Dunham v. Bent, 72 Fed. Rep. 60 . 
$\$ 329$. Owners of different patent rights in a single article. -Sereral wwers of different patent rights in a single artirle, may, for the purpose of putting their sereral patents where they can be nsed together and to the hest alvantage form a corporation, to which areh ownel gives the exchsive linense to sell the articles made under the patents, taking as an "puivalent for this licenso a part of the capital stock. Hence, an aprement antong these makers of a commodity, that, for three roars, they will sell at uniform prices fixed at the ontset, and to be ehangerl omly by consent of a majority of them, is not against public policy. Such an agreement does not provide to check competition from outside, as the parties have a monopoly by their patents, but only to restrict competition in price among themselves. ${ }^{1}$

And so, on the same principle an agreement by a patentce for the purpose of selling the patent to better advantage, and as a part of the transaction of sale, and for one and the same consideration received by him for the patent, is valid by which the patentee agrees to use his best efforts to invent improvements in the process and to transfer them to the rendee, to do no act which may injure the rendee or the business, and at no time to aid, assist or encourage in any manner, any competition against the same. ${ }^{2}$ Such a contract is not in restraint of trade, nor contrary to public policy; the patentee had a right to contract to render the rendee his exclusive services in this respect.

1. Plimpton v. Goodell, 143 Mass. 365,9 N. E. 791 ; Compare Merz Capsule Co. v. Capsule Co., 67 Fed. Rep. 414.

2. Norse Machine Co. r. Morse, 103 Mass. 73, 4 Am. Rep. 513. See. also, Gloueester, etc., Co. $r$ Russia Cement Co., 154 Mass. 92, 27 N. E. 1005, 12 L. R. A. 563, 26 Am. St. Rep. 214: Printing, ete., Registering Co. v. Sampson, 19 Eq. 462. 


\section{ARTICLE IV.}

\section{Parties in Pari Delicto.}

Section 330. Enforcement of Illegal Contracts. 331. Test of Illegality of Contracts.

332. Legality at Time of Enforcement.

\section{§ 330. Enforcement of illegal contracts.- Where an illegal} contract is fully executed, the law will not interfere at the instance of either party to undo that which it was originally unlawful to do. But there is distinction between an executory and executed void contract to the effect that while suits to enforce executory contracts may always be defended on the ground of their invalidity; but in respect to executed void contracts no relief can be had by either party. ${ }^{1}$

Courts will not lend their aid to enforce performance of a contract which is contrary to public policy or the law of the land, but will leave the parties in the place their own illegal action has placed them. ${ }^{2}$

Whenever the contract conflicts with the morals of the times and contravenes an established interest of society, it is void, and no right of action can spring out of an illegal contract. ${ }^{3}$

1. Morris v. Hale, 41 Ala. 510; Craddock v. Mortgage Co., 88 Ala. 281, 7 So. 148; Long v. Railroad Co., 91 Ala. 519, 8 so. 706, 24 Am. St. Rep. 931; Thomas v. Railroad Co., 101 U. S. 71 ; Parish v. Webster, 22 N. Y. 494; Terry v. Eagle Lock Co., 47 Conn. 141, 29 Am. Rep. 674 .

2. Central Transp. Co. v. Palace Car Co., 139 U. S. 24, 11 S. Ct. 478; Texas, ete., R. R. Co. v. Railroad Co., 41 La. Ann. 970, 6 So. 8ss, 17 Am. St. Rep. 445; Hope v. Association, 58 N. J. L. 627,34 A. 1070,55 Am. St. Rep. 614; Hooker v. Vandewater, 4 Denio (N. Y.), 349, 47 Am.
Dec. 258; Compare Central Trust Co. v. Railroad Co., 23 Fed. Rep. 306 ; Wright v. Gardner, $98 \mathrm{Ky}$. 454, 33 S. W. 622, 35 S. W. 1116 ; Winchester Elec. Light Co. v. Veal, 145 Ind. 506, 41 N. E. 334,44 N. E. 353.

3. Goodrich v. Tenney, $144 \mathrm{Ml}$. 422,33 N. E. 44,19 L. R. A. 371 and note, 36 Am. St. Rep. 459; Fearnley v. De Mandenville, 5 Col. App. 441, 39 P. 73; Collius v. Blantern, 2 Wilson, 34; Williams $v$. Bagley, 1 H. L. 200 ; Poole v. IVeggins, 3 Ping., N. C. 230 ; Insurance Co. v. Hull, 51 Ohio St. 270, 37 N. E. 1116,25 L. R. A. 37,46 Am. St. 
The principle of pullic polieg is this: Eict dolo malo won oritur actio, a right of aetion camnot arise out of frambl. No court will lend its aid to a man who hases his conce of action upon an immoral or an illegal act. If from the plaintiff's own stating or otherwise, the cause of action appears to arise $e x$ turpi causa, or the violation of the law of the eomtry, then the court says he has no right to be assisted. It is upon this ground, not for the sake of the defendant, but because the court will not lend its aid to such a plaintiff. So, if the plaintiff and defendant were to change sides, and the defendant were to bring his action against the plaintiff, the latter would have the adrantage, for where both are equally at fault, potior est conditio defendentis, better is the condition of the defendant than that of the plaintiff. There are exceptions to the general rule where the parties are not in pari delicto, ${ }^{4}$ and the less guilty is permitted to maintain his suit where the public interests will be therely advanced. ${ }^{5}$ And the parties may adjust their claims, divide the property, and the court will then enforce partition $;^{6}$ or they may place each other in statu quo $;^{7}$ and if one party is ignorant of the illegality but the other is not, the former may enforee it against the latter. ${ }^{8}$

\section{$\$ 33$ r. Test of illegaility of contract. - The court will not} assist either party to an illegal or void contract to enforce it against the other, or to recurer what he has parted with under the contract; and the test in determining when it applies to a plaintiff is whether his cause of action is founded on, or arises out of, the illegal contract. If the action is of that character,

Rep. 571: Sykes v. Beaden, 11 ('h. Dir. 195; Mexican Inter. Banking Co. v. Lichtenstein, 10. Utah, 338, 37 P. 574.

4. Savings Bank v. Burnes. 104 Cal. 473, 38 P. 102; Iiell v. ('ampbell, 123 Mo. 1, 25 s. W. 359. 45 Am. St. Rep. 505.

5. Thite v. Bank, 22 Pirk. (Mass.) 186; Osborne r. Willialins
Is Ves. 379 ; fiesnell r. sprye, 8 II:Ire, 2.2.2.

6. Norton $r$. Blinn, 39 Ohio st. 145; De Leon v. Frevino, 49 Tex. ss, 30 Am. Rep. 101 and note; Rhea v. White, 7 Lea ('Tenm.), lizs; Compare Northrup r. Phillips, 99 III. 449 .

7. Leat r. Cassan, 61 Mla. 312.

8. Wright $v$ Crabbs, is Ind. $48 \pi$. 
whether it appear from his own stating, or is shown by way of defense, he must fail; otherwise, not. ${ }^{1}$ If the plaintiff cannot open his case without showing that he has broken the law, the eourt will not assist him. ${ }^{2}$

While the general mule is that a demand on an illegal transaction will be enforced, if the plaintiff can make out his case without disclosing the illegality, ${ }^{3}$ yet that rule has not been invariably applied to contracts, where the illegal consideration is a violation of statute or an immorality detrimental to the public. In such cases, the courts may overlook the parties, and consider the question one of public policy. ${ }^{4}$ The maxim, nemo allegans turpitudinem suam, audiendus est, no one alleging his own turpitude is to be heard, is inflexible, as between the parties, but may yield to considerations of public policy and the duty of preventing the consummation of a fraudulent and illegal purpose. Nor is the rule universal in its applieation to cases where the consideration is violative of a statute. ${ }^{5}$

\section{$\S 332$. Legality at time of enforcement.-As has already} been stated, the court will not lend its aid to enforce the contract if, at the time its aid is sought, the contract is contrary to public policy. If, however, at the time when the aid of the court is sought to enforce the terms of an existing contract, the publio interests do not demand that the court should refuse to aid in enforcing the contract aceording to its terms, the court will not be justified in refusing its aid simply because at some previous time, such aid would have been refused if then demanded. ${ }^{6}$

1. Nester v. Brewing Co., $161 \mathrm{~Pa}$. St. 473,29 A. 102,24 L. R. A. 247 , 41 Am. St. Rep. 894.

2. Swan v. Scott, 11 Serg. \& R. (Pa.) 164; Morris Run Coal Co.v. Coal Co., 68 Pa. St. I73, 8 Am. Rep. 159; Holman v. Johnson, Cowp. 343.

3. Evans r. Dravo, $24 \mathrm{~Pa}$. St. 62, 62 Am. Dec. 359; Swan v. Scott, 11 Serg. \& R. (Pa.) 155.
4. Irvin v. Irvin, $169 \mathrm{~Pa}$. St. 529, 32 A. 445, 29 L. R. A. 292.

5. Irvin v. Irvin, $169 \mathrm{~Pa}$. St. 529, 32 A. 445,29 L. R. A. 292.

6. Hartford Fire Ins. Co. v. Railroad Co., 62 Fed. Rep. 904. See, also, Ewell v. Daggs, 108 U. S. 143,2 S. Ct. $40 \mathrm{~s}$. 
To sustain the objection to the enforcement of such a contract, it must appear that the contratet is arlveres to the existing public poliey of the State; for, unless that he true, the court is not justified in refusing its aid for the cuforement of a contract which is good between the parties thereto. The inquiry is, what is the public policy of the State where the action lies, when enforcement is souglit?

7. Hartford Fire Ins. Co. v. Railroad Co., 62 Fed. Rep. 904. 


\section{CHAPTER XIII.}

Trades Unions.

\section{ARTICLE I.}

\section{General Statement.}

Section 333. Organization of Workingmen.

334. Trades Unions are Lawful Combinations.

$\S 333$. Organization of workingmen.-The organization of workingmen is legal and, of course, not against public policy. The general rule is that men in all vocations may unite to achieve that which a single person cannot in his individual capacity. So partnerships are formed and corporations created to subserve the necessities of business and all industrial pursuits. So trades unions is a present need that the laborer may sell his labor for a reasonable compensation. Public policy and the interest of society favor the utmost freedom in the citizen to pursue his lawful trade or calling. But the right of men to leave their employment, where no contract is broken, is as perfect and complete as is the correlative right of all men to seek employment wherever they can find it, without let or hindrance, whether belonging to labor organizations or not. These are common rights, secured by the constitution. ${ }^{1}$

$\S$ 334. Trades unions are lawful combinations.- The authorities in America and England hold that trades unions, in the ordinary acceptation of that term, are not unlawful combi-

1. See "Do Trades Unions Limit Output?"-17 Political Science and Organized Labor."-34 Chicago Quarterly, 369; "The Injunction 
nations, so long as they do not resolt to acts of violence, or endeavor to accomplish some end that is contrary to public policy. It is then not illegal, per se, for a mion to adopt and endearor to mainain a scale of wases, or to endearor to limit and regulate the employment of apprentices. ${ }^{1}$

The later English authorities concede that members of trades unions binding themselves not to work exeept under certain conditions, and to support one another in the event of being thrown out of employnent in carrying ont the views of the majority, do not bring themselves within the criminal law or make contracts against public policy. ${ }^{2}$ And so, the later Aneriean cases, where not against statute, hold that trades unions, in the ordinary acceptation of the term, are not of themselves unlawful combinations. So a number of persons may associate themselves together, and agree that they will not work for or deal with certain men, or classes of men, or work under a certain price, or without certain conditions. ${ }^{3}$

But if the purpose of an organization or combination of workingmen be to hamper or to restrict the right to contract, and through contracts or arrangements with employers to coerce other workingmen to become members of such union and to come under its rules and conditions, under a penalty of the loss of their position and of deprivation of employment, the purpose of such organization is unlawful, because it is in conflict with that principle of public policy which prohibits monopolies and exclusive privileges, for it tends to deprive the publie of the services of men in useful employments and occupations."

1. Longshore Printing Co. v. Howell, 26 Oreg. $52 \%$, 38 P. 547,28 L. R. A. 464 and note, 46 Am. St. Rep. 640 .

2. Hormby v. Clark, L. R. 2 Q. B. 151; Farrar v. Close, L. R. 4 Q. B. 602.

3. Carew v. Rutherford, 106 Mass. 14, 8 Am. Rep. 287.

4. Curran v. Galen, 152 N. Y. 33 , 39, 46 N. E. 297.37 L. R. A. 802,57
Ain. St. Rep. 496. See, also, State ․ Gildden. 55 Conn. 46, 8 A. 890,3 Am. St. Rep. 23 ; State v. Stewart, 59 Vt. 273,9 A. 559, 59 Am. St. liep. 710 and note; State v. Dyer, 67 Vt. 690, 32 A. 149; Murdock v. Walker, 152 Pa. St. 595, 25 A. 492, 34 Am. St. Rep. 67s; Barr v. Trades Comeil, 53 N. J. Eq. 101, 30 A. S81; Sherry v. Perkins, 147 Mats. 212. 17 S. E. 307,9 Am. St. 
In C'anala a trade mion is "snch combination, whether temporary or permanent, for regulating the relations between workmen and masters, or between workmen and workmen, or between masters and masters, or for imposing restrictive conditions on the conduct of any trade or business, as would, if this act had not passed, have been deened to have been an unlawful combination by reason of some one or more of its purposes being in restraint of trade."

In England, prior to the Trade Union Act of 1871, strikes were illegal. But since the Trade Union Act of $1875^{5}$ strikes are legal. ${ }^{6}$

Notwithstanding the legality of trade unions, they have no right to inflict injury on others of the community with impunity. And if the organization has no legal entity, it is not without the control of the law; all of the nembers must be reached under the law. Thus, where $\mathrm{A}$ brings an action against the officers of a trade union, alleging that the defendants and the members of the union had illegally combined together to injure him, and had prevented him from obtaining employment as a stonecntter, a good cause of action is shown. ${ }^{7}$

This is the law of England, ${ }^{8}$ and in the United States. ${ }^{9}$ So, there can be no encouragement given to trade unions to evade incorporation and thereby become a legal entity, for such organized body, though having no legal existence as a body, must come under the law, and all of its members reached by legal process.

Rep. 689; Vegelahn v. Guntner, 167 Mass. 92, 44 N. E. 1077,35 L. R. A. 722, 37 Am. St. Rep. 443.

5. 38 and 39 Vict. c. 86 .

6. Temperton v. Russell, 1 Q. B. Div. 733; Lyons v. Wilkins (1896), 1 Ch. 828; Quinn v. Leatham (1891), A. C. 495.

7. Perrault v. Gauthier (Canada), 28 S. C. R. 211. See, also,
Lumley v. Gye, 2 E. \& B. 216 ; Temperton v. Russell, 1 Q. B. 715; Jyons v. Wilkins (1896), $1 \mathrm{Ch}$. S11.

8. Taff Vale Railroad Co. v. The Amalgamated Society of Railway Servants, 70 L. J., K. B. 905.

9. Beattie v. Callanan, 81 N. Y. S. 413, 82 App. Div. 7. 
AR'TICILE II.

Contiacteat Rematisis.

Section 335. Liability of Trades Unions.

336. Picketing.

337. Blacklisting.

338. The Coal Strike Commissinn.

\$ 335. Liability of trades unions. - The liability of trates unions has been settled in England, and the rule will bo and is followed in the United States. The English decision holds these principles: 1. The test for liability of damages is whether the injury was the natural incident or outgrowth of the existing relations of the party doing the injury to the condition out of which the act arose. 2. A malicious intent to injure is not required to make the party civilly liable. 3. The liability rests upon the whole body of the organization which by its anthorized agents and leaders produced the damage. 4. The damage may be collected from the general fund of the association. 5. The members of the organization are joint tort feasors. ${ }^{1}$ This clearly shows the liability of those organizations which cause a strike and interfere in the contractual relations of other parties.

It is also illegal for trarle unions to issne lists of unfair firms with a riew of preventing men from working for such firms or preventing other people from trading with them. It is illegill for trade unions to strike in order to compel men to join them. ${ }^{2}$ It is also illegal for trade unions during a dispute to peacefully persuade men not to enter the employ of a firm in conflict with trade unions. ${ }^{3}$ Yet it is legal for employers to refrain from

1. Taft Vale Railroad Co. v. The Analgamated Socjety of Raiiway Servants, 70 L. J., K. I. 905, overruling S. C. (1901), A. C. 426, S. C. $(1901), 1$ K. B. 170, S. C. 70 L. J. K. B. 219.
2. Lyons v. Wilkins (1S96), l Ch. S2S, 6s L. .J. Ch. 146: (1599), 1 Ch. 2.5.

3. Reid v. Friendly Soe of Operative Stonemasons, ‘l L. J.. K. B. $634 ;(1902)$, 2 K. B. 88 . 
trading with firms in order to compel the latter to join their combinations. ${ }^{4}$

So the law is that if a trade union, or similar combination, commits a wrong as set forth by the English courts, the person injured by such wrong can maintain an action against them as he would against other joint tort feasors; and so far as the form of the action is concerned, it may be brought against either representative defendants, who fairly represent the whole body, or they may be sued by their collective name, that is, in the name of the union. ${ }^{5}$

It is a violation of right to interfere with contractnal relations recognized by law if there be no sufficient justification for the interference. If the trade union is justified in interfering there arises no liability. ${ }^{6}$ So where a labor organization maliciously induced persons contracting with employers to violate their contract, the union is civilly liable in damages to the injured employer. ${ }^{7}$ So if a third party interferes without sufficient ground and cause a workman to be discharged the third party is liable in damages. Thus, where an employe of a corporation under a contract, terminable at the will of either party at any time, was discharged by his employer at the instance of a guaranty company so as to compel him to surrender and release a cause of action which he claimed against his employer, and for the satisfaction of which the guaranty company was liable as an insurer, and the employe was thereby damaged, the guaranty company, or the third party interfering, is liable in damages to the employe. ${ }^{8}$

4. Mogul Steamship Co. v. MeGregor, 23 Q. B. Div. 598.

5. Giblan v. Laborers' Union, 18 L. Times Rep. p. 500 (1903), 2 K. B. 600 ; Glamorgan Coal Co. v. South Wales Miners' Federation (1903), 1 K. B. 118. See, also, Curran v. Galon, 152 N. Y. 33,46 N. E. 297,37 L. R. A. 502, 57 Am. St. Rep. 496 ; Flood v. Allen (1898), A. C. 1.

6. Quinn v. Leatham (1901), A.
C. 510, 50 W. R. 139 ; National Protection Asso. v. Cummins, $170 \mathrm{~N}$. Y. 315,63 N. E. 369,58 L. R. A. 135, s8 Am. St. Rep. 648.

7. Beattie v. Callanan, 81 N. Y. S. 412, 82 App. Div. 7 .

8. London Guaranty and Accident Co. v. Horn, 206 Mll. 493, 69 N. E. 526, 99 Am. St. Rep. 185; Perkins v. Pendleton, 90 Ne. 166, 3S A. 96, 60 Am. St. Rep. 252. See, also, 
In the United States, injunetions have lieen grantred agrainst the acts of labor organizations in mary alses. In somo. States this right of action is governed ly statute. 'Thus, in Now York under the code, when an incorporated organization is composed of seven or nore persons, action ean be brought again it in the name of the president or treasurer. An action was brought for conspiracy resulting in plaintiff's discharge from employment. The defendant set up an acreement between the labor association and the employers' association that no employe should work more than four weeks withont beenming a members of the nuion. This defense was held bad on the ground that such an agreement was illegal. This case clearly sustains the liability of the unincorporated company to an action if it has committed wrong. ${ }^{10}$ But if no wrongful act of the organization has been committed, then no action will lic."

This doctrine is mpheld when, it seems, no statute controls, and the organization is not incorporated. ${ }^{12}$ The question to be settled is, is the act wrongful? if so, a right of action exists though the organization of laborers is unincorporated. ${ }^{13}$ A trade union can be sued under its name, though it is neither a corporation nor an individual; this is the undonbted rule in England and in the United States, when such organization has committed a wrongful act.

Doremus v. Hennessey, 176 Ill. 608, 52 N. E. 924,54 N. E. 524, 68 Am. St. Rep. 203; Compare Allen v. Flood (1898), A. C. l; Mogul Steamship Co. v. McGregor, 21 Q. B. D. 544; Huttley v. Simmons, 67 Q. 13. D. 213; Quinn v. Leatham (1901), A. C. 495. See The Anthority of Allen $r$. Flood, 1 Mich. Law Review, 28.

9. Arthur v. Oakes, $\div$ Inter. Com. Rep. 744,11 C. C. I. 299,24 U. S. App. 239, 63 Fed. Tiep. 310, 25 L. R. A. 414; Beck v. Railway Teamsters' Protect. Enion. Ils Mich. 497.77 N. W. 13. 42 L. R. A. 407.
74 Am. St. Rep. 421: Longshore l'rinting and Pub. Co. v. Howell, 26 Oreg. 527, 38 P. 547,28 L. R. A. 464, 46 Am. St. Rep. 640.

10. Curran v. Galen, 152 N. Y. 33, 46 N. E. 297,37 I. R. A. 802 , 57 Am. St. Rep. 496.

11. Wunchv. Shankland, 59 App. Dir. 482, 69 N. Y. S. 349.

12. Parker v. Bricklayers' Union, 21 Ohio L. Jour. 223, 10 Ohio Dee. Reprint, 45s: Noores v. Bricklayers' Union, 23 Ohio L. Jour. 48, 10 Ohio Dec. Reprint, 665.

13. Barr v. Essex Trades Council, 53 N. J. Eq. 101, 30 A. 881. 
A combination among traders to offer such facilities to customers as will attract the whole trade to themselves and ruin their rivals is not actionable, beeause every trader is entitled not only to seek his own advantage by trading upon terms which will injure his rivals, but he may also combine with others for the same purpose. The right of his rivals to trade is not an absolute, but a qualified right - a right conditioned by the like right to all others, and a right, therefore, to trade subjeet to competition. ${ }^{14}$ So, also, every workman is entitled to dispose of his labor on his own terms, but that right is conditioned by the right of every other workman to do the same. Each laborer is at liberty to deeide for himself whether he will or will not work along with another individual in the same employment; and if all the workmen but one determine that they will not continue their labor in company with that one, they may inform their employer of their deeision without ineurring liability. ${ }^{15}$ In Allen v. Flood, ${ }^{16}$ Allen, a walking delegate, informed his employers that unless they discharged certain persons his associates would quit work. It was held that there had becn, in fact, no threat made by the delegate, but simply a statement of what the men had resolved to do; the delegate neither uttered nor carried into effect any threat at all; he simply warned the employers of the discharged men, of what his men themselves, without his persuasion or influence, had determined to do, and hence the delegate had incurred no liability.

In Quinn v. Leathem, ${ }^{17}$ it was held that the eombination of workmen is perfectly legitimate so long as it does not take the form of an attack on the right of the individual workman. Each party, the individual workman on the one side, and the combination of workmen on the other, are entitled to the enjoyment of their rights to dispose of their labor as they please, subject only to the exereise of this right by the opposite party. But when the combination interferes with the individual workman by threats

14. Mogul Steamship Co. v. McGregor (1892), A. C. 25, 23 Q. B. D. Q. 25.

15. Giblan v. Laborers' Union,
(1903), 2 K. B. 600,18 L. Times Rep. 500.

16. $(1898)$, A. C. 1 .

17. (1901), A. C. 495 . 
uttered by the employer, then this right of the individual workman is invaded, and if damages follow he has a right of action.

In Giblan v. Laborers' Union, ${ }^{18}$ two mion oflicials harl combined to prevent a workman obtaining employment by threatening to call out the other' workmen if he was engaged. 'This workman, plaintiff in the case, had been a local treasurer of the union, and was indebted in respect to mnion funds, and the object was to make him pay this debt. The conrt held that the aggressive use of power of the trade union officials was a cause of action for interference with the plaintiff's right to dispose of his own labor as he pleased. The action lay for the unjustifiable interference with a man's liberty of action, and the defendants were held liable. So the indivdidual workman's rights can be protected.

$\S 33^{6}$. Picketing.- In case of a strike, it is the practice of the union to send out pickets to influence non-union laborers from entering the employment of the business thus under consideration. It is illegal to picket by labor unions, to intimidate workmen who have taken the places of strikers. ${ }^{1}$ A laborer has the undoubted right to leave his employment on a strike, but he must to so in a peaceful manner, and not in any manner injure the business of his employer by intimidating others so that they dare not take his place. ${ }^{2}$ Every act causing an obstruction to another, which is done not in the exercise of the actor's own

18. (1903), 2 K. B. 600,18 L. Times Rep. 500. See, “Do Trade Unions Limit Output?"-17 Political Seience Quarterly, 369; “Labor Competition and the Law."-19 Law Quarterly Rev. 37; "Some English Cases on Trade and Labor Disputes,"-42 Am. Law Register, N. S. 125; "Government by Injunetion."-11 Am. Lawyer, 5; "Ineidental Relief in Federal Injunction Cases."-23 Law Register, 150; "Trade and Labor Unions, Just Cause and Excuse in Labor Dis- putes."-40 Canada L. Jour. 410; "Liability of Trade Unions and Their Nembers."-2s Nat. Cor. Reporter, 620,621 ; " the lielation of labor and Capital, Organization of Employers and Employees, 29 Nat. Cor. Rep. $46,47,48$.

1. Union Pac. R. R. Co. v. Ruef, 1:0 Fed. Rep. 102: Vegrelahn r. Guntner, 167 Mass. 92, $44 \mathrm{~N}$. E. 1077,25 L. R. A. 722, 57 Ams. St. Rep. 443.

2. Wabash R. R. Co. v. Hannahan, 12l Fed. Rep. 563. 
right but for the purpose of obstruction, would, if damages should be caused thereby to the party obstructed, be a violation of the prohibition of the law against interference with the fullest right of every person to dispose of his labor or capital according to his own will, ${ }^{3}$ and is therefore illegal. Nor does it matter whether the wrongdoer effects his object by persuasion or by false representation. The courts look through the instrumentality or means used to the wrong perpetrated with the inalicious intent, and base the right of action upon that. ${ }^{4}$ An agreement to employ none but union laborers is against public policy and in violation of common right, and tends to create a monopoly and cannot be enforced. ${ }^{5}$

Picketing has been practiced in cases of strikes, whereby members of the union are stationed around the place of business to keep non-union men from engaging to work for the proprietors who have been placed on the unfair list. Whenever this picketing, the mumber of pickets being great or small, is sufficient in itself to intimidate men from entering the employment of the proprietors thus listed, then such picketing is unlawful, and intereferes with the contractual relations of employer and employe. Peaceable persuasion, without intimidation, is legal. ${ }^{6}$ Agreements whereby employers are required to unionize their business against their will, are against public policy and against the spirit of our institutions, ${ }^{7}$ and the employers will be protected.

3. Plant v. Wood, 176 Mass. 492 , 57 N. E. 1011,51 L. R. A. 339,79 Am. St. Rep. 330.

4. Barr v. Trades Council, 53 N. J. Eq. 101, 30 A. 881. See, also, Beck v. Teamsters' Protective Union, 118 Mich. 49, 77 N. W. 13, 42 L. R. A. 407,74 Am. St. Rep. 421 ; Shoe Co. v. Saxey, I31 Mo. 213, 32 S. W. 1106, 52 Am. St. Rep. 622; Flaccus v. Smith, 199 Pa. St. 128, 48 A. 894,85 Am. St. Rep. 779.

5. Curran v. Galen, 152 N. Y. 33 , 46 N E. 297,57 Am. St. Rep. 496. 6. Vegelahn v. Guntner, 167
Mass. 92,44 N. E. 1077,25 L. R. A. 722,57 Am. St. Rep. 443; Union. Pac. R. R. Co. v. Puef, 120 Fed. Rep. 102; Beaton v. Tarrant, 102 11l. App. 124; American Steel Co. v. Wire Drawers' Union, 90 Fed. Rep. 598.

7. Curran v. Galen, 152 N. Y. 33, 46 N. E. 297,57 Am. St. Rep. 496 ; Lucke v. Clothing Cutters, 77 Md. 396,26 A. 505, 19 L. R. A. 408, 39 Am. St. Rep. 421; Mills v. U. S. Printing Co., 32 N. Y. L. Jour. 1037, 100 App. Div. 
Strikers have the right to argue or discous the sulject of employment with the new employes, and persuade, if they can; but the new employes must be allowed the right to eome and go without fear or molestation, and without being compelled to discuss this or any other question, and withunt being guarded or picketed. Persistent and continuous persuasion by members is of itself intimidation. Pieketing which in fact annoys or intimidates employes is clearly an intereference witl their rights. Any unlawful nuisance may be ereated by a congregation of persons sufficient to obstruct a highway, although they are entirely peaceable. When a large number of persons assemble with the express purpose of harrassing or annoying others, to deter them from engaging in lawful employment, their conduct is unlawful. And especially where picketing is accompanied by more aggressive intimidation, not only by language villainous, vulgar and obscene, mixed with execrable oaths and threats of murder, and by outrageous and brutal assaults, these acts are unlawful. ${ }^{8}$ And a patrol of strikers in front of a factory is unlawful, because it is a means of intimidation when used in combination with social pressure, threats of personal injury and the like. ${ }^{9}$ Picketing in and of itself, when properly conducted, is not unlawful, but it is so when accompanied by violenee or any manner of coercion or intimidation. But it is very doubtful whether picketing has ever been, or will be, used by strikers except for the purpose of intinidation. And if a strike is ordered on buildings under construction, where work cannot be stopped without injury to the owner, such strike is unlawful, though the action was to force out non-union men or compel them to join the union. ${ }^{10}$

What is unlawful picketing is a question not settled. Mere picketing, if it is peaceable and without threats or intimidation, cannot really be considered as unlawful. ${ }^{11}$ But the use of threats, violence, or intimidating with the intent of preventing

8. Union Pac. R. R. Co. v. Ruef, 12u Fed. Rep. 102.

9. Vegelahn v. Guntner, 167 Mass. 92, 44 N. E. 1077,51 Am. St. Rep. 443,35 L. R. A. 722 .
10. Erdman v. Mitehell, $207 \mathrm{~Pa}$. 79, 56 А. 327, 63 L. li. A. 534.

11. Foster v. Protective Asso., is N. Y. S. 860,39 Mise. K. 48. 
laborers from entering the employment of employers or preventing enstomers entering the stmes of merehants, is mlawful. It is held that picketing itself is a threat which produces in the minuls of non-mion men a feeling of fear. ${ }^{12}$ But this doetrine is not generally upheld, and when there is no intimidation the picketing is not unlawful. ${ }^{13}$ But there ean be picketing which is unlawful, though there is no physical violence. So calling non-union men by approbrious names is unlawful interference. ${ }^{14}$ So to hold up non-minion laborers to the ridicule and contempt of bystanders is wrong. ${ }^{1 .}$ So holding a banner in front of a factory requesting workmen to keep away is a means of threat and intimidation to prevent laborers from entering the employment of the factory. ${ }^{16}$

The fact that the union strikers assemble in great crowds seems to be a threat and to convert persuasion into intimidation. ${ }^{17}$

The act committed must be unlawful and productive of injury of the party complaining. If the act is lawful and may be lawfully performed, it is an injury withont a remedy. ${ }^{18}$ But a combination to do injurious acts expressly directed to another, by way of intimidation or constraint, either of himself or of persons employed or secking employment by him, is a wrongful interference with the contractual rights of others. ${ }^{19}$

12. Otis Steel Co. v. Local Union, 110 Fed. Rep. 698.

13. Krebs v. Rosenstein, $67 \mathrm{~N}$. Y. S. 630,56 App. Div. 619 ; Standard Tube v. Inter. Union, 9 Ohio Dec. 692 .

14. O'Neil v. Behanna, $182 \mathrm{~Pa}$. St. 243,37 A. 843,61 Am. St. Rep. 702 and note; Murdock v. Walker, 152 Pa. St. 595, 25 A. 492, 34 Am. St. Rep. $67 \mathrm{~S}$.

15. Wick China Co. v. Brown, 164 Pa. St. 449, 30 A. 261.

16. Sherry v. Perkins, 147 Mass. 212, 17 N. E. 307, 9 Am. St. Rep. 689.
17. American Steel IVire Co. v. Wire Drawers, 90 Fed. Rep. 60s; United States v. Kane, 23 Fed. Rep. 750; People v. Wiljig, 4 N. Y. Cr. 403; Makall v. Ratchford, 82 Fed. Rep. 41.

18. Macauley v. Turney, $19 \mathrm{R}$. I. 255, 33 A. I, 6I Am. St. Rep. 770,37 L. R. A. 455.

19. Vegelahn v. Guntner, 167 Mass. 92,44 N. E. 1077,35 L. R. A. 722,57 Am. St. Rep. 443; O'Neil v. Behanna, 182 Pa. St. 236, 37 A. 843,38 L. R. A. 382,61 Am. St. Rep. 702. 
In general, threats of physical injury, or injury to the property of an employer, especially if aceompanied by assaults or overt acts, which will intimidate a man of ordinary courace so as to make him abandon his employer,--are an unlawful interference with personal rights. ${ }^{20}$

In the United States mere threats not producing intimidation are not lawful. ${ }^{21}$ But in England, by statute, such threats are unlawful..$^{22}$ A statute may provide that a peaccable combination may organize for or against employment; and in such case where there is no intimidation, the acts of the emplores aro not unlawful. ${ }^{23}$ But such statute does not make it lawful for such combination to injure a man in his business by a concerted action on the part of an immense number of persons to ceaso dealing with him, by threats to withdraw their custom from him, for the purpose of obliging him to accede to their demands, or, in other words, to boycott him. ${ }^{24}$

\$ 337. Blacklisting.- An employer may keep in a book the names of employes discharged because they were members of a labor union, and may invite inspection of that book by other employers, even though the latter therefore refuses to hire the discharged employes. The employer has a right to keep a blacklist which may be referred to by those interested. ${ }^{1}$

However, a statute which prohibits blacklisting is constitu-

20. Beck v. Protective Union, 118 Mich. 497,77 N. W. 13, 42 L. R. A. 407, 74 Am. St. Rep. 427 ; Manufacturer's' Ontlet Co. v. Longley, 20 R. I. S6, 37 A. 535; Curran v. Galen, 152 N. Y. 33, 46 N. E. 297,37 I. R. A. 892,57 Am. St. Rep. 496; Cumberland Glass Manuf. Co. v. Glass Bottle, etc. Asso., 59 N. J. Eq. 49, 46 A. 506 ; In re Debs, 158 U. S. 564,15 S. Ct. 900, 64 Fed. Rep. 724; Allen v. Flood (1898), A. C. 1.

21. Cumberland Glass Manuf.
Co. v. Glass Bottle, ete. Isso., $59 \mathrm{~N}$. J. Eq. 49, 46 A. 208.

22. Lyons v. Wilkins (1896), 1 Ch. 811,74 I. T. 355,60 J. P. 325.

23. Mayer v. Stone Cutters, 47 N. J. Eq. 519,20 A. 492.

24. Bar v. Trades Council, 53 N. J. Eq. 101, 30 A. s81. See, "Injunction and Organized Labor."34 Chi. L. News, 327 ; "Picketing a Store-Injunction."-52 Am. Law Register, 531.

1. Boyer v. Western Union Tel. Co., 124 Fed. Rep. 246; Young v. Railroad Co. (Ind.), 69 N. E. 300. 
tional, where there is express or implied malice. ${ }^{2}$ This statute should only apply to employers who act maliciously and wantonly, on their own initiative, and endeavor to prevent their cmployes from obtaining cmployment elsewhere; this is the only rational interpretation of such statute, because under the constitution, State and Federal, an employer, without malice, has a right to give information with respect to a former employe. It may be laid down as a general principle, that it is a violation of legal right to interfere with contractual relations recognized by law if there be no sufficient cause justifying the interference. ${ }^{3}$

So an employer has a right, in the absence of contractual relations, to discharge any employe with or without notice at any time, even for belonging to, or for joining a labor organization, and the same right to leave the service of an employer is accorded the employe; and the employer has the right to maintain, without malice, a blacklist and give it out to others. ${ }^{4}$ Because it is against public policy and common right, to compel another against his will, or to compel one to retain in his employment a man he does not want.

But it is held that a statute is constitutional which prohibits employers from combining for the purpose of interfering with or preventing any person, either by threats or blacklisting, from procuring employment. ${ }^{5}$

In blacklisting a correct account must be given. And so if a railroad company has a custom of keeping a record of the cause of the discharge of employes, and to decline to employ those discharged for certain causes, it is a part of the contract of employment that no false entry as to the cause of such dis-

2. State v. Justus, 85 Minn. 279 , 88 N. IV. 759,56 L. R. A. 757,89 All. St. Rep. 550.

3. London Guar. and Accident Co. v. Horn, 206 IlI. 493,69 N. E. 526, 99 Am. St. Rep. 185; Hollenback v. Restine, 114 Iowa, 358, 86 N. W. 377 ; Moran v. Dunphy, 177 Mass. 485,59 N. E. 125,52 L. R.
A. 115, 83 Am. St. Rep. 289; Perkins v. Pendleton, 90 Me. 166, 38 A. 96, 60 Am. St. Rep. 252.

4. Boyer v. Western Union Tel. Co., 124 Fed. Rep. 246.

5. State v. Justus, 85 Minn. 279, 88 N. W. 759,56 L. R. A. 757,89 Am. St. Rep. 550. 
charge shall be made, or enmmunicated, if made, to any other railroad company. ${ }^{6}$

$\S 338$. The coal strike commission.- In 1903 an anthracite coal strike neeurred in Pennsylvania and the Presirlent appointed a commission to settle it. The commission justified the use of the malitia to keep the peace, condemned boyeotts and violence, and forbid any effort of the strikers to restrict the output of mines, except by agreement with the operators, and also forbid discrimination against any workman because of membership or non-membership in any labor organization, and any interference by union men, and any interference by any labor organization. This decision is of the highest value, because it comes from eminent men from the most varied positions and vocations in life. This commission gave no countenance to tyranny, whether by capitalists or by unions, and tolerated no lawlessness. ${ }^{1}$

6. Hundley v. Louisville, etc. R. R. Co. (Ky.), 63 I. R. A. 289.

1. See "A Word More on the Coal Mines."-14 Green Bag, 570; "Legislation to Control the Anthracite Coal Corporations."-64 Albany Law Journal, 418; "The Coal
Mines and the Law."-14 Green Bag, 514; "Cause of the Coal War."-42 Legal Advisor, 176; “A Problem in Mining Law: Walrath v. Champion Mining Company."16 Harvard Law Review, 94. 



\section{PART IV.}

\section{OPERATION OF CONTRACTS.}





\section{PART TV.}

\section{CHAPTER XIV.}

\section{Contractual Relations.}

\section{ARTICLE I. \\ Contractual Relations.}

Section 339. Persons Affected.

340. Meeting of Minds-Right of Privacy.

341. Master and Servant-Interference of Third Parties-Boycott.

342. Duty not to Interfere In Any Contrat.

343. Restrieting the Rule to Servants.

344. When the Period of Employment is not Certain.

345. Doing an Aet which is Legal in Itself.

346. Fraudulent Representations.

347. To Sustain an Aetion the Diseharge Must Take Place.

348. As to Priorities of the Parties.

349. Water Companies--Rights of Third Persons.

350. Assignment of City Contract.

351. No Priority of Parties or of Consideration.

$\S 339$. Persons affected.-Generally only parties to a comtract are affected by it. Hence, a contract cannot impose liabilities on persons not parties to it, nor confer rights on them. In ease of agency the agent is obeying his principal's orders and is therefore acting for his principal, and so this is not, in fact, an exception to the general rule. And so the exception that rights and liabilities of a contract may pass by assignment by the parties or by operation of law to others, is only apparent. The assignees are substituted to the rights of the original parties. There ean be no privity of eontract only to those who are made 
parties. ${ }^{1}$ IIowever, the trend of decisions now is that a party for whom a contract is made may sue on it. This is upon the ground that the party, for whose benefit the contract was made, when he accepted the act of the original parties, is brought into privity with the promisor, and can therefore enforce it against him. ${ }^{2}$ But the law seems to be otherwise in England. ${ }^{3}$ But where no contractual relations exist, a party has no right to appropriate or take the property of another for his own benefit. Thus, a party has no right to copy from the electrical instruments and printing machines of another, known as tickers, for the purpose of publishing through his own tickers, or otherwise disposing of, or using any of the news or information which may thereafter be collected. Such information is the private property of the owner of the ticker and can only be used as he sees fit. ${ }^{4}$ But if property is dedicated to the public, the owner's rights are divested. Thus, when an architect publishes bis plans of a building, he loses his exclusive right to them. ${ }^{5}$ So a publisher cannot control the price of his publication by a reservation printed on the page following the title-page that if the book is sold for a less price than specified, he will consider it an infringement of the copyright. Because when a publisher transfers his title to a copy of his book, either to a reader, subscriber, or retailer, he has exercised his sole liberty of vending that particular copy, and is the only right protected by the copyright law. ${ }^{6}$ If a publisher wishes to control the sale of his work in the possession of the retailer, it must be by an agree-

1. Boston Ice Co. v. Potter, 123 Mass. 28, 25 Am. Rep. 9; Schmoling v. Thomlinson, 6 Taunt. 147; Fender v. Kelly, 58 Ill. App. 283; Lawrence v. United States, 71 Fed. Rep. 228; Gaitskill v. Chenaelt, 32 S. W. 757,17 Ky. L. J. 828; Martin v. Peet, 92 Hun, 133, 36 N. Y. S. 554 ; Freeman v. Railroad Co., 173 Pa. St. 274, 33 A. 1034.

2. Tweeddale v. Tweeddale, 116 Wis. 517,93 N. W. 440,61 L. R. A. 509, 96 Am. St. Rep. 1003 ; Law- rence v. Fox, 20 N. Y. 268; Pingrey on Mortg. 326, 1028, 1031.

3. Tweddle v. Atkinson, l B. \& S. 393 ; Compare In re Rothehan, etc. Co., 25 Ch. D. 111.

4. National News Tel. Co. v. Western Union Tel. Co., 119 Fed. Rep. 294,56 C. C. $\bar{A} .19 \overline{9}, 60$ L. R. A. 805 .

5. Wright v. Eisie, 83 N. Y. S. 887, 86 App. Div. 306.

6. Edison Phonograph Co. v. Pike, 116 Fed. Rep. 863; Victor 
ment. I reservation as to price cammot contmol, or be, an infringennent.

$\S 340$. Meeting of minds - Right of privacy. - In order to form a contract there must he a meeting of minds. So a party has a right to select the party with whon he will eontract, and camnot therefore be compelled to contract with a party withont his consent. ${ }^{1}$

Where there is no privity of contract, the possesion and use of property will not support an implied contract $;^{2}$ and no presumption of assent can be implied from the reception and use of property, where the recipient has no knowledge that it was furnished by one party, when he had a right to suppose that it was furnished by another under an express contract.

But if the recipient of the property has received notice that the contract to furuish property to him has heen assigned to another, and he continues to receive it, then an implied contract is created and a contract with the assignee exists. ${ }^{4}$

A roluntary payment made by one of a debt by another without his request ereates no assumpsit on the part of the latter to the former, ${ }^{5}$ because a party cannot make another his lebtor without the latter's consent. ${ }^{6}$ Under this head the question of the right of priracy comes. It has been decided that a party had no right to privacy in lis photograph; that a photograph may be used as a trade-ninark, and the subject whose photograph is used has no remedy. ${ }^{i}$ Such a doctrine is unjust and unwise,

Talking Mach. Co. v. The Fair, 118 Fel. Rep. 609 ; Bobbs-Merrill Co. v. Snellenburg, 131 Fed. Rep. 530. See, also, IIarrison v. Maynard, 61 Fed. Rep. 689, 10 C. C. A. 17, 26 U. S. App. 99; Publishing Co. v. Smyth, 27 Fed. Rep. 914.

1. Schmoling v. Thomlinson, 6 Taunt. 147 .

2. Hills v. Snell, 104 Mass. 173, $17 \pi$.

3. Boston Ice Co. v. Potter, 123 Mass. 2s.
4. Mudge v. Oliver, l Allen (Mins.). 7t: Oreuit r. Nelson. 1 (imy Mass.). 536: Mitehell v. Lapaye, Holt. N. 1'. 253.

5. Hearn v. Cullin, j4 Md. 533.

6. Durnford $v$. Messiter, 5 Maule \& Sel. 446.

7. Roberson v. Box Co.. $171 \mathrm{~N}$. Y. 53s, 64 X. l. 442. 59 L. R. A. 4is; Jarlin Fire Arms Co. v. Shields, 171 N. Y. 384, 64 N. E. 163, 59 L. R. A. 310 ; Changed by statute of 1903 , Ch. 132. 
and against the common sense of people in general, and has been repudiated in England, and the right of privacy upheld. The case is this: A father employed a photographer to photograph his two daughters and ordered and paid for a certain number of photographs. The photographer's successors in business, of their own accord, made enlargements of the photographs and exhibited them in their studio for the purpose of their trade. To this the father objected, and, on the photographers refusing to desist from exhibiting the photographs, brought an action of injunction, and the court held that a photographer who had been employed by a customer to take a portrait has no right to print copies of it for sale or exhibition without the customer's consent. The nature of a photographer's right in the negatives of photographs taken by him in the ordinary course of business was discussed, and it was held the photographer is entitled to the custody of the negative in order to secure to limself the privilege of supplying possible future orders, while the customer has an interest in it to the extent of entitling him to prevent the photographer using it except on his order and with his consent. ${ }^{8}$ This decision is in accord with reason and common sense. In fact, it is a doubtful question whether the State even has the right to take the photograph and the Bertillon measurement and publish them, of a suspected eriminal. ${ }^{9}$

It should be held that an implied contract exists between the photographer and the sitter that the negative shall not be used for any other purpose than to furnish photographs at the order of the sitter, and, therefore, the photographer has no right to sell the negative or to print photographs, only as ordered by the sitter. ${ }^{10}$

It is said that the right of privacy during life dies with the person, and therefore no person can maintain an action to pre-

8. MicCosh v. Crow, English Court of Sessions, March 17, 1903.

9. Owen v. Partridge, 82 N. Y. S. 248 .
10. Pollard v. Photograph Co., 40 Ch. D. 345 ; Levyeau v. Clements, 175 Mass. 376,56 N. E. 735 , 50 L. R. A. 391 and note; Boucas v. Cooke (1903), 2 K. B. 227. 
rent the exhibition of a picture of a deceaserl relative, unless the injury caused by that display is to himself, and the action carnot be brought simply because the exhibition will be disagreeable to the person whose portrait is to be exhibiterl had he been living. ${ }^{11}$ And where a party in his lifetime has permitted his photograph to be printed in newspapers and varions other publications, and he is a public man, there is no reason for preventing his photograph from publication after his death. ${ }^{12}$ Undoubtedly a distinetion should exist between private and public persons. A private individual should be protected in his right of privacy.

The photograph and measurement of a prisoner taken by officers in the line of their duty, cannot be surrendered to the prisoner after he has been set at liberty by reversal of the conviction. The plotograph and measurements are a part of the other records which go to make up the inevitable track of the released prisoner, and to undertake to blot out this record would be a public inconvenience, if not an impossibility. ${ }^{13}$

\section{$\S 34$ I. Master and servant - Interference of third parties}

- Boycotts. - While a contract does not impose a duty upon parties not in privity, yet it does impose a duty not to interfere with its operation. So an action of a servant can be maintained against a person who has malieiously procured the master to discharge snch servant from employment in which he is engaged under legal contract for a certain period, provided damages resulted to the employe from such diseharge. ${ }^{1}$ So boycotts

11. Schuyler v. Curtis, $147 \mathrm{~N}$. Y. 434,42 N. E. $\overline{2} 2,49$ Am. St. Rep. 671, 31 L. R. A. 286; Atkinson v. Doherty, 121 Mịch. 372, 80 N. W. 285,46 L. R. A. 219,80 Am. St. Rep. 507.

12. Corliss v. IValker Co., 57 Fed. Rep. 434, 31 L. R. A. 283 and note, 64 Fed. Rep. 380.

13. In re Molineux, $83 \mathrm{~N}$. Y. S. 943, 41 Miscel. 154. See, "Actions for Infringement of Right of Pri- vacy Based on Breach of Trust or Confidence."- $-\tilde{\tau}$ Cent. L. Jour. $3(61$; "The Right of l'rivacy."-36 Chicago Legal News, 126.

1. Chipley r. Atkinson, 23 Fla. 206, 1 So. 134, 11 Am. St. Rep. 367; Jones v. Blocker, 43 Ga. 331; Walker v. Cronin, 107 Mass. 555; Lueke v. Clothing Cutters, $77 \mathrm{Md}$. 396,26 A. 505,19 L. R. A. 408,39 Am. St. Rep. 421 ; Jones v. Stanley, 76 N. Car. 355 ; Haskins v. Roys- 
with unlawfulness and malicions intent are illegal. For every person has a right as between his fellow-citizen and himself, to carry on his business, within legal limits, according to his own discretion and choice, with any means which are safe and healthful, and to employ therein snch persons as he may select; and every other person is subject to the correlative duty arising therefrom, to refrain from any obstruction of the fullest exercise of this right, which can be made compatible with the exercise of similar rights by others. ${ }^{2}$

No one has a right to interfere with the business of another, his occupation, profession, or way of obtaining a livelihood; and it does not matter whether the interference is tainted with any moral turpitude or not. ${ }^{3}$

But it is said that this rule applies only to actions by masters or servants for interference of third party in their contracts for hire. Beyond this, it is held, the rule does not go, and has no

ton, 70 N. Car. 601, 16 Am. Rep. 780; Lumley v. Gye, 2 El. \& BI. 216; Gregory v. Brunswick, 6 Man. \& G. 205 ; Perkins v. Pendleton, 90 Me. 166, 38 A. 96, 60 Am. St. Rep. 252; Temperton v. Russell (1893), 1 Q. B. 715; Carew v. Rutherford, 106 Mass. 1, 8 Am. Rep. 287; Van Horn v. Van Horn, 52 N. J. L. 284, 20 A. 485,10 L. R. A. 184 ; Curran v. Galen, 22 N. Y. S. 826,152 N. Y. 33,46 N. E. 297,37 L. R. A. 802, 57 Am. St. Rep. 496; Bradley v. Pierson, $148 \mathrm{~Pa}$. St. 502, $24 \mathrm{~A}$. 65 ; Moores v. Bricklayer's' Union (Ohio), 23 Week. L. Bul. 48; Delz จ. Winfree, 80 Tex. 400,16 S. W. 111, 25 Am. St. Rep. 705; Jackson v. Stanfield, 137 Ind. 592, 36 N. E. 345,37 N. E. 14,23 L. R. A. 588 ; Bixby v. Dunlap, 56 N. H. 456 ; Manstick v. Ranege, 9 Neb. 390, 2 N. 739, 31 Am. Rep. 415; Barr v. Trades Council, 53 N. J. Eq. 101, 30 A. 881; Garrett v. Taylor, Cro.
Jac. 567; Keeble v. Hickeringill, 11 East, 574; Young v. Hicks, 6 Ad. \& E. 606 ; Bowen v. Hall, 6 Q. B. Div. 333 .

2. Barr v. Trades Council, $53 \mathrm{~N}$. J. Eq. 101, 30 A. 881; Hilton v. Eckersley, 6 El. \& Bl. 47. See, also, Mogul Steamship Co. v. McGregor, 23 Q. B. 608; Toledo, etc. Co. v. Penn. Co., 54 Fed. Rep. 730, 738; Hopkins v. Stove Co., 83 Fed. Rep. 912, 28 C. C. A. 99,49 U. S. App. 709; Exchange Tel. Co. v. Gregory, 73 L. T. 120.

3. Doremus v. Hennessey, 62 Ill. App. 391,176 Ill. 608, 52 N. E. 924, 54 N. E. 524, 43 L. R. A. 791, 68 Am. St. Rep. 203; Bowen v. Hall, 6 Q. B. D. 33 ; O'Neill v. Behanna, 182 Pa. St. 236, 37 A. 843, 38 L. R. A. 382, 61 Am. St. Rep. 702 and note; Lumley v. Gye, 2 El. \& Bl. 216; Mogul Steamship Co. v. McGregor, 21 Q. B. 544, 553, 23 Q. B. 598 . 
application to ordinary contracts ; but this is not upheld ly the weight of antherity.

Neither am the state boyout in rmming an employment burean, by discriminating against "mployers whose cmploy' are on a strike or locked ont, and not allowing surhe employers to patronize the burean. Such statute is in contlict with Fomrteenth Amendment to the Federal Constitution. ${ }^{5}$

As to boyouts in general, the following rules are controlling: 1. All laborers may lawfully combine and form mions for their mutual benefit, and may use all lawful means to promote their own interests, if they do not infringe upon the rights of others; 2, they may refuse to work on terms offerer by the enuluer; 3 , it is an unlawful neans to hinder or prevent others from working for an employer under such terms as they shall sce fit $:^{6} t$, one means of snch hindering and preventing is in varions ways, to render it either difficult or uncomfortable for such willing workmen so to labor; 5, another unlawful means is to hinder or prevent willing workmen from working and to compel emplorers to accede to terms which they would not otherwise adoptthis is the boyeott in its rarions forms. ${ }^{\text {? }}$

All the courts hold that contracts binding the employer to engage none but union employes, and to discharge no employe except for eanse satisfactory to the union, are against public poliey and unconstitutional. All men have a right to work where they desire when engaged, and the employers have a right to engage men from whatever source they please without discrimination against any on account of their affiliations or non-affiliations with organized labor. So in ease of a strike the employer has the right to engage other workmen. He may declare for an open shop, thereby engaging any laborer. and the

4. Glencer Sand Co. x. Hudson, 138 Io. 439,40 S. W. 93,36 L. R. A. $840,60 \mathrm{Am}$. St. Rep. 560 .

5. Nathews v. People. 202 Ill. 389,67 N. E. 28,95 Am. St. Rep. 241.

6. Martin v. MeFall (N. J. Eq.),
7. Mathew v. People, 202 Ill. 389, 67 ․ E. 28.95 Am. St. Rep. 241 ; Kellyville Coal Co. v. IIarrier. 207 IIl. 624, 99 Am. St. Rep. 240. See, also, Connelly v. United States Sewor Pipe Co., 184 U. S. 540, 22 S. Ct. 431 . 55 A. 465 . 
laborers camnot legally bind him to keep closed shop, or to hire none but union men. The right to contract cannot be circumscribed by contract. 8

So a statute forbidding, under penalty, an employer to discharge an employe because he is a member of a labor organization, violates the constitutional right of liberty and is therefore void. ${ }^{9}$

$\S 342$. Duty not to interfere - In any contract. - It is held that a third party has no right to interfere in any contract whether it be between master and servant or other parties. So remedies given by the common law in cases of malicious interference of third parties, are not in terms limited to any discription of servants or service; so in all cases where a man has a temporal loss or damage by the wrong of another, he may have an action upon the case, to be repaired in damages. ${ }^{1}$ Thus, where a third party has maliciously influenced an opera singer to break an engagement to sing at a theatre, the plaintiff may recover damages from the wrongdoer. ${ }^{2}$

And so it is held that an action will lie for the malicious procurement of a breach of contract, though not for personal service, if by the procurement damage is intended to result and did result to plaintiff. ${ }^{3}$

8. Gray v. Building Trades Council (Minn.), 97 N. W. 633, 63 L. R. A. 753 .

9. State v. Kreutsberg, 114 Wis. 530,90 N. W. 1098, 58 J. R. A. 748, 91 Am. St. Rep. 934. See "The Jaw of Strikes and Boycotts." -52 Am. L. Register, 73.

1. Temperton v. Russell (1893), 1 Q. B. 715 ; Bowen v. Hall, 6 Q. B. Div. 339; Haskins v. Royster, 70 N. Car. 601, 16 Am. Rep. 780.

2. Iumley v. Gye, \& El. \& Bl. 216, 228.

3. Lumley v. Gye, 2 El. \& Bl. 216; Traskins v. Royster, $70 \mathrm{~N}$.
Car. 601, 16 Am. Rep. 780; Chipley v. Atkinson, 23 Fla. 206, $11 \mathrm{Am}$. St. Rep. 367; Walker v. Cronin, 107 Mass. 555: Bowen v. Hall, 6 Q. B. Div. 339; Jones v. Blocker, 43 Ga. 331 ; Lucke v. Clothing Cutters, 77 Md. 396, 39 Am. St. Rep. 421, 26 A. 505, 19 L. R. A. 408; Doremus v. Hennessey, 62 Ill. App. 391, 176 Ill. 608, 52 N. E. 924, 54 N. E. 524,43 J. R. A. 797,68 Am. St. Rep. 203; Tarlton v. McGawley, Peak, N. P. C. 270; Clifford v. Brandon, 8 Camp. 358; Gregory v. Brumswick, 6 Man. \& G. 205; Garrett v. Taylor, Cro. Jac. 567. 
In England it is held that maliee or indirest motive, thongh accompanied by hes to another, is now definitely dechared to be in itself no cause of action. There must he some infepromlent, unlawful act. Therefore, it is actionable for 1 knowingly to procure $\mathrm{B}$ to break his eontract with $\mathrm{C}$; it is also actionable for $A$, by the use of illegal means, to proenre $P$ to to an act detrimental to C. But in both rases the gist of the artion is the prima facie unlawfulness which amounts to a civil wrong if it is aceompanied by knowledge on his part of the effect of his conduct. ${ }^{4}$ The facts of this case are these: In April, 1S94, two shipwrights, Flood and Taylor, were employed by the Glengall Iron Co. in repairing a steamship. Upon the same job other millwrights were employed, and also a number of ironworkers, who were members of the Boilermakers' Society, and it was a rule of their union that ironworkers ought to work in iron only and shipwrights in wool. Upon this job Flood and Taylor were working in accordance with the rule, but on a former occasion they had riolated it hy working in iron, and the iron workers decided to have no assoeiation with them. Mr. Allen, the delegate of the boilermakers' soeiety, was ealled upon to present these objections to the company, which he did, saving that mless Flood and Taylor were discharged the other men would quit work. They were discharged. This course was rendered praeticable withont any obvions illegality by the fact that the men of botll elasses were engaged merely by the day.

The diseharged men brought an aetion against Mllen, who had not proeured any breach of contract on the part of the eom-

4. Allen r. Flood (1898), A. C. 1, 177. This case eame on for trial before a judge and jury in 1894. and a verdict was rendered, for the plaintiff, of 20 pounds damages, the jury finding that Allen had acted malicionsly. Allen appealed. and the Court of Appeals unanimously affirmed the judgment, after learing two arguments and consulting officially with the law lords of the ligh cont. The ease was then earried to the Ilonse of Lords, the court of last resort, which reversed the case, the judges standing six for reversal to three for affirmation. In the enuts whore this eite was leand, from first to last. twenty-one judges werr engiged, of whom thirteen decided in faror of the diseharged men. Sice lluttley r. Simmons, 14 Times L. R. 150. 
pany, nor in luringing pressure to bear upon the manager had he used, or threatened to use, any violence. The only way, therefore, of supporting the action was to base it upon malice; that is, upon the intention of injuring Flood and Taylor for the sake of proving a benefit of the boilermakers' society. In this ease Allen did nothing unlawful. The House of Lords held that the action was based solely on malice, which was not enough to sustain the action.

$\S 343$. Restricting this rule to servants.- One line of cases holds that the malicions interference of a third party does not give the party injured any right of action, unless he be an apprentice, menial servants and others whose means of living is by mamal labor; but this exception exists by virtue of statute. ${ }^{1}$ Thus, when this statutory rule is adopted, if the defendant maliciously interfered and prevented a performance of a contract, not for labor, the plaintiff has no remedy for damages sustained. $^{2}$

In those jurisdictions where this statutory doctrine has not been adopted, the interference of a third person in any kind of a contract comes under the rule as to damages.

\section{$\S 344$. When the period of employment is not certain.-} Neither the fact that the term of service intermpted is not for a fixed period nor the fact that there is not a right of action against the person who is induced or influenced to terminate the service or to refuse to perform his agreement, is of itself a bar to an action against a third person malicionsly and wantonly procuring the termination of or a refusal to perform the

1. Statute of Laboreis. $25 \mathrm{Ed}$ ward IIT.

2. Chambers v. Baldwin, $91 \mathrm{Ky}$. 121,15 S. W. 57,11 I. R. A. 545 and note, $34 \mathrm{Am}$. St. Rep. 165; Ashley v. Dixon, 48 N. Y. 430,8 Am. Rep. 559; Boyon r. Thorn, 98 Cal. 578, 33 P. 442, 21 T. R. A. 233 and note: Heywood v. Tillson, 75
Me. 225, 46 Am. Rep. 373; Payne v. Railroad Co., 13 Lea (Tenn.), 507, 49 Am. Rep. 666; Fleneos Sand Co. v. Hudson, 138 Mo. 439, 40 S. W. 93,36 L. R. A. 804,60 Am. St. Rep. 560: Bourliev v. Macauley, 91 Ky. 135, 15 S. W. 60, 11 T. R. A. 550.34 Am. St. Rep. 171. 


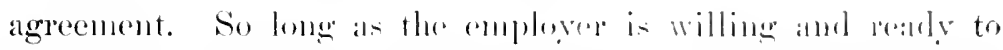

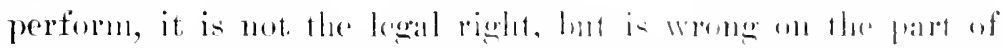
a third party malicionsly and wantunly, to presente the anpleyer to terminate or refuse to perform the antratet, which makes the third party liable. I servant whe is arming a living or otherwise enjoging the fruits and advantages of lis indu-try or enterprise or skill, has a right to pursu sulh mulnement undisturbed by mere malicious or wanton interferente."

And for a matster to maintain an aletion it is omough if the service is one at will, if sulwisting when intermpted ly an lawful act, ${ }^{2}$ and the rule applies as to the employe. ${ }^{3}$

\section{$\S 345$. Doing an act which is legal in itself.- Where one} does an act which is legal in itself and violates no right of another person, it is eenerally held that the fact that the act is done for malice on wher bad motive toward another, does not give the latter a riglit of action against the former. Though there be a loss or damage resulting to the other from the act, and the doer is prompted to it solely by malice, vet if the act be legal and violates no legal right of the other person there is no right of action to the injured person. ${ }^{4}$ But there are decisions.

1. Chipley v. Atkinson, 23 Fla. 206, 11 Am. St. Rep. 367.

2. Salter v. Howard, 43 Ga. 601 ; Sykes v. Dixon, 9 Ad. \& El. 244. See, also, Rice v. Manly, fit $\mathrm{X}$. Y. 8.2. 23 Am. Rep. 30; Gunter v. Astor, 4 J. B. Noore, 12; Glass Co. v. Binney, 4 Piek. (Mass.) 425; Compare Hart r. Aldridge. Cowp. 54: Green v. Button, 2 Cromp. M. \& R. 707: Harvester Co. v. Meinhardt, 24 Hun (N. Y.), 4s9: Benton v. Pratt. 2 Wend. (N. Y.) 385. 20 Amr. Dee. 623 and note.

3. Flood v. Jackson (1895), 2 Q. B. 21. See, also, Dorrmuls v. Hennessy, 62 Ill. App. 391, $176 \mathrm{Ill}$. lios, 52 X. T. 924. it X. E. 524. $4 ;$ L. R. A. 797. 6S Am. St. Rep. 203;
Compare Royeroft v. Tarntor, 68 Vt. 219, 35 A. 53, 33 L. R. A. 225 , it Am. St. Rep. Sse.

4. Bradiond Corporation v. Piekles (1895). A. C. .j8т: Phelps v. Yowlin, 72 N. Y. 39, as Am. Rep. 93 and note: Aeton $r$ Blundell, 12 Mees. \& Wel. 324; Orr r. Ins. Co., 12 Lil. Amn. 25.5; Wheatly v. Baugh. 25) 1'a. St. 528, 64 Am. Dee. 721 and sote: Chatfield r. Wilson, $28 \mathrm{Vt}$. 49; Sonth Royilton Pank y. Bank, $\therefore$ Vt. 50.5; llowird v. Benton, 32 it. 724: Bradley r. Fuller, 118 Vass. 239: Hunt $v$ Simonds, 19 Yo. 583: Jenkins r. Fowler, $2+\mathrm{Pa}$. st. 30s; Glenion Iron Co. v. Uhler. 7) Pa. St. 467,15 Am. Rep. 599 ; bradford v. Pickles (1s9.5), I Ch. 
that hold a contrary doctrine. Thus, if a party dig a well on his own land for the sole purpose of inflicting damages upon his neighlour who has a right to a spring, he will be liable, ${ }^{5}$ which is the rule of the civil and not of the common law. ${ }^{6}$

$\S 346$. Fraudulent representations. - Where a contract would have been fulfilled but for false and fraudulent representations of a third person, an action for damages will lie against such person, although the contract could not have been enforced. ${ }^{7}$ An action will lie by a party to a contract against a third person for fraudulent representations by the latter, inducing the other party to the contract to break it. ${ }^{8}$

\section{$\S 347$. To sustain an action the discharge must take place.} - An act done or attempt made by a third party with the malicious intent to procure such a discharge, but not successful in procuring it, will not support an action brought for maliciously procuring the discharge. The actual procurement of the discharge is an essential to such an action. ${ }^{9}$ If the servant is not discharged, but roluntarily leaves the employment on account of the conduct of the party charged with having procured his discharge, the action cannot be maintained. ${ }^{10}$

\section{$\S 348$. As to privity of the parties - Negligence. - Where} there is no question of agency or assignment of a contract, a

145; Hague v. Wheeler, $157 \mathrm{~Pa}$. St. 424, 27 A. 714; Chasemore v. Richards, 7 H. L. Cas. 349,387

5. Chesley v. King. it Me. 164, 43 Am. Rep. 569; Flaherty v. Noran, 81 Mich. 52,45 N. W. 381,8 L. R. A. 183, 21 Am. St. Rep. 510. 231.

6. Pingrey on Real Prop. 230 ,

7. Benton v. Pratt. 2 Wend. (N. Y.) $385,20 \mathrm{Am}$. Dec. 623 and note; Green v. Bulton, 2 Cromp. M. \& R. 707.
8. Rice v. Manley, 66 N. Y. 82, 23 Am. Rep. 30 ; Ashley v. Dixon, 48 N. Y. 430, 8 Am. Rep. 559.

9. Chipley v. Atkinson, 23 Fla. 206, 11 Am. St. Rep. 367.

10. Chipley v. Atkinson. 23 Fiti. 206. 11 Am. St. Rep. 367. See, also, Reynolds v. Everett, 144 N. Y. 189, 39 N. E. 72 ; People v. Hughes, 137 N. Y. 29,32 N. E. 1105 ; People v. Barondess, 133 N. Y. 649, 31 N. E. 240. 
stranger cammot acquire any rights monder it. Where thre is a contract between two parties, and a third party is a mere stranger and is not in privity with either of the contracting parties, and the contract is not made for his henefit, the third party has no rights under it and cannot claim any benefits. ${ }^{1}$

It is not every promise made by one to another, from the performance of which a benefit may ensue to a thirl, which gires a right of action to such third person, he being neither privy to the contract nor to the consideration. The contract must be made for his benefit, as its object, and he must be the party intended to be benefited. ${ }^{2}$ The rule is not so far extended as to give to a third person, who is only indirectly and incidentally henefited by the contract, a right to sue upon it. But the name of the person to be benefited by the contract need not be given, if he is otherwise sufficiently described or designated. He may be one of a class of persons, if the class is sufficiently described. ${ }^{3}$

In erery ase in which an action has been sustained there has been a debt or duty owing by the promisee to the party claiming to sue upon the promise. Whether the decisions rest upon the doctrine of agency, the promisee being regarded as the agent of the third party, who, by bringines his action adopts his acts, or upon the doctrine of a trust, the promisor being regarded as having receired money or other thing for the third party, is not material. In either case there must be a legal right fomnded upon some obligation of the promisor, in the third parts, to adopt and claim the promise so made for his benefit. ${ }^{4}$

1. Martin v. Peet, 92 Hun, 133, 36 N. Y. S. $554 ; 71$ N. Y. St. 725; Fenden r. Kelly, 58 Ill. App. 283; Insurance Co. v. Water Co., 42 Mo. App. 118: Howesmon r. Water Co.. 119 Mo. 304, 24 S. W. Tst. 22? I. R. A. 146 and note, $41 \mathrm{Am}$. St. Rep. 654: Freeman r. Railroad Co., 173 Pa. St. 274. 33 A. 1034.

2. Simon v. Brown. 68 N. Y. 355 ; Vrooman v. Turner, 69 N. Y. 2so,
25 Am. Rep. 195: Wright v. Terry, 23 Fla. 160: Justin r. Seligman, Is Fed. Rep. 519: Burton v. Larkin, 36 Kan. 246, 13 P. 39s, 59 Am. Rep. 541.

3. Burton v. Larkin, 36 Kan. 246. 13 P. 39s. 59 Am. Rep. 541: Iohames v. Ins. Co., 60 Wis. 50. 27 ․ W. 414. 57 Am. Rep. 249.

4. Trooman $\mathrm{r}$. Tumer, $69 \mathrm{~N}$. Y. 280, 25 Am. Rep. 195. See, also, 
Thus, where a party after agreeing to improve and sell defendant's lots, and with the proceeds pay for the lots, agrees to pay a third party commission for making the sale, defendant is not liable for such commission, as there is no privity of contract. ${ }^{\circ}$

And this principle is illustrated in the case of an action for negligence. So the acceptance of a thing sold, by the vendee, except under special circumstances, relieves the vendor from liability to a stranger for an injury resulting to him from the negligent manufacture or construction of the thing sold. Negligence to be actionable must oceur by breach of a legal duty arising out of a contract or otherwise owing to the person sustaining the loss. In such case there is no privity of contract between the manufacturer and the stranger, and hence the third party is without remedy, for the negligent manufacture of the article sold to the vendee. ${ }^{6}$

At common law a death of person by negligence or wrongful act gave no right of action. And so where an employer contracts with his employe to protect him from the wrongful acts of strikers, and the employe is killed by them, no action survives, and the employer is not responsible.

$\S 349$. Water companies - Rights of third persons. - The owner of property which has been destroyed by fire cannot maintain an action to recover damages from a water company, on the ground that the property was destroyed by the failure of the

Lawrence v. Fox, 20 N. Y. 268; Howsmon v. Water Co., 119 Mo. 304,24 S. IV. 784,23 L. R. A. 146 and note.

5. Crawford v. Brown, 21 Colo. 272, 40 P. 692. See, also, Lewis v. Land Co., 124 Mo. 672, 28 S. W. 324 .

6. Savings Bank v. Ward, 100 U. S. 195 ; Hill v. Lane, 37 N. J. I. 5; Goodlander Mill Co. v. Standard Oil Co., 63 Ferl. Rep. 400.
27 L. R. 1. 583, 11 C. C. A. 253, 24 U. S. Aple. 7 : Standard Oil Co. v. Murly, 119 Fed. Rep. 572, 57 C. C. A. 1. .5 Chi. I. News. 71: Bragdon r. Perkins-Campbell Co.. 87 Fod. Riep. 109. 30 C. C. A. 567, 58 U. S. App. 91: Necker v. Harvey, 49 Nich. 517,14 N. 503.

7. Lewis v. Coal Co., $112 \mathrm{Ky}$. S45, 66 S. WV. 1044. See 56 Cent. [.. J. 365 . 
water company to furnish a smply of water as reguiresl by the terms of its eontrats with the fown, sinm lhere is no privity of contract hetween the parties to the aldion. ${ }^{1}$. And the fact that the ordinance granting the tranchise repuires the company to supply the eity and its inhabitant- wilh suflicient water to put out fires, or to maintain the water at a certain pressure, does not ereate the necessary privity of contract. ${ }^{2}$

But where the statute requires that erely action must be prosecuted in the name of the real party in interest, it has been held in Kentucky that when the contract of a water company with a city declares that it is made for the henefit of the inhabitants, and for the protection of private property against destruction by fire, the owner of the property which is taxed for water rent, and is destroyed by fire through the failure of the company to supply a sufficient quantity of water to extiuguish the same, may in his own name, sne the enmpany on its contract with the eitr. ${ }^{3}$

And unless made so by statute, a eity is not liable for failing to protect the inhabitants against the destruction of property

1. Howsmon v. Water Co., 119 Mo. 304, 24 S. IV. 784, 23 L. R. A. 146 and note, $4 \mathrm{l}$ An. St. Rep. 654; Insurance Co. v. Water Co., 42 Mo. Apl. 11s; Davis v. WVater Works, 54 Towa, 59, 6 N. 126,37 Am. Rep. 185: Nickerson v. Hydraulic Co.. 4t; Comn. 24, 33 Am. riep. 1 and note; Ferris v. Water Co., 16 Nev. 44, 40 Anl. Rep. 485: Fowler v. Water Works Co., 83 Ga. $21 !, 9$ s. E. 673,20 lm. St. Rep. 313; Atkinson v. Water Works Co., L. R. 2 Exch. 44l: Faton v. Water Works Co., 37 Neb. 546.56 N. WV. 291,21 H. R. A. (i.3.3. 40 Ams. St. Rep. 510; Waimwight v. Water Works Co., 7s Hum, 146. 28 N. Y. S. 987,60 N. Y. St. 204: Foster v. Water Co., 3 Tea ('Temu.), 42 ; Britton v. Water Wrorks Co., SI Wis.
48, 51 N. IV. S4, 29 Am. St. Rep. 856 ; House v. Water Works, 88 Tex. 233, 31 S. IV. 179, 2S L. R. A. 532 ; Kansas City v. O'Connell, 99 Mo. 357,12 S. W. 791 ; Mott $v$. Water Co.. ts Kan. 12, gs P. 989. 15 L. R. A. 375,30 An. St. Rep. 267 .

2. Fowler v. Water Works Co. s. Ga. 219, 9 S. E. 673. 20 Am. St. Rep. 313; Eaton v. Water Works (\%o.. 37 Neb. 546.56 X. W. 211,21 1. R. 1. (is:). 40 Mm. St. liep. 510 : Britton $r$ Water Morkis Co.. Sl Wis. 4s, 51 N. W. St, 29 Am. St. liep. 856.

3. Paduca l,um. (‥ v. Water Co., 89 Ky. 340,12 S. IV. 554, 13 ․ W. 249.7 I. R. A. 77,25 Am. sit. lite. .30 . 
by fire. And the business to furnish water to extinguish fire does not anthorize the owner of property destroyed thereby to maintain an action of tort, since a non-breach, by omission only, of a contract entered into with the public, is not a tort, either direct or indireet, to the private property of an individual. $^{5}$

Not even will a statute requiring the pipes to be kept charged at a certain pressure give a citizen a right of action. ${ }^{6}$

The owner cannot maintain an action, even though the city has raised by taxation a special fund to which the planitiff contributed, to pay for a sufficient supply of water for use in case of fire $;^{7}$ nor if the citizens pay a special tax to the company, under its contraet with the eity. ${ }^{8}$

$\S 350$. Assignment by city of contract. $-\Lambda$ eity has no such interest in the property destroyed as to give it a right of action against the water company, and therefore, the owner of the property destroyed cannot maintain an action against the company as assignee of the right of action of the city. ${ }^{1}$ And a municipality has no power to contract by ordinance or otherwise with an individual or company, to indemnify a citizen and taxpayer for damages which he may sustain by reason of a failure to furnish water as provided in the contract, so as to enable the citizen to maintain an action therefor in his own name; nor is such power conferred by a statute authorizing cities to contract for the milding and operation of waterworks by individuals or companies. ${ }^{2}$

4. Wright v. Augusta, 78 Ga. 241, 6 Am. St. Rep. 256.

5. Fowler v. Water Works Co., 83 Ga. 219,9 S. E. $673,20 \mathrm{Am}$. St. Rep. 313.

6. Atkinson v. Water Works Co., 2 Exch. 441.

7. Becker v. Water Works, 79 Iowa, 419, 44 N. W. 694, 18 Am. St. Rep. 377 and note.

8. Howsmon v. Water Co., 119 Mo. 304, 24 S. IT. 784,23 I. R. A.
146 and note, 41 Am. St. Rep. 654.

1. Ferris v. Water Co., 16 Nev. 44, 40 Am. Rep. 485.

2. Vanhorn v. Des Moines, 63 Iowa, 447, 19 N. 293, 50 Am. Rep. 750 ; Becker v. Water Works, 79 Iowa, 419, 44 N. W. 694, 18 Am. St. Rep. 377 and note; Mott v. Water Works, 48 Kans. 12, 28 P. 989, 15 J. R. A. 375, 30 Am. St. Rep. 26 i ; Ins. Co. v. Water Co., 42 Mo. App. 118. 
$\S 35$ I. No privity of parties or of consideration.- Before a third party can avail hinself of a condition in a contract between two others, he must show that it was made for his benefit as its object, and that he was the party intenderl to be benefited. Thus, a manufacturing company, for a bems, contracted to eonstruet its plant on a land company's land, and to maintain it there for a certain time. The land company, to raise the bonus, sold lots, conditioned on the plant being placed on eertain ground. Under the eircumstances the purchasers of the lots were not parties to the eontract requiring the maintenance of the plant for a certain time, so as to anthorize them to rescind the purchases, because the plant was abandoned after construction. ${ }^{2}$ The location of the plant having been securel, the fact that the requisite number of lots was not sold, or the full amount of bonus was not paid, is not a sufficient ground for the rescission of notes given in completion of the contracts for the sale of the lots, as the latter conditions were merely minor matters conducing to the location of the plant $:^{3}$ and this is especially so as the lot purehasers derived no benefit whatever from the performance of the minor conditions, except as ther cansed the location of the plant. ${ }^{4}$ Beeause, if the end to he obtained has been secured, and if the contract has bcen substantially performed, minor matters and measures condueing thereto, which are means and conduits to that end, although they remain to some extent mpperformed, will be disregarded. ${ }^{5}$

1. Safe Co. v. Ward. $t 6$ N. J. L. 19; Lampert $v$. Gas light Co., 14 Mo. App. 383: Simpion v. Brown, 68 N. Y. 355: Vrooman v. Turner, 69 N. Y. 2811, 2.5 Am. Rep. 195; Burton v. Larkin, 36 Kin. 246. 13 P. 398, 59 Am. Rep. 541; Land Co. v. Pitt, 114 No. 135. 139, 21 S. IV. 449.

2. Lewis v. Land Company, 124 Mo. 672,28 S. IV. 324.

3. Lewis v. Land Company, 124 Mo. 672, 28 S. IT. 324.
4. Conn v. MeCollough. is Vr. App. 356: Railroad Co. v. Tygard, 84 Mo. 264, 54 Am. Rep. 97; People $v$. Holden, 82 Ill. 93: Bridge Co. v. Pomroy, 15 Pa. St. 151; Courtwright v. Deeds, 3i Iowa, 503 ; Railroad Co. v. Stockton, 51 Cal. 334; State v. Hastings, 24 Minn. is; Holmes v. Oil Co.. 13s Pa. St. 546. 21 A. $231 \geq 1$ Am. St. Rep. 919: Jackson r. Stokbridge, 29 Tex. 394, 94 Am. Dec. 290.

5. Jewis v. Land Co., $124 \mathrm{Mo.}$ 6.2. 28 S. IT. 324. 


\section{ARTICLE II.}

Pronise for the Beneft of a Third Person.

Section 352. When Third Person May Become a Party to a Contract.

353. Assumption of Mortgage Debt-Right of Mortgagee to Sue.

354. Must be Something More Than a Mere Promise.

355. Aceeptance by Third Person.

356. Contract for Benefit of Third Person-Modification of the General Rule.

357. Exeeptions to the Modified Rule.

358. Party to the Consideration-Trust.

359. Promisee as Agent.

360. Englislı Doetrine.

361. Next of Kin-Right to Sue.

362. Covenants.

363. Covenants-Another Rule.

364. Who May Bring Suit on Simple Contract.

365. Description of the Debts.

366. Agreement to Save Harmless.

367. Nany Promisors-Suit Against.

$\S 352$. When a third person may become a party to a contract.- The general rule is that in order that a promise made by one person to another, for the benefit of a third person, shall constitute the first a debtor of a third, and entitle the latter to sue the first on such promise, it must appear that there was a clear intent upon the part of the parties to the contract that the first person shall become such debtor. The mere fact that the third party may be benefited is not sufficient. ${ }^{1}$

1. State v. Railload Co., 125 Mo. 598, 28 S. IV. 75 ; Ellis v. Harrison. 104 Mo. 270, 16 S. W. 198; Bank v. Benoist, 10 Mo. 521; Meyer v. Lowell, 44 Mo. 328; Howsmon v. Water Co., 119 Mo. 304, 24 S. IV. 784, 23 L. R. A. 146 and note, 41 Am. St. Rep. 654: Wright v. Terry, 23 Fla. 160, 2 So. 6; Simson v. Brown, 68 N. Y. 355; Merrill v. Green, 50 N. Y. 270; Turk v. Ridge, 41 N. Y. 201; Lovejoy v. Howe, 55 Minn. 353, 57 N. IV. 57; Barnes v. Ins. Co., 56 Minn. 38, 57 N. W. 314, 45 Am. St. Rep. 438 and note; Barnett v. Pratt, 37 Neb. 349, 55 N. W. 1050; Gifford r. Corrigan, 117 N. Y. 257,22 N. E. 756,6 L. R. A. 610 and note, $15 \mathrm{Am}$. St. Rep. 508: MeDowell v. Laev, 35 Wis. 171: Bohanan v. Pope, $42 \mathrm{Me}$ 03; Whod v. Moriarity, I5 R. I. 518. 9 A. 427; Mason v. Hall, 30 Ala. 599: Brice v. King, 1 Head (Tenn.), 152; Allen v. Thomas, 3 Met. (Ky.) 198, 77 Am. Dee. 169; 
Thus, where a debtor assigus his property to a purchaser who, in consideration therent, algeres to pay the claim of the epelitors of the assignor, wuch ereditors may sme the purnatser directly upon his agreement." And so, where a wife his sepalpated from her husband, and the brother of the wife exentes a mortgage for a consideration to the hushand tw suppent the wife, the wife may elain the benefit from the mortenge."

The third person must he legally ampetent to reneive the thing or benefit, and perform his part, and receive the benefit with full knowledge, ${ }^{5}$ and take the entire benefit or mothing, and if framdulent the aceeptance must include the framl and the consequences.

If a party promises the father that if he will let him name the child of the former he will pay the child money, and the request is granted, the ehild can reecover on such contract $;^{8}$ and

Ballas v. Fogely, 19 1'a. St. 273; Joslin v. Car Spring Co., 36 N. J. L. 141; Kauffnam v. Cooper, 46 Neb. 644, 65 N. W. 796; Pugh v. Barnes, $108 \mathrm{Ala} .167,19$ So. 370; Knott v. Railroal Co., 84 Iowa, 462, $51 \mathrm{~N}$. IV. 57 : First Nat. Bank v. Rowley, 92 Iowa. 530, 61 X. W. 195 ; Crampton v. Ballard, 10 Vt. 251 ; Babcock v. Chase, 92 Hun, 264,36 N. Y. S. 879,72 N. Y. St. 401 ; Coleman v. Whituey, 62 Vt. 123, 20 A. 322,9 L. R. A. 517; Maxfield v. Schwartz, 43 Minn. 22], 45 N. W. 429 ; Hendrick v. Lindsay, 93 U. S. 143; Steene v. Aylesworth, 18 Conn. 244; Flint v. Cadenasso, 64 Cal. 83, 28 P. 62 Hecht v. Caughron, 46 Ark. 135; Derol v. Melntosh, 23 Incl. 529; Jones $v$. I'homas, 21 Gratt. (Va.) 96: Brown v. O'Brien, 1 Rich. (S. Car.) I. 268,44 Am. Dec. 254; Burr v. Beers, 24 N. Y. 178, so Am. Dec. 327 and note: Cook $v$. Berrott, $66 \mathrm{Hun}, 633,21 \mathrm{~N}$. Y. S. 358 ; Bassett $v$ Ihughes, 43 Wis.
319 ; Bristow v. Lane, 21 Ill. 194; Urquhart v. Brayton, 12 R. I. 169.

2. Maxfield v. Schwartz, 43 Minn. 221 , 45 X. W. t29: Lovejoy $r$ Howe, 55 Minn. 353,57 N. W. 57.

3. Coleman v. Whitney, $62 \mathrm{Vt}$. 1.23, 20 A. 322, 9 L. R. A. 517.

4. HeCracken $v$. San Franciseo, 16 Cal. 591; Ashbury, ete. Co. r. Riche, 7 H. L. 653, 674. See "Contracts for the Benefit of Thid Persons."-15 IIarv. L. Review, i67.

5. Rowan v. Hyatt. 45 X. Y. 138; (lark v. Lyon, 7 Neve i.j; 1)ickin. son v. Conway, l2 Allen (Mass.), 4si; lime Co. v. Green. I. R. 7 C. P. 43.

6. Southern Express Co. v. Palmer, fs (a. s.s; llenderson v. Cum. mings, 44 1ll. 325.

7. Cramz v. llumer, 28 న.. Y. 389 law 8 Grint. 3 i Wis. 5ts; Coms. pare lbrook r. Hook, L. R. 6 Exch. s9.

8. Eaton r. Libbey, 165 Mass. 2IS, 4. $x$. k. 11:7, 52 Am. St. liep. 5]l. 
the same rule applies where a child's name is changed hy request of a third party.

\section{$\S 353$. Assumption of mortgage debt - Right of mortgagee} to sue.- When the purchaser of mortgaged lands assumes the mortgage debt and agrees to pay it as a part of the consideration, the nortgagee can sue him for the debt, though some of the decisions hold that the snit must be brought in equity. ${ }^{1}$

The purchaser, by accepting the estate conveyed, must as a matter of law be presumed to have agreed to pay the notes secured upon it; for he does not simply buy the estate subject to the mortgage, but impliedly assumes to pay the mortgage as a part of the consideration. ${ }^{2}$

The contract, being implied, is not within the statute of frauds; and not being under seal, may be enforeed by an action of assumpsit. ${ }^{3}$ The agreenent implied between the purchaser and the mortgagor inures to the benefit of the mortgagee, so as to enable the mortgagee, as is generally held, to sue the purchaser of the mortgaged premises directly, as there is thus a privity of contract established. ${ }^{4}$

9. Babcock v. Chase, 92 Hun, 264,36 N. Y. S. 879,72 N. Y. St. 401.

1. Pingrey on Mort. 1028-1031, and cases cited; Winn v. Investment Co., 125 Mo. 528, 28 S. W. 998.

2. Braman v. Dowse, 12 Cush. (Mass.) 227; Pike v. Brown, 7 Cush. (Mass.) 133; Furnas v. Durgin, 119 Mass. 500, 20 Am. Rep. 34I ; Crawford v. Edwards 33 Mich. 354; Thorp v. Coal Co., 47 Barb. (N. Y.) 439; Gifford v. Correcan, 117 N. Y. 257, 27 N. E. 756, 6 L. R. A. 610 and note, 15 Am. St. Rep. 508.

3. Pike v. Brown, 7 Cush. (Mass.) 133; Goodwin v. Gilbert, 9 Mass. 510; Felch v. Taylor, 13
Pick. (Mass.) 133; Huff v. Nickerson, 27 Me. 106 ; Hinsdale v. Humphrey, 15 Conn. 431; Rawson v. Copland, 2 Sand. Ch. (N. Y.) 251.

4. Burr v. Beers, 24 N. Y. 178, 80 Am. Dec. 327 and note; Lawrence v. Fox, 20 N. Y. 268; Joslin v. Car Spring Co., 36 N. J. L. 141 ; Bassett $v$ Hughes, 43 Wis. 319 ; Lamb v. Tucker, 42 Iowa, 118; Putney v. Farnham, 27 Wis. 187, 9 Am. Rep. 459 ; Bristow v. Lane, 21 Ill. 194; Bohanan v. Pope, 42 Me. 93 ; Brown v. Ins. Co., 5 R. I. 394; Motley v. Ins. Co., 29 Me. 337, 50 Am. Dec. 591; Carnegie v. Morrison, 2 Met. (Mass.) 381; Brewer v. Dyer, 7 Cush. (Mass.) 337; Pingrey on Mort. 1031, and cases cited; Compare Mellen v. Whipple, 1 Gray 
And a servant may sue the purehase of his master's bueiness for back wages, which the purchaser as:munes als part of the price of the business."

$\S 354$. Must be something more than a mere promise.According to the general rule it is not sufficiont that the performance of the promise may benefit a thiml peron. It must be made for his henefit, or at least such benefit must be the direct result of performance and so within the emitemplation of the parties, and in addition, the grantor must hise a legal interest that the promise he performed in faror of the party claiming performance. ${ }^{1}$

If one party promises to do something for the lenefit of a stranger to the contract, there being nothing but the promise, and no consideration from the stranger, and no duty or obligation to him on the part of the promisee, the third party cannot recover upon such promise. ${ }^{2}$

Where a debt already exists from one person to another, a promise by a third person to pay such debt, inures only to the debtor, and the original creditor call bring no action against the promisor to collect such debt. ${ }^{3}$

Where a promise is made by one person to another for the benefit of a third, in the absence of any liability of the promisce to such third person, the latter cannot enforec it, ${ }^{4}$ and if a

(Mass.), 317; Crowell v. Currier, 27 N. J. Eq. 152.

5. Barnett v. Praft, 37 Neb. 349. 55 X. IT. 1050.

1. Gornsey r. Rogers, $4 \mathrm{~T} \mathrm{X}$. Y. 233, $7 \mathrm{Am}$. Rep. 440; Vrooman v. Turner. 69 N. Y. 280.25 Am. Rep. 195 ; Lorillard v. Clyde, $122 \mathrm{~N}$. Y. 498, 25 N. E. 917.10 T. R. A. 113; Burnherr v. Ran. 135 X. Y. 219, 32 N. E. 49 ; this limits Lawrence v. Fox, 20 N. Y. 268.

2. Jefferson v. Asch, 53 Minn. 446. 39 Am. St. Rep. 618, 55 X. W. 604, 25 L. R. A. פ57 and note. Sere also, Wheat v. Rice, 97 N. Y. 302 ; Clark v. Howard, 74 HIun (N. Y.), 228. 26 ․ Y. S. 620, 56 N. Y. St. 322.

3. Bank v. Grand Todge, 99 U. S. 123.

4. Townsend r. noekham. $143 \mathrm{~N}$. Y. 516,58 N. E. 731: Coleman v. Hiler, 85 Hun (N. Y.). 547. 33 N. Y. S. 357; Timueman v. Moross, 98 Mich. 17s, 57 N. W. 103, 39 Am. St. liep. 528 and note: Jackson Iron Co. v. Concentration Co., 65 Fed. liep. 298,12 C. C. 1.636 .31 U. S. Alp. 1. 
stranger incirlentally receives a benefit from the promise he cannot enforee it. ${ }^{5}$

$\S 355$. Acceptance by third person. - Where a party for whose benefit a contract has been made is a minor, it is not necessary that he should accept the same as the law puts in an acceptance for him. ${ }^{1}$ If the third party is an adult, a subsequent bringing of an action based on the contract is a sufficient acceptance of the same. ${ }^{2}$

The parties to the contract can mutually rescind it at any time before acceptance by the third. ${ }^{3}$ Ifter acceptance, the rescission requires the concmrence of the third.

\section{$\S 356$. Contract for benefit of third person - Modification} of gereral rule. - In some of the States the general rule is modified. Several States hold that a person who is not a party to a simple eontract, and from whom no consideration moves, cannot sue on the contract, and consequently a promise made by one person to another, for the benefit of a third person who is a stranger to the consideration, will not support an action by the latter. ${ }^{5}$ Hence, when the promise is to pay to another an existing indebtedness of the promisee, upon a consideration

5. Crandall v. Payne, 154 Ill. 627,39 N. E. 601 ; Burton v. Larkin, 36 Kan. 246, 13 P. 398, 59 Am. Rep. 541; Second Nat. Bank v. Grand Lodge, 98 U. S. 123.

1. Copeland v. Summers, 138 Ind. 219,35 N. E. 514,37 N. E. 971 ; Nolte v. Libbert, 34 Ind. 163; Pruitt v. Pruitt, 91 Ind. 595.

2. Copeland v. Summers, 138 Ind. 219,35 N. E. 514,37 N. E. 971.

3. Amonett v. Montague, $75 \mathrm{Mo}$. 43; Thompson v. Parker, 83 Ind. 96.

4. Levistone v. Landreaux, 6 La. Ann. 26. See, also, Grant v. Beard, 50 N. H. 129; Williams v. Butler, 35 Ill. 544 .
5. Mellen v. Whipple, 1 Gray (Mass.), 317; Millard v. Baldwin, 3 Gray (Mass.) , 484 ; Field v. Crawford, 6 Gray (Mass.), 116 ; Dow v. Clark, 7 Gray (Mass.), 198; Colburn v. Phillips, 13 Gray (Mass.), 64; Flint v. Pierce, 99 Mass. 68, 96 Am. Dec. 691; Exchange Bank v. Rice, 107 Mass. 37, 9 Am. Rep. 1; Rogers v. Union Stone Co., 130 Mass. 581, 39 Am. Rep. 478; Wheeler v. Stewart, 94 Mich. 445, 54 N. W. 172; Pipp v. Reynolds, 20 Mich. 88; Edwards v. Clement, 81 Micl. 515, 45 N. W. 1107 ; Wilbur v. Wilbur, 17 R. I. $295,21 \mathrm{~A}$. 497 ; Woodland v. Newhall, 31 Fed. Rep. 434; Second Nat. Bank v. Grand Lodge, 98 U. S. 123; Adams 
moving wholly from the latter, such promise is for the brefit of the promisee, the original debtor, and must be released on enforeed by him."

\section{$\S 357$. Exceptions to the modified rule.- There are excep-} tions to this modified rule. Thus, where one person entors into a contraet with another to pay money to a thirl, or to deliver some vahuable thing, and such third party is the only party interested in the payment or the delivery, he can release the promisor from performance or compel performance by suit. And among the exceptions are cases where the promise to pay the debt of a third person rests upon the fact that money or property is placed in the hands of the promisor for that particular purpose. Also where one buy's out a stock of goods of a tradesman and undertakes to take the place, fill the contracts, and pay the debts of his vendor. ${ }^{1}$ The right to sue by the third party arises out of an independent contract created by law, between the promisor and the third person. ${ }^{2}$ And so where a contractor agrees to abandon negotiations for the erection of a building and to allow another to obtain the contract, there is a sufficient consideration for the promise of such other party to pay a debt owed by the contractor to a third party; and such third party can sue the party promising to pay the debt and legally collect it. $^{3}$

v. Kuehn, 119 Pa. St. 76,13 A. 184 : Compare Carnegie v. Morrison, 2 Met. (Mass.) 381: Brewer v. Dyer, 7 Cush. (Mass.) 337.

6. Adams v. Kuehn, 119 Pa. st. 76, 13 A. 184; Blymere v. Boistle, 6 Watts (Pa.), 18̄̄, 31 Am. Dec. 458.

1. Mellen v. Whipple, 1 Gray (Mass.), 317 ; Frost v. Gage, 1 Allen (Mass.), 262; Putnam v. Field, 103 Mass. 556 ; Exchange Bank v. lice, 107 Mass. 43; Rogers v. Union Stone Co., 130 Mass. 581, $39 \mathrm{Am}$. Rep. 478.
2. Adams v. Kuehu, 119 l'a. St. 76,13 A. 184; Taylor v. Taylor, 20 III. 650 ; Lewis v. Sawyer, 44 Me. 332; Carnegie v. Morrison, 2 Met. (Mass.) 381: Putnam v. Fielı, 103 Mass. 556; Wood v. Moriarity, 15 R. I. 518,9 A. 427 ; Hostetter v. Hallinger, 117 Pa. St. 606. $12 \mathrm{~A}$. 741 ; Grim v. Iron Co., 115 Pa. St. 611, 8 A. 595: O'Neal r. Board, 27 Md. 227: IIosford v. Kianouse, 45 Mieh. 620, s X. 567 : Keene r. Sage, 75 Me. 138.

3. Moore r. Nat. Bank (Ala.), 36 So. $7 \%$. 
$\S 358$. Party to the consideration - Trusts. - Where one buys ont the stock of a tradesman and undertakes to take the place and carry on the business, paying debts and filling contracts of his vendor, and where one receives money or property on the promise to pay or deliver to the third person, are cases which create a condition in which the third person, although not a party to the contract, may be fairly said to be a party to the consideration on which it rests. In good conscience the title to the money or the thing which is the consideration of the promise passes to the beneficiary, and the promisor is turned in effect into a trustee. ${ }^{1}$

But these cases hold that when a promise is made to and in relief of one to whom the promise is made, upon a consideration moving from him, no particular fund or means of payment being placed in the hands of the promisor out of which the payment is to be made, there is no trust arising in the promisor and no title passing to the third person. The beneficiary is not an original creditor who is a stranger to the contract and the consideration, but the original debtor who is a party to both, and the right of action is in him alone. ${ }^{2}$

But where the promise is so framed as to make the promisor a trustee for such third person, the latter may enforce it. ${ }^{3}$

$\S$ 359. Promissee as agent.- These cases establishing the modified doctrine do not permit the person, for whose benefit a promise is made to another person from whom the only consideration moves, to maintain an action against the promisor, unless either the latter has also made an express promise to the plaintiff, or the promisee acts as the plaintiff's agent merely. ${ }^{4}$ Where the promisee is in fact acting as the agent of a third

1. Adams v. Kuehn, 119 Pa. St. 76, 13 A. 184.

2. Adams v. Kuehn, 119 Pa. St. 76, 13 A. 184 .

3. Preachers' Aid Soc. v. England, 106 Ill. 125; Mory v. Michael, 18 Md. 227. See, also, Ex parte
Pye, 18 Ves. 140; Davis v. Coburn, 128 Mass. 377; Chase v. Chapin, 130 Mass. 128; Duncan v. Jandon, 15 Wall. (U. S.) 165; Shaw v. Spencer, 100 Mass. 321.

4. Exchange Bank v. Rice, 107 Mass. 37, 9 Am. Rep. 1. 
person, althongh that is mknown to the promisor, the principal is the real party to the contract, and may therefore sue in his own mame on the promise made to his agent. ${ }^{5}$

§360. English doctrine.-The English foctrine is in aceord with the modified rule. So in England the rule dues not permit the person, for whose benefit a promise is made to another person from whom the only consideration moves, to maintain an action against the promisor, mless either the latter has also made an express promise to the plaintiff, or the promisce acted as the plaintiff's agent merely. ${ }^{6}$

In equity, in England, where money is payable to one person for the benefit of another, the latter can elaim under the contract as if it had been with himself. ${ }^{7}$

If the contract is so framed as to make one of the parties trustee for a third person for whose benefit it is made, such third person aequires rights by virtue of the trust. ${ }^{8}$ Where a transfer of property is male with a declaration of trust in faror of a third person, it must be distinguished from a mere corenant to pay money to that person. ${ }^{9}$

But a mere contract between two parties, that one of them shall pay money to a third, does not, as a rule. make the third person a cestui que trust. ${ }^{10}$ In order to do this there must he

5. Sims v. Bond, 5 Barn. \& Ad. 389, 2 Nev. \& Man. 608; Huntiugton v. Knox, 7 Cush. (Mrass.) 371 ; Barry v. Page, 10 Gray (Mass.), 39s: Hunter v. Giddings, 97 Mass. 41. $93 \mathrm{Am}$. Dee. 54; Ford v. Williams, 21 How. (U. S.) 287 ; Johnson v. Welch, 42 W. Va. 18, 94 S. E. 585. See, also, Barber Asphalt Paving Co. v. Denver, 72 Fed. Rep. 336,19 C. C. 入. 139,36 U. S. App. 499.

6. Chitt on Cont. 53: Sims v. Bond, 5 Barn. \& Ad. 389. 2 Ner. \& Man. 608. See, also, Lilly r. IIays, 5 Ad. \& El. 548. 1 Nev. \& Per. 26; Walker v. Rostron, 9 Mees. \& Wel.
411 ; Priee v. Easton, 4 Barn. \& Ad. 433; Tweddle v. Atkinson. I Best \& S. 393.

7. Touche v. Warehou-ine ('o.. 6 Ch. App. 671: Spiller v. skiting Rink, 7 Cls. Dir. 36s: Compare Eley v. Life Assur. Co.. I Wxeh. Div. Ss; In re limpress Eng. Co., 16 Ch. Div. 125.

8. Murray v. Flawell, 2.) Ch. Dir. sa. See, also, Strong v. Mird. T. R. is Eq. 315.

9. (ryegory $v$. Williams. : Meriv. 5s2; Lamb v. Nice, 6 Mees. \& Wel. 467: Tomlinson r. Gill, Amb. 330.

10. In re Rotheram Ilum Co.. 25 
some undertaking by one of the contracting parties to stand to the third person in the relation of trustee to the benficiary. ${ }^{11}$

$\S 36 \mathrm{r}$. Next of kin-Right to sue.-It was formerly held in England that a child might sne for a promise made to his parents for the former's benefit. ${ }^{1}$ But such doctrine has been reversed by the English courts, so that the next of kin are now considered as mere volunteers and cannot therefore sue. ${ }^{2}$ And at one time, in Massachusetts, a child might sue upon a promise made for its benefit to his father. ${ }^{3}$ But this is not the law now in this State; and so a child cannot recover, on the ground of relationship, upon a promise made for his benefit to his father, if the consideration for such promise moves wholly from the father $;^{4}$ and this seems to be the general doctrine. ${ }^{5}$

But the nearness of the relationship may be evidence that the promise to the father was made to him acting in behalf of, and as the agent of, the son, and therefore may be a promise to the son; but when it appears that the promise was not made to the son, and that the consideration did not move from him, the nearness of the relationship cannot change the general rule of law. ${ }^{6}$

Still some of the States hold that a child can recover for a promise made for his benefit to his parent, even if the consideration moves wholly from his parent. ${ }^{7}$

$\S 362$. Covenants. - The general rule is extended, by many courts, to sealed instruments. So where one person, for a val-

Ch. Div. 103; Eley v. Life Assur. Co., 1 Exch. Div. 20, 88.

11. Mulray v. Flavell, $25 \mathrm{Cl}$. Div. 89.

1. Dutton v. Poole, 2 Lev. 210 ; Bourne v. Mason, 1 Vent. 6.

2. Tweddle v. Atkinson, I Best \& S. 393.

3. Felton v. Dickinson, 10 Mass. 287.

4. Marston v. Bigelow, 150 Mass. 45, 22 N. E. 7 1, 5 L. R. A. 43 ; Ex- change Bank v. Price, 107 Mass. 37, 9 Am. Rep. 1.

5. Hall v. Huntoon, 17 Vt. 244, 251, 44 Am. Dec. 332; Ross v. Milne, 12 Leigh (Va.), 204, 223, 37 An. Dec. 646; Wilbur v. Wilbur, 17 R. I. 295,21 A. 497.

6. Marston v. Bigelow, 150 Mass. 45,22 N. E. 71,5 I. R. A. 43.

7. Benze v. Hiatt, $82 \mathrm{Ky} .666,56$ Am. Rep. 912. See, also, Clark v. McFarland, 5 Dana (Ky.), 45. 
nable consideration, engages with another, whether by simple contract or by covenant under seal, to to some aet for the bene fit of a third person, the latter may maintain an action against

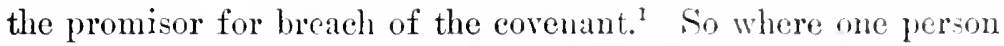
contracts, whether with or without scal, with another for the benefit of a third person, such third person may maintain an action on the agreement. ${ }^{2}$

$\S 363$. Covenants-Another rule.-But another line of authorities holds that a covenant eamot be sued on by the person for whose benefit it is made, if he is not a party to the debt, but the suit must be brought in the name of the person with whom the covenant is made. ${ }^{3}$

In regard to contracts under seal, in many of the States, the law has always been that only those who were parties to such contracts could sue upon them. ${ }^{4}$ And so a covenant cannot be created to arise wholly in the future between the covenantor and a party who at the time is unascertained, and from whom no consideration is to more, and who is not in any way privg to any present agreement by the covenantor. ${ }^{5}$

1. Bassett v. Hughes, 43 Wis. 319; McDowell v. Laev, 35 Wis. 171 ; Gifford v. Corrigan, $117 \mathrm{~N}$. Y. 257,22 N. E. 756,6 L. R. A. 610 and note; $15 \mathrm{Am}$. St. Rep. 508; Coster v. Pruyn, 43 N. Y. 399.

2. Van Sehaick v. Railroad Co., 38 N. Y. 346 ; Rogers v. Gosnell, 51 Mo. 466; Fitzgerald v. Baker, 85 Mo. 14; Ellis v. Harrison, 104 Mo. 270,16 S. IV. 198; State v. Railroad Co., 125 Mo. 596, 28 S. W. 1074; Kimball v. Noyes, 17 Wis. 695; Webster v. Flening, 17s Ill. 140,52 N. E. 975 , affirming Dean v. Walker, 107 Ill. 540, 47 Am. Rep. 467 and note. and overruling Harms v. MeCormick, 132 Ill. 104, 22 N. E. 511. In Illinois, under the statute, "a third party, for" whose benefit a. contract is made, may bring as- sumpsit in his own name, on the contraet, whether the contract is simple or under seal."-Webster v. Fleming, 178 Ill. 140, 52 x. E. 975.

3. Moore v. Honse, 64 III. 162 ; Gautzert v. Hoge, 73 Ill. 30 : Dean r. Walker, 107 Ill. $540,47 \mathrm{Am}$. Rep. 467; Hinekley $\checkmark$. Fowler, 15 Me. 285: Cocks v. Varney, 45 X. J. Eq. 72, 17 1. 108; NFillard v. Baldwin, 3 Gray (Mass.). 484: Seigman r. Hoffacker, 57 TId. 3:21; Hendricks v. Linilsay. 93 C. S. 143 .

4. Sanders v. Filly, le Piek. (Mass.) 554; Johnson v. Foster, 12 Met. (Mass.) 16 ; Northamptonv. Elwell, 4 Gray (Mass.), Sl ; Flynn v. Ins. Co., 11, Mass. 449; Flynn v. Benefit Asso., 152 Mass. 28s, 25 ‥ E. 716 .

5. Saunders v. Saunders, 154 
$\S 364$. Who may bring suit on simple contracts. - Where a promise is made to one person for the benefit of another it is generally held that the suit may be brought either by the third party or by the promisee. ${ }^{1}$ And the promisee may maintain an action against the promisor without first paying the debt himself. The measure of damages in such case is the amount of the debt agreed to be paid. ${ }^{2}$

In trust, the suit at law is in the name of the trustee $;^{3}$ in equity, oftener in the name of the cestui que trust, sometimes the trustee joining. ${ }^{4}$

Closely allied to this rule where a beneficiary may sue, is the right of a real estate broker to sue a purchaser for his commission, when the latter has refused to complete the deal. Thus, when the sale has been made and the purchaser refuses to take the property, the purchaser is liable to the broker for the damages thereby suffered by the broker, though he had agreed to look to the seller for his commission. ${ }^{5}$ And so one who, by mistake, sells to a person a poisonous drug for a harmless medicine is liable to a third person, who without negligence takes the drug for medicine, for damages resulting to him. ${ }^{6}$

$\S 365$. Description of the debts.-It is not necessary to specify the debts which the promisor assumes and agrees to pay. It is enough to speak of them as a class, and the particular debt in question may be shown to be one which falls within that class. ${ }^{7}$ So if a person makes an agreement with a party by which

Mass. 337,28 N. E. 270 . As to the Code States, see Bliss on Code Pl. 241.

1. Steene v. Aylesworth, 18 Conn. 244; Bell v. Chaplain. Hard. 321; Dutton v. Poole, 1 Vent. 318, 2 Lev. 210 ; Garnett v. Handley, 4 Barn. \& Cr. 664 .

2. Nerriam v. Lumber Co., 23 Minn. 314; In re Negus, 7 Wend. (N. Y.) 499; Wicker v. Hoppock, 6 Wall. (U. S. 94; Seigman v. Hoffacker, $57 \mathrm{Md}$. 321 .
3. Treat v. Stanton, 14 Conn. 445 .

4. Dunn v. Seymour, 3 Stockt. (N. J.) 220.

5. Livermore v. Crane, 26 Wash. 529, 67 P. 221,57 L. R. A. 401.

6. Peters $v$. Johnson, $50 \mathrm{~W}$. Va. 644,41 S. E. 190,57 L. R. A. 428, Ss Am. St. Rep. 909 and note.

7. Schmidt v. Glade, 126 Ill. 485, 18 N. E. 762; Schuster v. Railroad Co., 60 Mo. 290; State v. Railroad Co., 125 Mo. 596, 28 S. W. 1074; 
he buys of the other party credits and assmmes to pay all his debts, a ereditor of the second party may recover his debt of such first party. ${ }^{8}$

$\$ 366$. Agreement to save harmless.-It the agreement or covenant is simply one to indemnify and save hambles one of the parties to the contract against the claims of a third person, then such third person camot sue upon the acrerement or covenant. Such a contract muler seal or not is not al contract for the benefit of the third person within the meaning of the rule." Thus where two railroal companies enter into an agreement whereby one agrees to sare harmless the other from all its ohligations, and to pay and surrender them paid as fast as they were obtained, it does not give a creditor a right to sue the first for the debts of the second. ${ }^{10}$

$\S 367$. Many promisors - Suit against.- When the promisors are verp numerons it is often impracticable to bring them before the court. In chancery, under such circumstances, as there is privity of interest, the court will allow a bill to be brought by some of the parties in behalf of themselves and all the others, taking eare that there shall be a due representation of all substantial interests before the court. ${ }^{1}$

But at law this rule has not been adopted. Thus where an

Dean v. Walker, 107 IIl. 540, 47 Am. Rep. 467 and note; Redelsheimer v. Miller, 107 Ind. 486. $8 \mathrm{~N}$. E. 447 ; Cross v. Trusdale, 28 Ind. 44: Kingsbury v. Earle, 27 Kans. 141; Delaney r. Anderson, $54 \mathrm{Ga}$. 586; Railroad Co. v. Hopkins, 18 Kans. 494: Ramm v. Kaltwasser. 4 Mo. App. 573: Anthony v. Heman. 14 Kans. 494.

8. Snell v. Ires. 8.5 11l. 279 .

9. Kansas City v. OCommell, 99 Mo. 357, 12 S. WT. 791: Weller v. Goble. 66 Iowa. 113. 23 X. IV. 290; Houseman v. IFater Co.. 119 Mo.
304,24 S. W. 784,23 L. R. A. 146 and note. 41 Anı. St. Rep. 654; State v. Railroad Co.. 125 Mo. 596. 28 S. IV. 1074.

10. State v. Railroald Co., 125 Mo. 596,28 S. W. 1074.

1. Story on Eq. Pl. 97: Taylor v. Salmon, 4 Mylue \& Cr. 134; Walworth v. Holt, 4 Mylne \& $\mathrm{Cr}$. 619: Small v. Atwood, 1 Sommere. 407: Chancey r. May, Prec. in Clu. 592: Lilly $\vee$ Tobbein. 103 Mo. 47\%, 15 S. II. 618. $23 \mathrm{~lm}$. St. litp. Sat; Platt v. Colvin. so Olıio St. 703. 36 N. E. 735. 
unincorporated society has made a contract, and stipulated that the right of action should be vested in a manager or agent, the courts will not sustain such agreement. ${ }^{2}$

Many of the States have enacted that when the parties are very numerous and it is impracticable to bring them all before the court, one or more may sue for the benefit of all; and this applies to legal as well as to equitable actions. ${ }^{3}$

\section{AR'TICLE III.}

\section{Joint and Several Contracts.}

Section 368. Joint Contracts.

369. Disability of One Joint Promisor.

370. Judgment Against Joint Debtors.

371. Survivorship of Joint Liability.

372. In Equity-Survivorship of Joint Liability.

373. Under the Codes.

374. Surety.

375. Release by Act of Creditor.

376. Covenant Not to Sue.

377. Joint Creditors or Obligees.

378. Release with Provision.

379. Release Should be Under Seal.

380. Survivorship of Joint Creditors.

381. Release by Creditor.

382. Several Interests.

383. Subscriptions to Establish Business Enterprise.

384. Revocation.

385. Validity of Subscription Contracts.

386. Joint and Several Contracts.

387. Release of Joint and Several Promisors by Law.

38s. Contribution.

389. In What Property Payment May Be Made.

390. Right to Receive Contribution.

391. Insolvency of Co-sureties.

2. Gray v. Pearson, L. R. 5 C. P. Jones, 97 N. Car. 121,1 S. E. 692 ; 568. Gieske v. Anderson, 77 Cal. 247, 19

3. Platt v. Colvin, 50 Ohio St. P. 421; Alexander v. Gish, 88 Ky. 703,36 N. E. 735 ; Bronson v. Ins. 13, 9 S. W. 801; Gibson v. Trust Co., 85 N. Car. 414; Thames v. Co., 58 Hun, 443, 12 N. Y. S. 444. 
Sectiox 392. Must the Principal Debtor Be Insolvent. 393. Sureties Discharged by Ace of Promi-ee. 394. In Case of Tort.

$\S 368$. Joint contracts. $-\Lambda$ joint contract is one in which the contractors are jointly bound to perform the promise or ofligation therein contained, or entitled to receive the benefit of such promise or obligation. They must contract jointly as one party. Then they are jointly and not severally liable, and should all be sued if within the jurisdietion of the comrt.'

It is a general rule in ex contractu that obligations to the nonjoinder of a defendant can be taken only by plea in abatement, thereby giving the plaintiff a better writ, by therein disclosing the names of those who ought to be joined. ${ }^{2}$

But to this rule there is an exception, that if it appears from the face of the declaration or other pleading on the part of the plaintiff, that a person not made a defendant was a joint contractor with those who are defendants in the suit, there being no arerment of the death of such person, then such non-joinder is good ground for demurrer, as well as abatement. ${ }^{3}$ And if one of the joint promisors agrees with the other promisor that he will pay the debt himself, it does not give the promisee the right to sue such promisor alone. ${ }^{4}$ And at common law, in suing a partnership, all the partners must be made parties, as they were considered joint promisors; but statutes may change this rule. ${ }^{5}$

If a joint promisor, who is sued alone, pleads to the merits, then he has lost his right to object and show that he is only one

1. Meyers v. Estes, 164 Mass. 457,41 N. E. 683,32 I. R. A. 283 ; Forst v. Leonard, 112 Ala. 296, 20 So. $58 \vec{\imath}$; Field v. Runk, 22 N. J. I. 525: Eller v. Laç, 137 Ind. 436, 36 N. E. 1088; Murphy v. Weil, 92 Wis. 467,66 N. II. 532 .

2. Harwood v. Roberts, 5 Me. 442; Reid v. Wilson, 39 Me. 586; Riehmond v. Toothaker, 69 Me. 455 ; Potter v. McCay, 26 Pa. St. 458; Nash v. Skinner, 12 Vt. 219, $36 \mathrm{Am}$.
Dec. 338 ; Smith v. Miller, 49 N. J. 1. 521.13 A. 39: Henderson v. Hammond, 19 Ala. 340 : Hedsoe v. Irvin, 3.j Ind. 293.

3. Harwood v, Roberts, 5 Me. 442: Richmonil $r$. Toothaker, 69 Me. 45.5: MeGrogor v. Balch, $17 \mathrm{Vt}$. 567.

4. Lodge r. Dicas, 3 Barn. \& Ald. 611.

5. Wibaux v. Live Stock Co., 9 Mont. 154. 
of joint contractors, ${ }^{6}$ and will therefore become liable for the whole debt $;^{7}$ in this way lie becomes severally liable. ${ }^{8}$ But parties to a contract may not, withont statutory authority, designate a person to be sned for its breach, who is nowise liable upon its breach. ${ }^{9}$

$\$ 369$. Disability of one joint promisor.-When joint debtors execute a joint note and one is not bound by reason of some disability, the other remains bound especially when the facts which constitute the disability are known to the other. ${ }^{10}$

Thus, in those States where a married woman is not liable upon a promissory note made by her and her husband, payable to the latter's order and indorsed by him, the husband is liable as maker, though his wife will be discharged. ${ }^{11}$

\$370. Judgment against joint debtors. - A plaintiff when he has received a judgment against joint promisors, may take out an execution against one of them only and have only one satisfaction, thus making any one of them responsible for the whole debt. ${ }^{1}$ The entire cause of action is merged in such judgment, and any action is barred against any other joint debtor. ${ }^{2}$

The common law rule in England and in the United States is that a judgment against one upon a joint contract of several

6. Whelpale's Case, 5 Co. 119 ; Rice v. Shute, 5 Burr. 2613.

7. Nash v. Skinner, 12 Vt. 219 , 36 Am. Dec. 338 ; Hicks v. Cram, 17 Vt. 449; Ricev. Shute, 5 Burr. 2611; Richards v. Heather, I Barn. \& Ald. 29; Abbot v. Smith, 2 IV. Bl. 947 ; King v. Hoar, 13 Mees. \& Wel. 494.

8. Beeler v. Bank, 34 Neb. 348, 51 N. IV. 857; Maurer v. Midway, 25 Neb. 575, 41 N. W. 395; Davis v. Chouteau, 32 Minn. 548, 21 N. 748 ; Sandwich Manuf. Co. v. Herriott, 37 Minn. 214, 33 N. W. 782; Willson v. MeCormick, 86 Va. 995, 11 S. E. 976 ; Elder v. Thompson, 13 Gray (Mass.), 91.
9. Knorr v. Bates, 35 N. Y. S. 1060, 14 Misc. 501,70 N. Y. St. 686.

10. Woodward v. Newhall, 1 Pisk. (Mass.) 500; Tuttle v. Cooper, 10 Pick. (Mass.) 281; Yale v. Wheelock, 109 Mass. 502.

11. Browning v. Carson, 163 Mass. 255, 39 N. E. 1037.

1. Bird v. Randall, 1 W. Bl. 387, 388.

2. Mason v. Eldred, 6 Wall. (U. S.) 231. overruling, in effect, Sheehy v. Mandeville, 6 Cranch (U. S.), 254, and explaining Rice v. Shute, 5 Birr. 2511. 
persons, bars an action against the others, though tho latter wre dormant partners of the defendant in the original action, and this fact was mknown to the plaintiff when the aetion was eommenced, when the contract is joint, and mot joint and serral, the entire canse of action is nerged in the julgument. The joint liability of the parties not sned with those ananint whom the judgment is reeovered, being extinguished, their atire liability is gone. They cannot be sued separately for they have incurred no several obligation; they cannot be sued jointly with the others, because judgment has been already reovered against the latter, who would otherwise be subjected to two suits for the same cause. ${ }^{3}$

If a judgment is against one of several joint promisors, the claim against the other's is extinguished, at common law. ${ }^{*}$ On the same principle, if one of the partnership gives his individual bond for a simple contract debt of the firm, the elaim against the other partner's is discharged. ${ }^{5}$ And so where an oral contract has been merged in a specialty, the former is merged and discharged. ${ }^{6}$

$\S 37$ I. Survivorship of joint liability.-The general rule is that when one of joint promisors dies, a joint suit may be prosecuted against all of the surviving obligors or promisors, and

3. Mrason v. Eldred, 6 Wall. (U. S.) 231; Robertson v. Snith, 18 Johns. (N. Y.) 459, 9 Am. Dec. ㄹ.27: Ward v. Johnson, 13 Mass. 148: Wann v. MeNulty, 2 Gil. (Ill.) 359, 43 Am. Dee. 58; Smith v. Black, 9 Serg. \& R. (Pa.) 142, 11 Am. Dec. 686: King v. Hoar, 13 Mees. \& Wel. 495; Trafton v. United States, 3 Story, C. C. 651. In most of the States the rule of the common law is ehanged with respect to judgments upon demands of joint debtors, when some only of the parties are served with process. See Oakley v. Aspinwall, $4 \mathrm{~N}$. Y. 513; Bonesteel v. Told, 9 Mich.
379, s0 Anı. Dec. 90, for applications of such statutes.

4. Robertson r. Smith. Is Johus. (N. Y.) 459, 9 Am. Der. 22-: М MMaster v. Vernon. 3 Duer (X. Y.), 249: Clinton bank r. Hart. ; Ohio St. 33: Ward v. Johnson. 1:3 Mass. 148; Smith v. Black, : Serg. \& 1 . (Pa.) 142. 11 Am. Dee. 6sti: Candee v. Smith, 93 X. Y. 349: Benson v. Paune, I Hilton (N. Y.). 552.

5. Banorgee r. Henly, 5 Mass. 11. 4 Am. Dee. 17: Tom v. Goodrich, 2 Johns. ( X. Y.) 213.

6. Curson v. Menteiro, a Johns. (X. Y.) 308. 
the personal representatives of the deceased promisor or obligor must not be joined, sinee the same judgment could not be rendered against the surviving debtors and the executor or administrator of the deceased obligor or promisor. ${ }^{1}$

The death of one joint party transmits both his interest and his burdens, not to his administrator, but to his survivors. This rule extends to ordinary joint contractors and to partners. ${ }^{2}$ But when there remains no survivor, then all goes to the administrator of the one who died last. ${ }^{3}$ This is the common law rule, which has been changed by statute, and the court of equity will sometimes take jurisdiction to charge the estate of the deceased joint debtor.

\section{$\S$ 372. In Equity-Survivorship of joint liability.-Where} the obligators are all principal debtors, or receive some benefit from the joint obligation, courts of equity have taken jurisdiction in the case of death of one of the obligors, and enforced the obligation against his representatives. This is done upon the ground that in conscience the estate of the deceased obligor ought to respond to the obligation; and they will give relief in all cases where, in consequence of a primary liability on the part of the deceased obligor, or of a benefit received by him from the joint obligation, it is morally and equitably just that his estate should be made liable, and unconscionably that it should be discharged. ${ }^{4}$ In cases of partnership, courts of equity

1. Cummings v. People, $50 \mathrm{Ill}$. 132; 1 Chitty on Pl. 50 ; Ballance v. Samuel, 3 Scam. (Ill.) 380 ; Eggleston v. Buck, 31 Ill. 254; Stevens v. Catlin, 152 Ill. 56, 37 N. E. 1023 ; Dicey on Parties, 238; Richards v. Heather, 1 Barn. \& Ald. 29; Gere v. Clark, 6 Hill (N. Y.), 350 ; Clark v. Parrish, 1 Bibb (Ky.), 547; Foster v. Hooper, 2 Mass. 572; Atwell v. Milton, 4 Hen. \& M. (Va.) 253.

2. Haskinson v. Eliot, $62 \mathrm{~Pa}$. St.
393; Walker v. Maxwell, 1 Mass. 104; Smith v. Franklin, 1 Mass. 480; Hedderly v. Downs, 31 Minn. 183, 17 N. 274; Daley v. Ericsson, 45 N. Y. 786 ; Calder v. Rutherford, 3 Brod. \& B. 302 ; Jell v. Douglass, 4 Barn. \& Ald. 374.

3. Raus v. Yates, Yelv. 177; Stowell v. Drake, 23 N. J. I. 310; Gere v. Clark, 6 Hill (N. Y.), 350.

4. Gere v. Clark, 6 Hill (N. Y.), 350; Richardson v. Draper, $87 \mathrm{~N}$. Y. 337 . 
treat joint contrats as several and thus lransunit a right wr whigation to the administrator of the deceased party."

If, through firand, ignorance or mistake, the joint whigution does not express the nueaning of the parties, it will he reformed so as to conform to it. 'This has been done where there is a previous equity which gives the obligee the right to a secures indemnity from each of the obligors, as in the anse of money lent to both of them. There a court of equity will enfurce the obligation against the representatives of the deceatsed obligur, although the bond be joint and not several, on the ground that the lending to both creates a moral obligation in lwoth t" pay, and that the reasonable presumption is the parties intenlerl their contract to be joint and several, but through fraud, ignorance, mistake, or want of skill, failed to accomplish their object. ${ }^{6}$

$\S 373$. Under the codes. - The English courts no longer follow the old common law rule, making the solvent surviving joint obligor alone liable to the obligee in the joint contract. They permit the action to be brought at law against the administrator in the first instance, whether the surviror be solvent or not. Sereral of the American States hold with the English courts. ${ }^{1}$ However, some of the code States deny this procedure, and the suit must be brought in equity, if it ean be brought at all. ${ }^{2}$

The judgment against the administrator should be that he pay in due course of administration the amount duc. ${ }^{3}$ If a

5. Sumner v. Powell, 2 Meriv. 30; Beresford v. Browning, $1 \mathrm{Ch}$. D. 30, Story's Eq. 162-164.

6. United States r. Price, 9 How. (U. S.) 90 .

1. Pom. Rem. and Rem. Rierht;, 302-304: Bliss Cole Pl. 105, 106; Braxton v. State, 25 Ind. 82; Burgoyne v. Ins. Co., 5 Ohio St. 5s6; Trimmer v. Thompson, $10 \mathrm{~S}$. Car. 164; Fisher v. Hopkins, 4 Wyo. 379, 34 P. 899: Taylor r. Taylor, 5
Humpl. (Tenn.) 110; Williams v. Bradley, 5 Ohio Cir. Ct. Il4. See, alin, Bachelder $r$ Fiske, 17 Mass. 464.

2. Voorlis v. Child, 17 N. Y. 354; Sherman $r$ Kreul, 42 Wis. 33.

3. Rice v. Inskeep, 34 Cal. 22t; Seneseal v. Bolton, 7 N. Mex. 351. 34 P. 440: Fisher r. Hopkins, 4 Wyo. 379. 34 P. 899. 
judgment is entered against the administrator de bonis propriis it is error, ${ }^{4}$ bccause the executor or administrator will not be personally liable; the judgment should be de bonis testatoris, ${ }^{5}$ or in his representative capacity.

$\S 374$. Surety.-In case of joint obligation of sureties, if one of the sureties dies his representatives are, at common law, discharged, provided he receives no benefit whatever from the joint obligation, and the survivors alone can be sued $;^{6}$ and the estate of the deceased is absolutely discharged both at law and in equity. ${ }^{7}$

The surety's duty is measured alone by the legal force of the bond, and he is under no moral obligation whatever to pay the obligee, independent of his covenant, and consequently there is nothing on which to found an equity for the interposition of a court of chancery. ${ }^{8}$

But the death of a surety does not terminate his liability, where his contract is a continuing one; a continuing suretyship is not terminated by the death of the surety, but his estate is liable. ${ }^{9}$

$\$ 375$. Release by act of creditor.-It is ordinarily true that a release of one of joint obligees is a release of all, ${ }^{1}$ although 41.

4. Smith v. Chapman, 93 U. S. 26 Am. Rep. 528; Waters v. Riley,

5. Smith v. Chapman, 93 U. S. 41.

6. Richardson v. Draper, $87 \mathrm{~N}$. Y. 337.

7. Tower's v. Moore, 2 Vern. 9s; Simpson v. Vaughan, 2 Atk. 31; Bradley v. Burwell, 3 Denio (N. Y.), 61; Richter v. Pappenhausen, 42 N. Y. 393 ; Pickersgill v. Lahens, 15 Wall. (U. S.) 140; Getty v. Binsse, 40 N. Y. 388, 10 Am. Dec. 379: Risley v. Brown. 67 N. Y. 160 ; United States v. Price, 9 How. (U. S.) 90; Davis v. Van Buren, $72 \mathrm{~N}$. Y. 587: Wool v. Fisk, 63 N. Y. 245,
2 Har. \& G. (Md.) 305, 18 Am. Dec. 302; Compare Susong v. Vaiden, 10 S. Car. 247, 30 Am. Rep. 50 and note.

8. Pickersgill v. Lahens, 15 Wall. (U. S.) 140; Sumner v. Powell, 2 Meriv. 30, 1 Tur. \& Rus. 423; Weaver v. Shyrock, 6 Serg. \& R. (Pa.) 262; Richardson v. Horton, 6 Beav. 185; Rawstone r. Parr, 3 Russ. 539.

9. Pingrey's Surety. and Guar., sees. 84, 85, 201.

1. Brodeck v. Farnum, 11 Wash. 565, 40 P. 189: Maslin v. Hiett, 37 W. Va. 15,16 S. E. 437 ; Tncker- 
he may not, in fact, be liable for any of the obligation." Ind a payment made by one of several joint debtor's innres to the benetit of all the debtors, as a credit upon the debt. ${ }^{3}$

But where a release is given on a general settlement with a joint debtor without any referenee to the joint deht, it is no bar to the plaintiff to recover the share due from the other debtor, notwithstanding such settlement.'

The plaintiff must sue all the joint debtor's, if of finll age ${ }^{5}$ and alive. ${ }^{6}$ And if the plaintiff does not sue all, his suit, if properly defended, will not prevail. ${ }^{7}$

In many States this matter has been regulated by statute, which must be consulted to know the law in this respeet.

$\$ 376$. Covenant not to sue.-If a promise is made not to sue a debtor, if he be a sole debtor, it will release the debt; that is, if the covenant is perpetual, it will bar the covenantor's suit where there are no joint debtors $;^{s}$ but, if he be one of two or more joint debtors, such covenant eannot be set up in bar of a snit. ${ }^{9}$ Such a covenant is not properly a release, and cannot be pleaded in bar to an action. ${ }^{10}$

man v. Newhall, 17 Mass. 581; Hale $v$. Nianlding, 145 Mass. 482 , 14 N. E. 534, 1 Am. St. Rep. 475; Houston v. Darling, 16 Me. 413; Hall v. Gray, 5t Me. 230; Allin v. Shadburme, l Dana (Kr.), (is, 25 Am. Dee. 127 and note; Neweomb v. Raynor, 21 Wend. (N. Y.) 10S, 34 Am. Dre. els; Stone v. Dickinson. 5 Allen (Misss.), 2!, 8] Am. Dee. 727; Comparc State v. Watson, 44 Mo. 30.5 .

2. Leddy v. Barney, 139 Mass. 394. 2 N. 1. $10 \%$.

3. Crafts r. Sweeney. 1s R. I. 730, 30 A. 65s. See, also, Hale v. Spauldirg, 145 Mass. 4S?, I4 N. E. 534, 1 Am. St. Rep. 475 ; Clapp v. Pawtucket 1nst.. 15 R. T. 489, S A. 697, 2 Am. St. Rep. 915.
4. Cutts $v$. Gordon, 13 Me. 474, 29 Am. Dee. 520.

5. Livingston v. Tremper, 11 .Jolns. (N. Y.) 101.

6. Douglass v. Chapin, 2t Conn. 76; Brager v. Wotzel. 万) Blackf. (Ind.) 95.

7. Livingston v. Tremper, 11 .Tohns. (X. I.) 101: Tintle v. Cooper, 10 Pick. (Mass.) 2sl; Compare Bergman v. MeGuire, 32 Ark. 733. See Pingrey's Surety. and Guart. sec. 91 .

8. Ford v. Bereh, 11 Q. B. s5: Cuyler v. Cuyler. D. Johns. (X. Y.) 186.

9. Shed v. Pieree. 17 Mass. (i23.

10. Winston v. Dallyy, it S. Car. 299: Dean v. Newliall. S Term R. 16 s. 
A covenant not to sue one of several obligors is not pleadable in bar to au action on the bond; it does not amount to a release, but is a covenant only, and the covenantee is put to his crossaction to recover the damages which a breach may occasion him.

As an exception to this rule, a sole obligor may plead such eovenant in bar, to avoid circuity of action; for he should recover for breach of the covenant precisely the same damage that he had suffered by suit on the bond. ${ }^{11}$

$\S 377$. Joint creditors or obligees.--Joint contractors must all sue upon their joint contract. ${ }^{1}$ So, if the promise on which a suit is brought is made jointly to two or more persons, they must all, if living, join in the action, or they will be non-suited on the trial by a proper defense. ${ }^{2}$ So one joint obligee in a joint contract cannot sue upon the contract alone. But payment in full by obligor to one of the joint obligees discharges the obligation. $^{3}$

And so, a release of any one of several promisees is good as against all. ${ }^{4}$ Thus, where one partner signs and seals a composition deed it bars the partnership's claim. ${ }^{5}$ But a mere covenant not to sue is without effect except as foundation for a counter action. ${ }^{6}$

11. Lacy v. Kinoston, 1 Ld. Ray. 688; Hosack v. Rogers, 8 Paige (N. Y.), 237; Goodnow v. Smith, 18 Pick. (Mass.) 414, 29 Am. Dec. 600 ; Couch v. Mills, 21 Wend. (N. Y.) 424; Solly v. Forbes, 2 Brod. \& B. 38 .

1. Angus v. Robinson, $59 \mathrm{Vt}$. 585, S A. 497, 59 Am. Rep. 758.

2. Gould v. Gould, 6 Wend. (N. Y.) 263; Wright v. Post, 3 Conn. 142; Hewes v. Bayley, 20 Pick. (Mass.) 96; Archer v. Bogue, 3 Scam. (IIl.) 526; Wilson v. Wallace, 8 Serg. \& R. (Pa.) 53; Pease v. Hirst, 10 Barn. \& Cr. 122; Hatsall v. Griffth, 2 Cromp. \& M. 679; Sweigart v. Berk, 8 Serg. \& R. 308;
MeGilvery v. Moorhead, 3 Cal. 267.

3. Henry v. Township, 70 Mo. 500 ; Clark v. Cable, 21 Mo. 223, 64 Am. Dec. 234 and note; Slingersby's Case, 5 Coke, 19 ; Morrow v. Starke, 4 J. J. Marsh. (Ky.) 367.

4. Wild v. Williams, 6 Mees. \& Wel. 490; Wilkinson v. Lindo, 7 Mees. \& Wel. 81; Myrick v. Dame, 9 Cush. (Mass.) 248; Eastman v. Wright, 6 Pick. (Mass.) 316.

5. Wells v. Evans, 20 Wend. (N. Y.) 251; Bruen v. Marquand, 17 Johns. (N. Y.) 58; Morse v. Bellows, 7 N. H. 549 ; Smith v. Stone, 4 Gill \& J. (Md.) 310.

6. Walmesley v. Cooper, $11 \mathrm{Ad}$. \& EI. 216; Clayton v. Kynaston, 2 
All must sue. Even a disclaimer by one of the obligees, unless consented to by the obligor, will not anthorize the "ther joint ereditors to sue alone. ${ }^{7}$

When there is a misjoinder of plaintiffs, the defomdant may plead in abatement. If the defect appears npm the record, it niay be objected to by demurrer, or by motion in arre-t of judgment, or by error.

If the defect does not appear of record, the prout would not correspond to the pleadings, and this would prove fatal, unless the pleadings were aneuded. ${ }^{9}$

The principle that joint obligees or ereditors must all sue upon their joint contract, is not varied by the fact that one of them has been settled with, unless all the parties agree to the severance of the joint interest, and the obligor promises to pay each his several share, and the suit is based upon the new pronise. Then each may sne therefor, the suit being based upon the promise to pay each severally, and not on the original joint promise. ${ }^{10}$

$\S 378$. Release with provision._- Where a release is giren to one of joint obligors, which operates as an absolute discharge of such obligor, it will also operate to release his co-obligors, notwithstanding the instrunent eontains an express provision that such co-obligors shall not thereby be released. ${ }^{1}$ But if the instrument provides that if suit is brought against the obligor, the instrument shall become a good bar thereto and operate as an

Salk. 573; Couch v. Mills, 21 Wend. (N. Y.) 424; Walker v. MeCulloch. 4 Me. 421; MeClellan v. Bank, 24 Me. 566; Rowley v. Stoddarl, 7 - Johns. (N. Y.) 207 .

7. Angus v. Robinson, 59 Vt. 585, 8 A. 497. 59 Am. Rep. 758; Wetherell v. Langston, I lixch. 634.

8. Wiggin v. Cumings, $S$ Allen (Mass.), 353; Reach v. IIotchliss. 2 Conn. 697; Scott r. Godwin, 1 13ne. \& Pul. 67; Baker v. Jewell, 6 Mass. 460, + Am. Dee. l62; Petrie v. Berry. 3 Barn. \& C. 353; Pugh v. Stringfield. 3 C. B., X. S. $\mathbf{2}$; Davis r. Choutean. 32 Mim. 548, 21 N. 748.

9. Chanter r. Leese, 4 Hees. \& Wel. $29 \pi$.

10. Angur $v$ Robinson, $59 \mathrm{Vt}$. ה.т. \& A. 497. 59 An. liep. 7is.

1. Parmelee $r$ Lawrence, $4 t \mathrm{Ill}$. 40.5. 
absolnte release and acquittance on the bond as to him, and which deelares that it was not intended thereby to release or diseharge the other sureties, it is a covenant not to sue, and not a release, and eannot be set up by the defendant $;^{2}$ but it gives a right of action for every violation of the terms of the provision.

$\S 379$. Release should be under seal.-An agreement not under seal to discharge a particular party, or an agreement not to sue or the like, will not have that effeet beeause it does not extinguish it. ${ }^{1}$ And so, a release not under seal of one joint debtor by a creditor in consideration of a payment of part of the debt, is no discharge of the residue. ${ }^{2}$ The reason is because it cannot be inferred from such a covenant it was the intention of the parties to discharge the debt.

But a technical release to one of several joint debtors, being under seal, may be pleaded in bar to a suit. ${ }^{3}$

Though this rule rests upon reasons technical rather than satisfactory, it has been adopted and is supported by the great weight of authority. ${ }^{4}$ But it has been said that this rule has become so overburdened with exceptions and nice distinetions, and equivocal approbations by the numerous cases decided, that it is sometimes difficult to ascertain what the law is as applicable to a particular case. ${ }^{5}$

But the rule is, that where one of several joint debtors had been discharged from his share of the debt by an instrument

2. Bowne v. Bank, 45 N. J. L. 360 ; Dean v. Newhall, 8 Term R. 168; Thompson v. Jock, 3 C. B. 540; Crane v. Alling, 15 N. J. L. 423; Solly v. Forbes, 2 Brod. \& B. 38; Williams v. Hitchings, 10 Lea (Tenn.), 326; North v. Wakefield, 13 Q. B. 536 ; Price v. Barker, 4 El. \& B. 760 .

1. Shaw v. Pratt, 22 Pick. (Mass.) 305; Pond v. IVilliams, 1 Gray (Mass.), 630.

2. Bemis v. Hoseley, 16 Gray (Mass.), 63; Harriman v. Harri- man, 12 Gray (Mass.), 34l ; Drinkwater v. Jordan, 46 Me. 432; Walker v. McCulloch, 4 Me. 421; Catskill v. Messenger, 9 Cow. (N. Y.) 37; Brown v. Marsh, 7 Vt. 327; Shed v. Prince, 17 Mass. 623.

3. Drinkwater v. Jordan, $46 \mathrm{Me}$. 432; Line v. Nelson, 38 N. J. L. 358.

4. Daniels v. Hafeh, 21 N. J. L. 393, 47 Am. Dec. 169.

5. Morris Canal v. Van Vorst, 21 N. J. L. 119. 
not under seal, even though made mpon adequate consideration, such discharge constitutes no defense to any of them, in an action against them; ${ }^{5}$ and the remedy of the dischargerl debtor, if he should be afterwards molested on aceonnt of the debt, will be by an appropriate action founded upon a breach of the contract of discharge?

Of course a release by deed must be under seal, except in those States where the private seal is abolished, as a seal at common law imports a consideration. But there may be equally valid releases without any sealed instrument, as those by operation of law, or releases made in States where the prirate seal is abolished, or releases made by the parties upon good and valuable consideration, which are effectual and valid. ${ }^{\mathrm{s}}$

$\S 380$. Survivorship of joint creditors.-When one of the joint creditors dies the survivors take the whole interest, and they alone can sue. Thus, upon the death of one of the partners of a firm, the firm is dissolved, and the rights to recover all debts and elioses in action, in his own name, survives to the surviving partner, to enable him to collect all dues, but no general and ultimate right of property by survivorship arises, as in eases of joint tenancy, at common law. ${ }^{1}$ The representatices of the deceased ereditor cannot sue for the debts, as this right belongs to the survivors. ${ }^{2}$

$\S 38 \mathrm{r}$. Release by creditor.-One of the several creditors may release the debt and give acquittance to all the debtors. ${ }^{1}$

6. Harrison v. Close, 2 Johns. (N. Y.) 447; Rowley v. Stoddard, 7 Johns. (N. Y.) 207; Frink v. Green, 5 Barb. (N. Y.) 455; Shaw v. Pratt, 22 Pick. (Mass.) 305 ; Crane v. Alling, 15 N. J. I. 423.

7. McAllister $v$. Sprague, 34 Me. 296; Drinkwater v. Jordan, 46 Me. 432 .

8. Dunham r. Branch, 5 Cush. (Mass.) 558: Brown r. Cambridge.
3 Allen (Mass.), 4Tt; Goss v. Ellison, 136 Mass. 503.

1. Burnside v. Merrick, \& Met. (Mass.) 537; Murphy v. Bank, 5 Ala. 421.

2. Peters r. Daris, 7 Mass. 257; Anderson r. Martindale, 1 last. 497 ; Richards r. Heather, 1 Barn. \& Ald. 29; Daley $v$. Eriesson, t5 $\mathrm{x}$. Y. TsG: Calder v. Rutherford. 3 brod. \& B. 302; Walker v. Maxwell, I Mass. 104, 113. 
So, a release by two of three joint creditors is a bar to a suit by the third for one-third of the benefits. ${ }^{2}$ A release by one of joint creditors or promisees will not be set aside unless it is shown to have been made in frand to the other promisees, or unless the promisor be a mere nominal party to the action, having no interest whatever in the subject-matter of the contract. ${ }^{3}$ If one of the joint creditors has parted with all his interest he cannot then release. ${ }^{4}$

But so long as a person has an interest in a joint business, his interest, however small it may be, is sufficient to enable him to release the promisor. ${ }^{5}$

$\S 382$. Several interests.- Where the interest of each person to a contract is several and distinct, each may maintain a separate action for a breach without joining the others on the same side as himself. A contract by and between several persons ascertaining a separate and distinct interest, gives to each a right of action in his own name. ${ }^{1}$ The party suing may proceed against one or each singly, or jointly against all, but not against more than one and less than all. ${ }^{2}$ If a joint defendant pays the debt, it is discharged, and no judgment can be rendered: against another. ${ }^{3}$

Where the contracts are in every respect as distinct and several as if contained in scparate instruments, in each of which

1. Tuckerman v. Newhall, 17 Mass. 580; Bruen v. Marquard, 17 Johns. (N. Y.) 58; Wilkinson v. Lindo, 7 Mees. \& Wel. 81.

2. Myrick v. Dame, 9 Cush. (Mass.) 248.

3. Rawstorne v. Gaudell, 15 Mees. \& Wel. 304.

4. Phillips v. Clagett, 11 Mees. \& Wel. 84.

5. Rawstorne v. Gaudell, 15 Mees. \& Wel. 304.

1. Chitty on P1. 9-13; Boyd v.
Martin, 56 Ala. 336 ; Burton v. Henry, 90 Ala. 281, 7 So. 925; Browning v. Carson, 163 Mass. 255, 39 N. E. 1037.

2. Streatfield v. Halliday, 3 Term R. 779; Cleremont Bank v. Wood, 12 Vt. 252; Bangor Bank v. Treat, 6 Me. 207, 19 Am. Dec. 210.

3. Wallace v. Kelsall, 7 Mees. \& Wel. 264; Husband v. Daris, 10 C. B. 645 ; Beaumont v. Greathead, 2 C. B. 494; Griffin v. Thomas, 21 Ga. 198. 
the promisee has been named, it is a several contrat thomgh contained in one instrument. ${ }^{4}$

Debtors by mere aceount are not joint makers or promiers with one who has by a separate contrat wuaranteed parment of the account. The two contracts are several, not joint. The liability of each is several. Those who contraterl the acermut are not liable at all on the guarantee, and he who made the guaranty is not liable at all on the accomnt. ${ }^{5}$

And where the contract is several as to the promisees, they must sue separately, ${ }^{6}$ except where the statute has changed this rule. ${ }^{7}$ The statute must be consulted in respect to joint and several contracts.

Of course, the doctrine of survivorship cannot apply to several contracts. ${ }^{8}$

\section{$\S 383$. Subscriptions to establish business enterprises.-}

Where subscribers to a contract for the establishment of a business or location of a corporate plant, agree to pay the amount opposite their names, it is a several contract, unless other provisions control, and each subseriber is liable to pay the amount of his indiridual subscription only. ${ }^{1}$ The amount which each subscriber agrees to pay is limited to the amount he has sub-

4. Barabacher v. Lee, 16 Mich. 169 ; Yates v. Foot, 12 Johns. (N. Y.) 1; Geer v. School Dist., 6 Vt. 76; Hall v. Leigh, 8 Cranch (U. S.), 50; Catawissa R. R. Co. v. Titus, 49 Pa. St. 277; Chanter v. Leese, 4 Mees. \& Wel. 295.

5. Sims v. Clark, 91 Ga. 302,18 S. E. 158.

6. Prien v. Railroad Co., 18 Ind. 137; Independence $r$. Ott, 133 Mo. 301,36 S. W. 624; Daris r. Belford, 70 Mieh. 120, 37 N. W. 919.

7. Wibaux v. Live Stock Co., 9 Mont. 154, 22 P. 492: Brown v. Mckee, 108 N. Car. 38 7. 13 S. E. 8 ; Steffes v. Lemke, 40 Minn. 27, 41
N. W. 302 ; Wallis v. Carpenter, 13 Allen (Mass.), 19: Costigan v. Lunt, 104 Nass. 217.

8. Carthrae v. Brown, 3 Leigh (Va.), 98, 23 Am. Dec. 255.

1. Davis v. Belford. 70 Mich. 120, 37 X. W. 919; Mamuficturing Co. v. Barber, 51 Fet. Rep. 14s: Gibbons v. Grimell, 79 Wis. 370, $48 \mathrm{X}$. W. 2.5; Frost v. Milliams. 2 S. Dak. 457.50 N. W. 964: Davin r. Jones, 66 Fed. Rep. 124; Davis v. Murray, 102 Nich. 217. 60 N. W. 437; Daris v. Cupp, so Wis. 673. 62 X. IV. 520; Compare Divis v. Shafer. 50 Fed. Rep. 7tit: Diris v. Creamery Co., 48 Neb. 471,67 N. W. 430 . 
scribed; otherwise, a few responsible subscribers might be made liable for numerous irresponsible parties. ${ }^{2}$

But there may be provisions in the contract by which the subscribers may assume joint liability or obligations for the payment of the whole money subscribed for the enterprise or creation of a corporation, as by giving a joint note for the debt. ${ }^{3}$ But all subscription contracts, to be valid, must be delivered to a person to perform or secure the performance of the conditions therein imposed, as delivery as in other contracts, is essential. ${ }^{4}$

$\S 384$. Revocation.-While a subscription to an enterprise by several subscribers is a several contract between the promisors and promisee, it is also in a sense a contract among the subscribers themselves, and cannot be withdrawn or revoked as to one without the consent of all. ${ }^{1}$ Each of the subscribers contracts with the others to accomplish the purpose, and can compel the performance of the contract to the extent necessary to protect himself from any other or different liability than that which he assumes. ${ }^{2}$

While such a contract creates a several liability on the part of each subscriber to the amount of his subscription only, yet in other respects the interests of the subscribers are joint, and all must unite in order to repudiate and renounce an executory contract, subjecting themselves to such damages as will compensate the other party for being stopped in the performance of the con-

2. Landworlen v. Wheeler, 106 Ind. 523, 5 N. E. 888 ; Erie, etc. R. R. Co. v. Patrick, 2 Keyes (N. Y.), 256. See, also, Davis v. Creamery Co., 10 Ind. App. 42, 37 N. E. 549; Price v. Railroad Co., 18 Ind. 137; Davis v. Booth, 10 Ind. App. 364, 37 N. E. 549 ; Gibbons v. Bente, 51 Minn. 499,53 N. W. 756,22 L. R. A. 80 and note.

3. Davis v. Knoke, 55 Minn. 368 , 57 N. W. 62.
4. Heller v. Board of Trade, 18 Ind. App. 188, 47 N. E. 649.

1. Cravens v. Cotton Mills Co., 120 Ind. 6, 21 N. E. 984, 16 Am. St. Rep. 298; Current v. Fulton, 10 Ind. App. 617, 38 N. E. 419.

2. Zabriskie v. Railroad Co., 18 N. J. Eq. 184; Erwin v. Nav. Co., 27 Fed. Rep. 625; Brewer v. Boston Theater, 104 Mass. 378; Clearwater v. Meredith, 1 Wall. (U. S.) 25; Henry v. Dietrỉch, 84 Pa. St. 286. 
tract; ${ }^{3}$ one of the subscribers camnot revoke-it will takr all of them." He can have no such anthority of agency, nor ran he bind the others, so as to alter, renew or extend their liability. Where the relation is merely that of joint dehor, noithor is agent of the other to make new contracts."

$\S 385$. Validity of subscription contracts. - It is well settled that any bencfit or advantage to the party making the promise, or any inconvenience or danage sustainerl by the party to whom the promise is made, is a sufficient consileration to support a promise to pay by each subscriber. And many authorities hold that where sereral persons subseribe, or acree to entribute, to a common object, the promise of each is a goorl consideration for that of the others. But all the authorities acree that where the persons to whom the subseription runs have expended money or incurred ohligations on the faith of such subscriptions, it is a sufficient consideration to support the contract.'

$\S 386$. Joint and several contracts.-It is a familiar principle that where sereral persons contract, jointly and screrally,

3. Gibbons $v$. Bente, 51 Minn. 499,53 N. W. 756,22 L. R. A. So.

4. Gibbons v. Bente, 5 I Minn. 499. 53 X. IV. 756,22 T. R. A. 80 ; Compare Davis v. Bronson, $2 \mathrm{~N}$. Dak. 300. 50 N. IT. 326.33 Am. St. Rep. 783 and note, 16 L. R. A. 655 and note.

5. Willoughby v. Irish, 35 Minn. 63. 27 X. W. 379. 59 Am. Rep. 297; Vin Kensen v. Parmelee, $2 \mathrm{~N}$. Y. 529. $51 \mathrm{Am}$. Dee. 322 and note: Bell v. Morricon, I Pet. (L. S.) 351; Thompson v. Bownan. 6 Wall. (U. S.) 316; Thompoon v. Riehards. 14 Mich. li2: Wallis v. liamully. 81 N. Y. 164: Shoemaker r. Benedict. 11 N. Y. 176, 62 Am. Dec. 95 and note: Current $v$. Fulton. 10 Inel. App. 617. 35 N. E. 419: Gibbons r.
Bente, 51 Minn. 499. 5.3 x. W. 756. 22 L. R. A. 80.

1. Egeleshimer v. Van Antwerp. 13 Wis. 546: Lathrop v. Knapp, 27 IVis. 214: La Fayette \& M. Corpor. Magoon. 73 Wis. 627, $42 \mathrm{~N}$. W. 17. 3 L. R. A. 761 and note: Gibbons r. Grinell, 79 Wis. $365,4 s \mathrm{~N}$. $\mathrm{T}$. 255; Troy Conference teademy $v$. Yelson, of Yt. 189: Harnes r. Perine, 12 N. Y. 18: Pittv. Gentle. 49 Mo. 7t: Homan v. Stoele. 18 Neb. 65.2. 26 X. W. 472. Seet also, line-t. Ir. F. Chureh r. 1)onnell, 95 Jowa, 300) (it X. IT. 42 : superior Con. Lan 14 Co. v. Rickfort, 93 Wis. 200, 67 x. W. 45: Daris $\because$ Creamery Co., 48 Neb. 471,67 X. W. 436 ; Howell v. Church. 61 IIl. App. 121. 
the creditor may sue all in one action or may sue each one severally, but he camnot sue two and omit the others; for in such case they are sned neither jointly or severally as they promise. ${ }^{1}$

If the plaintiff does not see tit to proceed against them severally, it is the undoubted right of the defendants to have all joined with them in the suit. ${ }^{2} \Lambda$ bond of an officer is joint and several, and an action is properly instituted against all the obligors thereto for a breach of its conditions. ${ }^{3}$

\section{$\S 387$. Release of joint and several promisors by law.-As} nlready stated, if an obligee releases one of the obligors who are bound jointly and severally, the others are thereby discharged. ${ }^{1}$ But at common law, a release of one joint debtor by operation of law, as by a discharge in bankruptcy ${ }^{2}$ or insolvency, or a discharge by the exercise of a right as for infancy, or a discharge by operation of the statute of limitations, ${ }^{4}$ does not release the co-promisors, whose liability still remains. In such case the other debtors may be joined withont including the one discharged by law.

1. Howard v. Roberts, 5 Me. 441 ; Bangor Bank v. Treat, 6 Me. 207, 19 Am. Dec. 210 ; State v. Chandler, 79 Me. 172, 8 A. 553; Streatfield v. Halliday, 3 Term R. 779 ; Claremont Bank v. Wood, 12 Vt. 252; Schilling v. Black, 49 Kans. 552, 31 P. 143; Carter v. Carter, 2 Day (Conn.), 442, 2 Am. Dec. 113.

2. State v. Chandler, 79 Me. 172, 8 A. 553.

3. Jenks v. School Dist., 18 Kans. 356; Saurdsfeger v. State. 21 Kans. 475; Schilling v. Black, 49 Kans. 552, 31 P. 143; Klapp v. Kleckner, 3 Watts \& S. (Pa.) 519; Besore r. Potter, 2 Serg. \& R. (Pa.) 154; Wampler v. Shissler, I IVatts \& S. (Pa.) 365; Bradburne v. Botfield, 14 Mees. \& Wel. 559.
1. Co. Litt. 232a; Brooks v. Stuart, 9 Adol. \& E. 854; Maslin v. Hiett, 37 W. Va. 15,16 S. E. 437 .

2. Coburn v. Ware, $25 \mathrm{Me}$ 330; Turner v. Esselman, 15 Ala. 690; Garnett. v. Roper, lo Ala. 842.

3. Hartness v. Thompson, 5 Johns, (N. Y.) 160; Tuttle v. Cooper, 10 Pick. (Mass.) 281; Robertson v. Smith, 18 Johns. (N. Y.) $459.9 \mathrm{Am}$. Dee. 227.

4. Spaulding v. Ludlow. $36 \mathrm{Vt}$. 150; Demy v. Smith, 18 N. Y. 567 ; Cutler v. Wright, 22 N. Y. 472: Bruee v. Flagg, 1 Duteh (N. J.), 219; Fannin v. Anderson, 7 Q. B. s11. 
\$ 388. Contribution. - It one time il was a que tion when hrer parties jointly liable condd enforer contribution unless founded upon some positive contract between then incurring the liability. But now it may he enforeed at law, in most Statre, as well as in equity, althomgh no express contriat exists. And it matters not, in case of a debt, whether the sureties are jointly and severally bound, or only severally; whether their whligation arises under the same instrument, or under divers obligations or instruments, if all the instruments are for the same identieal debt. ${ }^{2}$ The aetion for contribution arises upon a principle of equity, though it is now established to be the foundation of an action at law. ${ }^{2}$

This rule of equity applies between sureties ${ }^{3}$ and other joint promisors. ${ }^{4}$ The gromul upon which a surety is entitled to contribution is that he has paid the debt for which he and his co-sureties are bound. He cannot maintain a suit on the original contract $;^{5}$ he need not wait until he is compelled to pay it. ${ }^{6}$

The doctrine of contribution is not founded on contract, but is the result of general equity, on the ground of equality of burden and benefit, and is equally so among principals as among sureties. $^{7}$ An express agreement will control though in parol, ${ }^{8}$ and sometimes other equities may change the rule.

In case of an assignment of property from the principal to a

1. Story Eq. Jur. 495.

2. Davies v. Humphreys, 6 Mees. \& Wel. 153: Bushnell r. Bushnell. 77 Wis. 435,46 N. T. 442,9 L. R. A. 411 and note; Fowler v. Donovan, 79 Ill. 310 ; Kincaid r. IIocker. 7.T. .T. Mar. (Kr.) 333.

3. Wells v. Miller, 66 N. Y. 255 : Bushnell v. Bushncll, 77 Vis. 435, 46 ‥ II. 442. 9 L. R. A. 411 and note: Robertson $v$. Deatherage, 82 Jll. 511 .

4. Chipman r. Morrill, 20 Cal. 130: Snyder v. Kirtley, 35 Mo. 423 .

5. Halliman v. Rogers, 6 Tex. 91.
6. Glasscock v. Hamilton. 62 Tex, 143; Jackson v. Murray. 77 Tex. 644. 14 S. W. 23.5: Kemp v. Fender, 12 Mees. \& II. 421: Chaffee v. Jones, 19 Pick. (Mass.) 260; Tayylor v. Savage 12 Mass. 98.

r. Fleteher v. Grower. 11 N. H. $3199.35 \mathrm{Am}$. Dee. 497 .

8. Robertson $\therefore$. Deatherage. s2 111. 511 .

9. Wells ․ Miller, 66 N. Y. 955 ; Scofield v. Gaskill, 60 (ial. 277: lealey r. Scofield, 60 Gal. 450 : Craven v. Freeman, sz $x$. Car. 361 . 
surety, for the purpose of indemnifying him in part, such assignment will inure to the benefit of all the sureties, and a surety who has received money from such a fund can only recover from his co-sureties their just proportions, or aliquot parts, of the sums he may have paid beyond the sum so received from the property assigned. ${ }^{10}$

A surety who has paid a judgment against himself and cosurety cannot, by taking an assignment thereof, enforce the full amount of the judgment against his co-surety. ${ }^{11}$ And a surety who voluntarily and unconditionally pays a judgment against himself and co-surety without taking an assignment thereof, cannot compel contribution from his co-surety on the original contract; ${ }^{12}$ to protect himself he must take an assignment of the judgment. ${ }^{13}$

\section{$\S 389$. In what property payment may be made.-When} one co-surety pays the debt in any mode, either in property, negotiable paper or securities, if such payment is received in full satisfaction of the original debt, it is equivalent to, and will be treated as, a payment in cash, and the payer has his right to contribution. ${ }^{1}$ But the refusal of a surety to accept property from his principal as indemnity will not defeat his right to contribution where he has pait the original debt. ${ }^{2}$

$\S 390$. Right to receive contribution. - It is well settled that before a surety is entitled to call upon a co-surety for contribu-

10. Batchelder v. Fisk, 17 Mass. 464.

11. McGinnis v. Loring, 126 Mo. 404, 28 S. W. 750 .

12. MeGinnis v. Loring, $126 \mathrm{Mo}$. 404, 28 S. W. 750.

13. Farwell v. Becker, 129 Ill. 274, 21 N. F. 792. See, also, Peebles v. Gay, 115 N. Car. 38, 20 S. E. 173 ,

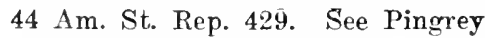
on Surety. and Guaranty, secs. 196 . 212.

1. Keller v. Boatman, 49 Ind. 104; Anthony v. Perciful, 8 Ark.
494; Pinkston v. Taliaferro, 9 Ala. 547; Brisendine v. Martin, 1 Ired. L. (N. Car.) 286: Ralston v. Wood, 15 Ill. 159; Witherby v. Mann, 11 Johns. (N. Y.) 518; Stone v. Porter, 4 Dana (Ky.), 207; Robinson v. Maxcey, 6 Dana (Ky.), 10l; Cornwall v. Gould, 4 Pick. (Mass.) 444; Stubbins v. Mitchell, $82 \mathrm{Ky}$. 536; Smith v. Mason, 44 Neb. 610, 63 N. W. 41.

2. Smith v. Mason, 44 Neb. 610, 63 N. W. 41. 
tion he must have actually paid the debt. ${ }^{1}$ bint this deetrine does not require that the indeldedness shall be pail in money by the surety. If there has been delivered to the obligee, property which is received in full satisfartion of the demand, it is equiralent to payment in eash, and will authorize the surety to call upon his eo-sureties for reimhursement on the basis of the value of the property so deliverel, not exceeding the debt thereby discharged, ${ }^{2}$ with interest only at the legal rate from date of payment. ${ }^{3}$

In some States contribution between sureties can be claimed in equity only and not at law, ${ }^{4}$ exeept where changed by statute.

$\S 39$ r. Insolvency of co-sureties.-Some calses hold that in an action for contribution the question of solveney or insolveney of the co-sureties is not material, and the one paying the debt is entitled to recover enntribution without regard to the insolvency of any of them. But the equitable rule is that contribution must be based upon the number of solvent eo-sureties. That is, the insolvent ones are to be excluded, and the burden is to be distributed equally among those who are solvent. ${ }^{1}$ This is the rule in equity in some States, ${ }^{2}$ but not at law, as at law the aliquot portion is to be ascertained on the basis of the number

1. Bisph. Eq. 330 .

2. Brandt on Suretrship, 285 ; Ralston v. Wood, I5 Ill. 159, 58 Am. Dec. 604; Atkinson v. Stewart, 2 B. Mon. (Ky.) 348; Stubbins v. Mitchell, 82 Ky. 536.

3. Bushnell $v$. Bushnell, 77 Wis. 435, 46 N. IV. 442,9 L. R. A. 411 and note: Smith v. Mason, 44 Neb. 610,63 N. IV. 41.

4. Hawker $v$. Moore, $40 \mathrm{IT}$. Va. 49,20 S. E. 848 ; MeDonald v. Magruder, 3 Pet. (U. S.) 470; Longley v. Griggs, 10 Pick. (Mass.) 121.

1. Acers v. Curtia, 6s Tex. 423, 4 S. W. 55l: Liddell $\vee$. Wiswell, 59 Vt. 365,8 A. 680; Michael v. Albright, 126 Ind. 172,25 N. F. 902 :
Young v. Clark, 2 Ala. 264: Young v. Lyons, s Gill (Mrd.), 162: Gross v. Davis. 87 Tenn. $226.10 \mathrm{Am}$. St. Pep. 635 and note. 11 S. IV. 92; Newton v. Pence. 10 Ind. App. 672, 38 N. F. 4S4: Breckinridge v. Taylor, s Dana (Kr.), 110: Boseley v. Taylor, 5 Dana (Ky.), 15z; Morrison r. Poyntz. I Danil (Ky.). 307, $32 \mathrm{Am}$. Dee. 92; Henderson $\mathrm{r}$. McDuffee. 5 X. H. 38. 20 Am. Dee. 557 and note: Broalsman v. Pinge. 11 X. II. 431: Burroughs v. Lott, 19 Cal. 125: Smith v. Mason, 44 Neb. 610. 63 X. W. 41.

2. Noore $v$. Bruner. 31 Ill. App. 402. 
of sureties, without regard to their solvency. ${ }^{3}$ In some of the States contribution is given at law as well as in equity, according to the number of solvent sureties, and in some States this is law under the statute. ${ }^{4}$

$\S 392$. Must the principal debtor be insolvent.-According to the weight of authority at law the right of the surety to recover contribution from a co-surety in any manner depends upon the insolvency of the principal debtor, ${ }^{1}$ although the decisions upon this point are not harmonious. Therefore, in order to recover contribution it is necessary by the weight of authority, to aver and prove the insolvency of the principal debtor, and this is so in equity. ${ }^{2}$

$\S 393$. Sureties discharged by act of promisee.-The promisee may give the principal debtor privileges which will discharge the sureties. Thus, where the principal and one of the sureties executed their note, which was accepted by the creditor, in payment of the former note, this has the effect to release and discharge the sureties who did not sign the last note, from their obligation to the creditor, as well as from contribution to their co-surety who signed the new note. ${ }^{1}$ So if the creditor extends the time of the payment of the note, for a valuable consideration, it releases the sureties who do not agree to it $;^{2}$ but if there was no consideration for the extension of the time, the agreement is void, and sureties are not discharged. ${ }^{3}$ 403.

3. Moore v. Bruner, 31 Ill. App.

4. Pingrey on Surety. and Guaranty, secs. 196, 197.

1. Roberts v. Adams, 6 Port. (Ala.) 361, 31 Am. Dec. 694; Brandt on Suretyship, 290; Judah v. Mienre, 5 Blackf. (Ind.) 171; Buckner v. Stewart, 34 Ala. 529; Sloo v. Pool, 15 Ill. 47; Rankin v. Collins, 50 Ind. 158.

2. Smith v. Mason, 44 Neb. 610, 63 N. W. 41 ; Mosely v. Fulleton, 59
Mo. App. 143: Compare Hawker v. Moore, 40 W. Va. 49, 20 S. E. 848; Pingrey on Surety. and Guaranty, sec. 197 .

1. Bell v. Boyd, 76 Tex. 133, 13 S. IV. 232.

2. Gordon v. Bank, 144 U. S. 97, 12 S. Ct. 657; Chemical Co. v. Pegram, 112 N. Car. 614, 17 S. E. 298; Rees v. Berrington, 2 Ves. Jr. 540 .

3. Burr v. Boyer, 2 Neb. 265; Dillon v. Russell, 5 Neb. 484 ; Smith 
But the mere voluntary forbearance on the part of the aresion, enlarging the time of payment, withent ansideration, wr thes mere failure to institute an action again-t thr principat debtur

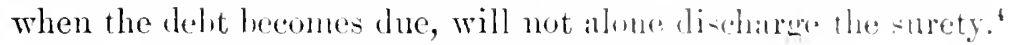
But if the surety demands that the areditor bringe suit to collect the note, the latter must do it within a raminalye time, for, after such demand, if the principal beconses lankinut, and the ereditor has been negligent in bringing snit, the surety will be discharged.

$\S 394$. In case of tort.-Between wrongloers there can be no contribution, the exception being where the act is not elearly illegal in itself. ${ }^{1}$ But in determining whether one joint wronsdoer is entitled to contribution from another the test is, whether the former knew, at the time of the commission of the act fin which he has been compelled to respond, that such act was wrongful. ${ }^{2}$ If all know that their act is wrong, none can compel contribution from his co-defendant. ${ }^{3}$

This rule will not affect cases of indemnity where one man employs another to do acts not unlawful in themselves for the purpose of asserting a right. ${ }^{4}$

v. Mason, 44 Neb. 610,63 N. W. 41 .

4. Smith v. Mason, 44 Neb. 6I0, 63 N. IV. 41 ; Dillon v. Russell, 5 Nel. 484; Sheldon v. Williams, 11 Neb. 272, 9 N. 86. See Pingrey on Surety. and Guaranty, secs. 100137.

1. Farwell v. Beeker, 129 IIl. 272. 21 N. E. 792,16 Am. St. Rep. 267: Betts v. Gibbins, 2 Ad. \& El. 57.

2. Torpy v. Jolmson; 43 Neb. ss?. 62 N. W. 253: Jolnann v. Torpy, 35 Neb. 604, 53 N. IV. 575. 37 Am. St. Rep. 447 ; Jacobs v. Pollard, 10 Cush. (Mass.) 287, 57 Am. Dec. 105: Armstrong Co. v. Clarion Co.,
66 Pa. St. 21s, 5 Am. Rep. 368: Lowell v. Railroad Co.. 23 Pick. (Mass.) 24, $34 \mathrm{Am}$. Dec. 33 and mote: Acheson v. Millor. 2 Ohio st. 203,59 Am. Dee. 663: Barley v. Bussing. 28 Comm. 455; Adamson r. Jarvis, 4 Bing. 66 .

3. Merryweather v. Nixan, 8 Term R. ist. See, also, Nichols $v$. Nowling, S2 Ind. 4ss: Miller $v$. Funton, 11 Paige (X. Y.), 1s; Vose v. Giant. 1.i Mass. 505.

4. Nerryweather $r$. Nixan, 8 Term Ri. 1s6. Soe, also, Betts $r$. Gibbins, 2 Ad. \& Fl. 57: Farwell $r$. Becker, 129 IlI. 272, 21 ․ E. 79:. 16 Am. St. Rep. 267. 


\section{CHAPTER XV.}

\section{Interstate Contracts.}

\section{ARTICLE I.}

\section{Law of the Place of Contract.}

Section 395. Validity of Contract-What Law Governs.

396. Intention and Agreement.

397. Capacity of Parties.

398. Sale of Personalty.

399. Bills and Notes.

400. Marriage Contracts.

401. Married Women.

402. Chattel Mortgage Lien Follows the Property.

403. Conveyances of Real Estate.

404. Insurance Contracts.

405. Assignment of Policy of Insurance.

406. Assignment of Property.

407. As to the Situs of Personal Property.

$\S 395$. Validity of contracts - What law governs.- Interstate laws, or private international law, interpret the contractual relations of persons in different States and nations, who have interstate or international dealings. Of course the law of one State has no force outside of the State, but in most cases, through comity of States, it is applied in other jurisdictions.

The general rule is that if a contract is valid where made it is valid everywhere and will be enforced in other jurisdictions, that is, by the lex fori. However, there are exceptions to this general rule which may be classified as follows: (1) When the enforcement of the interstate contract would militate against the policy of the forum; (2) where the enforcement of the 
interstate contract would work injury or injustice to the penple

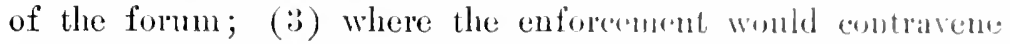
the principles of morality and decency of the commmnity of the formu; (4) where a foreign or interstate law is peranl in its nature; (5) where the contract relates to the transiol at titlo to real estate in the formu.

In short, the interstate contract will not be anforeed if it is clearly contrary to good morals, or repugnant to the established policy or positive statute of the jurisdirction in which it is songlit to be enforced. ${ }^{1}$ Thus, a contract of subscription to capital stock of a corporation made in Maryland, but to be performed in the State where the corporation is chartered, is to be governed by the laws of the State where the corporation is created. ${ }^{2}$ So, also deeds and notes relating to real property located in Maine, although dated in another State but relivered in Maine, will be governed by the law of the latter. ${ }^{3}$ Ind a guaranty executed and to be performed in Louisiana is a Louisiana contract and is governed by the laws of that State, though designed to obtain credit in another State."

Although a stipnlation in a contract of carriage, relieving the carrier from liability for injuries resulting from the negligenco of his serrants, is against problic policy of a State, if ralid in the country where made, it will be enforced in the former, if it is not immoral or illegal, on principle of comity. ${ }^{5}$

1. Minor's Conf. L. p. 9: Tilaen v. Blair. 21 Wall. (C. S.) 24l: Warne County Siviugs Bank $r$. Low, 81 N. Y. 566. 37 Am. Rep. 533; Hawley v. Bibb. 69 Ala. 52: Stix v. Matthews, 75 Mo. 96; Swann v. Swann, 21 Fel. Rep. 299; Burns v. Railroad Co., 113 Ind. 169. 15 N. F. 230: Flagg v. Baldwin, 38 N. .. Eq. 219; Hyatt v. Bank, 8 Bush. (Ky.) 193; Milliken v. Pratt, ]25 Mass. 374, $28 \mathrm{Am}$. Rep. 241; Hill v. Spear. 50 N. II. 253,9 Am. Rep. 205 ; Sondheim v. Gilbert, 117 Ind. 71 , is $\mathrm{N}$. E. 687.5 L. R. A. $432.10 \mathrm{Am}$. St.
Rep. 23 and note: Sullivan v. Sullivan. 70 Mich. 583, 38 N. W. 472: Fessenden v. Taft, 65 N. H. 39. 17 1. 713; Atlantic Phospluate Co. $r$. Hy, 82 Ga. 438,9 S. E. 170.

2. Fear v. liartlett. Sl Mil. 43i. 32 A. 322,33 1. R. A. 721 and note.

3. Holt r. Knnowlton, s6 Me. 456 , 29 . $111 \%$.

4. Jichman v. Block, 47 Ia. Inn. 50.5 .

5. Milliken v. Pratt. 125 Mass. 374. 28 Am. Rep. 241: Soudder v. Bank. 9l U. S. 406: Fonseca v. 
And where an assignment of a judgment conveys the legal title, the assignee can sue on it in her own name in another jurisdiction as the lex loci governs. ${ }^{6}$ So succession to a tangible thing may be taxed wherever the property is found. ${ }^{7}$ So the transfer of money of a non-resident, deposited in a certain state, depends upon the law of that State. The universal succession can be taxed in one State, and the singular succession in another. Thus, B domiciled in Illinois, deposited in a New York bank a certain amount of money to be left there temporarily, under conditions, but he died before withdrawing the deposit. A succession tax was imposed by the law of Illinois upon all his property including the deposit in New York. The State of New Tork imposed a succession tax upon the deposit in that State. Both succession taxes were legally imposed. ${ }^{8}$ The fact that two States, dealing each within its own law of succession and transfer, both of which a legatee, or legal representative of the estate has to invoke for his rights, have taxed the right which they respectively confer, gives no cause for complaint on constitutional grounds. ${ }^{9}$ One and the same State may tax on the one hand according to the fact of power, and on the other, at the same time, according to the fiction that, in succession after death, personalty follows the person and domicil governs the whole.

$\S 396$. Intention and agreement. - Where a contract is entered into between parties residing in different countries, where different systems of laws prevail, it is a question in each case with reference to what law the parties contracted, and according to what law it was their intention that their right, either under

Steamship Co., 153 Mass. 553, 27 N. E. 665,12 L. R. A. 340 and note, 25 Am. St. Rep. 600; Regan r. Steamship Co., 160 Mass. 356, 35 N. E. $1070,39 \mathrm{Am}$. St. Rep. 484.

6. Martin v. Wilson. 120 Fed. Rep. 202, 58 C. C. A. 181.
7. Eidmon v. Martinez, 184 U. S. 57 S, 22 S. Ct. 515.

8. Blackstone v. Miller, $188 \mathrm{U}$. S. 189,23 S. Ct. 277 .

9. Coe v. Erral, 116 U. S. 517,6 S. Ct. 475 ; Knowlton v. Moore, 178 U. S. 53,20 S. Ct. 747. 
the whole or in part of the contract, should be determined. ${ }^{1}$ So a life insurance policy issued in Pennsylvania which contains a stipulation that it is a contract and to be executed in the State of New York, and shall be eonstrued only according to the laws of that State, will be construed as though actually executed and delivered in New York." This is in accordance with the principle that where parties make a contract of loan in one State to be performed in another, they may in goorl faith and without intent to cvade the law, agree that the law of either State shall control. ${ }^{3}$

However, in many instances the intention caunot control, but the law and public policy must prevail which the intent of the parties cannot overthrow. Thus, a married woman who makes a contract prohibited by law, will not be held liable on the contract merely because she intended to make a valid contract. So a contract roid because it is not in writing cannot be made valid and enforced because the maker intended it to be valid. And so if one agrees to do something prohibited by law, his intent to make a valid contract does not control. So if one makes a contract whose consideration is illegal or immoral, his intent to bind himself does not make it a valid contract. ${ }^{4}$ So, in gencral, whether the question concerns an elenent of the contraet dependent upon the parties' intention or that independent of the intention, the law governing is that of the situs of the particular element, circumstanee, or act in controversy. If the contract is void in some partieular element, such as the mode of entering into it, or the act done as the consideration of the promise, ly the law governing that element, the courts of every State will up-

1. Hamlyn v. Talisker Distillery (1894), A. C. 202.

2. Griesemer v. Ins. Co., 10 Wash. 202, 38 P. 1031.

3. Robinson v. Bland, 2 Burr. 1177 ; Niller v. Tiffany, 1 Wall. (U. S.) 298; Martin v. Jolnson, 84 Ga. 481,10 S. E. 1092,8 I. R. A. 170 and note; Mott v. Rowland, 85 Mich. 561, 48 N. W. 638; Smith r.
Parsons, 55 Minn. 520, 57 X. W. 311 ; Jones r. 'Trust Co., 7 S. Ink. 122, 63 X. W. 553. See, also, Whitaker v. Security Co.. 97 Ga. 3:2?. 20. S. 1. 97s: Inited States Sar. \& 1. Asso. r. Seott. $95 \mathrm{Ky}$ 69.. 31 S. W. Rep. 235; Bascom v. Zediker, 48 Xeb. 380, 67 N. IV. 149.

4. Minor's Contl. L. p. 364. 
hold the law and policy of the State where the particular element in question arises or has its sitns. And the fact that the parties hat in view a different law governing the element has no effect whatever. ${ }^{5}$ The dignity of a local court is not involved when a contract is made between citizens of foreign States who make any reasonable arrangement for the settlement of their disputes, where there is only the narrowing of the foruni-area, and not an attempt to deprive a party of the right of appeal to the eourts. Such an arrangement is analogous to the limitation by contract of the time within which suits may be brought. Thus, in Mittenthal v. Maseagni, ${ }^{6}$ a contract came before the court, partly to be performed in Italy, but primarily in the United States. It also provided that it should be governed by the laws of Italy and that any suit brought under it should be instituted in the courts of Florence, Italy, except that Maseagni might sue for his compensation in the courts of New York. This contract was valid and meant to give exclusive jurisdiction to the Italian courts. The court held that parties may agree to arbitration in preliminary and incidental matters of dispute, so long as the right of appeal to the courts for the determination of any substantial question of liability is retained.

$\S 397$. Capacity of parties.-Continental jurists have maintained that personal laws of the domicil, affecting the status and capacity of all inhabitants of a particular class, bind them wherever they may go, upon the principle that each State has the rightful power of regulating the status and condition of its subjects, and, being best acquainted with the eircumstances of climate, race, character, manners, and eustoms, can best judge at what age young persons my begin to aet for themselves, and whether and how far married women may act independently of their husbands; that laws liniting the capacity of infants or of married women are intended for their protection, and cannot therefore be dispensed with by their agreement; that all eivil-

5. See Union Nat. Bank v. Chapman, 169 N. Y. 538, 62 N. E. 672, 57 L. R. A. 513 and note.
6. 183 Mass. 19,66 N. E. 425,60 L. R. A. 812,97 Am. St. Rep. 404. 
ized States recognize the ineaparity of infants and marroul women; and that a gerson, dealine with rither, orlinarily hat notice, by the apparent age or sex, that the persous is likny to lese of a elass whom the laws protect, and is thus put upun infuiry how far, by the law of the domicil of the persm, the protection extends. Tenee, these jurists generally hold that incaparity of the domieil attaches to and follows the person whrover he may go.

However, this is not the doctrine of the common law; the general eurent of the English and American anthoritios holds that a contract, which hy the law of the place is reengnized as lawfully made by a capable person, is valid everywere, although the person wonld not nuder the law of the domicil be deemed capable of making it. ${ }^{\mathrm{t}}$

This is the accepted doctrine in this country in so far as it relates to the enforcement of contracts in courts other than those of the domicil. Quite a different question is presented when the action is brouglt in the formm of the domicil. In such a case a very important qualification of private international law is to be considered, and this is that no State or nation will enforce a foreign law which is contrary to its fixed and settled polies. ${ }^{2}$ If a party makes a contract in the State of his domicil, though the contract is to be performed elsewhere, the law of his domieil governs as to this capacity to make the eontract. ${ }^{3}$ But the capacity of the party, when not at his domicil, to contraet is governed by his actual situs at the time he makes it, the lex loci celebrationis. But when the domicil of the party is the forum, in order to protect the citizens, the lex fori will govern."

1. Story on Confl. of L. 103, 104: Compare Wharton on Confl. of $\mathrm{l}$. $112,118$.

2. Story on Confl. of L. 37 : Bank v. Earle, 13 Pet. (C. S.) 519: Armstrong v. Best, lI2 N. Car. 5!, 17 S. E. 14.25 L. R. A. 158.34 Am. St. Rep. 473; Taylor v. Sharp. 108 N. Car. 377,13 S. E. 13 s.

3. Polson v. Stewart. 167 Mass.
211,45 N. E. 737,36 L. R. A. 731, $57 \mathrm{Am}$. St. Rep. 452: Freeman's Appeal, 68 Comn. 533. 32 A. 430.37 t. R. A. tie, it Am. St. Rep. 112: llill v. Bank, ti \. H1. 300: Armstrong r. Be-t. 11:2 X. (ar. 5!) 17 s. E. 14, 2.3 1. R. A. 1ss. 34 An. St. Rep. 473 .

4. Rohinson r. Gueen, si Tomn. $44 \bar{s}, 11$ S. W. 33.3 1. R. A. 214, 10 
If by the lex celebrationis the parties are incapable of making a contract, no other State will recognize such a contract. If the contract is void at the place of its execution, it is void every. where. $^{5}$ So if the parties enter into a contract in a particular State, the law of that State alone decides whether the parties had ability to contract.

$\S 398$. Sale of personalty.-If no place is designated by the contract, the place of sale is the point at which goods are ordered or purchased, set apart and delivered to the vendee, or to a common carrier, who, for the purpose of delivery, represents the vendee. $^{1}$

Personal property has a legal situs which is the domicil of the owner, and an actual situs, the place where it is located. Any transfer of it, if valid where made, will pass title though its actual situs is in another State. ${ }^{2}$

Where a place of performance is fixed by the parties, the presumption is that the parties contract with reference to the law of such place, the lex loci solutionis. ${ }^{3}$ Accordingly, a written contract for sale of lumber, to be sawed, inspected, paid for, delivered and received in Mississippi is governed by the laws of that State, both as to obligations and execution, though made and signed in Tennessee. ${ }^{4}$ It is not the lex loci contractus that governs in such cases, but the lex rei sitae; that is, the law of

Am. St. Rep. 690; Milliken v. Pratt, 125 Mass. 374, 28 Am. Rep. 241; First Nat. Bank v. Shaw, 109 Tenn. 237,70 S. W. 807,59 L. R. A. 498.

5. Campbell v. Crampton, 2 Fed. Rep. 417.

1. Perlman v. Satorius, $162 \mathrm{~Pa}$. St. 320,29 A. 852, 42 Am. St. Rep. 834; Schumacher v. Eley, $24 \mathrm{~Pa}$. St. 521; Schwertz v. Dwyer, 53 Pa. St. 335; Garbracht v. Commonwealth, 96 Pa. St. 449, 42 Am. Rep. 550 .

2. Ames Iron Works v. Warren, 76 Ind. 512, 40 Am. Rep. 258;
Partee v. Silliman, 44 Miss. 272; Cantee v. Bennett, 39 Tex. 303; Mayo v. Assurance Soc., 71 Miss. 590, 15 So. 791 .

3. Dalton v. Murphy, 30 Miss. 59 ; Hart v. Machine Co., 72 Miss. 809, 17 So. 769 ; Milwaukee, etc. R. R. Co. v. Smith, 74 Ill. 197; Cook v. Mofiat, 5 How. (U. S.) 295; Hyatt v. Bank, 8 Bush (Ky.), 193; Osgood v. Bauder, 82 Iowa, 171, 47 N. W. 1001.

4. Hart v. Machine Co., 72 Miss. 809, 17 So. 769. 
the place where the property is locatend at the time of the -ale.

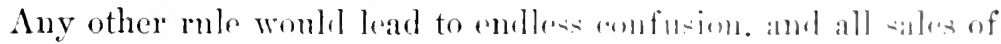
personal property made ontside of a sitate womld he sulijecte to review as soon as the property was hronght within the State.

A sale, if valid where male, is valid as hetwern thr parties in every jurisdiction where it is called into question: if invalid where made it is invalid in every other State."

Hence, if the sale of certain articles is invalid in one Siate but valid in another jurisdiction where the sale is made, it is valid in the former State, ${ }^{7}$ thongh the vendor, if he knew of the prohibition, will not be allowed to enforce the sale in the former State. ${ }^{8}$ Inul the vendor shonld not be allowed to collect the price in any State, the purpose being to violate law of another State. ${ }^{9}$

The place of the sale is where the final act is completed. The place where the order is given, or from where it is sont to the vendor, furnishes no safe guide in fixing the locus contractus. ${ }^{10}$ If an agent has full anthority to make a sale, the situs of the sale is where the agent actually cntered into the contract. If he has no authority to pass the title, but takes orders to send to his principal who passes upon them, then the situs of the sale is where the principal acts. ${ }^{11}$

5. Kurner v. ONeil. $39 \mathrm{~W}$. Va. 515, 20 S. E. 589. See, also, Gray r. Iron Work Co., 66 Fed. Rep. 606: Barrett v. Kelley, 66 Vt. 515. 27 A. 496, 44 Am. St. Rep. 862; Melane v. Creditors, 47 La. Ann. 134,16 So. 764 .

6. Fowler's Appeal. 125 Pa. St. 388, 17 A. 431, 11 Am. Sit. Rep. 902; Wenestine v. Frever, 93 Ala. 257, 9 So. $285,1 \cdot 2$ L. H. 1.700 and note.

7. Merehants' Bank v. Spalding, 9 N. Y. 58.

8. Webster $r$. Munger. \& Gray (Mass.), 584; Graves v. Johuson, 156 Mass. 211.30 ‥ E. S1s. $15 \mathrm{~L}$. R. A. S34 and note, $32 \mathrm{Am}$. St. Rep.
446. 4.j0 and noti. But this rule is not adopted by all the courts. See Hill $v$. Spear, 50 N. H. 253, 9 Am. Rep. 205: MeIntyre $v$. Parks, 3 Met. (Mass.) 207.

9. Weil v. Golden, ltl Mass. 364,6 X. F. 229?.

10. State r. Oeil, 58 Vt. 140, ¿ A. 586, 56 Am. liep. 5is: Tegler $\checkmark$ Shipman, 33 Jwa. 194. $11 \mathrm{Am}$. liep. 11s; Newmon $v$ Sheriff. 43 Ia. Inn. 712, ! So. 43!): Sullivan

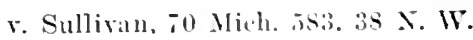
472.

11. Frman v. Tehman. ti La. Ann. loist. Is So. li50: Clatlin v. Mayer, tl La. Amn. lo4s, T So. 139 . 
The lex loci contractus governs in the interpretation of terms used and their legal meaning. So the law of the place of sale governs the question as to whether the vendor warranted the validity of bonds sold." So in a deed of personalty, "heirs at law" must be interpreted according to the place of the sale. ${ }^{13}$

A gift causa mortis is a voluntary and contractual act, and lence the lex loci contractus governs it. ${ }^{14}$ The title in the donee is conditional and revocable, but it is not testamentary, and so the lex domicillii cannot control the gift, though this solution is not free from doubt.

$\$ 399$. Bills and notes. $-\Lambda$ promissory note is not complete until it has been delivered, and it takes effect only from the day of its delivery. The place of contract evidenced by a promissory note does not depend upon where the note is dated, but upon the place where delivered. It is the delivery of the note that consummates the contract. ${ }^{1}$ As between the drawer and the payee the place of performance is the place where the bill is drawn. $^{2}$ Where a bill of exchange has been endorsed in a foreign conntry, in a form which would pass the title if done in the United States, ret inadequate there, it is invalid in this country. ${ }^{3}$

In general a note is governed by the law of the place where it is payable. ${ }^{4}$ But a note secured by mortgage on land in another State, is not necessarily a contract of the former State. ${ }^{5}$

12. Meyer v. Richards, 163 U. S. 385, 16 s. Ct. 1148.

13. Codman v. Krell, 152 Mlass. 214, 25 N. E. 90.

14. Emery v. Clough, $63 \mathrm{~N}$. H. 552, 4 A. 796.

1. Wells v. Vansickle, 64 Fell. Rep. 944; Hyde v. Goodnow. \& $\mathrm{N}$. Y. 266; Davis v. Coleman. i laed. (X. (ar.) 424.

2. Warner v. Bank, $6 \stackrel{\therefore}{\circ}$ Dak. 152, 60 N. IV. 746; Freese v. Brownell, 35 N. J. L. 285, 10 Am. Rep. 239: Hunt v. Stamlart. 1.s Ind. 33,75 Am. Der. 79 .
3. 'Trimley v. Vignier, I Bing. N. C. 151.6 Car. \& P. 25.

4. Tenant v. Tenant, $110 \mathrm{~Pa}$. St. 478, l A. 532; Barrett v. Dodge, 16 R. I. 740,19 A. 530,27 Am. St. Rep. 777 ; Compare American Freehold Land Mort. Co. v. Sewall, 92 Ala. 163, 9 So. 143, 13 L. R. A. 299 ; Kilcrease v. Johnson, S5 Ga. 600. 11 S. E. 870: Mott v. Rowland, S.5 Nich. 561, 48 N. W. 638; New England Mortg. Co. v. MeLaughlin, si Ga. 1. 13 S. E. 81.

5. Whitakor v. Security Co. 97 Ga. 329, 22 A. 1. 978; Lnited States 
In the abuence of any direct evidenee als to where a mote was delivered, it will he presumed that it was where the maker resided-that being the place where it was dated and simnerland it will be payalble there and governed by the law's of that State as to megotialsility, thomgl descriling the payere as of a certain plater in another State. ${ }^{6}$

Whether a note is negutiable as to maker is governed by the law of the place where payable. 'The lex solutionis governs as to whether the holder of a note is a bona ficle purchaser for value $;^{8}$ lex solutionis governs as to rlays of graes: ${ }^{9}$ also the presentment, notice of lishonor, protest, and the like $;^{10}$ and the rate of interest unless otherwise stipulated, ${ }^{11}$ but the lex celebrationis governs the interest after maturity if no stipulation controls." But if the interest agreed upon is that of the lex loci solutionis, that must control the interest after maturity. ${ }^{13}$ This question is now generally regulated by statute, and the interest is the legal rate after maturity ${ }^{14}$ in some States; but the law varies and local statutes must be consulted.

The general rule holds as to endorsements. So a contract of endorsement of a promissory note is governed by the law of the State where it is made, although the note itself is cxecuted and payalle in another State, unlous the intention is to negotiate the instrument elsewhere. ${ }^{15}$

Sav. \& 1. Asso. v. Stott, is liy. 695, 34 S. W. 235; Bascom v. Zediker, 48 Neb. 380,67 N. IV. 148.

6. Strawberry Point Bank $r$. Lee, 117 Mich. 122, 75 N. W. 444.

7. Barrett v. Dodge, 16 R. I. 740, 19 A. 530, 27 Am. St. Rep. 777 ; Rose r. Park Bank, 20 Ind. 94, 83 Am. Dec. 306: Supervisors v. Galbraith. !9 I. ‥ ㄴl14.

8. Webster v. Machine Co., $5 f$ Conn. 394, 7 A. 22; Woodruff v. Hill, 116 Mass. 310.

9. Skudder v. Bank, 9 I U. S. 406 ; Brown v. Jones, 125 Ind. $375,25 \mathrm{X}$. E. 452, 21 Am. St. Rep. 227.
10. Wooley v. Lyon, 117 Ill. 244, (i N. E. 885,57 Am. St. Rep. S67; Mason v. Lake, 4 How. (U. S.) 262.

11. Scotland County v. Hill, 132 l. S. 107.10 S. C'. 26 ; Morris v. Wibaux, 15!) Ill. (i27, 43 x. E. 837.

12. Cromwell v. County of sac, 9; U. S. 5 ).

13. Coghlan v. R. R. Co, 142 I. S. 101, 12 S. Ct. 150.

14. See Hurd's Hll. Stat. 1903, ch. 74 sec. 2.

15. Spies r. Rank, 17t N. Y. 202, 66 N. E. 736,61 L. R. A. 193. 
And so the transactions of a broker which become the basis of a note given and delivered by the principal, are to be taken into consideration in determining the validity of the consideration at the situs of such transactions. ${ }^{16}$

$\S 400$. Marriage contracts. - The validity of a marriage contract is governed by the place where made, or the lex loci, ${ }^{1}$ if not controlled by statute. When the statute is silent, questions of the validity of marriages are to be determined by the jus gentium, the common law of nations, the law of nature as generally recognized by all civilized peoples. By that law, the validity of a marriage depends upon the question whether it was valid where it was contracted; if valid there, it is generally valid everywhere. The only exceptions to the general rule in most of the States are: (1) Marriages which are deemed contrary to the law of nature as generally recognized in Christian countries. (2) Marriages which the legislature of the State has declared shall not be allowed any validity, because contrary to the policy of the laws.

The first class includes only those void for polygamy or for incest. $^{2}$

A marriage which is prohibited in a State, because contrary to the policy of the laws, is generally valid if celebrated elsewhere according to law of the place, even if the parties are citizens and residents of the former State, and have gone from it for the purpose of evading the laws, unless the legislature has clearly enacted that such marriages out of the State shall have no validity in the State from which the parties departed. ${ }^{3}$

16. Winward v. Lincoln, $23 \mathrm{R}$. I. 476,51 A. 106,64 L. R. A. 160 .

1. Clark v. Clark, 52 N. J. Eq. 650,36 A. $\$ 1$.

2. Wightman v. Wightman, 4 Johns. Ch. (N. Y.) 343, 349-351; Sutton v. Warner, 10 Met. (Mass.) 451 ; Stevenson v. Gray, 17 B. Mon. (Ky.) 193; Bowers v. Bowers, 10 Rich. Eq. (S. Car.) 551.
3. Medway v. Needham, 16 Mass. 157, 8 Am. Dec. 131 and note; Commonwealth v. Lane, 113 Mass. 458, 18 Am. Rep. 509 and note. See, also, Dickson v. Dickson, I Yerg. (Tenn.) 110, 24 Am. Dec. 444; Compare Brook v. Brook, 9 H. L. Cas 193, 3 Sm. \& Gifl. 481. 
And a voidable marriage contracted in England, and never avoided there, must, upon the subsequent removal of the parties to Massachusetts, and the question arising collaterally in an action at common law, be dcemed valid in the new domicil, although if contracted in Massachusetts, it would have been absolutely void. ${ }^{4}$

Marriages not naturally unlawful, but prohibited by the law of one State, and not of another, if celebrated where they are not prohibited, are valid in a State where they are not allowed. ${ }^{\mathbf{5}}$

If the parties arc domiciled in one State where they cannot marry, but go into another State where the law permits them to marry, such marriage is valid if impugned in any State other than that of their domicil. If such marriage is questioned in their domicil, another rule may apply; the decisions are in conflict and not reconcilable. Two doctrines are announced: (1) The first is that the lex celebrationis must gorern the capacities of the parties to enter the contract, as well as the forms of the ceremony, irrespective of the domiciliary law of the parties, if the marriage is not immoral. ${ }^{6}$ Under this doctrine nothing but a statutory prohibition will invalidate such marriage at the parties' domicil. (2) The other doctrine is, that if the domestic policy is so important and pronounced, or evils to be averted are so imminent, as to justify the enforcement of the lex domicillii it will be done and the marriage declared void. ${ }^{7}$ But this question is one of policy which each State will determine for itself,

4. Sutton v. Warren, 10 Met. (Mass.) 451.

5. 2 Kent's Com. 85, n. a.; Story on Confl. L. 116.

6. Van Voorhis v. Brintnall, 86 N. Y. 18, 40 Am. Rep. 505; Medway v. Needham, 16 Mass. 157, 8 Am. Dec. 131 and note; Stevenson v. Gray, 17 B. Mon. (Ky.) 193; Cum. mington v. Belehertown, 149 Mass. 223, 21 N. E. 435,4 I. R. A. 131 and note.
7. Kimey v. Com., 30 Gratt. (Va.) 858, 32 Am. Rep. 690; Pennegar v. State, 87 Tenn. 244, $10 \mathrm{~S}$. W. 305,2 L. R. A. 703 and note, 10 Am. St. Rep. 648; True v. Ranney, 21 N. H. 52, 53 Am. Dee. 164; Jackson v. Jackson, 82 Md. 17, 33 A. $317,3+$ L. R. A. 773 ; State $v$. Tutty, 41 Fed. Rep. 753, 7 L. R. A. 50; Brook v. Brook, 9 H. L. Cas. 193. 
so far as its own citizens are eoneerued; and the question may be settled by the courts as well as by the legislature. ${ }^{8}$

The same conflict of decisions appears in other cases as to the marriage of relatives. 9 The variance of opinions exists as to the effect of a foreign marriage by a guilty party to a divoree suit who has been prohibited to marry again. ${ }^{10}$

When a contract to marry is exceuted, it ereates a marital status which may be dissolyed by divorce, which proceedings being quasi in rem, it must be letermined what is the res, for the court's jurisdiction in proceedings in rem depends upon its jurisdiction of the res. The law now is that the courts of one State are not bound, under the full faith and credit provision of the Federal Constitution, to recognize a divoree granted in another State, in which neither of the parties was bona fide domieiled, even if the statute of the latter State purports to confer jurisdiction upon its courts under such circumstances, becanse the jurisdiction of the res depends upon domicil. Therefore, it is not dependent mon the morle of service, whether personal or by comatruction, and applies even when the conrt which granted the divoree had complete juristiction of the persons of both parties by their appearance. ${ }^{11}$

Another question arises when the party who procured the divoree was bona fide domiciled in the State of the formm where it was granted, but the other party was a non-resident and served constructively. In such case the court has jurisdiction of the res, but has no jurisdiction of the defendant, and the question is whether it can proceed without jurisdiction, and render

8. State $v$. Kennedy, 76 … Cir. 251, $23 \mathrm{Am}$. Riep. 683.

9. Brook v. Brook, 9 H. L. Cas. 193: Sottomayor v. De Birras, ; P. D. $5, \quad \bar{i}$, where the domiciliary law controls. But where the domiciliary law does not govern, see Stevenson v. Gray, 17 B. Mon. (Ky.) 193, and Com. v. Lane, 113 Mass. 458, 18 Am. Rep. 509 and note.
10. For one doctrine see Pennegar v. State, Si Tenu. 244, $10 \mathrm{~S}$. II. 305, 2 L. li. A. 703 and note, 10 An. St. Rep. 648; for the other line see Van Voorhis v. Brintnall, 86 N. L. 18, 40 Am. Rep. 505, and Com. v. Lane, 113 Mass. 458, 18 Am. Rep. 509 and note.

11. Andrews v. Andrews, $188 \mathrm{U}$. s. 14,23 S. Ct. 237. 
a decree of divorce against him or her, as the ase may he, which the courts of another State are bomml, muler the full faith and eredit provision, to reogenize as affecting the marital status of the non-resident defendant. The Supreme ('ourt of the United States auswers this question in the affimative, ${ }^{12}$ and wermies the New York doetrine that divoree proceeding are in personam, so that a foreign divorce obtained in a State where the plaintiff alone is domiciled will have no validity exterritorially, mless the defendant voluntarily appears or is personally served with process within the territorial jurisdiction of the divorce conrt. ${ }^{13}$ And the New Jersey doetrine ${ }^{14}$ is not affected by the Tnited States Supreme Court decision; for in New Jersey the nonresident defendant must have the best notice possible, after which the domiciled plaintiff can have a valid decree under the Federal Constitution.

Where the decree is rendered in a foreign conntry, the State courts can consult their own policy and reject the decree. When, however, it is a question of the recognition of such a decree rendered in another State of the Union, the court must recognize the decree under the Federal Constitntion requiring each State to give full faith and credit to the public acts and judicial proceedings of every other. ${ }^{15}$

And where one party leares his domicil and tries to acquire another by fraud, and there obtains a livorce, it is void, and a divoree obtained by the other party at her domicil will be ralid and be so accepted in all the States of the Union. ${ }^{16}$

$\$ 40 \mathrm{r}$. Married women-Infants.-The extent to which a married woman may bind her separate personal property or herself, is mima facie detemined by the law of the State in

12. Atherton v. Itherton, 181 U. S. 155. 45 I. El. 794, 21 s. Ct. 544.

13. In re kimball, 1.5.5 $\mathrm{X}$. $Y$. 62,49 N. E. 331 . The New Tork doctrine has been adopted in Cook v. Cook, 56 Mis. 195, 14 N. 33,443 , 43 Am. Rep. 706: Marris v. Harris,

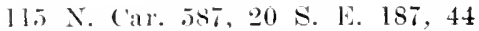
Am. St. Rep. 47 .

14. Doughty v. Doughty, $27 \mathrm{~N}$. .1. Eq. 31.

15. Art. 4, sec. 1.

16. Bull ․ Bell, 181 L. S. 175 , I I. ('t. 5.51. 
which the contract is made, it being also the place of her domicil. $\frac{1}{*}$ Where a note made in one State by a married woman is sued on in another, the liability of lier separate estate therefor will be determined by the laws of the latter. ${ }^{2}$

And a legal contract made in another State by a married woman, which she was not at the time capable of making under the law of her domicil, and which she cannot lawfully make at her domicil, is valid and can be enforced in the State of her domicil. $^{3}$

But a contract made at her domicil and void cannot therefore be enforced. Thus, in insolvency proceedings, a contract of guaranty dated and signed by parties in Chicago, and to be performed in Illinois, which was afterwards signed by a married woman who lived in Connecticut, and then delivered in Illinois, is, as to her, a Connecticut contract, and invalid under the laws of Connecticut for want of capacity to make such a contract. ${ }^{4}$ However, if a married woman has the general power to contract, her contracts will be as valid as those of other parties with full capacity. ${ }^{5}$ But the common law, which makes the contract of a married woman invalid, must still be accepted as the general rule for those States which have not made exceptions by statutes. Hence, a State of her domicil has the power to protect a married woman from the result of her contract made while personally present in such State, if it choose so to do. ${ }^{6}$

If the domicil and forum impose a total incapacity to contract on the part of a married woman, the law of the domicil

1. Dulin v. McCaw, 39 W. Va. 721,20 S. E. 681.

2. Read v. Brewer (Miss.), 16 South. Rep. 350; Frierson v. Williams, 57 Miss. 451.

3. Milliken v. Pratt, 125 Mass. 374, 28 Am. Rep. 24l. See, also, Baldwin v. Gray, 16 Martin (La.), 192; Saul v. Creditors, 17 Martin (Ia.), 569, 597; Andrews v. Creditors, 11 La. Ann. 464, 476; Compare Armstrong v. Best, $112 \mathrm{~N}$. Car. 59, 17 S. E. 14, 34 Am. St.
Rep. 473; Jolumson v. Gawtry, 11 Mo. App. 322; Bank v. Williams, 45 Miss. 618.

4. First Nat. Bank v. Mitchell, 84 Fed. Rep. 90, 180 U. S. 471, 21 S. Ct. 418.

5. Bowles r. Field, 78 Fed. Rep. 742; Milliken v. Pratt, 125 Mass. 374, 28 Am. Rep. 241 ; Bell v. Packard, 69 Me. 105, 31 Am. Rep. 251.

6. First Nat. Bank v. Mitchell, 84 Fed. Rep. 90, 180 U. S. 471,21 S. Ct. 418 . 
and forum will be substituted for the lex loci celebrationis, upon the ground that the policy of protection to the married women of the State is too important a policy to be set aside by a foreign law. ${ }^{7}$ But where the laws of the domicil and formm only declares a few of a married woman's contracts roid, a suit there upon a contract made in another State where it is valid, which contract is beyond her capacity under her domiciliary law, the contract will still be enforced against her, even at her domicil. Because the enforcement of the protective policy is of less importance to the community than the general policy of recognizing the binding effect of contracts and the sovereignty of another State over matters within its jurisdiction. ${ }^{8}$ So the rule is different where the married woman's capacity is total or partial. So if her contract is only voidable in her domiciliary courts, the lex celebrationis will be enforced there.

Where the common law prevails in full force, making a married woman totally incapable of entering into a contract, her incapacity must be considered as so fixed by the policy of the State for the protection of its own citizens, that it will not yield to the law of another State in which she might contract. ${ }^{9}$

If the police of protection to its citizens, adopted by the law of the domicil and formm, is not so pronounced as to make an infant's contract roid, but only voidable, the liability of an infant upon his contracts is to be determined, even in the courts of his domicil, by the lex celebrationis of his contract, and not by the law of the domicil and formm. ${ }^{10}$

Contracts of suretyship are governed by the law where executed. ${ }^{11}$ But it is not always clear where the execution was.

7. First National Bank v. Shaw, 100 Tenn. 237,70 S. W. 867 , 59 L. R. A. 498 ; Case r. Dolge, 18 R. I. 661,29 A. 785 ; Baum v. Birchall, 150 Pa. St. 164, $2+$ A. 620, 30 Am. St. Rep. 797; Hanover Nat. Bank v. Howell, 118 N. Car. 271, 23 S. E. 1005; Bowles v. Fields, is Fed. Rep. 742 .

8. Milliken v. Pratt, 125 Mass. 374, 2S Am. Rep. 241; Bell v. Pack- ard, 69 Me. 105, $31 \mathrm{Am}$. Rep. 251.

9. First Nat. Bank v. Shaw, 109 Tenn. 237, 70 S. W. 807,59 L. R. A. 498 ; Minor's Conf. L.. p. 147.

10. Thompson v. Ketcham, S Johns. (X. Y.) 189; Wilder's Succession, 22 La. Ann. 219. 2 Am. Rep. 721 ; Male $r$. Roberts, 3 Esp. 163.

11. Pingrey's Suretyship and Guar. 93. 
Thus, a manried woman's contract as surety on a note is governed by the law of the place of signing and delivery to payee, though the note is payable in another State and, as against the maker has no valid inception until its negotiation in the latter State, provided the surety hald no knowledge of its negotiation there, or intention that her contract shall be governed by the laws of that State. ${ }^{12}$ The lex loci contractus will also govern her contract, if she is not under total disability to contract at her domicil. Thus, a married woman became a guarantor for lier husband in Maine where her contract was valid; she was sued on this contract in Massachusetts, her domicil, where she could not make such a contract, and the contract was enforced. ${ }^{13}$ She was not totally disabled to contract in Massachusetts. If she had been totally unable to contract at her domicil, the contract would not have been enforced against her. ${ }^{14}$ So where there is a written promise of a married woman, domiciled in New Jersey, to pay a sum of money to the order of her husband, signed by her at her domicil, and carried by him with her acquiescence, to New York, and there endorsed, and there delivered in exchange for other notes in the State of New York, the capacity of the wife to bind herself by a contract of suretyship is to be determined by the law of New York. Such a contract is valid in New York and therefore can be enforced in any other State. ${ }^{15}$ Some other courts seem to decide contrary to this doctrine as to the situs of the contract, and hold that it is where the married woman signed the instrument. ${ }^{16}$ Thus, where a contract of guaranty is dated and signed by

12. Union Nat. Bank v. Chapman, 169 N. Y. 538, 62 N. E. 672 , 57 L. R. A. 513 and note, 88 Am. St. Rep. 664; First Nat. Bank v. Mitchell, 180 U. S. 471,21 S. Ct. 418.

13. Milliken v. Pratt, 125 Mass. 374, 28 Am. Rep. 241.

14. Armstrong v. Best, $112 \mathrm{~N}$. Car. 59,17 S. E. 14,25 L. R. A. 188.
15. Thompson v. Taylor, $66 \mathrm{~N}$. J. L. 253,49 A. 544,54 L. R. A. 585, ss Am. St. Rep. 485. See, also, Milliken v. Pratt, 125 Mass. 375 , 28 Am. Rep. 241; Bell v. Packard, 69 1le. 105, 31 Am. Rep. 251; Bowles v. Field, 78 Fed. Rep. 242; Skudder v. Bank, 91 U. S. 406.

16. Freeman's Appeal, 68 Conn. 533,37 A. 420,37 L. R. A. 452,57 Am. St. Rep. 112. 
others at Chicago, and to be performed in Illinois, and afterwards is sent to a married woman in Connecticut, who signed it in that State, and then gave it to her howstaml who delivered it in Illinois, the situs of the contract as to thr wife was in Connecticut, under whose laws she was not calpalle of making it, and therefore unenforcealle against her in any place. ${ }^{17}$ This doetrine was not accepted on appeal, and a majority of the appellate court said that the wife beeane liable in Illinois, although she could not be held according to law of her domicil if the contract had been executed there, that is, in Commecticut; that the question involved was one of general jurisdiction, in which case it was the duty of a Federal court to act independently of a State court deeision. ${ }^{18}$ Then the ease was taken to the United States Supreme Court, which reversed the United States Circuit Court of Appeals decision and affirmed the decision of the Cnited States Circuit Court. ${ }^{19}$ The court held that the law of the court of Connecticut should be followed. The question had beeu passed upon by the court of last resort of Comecticut, which held that the wife was not capaciated to make the contract; that it is not the place of delivery of a contract that always controls, but the power of delivery. Therefore, the wife having no legal capacity to deliver the contract to her husband or to any one, it was void. ${ }^{20}$ The United States Supreme Court held that the decision of the State court controlled and, therefore, the wife was not liable. As the bank of Illinois presented its claim in Connecticut, and as it was passed upon by the Connecticut court of last resort, the bank was bound ly the State decision though it had taken the case into the Federal courts, on the ground that a right, question or fact distinctly put in issue and directly determined by a court of competent jurisliction, as a ground of recovery, cannot be disputed in at subequent suit between the same parties

17. First Nat. Bank v. Mitehell, S4 Fed. Rep. 90.

18. 9.2 Fed. Rep. .76.5.

19. Mitehell r. Bank, 1 so $\mathrm{C}$. $\mathrm{s}$. 47.21 s. Ct. 418.
20. Freeman's Appeal, 68 Conn. 533, 37 A. 420.37 J. R. A. 452,57 Am. St. Rep. 11:2. 
or their privies; and even if the suit is for different canse of action, the right, question or fact once so determined must, as between the same parties or their privies, be taken as conclusively established, so long as the judgment in the first suit remains unmodified. ${ }^{21}$ The Connecticnt doctrine is against the weight of authority. The Connecticut doctrine is based on the assertion that the wife had no power to deliver the contract, so there was no legal delivery. In New York it is held that the contract of a married woman as surety on a note, is groverned by the law of the place where her signature is affixed and the instrument delivered to the payee, although the note is payable in another State and as against the makers has no valid inception until its negotiation in the latter State, if the surety or married woman has no knowledge that it is to be negotiated there or intention that her contract shall be governed by the laws of that State. ${ }^{22}$

\section{$\S$ 402. Chattel mortgage lien follows the property.- It is} the general rule that when the mortgagor removes to another State and takes the mortgaged property with him, the mortgage lien still attaches to the property, if the mortgage was duly executed in the former State. ${ }^{1}$

The general rule of comity as to this mortgage lien is not recognized in some States. In Louisiana, chattel mortgages are mnknown. So the court is not bound by the comity of nations to enforce a contract which, if made in this State, could not

21. Southern Pac. R. R. Co. v. United States, 168 U. S. 1, 18 S. Ct. 18.

22. Union Nat. Bank v. Chapman, 169 N. Y. 538,62 N. E. 672 , 57 L. R. A. 513 and note, 88 Am. St. Rep. 614. See Mutual Ins. Co. v. Cohen, 179 U. S. 262, 21 S. Ct. 106; Smith v. Ingram, 130 N. Car. 100, 40 S. E. 984,61 L. R. A. 878,132 N. Car. 959,44 S. E. 643,95 Am. St. Rep. 680.

1. National Bank v. Morris, 114
Mo. 255, 21 S. W. 511, 19 L. R. A. 463, 35 Am. St. Rep. 754; Bank v. Metcalf, 40 Mo. App. 501; Hinney v. Baldwin, 16 III. 108, 61 Am. Dec. 62 ; Smith v. Whitaker, 23 Ill. 369 ; Roundtree v. Baker, 52 Ill. 241, 4 Am. Rep. 597; Mumford v. Canty, 50 Ill. 370, 99 Am. Dec. 525; Wolf v. Shannon, 50 Ill. App. 396; Clough v. Kyne, 40 Ill. App. 234; Craig v. Williams, 90 Va. 500, 18 S. E. 899, 44 Am. St. Rep. 934; Hubbard v. Andrews, 76 Ga. 177; 
defeat the rights acquired by attachment laws. This lien is not recognized in Louisiana. ${ }^{2}$

In Penusylvania chattel mortgages are not in general use, and a chattel mortgage made in another State and valid there, may be enforced in Pennsylvania as between the parties, yet it eannot be enforced as against a creditor or purchaser who has acquired rights in the property after it has been brought into the State. ${ }^{3}$

In Michigan and Tennessee chattel mortgages are recognized and executed as in other States, but the rule adopted is in conflict with that accepted in other States. So if mortgaged property is carried into Michigan or Tennessee the legal execution of the mortgage in another State is no notice to purchasers or creditors of that State. ${ }^{4}$ In Tennessee actual notice of such mortgage will protect the mortgage in the other State.

So if the chattels are in another State and the mortgage is void there, but valid at the lex loci contractus, the lex fori et situs will usually govern upon the ground that the enforcement according to the lex loci contractus would contravene the policy of the forum or work injury to its citizens. ${ }^{5}$

Bank v. Lee, 13 Pet. (U. S.) 107; Beale v. Williamson, 14 Ala. 55; Jones v. Taylor, $30 \mathrm{Vt}$. 42; Wilson v. Carson, 12 Md. 54; Barker v. Stacy, 25 Miss. 477; Smith v. MeLean, 24 Iowa, 322 ; Offutt v. Flagg, 10 N. H. 46 ; Hornthal v. Burwell, 109 N. Car. 10, 13 S. E. 721, 13 L. R. A. 740 and note, 26 Am. St. Rep. 556; Handley v. Harris, 48 Kans. 606, 29 P. 115, 30 Am. St. Rep. 322; Feurt v. Rowell, 62 Mo. 524; Keenan v. Stimpson, 32 Minn. 377, 20 N. 364; Kanaga v. Taylor, 7 Ohio St. 134, $70 \mathrm{Am}$. Dec. 62 and note; Parr v. Brady, 37 N. J. L. 201 ; Cool v. Roche, 20 Neb. 550, 31 N. W. 367 ; Ryan v. Clanton, 3 Strob. (S. Car.) 4l3; Ferguson v. Clifford, 37 N. H. 87; Norris v. Sowles, 57 Vt. 360; Pingrey on
Chat. Mort. 410. See, also, Ballard v. Winter, 39 Conn. 179; Langworthy v. Little, 12 Cush. (Mass.) 111; Barrows v. 'Turner, 50 Me. 127 ; Iron Works v. Warner, 76 Ind. 512, 40 Am. Rep. 258.

2. Delop v. Windsor, 26 La. Ann. 185; Hughes v. Klingender, $14 \mathrm{La}$. Ann. 845.

3. MeCabe v. Blymyre, 9 Phila. (Pa.) 615 ; Jeter v. Fellows, $32 \mathrm{~Pa}$. St. 465 .

4. Boydson v. Goodrieh, 49 Mieh. 65, 12 N. 913; Montgomery v. Wright, 8 Mieh. 143; Snider v. Yates (Tenn.), 64 L. R. A. 353. See, also, Corbett v. Littlefield, 84 Mich. 30,47 N. IV. 581, 11 L. R. A. 95, 22 Am. St. Rep. 681.

5. Green v. Van Buskirk, 5 Wall. (U. S.) 307 ; Chillingworth v. Tin- 
In some States a chattel mortgage gives a mere lien, and does not convey the title with a defeasance. In these States the lien giren by the lex loci contraclus, thongh valid as between the parties, has no priority over domestic creditors of the mortgagor, recognized by the law of the last situs of the chattels and of the formm. ${ }^{6}$

In cases of the sale of chattels with a reservation of title in the vendor until the price is paid, the rule is that the law of the place where the subsequent dealings occur will govern.?

$\S 403$. Conveyance of real estate.-The law of the sovereignty in which the realty is sitnated governs as to the transfer of such property. whether conveyed absolutely or by mortgage. ${ }^{1}$ And so if a mortgage is executed in one State where it is invalid, if it is valid in the State where the land lies, it is sufficient and will be enforced in the latter. ${ }^{2}$ But where the conveyance of title is not involved the note is governed by the law of the place where payable. Thus, a note payable in Missouri is governed by the Missouri statute allowing four per cent. damages upon protested notes, although secured by a mortgage of Illinois land; and this notwithstanding the statute of Illinois proxides that when any written contract wherever payable shall be secured by mortgage on land in this State, it may bear any rate of interest allowed to be taken in this State. ${ }^{3}$

ware Co., 66 Conn. 306, 33 A. 1009 ; Smith v. Smith, 19 Gratt. (Va.) 545.

6. Cronan v. Fox, 50 N. J. I. 417, 14 A. 119 . See Walworth $v$. Harris, 129 U. S. 355,9 S. Ct. 340 .

7. Harvey v. Locomotive Works, 93 U. S. 664; Marvin Safe Co. v. Norton, 48 N. J. I. 412, 7 A. 418 , $57 \mathrm{Am}$. Rep. 566 and note. See "Conflict of Laws as to Sales of Live Stock in One State, Held Under Chattel Mortgage in Another." -54 Cent. L. J. 443.
1. Swank v. Hufnagle, 111 Ind. 453,12 N. 1. 303 ; Otis v. Gregory, 111 Ind. 504, 13 N. E. 39; Brown v. Bank, 44 Ohio St. 269,6 N. E. 648; Gates v. Gaither, 46 La. Am. 286,15 So. 50 ; Goddard v. Sawyer, () Allen (Mass.), 78; United States v. Crosby, 7 Cranch (U. S.), 115; ('nited States v. Fox, 94 U. S. 320 ; Commercial Bank v. Jackson, 7 Dak. 135, 63 N. IV. 54 S.

2. Post v. Bank, 138 Ill. 559, 28 N. E. 978 .

3. Guiguon v. Trust Co., 156 Ill. 135, 40 N. E. 556, 47 Am. St. Rep 186. 
In the abscnce of eridence explanatrory of the transaction the presumption is that the payment of the proceerls of a loan and the delivery of the note and mortgage are contemporaneons acts, and that the note is not a foreign contract although it appears from its face to have heen executed in one State some days previous to the execution of the mortgage in another State. ${ }^{4}$

The rights and obligations under acts passed in one State to be exercised in another, respecting transfer of real estate in the latter, are regulatel, in point of form, substance, and validity, by the laws of the State in which snch acts are to have effect. ${ }^{5}$ And so the law of the place where the land is situated, will govern the right of the parties in the enforcement of a covenant, in so far as it relates to the question of the corenant running with the land. ${ }^{6}$ Likewise the construction of a mortgage foreclosed in Nebraska on Towa lands will be in accordance with the law of Iowa, and so the proceeds arising from the sale of such land will be applied first to the payment of the notes in order of time in which they fall due. ${ }^{7}$

The general rule is that the lex situs must control so far as the covenants of the title rumning with the land are concerned. ${ }^{8}$ In Indiana the lex celebrationis of the cevenant is also lex solutionis, and must govern. ${ }^{9}$

The lex situs will govern the obligation of a contract to convey, the contract being made in another State. ${ }^{10}$ So a mechanic's lien is governed by the lex situs of the land on which the lien rests. ${ }^{11}$

4. Stark v. Olsen, 44 Neb. 646 , $63 \mathrm{~N} . \mathrm{W}, 37$.

5. Succession of Larendon, 39 La. Ann. 952, 3 So. 219; Succession of Cassidy, 40 La. Ann. 827, 5 So. 292.

6. Riley v. Burroughs, 41 Neb. 296,59 N. W. 929.

7. Whipple v. Fowler, 41 Neb. $675,60 \mathrm{~N} . \mathrm{W} .65$.

8. Tillotson v. Prichard, $60 \mathrm{Vt}$. 94, 14 A. 302, 6 Am. St. Rep. 95;
Succession of Cassidy, 40 La. Ann. 827, 5 So. 292.

9. Worley v. Hineman, 6 Ind. App. 240, 33 N. E. 260 ; Jackson v. Green, 112 Ind. 341,14 N. E. 89.

10. Ruslı r. Lander, 107 La. Ann. 549, 32 So. 95, 57 L. R. A. 353; Garden City Sand Co. v. Miller, 157 Ill. 225, 41 N. E. 753; Carnegie v. Morrison, 2 Met. (Mass.) 381.

11. Campbell r. Coon. $149 \mathrm{~N}$. Y. 
If the lex situs of the land requires a sale to be in writing, making the contract void if not in writing, the lex situs must govern. ${ }^{12}$ But there is no reason why the personal contract should not be enforced, according to the lex celebrationis, and specific performance may be decreed in a third State, and probably at the situs of the property $;^{13}$ or the promisee waiving all right to the land may recover damages. In such case, the lex celebrationis should govern, whether the action be brought in the courts of the situs of the locus celebrationis, of a third State. ${ }^{14}$ Where a married woman must be examined separate and apart from her husband, the lex situs must govern, as to the validity of the deed. ${ }^{15}$

$\S$ 4.04. Insurance contracts.-Contracts for the insurance of property against loss by fire is a mere contract for indemnity in case of loss, and in no way attaches to or affects title to such property. 1 And an insurance company of a State, within the State, may make a valid contract of insurance upon property of another party of the same State, although such property is situated in another State in which the insurance company has no authority to do business. ${ }^{2}$

And so when an insurance company takes a risk in another State, it voluntarily submits itself to the laws of that State as to the service of process upon it $;^{3}$ and it is not necessary that

556,44 N. E. 300,38 L. R. A. 410 and note; United States Invest. Co. v. Windmill Co., 54 Kan. 144, 37 P. 982.

12. Polson v. Stewart, 167 Mass. 211,45 N. E. 737,36 L. R. A. 771, 57 Am. St. Rep. 552.

13. Polson v. Stewart, 167 Mass. 211, 45 N. E. 737,36 L. R. A. 771, 67 Am. St. Rep. 552.

14. Wolf v. Burke, 18 Colo. 264, 32 P. 427,19 L. R. A. 792 and note; Miller v. Wilson, 146 Ill. 523, 34 N. E. 1111,37 Am. St. Rep. 186; Carnegie v. Morrison, 2 Met.
(Mass.) 381; Minor's Conf. L. 416, 417 ; Story's Conf. L., sec. 372d; Wharton's Conf. L., sec. 276a.

15. Smith v. Ingram, $130 \mathrm{~N}$. Car. 100, 40 S. E. 984,61 L. R. A. 878 , 132 N. Car. 959,44 S. E. 643, 95 Am. St. Rep. 680.

1. Darrell v. Tibbitts, 5 Q. B. Div. 560 ; Stanhilber v. Ins. Co., 76 Wis. 291, 45 N. W. 221.

2. Seamons v. Knapp Co., 89 Wis. 171,61 N. W. 757, 27 L. R. A. 362, 46 Am. St. Rep. 825.

3. Fireman's Ins. Co. v. Thompson, 155 111. 204,40 N. E. 488,46 
the right of service of process upon foreign insurance companiez doing business within a State should be dependent upon their first taking out a license to do business. ${ }^{4}$

If a place is designated for the payment of insurance money that is the locus solutionis. If the policy is in general terms, with no such place lesignated, then the locus solutionis, as is generally held, will be presumed to be the same as the locus celebrationis. ${ }^{5}$

Other cases hold that in case of insurance on buildings, the situs of the land is the locus solutionis. ${ }^{6}$ Other cases hold that where the insurance is only on personal property or on life, the domicil of the insurer is the locus solutionis. ${ }^{7}$ If the policy is binding as soon as issued or on approval of the company, the celebrationis is where the policy is issued or approved by the company. ${ }^{8}$

An insurance policy, like other contracts, is completed when delivered, and the place of delivery is the locus celebrationis. However, if the insured is to be notified by mail or otherwise that the risk is accepted, the place of the delivery of the policy is immaterial. ${ }^{10}$ If the policy is to be mailed to the insured,

Am. St. Rep. 335; State v. Indemnity Asso., 62 Wis. 174, $22 \mathrm{~N}$. W. 135 .

4. State v. Mut. Accident Asso., 67 Wis. 624,31 N. W. 229 ; Gibbs v. Ins. Co., $63 \mathrm{~N}$. Y. 114, $20 \mathrm{Im}$. Rep. 513; Pope v. Terre Haute, etc. Co., 87 N. Y. 137; Osborne v. Ins. Co., 51 N. Y. 278; MeNichol v. U. S. ete. Asso., 74 Mo. 4.5; Thoneux v. Corporation, L. R. 33 (h. Diy. 446; Griesemer v. Ins. Co., 10 Wash. 202, 38 P. 103].

5. Seamans v. Knapp Co., 89 Wis. 171,61 N. W. 757,46 Am. St.

Rep. 825,27 L. R. A. 362.

6. Gibsou v. Ins. Co., 77 Fed. Rep. 561 .

7. Inights Templars Asso. v. Greene, 79 Fed. Rep. 461; Wood v.
Ins. Co., 8 Wash. 427,36 P. 267, 40 Am. St. Rep. 917.

8. Voorhies v. Society, 91 Mich. 469,51 N. W. 1109 ; State, etc. Ins. Co. v. Brinkley, 61 Ark. 1, 31 S. E. 157, 54 Am. St. Rep. 191; Equitablo, etc. Society v. Redding, 83 Fed. Гep. 85,27 C. C. A. 404,48 U. S. App. 565.

9. Equitable, etc. Soe. v. Clements, 140 U. S. 225, 11 S. Ct. 822; Mutual I. Ins. Co. $v$. Cohen, 179 U. S. 262,15 S. Ct. 106 ; Perry v. Ins. Co., 67 N. H. 291, 33 A. 731, $68 \mathrm{Am}$. St. Rep. 668; Hicks v. Ins. Co., 60 Fed. Rep. 690,9 C. C. A. 215; In re Breitung. 78 Wis. 33,46 N. W. 891,47 N. W. 17.

10. Perry v. Ins. Co., 67 N. H. 291, 33 A. 731, 68 Am. St. Rep. 668 . 
then delivery is at the place of mailing; if mailed to a third person to be delivered, then the delivery takes place in the State where delivered. ${ }^{11}$ If the poliey only beeomes binding on payment of first premium, then the place where paid is the locus celebrationis. ${ }^{12}$ Or if the poliey is to be countersigned by an agent, or something else is to be done, the locus celebrationis is where the act is performed. ${ }^{13}$

A stipulation that the non-payment of premiums shall avoid the contract, is goverued by the lex celebrationis of the contraet ${ }^{14}$ though it has been held that the lex celebrationis is the place whose law the parties had in mind. ${ }^{15}$ If the policy provides that the suicide of the insured shall avoid the policy it is void in another State, if void by the Tex celebrationis. ${ }^{16}$ If the eontract is made in one State, the stipulation to submit the parties to another law is of no validity, because the law of the situs governs the validity of the eontract. If the parties desire a different law to govern their eontract they must go into another jurisdiction. ${ }^{17}$ And whether a party has an insurable interest in another's life is governed by the lex celebrationis. When there is no positive law to the contrary, the designating a beneficiary in a life policy is to be governed by the lex domicillii of the assured. ${ }^{18}$

The validity of premium notes depend upon the validity of

11. Equitable, etc. Soc. v. Clements, 140 U. S. 226,11 S. Ct. 822.

12. Equitable, etc. Soc. v. Clements, 140 U. S. 226,11 S. Ct. 822 ; Mutual L. Ins. Co. v. Cohn, 179 U. S. 262, 21 S. Ct. 106; Mandon v. Ins. Co., 85 Iowa, 584, $52 \mathrm{~N}$. W. 509, 39 Am. St. Rep. 316; Ford v. Ins. Co., 6 Bush. (Ky.), 133, 99 Am. Dec. 663 and note.

13. Gibson v. Ins. Co., 77 Fed. Rep. 561; Heebner v. Ins. Co., 10 Gray (Mass.), 131, 69 Am. Dec. 308.

14. Wall v. Equitable Soc., 32 Fed. Rep. 273; IIicks v. Ins. Co., 60 Fcd. Rep. 690, 9 C. C. A. 215.
15. Finney v. Ins. Co., 67 Fed. Rep. 493.

16. Knights Templar Indem. Co. v. Berry, 50 Fed. Rep. 511; Na. tional Union v. Marlow, 74 Fed. Rep. 775.

17. Perry v. Ins. Co., 67 N. H. 291, 33 A. 737, 68 Am. St. Rep. 668; Penn Mut. L. Ins. Co. v. Trust Co., 72 Fed. Rep. 413, 38 L. R. A. 33 and note.

18. Masonic Asso. v. Jones, 154 Pa. St. 107,26 A. 255; Knights Templars Asso. v. Greene, 79 Fed. Rep. 461 ; Mullen v. Reed, 64 Conn. 340.29 A. 478,25 J. R. A. 694. 
the contract of insurance. So if the conntract is phohibited in one State where made, it will not be enforced in annther State, and the notes will be invalid. ${ }^{19}$ But if valid where marle, and in direct violation of the laws of the State where the property has its situs and where the insured resides, it will not be enforeed in the latter State. ${ }^{20}$

However, this doctrine does not apply to a foreign policy, which, by statute, must have a correct copy thereof attached to it; such provision has no bearing on policies issued by foreign companies in other States, although they were on lives of persons domiciled in the State where the statute was enacted. ${ }^{21}$

$\S 405$. Assignment of policy of insurance.-Assignment of a life insurance policy is governed by the law of the place where the assignment is made, and not by the law of the place where the poliey is issued or insurance payable. ${ }^{1}$ In general an assignment of a poliey of insurance is not governed by the rules of law different from those in cases of assignment of choses in actions. If the assignment is void when made, though valid where the policy was issued, it will be void in the latter place also. ${ }^{2}$ Thus, when a Massachusetts corporation has issued an endowment poliey insuring a lusband's life for a period of time, payable to the wife, if living, in ease of husband's death during the endowment period, which was assigned by the husband and wife, who reside in New York, the laws of the latter State govern the validity of the assignment. ${ }^{3}$

19. Ford v. Ins. Co., 6 Busn (Ky.), 133, 99 Am. Dec. 663 and note; Blackwell v. Webster, 29 Fed. Rep. 614.

20. Swing v. Munson, $191 \mathrm{~Pa}$. St. 582,43 A. 342,59 L. R. A. 223 , 71 Am. St. Rep. 772.

21. Johnson v. Ins. Co., 180 Mass. 407,62 N. E. 733,63 L. R. A. 833.

1. Miller v. Campbell, 140 N. I. 457,35 N. E. 651 ; Criswell v. Wl:it- ney, 13 Ind. App. 67, 41 N. E. 78; Lee v. Abdy, 17 Q. B. Div. 30 ?.

2. Lee $v$. Abdy, 17 Q. B. Div. 309 ; Prentice v. Steele, 4 Montreal L. R. 319 ; Union Central Life Ins. Co. v. Woods, 11 Ind. App. 335,37 N. E. 180,39 N. E. 205.

3. Miller v. Campbell, 140 N. X. 457, 35 X. H. 651; In re Breitung, is Wis. 33,46 N. W. 891,47 N. W. 17. 
$\S$ 406. Assignment of property.-The general rule of law is that if a voluntary conveyance of personal property is valid by the law of the State where made, it passes the title wherever the property may be situated, and this rule is applicable to cases of voluntary assignment for the benefit of creditors. ${ }^{1}$

When a transfer of property is valid by the law where the vendor resides and the property is situated, though it would not be if executed in another State, the title is not displaced by subsequent removal of the property to the latter State, even as to creditors residing in the latter State seeking a remedy against it. ${ }^{2}$

The lex loci contractus governs the transfer, though the property be situated in another State, except when the enforcement of lex loci contractus would contravene public policy of the actual situs and forum, or would work injury or injustice to the citizens of the State. Then this law cannot govern and the courts will administer the lex fori. ${ }^{3}$

In regard to land the validity of the conveyance to pass title is governed by the lex situs, but the effect as an assignment is to be determined by the lex loci contractus, unless the enforcement of this law would contravene public policy or work injustice or injury to the citizens of the forum. ${ }^{4}$ However, some of the cases hold that the lex situs of the land controls under all circumstances. ${ }^{5}$ Resident creditors may always take advan-

1. Covey v. Cutler, 55 Minn. 18, 56 N. IV. 255; Pritchard v. Norton, 106 U. S. 124, 1 S. Ct. 102 ; Hanford v. Paine, 32 Vt. 442, 78 Am. Dec. 586 and note; Barnett v. Kinney, 147 U. S. 476,13 S. Ct. 403 ; Frazier v. Fredericks, $24 \mathrm{~N}$. J. L. 162 .

2. McKibben v. Ellingson, 58 Minn. 205, 59 N. IV. 1003, 49 Am. St. Rep. 499; Cragin v. Lamkin, 7 Allen (Mass.), 395 ; Cook v. Van Horn, 81 Wis. 291, 50 N. W. 893 ; May v. Wannamacher, 111 Mass. 202. See, also, Thompson v. Ellenz, 58 Minn. 301, 59 N. W. 1023.
3. Barnett v. Kimney, 147 U. S. 476, 13 ↔. Ct. 303; Egbert v. Baker, 58 Conı. 319, 20 A. 466; Frank v. Bobbitt, 155 Mass. 112, 29 N. E. 209; Walters v. Whitlock, 9 Fla. 86, 76 Am. Dec. 607.

4. May v. Bank, 122 Ill. 551,13 N. E. 806 ; Chafee v. Bank, 71 Me. 514, 36 Am. Rep. 345; Thornton v. Rosenfeld, 42 Mo. 474, 97 Am. Dec. 351.

5. Moore v. Church, 70 Iowa, 208, 30 N. W. 855, 59 Am. Rep. 439; Augusta Sav. Bank v. Stellings, 31 S. Car. 360,9 S. E. 1028. 
tage of the invalidity of the assignment under the lex fori et situs, validly executed in another State. ${ }^{6}$

Many cases make no difference whether the creditors aro citizens of the forum or non-residents, in substituting the lex fori for the lex celebrationis. ${ }^{7}$ But some of the court decide that the citizens of the locus contractus must abide by their own laws, giving the benefits of the lex fori et situs to all other creditors. $^{8}$

Involuntary assignment, if the title once vests in the assignee, and is not invalid by the lex fori et situs, is valid in every jurisdiction, as a legal exercise of the owner's rights to convey his property. ${ }^{9}$

Involuntary assignments pass the title to the assignee only of property within the State. This is the American doctrine. ${ }^{10}$ But where the rights of foreign creditors are not concerned, the lex domicillii will be recognized in other jurisdictions. ${ }^{11}$ However, if the property is non-negotiable chose in action, the assignee cannot sue in his own name unless the lex fori permits it. ${ }^{12}$

The lex fori demands the payment of taxes of the situs et

6. Green v. Iron Works, 49 N. J. Eq. 48, 23 A. 498; Woodward v. Brooks, 128 Ill. 222, 20 N. E. 685 , 3 L. R. A. 702 and note, $15 \mathrm{Am}$. St. Rep. 104.

7. Barth v. Backus, 140 N. Y. 230,35 N. E. 425,23 I. R. A. 47,37 Am. St. Rep. 545; Woodward v. Brooks, 128 Ill. 222, 20 N. E. 685, 3 L. R. A. 702 and note, 15 Am. St. Rep. 106; Augusta Bank v. Stellings, 31 S. Car. 360,9 S. E. 1028; First Nat. Bank v. Walker, 61 Conn. 154, 23 A. 696.

8. Cole v. Cunningham, 133 U. S. 107,10 S. Ct. 269; Woodward v. Brooks, 128 Ill. 222, 20 N. E. 685, 3 I. R. A. 702 and note, $15 \mathrm{Am}$.
St. Rep. 104; Faulkner v. Hymes, 142 Nass. 53,6 N. E. 846.

9. Askew v. Bank, 83 Mo. 366, 53 Am. Rep. 590; First Nat. Bank v. Walker, 61 Conn. 154, 23 A. 690 ; Crapo v. Kelly, 16 Wall. (U. S.) 622; Law v. Mills, 18 Pa. St. 185.

10. Crapo v. Kelly, 16 Wall. (U. S.) 610 ; Booth v. Clark, 17 How. (U. S.) 322 ; Paine v. Lester, 49 Coun. 196, 26 Am. St. Rep. 442.

11. Willetts v. Waite, $25 \mathrm{~N}$. Y. 583 ; Kirkland v. Lowe, 33 Miss. 423, $69 \mathrm{Am}$. Dec. 355 .

12. Mnlne v. Noreton, 6 Binn. (Pa.) 353, $6 \mathrm{Am}$. Dee. 466; Kirkland v. Lowe, 33 Miss. 423, $69 \mathrm{Am}$. Dece. 355. 
forum $^{13}$ and debts due to residents. ${ }^{14}$ And many of the courts give the privilege to non-resident creditors. ${ }^{15}$

In England the doctrine is sustained that an involuntary assignment conveys title in every jurisdiction, even against creditors resident in the actual situs et forum. ${ }^{16}$

$\S 407$. As to the situs of personal property.-Formerly it was held in England that personal property has no situs, and that with respect to the disposition and to the transmission of it, either by succession or act of the party, it follows the law of the person. ${ }^{1}$ But there has been a departure from this rule, as shown in the preceding section, and now a distinction is drawn between cases of succession, as in marriage, death and bankruptcy, where the property follows the person and so governed by the law of his domicil, and isolated transactions of alienation and the creation of special claims against the property, in which it is to be considered independently of its owner and so governed by the law where it is situated, lex rei sitae.

The present rule is this, that questions as to the transfer or acquisition of property in corporeal movables, or of any less extensive real rights in them, as pledge or lien, are generally decided by lex rei sitae. ${ }^{2}$

So as to priority of conflicting claims or liens, lex rei sitae prevails, the right of priority being a personal privilege, dependent on the place where the property has its actual situs

13. Harrison v. Sterry, 5 Cranch. (U. S.), 289.

14. Sturtevant v. Armsby Co., 66 N. H. 557, 23 A. 368, 49 Am. St. Rep. 627; May v. Bank, 122 Ill. 551,13 N. E. 806; Long v. Girdwood, 150 Pa. St. 413,24 A. 711,23 L. R. A. 33 and note.

15. Cole v. Cunningham, $133 \mathrm{U}$. S. $167,10 \mathrm{~S}$. Ct. 269; Barth v. Backus, 140 N. Y. 230, 35 N. F.
425, 23 L. R. A. 47, 37 Am. St. Rep. 545; Blake v. Williams. 6 Pick. (Mass.) 286, 17 Am. Dec. 372.

16. Paine v. Lester, 44 Conn. 196, 26 Am. Rep. 442; Booth v. Clark, 17 How. (U. S.) 322.

1. Sill v. Wooswick (179l), $1 \mathrm{H}$. B1. 665 .

2. Inglis v. Usherwood, 1 East, 515; Coote v. Jeeks, L. R. 13 Eq. 597. 
and where the court sits which has juriscliction. ${ }^{3}$ So in case there is a confliet between two States upon an assignment for the benefit of ereditors, made in one State, and an attachment of the property of the assignor in the other State, lex rei sitae, or aetual situs governs. ${ }^{4}$

The reason for applying the lex rei sitae or alctual situs to movables, is for the protection of citizens of the actual situs of the personalty. ${ }^{5}$ So in voluntary or involuntary assignments for benefit of creditors, lex rei sitae will govern. Thus, preferences will be denied under a voluntary assignment made in Minnesota for the benefit of creditors, to non-resident pledgees, who hold grain warehouse receipts as seeurity for promissory notes, the grain having its actual situs in Iowa, Nebraska, and South Dakota, where such pledge was invalid, because the transaetion was governed by lex rei silae, or actual situs of the grain. ${ }^{6}$

The old fietion, mobilia personam sequntur, has been rendered obsolete, as personal property, under certain conditions, has an actual as well as a legal situs. ${ }^{7}$

3. Harrison v. Sterry, 5 Cranch (U. S.), 289.

4. Warner v. Jeffray, $96 \mathrm{~N}$. Y. 248, 48 Am. Rep. 616; Green v. Van Buskirk, 5 Wall. (U. S.) 307.

5. Blake v. Williams, 6 Pick.
(Mass.) 286, 17 Am. Dec. 372; Taylor v. Boardman, 25 Vt. $58 \mathrm{I}$.

6. Swedish-Am. Nat. Bank v. Bank, 89 Minn. 98, 94 N. IV. 218.

7. Whar. Conf. L., pp. 297, 305 ; Westlake Priv. Int. L., p. 172: Savigny, VIII, sec. 366 . 


\section{ARTICLE II.}

\section{Exceptions to tile General Rule.}

Section 408. Exceptions to General Rule.

409. Selling Intoxicants.

410. Carriers-Stipulation Exempting from Negligence.

411. Interstate Commerce.

412. Sunday Contracts.

413. Gaming-Futures.

414. Smuggling Contracts.

415. Enforeing Revenue Laws of Another Country.

416. Repeal of Statute.

417. Usurious Contracts.

418. Void Usurious Contracts.

$\S 408$. Exceptions to general rule.-In general the validity of a contract is to be determined by the law of the place where it is made. If valid there, it is, by the general law of nations, held to be valid everywhere, by the tacit or implied consent of the parties; if void or illegal there, as a general rule, it is held void and illegal everywhere. The exceptions to this rule as to the validity of contracts is, that contracts which are in evasion or fraud of the laws of a country, or of the rights or duties of its subjects; which are against good morals, or against religion, or against public rights; and those opposed to the national policy or national institutions;-are declared affected by such considerations though they may be valid by the laws of the place where they are made. ${ }^{1} \quad$ A contract which has for its object the performance of an act which is prohibited by express stat-

1. Gist v. Tel. Co., 45 S. Car. 344 , 23 S. E. 143, 55 Am. St. Rep. 763 and note; Story on Confl. of L. 242244; Andrews v. Herriot, 4 Cow. (N. Y.) 508, 510; 2 Kent's Com. 457 ; Whitney v. Whitney, $35 \mathrm{~N}$. H. 457; Armstrong v. Best, 112 N. Car. 59,17 S. E. 14,25 L. R. A. 188,34 Am. St. Rep. 473; Oscanyan v. Arms Co., 103 U. S. 261; Bliss v.
Brainard, 41 N. H. 250; Phinney v. Baldwin, 16 Inl. 108, 61 Am. Dec. 62; Chewning v. Johnson, 5 La. Amu. 678, 52 Am. Dec. 610; Rousillon v. Rousillon, 14 Ch. D. 351 ; Klinek v. Price, 4 W. Va. 4, 6 Am. Rep. 268; Davis v. Bronson, 6 Iowa, 410; Thateher v. Morris, $11 \mathrm{~N}$. Y. 437 ; Flagg v. Baldwin, 38 N. J. Eq. 219. 
ute, or the commission of which incurs a penalty is as much illegal and void as if the statute in express terms had declared it to be so. ${ }^{2}$

A contract for the sale and delivery of merehandise in a State where such sale is not prohibited, may be sued in another State, where such merehandise eannot be lawfully imported. But if the delivery is to be in a State where the importation is interdicted, then the contract cannot be sued in the interdicting State, because the giving of legal effect to such contract will be repugnant to its rights and interest. And so if a foreign State allows marriages incestuous by the laws of nature, such marriage cannot be allowed to have any validity in the United States. But marriages not naturally unlawful, but prohibited by the laws of one State, and not of another, if celebrated where they are not prohibited, will be held valid in a State where they are not allowed. ${ }^{3}$

As stated, a contract valid by the law of the State in which it is made and is to be performed, is valid and enforceable everywhere, unless it is elearly contrary to good morals, or repugnant to the policy or positive statute of the jurisdiction in which it is sought to be enforced. ${ }^{4}$ However, if the contraet is valid and enforceable where made, yet if it is against the public policy or statute of a State where it is sued upon, the court will not enforce it. Thus, a court will not take jurisdiction of a case to charge a person on an unsigned representation as to the credit of another person, although it is valid where made, if the statute of the State of the forum provides that no suit shall be brought to charge one on such representation, unless it is in writing, signed by the party to be charged thereon. ${ }^{5}$

2. Territt v. Bartlett, 21 Vt. 184.

3. Greenwood v. Curtis, 6 Mass. 358, 378, 4 Am. Dec. 145.

4. Tilden v. Blair, 2l Wal. (U. S.) 241; Hill v. Spear, 50 N. II. 253, 4 Am. Rep. 205; Wayne County Sav. Bank v. Low, 81 N. Y. 566; Hawley v. Bibb, 69 Ala. 52; Stix v. Matthews, 75 Mo. 96; Burns v.
Railroad Co., 113 Ind. 169, $15 \mathrm{~N}$. E. 230 ; Flagg v. Baldwin, 38 N. J. Eq. 219, 48 Am. Rep. 308; Hyatt v. Bank, 8 Bush (Ky.), 193; Milliken v. Pratt, 125 Mass. 374,28 Am. Rep. 241.

5. Third Nat. Bank v. Steel, 129 Miel. 434; S8 N. IV. 1050, 64 L. R. A. 119. 
$\S 409$. Selling intoxicants.-It would be possible for an independent State to enforce all contracts made and to be performed within its territory, withont regard to how much they may contrarene the policy of the laws of other States. But no State has adopted this policy. As a general proposition, an agreement to break the laws of a foreign country is invalid. On this principle the courts hold a sale invalid when the contract contemplates a design on the part of the purchaser to resell contrary to the laws of a neighboring State, which is furthered by the vendor. ${ }^{1}$

It is not enough, however, as generaly held, to prevent a recovery of the price that the seller had reason to believe that the buyer intended to resell the goods in violation of law. ${ }^{2}$

So when a sale of intoxicating liquors in another State is made with a view to a breach of the law of another State, it is void. ${ }^{3}$ The right to contract with a view to a breach of the laws of another State of this Union ought not to be recognized as against a statute passed to carry out fundamental beliefs of right and wrong, shared by a large part of the American people."

1. Waywell v. Reid, 5 Term R. 599; Gaylord v. Soragen, $32 \mathrm{Vt}$. 110, 76 Am. Dee. 154; Fisher v. Lord, 63 N. H. 514, 3 A. 927; Hull v. Ruggles, 56 N. Y. 424.

2. Finch v. Mansfield, 97 Mass. 89 ; Adams v. Coulliard, 102 Mass. 167; Tracy v. Talmage, 4 Kernan (N. Y.), 162; Hodgson v. Temple, 5 Taunt. 181; MeIntyre v. Parks, 3 Met. (Mass.) 207; Sortnell v. Hughes, 1 Curtis, C. C. 244; Green v. Collins, 3 Cliff. 494; Hill v. Spear, 50 N. H. 253, 9 Am. Rep. 205 ; Dater v. Earl, 3 Gray (Mass.), 482; Compare Suit v. Woodhall, 113 Mass. 391; Pearse v. Brooks, L. R. 1 Exch. 213; Taylor v. Chester, L. R. 4 Q. B. 309, 311 .
3. Webster v. Munger, 8 Gray (Mass.), 584; Orcutt v. Nelson, 1 Gray (Mass.), 536; Hubbell v. Flint, 13 Gray (Mass.), 277 ; Aiken v. Blaisdell, 41 Vt. 655; Banchor v. Mansel, 47 Me. 58; Davis v. Bronson, 6 Iowa, 410; Adams v. Coulliard, 102 Mass. 107; Graves v. Johnson, 156 Mass. 211, $30 \mathrm{~N}$. E. 818,15 L. R. A. 834 and note, $32 \mathrm{Am}$. St. Rep. 446 and note.

4. Territt v. Bartlett, 21 Vt. 184. See, also, Banchor v. Mansel, 47 Me. 58; Graves v. Johnson, 156 Mass. 211, 30 N. E. 818,15 L. R. A. 834 and note, 32 Am. St. Rep. 446 and note, Aikens v. Blaisdell, 41 Vt. 655; Compare Brown v. Weiland, 116 Iowa. 711, 89 N. W. 171, 61 L. R. A. 417 and note. 
$\S 4$ I0. Carriers-Stipulation exempting from negligence.The Federal law of this country, by which stipulations of a common carricr exempting lim from the consequences of his own negligenee, are held to be extorted without and real assent of the shipper, and to be against public policy, and roid,-is controlling, in suits brought here upon instruments made here on board foreign ships, under bills of lading signed by foreigu masters, though such stipulations be valid by the law of the ship's country. ${ }^{1}$ So all stipulations made in this country designed to secure, directly or indirectly, the exemption of the carrier from the consequences of his own negligence, whether the carricr is a domestic or a forcign ship, are equally illegal and roid under the Federal law, ${ }^{2}$ and in the States. But such prohibition does not affect a contract made in one State for through shipment of a commodity to another State, when the charter of the carrier so contracting was granted in a third State and prohibited such stipulation. ${ }^{3}$

The State laws of exempting a carrier from liability are controlled by the lex loci celebrationis. In some States such stipulations are valid, ${ }^{4}$ in others they are roid. ${ }^{5}$ But this subject will be treated in another section. ${ }^{6}$

§ 4II. Interstate commerce.-In shipping merchandise from one State into another, interstate commerce brings the matter under the Federal law. So a citizen of one State has the right

1. Doherr v. The Etona, 64 Fed. Rep. 880 ; Monroe $v$. The Iowa, 50 Fed. Rep. 561; Hathaway r. The Brantford City, 29 Fed. Rep. 373.

2. Phoenix Ins. Co. v. Transp. Co., 117 U. S. $312,323.6$ S. Ct. 750 , 1176: The Hadji, 22 Bhatch. C. C. 235, 20 Fed. Repr. 875: New Jersey Steam Nar. Co. v. Bank, if Ilow. (U. S.) 344 ; Monroe v. The Iowa, 50 Fed. Rep. 561 ; Sloeum v. Assurance Co., t2 Fed. Rep. 2ast The Guildhall, 58 Fed. liep. 796: Doher: v. The Etona, 64 Fed. Rep. sso.
3. Thomas v. Railroad Co., 63 Fed. Rep. 200.

4. OKegan $v$. Cunard, ete. Co., 160 Mass. 356,35 X. E. 1070,39 Am. St. Rep. 4S4; Hazel v. R. R. Co., 82 Iowal, 47,45 N. W. 926.

5. Brockway v. Express Co.. 168 Mass. 257, 47 N. E. 83; Davis v. Railroad ('o., 9:3 Wis. 470, $67 \mathrm{~N}$. W. $16,1132,33$ l. I. A. $654,5 i$ Am. St. Rep. 935.

6. Seet. 421. This subject is often regulated by statute. 
to import beer into another State and sell it there in its oriminal packages; until sold by the importer it is not subject to State regulations, and a State law which forbids the sale of an imported article by the importer, in unbroken packages, is a regulation of interstate commerce and void. ${ }^{1}$ And so a State cannot prohibit a party from selling in its territory, by contract made there, his machinery manufactured in another State. ${ }^{2}$

But a statute prohibiting the manufacture or sale of intoxicating liquors, even for exportation, and prohibiting also the sale of imported foreign intoxicating liquor, unless in its original packages, is not in conflict with interstate commerce. ${ }^{3}$ Such contract being prohibited by the law of the State where made, is illegal and void there, and its invalidity constitutes a good defense in an action upon the contract in another State."

Sending lottery tickets from one State to another is interstate commerce and can be controlled by Congress. ${ }^{5}$

$\S 4$ r2. Sunday contracts. - Statutes against the performance of labor on Sunday do not invalidate a contract made in a State for labor to be performed on Sunday wholly outside of the State. ${ }^{6}$ So a vendor of personal property when sued upon his warranty, cannot defend upon the ground that the sale was mado on Sunday, if the sale occurred in a State where there was no law prohibiting the enforcement of Sunday contracts. ${ }^{7}$

If the statute declares such contracts void, a note made and delivered in a State on Sunday is void, although payable in another State. $^{8}$ But a contract made on Sunday in a State

1. Leisy v. Hardin, 135 U. S. 100, 10 S. Ct. 681.

2. Cooper Manuf. Co. v. Ferguson, 113 U. S. 727,5 S. Ct. 739.

3. Pearson v. Distillery Co., 72 Iowa, $348,34 \mathrm{~N}$. W. 1 ; Kidd $\mathbf{v}$. Pearson, 128 U. S. 1, 9 S. Ct. 6; Tredway v. Riley, 32 Neb. 495, 49 N. W. 268, 29 Am. St. Rep. 447.

4. Tredway v. Riley, 32 Neb. 495 , 49 N. W. 268.
5. Champion v. Ames, 188 U. S. 321, 23 S. Ct. 311, 26 Nat. Cor. Rep. 74.

6. Sảid v. Strowberg, 55 Mo. App. 438.

7. McKee v. Jones, 67 Miss. 405 , 7 So. 348.

8. Arbuckle v. Reaume, 96 Mich. 243, 55 N. W. 808. 
where it is valid is not against good morals and ean be cnforced in any State, ${ }^{9}$ where the statute does not prohilit.

§ 4r3. Gaming-Futures.-Option entracts are generally held roil. But a contract for the future delivery of commodities, made in a State and to be performer there for a principal residing in another State, is governed by the laws where it is made, and if ralid there it will be enforced in any other State, ${ }^{1}$ unless prohibited by statute. ${ }^{2}$ So commereial paper executed and issued in New York in the course of speculation in cotton options in that State, will be enforeed in Indiana in the hands of an innoeent holder, neither the statutes of either State declaring such paper roid in the hands of such holder. ${ }^{3}$

It is an unwarranted perversion of speeeh to hold that the consideration of a note which has been exeented to obtain money with which to purehase options, or to put up as margins in speculations, is money won by playing at a game or by betting on the hands of others who do play, or to repay money lent at the time and place of such play. However, much dealings in options may resemble gambling or betting, and demoralizing and pernicions as it may be, it cannot, with any degree of propriety, be said to be winning or losing money by playing at or betting upon any game, within the meaning of the statute. ${ }^{4}$

So statutes involving penal consequences cannot be extended by construetion so as to include aets not in terms forbidden, merely beeause of their resemblanee to the acts prohibited, or because they may be equally demoralizing and injurious. ${ }^{5}$

9. Swann v. Swann, 2l Fed. Rep. 299; Adams v. Gay, 19 Vt. 35S; Brown v. Browning, 15 R. I. 422 , 7 A. 403, 2 Am. St. Rep. 208; O'Rourke v. ORourke, 43 Mich. 58, 4 N. 531: Compare Gauthier v. Cole, 17 Fed. Rep. 716.

1. Lehman v. Feld, 37 Fed. Rep. 852 ; Ward v. Vosburgh, 31 Fed. Rep. 12.

2. Lemonius v. Mayer, $7 \mathrm{l}$ Miss.
514, 14 So. 33 ; Gist v. Tel. Co., 45 S. Car. 344,23 S. E. $143,55 \mathrm{Am}$. St. Rep. 763 and note.

3. Sondheim v. Gilbert, 117 Ind. 71, 15 N. E. 6s7, 10 Am. St. Rep. 23 and note, 5 L. R. A. 432.

4. White $v$. Barber, I23 U. S. 392,8 S. Ct. 221.

5. Shaw v. Clark, 49 Mieh. 3S4, 43 Am. Rep. 474. 
Hence, an option contract may be enforced in another State, where there is no statute prohibiting such contracts, either in the State of its inception or in the State where suit is brought to enforce it; it is not a gaming contract. ${ }^{6}$

If the consideration of a contract is a gaming debt, or the sale of lottery tickets, the validity depends upon the law of the situs of the consideration, which may not be the lex loci celebrationis or the lex loci solutionis. ${ }^{7}$ Hence, the validity of a note made in one State and payable there, giren in consideration of liquor sold and delirered to the maker of the note in another State, will be determined by the law of the latter State, so far as the sale of the liquor affeets it. The law of the place where the liquor is sold will govern the ralidity of the sale and the validity of the contract for the price. If the sale was invalid at the place where made, then the note is invalid. ${ }^{8}$ If the sale is valid there, then the note is valid, though the sale would have been invalid if made where the note was executed or where it was to be paid. ${ }^{9}$ In such case the lex celebrationis and the lex solutionis of the note had nothing to do with the matter as the sale was legal where made. So the validity of a contract, the consideration of which is the sale of a slave, will depend on the law of the place of sale, the lex loci considerationis. ${ }^{10}$

But where a note was given to settle a gambling debt, and valid in the hands of an innocent holder in New York, the innocent holder cannot enforce payment in Illinois, where a statute prohibits such contracts. ${ }^{11}$

6. Sondheim v. Gilbert, 117 Ind. 71,18 N. E. 687,5 L. R. A. 432,10 Am. St. Rep. 23 and note.

7. Peet v. Hatcher, 112 Ala. 514, 21 So. 711, 57 Am. St. Rep. 45; McIntyre v. Parks, 3 Met. (Mass.) 207.

8. Dolan v. Green, 110 Mass.
9. Webber v. Howe, 36 Mich. 150 , 24 Am. Rep. 590 ; Fred Miller Brew. ing Co. v. De France, 90 Iowa, 395, 57 N. W. 959.

10. Boundtree v. Baker, 52 Ill. 241, 4 Am. Rep. 597.

11. Pope v. Hanke, 155 Ill. 617, 40 N. E. 839,28 L. R. A. 568. 322. 
§ 4I4. Smuggling contracts. $-A$ contract made in another nation to smuggle dutiable goods into the United States, will be treated as void by our courts, ${ }^{12}$ if the vendor knows of the intention of the vendee, and packs them up and marks them in a mamer convenient for that purpose, he is equally guilty and the contract cannot be enforced. ${ }^{13}$ But if the vendor has only a mere knowledge of the intention of the rendee to smuggle the goods, and does not combine with the purchaser in act or intent, he can then collect the price. ${ }^{14}$

\section{$\S$ 4I5. Enforcing revenue laws of another country.- No} nation is bound to recognize or enforce contracts of another nation. Hence, when contracts which violate the revenue laws of a country where made, come before the courts of another nation, these courts will not take notice of the foreign revenue laws. ${ }^{1}$ So a contract which violates such laws may be enforced in another jurisdiction. ${ }^{2}$ But when the contract is void where made, because not stamped, it is void in every country where an action is brought to enforce it. ${ }^{3}$ The rule should be that though the parties bargain in one country to violate the revenue laws of another, if the contraet is not otherwise immoral or against public policy, it will be enforced in the place of its inception. ${ }^{4}$

\& 4I6. Repeal of statute. $-A$ subsequent repeal of a statute can have no effect upon a contract made while it was in force. ${ }^{5}$

12. Armstrong v. 'Toler, 11 Wheat (U. S.) 258; Holman v. Johnson, Cowp. 341 ; Cambioso v. Maffet, 2 Wash. C. C. 98 .

13. Waymell v. Reed. 5 Tern R. 599 ; Tracy v. Talmage, $14 \mathrm{~N}$. $\mathrm{Y}$. 162, 67 Am. Dec. 132 and note.

14. Holman v. Johnson. Cowp. 341.

1. Ivey v. Lelland, 42 Miss. 444, 2 Am. Rep. 606.

2. Kohn v. The Renaisance, 5 La. Ann. 25, 52 Am. Dec. 577.

3. Alves v. Hodgson, 7 'Term R.
241, 243; Clegg v. Levy, 3 Camp. 166; Bristow v. Sequeville, 5 Exch. 275. See Ludlow v. Van Rensselaer, 1 Johns. 94.

4. Armendiaz v. Serna, 40 Tex. 291 ; Merchants' Bank v. Spalding. 5 Selden (N. Y.), 53; Kohn v. The Renaisance, 5 La. Anu. 25, 52 Am. 1)ec. 577 ; Compare Graves v. Johnson, 156 Mass. 211,30 N. E. S18, 15 L. R. A. 834 and note, $32 \mathrm{Am}$. rit. Rep. 446 and note.

5. Lemonius $v$ Mayer, 71 Miss. 
The repeal of a law by the enactment of another statute will not give validity to a contract, if it was roid under the old law. ${ }^{6}$ The validity of a contract must be determined by the statute in force at the time it is made; if it is valid when made, a subsequent change or repeal of the law cannot impair its validity; and if it is roid when made, no subsequent law can import to it validity. $^{7}$ A subsequent law cannot affect the validity of a previous contract, which was void at its inception. ${ }^{8}$ Nor can the change of a law render invalid a contract which was valid at its inception. ${ }^{9}$

§ 4I7. Usurious contracts.-Persons making contracts for the payment of interest may contract to pay either at the rate of the place of contract or at the place of performance. The fact that the rate of the place at which it is agreed that it shall be paid is higher than the rate in the other place will not expose the transaction to the imputation of usury, unless the place agreed on was fixed for the purpose of obtaining the higher rate, and to evade the penalty of the usurious contract at the other place. ${ }^{1}$ So a bond executed and delivered in one State, but made payable in another, is governed, as to the objection of usury, by the laws of the latter State. ${ }^{2}$ Where the parties agree that a note shall operate, the law of that place will control as to usury, though inadvertently dated and made payable in another State. ${ }^{3}$ So where a proposition to lend money was accepted by the lender in another State where he resided, and

514,14 So. 33 ; Hathaway v. Moran, 44 Me. 67.

6. Milne v. Huber, 3 McLean, C. C. 212; MrKissick v. McKissick, 6 Humph. (Tenn.) 75.

7. Wright v. Bolling, 27 Ala. 259; Robinson v. Barrows, $48 \mathrm{Me}$. 186; Anding v. Levy, 57 Miss. 51, 34 Am. Rep. 435 and note.

8. Handy v. Publishing Co., 41 Minn. 18s, 42 N. W. 872,4 L. R.
A. 466,16 Am. St. Rep. 695 ; Gilliland v. Phillips, 1 S. Car. 152.

9. Boyce v. Tabb, 18 Wall. (U. S.) 546 .

1. Miller v. Tiffany, 1 Wall. (U. S.) 298; Sturdivant v. Bank, 60 Fed. Rep. 730.

2. Building and Loan Asso. v. Jogan, 66 Fed. Rep. 827.

3. Bank v. Mann, 94 Tenn. 17, 27 N. W. 1015,27 L. R. A. 565 and note. 
where the contract was made by its terms to be performed, the contract is governed by the laws of that Statc. ${ }^{4}$ So a judgment rendered in a State on an obligation made and entered into in another State, bears interest according to the law of the State where the judgment is rendered. ${ }^{5}$

The intention to charge usurions interest is an essential element of usury. ${ }^{6}$ So a contract will be sustained if possible. If the interest be higher at the lex loci celebrationis than at the lex loci solutionis, the parties may contract for the higher interest, ${ }^{7}$ if the statute at the place of making does not prohibit such contract at the domicil of the parties, which is the place of contract. ${ }^{8}$

Under this rule, when not prohibited by statute, the courts will sustain the contract, if secured by mortgage on land where the higher rate is legal, ${ }^{9}$ though this rule is not adopted in all the States. ${ }^{10}$ And so it has been held that the contract shall be sustained if the rate of interest is legal in the State where the money is to be used. ${ }^{11}$. However, this is not the law in other States. ${ }^{12}$

Several courts hold that the lex solutionis governs as to usury. ${ }^{13}$ The weight of authority is that the law of the place

4. Bank v. Gibson, 60 Ark. 269 , 30 S. W. 39.

5. Neil v. Bank, 50 Ohio St. 193, 33 N. E. 720.

6. Balfour v. Davis, 14 Oreg. 47 , 12 P. 89.

7. Miller v. Tiffany, l Wall. (U. S.) 298; Cromwell v. County of Sac, 96 U. S. 51.

8. See Hurd's Ill. Stat. 1903, Ch. 74 , sec. 8 .

9. Dugan v. Lewis, 79 Tex. 246, 14 S. IV. 1024, 23 Am. St. Rep. 332; Arnold v. Potter, 22 Iowa, 195; Jackson v. Mortg. Co., 88 Ga. 756,15 S. E. 812.

10. Odom v. Mortg. Co., $91 \mathrm{Ga}$
505, 18 S. E. 131; American Freehold, etc. Mortg. Co. v. Jefferson, 69 Miss. 770, 12 So. $464,30 \mathrm{Am}$. St. Rep. 587.

11. Kellogg v. Miller, 13 Fed. Rep. 198; Scott v. Perlee, 39 Ohio st. $s 1$.

12. Central Trust Co. v. Burton, 74 Wis. 329,43 N. W. 141 .

13. Dickinson v. Edwards, 77 N. Y. 573, $33 \mathrm{Am}$. St. Rep. 671; National, etc. Asso. v. Askworth, 91 Va. 726,22 S. E. 521 ; Pioneer Saving, ete. Co. v. Camnon, 96 Tenn. 599, 36 S. W. 386,54 Am. St. Rep. S58; Freese r. Brownell, 35 N. J. L. 285,10 Am. Rep. 239 . 
where the money is loaned governs as to the question of usury; that is the lex considerationis controls. ${ }^{14}$

The question of usury is governed by the situs of the land mortgaged, where the money is loaned by a foreign corporation who also has a situs in the State where the land is situated, and where the money is actually loaned, but notes are payable at the principal situs of the foreign corporation. ${ }^{15}$

$\S 4$ I8. Void usurious contracts.-A note being void at the place of the contract on account of usury, is void everywhere and will not be enforced $;^{1}$ and this is so though the same contract had been made in another State where it is sued upon, would have been valid if made in the latter State. Because if a contract is void in its inception it does not exist. ${ }^{2}$

\section{ARTICLE III.}

\section{Enforcement of Contract.}

Section 419. Interpretation of Contract.

420. Agreement as to What Law Shall Govern.

421. Common Carriers-Contract of Affreighment.

422. Alien Labor Acts.

$\S 4$ Ig. Interpretation of contract.-Much of the seeming conflict in the adjudications upon the subject of the lex loci contractus will disappear by carefully discriminating as to the precise nature of the issue and matter under consideration. Matters bearing upon the execution, interpretation, and valid-

14. DelWolf v. Johnson, 10 Wheat. (U. S.) 367 ; Akro v. Domond, 103 Mass. 318; Bennett v. Asso., 177 Pa. St. 233, 35 A. 684, 55 Am. St. Rep. 723; Watson v. Lane, 52 N. J. L. 550,20 A. 894; National B. \& L. Asso. v. Brahan, 80 Miss. 407,31 So. 840 , 57 L. R. A. 793.
15. National B. \& L. Asso. v. Brahan, 80 Miss. 407, 31 So. 840 , 57 L. R. A. 793.

1. McGarry v. Nicklin, 110 Ala. 559, 17 So. 726,55 Am. St. Rep. 40 and note.

2. McAllister v. Smith, 17 Ill. 328, 65 Am. Dec. 651; Yerger v. Raines, 4 Humph. (Tenn.) 259. 
ity of a contract are determined by the law of the place where it is made. Natters connected with its performanee are regulated by the law prevailing at the place of performance. Matters respecting the remedy depend upon the law of the place where the suit is brought. ${ }^{1}$

The lex loci regulates the right under a foreign contract, and the lex fori gives the remedy. ${ }^{2}$

A contract will be presumed to have been made in the State in which suit is brought, unless the contrary is made to appear. ${ }^{3}$ And when made in one State to be performed in another, the general rule is that it will be governed by the laws of the State where it is to be performed. ${ }^{4}$

In considering a contract five incidents must be considered: 1 , The validity of the contract ; 2 , the effect; 3 , the interpretation; 4, the discharge; 5 , the remedy for its breach. These incidents relate (a) to the making; (b) to the performance of the contract; (c) to the consideration; (d) to the intention of the parties, express or implied; (e) to the law controling the parties irrespective of intention. Everything relating to the making of the contract is to be gorerned by the lex loci contractus; ererything relating to the performance is governed by the lex loci solutionis; and everything relating to the validity of the consideration is governed by the lex loci considerationis, or

1. Scudder v. Bank, 91 U. S. 406.

2. Denny v. Faulkner, 22 Kan. 89 ; Laird v. Hodges, 26 Ark. 356 ; Partee r. Silliaman, 44 Miss. 272; Broadhead r. Noyes, 9 Mo. 56; Don v. Lippman, 5 Clark \& F. 1; Scoville v. Canfield, 14 Johns. (N. Y.) 338, 7 Am. Dec. 469; Mineral Point Railroad v. Barron, 83 Ill. 365.

3. Baltimore, etc. R. R. Co. v. Scholes, 14 Ind. App. 524, $43 \mathrm{~N}$. E. 156, $56 \mathrm{Am}$. St. Rep. 307 and note; Latham v. De Loeselle, 3 App. Div. 525, 38 N. Y. S. 270.
4. National Mut. Build. \& L. Asso. v. Ashworth, 91 Va. 706, 22 S. E. 521; Andrews v. Pond. 13 Pet. (U. S.) 65; Coghlan v. Railroad Co., 142 U. S. 101, $12 \mathrm{~S}$. Ct. 150 ; Fear v. Bartlett, Sl MId. 435 , 32 A. 322,33 L. R. A. 721 and note; Meroney v. Asso., 116 N. Car. 882, 21 S. E. 924, 47 Am. St. Rep. 84I; Wick v. Dawson, 42 W. Va. 43, 24 S. E. 587; Roberts r. Ins. Co., 118 ‥ Car. 429, 24 S. F. 780 ; Tillinghast v. Lumber Co., 39 S. Car. 484 , 1S S. E. 120, 22 L. R. A. 49. 
situs of the consideration. ${ }^{5}$ Put the place of contract is not necessarily one place. It is the law of all the places at which and for the purpose for which it has reference. Thus, a bill of exchange is to be construed according to the law of such place at which the contract contemplated that something is to be done by either of the parties. ${ }^{6}$

If in case of a sealed contract the question as to the form of the remedy, the lex for $i$ determines. ${ }^{7}$ But if the question is as to the effect and obligation of the contract, the lex loci contractus will govern. ${ }^{8}$

Whether the remedy shall be at law or in equity, in personam or in rem, is governed by the lex loci. ${ }^{9}$

Where an action is barred by the statute of limitations where suit is brought, and such judgment is final, thereby extinguishing the cause of action, no suit can be brought in another jurisdiction; otherwise if the canse of action is not extinguished. ${ }^{10}$

$\S$ 420. Agreement as to what law shall govern.-When parties living in different States execute a contract in one, or partly in one and partly in the other, and it is to be performed in the other, it is often a matter of great difficulty to decide by the law of which State the contract is to be construed, and its validity determined. Parties may avoid, when making such contracts, such questions by agreeing for themselves where the contract shall be performed. ${ }^{1}$

5. Skudder v. Bank, 91 U. S. 406.

6. Hibernia Nat. Bank v. Lacembe, 84 N. Y. 367.

7. Pritchard v. Norton, $106 \mathrm{U}$. S. 124, 1 S. Ct. 102; LeRoy v. Beard, 8 How. (U. S.) 45 l.

8. Pritchard v. Norton, 106 U. S. 124, 1 S. Ct. 102.

9. Burchard v. Dunbar, $82 \mathrm{Ill}$. 450, 25 Am. Rep. 334; Ruhe v. Buck, 124 Mo. 178, 27 S. W. 412, 25 I. R. A. 178 and note, 46 Am. St. Rep. 439 and note; New York, etc. Ins. Co. v. Aitkins, 125 N. Y. 666, 26 N. E. 732 ; Drake v. Rice, 130 Mass. 419.

10. Brand v. Brand (Ky.), 63 L. R. A. 206. See "Conflict of Laws: Substance or Obligation of Contract Distinguished from Remedy."-16 Harv. I. Review, 262.

1. Smith v. Parsons, 55 Minn. 520,57 N. W. 311 ; Penn. Mut. L. Ins. Co. v. Trust Co., 72 Fed. Rep. 413, 38 L. R. A. 33 and note, 19 C. C. A. 286,37 U. S. App. 692 . 
The rule upon the subject of constrnetion is well settled that contracts are to be construed aceording to the laws of the State where made, unless it is presumed from their tenor that they were entered into with a view to the laws of some other State. ${ }^{2}$

A court having before it a contract made between parties living under different systems of laws, is not bound, as a matter of law, to apply either the lex loci solutionis or the lex loci contractus; the question is what law the parties intended to govern the contract. ${ }^{3}$ The presumption that the lex loci contractus or lex loci solutionis governed the contract mas be displaced by other terms of the contract or cireumstances of the ease showing the intention. ${ }^{4}$ Hence, a life insurance policy issued in Pennsylvania which contains a stipulation that it is a contract made to be executed in the State of New York, and shall be construed only according to the laws of that State, will be construed as though actually executed and delivered in New York. $^{5}$ The weight of authority is that where parties make a contract of loan in one State to be performed in another they may, acting in good faith and without intent to erade the law, agree that the law of either State shall control. ${ }^{6}$

The law of the place where a contract is made governs its nature, obligation and interpretation, unless it appears that the parties, when entering into the contract, intended to be bound by the law of some other country. ${ }^{7}$

But it is a difficult question sometimes to ascertain where the situs of the contract is. The situs of the remedy when the parties are in different States, the situs of the performance, and

2. Hale v. Steam Nav. Co., 15 Conn. 538, 546 .

3. Hamlyn v. Talisker Distillery (1899), App. Cas. 20\%.

4. Jacobs v. Lyomnais, 12 Q. 13. Div. 589, 600.

5. Greesemer v. Ins. Co., 10 Wash. 202, 38 P. 1007.

6. Robinson v. Bland, 2 Burr. 107i: Miller v. Tiflany, l Wall. (L. S.) 298.
7. Cox v. United States, 6 Pet. (U. S.) 172; Scudder v. Bank, 91 U. S. 406 ; Pritchard v. Norton, 106 U. S. 124, 1 S. Ct. 102; Lamar v. Micou, 114 U. S. 218, 5 S. Ct. 857; Watts r. Camors, 115 U. S. 353, 362, 6 S. Ct. 91: Liverpool Steam Co. v. Ins. Co., 1:9 U. s. 397, 9 S. Ct. 469 ; Pope v. Nickerson, 3 Story, C. C. $465,484,485$. 
the situs of the consideration of the contract enter into the interpretation. If the situs of the making an exccutory contract, the performance and the consideration are the same, then the situs of the contract is at once determined. But when these elements are dissociated and the situs of the contract is no longer single and indivisible, then the difficulty arises, and the courts are in conflict as to the situs of these elements.

The definitions of the lex loci contractus may be resolved into three classes:

1. The laws of the place where a contract is made must govern the performance of its terms and conditions. But when it is to be performed in a different place, and under a different jurisdiction from that where it was entered into, then the law of the place of performance must govern. This makes the situs of the performance the locus contractus, though the contract was formed in another jurisdiction. ${ }^{8}$

2. The validity, the nature, the interpretation, and the obligation of contracts are governed by the lex loci contractus, the law of the place where the contract is made. ${ }^{9}$ This makes the situs of the lex loci celebrationis, the place of making of the contract, the locus contractus, though the contract is to be perfoormed in another jurisdiction.

3. The lex loci contractus is the law with reference to which the parties contracted; or the law which the parties had in mind when they made the contract; or the law which the parties intended should control the contract. ${ }^{10}$

8. Lewis v. Headley, 36 Ill. 433 , 87 Am. Dec. 27 ; Equitable Life Assur. Soc. v. Frommbold, 75 Ill. App. 43; Dickinson v. Edwards, 77 N. Y. 573, 33 Am. Rep. 671; The Bradford City, 29 Fed. Rep. 373; Compare Mutual L. Ins. Co. v. Cohen, 179 U. S. 262, 21 S. Ct. 106.

9. Milliken v. Pratt, 125 Mass. 374, 28 Am. Rep. 241; Commercial Bank v. Davidson, 18 Oreg. 57;
Taylor v. Sharp, 108 N. Car. 377, 13 S. E. 138; Ivey v. Lelland, 42 Miss. 444, 97 Am. Dec. 475; Lindsay v. Hill, 66 Me. 212.

10. Jacobs v. Credit Lyonnais, 12 Q. B. D. 589 ; Lloyd v. Guibert, L. R. 1 Q. B. 122 ; Liverpool Steam Co. v. Ins. Co., 129 U. S. 327,9 S Ct. 469; Hall v. Cordell, 142 U. S. 116, 12 S. Ct. 154; New England Mortg. Co. v. MeLaughlin, 87 Ga. 1, 13 S. E. 81; Thornton v. 
In these three divisions it is considered the locus contractus, or the situs of the contract, a single and indivisible unit to be determined by the application of a single general rule.

A better rule is, that the validity of the contract is to be determined by the lex loci contractus, and the intention of the parties governs only in the construction; that is, the lex loci contractus determines its validity and not the place of the intention. ${ }^{11}$

In many cases the element of dispute will not altogether depend on the intention of the parties, but in part on the law and public policy, which the intent of the partics cannot set aside. So the maxim " modus el conventio legem vincunt" cannot apply.

If the terms of a written contract do not indicate the intention of the parties as to the place of performance, then there is a prima facie presumption that the contract is to be performed in the State in which it is made. Thus, A employed B to superintend a factory in Kentucky, for two years, the written contract not stating the place of performance. Before the two years had expired, A moved the factory to Indiana; B refused to superintend the factory in the latter State and sued $A$ for breach of contract, and the court held that it was the prima facie presumption that the contract was to be pereformed in Kentucky. ${ }^{12}$ This presumption may or may not give effect to the intention of the parties; the difficulty can be met more satisfactorily by holding directly that such contract will be construed according to the law of the jurisdiction in which it was made. ${ }^{13}$ Such a presumption originated with those courts which hold that a contract must be construced according to the law of the jurisdiction in which it is to be performed. ${ }^{14}$

Dean, 19 S. Car. 583, 45 Am. Rep. 796; Bell v. Packard. 69 Me. 105, 31 Am. Rep. 251.

11. American Mortg. Co. v. Sewall, 92 Ala. 163, 9 So. 143, 13 L. R. A. 299 .
12. Cook v. Todd, 72 S. IV. 779, $24 \mathrm{~K}$. L. Rep. 1909.

13. Mittenthal v. Mascagni, 183 Mass. 19,66 N. E. 425,60 L. R. A. 812. 97 Am. Rep. 404.

14. Lewis v. Hadley, 36 Ill. 433, $87 \mathrm{Am}$. Dec. 227; Equitable $\mathrm{I}$. 
It wonld seem that the use of this presumption to determine the substantial rights of the parties is not sound law.

\section{$\S 42$ I. Common carriers-Contract of affreightment.-The} general rule is that the nature, the obligation and the interpretation of a contract are to be governed by the law of the place where it is made, unless the parties at the time of making it have some other law in view; and this rule requires a contract of affreightment, made in one country between citizens or residents thereof, and the performance of which being there, to be governed by the law of that country, unless the parties, when entering into the contract, clearly manifest a mutual intention that it shall be governed by the law of some other country. ${ }^{1}$ Hence, a contract of affreightment, made in an American port by an American shipper with an English steamship company doing business in such port, for the shipment of goods there and their carriage to and delivery in England, where the freight is payable in English currency, is an American contract, and governed by American law. ${ }^{2}$ When the contract is to be completed in a continulous act, the performance of which may run through several States, it is an entire contract and not divisible. But there are cases which hold that parts of the contract is completed before the distance is covered and the goods delivered. ${ }^{3}$ But the better rule is that the contract is continuous, and can have only one place of per-

Asur. Soc. v. Frommbold, 75 Ill. App. 43; DeSobry v. DeLaistre, 2 H. \& J. (Md.) 191, 3 Am. Dec. 535; Compare Mutual I. Ins. Co. v. Cohn, 179 U. S. 262, 21 S. Ct. 106.

1. Liverpool Steam Co. r. Ins. Co., 129 U. S. 397,9 S. Ct. 469 ; Pennsylvania Co. v. Fairchild, 69 Ill. 260 ; Brown v. Railroad Co., 83 Pa. St. 316; Curtis v. Railroad Co., 74 N. Y. 116, 30 Am. Rep. 271; Compare Barter v. Wheeler, $49 \mathrm{~N}$. H. 929, 6 Am. Rep. 434.
2. Liverpool Steam Co. v. Ins. Co., 129 U. S. 397, 9 S. Ct. 469; The Carib Prince, 63 Fed. Rep. 266 .

3. Burnett v. Railroad Co., 176 Pa. St. 45, 34 A. 972; Barter v. Wheeler, 49 N. H. 9, 6 Am. Rep. 434; Talbott v. Trans. Co., 41 Iowa, 247, 20 Am. Rep. 589; Curtis v. R. R. Co., 74 N. Y. 116, 30 Am. Rep. 271. 
formance, ${ }^{4}$ otherwise the carrier may be subject to different liabilities.

The lex celebrationis governs as to the validity of stipulations in bills of lading. ${ }^{5}$ And so the question whether a carrier may exempt himself, by public notice as insurer, is governed by the lex celebrationis, ${ }^{6}$ and he may limit his common law liabality, if the contract be valid at the lex celebrationis. ${ }^{7}$ And the rule applies as to the exemption from liability of a telegraph company. $^{8}$ But a contract of a telegraph company made where damages are not allowed for mental suffering for non-delivery of message on time, will not prevent a recovery of such damages in a State where such neglect is a public offense, subjecting the company to liability for the injuries thereby eaused, and whose courts permit the consideration of mental anguish in fixing the damages. ${ }^{9}$ And where the public policy of a State forbids the limitation of a carrier's liability, a contract of limitation will not be enforced as to property negligently injured within the State while being shipped on a through bill of lading into the State, where the contract was made and where it is valid. ${ }^{10}$

$\S$ 422. Alien labor acts.-The alien labor acts prohibit the contracting for non-resident aliens in a foreign country to perform labor in the United States, the contract being entered into in the foreign State. In cases founded upon these acts, the vital element of the offense is the making of a contract in a foreign country with the non-resident alien previous to the immi-

4. Liverpool Steam Co. v. Ins. Co., 129 U. S. 397,9 S. Ct. 469.

5. Hazel v. Railroad Co., $\$ 2$ Iowa, 477,48 N. W. 926 ; Davis v. Railroad Co., 93 ITis. 470, $67 \mathrm{~N}$. W. $16,1132,33$ L. R. A. 654,57 Am. St. Rep. 935.

6. Hale v. Navigation Co., 15 Conn. 539, 39 Aus. Dee. 398.

7. Nestern, ete. Railroad Co. v.
Cotton Mills, 81 Ga. 522, 7 S. E. 916,2 L. R. A. 102 and note.

8. Reed v. Tel. Co., 135 MT. 66I, 37 S. IV. 904,34 L. R. A. 492,58 Am. St. Rep. 69. This matter is generally regulated by statute.

9. Gray v. Tel. Co.. los Tenn. 39, 64 S. IT. 1063, 56 I. R. A. 301 , $91 \mathrm{Am}$. St. Rep. 706 and note.

10. Hughes r. Penn. R. R. Co., 202 Pa. St. 222, 63 L. R. A. 513. 
gration or importation of such alien into the United States to perform labor or service in this country, and in pursuance of which such non-resident alien comes to the United States and enters upon the performance of the contract. The character of the act is made to depend upon the locality of the execution of the prohibited contract. It is perfectly lawful, notwithstanding the alien labor acts, to contract with an alien within the jurisdiction of the United States. ${ }^{1}$

1. United States v. Craig, 28 Rep. 91, I C. C. A. 49, 4 U. S. App Fed. Rep. 795; United States v. 41.

Edgar, 45 Fed Rep. 44, 48 Fed. 


\section{CHAPTER XVI.}

\section{Implied Contracts.}

\section{ARTICLE I.}

\section{By Acts of the Parties.}

Section 423. Tolls.

424. Railway's Implied Contract to Send Baggage on Same Train with Passenger.

425. Gifts.

426. Impairing the Obligations of Contracts.

427. Frand and Mistake.

428. Pass-Book-Writing Up.

429. Burden of Proof.

$\S$ 423. Preliminary-Tolls.-The subject of implied contracts covers a large field of the law. In an express contract the expression of agreement may be in writing, or by words, or by signs. But when a contract arises by a course of conduct, it is an implied contract. An implied contract can exist only when there is no express contract concerning the same subject matter. Thus, if A makes an express contract with $\mathrm{B}$ to perform services for $\mathrm{C}, \mathrm{C}$ is not liable on the implied contract because he received the benefit. The two contracts cannot exist together governing the same transaction. There cannot be an express and an implied contract for the same thing, existing at the same time. It is only when parties do not expressly agree that the law interposes and raises a promise.

Only a few of these contracts can be given within the scope of this work. The first will be the implied contract arising with case of tolls.

Assumpsit lies for tolls due for passing upon a turnpike road. The law implies a promise to pay, notwithstanding the party 
using the road denies his liability and refuses payment. His denying his liability and refusing to pay does not ehange the rule $;^{1}$ and this is so even where the statute has provided a penalty. ${ }^{2}$ Beeause whatever the law orders one to pay, that becomes instantly a debt, which he has beforehand contracted to pay. ${ }^{3}$

So an aetion on an implied promise will lie to recover legal tolls for the use of a turnpike or other roads where tolls are legally eollectible, ${ }^{4}$ although the defendant has always claimed exemption from sueh tolls. ${ }^{5}$

\section{$\S 424$. Railway company's implied contract to send bag-} gage or same train with passenger.-A railway eompany impliedly undertakes that the baggage of a passenger duly checked shall go upon the same train on which he takes passage, unless he gives some direction, does something or omits to do something whieh authorizes the carrier to send the baggage by another train. ${ }^{6}$ So where a carrier without suffieient reason, fails to ship the baggage of a passenger upon the same train with the passenger, he is liable for its destruction upon another and later train. ${ }^{7}$ On the other hand, it has been lield that a trunk duly cheeked, implies that the owner is a passenger, and if there be no passenger and the trunk is lost, the railroad company can be held only as a gratuitous bailee, and

1. Proprietors v. Taylor, $6 \mathrm{~N}$. H. 499 ; Newport v. Saunders, 3 Barn. \& Adol. 411; Morris v. Burdett, 1 Camp. 222.

2. New Albany, etc. Co. v. Lewis, 49 Ind. 161; Central Bridge Corpo. v. Abbott, 4 Cush. (Mass.) 473.

3. 3 BI. Com. 160; Bowen v. Hoxie, 137 Mass. 527; Gray v. Bennett, 3 Met. (Mass.) 522.

4. New Albany, etc. Co. v. Lewis, 49 Ind. 161.

5. Central Bridge Corpo. v. Abbott, 4 Cush. (Mass.) 473.
6. Wilson v. Railroad Co., 56 Me. 60, 96 Am. Dec. 435, 57 Me. 138, 2 Am. Rep. 26; Fairfax v. Railroad Co., 73 N. Y. 167, 29 Am. Rep. 119; Toledo, etc. R. R. Co. v. Tapp, 6 Ind. App. 304, 33 N. E. 462 ; Wald v. Railroad Co., 162 Ill. 545,44 N. E. 888,35 L. R. A. 356 , 53 Am. St. Rep. 332.

7. Wald v. Railroad Co., 162 Ill. 545,44 N. E. 888,35 L. R. A. 356, 53 Am. St. Rep. 332. 
was not responsible in the absence of gross negligence; because baggage implies a passenger who intends to go upon the train and receive it upon the arrival of the train at the end of the journey. ${ }^{8}$

$\S$ 425. Gifts.-A gift of chattel, accompanied by delivery, is valid and irrevocable, and there is no implied contract that the donor may revoke it. ${ }^{9}$ Delivery is essential, both at law and in equity; but when the article is once delivered the gift is perfeet. $^{10}$ And so where a gift is made, the subsequent execution of a will by the donor does not operate to make void the gift, even though the property may fall within the provisions of the will. ${ }^{11}$

And if in a transaction, where chattels are delivered, if intended by the parties to be a gift, the law implies no agreement to pay for them, and there is no sale. ${ }^{12}$

$\S 426$. Impairing the obligation of contract.-An appointment to a public office is not a contract within the elause of the Federal Coonstitution, ${ }^{1}$ which forbids the State to pass any law impairing the obligation of contract. The design of that clause was to restrain the legislature from violating the right to property. But as an appointment or election to office is not such a contract, it is not within the prohibition of the Constitution. $^{2}$

8. Marshall v. Railroad Co., 126 Mich. 45, S5 N. W. 242; Compare The Elvira Harbeck, 2 Blatch. 336 ; Wilson v. Railroad Co., 56 Me. 60, $96 \mathrm{Am}$. Dec. 435, 57 Me. 138, 2 Am. Rep. 26.

9. Sanborn v. Goodhue, $28 \mathrm{~N}$. H. 48, 59 Am. Dec. 398; Smith v. Smith, 7 Car. \& P. 401 ; Marston v. Marston. 20 N. H. 573.

10. Cook r. Husted, 12 Johns. (N. Y.) IS8; Marston v. Marston, 20 N. H. 573 .
11. Sanborn v. Goodhue, $28 \mathrm{~N}$. II. 48, 59 Am. Dec. 398 .

12. Keiser v. State, $S 2$ Ind. 379 ; French v. Smith, 58 N. H. 323; Whaley v. Peak, 49 Yo. S0; Osier v. Hobbs, 33 Ark. 215; Watson, v. Ledoux, 8 La. Amn. 68, $28 \mathrm{Am}$. Dec. 129. See, also. Safety Deposit L. Ins. Co. v. Smith, 65 Ill. 309.

1. Article 1, sec. 10, subd. 1.

2. Dartmouth College v. Woodward, 4 Wheat. 51s, 627, 630; Hoboken v. Gear, 40 Miss. 265; Hall v. State, 39 Wis. 79 . 
The prospective salary or other emoluments of a public officer are not the property of the office nor the property of the State. They are not property at all. ${ }^{3}$

A person holding an office ousted by the legislature, has no vested right in it; but the legislature may at any time destroy it, ${ }^{4}$ when the tenure of the office is not fixed by the Constitution. ${ }^{5}$ The tenure and salary of a public officer, except when otherwise provided by the Constitution, are dependent upon legislation. ${ }^{6}$

$\S 427$. Fraud and mistake.-After an account stated has been accepted it can only be defeated by showing fraud or mistake. A stated account may be impeached either wholly or in part on the ground of frand or mistake. If there be fraud or if any mistake affects the whole account, the whole will be opened and a new account will be directed to be taken without reference to that which has been stated; but if there is no frand, and if no mistake affecting the whole account can be shown, but the correctness of some of the items in it is, nevertheless, disputed, the account already stated will not be treated as non-existing, but will be acted upon as correct, save so far as the party dissatisfied with any item can show it to be erroneous. As to disputed items and claims of each, denied by the other, it is not binding; these items and claims must be determined by the jury from the evidence. ${ }^{1}$ Such admission by the debtor only establishes, prima facie, the accuracy of the account, and dispenses with other proof of the correctness of the items. It is open to impeachment for fraud, mistake or errors. ${ }^{2}$ And where

3. Connor v. New York, 1 Seld. (N. Y.) 296.

4. State v. Douglass, 26 Wis. 428. 7 Am. Rep. 87; People v. Comptroller, 20 Wend. (N. Y.) 595 ; Hall v. State, 39 Wis. 79; Hoboken v. Gear, 27 N. J. L. 265.

5. Taft $v$ Adams, 3 Gray (Mass.), 126; Butler v. Pennsylvania. 10 How. (U. S.) 403.
6. Butler v. Pennsylvania, 10 How. (U. S.) 403.

1. Rehill v. Mc'Tague, $114 \mathrm{~Pa}$. St. 82, 7 A. 224, 60 Am. Rep. 341.

2. Cook v. Bouitz, 4 Daly (N. Y.), 117 ; Lockwood v. Thorne, 11 N. Y. 18; Rose v. Savory, 2 Bing. N. C. 145; Waldron v. Evans, 1 Dak. 11; Thomas v. Hawks, 8 Mees. \& Wel. 140; Gough v. Fin- 
the parties in settlement of a disputed elaim agrce upon the amount due, the defendant cannot then, in a suit against him, set up that there is nothing due against him. ${ }^{3}$ Such promise is founded upon a sufficient consideration and can be cnforced against the debtor, although he may be able to prove that nothing in fact is due from him. ${ }^{4}$

If parties have agreed upon an account, they may, by mutual consent, waive this, and agree to a reopening and restatement of the account; and if, after such statement, the creditor accepts the amount as thus stated as full payment of the account, without exception or reservation, this will constitute a full settlement of his whole claim, although the amount received is less than the sum agreed on as his due at the first settlement. ${ }^{5}$

The rule is well established that a settled account may be impeached and re-adjusted by proof of unfairness, fraud or mistake in law or fact. ${ }^{6}$ It may not be necessary in such case to open the whole account, but the mistake can be corrected and the rights of the parties re-adjusted as to such mistake.

$\S$ 428. Pass-book, written up.-The relation of a bank and its depositor is one simply of debtor and creditor, ${ }^{1}$ and that the

don, 7 Exch. 48; Bright v. Coffman, 15 Ind. 371, 77 Am. Dec. 96; Trueman v. Hurst, 1 Term R. 40; Ware v. Manning, 86 Ala. 238, 5 So. 682; Hawley v. Harran, 79 Wis. 379,48 N. W. 676,46 Am. St. Rep. 849 ; Neff v. Wooding, 83 Va. 432,2 S. E. 731 ; Dunham v. Griswold, 100 N. Y. 224, 3 N. E. 76.

3. Dunham ․ Griswold, $100 \mathrm{~N}$. Y. 224,3 N. E. 76 ; Compare Christian v. Ins. Co., 101 Ala. 634, 14 So. 374 .

4. Stewart v. Alrenfeldt, 4 Denio (N. Y.), 189; IJehrum v. Kuhn, 61 N. Y. 623 ; Fleeter r. Weber, 78 N. Y. 334; Compare Christian v. Ins. Co., 101 Ala. 634, $1+$ So. 374.
5. Horu v. Railroad Co., 37 Minn. 375.

6. Conville v. Sheridan, $144 \mathrm{~N}$. I. 686,39 N. E. 405 .

7. Weisser v. Denison, $10 \mathrm{~N}$. Y. 68, 61 Am. Rep. 731; Bruen v. Hone, 2 Barb. (N. Y.) 586; Phillips v. Belden, 2 Edw. Ch. (N. Y.) 1: Welsh v. Bank, 73 N. Y. 424, 29 A!n. Rep. 175 ; Carpenter v. Kent, 101 N. Y. 591.5 N. E. 787 ; Samson v. Freedman, 102 N. Y. 699, 7 ‥ E. 419 ; Wheadon v. Olds, 20 Wend. (N. Y.) 174; Malcolm v. Fullerton, 2 Term R. 645; First Nit. Bank v. Bank, 2 MeCreary, C. C. 438; Conville v. Sheridan, 144 ․ Y. 686,39 N. E. 405 .

1. Phoenix Bank v. Risley, 111 T. S. 125, 127, 4 S. Ct. 322 . 
depositor is not chargeable with any payments except such as are made in conformity with his orders.

The object of a pass-book is to inform the depositor from time to time of the condition of his account as it appears upon the books of the bank. The sending of his pass-book to be written up and returned with the vouchers, is, in effect, a demand to know what the bank claims to be the state of his account. And the return of the book, with the vouchers, is the answer to that demand, and, in effect, imparts a request by the bank that the depositor will, in proper time, examine the account so rendered, and either sanction or repudiate it ${ }^{2}$ his silence is regarded as an admission that the entries are correct, ${ }^{3}$ and can only be opened for mistake or fraud. ${ }^{4}$

The depositor of a bank must examine the account stated within a reasonable time, or he will be precluded from repudiating it only for fraud or mistake. ${ }^{5}$ There is a duty owing from the depositor or customer to the bank to act with that ordinary diligence and care that prudent business men generally bestow on such cases, in the examination and comparison of the debits and credits contained in the pass-book, in order to detect any errors or mistakes therein. ${ }^{6}$ More than this, under ordinary circumstances, could not be required.

The general rule is, that if a party so conducts himself that a reasonable man would take the representation to be true, and believe that it was meant that he should act upon it, and did act upon it as true, the party making the representation would be equally precluded from contesting its truth; and conduct,

2. Leather Manuf. Bank v. Morgan, 117 U. S. 96, 6 S. Ct. 657.

3. Devaynes v. Noble, 1 Merv. 530,535 .

4. Perkins v. Hart, 11 Wheat. (U. S.) 237, 256; Wiggins v. Burkham, 10 Wall. (U. S.) 129, 132.

5. Leather Manuf. Bank v. Morgan, 117 U. S. 96, 6 S. Ct. 657;
Compare Frank v. Bank, 84 N. Y. 209, 38 Am. Rep. 501; Manufacturers' Bank v. Barnes, 65 Ill. 69, 16 Am. Rep. 576; National Bank v. Tappan, 6 Kans. 456, 7 Am. Rep. 568.

6. Hardy v. Bank, 51 Md. 562, 591, 34 Am. Rep. 325; Dana v. Bank, 132 Mass. 156, 158. 
by negligence or onission, when there is a duty cast upon a person by usage of trade or otherwise to disclose the truth, may often liave the same effect. ${ }^{7}$

The courts are not in accord. It his been held that a passbook was merely an account stated, and that the neglect of the depositor to examine it would operate only to cast on him the burden of proving it to be incorrect, and there was no duty on his part to exanine it; and he incurs no liability for checks forged by his agent. ${ }^{8}$ This doctrine was qualified in a later decision ${ }^{9}$ but now in New York the doctrine is repudiated in toto. Thus, a depositor's clerk altered genuine checks which were paid by the bank. The depositor intrusted the rerification of the checks, to see that they corresponded with the pass-book and his cash-book, to the same clerk, and it was held that the failure to discover the fraud exonerated the bank from liability for subsequent checks, ${ }^{10}$ because the duty of reasonable verifcation of the returned checks, is placed on the basis of the wellestablished banking usage, and is regarded as a just mitigation of the vigorous liability imposed on the bank, ${ }^{11}$ and is now a well-established principle of law. ${ }^{12}$ However, the measure of diligence is less strict in the event of an indorsement being forged, as the drawer of a check cannot reasonably be supposed capable of determining the genuineness of the signature of the payee or a subsequent indorser. ${ }^{13}$ The depositor's duty to rerify

7. F'reeman v. Cooke, 2 Exch. 654; Carr v. Railway Co., L. R. 10 C. P. 307 . See, also, McKenzie v. Linen Co., 6 App. Cas. 82, 101; Miles v. Mellwraith, 8 App. Cas. 120, 133; Cornish v. Abington, 4 Hurl. \& N. 549, 556; Blair v. Wait, 69 N. Y. 113, 116.

8. Weisser v. Denison, $10 \mathrm{~N}$. Y. 68, $61 \mathrm{Am}$. Dec. 731; Welsh v. Bank, 73 N. Y. 424, 29 Am. Rep. 175.

9. Frank v. Bank, 84 N. Y. 209, 38 Am. Rep. 501.
10. Critten v. Bank, 171 N. Y. 219,63 N. E. 969,57 L. R. A. 529.

11. Dana v. Bank, 132 Mass. 186; Leather Manf. Bank v. Morgan, 117 U. S. 96,6 S. Ct. 657; Critten v. Bank, 171 N. Y. 219, 63 N. E. 969,57 L. R. A. 529.

12. Myers v. Bank, $193 \mathrm{~Pa}$. St. 1, 44 A. 280, 74 Am. St. Rep. 672.

13. Atlanta Nat. Bank v. Burke, 81 Ga. 597,7 S. E. 738,2 L. R. A. 96 and note; Shipman v. Bank, 126 N. Y. 318,27 N. E. 371,12 L. R. A. 791 and note, 22 Am. St. Rep. 821 . 
his account does not extend to the results arising from the neglect or failure to do so. Under the new rule a depositor cannot recover from the bank any forged or altered checks it may pay after he has had a reasonable time in which to discover the first fraud. But as to checks paid previously, the bank is still liable. ${ }^{14}$

But the courts are not in accord, and some courts make no distinction, and hold that the depositor's failure to discover the forgery is equivalent to a ratification of all the checks drawn, and he is therefore estopped to deny their genuineness, and is compelled to stand the loss. ${ }^{15}$

The damages to the bank, by reason of the depositor's negligence, is the difference between the whole amount and the amount recovered back by the bank. ${ }^{16}$

It is held by some authority that if the depositor intrusts the examination to a clerk who has forged the check, and thus the forgery is not discovered, the depositor is not liable, because notice to an agent who is acting contrary to his principal's interests, does not affect the principal. ${ }^{17}$ But another line of decisions holds that notice to the clerk is notice to his employer; that the clerk's knowledge must be imputed to the depositor, for intention is not the determining factor in the case. ${ }^{18}$ This is on the ground that the depositor has a positive duty to perform and by delegating it to his clerk does not lessen bis liability.

Courts are in conflict. The old rule was and is now, as set forth by some of the courts, that the loss arising from the

Denison, 10 N. Y. 68, 61 Am. Dec. 219,63 N. E. 969,57 L. R. A. 529.

15. Dana v. Bank, 132 Mass. 156 ; Leather Manuf. Bank v. Morgan, 117 U. S. 96,6 S. Ct. 657.

16. First Nat. Bank v. Allen, 100 Ala. 476, 14 So. 235, 27 L. R. A. 426 and note, 46 Am. St. Rep. 80.

17. Welsh v. Bank, 73 N. Y. 424, 29 Am. Rep. 175; Weisser v.
Bank, 10 N. Y. 68, 61 Am. Dec. 731; Hardy v. Bank, 51 Md. 562, 34 Am. Rep. 325.

18. Dana v. Bank, 132 Mass. 156 ; Leather Manuf. Bank v. Morgan, 117 U. S. 96,6 S. Ct. 657 ; Bank v. Allen, 100 Ala. 476, 17 So. 335, 27 L. R. A. 426 and note, 46 Am. St. Rep. 80; Critten v. Bank, 171 N. Y. 219,63 N. E. 969,57 L. R. A. 529 . 
payment of a forged eheek, must, as between the bank and the depositor, fall primarily upon the bank, as it pays the eheek at its peril. But under a new ruling, which is the law in some jurisdictions, the depositor owes a duty to examine the cheelss and his pass-book within a reasonable time, and if he neglects so to do, and a forgery is overlooked by him, the loss must fall on him. He eannot recover from the bank for any forged checks he may pay after he has had a reasonable time to diseover the fraud; but as to checks paid previously to such time, the bank is still liable. This rule applies though the depositor gives the checks into the hands of his clerk who forges them, as the notice of the elerk ean be inputed to the depositor. This undoubtedly is the better law.

$\$$ 429. Burden of proof.-The burden of proof is always upon the party having that liberty; for the court takes it as a stated account and establishes it. ${ }^{1}$ In ease of fraud, an account will be opened in toto, even after the lapse of a considerable time; but if no fraud be proved, an account which has been long settled will not be opened. ${ }^{2}$ The hurden of proof is on the party who assails the account stated. ${ }^{3}$

But the acount, in order to constitute a contract, should appear to be something more than a mere memorandum; it should show upon its face a final settlement, expressed with clearness and certainty. ${ }^{4}$

1. Pit v. Cholmondeley, 2 Ves. Sr. 565; Vernon v. Vawdey, 2 Atk. 119.

2. Rehill v. Mc'Tague, 114 Pa. St. 82,7 A. 224, 60 Am. Rep. 341 .

3. Ware v. Mamning, 86 Ala. 238, 6 So. 682; Cook v. Bouitz, 4 Daly (N. Y.), 117; Lockwood v.
Thorne, 18 N. Y. 292; Maybury v. Berkery, 102 Mich. 126, 60 N. W. 699 ; Take v. Tyson, 6 N. Y. 461 ; Davis v. Gallagher, 55 Hun (N. Y.), 593, 9 N. Y. S. 11.

4. Coffee v. Williams, $103 \mathrm{CaI}$. 550, 37 P. 504. 


\section{ARTICLE II.}

\section{Paying Another's Debts.}

Section 430. Paying Debts of Another.

431. Under Obligations.

432. Voluntary Payment Raises no Assumpsit.

433. Rights of Partners After Dissolution.

434. Suretyship.

435. To Save Property.

436. Contribution.

437. Contribution Among Wrongdoers.

438. Contribution Among Wrongdoers-Exceptions to General Rule.

439. Indemnity.

440. Fraud.

441. Payment.

442. Express Contracts.

443. Void Contracts.

444. Difference Between Express and Implied Contracts.

\section{$\S 430$. Paying debts of another.--Voluntary payment of an-} other's debts creates no liability against the debtor ${ }^{1}$ for no one can voluntarily pay another's debts and then insist on repayment to him. ${ }^{2}$ A man cannot of his own will pay another man's debt without his consent, and thereby commit himself into a creditor. ${ }^{3}$ The law does not permit a liability of a party for a debt to one person to be shifted so as to make him debtor to another without his consent, ${ }^{4}$ and assumpsit will not lie for money voluntarily paid by one on the debt of another without

1. Jackisch v. Hardtke, 50 Ill. App. 202; Johnson v. Packet Co., L. R. 3 C. P. 38, 43; Mayor v. Hughes, 1 Gill \& J. (Md.) 480, 19 Am. Dee. 243; Hearn v. Cullin, 54 Md. 533.

2. Keifer v. Summers, 137 Ind. 106,35 N. E. 1103,36 N. E. 894 ; Durnford v. Messiter, 5 Maule \& Sel. 446.

3. Durnford v. Messiter, 5 Maule
\& Sel. 446 ; Exall v. Partridge, 8 Term R. 30S, 310; Sleigh v. Sleigh, 5 Exch. 514; Blanchard v. Association, 59 Me. 202; Oden v. Elliott, 10 B. Mon. (Ky.) 313; South Scituate v. Hanover, 9 Gray (Mass.), 420; Little v. Gibbs, 1 South (N. J.), 211; Beach v. Vandeburgh, 10 Johns. (N. Y.) 361.

4. Winsor v. Savage, 9 Met. (Mass.) 348. 
the latter's consent. But if the creditor accepts it as payment, it extinguishes the debt at law.

$\S 43$ r. Under obligation.-In some transactions the law implies a fictitious request to pay the debts of another. So whenever one person allows another to assune such a position that the law will compel the latter to discharge a debt of the former, then the law imparts a request and promise hy the former to the latter to make the payment, the law creates the agreement and the former is under an obligation to reimburse the latter for such payment. ${ }^{6}$ But the obligation must be more than moral. $^{7}$

As a general rule, if one has paid money for the benefit of another, which the latter was legally bound to pay, and has done so for a reasonable cause and not officiously, he can recover the amount in assumpsit of the party for whose benefit it was paid. ${ }^{8}$

So when a carrier, by mistake, delivers goods to the wrong person, and he wrongfully detains them, so that the carrier is compelled to pay for them, he is liable to the carrier for money thus paid. ${ }^{9}$ And, so, when a partnership is compelled to pay the personal debt of one of the partners, he is liable to the partnership for the amount thus paid. ${ }^{10}$ But a mere volunteer in paying the debts of another has no remedy against the debtor. ${ }^{11}$

5. Martin v. Quinn, 37 Cal. 55; Harrison v. Hicks, 1 Port. (Ala.) 423, 27 Am. Dec. 638.

6. Hutton v. Eyre, 6 Taunt. 289; Hawley v. Beverley, 6 Man. \& G. 221 ; Johnson v. Packet Co., L. R. 3 C. P. 38 ; Sapsford v. Fleteher, 4 Term R. 511; Hales v. Freeman, 1 Brod. \& B. 391; Hutzler v. Lord, 64 Md. 534. 3 A. 891 ; Beard v. Horton, 86 Ala. 202, 5 So. 207; Houser v. MeGinnas, 108 N. Car. 631, 13 S. E. 139,23 Am. St. Rep. 49 ; Gressell v. Robinson, 3 Bing. $\mathrm{N}$. C. 10; Perin v. Parker, 25 Ill. App.
465; Tuttle v. Armstead, 53 Conn. 175. 22 A. 677 .

7. Atkins v. Banwell. 2 East 505.

8. Bailey v. Bussing, 28 Conn. 455, $6 \mathrm{~S} \mathrm{Am}$. Dec. 404 and note.

9. Brown v. Holgson, 4 Taunt. 188 .

10. Cross v. Cheshirc, 7 Exch. 43.

11 Bates v. 'lownley, 2 Exch. 152; Sleigh v. Sleigh, 5 Exch. 514: Jolnuson v. Packet Co., L. R. 3 C. P. 3S, 41; Winsor v. Savage, 9 Met. (Mass.) 346 . 


\section{$\S 432$. Voluntary payment raises no assumpsit.-Voluntary} payments give no cause of action against the debtor who has not requested the payer to discharge the debt. It falls within the rule of law, that the payment of the debt raises no assumpsit against the person whose debt is paid, and no action will lie by reason of such payment, mless a request, either express or implied, to make the payment is proved $;^{1}$ for no one can make himself the creditor of another who does not covenant either in fact or by legal implication. ${ }^{2}$

So a member of a corporation, who is not its financial officer, cannot without authority, make himself its creditor by the voluntary payment of its debts. ${ }^{3}$ But the payment is not necessarily voluntary, nor is it to be treated as a gift because the debtor did not act under compulsion in paying it a second time by mistake. ${ }^{4}$

$\S$ 433. Rights of patners after dissolution.-When a partnership has been dissolved, and its partnership accounts fully settled, an express promise to pay the balance is not necessary, because the promise is implied in closing the accounts and stating the balance; and one partner who has paid the partnership debts may maintain an action against the other for contribution, although there has been no express promise on his part to pay the balance ${ }^{5}$ and this is true although he gives his individual note as absolute payment for a debt due from the partnership to third parties. ${ }^{6}$

Of course, after the dissolution of the partnership one part-

1. Winsor v. Savage, 9 Met. (Mass.) 348; South Scituate v. Hanover, 9 Gray (Mass.), 420.

2. Jenkins v. School Dist., 39 Me. 220; Bancroft v. Abbott, 3 Allen (Mass.), 524; Jones v. Wilson, 3 Johns. (N. Y.) 434; Richardson v. Williams, 49 Me. 558; Lewis v. Lewis, 3 Strobh. (S. Car.) 530 ; Woodford v. Levenworth, 14 Ind. 311 .
3. Blanchard v. Association, 59 Me. 202.

4. Pool v. Allen, 7 Ired. (N. Car.) 120; Houser v. McGinnas, 108 N. Car. 63I, 13 S. E. 139.

5. Clouch v, Moyer, 23 Kan. 405 ; Brown v. Agnew, 6 Watts \& $\mathrm{S}$. (Pa.) 235; Whitstone v. Shaw, 70 Mo. 575; Sears v. Starbird, 78 Cal. 225, 20 P. 547.

6. Clouch v. Moyer, 23 Kan. 405. 
ner caunot revive a debt barred by the statute of limitations, but during the pendeney of the partnership each partner is an agent for all in making an acknowledgment under the statute of limitations.' But no action lies by one partner against another, unless there has been a settlement of areounts, and a promise to pay the balance.

$\S$ 434. Suretyship.-There is no doubt that contribution may be enforced at law as well as in equity, among co-sureties, although no such contract exists. And it matters not, in case of debt, whether the sureties are jointly and sererally boumd, or only severally; or whether their suretyship arises under the same obligation or instrument, or under divers obligations or instruments, if all the instruments are for the same identical debt. ${ }^{1}$ Contribution arises upon a principle of equity, though it is now established to be the foundation of an action at law. ${ }^{2}$ A request to pay and a promise to pay by a co-surety are created by law. ${ }^{3}$

It has been held that eo-sureties must enforee contribution in equity. ${ }^{4}$ But this is not the law at the present time. The surety may also recover the money paid, for his principal as for money paid at his request. ${ }^{5}$

7. Woods on Lim. 433; Parsons on Part. 188.

1. Story on Eq. Jur. 495.

2. Davies v. Humphreys, 6 Mees. \& W. 153.

3. Deering v. Winchelsea, 2 Bos. \& P. 270; Davies v. Humphreys, 6 Mees. \& W. 153; Kemp v. Fender, 12 Mees. \& IV. 421; Holmes v. Williamson, 6 Maule \& S. .158; Bushnell v. Bushnell, 77 Wis. 435,46 N. W. 442. 9 L. R. A. 411 and note; Gibbs v. Bryant, 1 Pick. (Mass.) 118; Kimble v. Cummins, 3 Met. (Ky.) 327 ; Exall v. Partridge, 8 Term R. 308; Clay v. Severance, 55 Vt. 300; Jackson v. Murray, 77
Tex. 644, 14 S. W. 235 ; Johnson v. Harrey, 84 N. Y. 363, 38 Am. Rep. 515; Aldrich v. Aldrich, 56 Vt. 324 , $48 \mathrm{Am}$. Rep. 791; Foster v. Burton, 62 Vt. 239, 20 A. 326; Logan v. Trayser, 77 Wis. $579,46 \mathrm{~N}$. W. 877; Wilton v. Tazwell, 86 Ill. 29; Fletcher v. Grover, 11 N. H. 368, 35 Am. Dec. 497.

4. Longley v. Griggs, 10 Pick. (Mass.) 121; McDonald v. Magruder, 3 Pet. (U. S.) 470.

5. Alexander $r$. Vane, 1 Mees. \& Wel. 511; Touissaint v. Martinant, 2 Term R. 100; Pownal v. Ferrand, 6 Barn. \& Cr. 439 ; Crisfield v. State, 55 Mfd. 192. 
$\S$ 435. To save property,-Assumpsit lies for money paid. Generally, it is sutticient if the money is paid for a reasonable cause and not ofliciously. ${ }^{1}$ So where one has paid to relieve a neigubur's goods from legal distraint in his absence, the law creates a contract, and the neighbor must reimburse the payer. ${ }^{2}$ So where one's own property can be preserved only by paying the debt of another, the debtor must repay the payer. ${ }^{3}$ So, for getting the defendant's goods free, which had been distrained by the landlord for the defendant's debts, they being at the time on the tenant's premises. ${ }^{4}$ Or for money paid to indemnify the owner for the loss of his goods, which the plaintiff, an auctioneer, had by mistake delivered to the defendant, who had appropriated them to his own use. ${ }^{5}$

So, where an importer has violated the revenue law, so as to render the goods liable to confiscation by the government, he will become liable to any innocent purchaser of those goods, who purchased in order to compromise a suit to confiscate the goods. $^{6}$

In paying money for the release of one's own property, it must be shown that its seizure was lawful, for if the seizure is unlawful, no liability arises as to the debtor. ${ }^{7}$

$\S 436$. Contribution.-The right to contribution between cosureties or joint promisors depends upon the principle of equity rather than upon contract. It is well settled that the liability exists, although the sureties are ignorant of each other's engagement. It is not sufficient that both parties are sureties, they must occupy the same position in respect to the principal,

1. Brown v. Hodgson, 4 Taunt. 189; Skillin v. Merrill, 16 Mass. 40; Jefierys v. Gurr, 2 Barn \& Ad. 833 ; Pownal v. Ferrand, 6 Barn. \& Cr. 439; Exall v. Partridge, 8 Term R. 308; Touissaint v. Martinant, 2 Term R. 100. 90.
3. Cole v. Malcom, 66 N. Y. 363 ; Exall v. Partridge, 8 Term R. 308.

4. Exall v. Partridge, 8 Term R. 308 .

5. Brown v. Hodgson, 4 Taunt. 189.

6. Summers v. Clark, 29 La. Ann. 93.

7. Myers v. Smith, 27 Md. 91. 
and without equities between themselves, giving an adrantage to one over the other. ${ }^{8}$

When persons are under legal obligations to pay a debt not in violation of law, and one of them pays it, the law creates a promise that his co-debtors will pay him their proportionate part. $^{9}$

$\S 437$. Contribution among wrongdoers.-Contribution cannot be enforeed among wrongdoers. ${ }^{1}$ The general rule is that between wrongdoers there is neither indemnity nor contribution; the exeeption is where the act is not clearly illegal. ${ }^{2}$

There is no implied obligation to eontribute between wrongdoers, and if such liability can be ereated by express promise, the promise must rest upon some other consideration than the fact of the tort and of the relation of the accused parties to each other in the wrongful transaction. There must be some new consideration, such as mutual promises, the transfer of some value, the deprivation of some right or advantage, or the like, which the law recognizes as constituting a ralid consideration. ${ }^{3}$ But this rule applies only to eases where there has been an intentional violation of law, or where the wrongdoer is to be presumed to have known that the act was unlawful. ${ }^{4}$

8. Wells v. Miller, 66 N. Y. 255 ; Craven v. Freeman, 82 N. Car. 361 ; Scofield v. Gaskill, 60 Ga. 277; Healey v. Scofield, $60 \mathrm{Ga} .450$.

9. Fowler v. Donovan, $79 \mathrm{\Pi ll}$. 310 ; Kineaid v. Hocker, 7 J. J. Marsh. (Ky.) 333; Robertson v. Deatherage, 82 Ill. 511; Snyder v. Kirtley, 35 Mo. 423; Chipman v. Morrill, 20 Cal. 130.

1. Boyer v. Bolender, 129 Pa. St. 324, 18 A. 127, 15 Am. St. Rep. 723; Spalding v. Oakes. 42 Vt. 343 ; Peck v. Ellis, 2 Johns. Ch. (N. Y.) 131; Cranston v. Limhet, 18 Ohio, 81, $51 \mathrm{Am}$. Dec. 442; Miller v. Fenton, 11 Paige (N. Y.), 18; Vose v. Grant, 15 Mass. 505; Hunt v. Lane, 9 Ind. 248; Merryweather v. Nixan, 8 Term R. 186; Betts v. Gibbins, 2 Ad. \& El. 57.

2. Betts v. Gibbins, 2 Ad. \& El. 57,74 .

3. Nichols v. Nowling, 82 Ind. 488.

4. Bailey v. Bussing, 28 Conn. 455. See, also, Adamson v. Jarvis, 4 Bing. 66; Wooley v. Batte, 2 Car. \& P. 417 : Pearson v. Skelton. 1 Mees. \& Wel. 504; Acheson v. Niller, 2 Ohio St. 203, 59 Am. Dec. 663; Moore v. Appleton, 26 Ala. 633. 
Contribution will not be enforced in favor of a wrongdoer who knew at the time of the commission of the act for which he has been compelled to respond, that such act was wrongful. ${ }^{5}$

\section{$\S 438$. Contribution among wrongdoers - Exceptions to} general rule.-The rule that there can be no contribution among wrongdoers applies to cases where there has been an intentional violation of law, or where the wrongdoer is presumed to have known that the act was unlawful. ${ }^{6}$ Hence, the rule does not apply where one of them is innocent of any intentional or actual wrong, and has been compelled to pay damages which the other, who was the actual wrongdoer, should have paid. ${ }^{7}$

If the party is imocent of the illegal purpose, ignorant of the nature of the act, which was apparently correct and proper, the general rule will change with its reason, and he may then have a contribution, and it can be enforced by action if refused, whether the person seeking it has been subjected, in case or assumpsit, to the damages of which he complains. ${ }^{8}$

$\S$ 439. Indemnity.-The general rule is that between wrondoers there is neither indemnity or contribution. The exception is where the act is clearly not illegal in itself. ${ }^{9}$ There may be an indemnity between wrongdoers unless it appears that they have been jointly concerned in a transaction which the party complaining knew to be illegal. ${ }^{10}$ The general rule does not

5. Johnson v. Torpy, 35 Ncb. 604 , 53 N. IV. 575, 37 Am. St. Rep. 447; Torpy v. Johnson, 43 Neb. 882, 62 N. IV. 253.

6. Farwell v. Becker, 129 Ill. 261, 21 N. E. 792,6 L. R. A. 400, 16 Am. St. Rep. 207; Armstrong Co. v. Clanen Co., 66 Pa. St. 218, 5 Am. Rep. 368; Bailey v. Bussing, 28 Conn. 455; Jacobs v. Pollard, 10 Cush. (Mags.) 287, 57 Am. Dee. 105; Betts v. Gibbins, 2 Ad. \& El. 57 ; Acheson v. Miller, 2 Ohio St. 203, 59 Am. Dec. 663; Gray v. Gas
Light Co., 114 Mass. 149, 19 Am. Rep. 324; Churchill v. Holt, 127 Mass. 165, $34 \mathrm{Am}$. Rep. 355.

7. Bailey v. Bussing, 28 Conn. 455 ; Port Jervis v. Bank, 96 N. Y. 550 ; Farwell v. Becker, 129 Ill. 2(i1, 21 N. E. 792,6 L. R. A. 400 , 16 Am. St. Rep. 267.

8. Bailey v. Bussing, 28 Conn. 455.

9. Betts v. Gibbins, 2 Ad. \& El. 57.

10. Battersey's Case, Winch, 48. . 
affect cases of indemnity, where one man employs another to do acts, not unlawful in themselves, for the purpose of asserting a right."

$\S 440$. Fraud.-Where a party has fraudulently eaused damage to another he is responsible. So a party must make good any loss or damage which, by his aet or onission or legal default, has been occasioned to another. ${ }^{12}$ And so where one has been compelled to pay money to a third party by the fraud of another, the wrongdoer is liable to him for money thus paid. ${ }^{13}$

Where money has been obtained by fraud or deceit, the law implies a promise by the wrongful doer to restore it. ${ }^{14}$

$\S 44$ I. Payment.-Before the law ereates an implied contract there must he a payment by the party complaining. Payment of a money debt as surety or indorser by conveying land, which is received as payment, is sufficient to give rise to contribution. ${ }^{1}$ The giving of a promissory note may, in some cases, be equivalent to the payment of money; but the giving of a bond is not such a payment. ${ }^{2}$ If a note is received as an absolute payment of the debt, that is sufficient though it has not been paid. $^{3}$

$\S$ 442. Express contract.-There ean be no implied contract between parties so long as there is a written contract covering the same thing; for there ean be but one contract at the same time between the same parties tonching the same subject mat-

11. Merryweather v. Nivan, 8 Term R. 186.

12. Noule v. Garrett, L. R. 7 Exch. 101.

13. Van Santen v. Oil Co., 81 N. Y. 171 ; Bleaden $r$. Charles. 7 Bing. 248.

14. Garber $v$ Armentrout, 32 Gratt. (Va.) 235; Bliss v. Thompson, 4 Mass. 488; Tỵon v. Annable. 4 Conn. 350 ; Robinson v. Welly.
40 W. Va. 385,22 S. E. 73 : Bull v. Quincey, 5: Ill. App. 186.

1. Ainslie v. Wilson, $7 \mathrm{Cow}$. (N. Y.) 662, 17 Am. Dee. 532; Randall v. Rieh, 11 Mass. 494.

2. Taylor v. Higgins, 3 East, 169 ; Cumning v. Fisher, 8 Johns. (N. Y.) 202 .

3. Clouch v. Moyer, 23 Kans. 404. 
ter; and if a written contract exists it takes precedence of all others, and forms the only contract between the parties during the time of its existence. ${ }^{1}$ As the law has prescribed different forms of action on different securities, assumpsit cannot be supported where there has been an express promise under seal or of record; but the party must proceed in debt or covenant where the contract is under seal. ${ }^{2}$ So long as the express contract remains in force, the party cannot abandon it and recover on an implied one. Where an express contract is shown, it follows as one of the fundamental principles of the law that none can be implied. ${ }^{3}$ But this rule has been qualified. If the express contract is not under seal, and embraces only what the law would imply, a party may sue on it or on the implied contract at his election. ${ }^{4}$

$\S 443$. Void contract.-A void contract is no contract at all; and if money is paid on such contract, it is paid without consideration either good or valuable and may be recovered back, unless the contract is of such a character that the law will not aid either party. ${ }^{5}$ And if it is void for one party it is void for the other, and the defendant cannot set it up as a defense and discharge of a debt honestly due the plaintiff. If the express contract fails on account of being void, the complaining party may recover pay on a contract created by law. ${ }^{6}$

1. Tietz v. Tietz, 90 Wis. 66,62 N. W. 339 ; Barry v. Ryan, 4 Gray (Mass.), 523; North v. Nichols, 37 Conn. 375; Spencer v. Parry, 3 Adol. \& El. 331 ; Lubbock v. Tribe, 3 Mecs. \& IVel. 607.

2. Chitty on Plead. 98, 344; Brewer v. Dyer, 7 Cush. (Mass.) 337; Colman v. Jenkins, 14 Mass. 93.

3. Holden Steam Mill Co. v. Westervelt, 67 Me. 446; Touissaint $v$. Martinant, 2 Term R. 100; Draper v. Randolph, 4 Harr. (Del.) 454; Voorhees v. Combs, 33 N. J.
L. 494. See, also, Walker v. Brown, 28 Ill. 378, 81 Am. Dec. 287; Dermott v. Jones, 2 Wall. (U. S.) 1; Western v. Sharp, 14 B. Mon. (Ky.) 177.

4. Gibbs v. Bryant, 1 Pick. (Mass.) 118; Princeton, etc. Turnpike Co. v. Gulick, 16 N. J. L. 161.

5. Gist v. Smith, $78 \mathrm{Ky} .367$.

6. Thurston v. Percival, 1 Pick. (Mass.) 415; Morier v. Morgan, 58 Ill. App. 235 ; Holbrook v. Clapp, I65 Mass. 563, 43 N. E. 508; Dowling v. MícKenny, 124 Mass. 478; Duquette v. Richar, 102 Mich. 483, 
$\S$ 444. Difference between express and implied contracts.The difference between express and implied contracts is merely a difference in the mode of proot; and at common law, in pleading the form of action for an implied contract is assumpsit. $^{2}$ Implied contracts are alleged in the declaration, the same as express ones, ${ }^{3}$ and a consideration is alleged. ${ }^{4}$ The statutes may now eontrol this mode of plearling.

\section{ARTICLE III.}

Receiving Money for the Usf of Anotiner.

Section 445. Receiving Money which Belongs to Another.

446. Receiving Property.

447. Illegal Contraets.

448. Want of Consideration-Recovering Back Money Paid.

449. Voluntary Payment with Knowledge of all the Facts.

450. Payment Under Mistake of Faet.

451. Agent of Both Seller and Purehaser-Payment of Commission.

452. Mistake of Law.

453. Mistake of Law in Equity.

454. Compromise.

455. Duress.

456. Payment of Taxes and Assessments.

\section{$\S$ 445. Receiving money which belongs to another.-If one} man has obtained money from another, through the medium of oppression, imposition, extortion or deceit, such money is, in contemplation of law, money received for the use of the in-

$60 \mathrm{~N}$ IV. 974; Hart v. Maney, 12 Wash. 260. 40 P. 987; Pracht v. Daniels, 20 Colo. 100, 36 P. 845. See, also, Lytle v. Bowden, 107 Ala. 361, 18 So. 130: Burton Lum. Co. v. Wilder. 108 Ala. 669, 18 So. 552.

1. Chureh v. Coke Co.. 6 Ad. \& El. 846 .
2. I Chitty on Plead. 302: Monson v. Williams, 6 Gray (Mass.), 416; Pawlet v. Silndgate, $19 \mathrm{Vt}$. 621 ; Downing $v$, Freeman, 13 Me. 90.

3. Bailey v. Bussing, 2s Conn. 1. 455. 21 Conn. 1.

4. Wingo v. Brown, l:s lich. (S. Car.) I. 279. 
jured party, which can be recovered back. ${ }^{1}$ And so, when money is received as a gift from a person of unsound mind, the law implies that it is held by the donee for the use of the donor. ${ }^{2}$

If property or anything else be received as the equivalent of money, by one who assumes to cancel or dispose of a property right, for which, by contract, or liability, legal or equitable, it is his duty to accomnt to another, the latter may treat the transaction as a receipt of money, and sue for it as such, in assumpsit. $^{3}$

Privity of estate is created where the defendant has received money belonging to the plaintiff, which in equity and good conscience he ought to repay. ${ }^{4}$ Thus, when a party sells land not belonging to him and receives the money, he becomes at once liable to the vendee for the money thus paid. ${ }^{5}$ So a party selling land which is owned jointly by himself and another, the latter can recover his share from the former. ${ }^{6}$

1. MeQueen v. Bank, 2 Ind. 413 ; Moore v. Shields, 121 Ind. 267, 23 N. E. 89 ; Bullard v. Haseall, 25 Mich. 132; Mason v. Waite, 17 Mass. 560 .

2. Teegarder v. Lewis, 145 Ind. 98, 40 N. E. 1047,44 N. E. 9. See, also, Walker v. Conant, 65 Mieh. 794, 31 N. W. 786 ; People v. Speir, 77 N. Y. 144.

3. Stewart v. Connor, 9 Ala. 803 ; Cameron v. Clark, 8 Ala. 259; Strickland v. Burns, 14 Ala. 511: Thompson v. Thompson, 5 IV. Va. 190 ; Jaekson v. Hough. 38 W. Va. 236, 18 S. E. 575 ; Vrooman v. MeKaig, 4 Md. 450, 59 Am. Dec 85 ; Lawson v. Lawson, 16 Gratt. (Va.) 230, 80 Am. Dee. 702; Merehants' lank v. Rawls, 7 Ga. 191, 50 Am. Dec. 394; Boyett r. Potter, 80 Ala. 476, 2 So. 1534; Barnett v. Warren, 82 Ala. 557, 2 So. 457; Glasseoek v. Lyons, 20 Ind. 1, $83 \mathrm{Am}$. Dee. 299 ; O'Fallon v. Boismenn, 3 Mo.
405, 26 Am. Dee. 678; O'Conley v. Natehes, 1 Sm. \& M. (Miss.) 31, $40 \mathrm{Am}$. Dee. 87; Barnes v. Johnson, 84 Ill. 95; Chemieal Nat. Bank v. Bank, 156 Ill. 149, 41 N. E. 225.

4. Walker v. Conant, 65 Mich. 194, 31 N. W. 786 ; Drake v. Whaley, 35 S. Car. 187,14 S. E. 397 ; Compare Sergeant v. Stryker, $16 \mathrm{~N}$. J. L. 464, 32 Am. Dec. 404 .

5. Pevey v. Jones, 71 Miss. 647, 16 So. 252, 42 Am. St. Rep. 486. See, also, Birmingham Lumber Co. v. Brinson, 94 Ga. 517, 20 S. E. 437 ; Paul v. Grimm, 165 Pa. St. 451, 30 A. 721 .

6. Gottschalk v. Smith, 156 Ill. 377,40 N. E. 937. See, also, Zang Brewing Co. v. Bernheim, 7 Colo. App. 528, 44 P. 380 : Brand v. Williams, 29 Minn. 238, 13 N. 42; Haebler v. Myers, 132 N. Y. 363, 30 N. E. 963,15 L. R. A. 588; Clark v. Pinney, 6 Cow. (N. Y.) 297. 
$\$$ 446. Receiving property.- In action to reorere for money paid, or had and reseived, will nut generally lie except upon the payment of maney. But if property, on anything else, be received as the equivalent of noney, by a perion who has assumed to ancel or dispose of a property right, for which he is liable legally or epuitably, to aceount to another, the latter may treat the transaction as a receipt of money, and sue for money had and received. ${ }^{2}$

The action may lie when the equivalent of money has been actuilly accepted as noney, by the party receiving it, as where an agent has discharged his principal's debt br applying thereon a debt owing by himself ${ }^{3}$ or where a surety has transferred property to the ereditor, who received it in payment of a judgment. ${ }^{4}$

But where property has been received by the defendant, but has not been converted into money, and is not received as an equivalent of money, there is no implied contract for money had and received $;^{5}$ lut so soon as the property has been sold and converted to the defendant's use, then it can be recovered as money had and received $;$ or has had the property so long that a presumption of its sale arises. ${ }^{7}$

It has been held that no action for money had and receired will lie, if the amount of the property cannot be ascertained

1. National Trust Co. v. Gleason, 77 N. Y. 400, 33 Am. Rep. 632 and note; Cumming v. Hackley, s Johns. (N. I.) 202; Moyer v. Shoemaker, 5 Barb. (N. Y.) 319.

2. Barnett v. Warren, 8உ Ala. 557, 2 So. 457; Brundage r. Port. chester, 102 N. Y. 494,7 N. E. 398 ; Balch v. Patten, 45 Me. $41,71 \mathrm{Am}$. Dec. 526 ; Libby $r$. Robinson, $79 \mathrm{M}$ e. 168, 9 A. 24; Atkins r. Owen, 4 Adol. \& El. S19; Lee v. Mleritt, s Q. B. 820 .

3. Beardsley v. Root, 11 , lohns. (N. Y.) $46 t, 6 \mathrm{Am}$. Dec. 386 .

4. Bonney $r$. Seely, 2 Wend. (X. Y.) 481 .
5. Moody v. Walker, 89 Ala. 619 , 7 So. 246; Tuttle v. Campbell, 74 Mich. 652, 42 N. W. $384,16 \mathrm{Am}$. St. Rep. 652 and note; Stearns $r$. Dillingham, 22 Vt. 624, $54 \mathrm{Am}$. Dec. 88; Hendricks v. (ioodrich, 15 Wis. 679; Thurston v. Mills, 16 East, 254.

6. Staat v. Evans, 35 III. 455; Comstock v. Hier, 73 ‥ Y. 269,29 Am. Rep. 142; Gilnore v. Wilbur, 12 Pick. (Mass.) 120, $22 \mathrm{Am}$. Dec. 410; Olive r. Olive, 95 X. Car. 485.

7. Moody r. Walker, 89 Ala. 619 , 7. So. 246 . 
though sold; or if the property has been exchanged for other property $;^{9}$ or if the money or an equivalent is not received. ${ }^{10}$

$\$ 447$. Illegal contract.- The principle of law is ex dolo malo oritur actio-a right of action cannot arise ont of fraud. So no conrt will lend its aid to a man who founds his cause of action upon an immoral or illegal action. ${ }^{11}$ Hence, where a party has knowingly paid money under an illegal or immoral contract, he cannot recorer it back. ${ }^{12}$

And, so, if a man loans moncy with the intention and understanding on his part that it is to be used for an illegal purpose, and it is so used, he cannot recover it back from the borrower; he must loan his money for the express purpose of promoting the illegal design of the borrower. ${ }^{13}$

\section{$\S 448$. Want of consideration - Recovering back money} paid.-Wherever a contract is rescinded according to the original terms of it, the purchaser may well recover the price as money had and received to his use. ${ }^{1}$ So where a contract is defeated by the negligence or misconduct of one party, the other may have his election to rescind the contract and recover

8. Saville v. Welch, 58 Vt. 683 , 5 A. 491; Glascock v. Hazell, 109 N. Car. 457,13 S. E. 789 .

9. Fuller v. Duven, 36 Ala. 73, 76 Am. Dec. 318; Kidney v. Persons, 41 Vt. 386, 98 Am. Dec. 595.

10. Budd v. Hiler, 27 N. J. L. 43.

11. Holman v. Johnson, 1 Cowp. 341 .

12. Gaylord v. Soragen, $32 \mathrm{Vt}$. 110. 76 Am. Dec. 154; Hill : Spear, 50 N. H. 253, 9 Am. Rep. 205.

13. Tyler v. Carlisle, 79 Me. 210 , 2 A. S45, 1 Am. St. Fep. $: 1$ and note; Green v. Collins, 3 Cliff C. C. 494; Peck v. Briggs, 3 Denio ( $\mathrm{N}$. Y.), 107 ; McIntyre v. Parks, 3
Met. (Mass.) 207 ; Banchor v. Mansel. 47 Me. 58; Cannan v. Bryce, 3 Barn. \& Ald. 179; McKinnell v. Robinson, 3 Mees. \& Wel. 434; Tracy v. Talmage, 14 N. Y. 162, 67 Am. Dec. 132 and note.

1. Towers v. Barrett, 1 Term R. 133; Giles $\because$ Edwards, 7 Term R. 181; Devaux v. Conolly, 8 é. B. 640; Earl v. Bickford, 6 Allen (Mlass.), 549, 83 Am. Dec. 651; . Tolınson v. Jennings, 10 Gratt. (Va.) 1, 60 Am. Dec. 323: Claflin v. Godfrey, 21 lick. (Mass.) 1 ; Cripps v. Reade, 6 Term R. 606; Wright v. Dickenson, 67 Mich. 580, 42 N. IV. 849, 11 Am. St. Rep. 602 ; słhwinger v. Hickol, 53 N. Y. 280. 
baek the purchisemoney, or to enforee it, and recorer damages for its breach. ${ }^{2}$

And if a person sells bills, notes and other paper, which turn ont to be forgeries, or for other anses are of no value, the purchaser can lning an action to recorer back the purchasemoney $;^{3}$ so if a person sells land but conveys no title, money paid can be recorered back as money had and receired."

But if a party rescind a contract, he must do it in toto. He camnot diselaim it in part and enforce it in part. So, also, the party reseinding must place the other party in statu quo. If this camnot be done, the contract cannot be rescinded. Hence, if the contract be in any part executed, it cannot be discarded, ${ }^{5}$ and the injured party, if he has a remedy, must sue for breach of the contractt. ${ }^{6}$

Therefore, when several chattels are sold in gross, for one sum, which is paid by the purchaser, and part of them are delivered, but the seller refuses to deliver the remainder, the purchaser cannot, if he retains those already delivered, recover back any portion of the purchase-money, in an action for money paid, or money had and received, and his remedy is upon the special contract for damages. ${ }^{7}$

But where the contract embraces two or more subjects, the performance of one of them does not supersede the agreement

2. Giles v. Edwards, 7 Term R. 181.

3. Wood v. Sheldon, 42 N. J. L. 421, 56 Am. Rep. 523; Watson v. Cresap, I B. Mon. (Ky.) 195, 36 Am. Dec. 572; Ripley v. Case, 86 Mieh. 261, 49 N. W. 45: Moore $v$. Garwood, 4 Exch. 681; Burchfield v. Moore, 3 El. \& Bl. 683; Gurney v. Womersley, 4 El. \& Bl. 133 ; Westropp v. Solomon, 8 C. 13. 345.

4. Schwinger v. llickok, $53 \mathrm{~N}$. Y. 280 ; Earle v. Bickford, 6 Allen (Mass.), 549, 18 Am. Dec. 651.

5. Hunt r. Sick, 5 East, 449 ; Kimball v. Cumningham. 4 Mass.
502, 3 Am. Dec. 230 ; Conner v. Henderson, 15 Nass. 319, 8 Am. Dec. 103; Rand v. Webber, 64 Me. 191 ; Clark v. Baker, 5 Met. (Mass.) 452; Morse v. Brackett, 98 Mass, 205; Johnson v. Johnson, 3 Bos. \& Pul. 162; Way v. Cutting, 17 N. H. 450 ; Bassett $v$ Percival, 5 Allen (Mass.), 345.

6. Blackburn $v$. Smith, 2 Exch. 793 ; Swart v. Gale, 62 న. H. 62.

7. Miner v. Bradley, 22 Pick. (Mass.) 45T; Johnson v. Johnson, 3 Bos. \& Pul. 162. See, also, Gomjertz r. Denton, I Cromp. \& M. 207. 
as to the others. If the eonsideration is severable, the part failing may be recovered back as money had and received. ${ }^{8}$

The party cansing the failure of eonsideration by his own default, camnot recover the money paid ${ }^{9}$ and where he buys property at his own risk and pays aceordingly, he eannot recover if it loes not prove of any value $;^{10}$ if the purchaser receives what he bargains for, he has no cause of complaint. ${ }^{11}$

$\S 449$. Voluntary payment with knowledge of all the facts. -A voluntary payment, made with full knowledge of all the facts and circumstances of the ease, though made under a mistaken view of the law, cannot be revoked, and the money so paid cannot be recorered back. ${ }^{12}$ This rule rests upon the general prineiple of public convenience and applies to a corportation as well as to a natural person. ${ }^{13}$

And, so, when one voluntarily pays a void contract with knowl-

8. Laflin v. Howe, 112 Ill. 253; Miner v. Bradley, 22 Pick. (Mass.) 457 ; Goodspeed v. Fuller, $46 \mathrm{Me}$. 141; Johnson v. Johnson, 3 Bas. \& Pul. 162; Devaux v. Conolly, 8 C. B. 640 .

9. Stray v. Russell, l El. \& El. 888.

10. Lambert v. Heath, 15 Hees. \& Wel. 486; Morley v. Attenberough, 3 Exch. 500; Westlake v. Adams, 5 C. B., N. S. 266.

11. Taylor v. Hare, l Bos. \& Pul., N. R. 260; Westlake v. Adams, 5 C. B., N. S. 266.

12. Clark v. Dutcher, 9 Cow. (N. Y.) $67+$; Lge v. Koontz, 8 Pa. St. 109 ; Boston, etc. Co. v. Boston, 4 Met. (Mass.) 181; Benson v. Womroe, 7 Cush. (Mass.) 125, 54 Am. Dec. 116; Melins v. Duncan, 6 Barn. \& Cr. 671; Stewart v. Stewart, 6 Cl. \& Fin. 911; Lamborn v. Commissioners, 97 U. S. 181; Carson r. Coeluan, 5e Minn. 65. 53
N. IV. 1130 ; Bryson v. Home, 168 Pa. St. 352, 31 A. 1008; Armstrong r. Latimer, 165 Pa. St. 398, 30 A. 990 ; Hickman v. Eggmann, 53 Ill. App. 561; Garretson v. Joseph, 100 Ala. 279,13 So. 948; Wessel v. i.and Co., 3 N. Dak. 160, 54 N. W. 922 ; Evans r. Hughes, 3 S. Dak. 244, 52 N. W. 1062; Vanderback v. Rochester, 122 N. Y. 285,25 N. E. 408 ; Wayne County v. Randall, 43 Mich. 137, 5 N. 7.5; Valley Railroad Co. v. Iron Co., 16 Ohio St. 4.1, 18 X. E. 486, 1 L. R. A. 412; ('hristy v. Sullivan, 50 Cal. 337,19 - An. Rep. 655; Mutual Sav. Inst. v. Enslin, 46 Mo. 200; Trigg v. Read, 5 Humph. (Tenn.) 529; Bearl v. 13eard, 25 W. Va. 486, 52 An. R(p. 21!); Snelson v. State, 16 Ind. 29.

13. Valley Railroad Co. v. Iron Co., 4 ti Ohio St. 44,18 N. W. 486,1 L. R. A. 412. 
edge of the facts remlering it roid, he anuot recover lack the money paid. ${ }^{14}$ So if a party voluntarily, and without mistake of faet, pays as interest a greater anmomt flom is legally enforceable, but not nsurions, the appropriation thus marle by the parties will not lee disturbed, but will stand as a voluntary payment. ${ }^{15}$

$\S 45^{\circ}$. Payment under mistake of fact.-The general rule is that where a person makes a payment to another under such a mistake as to material facts as to create a belief in the existence of a liability to pay, which does not really exist, he can recover it back as money had and received for his nse. ${ }^{1}$

But money paid under a mistake of facts cannot be reelaimed where the party paying it has derived a substantial benefit from the payment; nor where the party to whom paid received it in good faith in satisfaction of an equitable claim, nor where it was due in honor and conscience. The right to remedy in such eases turns upon the question as to whether the party receiving the money paid by mistake ean in good faith retain it. $^{2}$

Money paid under a mistake of fact to which the plaintiff's negligence has in no way contributed, may be recovered back by lim, ${ }^{3}$ and it is no defense to an action bronght to recover it

14. Powell v. Supervisors, $46 \mathrm{~W}$ is. 210,50 N. W. 1013 ; Mayor v. Leffernan, 4 Gill (Md.) 425, $45 \mathrm{Am}$. Dec. 145 and note; Babcock v. Fond du Lac, 58 Wis. 230. 16 N. 625: Irvine v. Hanlin, 10 Serg. \& $R$. (Pa.) 219; Mills v. MeDaniels, 59 Mo. App. 331.

15. Carson v. Cochran, 52 Minn. 67, 53 N. W. 1130. See, also, Holt v. Thomas, 105 Cal. 273, 38 P. S9l; Richey v. Clark, 11 Utah, 467, 40 P. 7l7: Edwaleds v. Haldware Mannf. Co., 59 Minm. 178, $60 \mathrm{~N}$. IV. $109 \%$.

1. Mayor v. New York, 63 N. Y.
455; Glenu v. Shannon, 1: S. Car. 570; Hazard v. Ins. Co.. 7 R. I. 429: Citizens lsank v. Grafllin, 31 Mil. $507,100 \mathrm{Am}$. 1)ee. 66 ; MeDonald v. Jyzuch, 59 Mo. 350.

2. Norton v. Marden. 15 Me. 45 . $3: 2$ Am. Dee 132; Moore v. Eddowes, 2 Ad. \& kl. 133: Glenn v. Shannon, 12 s. Car. 570 ; Foster v. kirby, 31 Mo. 496; lirisbane $v$. Dacres, 5 Taunt. 143, l133; Farmer v. Armulel, 2 W. Bl. S24: Pensacolar ete. R. R. Co. r. Braxton. 34 Fla. 471.

3. Jilinchard v. Low, 164 Mass. 118,41 N. E. 118. 
that the mistake arose through the plaintiff's negligence, if such negligence caused the defendant no harm. ${ }^{4}$ And in general, to defeat an action for money voluntarily paid under a mistake of fact, it is not sufficient that the plaintiff might have known the facts bad he arailed himself of the means of information possessed by him, ${ }^{5}$ provided the defendant has not changed his position so that he cannot be placed in statu quo. ${ }^{6}$

But if the money is paid with the intention that the person receiving shall have the money at all events, irrespective of the facts, it cannot be recovered back $;^{7}$ or if he has recovered that for which he bargainerl. And so a bank can recover back from the payee of a check, the amount above the depositor's credit, when the bank supposed the depositor had sufficient funds in the bank to pay the check in full. ${ }^{8}$

Money paid to a bank by the indorser of an instrument, which has been discounted by the bank, and which both supposed erroneously was a negotiable promissory note, cannot be recovered back. ${ }^{9}$

4. Appleton Bank v. McGilvrey, 4 Gray (Mass.), 518, 64 Am. Dec. 92; Kingston Bank r. Ettinger, 40 N. Y. 391,100 Am. Dec. 516.

5. Kelly v. Solari, 9 Mees. \& IVel. 54; Bell v. Gardiner, 4 Mann. \& Gr. 11; Franker v. Little, 24 Kan. 598, 36 Am. Rep. 262: Waite v. Leggett. 8 Cow. (X. I.) 195, 18 Am. Dec. 441 ; Wheadon v. Olds, 20 Wend. (N. Y.) 174; Devine v. Edwards, 87 IH. 177: Alston v. Richardson, 51 Tex. 1; Lyle v. Shinnebarger, 17 Mo. App. 74; Dobson $\mathrm{r}$. Wimmer, 26 Mo. App. 329; MoCracken v. San Francisco, 16 Cal. 591; Douglas County v. Kicller, 43 Nebr. 635, 62 N. W. 60; Rutherford v. MeIvor, 21 Ala. 750 ; Koontz v. Bank, 5l Mo. 275; Walker v. Conant, 65 Mich. 194, 31 N. W. 786;
Lawrence v. Bank, 54 N. Y. 432; Brown v. Road Co., 56 Ind. 110; Compare WVilson v. Barker, 50 Me. 447 ; Brummitt v. McGuire, $107 \mathrm{~N}$. Car. 351,12 S. E. 191.

6. Walker v. Conant, 65 Mieh. 194, 31 N. W. 786.

7. Troy v. Bland, 58 Ala. 197; Kelly v. Solari, 9 Mees. \& Wel. 54; Buffalo v. O'vlalley, 61 Wis. 255, 20 N. 913, 50 Am. Rep. 137 and note; McArthur v. Luee, 43 Mich. 435. 5 N. 451, 38 Am. Rep. 204; Bergenthal v. Fiebrantz, 48 Wis. 435. 4 N. 89.

8. Merchants" Nat. Bank v. Bank, 139 Mass. 513, 2 N. E. 89.

9. Alton v. Bank, 157 Mass. 341, 32 N. E. 228,18 L. R. A. 144, 34 An. St. Rep. 285. 
$\$ 45$ I. Agent of both seller and purchaser - Payment of commissions.-One cammot act as agent for both seller and purchaser, moless both prineipals know of and assent to his mndertaking such aceney and reopivine andmisions form both. ${ }^{10}$ And so money paid lie a principal to his agent tor the latter's services in the sale of property may be recovered back, in an action at law, when it appears that such agent has recejved or was to receive a commission from the other party to the trade or sale for similar services, if it also appen that at the time snch principal made the payment he was ignorant of the fact that his agent was agent of the other principal. ${ }^{11}$

$\$$ 452. Mistake of law.-Where the mistake is of law and not of fact, the payment will be considered as voluntary and cannot be recovered back. ${ }^{1}$ Thus, where the payment is made with full knowledge of all the facts in the case, ignorance of the law will not give the plaintiff a right of action, he having made payment voluntarily and not under compulsion ${ }^{2}$ he cannot recover back though he was not liable upon the debt demanded. ${ }^{3}$

10. Holcomb v. Wea ver, 136 Mass. 265; Byrd v. Hughes, 84 Ill. 174 , 25 Am. Rep. 442; Atlee v. Fink, 75 Mo. 100; 42 Am. Rep. 385 and note; Scribner v. Collar, 40 Mich. 375, 29 Anı. Rep. 541.

11. Cannell v. Smitl, 142 Pal. St. 25, 21 A. 793, 12 L. R. A. 395 and note; Campbell v. Baxter, 41 Neb. 729, 60 N. W. 90. See, also, Kelly r. Solari, 9 Mces. \& Wel. 54; Everhart v. Searle, 71 Pa. St. 256; Raisin v. Clark, 41 Md. 158, 20 Am. Rep. 60: Farusworth v. Hemmer, I Allell (Mass.), 494, 79 Am. Dee. 756.

1. Gage v. Allen, 89 Wis. 98,61 N. IV. 361 ; Pass v. Grenada County, 71 Miss. 426, 14 So. 447; Snell v. Ins. Co., 98 [. S. 85 ; llunt v.
Rousmanier, 1 Pet. (U. S.) 1, 8 Wheat. (U. S.) 174; Price v. Estill, 87 Mo. 378; Norton v. Highley. man, 88 Mo. 621 ; Harralson v. Barrett, 99 Cal. 607,34 P. 342.

2. Cook v. Boston, 9 Allen (Mass.), 393 Benson v. Monroe, 7 Cush. (Mass.) 125, 54 Am. Dec. 716; Forbes v. Appleton, 5 Cush. (Mass.) 115; Brisbane v. Dacres, 5 Taunt. 144; Couch v. Fansas City, 127 Mo. 436, 30 S. W. 117. See, also, Camptehl v. Clark, 44 Mo. App. 249.

3. Vanderbeek $r$. Rochester, 122 N. Y. 285,25 N. E. 408: Hubbard v. Martin, 8 Yerg. (Tenn.) 498: Wayne County v. Randall, 43 Mich. 137,5 N. 75 ; Berklıauser $r$. Schmitt. 45 Wis. 316, 30 Am. Rep. 
Where the law is musettled and is in doubt, money paid with full knowledge of the facts, but under mistake of the true construction of the law, may loe considered in the nature of a compromice, and camnot be recoveresl back, mless the transaction be between persons who do not stand on equal footing. ${ }^{4}$ Hence, a private eitizen buying public land, and a receiver of the land officer acting under the instructions of his superior, do not stand on an equal footing as to the law governing such transaction; and money paid by such citizen for land at a higher price than the statute requires, may be reeovered back, though paid without objection or protest. ${ }^{5}$

It numst be remembered that the money paid in mistake of law, must be without frand or mistake of fact, in order that it cannot be recovered. ${ }^{6}$

Where the parties are not on equal terms, the general rule does not apply. Thus, a payment marle to a public officer in discharge of a fee or tax illegally exacted, is not such a voluntary payment as will preclude the party from recovering it back. $^{7}$

Where the payment is made muler a speries of duress, the rule does not apply. Thns, in ease where money is paid in excess of what is due in order to prevent a threatened sale of mortgaged property $;^{8}$ and so payments made to a common carrier to induce it to do what by law, withont them it was bound to do, are not voluntary $;^{9}$ and so illegal interest, paid as a condition to redeem a pledge is a payment by compulsion, and not voluntary; $;^{10}$ and so illegal fees exacted by a collector,

740; Needles v. Burk, 81 Mo. 349, 51 Am. Fep. 25l; Langevin v. St. Paul, 49 Minn. 189. 51 N. W. 817 ; Beard v. Beard. 25 W. Va. 486,52 Am. Rep. 219.

4. Healey v. United States, 29 Ct. Cl. 115 .

5. Healey v. United States, 2! Ct. Cl. 115.

6. Scotland County v. Ewing. 116 Mo. 129, 22 S. W. 476; Snelson v. State, 16 Ind. 31: Supervisors v.
Briggs, 2 Denio (N. Y.), 26; Iowa City v. Johnson County, 99 Iowa. 513,68 N. W. 815.

7. Swift Co. v. United States, 111 C. S. 22, 4 S. Ct. 244.

8. Close v. Phipps, 7 Man. \& Gr. 5.si.

9. Parker v. Railway Co., 7 Man. \& Gr. 253.

10. Astley v. Reynolds, 2 Strange, 915; Tutt v. Ide, 3 Blatchf. C. C. 249. 
though sanctioned by a long continued usage and practice in the office, unter a mistaken construction of the statute, even when paid without protest, may he recovered back, on the ground that the payment was compulsory and not roluntar.."

To make a parment involuntary, it is not necessary that it should be by actual riolence or any plysical duress. It is sufficient if the payment is caused on the one part by an illegal demand, and made on the other part reluctantly, and in consequence of that illegality, and without being able to regain possession of his property, except by submitting to the payment. ${ }^{12}$ To make the payment a voluntary one, the parties should stand upon an equal footing. ${ }^{13}$

If a person illegally claims a fee colore officii, the payment is not voluntary so as to preclude the party from recovering back. ${ }^{14}$ And one who is compelled to pay more than his shares of the fees of a tax collector in order to prevent a tax sale of his land, may recover the excess in assumpsit. ${ }^{15}$

$\S$ 453. Mistake of law-In equity.-Mistakes of law cannot generally be admitted as a ground of relief in equity, but this rule is not of universal application. ${ }^{1}$ And where there is a mixed mistake of law and of fact, relief in equity will be granted. ${ }^{2}$

Upon the general question whetiner, where all the facts are known, or may with ordinary diligence be known, money paid under a mistake of law may be recorered back, the authorities conflict.

11. Ogden v. Maxwell, 3 Blatehf. C. C. 319 .

12. Maxwell v. Griswold, 10 How. (U.S.) 242; American Steamship Co. v. Young, 89 Pa. St. 186, 33 Am. Rep. 748; Cunniugham v. Monroe, 15 Gray (Mass.), 471; Carew v. Rutherford, 106 Mass. 1, 8 Am. Rep. 287; Preston v. Boston, 12 Pick. (Mass.) 17.

13. Beckwith v. Frisbie, s: vt. 559,566 .
14. Morgan $v$ Palmer, 2 Barn. \& Cr. 729 ; Steele v. Williams, 8 Exch. 6.25.

15. Benton $\mathrm{r}$. Goodale, $66 \mathrm{~N}$. H. 424, 30 A. 1121: Cardigan $\%$ Page, (i) N. H. 182 .

1. Baker r. Massey, 50 Towa, 399: Iowa City r. Johnson County, 99 Iowa. 5ł3. 68 N. W. S15.

2. (iriffith r. Townley, 69 Mo. 13. 33 Am. Rep. 476. 
It is lield by some courts that money paid under a mistake either of law or of fact, is no defense to an action brouglit to recover it, that the mistake arose through the plaintiff's negligence, if such negligence caused the defendant no harm. ${ }^{3}$ And this is especially so where the party making the payment acts in a fiduciary capacity. So a recovery cannot be prevented in all cases where money is paid under a mistake of law. ${ }^{4}$

The rule to entitle the plaintiff to recover money paid under mistake of fact is: 1 . The money must be paid by one under a mistake of his rights and his duty, and be such as he is under no moral or legal obligation to pay. 2. The recipient of the money must have no right in good conscience to retain it. ${ }^{5}$

And so where an administrator, under a mistake of law, makes an over payment of a claim, he can recover back the surplus. ${ }^{6}$

$\S$ 454. Compromise.-If, in a settlement of mutual accounts, one party thereto allows, without being induced by fraud, a certain sum of money by way of compromise of a doubtful claim, he cannot recover it back. ${ }^{1}$ If the settlement is the result of a compromise, it is, in absence of frand, binding and conclusive. It is sufficient to render the settlement valid if there are questions in dispute between the parties which have been decided. ${ }^{2}$ Where the settlement is made by both parties without fraud on the one side, or ignorance or misunder-

3. Northrop v. Graves, 19 Conn. 548, 50 Am. Dec. 264; Culbreath v. Culbreath, 7 Ga. 64, 50 Am. Dec. 375 ; Stevens v. Goodsell, 3 Met. (Mass.) 34 Rogers v. Weaver, 5 Ham. (Ohio) 536; Beatty v. Dufief, 11 La. Ann. 74; Mansfield v. Lynch, 59 Conn. 320, 22 A. 313, 12 L. R. A. 285 .

4. Mansfield v. Lynch, 59 Conn. 320, 22 A. 313, 12 L. R. A. 285.

5. Mansfield v. Lynch, 59 Conn. 320, 22 A. 313, 12 L. R. A. 285;
Northrop v. Graves, 19 Conn. 548, 50 Am. Dec. 268. See, also, Culbreath v. Culbreath, 7 Ga. 64, 50 Am. Dec. 375; Stevens v. Goodsell, 3 Met. (Mass.) 34; Rogers v. Weaver, 5 Ham. (Ohio) 536; Beatty v. Dufief, 11 La. Ann. 74.

6. Mansfield v. Lynch, 59 Conn. 320, 22 A. 313, 12 L. R. A. 285.

1. Stuart v. Sears, 119 Mass. 143.

2. Barlow v. Ins. Co., 4 Met. (Mass.) 270; Kerr v. Lucas, 1 Allen (Mass.), 279. 
standing of any material facts on the other side, it is conclusive. ${ }^{3}$

But if there be a mistake as to a milterial fact, whirh was believed to be true, and on the belief in the truth the eompromise was made, then the payment of money may he reeorered baek, the law creating an implied contract to repay. ${ }^{4}$

$\S$ 455. Duress.-Payment by a person prima facie liahle for a debt under a threat by the creditor to sue therefor unless it is paid, is not a payment under duress, and it camnot be recovered back $;^{5}$ for it is not duress to threaten to or actually take advantage of the usual remedy for the enforcement of a debt or obligation $;^{6}$ and this is true even if the elaim be an illegal one. $^{\text {? }}$

But where an arrest is made for the purpose of extortion, money paid by the person arrested while under duress by imprisonment and threats, may be recovered though there is probable cause and the warrant was irregular, as for money had and received.

$\S 456$. Payment of taxes and assessments.-Where one pays an illegal demand for taxes with a full knowledge of all the facts which render such demand illegal, without an immediate and urgent necessity, or unless to release his person or property from detention, or to prevent an immediate seizure of his person or property, such payment must be deemed voluntary and cannot be recovered back; $;^{1}$ and the fact that the party at the

3. Diebold, etc. Lock Co. v. Barnes, 53 Ill. App. 144.

4. Rheel v. Hicks, 25 N. Y. 289.

5. Holt v. Thomas, 105 Cal. 273, 38 P. 891.

6. Brumaguire v. 'Tillinghast, 18 Cal. 271,79 Am. Dec. 176; Bucknall v. Story, 46 Cal. 587: Mayol v. Lefferman, 4 Gill (Md.), 425, 45 An. Dec. 145 and note; Weber $r$. Kerkendall, 44 Neb. 766,63 N. W. 35.
7. Preston v. Boston, 12 Pick. (Mass.) 12; Holt v. Thomas, 105 Cal. 273, 38 P. 891.

8. Fillman v. Ryon. 168 Pa. St. 404, 32 A. 89.

1. Dixon County r. Beardshear, 35 Neb. 389,56 N. W. 990 ; Flopkins r. Butte, 16 .11ont. 103, 40 P. S65; First Nat. Bank r. Mayor, 68 Ga. 120, 45 Am. Rep. 476; Rogers v. Grecnbush, 5s Me. 392, 4 Am. Rep. 
time of making the payment files a written protest, does not make the payment involuntary. ${ }^{2}$

And money voluntarily paid by the holder of a tax sale certificate for subsequent taxes on the property, cannot be recovered back, in the absence of frand and mistake. ${ }^{3}$

But where money has been paid on an assessment which is roid for want of jurisdiction, ${ }^{4}$ or where authority to levy a tax is wholly wanting, ${ }^{5}$ the money may be recovered back. And so when a party not liable to taxation is called upon peremptorily to pay taxes, and he can save his property and himself in no other way than by paying the illegal demand, he may pay under protest and then reeover the money so paid. ${ }^{6}$

But where the assessment is illegal and the city has no means to enforce it, or of seizing the person or property of the party, or of selling lis property and giving the purchaser a color of title, and the party knows the facts, and pays the demand, he cannot recover it back. ${ }^{\text {? }}$

292; Bowman v. Boyd, 21 Nev. 281, 30 P. 823 ; Richardson v. Denver, 17 Colo. 398, 30 P. 333; Swift v. Poughkeepsie, 37 N. Y. 511.

2. Wabaunsee County v. Walker, 8 Kan. 431; Union, etc. R. R. Co. v. Dodge County, 98 U. S. 541; Ligonier v. Ackerman, 46 Ind. 552, 15 Am. Rep. 323; Morris v. Mayor, 5 Gill (Md.), 244; Goddard v. Seymour, 30 Conn. 394; Garrigan v. Knight, 47 Iowa, 525; Powell v. St. Croix County, 46 Wis. 210, 50 N. W. 1013; Little v. Bowers, 134 U. S. 547,10 S. Ct. 620 ; Hopkins v. Butte, 16 Mont. 103, 40 P. 865.

3. Lindsey v. Boone County, 92 lowa, $86,60 \mathrm{~N} . \mathrm{W} .173$.

4. Mutual Life Ins. Co. v. New
York, 144 N. Y. 494,39 N. E. 386 ; Jex v. Mayor, 103 N. Y. 536, 9 N. E. 39.

5. Shoup v. Wills, 2 Idaho, 108, 6 P. 124; Gillette v. Hartford, 31 Conn. 351; Newman v. Supervisors, 45 N. Y. 676.

- 6. Manufacturing Co. v. Amesl)urg, 17 Mass. 461; Preston v. Boston, 12 Pick. (Mass.) 14; Erskine v. Van Arsdale, 15 Wall. (U. S.) 75; Whitney v. Port Huron, 88 Mich. 268, 50 N. W. 316, 26 Am. St. Rep. 291.

7. Newcome v. Davenport, 86 Jowa, 291, 53 N. W. 232. See, also, Bucknell v. Story, 46 Cal. 595, 13 Am. Rep. 220; Rutledge v. Price County, 66 Wis. 35,27 N. W. 819 . 


\section{AR'TICLE IV.}

\section{Rechenat Benfate from Another.}

Secriox 45\%. Voluntary lienefits conferred.

458. Voluntary Acceptance of Benetits.

459. Municipal Corporations.

460. Family lielations-Benefits Received.

461 . Services of a Supposed Wife.

462. Extra Services.

463. Corporation's liability to Its Promoters.

464. Implied Assumpit-Waiving a Tort.

465. Oral Agreement to Bequeath or Devise Property.

466. Enforcement in Equity and in Law.

467. Parol Contract.

468. Necessaries for Wife.

469. Necessaries for Minor-Money Furnished by Another.

470. Father Liable for Necessaries for Minor Children.

471. Necessaries for Insane Person.

472. Liability of Insane Person's Estate.

473. Part Performance-Quantum Meruit.

474. Wilful Default-Wages.

475. Default not Wilful-Personal Service.

476. Promise to Marry.

477. Substantial Performance.

478. Order Given by One and Filled by Another.

479. Part Performance Under a Void Contract.

480. Under no Obligations to Perform-Part Performance.

481. Failure to Pay in a Manner Agreed to.

482. Part Performance-Rescission of Contract.

483. Work and Labor.

484. Physician's Services.

485. Burial of the Dead.

$\S 457$. Voluntary benefits conferred.-Any act done for the benefit of another without his acceptance is to be deemed a voluntary act, for whicli no action can be sustained, muless after knowing of the scrvice the person benefited promises to pay for it. ${ }^{1}$

1. New Orleans, etc. R. R. Co. v. Turcan, 46 La. Anu. 155, 15 So. 187; Cahill v. Hall, I61 Mass. 512, 37 N. E. 513 ; Bartholomew v. Jack- son, 20 Johns. (N. Y.) 29, 1 I Am. Dee. 238 and note; Glenn v. Savage, 14 Oreg. 567; Reus Glass Factory v. Reed, 5 Cow. (N. Y.) 587 ; Lynch 
A party has a right to select and determine with whom he will contract, and cannot have another person thrust upon him without his consent. In all cases of express contract a party may contract with whom he pleases; the sufficiency of his reasons for so doing cannot be inquired into. But there are cases where the law will imply a promise to pay by a party who protests he will not pay; but those cases are cases in which the law creates a duty to perform that for which it implies a promise to pay, notwithstanding the party owing the duty absolutely refuses to pay. If a man absolutely refuses to furnish necessaries to his wife and minor children, the law will compel lim to do it, and imply a promise against his protestations. But such promise will never be implied against his protest, except in cases where the law itself imposes a duty; and this duty must be a legal duty. Hence, a promise will not be implied against the express declaration of a person upon whom no legal duty is imposed by law. ${ }^{2}$ And so a promise will not necessarily be implied from the mere fact of having denied a benefit. ${ }^{3}$

Because there is no privity of contract between the parties, and without such privity the possession and use of property of another will not support implied assumpsit. ${ }^{4}$

Thus, where an ice company can no longer perform its contract with a consumer, and sells its business to another company who, unknown to the consumer, furnishes the ice, the consumer is not liable for the ice so furnished by the grantee of the original company with whom he had a contract. ${ }^{5}$ If he

v. Bogy, 19 Mo. 170; Bailey v. Gibbs, 9 Mo. 45; Jones v. Wilson, 3 Johns. (N. Y.) 434; Beach v. Vanderbergh, 10 Johns. (N. Y.) 360 ; Shaw v. Graves, 79 Me. 166, 8 A. 884 ; White v. Jones, 14 La. Ann. 681 ; Potter v. Carpenter, 76 N. Y. 157 ; Jared v. Vanvleet, 13 Ill. App. 334.

2. Earle v. Coburn, 130 Mass. 596 ; Whiting v. Sullivan, 7 Mass. 107.
3. Boston Ice Co. v. Potter, 123 Mass. 28, 25 Am. Rep. 9. See, also, Sehmaling v. Tomlinson. 6 Taunt. 147 ; Boulton v. Jones, 2 Hurl. \& N. 564.

4. Hills v. Snell, 104 Mass. 173, 6 Am. Rep. 216; Boston Ice Co. v. Potter, 123 Mass. 28.

5. Boston Ice Co. v. Potter, 123 Mass. 28, 25 Am. Rep. 9. See, also, Orcutt v. Nelcon, 1 Gray (Mass.), 536; Hardman v. Booth, 1 Hurl. \& 
had received notice of the change and then continued to take the ice as delivered, a contract would be implied. ${ }^{6}$

$\S 458$. Voluntary acceptance of benefits. - Ordinarily, where services are rendered and voluntarily accepted, the law will imply a promise upon the part of the recipient to pay for them. ${ }^{1}$ The services must be known and accepted by the recipient, to have the law imply a promise on his part to pay for them. ${ }^{2}$

But where one agrees to work for another for nothing, he may afterwards refuse to work. But if he voluntarily performs his promise and does the work, he cannot afterwards compel payment for the work. ${ }^{3}$

A party knowingly receiving the benefits from another, creates a promise to pay for them."

If a party voluntarily accepts and avails himself of valuable services rendered for his benefit, when he has the option to accept or reject them, even if there is no distinct proof that they were rendered by his authority or request, a promise to pay for them may be inferred. His knowledge that the benefits were valuable, and his exercise of the option to avail himself of them, justify this inference. ${ }^{5}$

C. 803 ; Humble v. Hunter, 12 Q. B. 310; Robson v. Drummond, 2 Barn. \& Ad. 303; Winchester v. Howard, 97 Mass. 303, 93 Am. Dec. 93; Boulton v. Jones, 2 Hurl. \& N. 564.

6. Mudge v. Oliver, 1 Allen (Mass.), 74; Orcutt v. Nelson, 1 Gray (Mass.), 536 ; Mitchell v. La. page, Holt, N. P. 253.

1. Disbrow v. Durand, 54 N. J. L. 343,24 A. 545, 33 Am. St. Rep. 678.

2. Scully v. Scully, 28 Iowa, 548.

3. Doyle v. Trinity Church, 133 N. Y. 372,31 N. E. 221 . See, also, Force v. Haines, 2 Harr. (N. J.) 385; Watson v. Ledonx, 8 La. Ann. 68.
4. Ford v. Ward, 26 Ark. 360; St. Patrick's Church v. Abst, 76 Ill. 252; Hearst v. Hite, 20 W. Va. 183; Jones v. Smith, $76 \mathrm{~Pa}$. St. 408; Moreland v. Davidson, 71 Pa. St. 371 ; Dougherty $v$. Whitehead, 31 Mo. 255; Disbrow v. Durand. $54 \mathrm{~N}$. J. L. 343,24 A. 545, 33 Am. St. Rep. 678: Farmington Academy $v$. Allen, 14 Mass. 172, 7 Am. Dec. 201 ; MeCrary v. Ruddick, 33 Iowa, 521 ; Scully v. Scully, 28 Iowa, 548.

5. Spencer $v$. Trafford, 42 MId. 20: Day v. Caton, 119 Mass. 513, 20 Am. Rep. 347 ; Wallace v. Schaub, 81 IId. 594, 32 A. 324. 
As between persons not members of the same family, the mere fact of rendering services useful to the defendant will furnish prima facie evidence of their acceptance, and in the absence of some proof to the contrary, will raise an obligation to pay him what they were worth, there being no proof of special value. ${ }^{6}$

$\S$ 459. Municipal corporations.-A city is liable for gas furnished it, with knowledge of the council, though no ordinance or resolution was passed anthorizing it to be furnished. ${ }^{1}$ And so when a city, restricted by its charter to contract in writing, and to create no general liability, is nevertheless liable, upon an implied contract, to compensate a party who has furnished gas for use upon its streets, when a specific tax has been levied and collected for that purpose, which cannot be lawfully diverted to any other. ${ }^{2}$ Cities and private corporations must account for money or other property applied by their officers to authorized uses, although the money or property so applied was received under an agreement which was wholly void. ${ }^{3}$

The doctrine of implied contract applies to cases where money or other property is received under such circumstances that the general law, independent of express contract, imposes an obligation upon the eity to do justice with respect to the same. If the city obtain money of another by mistake or without any contract entered into by it on the subject, from general obligation to do justice, it is liable, on an implied contract, to account for it.

$\S 460$. Family relations - Benefits received.-Where the services are rendered by members of a family, living as one household, to each other, there is no implication of a contract of payment from the mere rendition and acceptance of the

6. Spencer v. Trafford, 42 Md. 20. See, also, Wallace v. Schaub, $81 \mathrm{Md}$. 594,32 A. 324 .

1. Gas Company v. San Francisco, 9 Cal. 453.
2. Gas Light Co. v. Memphis, 93 Temn. 612, 30 S. W. 25.

3. Hitcheock v. Galveston, $96 \mathrm{U}$. s. 350 . 
services. In order to recover for the services, the plaintiff must affirmatively show, either that an exprese contract for remuneration existed, or that the circumstances under which the services were rendered were such as exhibit a reasonable and proper expectation that there would be compensation. ${ }^{1}$ The household family relationship is presumed to abound in reciprocal acts of kindness and good-will, which tend to the inutual comfort and convenience of the members of the family, and gratuitonsly performed. This relationship prevents the implication of a promise to pay for services. And this exception should not be limited to mere propinquity of kindred. This family relation shonld be extended to remote relations, and even to persons between whom there is no tie of blood. ${ }^{2}$

Most of the eases treat of this subject only with the relation of parent and child, or the eases where one party stands in loco parentis. $^{3}$ But the rule shonld not be limited to that relation, for it contemplates children, parents, grandparents, brothers, step-ehildren and other relations. ${ }^{4}$ This rule should apply to all cases where the parties stand in the relation to each other

1. In re Sehmidt's Estate, 93 Wis. 120,67 N. W. 37; Plate v. Durst, 42 IV. Va. 63, 24 S. E. 580, 32 I. R. A. 404; Callahan v. IVood, 118 N. Car. 752, 24 S. E. 542; Tank v. Rohweder, 9S Iowa, I54, 67 N. W. 106 ; Brown v. Buttle, 80 Me. 162, 13 A. 583 ; Collyer v. Collyer, 113 N. Y. 442, 21 N. E. 114; Collar v. Patterson, 137 Ill. 40:3. 27 N. E. 604; Heffron v. Brown. 155 Ill. 322, 40 N. E. 5S3; Disbrow v. Durand, 54 N. J. L. 343,24 A. 545, 33 Am. St. Rep. 67s; Harris v. Currier, 44 Vt. 468 ; Wilson v. Wilson, 52 Iowa, 44, 2 N. 615; suser v. Mowry, is R. I. 424, 28 A. 606; Greenwell v. Greenwell, 28 Kan. 675; Wallace $\checkmark$ Sehaub. 81 Md. 599, 32 A. 324: Hayes v. MeConnell, 42 Ind. 285: Cohen v.
Cohen, 2 Mack. D. C. 227; In re Kessler's Estate, 87 Wis. 660, 59 N. W. 29, 41 Am. St. Rep. 74.

2. Đisbrow v. Durand. 54 N. J. L. 343,24 A. $545,33 \mathrm{Am}$. St. Rep. 678.

3. Windhand v. Deeds, 44 Iowa, 98; Snith v. Jolmson, 45 Iowa, 308; Thorp v. Bateman, 37 Mich. 68, 26 Am. Rep. 487; Ryan v. Lynch, 9 No. App. 1s; Mariner r. Collins, 5 Harr. (Del.) 290: Kegan v. Malone, 62 Iowa. 201,17 X. 461 : Harris v. Currier. $44 \mathrm{~V}$ t. $46 \mathrm{~S}$; Stone r. Todd, 49 N. J. I. 2.7t. 280 : Kendall v. Kendall, 36 N. J. Eq. 91. 99 ; Ridgway r. English, 22 N. J. T. 409.

4. Lpdike r. Titus, 13 x. J. L. 151 . 
of support on one side and services on the other. ${ }^{5}$ 'The rule should extend beyond parent and child, and to those parties where close family relationship is shown to exist. ${ }^{6}$

Where it is shown that the person rendering the services is a nember of the family of the person served and receiving support therein, either as a child or relative or a visitor, a presumption of law arises that such services were gratuitous and, in such case, before the person rendering the service can recover, the express promise of the party served must be shown, or such facts and circumstances as will authorize the jury to find that the services were rendered in the expectation by ono receiving and by the other making compensation therefor. ${ }^{7}$

Thus, the rule should apply as between brother-in-law and sister-in-law $;^{8}$ and where there is a household relation, it should embrace not only remote kindred, but also those who stand in the place of kindred. ${ }^{9}$

But some of the conrts speak of this relation as restricted to cases where such a relationship in blood existed. Thus, the relation of granddaughter has been deemed not alone sufficient to rebut the presumed obligation to pay for services rendered in the grandfather's family. ${ }^{10}$

In Pennsylvania presumption that the scrvices were gratuitous, applies only in the case of parent and child. In all other cases, there must be evidence beyond the relationship that the creation of no debt was intended. ${ }^{11}$

5. Horner v. Webster, 33 N. J. L. 411 .

6. Robinson v. Eastman, 2 Denio (N. Y.), 152; Scully v. Scully, 28 Iowa, 548; Kegan v. Malone, 62 Iowa, 208, 17 N. 461 ; Hall v. Finch, 29 Wis. 278, 9 Am. Rep. 559; Bundy v. Hyde, 50 N. H. 116.

7. Scully v. Scully, 28 Iowa, 548; Kegan v. Malone, 62 Towa, 208, 17 N. 461 .

8. Bundy v. Hyde, 50 N. H. 116.
9. Disbrow v. Durand, 54 N. J. l. 343,24 A. 545,33 Am. St. Rep. 678.

10. Hanser v. Sane, 74 N. Car. 552.

11. Gerz v. Demarra, $162 \mathrm{~Pa}$. St. 530, 29 A. 761, 42 Am. St. Rep. 842. See, also, Perkins v. Hasbrouck, 155 Pa. St. 494, 26 A. 695; Smith v. Milligan, 43 I'a. St. 107 ; Miller's Appeal, 100 Pa. St. 568, 45 Am. Rep. 394 ; Stafford v. Devereux, 166 Pa. St. 277, 31 A. 87. 
$\$ 46 \mathrm{r}$. Services of a supposed wife.-Where a woman marries a man and lives with him as his wife during his life, she cannot recover for services rendered as his honsekeeper, the husband having a wife when he married her, thrs rendering the last marriage roid: no implied contract was created to pay her. ${ }^{1}$

The actual relations and the cireunstanees under which the work was performed, negatived any implication of an agreement or promise that it should be paid for. ${ }^{2}$ IJer renedy was by an action of tort for the deceit in indneing her to marry him by false representations, or by a false promise. ${ }^{3}$

There are cases where the same transaction mar eonstitute a cause of action both in contract and in tort, and a party may have an election to pursue either remedy. But a right of action in contract eamnot be created by waiving a tort, and the duty to pay damages for a tort does not imply a promise to pay them, upon which assumpsit can be maintained. ${ }^{4}$

If a man and woman mutually agree to live together as husband and wife without being married, after separation the woman cannot recover for services rendered in keeping louse in that relation. ${ }^{5}$ In this case the services rendered was in furtherance, and for the continuation of an unlawful relation, and no implication arises that the woman was to receive par for her services. If there had been an express promise for payment, the court could not enforce it ${ }^{6}$ because the parties living together were violating the prineiples of morality and chastity as well as of positive law. ${ }^{7}$

1. Cooper v. Cooper, 147 Mass. 370,17 N. E. 892,9 Am. St. Rep. 721.

2. Robbins v. Potter, 11 Allen (Mass.), 588, 98 Mass. 532.

3. Blossom v. Barrett, $37 \mathrm{~N}$. Y. 434, $97 \mathrm{Am}$. Dee. 747 .

4. Jones v. Hoar, 5 Pick. (Mass.) 285; Brown v. Holbrook. + Gray
(Mass.), 102: Ferguson r. Carrington, 9 Barn. \& Cr. 59.

5. Brown v. Tuttle, 80 Me. 162, 13 A. 583.

6. White $r$ Buss, 3 Cush. (Mass.) 448; Gilmore r. Woodeock, 69 Me. 118, 31 Am. Rep. 255.

7. Brown v. Tuttle, 80 Me. 162, 13 A. 583. 
§ 462. Extra services. - When a party is working under a salary, he is expected to perform all services incident to his employment for the compensation agreed upon. The mere fact that valuable services are rendered outside of the party's employment, does not make his employer liable for them. To render the party liable as a debtor under an implied promise to pay for extra service, it must be shown that the services were valuable, and that they were rendered under such circumstances as to raise the fair presumption that the parties intended and understood that they were to be paid for; or, at least, that the circumstances were such that a reasonable man in the same situation with the person who receives and is benefited by them would and ought to understand that compensation was to be paid for them. ${ }^{1}$

Thus, in the repairing of a bank building, the president superintended the work of repairs and then demanded pay for extra services, and it was held that there was no implied promise that the corporation would pay him for such work, and that he could not recover; ${ }^{2}$ such services can be paid for only when there is an express contract to that effect. ${ }^{3}$

$\S 463$. Corporation's liability to its promoters. - A corporation cannot incur a debt before its incorporation. Hence, a claim for money expended and time employed for the organization of a corporation before its incorporation, is not a debt which the corporation can loe made to pay. ${ }^{4}$ So, also, a corporation after its organization is not liable for payment of debts contracted previously thereto, withont express promise to pay then; but acceptance and receipt of the benefits of that for which they were incurred, ${ }^{5}$ is a ratification equivalent to the excention of an original contract as is generally held by the courts. ${ }^{6}$

1. Sawyer v. Bank, 6 Allen (Mass.), 207.

2. Pew v. Bank, 130 Mass. 391.

3. Levisee v. Railroad Co., 27 La. Ann. 641.

4. Marchaud v. Association, 26
5. Rockford, etc. R. R. Co. v. Sage, 65 Ill. 328, 16 Am. Rep. 587; Outhouse v. Allen, 72 Ill. 529.

6. Queen City Furniture Co. v. Crawford, 127 Mo. 356,30 S. W. 163.

La. Ann. 389. 
$\$$ 464. Implied assumpsit-Waiving a tort.-The right to waive a tort, and to recover on an implied assumpsit, is not to recover damages for the tort, but to recover the value of that which the wrongdoer has appropriated to his own use, the law implying a promise to pay its reasonable value. But a mere naked trespass, although ereating a liability for damages, cannot be the basis of an implied assumpsit. ${ }^{1}$

The right to waive a tort, and to recover as on implied assumpsit, has generally been extended to cases where thero has been a wrongful colversion of property of one person to the use of another, whether sold or not by the latter, and also to cases where a trespasser has severed trees from the land in possession of the owner, or has quarried stone thereon, and has afterwards taken the trees or stone away, converting the same to his own use, so that trover or replevin would lie. ${ }^{2}$ This implied promise is arailable in the case of personal property severed from the land as already stated. ${ }^{3}$

This rule extends to those cases where property has been severed from real estate by a wrongdoer, carried from the freehold, and converted to his own use; and the rightful owner may sue and recover its value as on an implied contract, although it mas not be in harmony with the principles of reformed system of pleading. No reason exists why it should not include cases arising out of a trespass, to the extent that the property severed and carried away is beneficial to the trespasser, except when it would involve a trial of title to real

1. Downs v. Finnegan, 58 Minn. 112, 59 N. W. 381, 49 Am. St. Rep. 488.

2. Evans v. Miller, 58 Miss. 120 ; Logan v. Wallis, 76 N.'Car. 416; Toledo, ete. R. R. Co. v. Chew, 67 I1l. 378; Downs v. Finnegan, 58 Minn. 112, 59 N. W. 381,49 Am. St. Rep. 488; Newton Manuf. Co. v. White, 53 Ga. 395 ; Wilson r. Force. 6 Johns. (N. Y.) 110, 5 Am. Dec. 195; Goodwin v. Giffis, 88 N. Y. 629; Morford v. White, 53 Ind.
547 ; Deitz v. Sutcliffe, 80 Ky. 650; Lehman v. Schmidt, 87 Cal. 15, 25 P. 161; Walker v. 1)uncan, is Wis. 624, 32 N. W. 689; Aldine Manuf. Co. v. Barnard, 84 Mich. 632, 48 N. W. 280 ; Blalock v. Phillips, 38 Ga. 216; Isaaes $r$. Hermann, 49 Miss. 449; Norden v. Jones, 33 Wis. 600 , 14 Am. Rep. 782; Andrews v. Bank, 26 N. Y. 298.

3. Rowell v. Rees, 7 Allol. \& El. 426; Halleck v. Mixer, 16 Cal. 574; Budd v. Hiler, 27 N. J. L. 43. 
estate. ${ }^{*}$ The right to waive the tort and to recover as an implied assumpsit is an exception to the principles of code pleading, and there must be no extension beyond what is allowed at common law. ${ }^{5}$

But formerly, and now in many jurisdictions, it was held that the right to waive a tort and to sue on the implied assumpsit must be limited to eases where goods and chattels have been wrongfully taken and sold by the wrongdoer. The owner might then disaffirm the act, and treating him as a wrongdoer, sue in trespass, or he might affirm the aet, and treating the wrongdoer as an agent, claim the benefit of the transaction. ${ }^{6}$

But this former rule is too restricted; because under it a party cannot waive the tort and reeover the value of the goods or chattels, mless the party converting has sold them and received the money, or has taken them for the purpose of sale and there be no evidence to rebut the presumption of sale and the receipt of the money. ${ }^{7}$

\section{$\S 465$. Oral agreements to bequeath or demise property.-} The rule is well settled, that where services are rendered gratuitously or without any view of compensation, but in the hope of receiving a legacy or devise from the person to whom the services are rendered, the person rendering the services can recover no compensation on an implied contract. ${ }^{1}$

4. Downs v. Finnegan, 58 Minn. 112, 59 N. IV. 381, 49 Am. St. Rep. 488; Evans v. Millei, 58 Miss. 120.

5. Hurley v. Lamoreanx, 29 Minm. 138, 12 A. 447; Downs v. Finnegan, 582 Minn. $112,59 \mathrm{~N}$. IV. 381, 49 Am. St. Rep. 488; Russell v. Bell, 10 Mees. \& Wel. 340 .

6. Sandren v. Railroad Co., 79 Mo. 278; Winchell v. Noyes, $23 \mathrm{Vt}$. 303; Allen v. Ford, 19 Pick. (Mass.) 217; Androscoggin Water Power Co. v. Metcalf, 65 Me. 40; Noyes v. Loring, 55 Me. 408; Paine v. McGinchey, 56 Me. 50; Bethle- hem Borough v. Ins. Co., $81 \mathrm{~Pa}$. St. 445; Strother v. Butler, 17 Ala. 733; Ferguson v. Carriugton, 9 Barn. \& Cr. 59; Rodgers v. Maw, 15 Mees. \& Wel. 444; Smith v. Baker, L. R. 8 C. P. 350 ; Oughton v. Seppings, 1 Barn. \& Ad. 241; (Gilmore v. Wilbur, 12 Pick. (Mass.) 120, 124, 22 Am. Dec. 410.

7. Bethlehem Borough v. Ins. Co., 81 Pa. St. 445.

1. Osborn v. Guy's Hospital, 2 Strange, 728; Le Sage v. Coussmaker, 1 Esp. 187; Little v. Dawson, 4 Dall. (U. S.) 111; Davison 
But verbal agreement may be made between a father and his ehild that the former will give the latter his real property, in case he shall support the former until death. If it appears that the ehild's services were rendered to his father not gratuitously, but upon a distinct understanding between them that the ehild should be compensated for his services, and that the agreement was that upon the father's death, provided the child continued to serve the father during his life, he shall receive the real estate of the father, such an agreement is valid in law, ${ }^{2}$ and may be enforeed in equity. ${ }^{3}$

The part of the agreement which the child is to perform is to be performed in praesenti, and that part to be performed by the father is to be performed in futuro. Hence, there can be no uncertainty about the agreement, beeanse it is definite and certain in every particular. ${ }^{4}$

\section{$\S 466$. Enforcement in equity and in law.-A court of equity} will deeree the specific performance of an agreement between father and child that the latter shall have the former's real estate at his death provided the latter supports the former, upon the recognized principles by which it is governed in the exereise of this braneh of its jurisdiction. ${ }^{5}$ Courts of equity will deeree the specific performance of agreements connected with testamentary or other settlements. ${ }^{6}$

v. Davison, 13 N. J. Eq. 246; Lee v. Lee, 6 Gill \& J. (Md.) 316 ; Kennard v. Whitson, l Houst. (Del.) 36; Compare Baxter v. Gray, 4 Scott, N. R. 374, 3 Man. \& Gr. 771.

2. Davison v. Davison, $13 \mathrm{~N}$.

J. Eq. 246; Jacobson v. Le Grange, 3 Johns. (N. Y.) 199; Paterson v. Paterson, 13 Johns. (N. Y.) 379.

3. Gary v. James, 2 Dess. (S. Car.) Eq. 1s5, 2 Am. Dec. 686; Johnson v. Hubbell, 2 Stocht. (N. J.) 332, $66 \mathrm{Am}$. Dec. 773 and note; Davison v. Davison, 13 N. J. Eq. 246.
4. Johnson v. Hubbell, 2 Stockt. (N. J.) 332. See, also, Graham v. Wickham, I DeG. J. \& S. 474; Hammersley v. De Bicl, 12 Cl. \& F. 45; De Biel v. Thomson, 3 Beav. 469 .

5. Rivers v. Rivers, 3 Dessau. (S. Car.) Eq. 195, 4 Am. Dec. 609 ; Johnson v. Hubbell, 2 Stockt. (N. J.) 332, $66 \mathrm{Am}$. Dec. 773 and note.

6. Izard v. Izard, 1 Dessau. (S. Car.) Eq. 116; Walpole v. Oxford, 3 Ves. 402, 7 Term R. 138; Lewis v. Maddocks, 6 Ves. 150; Fortescue v. Hannah, 19 Ves. 71 ; Jones v. 
In the United States an action at law may, after the party dies without fulfilling his agreement, be maintained against the estate or executor to recover the value of the services. ${ }^{7}$ And if the will provides only in part for payment of services, an action is maintained against the estate for the residue. $^{8}$

$\S 467$. Parol contract.-Although the agreement is by parol, and land is to be conveyed, if there is a part performance of such a character as, upon the principles recognized by a court of equity, will take a parol agreement ont of the statute of frauds, then there is nothing peculiar about an agreement of this kind to exclude it from the operation of those principles. ${ }^{1}$ It may be enforced though in parol, by a decree of specific performance by the promisee to the extent of irretrievably altering his position, so that it would be a fraud upon him to refuse the performance of the other part of the contract; ${ }^{2}$ part performance takes the case out of the operation of the statute of frauds. ${ }^{3}$

$\S$ 468. Necessaries for wife.-The law implies a contract that a husband will supply his wife with necessaries. It is

Martin, 3 Anst. 882; Padmore v. Gunning, 9 Sim. 644; Noorhouse v. Colvin, 9 Eng. L. \& Eq. 136; Logan v. Weinholt, 7 Bligh, 53, 54, 2 Story on Eq. 786; Johnson v. Hubbell, 2 Stockt. (N. J.) 332, 66 Am. Dee. 773 and note; Mundorff v. Kilbourn, $4 \mathrm{Md}$. 459; Parsell v. Stryker, 41 N. Y. 480 ; Robinson v. Mandell, 3 Cliff. C. C. 169.

7. Taylor v. Wood, 4 Lea (Tenn.), 504; Frost v. Tarr, 53 Ind. 390; Martin v. Wright, 13 Wend. (N. Y.) 460, 28 Am. Dec. 468; Shakespeare v. Markham, 10 Hun (N. Y.), 311.

8. Reynolds v. Robinson, $64 \mathrm{~N}$. Y. 589. As to specific performance, see Pingrey on Real Property, 1533.
1. Johmson v. Hubbell, 2 Stockt. (N. J.) 332, 56 Am. Dec. 773 and note; Fuchs v. Fuchs, 48 Mo. App. 18; Lee's Appeal, 53 Conn. 363, 2 A. 758; McKeegan v. O'Neil, $22 \mathrm{~S}$. Car. 454; Whitstine v. Wilson, 104 N. Car. 385,10 S. E. 471 ; Compare Ellis v. Cary, 74 Wis. 176, 42 N. W. 252,4 L. R. A. 5.5. 17 Am. St. Rep. 125.

2. Wright's Appeal, $155 \mathrm{~Pa}$. St. 64. 25 A. 877 ; Hale v. Hale, 90 Va. 728,19 S. F. 739 ; Pingrey on Real Estate, 1531.

3. Davison v. Davison, 13 N. J. Eq. 246. As to the amendment of the bill for variance in the proof, see Bellows v. Stone, 14 N. H. 175; Story on Eq. Pl. 394, n. 2. 
an authority conferred on the wife to do for him when neeessary, what the law and duty require him to do, and which he neglects or refuses to do for hinself, and is applicable as well to supplies furnished to the wife when she is sick, insensible or insane, and to the care of her lifeles: body, as to contracts expressly made by her. ${ }^{1}$

The necessaries for a married infant are such as pertain to himself and family; and those of a married infant to whom the law has intrusted his estate are such as pertain to himself, his family, and his estate; the control of the estate creates in its owner the capacity to make such contracts as are necessary to secure its preservation and beneficial enjoyment. ${ }^{2}$ An infant is liable for the necessaries furnished his wife. ${ }^{3}$

$\S 469$. Necessaries for minors - Money furnished by another.-If a creditor furnishes money to a minor, which he uses to purchase necessaries, and the creditor shows its application for the purchase of necessaries, the minor, in equity, will be liable; or where a person lends money to a minor to pay a debt incurred for necessaries, and the debt is actually paid, he will stand in equity in the place of the original creditor, and the minor will be liable to him. ${ }^{4}$

1. Cumningham v. Reardon, 98 Mass. 538, $96 \mathrm{Am}$. Dec. 670; Tulner v. Frisby, I Strange, 168 ; Cantine v. Phillips, 5 Harr. (Del.) 428; Read v. Legard, 6 Exch. 636 ; Chapple v. Cooper. 13 Nees. \& Wel. 252.

2. Chapman v. Hughes, 61 Miss. 339.

3. Williams v. Harrison, Holt. 359: Clowes v. Brooke, 2 Strange, 1101; Hands v. Slaney, 8 Term R. 578 ; Beeler v. Young, I Bibb (Ky.), 519; Stanton v. Wilson, 3 Day (Conn.), 3i, 3 Am. Dee. 255; Price v. Sanders, 60 Ind. 310 ; Bent v. Manning, $10 \mathrm{Vt}$. 225; Mason v. Wright, 13 Met. (Mass.) 306 :
Phelps $v$. Worcester, 11 N. II. 51 ; (race v. Hale, 2 Hmmph. (Tenn.) $2 \tau, 36 \mathrm{Am}$. Dec. 296; Cunningham v. Irwin, 7 Serg. \& R. (Pa.) 247 . $10 \mathrm{Am}$. Dec. 458 and note; Carpenter v. Carpenter, 45 Ind. 142; Peters v. Fleming, 6 Mees. \& Wel. 42 ; Burghart v. Hall, 4 Mees. \& 11el. $72 \%$.

4. Harris r. l.ee, 1 P. Wm. 4S2; Narlow v. Pittsield, 1 P. Wm. 558; Darby v. Boucher, 1 Salk. 279; Ellis v. Ellis, 1 Ld. Raym. 34t: Clarke v. Leslie, 5 Esp. 2S; Conn v. Coburn, 7 N. H. $368,26 \mathrm{Am}$. Dec. 746; Price r. Sanders, 60 Ind. 310. 
$\S 470$. Father liable for necessaries for minor children.A father is entitled by law to the services and earnings of his minor children. This right is founded upon the obligation which the law imposes upon him to nurture, support and educate them during infancy and early youth, and it continues until their majority, when the law determines that they are capable of providing for themselves. ${ }^{1}$ This is upon the ground of ageney. ${ }^{2}$ But a minor who voliuntarily abandons his father's house, without any fault of the parent, carries with him no eredit on his father's account even for necessaries. ${ }^{3}$

So, also, when necessaries are furnished by the town to minor children between whom and their father, though they live apart, the parental and filial relations still subsist, such supplies are considered in law supplies indireetly furnished the father, because he is bound in law to support them. ${ }^{4}$

But in New Hampshire and Vermont it is held that a parent is under no legal obligation, independent of statutory provision, to maintain his minor child, and that in the absence of any contract on the part of the father, he cannot be held except under the panper laws of those States. ${ }^{5}$

During the life of the father, the mother, in the absence of statutory provisions, or decree relating thereto, not being entitled to the services of their minor ehildren, is not bound by law to support them. ${ }^{6}$

1. Benson v. Remington, 2 Mass. 113; Dawes v. Howard, 4 Mass. 98; Nightingale v. Withington, 15 Mass. 274, 8 Am. Dec. 101; State v. Smith, 6 Me. 462, 464, 20 Am. Dec. 324 and note; Dennis v. Clark, 2 Cush. (Mass.) 252; Reynolds, v. Sweetser, 15 Gray (Mass.), 80; Garland v. Dover, 19 Me. 441, 36 Am. Dec. 732; Van Valkenburgh v. Watson, 13 Johns. (N. Y.) 480, 7 Am. Dec. 395; Furman v. Van Sise, 56 N. Y. 435, 15 Am. Rep. 441 ; People v. Moores, 4 Denio (N. Y.), 518, 47 Am. Dec. 272; In re
Ryder, 11 Paige (N. Y.), 185, 42 Am. Dec. 109.

2. Reynolds v. Sweetser, 15 Gray (Mass.), 80; Hall v. Wier, 1 Allen (Mass.), 261; Camerlin v. Palmer Co., 10 Allen (Mass.), 539.

3. Weeks v. Merrow, $40 \mathrm{Me}$. 151; Angel v. MeLellan, 16 Mass. 27.

4. Garland v. Dover, 19 Me. 441.

5. Kelley v. Davis, 49 N. H. 187, 6 Am. Rep. 499; Gordon v. Potter, 17 Vt. 348.

6. Whipple v. Dow, 2 Mass. 415 ; Dawes v. Howard, 4 Mass. 97; Weeks v. Merrow, 40 Me. 151; 
This liability of the father would seem to cease when a decree of divoree is rendered dissolving the marriage relations and committing the enstorly of the minor children to the mother. For when such a decree is mante then the father will have no right, either to take them into his custody and support them or employ any one else to do so, without the consent of the mother. ${ }^{7}$ But some courts hold that the father is liable for the support of his minor ehildren after their custorly is decreed to the mother. ${ }^{8}$

If the custody of the children is not decreed to the wife, then the father is liable for the support of his minor chillren. ${ }^{9}$

The mother may maintain an action against the father for the necessary support of their ninor ehildren, furnished by her after an absolute divoree, no decree for custody or alimony having been made. ${ }^{10}$

A father may contract with his minor child and pay him wages $;^{11}$ he may emancipate the child, ${ }^{12}$ give him his earnings ${ }^{13}$ goods and other chattels. ${ }^{14}$

$\S 47$ r. Necessaries for insane persons.-Insane persons are liable for necessaries furnished them. ${ }^{1}$ If one furnishes an insane person necessaries, which are required for his support or comfort, and suitable to his means, condition, and habits of life, and which he has not already in his keeping, the seller

Gilley v. Gilley, 79 Me. 292, 9 A. 623, 1 Anı. St. Rep. 307.

7. Hancock v. Merrick, 10 Cush. (Mass.) 41; Brown v. Brightman, 136 Mass. 187; Finch v. Finch, 22 Conn. 410.

8. Holt v. llolt, 42 Ark. 495; Courtwright v. Courtwright, 40 Mich. 633; Plaster v. Plaster, 47 111. 290 .

9. Finch v. Finch, 2.2 Comn. 411 ; Hancock v. Merrick, 10 Cush. (Mass.) 41: Brown v. Brightman, 136 Mass. 107; Husband v. Husband, 67 Ind. 583, 33 Am. Rep. 101.
10. Gilley v. Gilley, 79 Me. 292 , 9 A. 623, 1 Am. St. Rep. 307.

11. Titman v. Titman, 64 Pa. St. 480, 3 Am. Rep. 608; Wilson v. MeMillan, 62 Ga. 16, 35 Am. Rep. 115 and note.

12. Farrell v. Farrell, 3 Houst. (Del.) 633.

13. Monaghan v. School Dist., 38 IVis. 100 .

14. Smith v. Smith, 7 Carr. \& P. 401 .

1. Baxter v. Portsmouth, 5 Barn. \& Cr. 172; Thompson r. Leach, 3 Mod. 310. 
ean recover of the insane party upon a promise implied by law, what the supplies are reasonably worth. ${ }^{2}$

Insane persons stand in the position as minors and are liable for necessaries. ${ }^{3}$ Such is the rule of the common law.

$\S 472$. Liability of insane person's estate.-The estate of the insane is legally, as well as equitably, liable for necessaries furnished in good faith, and under cireumstances justifying their being so furnished. ${ }^{4}$

Other contracts with lunatics not strietly for necessaries, which have been fully exeeuted, and on which a consideration or benefit to the lunatic has been given, may be within the reason of this exception, where the transaction is shown to be perfectly fair and reasonable, at least, so far as to allow the recovery back of the consideration given, or to prevent a rescission by the lunatic or his representatives, without restoring the consideration, when the restoration is practicable. The liability of a lunatic in such cases is upheld, not on the ground of contract, but on the fact that the lunatic has received and enjoyed an actual benefit from the contract. ${ }^{5}$

\section{$\S$ 473. Part performance-Quantum meruit.-Many English} and American cases hold that no recovery can be had for labor

2. Leach v. Marsh, 47 Me. 548, 74 Am. Dec. 403; Pearl v. McDowell, 3 J. J. Marsh. (Ky.) 658; Sawyer v. Lufkin, 56 Me. 308.

3. Seaver v. Phelps, 11 Pick. (Mass.) 304, 22 Am. Dec. 372; Leach v. Marsh, 47 Me. 548, 74 Am. Dec. 503. See, also, Williams v. Wentworth, 5 Beav. 325; Richardson v. Strong, 13 Ired. (N. Car.) 106, 55 Am. Dec. 430.

4. MeCrillis v. Bartlett, $S$ N. H. 569 ; Sawyer v. Lufkin, 56 Me. 308; La Rue v. Gilkyson, 4 Pa. St. 375, 45 Am. Dec. 700 ; Baxter v. Portsmouth, 2 Car. \& P. 178; Lancaster
County Nat. Bank v. Moore, $78 \mathrm{~Pa}$. St. 407, 21 Am. Rep. 24 and note.

5. Gore v. Gibson, 13 Mees. \& Wel. 626 ; Lincoln v. Buckmaster, 32 Vt. 658; Brown v. Jodrell, 3 Car. \& P. 30 ; Dane v. Kirkwall, 8 Car. \& P. 675; Niell v. Morley, 9 Ves. 478; Selby v. Jackson, 6 Beav. 192; Matthiesson v. McMahon, 38 N. J. L. 536; Wilder v. Weakley, 34 Ind. 181; Behrans v. MeKenzie, 23 Iowa, 333, 92 Am. Dec. 428; Abbott v. Creal, 56 Iowa, 175, $9 \mathrm{~N}$. 115; Sims v. McLure, 8 Rich. Eq. (S. Car.) 286, 70 Am. Dec. 196. 
or material furnished under special contract, mless the contract has been performed, or its performance has been dispensed with by the other party. ${ }^{1}$

The hardship of this rule upon the contractor who has undesignedly violated his contract, and the inequitable adrantage it gives to the party who receires and retains the benefit of his labor and materials, has led to its qualification so that now the weight of authority is clearly in favor of allowing compensation for serrices rendered and material furnished, under a special contract, but not in entire conformity with it, prorided the deriation from the contract was not wilful and that the other party has arailed himself of, and been benefited by, such labor and materials; and as a general rule the amount of such compensation is to depend upon the extent of the benefit conferred, haring reference to the contract price for the entire work. $^{2}$

There is a line of cases that holds that when a contract remains open and umperformed, though in slight particulars, no recovery can be had either upon it or upon an implied contract. $^{3}$

Another line of cases holds that recovery upon such and similar contracts will not be refused for mere technical, inadvertent or unimportant deviations from the terms, but that wherever there has been a substantial compliance with the contract, recovery may be had thereon, a proper allowance

1. Cohn v. Plumer, 85 Wis. 622 , 60 N. W. 1000 ; Succession of Jackson, 47 La. Ann. 1089, 17 So. 598; Dawes v. Hubbard. 41 WVis. 408; Palm v. Railroad Co., 18 Ill. 217 ; United States v. Behan, 110 U. S. 339, 4 S. Ct. 81 .

2. Hayward v. Leonard, 7 Pick. (Mass.) 181, 19 Am. Dec. 268 and note; Smith v. Meeting House. 8 Pick. (Mass.) 17s; Moulton v. MeOwen, 103 Mass. 591; Reid v. Scituate, 7 Allen (Mass.), 14l; Atkins v. Barnstable. 97 Mass. 429 : Den- ham v. Bryant, 139 Mass. 110, 28 N. E. 691; Blood v. Wilson, 141 Mass. 25, 6 N. E. 362 ; Kelly v. Bradford, 33 Vt. 35; Corwin v. Wallace, 17 Iowa, 374; White v. Oliver, 36 Me. 92; Dermott r. Jones. 20 How. (U. S.) 220: Smith v. School Dist.. 20 Conn. 312; Blakeslee $v$. Holt. 42 Coun. 226: Lucas $r$. Gadwin. 3 Bing. N. C. 104; Pinches v. Church, 55 Conn. 183, 10 A. 264.

3. Ellis v. Hamlen, 3 Taunt. 53; Munro v. Butt. S El. \& Bl. 738. 
or reduction from the contract price being made for deficiency. ${ }^{4}$

One class of cases holds that a recovery should be had in such cases whenerer the work and materials are of any value to the owner of the lands to which they have been affixed, and that the proper measure of damages is the contract price, deducting therefrom so much as the building was worth, less on account of variations from the contract. ${ }^{5}$

Another class holds that while a contractor guilty of fraud or having wilfully abandoned the work unfinished, cannot recover in any form of action, he may recover in assumpsit when he has, in good faith, done work which, though not done according to the contract, has been accepted by the owner. ${ }^{6}$

In each class of cases acceptance is the basis of recovery. One class requires the acceptance to be actual; this assumes it to exist in all cases where value has been conferred upon the property, and there has been no gross or fraudulent violation of the contract; where such a violation occurs, actual acceptance is necessary to recovery. ${ }^{7}$

$\S 474$. Wilful default-Wages.-The weight of authority is that if a party wilfully abandons a special contract before it is fully performed, he can recover nothing for what he has done. ${ }^{1}$ So where a contractor abandons work before its completion, he cannot recover in an action upon the contract, unless

4. Glacius v. Black, 50 N. Y. 145, 10 Am. Rep. 449; Cutter v. Close, 5 Car. \& P. 337 ; Dallman v. King, 4 Bing. N. C. 105; Stodhard v. Lee, 3 Best \& S. 364.

5. Hayward v. Leonard, 7 Pick. (Mass.) 180; Smith v. Church, 8 Pick. (Mass.) 178.

6. Dermott v. Jones, 2 Wall. (U. S.) 1 .

7. Bozarth v. Dudley, 44 N. J. L. 304, 43 Am. Rep. 373.

1. Demmead v. Coburn, $15 \mathrm{Md}$. 44; Faxon v. Mansfield, 2 Mass. 147; Stark v. Parker, 2 Pick.
(Mass.) 267, 13 Am. Dec. 425; Gill v. Vogler, 52 Md. 663; Moritz v. Larsen, 70 Wis. 569,36 N. W. 331 ; Hansell v. Erickson, 28 Ill. 257 ; Scheible v. Klein, 89 Mich. 376, 50 N. W. 857 ; Olmstead v. Beale, 19 Pick. (Mass.) 528; Miller v. Goddard, 34 Me. 102, 56 Am. Dec. 638 ; Kryer v. Lippel, 42 Minn. 6, $43 \mathrm{~N}$. W. 484; Gillespie Tool Co. v. Wilson, 123 Pa. St. 19, 16 A. 36 ; Peterson v. Neazer, 46 Minn. 468, $49 \mathrm{~N}$. IV. 245; Hapgood v. Shaw, 105 Mass. 276 . 
he was prevented from completing it by the wrongful action of the defendant. ${ }^{2}$

In general, to recover on a special contraet, the plaintiff must show full performance on his part or a release by his employer or some justifying cause for non-performance. ${ }^{3}$

But there are many decisions which hold that one who has performed services for another under a speeial contract may recover for the value of the services rendered, though he may not have fully completed his term of service, sulject to the right of the employer to deduct any damages he may have sustained by the breach of the contract on the part of the employee. ${ }^{4}$ This doetrine has gradually been adopted by the courts. It stands on justice, and is right on principle, though opposed to the common law rule, which holds that the servant cannot recover, unless he shows that he has performed the contract in full.

If a single woman engages to work and take care of a man during his life and then to receive compensation, and agrees not to marry, the agreement not to marry is only incident to the main contract which is valid, and she can recover from the estate of the promisor after his death. ${ }^{5}$ If there is no pro-

2. Scheible v. Klein, 89 Mich. 376,50 N. W. 857 .

3. Eldridge v. Rowe, 2 Gil. (Ill.) 98, 43 Am. Dec. 4l; Swanzey v. Noore, 22 Ill. 63, 74 Am. Dec. 134; 'lurift v. Payne, 71 Ill. 408. See, also. Lantry v. Parks, S Cow. (N. Y.) 63; Catlin v. Tobias, 26 N. Y. 217, S4 Am. Dec. 183; Champlin v. Rowley, 18 Wend. (X. Y.) 187; Timberlake $\mathrm{v}$. Thayer, 71 Miss. 279, 14 So. 446,24 L. R. A. 231 and note; Newcomb v. Ins. Co., 51 Fed. Rep. 725.

4. Britton v. Turner, 6 N. H. 481. 26 Am. Dec. 713; Pixler v. Nichols, 8 Iowa, 106, $74 \mathrm{Am}$. Dec. 298; Lomen v. Crossman, 8 Iowa, 325; McClay v. Hedges, 18 Iowa,
66; McAfferty v. Hall, 24 Iowa, 382; Byerlee v. Mendel, 39 Iora, 382; Duncan v. Baker, 21 Kan. 99; Parcell v. McComber, 11 Neb. 209, 7 N. 529, 38 Am. Rep. 366 and note; Bedow v. Tonkin, 5 S. Dak. 432, 59 ․ IV. 222; Hillyard v. Crabtree. 11 Tex. 264, 62 Am. Dec. 475: Chamblee v. Baker. 95 X. Car. 98; Carroll v. Welch, 26 Tex. 14i; Hellis v. Chapman, 36 Tex. 1; Epperly v. Bailey, 3 Ind. 73 ; Fenton v. Clark, 11 Vt. 560; Ryan r. Dayton, 25 Conn. 18s, $65 \mathrm{Am}$. Dec. 560; Wolf v. Gerr, 43 Iowa, 339. Sec, also, Lamb v. Bralaski, 38 Mo. 51 ; Patnote v. Sanders, 41 Vt. $66,95 \mathrm{Am}$. Dec. 564 .

5. King $v$. King, 63 Olio St. 363 , 
rision against her marriage, and she does marry, then it is a question of fact whether she has broken her contract, and whether she can recover if discharged by her employer. ${ }^{6}$ But if the contract had provided that the woman should remain unmarried, then there is no reason why, if she marries, it will not rescind the contract. On general principles, an employer may provide in the contract that the employee shall remain single while engaged in the service.

\section{$\S$ 475. Default not wilful-Personal service.-Contracts for} personal service, whether of the contracting party or of a third person, requiring skill, and which can only be performed by the particular individual named, are not in their nature, of absolute obligation under all circumstances. Both parties must be supposed to contemplate the continuance of the ability of the person whose skilled services are the subject of the contract, as one of its conditions.

Contracts for personal services are subject to this implied condition, that the person shall be able at the time appointed to perform them, and if he dies, or without fault on the part of the covenantor becomes disabled, the obligation to perform is extinguished. ${ }^{1}$

If the default is caused by death, sickness or by prevention of the other party, or by any cause for which he is not responsible, which excuses the performance, then he may recover in an action of quantum meruit on an implied promise to pay for work already completed. ${ }^{2}$

59 N. E. 111, 52 L. R. A. 157,81 Am. St. Rep. 635.

6. Edgecomb v. Buckhout, 146 N. Y. 332,40 N. E. 991,28 L. R. A. 816.

1. People v. Manning, 8 Cow. (N. Y.) 297, $18 \mathrm{Am}$. Dec. $45 \mathrm{l}$ and note; . Tones v. Judd, 4 N. Y. 411 ; Clark v. Gilbert, 26 N. Y. $279,84 \mathrm{Am}$. Vee. 189; Wolfe v. Howes, 24 Barb. (N. Y.) 174,20 N. Y. 197 ; Gray v.
Murray, 3 Johns. (N. Y.) 167 ; liobinson v. Davison, I. R. 6 Exch. 268 ; Dexter v. Norton. 47 N. Y. 62, 7 Am. Rep. 415; Spalding v. Rosa, 71 N. Y. 40, 27 Am. Rep. 7 ; Lakeman v. Pollard, 43 Me. 463; Green v. Gilbert, 21 Wis. 395 ; Martus v. Houck, 39 Mich. 431, 33 Am. Rep. 409.

2. Shulz v. Johnson, 5 B. Mon. (Ky.) 497; Pinches v. Church, 55 
$\S 476$. Promise to marry.-The usual and legitimate objects to be sought to bo attained by agreement to marry, are the comfort of association, the consortium ritae. And if either party should thereafter become, by the act of God and without fault on his own part, unfit for such a relation and incapable of performing the duties incident thereto, then the law will excuse a non-compliance with the promise. ${ }^{3}$

$\S 477$. Substantial performance.-It is held by many courts that where a contract has been substantially though not strictly performed, where the party failing to perform according to the terms of the contract has not been guilty of a voluntary abandonment or wilful departure from the contract, has acted in good faith, intending to perform the contract according to its stipulations, but has failed in a strict compliance with its provisions, and where from the nature of the contract and of the labor performed, the parties cannot rescind, and stand in statu quo, but one of them must derive some benefit from the labor or money of the other, -in such case the party failing to perform his contract strictly may recover of the other, as upon a quantum meruit, for such a sum only as the contrace as performed has been of real and actual benefit to the other party, estimating such benefit by reference to the contract price of the whole work. ${ }^{1}$ If he has performed in good faith and substantially completed the contract, he can recover."

Conn. 183, 10 A. 264; Yerrinton r. Green, 7 R. I. 589, 84 Am. Dec. 578; Mooney v. Iron Co., 82 Mich. 263, 46 N. W. 376 ; Adams v. Crosby, 48 Ind. 153; Hubbard v. Belden, 27 Vt. 645: Harrington v. Iron Works. 119 Mass. 82; Stewart v. Loring, 5 Allen (Mass.), 306, 81 Am. Dee. 747; Fuller v. Brown, 11 Met. (Mass.) 440 ; Seully v. Kirkpatrick, 79 Pa. St. 324, 21 Am. Rep. 62.

3. Pollock on Cont. 370. Compare Hall v. Wright, El., Bl. \& El. 746, which is not authority now. See, also, Barnes v. Brown, $69 \mathrm{~N}$. Car. 439; Shuler v. Millsap, $71 \mathrm{~N}$.
Car. 297; Allen v. Baker, 86 X. Car. 9 , decided under a statute.

1. Dyer v. Jones, 8 Vt. 205 ; Gilmall v. Hall, 11 Vt. 510,34 Am. bec. 700 ; Kelly r. Bradford, $33 \mathrm{Vt}$. :55; Blood v. Wilson, 141 Mass. 25, 6 N. E. 362; Dermott v. Jones, 23 llow. (U. S.) 220 ; Parker v. Stced, 1 Lea (Tenn.), 206; Taylor v. Williams, 6 Wis. 363; MeNillan $r$. Nallay, 10 Neb. 228, 4 N. 1004, 35 Am. Rep. $47 \mathrm{l}$ and note; Hayward v. Leonard, 7 Pick. (Mass.) 181, $19 \mathrm{Am}$. Dec. 268 and note; Corwin ๖. Wallace, 17 Iowa, 374.

2. White v. Oliver, 36 Me. 92 ; 
But this doctrine is not accepted in full, but is morlified by some courts. The mere fact that a partial performance is beneficial to a party is not enough from which to imply a promise to pay for it. That the doctrine of substantial compliance with the contract does not apply when the omissions or departures from the contract are intentional, and so substantial as to be incapable of remedy so that an allowance out of the contract price would not give the owner essentially what he contracted for. ${ }^{3}$

So in case of a building on land under a contract which the builder fails to complete, or which he completes in a manner not conforming to the contract, so that the owner cannot be charged with the contract price, the mere fact of the building remaining on the land, and that the owner resumed possession and enjoys the fruits of the labor, is not such an acceptance as alone will imply a promise to pay for it; for the possession of the land necessarily involves possession of the buildings in their existing state, and the owner has no option of rejecting them. ${ }^{4}$

$\S 478$. Order given by one and filled by another.-To support a recovery for goods sold and delivered, there must be a contract, either express or implied, between the persons that ordered and the one who supplied the goods. Where goods ordered of one person are supplied by another, the acceptance and use of the goods without notice that they have been so supplied will not create that privity of contract between the person ordering the goods and the one who thus supplies them, which is essential to support an implied assumpsit. ${ }^{1}$

Lucas v. Godwin, 3 Bing. N. C. 773 ; Blakeslee v. Holt, 42 Conn. 226; Pinches v. Church, 55 Conn. 183, 10 A. 264.

3. Elliott v. Caldwell, 43 Minn. 357,45 N. W. 845 ; Smith v. Brady, 17 N. Y. 173, 72 Am. Dec. 442; Catlin v. Tobias, 26 N. Y. 217,84 Am. Dec. 183; Champlin v. Rowley,
18 Wend. (N. Y.) 187; Munro v. Butt, 8 El. \& Bl. 738.

4. Munro v. Butt, 8 El. \& Bl. 738 . See, also, Bozarth v. Dudley, 44 N. J. L. 304, 43 Am. Rep. 378; Miller v. Phillips, $31 \mathrm{~Pa}$. St. 218.

1. Hills v. Snell, 104 Mass. 173, 6 Am. Rep. 216; Boston Ice Co. v. Potter, 123 Mass. 28, 25 Am. Rep. 
If the person ordering the goods receives notice lefore the goods are appropriated or converted that they have heen thus furnished by another, and is also notified that they are furnished upon such terms as impart that the person supplying the goods contemplated a sale upon terms stated, and the person who sent the order afterwards receives and appropriates then, he thereby assents to and satisfies the filling of the order, and such assent and ratifieation relate back and give the order the same effect as if it had been originally given to the person who filled it. ${ }^{2}$

If a vendec receives a part of the goods purchased from another, and retains them after a failure of the vendor to supply the rest of the goods, the law implies a contract and he must pay for them. ${ }^{3}$

But this rule is not adopted by all the courts. Thus, in New York, where goods are received and used by the rendee under a contract for the delivery of a specified quantity, the quantity delivered being less than that required by the contract, such breach is a bar to an action by the rendor for the price of the goods delivered. ${ }^{4}$ Such a contract is entire and calls for an entire performance, and until performance is made or tendered there is no liability on the part of the defendant; where the rendor refused to perform the contract, without excuse, the rendee is not bound to return what he has receired, nor can he be compelled to pay for a part performance. ${ }^{5}$

The vendee under such a contract has a right to expend the goods delivered as requirer in his business, withont waiting for the expiration of the time for delivery of all the goods to see whether the vendor will fully perform his contract, and

9 ; Boulton v. Jones, 2 Hurl. \& N. 564.

2. Orcutt v. Nelson, 1 Gray (Mlass.), 536; Mudge r. Oliver, 1 Allen (Mass.), 74; Wellaner v. Fellows, 48 Wis. 105,41 N. 114; Barnes v. Shoemaker, 112 Ind. 512, 14 N. E. 367. See, also, Shipton v. Casson, 5 Barn. \& Cr. 378; Oxen- dale v. Wetherell, 9 Barn. \& Cr. 386.

3. Shipton v. Calsson, 5 Barn. \& Cr. 378; Oxenlale v. Wetherell, 9 barn. \& Cr. 386.

4. Catlin v. Tobias, 26 N. Y. 217 , 84 Am. Dec. 183.

5. Smith v. 13rady, 17 N. Y. 173, 72 Am. Dec. 442. 
such use is no waiver of his defense in case of the vendor's breach of contract. ${ }^{6}$

$\S$ 479. Part performance under a void contract.-An action may be maintained for the reasonable value of work done under a void contract, as the law will imply a contract for the payment of a reasonable compensation for such work. ${ }^{1}$ And so, though a parol contract for the conveyance of land for services to be rendered may not be enforced, an action may be maintained to recover the value of the services performed under it, if services are rendered in good faith and the vendor accepts them, the vendee may recover on a quantum meruit. ${ }^{2}$

And so recovery on quantum meruit may be had for labor and services performed under a contract void by the statute of frauds. ${ }^{3}$ In general, it is held that a party who delivers goods, or conveys land, or renders services for another under a contract which is void or unenforceable, but not illegal, may recover on a quantum meruit. ${ }^{4}$

And so where a contract under seal containing mutual covenants, and which imposes an obligation upon one party to pay money to the other, but contains no covenant or promise to pay it, the contract having been wholly performed in all other respects, the money may be recovered in an action upon an implied promise. ${ }^{5}$

6. Catlin v. Tobias, 26 N. Y. 217, 84 Am. Dec. 183.

1. Rebman v. Land Water Co., 95 Cal. 390, 30 P. 564; Holland v. Wilson, 76 Cal. 434, 18 P. 412; Nugent v. Teachout, 67 Mich. 571, 35 N. W. 254; Cadman v. Markle, 76 Mich. 448, 43 N. W. 315; Ellis v. Carey, 74 Wis. 176, 42 N.W. 252, 4 L. R. A. 55, 77 Am. St. Rep. 125.

2. King v. Brown, 2 Hill ( $\mathrm{N}$. Y.), 485; Stevens v. Lee, 70 Tex. 279,8 S. IV. 40; Schoonover v. Vachou, 121 Ind. 3, 22 N. E. 777; Miller v. Eldridge, 126 Ind. 461, 27
N. E. 132 ; Baker v. Lauterbach, 68 Md. 64,11 A. 703 .

3. Lapham v. Osborne, 20 Nev. 168, 18 P. 881; Smith v. Woodin, 20 Ala. 324; Montague v. Garnett, 3 Bush (Ky.), 297; Walker v. Shackelford, 40 Ark. 503; Wonsettler v. Lee, 40 Kans. 367, 19 P. 862 ; Whipple v. Parker, 29 Mich. 369.

4. Cadman v. Markle, 76 Mich. 448, 43 N. W. 315; Ellis v. Cary, 74 Wis. 176,42 N. W. 252, 17 Am. St. Rep. 125, 4 L. R. A. 55 ; Lapham v. Osborne, 20 Nev. 168, 18 P. 884.

5. Varney v. Bradford, 86 Me. 
$\S 480$. Under no obligations to perform-Part performance. -It has been held by numerous decisions that an action will lie to recover back money paid or for services remlered by one party to an agreement which is invalid by the statute of frauds, and which the other party refuses to perform. ${ }^{1}$ But the plaintiff must hing himself within the rule. ${ }^{2}$ But if one party abandons the contract after part performance, he cammot. recover, if the other party is willing to perform. ${ }^{3}$

And so in many English cases and in many States it is held, as cases already cited show, that money paid on a purchase of land cannot be recovered back, if the vendor is able and willing to carry out the contract of sale, although he may be muler no obligation to perform. But this doctrine is not accepted by some of the courts, which hold that money paid under a roid contract may be recovered back whether the other party is willing to perform or not. ${ }^{4}$ But this rule is regarded as harsh and inequitable by the weight of authority, for it is generally held that the defaulting party cannot recover money already paid if the other party stands ready to perform on his part. ${ }^{5}$

510,30 A. 115; Hinckley v. Fowler, 15 Míe. 285.

1. Kidder v. Hunt, l Pick. (Mass.) 328, 11 Am. Dec. 183; Gillet v. Maynard, 5 Johns. (N. Y.) 85, 4 Am. Dec. 329; Gray v. Hill, Ry. \& Wood. 420; King v. Brown, 2 Hill (N. Y.), 485; Basford v. Pearson, 9 Allen (Mass.), 389, 85 An. Dec. 764; Williams v. Bemis, 108 Mass. 91, 11 An. Rep. 318; Parker v. 'Taintor, 123 Mass. 18.j.

2. Riley v. Williams, 123 Mass. 506.

3. Kreger v. Leppel. 42 Minn. 6, 43 N. W. 484 ; Sims v. Hutchins, 8 Sm. \& M. (Miss.) 331; McKenney v. Harvie, 38 Mlinn. 18. 35 $\mathrm{N}$. W. 668; Greton v. Smith, 33 N. Y. 245 ; Abbott v. Inskip. 29 Ohio St. 59; Philbrook v. Belknap, 6 Vt.
383; Galway v. Shields, 66 Mo. 313.

4. Nelson v. Imp. Co., 96 Ala. 515, 11 So. 695, 38 Am. St. Rep. $116^{\circ}$; Flim v. Barber, 64 Ala. 193; Koch r. Williams, 82 Wis. 186, 52 N. W. 257; King v. Welcome, 5 Gray (Mass.), 41 ; Shute v. Dorr. 5 Wend. (N. Y.) 204; Cowes $r$. Lawson, 16 Conn. 246.

5. Coughlin v. Knowles, 7 Met. (Mass.) 57, 39 Am. Dec. 759; Collier v. Coates, 17 Barb. (N. Y.) 471 ; Abbott $v$. Draper, 4 Denio ( $N$. Y.), 51; Johnson v. Krassin, 25 Minn. 117; Semnett v. Shehan, 27 Minn. 328. 7 N. 266; Plummer v. liuckman, 5.5 Ye. 10.5; Shaw v. Shaw, 6 Vt. 69: Hawley v. Moody, 24 Vt. 605. 
$\S 48$ I. Failure to pay in a manner agreed to.--If services are rendered, to be paid for in a certain way which is not enforceable, upon refusal to pay in the manner agreed upon, the one performing such serrices is entitled to compensation in money for what such services are reasonably worth. ${ }^{1}$ Thus, if one party performs services in payment of land, which contract is contrary to the statute of frauds, and the land is not conveyed, then the party performing the services can recover a reasonable compensation in money for his services. ${ }^{2}$

And so if a contract is void under the statute of frauds, the grantor may recover of the grantee the value of the property conveyed. ${ }^{3}$ The action in such case does not rest upon the contract except as there arises an implied contract to pay the value of that which the party sought to be charged received upon the faith of the repudiated void promise from the grantor. ${ }^{4}$

\section{$\S$ 482. Part performance-Rescission of contract.-If a} party enters into a contract and then the other party abandons it without cause, the former may recover for the work. Thus, if a party is engaged to write a treatise for another for publication, and then the latter abandons the publication, the former may rescind and recover without tendering the treatise. ${ }^{5}$ So when the plaintiff has performed, but the defendant refuses to pay, the plaintiff has an election either to stand upon the special contract and recover for its breach, or to treat it as rescinded, and recover the value of his services as if the special contract had not been made. ${ }^{6}$ And if the contract is voidable,

1. Shane v. Smith, 37 Kans. 55, 14 P. 477.

2. Stone v. Stone, $43 \mathrm{Vt} .180$.

3. Robinson v. Raynor, 28 N. Y. 494 ; Reed v. MeConnell, 133 N. Y. 425, 31 N. E. 22 ; Henning v. Miller, 83 Hun (N. Y.), 403, 31 N. Y. S. 878,64 N. Y. St. 667.

4. Henning v. Miller, 83 Hun (N. Y.), 403, 31 N. Y. S. 878,64 N. Y. St. 667 .

\section{Plance v. Colburn, 8 Bing.} 14.

6. Williams v. Bemis, 108 Mass. 91, 11 Am. Rep. 318; Brown v. Railroad Co., 36 Minn. 236, $31 \mathrm{~N}$. W. 941; Medbury v. Watrous, 7 Hill (N. Y.), 110; Ex parte Maclure, L. R. 5 Ch. App. 737 ; Siefel v. Ins. Co., $84 \mathrm{~Pa}$. St. 47 ; Keys v. Harwood, 2 C. B. 905; Drew v. Claggett, 39 N. H. 431; Lawrence 
the party may rescind and recover for his services. Thus, a special contract by a minor for services is roidable, and if he avoids it, he may recover upon a quantum meruit, as if no contract had been made. ${ }^{7}$ And so where a minor goes on a whaling voyage, he may avoid the contract by desertion during the voyage, and then recover on a quantum meruit for his services. ${ }^{8}$ But if the contract proves bencficial to the minor and is executed on both sides, it is not voidable by the minor. ${ }^{9}$

In such cases the commencement of the action to recorer the value of the services, is a sufficient notice of his election to sne on the implied contract though he has an action on the special contract for its breach. ${ }^{10}$

$\S 483$. Work and labor.-When a party performs work for another with the latter's knowledge and assent, and it is accepted, the law construes the acceptance of the work to be an implied contract therefor. ${ }^{1}$ If there is no special contract, but the services are rendered and the other party accepts the benefit of the services rendered by the other, then the law establishes an implied contract on which he is entitled to recorer what he proves the services reasonably worth. ${ }^{2}$

A part owner of a business may engage for a salary to conduct the affairs of the concern, in such a manner that the law will imply a contract that he is to be paid for his services. ${ }^{2}$ So where services are rendered an old man who is sick and in

v. Taylor, 5 Hill (N. Y.), 114; Graves v. White, 87 N. Y. 463; Gaffney v. Hayden, 110 Mass. 137, 14 Am. Rep. 580.

7. Moses v. Stone, 2 Pick. (Mass.) 332; Gaffney .x. Hayden. 110 Mass. 137, 14 Am. Rep. 580.

8. Vent v. Osgood, 19 Pick. (Mass.) 572.

9. Stone v. Dennison, 13 Pick. (Mass. 1, $23 \mathrm{Am}$. Dec. 654.

10. Lawrence v. Taylor. 5 Hill (N. Y.), 107, 114, 115; Graves v. White, 87 N. Y. 463: Graham v. Holloway, 44 Ill. 385.
1. Hood $v$. League, 102 Ala. 228, 14 So. 572; MeClary v. Ratilroad Co., 102 Mich. 312 , 60 N. W. 695 ; Mancy v. Hart, 11 Wash. 67, 39 P. -68: Liser v. Halladay. 29 Oreg. 338, 45 P. 759: Howard v. Gobel, 62 11l. App. 497: Joseph r. Maelsine ('o., 99 Ala. 47,10 so. 327.

2. Nichols v. Vinson, 9 Houst. (1)el.) 274: Fisl v. Stamping Co.. 58 Ill. App. 663.

3. Niekerson v. Spindell 1 it. Mass. 25,41 N. E. 105. 
need of special care, his estate is liable for reasonable compensation, though there was no contract for the same. ${ }^{4}$

But not every case of services implies a compensation. Thus, in cases of a flood, as in those of conflagration, services rendered voluntarily to preserve another man's property from destruction, are presumed to be gratuitous and give no cause of action. ${ }^{5}$ So where a person lends a horse to another, it does not of itself authorize the borrower to make him answerable for its keep or improvement. ${ }^{6}$ Nor will a suit lie against a husband by a solicitor for services to the wife in defending a divorce suit. The only remedy is in equity on an application in the divorce proceedings by the wife for alimony and counsel fees. ${ }^{?}$

$\S$ 484. Physician's services.--If a physician should be called, in an emergency, to prescribe for an unconscious person, whose immediate attention was necessary to save the patient's life, and who expected compensation, the law would imply a contract for payment by the patient. ${ }^{1}$ But a physician who is called by a third person to attend to an injured employe, cannot recover from the employer on an implied promise. ${ }^{2}$

And a master who requests a physician to perform services for his servant does not impliedly promise to pay for them, since he is under no legal obligation to do so. ${ }^{3}$

$\S 485$. Burial of the dead.-The dead must be buried. And in case those to whom this duty belongs are absent or neglects to perform it, any other person may perform this duty and then recover, as on an implied contract, his reasonable compen-

4. Dannenhauer v. Browne, 47 La. Ann. 341,16 So. 827.

5. New Orleans, etc. R. R. Co. v. Turean, 46 La. Ann. 155, 15 So. 187; Compare Watson v. Le Doux, 8 La. Aun. 68, 28 Am. Dec. 129.

6. Cahill v. Hall, 161 Mass. 512, 37 N. E. 573.
7. Westcott v. Hinckley, $56 \mathrm{~N}$. J. J. 343,29 A. 154 .

1. Bishop on Cont. 231 ; Richardson v. Strong, 13 Ired. (N. Car.) 106, $55 \mathrm{Am}$. Dec. 430.

2. Malone v. Ice Co., 88 Wis. 542 , 60 N. W. 999.

3. Jesserich v. Walruff, 51 Mo. App. 270. 
sation $;^{1}$ and it makes no difference whether the party inemring this expense is an undertaker or a mere volunteer. ${ }^{2}$ But only such necessaries for the funeral of the deoedent and are of his estate as cannot properly be postponed until an administrator shall be appointed, are chargealle agrinst the estate. ${ }^{3}$

The modern English doctrine is that if the executor or administrator gives orders for the funeral, or ratifies or adopts the acts of another party who has given order, he makes himself liable personally and not in his representative capacity. ${ }^{4}$

In the United States, it is held by the conrts that the exeeutor or administrator nua be charged in his representative character, and judgment be rendered de bonis testatoris. ${ }^{5}$ But this question is regulated by statutory provisions in most of the States.

An executor who pays the debts and funeral expenses of his testator, for the discharge of which there is no personal estate, is entitled in equity to be reimbursed therefor out of the real estate. ${ }^{6}$

The old doctrine seems to be that, upon any promise made after the death of the testator or intestate, the executor or administrator was chargeable, if at all, as of his own goods, and not in his representative capacity. ${ }^{7}$

But now, in some cases, an executor may be sued in his representative capacity on a promise made by him as executor; and a judgment had de bonis testatoris. But in these cases, that which constituted the consideration of the promise or the cause of action arose in the lifetime of the testator. ${ }^{8}$ And an

1. Jenkins v. Tucker, I H. Bl. 90; Bradshaw v. Beard, 12 C. B., N. S. 344 .

2. Ambrose v. Kerrison, 10 C. B. 776.

3. Samuel v. Thomas, 51 Wis. 549, \& N. 361 . See, also, Foley v. Bushway, 71 ก1l. 386.

4. Briee v. Wilson, 8 Ad. \& El. 349, n.; Corner v. Shew, 3 Mees. \& Wel. 350.
5. Hapgood v. Houghton, 10 Piek. (Mass.) 154.

6. Clayton v. Somers, $27 \mathrm{~N}$. J. Eq. 230; Green v. Salmon. 8 Ad. \& El. 348 .

7. Trewinian r. Howell, Cro. Eliz. 91; Hawkes v. Saunders, Cowp. 289; Jennings v. Newman, 4 'Term R. 348 ; Bridgen v. Parkes, 2 Bos. \& Pul. 424.

8. Dowse v. Coxe, 3 Bing. 26; 
action for goods sold and delivered to one as an executor, or for work done for one as executor, charges the defendant personally, and not in his representative character. ${ }^{9}$

\section{ARTICLE V. \\ Waiving of Tort.}

Section 486. Waiving the Tort and Suing on the Implied Contract.

487. When Waiver May Be Made.

488. Doctrine that the Property Must Be Sold.

489. Doctrine that the Property Need Not Be Converted into Money.

490. Counter Claim or Set-off.

491. Privity of Contract.

492. Implied Assumpsit Lies for Trees or Stone Severed and Converted.

493. When Wrongdoer has Adverse Possession of Land.

494. Right of Agent of Injured Party to Sue in Assumpsit.

495. Several Tort Feasors.

496. Duress.

497. Duress of Goods.

498. Imprisonment.

499. Threats of Imprisonment.

500. Compounding Felony.

501. Voluntary Payment of Money.

502. As to Third Parties with Notice.

503. Receiving Benefits of a Fraud-Agency.

504. Money Received in Payment of Debts.

505. Chattels Wrongfully Obtained.

$\S 486$. Waiving the tort and suing on the implied contract. -A mere naked trespass, although creating a liability for damages, cannot be the basis of an action as an implied as-

Powell v. Graham, 7 Taunt. 581; Ashley v. Ashley, 7 Barn. \& Cr. 444.

9. Corner v. Shew, 3 Mees. \& Wel. 350. See, also, Foster v. Fuller, 6 Mass. 58, 4 Am. Dee. 87; Sumner v. Williams, 8 Mass. 162, 5 Am. Dec. 83; Davis v. French, 20 Me. 21, 37 Am. Dec. 36; Myer v. Cole, I2
Johns. (N. Y.) 349. For the right of possession of a dead body, see MeQueen v. Fox, 2 Q. B. 246; Williams v. Williams, 20 Ch. D. 659; Pierce v. Cenultry, 10 R. I. 227, 4 Am. Rep. 667; Hackett v. Hackett, Is R. I. 155, 26 A. 42,19 L. R. A. 55S, 49 Am. St. Rep. 762; Larson v. Chase, 47 Minn. 307, 50 N. W. 230, 
sumpsit. ${ }^{1}$ The law will not under all ciremmstances treat that as a contract which, in fact, is a tort. ${ }^{2}$ An action on implied assumpsit is not to recover damages for the tort, but to recover the value of that which the wrongdoer has appropriated to his own use, the law implying a promise to pay its reasonable value. $^{3}$

Where no benefits are received by the wrongdoer, the liability is only for damages for the tort. ${ }^{4}$ Where the plaintiff can waive the tort and sue in assumpsit he may bring assumpsit in the common counts. But the rule must be taken with this qualification: That the defendant is not therehy to be depriced of any benefit, which he could have derived under the appropriate form of action in tort. ${ }^{5}$

Actions ex delicto and ex contractu in these cases are concurrent; but the proof must be the same in each. ${ }^{6}$ The declaration may contain a count for money had and received, and other counts alleging facts of the fraudulent transaction which was the foundation of the suit. ${ }^{7}$ The declaration may contain special counts setting out the instrument as inducement, and it may allege the utter falsity of its recitations and the fraud of the whole transaction, and contain also the common counts. ${ }^{8}$

14 L. R. A. $S 5$ and note, 28 Am. St. Rep. 370; loley v. Phelps, 1 App. Div. 551, 37 N. Y. S. 471 ; Renihan v. Wright 125 Ind. 536, 25 N. E. 822,9 I. R. A. 514, 21 Am. St. Rep. 249; Younge v. College, 81 Ml. 358,32 A. 177,31 L. R. A. 540 and note; Driscoll v. Nichols, 5 Gray (Mass.), 488; Weed v. Walker, 130 Mass. 422, 39 Am. Rep. 465.

1. Downs v. Fimegan, 58 Minn. 112, 59 N. W. $981,4 !$ Am. St. Rep. 488 .

2. Jones v. Hoard, 5 Pick. (Mass.) 2S5; Balch v. Patten, 45 Me. 4l. 71 Am. Rep. 526; Raymond v. Lowe, 87 Me. 329,32 A. 964;
Fuller v. Duren, 36 Ala. 73, 76 Am. Dee. 318.

3. Downs v. Finnegan, $5 \mathrm{~S}$ Minn. 112. 59 N. IV. $981,49 \mathrm{Am}$. St. Rep. 488 .

4. Braithwaite v. Aiken, $3 \mathrm{~N}$. 1)ak. 365,56 N. W. 133.

5. 2 Greenl. on Ev. 1:0; Doherty v. Shields, 86 Hum, 303,33 N. Y. S. 497,67 N. Y. St. 211.

6. Sproor v. Newell, 3 Hill (N. Y.). 30s; Doherty v. Shields, 86 Hun, 303, 33 N. Y. S. 497,67 N. Y. St. 211 .

7. Steiner v. Clisby, 103 Ala. 181, 15 So. 612 .

8. Burton v. Driggs, 20 Wall. (C. S.) 125 . 
$\S 487$. When waiver may be made.-Where one person has wrongfully taken the money of another, or taken his property and converted it into money, the injured party has a right of action ex delicto for the injury, such as an action of trespass or trover or an action for deceit. But in many eases he may waive the tort and sue on the implied contract and recover the value of the money or property. ${ }^{1}$

After the election has been made and the plaintiff sues on the implied contract, he cannot then resort to an action on the tort. $^{2}$ He cannot waive in part only, but must elect as to the whole transaction. ${ }^{3}$

$\S 488$. Doctrine that the property must be sold.-It is held by one class of cases that the injured party may waive the tort and sue in assumpsit only when the wrongdoer has sold the property, and received money therefor or money's worth. ${ }^{4}$

1. Braithwaite v. Aiken, $3 \mathrm{~N}$. Dak. 365, 56 N. W. 133; Norden v. Jones, 33 Wis. 600, 14 Am. Rep. 782 ; Barker v. Cory, 15 Ohio, 9; Terry v. Munger, 121 N. Y. 161, 24 N. E. 272,8 L. R. A. 216 and note, 18 Am. St. Rep. 803; Fratt v. Clark, 12 Cal. 89; Jones v. Hoar, 5 Pick. (Mass.) 290; Mahoon v. Grecnfield, 52 Miss. 434; Cooper v. Cooper, 147 Mass. 370,17 N. E. 892 , 9 Am. St. Rep. 121; Neate v. Harding, 6 Exch. 349 ; Carey v. Freeholders, 47 N. J. I. 181, 1 A. 473; Dashaway Asso, v. Rogers, 79 Cal. 211, 21 P. 742; Smith v. Baker, L. R. 8 C. P. 350 ; Gilmore v. Wilbur, 12 Pick. (Mass.) 120, 22 Am. Dec. 410.

2. Thompson v. Howard, 31 Mich. 309; Hoffman v. Bughlett, 11 Lea (Tenn.), 549; Brewer v. Sparrow, 7 Barn. \& Cr. 310; Cooper v. Cooper, 147 Mass. 370,17 N. E. 892, 9 Am. St. Rep. 721.
3. Lytligoe v. Vernon, 5 Hurl. \& N. 180 .

4. Jones v. flloar, 5 Pick. (Mass.) $290 ;$ Moses v. Arnold, 43 Iowa, 187, 22 Am. Rep. 239; Tuttle v. Campbell, $7 \pm$ Mich. 652, 42 N. W. 384, 16 Am. St. Rep. 652 and note; Mahoon v. Greenfield, 52 Miss. 434; Willet v. Willet, 3 Watts (Pa.), 275 ; Stearns v. Dillingham, $22 \mathrm{Vt}$. 624, 5t Am. Dec. 88; Watson v. Stever, 25 Mich. 387; Balch v. Pattee, 45 Me. 41, 71 Am. Dec. 526; Kidney v. Persons, 41 Vt. 386, 98 Am. Dec. 595; Gilmore v. Wilbur, 12 Pick. (Mass.) 120, 22 Am. Dec. 410; Jones v. Baird, 7 Jones (N. Car.) 152; Steiner v. Clisby, 103 Ala. 181, 15 So. 612. See, also, McConnel v. Delaware, is Ill. 229; Johnson v. Ins. Co., 39 Mich. 33; Magoffin v. Muldrow, 12 Mo. 512; Walker v. Coleman, 81 11l. 390, 25 Am. Rep. 285; Bliss v. Thompson, 4 Mass. 488; Howe v. Clancey, 53 Me. 130. 
All the authorities agree that one who takes and sells personal property belonging to another, withont the consent of the owner, is liable for its value in an action upon an inplied promise to pay for the property. ${ }^{5}$ But it is hed that where the wrongdoer has the property only temporarily with $n o$ intention to keep it permanently, he is only liable for the tort in damages. ${ }^{6}$

\section{$\S 489$. Doctrine that the property need not be converted} into money.-The authorities differ as to whether such an action will lie where the wrongdoer does not sell the property, but retains it for his own use. However, the weight of authority holds that the action will lie where the wrongdoer enriches himself or makes a profit from the property, either by selling it or by retaining it and using it himself, with the intention to convert it permanently. ${ }^{1}$

The right of the injured party to sue on the implied promise, where the wrongdoer has been benefited by the conversion, whether the property is sold or not, eannot be denied only by creating a fiction. The fact that the property has not been sold by the wrongdocr, when he intends to keep it permanently, is important. The rule should be, that the owner of property converted may waive the tort and sue in assumpsit for the benefits received whenever the tort-feasor receives benefits of any kind from the wrong committed, whether by sale or by retention of the converted property, or in any other manner $;^{2}$ of

5. Reynolds v. Padgett, 94 Ga. 347,19 S. E. 906 ; Steiner v. Clisby, 103 Ala. 181, 15 So. 612.

6. Reyuolds v. Padgett, 94 Ga. $34 \bar{\imath}, 19$ S. E. 906.

1. Braithwaite v. Aiken, $3 \mathrm{~N}$. Dak. 365,56 N. W. 133 ; Norden v. Jones, 33 Wis. 600, It Am. liep. 782 ; Terry v. Munger. I21 N. Y. 161,24 N. E. 272,8 1. R. A. 216 and note, is Am. St. Rep. S03; Fratt v. Clark, 12 Cal. 89; Hill v.
Davis, 3 N. H. 384; Stockett v. Watkins, 2 Gill. \& J. (Md.) 326, 20 An. Dec. 438 ; Barker v. Cory, 15 Ohio, 9; Berly r. Taylor, 5 Hill ( N. Y.), 583; Doherty v. Shields, S6 Hun (N. Y.), 303, 33 N. Y. S. 497 ; Downs v. Finnegan, 58 Minn. 112,59 N. IV. 981,49 Am. St. Rep. 488.

2. Braithwaite v. Aiken, $3 \mathrm{~N}$. Dak. 365. 56 N. IV. 133 ; Pomeroy's Code Rem. 567, 569. 
course, if the wrongdoer only has the property temporarily and then offers to return it, there is only a tort. ${ }^{3}$

$\S 490$. Counter-claim or set-off.-By waiving the tort and suing in assumpsit, a counter-claim may be made. One of the sole objects in waiving the tort is often for the purpose of enabling the injured party to set up his claim as an offset, where, without such waiver, he could not, because of its tort nature, use it as a counter-claim or set-off. ${ }^{4}$

If the action of assumpsit can only be brought in case of money retained by the wrongdoer, or where he has sold the property and received the money therefor, then the injured may be deprived of his right of counter-claim or set-off, if the property has not been sold. ${ }^{5}$

$\S 49$ I. Privity of contract. - The action for money had and received is a liberal and equitable action, and on the principle of natural justice and equity, will be supported, where the defendant has received money, which in good conscience he ought not to retain, and which, ex equo et bono, belongs to the plaintiff. The law implies a promise that he will pay it; and the only privity between the parties that need be shown in such an action arises from this promise implied by law, that the defendant, having in his hands money which belongs to the plaintiff, will pay it over to him. ${ }^{1}$

3. Revnolds v. Padgett, 94 Ga. 347,19 S. E. 906.

4. Norden v. Jones, $33 \mathrm{Wis}$. 600 , 14 Am. Rep. 782; Coit v. Stewart, 50 N. Y. 17 ; Brady v. Brennan, 25 Minn. 210; Starr Cash Car Co. v. Reinhardt, 20 N. Y. S. 872, 2 Misc. 116,49 N. Y. St. 228; Wood v. Mayor, 73 N. Y. 556; Barnes v. McMullins, 78 Mo. 260; Becker v. Northway, 44 Minn. 61, 46 N. IV. 210, 20 Am. St. Rep. 543; Evans v. Miller, 58 Miss. 120, 38 Am. Rep. 313 and note; Downs v. Finnegan,
58 Minn. 112, 59 N. W. 981, 49 Am. St. Rep. 488.

5. Braithwaite v. Aiken, $3 \mathrm{~N}$. Dak. 365,56 N. W. 133.

1. Boyett v. Potter, 80 Ala. 479, 2 So. 534 ; Mason v. Waite, 17 Mass. 562 ; Steiner v. Clisby, 103 Ala. 181, 15 So. 612; Houston v. Frazier, 8 Ala. 84; Burton v. Driggs, 20 Wall. (U. S.) 125. See, also, Wilkinson v. Wilkinson, 62 Mo. App. 249 ; Williams v. Ladew, 171 Pa. St. 369, 33 A. 329 ; Emery v. Emery, s7 Me. 281, 32 A. 900. 
$\S$ 492. Implied assumpsit lies for trees or stone severed and converted.-Inder the modern decisions a tort ean be waiverl and assumpsit hronght on the implied promian, where there has been a wrongful conversion of property of one person to the use of another, whether sold or not by the wrongdoer; and this applies to cases where trees have been severed by a trespasser from land in possession of the owner, and to guarried stone thereon, and the wrongdoer has afterwards taken the trees or stone away, converting the same to his own use, so that trover or replevin would lie. ${ }^{1}$

And it has been held in an action of tort that the owner of trees cut from his land by a wilful trespass, and by him manufactured into railroad ties, and sold to an innocent purchaser, may recover from the latter their value as ties, withont any allowance for the increased value put upon the timber by the trespasser. ${ }^{2}$

The weight of authority is that where an action is brought for damages for logs cut and removed in the honest belief on the part of the purchaser that he had title to them, the measure of damages is the value in the woods from which they were taken, with the amount of injury incident to removal, and not at the mill where they were carried to be sawed. ${ }^{3}$

1. Downs v. Finnegạn, 5s Minn. 112, 59 N. W. 981, 49 Am. St. Rep. 488.

2. Powers v. Tilley, 87 Me. 34, 32 A. 714, 47 Am. St. Rep. 304. See, also, Strubbles v. Railroad Co., $7 \mathrm{~S}$ Ky. 481; Heard v. James, 49 Miss. 236; Gaskins v. Davis, 115 N. Car. S5, 20 S. E. 188,25 L. R. A. $\$ 13,44$ Am. St. Rep. 439 and note; Franklin Coal Co. v. MeMillan, 49 Md. 549, $33 \mathrm{Am}$. Ricp. 280 and note; Compare Omaha, ete. Co. v. Tabor, 13 Colo. 41, 21 P. 925, 5 L. R. A. 236, 16 Am. St. Rep. 185; Beede v. Lumprey, 64 N. H. 510, 15 A. 133, $10 \mathrm{Am}$. St. Rep. 426.

3. Gaskin v. Davis, $115 \mathrm{~N}$. Car.
85, 20 S. E. 188, 25 L. R. A. 813,44 Am. St. Rep. 439 and note; Railroad Co. v. Hutchins, 32 Ohio St. 571,30 Am. Rep. 629; Tilden v. Jolınson, $52 \mathrm{Vt}$. 628, $36 \mathrm{Am}$. Rep. 769 and note; IIerdie v. Young. 55 Pa. St. 176, 93 Am. Rep. 739; Hill v. Canfield, 56 Pa. St. 454; Moody v. Longfellow, 26 Me. 306 : Galler v. Fett, 30 Cal. 4S2; Foot v. Merrill, 54 N. H. 490, 20 Am. Rep. 157. Sec, also, Waters v. Stevenson, 13 Ner. 157; Rose v. Scott, 15 Lea (Tenn.), 479: Forsyth v. Wells, 41 Pa. St. 291. 80 Am. Dec. 61\%: Coal Creek M. Co, v. Moses, 15 Lea (Tenn.). 300, 54 Am. Rep. 415 and note; Burton Coal Co. v. Cox, 39 


\section{$\S 493$. When wrongdoer has adverse possession of land.-} If the wrongdoer severs trees or takes away quarried stone or other articles severed from the realty, and converts them, but has adverse possession of the land injured, assumpsit for their value by the real owner will not lie, because title to land cannot be tried ex directo in transitory actions. ${ }^{1}$ An action in assumpsit, in such eases, cannot be maintained where the title of the land is involved in the suit. ${ }^{2}$ So that, in order to maintain assumpsit for the value of the stone excavated from the soil or other property and converted by the wrongdoer, the owner must have actual or constructive possession of the land, in addition to his paper title. ${ }^{3}$

\section{$\S 494$. Right of agent of injured party to sue in assumpsit.} -An agent cannot waive the tort and sue in assumpsit, making the case his own. Because the principle of recovery is that the wrongdoer received the money or property, where, ex equo et bono, it belonged to the injured party and not to his agent. In such case the burden is on the injured party to show that he is legally entitled to the money or value of the converted property, and it is not enough to show that the defendant has no right to it. If neither party is entitled to the money, neither can recover from the other. ${ }^{4}$

The one who has been damaged by acting on a false and fraudulent representation made to him as an agent of another, but not intended to be acted upon by him, has no action for

Md. 1, 17 Am. Rep. 525; Blaen Avon Coal Co. v. MeCulloh, 59 Me. 403, 43 Am. Rep. 560 and note; Franklin Coal Co. v. MeMillan, 49 Md. 549, 33 Am. Rep. 280 and note; Austin v. Coal Co., 72 Mo. 535, 37 Am. Rep. 446; Compare Isle Royal Mine Co. v. Herten, 37 Mieh. 332, 26 Am. Rep. 514 and note; Hazelton v. Week, 49 Wis. $661,6 \mathrm{~N}$. 309, 35 Am. Rep. 796.

1. Washburn v. Cutler, 17 Minn. 361; Downs v. Finnegan, 58 Minn.
112, 59 N. W. 981, 49 Am. St. Rep. 488.

2. Powell v. Smith, 2 Watts (Pa.), 126; Baker v. Howell, 6 Serg. \& R. (Pa.) 481.

3. Downs v. Finnegan, 58 Minn. 112, 59 N. W. 981, 49 Am. St. Rep. 488.

4. Hungerford v. Moore, 65 Ala. 232; Mobile, ete. R. R. Co. v. Felrath, 67 Ala. 189. See, also, Steiner v. Clisby, 103 Ala. 181, 15 So. 612 . 
deceit against the party making the representation. 'The false and fraudulent representations must have been intended to be acted on, in a manner affecting himself, by the party who seeks redress for the consequential injuries. ${ }^{5}$

If the false representation is made to $A$ to induce him to part with his money, and he does so, $\Lambda$ must sue; but, if made to him to induce $B$ to part with his, and $\mathrm{B}$ is induced thereby to do so, he, and not $A$, is the party injured, who may maintain the action. In every case the money to be recovered must be the money of the plaintiff or the injured party, ${ }^{6}$ and not his agent.

$\S$ 495. Several tort feasors.-In order to maintain an action in assumpsit, it is necessary to show that the defendant has received money belonging to the plaintiff. But where sereral persons are parties to the injury of another, the action is maintainable against all, and it is not necessary to show that each of the defendants received a share of the proceeds. ${ }^{1}$ And this result will not be varied by the fact that the common agent failed to account with his associates and absconded with the proceeds. $^{2}$

And the commencement of an action by the injured party against one of a series of tort-feasors upon an implied contract arising from a conversion of personalty or withlolding and appropriating money, will not be a waiver of his rights against the other tort-feasors. ${ }^{3}$

But a wife who merely aids her husband in a forgery, or a mechanic who is simply employed to execute some portion of the work and is paid for his serrices, having no coneern or interest in the fruits of the crime, is not liable in an action ex contractu for money advanced upon the forged instrument."

5. Wells r. Cook, 16 Ohio St. 67, 77 X. Y. 400, 33 Am. Rep. 632 and $88 \mathrm{Am}$. Dec. 436 and note.

6. 2 Greenl. on Ev. 120.

1. National Trust Co. r. Gleason, 77 N. Y. 400, 33 Am. Rep. 632 and note.

2. National Trust Co. v. Gleason. note.

3. Huffman v. Houghlett, 11 Lea (Tenn.), 549.

4. National Trust Co. v. Gleason, 77 N. Y. 400, 33 Am. Rep. 632 and note. 
§ 496. Duress.-Money obtained under duress may be recorered under an implied contract to repay. Thus, where a party is not liable for taxes, who is called upon peremptorily to pay taxes by the collector and he can save himself and his property in no other way than by paying the illegal demand, he may give notice he pays the taxes under duress and not voluntarily, and then show that he was not liable and recover back the money thus paid. ${ }^{5}$ Where there exists coercion, threats, compulsion and undue influence, there is no volition. There is no intention or purpose but to yield to moral pressure for relief from it. No title is made through a possession thus acquired and the money may be recovered. ${ }^{6}$

$\S 497$. Duress of goods.-Where a party fraudulently and wrongfully knows that he has no just claim against another arrests him or seizes his goods for the purpose of extorting money from lim, the payment of money by the latter to the former, in order to release himself or his goods from such fraudulent and wrongful detention, is not voluntary, but by compulsion; and the money so paid may be recovered back, without proof of such termination of the former suit as would be necessary to maintain an action for malicious prosecution. ${ }^{1}$

And, so, where a carrier has exacted money by duress it may be recovered back. ${ }^{2}$

5. Amesbury, etc. Manuf. Co. v. Amesbury, 17 Mass. 461; Preston v. Boston, 12 Pick. (Mass.) 7.

6. Barry v. Assur. Co., 59 N. Y. 587 ; Thornett v. Haines, 15 Mees. \& Wel. 367; Foster v. Bartlett, 62 N. H. 617 ; Street v. Blay, 2 Barn. \& Adol. 456; Gompertz v. Denton, 1 Comp. \& M. 207.

1. Watkins v. Baird, 6 Mass. 506 , 4 Am. Dec. 170; Benson v. Monroe, 7 Cush. (Mass.) 125, 54 Am. Dec. 716; Carew v. Rutherford, 106 Mass. 1, 8 Am. Rep. 287; Richardson v. Duncan, 3 N. H. 508; Sartwell v. Fiorton, 28 Vt. 370 ; Colwell v. Peden, 3 Watts (Pa.), 327; Cadaval v. Collins, 4 Ad. \& El. 858, 6 Nev. \& Man. 324 ; Oates v. Hudson, 6 Exch. 346 ; Parker v. Railway Co., 6 Exch. 702; Chandler v. Sanger, $11+$ Mass. 364, 19 Am. Rep. 367; Cobb v. Charter, 32 Comn. 358, 87 Am. Dec. 178; Robertson v. Frank, 132 U. S. 17,10 S. Ct. 5 ; Briggs v. Boyd, 56 N. Y. 289.

2. McGregor v. Railroad Co., 35 N. J. L. 89 ; Baldwin v. Steamship Co., 74 N. Y. 125, 30 Am. Rep. 277; Peters v. Railroad Co., 42 Ohio St. 275, 51 Am. Rep. 814 and note. 
$\S$ 498. Imprisonment.- $\lambda$ though an arrest may be for a just cause and under a valid procese, yet if it he for an illegal purpose, and the person arrested pays the money for his release, he may be considered as having paid it hy ruress of imprisonment and may recover it back. ${ }^{3}$

Where there is an arrest for an improper purpose without just cause, or an arrest for just cause but without authority, or for just cause but for an unlawful purpose, even though under process, it is duress of imprisomment; and if the person thus arrested exccuted a contract or pays money for his release, he may aroid the contract or recover the money paid in a suit of assumpsit. ${ }^{4}$

But if such money was paid by the injured party voluntarily and after the duress and the influence thereof had ceased, it cannot be recovered back. ${ }^{5}$

Where money has been wrongfully obtained by means of a voidable contract, for which there was reccived no valuable consideration, a demand before suit is not necessary. ${ }^{6}$

$\S$ 499. Threats of imprisonment.-It is held by some of the courts that mere threats of criminal prosecution, where neither warrant has issued or proceedings commenced, do not constitute duress $;^{1}$ and others hold that a threat of arrest for which there

3. Richardson v. Duncan, $3 \mathrm{~N}$. H. 508 ; Severance v. Kimball, 8 N. H. 386 ; Hackett v. King, 6 Allen (Mass.), 5S; De Mesnil v. Dakin, L. R. 3 Q. B. 18; Heckman v. Swartz, 64 Wis. 48,24 N. W. 478 ; Bush v. Brown, 49 Ind. 573, 19 Am. Rep. 695; Walker v. Larkin, 127 Ind. 100,26 N. E. 68t; Tilley v. Damon, 11 Cush. (Mass.) 247; Richards v. Vanderpool, l Daly (N. Y.), 71; Foshay v. Ferguson, 5 Hill (N. Y.), 154; Brooks v. Berryhill, 20 Ind. 97; Fisher v. Shattuck, 17 Pick. (Mass.) 252.

4. Watkins v. Baird, 6 Mass.
506, $4 \mathrm{Am}$. Dec. 170; Severance v. Kimball, 8 N. H. 386; Richardson v. Duncan, 3 N. H. 508; Heckman v. Swartz, 64 Wis. 48,24 N. W. 473.

5. Heckman v. Swartz, 64 Wis. 48, 24 N. W. 473.

6. Baldwin $v$. Hutchinson, 8 Ind. App. 454. 35 N. E. 511 ; Thompson v. Peck, 115 Ind. 512, is N. E. 16, l f. R. A. 201.

1. Buchanan v. Sahlein, 9 Mo. App. 552; Higgins v. Brown, $78 \mathrm{Me}$ 473,5 A. 269; Council v. Burnett, 34 Ala. 400 . 
is no ground does not constitute duress, as the party conld not be put in fear thereby. ${ }^{2}$ These eases have no regard to the eondition of the mind of the person acted upon by the threat, nor do they take into consideration the age, disposition, or intelleet of the person threatened; and leave the old, the ignorant, the weak, and the timid at the mercy of the villain and shyster who operate upon their fears to extort money from them. So the threats to imprison an aged man may be duress, and the money may be reeovered back. ${ }^{3}$

And a threat to procure the arrest and imprisonment of one's son under a false and eriminal charge, and reasonable ground to believe that such threat will be executed, constitutes duress, and money paid to prevent such action may be recovered back. ${ }^{4}$ And so where a wife is indueed, by a threat of her husband's arrest, to pay a debt due from him to the ereditor, she may reeover back the money paid as obtained by undue influence, and it is immaterial whether or not there was a lawful ground for the arrest. ${ }^{5}$

$\S 500$. Compounding felony. - Where a note is given or money paid to eompound a felony, the contract is illegal, and the money cannot be recovered nor the note eollected. ${ }^{1}$ The law is well settled that eontraets made in violation of law cannot be enforeed; where, howerer, such contraets have been exeented

2. Knapp v. Hyde, 60 Barb. (N. Y.) 80 ; Preston v. Boston, 12 Pick. (Mass.) 12.

3. Cribbs v. Sowle, 87 Mich. 340 , 49 N. IV. 587, 24 Am. St. Rep. 166.

4. Schultz v. Culbertson, 46 Wis. 313,1 N. W. 19 ; Meech v. Lee, 82 Mich. 274, 46 N. W. 383 ; Eadie v. Slimmon, 26 N. Y. 9, 82 Am. Dec. 395 and note; Adams v. Bank, 116 N. Y. 606,23 N. E. 7, 6 L. R. A. 491 and note, 15 Am. St. Rep. 447; Green v. Scranage, 19 Iowa, 46, 87 Am. Dec. 441; Taylor v. Jaques, 106 Mass. 291.
5. Adams v. Bank, 116 N. Y. 606,23 N. E. 7,6 L. R. A. 491,15 Am. St. Rep. 447. See, also, Eadio v. Slimmon, 26 N. Y. 9, 82 Am. Dec. 395 and note; Peyser v. Mayor, 70 N. Y. 501, 26 Am. Rep. 624; Fisher v. Bishop, 36 Hun (N. Y.), 114 ; Lomerson v. Johnston, $44 \mathrm{~N}$. r. Eq. 93, 13 A. 8; Ingersoll v. Roe, 65 Barb. (N. Y.) 346.

1. Haynes v. Rudd, 83 N. Y. 251, 102 N. Y. 372, 55 Am. Rep. 815; Smith v. Rowley, 66 Barb. (N. Y.) 502. 


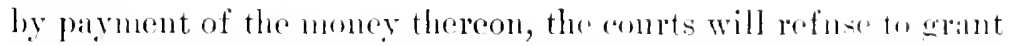
relief and leave the parties where they have placed themselves. An action for money so paid camnot he maintainerl were the parties ale really in pari delicto.

There is a distinction between those cases in which one of the partics has. by an illegal act, taken an alvantace of and oppressed the othere, and those in which it is not possible to distimguish hetween the parties as to the degree of their criminality. Thus, whele usury has been paid, it is considered that the lender has arailed himself of the distress of the borrower and has riolated the law to extort from him more than the lawful late of interest. $^{3}$ In transactions prohibited by statute for the protection of one set of men from another set of men the parties are not in pari delicto. ${ }^{4}$

While a contract may be illegal, set the parties may not be in pari delicto. Thus, a business of promoting marriages is against policy of the law and public interest, and a party paying money to a matrimonial bureau may recover it back. ${ }^{5}$ Unless the parties are in pari delicto as well as particeps criminis, the courts, although the contract is illegal, will afford relief to the more innocent part ${ }^{6}{ }^{6}$ So preminms paid for the insurance of lottery tickets may be recovered, as the plaintiff is not equally guilty with the defendant. ${ }^{7}$

Courts, both of law and equity, hold that two parties may concur in an illegal act without being deemed in all respects in pari delicto.

In such ases relief will he afforded to the less guilty party

2. Gotwaet v. Neal, 25 1ld. 435 ; Dixon r. Olmstead, 9 Vt. 310,31 Am. Dec. 629; Collins v. Blantern, 2 Wilson, 341: Wilder v. Collier, 7 Md. $273,61 \mathrm{Am}$. Dee. 346 .

3. Wheaton $\mathrm{v}$. Hibbard, 20 Johns. (N. Y.) 290, 11 Am. Dee. 284.

4. Browning v. Morris, 2 Cowp. 790. See, also. Smith v. Bromley, 6 Doug. 696; Schroeppel v. Corning, 6 N. Y. $107,115,116$.
5. Duval v. Wellman, $124 \mathrm{~N}$. Y. 156, 26 N. E. 343 ; Snith v. Bruming. 2 Vern. 392; Boynton v. llubbard, 7 Mass. 112; Goldsmith v. Proning. 1 Eq. Cas. Abr. 89 ; Crawford r. liussell, 62 Barb. (N. Y.) 92.

6. Tracy r. Talmiage lt N. Y. 162, 67 Am. Dee. 132 and note.

7. Mount v. Waite. 7 Johns. (N. Y.) 433 . 
where he appears to have acted under circumstances of imposition, hardship, or undue influence, and especially where there is a necessity of supporting public interest, or a well-settled policy of the law, whether that policy be declared in the statutes of the State or be the outgrowth of the decisions of the courts. ${ }^{8}$

$\S 50$. Voluntary payment of money.-If a party, with full knowledge of the facts, voluntarily pays a demand unjustly made on him, and attempted to be enforced by legal proceedings, he cannot recover back the money, as paid by compulsion, unless there be fraud in the party enforcing the claim, and a knowledge that the claim is unjust. And the case is not altered by the fact that the party, so paying, protests that he is not answerable, and gives notice that he shall bring an action to recover the money back; the party has an option, whether to litigate the question or submit to the demand and pay the money. ${ }^{9}$

An early case $^{10}$ decided that money paid, even under a judgment of a court of competent jurisdiction, could be recovered back, if in equity and good conscience the party receiving it was not entitled to hold it; this doctrine was never deemed satisfactory. The courts for a long time endeavored to sustain this doctrine; but finally established this rule that a party may in equity and good conscience continue to hold money voluntarily paid to him under no mistake of fact, and without fraud on his part. ${ }^{11}$ The rule is now, that wherever a party has an opportunity to plead and avail himself of a legal defense, and pays money, though under protest, he cannot recover it back, for the 300 .

8. 1 Pom. Eq. 403; Story's Eq.

9. Brisbane v. Dacres, 5 Taunt. 152; Brown v. McKinally, 1 Esp. 279: Milnes v. Duncan, 6 Barn. \& Cr. 679; Cadaval v. Collins, 4 Adol. \& El. 858, 6 Nev. \& Man. 324; Benson v. Monroe, 7 Cush. (Mass.) 125, $54 \mathrm{Am}$. Dec. 716; Bacon v. Bacon, 17 Pick. (Mass.) 134; Forbes v. Appleton, 5 Cush.
(Mass.) 115; Regan v. Baldwin, 126 Mass. 485, 30 Am. Rep. 689.

10. Moses v. Macpherlan, $1 \mathrm{~W}$. Bl. 219.

11. Rrisbane v. Dacres, 5 Taunt. 143; Benson v. Monroe, 7 Cush. (Mass.) 125, 54 Am. Dec. 716; Regan v. Baldwin, 126 Mass. 485, 30 Am. Rep. 689 ; Brown v. MeKinally, 1 Esp. 279. 
payment is not compulsory but voluntary. ${ }^{12}$ So where a shop was remdered unfit for use by fire, and the lessor does not repair as he was legally hound to do, and refuces to make a rebate of rent to the tenint, and demands full rent of the lessce which is paid under protest by the latter, the lessee cannot recover backi the overpayment, for the payment was voluntary. ${ }^{13}$

$\S 502$. As to third parties with notice. - When a third party who has received a specific sum of money, which he knows belongs to another, refuses to deliver it to the owner, the latter can recover it in an action of assumpsit. ${ }^{1}$ Thus, moncy bet on an election ean be recovered by the person depositing it with the stakeholder if demanded before payment to the winner, on the ground that such bet being prohibited by law, there is an implied promise on the part of the stakeholder to repay the money to its legal owner. ${ }^{2}$ So the holder of stolen money, if he has knowledge of the theft, holds the money for the rightful owner who can recover it on the implied promise to pay it. ${ }^{3}$ An action for money had and received will lie by the true owner of money against a third person into whose hands it eame mala fide, provided identity ean be traced or ascertained." Thus, when a payee of a promissory note has placed it in the hands of an agent, who has in turn placed it in the hands of a third person, who has made the collection and misapplicd the proecels, an action by the payee for money had and received, lies against the third person. ${ }^{5}$ And money fraudulently obtained

4. Hanlet v. Richardson, 9 Bing. 644: Benson v. Monroe, 7 Cush. (Mass.) 125, 54 Am. Dec. 716.

5. Regan v. Baldwin, 126 Mass. 485, $30 \mathrm{Am}$. Rep. 689 .

1. Mason v. Prendergast, 120 N. Y. 536, 24 N. E. S06; Bayne v. United States, 93 U. S. 642; Calland v. Loyd, 6 Mees. \& Wel. 26.

2. McAllister v. Hoffman, 16 Serg. \& R. (Pa.) 147, 16 Am. Dec.
556; Forseht v. Green, $53 \mathrm{~Pa}$. St. 138.

3. Hindmarek v. Hoffman, 127 Pa. St. 284, is A. 14, 4 L. R. A. 3 is' and note.

4. Clarke v. Shee, 1 Cowp. 197.

5. Harrison Mach. Works r. Coquillard, 26 Ill. App. 513. See, also, Drovers Nat. Bank v. O'Hare, 119 111. 646,10 N. E. 360 ; Allen v. Stenger, 74 Ill, 120. 
and in the hands of a mere depositary, may be recovered by the true ownel. ${ }^{6}$

$\$ 503$. Receiving benefits of a fraud-Agency.-The doctrine prevails at law and in equity, that a person, though imnocent, cannot avail himself of an advantage obtained by the frand of another, unless there is some consideration moving from him. Although a third person shall not be punished for the fraud of another, he shall not avail himself of it." The rule is general, that if one who assumes to do an act which will be for the benefit of another commits a fraud in so doing, and the person to whose benefit the fraud will enure seeks, after knowledge of the fraud, to avail himself of that act, and to retain the benefit of it, he must be held to adopt the whole act, fraud and all, and to be chargeable with the knowledge of it, so far, at least, as relates to his right to retain the benefit so received. ${ }^{8}$

Therefore, if a treasurer of a corporation is a defaulter, and his defalcation is unknown, and he steals money from a third person and places it with the funds of the corporation in order to conceal and make good his defalcation, and the corporation uses the money as its own, no other officer knowing any of the facts, the corporation does not thereby acquire a good title to the money, as against the true owner, but the latter may main-

6. Tradesman's Bank v. Merritt, 1 Paige (N. Y.), 302 ; Mechanic's Bank v. Levy, 3 Paige (N. Y.), 606; Pennell v. Deffell, 4 De G. M. \& G. 372.

7. Robson v. Calze, l Doug. 228; Atlantic Bank v. Bank, 10 Gray (Mass.), 532; Olmsted v. Hotailing, 1 Hill (N. Y.), 317 ; Udell v. Atherton, 7 Hurl. \& N. 171; Huguenn v. Boseley, 14 Ves. 273; Scholefield v. Templer, 4 De G. \& J. 429; Tapham v. Portland, 1 De G. J. \& S. 517; Russell v. Jackson, 10 Hare, 204.
8. Bush v. Moore, 133 Mass. 198; Rogers v. Palmer, 102 U. S. 263; National Security Bank v. Cushman, 121 Mass. 490 ; Suit v. Woodhall, 113 Mass. 391; Bennett v. Judson, 21 N. Y. 238; Grans v. Hunter, 28 N. Y. 389; Glyn v. Baker, 13 East, 509; Dresser v. Norwood, 17 C. B., N. S. 466 ; Boursot v. Savage, L. R. 2 Eq. 134; Rolland v. Hart, L. R. 6 Ch. 678 ; Espin v. Pemberton, 3 De G. \& J. 547 ; British, etc. Tel. Co. v. Bank, L. R. 7 Exch. 119; Bradley v. Riches, 9 Ch. D. 189; Blackburn v. 
tain an action against the corporation to recoser latek the same. ${ }^{9}$

$\S 504$. Money received in payment of debts.--Money reecived by frand or felony eamnot be followed by the true owner into the hands of one who has received it bome fide for a valuable consideration in due conrse of business. It is alsolutely necessary for practical business transactions that the payee of money in due course of husiness shall not be put upon injuiry at his peril as to the title of the payer. It wonld introdure great confusion into commereial dealings if the creditor who receives money in parment of a debt is subject to the riak of aceomnting therefor to a third person who may be able to show that the debtor obtained it from the latter by felony or fraud. The law wisely, from considerations of public policy and convenience, and to give security and certainty to business transactions, adjudges that the possession of money rests the title in the holder as to third persons dealing with him and receiving it in due course of business and in good faith upon a valid consideration. If the consideration is good betreen the parties, it is good as to all the world. ${ }^{2}$

Money, or negotiable securities, transferred to a third person, who receives them innocently as property of the person from whom they came, for a valuable consideration, cannot be followed by the true owner; and the same rule extends to such property received by a firm from one of its members. ${ }^{3}$

A large share of the business of the world is carried on by

Vigors, 17 Q. B. D. 553, 12 App. Cas. 531 .

9. Atlantic Cotton Mills v. Orchard Mills, 147 Mass. 268, $17 \mathrm{~N}$. E. $496,9 \mathrm{Am}$. St. Rep. 698 .

1. Miller v. Race, 4 Burr. 452.

2. Stephens v. Board, 79 N. Y. 183, 35 Am. Rep. 511; Miller v. Race, 4 Burr. 452; Newhall $v$. Wyatt, 139 N. Y. 452,36 Am. St. Rep. 712, 34 N. E. 1045; South- wick v. Bank, 84 N. Y. 420,434 ; Justh v. Bank, 56 N. Y. 478.

3. Lime Rock Bank v. Plimpton, 17 Mass. 159; Greenfield School Dist. v. Bank, 102 Mass. 174; Thacher v. Pray, 113 Mass. 291, 18 Am. Rep. 480; Ex parte Apsey, 3 Bro. C. C. 265: Jaques v. Marquand, 6 Cow. (N. Y.) 497; Dumlap $\vee$. Lewis, 49 Iowa, 177. 
means of bills of exchange drawn upon persons liable to pay or for the accommodation of the drawers willing to pay them. Hence, the protection and encouragement of trade and commerce and considerations of public policy and convenience, require that when such a bill is paid to one who holds it in good faith and for value he should not be called upon afterwards to account for the money paid. ${ }^{4}$

The doctrine that an antecedent debt is not such a consideration as will cut off the equities of third parties, in respect to negotiable securities obtained by frand, has no application to money so obtained. ${ }^{5}$

$\S 505$. Chattels wrongfully obtained.-If a third party receives goods which have been wrongfully obtained and converts or sells them, the rightful owner may recover from him the value of the goods, unless the recipient has received them bona fide and paid a valuable consideration. Bank notes are now so far considered like common current money that they cannot be followed by the original owner into the hands of a bona fide holder for a valuable consideration without notice. ${ }^{1}$

A check must be considered in the same right as a promissory note taken after it is due. A check is payable immediately, and the holder keeps it at his peril, and a person taking it after it is due, takes it with all the equities. So where a check is taken by a third party after its date of execution, and which had heen lost and found by the second party who passed it, the third party is liable to the real owner for it. $^{2}$

12. Hamlet v. Richardson, 9 Bing. 344 ; Stephens v. Board, 79 N. Y. 183, 35 Am. Rep. 511; Foster v. Green, 7 Hurl. \& N. 881; State Bank v. United States, 114 U. S. 401, 5 S. Ct. 888 .

13. Regan v. Baldwin, 126 Mass. 183, 35 Am. Rep. 511.
1. Lowndes v. Anderson, 13 East, 130; Safford v. Wyckoff, 4 Hill (N. Y.), 442; Glyn v. Baker, 13 East, 509.

2. Down v. Halling, 4 Barn. \& Cr. 330 . 


\title{
CHAPTER XVII.
}

\author{
Assignments.
}

\section{AR'TICLE I.}

\section{Voluntary Assignments.}

Section 506. For Benefit of Creditors.

507. Sct-off Against Assignee.

jos. Priorities.

509. Coupons-Theater Tickets.

510 . Bills of Lading.

511. Drawing 1)raft by Consignor.

512. Bills of Lading-Negotiability.

513. Warehouse Receipts.

514. Nature of Warehouse Receipts.

$\S 506$. Voluntary assignment for benefit of creditors.-The assignee of an insolvent assignor or corporation under an assignment for the benefit of ereditors, takes the property subject to whatever equities existed against the assignor, the assignee sueceeds to the rights of the insolvent assignor or corporation as they existed at the date of the assignment, and no other or greater rights. However, the authorities are not entirely harmonious, but the rule as stated in the text has the following of the majority of the courts and text writers, and is the more equitable. ${ }^{1}$

1. McCagg v. Woodman, 28 Ill. 84; Rothschild v. Mack, $115 \mathrm{~N}$. Y. 1; 21 N. E. 726 ; Hade v. McVay, 31 Ohio St. 231: American Bank v. Wall. 56 Me. 167 ; Chace v. Chapin, 130 Mass. 130; Cook v. Cole, 55 Iowa, 70, 7 N. 419; Farmers' Deposit N. Bank r. Bank, $123 \mathrm{~Pa}$. St.
283, 16 A. 761; Van Wagoner v. Gas Light Co., 23 N. J. I. 2S3: Clarke v. Hawkins, 5 R. I. 219 ; Nashrille Trust Co. v. Bank, 91 Tenu. 336, 19 S. W. S.2, 15 L. R. A. 710 ant note: Merwin $v$ Austin, is Comm. 22. is A. 1029, T L. R. A. 84 and note; Salladin v. Mitchell, 
In those States where the real party in interest must sue the clain, the right of set-off exists in favor of one who has acquired the title to money due from an insolvent bank on a certificate of deposit issued to a third person with a formal assignment by the latter. ${ }^{2}$

$\S$ 507. Set-off against assignee.-The debtor may set-off any claim due him from the creditor at the time of the assignment. Thus, the maker of a non-negotiable note which has been assigned by the payee to a third party, may set-off against it a note of the payee which he has purchased before notice of the assignment of the note executed by himself. ${ }^{3}$ But the debtor cannot set-off an unmatured debt at the time of the assignment of the assignor against the assignee. ${ }^{*}$ And the debtor cannot set-off a claim afterwards aequired. ${ }^{5}$ So where a laborer has assigned his wages which are to be earned in the future under a contract already made, he cannot set up a claim against the assignee which is wholly independent of the contract of assignment, and which accrued after the assignment. ${ }^{6}$

$\S 508$. Priorities. - The question which of different assignees of a chose in action by express assignment from the same person will have the prior right is one in respect to which there is much conflict of authority. ${ }^{1}$ But the better rule is that where two assignments of a chose in action, for a raluable consideration, are made to different persons, the assignee who first

42 Nebr. 859, 61 N. IV. $127 ; \operatorname{Cox} v$. Valkert, 86 Mo. 505; Schuler v. Israel, 120 U. S. 506, 7 S. Ct. 648; Carr v. Hamilton, 129 U. S. 252, 9 S. Ct. 295; Pom. on Rem. 163, 169. Compare Eastern Bank v. Capron, 22 Conn. 639; Haxton v. Bishop, 3 Wend. (N. Y.) 13.

2. Salladin v. Mitehell, 42 Neb. 859. 61 N. IV. 127.

3. St. Louis Nat. Bank v. Gay, 101 Cal. 286, 35 P. 876; MeCabe v. Gray, 20 Cal. 509; Adams v. Jueav- ens, 20 Conn. 73; Abshire v. Corey, 113 Ind. 484,15 N. E. 685.

4. Follett v. Buyer, 4 Ohio St. 586; Baekus v. Spanlding, 129 Mass. 234; Roberts v. Carter, 38 N. Y. 107.

5. Weeks v. Hunt, 6 Vt. 15; Goodwin v. Cunningham, 12 Mass. 192; Crayton v. Clark, 11 Ala. 787.

6. St. Andrew v. Manuf. Co., 134 Mass. 42.

1. Pom. Eq. Jur. 693; Story Eq. Jur. 1047. 
gives notice of his elaim to the debtor has the prior right, though the assigmment to him is later in date than that to the other assignee."

It is held that in order to perfoet the assignec's title he must immediately give notice of the assigmuent to the debtor, for otherwise a priority of right may be obtained ly a sulserguent assignee, or the debt may be discharged by a parment before sueh notice. ${ }^{3}$ so a sulsequent purchaser of a chose in action will be preferred orer a prior purchaser, who neglects to give notice of his assignment, and warns other's not to buy. ${ }^{4}$ Hence, notice of an assignment of a denand or obligation given to a debtor tixes the right of the parties and protects the assignee, thongh it he a partial assignment. ${ }^{5}$

But this is not the rule aropted by all the courts.

In many States the assignment of a chose in action is complete upon the mutual assent of the assignor and assignee, and gains no additional validity as against third persons by notice

2. 'Tuder v. Perkins. 3 Day (Conn.). 364: Vanbuskirk v. Ins. Co., 14 Conn. 444, 36 Am. Dee. 492; Dearle v. Hall, 3 Russ. 1; Loveridge v. Cooper, 3 Russ. 30 ; Timson v. Ramsbottom, 2 Keen, 35; Foster v. Cockercll, 3 Ch. \& F. 456; Barney v. Douglass, 19 Vt. 9S; Bishop v. Slocomb, 10 Conm. 446 : Julson v. Coreoran, 17 How. (U. S.) 612; Spain v. Hamilton, 1 Wall. (U. S.) 604: Bisph. Eq. 169: Stocks r. Dobson, + DeG. M. \& G. 15: In re Gillespie, 15 Ferl. Rep. 734: Methven $v$. Ileat \& Power Co.. (66) Fed. Rep. 113; White v. Prentiss. 3 T. B. Mon. (Ky.) 448: Clodfelter v. Cox, l Sneed (Tern.). 380, (60) Am. Dec. 15i: Murdock r. Finney. 21 Mo. 138; Ward v. Morrison. 2.3 vt. 593: Foster v. Blackstone, 1 Myl. \& K. 297; Willes v. Greenlill. 4 D. F. \& J. 147: In re Wyatt
(1892), l Ch. 18s; Ward v. Doncombe (1893), App. Cas. 369, 2 Lead. Cas. Eq. (part 2), $116.5,1166$, and cases cited; Cooper v. Fynmore, 3 Russ. 60 ; Bloomer v. Henderson, 8 Mich. 395, 77 Am. Dec. 453; Meux v. Bell, I Hare, 73; Adams Eq. 53: Natt v. Clark, 9 Pal. St. 399, 49 Am. Dec. 55(j: Smitl v. Smitl, 2 Cromp. \& 11.231.

3. Loveridge v. Cooper, 3 Russ. 30. See. also, Murray v. Lýlburn, 2 Johns. Ch. (X. Y.) t\&: Moore v. IIolcombe, 3 Leigh (Va.). 597. $24 \mathrm{Am}$. Dee. 6S3. Compare Garland v. Richeson, + Rand. (Va.) $\mathbf{2} \mathbf{T}$.

4. Jutkon v. Corcoran, 17 IIow. (U. S.) 612: Bayley v. Greenleaf, 7 Wheat. (U. S.) 46.

5. Schilling v. Mullen, 55 Minn. 122, $56 \mathrm{~N} . \mathrm{W} .586,43 \mathrm{Am}$. St. Rep. 475 . 
to the debtor. ${ }^{6}$ So as between a prior and subsequent assignee of the same debt it is not necessary to the validity of the first assignment, that notice thereof should be given to the debtor. ${ }^{7}$ Because there being no legal title in the assignees of a chose in action, and the equities being equal, he who is first in time has the better right. ${ }^{8}$ That the failure to give notice of an assignment is immaterial, as regards one claiming under the assignor as a creditor or volunteer, it being a general, if not invariable rule, that one cannot give what he could not justly hold, and that the right of a creditor does not rise higher than that of the debtor, and is subject to all the equities that could have been enforeed against him. ${ }^{9}$

So a subsequent assignee takes the title of the chose in action subject to all equities existing between any prior assignor and assignee. $^{10}$ And when there is a secret agreement between the obligor and obligee restricting the collection of the bond to certain property of the obligor, and the assignee of the bond for value who purchases without notice of the agreement, but without inquiry of the obligor, will be affected thereby. ${ }^{11}$

6. Thayer v. Daniels, 113 Mass. 129.

7. Bank v. Gettinger, $3 \mathrm{~W}$. Va. 317; Harrison v. Bank, 9 IV. Va. 424; Tingle v. Fisher, $20 \mathrm{~W}$. Va. 497.

8. Tingle v. Fisher, $20 \mathrm{~W}$. Va. 497 ; Muir v. Schenck, 3 Hill (N. Y.), 228, 3S Am. Dec. 633; Kamena v. Huelbig, 23 N. J. Eq. 78; Newby v. Hill, 2 Met. (Ky.) 530; Ohio Ins. Co. v. Ross, $2 \mathrm{Mr}$. Ch. 25; Harrison v. Bank, 9 W. Va. 424 ; Com. Nat. Bank v. Bureh, 141 Ill. 519, 31 N. E. 420, 33 Am. St. Rep. 331 and note; Shafer v. Riley, 50 N. Y. 66 ; Moore v. Bank, 55 N. Y. 41, 14 Am. Rep. 173; Greentree v. Rosenstock, 61 N. Y. 593; Trustees v. Wheeler, 61 N. Y. 104; Summers v. Huston, 48 Ind. 230 ; Wake- field v. Martin, 3 Mass. 558; Dix v. Cobb, 4 Mass. 508; Wood v. Partridge, 11 Mass. 488; Providence County Bank v. Benson, 24 Pick. (Mass.) 204; Martin v. Potter, 11 Gray (Mass.), 37, 71 Am. Dec. 689; Richards v. Smith, 9 Gray (Mass.), 315; Kingman v. Perkins, 105 Mass. 111. See, also, McClintie v. Wise, 25 Gratt. (Va.) 448, 18 Am. Rep. 694; Grubb v. Wysor, 32 Gratt. (Va.) 127.

9. Beavan v. Oxford, 6 DeG. M. \& G. 492; Kendricky v. Jervis, 22 Beavan, 1; Pickering v. Railway Co., J. R. 3 C. P. 235, 248.

10. Sutherland v. Reeve, $151 \mathrm{Ill}$. 384,38 N. E. 130.

11. Lane v. Smitl, $103 \mathrm{~Pa}$. St. 415. 
$\$$ 509. Coupons-Theatre ticksts. If “онимm- are drawn so that they wan be separated from the bund, whey aro like the bond negotiahle, if having that forms; the owner of them can sue on the anpon withont produring the buml wo whele they were attached, w without heing interested in the bust. ${ }^{1}$ Bonds

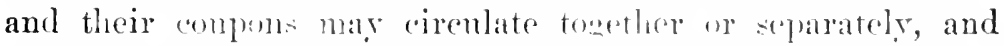
snits on compons are sustained entirely independently of the bonds to which they were originally amexed. And it is of no consequence whether ther are promissory notes, lills, drafts, or eheeks, for they have the same quality of negotialility as any of those instruments, and the holder sues upon them and recovers in his own name. ${ }^{2}$

But a coupon to be negotiable, must be so upon its face without reference to any other paper. ${ }^{3}$

A theater ticket is commonly held to be a more license, and not a contract which may be assigned. ${ }^{4}$ This is on the ground that the proprietor of a theater has a right to say whom he will or will not admit to his theater. A theater ticket is simply a license to the party presenting the same to witness a performance to be given at a certain time, and being a personal licenso it may be revoked. ${ }^{5}$ But if the ticket to a theater or eoncert is not a contract, there is a contract behind it, a contract of purchase. If the ticket is refused and the purchaser is not permitted to enter the theater or concert hall, then he may re cover back the purchase price and also the damages that may direetly result therefrom. ${ }^{6}$ Henee, there must be a eontract between the parties and an implied provision exists that the purchaser has a right to transfer it. And so it seems that such

1. Thompson v. Lee County, 3 Wall. (U. S.) 327; Beaver County v. Armstrong, 44 Pa. St. 63 ; Haven Railroad Co., 109 Mass. 88.

2. Beaver County v. Armstrong, 44 Pa. St. 63; Thomas v. Lee County, 3 Wall. (U.S.) 327 ; lienard $v$. Cass, 3 Dillon, C. C. 147: Haven v. Railroad Co., 109 Mass. 88.
3. Augusta Bank v. Augu-til, 49 Me. 507 .

4. Collister v. IJayman. $75 \mathrm{X}$ Y. S. 1102. il App. Div. 316.

5. Purcell v. Daly, $1: 1$ Ablot's New Catses, 301; Coleman v. Foster. 1 Hurl. and Norm. 37: J joke v. Wells, ll Allen (Mass.). 144.

6. Pureell v. Daly, 19 Abb. N. Cas. $30 \mathrm{I}$. 
a ticket gives something more than a license to enter the theater or concert hall. ${ }^{7}$ If the ticket contains a statement that it is a personal license and not transferable, yet in some States actual notice of this provision must he brought home to the purchaser by actual notice and his acceptance before it will bind him. In other jurisdictions, the mere acceptance of the ticket binds the rendee as to such provision. ${ }^{8}$ Whether such a right to transfer is implied or not in such a case is certainly un open question.

The doctrine that a theater ticket, or other ticket for a public entertainment is a mere license which can be revoked at any time was announced in England years ago, ${ }^{9}$ and has been followed by many courts in the United States. This doctrine is not in accordance with the view of Amcrican citizens. It has been correctly held that the holder of a ticket for a reserved seat in a theater is entitled to that particular seat for the time specified by such ticket, and has more than a mere license to enter the theater, revocable at the will of the seller, that his right under such ticket is more in the nature of a lease. ${ }^{10}$ And this view is sustained in the dissenting opinion of Justice Harlan in the Civil Rights Cases, ${ }^{11}$ where it is logically held that a licensed theatrical manager, whose place of amusement is open for public entertainment and to which the public are invited to go and pay their money for the use of a seat, is not a mere private enterprise owing no duty to the public, but is a place clothed with a public interest because used in a manner to make it of public consequence and to affect the community at large. This is the true American doctrine though the English precedents are against it.

$\S 5$ ro. Bills of lading.-By statute in many States and under the law merchant, a bill of lading is a receipt given by a car-

7. Drew v. Peer, 93 Pa. St. 234. See, also, Fiteh v. Constantine $\mathrm{Hy}$ draulic Co., 44 Mich. 74, 6 N. 91.

8. See Hoalley v. Transportation Co., 115 Mass. 304, 15 Am. Rep. 106.
9. Wood v. Leadbetter, 13 M. \& W. 387 .

10. Drew v. Peer, 93 Pa. St. 236.

11. 109 U. S. $3,42,3$ s. Ct. 18. 
rier of the anouls to the rendor, for their delivery to the consignee. Numerous decisions both in England and America hold that where goods are consignerl by the rendor to the rendee, under bills of lading in the usual form, an attempt by the vendor to stop the goods in transitu will be mavailing as against an assignee of the bill of lading, who took it in good faith, for a valuable consideration, in the usual course of business, before the attempted stoppage. ${ }^{1}$

If the bill of lading is assigned, and the legal title passes to a bona fide purchaser for a valuable consideration before the right of stoppage is excreised, the lien of the rendor ceases as against the assignee, on the well known principle that a seeret trust will not be enforced as against a bona fide holder for value of the legal title. ${ }^{2}$ The rendor places in the hands of the vendee a mumiment of title, elothing him with the apparent ownership of the gools; and a person dealing with him in the usual course of business, who takes an assignment for a valuable consideration, without notice of such eireumstances as under the bill of lading, not fairly and honestly assignable, has a superior equity to that of the rendor asserting a recent lien, known, perhaps, only to himself and the vendee. ${ }^{3}$

The right of stoppage by the rendor is lost when, before it is exercised, the rendee has sold the goods and indorsed the bill of lading to a sub-purchaser for vahe in good faith. ${ }^{4}$

\section{\$ 5 II. Drawing of draft by consignor.-The discount of a} draft drawn by a consignor upon his consignee, which is accompanied by the delivery of a bill of lading to the party making the advance, not only passes to such party the legal title to such property, but in the eye of the law the transfer

1. First Nat. Bank v. Schmidt. 6 Colo. App. 216,40 P. 479: Lickbarrow v. Mason, 2 Term R. 63, 1 Smith, Lead. Cas. 825.

2. Newhall v. Railroad Co.. 51 Cal. 345, 21 Am. Rep. 713.
3. Brewster v. Sims, 4. Cal. 130; Becker v. Hallgarten, s6 X. Y. 167; Forbes v. Railroad Co., 133 Mass. 154: Kearney Milling and Elevator Co. v. Railroad Co., 97 Iowa, 719, 66 ․ IV. 1059, 59 Am. St. Rep. 4it.

4. Loeb v. Peters, 63 Ala. 130. 
of the bill of lading is regarded as an actnal lelivery and an actual change of possession of the property. ${ }^{5}$ And the fact that the bill of lading is drawn to order does not prevent its transfer by delivery to a third person without indorsement. ${ }^{6}$

5 52. Bills of lading-Negotiability.--It does not necessarily follow that because a statute has made bills of lading negotiable by indorsement and delivery, all the conseqnences of an indorsement and delivery of bills and notes before maturity ensue or are intended to result from such negotiation. As to promissory notes the purchaser is not to look beyond the instrument. ${ }^{1}$ This rule was first applied to the case of a lost bank-note, ${ }^{2}$ and was put upon the gronnd that the interests of the trade, the nsual course of business, and the fact that bank-notes pass from hand to hand as coin, require it. It was subsequently held applicable to drafts. ${ }^{3}$

But these principles can have no application to the case of a lost or stolen bill of lading, becanse the function of that instrument is entirely different from that of a bill or note. It is not a representative of money, used for transmission of money, or for the payment of debts or for purchases. It does not pass from hand to hand as bank-notes or coin. It is a contract for the performance of a certain duty. The purchaser of a bill of lading who has reason to believe that his vendor was not the owner thereof, or that it was held to secure an outstanding draft, is not a bona fide purehaser, nor entitled to hold the property covered by the bill against its true owner. ${ }^{4}$

5. Bank v. Jones, 4 N. Y. 497,55 Am. Dec. 290 and note; lirst Nat. Bank r. Kelly, 57 N. Y. 37, 4 Am. Rep. 650; City Bank v. Railroad Co., 44 N. I. 136; Merchant,' Bank v. Railroad Co., (i9) N. Y. 379: First Nat. Bank v. Railroad Co., $8: \mathrm{Hm}$, 160,32 N. Y. S. 604,66 N. Y. St. 172.

6. Merehants' Bank v. Railroad Co., 69 N. Y. 37!; First Nit. Bank v. Railroad Co., $85 \mathrm{Hm}, 160,32$ N. Y. S. 604,60 N. Y. St. 112.
1. Goodman v. Harvey, 4 Ad. \& E. 870 ; Goodman v. Simonds, 20 How. (U. S.) 343 ; Murray v. Lardner, 2 Wall. (U. S.) 100 ; Matthews v. Poytress, 4 Ga. 287.

2. Miller v. Race, 1 Burr. 452.

3. Peacock v. Rhodes, 2 Doug. 633.

4. Shaw v. Railroad Co., 101 U. S. 557. Compare Tiedman v. Knox, 53 M!? 612. 
Therefore, a stolen hill of larling. or whieh has loem illewally transterred, gives no rightsts even 16 a bona fide indorsere: it is at most a contract assignable, but incapalile of giving a better title than is possesed by the assignor. ${ }^{5}$

A bill of ladling, though transferable by delivery like mereantile paper, is mlike such paper in this: the assignor eannot acquire a better title to the property thus swmberically delivered than his assignor had at the time of the assignment. ${ }^{\circ}$ ind the possession of the bill of lading by one other than the consignee without indorsement does not justify the delivery of the goods to $\lim ^{7}{ }^{7}$

$\S$ 513. Warehouse receipts. - Warehonse receipts are made negotiable by most of the States by statute, and hare, in many respects, the characteristics of negotiable paper. So the indorsement and delivery of a warchouseman's receipt by the owner of the property described in the receipt, to secure a debt, passes the title of the property to the indorsee, as against the claims of purchasers and ereditors of the indorser. ${ }^{8}$ If the transfer is made by the owner of the property, to whom the receipt was given, for the purpose of securing a debt for adrances of money made on the faith of such transfer, it is a symbolic delivery of the property that the reeeipt purports to represent, sufficient to create a pledge, and is equivalent to an actual delivery, and will protect the person to whom it is transferred against the claims of creditors and purchasers. The indorsement and delirery of the receipt have the sane effect in transferring the title as the delivery of the property. The

5. Shaw v. Railroad Co., 101 L. S. 557; Gurney v. Behrend, 3 El. \& Bl. 622: Tison v. Howart. 57 Gal. 410 ; Decan v. Shipper. $35 \mathrm{~Pa}$. St.

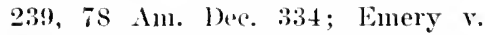
Bimk, 25 Ohio St. 360. $18 \mathrm{Am}$. Rep. 299 ; Straus v. Wessel, 30 Ohio St. 211 ; Dows v. Perrin. 16 N. 1. 325; First Nat. Bank r. Slaw. (i) N. Y. 283.
6. Limery r. Bank, $2 \tilde{z}$ Ohio St. 360 , 18 Am. Rep. 299 : Straus v. Wessel. 30 Ohio st. 2ll.

7. Lonisville, ete. R. R. Co. v. Barklouse, 100 Ala. 543, 13 So. 534.

8. Bank v. Hirsch, 59 Ark. 225, 27 s. W. 7 . 
warehouseman becomes the bailee of the holder of the receipt to whom it is transferred, and ceases to hold for the former owner. ${ }^{9}$

While a warehouse receipt is not negotiable in the sense in which that term is applied to a promissory note, yet the transfer of such a receipt, accompanied by a sale or pledge of the property specified in the receipt, will have the same effect as the delivery of the property to the transferee. ${ }^{10}$

$\S 5$ I4. Nature of a warehouse receipt.--The receipt is not required to be in any particular form. ${ }^{1}$ If the warehouse receipt is a contract it cannot be contradicted by oral evidence $;^{2}$ but if it is a mere receipt it can be explained like other receipts. ${ }^{3}$ An instrument executed and signed by the warehouseman giving full description of the property so that it can be identified is sufficient; ${ }^{4}$ though no minute description of the property is necessary. ${ }^{5}$

9. Harris v. Badley, 2 Dill. C. C. 284; Shepardson v. Cary, 29 Wis. 34 ; Puckett v. Reed, 31 Ark. 131 ; Durr v. Hervey, 44 Ark. 301, 51 Am. Rep. 594; Ferguson v. Bank, 14 Bush (Ky.), 555, 29 Am. Dec. 418; Young v. Lambert, L. R. 3 C. P. 142; Stewart v. Ins. Co., 9 Lea (Tenn.), 104; McNeil v. Hill, 1 Woolw. C. C. 96; Yenni v. McNamee, 45 N. Y. 614; Broadwell v. Howard, 77 Ill. 305.

10. Burton v. Curyea, 40 Ill. 320 , 89 Am. Dec. 350 ; Gibson v. Stevens, 8 How. (U. S.) 384.
1. Gibson $v$. Stcvens, 8 How. (U. S.) 384. See, also, Harris v. Bradley, 2 Dill. C. C. 284; Puckett v. Reed, 31 Ark. 131.

2. Stewart v. Ins. Co., 9 Lea (Tenn.), 104; Johnston v. Browne, 37 Iowa, 200.

3. Hughes v. Stanley, 45 Iowa, 622; Carrall v. Railroad Co., 14 Mo. App. 490.

4. Harris v. Bradley, 2 Dill. C. C. 284: Puckett v. Reed, 31 Ark. 131.

5. Bank v. Hirsch, 59 Ark. 225 27 S. W. 74. 


\section{ARTICLE II.}

\section{Assignalent of Wages and Salatir.}

Section 515. In Equity-Unearned Wages.

516. Effect of Assignor's Diseharge in Bankruptey.

517. Unearned stalary of Public Otficers.

$\S$ 515. In equity-Unearned wages.-It is settled that in equity an assignment of moneys not yet due or earned, but which are expected to be earned in the future under an existing contract, is binding and will be enforced. "But such an assignment may be subject to claims of other parties and must be taken by the assignee cum onere. ${ }^{2}$

A person, however, who assigns his future earnings must be in the actual employment of another. One not engaged in any employment for another, and not under contract for employment, cannot, even for a valuable consideration, make a valid assignment of wages he may earn in the future. Such an assignment is a mere possibility of a sebsequent acquisition of property, which is too vague and uncertain to be sustained as a valid assigmment and transfer of property. ${ }^{3}$

So a school teacher who is indebted to another has the legal right to make an assignment of his wages to acerue under his contract with the school board; and when he draws an order on the school treasurer in favor of his creditor, which is ac-

1. Brewer v. Grieshcimer, 104 Ill. App. 323, 35 Chic. L. News, 144; Mallan v. Wenham, 209 Ill. 253; East Lewisburg L. \& Manuf. Co. v. Marsh. 91 Pa. St. 96; Ruple v. Bindley, 91 Pa. St. 296; Taylor v. Lyncli, 5 Gray (Mass), 49; Payne v. Mayor, 4 Ala. 333, 37 Am. Dec. 744; Greene v. Bartholomew, 34 Ind. 235; Spain v. Hamilton, 1 Wall. (U. S.) 601; Code v. Carlton, 18 Neb. 328, 25 N. W. 353; Perkins v. Butler County, 44 Neb. 110, 62 N. IV. 308 .

2. Union Pacific, ete. IR. R. Co. r. Bank. 42 Neb. 469, 60 X. W. $8 S 6$.

3. Lehigh Valley R. R. Co. v. Woodring, 116 Pa. St. 513, 9 A. 5s; Mulhall v. Quinn, I Gray (Mass.), 105, 61 Am. Dec. 414; Hamilton v. Rogers, \& MId. 301. Compare Edwards v. Peterson, So Me. 367,14 A. 936,6 Am. St. Rep. 207 ; lightbody v. Smith, 125 Mass. 51. 
cepted by the proper officer of the school district, conditioned on his completing his contract, and the creditor authorized the school secretary to draw the money for him, which he did before it was garnished, then the fund was not subjeet to garnishment by ereditor's of the teacher. ${ }^{4}$

And so when one assigns his wages to be earned nnder an engagement then existing, and when he is actually at work thereunder, at a fixed price, payable at a certain time, thongh no contract of employment existed for any stipulated time, such assignment, if accepted, is good as against a garnishment by creditors of the assignor. ${ }^{5}$ And snch an assignment is good in the absence of an express contract fixing a time of employment, as where the assignor, when he executed the assignment, was employed at piece work or by the day. ${ }^{6}$ And it is equally well settled that an assignment of wages expected to be earned in the future, and not based upon an existing contract, engagement, or employment is void. ${ }^{7}$

The true rule is that an assigmment of wages to be earned is good if accepted, and if at the time it is made there is an existing engagement or employment by virtue of which wages are being, and at future may reasonably be expected to be, earned, even though there is no contract or fixed time of employment. And in the case of a contract for work or labor an

4. Johmson v. Pace, is Jll. 143; Ruple v. Bindley, $91 \mathrm{~Pa}$. St. 296.

5. Taylor v. Lynch, 5 Gray (Mass.), 49; Lannan v. Smith, 7 Gray (Mass.), 150; Hartley v. Tapley, 2 Gray (Mass.), 566; Weed v. Jewett, 7 Met. (Mass.) 60S; Brackett v. Blake, 7 Met. (Mass.) 335, 41 Am. Dec. 442 and note; Emery v. Lawrence, 8 Cush. (Mass.) 152: Thayer v. Kelley, 28 Vt. 19, 65 Am. Dec. 220; Angur v. Belting Co., 39 Conn. 536; Garland v. Harrington, 51 N. H. 409 ; Wallace v. Chair Co., 16 Gray (Mass.), 209; Metcalf v. Kincaid, 87 Iowa, 443, 54 N. W.
867, 43 Am. St. Rep. 391; Batts v. Richards Lumber Co., 56 Minn. 14, 57 N. IV. 218.

6. Lannan v. Smith, 7 Gray (Mass.), 150; Kane v. Clough, 36 Mich. 436, 24 Am. Rep. 599.

7. Mulhall v. Quinn, 1 Gray (Mass.), 105, 61 Am. Dec. 414; Jermyn v. Moffitt, 75 Pa. St. 402; Ruple v. Bindley, 91 Pa. St. 296; Morrill v. Noyes, 56 Me. 458, 96 Am. Dec. 486; Rumnells v. Bosquet, 60 ․ H. 38 : Lehigh Valley R. R. Co. v. Woodring, 116 Pa. St. 513, 9 A. 58 . 
assigmment of the fruits of it may be good thongh the labor to be performed moder it has not ret been commenced. ${ }^{8}$

Courts of equity will support ascigmments, not only of choses in action, but of contingent interests and expectancies, and of things which have no present actual existence, but rest in potentiality only, provided the agreements are fairly made, and not against public policy. And if the workman is employed by the piece, for no definite time does not elange the rule $^{10}$ or by the day, the rule is the same. ${ }^{11}$ Nere possibilities and expectancies, according to the general course of decisions, are assignable in equity for a valuable consideration, and equity will enforce the assignment when the possibility or expeetancies lave changed into a rested interest of possession. ${ }^{12}$ Whether such an assignment must be for a reasonable time is a question not ret settled by any decisions; but it would seem that the time of the assignment of future earnings should be limited to a reasonable time. ${ }^{13}$ But under this prineiple, the exemptions of a married debtor do not come, and, therefore, he cannot waive his exemptions, because the exemptions are for the benefit of the family of which he is the head. ${ }^{14}$

8. Metcalf $v$. Kincaid, $8 \bar{t}$ Iowa, 443,54 N. IV. 867,43 Am. St. Rep. 391; Hawley v. Bristol, 39 Conn. 26; Devlin v. New York, $63 \mathrm{~N}$. Y. 8; Thayer v. Kelley, 2s Vt. 19, 65 Am. Dec. 220; Augur v. Belting Co., 39 Conn. 536; Greene r. Bartholomew, 34 lnd. 235; Shaffer v. Mlining Co.. 55 Md. 74; Crawford v. Brooke, 4 Gill (Mrd.), 213; Weed v. Jewett, 2 Met. (Mrss.) 60s, $37 \mathrm{Am}$. Dec. 115; Field v. New York, $6 \mathrm{~N}$. Y. $179,57 \mathrm{Am}$. Dee. 435 and note; Garland v. Harrington, 51 N. H. 409: Brackett $v$ Blake, 7 Met. (Mlass.) 335, 41 Am. Dec. 442 and note; Emery v. Lawrence, 8 Cusl. (Mass.) 151; Young v. Iones, 180 Ill. 216,54 N. E. 235 ; Hax v. Acme, etc. Plaster Co., 82 MLo. App. 447, 454 .

9. Field v. New York, 6 N. Y. $179,57 \mathrm{Am}$. Dec. 435 and note.

10. Hartley v. Tapley, 2 Gray (Mass.), 206.5.

11. Hax v. Acme, etc. Plaster Co., 82 Mo. App. 447 .

12. Warren v. Bank, 149 Ill. 9, 38 N. E. 1.2. 25 L. R. A. 746 ; Young r. Jones, 180 111. 216, 54 N. E. 235.

13. See Boyland $v$. leonard, 2 Allen (Mass.), 497; Brewer v. Griesheimer, 104 Ill. Аpp. 323, 35 (hii. T. News. 114.

14. Reeht v. Kelly. 8:2 Ill. 147, 25. Am. Rep. 301. 
And besides exemption laws do not relate to the power to eontract in regard to matters of general right. ${ }^{15}$

The assignment of unearned wages, or salary, is controlled by statute in some States. Thus, in Indiana, the assignment of future wages to become due to employes, from persons, companies, corporations, or associations affected by such act, is prohibited, and any agreement to assign is declared invalid. This statute has been sustained as valid and constitutional. So an agreement made by an employe to assign part of his future wages for instruction in architecture is void. The assignment was in the form of an order made by the employe upon the employer who accepted it. ${ }^{16}$ If this statute be constitutional, then why will not a statute be constitutional controlling the salary of an employe, compelling him to make no contract in paying over his wages except as ordered by some authority established by the State? Under the same principle an employe may be compelled to deposit a part of his wages as received for the purpose of accumulation so that he may purchase a house of a certain value. Such statute restricts the capacity of an employe to contract in a manner before unknown to the law and places an employe in this way in the class of infants and insane persons. This statute contrarenes the constitutional right to contract in lawful vocations, and is neither based on reason or the police power of the State.

When the debt for which unearned wages are assigned as security, is discharged, the securities springing into existence subsequent to the discharge by reason of a prior executory contract, cannot be held for the payment of the discharged debt. ${ }^{17}$ Thus, a laborer who makes an assignment of his unearned wages, and then goes into bankruptcy and receives his discharge, makes the assigninent of no further validity. The debt being paid and discharged by law, the assignment falls. ${ }^{18}$

15. Frorer v. People, 141 Ill. 171, 31 N. E. 395,16 L. R. A. 492 and note.

16. International Text Book Co. v. Weissinger, 160 Ind. 349, 65 N. E. 521, 98 Am. St. Rep. 334.
17. Thomas v. Cohen, 7 L. Rep. Q. B. 527; Cole v. Kernon, 7 L. liep., Q. B. 534 .

18. Mallan v. Wenham (Cir. Ct. of Chicago), 33 Chi. L. News, 31l, 209 11l. 253. 
\$ 516. Assignor's discharge in bankruptcy. - ! i mmmously stated that the assignment of mearned wages in the nature of a mortgage or pledge, and while the debt is discharged in the bankruptey proceedinge in so far as it is enforceable against the debtor personally, yet it can be enforced in rem. that $\mathrm{is}$, against the future wages which the debtor has pledged, and hence, such wages are not affected by the discharge in bankrupter; but this is not the law. ${ }^{20}$

$\S 5$ r7. Unearned salary of public officer.-But there are assigmments of salaries which are against public police and will not be upheld at law or in equity. So an assignment by a public officer of the future salary of his office is void because it is against public policy. And this is the doctrine in England, and an unearned salary of a public officer cannot be assigned. ${ }^{2}$

So a municipal cannot assign his unearned salary. The public interests are such that an assignment by a public officer of his unearned salary camnot be permitted or treated by the courts only as a void agreement. ${ }^{3}$ And no one can do by indi-

19. See Mallan v. Wenham, 209 111. 253. Hence it would seem that the only practical way in which such debtor can aroid the effect of his assignment, though discharged in bankruptey, is to cease the employment existing at the time of the execution of the assignment and to seek a different engagement elsewhere.

20. In re West, 11 Am. B. R. 782. l.2S Fed. Rep. 205.

1. Stevenson v. hyle, t2 IV. Va. 229, 24 S. E. 886,57 Am. St. Rep. 854; Bliss v. Lawrence, is N. Y. 442, 17 Am. Rep. 273; National Bank v. Fink, 86 Tex. 303, 24 S. W. 256, 40 Am. St. Rep. 833: State v. Williams, 118 Mo. 146, 23 S. WV. 1054, 21 L. R. A. 827,40 Am. St. Rep. 358; Schwenk v. Wycks, $46 \mathrm{~N}$. J. Eq. 560, 20 A. 259, 9 L. R. A.
221; Field v. Chipley, 79 Ky. 260, $42 \mathrm{Am}$. Rep. 215 and note; Bell v. McVicker, S Mo. App. 202; Compare State Bank v. Hastings, 15 Wis. 18.

2. Florty v. Oldham, 3 Term R. 681; Stone v. Lidderdale, 2 Anst. 233 ; Davis v. Marlboro, 1 Swanst. 79 ; Lidderdale v. Montrose, 4 Term R. 248; Barwick v. Read, l H. Bl. 627; Arbuckle v. Cawhan, 3 Bos. \& P. 328: Wells v. Foster, 8 Mees. \& II el. 149; Hunter $\vee$. Gardner, 6 Wilson \& Slaw, 61s: IIill v. Paul, 8 Cl. \& F. 307: Palmer v. Bates, 2 Brod. \& B. 673; Liverpool v. Wright, थs L. J. Ch., N. S. 871.

3. Jolnson v. Pace, is Ill. 143; Nerwin v. Chicago, 45 1ll. 133, 92 Am. Dee. 204; Addyston Pipe and Steel Co. v. Chicagro, 170 IIl. 580, 48 N. E. 967,44 L. R. A. 405 ; Peo- 
rect means what the law prohibits. Thus, a power of attorney, though irrevocalle in terms, does not amount to an assignment of a public officer's unearned or earned salary, when there is no assignable interests at the time the power was excented. ${ }^{4}$ The doctrine is well settled that a public officer cannot assign his unearned salary. And the law prolibits assignments of such salary being had by indirection or effected by having the official appoint an attorney authorized to receive the salary and turn the same over to an assignee.

\section{AR'TICLE III.}

\section{Interests Tilat May Be Assigned.}

Section 518. What is Assignable.

519. Agreements of Personal Trusts Involving Personal Skill.

520. Assignment of Expectancies.

521. Partial Assignments at Law.

522. Partial Assignments with Consent of Debtor.

523. Partial Assignment-City as Debtor.

524. Partial Assignment in Equity.

525. Difierence Between an Equitable and Legal Assignment.

526. When Partial Assignments will be Sustained.

527. Modification by Statute.

$\S 5$ I8. What is assignable.-Where an executory contract is not necessarily personal in its character, it may be assigned. Anything directly or indirectly involving a right of property it assignable, ${ }^{1}$ when it is not against public policy. The right

ple v. Omaha, 2 Neb. 169; Bliss v. Lawrence, 58 N. Y. 442, 17 Am. Rep. 273; Wallace v. Lawyer, 54 Ind. 501, 23 Am. Rep. 661; Hightower v. Slayton, 54 Ga. 10S, 21 Anı. Rep. 273: Schloss v. Hewlett. 81 Ala. 266, 1 So. 263.

4. Lehigh Valley R. R. Co. V. Woodring, 116 Pa. St. 513, 9 A. 58.
1. La Rue v. Groezinger, 84 Cal. 281, 24 P. 42, 18 Am. St. Rep. 179; Mulhall v. Quinn, l Gray (Mass.), 105, 61 Am. Dec. 414; Cook v. Bell, 18 Mieh. 387 ; Harboard v. Cooper, 43 Minn. 466, 45 N. IV. 860; Devlin v. New York, 63 N. Y. 8; Grant v. Ludlow, 8 Ohio St. 1; Gray v. Garrison, 9 Cal. 325; Dayton v. Fargo, 45 Mich. 153, 7 N. 758. 
assignable must have at least a potential existenes at the time of the assignment. ${ }^{2}$ Artual existenee is not unneenseary. If the thing rests in posibility only at the time of the assignment, the assigmment is valid, though the coutract may nover be performed. Expectancies, as well as existing rights of action, may he asigned, and the rights of the assignes will be proteeted and enforced at law. An assignuent may inelude all contingent and ineidental benefits or results of an exeeutory contrilct, as well as all direct fruits and earning under it, and thus entitle the assignee to the damages resulting from a violation of its terms. The right of action for a breach of the contract, resulting in precuniary loss to the contractor, wonld survive to the personal representatives of the agrrieved party, and that is one test of the assignability of contracts and choses in action. ${ }^{4}$

1 perfected claim to any thing, whether money or goods, may be assigned so as to vest in the assignee the equitable interest, and in some of the States the legal interest. ${ }^{5}$

Commissions on renewal premiums in insurance to accrue annually for a given period in the future, is assignable by the agent ${ }^{6}$ so a lessor can assign future rent under an existing lease, ${ }^{7}$ though it is not probable he could assign rent under a lease not yet made; and so a man may assign money under an insurance policy already issued before any loss, though he

2. Metealf $v$. Kineaid, 87 Iowa, 443, 54 N. Wr. 867,48 Am. St. Rep. 400 ; Thallhoimer v. Brinckerhoff. 3 Cow. (N. Y.) 623, 15 Am. Dec. $30 \mathrm{~s}$ and note: Skipper $r$. Stokes, 42 Ali. 255, $94 \mathrm{Am}$. Dee. 646 and note; Kassie v. Congregation, 35 Cal. 378; Moody v. Wright, 13 Met. (Mass.) 17, $46 \mathrm{Am}$. Dee. 706 and note; Needles $v$ Needles, 7 Ohio St. 432, $70 \mathrm{Am}$. Dee. 85 and note.

3. Field v. Mayor, 2 Seld. (N. I.) 179 ; Hall v. Buffalo, $2 \mathrm{Abb}$. Ct. of App. Dee. 301; Devlin v. New York, 63 N. Y. 8.

4. Brrbie v. Wood, $2 t \mathrm{~N}$. Y. 607 ; MeKee v. Judd, 2 Kern. (X. Y.) 622; Zabriskie r. Smith, 3 Kein. (N. I.) 322.

5. Gray v. Garricon, 9 Cal. 325; Pier v. George, s6 X. Y. 613; Bull v. Taulkner, 2 De G. \& S. 772 .

6. Knevals $v$ likurelt, 82 Me. 4.5. 19 A. S1s.

7. Demorest v. Willard, 8 Cow. (N. I.) 206 . 
conld not assign money before the issuance of the policy. ${ }^{8}$ And so a contract to sell all the grapes of a certain standard which the contractor may raise upon a certain vineyard during a certain period is assignable by the party selling. ${ }^{9}$

If the assignment is the mere possibility of a subsequent acquisition of property, which is vague and uncertain, it will not be sustained as a valid assignment. ${ }^{10}$

"Services" rendered under a contract for the erection of a building includes claims for money due for expenditures under the contract as well as for labor performed thereunder, and goes with the assignment of the contract. ${ }^{11}$

\section{$\S$ 519. Agreements of personal trust involving personal} skill.-Every kind of a contract is not assignable. Contracts for personal services, or contracts otherwise involving personal credit, trust or confidence cannot be assigned. ${ }^{1}$ Thus a master

8. Bergson v. Ins. Co., 38 Cal. 541 .

9. La Rue v. Groezinger, 84 Cal. 281, 24 A. 42, 18 Am. St. Rep. 179.

10. Mulhall v. Quinn, l Gray (Mass.), 105, 61 Am. Dec. 414; Jermyn v. Moffitt, 75 Pa. St. 402; Ruple v. Bindley, 91 Pa. St. 296; Leligh Valley R. R. Co. v. Woodring, $116 \mathrm{~Pa}$. St. 513, 9 A. 58; Rumnells v. Bosquest, 60 N. H. 38 ; Metcalf v. Kincaid, 87 Iowa, 443, 54 N. W. 867, 43 Am. St. Rep. 391; Morrill v. Noyes, 56 Me. 458, 96 Am. Dec. 486. Compare Edwards v. Peterson, $80 \mathrm{Me} .367,14$ A. 936, 6 Am. St. Rep. 207.

11. Tracy v. Water's, 162 Mass. 562, 39 N. E. 190. See, also, Union Pac. R. R. Co. v. Bank, 42 Neb. 469, 60 N. W. 866; Hooper v. Van Husen, 105 Mich. 592, 63 N. W. 522.

1. Robson v. Drummond, 2 Barn. \& Ad. 303; Bethlehem v. Annis, 40
N. H. 34, 77 Am. Dec. 700; Joslyn v. Parlin, 54 Vt. 670 ; Lansden v. MeCarthy, 45 Mo. 106; Munsell v. Temple, 3 Gil. (III.) 93; Schultz v. Johnson, 5 B. Mon. (Ky.) 497; Wheeler v. IValton, 64 Fed. Rep. 664; Boykin v. Campbell, 9 Mo. App. 495; Redheffer v. Leathe, 15 Mo. App. 12; Boston Ice Co. v. Potter, 123 Mass. 28, 25 Am. Rep. 9; Hardy Implement Co. v. Iron Works, 129 Mo. 222, 31 S. W. 599; Humble v. Hunter, 12 Q. B. 311; Boulton v. Jones, 2 Hull. \& N. 564; Devlin v. New York, 63 N. Y. 8; Taylor v. Palmer, 31 Cal. 241; British Wagon Co. v. Lea, 5 Q. B. Div. 149; Arkansas Valley Smelting Co. v. Min. Co., 127 U. S. 379,8 S. Ct. 1308; Rappleye v. Seeder Co., 79 Iowa, 220, 44 N. IV. 363, 7 L. R. A. 139 ; Sloan v. Williams, 138 Ill. 43,27 N. E. 531,12 L. R. A. 496 and note; Chapin v. Longworth, 31 Ohio St. 421 ; Grieswold v. Rail- 
cannot assign over his apprentice." So a contract hy a publisher with an author to publish a work is not ascignable by the publisher without the author's eonent, because of the personal trust placed in the publisher by the author: that the contraet was made in reference to the character and facilities of the contraeting firm as a publishing honse, and was in the nature of a partnership in so far as it provided for a division of the profits of the work to be published. ${ }^{3}$ So a eontract to deliver meat to a hotel, to be paid for at the end of each month, cannot be assigned by the hotel-keeper, because the pecmmiary eredit and standing of the hotel-keeper constituted an important inducement to the contract. ${ }^{4}$ So a contract to sell ore to a smelting company, the price of which is to be adjusted and paid by the mutual acts of the parties after delivery, is not assignable by the smelting company; because during the time that must elapse between the delivery of the ore and the ascertainment and payment of the price, the party furnishing the ore had no seeurity for its payment, exeept in the character and solveney of the smelting company. ${ }^{5}$ And there mar be extraneous eircumstanees showing that the party's intention was not to deal with the assignee. ${ }^{6}$

Although the language may not show an intention that the contract should not be assigned, yet the nature of the case may be such that performance by another would be an essentially different thing from that eontracted for. Thus, a picture by an artist is an essentially different thing from a picture on the same subject by another artist; and so of a book composed by

road Co., 18 Mo. App. 52; Daly v. Stetson, 54 N. Y. Super. Ct. 202; Davenport v. Gentry, 9. B. Mon. (Ky.) 427; Burger r. lice. 3 Ind. 125.

2. Caster v. Aicles, l Salk. 6s; Davis v. Coburn, S Mass. 299; Nickerson v. Howard. 19 Johns. (N. Y.) 113; Stringfield v. IIeiskell, 2 Yerg. (Tenn.) 546; Handy v. Brown. I Crancl, C. C. 610 .
3. Stevens v. Benning, 6 De G. 1T. \& G. 223, 1 Kay \& J. I6s; Gibson v. Carruthers, 8 Mres. \& Wel. $3221,343$.

4. Lansden $v$ McCarthy, 45 Mfo. 106.

5. Arkansas Valley Smelting Co. r. Belden Min. Co., 127 U. S. 38s, S S. Ct. 1308.

6. Boston Iee Co. v. Potter, 123 Mass. 28, 30, 25 Am. liep. 9. 
an author, or any other act or thing where the skill, erestit, or other personal quality or circumstance of the party is a distinctive eharacteristic of the thing contracted for, or a material inducement to the contract. Under this gencral head, many cases have already been cited to establish this self-evident doctrine.

While a contract right to render personal service cannot be assigned without conscnt of the person to whom the services are due, the right to receive pay for such services when rendered is assignable, in the absence of statute or stipulation to the contrary, ${ }^{7}$ even when the fund has only a potential existence. ${ }^{8}$

$\S$ 520. Assignment of expectancies.-It is a general rule that an assignment at law will not be sustained, unless the subject-matter has an actual or potential existence when the assignment is made. In equity the rule is different; so an expectancy of an heir in an ancestor's estate may become subject of contract, and may be assigned in equity. Courts of equity will uphold such an agreement of an heir-apparent, when it is fairly made for an adequate consideration. If no unjust advantage is taken of the indiscretion or necessities of the heir, and if the agreement is not unconscionable and is not obtained by frand or oppression, it may be enforeed in equity after the death of the ancestor, ${ }^{9}$ provided such conveyance contains covenants of warranty or recitals, or the grantor has acted so as to

7. Ryan v. Douglas County, 47 Neb. 9, 66 N. W. 30 ; Perkins v. Butler County, 44 Neb. $110,62 \mathrm{~V}$. W. 308, 3 Pom. Eq. Jur. 1280.

8. Brill v. Tuttle, 81 N. Y. 454 , 37 Am. Rep. 515; Lealyy v. Dugdale, 27 Mo. 437; Devlin v. New York, 63 N. Y. 8 ; Cutts v. Perkins, 12 Mass. 206; Hawley v. Bristol, 39 Conn. 26; Brown v. Dumn, 50 N. J. L. 111, 11 A. 149.

9. Steele v. Fierson, 85 Tenn. 430,3 S. W. 649 ; Clendening v.
Wyatt, 54 Kans. 523, 38 P. 792, 33 L. R. A. 278; Patterson v. Caldwell, 124 Pa. St. 455, 16 A. 496, 10 Am. St. Rep. 598; Kulm's Estate, 163 Pa. St. 438, 30 A. 215; Kinyon v. Kinyon, 72 Hun, 452, 25 N. Y. S. 225; Bacon v. Bonham, 33 N. J. Eq. 614: In re Garcelon, 104 Cal. 570, 38 P. 414,32 L. R. A. 595 and note, $34 \mathrm{Am}$. St. Rep. 134. See, also, Kershaw v. Kershaw, 102 Ill. 307; Crum v. Sawyer, 132 Ill. 443, 24 N. E. 956. Compare Alves v. 
give rise to equitable estoppel $;^{10}$ and it is held that the ancestor must acquiesce at such conveyance. ${ }^{11}$ If the ancestor makes a will and the heir never takes muler it, then his conveyance is void. ${ }^{12}$

$\S$ 52I. Partial assignment at law.-It is well settled that a creditor cannot without the consent of the debtor, split up an entire demand into distinct parts, and maintain separate actions at law upon each. In such case a recovery in one action bars the others. ${ }^{1}$ The debtor's liability usually depends upon the entire contract, and if the creditor could, without the debtor's consent, split up a claim at all, and assign any portion of it, he could do so indefinitely, and thus subject the debtor to many actions involving great outlay in costs and disbursements, not contemplated by the contract, which was limited to a single liability upon an entire demand. ${ }^{2}$

Partial assignments the common law courts have never recognized, because an entire debt cannot be divided into parts by the creditor without the consent of the debtor. The rule has been established, partially at least, on the ground of the entirety of the contract, because a creditor cannot sue his debtor for a part of an entire debt; and, if he brings such an action and recovers judgment, the judgment is a bar to an action to recover the remaining part. There must be distinct promises to maintain more than one action. ${ }^{3}$

At law a partial assignment may be good between the parties,

Schlesinger, $81 \mathrm{Ky}$. 290; In re Fritz's Estate, $160 \mathrm{~Pa}$. St. 156, 28 A. 642 .

10. Hart v. Gregg, 32 Ohio St. 502.

11. MeClure v. Raben, 125 Ind. 139,25 N. F. 179,9 L. R. A. 477 ; Pingrey on Real Prop. 1212.

12. Ebey v. Adams, 135 Ill. 80 , 25 N. E. 1013,10 I. R. A. 162 . See, also, MeCall v. Hampton, $98 \mathrm{~K} 5$. 166,32 S. IV. 406,33 L. R. A. 266 and note; 56 Am. St. Rep. 335 and note.

1. Smith v. Jones, 15 Jolnns. (N. Y.) 229 ; Willard v. Sperry, 18 Johns. (N. Y.) 121; Larziou v. Piochi, 8 Cal. 536; Herriter v. Porter, 23 Cal. 385.

2. Mandville $v$. Welch, 5 Wheat. (U. S.) 277 .

3. Warren r. Comings, 6 Cush. (Mass.) 103. 
and, if the assignor collects the money, he would in such case hold it as trustee of the assignee. But the assignee has no legal remedy against the debtor who does not become a party to the agrecment. The law permits the transfer of an entire cause of action from one person to another, beeause in such ease the only inconvenience is the substitution of one creditor for another. But if assigned in parts, the debtor has to deal with a plurality of creditors. If his liability can be legally divided at all without his consent, it can be divided and subdivided indefinitely. He would have to ascertain the relative shares and rights of the substituted creditors. He would have, instead of a single contract, a number of contracts to perform. A partial assignment would impose upon him burdens which his contract does not compel him to bear. ${ }^{4}$

$\S 5$ 22. Partial assignment with consent of debtor. - If, however, the assignment of a part of a claim is made with the consent of the debtor, the assignee may bring his action upon it without making other holders of the demand parties to the suit. ${ }^{5}$ The right to sue upon the debtor's assent to a partial assignment of a demand rests upon the theory that the assignment of the property in the sum transferred to the assignee is

4. Robbins v. Bacon, 3 Me. 346 ; Gibson v. Cooke, 20 Pick. (Mass.) 15, 32 Am. Dee. 194; Tierman v. Jackson, 5 Pet. (U. S.) 580 ; James v. Newton, 142 Mass. 366,8 N. E. 122, 56 Ain. Rep. 692; Carter v. Nichols, 58 Vt. 553, 5 A. 197 ; National Exch. Bank r. MeLoon, 73 Me. 498, 40 Am. Rep. 388; Getehell v. Manev, 69 Me. 442; Knowlton v. Cooley, 102 Mass. 233; Miller v. Bledsoe, 1 Scam. (IIl.) 530, 32 Am. Dee. 37 ; Philadelphia's Appeal, 86 l'a. St. 179; Grain v. Aldrich, 38 Cal. 514, 99 Am. Dec. 423; Milroy v. Iron Co., 43 Mich. 231, 5 N. 287 ; Tripp r. Brownell, 12 Cush.
(Mass.) 382; Phillips v. Edsall, 127 Ill. 535, 20 N. E. 801; Warren v. Bank, 149 Ill. 9, 38 N. E. 122, 25 L. R. A. 746; Geist's Appeal, 104 Pa. St. 351; Williams v. Webb, 32 Iowa, 57 $;$; Little v. Portland, 26 Oreg. 235, 37 P. 911; Insurance Co. v. Bullene, 51 Kans. 764, $33 \mathrm{P}$. 467; Weleh v. Mayer, 4 Colo. App. 440, 36 P. 613 ; Snelden v. Harmes, 5 Colo. App. 477, 39 P. 68; Beardsley v. Morguer, 73 Mo. 22.

5. Grain v. Aldrich. 38 Cal. 514. 99 Am. Dec. 422; National Exch. Bank v. MeLoon, 73 Me. 498, 40 Am. Rep. 388; Little v. Portland, 26 Oreg. 235, 37 P. 911. 
a good consideration for the debtor's promise to par the assignee, and hy this pamise the indehterlness to the assignor is pro tanto discharged. ${ }^{6}$

$\S$ 523. Partial assignment-City as debtor-Consent.-The same rule applies to a municipal corporation. The eontract of a city in accepting and agreeing to pay a part of a demand against it to an assignee of its ereditor, will, in the absence of any statute to the contrary, be treated as is a contract of a private person and the city will be liable. ${ }^{1}$ And so when a eity splits up a demand of a contractor against it by executing warrants therefor in different amounts, it cannot eseape liability on one of the warrants on the ground that the contract was entire, and that an action had previonsly been brought on another warrant. ${ }^{2}$ And by drawing such warrants the city consents to the assignment by the contractor of such parts of his elaim, so as to entitle his assignees thereof to sue separately therefor. ${ }^{3}$

But in Pennsylrania the court refused to apply this rule to a debt due from a mmicipal corporation, on the ground that the poliey of the law is against permitting individuals by their private contracts to embarrass the principal officers of a municipality. But there is no ground for such a decision and is against the weight of authority.

$\S$ 524. Partial assignment in equity.-It is established in equity that a partial assignment may be sustained. In order that a court will take jurisdiction there must be a special fund, sum of money, or debt actually existing or to become so in futuro, upon which an assigmment may operate, and the agreement, direction for payment, or order must be in effect an as-

6. James $r$. Newton, 142 Mass. 366,8 N. E. 122, 56 Am. Rep. 692. See, also, Taylor v. Lunch, 5 Gray (Mass.), 49; Lannan $r$. Smith, 7 Gray (Mass.), 150; Bourne $r$. Cohat, 3 Met. (Mass.) 305.

1. James v. Newton, 142 Misss. 366, 8 N. E. 122, 56 Am. Rep. 692.
2. Little r. Portland, 26 Oreg. 235, 37 P. 911.

3. Little v. Portland, 26 Oreg. 235, 37 P. 911; Seattle v. Liberman, 9 Wash. 276,37 P. 433.

4. Pbiladelphia's Appeal, 86 Pa. St. 179 . 
signment of that fund, or of some definite portion of it. ${ }^{1}$ And an assignee of a part of a debt may enforee, in equity, its payment and if it be a fund he may enforce its payment to him, with notice of the assignment to the holder who has no superior claim to it. ${ }^{2}$ While a part of a debt or chose in action is not assignable at law, it may be assigned in equity; and in such case a trust will be ereated in favor of an equitable assignment of the fund, and will constitute an equitable lien upon it. ${ }^{3}$

\section{$\S$ 525. Difference between an equitable and legal assign-} ment.-The equitable modification of the common law rule was an outgrowth of a commercial era, made necessary to adapt to the condition of a trading people. In many eases, directly or indirectly, do circumstances create assignments of parts of funds, in dealing through servants, tenants, consignees. bankers and other agencies.

An assignment to be valid at law must be of a debt or fund in existence at the time, and of the whole thereof, or of a part of a debt or fund then in existence, and the assigument or order transferring the fund must be accepted by the debtor or person holding the fund. In an equitable assignment of a specific

1. Wright v. Ellison, 1 Wall. (U. S.) 16; Pengh v. Porter, 112 U. S. 737, 5 S. Ct. 622; National Exch. Bank v. McLoon, 73 Me. 498, 40 Am. Rep. 388; Grain v. Aldrich, 38 Cal. 514, 99 Am. Dec. 423; Parker v. Syracuse, 31 N. Y. 376 ; Brill v. Tuttle, 81 N. Y. 454, 37 Am. Rep. 514; Risley v. Bank, 83 N. Y. 318, 38 Am. Rep. 421 and note; Fordyce v. Nelson, 91 Ind. 147; County v. Hinkley, 62 Iowa, 627, 17 N. 915; James v. Newton, 142 Mass. 366, 8 N. E. 122, 56 Am. Rep. 692; Daniels v. Weinhard, $53 \mathrm{Ga} .359$ : Canty v. Latterner, 31 Minn. 239, $17 \mathrm{~N}$. 385 ; Bank v. Kimberlands, 16 W. Va. 555 .

2. Savage v. Gregg, 150 Ill. 161,
37 N. E. 312; Sykes v. Bank, 2 S. Dak. 242, 49 N. W. 1058.

3. Phillips v. Edsall, $127 \mathrm{\Pi l}$. 535, 20 N. E. 801 ; Warren v. Bank, 149 Ill. 9, 38 N. E. I22, 25 L. R. A. 746; Kingsbury v. Burrill, 151 Mass. 199, 24 N. E. 36; Bower v. Hadden, 30 N. J. Eq. 171; Ethe*idge v. Vernoy, 74 N. Car. 800; Grain v. Aldrich, 38 Cal. 514, 99 Am. Dec. 423; County v. Hinkley, 62 Iowa, 637, 17 N. 915; James v. Newton, 142 Mass. 366,8 N. E. 122 , 56 Am. Rep. 692; Naticnal Exci. Bank v. McLoon, 73 Me. 498, 40 Am. Rep. 38s; Bank v. Kimberlands, 16 W. Va. 555. Compare Burnett v. Crandall, 03 No. 410 ; Gardner v. Smith. 5 Heisk. (Tenn.) 256. 
debt or fund, it is not an essential element that the debt should have been earned or the fund he in esse at the time of the assignment or order transferring the debt or fund, or that the assignment or order transferring the specifie lebt or fund, or a part thereof, should be accepted by the debtor or holder of the specific fund. ${ }^{1}$

When the subject of the assignment is not in esse and may never be, and camnot be reached by garnishment, then upon such assignment, no action at law can be maintained. To make an assignment valid at law, the thing assigned must have an actual existence at the date of the assigmment. ${ }^{2}$

$\S 526$. When partial assignment will be sustained.-Partial assignments will be sustained in equity, in all cases where it can be done without detriment to the debtor or fund-holder, whenever equitable and just results mar be accomplished. This doctrine is upheld by the courts. ${ }^{3}$ So in equity, an order given by a debtor to his creditor upon a third person having funds of the debtor, to pay the creditor out of such fund, is a binding equitable assignment of so much of the funds. ${ }^{4}$ It is a credit on the fund, and must amount to an assignment of so much of the debt; and though the law does not admit an assignment of a chose in action, a court of equity will, and any words will do, no particular words being necessary thereto. ${ }^{5}$

The modern decisions fully protect the equitable rights of the assignee of choses in action. ${ }^{6}$

1. Sykes v. Bank, 2 S. Dak. 242, 49 N. W. 1058 .

2. Grain v. Aldrich, 38 Cal. 514, 99 Am. Dec. 423.

3. Row v. Dawson, '1 Ves. Sr. 431 ; Ieates $v$. Groves, 1 Ves. Jr. 481; Ex parte South, 3 Swanst. 392; Fitzgerald v. Stewart, $2 \mathrm{Sim}$. 33, 2 Russ. \& My. 457; Lett v. Morris, 4 Sim. 607 ; Watson v. Wellington, 1 Russ. \& My. 602.

4. Burn v. Carvalho, 4 Nylne \& Cr. 690 .

5. Row r. Dawson, l Ves. Sr.
431 ; Rodick v. Gandell, 1 De G. M. \& G. 763, 12 Beav. 325; Addison v. Cox, L. R. 8 Ch. 76 ; Brice v. Bannister, L. R. 3 Q. B. 569 ; Ranken v. Alfaro, I. R. 5 Ch. D. $786 ; \mathrm{Ex}$ parte IIall, L. R. 10 Ch. D. 615; Hopkinson v. Forster, L. R. 19 Eq. 74; Thompson v. Simpion, L. R. 5 Ch. 659: Brown v. Bateman, L. R. 2 C. P. 272; Field v. Magaw, L. R. 4 C. P. 660 ; Tibbetts v. George, 5 Ad. \& El. 107.

6. Morton v. Naylor, 1 Hill (N. Y.), 583: Bradley $r$. Root, 5 Paige 
So a holder of a fire insurance poliey, after a loss, may assign in writing an interest in the same to a ereditor to the extent of the creditor's debt; this will prevent an attachment of this fund as the property of the assignor. ${ }^{7}$ Equitable assignments of part of the chose in action is recognized by all the courts, where equity and good conscience require it. ${ }^{8}$

$\S$ 527. Modification by statute.-Many of the States have passed laws allowing an assignee of a chose of action to prosecute the claim in his own name. This is now the law of England. ${ }^{1}$

In many States a new system of pleading is adopted, and equity and law are administered in the same court by the same judge. So the distinetion between actions at law and suits in equity, and the forms of all such actions and suits, heretofore existing, are abolished. But law and equity as two distinct systems, still remain. It is the distinction between the forms of actions at law and suits in equity only that has been abolished. And where the facts stated and the subject matter show that the controversy is equitable, the suit must be tried in equity and not at law. ${ }^{2}$

(N. Y.), 632; Marshall v. Meech, 51 N. Y. 140, 10 Ans. Rep. 572; Alger v. Scott, 54 N. Y. 14; Field v. New York, 2 Seld. (N. Y.) 179; Risley v. Bank, 83 N. Y. :18, 38 Am. Rep. 421 and note; Etheridge v. Vernoy, 74 N. Car. 809; Philadelphia's Appeal, 86 Pa. St. 179.

7. Daniels v. Meinhard, 5i Ga. 359.

8. Stanbery v. Smythe, 13 Ohio St. 495; Bowell r. Caldwell, 4 Saw. C. C. 217; Isapping v. Dutly, 47 Ind. 51; Whitney v. Cowan, 55 Miss. 626; Warren v. Bank, 149111. 9,38 N. E. 122,25 L. R. A. 746 ; Little v. Portland, 26 Oreg. 235, 37 P. 911: Conway v. Cutting, $51 \mathrm{~N}$. H. 407: Christie r. Nawyen, 4 .
H. 298; Public Schools v. Heath, 15 N. J. Eq. 22; Claflin v. Kimball, 52 Vt. 7; Christmas v. Russell, 14 Wall. (U. S.) 69 ; Trist v. Child, 21 TVall. (U. S.) 441; James v. Newton, 142 Mass. 366, 56 Am. Rep. 692, 8 N. E. 122; National Exch. Bank v. MeLoon, 73 Me. 498, 40 Am. Rep. 3SS; Canty v. Latterner, 31 Minn. 239, 17 N. 385; Bank v. Kimberlands, 16 W. Va. 555; County v. Hinkley, 62 Iowa. 637, 17 N. 915. Compare Burnett v. Crandall, 63 Mo. 410; Gardner v. Simith, 5 Heisk. (Tenm.) 256.

1. 36 \& 37 Vict. c. 66 . ree. 25 , subsec. 6 .

2. Sykes v. Bank, 2 S. Mak. 242, 49 N. W. 1058. 


\section{CHAPTER XVIII.}

\section{Impairment of the Obligation of Contracts and the Right to Contract.}

\section{ARTICLE I.}

\section{The Contract.}

Section 528. Reduction of Periods of Limitations.

529. Gold Clause.

530. Salaries of Public Officers.

531. Decisions Under Prior Statutes.

532. Retrospective Laws.

533. Conflict of Laws.

$\S 528$. Reduction of periods of limitations.--It is well settled that a reasonable limitation of the time within which a material contractual obligation may be enforeed by suit does not impair the obligation of the eontract in the sense of the constitutional prohibition; hence, a limitation to one year, or to six months, is not unreasonable, and does not impair the obligation of the contract nor deprive the obligee of an adequate remedy. ${ }^{1}$ Hence, the fact that prior to the passage of an act, there was no statutory limitation of the time within which a deed must bo made by the tax colleetor, after the period allowed for redemption, does not render the last aet unconstitutional as impairing the obligation of the contract of sale, provided the last act is a reasonable limitation of the time within which a remedy mas be allowed for the enforeement of the obligation after the passage of the aet. ${ }^{2}$ Of course, this applies where no limitation existed

1. Terry v. Anderson, 9.) U. S. 628 ; Tuttle v. Block, $10+$ Cal. 443 , 38 P. 109 ; Herekhofl, etc. Lum. Co. v. Olmstead, 85 Cal. 80, 24 P. 648; Vance v. Vance, 108 U. S. 514,2
S. Ct. s:34: Wheeler v. Jackson, 137 U. S. 24.5, 11 s. Ct. 76 ; Korn v. Browne, 64 Pa. St. 55.

2. 'Tuttle v. Block, 104 Cal. 443. 38 P. 10!. See, also, MeGahey $v$ 
when the contract was made. If any law of limitations existed at the time the contract was marle, that was a part of the contract and could not be changed, for laws relating to the validity, construction, discharge, and enforcement are part of the contract. $^{3}$

$\S 529$. Gold clause.- While the clanse of the constitution prohibiting legislation impairing the obligation of contracts is not binding upon Congress, ret Congress, in certain cases, has no inherent power to legislate. In the various decisions of the United States Supreme Court sustaining the validity of government notes as payment, exceptions have been uniformly made of contracts stipulating for specific kind of money. And express contracts for payment of coin have been treated like contracts for the delivery of any specific commodity. A contract to pay a certain number of dollars in gold coin is, in legal import, nothing else than an agreement to deliver a certain weight of standard gold, to be ascertained by a count of coins, each of which is certified to contain a definite portion of that weight. It is a contract to leliver an equal weight of bullion or equal fineness. ${ }^{1}$

A party agreeing to pay or deliver gold coin at a future day not only creates a lebt which he agrees to pay or discharge, but he also waives the privilege which the law would have guaranteed to him had he not voluntarily renounced it, and takes upon himself an obligation to pay it in a specific kind of lawful money, and nothing else. The waiver and obligation are essential conditions and parts of the consideration of the contract, without which the contract would not have been made. The agreement to pay in coin is as much a part of the consideration as the agreement to pay at all, and the presumption is that an ample equivalent has been received for the promise. The parties are competent to contract, the contract is not against public

Virginia, 135 U. S. 662,10 S. Ct. 972; People v. Campbell, 59 Cal. 243.

3. Edwards v. Kearzey, 96 U. S. 595; Von Hofiman v. Quincey, 4
Wall. (U. S.) 535; MeCracken v. Hayward, 2 How. (U. S.) 608.

1. Bronson v. Rodes, 7 Wall. (U. S.) 229 ; Butler v. Horwitz, 7 Wall. (U. S.) 258 . 
policy, is not prohibited by law, is parable in a lawful kind of money, and is a law ful contract."

Congress cannot interfere with and assume to regulate the business dealing of eitizens except under some power expressly or impliedly granted by the constitution. And as the United States Supreme Court has already decided that contracts to pay gold coin are simply engagements for the delivery of a specific commodity, and as Congress eannot say that a eitizen shall not be permitted to make and enforce a contract for the delivery of a specific commodity, so it cannot prohibit a citizen from dealing in gold coin.

$\S 530$. Salaries of public officers. - $A$ legislative act ereating an office, or fixing a salary, is not a contract within the prohibition of the Federal constitution forbidding the States to pass laws impairing the obligation of contracts. ${ }^{3}$

Of course, the State constitution can control this matter which may declare for the permaneney of salaries of public officers. ${ }^{4}$

The legislature may provide for compensating all public officers by salaries. Or if the legislature should see proper to do so, there is no provision of the constitution that will forbid exacting from persons requiring, and who are specially benefited by the performance of official services, a reasonable compensation therefor, to be paid into the public treasury to reimburse the public for the expense incurred in promoting and

2. Carpenter v. Atherton, $25 \mathrm{Cal}$. 564. See, also, Wallace v. Eldredge, 27 Cal. 498 ; Harding v. Cowing, 28 Cal. 213; Trebitcock v. Wilson, 12 Wall. (U. S.) 687; Maryland v. Railroad Co., 22 Wall. (U.S.) 105; Juilliard v. Greenman, 110 U. S. 421 , 4 S. Ct. 122; Hagar v. Reelamation Dist., 111 U. S. 701, 4 S. Ct. 663; Woodruff v. Mississippi, 162 C. S. $29 \%$. 16 S. Ct. 820: Bel. ford v. Woodward, 158 Ill. 122, 41 N. F. 1097,29 L. R. A. 593 and note.

3. Butler v. Pennsylvania, 10 How. (U. S.) 40; Hoboken v. Gear, 3 Dutch. (N. J.) 265 ; State v. Smedes, 26 Niss. 47: Swann v. Buck, 40 Miss. 268.

4. Koontz v. Franklin. $75 \mathrm{~Pa}$. St. 1.: 
maintaining such offices. And such process of raising money is no impairment of contract. ${ }^{5}$

$\S 53$ I. Decisions under prior statutes.-Courts must declare what the law is and has been, and not what it shall be in the future. Hence, they are not bound by their prior decisions, for they may correct their errors. ${ }^{1}$ And so the construction placed upon one statute implies no obligation on its part to put the same construction upon a different statute, though the language of the two may be similar. ${ }^{2}$

The United States Supreme Court has no jurisdiction because a State court changes its views in regard to the proper construction of its State statute, although the effect of such judgment may be to impair the value of what the State court had before that held to be a valid contract. But where a case is brought in the United States courts, comity generally requires of the United States Supreme Court that in matters relating to the proper construction of the laws of the constitution of its own State, the United States Supreme Court should follow the decisions of the State court; yet in exceptional cases ${ }^{3}$ the United States Supreme Court has refused to be bound by such rule, and has refused to follow the later decisions of the State court. Thus, a writ of error has been dismissed in the United States Supreme Court, ${ }^{4}$ where the judgment sought to be reviewed was that of a State court, holding that certain bonds are void upou precisely the same facts that the United

5. Harrison v. Willis, 7 Heisk. (Temn.) 35, 19 Am. Rep. 604; State v. Howran, 8 Heisk. (Tenn.) 824; Adae v. Zangs, 41 Iowa, 536; Steele v. Railroad Co., 43 Iowa, 109; State v. Verwayne, 44 Iowa, 621 ; State v. Board, 4 Neb. 537, 19 Am. Rep. 641; Perce v. Hallett, 13 R. I. 363 ; Lee County v. Abrahams, 34 Ark. 166; Nurphy v. State, 38 Ark. 514; Hewlett v. Nutt, $70 \mathrm{~N}$. Car. 263; State v. Judges, 21 Ohio St. 1; State v. Forgus, $19 \mathrm{Nev} 247$,
9 P. 123; State v. Ream, 16 Neb. 681, 21 N. 398; Henderson v. State, 137 Ind. 552,36 N. E. 257,24 L. R. A. 469 .

1. Beveridge v. Livingston, 54 Cal. 54.

2. Wood v. Brady, 150 U. S. Is, 14 S. Ct. 6.

3. Gelpcke v. Dubuque, l Wall. (U. S.) 175 .

4. Railroad Co. v. MeClure, 10 Wall. (U. S.) 511 . 
States Supreme Court in another "ase held were valid. There was no subsequent legislative act impairing their obligations, and hence the United States Supreme Court had no jurisdiction to review the judgment of the State court. ${ }^{6}$ There must be some subsequent act of the legislature to which effect has been given by the judgment of the State court, before there can be an impairment of obligations of contracts; a change in the construction of an act is not an impairment. ${ }^{7}$

Where there are two grounds for the judgment of a State court, one only of which involves a Federal question, and the other is decided upon an independent ground and broad enough to maintain a judgment sought to be reviewed, the United States Supreme Court will not look into the Federal question. ${ }^{8}$

$\S$ 532. Retrospective laws.-A retrospective statute affecting vested rights resulting from contracts is unconstitutional. But this doctrine does not apply to remedial statutes, which may be retrospective in their nature, prorided they do not impair contracts, and only go to confirm rights already existing.

The constitutional prohibition does not deny remedial legislation, nor stand in the way of statutes passed to cure some defect or omission in former proceedings or enactments. ${ }^{2}$ A

5. Gelpeke v. Dubuque, 1 Wall. (U. S.) 175 .

6. Baeon v. Texas, 163 U. S. 207, 16 S. Ct. 1023.

7. New Orleans Water Works Co. v. Sugar Refining Co., 125 U. S. 18, 8 s. Ct. 741 ; Central Laud Co. Laidley, 159 U. S. $103,16 \mathrm{~s}$. Ct. 80 ; Bacon v. Texas, 163 U. S. 207 , 16 S. Ct. 1023.

8. Bacon r. Texas, 163 [. S. 207 , $16 \mathrm{~S} . \mathrm{Ct} .1023$; liutland R. R. Co. v. Raiload Co., 1.59 U. S. 630, $16 \mathrm{~S}$. Ct. So: Gillis $r$. stinchfield, 159 L. S. (i.s), 16 S. Ct. 131; Seneea Nation v. Christy, 162 U. S. 283, 16 S. Ct. S2S; Eustis v. Bolles, 150 U. S. $361,14 \mathrm{~S}$. Ct.
131 ; Beaupre v. Noyes, 138 L. S. $397,402,11$ S. Ct. 296.

1. Wymne v. Wynne, 2 Swan (Tenn.), 205; Collins v. Railroad Co., 9 Heisk. (Tenn.) 847.

2. Shields v. Land Co., 94 Tenu. 123. 28 S. W. 668, 26 L. R. A. 509, 40 Am. St. Rep. 700; Demoville r. bavilion County, s7 Tenn. 2223; 10 S. II. 3.5; Munn v. Illinois, 94 U. S. 113: Berer Co. v. Massachusetts. 97 U. S. 25 ; Ntone r. Mississippi, 101 U. S. 814; Lwell v. Datgres, $10 \mathrm{~s}$ [. S. 150, $2 \mathrm{~s}$. Ct. $40 \mathrm{~s}$; Gross v. Hort. Co., 108 U. S. 488, 2 S. Ct. 940 ; Satterlee v. Matthewson, 2 Pet. (U. S.) 412. 
law that gives validity to a contract cannot impair the obligation of that contract. ${ }^{3}$

A stipulation in the face of a note for wsurious interest can be taken advantage of by the maker of the note when due; but he has no such vested right in this defense or the contract or the usury statutes, so that the law may not be repealed, and the note made collectible by a retrospective law. ${ }^{4}$

And so a loan of money made in one State by a corporation in another State, though not valid at the time because contrary to the law of the State where made, may be rendered collectible by a subsequent law. The latter law, though destroying a complete defense to any suit brought for the collection of the loan, does not impair the obligation of the contract. It enables the parties to enforce the contract they intended to make, and does not impair the obligation. ${ }^{5}$

And so a statute curing a defective acknowledgment that renders a corporate charter void, and thereby defeats an existing liability of the corporators under the contract of the company, does not impair any contract obligation of the other parties to the contract. ${ }^{6}$

$\S$ 533. Conflict of laws. - The construction, so far as contract obligations under a contract are concerned, constitutes a part of the law as much as if embodied in it. So far does this doctrine extend, that where a statute of two States, expressed in the same terms, is construed differently by the highest courts, they are treated by the United States Supreme Court as different laws, each embodying the particular construction of its own State, and enforced in accordance with it in all cases arising under it. ${ }^{7}$

The rule of construction adopted by the highest court of the State, in construing its own constitution and one of its own

3. Satterlee v. Matthewson, 2 Pet. (U. S.) 412.

4. Ewell v. Daggs, 108 U. S. 150, 2 S. Ct. 408.

5. Gross v. Mort. Co., 108 U. S. 488, 2 S. Ct. 940.
6. Shields v. Land Co., 94 Tenn. 123, 28 S. W. 668,26 L. R. A. 509, 40 Am. St. Rep. 700.

7. Louisiana v. Pilsbury, 105 U. s. $278,294$. 
statutes in a ease not involving any question re-examinable in the United States Supreme Court under the twenty-fifth seetion of the judiciary act, must be regarded as conclusive in this court. ${ }^{8}$

The construction given to a statute of a State by the highest judicial tribunal of a State is a part of the statute, and is as binding upon the court of the United States as the text of the statute $;^{9}$ though the United States Supreme Court can inquire as to the validity of the statute itself, as construed by the State court, where properly presented. ${ }^{10}$

\section{ARTICLE II.}

\section{Corporate Charters and Franchises.}

Section 534. Charter Grantee.

535. Exclusive Franchise.

536. State Regulations of Corporations.

537. Subsequent Acts Regulating Railroad Companies.

538. Establishing Maximum Rates.

539. Legislature Must not Destroy a Business by Establishing Maximum Rates.

540. Private Contracts.

54l. Reservation in Charter.

$\S$ 534. Charter grantee.-A charter is a contract between the State and the corporation receiving it. ${ }^{1}$ The grantee of the charter takes nothing by implication, and the State is not further bound, nor interested, than can be read in the act. ${ }^{2}$ The

8. Provident Institutions v. Massachusetts, 6 Wall. (U. S.) 611 ; Randall v. Brigham, 7 Wäll. (U. S.) 523 ; Morley v. Railroad Co., 146 U. S. 162, 13 S. Ct. 54,

9. Leffingwell v. Warren, 2 Black (U. S.) 599, 603.

10. Morley v. Raslroad Co., 146 U. S. 162,13 s. Ct. 54.

1. Dartmouth College v. Woodward, 4 Wheat. (U.S.) 218 ; Prov- idence Bank $v$. Billings, 4 Pet. (U. S.) 5l4; Wales v. Stetson, 2 Mass. 149 ; State Bank v. Knoop, lo How. (U. S.) 369 ; Dodge v. Woolsey, 18 How. (U. S.) 331; Jefferson Branch Bank v. Shelly, I Black (U. S.), 436.

2. Charles River Bridge v. Warren Bridge, 11 Pet. (U. S.) 420; Stein v. Bienville Co., 141 U. S. 67 , 11 S. Ct. 892; Syracuse Water Co. 
doctrine now is that a strict construction is required of public grants of franchises and it denies to the grantee anything by implication, ${ }^{3}$ though there may be incidental rights. ${ }^{4}$

The corporation is entitled to the benefits of the contract, and they cannot be taken away by statute. Thus, a proviso exempting the company's net earnings up to a certain amount, is not a mere gratuity, but a contract, and the exemption cannot be repealed by statute. ${ }^{5}$

The rights of the public are never presumed to be surrendered to a corporation, mless the intention to surrender clearly appears in the law. ${ }^{6}$ So a franchise must be created by express terms and cannot be inferred from the mere silence of the charter. $^{7}$ When a corporation is engaged in a business of such a character that the public are directly interested in its proper management, it is subject to such reasonable regulations as will secure the ends of its creation. The State must see that the laws are enforced as will enable the State to know whether corporations are properly exereising their corporate privileges. ${ }^{8}$ What is not granted in terms to a corporation, or is incidental thereto, is reserved to the State. ${ }^{9}$

v. Syraeuse, 116 N. Y. 167,22 N. E. 38,5 L. R. A. 546 ; In re Brooklyn, 143 N. Y. 596,38 N. E. 983,26 L. R. A. 270 ; Power v. Athens, $99 \mathrm{~N}$. Y. 592,2 N. E. 609 ; Chenango Bridge Co. v. Bridge Co., 27 N. Y. 87.

3. Stein v. Bienville Co., 141 U. S. 67, 11 S. Ct. 892 ; Proprietors v. Wheeley, 2 Barn. \& Ad. 793; Syracuse Water Co. v. Syraeuse, $116 \mathrm{~N}$. Y. 167,22 N. E. 38,5 L. R. A. 546 ; In re Brooklyn, I43 N. Y. 596, 38 N. E. 983,26 I. R. A. 270 . The case of Ogden v. Gibbons, 4 Johns. Ch. (N. X.) 150, and Newburgh, ete., Turnpike Co. v. Welter, 5 Johns. Ch. (N. Y.) 101, 9 Am. Dee. 274, were overruled in Charles River Bridge v. Warren Bridge, 11 l'et. (U. S.) 548.
4. Mintern v. Laru, 23 How. (U. S.) 435; Barnett v. Denison, 145 U. S. 135,12 S. Ct. 819; Hamilton Gaslight Co. v. Hamilton City, 146 U. S. 258, 13 s. Ct. 90 .

5. Commonwealth v. Railroad Co., 164 Pa. St. 252, 30 A. 145.

6. Perrin v. Canal Co., 9 How. (U.S.) 192.

7. Zanesville v. Gaslight Co., 47 Olio St. 31, 23 N. E. 55.

8. State v. Ins Co., 50 Ohio St. 252, 33 N. E. 1056.

9. Providence Bank v. Billings, 4 Pet. (U. S.) 515; Charles River Bridge v. Warren Bridge, 11 Pet. (U. S.) 544; Thorpe v. Railroad Co., 27 Vt. 140, $62 \mathrm{Am}$. Dec. 625 ; Fertilizing Co. v. Hyde Park, 97 U. S. 659; Georgia 
$\$$ 535. Exclusive franchise. - Where the charter gives no exclusive franchise in terms, none can he inferred.' The legislature camnot be restricter in its grants of corporate franchises which are within comstitutional limitations, save by its own express grant, even though the consequences of such grant may be to entail loss upon existing corporations through competition. ${ }^{2}$ But the legislature camnot consolidate similar corporations under a prior charter of the original corporation whose charter was unalterable, and pass to the merging corporations special privileges and immunities prohibited by the constitution. ${ }^{3}$

\section{$\S 536$. State regulations of corporations.-Charters are con-} tracts, but it does not follow that the rights secured by them are not subject to State regulation. The rights and privileges which come into existence under a charter are placed upon the same footing with other legal rights and privileges of the citizens, and subject in like manner to proper rules for their due regulation. The rights insured to private corporations by their charters, and the manner of their exercise, are subject to such new regulations as from time to time may be made by the State with a view to the public protection, health, and safety, and in order to guard properly the rights of other individuals and corporations. ${ }^{4}$

The charter is taken subject to the understanding that in its operation affecting the interests of society, it will be controlled by such reasonable enactments as may be passed for the preservation of the persons, lives and property of the people, where

Banking Co. v. Smith, 128 U. S. 174, 9 S. Ct. 47 ; State v. Coke Co., 34 Ohio St. 572, 32 Am. liep. 390.

1. In re Brooklyn, 143 N. Y. 596 , 38 N. E. 983,26 L. R. A. 270.

2. Charles River Bridge v. Warren Bridge, 11 Pet. (U.S.) 548; In re Brooklyn, 143 N. Y. 596,38 N. E. 983, 26 L. R. A. 270: Butehers, ete.. Co., v. Crescent City, ete., Co., 111 U. S. 746,4 S. Ct. 652 ; Fort Plain
Bridge v. Smith, 30 N. Y. 44; Shorter v. Smith, 9 Ga. 517; Collins v. Sherman, 31 Miss. 679.

3. People's Gas Light and Coke Co. v. Chicago, 194 U. S. 1, overruling in part People v. Gas Light and Coke Co., 205 11l. 482, 98 Am. St. Rep. 244. The Illinois Supreme Court held this merger good.

4. Gorman v. Railroad Co., 26 Mo. 441, 72 Am. Dec. 220. 
such enactments do not contravene the expressed provision of the charter. ${ }^{5}$

$\S 537$. Subsequent acts regulating railroad companies. The right to use the parcel of land appropriated to a railroad does not deprive the legislature of the power to enact such regulations, and impose such liabilities for injuries suffered from the mode of using the road, as the occasion and circumstances may reasonably justify. ${ }^{1}$ So a statute making railroad companies responsible for injuries by fire communicated from their locomotives applies to railroads established before as well as since its passage. ${ }^{2}$ And so an act requiring all railroads that are in running order to be fenced is not unconstitutional as impairing the rights given to a railroad by its previously granted charter, by subjecting it to an increased burden. ${ }^{3}$

But a statute which provides that certain classes of employers shall give their dicharged employes the reason for their discharge, is unconstitutional. A statute which undertakes to make it the duty of incorporated railroad, express, telegraph, and other companies to engage in correspondence of this kind with their discharged employes, is void. ${ }^{4}$

$\S 538$. Establishing maximum rates. $-A$ law of the legislature establishing a reasonable maximum rate of charges for

5. Thorpe v. Railroad Co., $27 \mathrm{Vt}$. 140, 62 Am. Dec. 625; Hart v. Railroad Co., 13 Met. (Mass.) 99. 46 Am. Dec. 719 and note; Ross v. Pailroad Co., 6 Allen (Mass.), 87; Pierce v. Railroad Co., 105 Mass. 199.

1. Pierce v. Railroad Co., 105 Mass. 199.

2. Lyman v. Railroad Co., 4 Cush. (Mass.), 288; Mathews v. Railroad Co., 121 Mo. 298, 24 S. W. 591, 25 L. R. A. 161 and note; Chapman v. Railroad Co., 37 Me. 92; Pratt v. liailroad Co., 42 Me. 579; Hooksett v. Railroad Co., 38 N. H. 242; Rod- emacher v. Railroad Co., 41 Iowa, 297, 20 Am. Rep. 592; Drady v. Railroad Co., 57 Iowa, 393, $10 \mathrm{~N}$. 754; Grissell v. Railroad Co., 54 Conn. 447, 9 A. 137, 1 Am. St. Rep. 138; Un. Pac. R. R. Co. v. De Busk, 12 Colo. 294, 20 P. 752,3 L. R. A. 350, 13 Am. St. Rep. 221; State v. Manuf. Co., 18 R. I. 16, 25 A. 246, 17 L. R. A. 856.

3. Railroad Co. v. McClelland, 25 Ill. 140; Boston, etc. R. R. Co. v. County, 79 Me. 386,10 A. 113.

4. Wallace v. Railroad Co., 04 Ga. 732, 22 S. E. 579. 
the transportation of passengers or property on railroads in a State, is a valid and constitutional law. Such a law or regulation does not impair the obligation of the contract in the charter of the railway company. ${ }^{1}$

When an employment or business becomes a matter of such public interest and importance as to create a common charge or burden upon the citizen; or when it becomes a practical monopoly, to which the citizen is compelled to resort, and by means of which a tribute can be exacted from the community, it is a subject for regulation by legislative power. Thus, it is within the power of the State to regulate the price at which water shall be sold by one who enjoys a virtual monopoly of the sale. ${ }^{2}$

It is competent for the legislature to fix the maximum charges by individuals keeping public warehouses for storing, handling and shipping grain, and that, too, when such persons had derived no special privileges from the State, but were, as citizens of the State, exereising the business of storing and handling grain for individuals. ${ }^{3}$

1. People v. Guthrie, 149 Ill. 360 , 38 N. E. 549 ; Munn v. Illinois, 94 U. S. 113; Chicago v. Railroad Co., 94 U. S. 155; Budd v. New York, 143 U. S. 517,12 S. Ct. 468 , explaining Chicago, etc. R. R. Co. v. Minnesota, 134 U. S. 418,10 S. Ct. 462 ; People v. Budd, 117 N. Y. 1, 22 N. L. 670,5 L. R. A. 559 and note, 15 Am. St. Rep. 460 and note.

2. Spring Valley Water Works v. Schottler, 110 U. S. $34 \pi, 4$ S. Ct. 48 .

3. Munn v. People, 69 IIl. 80 ; Ruggles v. People, 91 Ill. 256; People v. Budd, 117 N. Y. 1, 22 N. E. 670, 682, 5 L. R. $A .559$ and note, $15 \mathrm{Am}$. St. Rep. 460 and note; Mumn v. Illinois, 94 U. S. 113; Budd v. New York, 143 U. S. 517 , 12 S. Ct. 46s. See, also. Dow v. Beidelman, 125 U. S. 680. 8. S. Ct. 102S; Railroad Co. v. Railroad Co.,
30 Ohio St. 604; State v. Gas Co., 34 Onio St. 592; Davis v. State, 64 Ala. 58, 44 Am. Rep. I28; Baker v. State, 54 Wis. 368,12 N. 12 ; Nash v. Page, 80 Ky. 539, 44 Am. Rep. 490 ; Girard Storage Co. v. Sothward Co., 105 Pa. St. 248; Sawyer v. Daris, 136 Mass. 239, 49 Am. Rep. 27; Brechlill v. Randall, 102 Ind. 528, 1 N. E. 362. $52 \mathrm{Am}$. Rep. 693 , Stone v. Railroad Co., 62 Miss. 607, $52 \mathrm{Am}$. Rep. 193; Hockett v. State, 105 Ind. 250,5 N. E. 178, 55 Am. Rep. 201; Central Union Tel. Co. r. Bradbury, 106 Ind. 1, 5 N. E. $7: 21$; Central Inion Tel. Co. v. State, 118 Ind. 194,19 N. E. 604,10 Am. St. Rep. 114 and note; Chesapeake and Potomac Telephone Co. v. Tel. Co., 66 Md. 399,7 A. 809,59 Am. Rep. 167 and note; Delaware, ete. R. R. Co. r. Stock-yard Co., 45 N. J. Eq. 50, 17 A. 146, 6 L. R. A. 
It is the right of the State to establish limitations upon the power of railroad companies to fix the price at which they shall carry passengers and freiglit, and the question is of the same character as that involved in fixing the eharges to be made by the persons engaged in the warehousing business. ${ }^{4}$ And so the legislature can declare what shall be a reasonable compensation for the services of persons exereising a public employment, or fix a maximum beyond which any charge made will be unreasonable. ${ }^{5}$

\section{$\S 539$. Legislature must not destroy a business by establish-} ing maximum rates.-While the legislature may itself fix a maximum beyond which any charge would be unreasonable, in respect to services rendered in a public employment, or for the use of property in which the public has an interest, it is subjeet to the proviso, however, that such power of limitation or regulation is not without limit, and is not a power to destroy, or a power to compel the doing of the services without reward, or to take prirate property for public use withont just compensation or without due process of law. ${ }^{1}$

The United States Supreme Court has adjudged in numerous cases that the legislature of a State has the power to prescribe the eharges of a railroad company for the carriage of persons and merehandise within its limits, subject to the limitation that the carriage is not required without reward, or upon conditions amounting to the taking of property for publie use without just conpensation; and what is done must not amount to a regulalation of foreign or interstate commerce. ${ }^{2}$

855 and note; Zanesville v. Gaslight Co., 47 Ohio st. 1, 2 N. E. 60.

4. Wabash, ete. R. R. Co. v. Illinois, 118 U. S. 557,7 S. Ct. 4.

5. Dow v. Beidelman, $125 \mathrm{U}$. S. 680, 8 S. Ct. 1028 .

1. Smyth v. Ames, 169 U. S. 466. 18 S. Ct. 418, 171 U. S. $361,18 \mathrm{~S}$. Ct. 888 ; Dow v. Beidehman. 125 U. S. 680,8 s. Ct. 1028 .

2. Georgia Banking Co. v. Smith, l.28 U. S. 174, 9 S. Ct. 47. See, also, Stone v. Railroad Co., 116 U. S. 347, 352; Stone v. Trust Co. 116 U. S. 307 ; Munn v. Illinois, 94 U. S. 113: Chicago, ete. R. R. Co. v. Iowa, 94 U. S. 155 ; Peik v. Railroad Co., 94 U. S. 164; Chicago, ete. R. R. Co. v. Ackley, 94 U. S. 179: Winona, ete. R. R. Co. v. Blake, 94 U. S. 180 ; Stone v. Wisconsin, 94 U. S. 181 ; Ruggles v. 11- 
$\S 540$. Private contracts.-Where private contracts are unaffected by any public interest or duty to person ol government, and the parties are eapable of contracting, then the legislature cannot interfere for the purpose of prohibiting the contract or controlling the terms thereof. ${ }^{3}$ But the government may regulate by law so that a person who hat contraeted to receive a rard of cloth or a bushel of eorn, shall not be required to acept a short yard or light bushel as the seller may ehoose to impose upon him. ${ }^{4}$

Because a law is unjust, impolitic or oppressive, it will not authorize a court to deelare it illegal, unless it violates some specifie provision of the eonstitution. A law may be unjust in its operation, or even in the prineiples upon which it was founded; but that will not justify a court in expanding the prohibitions in the eonstitution beyond their natural and original meaning, in order to remedy an evil in any particular ease. Such extension would impair the obligation of contracts. ${ }^{5}$

linois, 108 U. S. 526, 2 S. Ct. 832 ; Ill. Cent. R. R. Co. v. Illinois, $10 \mathrm{~S}$ U. S. $5+1,2$ S. Ct. 839 ; St. Louis, etc, R. R. Co. v. Gill, $15 t$ U. S. 649, 657, 15 S. Ct. 484; Covington, etc. R. R. v. Sanford, 164 U. S. 578,17 S. Ct. 19s; Chicago, etc. R. R. Co. v. Minnesota, 134 U. S. $41 \mathrm{~s}, 10 \mathrm{~s}$. Ct. 462,702 ; Reagan v. Trust Co., 154 U. S. 362,14 S. Ct. 1060 ; Chicago, etc. R. R. Co. v. Chicago, 166 U. S. 226, 241, 17 S. Ct. 581; Chicago, etc. R. R. Co. v. Wellman, 143 U. S. $339,344,12 \mathrm{~S}$. Ct. 400 ; Budd v. New Jork, 143 U. S. 517,12 S. Ct. 468.

3. State $r$ Goodwill, 33 W. Va. 179,10 S. E. 285,6 L. R. A. 6221 and note, $25 \mathrm{Am}$. St. Rep. 863 and note; State v. Loomis, 115 Mo. 307, 22 S. W. 350,21 L. R. A. 789 and note; Godeharles v. Wigeman, 113 Pa. St. 431, 6 A. 354; State v. Coal and Colie Co., 33 W. Va. 188, 10 S. E. 288,6 L. R. A. 359,25 Am.
St. Rep. S91; Ramsey r. People, 142 111. 350,22 ‥ E. 364,17 L. K. A. 853 ; Braceville Coal Co. v. Pcople, 147 Ill. 66, 35 N. E. 621,37 Am. St. Rep. 206 ; Froler v. People, 141 Ill. 171,31 N. E. 395,22 L. R. A. 340 ; Willett v. People, 117 Ill. 294,7 N. E. 631,57 Am. Rep. 869 ; Commonwealth v. Perry, 15.5 Mass. 117,28 N. E. 1126, 31 Am. St. Rep. 533; People v. Otis, 90 X. Y. 48; Ragio v. State, so Tem. $272,6 \mathrm{~S}$. 11. 401. Compare In re Housebill, 23 Colo. 504, ts P. .7.2.

4. Charleston v. Rogers, 2 llceord (S. Car.), 495, 13 Am. Dee. 751 ; Stokes v. N'ew York, 14 Wend. (N. Y.), si; Green v. Moffet, 22 Мo. 529; Yates v. Milwaukee, 12 IVis. 673; Eaton v. Kegan, 114 Mliss. 433.

5. County Court r. Griswold, 58 No. 192; Hamilton v. County Court, 15 Mo. 3. 
However, many statutes interfering with private rights are valid. Thus, a statute prohibiting citizens from assigning certain claims against others, for the purpose of a suit in another State, is valid. ${ }^{6}$

And so Congress may limit the amount of attorney fee in collecting a pension, and no right of contracting will be impaired. ${ }^{7}$

$\S$ 54I. Reservation in charter. - Corporations possess only those powers or properties which the charters of their creation confer upon them, either expressly, or as incidental to their existence. The rights legally vested in all corporations cannot be controlled or destroyed by any subsequent statute, unless power for that purpose be reserved to the legislature in the act of incorporation. ${ }^{1}$ So after such reservation in the charter, a legislature may pass an act requiring the corporation to pay weekly the laborers engaged in its business the wages earned by them to within nine days of the date of such payment, unless prevented by inevitable casualty. ${ }^{2}$ By such restrictions imposed on a corporation, it is competent for the legislature, by passing a law, to amend the charter. ${ }^{3}$ So a legislature may prohibit a corporation from withholding employe's wages. ${ }^{4}$

But this reserved power cannot be used to take away property already acquired under the operation of the charter, or to deprive the corporation of the fruits actually reduced to possessions of contracts lawfully made. ${ }^{5}$ The alterations must be reasonable; they must be made in good faith, and be consistent

6. Sweeney v. Hunter, $145 \mathrm{~Pa}$. St. 363,22 A. 653,14 L. R. A. 594.

7. Fisbie v. United States, 157 U. S. 160,15 S. Ct. 586.

1. Wales v. Stetson, 2 Mass. 143 , 3 Am. Dec. 39; Greenwood v. Freight Co., 105 U. S. 13; Sherman v. Smith, I Black. (U. S.), 587; State v. Person, 32 N. J. L. 134.

2. State v. Manuf. Co., 18 R. I. 16, 25 A. 246, 17 L. R. A. 856.
3. Shaffer v. Mining Co., $55 \mathrm{Md}$. 74.

4. Leep v. Railroad Co., 58 Ark. 407,25 S. IV. 75,23 L. R. A. 264, 41 Am. St. Rep. 109.

5. Sinking Fund Cases, 99 U. S. 700 ; Miller v. State, 15 Wall. (U. S.), 498; Holyoke Co. v. Lyman, 15 Wall. (U. S.), 519 ; Tomlinson v. Jessup, 15 Wall. (U. S.) 459 ; Railroad Co. v. Maine, 96 U. S. 510. 
with the object and scope of the act of incorporation. Shecr oppression and wrong cannot be inflicted under the guise of an amendment or alteration. ${ }^{6}$

The object of the reservation is to prescrve to the State the control over corporate grants, and to permit the legislature at any time to exereise this reserved power when necessary and proper, ${ }^{7}$ although the nature and character of the charter cannot be fundamentally changed. ${ }^{8}$ The reservation is, therefore, a condition upon which the eharter is granted, and when it is accepted the right to exercise the power is as binding as if it was written in the body of the charter itself. ${ }^{9}$

Under such a law the legislature has the authority to make any alteration in a charter granted subject to it, that will not defeat or substantially impair the object of the grant, or any rights which have vested under it, and that the legislature may deem necessary to secure that object or other public or private rights. ${ }^{10}$ Thus, the legislature may make the stockholders of an incorporated bank liable for the future debts of the corporation. ${ }^{11}$ It may vary the measure, and thus enlarge the proportion of the profits which a mutual life insurance company is required by the terms of its charter to pay to charitable institutions. ${ }^{12}$

Railroad corporations may be compelled to make changes in the level, grade and surface of the roadbed, new struetures at crossings of other railroads or of highways, or stations at partieular places, in a manner, and to be enforced by forms of process different from those provided for or contemplated by the original charter. ${ }^{13}$

6. Shields v. Ohio, 95 U. S. 324 .

7. State v. Railroad Co., 44 MId. 131.

8. Webster v. Seminary, 78 Md. 193, 28 A. 25 .

9. Jackson v. Walsh, 75 MId. 304, 23 A. 778.

10. Commissioners v. Water Power Co., 104 Mass. 451.

11. Sherman v. Smith, 1 Black (U. S.), 587, 21 N. Y. 9.
12. Massachusetts Gen. Hospital v. Asso. Co., 4 Gray (Mass.), 227.

13. Roxbury v. Railroad Co., 6 Cush. (Mass.), 434; Fitchburgh Railroad Co. v. Depot Co., 4 Allen. (Mass.), 198; Commonwealth v. Railroad Co., 103 Mass. 254, 4 Am. Rep. 555; Albany and Northern R. R. Co. v. Brownell, 24 N. Y. 345 , overruling Miller v. Railroad Co., 21 Barb. (N. Y.), 513. See, also, 
And so a statute giving prior liens upon the property of manufacturing corporations for supplies is not invalid as impairing the charter right of such corporation to issue its bonds and secure them. ${ }^{14}$

\section{ARTICLE III.}

\section{Police Power of tile State.}

\section{Section 542. Regulating the Sale of Food.}

543. Reasonableness of Food Regulations.

544. As to Occupations.

545. Insurance.

546. Destruction of Property.

$\S 54^{2}$. Regulating the sale of food.-The police power of the State may operate to regulate the sale of food products and their manufacture. Thus, adding a foreign and artificial ingredient to a food product, even for the purpose of color merely, is in effect an adulteration, and the legislature has the power absolutely to prohibit it. ${ }^{1}$ This applies to coloring matter used in vinegar. This provision against coloring matter is for the prevention of frand, as the coloring of vinegar can only be for the purpose of deception and to defrand the buyer. ${ }^{2}$

The tendency of such a device is to deceive the public, and such statute affords protection therefrom, and is clearly within the proper exercise of the police power of the State. Every one has a right to distinguish for limself what an article of food is, and have the means of judging for himself its quality and value. ${ }^{3}$

Spring Valley Water Works v. Schottler, 110 U. S. 347,4 S. Ct. 48.

14. Virginia Development Co. v. Iron Co., 90 Va. 126, 17 S. E. 806, 44 Am. St. Rep. 893. See, also, Pennsylvania R. R. Co. v. Miller, 132 U. S. $75,10 \mathrm{~S}$. Ct. 34.
1. People v. Girard, 145 N. Y. 105, 39 N. E. $8 ะ 3,45$ Am. St. Rep. 595.

2. People v. Girard, 145 N. Y. 105, 39 N. E. 823,45 Am. St. Rep. 595; Weller v. State, 53 Ohio St. 77. 40 N. E. 1001.

3. Palmer V. State, 39 Ohio St. 
So the legislature may prohibit the mamnfacture and sale of oleomargarine, or the keeping of the prodnct with intent to sell. ${ }^{*}$ And so the legislature, in the exereise of the police power, for the purpose of preventing fraul, may prohibit the sale of pure milk mixed with part water, or below a certain standard. ${ }^{5}$

$\S 543$. Reasonableness of food regulation.-The test of the reasonableness of a police regulation prohibiting the making and rending of a particular article of foor is not alone whether it is in part mwholesome and injurions. The mere fact that experts may pronomee a manufactured article intended for food to be wholesome or harmless does not render it incompetent for the legislature to prohibit the manufacture and sale of the article. ${ }^{1}$

If there is a probable ground for believing that the only way to protect the public from being defrauded into the purchasing of the counterfeit food for the genuine, then the statute will be upheld though it prohibits the manufacture of the article, even though the article prohibited is in fact innocnons, and its production might be fonnd beneficial to the public, if in buying it, it conld be distinguished from the genuine product. ${ }^{2}$

236, 48 Am. Rep. 429; Powell v. Commonwealth, 114 Pa. St. 265, 7 A. 913, 60 Am. Rep. 350; Powell v. Pennsylvania, 127 C. S. 678. 8 S. Ct. 992, 1257; State v. Horgan, 55 Minn. 185, 56 N. W. 688; Butler v. Clrambers, 36 Minn. 69, 30 ․ W. 308, 1 Am. St. Rep. 638 and mote: State r. Thompsom. 44 Mim. 27l, 46 N. W. 410; State v. Nelson. 50 Minn. 1, 52 N. W. 220; Sitate $v$. Addington, $7 \mathrm{i}$ Mo. 110 ; People $\mathrm{r}$. Armstrong, 105 N. Y. 123. 11 N. E. 277. 59 Am. liep. 483.

4. State v. Mlarshall, $64 \mathrm{~N}$. H. 549,15 A. 210,1 L. R. A. 51 and note.

5. State v. Campbell, $64 \mathrm{~N}$. H. 402, 13 A. 585; Commonwealth v.
Waite, 11 Allen (Mass.), 264, 87 Am. Dee. 711 ; Commonwealth v. Evans, 132 Mass. 11; State v. Smith, 14 R. I. 100, 51 . Am. Rep. 344 and note; People v. Cipperly, 101 N. Y. 634, 4 N. F. 107 : People v. West, 106 N. Y. 293, Iอ N. E. 610, 60 Am. Rep. 452; Shivers v. Newton, 45 X. J. L. 469 ; ('ommonwealth r. Farren, 9 Allen (Mass.), 489.

1. Powell r. Comonwealth, 114 Pa. St. 265. 7 A. 913, 60 .1m. Rep. 350: Weller r. State. 53 Ohio St. 7., 40 N. 1. 1001 ; People v. Girard, 145 N. Y. 105.39 N. E. $8 \geq 3.45$ Am. St. Rep. 59\%.

2. State v. Adliugton, it Mo. 110. 
$\S 544$. As to occupations. - Statutes have often been passed for the protection of minors and women. In Massachusetts a law which merely prohibits a woman's being employed in any manufacturing establishment more than a certain number of hours per day or week, does not violate her right to labor as many hours per day or week as she may see fit, and is within the police power. Such law merely provides that in an employment, which the legislature deems to some extent dangerous to health, no person shall be engaged in labor more than a certain number of hours per day or week, and can be upheld as a police regulation. If the services to be performed are against the policy of the State, or if the employment is not suited to the person, then the State may regulate the employment. ${ }^{1}$ So the State may regulate the work of laborers in mines and smelters. ${ }^{2}$

In Illinois a woman is considered a person sui juris, hence her hours of labor cannot be controlled under the police power, because the court says that sex alone will not justify the exercise of the police power for the purpose of limiting her right to contract. $^{3}$ It is generally held that an act of the legislature forbidding the employment of bar-maids is constitutional as an exercise of the police power. ${ }^{4}$

And such statute does not abridge the privileges and immunities of eitizens, or deny the equal protection of the laws, within the meaning of the fourteenth amendment of the Federal constitution, but is a valid exercise of the police power of the State. ${ }^{5}$

1. Commonwealth v. Hamilton Mfg. Co., 120 Mass. 383; State v. Buchanan, 29 Wash. 602, 70 P. 52, 59 L. R. A. 342,92 Am. St. Rep. 930 ; Wenham v. State (Neb.), $91 \mathrm{~N}$. W. 421,58 L. R. A. 825 .

2. Holden v. Hardy, 169 U. S. 366,18 S. Ct. 383.

3. Ritchie v. People, 155 Ill. 98, 40 N. E. 454,29 L. R. A. 79,46 Am. St. Rep. 315. This decision declared a statute regulating the hours that a woman should work in a "sweat shop," void.
4. Bergman v. Cleveland, 39 Ohio St. 651 ; State v. Reynolds, 14 Mont. 383,36 P. 449 ; State v. Considine, 16 Wash. 358, 47 P. 755; Ex parte Hayes, 98 Cal. 555, 33 P. 337,20 L. R. A. 701; Foster v. Commissioners, 102 Cal. 483, 37 P. 763, 41 Am. St. Rep. 194; overruling In re Maguire, 57 Cal. 604, 40 Am. Rep. 125. Compare Gastenau v. Commonwealth, $108 \mathrm{Ky} \cdot 473$, 56 S. W. 705, 94 Am. St. Rep. 386. 5. In re Considine, 83 Fed. Rep. 157. 
$\S 545$. Insurance.-The business of insurance against loss by fire is, by reason of its magnitude, its importance to property owners, and the nature of the business, a proper subject for the exercise of the police power of the State. Therefore, a State which prohibits any person, partnership or association, from issuing any policy or making a contract of indemnity against loss by fire without authority expressly conferred by a charter of incorporation, is a valid exercise of the police power. ${ }^{1}$ Because a State has a right to impose conditions, not in conflict with the constitution of the United States, on the doing of insurance business within its territorial bounds by insurance companies chartered by another State or to exclude them altogether. ${ }^{2}$

In life insurance, if the insured commits a crime and is legally executed, the policy lapses. The rule is general that losses resulting from the criminal act of the insured will not be covered by policies of insurance upon life or property. For it is against public policy to offer a reward in the nature of insurance for the commission of crime. And if the insured be convicted and executed, though he be innocent of the crime, the policy cannot be collected. It is the policy of every State to uphold the dignity and integrity of its courts of justice, and public policy forbids sustaining any policy of insurance which depends upon proving a miscarriage of justice. The policy of the law often permits, and even requires, for error, a new trial of a convicted defendant, but never after his execution. So, if he be legally executed, but is not guilty in fact, the policy on his life becomes void. ${ }^{3}$ And any wager of this kind to show that the court erred in the judgment of execution, is void and against public policy. ${ }^{4}$

$\S 546$. Destruction of property.-A prohibition simply upon the use of property for purposes that are declared, by valid legislation, to be injurious to the health, morals, or safety of the

1. Commonwealth v. Vrooman, $164 \mathrm{~Pa}$. St. 306, 30 A. 217,25 L. R. A. 250, 44 Am. St. Rep. 603 .

2. Doyle v. Ins. Co., 94 U. S. 535.
3. Burt v. Union Cent. L. Ins. Co., 187 U. S. 362, 23 S. Ct. 139.

4. Evans v. Jones, 5 Mees. \& W. 77. 
community, cannot be deemed a taking or an appropriation of property for the public health. The exercise of the police power by the destruction of property which is itself a public nuisance, or the prohibition of its use in a particular way, whereby its value becomes depreciated, is a valid use of the police power. ${ }^{1}$ Thus, a State has the constitutional power to declare that any place kept and maintained for the illegal manufacture and sale of intoxicating liquors shall be deemed a common nuisance, and be abated, although that when the owners purchased the property the laws of the State did not forbid the manufacture of intoxicating liquors. ${ }^{2}$

The supervision of the public health and the public morals is a gorernmental power, continuing in its nature to be dealt with as the special exigencies of the moment may require; for this purpose the largest legislative discretion is allowed, and the discretion cannot be parted with any more than the power itself. $^{3}$

\section{ARTICLE IV.}

\section{Police Power and Interstate Commerce.}

Section 547. Police Power Controlled by Federal Constitution.

548. Interstate Commerce-Police Power.

549. State Statutes Interfering with Interstate Commerce.

550. Surrender of the Police Power of the State.

551. Imposing a Tax Upon Selling Goods.

552. Tax Upon Interstate Commerce.

553. When is the Imported Commodity Incorporated with the General Mass of Property.

554. Statute Incorporating Imported Goods.

\section{$\S 547$. Police power controlled by federal constitution.-} The State, when providing, by legislation, for the protection of the public health, the public morals, or the public safety,

1. Mugler v. Kansas, 123 U. S. 623, 8 s. Ct. 273.

2. Mugler v. Kansas, 123 U. S. 623, 8 S. Ct. 273.
3. Stone v. Mississippi, l0l U. S. 814. 
is subject to the paramount anthority of the constitution of the United States, and may not violate rights secured or guaranteed by that instrument, or interfere with the execution of the powers confided to the general government.' And so no State cammot, by any contract, limit the exereise of the police power to the prejudice of the public health and the pullie morals. ${ }^{2}$

If a State should grant a charter to a private corporation to conduct a lottery, and for which the eorporation pail to the State a valuable consideration in money, the lecislature may revoke the charter, because no State can bargain away the public health or the public morals. ${ }^{3}$

The constitutional prohibition upon State laws impairing the obligation of contracts does not restriet the power of the State to protect the public health, the publie morals, or the public safety, as the one or the other may be involved in the execution of such contracts. The same rule applies to such contracts as to all other contracts and property, whether owned by national persons or by corporations. All property in this country is held under the implied obligation that the owner's use of it shall not be injurious to the community. ${ }^{4}$

And while a State cannot impair the exclusive right of a patentee, or of his assignee, in the discorery described in the letter-patent, the tangible property, the fruit of the discovery, is not beyond control in the exercise of a State's police power. ${ }^{5}$ Congress has uniformly recognized the necessity, growing ont of the fundamental conditions of society, of upholding State police regulations which are enacted in good faith, and has ap-

1. Henderson v. New York, 92 U. S. 259; Railroad Co. v. Husen, 95 U. S. 465; New Orleans Gas Co. v. Light Co., 115 U. S. 650, $6 \mathrm{~s}$. Ct. 252; Walling $\mathrm{r}$ Michigan. $116 \mathrm{U}$. S. 446,6 S. Ct. 454 ; Yick Wo v. Hopkius, 118 U. S. 356,6 S. Ct. 1064: Morgan's Steamship Co. v. Board, 11 S U. S. 455, 6 S. Ct. 1114.

2. Butchers' Union Co. v. Cres- cent City Co., 111 U. S. 746, 4 S. Ct. 652 .

3. Stone v. Mississippi, $101 \mathrm{U}$. S. 814; Douglas v. Kentucky, 168 U. S. 485,18 S. Ct. 199.

4. Beer Co. v. Massachusetts, 97 U. S. 25; Commonwealth v. Alger, 7 Cush. (Mass.) 53.

5. Patterson v. Ḱentucky, $97 \mathrm{U}$. S. 501. 
propriate and direct eonnection with the protection to life, health, and property which each State owes to its citizens. ${ }^{6}$

So the enforcement of an ordinance may operate to destroy the business of a company, and seriously to impair the value of its property, yet the police power will uphold it if appropriate to the subject. ${ }^{7}$ Therefore, a party in contracting must take into eonsideration his rights under the police power.

\$ 548. Interstate commerce - Police power. - Interstate commerce consists in the transportation, purchase, sale and exchange of commodities among the States, and is national in its character and must be governed by a uniform system, which does not come under the police power of any State. So, where laws are enacted in the exercise of the police power of the State, they are not valid if they inhibit the receipt of an imported commodity, or its disposition before it has ceased to become an article of trade between the States, or another country and this, because they amount to a regulation of interstate commerce. ${ }^{1}$

Congress cannot transfer legislative powers to a State nor sanction a State law in violation of the Federal constitution; and if it adopts a State law as its own, it must be one competent for it to enact itself, and not a law passed in the exercise of the police power. ${ }^{2}$ Congress can neither delegate its own powers nor enlarge those of the State.

\section{$\S 549$. State statutes interfering with interstate commerce.} - So where a statute interferes with interstate commerce, though enacted as a police measure, it is unconstitutional. Thus, where a State prohibits a certain class of cattle to be

6. Patterson v. Kentucky, 97 U. S. 501 ; United States v. Dewitt, 9 Wall. (U. S.) 4l; License Tax Cases, 5 Wall. (U. S.), 462; Pervear v. Commonwealth, 5 Wall. (U. S.) , 475 .

7. Fertilizing Co. v. Hyde Park, 97 U. S. 659.
1. Bowman v. Railroad Co., $125 \mathrm{U}$. S. 465,8 S. Ct. 689 , 1062 ; Leisy v. Hardin, 135 U. S. 100, 10 S Ct. 681.

2. Cooley v. Wardens, 12 How. (U. S.), 299; Gunn v. Barry, 15 Wall. (U. S.), 610; United States v. Dewitt, 9 Wall. (U. S.), 4 l. 
shipped through its territory, and the object of the statute is not a quarantine or inspection law, it is invalid, as its enforcement would obstruct interstate commerce and discriminate between the property of citizens of one State and that of citizens of other States. ${ }^{1}$ And so where a statute, by its necessary operation, excludes from the market of a State all fresh beef, veal, mutton, lamb, or pork, in whatever form, and although entircly sound, healthy, and fit for human food taken from animals slaughtered in other States, it is unconstitutional; such statute discriminates against the products of other States and, therefore, interferes with interstate commerce. ${ }^{2}$

A State may establish regulations for the protection of its people against the sale of unwholesome meats, provided such regulations do not conflict with the powers conferred by the constitution upon Congress, or infringe rights granted or secured by that instrument. ${ }^{3}$ Any local regulation which, in terms or by its necessary operation, denies equality to all in the markets of the State, is, when applied to the people and products or industries of other States, a direct burden upon commerce among the States, and, therefore, void. Thus, a statute relating to the inspection of flour brought into a State, is unconstitutional, if it requires inspection of flour from other States, where no such inspection is required of flour manufactured at home. ${ }^{4}$ And so where a statute imposes a tax upon persons not residing or having their principal places of business within the State, but engaged there in the business of selling or soliciting the sale of intoxicating liquors to be shipped into the State from places without it, but not imposing a similar tax upon persons selling or soliciting the sale of intoxicating liquors manufactured in that State, it is invalid. ${ }^{5}$

But a State statute is not to be deemed a regulation of com-

1. Railroad Co. v. Husen, 95 U. S. 465 .

2. Minnesota v. Barber, 136 U. S. 313,10 S. Ct. 862.

3. Brimmer v. Rebman, 138 U. S. 78, 11 S. Ct. 213.
4. Voight v. Wright, 141 U. S. 62. 11 S. Ct. 855 .

5. Walling v. Michigan, $116 \mathrm{U}$. S. 446,6 S. Ct. 454 . 
merce among the States simply because it may indirectly or incidentally affect such commerce. ${ }^{6}$ So a State statute imposing a penalty for the violation of a duty of a telegraph company, though it does interstate business, which duty the company owes by the general law of the land, is no regulation of or an obstruction to interstate commerce. ${ }^{7}$

The citizens of one State have the right to enter the markets of every other State to sell their products, or to buy whatever they need, and all interference with the freedom with interstate commerce by State legislation is void. Under the constitution of the United States, business transactions cannot be delimited by State boundaries. ${ }^{8}$ Thus, where a statute provides that a city and contractor shall not purchase certain lines of dressed stone to be used in the city improvements, outside of the State, it is roid. ${ }^{9}$ And a contract made under such statute has a tendency to restrict interstate commerce; the statute and contract must fall together. ${ }^{10}$

$\S 55^{\circ}$. Surrender of the police power of the state.-The reserved police power of the States cannot control the prolibitions of the Federal constitution nor the powers of the government it created, ${ }^{1}$ but the grant to Congress of authority to regulate foreign and interstate commerce does not involve a surrender by the States of their police power. Thus, a statute to prevent deception in the manufacture and sale of imitation butter, in its

6. Hennington v. Georgia, $163 \mathrm{U}$. S. 299,16 S. Ct. 1086 ; New York, etc. R. R. C'o. v. New York, 165 U. S. 628,17 S. Ct. 418; Chicago, etc. R. R. Co. v. Solan, 169 U. S. 133 , 18 S. Ct. 289 ; Richmond, etc. R. R. Co. v. Tobacco Co., 169 U. S. 311 , 18 S. Ct 335 ; Missouri, ete. R. R. Co. v. Haber, 169 U. S. 613, $18 \mathrm{~S}$. Ct. 488 .

7. Western Union Tel. Co. v. James, 162 U. S. $650,16 \mathrm{~S}$. Ct. 931. See, also, Missonri, etc. R. R. Co. v. Haber, 169 U. S. 513, 18 S. Ct. 488 .
8. People v. Hawkins, 157 N. Y. 1, 51 N. E. 257,42 L. R. A. 490,68 Am. St. Rep. 736; People v. Buffalo Fish Co., 164 N. Y. 193, 58 N. E. 34.

9. People v. Coler, 166 N. Y. 144, 59 N. E. 776 . See, also, Allgeyer v. l.onisiana, 165 U. S. 578,17 S. Ct. 427.

10. Addyston Pipe and Steel Co. v. United States, 175 U. S. 211, 20 S. Ct. 96 .

1. New Orleans Gas Co. v. Light Co., 115 U. S. 650, 6 S. Ct. 252. 
application to the sales of oleomargarine artificially eolored so as to cause it to look like rellow butter and brought into the State, is not in conflict with Federal constitution. ${ }^{2}$

So a State statute may preseribe regulations, applicable to carriers engaged in interstate and foreign commerce, to insure the safety of persons carried by them ats well as the afety of persons and things liable to be affected by their acts while they are within the territorial jurisdiction of the State. ${ }^{3}$ So a statute making it a public offense for any one to practice nedieine in the State without complying with eertain prescribed conditions, is valid. ${ }^{4}$

A State is not powerless to prevent the sale of artieles of food manufactured in or bronght from another State, and subjects of traffic or commeree, if their sale may cheat the people into purchasing something they do not intend to buy, and which is wholly different from what its condition and appearance impart. ${ }^{5}$

The judiciary of the United States will not strike down a legislative enactment of a State, especially if it has direct connection with the soeial order, the health and the morals of a people, unless such legislation plainly and palpably violates some rights granted or seeured by the national constitution or encroachment upon the authority delegated to the United States for the attaimment of objects of national concern. ${ }^{6}$

$\$ 55$ I. Imposing a tax upon selling goods.-Statutes imposing a penalty for peddling without a license, all goods of particular kinds, and not discriminating against goods brought from other States, or from foreign countries, are ralid and not unconstitutional. ${ }^{1}$

2. Phumley v. Massachusetts, 155 U. S. 461, 15 S. Ct. 154. See, also, Powell v. Pennsylvania, 127 U. S. 678, 8 S. Ct. $992,1257$.

3. Smith v. Alabama, 124 U. S. 465, 8 S. Ct. 564 .

4. Dent v. West Virginia, 129 U. S. 114,9 S. Ct. 231.
5. Plumley v. Massachusetts, 155 U. S. 461,15 S. Ct. 154; Gibbons v. Ogden, 9 Wheat. (U. S.), 1, 203.

6. Gibbons $v$ Ogden, 9 Wheat. (U. S.) 1, 203 ; Plumley v. Massachusetts, 155 U. S. $461,15 \mathrm{~S}$. Ct. 154.

1. Commonwealth v. Harmel, 166 
If a discrimination is made against imported goods, the statute is invalid. ${ }^{2}$ And the rights conferred by the patent laws to inventor's to sell their inventions does not take the tangible property from the operation of the tax and license laws of a State; and one reason why a tax imposed by a State upon persons selling, without license, patented articles not owned by them, is invalid, as applied to patented articles manufactured in another State, is where the statute makes a clear discrimination in favor of home manufacturer's and against the manufacturers of other States. ${ }^{3}$

But where goods have arrived within the State and have become a part of all property, a tax laid alike on all property within a city, is valid and not a law regulating interstate commerce. $^{4}$

$\S$ 552. Tax upon interstate commerce.-The States cannot tax or regulate interstate commerce. So a lincense applied to persons soliciting orders for goods on behalf of a firm in another State, is unconstitutional as inconsistent with the power of Congress to regulate commerce among the States. ${ }^{1}$ But as soon as the goods are in the State and become part of the general mass

Pa. St. 89, 30 A. 1036, 27 L. R. A. 388; Cowles v. Brittain, 2 Hawks, (N. Car.) 204; Wynne v. Wright, 1 Dev. and Bat. (N. Car.), 19 ; Traey v. State, 3 Mo. 3 ; Morrill v. State, 38 Wis. 428, 20 Am. Rep. 12; Howe Machine Co. v. Gage, 9 Baxt. (Tenn.), 518; Graffty v. Rushville, 107 Ind. 502,8 N. E. $609,57 \mathrm{Am}$. Rep. 128 and note; State v. Richards, 32 W. Va. 348,9 S. E. 245 , 3 L. R. A. 705 and note; Commonwealth v. Gardner, 133 Pa. St. 284, 19 A. 550,37 L. R. A. 666 and note, 19 Am. St. Rep. 645; Emert v. Missouri, 156 U. S. $296,15 \mathrm{~S}$. Ct. 367 ; Attorney General v. 'Tongue, 12 Price, 51, 60; Commonwealth v. Ober, 12 Cush. (Mass.)
493; People v. Russell, 49 Mich. 617, 14 N. 568, 43 Am. Rep. 478; Howe Machine Co. v. Gage, 100 U. S. 676 .

2. Cook v. Pennsylvania, 97 U. S. 566; Woodruff v. Parham, 8 Wall. (U. S.), 123; Hinson v. Lott, 8 Wall. (U. S.), 148; Welton v. Missouri, 91 U. S. 275.

3. Webber v. Virginia, 103 U. s'. 344.

4. Brown v. Houston, 114 U. S. 622, 632, 5 S. Ct. 1091.

1. Robbins v. Shelly Taxing Dist., 120 U. S. 489,7 S. Ct. 592 ; Asher v. Texas, 128 U. S. 129. $9 \mathrm{~S}$. Ct. 1 ; Brennan v. Titusville, $153 \mathrm{U}$. S. 289,14 S. Ct. 829 . 
of property, they will become liable to be taxerl in the same manner as other property of similar character. ${ }^{2}$

Where goods are sent from one State to another for sale, or in consequence of a sale, they become part of its general property and amenable to its laws; provided that no discrimination be made against them as goods from another State, and that they be not taxed by reason of being brought from another State, but only taxed in the usual way as other goods are. ${ }^{3}$ But this exemption of interstate and foreign commerce from State regulation does not prevent the State from taxing the property of those engaged in such commerce located within the State, as the property of other citizens is taxed, nor from regulating matters of local concern which may incidentally affect commerce. ${ }^{4}$

But a statute prohibiting the sale of intoxicating liquors without a license is, as applied to a sale of liquors in the original packages and by the person who had brought them into the State from another State, inconsistent with the powers of Congress to regulate commerce among the States, and unconstitutional. ${ }^{5}$

$\S 553$. When is the imported commodity incorporated with the general mass of property.-The point of time, when the prohibition ceases and the power of the State to tax commences, is not the instant when the article enters the country, but when the importer has so acted upon it that it has become incorporated and mixed up with the mass of property in the country, which happens when the original package is no longer such in his hands; that the distinction is obvions between a tax

2. Brown v. Houston, 114 U. S. 622, 5 S. Ct. 1091.

3. Howe Machine Co. v. Gage, 100 U. S. 676.

4. Leloup v. Mobile, 127 U. S. 640, 8 S. Ct. 13s0. See, also, Pullman Car. Co. v. Peunsylvania. 141 U. S. 18,11 S. Ct. S76; Ficklin v. Shelly Taxing Dist., $145 \mathrm{U}$.
S. 1,12 S. Ct. 810 ; Postal Telegraph Co. v. Charleston, $153 \mathrm{U}$. S. 692, 14 S. Ct. 1094; Postal Telegraph Co. v. Adams, 15j U. S. 68s, 15 S. Ct. 268, 360.

5. Leisy r. Lardin, 135 U. S. 100, 10 S. Ct. 681 ; Lyng v. Michigan, 13.5 U. S. 161,10 S. Ct. 725. 
which intercepts the import as an import on its way to become incorporated with the general mass of property, and a tax which finds the article already incorporated with that mass by the act of the importer. ${ }^{5}$

554. Statute incorporating imported goods.-Congress has enacted that all imported liquors or liquids shall, upon arrival in a State, fall within the category of domestic articles of a similar nature; that they shall be subject to the operation and effect of the laws of such State enacted in the exercise of the police power, to the same extent and in the same manner as though such liquids or liquors had been produced in such State, and shall not be exempt therefrom by reason of being introduced therein in original packages or otherwise.' This statute is valid and is a constitutional exercise of the legislative power conferred upon Congress. After this act took effect such liquors or liquids, introduced into a State, whether in original packages or otherwise, became subject to the operation of such of its then existing laws as has been properly enated in the exercise of its police power. ${ }^{2}$

5. Brown v. Maryland, 12 Wheat. (U. S.) , 419.

1. 26 U. S. Stat. 313 .
2. In re Rahrer, 140 U. S. 545. 11 S. Ct. 865 . 


\section{ARTICLE V. \\ Imparment of Remedy.}

SEctron 555. Laws Enter into the Contract.

556. Altering the Remedy.

557. Ret rospective Aets.

558. Exemptions.

559. Limitations.

560. Abolishing Remedy.

561. Redemption from Sales of Real Estate.

562. Speeific Liens.

563. Changing Rate of Interest on Judgment.

564 . Reducing liate of Interest in Redemption.

565. Change of Procedure.

566. Extending the Period of Redemption.

567. Resale When Bought by Mortgagor for Less than the Debt.

$\S 555$. Laws enter into the contract.-The laws subsisting in a State at the time a contract is made, including those which affect its validity, construction, discharge, or enforcement, enter into and form a part of the contract, as if they were expressly referred to or incorporated in its terms. ${ }^{1}$ And so the laws which prescribe the mode of enforcement of a contract, which are in existence when it is made, are so far a part of it that no changes in these laws which seriously interfere with that enforcement are valid, because they impair its obligation within the meaning of the Federal constitution. ${ }^{2}$ The meaning of this rule is that the laws exist-

1. Van Hoffman v. Quiney, 4 Wall. (U. S.), 550; Walker v. Whitehead, I6 Wall. (U. S.), 314; Edwards v. Kearzey, 96 U. S. 595; Seibert v. Tewis, 122 U. S. 284,7 S. Ct. 1190; Louisiana v. New Orleans, 102 U. S. 206; Robards v. Brown, 40 Ark. 423; Webster v. Rees, 23 Iowa, 269; Rogers v. Allen, 47 N. H. 529; Roberts v. Cocke, 28 Gratt. (Va.) 207; Van Schoonhoven v. Curley, 86 N. Y. 187; Brine v. Ins. Co., 96 U. S. 627: O'Kelly v.
Williams, 84 N. Car. 281; Banks v. Dewitt, 42 Ohio St. 263; Elliott v. Railway Co., 10 II. L. Cas. 333.

2. Barnitz v. Beverly, 163 U. S. 118, $16 \mathrm{~S}$. Ct. 1042; Watkins v. Glenn, 55 Kan. 417, 40 1'. 316; Greenwood $v$. Butler, 52 Kan. 424, i4 P. 967, 22 L. R. A. 465 ; Bronson v. Kinzie, l How. (U. S.) 316 ; Ogden v. Sanders, 12 Wheat. (U. S.) 259 ; MeCracken v. Hayward, 2 How. (U. S.) 612. 
ing at the time a contract is made, which enter into and form a part of it, are only those which, in their direct or necessary legal operation, control or affect the obligations of such contract. $^{3}$

$\S 556$. Altering the remedy.- Whatever belongs merely to the remerly may be altered according to the will of the State, provided the change does not impair the obligation of the contract. If it makes a material alteration, it is immaterial whether it is done by acting on the remedy or directly on the contract itself. In either case it is prohibited by the constitution. ${ }^{4}$ So an act requiring the holder of certain coupons first to pay his taxes in cash, and file his coupon in the court, and afterwards, in a circuitous way, receive back his money, is an act affecting the remedy only, and does not impair the obligation of contract, although the funding act under which the coupons were issued required the State to receive them for all taxes and demands due her. ${ }^{5}$

The laws in reference to which the parties must be assumed to have contracted are those which in their direct or necessary legal operation control or affect the construction and operation and obligations of the contract, and not those which affect merely the remedy. ${ }^{\circ}$

$\S 557$. Retrospective acts.-A statute may not be void because retrospective. Thus, a statute requiring the holder of a

3. Conn. Muı. L. etc. Insurance Co. v. Cushman, 108 U. S. 51, 65, 2 S. Ct. 949. See, also, Gantly v. Ewing, 3 How. (U. S.) 716; Ex parte Christy, 3 How. (U. S.) 328 ; Clark v. Reyburn, 8 Wall. (U. S.), 322 ; Walker v. Whitehead, 16 Wall. (U. S.) 314 ; Howard v. Bugbee, 24 How. (U. S.) 46l; Gunn v. Barry, 15 Wall. (U. S.), 601 : Memphis v. United States, 97 U. S. 293 ; Kring v. Missouri, 107 U. S. 233 , 2 S. Ct. 443 ; Britz v. Muscatine, 8
Wall. (U. S.), 575; Mobile v. Watson, 116 U. S. 305,6 S. Ct. 398.

4. Bronson v. Kinzie, 1 How. (U. S.) 311 ; Temmessee v. Sneed, 96 U. S. 74 .

5. Antoni v. Greenbow, 107 U. S. 769, 2 s. Ct. 91.

6. Connecticut Mut. L. etc. Insurance Co. v. Cushman, 108 U. S. 51, 2 S. Ct. 236 ; Morly v. Railroad Co., 146 U. S. 162,13 S. Ct. 54; Fourth Nat. Bank v. Franklyn, 120 U. S. 747,7 S. Ct. 757 ; Curtis v. Whitney, 13 Wall. (U. S.) 68. 
tax sale certifieate, made before its passage, to give the occupant of the land three monthe' notiee, trigether with a copy of the certificate and the name of the holder, does not impair the obligation of the contract evidenced by the certificate.

It is one of the contingeneies to which parties look now in making contracts that they may be affected in many ways by State and national legislation. For such legislation, demanded by the publie good, however it may retroact on contracts previously made, and enlance the cost and difficulty of performance, or diminish the value of such performance to the other party, there is no restraint in the Federal eonstitution, so long as the obligation of performance remains in full force. ${ }^{8}$

Hence, a law relieving a debtor from imprisonment for debt does not impair the obligation of contract, becanse it is only a modification of the remedy given by the legislature for the enforcement of the contract, and not a part of the obligation. ${ }^{9}$ And a retroactive effect is not given to a statute making combinations in restraint of trade illegal, by applying the statute to a continuation, after its passage, of a pre-existing contract. ${ }^{10}$

$\S 55^{8}$. Exemptions.-Exemption laws operate on the remedy for a breach of contracts, and the legislature has the power to change them according to its own views of policy so as to affect the remedy upon existing eontracts, but not to the extent of reudering it mugatory and impracticable. ${ }^{1}$ It is constitutionally competent for the legislature to determine the amount of property that shall be exempt from seizure or sale for the parment of any debt or liability, and to increase and diminish such amount

7. Curtis v. Whitney, 13 Wall. (U. S.) 6s. See, also, United States v. Freight Asso., 166 U. S. 290, IT S. Ct. $5+0$.

8. Curtis v. Whitney, 13 Will. (U. S.) 68.

9. Sturges $v$. Crowninshield, 4 Wheat. (U. S.) 122; Mason v. Haile, 12 Wheat. (U.S.) 370 ; Edwards v. Kearzey, 96 U. S. 595;
Fisher v. Lackey, 6 Black (Ind.), 373 ; Penniman's Case, 103 U. S. 714; Brunson v. Newbury, 2 Doug. (Mich.) 38.

10. United States v. Freight Asso., 166 U. S. 290, 17 S. Ct. 540.

1. Stephenson v. Osborne, 41 Miss. $119,90 \mathrm{Am}$. Dec. 358 and note; Morse v. Goold, 11 N. Y. 281, 62 Am. Dec. 103. 
from time to time, but it camnot in its exemption laws discriminate between different classes of creditors and kinds of debts. ${ }^{2}$ If the law is reasonable, it applies to past as well as to future contracts. $^{3}$ It has been held that a homestead exemption given by the constitution can be maintained by the debtor as against a judgment rendered before the adoption of the constitution, where no such exemption cxisted, ${ }^{4}$ provided it is reasonable. But if such exemption had been excessive and unreasonable as applies to obligations existing prior to the adoption of the constitution, it will be declared unconstitutional and roid. ${ }^{5}$

$\$ 559$. Limitations.-The law of limitations is not considered a part of the contract; hence, the legislature may enact a law limiting the time within which actions may be brought to enforce demands where there was before no period of limitation, or may shorten the existing time of limitation; and such a law may operate upon existing contracts, as it does not come under the constitutional prohibition. ${ }^{6}$

$\S 560$. Abolishing remedy.-Where the act merely modifies the remedy or gives another in its place, for enforcing contracts, it does not conflict with the Federal constitution. So the right to distrain for suit may be abolished, and such law applies to leases in existence when the act was passed. ${ }^{1}$

And so a law subsequently enacted may deprive a creditor, under certain circumstances, of his remedy by attachment,

2. Coleman v. Ballandi, 22 Minn. 144; Tuttle v. Stout, 7 Minn. 465, $82 \mathrm{Am}$. Dec. 108 and note; Cogel v. Mickow, 11 Minn. 475.

3. Taylor v. Stockwell, 66 Ind. 505 ; Rockwell v. Hubbell, 2 Doug. (Mich.) 197, 45 Am. Dec. 246 and note; Sneider v. Heidelberger, 45 Ala. 126; Hardeman v. Donovan, 39 Ga. 425.

4. Cusic v. Douglas, 3 Kan. 123, $87 \mathrm{Am}$. Dec. 458 and note. This case is undoubtedly carried too far.
5. Edwards v. Kearzey, 96 U. S. 595.

6. Sturges v. Crowninshield, 4 Wheat. (U. S.) 122; Hawkins v. Barney, 5 Pet. (U. S.) 457 ; Smith v. Morrison, 22 Pick. (Mass.) 430 ; Call v Hagger, 8 Mass. 423; Smith v. Packard, 12 Wis. 371 ; Kenyon v. Stewart, $44 \mathrm{~Pa}$. St. 179.

1. Stocking v. Hunt, 3 Denio ( $N$. Y.), 274 ; Conkey v. Hart, 14 N. Y. 22. 
which existed in full foree when the contract was marle? A creditor of an assigning debtor acquires no vesterl right in the assets by means of the assignment. The assignes is the agent of the law, and all the proceerlings in the future settlemente of the assets are subject to the law of the legislature.

In act providing that in forectosure procesting thereatter commeneed no perwonal judgment shonkt be taken is valid as to past contracts, the remerly by action at law for the defieieney being still left. ${ }^{+}$So a litw is valid which proviles that no eivil process shonld issue or he enforced against any person in the military service of the State or the United States; and it applies to a writ of scirr facias upon a mortgage, mless expressly prohibited by the act of the contracting parties, and is not umconstitutional as impairing the obligation of contracts.

Legal remedie: are in the fullest sense under the rightiul control of the legislature of the several States, notwithstanding the provision in the constitution of the United States prohiliting the impairment of the obligation of contracts; and it is no valid objection to legislation on that subject, that the substituted remedy is less beneficial to the creditor than the one which existed at the time the debt was contracted. ${ }^{6}$

The legislature may change and modify remedies, forms of proceedings, and the tribunal itself, but it shall not directly or indirectly destroy or abolish all remedy whatever, by which the contracts are to be enforced. ${ }^{7}$

An adequate and reasonable mode of enforeing the right must remain, or be providerl, which leaves the value of the contract

2. Bigelow v. Pritchard, 21 Pick. (Mass.) 169 .

3. In re Mechanies and 'Farmers' Bank, 31 Conn. 63.

4. Newark Sav. Inst. v. Forman, 33 N. J. Eq. 436.

5. Coxe v. Martin, $44 \mathrm{~Pa}$. St. 322. See, also, Evans v. Montgomery, 4 Watts \& S. (Pa.) 218; Van Rensselaer v. Hayes, 19 N. Y. 68, 75 Am. Dec. $27 \mathrm{~S}$ and note; Wason v. Railroad Co., 47 N. Y. 157.
6. In re Mechanies and Farmers' Bank, 31 Conn. 63; Wolff' v. New Orleans, 103 U. S. 35s; Penrose v. Canal Co., $56 \mathrm{~Pa}$. St. 46, $93 \mathrm{Am}$. Dee. 77s: Simpson v. Bank, $56 \mathrm{~N}$. H. 466, 2.2 Am. Rep. 491.

7. Richardson $v$. Cook, $3 i$ Vt. 599, ss Am. Hee. 622; Baldwin $v$. Newark, 38 N. J. L. 158; MeMillan v. Sprague, 4 How. (Miss.) 647, 35 Am. Dec. 412. 
without substantial depreciation or impaiment. ${ }^{8}$ Therefore the legislature may modify or change existing remedies or prescribe new modes of procedure, withont impairing the obligation of contracts, provided a substantial or efficacious remedy remains or is given by means of which a party can enforce his rights under the contraet. ${ }^{9}$

$\S 56 \mathrm{I}$. Redemption from sales of real estate. - A law made after the date of a contract, which gives a more speedy and efficacious remedy to the creditor, is not unconstitutional. It is only where, by a change of the remedy, the obligation of the contract is impaired that the constitution is violated. ${ }^{1}$

The eollection laws existing when a contract is made are no part of the contract, and give the debtor no vested right. ${ }^{2}$ But. a sale of real estate under a judgment rendered before a statute is enacted, should conform to the law in foree at the time the judgment was rendered. ${ }^{3}$

The right to acquire a lien upon real estate by judgment, and the right to sell real estate upon exeention, are derived from the statute. These are rights altogether ontside of the creditor's contract. A creditor, even though he may have reduced his elaim to judgment, has no contractual interest or estate in his debtor's land. ${ }^{4}$

8. Lockett $v$. Usry, 28 Ga. 345 ; Read v. Bank, 23 Me. 318; White v. Hart, 13 Wall. (U. S.) 646; Davis v. Rupe, 114 Ind. 588, 17 N. E. 163; Lessley v. Phipps, 49 Miss. 790; Planters' Bank v. Sharp, 6 How. (U. S.) 301 ; Taylor v. Stockwell, 66 Ind. 505; Stocking v. Hunt, 3 Denio (N. Y.), 274; Tennessee v. Sneed, 96 U. S. 69; Newark Sav. lnst. v. Forman, 33 N. J. Eq. 436 ; Morse v. Gould, 11 N. Y. 281, 62 Am. Dec. 103; Edwards v. Kearzey, 96 U. S. 595.

9. Green v. Biddle, 8 Wheat. (U. S.) 1; Bronson v. Kinzie, l How. (U. S.) 317 ; MeCullough v. Vir- ginia, 172 U. S. 102, 19 S. Ct. 134 ; Oskosh Water Works Co. v. Oskosh, 187 U. S. 437,23 S. Ct. 234; Vance v. Vance, 108 U. S. 514, 2 S. Ct. 854 .

1. Blair $\because$ Williams, 4 Litt. (Ky.) 34; Lapsley v. Brashear, 4 Litt. (Ky.) 47 ; Sturges v. Crowninshield, 4 Wheat. (U. S.) 122. Compare Cargill v. Power, 1 Mieh. 370.

2. Grubbs v. Harris, 1 Bibb (Ky.), 567; Reardon v. Searcy, 2 Bibb (Ky.), 202.

3. Holland v. Dickerson, 41 Iowa, 367.

4. Gimbel v. Stalte, 59 Ind. 446 ; Iverson v. Shorter, 9 Ala. 713; Ber- 
The rights and remedies given by statute are not secured by contract, and the ereditor stands wholly upon the law which gives him the renedy for the collection of his deht. Iraving contracts for no speeific lien or renedy, the ereditor agrees, in effect, that he will take the remedy as he may find it, subjeet only to the condition that it shall be reasonably adequate to make his contract effectual by legal compulsion, and such as other creditors in like ciremustances are entitled to by the laws of the land. ${ }^{5}$

$\S$ 562. Specific liens.-Where the ereditor has aequired a speeific lien upon or interest in property by contract, his rights in the specifie property are then contractual, and it is not competent for the legislature to interpose in behalf of the debtor, and, by enlarging his rights, or by modifying the rights of the creditor, to impair or depreciate the value of an antecedent debt or security. So the vendible value of the estate or interest of a mortgagee, or other holder of a specific lien upon real estate, cannot be materially affected or appreciably diminished by an act of the legislature which rendered consummate the prior inchoate right of a married woman in the real estate of her husband. ${ }^{1}$

Likewise a redemption law, the effect of which is to depreciate the value of an antecedent security, existing by way of mortgage, or which changes the character of the estate which passes by sale under a power contained in the mortgage, camot be upheld. ${ }^{2}$ And the seeurity or danger clanse in a chattel mortgage is a contract right and cannot be nullified by subsequent legislation. ${ }^{3}$

thold v. Fox, 13 Minn. 501, $97 \mathrm{Am}$. Dec. 243; 'Thorn v. Sin Francisco, 4 Cal. 127; Watson v. Railroad Co., 47 N. Y. 157 ; Moore v. Martin, 38 Cal. 428; Butler v. Palmer, 1 IIill (N. Y.), 324; Daris r. Rupe, 114 Ind. 588,17 N. E. 163.

5. Davis v. Rupe, 114 Ind. 588. 17 N. E. 163.
1. Helphenstine $v$. Meredith, 84 Ind. 1 ; Buser v. Shepard. $10 \bar{t}$ Ind. 417. 8 N. E. 280 .

2. Codington v. Bispham, $36 \mathrm{~N}$. J. Eq. 574: llillebert v. Porter. 28 Ninn. 496, 11 N. 44.

3. Boice $v$. Boice, 27 Minn. 371 , 7 N. 687. 
So the law in force at the time a mortgage is executed gives the mortgagee a specific lien upon the mortgaged premises. The remedy to redeem provided when the mortgage is executed enters into the convention of the parties, in so far that any change by the legislature which affects it substantially to the injury of the mortgage, is a law impairing the obligation of contracts within the meaning of the constitution of the United States. ${ }^{*}$

$\S 563$. Changing rate of interest on judgment.-One line of decisions holds that the constitutional prohibition does not forbid a State from legislating, within its discretion, to reduce the rate of interest upon judgment previously obtained in its courts; as the judgment creditor has no contract whatever in that respect with the judgment debtor, and as the former's right to receive, and the latter's obligation to pay exist only as to such amount of interest as the State chooses to prescribe as a penalty or liquidated damages for the nonpayment of the judgment. ${ }^{5}$

But other decisions hold the contrary, because the effect of a judgment is to fix the rights of the parties thereto by the solemn adjudication of a court having jurisdiction, and such rights cannot be affected by subsequent legislation. Changing the rate of interest does not affect existing contracts or debts due prior to such enactment, whether they are evidenced by statute, by judgment, or by agreement of the parties. The parties' rights are fixed by the judgment of the court and the judgment carries with it its incidents, equally determined and all relating to the date of its entry; and, hence, the interest on

4. Pingrey on Mortg. 2138; Baldwin v. Flagg, 43 N. J. L. 495 ; Robards v. Brown, 40 Ark. 423; Allen v. Allen, 95 Cal. 184, 30 P. 213; Phinney v. Phinney, 81 Me. 450,17 A. 405,4 L. R. A. 348 and note, 16 Am. St. Rep. 266; Howard v. Bugbee, 24 How. (U. S.) 461; Champion v. Hinkle, 45 N. J. Eq. 162, 16 A. 701; Gunn v. Barry, 15 Wall. (U. S.) 610 .

5. Morley v. Railroad Co., 146 U. S. 162,13 S. Ct. 54, affirming O'Brien v. Young, 95 N. Y. 428. 
a judgment cannot be reduced." And it is of no consequemos that the judgment, althongh calling for interest on the anomut adjudged, did not speoify the rate. The statute, them in foree, fixed the rate, as the interest 10 mon a julgumost, secured by pusi-

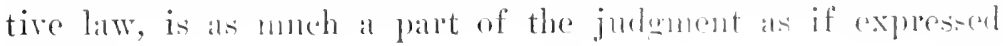
in it. ${ }^{7}$

$\$ 564$. Reducing rate of interest in redemption. The pul'chaser at a decretal sale is entitled to interest at the rate presseribed by the statute when he purehased; and this rule is applieable to all decretal sales of mortgaged premises thereafter made, althongh the nortgage was given before the pasaage of the act. Sneh a rednetion in the rate of interest does not inpair the obligation of contraets between mortgagor and mortgagee, because the subsequent statute does not diminish the duty of the mortgagor to pay what he agreed to pay, or shorten the period of parment, or affect any remedy which the mortgagee had, by existing law, for the enforcement of his contract.

$\S 565$. Change of procedure.-Where the change in the procedure to collect debts does not materially affeet the obligation it will be upheld. Thus, where the stockholders of a company are made jointly and severally liable for all debts of the company until the whole amount is paid, a subsequent statute may change the right to proceed as specified in the original statute, and provide that all proceedings to enforce the liability of a stockholder for the debts of the company shall be either by suit in equity or by an aetion of debt upon the judgment obtained against the company or corporation, notwithstanding the fact that creditors were delayed. ${ }^{1}$

6. Cox v. Mailatt, 36 N. J. I. 389, and cases cited, $13 \mathrm{Am}$. Rep. 454 .

7. Amis v. Smith, 16 Pet. (U. S.) 303,311 .

8. Conn. Mrut. L. etc. Insurance Co. v. Cushman, 108 U. S. 51, 2 S. Ct. 236; Robertson v. Van Cleave,
129 Ind. 217,26 N. E. 899,29 N. E. 781,15 L. R. A. 68 and note.

1. Oshkosh Wiater Works Co. v. Oshkosh, 1ST U. S. 437,23 S. Ct. 234; McCullough v. Virginia, 172 U. S. 102,19 S. Ct. 134; Fourth Nat. Bank v. Francklyn, 120 U. S. 747,7 S. Ct. 757. 
But a statute which provides that a sale shall not be made of property levied on under an exeention, unless it shall bring two-thirds of its valuation according to the opinion of three householders, is unconstitutional, because any law in its operation amounts to a denial or obstruction of the rights accruing by a contract, though professing to act only on the remedy. This subsequent law impairs the obligation of the contract, by superadding a condition that there shall be no sale for any sum less than the valne of the property levied on, to be ascertained by appraisement, or any other mode of valuation than a public sale, and affects the obligation of the contract, for it can be enforced only by a sale of the defendant's property, and the prevention of such sale is the denial of a right. ${ }^{2}$

So a statute authorizing redemption of mortgaged property in two years after the sale under a decree, by bona fide creditors of the mortgagor, is unconstitutional and void as to sales made under mortgages executed prior to the enactment. ${ }^{3}$ And so where a State gives a time for redemption to mortgage sales, the United States courts must follow such law and allow the mortgagor the preseribed time to redeem. ${ }^{4}$

$\S 566$. Extending the period of redemption.-Whatever belongs merely to the remedy may be altered according to the will of the State, provided the alteration does not impair the obligation of the contract. But if the obligation is impaired, it is immaterial whether it is done by acting on the remedy or directly on the contract itself. In either case it is prohibited by the constitution. ${ }^{1}$ Where the subsequent statute does not act upon the remedy but directly upon the contract itself, and adds a new condition injurious and unjust to the mortgagee, it is unconstitutional. Thus, when the subsequent statute declares that the equitable estate of the mortgagor after breach shall

2. McCracken v. Hayward, 2 How. (U. S.) 608 .

3. Howard v. Bugbee, 24 How. (U. S.) 461. See, also, Bronson v. Kinzie, l How. (U. S.) 311.
4. Brine v. Ins. Co., 96 U. S. 627 , 637.

1. Bronson v. Kinzie, 1 How. (U. S.) 311 ; Green v. Biddle, 8 Wheat. (U. S.) 75 . 
continue twelve months after the sale, a right which is adred to the original contract by legislation, the statute is void as impairing the obligation of contract. ${ }^{2}$ So a subsequent statute which authorizes the redemption of property sold upon fore. closure of a mortgage, where no right of redemption previonsly existed, or which extends the period of rectemption beyond the time formerly allowed, is unconstitutional as applied to a sale under a mortgage excented before its passage. ${ }^{3}$

The law subsequently cannot carve out for the mortgagor or the owner of the mortgaged property an estate of several months more than was obtainable by him under the former law, with full right of possession, and without paying rent or accounting for profits in the meantime. What is sold under the subsequent act is not the estate mortgaged, but an estate subject to the possession, for the time extended, of another person who is under no obligation to pay rent or to account for profits, and the act therefore impairs the obligation of contract, and is void. ${ }^{4}$

\section{$\S 567$. Resale when bought by mortgagor for less than the} debt. $-\Lambda$ statute providing that property once sold under a mortgage foreclosure shall not be resold if bought by the mortgagor for less than the debt, to satisfy the unpaid part of the debt, is void as to mortgages exeented before the law was enacted. Such a change in the law is not merely the substitution of one remedy for another, but is a substantial impairment of the rights of the mortgagee, as expressed in the contract, and is uneonstitutional. ${ }^{1}$

2. Bronson v. Kinzie, 1 How. (U. S.) 311. See, also, McCracken v. Hayward, 2 How. (U. S.) 608; Howard v. Bugbee, 24 How. (U. S.) 461.

3. Barnitz v. Beverly, 163 U. S. 118, 16 S. Ct. 1042, overruling Beverly v. Barnitz, 55 Kan. 461, 42 P. 725, and, in effeet, overruling State v. Sears, 29 Oreg. 580, 43 P. 482, 46 P. 7S5. 54 Am. St. Rep. S0s; Van Baumbach v. Bade, 9 Wis. 559, $76 \mathrm{Am}$. Dec. 283.
4. Barnitz v. Beverly, 163 U. S. 118,16 S. Ct. 1042; Howard v. Brigbee, 24 How. (U.S.) 461 ; Greenwood v. Butler, 52 Kan. 424, 34 P. 967,22 L. R. A. 465 ; Watkins v. Glenn, 55 Kan. 417, 40 P. 316; State v. Gilliam, is Mont. 94, 45 P. 661, overruling same case, $44 \mathrm{P}$. 394,33 L. R. A. 556.

1. Barnitz v. Beverly, 163 U. S. 118, 16 S. Ct. 1042. 
But if the law was in force when the mortgage was executed it will apply. Thus, many statutes declare that the sale on a judgment or decree exhausts it as to the property sold, and the judgment creditor cannot, after redemption by a junior encumbrancer, resell the land to enforce payment of an unsatisfied part of the judgment or decree. ${ }^{2}$

The object of the law is to compel creditors to bid a fair and adequate price for the debtor's property, and to prevent them from bidding a small sum, and, in the event of a redemption, again subject the property to sale. The policy of the law is to prohibit the creditor from selling the property more than once for his own benefit, and to secure a just and fair price for the property in the first instance. ${ }^{3}$

2. Horn v. Bank, 125 Ind. 381,25 N. E. 558,9 L. R. A. 676,21 Am. St. Rep. 231 and note; Anderson v. Anderson, 129 Ind. 573, 29 N. E. 35, 28 Am. St. Rep. 211; Green v. Stobo, 118 Ind. 332, 20 N. E. 850; Hervey v. Krost, 116 Ind. 268, 19 N. H. 125; Simpson v. Castle, 52
Cal. 644; People v. Eastern, 2 Wend. (N. Y.) 298; Russell v. Allen, 10 Paige (N. Y.), 249; Clayton v. Ellis, 50 Iowa, 590.

3. Anderson v. Anderson, 129 Ind. 573,29 N. E. 35,28 Am. St. Rep. 211. 


\section{PART V.}

TERMINATION OF CONTRACTS. 



\title{
PAR'T V.
}

CHAPTER XIX.

Impossible Contracts.

\begin{abstract}
ARTICLE I.
Discharge by Impossibility of Contract.
\end{abstract}

Section 568. Impossible.

569. Difliculty and Hardship.

570. Condition Precedent.

571. Nonexistence of Subject-Matter.

572. Subject-Matter Ceasing to Exist.

573. Impossibility of Performing a Contract Subsequently Arising.

574. In Commercial Transactions.

575. Bailment of an Article to Be Repaired.

576. Excused by Act of Law.

577. Two Ways of Performance.

578. Judgments and Other Judicial Processes.

579. Promisee Preventing Performance.

§ 568. Impossible.-Every person who, in eonsideration of some advantage either to himself or to another person, promises a benefit, must have the power of conferring that benefit up to the existence to which that benefit professes to go, and that not only in fact but in law; that is, the thing to be done should, in itself, be legal, and the party by whom the promise is made should have the power of carrying it into effeet. If these conditions do not exist, the undertaking has no elements of a contraet and is therefore of no avail to either party. ${ }^{1}$

It is elementary law that when the contract is to do a thing

1. Nerot v. Wallace, 3 Term R. 17. 
which is possible in itself, the promisor will be liable for a breach thereof, notwithstanding it was beyond his power to perform it, for it was his own fault of running such risk of undertaking to perform an impossibility, when he may have provided against it by his contract. But where from the nature of the covenant it is apparent that the parties contract on the basis of a continued existence of a given person or thing, condition is implied that if the performance becomes impossible, from the perishing of the person or thing that shall excuse such performance. $^{2}$

And if the performance of a condition be prevented by the party entitled to take advantage of a breach, this excuses the performance. ${ }^{3}$

If the thing is only improbable, or ont of the power of the promisor, it is not in law deemed impossible. ${ }^{4}$ Impossibility does not mean anything more than a prima facie legal impossibility or physical impossibility according to the state of knowledge of the period. ${ }^{5}$ The contract may be either impossible at law or in fact. ${ }^{6}$ So where there is obvious physical impossibility, or legal impossibility, which is apparent on the face of the contract, the contract is void. ${ }^{7}$ Where a contract shows that it is based on certain facts which have no existence, the contract is invalid. ${ }^{8}$

The principle deducible from the authorities is that, if what is agreed to be done is possible and lawful, it must be done. Difficulty or improbability of accomplishing the understanding will not avail the defendant. It must be shown that the thing

2. Walker v. Tucker, 70 1ll. 524.

3. Whitney v. Speneer, 4 Cow. (N. Y.) 39 ; Carpenter v. Stevens, 12 Vend. (N. Y.) 589; People v. Partlett, 3 Hill (N. Y.), 370; Willianıs v. Bank, 2 Pet. (U. S.) 97 ; Holme v. Guppy, 3 Mees. \& Wel. 387.

4. Clifford v. Watts, L. R. 5 C. P. 588; Beebe v. Johnson, 19 Wend. (N. Y.) 500, 32 Am. Dec. 518.
5. Cliftord v. Watts, L. R. 5 P. C. 588 .

6. Harvey v. Gibbons, 2 Lev. 161; James v. Morgan, 1 Lev. 111 ; Thornborow v. Whiteacre, 2 Ld. Raym. 1164.

7. Jacksonville, ete. Railway v. Hooper, 160 U. S. 514,16 S. Ct. 379.

8. Nordyke v. Kehlor, 155 Mo. 643, 56 S. W. 287, 78 Am. St. Rep. 
cannot by any means be effected. Nothing short of this will excuse nonperformance. ${ }^{9}$

The general rule is that where an inpossibility exists as to the performance of the contract, which is known to the promisor but not to the promisee, the former is liable in damages for failure to perform. Thus, where a telegraph company accepts a message for transmission, but knows that its lines are down and the message cannot be sent, it is liable in damages to the party who gave the dispateh, he not being informed of the impossibility. ${ }^{10}$

$\S 569$. Difficulty and hardship.-If what is agreed to be done is possible and lawful, it must be done. ${ }^{1}$ Difficulty or improbability of accomplishing the undertaking will not arail the defendant. It must be shown that the thing camnot by any means be effected. Nothing short of this will exeuse nonperformance. ${ }^{2}$ The answer to the objection of hardship in all such cases is that it might have been guarded against by a proper stipulation.

It is the province of the court to enforce contracts, not to make or modify them. Where there is neither frand, accident, nor mistake, the exercise of dispensing power is not a judicial function. $^{3}$

Impossible conditions cannot be performed; and if a person contracts to do what at the time is absolutely impossible, the contract will not bind him, because no man ean be obliged to perfor'm an impossibility. But where the contract is to do a thing which is possible in itself, the performance is not excused

600; Gardner v. Lane, 9 Allen (Mass.), 492.

9. The Harriman, 9 Wall. (U. S.) 172,19 L. Ed. 633 .

10. Swan v. West. U. Tel. Co., 127 Fed. Rep. 730: Fleischner v. Paeific l'ost. Tel. Co., 55 Fed. Rep. 738, 60 Fed. Rep. 899 . See "Impossible Contracts." - $\tau$ Western Reserve Law Journal, 99.

l. Touteng v. Ilubbard, 3 Bos. \& Pul. 300 .
2. Beebe v. Johmson, 19 Wend. (X. Y.) 500, 32 Am. Dee. 5ls; Kitzinger $v$. Samborn, 70 lll. 146.

3. The Harriman, 9 Wall. (U. s.) 161. See, also, Blight v. Page, 3 Bos. \& Pul. 295 ; Barker v. llodgson. 3 Maule \& Sel. 271; Mederas v. Hill, 8 Bing. 235; Osgood v. Groning, 2 Camp. 466; Lorillard v. Palmer, 15 Johns. (N. Y.) 114. 
by the occurrence of an inevitable accident, or other contingency, although it was not foreseen by the party, nor within his control. ${ }^{4}$

$\$ 570$. Conditions precedent.-A condition, inserted for the benefit of the party chargeable by the contract, must, in order to avoid the contract, be strictly performed. ${ }^{5}$ But where a condition, either precedent or subsequent, is impossible but not unlawful, it only is void, and the rest of the contract takes effect or is enforceable as though it contained no condition. ${ }^{6}$ If the condition precedent is not known to be impossible when the contract is executed, and it becomes so by the act of God, the other party cannot be placed in default for this cause.

$\S 57$ I. Non-existence of subject matter.-If the contract is made concerning a thing which does not exist, and both parties are acting in good faith, the contract is void, ${ }^{8}$ even though the subject-matter of the contract be known to both parties to be liable to a contingency which may destroy it immediately; yet if the contingency has already happened, the contract will be void. ${ }^{9}$ And this rule may apply to a contract where part only

4. Jones v. United States, $96 \mathrm{U}$. S. 24, 29; Jacksonville, etc. Railway v. Hooper, 160 U. S. 514, 16 S. Ct. 379 .

5. Bruce v. Snow, 20 N. H. 484; Oakley v. Morton, 1 Ker. (N. Y.) 25 .

6. Merrill v. Bell, 6 Sm. \& M. (Miss.) 730; Hughes v. Edwards, 9 Wheat. (U. S.) 489.

7. Howell v. Knickerbocker Ins. Co., 44 N. Y. 276, 4 Am. Rep. 675; Mezell v. Burnett, 4 Jones (N. Car.), 249.

8. Suydam v. Clark, 2 Sand. (N. Y.) 133; Sherman v. Barnard, 19 Barb. (N. Y.) 291; Hazard v. Ins. Co., 1 Sumner, C. C. 218 ; Couturier v. Hastie, 5 H. L. Cas. 673; Smith v. Tiden, I. R. 9 Q. B. 446 ; Gibson v. Pelkie, 37 Mich. 380 .

9. Hitcheock v. Giddings, Daniel, I; Allen v. Hammond, 11 Pet. (U. S.) 63; Daniel v. Mitchel, I Story, C. C. 172; Miles v. Stevens, $3 \mathrm{~Pa}$. St. 21, 45 Am. Dec. 621 and note; Scruggs v. Driver, 3I Ala. 274; French v. Townes, 10 Gratt. (Va.) 513; Ketchum v. Catlin, 21 Vt. 191; Anderson v. Amstead, 69 Ill. 452; Bradford v. Chicago, 25 Ill. 411; Thompson v. Gould, 20 Pick. (Mass.) 134; Silvernail v. Cole, 12 Barb. (N. Y.) 685; Scioto Brick Co. v. Pond, 38 Ohio St. 65; King v. Doolittle, l Head (Tenn.), 77; Harrell v. De Normandie, 26 Tex. 120; Hopkins v. Hinkley, 61 Md. 
of the subjeet-matter is not in existence, thus being valid in part and roid in part. ${ }^{10}$

$\S$ 572. Subject-matter ceasing to exist.-But there is such a defense as an impossibility of performance. Instances of such a defense are found in cases where the subject-matter of the contract had ceased to exist, as where there was a contract of sale of a cargo of grain supposed by the parties to be on its voyage to England, but which, having become heated on the royage, had been unloaded and sold. This contract was void because it imputed that there was something to be sold and purchased at the time of the contract, which had ceased to exist. ${ }^{1}$ So, where a person purchased an annuity which, at the time of the purchase, had ceased to exist owing to the death of the annuitant, the contract was void, and the party could recover the amount paid for it. $^{2}$ This is on the principle that the parties had been mutually mistaken and the contract no longer remains. ${ }^{3}$

Where the continued existence of a thing is essential to the performance of the contract, its destruction ends the contract if both parties are not in fault. ${ }^{4}$ Thus, a lessor of a hotel covenanted with the lessee that the latter should be supplied with water from a spring which became drs, and it was held that the contract ceased. ${ }^{5}$ And so, where a music hall, after being let, was consumed by fire, before the day of performance, the contract ceases and the lessor is not liable. ${ }^{6}$

584; Rogers v. Walsh, 12 Neb. 28, 10 N. 467 ; State v. Illyes, 87 Ind. 405 .

10. Clifford v. Watts, L. R. 5 C. P. 577 .

1. Courturier v. Hastie, $5 \mathrm{H}$. L. Cas. 673; Allen v. Hammond, 11 Pet. (U. S.) 63 .

2. Strickland v. Turner, 7 Exch. 208.

3. Taylor v. Caldwell, 3 Best \& S. 826 ; Walker v. Tucker, 70 Ill. 527 .
4. The Tornado, $10 \mathrm{~S}$ U. S. 342,2 S. Ct. 746 ; Ward v. Vance, $93 \mathrm{~Pa}$. St. 499 ; Dexter v. Norton, 47 N. Y. 62, 7 Am. Rep. 4l5; IVells v. Calnan, $10 \tau$ Mass. 5l4, 9 Am. Rep. 65: Lord v. Wheeler, l Gray (Mass.), 282; Gould v. Murch, 70 Me. 28s, 35 Am. Rep. 325.

5. Ward r. Vance, 93 Pa. St. 499 .

6. Taylor v. Caldwell, 3 Best \& S. 820 . 
And so, where a party endeavored to put machinery into a building of another, and the structure was consumed by fire, no liability could be attached to the owner of the building, and the machinist had no remedy for the work already done.

And where parties paid a wife certain compensation so long as she remained apart from husband, the death of the husband put an end to the contract. ${ }^{8}$ An owner of a stallion insured the mares served by his horse, with a further agreement, that if the service did not prove effective, a free service should be given the following year. Upon this condition, if the stallion dies before the second year, a party whose mare failed to be with foal the first year, must pay for the service $;^{9}$ because the minds of the parties are presumed to have contemplated the possible destruction of the property.

\section{$\S 573$. Impossibility of performing a contract subsequently} arising.-Impossibility of performing a contract, arising after the making of it, although without any fault on the part of the covenantor, does not discharge him from his liability under it. ${ }^{1}$ Where a party by his own contract creates a duty or charge upon himself, he is bound to make it good if he may, notwithstanding any accident by inevitable necessity, because he might have provided against it by his contract. ${ }^{2}$

7. Appleby v. Myers, L. R. 2 C. P. 651, reversing same case in $1 \mathrm{C}$. P. 615. Compare Cleary v. Sohier, 120 Mass. 210; Richardson v. Shaw, 1 Mo. App. 234.

8. Miller v. Woodward, 2 Beav. 271.

9. Price v. Pepper, 13 Bush. (Ky.) 42.

1. Jacksonville, etc. Railroad Co. v. Hooper, 160 U. S. 514,16 S. Ct. 379; Paradine v. Jane, Aleyn, 26; Bunn v. Prather, 21 Ill. 217 ; School District v. Dauchy, 25 Conn. 530, 68 Am. Dec. 371; Davis v. Smith, 15 Mo. 467; Jemison v. MeDaniel,
25 Miss. 83; Engster v. West, 35 La. Ann. 119, 48 Am. Rep. 232; Dermott v. Jones, 2 Wall. (U. S.) 1 .

2. Paradine v. Jane, Aleyn, 26; Walton v. Waterhouse, $2 \mathrm{Wm}$. Saund. 422, a; Brecknoek Company v. Pritehard, 6 Term R. 750; Ford v. Cotesworth, L. R. 4 Q. B. 127; Kearson v. Pearson, 7 Hurl. \& N. 386 ; Booth v. Mill Co., 60 N. Y. 487; Stees v. Leonard, 20 Minn. 494; Kitzinger v. Sinborn, $70 \mathrm{Ill}$. 146; Bacon v. Cobb, 45 11l. 47 ; Harrison v. Railroad Co., 74 Mo. 364, 41 Am. Rep. 318; Adams v. Nichols, 
Thus, if a person contracts to build a house, he is neither excused from performance, nor entitled to recover for what he has done, when the house is destroyed by fire or other cause beyond his control, before completion of the work and acceptance by the owner. ${ }^{3}$

If a man modertakes what he cannot perform, he is responsible to the person with whom he eontracts.

\$574. In commercial transactions.-In establishing rules of liability in commercial transactions, they should be uniform and certain. It is presumed that the parties contemplated the continued existence of the subject-matter of the contract. Thus, where a contract is made for the sale and delivery of specified articles of personal property, under such circumstances that the title does not vest in the vendee, if the property is destroyed by accident, without the fault of the vendor, so that the delivery is never made, the vendor is not liable to the rendee in damages for nondelivery. ${ }^{1}$

So, if a party agrees to sell and deliver personal property to the rendee on a fixed day, and the property is destroyed in the interval, the obligation ceases and the vendee has no remedy. ${ }^{2}$ There is no hardship in placing the parties in the position they were in before the contract was made. And it can

19 Pick. (Mass.) 275, 31 Am. Dec. 137; School Trustees v. Bennett, 27 N. J. L. 513, 72 Am. Dec. 373: The Harriman, 9 Wall. (U. S.) 161 ; Jacksonville, etc. Railway $r$. Hooper, 160 U. S. 514,16 S. Ct. 379 ; Atkinson $r$. Ritehie, 10 East, 530. See, also, Bullock $\dot{v}$. Dommit, 6 Term R. 650; Phillips v. Stevens, I6 Mass. 23s; Gates v. (ireen, 4 Paige (N. Y.), 35. $27 \mathrm{Am}$. Dee. 68; Holtzapffell v. Baker, is Ves. 115 .

3. School Trustees v. Bennett, 27 N. J. L. 513, 72 Am. Dec. 373; Feldew v. Besley, 42 Mich. 100, $3 \mathrm{~N}$. 27S, $36 \mathrm{Am}$. Rep. 433 and note;
Lawing v. Rentles, 97 N. Car. 350, 21 S. E. 252. See, also, Brecknock Company v. Pritchard, 6 Term R. 750 ; Siegel v. Eaton, Ilis 111 . 550,46 N. E. 449.

4. Blight v. Page, 3 Bos. \& Pul. 295; Baker v. Hodgson, 3 Maule \& Sel. 271; Mederes v. Hill, S Bing. 235; Osgood v. Groning, 2 Cump. 466: Market Co. v. New Orleans, 47 La. An11. 205, 16 So. 83I : Mississippi Logging Co. v. Robson, 69 Fed. Rep. 773.

1. Dexter v. Norton, 47 N. Y. 62. 7 Am. Rep. 415.

2. Benjamin on Sales, 424. 
nake no difference how the property was destroyed, so long as the party was not in any degree in fault. The minds of the parties are presumed to have contemplated the possible destruction of the property, and not the manner of its destruetion.

\section{$\S 575$. Bailment of an article to be repaired.-The case of a} bailment of an article, locatio operis faciendi, is generally controlled by a different rule. If the article intrusted to the workman is lost without his fanlt, the owner must sustain the loss, beeause there is no express agreement to return the article to the owner in a finished condition. There is an implied obligation of the workman to do the work in a proper manner, and to employ the materials furnished in the right way. ${ }^{3}$ These obligations grow out of the act of bailment; they are its legal consequences, and the law declares them to be so.

Under the bankrupt law cases may arise, involving the question, when, under the circumstances of each case, the property in an incomplete chattel in process of manufacture passes out of the bankrupt, so as not to belong to his assignee, and the question, upon whom the loss is to fall, occasioned by an inevitable accident, may be settled by determining what is equitable. ${ }^{4}$

\section{$\S 576$. Excused by act of law.-The nonperformance of a} contract will always be excused where it is based upon an act of law. ${ }^{1}$ So a covenant in a lease of a wooden building binding

3. Menetone v. Athawes, 3 Burr. 1592; Jord v. Wheeler, I Gray (Mass.), 282; Weis v. Devlin, 67 Tex. 507, 3 S. W. 726, 60 Am. Rep. 38 ; Wheelan v. Clock Co., 97 N. Y. 293; Haynes v. Church, 88 Mo. 285, 57 Am. Rep. 4l3; Hindrey v. Williams, 9 Colo. 371, 12 P. 436; Wells v. Calnan, 107 Mass. 514, 9 Am. Rep. 65 ; Butterfield v. Byron, 153 Mass. 517,27 N. E. 667,12 L. R. A. 571 and note, 25 Am. St. Rep. 654; Cook v. McCabe, 53 Wis. 250, 10 N. 507, 40 Am. Rep. 765.
4. Tripp v. Armitage, 4 Mees. \& Wels. 689; Woods v. Russell, 5 Barn. \& Ald. 942; Clarks v. Spence, 4 Ad. \& El. 448.

1. Cheny v. Cowan, 1 Dev. \& Bat. (N. Car.) 402 ; Stern v. Dermis, 3 Port. (Ala.) 231; Trimmier v. Thompson, 10 S. Car. 164; Mississippi, etc. R. R. Co. v. Green, 9 Heisk. (Tenn.) 588; Baker v. Johnson, 42 N. Y. 126; Bailey v. De Crespigny, L. R. 4 Q. B. 180,186 , 187; Cordes v. Miller, 39 Mich. 581, 33 Am. Rep. 430; Buftalo, etc. 
the lessor to rebuilu in case it burns, is released by the fasiatee of a ralid municipal ordinance forlidding the erection of wooden buildings. ${ }^{2}$

But if the change in the law is only temporary, the liability is suspended and not anmulled, and the contract munst be performed when the law is revivel. ${ }^{3}$ And the fact that the performance of a contract is rendered more burdensome and expensive by law after it is entered into never exonerates a party from his obligation, ${ }^{,}$provided it is still possible of performance.

$\S 577$. Two ways of performance.-If a promisor makes his contract unconditionally to do a thing he is bound, because he takes the risk of being liable even though performance becomes impossible by reason of ciremmstances besond his control. And where he has an option to perform his contract in one of two ways, and it becomes impossible of performance in one of those ways, he must perform it in the other way. ${ }^{1}$

\section{$\S 578$. Judgments and other judicial processes._Judgments} and other judicial processes may be discharged by act of law. So long as a judgment debt exists, it may be enforced for the benefit of the judgment creditor. But a judgment is subject, however, like other debts, to the bankrupt and insolvent laws. So a judgment debtor, being discharged from his debts, pur-

R. R. Co. v. Railroad Co., $111 \mathrm{~N}$. Y. 132. 19 N. E. 63,2 I. R. A. 384 ; Calhoun v. Calloun, 2 S. Car. 283; People v. Ins. Co., 91 N. Y. 174; Espasito v. Bowden, 7 El. \& $B$. 763; Jones v. Judd, 4 N. Y. 411 ; Brick Presbyterian Church v. New Tork, 5 Cow. (N. I.) 538; Semmes v. Ins. Co., 13 Wall. (U. S.) 158; Brewster v. Kitchell, 1 Salk. 198; Anglesea v. Rugeley, 6 Q. B. 107: Brown v. Dillahunts, 4 Sm. \& M. (Miss.) 713, 43 Am. Dec. 499.

2. Cordes v. Miller, 39 Mich. 581 , 33 Am. Rep. 430.

3. Iladley v. Clarke. s Term R.
259 ; Baglies v. Fettyplace. 7 Mass. 325.

4. Baker v. Johnson, 42 X. Y'. 126 .

1. Studholme v. Mandell. 1 Ld. Raym. 279; Mcllquhan v. Taylor (1895), l Ch. 53, 8 Reports, 750 ; Jacquinct v. Boutron, 19 La. Anm. 30: State v. Worthington. F Ohio, 171 ; Drake v. White, 117 Mass. 10 ; 1)a Costa v. Daris, 1 Bos. \& Pul242: Siterens r. Webb, 7 Car. \& P. 60; Backworth v. Young, 4 Drew. 1. See, also. Edwards v. West, 7 Ch. D. S53; Brown v. Ins. Co., 1 El. \& F. 853: Erie Railway v. Locomotive Co.. 35 N. J. L. 240. 
suant to the provision of the bankrupt or insolvent law, the debt is also cancelled and the judgment cannot thereafter be enforced. ${ }^{1}$

And other judicial processes may discharge a debt, by rendering its enforcement impossible. ${ }^{2}$ But a party is not discharged from his obligation to perform his contract by the fact that he is arrested and detained in jail, even though it is without any fault of his. In such case the other party may rescind the contract. This is especially so between master and servant. If the servant is arrested and placed in jail, he breaks his contract of employment and the master may declare the contract forfeited. $^{3}$

$\S$ 579. Promissee preventing performance. - Where the promisee prevents performance, the promisor is discharged, and the promisee cannot escape liability because he has not signed the contract. Where a contract on its face appears to be obligatory upon one party only, but it is manifest that it was the intention of the parties, and the consideration upon which the one party assumed an express obligation was, that there should be a corresponding and correllative obligation on the other party, such obligation will be implied. ${ }^{4}$ And if the promisee prevents the fulfilment of the contract, the promisor will be discharged. ${ }^{5}$

And the acceptance of a building as finished but not in accordance with the original contract, waives the contract condition, and the contractor is discharged from the condition. ${ }^{6}$

1. Blumenthal v. Anderson, 91 N. Y. 171 .

2. Leopold v. Salkey, 89 11. 412 , 31 Am. Rep. 93 and note; Walker v. Fitts, 24 Pick. (Mass.) 191, 35 Am. Dec. 296; Lord v. Thomas, 64 N. Y. 107.

3. Leopold v. Salkey, 89 IIl. 412 , 31 Am. Rep. 93 and note.

4. Black v. Woodrow, $39 \mathrm{Md}$. 194; Churchward v. Queen, 6 Best
\& S. 807 ; Pordage v. Cole, $1 \mathrm{Wm}$. Saund. 319.

5. Cort v. Railway Co., 17 Ad. \& El. 127; Derby v. Johnson, 21 vt. 17 ; Clark v. Marsiglia, 1 Denio (N. Y.), 317, 43 Am. Dec. 670 and note; Black v. Woodrow, 39 Md. 194.

6. Smith v. Aiker, 102 N. Y. 87, 5 N. E. 791. 


\section{ARTICLE II.}

Performance Excused by Act of God and Pubuc Enemy.

Section 580. Act of Goul will Excuse Performance.

581. By Publie Enemy.

582. Aet of God-Common Carriers.

583. Common Carriers-When Liable for Loss by Act of God.

584. Where Law Imposes a Duty.

585. Imnkeepers.

586. Failure of Consideration by Act of God.

587. Destruction by Fire.

5ss. Performance-Intervention of the Act of God.

$\S 580$. Act of God will excuse performance.-By the act of God is meant something superhuman or something in opposition to the act of man. ${ }^{1}$ The act of God is some manifestation of nature to which man has not contributed and which he cannot avert or overcome, such as lightning, cold, or a tempest; fire caused by lightning but not from an ordinary accident. ${ }^{2}$ So where the thing contracted for becomes impossible, by the act of God, the obligated party is excused from performance. ${ }^{3}$

Another class of cases holds that the act of God will excuse the nonperformance of a duty created by law, but not of one created by contract. ${ }^{4}$

But the general rule is that a loss or injury is due to the act of God when it is occasioned exclusively by natural causes such as could not be prevented by human care, skill and fore-

1. Chicago, ete. R. R. Co. v. Sawyer, 69 Ill. 285, 18 Am. Rep. 613; Hale v. Navigation Co., 15 Conn. 539, 39 An. Jec. 398; Nichols v. Marsland, L. R. 10 Exch. 255.

2. Price v. Hartshorn, $44 \mathrm{~N}$. Y. 94, 4 Am. liep. 645; Merchants' Despatch Co. v. Sunith, 76 111. 542; Vail v. Railroad ('o., 63 No. 230.

3. Walton $v$. Hollis (Miss.), 16 Soutl. Rep. 260; Burrill v. Crossman, 65 Fed. Rep. 104; Bullman v. Fenwick (1894), l Q. B. 179;
Browne v. United States, $30 \mathrm{Ct}$. Cl. 124; Usher v. Hiatt, 18 Kan. 195; Selden v. Preston, 11 Bush (Ky.), 191; Norrow v. Campbell, 7 Port. (Ala.) 4l, 31 Am. Dec. 704; Baily v. De Crespigny, L. R. 4 Q. B. 180 , 185.

4. School 1)ist. v. Dauchy, 25 Conn. 530, 68 Am. Dec. 371. See, also, Jemison v. MeDaniel, 25 Miss. 83; Bryan v. Spurgin, 5 Sneed (Temr.), 681; Claney v. Overman, 1 Der. \& Bat. (N. Car.) 402. 
sight, and such act will excuse performance. ${ }^{5}$ An unprecedented flood, by reason of which the baggage of a passenger is swept away, is an act of God. ${ }^{6}$

$\S 58$ r. By the public enemy.-A performance may be excused by the public enemies of the parties' nation. But by enemies is to be understood, enemies with whom the nation is itself at open war, and not merely robbers, thieves and other private depredators, however much they may be deemed in a moral sense at war with society. Losses, therefore, which are occasioned by robbery on the highway or by the depredations of mobs, riots, insurrections and other felonies, are not deemed losses by enemies within the meaning of the exceptions, and do not excuse the performance of contracts. ${ }^{7}$

$\S$ 582. Act of God-Common carriers.-A common carrier must carry the goods safely. If the goods are destroyed, not by the act of God or the public enemy, the carrier is responsible. ${ }^{1}$ Acts of God excuse the carrier when diligence is used. ${ }^{2}$ Thus, the bursting of a waterspout, causing an accident on a railroad train, is an act of God. ${ }^{3}$ And so is an unprecedented flood an act of God. ${ }^{4}$ Where the act is produced exclusively by

5. Wald v. Railroad Co., 162 Ill. 545, 44 N. E. 888,35 L. R. A. 356 , $53 \mathrm{Am}$. St. Rep. 332.

6. Wald v. Railroad Co., $162 \mathrm{Ill}$. 545, 44 N. E. 888,35 L. R. A. 356 , 53 Am. St. Rep. 332.

7. State v. Moore, 74 Mo. 413, 41 Am. Rep. 322; Forward v. Pittard, 1 Term R. 27, 34; Gordon v. Pimmington, 1 Camp. 123; Sugarman v. State, 28 Ark. 142.

1. Holladay v. Kennard, 12 Wall. (U. S.) 254; Packard v. Taylor, 35 Ark. 402, 37 Am. Rep. 37; Miltimore v. Railroad Co., 37 Wis. 190.

2. Curtis v. Railroad Co., $18 \mathrm{~N}$. Y. 534, 75 Am. Dec. 258 and note; Railroad Co. v. Reed, 10 Wall. (U. S.) 176; Gillespie v. Railroad Co.,
6 Mo. App. 554; Long v. Railroad Co., 147 Pa. St. 343,23 A. 459, 14 L. R. A. 741, 30 Am. St. Rep. 732 and note; Transportation Co. v. Downie, 11 Wall. (U. S.) 130; Norfolk, etc. R. R. Co. v. Marshall, 90 Va. 836,20 S. E. 823 ; Wald v. Railroad Co., 162 Ill. 545, 44 N. E. 888, 35 L. R. A. 356,53 Am. St. Rep. 332; Strohn v. Railroad Co., 23 Wis. 126, 99 Am. Dec. 114 and note; Wallace v. Sanders, $42 \mathrm{Ga}$. 486; Houston, etc. R. R. Co. v. Harn, 44 Tex. 628.

3. Norfolk, etc. R. R. Co. v. Marshall, 90 Va. 836,20 S. E. 823 .

4. Wald v. Railroad Co., 162 Ill. 545, 44 N. E. 888,35 L. R. A. 356, 53 Am. St. Rep. 332. 
natural canses such as could not be prevented by human care, skill and foresight, the common carricr is excused. ${ }^{5}$

\section{$\S 583$. Common carrier-When liable for loss by act of God.} -Unnecessary delay of a carrier which subjects the goods in its possession to a loss by an act of God which they would not otherwise have met with, is of itself such negligence as will make the carrier liable for the loss. ${ }^{1}$

Thus, a deviation from the usual course by master of a ressel, during which time a cargo is injured by a storm at sea, is a sufficient proximate cause of the loss to entitle the shipper to recover, as it brings the vessel in contact with the storm, in itself the act of God. ${ }^{2}$ Where the loss is caused by the act of God, if the negligence of the carrier mingles with it as an active and co-operative cause, the carrier will be responsible. ${ }^{3}$ Therefore, a carrier, withont sufficient reason, which fails to forward the baggage upon a limited train taken by the owner of it, is liable for its destruction by a flood which comes upon the later train on which it is shipped, though such flood is in itself an act of God. ${ }^{4}$

5. Wald v. Railroad Co., $162 \mathrm{Ill}$. 545, 44 N. E. 888,35 L. R. A. 356 , 53 Am. St. Rep. 332 ; Long v. Railroad Co., 147 Pa. St. 343, 23 A. 459. 14 L. R. A. 741,30 Am. St. Rep. 732 and note; Railroad Co. v. Reed, 10 Wall. (U. S.) 176.

1. Baltimore, etc. R. R. Co. v. School Dist., 96 Pa. St. 65, 42 An. Rep. 5:9; Philadelphia, etc. R. R. Co. v. Anderson, 107 Pa. St. 360; Michigan Central R. R. Co. v. Curtis, 80 Ill. 324 ; Wald v. Railroad Co., 162 Ill. 545.44 N. E. 888,35 L. R. A. 356, 53 Am. St. Rep. 332 ; Michacls v. Railroad Co., 30 N. Y. 564; Read v. Spaulding, 30 N. Y. 630. $86 \mathrm{Am}$. Dec. 415; Dening $v$. Railroad Co., 48 N. H. 455, 2 Anı.
Rej. 267; Read v. Railroad Co., 60 Mo. 199; Williams v. Grant, 1 Conn. 487; Davis v. Garrett, 6 Bing. 716; Crosby v. Fitch, 12 Conn. 410, 31 Am. Dec. 745 ; Rodger's v. Railroad Co., 67 Cal. 606, 8 P. 377 ; Salesbury v. Herchenroder, 106 Mass. 458; Liggins $v$. Dewey, 107 Mass. 494, 8 Am. Rep. 354. Compare Denny v. Railroad Co., 13 Gray (Mass.), 481, 74 Am. Dec. 645; Morrison v. Davis, $20 \mathrm{~Pa}$. St. 171, 57 Am. Dec. 695 and note.

2. Davis v. Garrett, 6 Bing. 716 .

3. Wolf v. Express Co., 43 Mo. 421, $97 \mathrm{Am}$. Dec. 406 and note.

4. Wild v. Railroad Co., $162 \mathrm{Ill}$. 545,44 N. E. 858,35 L. R. A. 356, 53 Am. St. Rep. 332. 
$\S$ 584. Where law imposes a duty.-Where the law imposes a duty upon a party, and he is disabled to perform it by the act of God, the performance is excused. ${ }^{5}$ But where the promisor is a public officer the case is different. A public officer insures the safetly of all moneys officially received by him against loss by any means whatever, including such loss as arises from the act of God or the public enemy. And this liability is mainly due to public policy and the evil consequences which would follow from any less rigid rule. ${ }^{6}$

But the case of a public officer is different from that of a guardian who is liable only for honesty and due diligence.

$\S$ 585. Innkeepers.-Innkeepers are insurers of the property of their gnests committed to their care, and are liable for its loss or injury, when not caused by the act of God, the public enemy, or the neglect or fault of the owner or his servants. ${ }^{1}$ Upon proof of loss, the onus of bringing the case within the exception is upon the innkeeper. ${ }^{2}$

The statute now gives the innkeeper a right to make reasonable rules as to the disposition of a guest's baggage, money and other valuables, which must be complied with in order to make the innkeeper liable.

When a guest's goods are at a hotel and he leaves, he has a reasonable time to remove them, ${ }^{3}$ and the innkeeper's extraor-

5. Mosely v. Baker, 2 Sneed (Tenn.), 362, 58 Am. Dec. 63; Rylands v. Fletcher, L. R. 3 H. L. 330, 340; Rea v. Somerset, 8 Term R. 312 .

6. United States v. Dashiell, 4 How. (U. S.) 182; United States v. Prescott, 4 How. (U. S.) 587; United States v. Keeler, 1 Wall. (U. s.) 83; Thompson v. Trustees, 30 11l. 99; Hancock v. Hazzard, 12 Cusl. (Mass.) 112, 59 Am. Dec. 171; Muzzy v. Shattuck, 1 Denio (N. Y.), 233; Havens v. Lathene, 75 N. Car. 505; State v. Bladen County, 73 N. Car. 255.
7. Atkinson v. Whitehead, $66 \mathrm{~N}$. Car. 296.

1. Norcross v. Norcross, $51 \mathrm{Me}$. 163.

2. Shaw v. Berry, 31 Me. 479, 52 Am. Dec. 628; Mason v. Thompson, 9 Pick. (Mass.) 280, 20 Am. Dec. 471 ; Noreross v. Noreross, 51 Me. 163.

3. Nurray v. Marshall, 9 Colo. 482, 13 P. 589, 59 Am. Rep. 152; Maxwell v. Gerard, 84 Hun, 537, 32 N. Y. S. 849,66 N. Y. St. 323 ; Adams v. Clem, 41 Ga. 65, 5 Am. kep. 524. 
dinary liability would remain until the expiration of such reasonable time, which will vary according to the circumstanees.' Ind when a clerk of the hotel agrees with a gnest to forward packages and letters that shall come to the latter, he acts as an agent of his principal, the hotel owner, or landlord, who is bound so far as such acts are within the duties and liabilities of an innkeeper. And an agreement to forward letters and packages by the elerk is within the scope of his business and binds his principal. Innkecpers and travelers recognize the fact that it is essential to the proper conduct of business that letters and packages to business and traveling men be forwarded; it is a general practice on account of the increased demand for more extended accommodations in this respect. But innkeepers are not liable after the relation of guest and innkecper has ceased and the guest has left. ${ }^{5}$

$\S 586$. Failure of consideration by act of God.-A consideration may fail by some superhuman agency. Thus, no action lies on an agreement by a student, promising to pay for tuition for a specified time if, during the interval of that period, the promisor is prevented by sickness from attending and receiving the instruction. As the instruction was not receired, the consideration had failed. For the parties have acted upon the assumption of the continuing ability of the promisee to give and of the promisor to receive the proposed instruction. ${ }^{6}$

\$ 587. Destruction by fire.-Destruction by fire does not discharge the promisor. Thus, where a person has contracted unconditionally to build a house on the land of another, and the house is partially completed when it is consumed by fire, the promisor is not discharged from his obligation to fulfill the contract. ${ }^{7}$ Such a fire is not the act of God. And so, where

4. Baehr v. Downey, 132 Mich. 142.

5. O'Brien v. Vail, 22 Fla. 627 , 1 So. 137, l Am. St. Rep. 219; Glenn v. Jackson, 93 Ala. $34: 9$ So.
259,12 L. R. A. 382 and note; Hays $\checkmark$ Turner, 23 Iowa, 214.

6. Stewart v. Loring, 5 Allen (Mass.), 306, 81 Am. Dec. 747.

7. Adams v. Nichols, 19 Pick. 
a publisher has been employed to publish a certain number of copies of a work, and prints them and delivers a part, and the rest is consumed by fire, he cannot recover for those delivered, and his contract is still binding to deliver the remainder. ${ }^{8}$ But fire caused by lightning is an act of God. ${ }^{9}$

Ship-owners, by act of Congress of 1851, are relieved from all responsibility by fire, when acting with due diligence. ${ }^{10}$

Under the general rule, if a schoolhouse burns, and a school is in progress, the school authorities must find a place to continue the school, and if they do not the teacher can recover for the entire time of his contract, though the school is suspended."

\section{$\S$ 588. Performance-Intervention of the act of God.-The} nonperformance of a contract is not excused by the act of God, where it may be substantially carried into effect, although the act of God makes a literal and precise performance of it impossible. ${ }^{1}$ And the most a court of equity can do in a case where an agreement cannot be carried out according to the intention of the parties, in consequence of an act of God or something over which the parties could have no control, is to adopt such an equitable arrangement as the parties probably would have inserted in the agreement on that subject, if they had foreseen the probability of such an event and provided for the same. ${ }^{2}$ The rule that if the thing to be done becomes physically im-

(Mass.) 275, 31 Am. Dec. 137; Jones v. United States, 96 U. S. 24 ; School Trustees v. Bennett, 27 N. J. L. 513, 72 Am. Dec. 373; Fildew v. Basley, 42 Mich. 100, 3 N. 278, 36 Am. Rep. 433 and note; Dermott v. Jones, 2 Wall. (U. S.) 1; Lawing v. Rintles, 97 N. Car. 350,2 S. L. 252.

8. Adlard v. Booth, 7 Car. \& P. 108.

9. Bishop on Cont. 593. As to discharge of contract by a fire caused by lightning, see School
Dist. v. Dauchy, 25 Conn. 530, 68 Am. Dec. 371.

10. N. Y. Cent. Railroad Co. v. Lockwood, 17 Wall. (U. S.) 357.

11. Charlestown School Town v. Hay, 74 Ind. 127.

1. Williams v. Vanderbilt, $28 \mathrm{~N}$. Y. 217. Compare Briggs v. Vanderbilt, 19 Barb. (N. Y.) 222; Bonsteel v. Vanderbilt, 21 Barb. (N. Y.) 26.

2. Newton v. Rowse, I Vern. 460; Quick v. Stuyvesant, 2 Paige (N. Y.), 84; Chase v. Barrett, 4 Paige (N. Y.), 148. 
possible to be done by the act of God, performance is excused, docs not prevail when the essential purpose of the contract may be accomplished. If the intention of the parties can be substantially, though not literally excuted, performance is not excused. ${ }^{3}$ And where a statute makes a contract in part unlawful, if justice can be done, the lawful part should be performed, otherwise not. ${ }^{4}$

The fact that the performance of a contract to furnish hay has been rendered impossible by failure of the crop through natural causes, relieves the party of the duty to perform. ${ }^{5}$ Where performance is prevented by the act of God, no breach can be assigned, although no reference thereto was made in the contract. $^{6}$ The breaking of machinery is not an act of God and does not excuse performance of contract. ${ }^{7}$ But where some fortuitous event prevents performance, the defendant will be excused. ${ }^{8}$

So a failure to run street cars at certain intervals according to contract, is excused by heary fall of snow, provided the street car company exercised due diligence to make the trips. ${ }^{9}$

3. White v. Mann, 26 Me. $36 \mathrm{l}$; Chapman v. Dalton, Plowd. 284; Haltham v. Ryland, I Eq. Cas. Abr. 18.

4. Bettsworth v. St. Paul, I Bro. P. C. 240.

5. Browne v. United States, 30 Ct. Cl. 124
6. Gleason v. United States, 33 Ct. Cl. 65.

7. Day v. Jeffords, 102 Ga. 714, 29 S. E. 591.

8. Romero v. Newman, 50 La. Ann. 80, 23 S. E. 493.

9. Buffalo, etc. Land Co. v. Bellevue, etc. Imp. Co., 165 N. Y. 247, 59 X. E. 5, 51 L. R. A. 951. 


\section{ARTICLE III.}

Nonperformance of Contract of Personal Service.

Section 589. Personal Service.

590. Where Personal Skill is not Required.

591. Sickness.

592. Death of Employer.

$\S 589$. Personal service.-Contracts for the personal services, whether of the contracting or of a third person, requiring skill, and which can only be performed by the particular individual named, are not in their nature, of absolute obligation under all circumstances. Both parties contemplate the continuance of the ability of the person whose skilled services are the subject of the contract, as one of the conditions of the contract. Contracts for personal services are subject to this implied condition, that the person shall be able at the time appointed to perform them; and if he dies, or without fault on the part of the covenantor becomes disabled, the obligation to perform is extinguished. ${ }^{1}$

Thus, where the principal singer in an opera troupe is sick, the manager of the troupe is excused from performing, though he luad made a contract with the proprietor of the theatre to perform. $^{2} \quad$ But if the failure to perform is from a less serious cause than sickness, the promisor will not be excused. ${ }^{3}$

1. Robinson v. Davisou, L. R. 6 Excl. 268; Boast v. Firth, 4 C. P. 1 ; People v. Manning, 8 Cow. (N. Y.) 297; Jones v. Judd, 4 N. Y. 411; Clark v. Gilbert, $26 \mathrm{~N}$. Y. $279,8 \pm$ Am. Dec. 189; Wolfe v. Howes, 24 Barb. (N. Y.) 174, 20 N. Y. 197, 75 Am. Dec. 388; Gray v. Miurray, 3 Johus. Cas. (N. Y.) 167 ; Knight v. Bean, 22 Me. 531; Poussard v. Spiers, 1 Q. B. D. 410 ; Harrington v. Iron Works, 119 Mass. 82: Siler v. Gray. $86 \mathrm{~N}$. Car.
506; Green v. Gilbert, 21 Wis. 401; Jennings v. Lyons, 39 Wis. 553, 20 Am. Rep. 57; Allen v. Baker, 86 N. Car. 91, 41 Am. Rep. 4.45: Fenton v. Clark, 11 Vt. 557; Hubbard v. Belden, 27 Vt. 645: Fuller v. Brown, 11 Met. (Mass.) 440 ; Shulz v. Johnson. 5 B. Mon. (Ky.) 497: Scully v. Kirkpatrick, 79 Pa. St. 324, 21 Am. Rep. 62.

2. Spalding v. Rosa, 71 N. Y. 40, 27 Am. Rep. 7.

3. Earp v. Tyler, 73 Mo. 617. 
$\Lambda$ contract made by a painter to paint a picturc, or an author to write a book, or an apprentice to serve his master a specified number of year's, or in any coutraet for personal serrices dependent upon the life of the individual making it, the contract is discharged upon the death of the party, in aceordance with the condition of continued existence raised by implication. In contracts in which performance depends on the continued existence of a given person or thing, a condition is implied that the impossibility of performance, arising from the perishing of the person or thing, shall excuse the performance; because from the nature of the contract, it is apparent that the parties contracted on the basis of the continued existence of the particular person or thing. ${ }^{4}$

Where one employed to teach in a public school for a certain period, the fact that the school was necessarily closed for part of the time by order of the Board of Health, does not deprive the teacher of the right of compensation for the entire time, since such closing of the schools was not the act of God. ${ }^{5}$

$\S 590$. Where personal skill is not required.-The performance of all contracts does not require personal skill of the promisor, and others may fulfill the conditions. Thus, the personal representatives of a deceased promisor may be called upon to perform the agreement where the services are of such a character that they may be just as well performed by them. ${ }^{6}$ Hence, the sickness of a contractor does not excuse his performance, because he can build the house by proxy. ${ }^{7}$ In such case if the promisor dies his personal representatives take his

4. Taylor v. Caldwell, 3 Best \& S. S26, 2 Smith's Lead. Cas. 50; Pothier on Contracts and Sales, art. 4, see. 1, p. 31 .

5. Carthage v. Gray, 10 Ind. App. 42 S. 37 N. E. 1059.

6. Siler v. Gray, 86 N. Car. 566; Billing's Appeal, $106 \mathrm{~Pa}$. St. 558; Hawkins v. Ball, 1s B. Mon. (Ky.) 816, 68 Am. Dee. 755 and note:
Shulz v. Johnson, 5 B. Mon. (Kr.) ¿97; Janin v. Brown, 59 Cal. 37; Howe Sew. Mach. Co. r. Rosenteel, 24 Fed. Rep. 583: Werner v. IIumplreys, 3 scott, N. R. 226, 2 Man. \& Gr. S53; Smith r. Coal Co., 83 111. 498 .

7. Cassady v. Clarke, 7 Ark. 123. 
place and are subject to fulfill his promises and to carry them into effect. ${ }^{8}$

$\S 59$ r. Sickness.-If the performance of the contract becomes impossible by sickness or similar disability, the contractor may recover a quantum meruit for what he did perform, as sickness is an excuse for nonperformance of personal obligations. ${ }^{9}$ But a contagious disease like small-pox is not the act of God in such a sense as to excuse a school district from liability on a contract with a teacher, the performance of which the district has prevented by closing school, and the teacher may recover his salary for the time of suspension of school. ${ }^{10}$

$\S$ 592. Death of employer.-The death of the employer excuses the employe from completing his contract where it is for personal services. ${ }^{11}$ The death of one of the parties discharges the contract, or excuses its further performance. This is the case where the engagement is of a strictly personal character, requiring personal skill or capacity, as a contract to write a book for a publisher, or a contract by a physician to cure a particular disease, and the like.

But the death of one of two joint contractors who has agreed to employ a party, does not discharge the survivor from the obligation of the contract, ${ }^{12}$ because the joint contractor has assumed the responsibility as a joint promisor; and neither the insolvency nor the death of his copromisor will discharge the contract, or release him from the obligation he has assumed. ${ }^{13}$

8. Werner v. Humphreys, 2 Man. \& Gr. 853; Sinith v. Coal Co., 83 III. 498; Hawkins v. Ball, 18 B. Mon. (Ky.) 816, 68 Am. Dec. 755 and note; Siler v. Gray, 86 N. Car. 566 ; White v. Allen, 133 Mass. 423.

9. Lakeman v. Pollard, $43 \mathrm{Me}$. 463. See, also, Harrington v. Iron Works, 119 Mass. 82; Sickles v. United States, 1 Ct. Cl. 214.
10. Dewey v. School Dist., 43 Mich. 480, 5 N. 646, 38 Am. Rep. 200 and note; Carthage v. Gray, 10 Ind. App. 428, 37 N. E. 1059.

11. Yerrington v. Green, 7 R. I. 589, 84 Am. Dec. 578.

12. Martin v. Hunt, l Allen (Mass.), 418.

13. Martin v. Hunt, 1 Allen (Mass.), 418. 


\section{CHAPTER XX.}

\section{Rescission of Contract.}

\section{ARTICLE I.}

\section{Right to Rescind.}

Section 593. Executed Contract.

594. Notice and Acceptance.

595. Right to Rescind.

596. Time to Rescind.

597. Notice to Rescind.

598. Rescission in Part.

599. Recovering Back Consideration Paid.

600. Affirmance.

601. Sealed Contracts-To Recover Money Paid.

$\S 593$. Executed contracts.-It is only executory contracts that can be rescinded. And when a contract is executed an attempt to rescind will be futile, as there can be nothing to rescind. ${ }^{1}$

Thus, in case there is an absolute sale, proved in the usual manner, and an acknowledgment of an executed delivery of property to vendee, the contract is executed and not executory, and cannot then be rescinded. ${ }^{2}$ And so after goods are sold, and remain in the warehouse of the vendor who receives rent for storage of them, the acceptance of the warehouse rent is a complete transfer of the goods to the vendee; such is an executed delivery by the vendor to the vendee, and the transitus is at an end. ${ }^{3}$ A reversal of what has been executed in such case can only be effected by the substitution of a new agreement with a consideration; it can be effected only by a new contract. ${ }^{4}$

1. Chapman v. Searle, 3 Pick. (Mass.) 38; Quincy v. Tilton, 5 Me. 277 .

2. Chapman v. Searle, 3 Pick. (Mass.) 38.
3. Hurry v. Mangles, 1 Camp. 452; Noble v. Adams, 7 Taunt. 59; Barrett v. Goddard, 3 Mason, C. C. 107.

4. Quincy v. Tilton, 5 Me. 277. 
$\S 594$. Notice and acceptance-Rescission of contract.-By one line of authorities, where one party to the contract declares that he will not perform his part on the day fixed and so stands until the time, the other may then sue; that is, he cannot sue until the day fixed has arrived and he tenders performance. ${ }^{1}$

The law now in England is that a positive, absolute refusal by one party to carry out the contract, is in itself an immediate, complete breach of it on his part, and dispenses with the formality of tendering performance by the other party, and gives the immediate right of action before the day fixed. ${ }^{2}$ And the Supreme Court of the United States holds, that an unqualified and positive refusal to perform a contract, though the performance thereof is not yet due, may, if the renunciation goes to the whole contract, be treated as a complete breach, which will entitle the injured party to bring his action at once, and that the damages for breach of contract by renunciation thereof before performance is due, are measured by what the injured party would have suffered by the continued breach of the other party, down to the time of complete performance, less any abatement by reason of circumstances of which he ought reasonably to have availed himself. ${ }^{3}$ This is the best doctrine and must find a following by all the courts not already bound by precedent to a different conclusion. The renunciation, to be effectual, must be an unequivocal one; and a refusal to treat the contract as a broken one by the promisee prevents his right to bring suit until time of performance. A mere assertion that the party will be unable or will refuse to perform his contract is not sufficient, and if the promisee afterwards continues to urge or de-

1. Ford v. Tiley, 6 Barn. \& Cr. 325 ; Franchot v. Leach, 5 Cow. (N. Y.) 506 ; Traver v. Halsted, 23 Wend. (N. Y.) 66; Shaw v. Ins. Co., 69 N. Y. 286; Johnstone v. Milling, 16 Q. B. 1). 460; Mersey, etc. Co. v. Naylor, 9 App. Cas. 434.

2. Cort v. Railway Co., 6 Eng. L. \& Eq. 230; Hochster v. De La Tour, 20 Eng. L. \& Eq. 157, 2 E. \&
B. 678 ; Frost v. Knight, L. R. Exch. 111.

3. Roehm v. Horst, 178 U. S. 1, 20 S. Ct. 780,84 Fed. Rep. 565, 62 U. S. App. 520, 21 N. Cor. Rep., pp. $64,92,125,156$, where this question is discussed. Chief Justice Fuller, who rendered this decision, has exhaustively reviewed the authorities. 
mand a compliance with the contract, he has not put himsclf in a position to sue for a breach at once. ${ }^{4}$ A renunciation of itself does not create a breach. There must be an adoption of the renumciation. There must be opportunity left to the promisee thereafter to insist upon performance if that shall prove more adrantageous, or sue for damages for a breach if erents shall render that cause the more promising afterwards. The renunciation must be so distinct that its purpose is manifest and it must be absolute and final. The acquiescence therein must be as certain, and this can be evidenced by suit at once for damages. ${ }^{5}$

The doctrine of an inticipatory breach of contract, is that a renunciation of a contract-that is, a total refusal to perform it, by one party, before the time for performance arrives, does not by itself amount to a breach of contract, but may be acted upon and adopted by the other party as a rescission of the contract as to give an immediate right of action. Such a renunciation does not of itself amount to a rescission of the contract, because one party cannot himself rescind it; but the other party is then entitled to agree to such renunciation, subject to the retention by him of his right to bring an action in respect of such wrongful rescission. ${ }^{6}$

4. Smoot's Case, 15 Wall. (U. S.) 36,21 L. Ed. 107; Dingley v. Oler, 117 U. S. 490, 29 L. Ed. 984, 6 S. Ct. 850 ; Roehm v. Horst, 178 U. S. 1,20 S. Ct. 780,44 L. Ed. 953; Jolnnstone v. Willing, L. R. 16 Q. B. 460; Avery v. Bowlen, 5 E. \& B. 714; Wells v. Hartford Manilla Co. (N. J.), 55 A. 599.

5. Windmuller v. Pope, $10 \mathrm{~T}$. Y. 674, 14 N. E. 608; Gray v. Green, 9 Hun (N. Y.), 334; Zuck v. MeClure, 98 Pa. St. 54l; Roebling Sons Co. v. Fence Co., 130 IIl. 660,22 N. E. 518; Crabtree v.
Messersmitl, 19 Iowa, 179; Howe v. Conduitt, 76 Ind. 598 ; Platt v. Brand, 26 Mich. 173; Davis v. Furniture Co., 41 IV. Va. 717,24 S. E. 630; Wells v. Hartford Manilla Co. (N. J.) 55 A. 599 . Compare Daniels v. Newton, 114 Mass. 530, 19 Am. Rep. 384; Stanford v. MeGill, 6 N. Dak. 536, 72 N. W. 938, 38 L. R. A. 760.

6. Johnstone v. IVilling, L. R. 16 Q. B. 400 ; Roehm v. Horst, 178 U. S. 1,20 S. Ct. 780,44 L. Ed. 953; Wells r. Hartford Manila Co. ( .. J.), 55 A. 599 . 
$\S 595$. Right to rescind.- It is not essential to the right of a party to a contract to rescind it that its violation by the other party was wilful. ${ }^{1}$

On the failure of consideration for a contract of sale on which the purchaser has advanced money, the other party may be required to pay back the price. ${ }^{2}$ If one fails to perform the condition of the contract, the other may rescind, ${ }^{3}$ or if he disqualifies himself to perform, the other may rescind $;^{4}$ so if he refuses to sign a written agreement as agreed to in the oral contract the other may rescind $;^{5}$ but every shortcoming of a party is not a ground for rescission by the other. ${ }^{6}$

The breach to justify a rescission must be of a dependent covenant, or conduct which evinces an intention no longer to be bound by the contract. ${ }^{7}$

A grantee who had agreed to support the grantor during life in consideration of the conveyance of certain property will not be discharged from his obligation by the bringing a suit to set aside the conveyance and recovering back the property, where the suit has been abandoned and dismissed without trial, and the grantee can not be disturbed in the possession or enjoyment of the property. ${ }^{8}$

When one party to an entire executory contract has failed to perform it on his part, and the other party is not in default, and in a condition to rescind, he may abandon the contract.? There may be cases where the parties cannot be placed in statu quo when the right to rescind cannot be exercised, or where

1. Bacon v. Green, 36 Fla. 325, 18 S. E. 870.

2. Flandrow v. Hammond, 148 N. Y. 129,42 N. E. 511.

3. Anderson v. Haskell, 45 Iowa, 45 ; Reed v. Golden, 26 Kan. 500.

4. Warren v. Richmond, 53 Ill. 52 ; Little v. Thurston, 58 Me. 86.

5. Gullich v. Alford, 61 Miss. 224.

6. Weintz v. Hafner, 78 กl. 27 ; Franklin v. Miller, 4 Ad. \& El. 599.
7. Freeth v. Burr, L. R. 9 C. P. 208.

8. Tuttle v. Burgett, 53 Ohio, 498,42 N. E. 427,30 L. R. A. 214 , 53 Am. St. Rep. 649.

9. Bacon v. Green, 36 Fla. 325, 18 S. E. 870 ; Brown v. Harris, 2 Gray (Mass.), 359; Giles v. Edwards, 7 Term R. 181; Webster v. Enfield, 5 Gilm. (Ill.) 298; Evans v. Givens, 22 Fla. 476. 
one party to a contract has received benefits thereunder which he cannot retain and rescind. ${ }^{10} \mathrm{~A}$ breach by one party which will give the other a right to rescind, need not necessarily be such as will sustain an action for damages. ${ }^{11}$

$\S 596$. Time to rescind. - An exccutory contract that contains no stipulation for its rescission and that has not been induced by fraud, may, in general, be rescinded by one party only when the other expressly refuses to perform, or has rendered himself incapable of performing it. More delay in the execution of a contract whose terms will be satisfied by performance within a reasonable time does not of itself entitle the other party to rescind. To have that effect, the implication arising from the non-performance of the contract must be inconsistent with its being still in force. ${ }^{1}$

Where the facts are not disputed, the question of what is a reasonable time in which to rescind a contract is a question for the court to decide $;^{2}$ and so the court may instruct the jury that on the undisputed facts a given time is or is not reasonable. ${ }^{3}$ The facts of each particular case will control as to the reasonableness of time to rescind $;^{4}$ or the contract itself may provide the method, when it must be followed. ${ }^{5}$

$\$ 597$. Notice to rescind.-When a party rescinds a contract he must notify the other party. ${ }^{1}$ And the notice should be

10. Bacon v. Green, 36 Fla. 325 , 18 S. E. 870 .

11. Wright v. Haskell, $45 \mathrm{Me}$ 489; Gatlin v. Wilcox, 26 Ark. 309; Townsend v. Hurst, 37 .Miss. 679; Hime v. Klasey, 9 Ill. App. 190.

1. MeTague v. Association, 57 N. J. I. 427, 31 A. 727; Fox v. Tabel, 66 Conn. 397,34 A. 101.

2. Bacon v. Green, 36 Fla. 325 , 18 S. E. 870; Gordon v. Simontou, 10 Fla. 179; Holbrook v. Burt, 22 Pick. (Mass.) 546 .

3. Holbrook v. Purt, 22 Pick.
(Mass.) 546: Bacon v. Green, 36 Fla. 325,18 s. E. 870.

4. Grymer v. Sanders, 93 U. S. 55; Calncy v. Newberry, 24 Ill. 203; Memphis, ete. Railroad Co. v. Neighlors, 51 Miss. 412.

5. MeKay r. Carrington, 1 McLean, C. C. 50.

1. Carney v. Newberry, 24 Ill. 203: Henderson v. Hicks, is Cal. 364; Mullin v. Bloomer, 11 Iowa, 360 ; Parmlee v. Adolph, 28 Ohio St. 10 . 
served on a week day; though if the statute does not make it illegal to serve it on Sunday, it may be served on that day. ${ }^{2}$

It is not always necessary to give an express notice of rescission, for acts may indicate the intention to rescind. In some case bringing a suit to recover back money paid, when followed to its termination, is sufficient notice $;^{3}$ but a judicial proceeding is not always a sufficient notice, where it is dismissed and the defendant has received no damages. ${ }^{4}$ And so when a lessor under a power contained in a lease, gives notice to the lessee of his intention to cancel the lease and take possession at the end of the time specified according to law, for non-payment of rent, such notice is not an offer which may be accepted by the tenant and thus made irrevocable, but the lessor may withdraw it and sue for the rest. ${ }^{5}$ And so a party who stipulated under seal to pay a certain sum annually to another so long as the latter would refrain from erecting on his land buildings that might obstruct the former's windows, is bound and cannot rescind by giving notice. ${ }^{6}$

$\S 598$. Rescission in part.-A contract cannot be rescinded in part and ratified in part against the wishes of the other party. It is the duty of the injured party in such case to rescind the contract as a whole or not at all. ${ }^{7}$ And so where a party makes several contracts with another, he cannot claim the benefit of such as are profitable and repudiate those that are unprofitable, when they are of the same kind. ${ }^{8}$

2. Merritt v. Robinson, 35 Ark. 483; Benedict v. Bachelder, 24 Mich. 425, 9 Am. Rep. 130; Pence v. Langdon, 99 U. S. 578.

3. Graham v. Hollaway, $44 \mathrm{Ill}$. 385; Moore v. Rogers, 19 11l. 347; Howard v. Hunt, 57 N. H. 467.

4. Tuttle v. Burgett, 53 Ohio, 498, 42 N. E. 427,30 L. R. A. 214 , 53 Am. St. Rep. 649.

5. Warehouse Co. v. Duke, 116 N. Car. 202, 21 S. E. 178. See, also,
Patrick v. Railroad Co., 93 N. Car. 422.

6. First Presb. Church v. Bank, 57 N. J. L. 27, 31 A. 727.

7. Raymond v. Bearnard, 12 Jolns. (N. Y.) 274, 7 Am. Dec. 317; Hendricks v. Goodrich, 15 Wis. 679; Bainter v. Fults, 15 Kan. 323; Higham v. Harris, 108 Ind. 246, S N. E. 255; Bam Iron Co. v. Burg, 47 Neb. 2I, 66 N. W. 8; Wolf v. Dietzseh, 75 Ill. 205.

8. Wolcott v. Heath, 78 Ill. 433. 
The rescission must be for the whole contract and not for a part. ${ }^{9}$ But if the parties agree, part of the contract may be rescinded and another part repudiated. ${ }^{10}$

\$59. Recovering back consideration paid. - When one party to an entire executory contract has failed to perform on his part, and the other party is not in defanlt, and in a condition to rescind, he may abandon the contract and bring an action of assumpsit to recover back what he has paid thereunder, whenever assumpsit will lie independent of the contract. $^{1}$ Howerer, one who is in fault and has abandoned his contract without just cause, cannot recover. ${ }^{2}$

A party cannot rescind a contract and at the same time retain the consideration he has received. He must place the other party in as good a condition as he was before the contract was made by an offer to return what he has received. ${ }^{3}$ The doctrine is well established that no contract can be rescinded unless both parties can be restored to the condition in which they were before the contract was made. If, therefore, one of the parties has dericed an advantage from the performance of the contract, he cannot hold this and consider the contract as rescinded, but must do all the contract obliges him to do. ${ }^{4}$

9. Raymond v. Bearnard, 12 Johns. (N. Y.) 274, 7 Am. Dec. 317.

10. Borum v. Garland, 9 Ala. 452.

1. Nash v. Towne, 5 Wall. (U. S.) 689 ; Bacon v. Green: 36 Fla. 325 , 18 S. E. 870 ; Brown v. Harris, 2 Gray (Mlass.), 359 ; Giles v. Edwards, 7 Term R. 181; Evans v. Givar, 22 Fla. 476; Fitzgerald v. Allen, 128 Mass. 232; Warren v. Tyler, 81 Ill. 15; Chamberlin v. Scott, 33 Vt. 80; Brown v. Mahorin, 39 N. H. 156; Drew v. Claggett, 39 N. H. 43l; Feay v. Decamp, 15 Serg. \& R. (Pa.) 227.
2. Plummer v. Bucknam, 55 Me. 105; Robinson v. Raynor, 28 N. Y. 494; Haslack v. Mayers, 2 Dutch. (N. J.) 284; Clark v. Sehool Dist., 29 Vt. 217.

3. Duncan v. Humphries, 58 Ill. App. 440; Wolf v. Deitzsch, 75 Ill. 205; Merchants, ete. Ins. Co. v. McLain, 48 La. Ann. 109, 20 So. 278; Gassett v. Glazicr, 165 Mass. 473, 43 N. E. 193; Rydon v. Walcott, 141 111. 649, 31 న. E. 158; Doane v. Lockwood, 115 Ill. 490, 4 N. E. 506 .

4. Hunt v. Silk, 5 East. 449 ; Poor v. Woodward, 25 Vt. 445; Miner v. Bradley, 22 Pick. (Mass.) 
$\S 600$. Affrmance.-Where a party has a right to rescind, he must announce his purpose and adhere to it. If he is silent and continues to treat the contract as binding, he will be held to have waived the objection, and will be bound by the contract. If he does anything in recognition of its continued existence he is bound by it. ${ }^{1}$

But a party cannot rescind because he has failed to exercise due diligence in making the contract. ${ }^{2}$ So the lessee of a mill, after remaining in possession for a year, cannot rescind the lease for fraudulent representations as to the capacity and condition of the mill. ${ }^{3}$

$\S 601$. Sealed contracts-To recover money paid.-In an action of assumpsit to recover back money paid under a contract alleged to have been violated by the parties thereto, sued as defendants, and rescinded by the plaintiff, the other party to it, the form of action will not be affected in any way by the consideration, whether the contract is under seal or not as to all the parties executing it, as the suit is not one on the contract, but in assumpsit to recover money received."

458 ; Weeks v. Robie, 42 N. H. 316 ; Young v. Stevens, 48 N. H. 133, 97 Am. Dec. 592; Desha v. Robinson, 17 Ark. 228; Burge v. Cedar, etc. Railroad Co., 32 Iowa, 101.

1. Thomas v. Bartow, $48 \mathrm{~N}$. Y. 200 ; Flint v. Wood, 9 Hare, 622; Jennings v. Broughton, 5 DeG. M. $\&$ G. 139; Lloyd v. Brewster, 4 Paige (N. Y.), 537, 27 Am. Dec. 8S; Campbell v. Fleming, 1 Ad. \& El. 41; Diman v. Railroad Co., 5 R. I. 130; Grymes v. Sanders, 93 U. S. 55; Wilson v. Irish, 62 Iowa,
260, 17 N. 511; Fitzpatrick v. Woodruff, 96 N. Y. 561; Pratt v. Philbrook, 41 Me. 132; Akerly v. Vilas, 21 Wis. 88; Crane v. Kildorf, 91 Ill. 567.

2. Seton v. Slade, 7 Ves. 269; Mauser v. Davis, 6 Ves. 678; Atwood v. Small, 6 Cl. \& F. 338; Garrett v. Burleson, 25 Tex. 44; Lamb v. Harris, 8 Ga. 546 .

3. Richardson v. Horn, 8 Houst. (Del.) 26.

4. Bacon v. Green, 36 Fla. 325, 18 S. E. 870. 


\section{ARTICLE II.}

\section{WORK AND LABOR.}

Secrion 602. Wrongful Discharge of Employe.

603. Constructive Service.

604. Services to be Performed in the Future.

605. Duty of Employe to Seek Other Work.

606. Offer to Render Service.

607. Mode of Rescission by Employer.

608. Employing Another to Work on Personalty.

609. Employing Another to Affix to Real Estate a Machine.

610. Damages Recoverable.

611. After Notice of Rescission-Duty of the Employe.

$\S 602$. Wrongful discharge of employe.-A servant wrongfully discharged has but two remedies growing out of the wrongful act: 1 . He may treat the contract of hiring as continuing, though broken by the master, and may recorer damages for the breach. ${ }^{1}$ 2. He may rescind the contract, in which case he can sue on a quantum meruit, for services actually rendered. ${ }^{2}$ These remedies are independent of and additional to his right to sue for wages, for sums actually earned and due by the terms of the contract.

$\S 603$. Constructive service. - It has been held by a few cases, incorrectly however, that a servant wrongfully discharged has his election to sue for wages as they become due from time to time, or for damages. This doctrine that he can

1. Miller v. Goddard, 34 Me. 102, 56 Am. Dec. 638; East Tennessee, etc. R. R. Co. v. Staub, 7 Lea (Tenn.), 397; Howard v. Daly, 61 N. Y. 362, 19 Am. Rep. 285.

2. Chamberlin v. Morgan, $68 \mathrm{~Pa}$. St. 168; King v. Steiren, $44 \mathrm{~Pa}$. St. 99, 84 Am. Dec. 419; Howard v. Daly, 61 N. Y. 362, 19 Am. Rep. 285; MeDaniel v. Parks, 19 Ark. 671 ; Isaaes v. Davis, 68 Ga. 169; Fuller v. Little, 61 Ill. 21; Baker v. Ins. Co., 24 Wis. 630 ; Ricks $v$. Yates, 5 Ind. 115 ; Costigan v. Railroad Co., 2 Denio (N. Y.), 609, 43 Am. Dec. 758 and note; Halloway v. Talbot, 70 Ala. 389 ; Webster v. Wade, 19 Cal. 291, 79 Am. Dec. 218; Britt v. Hays, 21 Ga. 157; Pritchard v. Martin, 27 Miss. 305; Emmons v. Elderton, 4 H. L. Cas. 646: Dillon $v$. Anderson, 43 N. Y. 231: Hamilton v. McPherson, 28 N. I. $76,84 \mathrm{Am}$. Dec. 330 . 
sue for wages is based upon construciuve service. ${ }^{1}$ This doctrine that a servant can sue from time to time for his wages as they would fall due, after his wrongful discharge, is opposed to the great mass of authorities. It holds that a person may remain idle, and not accept employment elsewhere, and that he cannot seek it. If a person discharged from service may recover wages, or treat the contract as still subsisting, then he must remain idle in order to be always ready to perform the service. The doctrine of constructive service is opposed to principle and to political economy, as it encourages idleness and gives compensation to men who fold their hands and decline service, equal to those who perform their stipulated work. Though the master has committed a wrong, the employe is not released from the rule that he should labor; and no rule can be sound which gives him full wages while living in voluntary idleness.

This view of constructive services has been discarded in later decisions and is not good law; and now a serrant wrongfully discharged cannot recover wages as they become due from time to time; $;^{2}$ because if he sues and recovers his wages for past services, this ends his recovery for future time, and he cannot wait until another period has passed and then sue for that time; the first suit for wages bars all other suits. ${ }^{3}$

1. Thompson v. Wood, 1 Hilt. (N. Y.) 96 ; Huntington v. Railroad Co., 33 How. Pr. (N. Y.) 416; Fowler v. Armour, 24 Ala. 194; Armfield v. Nash, 31 Miss. 361; Gordon v. Brewster, 7 Wis. 355; Booge v. Railroad Co., 33 Mo. 212, 82 Am. Dec. 160; Gaudell v. Poutigney, 4 Camp. 375; Collins v. Price, 4 Bing. 132.

2. Archard r. Hornor, 3 Car. \& P. 349 ; Smith v. Hayward, 7 Ad. \& El. 544; Aspdin v. Austin, 5 Ad. \& 1El., N. S. 67I; Fewings v.
Tisdal, 1 Exch. 295; Elderton v. Emmons, 6 C. B. 178; Goodman v. Pocock, 15 Ad. \& El., N. S. 582; Whitaker v. Sandifer, 1 Duval (Ky.), 261; Chamberlin v. MeCallister, 6 Dana (Ky.), 352; Clark v. Marsiglia, 1 Denio (N. Y.), 317, 43 Am. Dec. 670 and note; Durkee v. Mott, 8 Barb. (N. Y.) 423; Moody v. Leverich, 4 Daly (N. Y.), 801 .

3. Keedy v. Long, 71 Md. 385, 1s A. 707,5 L. R. A. 759 and note. 
$\S 604$. Services to be performed in the future.-It is now well settled that if a person enters into a contract for services, to commence at a future day, and before that time arrives does an act inconsistent with the continuance of the contract, an action may be immediately brought by the other party; and without averring performanee, or readiness to perform. ${ }^{1}$

The law with reference to a contract to be performed at a future time, when the party bound to the performance announces, prior to the time, his intention not to perform it is this: 1. The promisee, if he so elects, may treat the notice of intention as inoperative, and await the time when the contract is to be executed, and then hold the other party responsible for all the consequences of non-performance; in this manner he keeps alive the contract for the benefit of the other party as well as his own; he remains subject to all his own obligations and liabilities under it, and enables the other party not only to complete the contract, if so advised, notwithstanding his previous repudiation of it, but also to take advantage of any supervening circumstances which would justify him in declining to complete it. 2. The promisee may, if he so elects, treat the repudiation of the other party as a wrongful rescission, and may at once bring his action as on a breach of it; and in such action he will be entitled to such damages as would have arisen from the non-performance of the contract at the appointed time; subject to abatement in respect of any circumstances which may have afforded him the means of mitigating lis loss. ${ }^{2}$

1. Hochster v. De La Tour, 2 El. \& Bl. 678; Frost v. Kinight. L. R. 7 Exch. 111, reversing 5 Exch. 322; Roper v. Johnson. L. R. 8 C. P. 167 ; Burtis v. Thompson, 42 N. Y. 246, 1 Am. Rep. 516 and note; Christ v. Armour, 34 larb. (N. Y.) 378; Howard v. Daly, 61 N. Y. 362. 19 Am. Rep. 285: Danube, etc. Co. v. Xenos, 13 C. B., N. S. 825: Wilkinson v. Verity, L. R. 6 C. P. 206.
Compare Philpotts v. Evans, 5 Mees. \& W. 475: Ripley v. McClure, 4 Exch. 359. Compare Daniels $v$. Newton, 114 Mass. 530, 19 Im. Rep. 384 .

2. Frost v. Knight, 7 Exch. 111. See, also, Roper v. Johnson, L. R. S C. P. 167; Howard v. Daly, 61 N. Y. 362, 19 Am. Rep. 516 and note; Brown v. Mullin, L. R. 7 Exch. 323. 
$\S 605$. Duty of employe to seek other work.-After an employee has been wrongfully discharged, his duty is to use reasonable care and diligence in entering into other employment of the same kind, and thus to reduce the damages. ${ }^{1}$ It is the duty of a dismissed servant not to remain idle, and the employer may show, in mitigation of damages, that the employe might have procured employment. Prima facie this employe is damaged to the extent of the amount stipulated to be paid. The burden of proof is on the discharging party to show either that the other has found employment elsewhere, or that other similar employment has been offered him and declined, or, at least, that such employment might have been found. The employe is not bound to show affirmatively, as a part of his case, that such employment was sought for and could not be found. ${ }^{2}$

$\S 606$. Offer to render service. - After the employer has wrongfully rescinded the contract for labor, in order for the employe to recover, he must be ready and willing to comply with the contract at the time of the refusal to receive the labor. ${ }^{3}$ But it is not necessary for the employe to go through the naked form of offering to render the service. ${ }^{4}$

Tender of performance is not necessary when there is wil-

1. Chamberlin v. Morgan, $68 \mathrm{~Pa}$. St. 168; King v. Steiren, 44 Pa. St. 99, 84 Am. Dec. 419; Jones v. Jones, 2 Swan (Tenn.), 605; Fuller v. Little, 61 Ill. 21; Crescent Manuf. Co. v. Manuf. Co., 100 Mo. $325,13 \mathrm{~S}$. W. 503 ; Isaacs v. Davies, 68 Ga. 169; Halloway v. Talbot, 70 Ala. 389 .

2. Costigan v. Railroad Co., 2 Denio (N. Y.), 609, 43 Am. Dec. 758 and note, 2 Greenl. on Evi. 261, a F Fuller v. Little, 61 Ill. 21 ; Pritchard v. Martin, 27 Miss. 305; McDaniel v. Parks, 19 Ark. 671; Barker v. Ins. Co., 24 Wis. 630; Webster v. Wade, 19 Cal. 291, 79 Am.
Dec. 218; Byrd v. Boyd, 4 MeCord (S. Car.), 246, 17 Am. Dec. 740; Colburn v. Woodworth, 31 Barb. (N. Y.) 381 ; Bradshaw v. Branan, 5 Rich. (S. Car.) 465; Enmons v. Elderton, 4 H. L. Cas. 646; Dillon v. Anderson, 43 N. Y. 231; Hamilton v. MePherson, 28 N. Y. 76, 84 Am. Dee. 330.

3. Peeters v. Opie, $2 \mathrm{Wm}$. Saund. 352 , note.

4. Wallis v. Warren, 4 Exch. 361; Levy v. Herbert, 7 Taunt. 314; Carpenter v. Holcomb, 105 Mass. 284; Howard v. Daly, $61 \mathrm{~N}$. Y. 362, 19 Am. Rep. 285. 
ingness and ability to perform, and actual performance has been prevented or expressly waived by the parties to whom performance is due. ${ }^{5}$

$\S 607$. Mode of rescission by employer.-No precise form of words is necessary by the employer to rescind the contract for services. If the obligation of the contract is created, a denial of its existence is equivalent to a refusal to allow the employe to go on with the labor. The employer may reject the services indirectly as well as directly. The sole inquiry is, has the employer done an act inconsistent with the supposition that the serrices continue. Thus, if a man promises to marry a woman on a future day, and before that time marries another, he has rescinded the contract with the first woman, because the act done was inconsistent with the contract relations of the parties. ${ }^{1}$ So an agreement to marry "in the fall" may be broken by the promisor announcing to the woman in October that he will not perform his contract, and she may commence her action immediately. ${ }^{2}$ And this rule is universal and applies to all contracts to be performed at a future dar, ${ }^{3}$ where there are mutual stipulations.

$\S 608$. Employing another to work on personalty.-Where a person renounces his contract for work to be done on personal property at a certain price, the laborer cannot go on and do the work, and then sne for the whole price. He las no right to proceed with the work after such rescission, but must stop, and sue for damages. ${ }^{4}$ The party employed cannot persist in working, though he is entitled to the damages conse-

5. Franchot v. Leach, 5 Cow. (N. Y.) 506; Cort r. Railway Co., 17 Ad. \& EI., N. S. 127. See, also, Nelson v. Plimpton, etc. Co., $55 \mathrm{~N}$. Y. 480; Howard v. Daly, 61 N. Y. 362, 19 Am. Rep. 285.

1. Short v. Stone, 8 Ad. \& EI., N. S. 358. See, also, Lovelock r. Franklyn, 8 Ad. \& El., N. S. 371.
2. Burtis v. Thompson, 42 N. Y. 246, 1 Am. Rep. 516 and note.

3. Hochster v. De La Tour, $2 \mathrm{El}$. \& Bl. 678; Howard v. Daly, 61 N. Y. 362, 19 Am. Rep. 285.

4. Lord v. Thomas, 64 N. Y. 107 ; Gibbons v. Bente, 51 Minn. 499. 53 N. W. 756,22 L. R. A. 80 and note; Heaver $v$. Lanahan, 74 Md. 493, 22 
quent upon his disappointment. So where one has given pictures to another to le repaired at a price agreed upon, and the former countermands his direction and forbids further execution of the work, after the latter has commenced work, the work must cease and the workman may recover a just recompense for such injury as the party employed has received on account of the breach of the agreement. ${ }^{5}$ The party employed has no right, after rescission, to proceed with the work. In all such cases the just claims of the party employed are satisfied when he is fully recompensed for his past performance and indemnified for his loss in respect to the part left unexecuted; and to persist to complete the work is not consistent with good faith towards the employer. ${ }^{6}$

\section{$\S 609$. Employing another to affix to real estate a machine.} -And so where one is employed to furnish materials and perform labor upon them for the other party to improve his realty, and then the contract is rescinded by the employer, the employe cannot recover any part of the contract price as it is not devisible. ${ }^{1}$ But he may recover what he has lost thereby or the damages sustained, but he cannot go on with the work after the rescission. $^{2}$

$\S$ 6ro. Damages recoverable.-It has been laid down that in an action brought upon an agreement, full performance of which has been prevented by the defendant, the damages of the plaintiff are such profits as he would have made had the

A. 263; Collyer v. Moulton, 9 R. I. 80, 98 Am. Dec. 370; Smith v. O'Donnell, 8 Lea (Tenn.), 468; Eckeurode v. Chemical Co., $55 \mathrm{Md}$. 51; Zuck v. MeClure, $98 \mathrm{~Pa}$. St. 541.

5. Clark v. Marsiglia, 1 Denio (N. Y.), 317, 13 Am. Dee. 670 and note.

6. Clark v. Marsiglia, 1 Denio (N. Y.), 317, 319, 43 Am. Dec. 670 and note.
1. Inchbald v. Western, $17 \mathrm{C}$. B., N. S. 733; Blanch v. Cochran, 8 Bing. 14.

2. Hosmer v. Wilson, 7 Mich. 294, 74 Am. Dec. 716; Butler v. Butler, 77 N. Y. 472, 33 Am. Rep. 648; Smith v. Wheeler, 7 Oreg. 49, 33 Am. Dec. 698 and note; Marsh v. McPherson, 105 U. S. 709 . 
contract been fully carried ont. ${ }^{1}$ But in many cases materials for the performance of the contract may have been furnished, and labor expended in good faith before notice to stop has been given, and the materials, by the labor put upon them for a particular purpose, may be depreciated in value for general purposes. So the plaintiff cannot be fully indemnified in such case without he is repaid for such labor and for any loss sustained upon such materials. ${ }^{2}$

\section{$\S 6$ II. After notice of rescission-Duty of the employe.-} It is the duty of the employe, as soon as due notice is given, to act in such a manner as to save the defendant from further damage, so far as it was in his power, cren to the performance of affirmative action on his part. ${ }^{3}$ And notice given to an agent who is authorized to stand in the place of and represents the plaintiff in his business, is sufficient, and after such notice to the agent, his principal must cease work and save the defendant from further damages. ${ }^{4}$

1. Clark v. Mayor, 4 N. Y. 338 , 53 Am. Dec. 379; Railroad Co. v. Howard, 13 How. (U. S.) 307.

2. Hosmer v. Wilson, 7 Mich. 294, 74 Am. Dec. 716; Dillon v. Anderson, 43 N. Y. 231.

3. Hamilton v. MePherson, 28
N. Y. 72, 84 Am. Dec. 330; Strauss v. Meertief, 64 Ala. 299, 38 Am. Rep. 8; Chamberlin v. Morgan, 68 Pa. St. 168; Dillon v. Anderson, 43 N. Y. 231.

4. Dillon v. Anderson, $43 \mathrm{~N}$. Y. 231. 


\section{ARTICLE III.}

\section{Rescission Controlled by Condition Subsequent.}

Section 612. Selling by Sample.

613. Option to Purchase.

614. Contract of Hiring-Employe Guarantees Satisfaction.

615. Contracts of Common Carriers.

616. Act of God that will Excuse a Common Carrier.

617. Shipment of live Stock.

618. Hiring Contracts-Implication of Discharge.

619. Reservation of Wages, Payable at Certain Intervas.

620. Extra Services.

621. Reservation of Right to Terminate.

622. No Limitation as to Term of Hiring.

623. Notice of Termination-Reservation.

$\S 6$ r2. Selling by sample.-Where there is an executory orn. tract for the sale of goods warranted to be of a particnlar quantity or description, they must conform to the warranty or the rendee is not bound to receive or accept them. ${ }^{1}$ And a sale by sample implies a warranty that the bulk of the article shall correspond in quality with the article exhibited. ${ }^{2}$

If the article does not correspond with the warranty when delivered the vendee is not merely justified in not receiving it, but he may receive it for the purpose of examination, and if found not to be of the quality or description warranted, or, what is the same thing, not to correspond with the sample, he may return it to the vendor, the examination and returu being within a reasonable time. ${ }^{3}$ And the burden of proof as to whether they correspond with the sample or not, in a suit brought by the vendor for the price, is on the vendor and not on the vendee. ${ }^{4}$

1. Wright v. Barnes, 14 Conn. 518.

2. Bradford v. Manly, 13 Mass. 139, 7 Am. Dec. 122 and note: Waring v. Mason, is Wend. ( $\mathrm{N}$. Y.) 425; Merriman v. Chapman, 32 Conn. 146; C. and C. Electric
Motor Co. v. Frisbie, 66 Conn. 67, 33 A. 604.

3. Street v. Blay, 2 Barn. \& Ad. 456.

4. Merriman v. Chapman, 32 Comn. 146. 
The vendee will have a reasonable time to examine and to return, and a failure to make the examination within a reasonable time may preclude him from offering the property back, rescinding the sale, and aroiding payment on that ground; but in case he keeps them he may rely upon the breach of the warranty and receive damages. ${ }^{5}$

The right to return chattels sold by sample as not being equal to the sample, is a right to return all or none. ${ }^{6}$

$\S 6$ I3. Option to purchase.-An option to purchase if the vendee should so decide is essentially different from an option to return the chattel if he should not like it. In one case the title will not pass until the option is determined; in the other the property passes at once subject to the right to rescind and return. ${ }^{1}$

Where the buyer takes property upon trial he is the sole judge of its merits. It is a sale at his option and he must comply with his part of the agreement. If he does not return it within a reasonable time, the vendor may treat the transaction as an absolute sale. ${ }^{2}$

And in case of depreciation of the property, nobody being at fault, the person who is eventually to have the title must bear the loss. ${ }^{3}$ But if the purchaser injures the property while in his possession he must bear the loss. ${ }^{4}$ What is a reasonable time in which to return the chattel, when the contract is silent

5. Underwood v. Wolf, $131 \mathrm{Ill}$. 425, 23 N. E. 598, 19 Am. St. Rep. 40; Douglas Ax Manuf. Co. v. Gardner, 10 Cush. (Mass.) 88; McCormick v. Danville, 36 Iowa, 645; Aultman v. Fliun, $3 \pm$ Iowa, 272; Mandel v. Butler, 21 Minn. 397; Sugworth $v$. Leflel, $76 \mathrm{~Pa}$. St. 477; Fielder v. Starkin, 1 H. Bl. 17; Poulton v. Lattimore, 9 Barn. \& Cr. 359 ; Pateshall v. Tranter, : Ad. \& El. 103.

6. 'Telford v. Albro, 60 Ill. App.
359 ; Harsfield v. Converse, 105 Ill. 534.

1. Hunt v. Wyman, 100 Mass. 198.

2. Dewey v. Erie. 14 Pa. St. 211, 53 An. Dec. 533; Spickler v. Marsh, 36 Md. 22.2; Kimball v. Vroman. 35 Mich. 310, 24 Am. Rep. 558; Bushwell v. Bicknell, 17 Me. 344, $35 \mathrm{Am}$. Dee. 262.

3. Head v. Tattersall. L. R. 7 Exeh. 7.

4. Ray r. Thompson, 12 Cush. (Mass.) 281, 59 Am. Dee. 187. 
as to this matter, depends upon the character of the property and all the circumstances connected with the casc. ${ }^{5}$

\section{\$ 6I4. Contract of hiring-Employe guarantees satisfaction.} -A stipulation is often included in a contract that the employee shall give satisfaction to the employer, and in case he does not the latter may discharge the former. The cases are not harmonious as to the question whether the employer may discharge the employee without judicial determination as to right of dismissal. It is generally held that whenever the contract is to gratify taste, serve personal convenience or satisfy individual preference in regard to the employer, that is, whenever the feelings, taste, sensibilities or judgment of the promisor are involved, he has the absolute right to decide and his decision cannot be reviewed. ${ }^{1}$ But whenever the contract involves some definite purpose or end, of the performance of which others could judge just as well as the parties can, and which involves no consideration strictly personal, the stipuation that it shall be done to the satisfaction of the party has been generally held not to be controlling. In such case all the promisor undertakes to do is that he will reasonably and fairly judge, and of comrse his decision is subject to review. ${ }^{2}$

A contract employing a servant not to do a fixed and definite

5. Washington v. Johnson, 7 Humph. (Temn.) 468; Hickman v. Shimp, 109 Pa. St. 16.

1. Duplex Saf. Boiler Co. v. Garden, 101 N. Y. 387, 4 N. E. 749, 54 Am. Rep. 709 and note; Gibson v. Carnage, 39 Mich. 49, 33 An. Rep. 351 and note; Hollman v. Gallaher, 6 Daly (N. Y.), 42; Brown v. Foster, 113 Mass. 136, 18 Am. Rep. 463; Zaleski v. Clark, 44 Conn. 218, 26 Am. Rep. 446; MeCarren r. McNulty, 7 Gray (Mass.), 139; Hart v. Hart, 22 Barb. (N. Y.) 606; Frary v. Rubber Co., 52 Minn. 264, 53 N. IV.
1156,18 L. R. A. 644; Koehler v. Buhl, 94 Mich. 496, 54 N. W. 157 ; Allen v. Compress Co., 101 Ala. 575,14 So. 362; Wood Reap. \& Mow. Mach. Co. v. Smith, 50 Mich. 565, 15 N. 906, 45 Am. Rep. 57.

2. Falliard v. Wallace, 2 Johns. (N. Y.) 395 ; Burns v. Munger, 45 Hun (N. Y.), 75; Brooklyn v. Railroad Co., 47 N. Y. 475,7 Am. Rep. 469; Grimnell v. Kiralfy, 55 Hun, 422, 8 N. Y. S. 623; Doll v. Noble, 116 N. Y. 230, 22 N. E. 406, 5 I. R. A. 554, 15 Am. St. Rep. 398 . 
work but to renter fersonal scrvices, general in their nature, and especially where the employment involves consileration of fitness, business capacity, integrity, trust, and confidence, the employer's decision of discharge is final if he is not satisfied. ${ }^{3}$

In another elass of cases there must be an actual canse. Thus, where a party purchases milk pans, and the stipulation was that the purchaser was to pay for them if satisfied, the purchaser has no right to say witlont canse that he was dissatisfied and would not pay for the pans, because his dissatisfaction must be actual, not feigned, real, not merely pretended. ${ }^{4}$ And where the grantee in a deed judges as to the title of the land, whether good or not, he cannot make an arbitrary decision not founded on any reasonable ground. ${ }^{5}$

$\S 615$. Contracts of common carriers. - In the absence of special contract there is no absolute duty resting on a common carrier to deliver goods intrusted to it within what, under ordinary circumstances, would be a reasonable time. Not only storms and floods and other natural causes may excuse delay, but the conduct of men may also do so. An incendiary may burn down a bridge, a mob may tear up the track or disable the rolling stock or interpose irresistible force or overpowering intimidation, and the only duty resting upon the carrier, not otherwise in fault, is to use reasonable cfiort and diligence to overcome the obstacle thus interposed, and to forward the goods to their destination. ${ }^{1}$ A common earrier is not liable for losses eaused by the aet of God, by the public enemy, by the inherent defect, quality or vice of the thing earried, by the seizure of goods or chattels in its hands, under legal process, by some act or onission of the owner of the

3. Frary v. Rubber Co., 52 Minn. 264,53 N. W. 1156, is L. R. A. 644.

4. Dagget $v$. Johnson, 49 Vt. 34.5. See, also, Anvil Min. Co. v. Humble. 153 U. S. 540,14 s. Ct. 376.

5. Falliard v. II allace. 2 . Iohnis. (N. Y.) 395 .
1. Wibert v. Railroad Co., 12 N. Y. 245 ; Blackstock v. Raitroad Co., 20 N. I. 43. 75 Am. Dec. 372; Thayer v. Burchard, 99 Mass. 521; Geismer r. hailroad Co.. 102 N. Y. 56i3. 7 N. E. 828.55 Am. Rep. 837. 
goods. $^{2}$ So when a common carrier is prevented by nob violence which it camnot by reasonable efforts overcome, a delay in the delivers of goods may be exeused $:^{3}$ and it is not liable for the act of Gorl when it uses due diligence."

Some courts construe the "act of God" as synonvmous with "inevitable accident," or " nnavoidable accident;" but this construction is not accepted by all the courts, as such accidents may be caused by human agency, ${ }^{6}$ which is excluded from the act of God. ${ }^{7}$

A shipowner may be released by the occurrence of an excepted risk provided he uses due diligence. ${ }^{8}$

\section{$\S 6$ r6. Act of God that will excuse a common carrier.-The} act of God which will excuse a common carrier from performing his contract, must be the proximate, not merely the remote, cause of the loss or injury to the property carried. ${ }^{8}$ Common carriers are not bound to provide against unusual or extraordinary floods, such as have never been known, and which could not have reasonably been foreseen by competent and skilled per-

2. Parsons v. Monteath, 1:3 Barb. (N. Y.) 353 ; Merritt v. Earle, 31 Barb. (N. Y.) 38,29 N. Y. 115; Hall v. Renfro, 3 Met. (Ky.) 51; Cragin v. Railroad Co., 51 N. Y. 61, 10 Am. Rep. 559; Storer v. Gordon, 3 liaule \& S. 308; Norris v. Railroad Co., 23 Fla. 182, 1 So. 475, 11 Am. St. Rep. 355 and note; Southern Express Co. v. Glenn, 16 Lea (Tenn.), 472, 1 S. W. 102.

3. Pittslurg, etc. R. R. Co. v. Hogen, 84 Ill. 36, 25 Am. Rep. 422; Pittsburg, etc. R. R. Co. v. Hallowell, 65 Ind. 188; Geismer v. Railroad Co., 102 N. Y. 563, 7 N. E. 828, 55 Am. Rep. 837; Haas v. Railroad Co., 81 Gia. 792, 7 N. E. 629.

4. Black v. Railroad Co., 30 Neb. 197, 46 N. IV. 197; Nugent v. Snith, 1 C. P. Div. 441.
5. Crosby v. Fitch, 12 Conn. 410 , 31 Am. Dec. 745; Blythe v. Railroad Co., 15 Colo. 333, 25 P. 702, 11 L. R. A. 615 and note, 22 Am. St. Rep. 403; Neal v. Saunderson, 2 Sm. \& M. (Miss.) 572.

6. Central Line v. Lowe, 50 Ga. 509.

7. Fish r. Chapman, 2 Ga. 349, 46 Am. Dee. 393.

8. Geipel v. Smith, L. R. 7 Q. B. 404.

9. New Brunswick Steamboat Co. v. Tiers, 4 Zab. (N. J.) 697, 64 Am. Dee. 394; Backhouse v. Sneed, 1 Murphy (N. Car.), 173; Railroad Co. v. Reeves, 10 Wall. (U. S.) 176 ; Converse v. Brainerd, 27 Conn. 607 ; Express Co. v. Jackson, 92 Tenn. 326, 21 S. W. 666; Morrison v. Davis, $20 \mathrm{~Pa}$. St. $171,57 \mathrm{Am}$. Dec. 695 and note: Lang v. Rail- 
sons. ${ }^{10}$ So an umprecedented storm may excuse a common earrier in delivering a shipment. ${ }^{11}$

$\S 6$ I7. Shipment of live stock. $-A$ common carrier which undertakes to transport live stock for hire becomes chargeable with the duties and obligations which are incident to that relation. ${ }^{1}$ But the carrier is not an insurer of the property as respcets injury which it may suffer from all causes. A common carrier is not an insurer in respect to any injury mavoidably resulting from the essential nature of the property itself, such as the natural decay of fruit, although it must use reasonable care for its preservation. The common-law liability of the carrier is subject to some modifications arising from the nature and propensities of the amimals, and their capacity for inflicting injuries upon themselves and upon each other, when live stock is the subject of transportation. ${ }^{2}$ In the absence of a special agreement, the carrier is responsible for any injury which can be prevented by foresight, rigilance and care, although arising from the conduct of the animals. ${ }^{3}$ In case of injury to live animals which may be caused by each other, or by inherent liability to sickness and death or self-inflicted injury in case of

road Co., 154 Pa. St. 342, 26 A. 370, 20 I. R. A. 360,35 Am. St. Rep. 846.

10. Columbus, ete. R. R. Co. v. Bridges, 86 Ala. 452, 5 So. 864, 11 Am. St. Rep. 58 and note; Coosa River steamboat v. Barelay, 30 Ala. 126; Smith v. Railroad Co., 91 Ala. 455, 8 S. W. 754, 24 Am. St. Rep. 829, 11 L. R. A. 619.

11. Black v. Railroad Co., 30 Neb. 197,46 N. IV. 197.

1. Kimball v. Railroad Co., 26 Vt. 247, 62 Am. Dec. 567; Rexford v. Smith, 52 N. H. 355,13 Am. Rep. 42 and note: Clark v. Railroad Co., 14 N. Y. 570, 67 Am. Dec. 205 and note; Evans v. Railroad Co., 111 Mass. 142, 15 Am.
Rep. 19 ; St. Louis, etc. R. R. Co. v. Dorman, 72 111. 504; Powell v. Railyond Co., 32 Pa. St. 414, 75 Am. Dec. 564.

2. Mloulton v. Ralload Co., 3I Minn. 85, 16 N. 497, 47 Am. Rep. 781; Lindsley v. Railroad Co., 36 Minn. 539, 33 N. WV. 7, I Am. St. Rep. 692; Coupland v. Railroad Co., 61 Comn. 531, 23 A. S70; Selby r. Railroad Co., 113 N. Car. 588, 18 S. E. SS, 37 Am. St. Rep. 635 ; Missouri, ete. R. R. Co. v. Fagan, 72 Texas, 127. 13 An. St. Rep. 776 and note, 9 S. W. 749,2 L. R. $\lambda .75$ and note.

3. Clarke v. Railroad Co., 14 N. I. 570, 67 Am. Dec. 205 and note; Palmer v. Railroad Co., 4 
confinement, if the carrier does all toward their safe carriage which should be done, and injury result no responsibility should be fastened upon the carrier. ${ }^{4}$

\section{$\$ 6$ I8. Hiring contracts - Implication of discharge.-In} every contract of hiring, there is an implication that the servant may be discharged under certain circumstances. If the servant proves to be incompetent to do the thing he is employed to do, and the thing he represents himself qualified to do, the employer has the undoubted right to dismiss him and thus terminate the contract. ${ }^{5}$ So where a servant either neglects, or for want of eapacity makes mistakes about his master's business detrimental to the latter's interest, the latter may discharge him and need not wait until the mistakes of the servant work great damages to him. ${ }^{6}$

The employe is bound to serve the employer faithfully and to refrain from doing any act knowingly and willingly which may affect injuriously the business of his employer; if he does otherwise, the employer may terminate the contract. ${ }^{7}$

\section{\$6rg. Reservation of wages payable at certain intervals. -} The reservation of wages, payable monthly or weekly, will not control the contract so as to destroy its entirety, when the parties have expressly agreed for a specified term, als for a year; but if the payment of monthly or weekly wages is the only circumstance from which the duration of the contract is to be inferred, it will be taken to be a hiring for a month or a week. ${ }^{1}$

Mees. \& W. 749 ; Boyce v. Anderson, 2 Pet. (U. S.), 150.

4. Chicago, etc. R. R. Co. v. Abels, 60 Miss. 1017.

5. Harmer v. Cornelius, 94 Eng. C. L. 236; Keedy v. Long, 71 Md. 385, 18 A. 707.5 L. R. A. 759 and note; Beeston v. Caller, 2 Car. \& P. 607 ; Fillieuk v. Armstrong, 7 Ad. \& El. 557.

6. Newman v. Reagon, 153 Ga.
755; Callo v. Brouncker, 4 Car. \& l. 518; Leatherberry v. Odell, 7 Fed. Rep. $6+1$.

7. Nichols v. Mantyn, 2 Esp. 732; Lacy v. Osbaldiston, 8 Car. \& P. 80 ; Jafray v. King, 34 Md. 220 ; Express Co. v. Trego, 35 Mli. $4 \pi$.

1. King v. Birdbrooke, 4 T'erm R. 245; King v. Toney, 2 Term R. 453 ; King v. Inlabitants, 12 East, 
If the servant fails to perform his part of the contract, and is discharged before the time of the periodieal payment of his wages arrives, he can recorer nothing for the broken period of service when the contract is entire, becance the contract is entire, and the performance of the services for the whole time agreed upon was in the nature of a condition precedent to his right to recover for wages.

But a contract for service "at a salary of $\$ 2,500$ per annum" is not a contract for any definite time and at a fixed price, the complete performance of which is a condition precedent to a right to compensation. It is but a stipulation of the rates at which the employe is to be compensated for the services performed. He is not bound to scrve for any definite time to entitle him to compensation. ${ }^{3}$

$\S$ 620. Extra services.-It is the general rule in agencies, that where a principal has an agent employed at an agreed compensation, and the principal confers on him additional powers which involve greater duties, with no stipulation for additional compensation, he cannot recover extra wages for the additional services, unless a custom fixes it otherwise. ${ }^{4}$

In building contracts where there is a deviation from the original plan, the rule is, that if the plan is wholly changed, or so much so that the work cannot be traced by the contract, the work must be paid for according to ralue and not by the contract. $^{5}$ So after an agency is terminated, if the former

351 ; Beach v. Mullen, 34 N. J. L. 343; Evans v. Railroad Co., 24 Mo. App. 11t; Thomas v. Hatch, 53 Wis. 296, 10 N. 393; Babcock v. Moore, 62 MId. 161; McCullough Iron Co. v. Carpenter, 67 Md. 554, I1 A. 176: Prentiss v. Ledyard, 28 Wis. 131 .

2. Turner v. Robinson, 6 Car. \& P. 15; Ridgway v. Market Co., 3 Ad. \& El. 171; Lilley v. Elwin, 11 Q. B. $7+2$; Turner v. Mason, 14
Nees. \& W. 112; Libhart r. Wood, l Watts \& S. (l'a.) 265, 37 Am. Dee. 461 ; Singer v. McCormick, 4 Watts \& S. (1'a.) 266.

3. Haney r. Caldwell, 35 Ark. 156.

4. United States $v$ M[cDaniel, 7 Pet. (U. S.) 1; Moreau v. Dumagene, 20 La. Ann. 230; Succession of Jackson, 47 La. Ann. 10S9, 17 So. 598.

5. Aild. on Cont. 555. 870 . 
agent is still employed to do other work he is entitled to recover what the time so occupied and the services so rendered are reasonably worth. ${ }^{6}$

$\S 62$. Reservation of right to terminate.-When the right to terminate a contract on notice, is reserved without any fraud or mistake, but with the actual knowledge and consent of the parties to the contract, it is as valid in law as any other clause of the instrument, and the courts, when called upon, will enforce it, unless to do so would be manifestly contrary to equity and good conscience. ${ }^{7}$

Thus, where parties contract to manufacture jars under a license of patentee, to be terminated after thirty days from notice, the courts will enforce it. ${ }^{8}$

And a contract of hiring by the year may be terminated within the year upon notice by one of the parties to the other, if that condition is inferable as a part of the contract from their negotiation, or from usage known to them and understood to be applicable to such arrangement. ${ }^{9}$

$\S 622$. No limitation as to term of hiring.-The rule of hiring without express contract where the service is continued for a long time, is that the hiring will be understood to be by the year, unless circumstances and the dealing of the parties indicate a less period of time. ${ }^{1}$ But when there is no stipulation as to the duration of the employment which is not continued for a long time, and no custom to control, the principal may discharge his agent at any time; but this power to revoke may

6. Attrill v. Patterson, 5 Md. 228 ; Pritchet v. Badger, 87 Eng. C. L. 295; Tombs v. Alexander, 101 Mass. 256, 3 Am. Rep. 349 ; Walker v. Tyrrel, 101 Mass. 257, 3 Am. Rep. 352; Coflin v. Landis, $46 \mathrm{~Pa}$. St. 426.

7. Morrissey v. Broomal, 37 Neb. 766,56 N. W. 383; Fitzgerald v. Allen, 128 Mass. 232; Dick v. Ireland, 130 Pa. St. 299, 18 A. 735;
Fitzpatrick v. Woodruff, 96 N. Y. 561 ; Patrick v. Railroad Co., 93 N. Car. 422; Thayer v. Allison, 109 III. 180 .

8. Dick v. Ireland, $130 \mathrm{~Pa}$. St. 299, 18 A. 135.

9. Patterson v. Manuf. Co., 106 Mass. 56.

1. Ennis v. Palace Car Co., 165 III. 164,46 N. E. 439 . 
be restrained by express stipulation or unless the hiring is for a valuable consideration. Thus, when one as an agent for another contracts to sell lands of the latter, in consideration of one-half the net proceeds of the sale, and there is no stipulation in the contract as to the duration of the employment, cither party may terminate the contract at any time, even without notice $;^{2}$ and this may be done by parol where the agcncy is conferred by an instrument under seal $;^{3}$ and this may be done though the face of the instrument says the agency is irrevocable. ${ }^{4}$ So when a party is hired for a time not exceeding five years, the minimum term is not defined and is necessarily at will of either party $;^{5}$ when parties have entered into written engagements, with express stipulations, it is manifestly not desirable to extend them by implication; the presumption being that having expressed some, they have expressed all the conditions by which they intend to be bound under that instrument, and the court should not add to the obligations by which the parties have bound themselves.

In England there is a class of contracts for the employment of servants where the law presumes the contracts to be a yearly or monthly employment, though nothing is said of the duration of service. They relate to contracts of hire, of menial, domestic, and husbandry servants. They are so construed because such hirings are customarily for a year or a month, and the English courts recognize that custom $;^{7}$ but in the United States it is dombtful if any such custom prevails.

2. Coffin v. Landis, $46 \mathrm{~Pa}$. St. 426. See, also, Smart v. Sanders, 5 Man. Gr. \& S. 895; Peacock v. Cummings, 46 Pa. St. 434; Walker v. Denison, 86 1ll. 142; Conrey v. Brandegee, 2 La. Ann. 132; Trumbull v. Nicholson, 27 Ill. 149; Phillip v. Howell, 60 Ga. 411.

3. Blackstone v. Buttemon, 53 Pa. St. 266, 91 Am. Dec. 203; Brookshire v. Brookshire, 8 Ired. (N. Car.) 74, 47 Am. Dec. 341 and note.
4. McGregor v. Gardner, 14 Iowa, 326 ; Walker v. Denison, 86 Ill. 142.

5. Peacock v. Cummings, $46 \mathrm{~Pa}$. St. 434 .

6. Aspden v. Austin, 5 Ad. \& El., N. S. 671: Dunn v. Sayles, 5 Ad. \& El., N. S. 685 .

7. Huttman v. Boulnois, 2 Car. \& P. 510; Fawcett v. Cash, 5 Barn. \& Ad. 907; Holcroft v. Barber, 1 
$\S$ 623. Notice of termination-Reservation.-To terminate a contract in which there is a stipulation that it may cease by notice of either party, the notice must be clear and unequivocal ${ }^{1}$ and a failure to give such notice will not discharge the contract, ${ }^{2}$ where a specific contract to pay a certain sum for a year, provides that the employer may dismiss the employe at any time during the year upon giving a month's notice, and the latter is so dismissed, the contract is not violated or rescinded, and the employe must recover upon it, and cannot resort to a quantum meruit action. ${ }^{3}$

Car. \& K. 4. See, aıso, Butterfield v. Merlin, 3 Car. \& K. 163; Chitty on Cont. 502; Addison on Cont. 431.

1. Crescent Manuf. Co. v. Manuf. Co., 100 Mo. 325 , 13 S. W. 503; Al- dine Press Co. v. Estes, 75 Mich. 100,42 N. IV. 667.

2. Bour v. Kimball, 46 Ill. App. 327.

3. Jenkins v. Long, $8 \mathrm{Md}$. 132. 


\section{CHAPTER XXI.}

\section{Statute of Limitations.}

\section{ARTICLE I.}

\section{Discharge by Lapse of Time.}

Section 624. At Law.

625. In Equity.

626. Gross Laches.

627. Rebuttal of Presumption-Continuing Contract.

$\S$ 624. At law.-Lapse of time after a debt is contracted is always material, as to its payment irrespective of the statute of limitations; and the doctrine is that payment of any debt, specialty or judgment, will, in a case where there is no recognition of it by the debtor, be presumed after the delay of twenty years. ${ }^{1}$

The presumption of payment, which in reference to debts not embraced in the statute of limitations, arises after the lapse of twenty years, is not a presumption of law, that is, a rule which the court itself may apply, but is a presumption of fact, recognized by the law, from which a conclusion ought to be deduced by a jury. ${ }^{2}$ At common law it is a presumption that payment of a debt, even one due by specialty where it has been

1. Colsell v. Budd, 1 Camp. 27; Hillary $v$. Waller, 12 Ves. 239; Morrow v. Robinson, 4 Del. Ch. Bailey v. Jackson, 16 Johns. (N. 521; Gaines v. Niller, 111 U. S. Y.) 210, 8 Am. Dec. 309; Brubaker 395,4 S. Ct. 426; Rowland v. $\quad$. Taylor, 76 Pa. St. 83 ; Knight v. Windley, 86 N. Car. 36. McKinney, 84 Me. 107, 24 A. 744;

2. Stover v. Duren, 3 Strob. (S. Walker v. Emerson, 20 Tex. 706, 73 Car.) 450 ; Boyce v. Lake. 17 S. Am. Dec. 207; Atkinson v. Dance, Car. 481, 43 Am. Rep. 61s: Shubrick v. Adams, 20 S. Car. 4\%:

9 Yerg. (Tenn.) 424, $30 \mathrm{Am}$. Dec. 422. 
unclaimed and without recognition for twenty years in the absence of evidence to the contrary, has been made. And this common law presumption is independent of and unaffected by the statute of limitations. ${ }^{3}$

Hence, early in England and in this eountry, in cases outside of the statute, the courts had resort to presumption to take the place of evidence and frequently of belief as a general common law prineiple. ${ }^{4}$

A conflict of decisions exist in England which is due to the different views in regard to the ground of limitations. One line of decisions is based on the theory of presumption of payment, as was the common law limitation; the other theory on the impolicy in suffering debts to be unsettled for a long period of time, and the danger of injustice in the enforcement of State claims. The question is whether a statute of limitations is one of presumption or of repose. If it be one of presumption of payment, it is overcome by whatever will rebut a presumption of payment, and anything will do this which implies, or amounts to an acknowledgment, that the debt has not been paid. So the slightest acknowledgment will take the case out of the statute. But if it be a statute of repose, it remains a bar to the enforeement of a debt within its provisions, unless the debtor voluntarily renounces its benefit and makes a new promise to pay the old debt. ${ }^{5}$ The prevailing theory in England and in the United States is, that the statute of limitations is one of repose. So whenever the text speaks of presumption, it has reference to the common-law doctrine which held that it might be presumed that payment had been made after long lapse of time.

$\S 625$. In equity.-A court of equity applies the rules of laches according to its own ideas of right and justice, and the courts have never prescribed any specific period applicable to

3. Carr v. Dings, 54 Mo. 95; Clemens v. Wilkinson, 10 Mo. 97; Williams v. Mitchell, 112 Mo. 300, 20 S. W. 647.
4. Hillary v. Walter, 12 Ves. 267.

5. Truman v. Fenton, 1 Cowp. 548. 
every case, like the statute of limitations; and what constitutes a reasonable time within which suit must be brought depends upon the facts and circumstances of each particular case. ${ }^{6}$ And this rule is peculiarly applicable where the property, the subject of litigation, is subject to rapid or frequent changes in value, as stocks, oil wells, mining property and the like.

$\S 626$. Gross laches.-It is an inherent doctrine of the courts of equity to refuse relief where there has been gross laches in prosecuting rights, or long and unreasonable acquiescence in the assertion of adverse rights. And the principle, founded as it is upon consideration of natural justice and public policy, is always firmly enforced, especially in cases involving transactions to which immediate parties are dead. ${ }^{1}$

Where a party injured by fraud is in ignorance of its existence, the duty to commence proceedings arises only upon discovery. $^{2}$ But the party must distinctly state in his allegations, and prove at the hearing, the time of the discovery and what the discovery was, so that the court may really see whether by the exercise of ordinary diligence, the discovery might not hare been made before. ${ }^{3}$

The law is well settled that where the question of laches is

6. Brown v. Buena Vista Co., 95 U. S. 157, 160; Wood v. Carpenter, 101 U. S. 140; Twin Lick Oil Co. v. Marbury, 91 U. S. 587 ; Rogers v. Van Nortwick, 87 Wis. 414, $58 \mathrm{~N}$. W. 757; Rogers v. Saunders, 16 Me. 92, 33 Am. Dec. 635; Patterson v. Martz, 8 Watts (Pa.), 374, 34 Am. Dec. 474; Southcombe v. Bishop, 6 Hare, 213; Eads v. Williams, 4 DeG. M. \& G. 674; Daggers v. Van Dyck, 37 N. J. Eq. 130; Hall v. Denckla, $2 S$ Ark. 506; Trader v. Jarvis, 23 W. Va. 100.

7. Twin Lick Oil Co. v. Marbury, 91 U. S. 587; Johnston v. Mining Co., 148 U. S. $360,370,13$ S. Ct. 585. See, also, Combs v. Scott, 76
IVis. 662, 45 N. IV. 532 ; Galway v. Railroad Co., 128 N. Y. 132, 153, 28 N. E. 479,13 L. R. A. 788.

1. Harrison v. Gibson, 23 Gratt. (Va.) 212, 223; Smitl v. Clay, 3 Bro. C. C. 639 , n; Hateher v. Hall, $77 \mathrm{Va} .573$; Carr v. Chapman. 5 Leigh (Va.) 17ti ; Hill v. Umberger, 77 Va. 653; Defiance Water Co. v. Defiance, 68 Ohio St. 520, $67 \mathrm{~N}$. E. 1052 .

2. Maeder v. Norton, 11 Wall. (U. S.) 458; Kilbourn v. Sunderland, 130 U. S. 518,9 S. Ct. 594.

3. Stearns v. Page, 7 How. (U. S.) 819 : Balger v. Badger, 2 Wall. (U.S.) $87,9 \tilde{\text {. }}$ 
in issue, the plaintiff is chargeable with such knowledge as he might have obtained upon inquiry, provided the facts already known by him were such as to put upon a man of ordinary intelligence the duty of inquiry. ${ }^{4}$ And the duty is more peremptory where the property itself is of uncertain value, and considerable expenditures are boing made, and it is liable to greatly increase in value. In such cases the court looks with disfavor upon the clains of those who have waited to decide, when the danger is over, which has been at the risk of another, to come in and claim the profits of the event. ${ }^{5}$ Poverty or pecuniary embarrassment is not a sufficient excuse for postponing the assertion of one's rights. ${ }^{6}$

\section{$\S 627$. Rebuttal of presumption - Continuing contracts.} The lapse of twenty years raises a presumption of payment at common law as to contracts, even sealed instruments, which, though not a presumption of law, and not therefore conclusive, yet it is a presumption of fact which has acquired an artificial force, subject to be rebutted; but the facts relied on for this rebuttal must be stronger than mere belief deduced from the weight of testimony being on that side. They must be of a character which would revive a contract bound by the statute of limitations. ${ }^{1}$

Whether the statute has run often comes into consideration in cases of service in a family. Thus, in an action against administrators of a decedent's estate for work and labor performed by the plaintiff, the rule was announced if plaintiff performed labor for the intestate under an agree-

4. Wood v. Carpenter, 101 U. S. 141; Kennedy v. Green, 3 Myl. \& K. 699 ; Erlanger v. Phosphate Co., L. R. 3 App. Cas. 1231; Carr v. Hilton, 1 Curt. C. C. 390, 394; Buckner v. Calcote, 28 Miss. 432; Johnston v. Mining Co., 148 U. S. 370,13 S. Ct. 585.

5. Cox v. Montgomery, 36 Ill. 396 .
6. Hayward v. Bank, 96 U. S. 618. See, also, Rogers v. Van Nortwick, 87 Wis. 414,58 N. W. 757 ; Voight v. Raby, 90 Va. 799, 20 S. E. 824.

1. Boyce v. Lake, 17 S. Car. 481, 43 Am. Rep. 618; Williaume v. Gorges, 1 Camp. 217. 
ment to be paid therefor, withont specifying at what time the payment should he made, or how long the labor should continue, the statute of limitations would not begin ito run until the labor was ended; that there heing an entire contract to serve for an indefinite period, the rule that in an action on account, when all items of account are on one side, the fact that some items are within the period of limitation, does not take the others of a longer standing out of the operation of the statute, would not apply to such action upon an entire continuing contract. ${ }^{2}$ Such a continuing contract may be an implied contract, and the same rule will apply to it. ${ }^{3}$ In the application of this rule that the contract is a continuing one and therefore the statute of limitations does not begin to run until the work is ended, applies to an implied contract the same as to a contract expressed." In New York the rule is different, and an action on such entire continuing contract is treated as if upon an account of distinct items all on one side. and the fact that some items are within the period of limitation does not take the others of longer standing out of the operation of the statute. ${ }^{5}$

2. Littler v. Smiley, 9 Ind. 116.

3. Crampton v. Logan, $2 S$ Ind. App. 405, 63 N. E. 50 ; Knight v. Knight, 6 Ind. App. 268, 33 N. E. 456.

4. Schoonover v. Vachou, 121 Ind. 3, 22 N. E. 777 ; Bartel v.
Mathias, 19 Oreg. 482, 24 P. 918; Hickam v. Hickam, 46 Mo. App. 496: O'Brien v. Sexton, 140 Ill. 517, 36 N. E. 461; Frost v. Tarr, 53 Ind. 390.

5. In re Gardner, 103 N. Y. 533 , 9 N. F. 306,57 Am. Rep. 768 . 


\title{
ARTICLE II.
}

\section{Application of Statute.}

\author{
Sectron 628. Beginning to Run. \\ 629. Continuing to Run. \\ 630. Trusts-Unpaid Subscription. \\ 631. Death of Ancestor. \\ 632. Absence of Debtol from the State. \\ 633. Absence of Creditor from the State. \\ 634. Joint Debtor. \\ 635. Surety's Liability. \\ 636. Statutory Provisions. \\ 637. Waiver of the Statute. \\ 638. What Law Governs.
}

$\S 628$. Beginning to run.-The statute of limitations begins to run from the time when the right of action accrues. ${ }^{1}$ Thus, on a deposit of money to be kept until demanded, no action accrues until demand is made. ${ }^{2}$ But a promise to pay a note on demand, such may be brought immediately because the action has accrued and the beginning of a suit is a sufficient demand, and the statute begins to run from the date of the promise. ${ }^{3}$ Statutes of limitation do not run against the United States and the States except where it is enacted that it shall so run $;^{4}$ but municipal corporations are not generally excepted, ${ }^{5}$ and they may plead it. ${ }^{6}$

When the hiring of a party is by the month, salary payable at the end of each month, the statute begins to run against the

1. Odlin v. Greenleaf, $3 \mathrm{~N} . \mathrm{H}$. 270; Withers v. Richardson, $5 \mathrm{~T}$. B. Mon. (Ky.) 94; Jones v. Jones, 91 Ind. 378; Medichael v. Carlyle, 53 Wis. 504, 10 N. 656.

2. Zuck v. Culp, 59 Cal. 142.

3. Ardress's Appeal, 99 Pa. St. 421; Farquhar v. Morris, T Term R. 124.

4. United States r. Coul Co., 5
MeCrary, C. C. 563 ; Swann v. Lindsey, 70 Ala. 507.

5. Oxford v. Columbia, 38 Ohio St. 87; Gaines v. Hot Springs, 39 Ark. 262; Forsyth v. Wheeling, 19 W. Va. 318; Coleman v. Thurmond, 56 Tex. 514.

6. Board v. Blodgett, $155 \mathrm{Ill}$. 441,40 N. E. 1025, 31 L. R. A. 70, 46 An. Sit. Rep. 348. 
right of action for each month's services on the first day of each succeding month. ${ }^{7}$

The rule as affecting retainers of and services dne to attorneys at law is this:

1. Where an attorney is eonducting a single suit, the statute will not begin to run until the end of the suit or the termination of the retainer in sume other mode.

2. When the attorneys are regularly employed at a salary, given for advice and legal superintendence, and other scrvices reudered from day to day, they stand upon the same footing as other salaried employes, so far as the statute affeets them.

3. Ordinarily when a man is employed under a general agreement, fixing no term of service, but he eontinnes in service a long time, his hiring will be treated as a hiring by the year. But in such ease the statute will ordinarily have a elaim for all ontside of the prescriptive time, immediately before the commencement of the action, muless there is evidence to take it out of the operation of the statute.

4. The rule of hiring without express contract where the service is continued for a long time, the hiring will be understood to be by the vear, unless circumstances and the dealing of the parties indicate a less period of time. ${ }^{8}$ In ease of a physician who eauses injury by his unskillful work, the statute begins to run from the time his professional relation has eeased with his patient, as to bringing suit by the patient to collect damages. ${ }^{9}$

$\S$ 629. Continuing to run. - The English statute provides that if the plaintiff, at the time the action accrues, be an infant, feme covert, non compos mentis, imprisoned, or beyond the seas, he may bring his action at any time within the preseribed period of limitation after the disability ceases. If several disabilities co-exist when the right of action accrues, the statute does not begin to rum until all are remored. But

7. Ennis v. Palace Car Co., 165 111. 164,46 N. E. 439 .

8. Ennis v. Palace Car Co., 165 Ill. 164,46 N. E. 439 .
9. Gillette r. Tucker, 67 Ohio, 106, 64 N. E. 865,93 Am. St. Rep. 639 and note. 
if only one exists where the canse of action accrues, other disabilities arising afterwards cannot be tacked to the first, so as to extend the time of limitation. The phrase in the English statute "beyond the seas," or similar phrases, are used in some of the American statutes. Their interpretation has not been the same. Some courts construe the phrase to mean beyond the limits of the United States, while others hold that the phrase means beyond the State or jurisdiction where the action is tried.

Where a statute of limitations begins to run it will continue to run until it produces a complete bar, unless there is some saving or qualification in the statute itself. ${ }^{1}$

A statute of limitation does not run where there is no one who has the right and the capacity to sue, and where there is no one capable of being sued. But when the statute once has commenced to run, it does not cease to run on account of any intervening disability to sue and to be sued. ${ }^{2}$

The statute of limitations effects the remedy only; it does not discharge the delst, but simply bars an action upon it after the statute has run. Though the remedy by action is gone, a lien or security for the debt is not lost by the running of the statute. So if a note should be given, which is barred in ten years after due, it will not prevent the foreclosure of a mortgage to secure it on real estate, which runs twenty years. The barring of the debt does not effect the lien unless so provided by statute. The security and the debt are separate as to the statute. ${ }^{3}$

When the statute of limitations has begmn to run, it continues to run, notwithstanding the subsequent occurrence of

1. Peoria County v. Gordon, 82 Ill. 435; People v. White, 11 Ill. 342 ; Rhodes v. Smithurst. 4 Mees. \& Wel. 42; Cotterell v. Dutton, 4 Taunt. S26; Peck v. Randall. I Johns. ( N. Y.) 165; Rogers v. Hillhouse, 3 Conn. 398; MeAuliff v. Parker, 10 Wash. 141, 3s P. 74t; Langford v. Gentry, 4 Bibb (Ky.),
468; Granger r. Granger, 6 Ohio, 17 ; Mine's Appeal, $99 \mathrm{~Pa}$. St. 483; Kistler v. Hereth, 75 Ind. 177, 39 Am. Rep. 131 and note; Henton v. Niehols, 55 Tex. 217.

2. Underhill v. Ins. Co., 67 Ala. 45 .

3. Pratt v. Huggins, 29 Barb. (N. Y.) 277 ; Alexander v. Whipple, 
some disability which did not exist at the commencement of the action, and which, had it then existed, would have postponed the ruming of the statute until removal of the disability. ${ }^{4}$

\section{$\S$ 630. Trusts-Unpaid subscription to corporation stock.-} The statute begins to run from the time that the trustee has openly repudiated or disclaimed the trust. ${ }^{5}$ So delay on the part of the heir for an unreasonable period after reaching his majority, to set aside a purchase of his ancestor's land by the administrator, will bar relief where the administrator during that time was openly and continuously in adverse possession within the knowledge of the heir. ${ }^{6}$

Subseriptions to corporate stock are a fund in the hands of the stockholder's, charged with a trust for the payment of corporate debts. This trust does not depend on any statute, but is deduced from the general principles of equity, from the premise that the capital is publicly pledged to those who deal with the corporation for their security. When the corporation becomes insolvent, the unpaid subscription becomes a fund for the payment of corporate debts. Then an interesting question arises whether the statute of limitations begins to run against the liability of the stockholders to the creditors of the corporation, on their umpaid subscription at the time of the insolvency of the corporation, as shown by its assignment for creditors, or from its bankruptey. But this unpaid fund is not to be put into distribution until the insufficiency of the other corporate assets is shown. The better rule is that the creditor need not wait until full administration has exhansted the other assets. The creditor should have the right to bring hiv action to ascertain

45 N. H. 502 ; Mayor v. Colgate, 12 N. I. 140 ; Spears v. Hartley, 3 Esp. 81; Williams v. Jones, 13 East, 439; Iliggins v. Scott, ? 13 . \& Ad. 413.

4. Harris v. MaGoverns, 99 U. S. 161 ; People v. Gordon, 82 Ill. 435 ; Hunton v. Nichols, 55 Tex. 217.
5. Hiand r. Fleeman, 5s Ark. 90, 23 S. W. 4 ; Merriam v. Hassam, 14 Allen (Mass.), 516, 92 An. Dee. 795: Kane v. I3loodgood, 7 Johns. ('h. (X. Y.) 90, 11 Am. Dec. 417 ; Wood v. Carpenter. 101 U. S. 139.

6. Thomas v. Sypert, 61 Ark. 575,33 S. W. 1059. 
the liability of the stockholder while eridence on disputorl facts is obtainable. ${ }^{7}$ But other courts hold differently, and declare that the other assets must be fully administered before suit can be bronght against the stockholder who has not paid in full for his stock. Under this rule, the main suit for the exhanstion of the corporate assets may be so prolonged as to permit the statute of limitations to rum successfully in faror of stockholders who are debtors of insolvent corporations, for unpaid stock.

As a general rule the statute does not run as between trustee and cestui que trust in express trusts, but the rule is otherwise as to constructive trusts. ${ }^{8}$

$\S 63$ r. Death of ancestor.-- Where a person who conld have maintained an action to recover an interest in his lifetime dies, the running of the statute of limitations is not suspended during the minority of one who claims under the decedent. ${ }^{1}$

A provision of a statute for deducting from the period of limitations the time of absence of the debtor from the State, ceases to apply upon his death in another State. ${ }^{2}$ And when the statute extends the time within which a personal action may be brought in case of the death of the person entitled to bring, or liable to such action, to a specified time from the date of such death, the action will become barred without reference to the appointment of an administrator, in the time named. ${ }^{3}$

And the fact that the right of parties claiming an interest in lands by right of heirship and as remaindermen was con-

7. Swearington v. Dairy Co., 198 Pa. St. 68,47 A. 941,53 L. R. A. 471.

8. Redford v. Clarke (Ta.), 41 s. E. 720 .

1. Grether v. Clark, 75 Iowa, 383, 39 N. W. 655, 9 Am. St. Rep. 491 ; Chauncey v. Powell, $103 \mathrm{~N}$. Car. 159, 9 S. E. 298; Frederick v. Williams, 103 N. Car. 189; McLaran v. Benton, 73 Cal. 329, $2 \mathrm{Am}$. St. Rep. 814, 14 P. 879 ; Castro v. Geil, 110 Cal. 202, 42 P. S04, 52
Am. St. Rep. 84; Thompson v. Smith, 7 Serg. \& R. (Pa.) 209, 10 Am. Dec. 453 ; Piper v. Hoards, 107 N. Y. 67,13 N. E. 632, 1 Am. St. Rep. 785. See, also, Oates v. Buckwith, 112 Ala. 356, 20 So. 399; Meinlifl v. Parker, 10 Wash. 141, 3s P. 744.

2. Hibernian Banking Asso. v. Bank, 157 Ill. 524, 4 l N. E. 284.

3. Hughston v. Nail, 73 Miss. 284, 18 So. 920 . 
sidered very donbtful for several years after the falling of the life estate, and until their rights were made elear by a decision in a suit between other parties, is $n$ orome for holding that the statute of limitations was in the meantime suspended as against them. ${ }^{4}$

$\S$ 632. Absence of debtor from the State.-In most of the States it is provided that after a cause of action has arisen against a person and he departs from the State, the statute of limitations is suspended while he is absent, and does not begin to run again until his return. In such case the party must depart after the cause of action has accrued and be continuously absent from the State, and he must reside without the State. All these elements must concur in order to suspend the operation of the statute. But a person who has a residence and domicile in a state, and departs as a traveler for business or pleasure in another country, does not by his absence acquire a residence or reside in that country. He must while so absent at least take up his temporary abode at some particular place with the intention of making it his home while so absent, and actually reside there. ${ }^{1}$

Neither a residence or domicile is acquired by a mere visitor from this country traveling from place to place in Europe, all the time intending when the purpose of the journey is satisfied to return to his home here. ${ }^{2}$

So where a debtor removes from a State before the action accrues, periods which he subsequently spends in the State as a salesman traveling from place to place, and remaining only a few days in each place, cannot be included to complete the period of limitations. ${ }^{3}$

4. Elder v. McClaskey, 70 Fed. Rep. 529.17 C. C. A. 251,37 U. S. App. 1, 199.

1. Hart v. Kip, 148 N. Y. 306 , 42 N. E. 712 ; Dupuy v. Wurtz, 53 N. Y. 556 ; People v. Platt, 117 N. Y. 159, 22 N. E. 937 ; DeMeli v. De-
Meli, 120 N. Y. 485,24 N. E. 996. $17 \mathrm{Am}$. St. Rep. 65.

2. Hart v. Kip, 148 N. Y. 306 , 42 N. E. 712.

3. Weille v. Levy, it Miss. 34, 20 So. 3, 60 Am. St. Rep. 500. See, also, Lee v. Mcliay, $11 \mathrm{~S}$ N. Car. 518,24 S. E. 210. 
The debtor's absence from the State is not to be included when applying the statute of limitations. ${ }^{4}$ In many States, though not in all, a statute barring a debt arising in another State when barred in the latter State, does not apply to a debt accruing in a State against a resident thereof who removes to another State after the action acerues. ${ }^{5}$ But this matter is controlled by statutory provisions, and it makes no difference where the cause of action arises. ${ }^{6}$

$\S$ 633. Absence of creditor from the State.-The English statute of limitations which saved to persons "beyond the sea," when their cause of action acerued, a limited time after their return, within which to sue, runs from the time the party returns, and his going abroad again gives him no privilege, for that is gone by his having once returned to the kingdom, after his eanse of aetion acerued. ${ }^{7}$

A disability is removed, within the purview of the statute, when it no longer exists; that of absenee from the State ends when the personal presence of the ereditor in the State begins; and once ended by such presence, though it be but for a temporary purpose and of short duration, the disability does not revive by subsequent absence however permanent in its eharaeter, or long contimned, ${ }^{8}$ even when commeneed during his infaney. ${ }^{9}$

Every person who is absent from the State when his eause of aetion arises, whether of consenting eapacity or not, is included in the saving clause of a statute, miless excepted from

4. Hampton v. France, $32 \mathrm{~S}$. W. 950,33 S. W. $826,17 \mathrm{Ky}$. L. R. 980.

5. Hibernian Banking Asso. v. Bank, 157 Ill. 520, 41 N. E. 918. See, also, Bagwell v. McTighe, 85 Tenn. 616, 4 S. W. 46 ; Kempe v. Bader, 86 Tenn. 189, 6 S. IV. 126 ; Chevrier v. Robert, 6 Mont, 319, 12 P. 702; Lloyd v. Perry, 32 Iowa, 144; Davis v. Harper, 48 Iowa, 513; Mechanics Build. Asso. v. Whitacre, 92 Ind. 547.
G. Nebster v. Davies, 44 Neb. $301,62 \mathrm{~N}$. W. 484. S'ee, also, Thompson v. Read, $4 l$ Iowa, 48; Goodnow r. Stryker, 62 Jowa, 221, 14 N. 345,17 N. 506 ; Wright v. Johnson, 42 Ind. 2 ?

7. Sturt v. Mellich, 2 Atk. 610 .

8. Faw v. Roberdeau, 3 Cranch (U. S.), 174.

9. Powell v. KKoehler, 52 Ohio St. 103,39 N. E. 195,26 L. R. A. 480, 49 Am. St. Rep. 705 and note. 
its aetion. 'The disability may lo an absence from the State; where such is the ease, the only fart esential to its removal is the actual presence of the person in the State; no distinction having been made hy the statute, either with respect to the disability, or its removal, on account of the age, or capacity of the person, or other circumstances. And such disability as absence from the State ceases from the time the actual presence of the person in the State begins, though such presence be of short duration and while the person is an infant. ${ }^{10}$

$\S 634$. Joint debtor.-In some of the States the absence from the State of one of the joint debtors suspends the statute of limitations as to all. ${ }^{1}$

In England, if the right of action accrues against several persons one of whom is beyond the seas, the statute of limitations does not run until his return, though the others have never been absent $;^{2}$ but this matter is regulated by the various statutes which must be consulted as there are decisions otherwise. $^{3}$ Thus, in New York, in case of joint debtors, the statute runs against the one who remains at home, but not against the one who has gone out of the State. ${ }^{4}$

The general American doetrine is that a part payment of a matured debt by one of several joint debtors is inoperative to prevent the running of the statute as to the others. ${ }^{5}$ In order to prevent the running of the statute in favor of a joint debtor, he must make payment in person, or by an authorized agent. The mere fact that he has knowledge of payment being made by his co-debtors is not sufficient. ${ }^{6}$ Therefore, a partial payment

10. Powell v. Koehler, 52 Ohio st. 103,39 N. E. 195,26 . L. R. A. 480, 49 Am. St. Rep. 705 and note.

1. Reŗbold v. Parker, 7 Houst. (Del.) 526 .

2. Fanning v. Anderson, $7 \mathrm{Ad}$. \& El., N. S. 811; Townsend v. Mead, 16 C. B. 123 .

3. Brown v. Delafield, 1 Denio (N. Y.), 445; Denny v. Smith, 18 N. Y. 567.
4. Brewster r. Bates. 81 Hun, 294, 30 N. Y. S. 780.62 N. Y. Sit. 744.

5. Waughop v. Bartlett, 165 Ill. 124,46 N. E. 197 ; Willoughby v. Irish, 35 Minn. 63, 37 N. W. 379 , 59 Am. Rep. 297.

6. Medlillen v. Rafferty, $89 \mathrm{~N}$. Y. 456: Littlefield v. Littlefield, 91 N. Y. 203, 43 Am. Rep. 663. 
of a promissory note matured, or a debt due by the principal, will not suspend the statute as to the surety. ${ }^{7}$ Because the partial payment voluntarily made by a debtor upon a debt is in the nature of an acknowledgment or admission by him of his liability for the whole demand, and from the fact that he made the payment, a new promise on his part to pay the remainder of the debt may be implied, and under this legal inference such new promise arises at the time the partial payment is made, but this does not renew the debt as to his co-debtors. ${ }^{8}$ But other courts, following the English rule, hold that part payment by one of the several and joint debtors, before the statute attaches, takes it out of the operation of the statute as to the other debtors, or makers.

The principle on which part payment by a joint debtor is allowed to affect the other parties, is the community of interests among them, which creates the presumption that the party paying would not acknowledge that which is adverse to his own interest, and therefore it will be in the interest of the others and bind them. ${ }^{9}$

$\S 635$. Surety's liability in case of fraud by principal.-.The fraudulent concealment of principal does not release surety.

7. Mozingo v. Ross, 150 Ind. 688 , 50 N. E. 867,41 L. R. A. 612,65 Am. St. Rep. 387 ; Steele v. Souder, 20 Kan. 39; Waughop v. Bartlett, 165 Ill. 124,46 N. E. 197.

8. Van Keuren v. Parmelee, 2 N. Y. 523, 51 Am. Dec. 322 and note; Shoemaker v. Benedict, 11 N. Y. 176,62 Am. Dec. 95 and note; Winchell v. Hicks, 18 N. Y. 558; MeLaren v. McMartin, $36 \mathrm{~N}$. Y. 88: Harper v. Fairley, 53 N. Y. 442; Graham v. Selover, 59 Barb. (N. Y.) 313 ; Succession of Voorhies, 21 La. Ann. 659; Smith v. Coon, 22 La. Ann. 445; Hunter v. Robertson, 30 Ga. 479; Bell v. Morrison, 1 Pet. (U. S.) 351 ; Morien- thal v. Mosier, 16 Ohio St. 566; Vance v. Hair, 25 Ohio St. 349 ; Steele v. Souder, 20 Kan. 39 ; Davis v. Clark, 58 Kan. 454, $49 \mathrm{P}$. 665; Pfenninger v. Kokesch, 68 Minn. 81, 70 N. W. 867; Willoughby v. Irish, 35 Minn. 63, 37 N. W. 379, 59 Am. Rep. 297.

9. Block v. Dorman, 51 Mo. 31 ; Disbrough r. Bideman, 20 N. J. L. 275 ; Corliss v. Fleming, 20 N. J. L. 349 ; Whitlock v. Doolittle, $18 \mathrm{Vt}$. 440, 46 Am. Dec. 163; Pike v. Warren, 15 Mo. 390, 57 Am. Dec. 207 ; Hunt v. Brigham, 2 Pick. (Mass.) 581, 13 Am. Dec. 45s; Calwell v. Signourney, 19 Conn. 37; Perkins v. Barstow, 6 R. I. 505. 
Hence, if a cause of action for the breach of the condition of a bond is fraudulently concealed by the prineipal, the surety is still held, and against the latter the cause of action must be decmed to have accrued where the fraud was first discorered, at which time the statute of limitations began to rum. ${ }^{1}$

The liability of a surety on a claim which is good as against the principal, ceases as soon as the claim is extinguished by the principal. Without a principal there can be no accessory. Nor can the obligation of the surety, as such, exceed that of the principal. $^{2}$ So where the fraudulent concealment of the prineipal prevents the statute of limitations from running in his favor, it also stops it from ruming in faror of his surety. ${ }^{3}$

The existence of a principal debtor is a condition precedent to the operation of the contract of a surety. ${ }^{4}$ This is in accordance with the general law of contracts, which prevents a contract from becoming operative, unless and until all conditions precedent are fulfilled. ${ }^{5}$

Where the principal extinguishes the debt by payment, this discharges the surety. Ordinarily the liability of a surety is measured by the liability of the principal. ${ }^{6}$ But where the statute does not intervene, the liability of the surety is not changed by the insolvency and discharge of the principal in the bond of attachment. And the surety is still liable, though

1. MeMullen v. Winfield, etc. Asso., 64 Kan. 298, 67 P. 892, 50 L. R. A. 924, 91 Am. St. Rep. 236 ; Eissing v. Andrews, 66 Conn. 58, 33 A. 585, 50 Am. St. Rep. 75.

2. Ferry v. Burchard, 21 Conn. 603; Willey v. Paulk, 6 Conn. 74; Candee v. Skinner, 40 Conn. 464.

3. Bradford v. McCormick, 71 lowa, 129, 32 N. W. 93; Boone County v. Jones, 54 Iowa, 669, 2 N. 987, 7 N. 155; Charles v. Hoskins, 14 Iowa, 47l, $83 \mathrm{Am}$. Dec. 378 and note; Eising v. Andrews, 66
Conn. 58, 33 A. 585, 50 Am. St. Rep. 75.

4. Hazard v. Irwin, 18 Pick. (Mass.) 95; Swift v. Beers, 3 Denio (N. Y.), 70; Mountstephen v. Lakeman, L. R. 7 Q. B. 202 ; Mallet v. Bateman, L. R. I C. P. 163.

5. Farmers and Mechanics' Bank v. Kingsley, 2 Doug. (Mich.) 379.

6. Seaver v. Young, $16 \mathrm{Vt}$. 658; Boone County v. Jones, jt Iowa, 709, 2 N. 987, 7 N. 155: Patterson's Appeal, $48 \mathrm{~Pa}$. St. 345 ; MeCabe v. Raney, 32 Ind. 309. 
the principal is discharged in bankruptcy. ${ }^{7}$ Disability of principal will not discharge the surety. ${ }^{8}$

$\$ 636$. Statutory provisions. - The general rule is that no contract or agreement can modify a law, but exceptions are, that where no principle of public policy is violated, parties are at liberty to forego the protection of the law. Statutory provisions, designed for the benefit of individuals, may be waived, but where the enactment is to secure general objects of policy or morals, no consent will render a noncompliance with the statute effectual. But a statute limiting the time within winich actions shall be brought is for the benefit and repose of individuals and not to secure general objects of policy or morals. ${ }^{9}$

$\S 637$. Waiving of the statute.-A statute of limitations is for the benefit of individuals and not to secure general objects of policy or morals. Its protection, therefore, may be waived in legal form by those who are entitled to it, and such waiver, when acted upon, becomes an estoppel to plead the statute. ${ }^{10}$ And this agreement to waive the statute need not be in writing. ${ }^{13}$ Where such waiver is made it is continuous, unless by its terms it is limited to a specified time. ${ }^{12}$

$\S 638$. What law governs.-Limitations of actions is governed by the lex fori and is controlled by the legislature of the State in which the action is brought, as construed by the highest court of that State, even if the legislative act or the judicial construction differs from that prevailing in other jurisdictions. ${ }^{1}$

7. Pingrey on Suretyship and Guar. 131, 212, 408.

8. Pingrey on Suretyship and Guar. $92,135,190,376,379$.

9. Quick v. Corliss, 39 N. J. L. 11; Burton v. Stevens, 24 Vt. 131, 58 Am. Dec. 153.

10. Quick v. Corliss, 39 N. J. L. 11 ; Burton v. Stevens, 24 Vt. 131, 58 Am. Dec. 153; Gay v. Hassom, 64 Vt. 495, 24 A. 715; Random v. Tobey, 11 How. (U. S.) 493; State
Trust Co. v. Sheldon, 68 Vt. 259, 35 A. 177 ; Bridges v. Stephens, 132 Mo. 524, 34 S. W. 555.

11. Brídges v. Stephens, $132 \mathrm{Mo}$. 524,34 S. W. 555.

12. State Trust Co. v. Sheldon, 68 Vt. 259, 35 A. 177.

1. McElmoyle v. Cohen, 13 Pet. (U. S.) 312 ; Bauserman v. Blunt, 147 U. S. 647,13 S. Ct. 466 ; Metcalf v. Waterman, 153 U. S. 611, 14 S. Ct. 947 ; Obear v. Bank, 97 
So an action bronght by a non-resident against a resident of a State, is governed by the statute of linitations of the State where the action is hrought, ${ }^{2}$ muless the statute permits the law of the lex loci cclebrationis also to be pleaded. ${ }^{3}$ This is a question pertaining essentially to the remedy, and not to the obligation of the debtor; for a retrospective statute, either adding to or diminishing the period within which an aetion may be brought upon a contract, does not impair its obligations, provided a reasonable time is allowed the creditor within which to sue. ${ }^{4}$ Therefore, the lex fori must govern the period within which the action is to be brought. ${ }^{5}$ So the effect of part payment as to reviving the debt, or preventing the statute from running, is a matter to be deternined by the lex fori. ${ }^{6}$ And the same doctrine holds as to the written acknowledgment of the debt. ${ }^{7}$ The lex fori governs as to the running of the statute against a foreign judgment. ${ }^{8}$ If the defendant sets up the lex fori which prevents an action and judgment is rendered in his favor, this will prevent the creditor from suing him in another State where the lex fori will permit an aetion. ${ }^{9}$ But in case of judgment for the defendant on the plea that the contract is not in writing under the statute of frauds by the lex fori, or any other defense not going to the merits of the case, it does not preelude the creditor from suing in another State. ${ }^{10}$

Ga. 587,25 S. E. 335,33 L. R. A. 384 ; Balkau v. Woodstock Iron Co., 154 U. S. 177,14 S. Ct. 1010 ; Martin v. Wilson, 120 Fed. Rep. 202, 58 C. C. A. 181 ; Great Western Tel. Co. v. Purdy, 162 U. S. 329, 16 S. Ct. 810; Bain v. Whitehaven, $3 \mathrm{H}$. L. Cas. 1 .

2. Fearing v. Glenn, 73 Fed. Rep. 116, 19 C. C. A. $38 s$.

3. Hurd's Ill. Stat. (1903), ch. 83 , sec. 20.

4. Wheeler v. Jackson, 137 U. S. 245, 11 S. Ct. 76 ; Ball v. Morrison. 1 Pet. (U. S.) 351.
5. Minor's Conf. L. p. 522; Story's Conf. L. secs. 576, 577.

6. Obear v. Bank, 97 Ga. 587, 25 S. E. 335,33 I. R. A. 384 .

7. Walsh v. Mayer, 111 U. S. 31, 4 S. Ct. 260.

8. Ambler v. Whipple, 139 Ill. 311, 28 N. E. 841,32 Am. St. Rep. 202.

9. Bank v. Donnally, s Pet. (U. s.) 361 .

10. Minor's Conf. L. p. 522, note. 


\title{
CHAPTER XXII.
}

\author{
Performance.
}

\section{ARTICLE I.}

\section{Specified Mode.}

Shotron 639. To Perform Work and Furnish Materials.

640. Substantial Performance-Good F'aith.

64l. Time of Performance.

$\S 639$. To perform work and furnish materials. - It is the general rule that where a party has entered into a contract to perform work and furnish materials of a specified character, and the other party agrees to pay for the same upon the performance of the contract, although the work may be performed and materials furnished, yet, if not done in the manner stipulated, the contract is not performed and no action will lie for compensation. ${ }^{1}$ A substantial performance must be shown, unless it has been waived or released. ${ }^{2}$

Where the contract provides that the work shall be to the satisfaction of the promisee, this means, according to some authorities, that the articles must be accepted as satisfactory before payment can be recovered, even though the promisee has arbitrarily refused them. ${ }^{3}$ But other authorities hold that the prom-

1. Smith v. Brady, 17 N. Y. 173 , 72 Am. Dec. 442; Glacius v. Black, 50 N. Y. 145, 10 Am. Rep. 449; Dauchey v. Drake, 85 N. Y. 407.

2. Glacius v. Black, 50 N. Y. 145, $10 \mathrm{Am}$. Rep. 449; Chandler v. State, 38 Ark. 197; Loren v. Hillhouse, 40 Ohio St. 302; Hovey v. Pitcher, 13 Mo. 191.
3. Zaleski v. Clark, 44 Conn. 218, 26 Am. Rep. 446 ; Brown v. Foster, 113 Mass. 136, 18 Am. Rep. 463; Singerly v. Thayer, 108 Pa. St. 291, 2 A. 230; Wood Reaping, etc. Co. v. Smith, 50 Mich. 565,15 N. 906, 45 Am. Rep. 57; Gibson v. Cranage, 39 Mich. 49, 33 Am. Rep. 351 and note. 
isee, in refusing, must act lonestly and not in an arbitrary manner. 'Thus, printing a lithographed cover design with the addition, for advertising purposes, of the lithographer's name, which is made after the approval of the proofs, is a breach of a contract to furnish finished work equal in good effect to the proots, the approval resting with the customer. And this is so thongh the addition does not detract from the merit or usefulness of the corer: and though it is enstomary to make it unless an agreement to the contrary is subsequently made. ${ }^{5}$

$\S$ 640. Substantial performance in good faith. - Bnilders must perform their contract according to conditions. But building contracts embrace many particulars which it is impracticable sometimes to comply with, with entire exactness; hence, the rule has been relaxed that a substantial compliance will be deemed sufficient. If there has been no wilful departure from the terms of the contract, or omission in essential points, and the contractor has honestly and faithfully performed the contract in all its material and substantial particulars, he will not forfeit his right to remuneration by reason of technical, inadvertent or unimportant omissions or defects. ${ }^{1}$ The court will enforce the rights of the contractor, but will permit the owner of the real estate or other property to recoup, set-off, or to file a cross action. ${ }^{2}$

4. MeClune v. Briggs, 58 Vt. 82 , 2 A. 583, 56 Am. Rep. 557; Duplex Safety Boiler Co. $v$ Garden, 101 N. Y. 387,4 N. E. 749,54 Am. Rep. 709 and note; Baltimore, etc. R. R. Co. v. Brydon, 65 Md. 198, 3 A. 306,9 A. 126.

5. Harris v. Sharples, $202 \mathrm{~Pa}$ St. 243,51 A. 965,57 Am. Rep. 318 , is L. R. A. 214.

1. Smith v. Brady, 17 N. Y. 173, 72 Am. Dec. 442; Sinclair v. Talmadge, 35 Barb. (N. Y.) 602; Glacius v. Black, 50 N. Y. 145,10 Am. Rep. 449; Beach v. Mullen, 34
N. J. L. 343 ; Wade v. Haycoek, 25 Pit. St. 382; Meincke v. Falk, 6 I Wis. 623,21 N. 785,50 Am. Rep. 157; Gleason v. Smith, 9 Cush. (Mass.) 484. $57 \mathrm{Am}$. Dec. 62.

2. Williams v. Schmidt, $54 \mathrm{Ill}$. 205; Garfield v. Huls, 54 Ill. 427; Parker v. Platt, it 1ll. 430; Phillip v. Gallant, 62 N. Y. 256 ; Hickman r. Pinkney, sl N. Y. 211; Hovey v. Pitcher, 13 Mo. 191; Patterson v. Judd, 27 Mo. 563: Porter v. Woods, 3 Humpli. (Tenn.) 56, 39 Am. Dee. 153; Cutler v. Close, 5 Car. \& P. 337. 
It is now the rule that where a builder has in good faith intended to comply with the contract, and has substantially complied with it, although there may be slight defects eaused by inadvertence or unintentional omissions, he may recover the contract price, less the damage on account of such defects. ${ }^{3}$

But the defects must not run through the whole, nor be so essential as that the objects of the parties, to have a specified amount of work done in a particular time, is not accomplished. ${ }^{4}$ And the mere belief of the contractor that he has performed, when he has not, will not avail him. ${ }^{5}$

It is held by one line of cases, that where one party enters into a special contract to perform work for another and furnish materials, and the work is done and the materials are furnished, but not in a manner stipulated in the contract, yet, if the work and materials are of any value and benefit to the other party, he is answerable to the amount whereby he is benefited. $^{6}$

However, some of the decisions hold that there can be no recovery at all even though the owner, where the building is on his land, uses it and derives a benefit from it, and though the contractor acted in good faith, provided there is not a substantial compliance with the contract. ${ }^{7}$

3. Sinclair v. Talmadge, 35 Barb. (N. Y.) 602; Jolunson v. De Pey. ster, 50 N. Y. 666; Glacius v. Black, 50 N. Y. 145, 10 Am. Rep. 449; Phillips v. Gallant, 62 N. Y. 264; Kenworthy v. Stevens, 132 Mass. 123; Warren v. Stoddart, 105 U. S. 224 ; Houston, etc. R. R. Co. v. Snelling, 59 Tex. 116; Dunlap v. Hand, 26 Miss. 460; Noble v. James, 2 Grant (Pa.), 278; Van Buren v. Digges, 11 How. (U. S.) 461; State v. Bain, 36 Ohio St. 429; Reed v. Gallaher, 53 Ga. 456; Eaton v. Woolly, 28 Wis. 628.

4. Phillips v. Gallant, 62 N. Y. 264; Woodward v. Fuller, 80 N. Y. 312.
5. Smyth v. Ward, 46 Iowa, 339 ; Devine v. Edwards, 101 Ill. 138.

6. Hayward v. Leonard, 7 Pick. (Mass.) 181, 19 Am. Dec. 268 and note; Cutler v. Close, 5 Car. \& P. 337; Norris v. School Dist., $12 \mathrm{Me}$. 293, 28 Am. Dec. 182; Adams v. Crossly, 48 Ind. 153; Pinches v. Chureh, 55 Conn. 183, 10 A. 264; Gilman v. Hall, 11 Vt. 510, 34 Am. Dec. 700; Masters v. Houck, 39 Mich. 431, 23 Am. Rep. 409.

7. Elliott v. Caldwell, 43 Minn. 357,45 N. W. 845,9 L. R. A. 52 and note; Smitl v. Brady, 17 N. Y. 173, 72 Am. Dec. 442; Woodward v. Fuller, 80 N. I. 312 ; Miller v. Phillips, $31 \mathrm{~Pa}$. St. 218; Bozarth 
$\S 64 \mathrm{I}$. Time of performance.-When a contract is completed with a term omitted as to time of performance, the legal effect is an engagement on the part of the promisor to perform within a reasonable time. ${ }^{1}$

The time when a promise is to be performed is always material and must be stated according to the truth, and proved as stated, whether it be upon the request of the plaintiff, or upon a particular day, or in a reasonable time. ${ }^{2}$

When an exccutory contract for the sale of goods contains no provision as to the time when delivery is to be made by the vendor, its legal effect is an arrangement to deliver within a reasonable time. ${ }^{3}$ Reasonable time is what is meant when not specified, and it is to be measured upon the facts and circumstances of each case. ${ }^{4}$

The promise to pay a sum on demand may be enforced immediately. ${ }^{5}$ And where a day is fixed for performance, or where the performance is to be within a certain time, the contract must be performed at any time during the day, or during the last of the period designated. ${ }^{6}$

v. Dudley, 44 N. J. L. 304, 43 Am. Rep. 373.

1. Phillips v. Morrison, 3 Bibb (Ky.), 105, 6 Am. Dec. 638; Atwood v. Cobb, 16 Pick. (Mass.) 227, 26 Am. Dec. 657 and note.

2. Osborne v. Lawrence, 9 Wend. (N. Y.) 135 .

3. Benj. on Sales, 683, n; Pope v. Manuf. Co., 107 N. Y. $61 ; 13$ N. E. 592 .

4. Stewart v. Marvel, $101 \mathrm{~N}$. Y. 357,4 N. E. 743 ; Ellis v. Thomp- son, 3 Mees. \& Wel. 445; Davis $v$. Talcott, 14 Barb. (N. Y.) 611; Railroad Co. v. Smith, 21 Wall. (U. S.) 162; Palmer v. Breen, 34 Minn. 39, 24 N. W. 322 ; Minneapolis, etc. Manuf. Co. v. Manuf. Co., 122 U. S. 300,7 S. Ct. $118 i$.

5. Omohundro v. Omoliundro, 21 Gratt. (Va.) 626; Warren v. Wheeler, 8 Met. (Mass.) 97 .

6. Startup v. Macdonald, 6 Man. \& Gr. 593. 


\section{ARTICLE II.}

\section{Decision of Arbiter, Arcilitect or Engineer.}

Section 642. Provision in Contract for Arbiter as to Performance.

643. Arbitration Clause.

644. The Arbiter's Decision Must be Pertinent.

645. Fraud.

646. Dispense with the Production of the Architect's Certificate.

647. Time of Performance of the Work.

648. Waiver of Time of Performance.

649. One Party Acting Through a Partnership.

650. Work Must be Performed in a Workmanship Manner.

651. Receiving Benefits of Service.

652. Partial Payment as Evidence of Acceptance of Work.

653. Sufficiency of Performance.

654. Manufacturing Articles According to Samples-Delivery.

655. Substantial Performance.

656. Natters Excusing Nonperformance.

657. Implied Condition as to Contingent Impossibility of Performance.

658. Implied Condition of Contracts.

659. Why Implied Condition Attaches to the Contract.

660. Failure of Performance by Acts of the Promisor.

661. Matters Excusing Delay.

662. What Constitutes Breach.

663. Owner of Building Promising to See Seller of Materials Paid.

664. Acceptance and Waiver.

665. Risks During Performance.

666. Part Performance.

\section{$\S 642$. Provision in contract for arbiter as to performance.-}

In building and construction contracts, generally a provision is inserted that the report of an engineer, inspector, or abiter as to the amount and quality of the work done or material furnished under the contract, shall be conclusive upon the parties to the agreement; such provision is a legal and binding stipulation, and can only be set aside for fraud, or for such gross mistakes as imply bad faith or a failure to exercise an honest judgment. ${ }^{1}$

1. Elliott v. Railroad Co., 74 Fed. Rep. 707 ; Williams v. Railroad Lewis v. Railroad Co., 49 Fed. Rep. 708; Killberg v. United States, 97 Co., 112 Mo. 463, 20 S. W. 631; U. S. 393; Sweeney v. United 
There is no moral law and no rule of public policy which forbids parties to submit to another for determination or decision a question of count, measurement, or distance, although these questions may be capable of aceurate ascertainment. ${ }^{2}$ The legal presmmption is that the measurements, inspection, and classification of the arbiter are accurate and just. ${ }^{3}$

So a contract to make an excavation for a building under the instruction of an architect, to be completed when the architect so declares, his decision that the work is performed is final whether done in accordance with the drawings or not. ${ }^{4}$ But an engincer's final certificate based upon an erroneons construction of the contract, is not conchusive. ${ }^{5}$

$\S$ 643. Arbitration clause. - The rule is woll settled that where parties to a construction contract of any kind agree to submit difference, or questions of any character arising in the construction of the work, to the decision of an architect or of an engineer, the decision of such arbiter is final, and all parties are bound by it, unless it be shown that the estimate or conclusion is fraudulent or so excessive or so palpably unjust as to imply bad faith or gross neglect; ${ }^{6}$ an arbiter's estimates may be impeached only for fraud or gross mistake implying bad faith. ${ }^{7}$

States, 109 U. S. 618, 3 S. Ct. 344; Martinsburg, etc. Railroad Co. v. March, 114 U. S. 549, 5 S. Ct. 1035; Chicago, S. F. R. R. Co. v. Price, 138 U. S. 185,11 S. Ct. 290.

2. Kihlberg v. United States, 97 U. S. 398 .

3. Lewis v. Railroad Co., 49 Fed. Rep. 708; Bumpass v. Webb, 4 Port. (Ala.) 65, 29 Am. Dec. 274; Pleasants v. Ross, 1 Wash. (Va.) 156, 1 Am. Dee. 449; Elliott v. Railroad Co., 74 Fed. Rep. 707.

4. Smith v. Trust Co., 97 Iowa, 117,66 N. IV. 84. See, also, Bank v. WTebb (Ky.), 33 S. IV. Rep. 1109, 17 Ky. L. Rep. 1184; Mackler v.
Railroad Co., 62 Mo. App. 677; Kenney v. Queen, 26 Can. S. Ct. 203.

5. Burke v. Mayor, 7 App. Div. 128,40 N. Y. S. S1. See, also, Goudon v. Railroad Co., 17 I Pa. St. 492,33 A. 61 .

6. MeDonald v. Railload, 93 Tenn. 281, 24 S. W. 252; Railroad Co. v. Central Lumber Co., 95 Tenn. 538, 32 S. W. 635; Martinsburg, etc. Railroad Co. v. March, $114 \mathrm{U}$. S. 540, 5 S. Ct. 1035; Sweeney v. United States, 109 U. S. 618, 3 S. Ct. 344.

7. Williams v. Railroad Co., 112 Mo. 463, 20 S. IV. 631,34 Am. St. 
$\S 644$. The arbiter's decision must be pertinent.-An engineer or other arbiter cannot bind the parties by doing or certifying what was not authorized by his appointment. ${ }^{8}$ The law does not require that any particular language shall be used by the arbiter in his certificate, and if it is in substantial compliance with the requirements of the contract it is sufficient and conclusive, unless there be fraud or mistake. ${ }^{9}$ The statement by an engineer, that the section of a railroad was in suitable condition for traffic, is but an expression of opinion and is entitled to no consideration. ${ }^{10}$

$\S$ 645. Fraud.-The arbiter must exercise an honest judgment and commit no such mistakes as, under all the circumstances, will imply bad faith. ${ }^{1}$ Where the contractor's certificate is final, it is not a sufficient excuse for failure to produce such certificate that the contractor feared to apply for it because he believed the architect to be fraudulently prejudiced against him. ${ }^{2}$ And the mere fact that the architect's decision is, in the opinion of others, erroneous, does not show that it is void because fraudulent. ${ }^{3}$

Rep. 403; Railroad Co. v. March, 114 U. S. 540,5 S. Ct. 1035 ; Railroad Co. v. Price, 138 U. S. 185, 11 S. Ct. 290; Kansas City, etc. Railroad Co. v. Perkins, 88 Tex. 66, 29 S. W. 1048; Sheffield, etc. R. R. Co. v. Gordon, 151 U. S. 285, 14 S. Ct. 343; Canal Trustees v. Lynch, 5 Gil. (Ill.) 521; McAuley v. Carter, 22 Ill. 53; Michaelis v. Wolf, 136 Ill. 68, 26 N. E. 384; Arnold v. Bournique, 144 Ill. 132,33 N. E. 530, 20 I. R. A. 493,36 Am. St. Rep. 419; Gilmore v. Courtney, 158 Ill. 432, 41 N. E. 1023; Thomas v. Fleury, 26 N. Y. 26; Noland v. Whitney, 88 N. Y. 648; Weeks v. O'Brien, $141 \mathrm{~N}$. Y. 199,36 N. E. 185; Chism v. Schipper, 51 N. J. L. 1, 16 A. 316, 14 Am. St. Rep. 668.
8. Kansas City, etc. Railroad Co. v. Perkins, 88 Tex. 66, 29 S. W. 1048 .

9. Railroad Co. v. Henry, 65 Tex. 691; O'Neal v. King, 3 Jones L. (N. Car.) 518; Johnson v. University, 35 Ml. 518; Kansas City, etc. Railroad Co. v. Perkins, 88 Tex. 66, 29 S. W. 1048.

10. Kansas City, etc. Railroad Co. v. Perkins, 88 Tex. 66, 29 S. W. 1048.

1. Martinsburg, etc. Railroad Co. v. Marsh, 114 U. S. 549, 5 S. Ct. 1035; Elliott v. Railroad Co., 74 Fed. Rep. 707 ; Kihlberg v. United States, 97 U. S. 398.

2. Gilmore v. Courtney, 158 Ill. 432, 41 N. E. 1023.

3. Gilmore v. Courtney, 158 IIl. 432,41 N. E. 1023. 
In general, the decision of the arliter can only be set aside for frand or for such gross mistake as imply bad faith or a failure to exercise an honest judgment. ${ }^{4}$ If the decision is fraudulent, or so excessive or umjust as to imply bad faith or gross neglect, it will be set aside. ${ }^{5}$

\section{$\S 646$. Dispense with the production of the architect's cer-} tificate.-In many cases the contract provides that the architect shall give his certificate to the contractor on the completion of the building, which is a condition precedent to the recovery of the contract price from the owner of the building. But the fraudulent failure of the architect will release the contractor from its production, and he can collect without it. ${ }^{1}$

Fraud in the decision of the architect or superintendent will excuse the failure to obtain his decision where it is a condition precedent; this, too, without regard to whether the architect or superintendent is the agent of the owner of the building or not, because of the architect's fraudulent decision, and his frand relieves the contractor from the performance of a condition prece-

4. Elliott v. Railroad Co., 74 Fed. Rep. 707; IVilliams v. Railroad Co., 112 Mo. 463, 20 S. W. 631, 34 Am. St. Rep. 403; Kihlberg v. United States, 97 U. S. 398 .

5. Railroad Co. v. Central Lumber Co., 95 'Tenn. 538, 32 S. IV. 635 ; MeDonald v. Railroad Co., 93 Tenn. 281, 24 S. IV. 252; Sweeney v. United States, 109 U. S. 618, 3 S. Ct. 344; Railroad Co. v. March, 114 U. S. 549,5 S. Ct. 1035 ; Railroad Co. v. Priee, 128 U. S. 185,11 S. Ct. 290 ; Lewis v. Railroad Co., 49 Fed. Rep. 708; Kennedy v. Poor, 151 Pa. St. 472, 25 A. 119 ; Baltimore, ete. R. R. Co. v. Brydon, 65 Md. 198, 3 A. 306, 9 A. 126. 57 Am. Rep. 31s; Whelen v. Boyd, $114 \mathrm{~Pa}$. St. 228, 6 A. 384. See, also, Vaught v. Williams, 120 N. Y. 253,24 N. E.
195, 8 L. R. A. 591, 17 Am. St. Rep. 634; Lull v. Korf, 84 Ill. 225.

1. Bradner v. Roffsell, 57 N. J. L. 32,29 A. 317 ; Murdock v. Jones (N. Y.), 3 App. Div. 221,38 N. Y. S. 161 ; Chism v. Sehipper, 51 N. J. ᄃ. 1,16 A. 316,14 Am. St. Rep. 668; Baltimore, etc. R. R. Co. v. Polly, 14 Gratt. (Va.) 44 $\bar{i}$; Lyun v. Railroad Co., 60 NIA. 404, 45 Am. Rep. 741; Herriek v. Belknap, 27 Vt. 673; Snell v. Brown, $71 \mathrm{Ill}$. 133; Wyckoff v. Meyers, $44 \mathrm{~N}$. Y. 143; Thomas v. Fleury, 26 N. Y. 26 ; Bowery Nat. Bank v. Mayor, 63 N. Y. 336; Batehelor v. Kirkbride, 27 Fell. Rep. 599 ; Batterbury v. Vyse, 2 Hurlst. \& C. 41 ; Pawley v. Turnbull, 7 Jurist. N. S. 792; Compare Clark v. Watson, $18 \mathrm{C}$. B., N. S. 278; Milne v. Field, 5 Exel. 829. 
dent, requiring his decision or certificate. So fraud on the part of an engineer who was to certify to the performance of a contract, as a condition precedent to a recovery, will allow the contractor to recover, upon proof of the quantity and value of the work done. ${ }^{2}$

$\$ 647$. Time of performance of the work.-Where the par. ties make time the essence of the contract, it must be performed within the period limited. ${ }^{3}$ Time not being the essence of the contract for payment for the performance of specific work, the party entitled to the services does not forfeit them absolutely by failing to require performance within the time named in the contract. $^{4}$ In the absence of the term of a building contract, the contract price is presumed to be payable only on completion of the work. ${ }^{5}$

$\S 648$. Waiver of time of performance.-It is the settled doctrine of the English courts that a contract within the statute of frauds cannot be changed as to the mode or time of performance by an oral executed contract. ${ }^{1}$

In the United States the general rule is that a party to a written contract, sealed or unsealed, within or without the statute of frauds, who is entitled to demand performance by the other party of act within a specified time, and who has consented orally to the postponement of the performance to a time subsequent to that fixed by the contract, where the other party has acted upon such consent and in reliance thereon has permitted the contract time to pass without performance, is estopped from subsequently recalling consent, and waives his

2. Lynn v. Railroad Co., 60 Md. 401, 45 Am. Rep. 741; Baltimore, etc. R. R. Co. v. Polly, 14 Gratt. (Va.) 447.

3. Moot v. Association, 90 Hun (N. Y.), 155,35 N. Y. S. 737,70 N. Y. St. 533 .

4. Kanapolis Land Co. v. Morgan, 1 Kan. App. 65, 41 P. 206.
5. Smith v. Sheltering Arms, 89 Hun, 70,35 N. Y. S. 62,69 N. Y. st. 273.

1. Stead v. Dawbar, 10 Ad. \& El. 57; Hickman v. Haynes, L. R. 10 C. P. 598. Compare Cuff v. Penn, 1 Maule \& S. 21. 
right to treat the nouperformance within the original time as a breach of the eontract. ${ }^{2}$

The original contraet is not ehanged by sueh a waiver, but it stands as an auswer to the other party who seeks to recover damages for nonperformance by an umrecalled eonsent. The party mar, in the absence of a valid and binding agreement to extend the time, reroke his eonsent so far as it has not been acted upon, but it would be inequitable to hold that a default, justified by the eonsent, happening during its existence, should furnish a ground of action. It should make no difference what the eharacter of the original may be, whether one within or without the statute of frauds, sealed or unsealed, where one party to a contract, before the time for performanee by the other party has arrived, eonsents, upon his request, to extend the time of performance, he must be presumed to know that the other party relies upon the eonsent, and until his giren notice of withdrawal he has no just right to eonsider the latter in default, although meanwhile the contract time has elapsed. The prineiple of equitable estoppel applies. ${ }^{3}$

$\S 649$. One party acting through a partnership. - Where one party agrees to furnish another with certain artieles, and while the eontract is in foree, the former forms a partnership with a third party without the consent of the other party, articles subsequently furnished by the partnership, as between the parties, must be regarded as furnished by the original party, aeting through the partnership in pursuance of the contract. This is not a case where a stranger to a eontract roluntarily undertakes to perform it. After the formation of the partnership the articles were furnished, in legal eontemplation, by the original party, aeting through the partnership of whieh he was a member. ${ }^{1}$

2. Thomson $v$. Poor, 147 N. Y. ᄂ20, 42 N. E. 13.

3. 'Thomson v. Poor, 147 N. Y. 402,42 N. E. 13; Longfellow v. Moore, 102 Ill. 289: Pierrepont v. Barnard, 6 N. Y. 279 ; Hoadley v.
MeLaine, 10 Bing. 482; Leather Co. r. Hieronimous, L. R. 10 Q. B. 140 .

1. Meyer v. Estes, 164 Mass. 457, 41 N. E. 683,32 L. R. A. 283. 


\section{$\S 65^{\circ}$. Work must be performed in a workmanlike manner.} -The law implies an undertaking on the part of the party performing the work that he performs it in a reasonably workmanlike manner, having regard to the general nature and kind of work and the purpose for which it was manifestly designed. ${ }^{1}$ And the defendant, in the same action, is entitled to have dedueted from the contract price, by way of recoupment, all damages arising from a disregard of the obligations imposed by law in the performance of the contract; as well as those oceasioned by a violation on the part of the plaintiff of the express terms of the contract. ${ }^{2}$

The right to recoupment is extensive with the duties and obligations of the parties respectively, both to do and forbear. It extends to damages resulting from negligence where eare, activity and diligence are required, and from ignorance where knowledge and skill are required. ${ }^{3}$

$\S 65 \mathrm{I}$. Receiving benefits of services.-If the party doing the work has done so in good faith, although the services have not been rendered according to the obligations imposed by the terms of the agreement and created by the law, he may recover for his services the contract price after deducting so much as they are worth less an account of such imperfeet performance of the contract, where the other party has received the benefits of the services performed under the agreement. ${ }^{4}$ In other words, the party performing is entitled to recover the fair value of his services, having regard to and not exceeding the contract price after dedueting the damages sustained by the defendant on aceount of the breach of the stipulation in the contract. ${ }^{5}$

1. Thomas Fruit Co. v. Start, 107 Cal. 206, 40 P. 336; Hattin v. Chase, 88 Me. 237, 33 A. 989.

2. Hattin v. Chase, 88 Me. 237, 33 A. 989.

3. Austin v. Foster, 9 Pick. (Mass.) 341; Cota v. Mishow, 62 Me. 124.

4. White v. Oliver, 36 Me. 92; Hattin v. Chase, 88 Me. 237, 33 A.
989; Gleason v. Smith, 9 Cush. (Mass.) 484, 57 Am. Dec. 62; Moulton v. McOwen, 103 Mass. 587; Morgan v. Hefler, 68 Me. 131; Beach v. Mullin, 34 N. J. L. 343 ; Wade v. Haycock, 25 Pa. St. 382: Parker v. Platt, 74 Ill. 430; War. ren v. Stoddart, 105 U. S. 224; Dunlap v. Hand, 26 Miss. 460. 5. Blood v. Wilson, 141 Mass. 


\section{$\$ 652$. Partial payment as evidence of acceptance of work.} - A partial payment made with full knowledge of the eondition of the work, and without objection to it, is competent evidence with all the other facts and cireumstances, as having some tendeney to show wairer of defeets in the work and acceptance; but it is not eonelusive. Henee, it is erronenous to instruct a jury that a partial payment is ipso facto, such an acceptanee and waiver as will preclude the defendant from claiming damages by way of recoupment for violation of the contract on the part of the plaintiff in construetion of the work. ${ }^{6}$

$\S 653$. Sufficiency of performance.-If there be no wilful departure from the contraet, or omissions in essential parts, and the laborer has honestly and faithfully performed the contract in all its material and substantial features, this is a sufficient performance, as a mere technical, inadvertent and unimportant omission or defects will not be considered a breach of the contract. ${ }^{1}$ But the work must not be defeetive in essential parts, and the contract substantially fulfilled. Thus, where a party agrces in writing to pay for materials which another should use in finishing a job, before a recovery can be had, it must be shown that the materials were furnished and used in finishing the work. $^{2}$ And completion of work to the satisfaction of a party as mentioned in a contract, means, in many States, completion of work in accordance with the contract in such manner that the party ought to bo satisfied. ${ }^{3}$

\section{$\S 654$. Manufacturing articles according to sample-Deliv-} ery.-When articles are manufactured according to sample,

25, 6 N. E. 362 ; Powell v. Howard, 109 Mass. 192.

6. Button v. Russell, 55 Mich. 478,21 N. IV. 899; Flannery v. Rohrmayer, 46 Conn. 558; Davis v. School Dist., 24 Me. 349; Andrews v. Portland, 35 Me. 475; White v. Oliver, 36 Me. 92 ; Hattin v. Chase, 88 Me. 237,33 A. 989 ; Moulton v. McOwen, 103 Mass. 587.
1. Sinclair v. Talmadge, 35 Barb. (N. Y.) 602; Hattin v. Chase, 88 Me. 237,33 A. 989 . See, also, Grannis v. Quintain, 69 Fed. Rep. 206: Gubbins v. Lautenschlager. 74 Fed. Rep. 160.

2. Heath v. Flannery, 58 Ill. App. 300.

3. Keeler v. Clifford, 62 Ill. App. 64. 
and the contract specifies no place of delivery, the articles will be delivered at the manufacturer's place of business or factory. The manufacturer, on completion of the goods, must notify the other party and give him an opportunity to inspect the articles at the place they were manufactured to determine whether they correspond with the provisions of the contract. If they do the purchaser must take them and pay for them. ${ }^{4}$ A notice that the articles were manufactured and a demand of payment was an offer to deliver upon payment and was sufficient. After doing this the manufacturer had done all that could properly be required to impose upon the defendant the duty of taking and paying for the articles. ${ }^{5}$

$\S 655$. Substantial performance.-A party, in order to recover on an alleged performance by him of all the terms of a contract must show a substantial compliance with each requirement thereof, where there has been neither a waiver nor acceptance of benefits thereunder by the other contracting party, unless he can allege and prove a legal excuse of being prevented by the employer, the act of God, or the law, but not otherwise. ${ }^{2}$ If he cannot do this, and the defendant has not accepted the work nor the benefits, he cannot recover as there is not a substantial performance of the contract. ${ }^{3}$

Where there is a substantial, though not a technical performance, and the party has received and retained the benefits of such performance, the defendant cannot insist on such technical failure of performance as a defense, but will be limited

4. Bliss Co. v. Gas Light Co., 149 N. Y. 300,43 N. E. 859.

5. Canda v. Wick, 100 N. Y. 127 , 2 N. E. 381.

1. Omaha Consolidated Vinegar Co. v. Burns, 44 Neb. 21, 62 N. W. 301; Coates v. Sangston, 5 Md. 121.

2. Estep v. Fenton, 66 IIl. 467; Taylor v. Beck, 13 Ill. 376; Smith v. Gugerty, 4 Barb. (N. Y.) 614.
3. Smith v. Sheltering Arms, 89 Hun, 70, 35 N. Y. S. 62; Cahill v. Hcuser, 2 App. Div. 292, 37 N. Y. S. 736,73 N. Y. St. 450 ; Taylor v. Mareum, 60 Minn. 292, 62 N. W. 330; Chandler v. State, 38 Ark. 197; Malbon v. Birney, 11 Wis. 107 ; Hovey v. Pitcher, 13 Mo. 124; Loren v. Hillhouse, 40 Ohio St. 302. 
to alleging and proving damages by way of counterclaim or recompment in the action brought to recorer payment for the performance. ${ }^{4}$

If the owner acquiesces in a partial breach, the contractor may recover on a quantum meruit for what he has done." But the mere fact that the owner occupies the building after a breach by the contractor, is not a waiver of the breach. ${ }^{6}$

§ 656. Matters excusing nonperformance. - Matters may occur which will excuse nonperformance of the contract. Impossibility of performance is, in general, no answer to an action for damages for nonperformance, provided the contingency was such that the promisor should have foreseen and provided against when he made the promise, nor will it permit a recovery for part performance of an entire contract. If, however, the impossibility arises, even indirectly, from the acts of the promisee, it is a sufficient excuse for nonperformance. ${ }^{1}$

This is upon the principle that he who prevents a thing from being done may not avail himself of the nomperformance, which he himself occasioned. ${ }^{2}$ One party may so act as to compel the other party from performing. Thus, where a party hires another to take and care for his cattle, and the latter steals them, the former is not obligated to perform but may begin suit at once for the cattle. ${ }^{3}$

\section{$\S 657$. Implied condition as to contingent impossibility of} performance.-It is well settled that where there is a positive

4. Leeds v. Little, 42 Minn. 414 , 44 N. IV. 309 ; O'Dea v. Winona, 41 Minn. 424, 43 N. W. 97 ; Taylor v. Marcum, 60 Minn. 292, 62 N. W. 330 ; Hattin v. Chase, 88 Me. 237, 33 A. 989; Moulton v. McOwen, 103 Mass. 587; Blood v. Wilson, 141 Mass. 25, 6 N. E. 362 ; Morgan v. Hefler, is Me. 131.

5. Dermott v. Jones, 23 How. (U. S.) 220 .

6. Smith v. Brady, 17 N. Y. 173, 72 Am. Dec. 442; Elliott v. Cald- well, 43 Minn. 357,45 N. W. 845 , 9 L. R. A. 52 and note. Compare Presbyterian Church v. Paint Co., 66 Md. 598, S A. 752.

1. United States v. Peck, $102 \mathrm{U}$. S. 64; Gallagher v. Nichols, $60 \mathrm{~N}$. Y. 438; European, etc. Mail Co. v. Packet Co., 30 L. J., C. P. 247 .

2. West v. Blakeway, 2 Man. \& Gr. 751.

3. Cassidy v. Cattle Co., 58 Ill. Аpp. 39. 
contract to do a thing, not in itself unlawful, the contractor must perform it or pay damages for not doing it, although, in consequence of unforeseen accidents, the performance of his contract has become unexpectedly burdensome or even impossible. ${ }^{1}$

But this rule is only applicable when the contract is positive and absolute, and not subject to any condition, either express or implied. Hence, where, from the nature of the contract, it appears that the parties must from the beginning have known that it could not be fulfilled unless, when the time for fulfillment of the contract arrived, some particular specified thing continued to exist, so that when entering into the contract they must have contemplated such continued existence as the foundation of what was to be done, then in the absence of any express or implied warranty that the thing shall exist, the contract is not to be construed as a positive contract, but as subject to an implied condition that the parties shall be excused in case, before breach, performance becomes impossible from the perishing of the thing, without default of the contractor. ${ }^{2}$

Therefore, under the implied condition of a contract for work, the parties are to be excused from performance if a certain event happens, and by reason of the happening of the event it becomes impossible to fully perform the contract; and, hence, there may be a pro rata recovery for part performance by the one party, at least when what has been done is of benefit to the other. ${ }^{3}$ Thus, a sub-contractor can recover pro rata for his work done, from the contractor to build a railroad, where the sub-contractor has been stopped by reason of nonconsent of grantor of primary contract. ${ }^{4}$

$\S 658$. Implied condition of contract. - Contracts may be subject to conditions express or implied. Thus, the sale and

1. Reichenbach v. Sage, 13 Vash. 364, 43 P. 354, 52 An. St. Rep. 51; Taylor v. Caldwell, 32 L. J., Q. B. 164; Dolan v. Rodgers, 149 N. Y. 489,44 N. E. 167.
2. Taylor v. Caldwell, 32 L. J., Q. B. 164 .

3. Dolan v. Rodgers, 149 N. Y. 489,44 N. E. 167.

4. Dolan v. Rodgers, 149 N. Y. 489,44 N. E. 167 . 
delivery of specified articles of personal property, under such eircumstances that the title did not rest in the rendce, may be aroided and the vendor need not fulfill the eontract where the property is destroyed by aceident, without the fault of the rendor; and the latter is not liable to the vendce in damages for nondelivery, because the law implied a condition that the property should contimue to exist. ${ }^{1}$

So contracts for personal services requiring skill, which can only be performed by the person named, are not absolute obligations, under all circumstanees, but subject to the implied condition that the person designatel shall be able to perform at the time specified. Because both parties eontracted as a matter of law that the party should continue to be able to perform, otherwise he would be excused. ${ }^{2}$ And so where a party guarantees the payment of dividends by a corporation, he is excused from performing if the State dissolves the corporation before the time designated to pay dividends expires, beeause, if after a contract is made, the law interferes and makes a subsequent performance impossible, the party is excused from performing. ${ }^{3}$

\section{$\S 659$. When implied condition attaches to the contract.-} The continued existence of the means of performance is an implied condition, and the parties necessarily intended an exception which operates to carry ont the intention of the parties under most circumstances and is just. ${ }^{4}$

In England this rule relieves both parties from any obligation under an entire eontraet, with reference either to future or the past. In the United States the rule is that there may be a pro

1. Dexter v. Norton, 47 N. Y. 62, 7 Am. Rep. 415.

2. Spalding v. Rosa, 71 N. Y. 40 , 44, 27 Am. Rep. 7 .

3. Lorillard v. Clyde, 142 N. Y. 456, 462, 37 N. E. 489, 24 L. R. A. 113.

4. Walker v. Tucker, 70 Ill. 527 ; Thomas v. Knowles, 128 Mass. 22; lield v. Brackett, 56 Me. 121; Scully v. Kirkpatrick, $79 \mathrm{~Pa}$. St. 324, 21 Am. Rep. 55; Shear $\nabla$. Wright, 60 Mich. $159,26 \mathrm{~N}$. W. 871; Dexter v. Norton, 47 N. Y. 62 , 7 Am. Rep. 415; Dolan v. Rodgers, 149 N. Y. 489,44 N. E. 167 ; Appleby v. Myers, 36 L. J., C. P. 331, 336; Robinson v. Davison, 40 L. J. 
rata recovery for part performance by the one party, at least where what has been done is of benefit to the other. ${ }^{5}$

Under an implied condition of a contract, that the parties are to be excused from performance if a certain event happens, and by reason of the happening of the event it becomes impossible to that which was contemplated by the contract, there is an implied assumpsit for what has properly been done by either of them. ${ }^{6}$

\section{$\S 660$. Failure of performance by acts of the promisor.-} Where the owner of a building has by positive aets prevented the full performance upon the part of the contractor, the latter will have a lien for materials furnished and labor performed, so far as he has in good faith proceeded under the contract. ${ }^{1}$ So defendant cannot defeat recovery on the ground that the contract was entire and that the plaintiff did not fully perform it, where the plaintiff's failure was caused by the defendant's failure to carry out his part of the contract. ${ }^{2}$

In general, where a party's failure to fully perform the contract is due to the fault of the other party, or act of God, or of law, without fault of the other party, he can recover what his services are reasonably worth, and the defendant is not entitled to damages for the plaintiff's nonperformance. ${ }^{3}$

Ex. 172; Howell v. Coupland, L. R. 1 Q. B. D. 258; Makin v. Watkinson, L. R. 6 Eq. 25.

5. Dolan v. Rodgers, 149 N. Y. 489,44 N. E. I67; Jones v. Judd, 4 N. Y. 412 ; Cleary v. Sohier, 120 Mass. 210; Butterfield v. Byron, 153 Mass. 517,27 N. E. 667,12 L. R. A. 571 and note, 25 Am. St. Rep. 654; Niblo v. Binsse, 1 Keyes (N. Y.), 476; Cook v. MeCabe, 53 Wis. 250, 10 N. 507, 40 Am. Rep. 765; Schwartz v. Saunders, 46 Ill. 18.

6. Butterfield v. Byron, 153 Mass. 517,27 N. E. 667,12 L. R. A. 571 and note, $25 \mathrm{Am}$. St. Rep. 634.

1. Justice v. Elwert, 28 Oreg.
460, 43 P. 649; Howes v. Wire Works Co., 46 Minn. 47, 48 N. W. 448; Charnley v. Honig, 74 Wis. 163, 42 N. WV. 220; Smith v. Morris, 120 Mass. 63; Merchants', etc. Bank v. Dashiell, 25 Gratt. (Va.) 625.

2. Bowdish v. Briggs, 5 App. Div. 592, 39 N. Y. S. 371.

3. Theobald v. Burleigh, 66 N. H. 574, 23 A. 367 ; Melville v. DeWolf, 4 El. \& Bl. 844; Mill Dam Foundry v. Hovey, 21 Pick. (Mass.) 417; Walker v. Fitts, 24 Pick. (Mass.) 191 ; Jones v. Judd, 4 N. Y. 411 ; Heine v. Meyer, 61 N. Y. 171 ; Harvey v. Coffin, 44 N. H. 563. 
$\$ 66 r$. Matters excusing delay.-Where the contraet is so framed that it linds the party contracting to do the work, it implies a correlative obligation on the other party to do what is necessary on his part to enable the party so contracting to fulfili his part of the contract. ${ }^{1}$ So, if the owner of the building is the cause of the delay in completing the work, he camnot object. ${ }^{2}$ And a written contract for doing the work within a specified time may be supplemented br a subsequent oral agreement as to the time when the work shall be finished. ${ }^{3}$ If the contract is absolute, delay cannot be excused by bad weather. ${ }^{4}$

$\S 662$. What constitutes breach.-Trivial defects in a building is no defense, nor the refusal of the owner to pay the contractor a disputed balance. ${ }^{5}$

Where a note is given for work, a failure of the consideration will aroid it. ${ }^{6}$ But where a sale of materials provides for delivery in installments and payment for each installment on delivery, a refusal to deliver an installment until a former installment has been paid does not constitute a breach of the contract on the part of the seller. ${ }^{\text {? }}$

\section{$\S 663$. Owner of building promising to see seller of mate-} rials paid.-Where the contractor has failed to pay for materials and the material-man refuses to deliver any more, a promise by the owner of the building to see the material-man paid if he will deliver the materials, is a valid promise, if acted upon

1. Hudson Canal Co. v. Coal Co., 8 Wall. (U. S.) 288; Churchward r. Reg, L. R. 1 Q. B. 195 ; Currier v. Kailroad Co., 34 N. H. 498.

2. Willis v. Webster, l App. Div. 301,37 N. Y. S. 354,72 N. Y. St. 743 ; Davis v. Light Co., 57 Minn. 402,59 N. W. 482, 47 Am. St. Rep. 622 .

3. Manistee Iron Works Co. v. Lumber Co., 92 Wis. 21, 65 N. W. 863; Thomson v. Poor, 147 N. Y. 402,42 N. E. 13.
4. Cochran v. Railroad Co., 131 No. 607, 33 S. W. 177; Reichen. bach v. Sage, 13 Wash. $364,43 \mathrm{P}$. 354, 52 Am. St. Rep. 51.

5. Greenwald v. Hahn, $176 \mathrm{~Pa}$. St. 37,34 A. 972.

6. Slater v. Foster, 62 Minn. 150,64 N. W. 160.

7. Raabe v. Squnre, 148 N. Y. 81 , 42 N. E. 516 . See, also, Bean v. Bunker, 68 Vt. 72,33 A. 1068. 
by the promisee ${ }^{8}$ but the refusal of the contractor to pay for the materials is not a breach of contract by the material-man.

The material-man having relied upon the promise of the owner of the building, the latter was liable, as the promise thus made was original and founded upon a new consideration, that of the materials furnished after the promise. Because where the primary debt subsists and was antecedently contracted, the promise to pay it is original when it is founded on a new consideration moving to the promisor and beneficial to him, and such that the promisor thereby comes under an independent duty of payment irrespective of the liability of the principal debtor. ${ }^{9}$

$\S 664$. Acceptance and waiver.-The contractor may recover for his work, though he has not complied with the contract, when the owner of the building has accepted the work as complete or waived the time for completion. But a mere ordering of extra work will not absolve the builder from the consequence of a delay in completing the work in accordance with the terms of his contract. ${ }^{1}$ But taking possession of a building by the owner and acceptance of the work does not waive the owner's right to recoup such damages as he may have sustained because of the delay, if the delay was not caused by him. ${ }^{2}$

But one who accepts the work as complete cannot complain that the work was not performed. ${ }^{3}$

A mere partial payment is not of itself a waiver of defects in the work. ${ }^{4}$ But when the work is accepted with its known de-

8. Raabe v. Squire, 148 N. Y. 81 , 42 N. E. 516.

9. White v. Rintone, 108 N. Y. 222, 15 N. E. 318 ; Bayles v. Wallace, 56 Hun (N. Y.), 428, 10 N. Y. S. 191 ; Ackley v. Parmenter, $98 \mathrm{~N}$. Y. 425, 50 Anı. Rep. 693; Prime v. Koehler, 77 N. Y. 91; Wilks v. Rich, 80 N. Y. 269,36 Am. Rep. 615 .

1. Hlarris v, Trickett, $57 \quad 111$. App. 515.
2. Snell v. Cottingham, 72 Ill. 161; Padock v. Stout, 121 Ill. '571, 13 N. E. 182; Filt v. Smith, 62 Inl. App. 637 ; Nibbe v. Brauhn, 24 Ill. 268.

3. Elwood, etc. Oil Co. v. Baker, 13 Ind. App. 576, 41 N. E. 1063 ; Hutchins v. Webster, 165 Mass. 439,43 N. E. 186.

4. Hattin v. Chase, 88 Me. 237, 33 A. 989. 
fects, the acceptor waives his right to recover for such deficiencies. Thus, if the trustees of a church accept defective pews and place them in the church, knowing that they do not conform to the specifications, they are charged with knowledge of such nonconformity. ${ }^{5}$

A party who accepts a reduced salary for a long time, waives his right to receive the salary provided in the contract. ${ }^{6}$ So where a vendor accepts a draft, not according to the agreement, and retains it for a reasonable time, he waires his right to demand a draft stipulated in the agreement. ${ }^{7}$

$\S 665$. Risks during performance.- Where an entire contract is entered into to do work, and an accident happens without the fault of either party, the contractor must bear the loss. ${ }^{8}$ But if the contract is not entire the rule is different. Thus, where a point is reached in the performance of a contract to put work into a building, at which the party doing the work is entitlcd to be paid, he can recover the money thus earned, notwithstanding the work done and the building into which it was put is destroyed by fire or other accident. ${ }^{9}$

So, in case of a partial performance of a contract to lath and plaster a building which was destroyed by fire while the work was in progress, without the fanlt of either party, the contractor may recover the reasonable worth of the work and material furnished, under the appropriate common count. ${ }^{10}$ So, where a party has contracted to furmish the iron work for a building

5. Harrisburg Lumber Co. v. Washburn, 29 Oreg. 150, 44 P. 390. See, also, Stewart v. McQuade, 48 Pa. St. 191.

6. Brighton v. Railroad Co., 103 Micl. 420,61 N. W. 550.

7. Ryalls v. Moody, 102 Ala. 519, 15 So. 240 .

8. Norton v. Faneher, 92 Hun, 463,36 N. Y. S. 1032,72 N. Y. St. 434; Harmony v. Bingham, 12 N. Y. 99, 62 Am. Dee. 142 and note; Satterlee v. United States,
30 Ct. Cl. 31; Leavitt v. Dover, 67 N. II. 94, 32 A. 156, 6s Am. St. Rep. 640; Wisconsin v. Thompson, 94 Iowa, 607, $63 \mathrm{~N}$. W. Rep. 346 ; Rothwell v. Dean, 60 Mo. App. $4: 8$; Tompkins v. Dudley, 25 N. Y. - $272,8 \div$ Am. Dee. 349 .

9. Siegel v. Eaton, 60 Ill. App. 639; Cleary v. Sohier, 120 Mass. 210. See, also, Wilson v. Piekwick Co., 30 Ill. App. 333.

10. Cleary v. Sohier, 120 Mass. 210. 
which was subsequently destroyed by fire, after he has manufactured the iron, he can recover'; furnishing the iron was distinct from that for putting it in the building. ${ }^{11}$

$\S$ 666. Part performance.-Part performance does not comply with the contract. So, where there has not been a substantial compliance on the part of the contractor with the building contract, nor an acceptance of the work by the other party, the contractor cannot recover in an action on the specific contract, the contract price less allowances for the defects. ${ }^{1}$ A part performance of an entire contract docs not comply with the contract and the contractor cannot recover for part performance, ${ }^{2}$ unless he was prevented from performing by the other contracting party, or so trifled with that he could legally declare the contract at an end. ${ }^{3}$

But if the other party accepts the work and the materials received are of any value or benefit to the other party, he is answerable to the amount whereby he has been benefited. ${ }^{4}$

Where the contract is entire, and there is a failure on one part to perform the service which is stipulated for, and no express or implied waiver on the other part of the strict letter of the contract, the condition must be substantially performed before a recovery can be had on the common counts for labor and materials. $^{5}$

When a contractor has substantially performed a contract, but fails in some minor particulars, he can recover, according to one line of cases, the contract price less the difference between

11. Rawson v. Clark, 70 Ill. 656.

1. Hulst v. Asso., 9 S. Dak. 144, 68 N. W. 200.

2. Martin v. Schoenberger, 8 Watts. \& S. (Pa.), 367 ; Gillespie Tool Co. v. Wilson, $123 \mathrm{~Pa}$. St. 19 , 16 A. 36 ; Hartman v. Meighan, $171 \mathrm{~Pa}$. St. 46,33 A. 123.

3. Hartman v. Meighan, $171 \mathrm{~Pa}$. St. 46, 33 A. 123; Dauchey v. Drake, 85 N. Y. 407; Glacius v. Black, 50 N. Y. 145, 10 Am. Rep.
449; Smith v. Brady, 17 N. Y. 173, 72 Am. Dec. 442.

4. Norris v. School Dist., $12 \mathrm{Me}$ 293, 28 Am. Dec. 182: Pinches v. Church, 55 Conn. 183, 10 A. 264; Hayward v. Leonard, 7 Pick. (Mass.), 18, 19 Am. Dec. 268 and note; Hulst v. Asso., 9 S. Dak. 144, 68 N. W. 200 ; Adams v. Crossly, 48 Ind. 153.

5. Hayward v. Leonard, 7 Pick. (Mass.) 181, 19 Am. Dec. 268 and 
the value of the building as completed and its value as it should have been completed; and, according to another class of decisions, the contract price, less the sum it would take to complete the building in accordance with the contract. ${ }^{6}$ However, if the default is wilful, the contractor cannot recover even for a substantial performance. ${ }^{7}$

\section{ARTICLE III.}

\section{Specific Performance.}

Section 667. Specific Performance-When Enforced-Contracts to Devise. 668. Requisites of Contract-Building Contracts.

669. Mutuality in Obligations and Remedy.

670. Contracts as to Personal Property.

671. When there is an Adequate Remedy at Law.

672. Clange of Condition of One of the Parties.

673. Sale of Patent Rights.

674. Sale of Personalty.

675. Sale of Chattels Having a Special Value.

676. Supervision of the Court-Continuous Acts.

677. Contracts Involving the Exercise of Skill, Personal Labor and Cultivated Judgment.

678. Tender of Performance.

679. Time of Performance.

680. Contracts Subject to Conditions.

681. Part Performance.

\section{$\S 667$. Specific performance - Contracts to devise-When} enforced.-In some cases damages for a breach of the contract

note; Olmstead v. Beale, 19 Pick. (Mass.), 528; Jennings v. Camp, 13 Johns. (N. Y.), 99, 7 An. Dec. 867 ; Kittle v. Harvey, 21 Vt. 301 Wadligh v. Sutton, 6 N. H. 15, 23 Am. Dec. 704; Burn v. Miller, 4 T. R. 745; Chapel v. Hicks, $2 \mathrm{Cr}$. \& M. 214.

6. Stillwell, etc. Co. v. Phelps, 130 U. S. 520, 9 S. Ct. 607; Glacius v. Black, 50 N. Y. 145, 10 Am. Rep. 449 ; Pepper v. Philadelphia, 114 Pa. St. 96,6 A. 899 ; Sticker v. Ove- peck, $127 \mathrm{~Pa}$. St. 446, $17 \mathrm{~A}$. 1100 ; Woodward v. Fuller, $80 \mathrm{~N}$. Y. 312; Leeds v. Little, 42 Minn. 414,44 N. IV. 309; Gleason v. Smitl, 9 Cush. (Mass.), 484, 57 Am. Dec. 62; Cullen v. Sears, 112 Mass. 299; Maulton v. MeOwen, 103 Mass. 587; Hulst v. Association, 9 S. Dak. 144, 68 N. W. 200.

7. Schcible v. Klein, 89 Mich. 376,50 N. W. 857 ; Gill v. Vogler, 52 Md. 663; Gillespie Tool Co. v. Wilson, 123 Pa. St. 19, 16 A. 56. 
do not furnish a just remedy. The remedy of specific performance of a contract is purely equitable, given as a substitute for the legal remedy of compensation whenever the legal remedy is inadequate or impracticable. The principle which is material to be considered is that the court gives specific performance, instead of damages, only when it can by that means do more perfect and complete justice ${ }^{1}$ it is within the discretion of the court where it will take jurisdiction. ${ }^{2}$

It is necessary, in order to give a court of equity jurisdiction that the contract shall be complete and certain as well as fair, just and equal in all its parts, and that it be founded on a valuable consideration. It must be capable of being specifically enforced, and be of a nature that the court can decree its complete performance against both parties without adding to its terms. It must appear that the plaintiff had no adequate remedy at law, and that a refusal to perform the contract would be a fraud upon lim. ${ }^{3}$

An injunction restraining the breach of a contract is a negative specific performance of that contract, and the jurisdiction of equity to grant such injunction is substantially co-incident with its jurisdiction to compel a specific performance. And generally, courts of equity will not restrain by injunction the violation of contracts of a character where they cannot decree specific performance $;^{4}$ and courts will not enforce specific per-

1. Young Lock Nut Co. v. Mfg. Co. (N. J.), 34 At. Rep. 947 ; Ten Eyek v. Manning, 52 N. J. Eq. 47, 27 A. 900 ; Hissam v. Parrish, 41 W. Va. 686, 24 S. E. $600,56 \mathrm{Am}$. St. Rep. 982; Campbell v. Potter, 147 Ill. 576,35 N. E. 364; Townsend v. Vanderworker, 20 D. C. 197; Gove v. Biddleford, $85 \mathrm{Me}$ 393, 27 A. 264; Porter v. Water Co., 84 Me. 195, 24 A. 814; American Box Machine Co. v. Crossman, 61 Fed. Rep. 8s8, 10 C. C. A. 146, 21 U. S. App. 383.

2. Homan v. Stewart, 103 Ala. 644,16 So. 35 .
3. Modisett v. Johnson, 2 Black. (Ind.) 431; Ikerd v. Beavers, 106 Ind. 483, 7 N. E. 326 ; Louisville, ete. R. R. Co. v. Bodensehatz, 141 Ind. 2.51, 39 N. E. 703; Seymour v. Delaney, 6 Johns. Ch. (N. Y.) 222; Carberry v. Tannehill, 1 Har. \& J. (Md.) 224; Marble Co. v. Ripley, 10 Wall. (U. S.), 339; Atlanta, etc. R. R. Co. v. Speer, 32 Ga. 550, 79 Am. Dee. 305; Adderly v. Dixon, I Sim. \& St. 607.

4. Welty v. Jacobs, 171 Ill. 624 , 49 N. E. 723,40 L. R. A. 98. 
formance of particular stipulations from the rest of the eontract where they do not stand elearly by themselves, unaffected by other provisions. ${ }^{5}$

A party may, for a valuable consideration, renounce the absolute power to dispose of his property by will to a particular person, and such eontract may be enforeed either by an aetion for its breach against his personal representatives, or, in a proper case, by a bill for specific performanee against his heirs, devisees or personal representatives. ${ }^{6}$ He ean make a valid agreement binding himself to make a particular disposition of his property by will, and this contract may be enforced after his death, as though the deceased obligee were a party to the suit. ${ }^{7}$ The principle on which courts of equity undertake to enforee the execution of such agreements is referable to their jurisdiction over the subjeet of speeific performanee. The theory on which the courts proeeed, is to construe such agreement, unless void under the statute of frauds, or for other reasons, to bind the property of the testator or intestate so far as to fasten a trust in faror of the promisee, and to enforee such a trust against the heirs and personal representatives of the deeeased, or others holding under them charged with notice of the trust. ${ }^{8}$ Such contraet must not be uneonscionable, inequitable, or unjust, for no eourt of equity will enforee specifie performance of a contract of that eharaeter, as its enforeement rests in the sound discretion of the court. ${ }^{9}$ But a contract in relation to the making of a will, which can have specific performance deereed, must he

5. Baldwin v. Fleteher, 48 Mich. 604,12 N. 873.

6. Johnson v. Hubbell, $10 \mathrm{~N}$. .J. Eq. 332, 66 Anı. Dec. 773 and note; Wright v. Tinsley, 30 Mo. 389; Parsell v. Stryker, 41 N. Y. 480.

7. Manning v. Pippen, So Ala. 257; Maddox v. Row, 23 Ga. 431, 68 Am. Dee. 535; Wallace v. Long, 105 Ind. 525,5 N. E. 666, 55 Am. Rep. 222; Frisby v. Parkhurst, 29 Md. 5S, 96 Am. Dee. 503 ; Leonardson v. Hulin, 64 Mich. 1, 31 N. W.
26; Taylor v. Mitchell, Si Pa. St. 518, 30 Am. Rep. 383; Fortescue v. Hemah, 19 Ves. 67.

8. Rivers v. Rivers, 3 Des. Eq. (S. Car.), 190, 4 Am. Dec. 609; Jones v. Martin. 3 Anstr. Ss2; Podmore v. Gunning, 7 Sim. 644; Emery v. Darling, 50 Ohio St. 160, 33 N. E. 715.

9. Hamilton v. Harrey, 121 Ill. 469,13 N. E. 210,2 Am. St. Rep. 118; Crandall v. Wellig, $166 \mathrm{Iml}$ 233,46 N. E. 755 . 
absolute in its terms. So, if a contract to devise is in the alternative, or its construction doubtful, it will not be specifically enforced..$^{10}$

The party seeking specific performance of the contract for the conveyance of land must perform his part of it. If he refuses or neglects to do so, he cannot compel specific performance. ${ }^{11}$ Thus, where husband and wife mutually agree as to the disposition of their property, and one of them dies, third parties in interest can compel specific performance as to the surviving spouse. ${ }^{12}$ One party cannot annul such a contract without the consent of the other; its obligations cannot be impaired. ${ }^{13}$

\section{$\S 668$. Requisites of contract - Building contracts. - In} order that a contract may be specifically enforced in a court of equity, the contract must be upon a valuable consideration, reasonably certain as to its subject-matter, its stipulations, its purposes, its parties, and the circumstances under which it is made; it must be mutual in its obligations and its remedy. ${ }^{1}$ A party's right to the aid of the court does not depend upon his subsequent offer to perform the contract on his part, but upon its original obligatory character. ${ }^{2}$

The remedy by specific performance is not a matter of strict right but of sound judicial discretion, and will be granted or denied as the justice and right of the particular case shall seem to the court, on full consideration of the rights and equities of the parties, to require. ${ }^{3}$

10. Barrett v. Geisinger, $148 \mathrm{Ill}$. 98, 35 N. E. 354.

11. Weingaertner Probst, $115 \mathrm{Ill}$. 412,5 N. E. 885; Cronk v. Trumble, 66 Ill. 428.

12. Carmichael v. Carmichael, 72 Mich. 76, 40 N. W. 173, 1 L. R. A. 596, 16 Am. St. Rep. 528 and note.

13. People v. Supervisors, $47 \mathrm{Ill}$. 256; Myers v. Gross, 59 Ill. 436; Bird v. Pope, 73 Mich. 483, 41 N. W. 514 .
I. Stokes v. Stokes, 148 N. Y. 708, 43 N. E. 989; Louisville, etc. R. R. Co. v. Bodenschatz, 141 Ind. 251, 39 N. E. 703; Hissam v. Parrish, 41 W. Va. 686, 24 S. E. 600, 56 Am. St. Rep. 892.

2. Bodine v. Glading, $21 \mathrm{~Pa}$. St. 50, 59 Am. Dec. 749; Duvall v. Myers, 2 Mrd. Ch. 401.

3. Fry Spec. Perf. 286; Ten Eyck v. Manning, 52 N. J. Eq. 47, 27 A. 900 . 
Specific performance of a contract will not be decreed under the following conditions:

1. As against one party in faror of another who has disregarded his own reciprocal obligations in the matter.

2. Nor where the duties to be fulfilled by the party are continuous and involve the exercise of skill, personal labor, and cultivated judgment. ${ }^{5}$

3. Nor where there is a want of mutuality in the contract. ${ }^{8}$

4. Nor where the party has a complete remedy at law. ${ }^{7}$

Under the fourth head especially come building contracts. Equity has no jurisdiction to compel specific performance where there is an adequate remedy at law. ${ }^{8}$ But it is held that a contract for repairs can be specifically enforced. ${ }^{9}$ But it has been held that a lessor, leasing a building to be crected, must comply with his agreement after the building has been erected, and furnish lights and other apparatus, and that specific performance would be decreed. ${ }^{10}$ This decision is against the weight of authority. But specific performance will be decreed in eases where the owner of land agrees to build thereon in consideration of certain benefits or privileges. Thus, where A contracts to build on his own land, or on land in which he has a possessory interest, with $B$, the latter to be benefited materially by such building, or is to receive some material benefit by such building,

4 Electric Secret Service Co. v. Manuf. Co., 125 Mo. 140, 28 S. IV. 486 ; Marble Co. v. Ripley, 10 Wall. (U. S.), 339; Young Lock Nut Co. v. Manuf. Co. (N. J. Ch.), 34 At. Rep. 947.

5. Grape Creek Coal Co. v. Spellman, 39 Ill. App. 630;' Wilson v. Railway Co., 9 Ch. App. 279; Port Clinton, ete. R. R. Co. r. Railroad Co., 13 Ohio, 544.

6. Ten Eyck v. Manning, $52 \mathrm{~N}$. J. Eq. 47, 27 A. 900 ; Hissam v. Parrish, 41 W. Va. 686, 24 S. E. 600, 56 Am. St. Rep. 892; Lumley v. Ravenscroft (1895), 1 Q. B. 683;
Flight v. Bolland, 4 Russ. 298; Gapen v. Gapen, 41 W. Va. 422, 23 S. E. 579 .

7. Holley v. Anness, $41 \mathrm{~S}$. Car. 349,19 S. E. 646 ; Campbell v. Patton, 147 Ill. 576, 35 N. E. 364 ; Young Lock Nut Co. v. Manuf. Co. (N. J. Eq.), 34 At. Rep. 947.

8. Errington v. Aynesly, 2 Dick. 692 ; Mastin v. Halley, 61 Mo. 196.

9. Paxton v. Newton, 2 Sin. \& Gif. 437; Beck v. Allison, 4 Daly (N. Y.), 14.

10. Jones v. Parker, 163 Mass. 564, 40 N. E. 1044, 47 Am. St. Rep. 485. 
or is to receive some privilege by reason of the building, and such benefit or privilege is part consideration of the contract, specific performance will be decreed if A refuses to carry out the contract. ${ }^{11}$ But in this class of cases, the contract will not be decreed specifically performed, if the terms are uncertain, indefinite and vague. ${ }^{12}$ Neither will it be decreed if it violates the statute of frauds. ${ }^{13}$ And specific performance will be decreed where there are continuing duties to be performed. Thus, a railroad company will be compelled to permit another company to its tracks as per agreement. ${ }^{14}$

Ordinary contracts to perform labor or work will not be specifically enforced, as there is an adequate remedy at law, for the injured party may at once hire other parties to complete the building. But where a party is in posscssion of land and contracts with another to build on that land, a consideration being given, and the terms of the contract are clear and definite, a court of equity will decree specific performance. ${ }^{15}$ Thus, where a party conveyed land to a railroad corporation, which agreed to build a railroad on the premises, and part of the consideration for such conveyance was an agreement by the railroad corporation to build certain definite crossings, the railroad acted but not in accordance with the agreement, and the court decreed specific performance. ${ }^{16}$

$\S 669$. Mutuality in obligations and remedy.-A contract to be specifically performed, must be mutual, so that at the time of execution it might have been enforced by either of the parties against the other. ${ }^{1}$ Whenever, therefore, whether from personal

11. Pembroke v. Thorpe, 3 Swan. 437; Price v. Mayor, 4 Hare, 506; Sanderson v. Railroad Co.. 11 Beav. 497 ; Rindge v. Baker, 57 N. Y. 209, 15 Am. Rep. 475; Gregory v. Ingwersen, 32 N. J. Eq. 199; Randall v. Latham, 36 Conn. 48 ; Willard v. Ford, 16 Neb. 543, 20 N. 859.

12. Brace v. Wehnert, 25 Beav. 358; Stanton v. Singleton, $126 \mathrm{Cal}$. 647, 59 P. 146.
13. Halsten v. Savannah, etc. R. R. Co.. 51 Ga. 199.

14. Joy v. St. Louis, 138 U. S. 1, 11 S. Ct. 246.

15. Rindge v. Baker, 57 N. Y. 209, 15 Am. Rep. 475.

16. Sanderson v. Railroad Co., 11 Beav. 4, 97.

1. Louisville, etc. R. R. Co. v. Bodenschatz, 141 Ind. 251, 39 N. E. 703 ; Benedict v. Lynch, 1 Johns. 
incapaeity, the nature of the eontract, or any other canse, the contrat is ineapable of being enfored against one party, that party is equally ineapable of enforemg it against the other, though its exeeution in the latter way might in itself be free from diffienlty attending its execution in the former. ${ }^{2}$

IIence, an infant cannot enforee a contraet by speeifie performance, if the contraet eamot be enforcerl against him $;^{3}$ the same rule applies to a man of unsonnd mind. ${ }^{4}$

So where a husband agrees to exchange land belonging to his wife for land of another party, and the title to the land which the hushand agreed to convey is still in the wife when the husband snes, and also when deeree is to be pronomneed, no decree of speeific performance ean he made, ${ }^{5}$ becanse the right to the remedy is not reciproeal.

And so it is, as a general rule, that speeific performanee will not be deereed in any ease where mutuality of obligation and remedy does not exist. But this general rule is subject to exeeptions. Thus, a covenant to renew a lease will be enforced against a lessor, though the lessee is under no reeiprocal obligations to aceept an additional term. ${ }^{6}$

And so where an optional or unilateral contract to convey rests upon a sufficient consideration to make it obligatory, the eontract may be specifieally enforced. Thus, if the lessor, in the lease, agrees to convey the demised premises to the lessee at a future time, at a fixed price, the lessee not agreeing to purchase, the latter can enforee specific performance against the

Ch. (N. Y.) 370, 7 Am. Dec. 484 and note; Adderley v. Dixon, 1 Sim. \& St. 607; Ten Eyek v. Manning, 52 N. J. Eq. 47, 27 A. 900; Waring v. Railway Co.; 7 Hare, 481, 492; Van Doren v. Robinson, 16 N. J. Eq. 256; Beard v. Linthicum, l Mid. Ch. 345; Duval v. Myers, 2 Md. Ch. 401, 405; Morris v. Fox, 45 Fed. Rep. 406; Lawrenson v. Butler, l Sch. \& L. 13, 18; Richards v. Green, 23 N. J. Eq. 536,537 .
2. Hissam v. Parrish, $4 \mathrm{l}$ W. Va. 686,24 S. E. 600,56 Am. St. Rep. 892.

3. Flight v. Bolland, 4 Russ. 298.

4. Gapen v. Gapen, 41 W. Va. 422, 23 S. E. 579.

5. Luce v. Deitz, 46 Iowa, 205; Ten Eyek v. Mamuing, 52 N. J. Eq. 47, 27 A. 900.

6. Van Doren v. Robinson, $16 \mathrm{~N}$. J. Eq. 256. 
lessor, the presumption being that the lessee agreed to pay a larger sum as rent, in consideration of the optional right to purchase, than he otherwise would have agreed to pay. ${ }^{7}$ But in all cases not resting on a similar basis as these, no specific performance will be decreed in any case when reciprocity of remedy does not exist. ${ }^{8}$

An option contract conreys no estate or interest in the property. It is but a continuing offer to sell, which may be accepted, and when accepted takes effect and not from the date of the offer. The contract takes effect upon its execution. But no interest in the remedy arises until acceptance of the offer by the vendee, after which, if the vendor dies or the buildings are destroyed, the vendee may nevertheless have performance of his contract, and the property destroyed must be restored or an abatement in the price be allowed. But this rule does not apply to option contracts, where the property is destroyed prior to an acceptance. The reason is this: A contract of purchase vests an interest in the vendee and the contract is executory, while in an option contract to purchase the vendee takes no interest, and the contract lacks mutuality until acceptance, and when accepted it does not relate back to the date of the offer, and has no more effect than if the offer had been made on the day of the acceptance, and the election to accept the offer relates to the property as it is on the date of acceptance. Therefore, if, intervening the offer and acceptance, the improvements on the property are destroyed by fire or otherwise, equity will not decree specific performance of the contract with the improvements restored or with an abatement in price equal to the value of the lost improvements. ${ }^{9}$

$\S 670$. Contracts as to personal property. - Although performance of a contract relating to personal property may not

7. Hawralty v. Warren, $18 \mathrm{~N}$. J. Eq. 124, 126, 90 Am. Dec. 613; Lumley v. Ravenscroft (1895), 1 Q. B. 683 .

8. Louisville, etc. R. R. Co. v. Bodenschatz, 141 Ind. 251, 39 N. E.
703; Carberry v. Tannehill, 1 Har. \& J. (Md.) 224; Ikerd v. Beavers, 106 Ind. 483,7 N. E. 326.

9. Caldwell v. Frazier, 65 Kan. 24, 68 P. 1076, 35 Chi. L. News. 390. 
be demanded as a right, it rests in the sound discretion of the court where compensation in damages would be difficult, if not impossible, owing to the fact that the matter was in the nature of an experiment, contracted for but not made, so that the result, of necessity, could never be known. ${ }^{1}$

But a court of equity will not entertain jurisdiction for specific performance of an agreement respecting goorls, chattels, stock, choses in action, and other things of a merely personal nature, where conpensation in damages furnishes a complete and satisfactory remedy. ${ }^{2}$

$\S 67 \mathrm{I}$. When there is an adequate remedy at law.- $\mathrm{A}$ court of equity will not take jurisdiction to decree specific performance of a contract when there is an adequate remedy by action at law for breach of the contract. ${ }^{3}$ For the breach of contracts the common law gives a single remedy. It requires the party in default to pay a sum of money as compensation. Where the contract broken is an obligation to pay money, that remedy amounts to specific performance. But there are many contracts for the breach of which such a remedy is inadequate, and this inadequacy has given rise to the jurisdiction of equity to enforce specific performance of contract, requiring the performance or omission of the very acts agreed upon. The inadequacy of the legal remedy, by compensation in damages, is generally regarded as conspicuous in cases of agreements for the sale and purchase of lands, each parcel differs in some respects from others. Such property is usually bought because it possesses some feature which attracts by personal gratification and determines the purchaser to make some particular use of it.

1. In re Argus Co., $138 \mathrm{~N}$. Y. 557, 573, 34 N. E. $38 s$; William v. Montgomery, 148 N. Y. $519,43 \mathrm{~N}$. E. 57 .

2. Hissam v. Parrish, $41 \mathrm{~W}$. Va. 686, 24 S. E. 600,56 Am. St. Rep. 892.

3. Ewing v. Litchfield, 91 Va.
575,22 S. E. 362: Holley v. Amness, 41 S. Car. 349 . 19 S. E. 646 ; Campbell v. Patton, 147 Ill. $576.35 \mathrm{~N}$. E. 364; Young Lock Nut Co. v. Manuf. Co. (N. J. Eq.) 34 At. Rep. 947; Lane v. Crossman, 58 IIl. App. 386. See, also, Laroussini v. Weslein, 48 La. Ann. 13, 18 So. 704. 
So when the contract for the sale of land provides for payinent of liquidated damages, and then the grantor arbitrarily refuses to make a deed, a court of equity will compel specific damages; as the stipulated damages were not provided for such a breach, but for failure after bona fide effort to make title to the purchaser. ${ }^{4}$

\section{$\S 672$. Change of condition of one of the parties. - Where} there is a change of condition as to unfavorably affect one of the parties to a contract having a long time to run, this is no cause not to compel specific performance of the contract by the party so affected, unless such change had made performance so onerous that the enforcement will impose great hardship upon that party and will be of little or no benefit to the other party. ${ }^{5}$

A contract is to be judged at the time when it was executed, and if fair then, the fact that it has become a hard one for one of the parties, by the force of subsequent circumstances or changing events, will not necessarily prevent specific performance. $^{6}$

The question of the want of equality and fairness, and of the hardship of the contract, should, as a general rule, be judged of in relation to the time of the contract, and not by subsequent events; and so mere decline in value since the date of the contract is not to be regarded by the court in cases of this nature. ${ }^{?}$

$\S 673$. Sale of patent rights.-Though contracts for the sale of rights under patents may affect only personal property, yet

4. O'Connor v. Tyrrell, 53 N. J. Eq. 15, 30 A. 1061.

5. Columbia College v. Thacher, 87 N. Y. 316, 41 Am. Rep. 365; Murdfeldt v. Railroad Co., $102 \mathrm{~N}$. Y. 703,7 N. E. 404.

6. Prospect Park, etc. R. R. Co. v. Railroad Co.. 144 N. Y. 152, 39 N. L. 17,26 L. R. A. 610 ; Franklin Tel. Co. v. Harrison, 145 U. S. 459,12 S. Ct. 900 ; Union Pac. R. R. Co. v. Railroad Co., 163
U. S. 564, 16 S. Ct. 163; Stuart v. Railway Co., 15 Beav. 513; Mortimer v. Capper, 1 Bro. C. C. 156; Jackson v. Lever, 3 Bro. C. C. 605 ; Paine v. Mellor, 6 Ves. 349 ; Paine v. Hutchinson, L. R. 3 Eq. Cas. 257 ; Marble Co. v. Ripley, 10 Wall. (U. S.), 339.

7. Lee v. Kirby, 104 Mass. 420; Revell v. Hussey, 2 Ball \& Beat. 280 ; Paine v. Mellor, 6 Ves. 349. 
equity may properly take jurisdiction of them and decree specifie performance. ${ }^{1}$ Rights acquired moler letter patents for inventions are of such a peculiar nature that they are justly considered proper subject-matter for suits for specific perfor'mance." But a contract to assign a patent will not he enforced where the patent is worthless. ${ }^{3}$

$\$ 674$. Sale of personalty.-A court of equity will not generally decree specifie performance of a contract for sale of personalty, not because of its personal nature, but because the damages at law, calculated on the market price of the stock or goods or other personalty, are a complete remedy to the purchaser as the delivery of the goods or stock contracted for, inasmuch as with the damages he may ordinarily purchase the same quantity of the like stock or goods. ${ }^{4}$ But a court of equity will decree the execution of a trust of personalty. ${ }^{5}$

$\S 675$. Sale of chattels having a special value.-But a court of equity will decree the delivery of specific articles which have a special and peculiar value, and where the remedy at law in dannages would be utterly inadequate, and where the chattcl

I. Cosbin v. Tracy, 34 Conn. 325; Electric Secret Service Co. v. Manuf. Co., 125 Mo. 140, 2S S. IV. 486; Binney v. Annan, 107 Mass. 94. 9 Am. Rep. 10.

2. Electric Secret Service Co. v. Manuf. Co., 125 Mo. 140, 26 S. IV. 486.

3. Johnson v. Steffons, 54 Ill. App. 196.

4. Bumgardner v. Leavitt, 35 IV. Va. 194,13 S. E. 67,12 L. R. A. 776 and note; Cliaffee v. Sprague, 16 R. I. 189, 13 A. 121; Nortliern Trust Co. v. Markell, 61 Minn. 271, 63 N. W. 735; Rollins Invest. Co. v. George, 48 Fed. Rep. 776 ; Womack v. Smith, 11 Humph.
(Tenn.), 478, 54 Am. Dec. 51; Cuddee v. Rutter, 1 P. Wm. 569; . Tohnson r. Brooks, 93 ․ Y. 33i; Treasurer v. Mlining Co., 23 Cal. 390 ; Eckstein v. Downing, 64 N. H. 248, 10 Am. St. Rep. 404, 9 A. 626; Todd v. Taft, 7 Allen (Mass.), 37 ; Now England Trust Co. v. Abbott, 162 Mass. 148. 34 N. E. 432,27 L. R. A. 271 and note.

5. Kimball v. Norton, $5 \mathrm{~N}$. J. Eq. $26,43 \mathrm{Am}$. Dee. $62 \mathrm{l}$; Chaffee $\mathrm{v}$. Sprague, 16 R. I. 189, 13 A. 121 ; Goodwin Gas Stove's Appeal 117 Pa. St. 51t, 12 A. 736,2 Am. St. Rep. 696; Johnson v. Brooks, 93 N. Y. 337 ; Krohn v. Williamson, 62 Fed. Rep. 869. 
is a family relic or ornament. ${ }^{6}$ And this special value may be on account of their beauty, or some other interest attaching to them. ${ }^{7}$

So equity will decree the specific performance of a contract to convey personal property where like property cannot be obtained elsewhere or for other reasons an action at law for damages will afford an adequate remedy. ${ }^{8}$

\section{$\S 676$. Supervision of the court-Continuous acts.-A court} of equity will not decree specific performance of contracts requiring continuous personal action, and running through an indefinite period of time, ${ }^{1}$ and which by their terms call for a succession of acts whose performance cannot be consummated by one transaction, and which require protracted supervision and direction. ${ }^{2}$ Thus, a court of equity would not undertake to compel a contractor to build a railroad or a warehouse, nor can it successfully an agreement for the operation of a mine or a manufactory. Such relief as that is not practicable. A court cannot compel a party to employ men to work his mine, operate his machinery, furnish necessary supplies, produce the coal, and deliver it to the other party. A succession of continuous acts calling for his personal services and for the exercise of his judgment, experience and tact in reference to a complicated business, cannot be specifically compelled. ${ }^{3}$

6. Cheale v. Kenward, 3 DeG. \& J. 27 ; Manton v. Ray, 18 R. I. 672, 20 A. 998, 49 Am. St. Rep. 811; Womack v. Smith, 11 Humph. (Tenn.) 478, 54 Am. Dec. 51 ; Lee v. Core, 4 Cold. (Tenn.) 395.

7. Buxton v. Lester, 3 Atk. 384 , Womack v. Smith, 11 Humph. (Tenn.) 478, 54 Am. Dec. 51.

8. Manton v. Ray, 18 R. I. 672 ; 20 A. 998, 49 Am. St. Rep. 811; Cheale v. Kenward, 3 DeG. \& J. 27.
1. Louisville, etc. R. R. Co. จ. Bodenschatz, 141 Ind. 251, 39 N. E. 703 ; Port Clinton, etc. R. R. Co. v. Railroad Co., 13 Ohio, 544.

2. Grape Creek Coal Co. v. Spellman, 39 Ill. App. 630; Wilson v. Railway Co., 9 Ch. App. 279.

3. Grape Creek Coal Co. v. Spellman, 39 Ill. App. 630; Union Pac., etc. R. R. Co. v. Railroad Co., 163 U. S. 564,16 S. Ct. 1173 ; Electric Light Co. v. Railroad Co., 109 Ala. 190, 19 So. 721, 55 Am. St. Rep. 227; Thiebaud v. Furniture Co., 
But a court of equity will enforce a contract for a long time, such as the ruming of a railroad by a receiver, and make supplemental decrees as occasion requires. ${ }^{4}$

\section{$\S 677$. Contracts involving the exercise of skill, personal} labor and cultivated judgment.-A court of equity will not enforce specific performance of a contract where the duties are continuous and involve the exercise of skill, personal labor, and cultivated judgment. Thus, it will not compel the delivery of marble of a certain kind, and in blocks of a kind that the court is incapable of determining whether they accord with the contract or not. ${ }^{1}$ If performance be decreed in such a case, the cause of action must remain in court to the end of the time of the contract, no matter how long the time, and the court may be called upon to determine, not only whether the prescribed quantity of the subject-matter has been delivered, but whether every piece is from the right place, whether it is sound, whether it is of suitable size, or shape, or proportion. A court of equity cannot superintend the execution of such a decree. It is impracticable. And equity will not enforce part of a contract, unless that part is clearly severable from the remainder. ${ }^{2}$

While a positive and a negative stipulation of an agreement form but one contract, a court may interfere to prevent the violation of the negative stipulation, although it cannot enforce specific performance of the entire contract. Thus, where a professional singer was sued by the proprietor of a theatre for spe-

143 Ind. 340,42 N. E. 741 ; Ewing v. Litchfield, 91 Va. 575, 22 S. E. 362 ; Louisville, etc. R. R. Co. v. Bodenschatz, 141 Ind. 251, 39 N. E. 703; Atlanta, etc. R. R. Co. v. Speer, 32 Ga. 550, 79 Am. Dec. 305 ; Beck v. Allison, 56 N. Y. 366 , 15 Am. Rep. 430; Blanchard v. Railroad Co., 31 Mich. 43, 18 Am. Rep. 142; Columbus, etc. R. R. Co. v. Watson, 26 Ind. 50; New South Wales, etc. R. R. v. Wythes, Kay \& J. 186.
4. Joy v. St. Louis, 138 U. S. 1, 47, 11 S. Ct. 243. See, also, Storer v. Railway Co., 2 Younge \& Col., N. R. 4S; Green v. Railway Co., L. R. 13 Eq. 44; Prospect Park, etc. R. R. Co. v. Railroad Co., 144 N. Y. 152,39 N. E. 17,26 L. R. A. 610.

1. Marble Co. v. Ripley, 10 Wall. (U. S.), 339 ; Louisville, etc. R. R. Co. v. Bodenschatz, 141 Ind. 25l, 39 N. E. 703.

2. Ogden v. Fossick, 9 Jurist, N. S. 238 . 
cific performance of a contract to sing in his theatre upon certain terms, for a certain time, and not to sing elsewhere during that period, the court interfered to prevent the violation of the negative stipulation, but not that of the positive, that is, it would not enforce the contract to sing, but would enjoin the party from singing elsewhere. ${ }^{3}$ This doctrine is now generally received as the better rule. ${ }^{4}$

The general rule is that a contract for services cannot be specifically enforced. ${ }^{5}$ Nor can this be done indirectly by restraining the employe in equity from leaving the service. ${ }^{6}$ But if the contract contains a stipulation not to perform services for another during the term, that provision may be enforced by an injunction, provided the services are of an unique and extraordinary character which cannot be obtained elsewhere. ${ }^{7}$ In the English cases an express negative stipulation is required or the injunction will not issue. In some of the American cases the agreement to serve the hirer during a certain term is construed as an agreement to serve no one else during that term.

In nearly all the cases is involved the exercise of mental and intellectual powers, - authors, singers, actors, and the like. ${ }^{8}$

Acrobats and tumblers do not come under the class whose performance is unique or of unusual character. So an injunc-

3. Lumley v. Wagner, 1 DeGex, M. \& G. 604, overruling Kemble v. Kean, 6 Sim. 333, and Kimberley v. Jeunings, 6 Sim. 340.

4. South Wales R. R. Co. v. Wythes, 5 DeG. M. \& G. 880; Catt v. Toole, L. R. 4 Ch. App. 654; Peabody v. Norfolk, 98 Mass. 452, 96 Am. Dec. 664. Compare Mair v. Tea Co., L. R. 1 Eq. 411; Hope v. Hope, 22 Beav. 351; Sanders v. Rodway, 16 Beav. 207; Paxton v. Newton, 2 Sm. \& Gif. 437.

5. Stocker v. Brockilbank, : Mae. N. \& G. 250.

6. Arthur v. Oakes, 63 Fed. Rep. $.310,25$ I. R. A. $4\lceil 4,11$ C. C. A.
209, 24 U. S. App. 239; Toledo Railroad Co. v. Penn. Co., 54 Fed. Rep. 743 .

7. Lumley v. Wagner, 1 DeG. M. \& G. 604, 5 De G. \& Sm. 485; Grimston v. Cunninglam (1894), l Q. B. 125; Whitford Chemical Co. v. Hardman, 2 Ch. 416, disapproving Montague v. Flocton, 16 L. R. Eq. 189; Duff v. Russell, 133 N. Y. 678,31 N. E. 622.

8. Lumley v. Wagner, 1 DeG. M. \& G. 604; Daly v. Smith, 49 How. Pr. 150; Hahn v. Concordia Soc., 42 Md. 465 ; MeCaull v. Graham, 16 Fed. Rep. 37 ; Fredericks v. Mayer, 13 How. Pr. 567. 
tion will not lie against them to prevent service for another party. ${ }^{9}$ The same rule applies to a sketch artist. ${ }^{10}$ So an injunction will not lie to restrain a ball player from engaging to another party. ${ }^{11}$ But in another ease a base ball player was restrained from hiring to another party, because his services are of such an unique character, and display such a special knowledge, skill and ability, as render them of peculiar value to the employer, and diffieult of substitution, ${ }^{12}$ but this decision is against the weight of authority. A prize fighter will not be restrained from breaking his contract. The court said that the relief sought must be refused, "not out of tenderness to the defendant," but because the contract, the enforcement of which is negatively sought, is illegal; ex pacto illicito non oritur actio. $^{13}$

A skilled employe who enters the employment with the agreement that whatever improvements he shall make in the machinery shall inure to the employer, is bound, as the contract is valid. ${ }^{14}$

$\S 678$. Tender of performance.-The plaintiff, before bringing suit must tender performance. ${ }^{1}$ The refusal to accept tender of performance of a contract based solely upon elaim of forfeiture, makes it immaterial whether such tender strictly

9. Cort v. Lassard, 18 Oreg. 221 , 22 P. 1054, 6 L. R. A. 653 and note, $17 \mathrm{Am}$. St. Rep. 726.

10. Strobridge Lith. Co. v. Crane, 58 Hun, 611, 12 N. Y. S. 834,35 N. Y. St. 473.

11. American Baseball, etc. Co. v. Harper, St. Louis Circuit Court. 54 Cent. Law Jour. 449 and note by John D. Lawson. This decision was rendered May, 1902. Of course, this decision comes from a nisi prius court. The note is a valuable exposition of the law on this subject.

12. Philadelphia Ball Club v.
Lajoie, 202 Pa. St. 210, 51 A. 973, 58 L. R. A. $22 i, 90$ Am. St. Rep. 627 and note.

13. MeDonald v. MeCallon, (Baltimore Cir. Ct.), 33 Chi. L. News, 438.

14. Thibodeau v. Hillreth, $63 \mathrm{~L}$. R. A. $480,12 \dot{4}$ Fed. Rep. S92, 60 C. C. A. 78. See "Mutuality in the Enforcement of Contracts for Personal Service."-55 Cent. Law Jour. 64.

1. Soper v. Gabe, 55 Kan. 646, 41 P. 969; Kelsey v. Crowther, 162 U. S. 404,16 S. Ct. 808. 
conforms to the contract. ${ }^{2}$ If circumstances are such that a tender would be of no importance, and must be refused by the other party, it need not be made. ${ }^{3}$

But general tender of performance must be made. Thus, if the vendee of land wishes to compel the other to fulfill the contract, he must make his part of the agreement precedent, and cannot proceed against the other without actual performance of the agreement on his part or tender of performance. ${ }^{4}$

$\S 679$. Time of performance.-While the court of equity does not regard time as of the essence of the contract unless it is so expressly stipulated, yet it will require of one who seeks specific performance of a contract that he shall not be guilty of unreasonable delay. ${ }^{1}$ Still in contracts giving a person an option to purchase a chattel for a given price within a limited time, time is then of the essence of the contract so as to prevent specific performance on failure without excuse to purchase within the specified time. ${ }^{2}$

$\S 680$. Contracts subject to conditions.-When a condition is precedent and material it must be performed before a court of equity will take jurisdiction to enforce performance. But provisions in a contract for referees in certain contingencies, which are not of the essence of the contract, are not ground for refusal of specific performance. ${ }^{3}$ And a party may waive such condition by his own acts, and then the contract may be specifically performed. ${ }^{4}$

2. Monson v. Bragdon, 159 Ill. 61, 42 N. E. 383.

3. Bucklen v. Hasterlik, 155 Ill. 423, 40 N. E. 561 .

4. Bank v. Hagner, l Pet. (U. S.), 455; Marble Co. v. Ripley, 10 Wall. (U. S.), 339 ; Jenkins v. Locke, 3 App. 1). C. 485.

1. Tate v. Development Co., 37 Fla. 439, 20 So. 542, 53 Am. St.
Rep. 251; Chabot v. Park Co., 34 Fla. 258, 15 So. 156, 43 Am. St. Rep. 192.

2. Roberts v. Norton, 66 Conn. 1 , 33 A. 532.

3. Union Paci $f_{i}$, etc. R. R. Co. v. Railroad Co., 163 U. S. 564,16 S. Ct. 1173.

4. Work v. Walsh, 160 Ill. 468, 43 N. E. 719. 
$\S$ 68r. Part performance.-Where a contract is entire and indivisible, it must be enforced as an indivisible interger, or not at all; it cannot be enforced by parts. ${ }^{1}$ Hence, a vendor cannot enforce the specific performance as to a part of a contract for the purchase of land. If enforcible at all it must be in its entirety. ${ }^{2}$

1. Dalby v. Pullman, 3 Sim. 29 ; Baldwin v. Fletcher, 48 Mich. 604, 12 N. 872; Kenner v. Bitely, 45
Fed. Rep. 133; Cato v. Thompson, 9 Q. B. Div. 616.

2. Hill v. Mining Co., 119 Mo. 9, 24 S. W. 223. 


\section{CHAPTER XXIII.}

\section{Breach and Discharge.}

\section{ARTICLE I.}

\section{Measure of Damages.}

Section 682. Object in Awarding Damages.

683. Rule for Estimating Damages.

684. As to Common Carrier.

685. Sale of Property for Special Purpose.

686. Breach of Contract for Personal Services-Duty of Laborer to Protect Himself.

687. Contract Not for the Use of Some Special Instrumentality. 688. Part Performance.

689. Appreciation in the Value of Land.

690. Uncertain and Contingent Damages.

691. Interest Upon Unliquidated Damages.

692. Breach by Telegraph Company.

693. Breach by Telegraph Company-Mental Suffering.

694. Contract to Furnish Special Material.

695. Profits as Damages-General Rule.

696. Profits which Would Have Been Realized.

697. Contingent Profits not Allowed.

698. Resale by Purchaser.

699. Building Contracts.

$\S$ 682. Object in awarding damages.-The primary object in awarding damages at common law is compensation to the injured party, but the damages allowed for this purpose must be the natural and proximate result of the wrongdoer. ${ }^{1}$ This is not, however, the invariable rule in all cases. ${ }^{2}$ Where a party sustains loss by reason of a breach of contract, he shall, so far

1. Hodges v. Fries, 34 Fla. 63, 15 So. 682; Robinson v. Hyer, 35 Fla. 544,17 So. 745 .
2. Messmore v. Lead Co., $40 \mathrm{~N}$. Y. 422 . 
as money can do it, be placed in the same situation, with respect to damages, as if the contract had been performed. ${ }^{3}$

$\S 683$. Rule for estimating damages.-It may be laid down as the general rule that where one party has broken the contract, the damages which the other party should receive in respect to such breach of contract should be such as may fairly and reasonably be considered either arising naturally-that is, according to the nsual course of things, from such breach of contract itself, or as may reasonably be supposed to have been in the contemplation of both parties, at the time they made the contract, as the probable result of the breach of it. And if the special circmmstances under which the contract was actually made were communicated by the plaintiff to the defendant, and thus known to both parties, the damages resulting from the breach of such a contract, which they would reasonably contemplate, would be the amount of injury which would ordinarily follow from the breach of contract nnder these special circumstances so known and communicated. But, on the other hand, if these special circumstances were wholly unknown to the party breaking the contract, he, at the most, conld only be supposed to have had in his contemplation the amount of injury which would arise generally and in the great multitude of cases not affected by any special circumstances, from such a breach of contract. ${ }^{1}$

3. McHose v. Fulmer, $73 \mathrm{~Pa}$. St. 365 ; Chicago, etc. R. R. Co. v. Hale, 83 Ill. 360. 25 Am. Rep. 403; Bell r. Reynolds, 78 Ala. 511.

1. Hadley v. Baxendale, 9 Exch. 341 ; Vicksburg, etc. R. R. Co. v. Ragsdale, 46 Miss. 45s; Griffin v. Colver, 16 N. I. 490,69 Am. Dec. 78 and note; Richardson v. Chynoweth, 26 Wis. 656 ; Thomas v. Railroad Co., 62 Wis. 642, 22 N. 827 , 51 Am. Rep. 725 ; Smud v. Foard, 1 El. \& El. 602; Gee v. Railroad Co., 6 Hurl. \& N. 211; Collard v. Rail- road Co., 7 Hurl. \& N. 79; Elbinger Actien-Gesellschafft v. Armstrong, L. R. 9 Q. B. 473; Wilson r. Railroad Co., 9 C. B. N. S. 632 ; Robinson v. Harman, 1 Exch. 855; Beaumont v. Greathead, 2 C. B. 494; Horton r. Bauer, 129 N. Y. 148. 29 N. E. 1: Barnes v. Brown, $130 \mathrm{~N}$. Y. 372,29 N. E. 760 : Priestly v. Railroad Co., 26 Ill. 205; Weber v. Squier, 51 Mo. App. 601: GrebertBorgnis v. Nugent, 15 Q. B. Div. 85. Compare Hamiton v. Magill, L. R. 12 Ire. 202. 
But it is not practicable to state a fixed rule for estimating damages for many contracts, but the following rules are well settled: 1. The proximate and natural consequences of the breach must always be considered. 2. The consequences must be such as, from the nature and subject-matter of the contract, may be reasonably deemed to have been in the contemplation of the parties at the time of the execution of the contract. 3. But damages, which may fairly be supposed not to have been the necessary and natural sequence of the breach, shall not be recovered, unless by the terms of the agreement, or by direct notice, they are brought within the expectation of the parties. 4. Loss of profits in business cannot be allowed, unless the data of estimation are so definite and certain that they can be ascertained reasonably by calculation, and then the party in fault must have had notice, either from the nature of the contract itself, or by explanation of the circumstances, at the time the contract was made, that such damages would ensue from nonperformance. 5. If the contract is made with reference to embarking in a new business, the speculative profits which might be supposed to arise, but which were defeated because of a breach of contract, which delayed the business, cannot be looked to as an element of damages. 6. If the delay in the transportation of machinery, to be applied to a special use, and that is known to the carrier, he is responsible for such damages as are fairly attributable to the delay; that is, such as the value of the use of the machinery, to be tested by its rental price, or other approximate means, and the expense of handling and the like. 7. The party injured by the delay must not remain inactive, but should make reasonable exertion to help himself, and thereby reduce his losses and diminish the responsibility of the party in default to him. ${ }^{2}$

$\S 684$. As to common carrier.-As a general rule, the appropriate compensation for the breach of a contract to deliver

2. Vicksburg, etc. R. R. Co. v. Raggsdale, 46 Miss. 458 , by Simerall, J. 
goods, is their market value in money at the time and place at which they should have been delivered, with interest thereon; and such is the rule in an action against a common carrier if the goods are never delivered. ${ }^{3}$ It is also settled that when a carrier negligently delays the delivery of goods, knowing that the owner intends to sell them in the market, he is liable for the diminution in their market value during the delay. ${ }^{4}$

Whenever, by reason of inexcusable delay of the carrier, the goods are not delivered until after they have diminished in market ralue, the measure of damages is the amount of the diminution; this rule depends on the general market value of the goods, and involves no question of contingent or speculative profits, and no consideration of any other contracts made or omitted to be made by the plaintiff in view of his contract with the defendant. ${ }^{5}$

$\S 685$. Sale of property for special purpose. - Ordinarily upon the sale and delivery of a chattel accompanied by a warranty, which is broken, the measure of damages is the difference between its value had it been as warranted and as it proved to be. But this rule does not apply to cases where a manufacturer sells goods to a purchaser to be used for a particular purpose, which is known to the vendor at the time of the sale, for then a more liberal rule prevails than in cases where like articles are sold as merchandise for general purposes. In the case of sale for a particular purpose, the profits and expenses incurred may be recovered. ${ }^{1}$ This doctrine is that where a party sustains a

3. Spring v. Haskell, 4 Allen (Mass.), 112.

4. Smith v. Railroad Co., $12 \mathrm{Al}$ len (Mass.), 531, 9 Am. Dec. 166; Cutting v. Railroad Co., 13 Allen (Mass.), 531 ; Hamilton v. MePherson, $28 \mathrm{~N}$. Y. 77. 84 Am. Dec. 330; King v. Woodbridge, 34 Vt. 565.

5. Fox v. Harding, 7 Cush. (Mass.), 516; Le Peinter v. Railroad Co., 2 L. T. N. S. 170; Gee v. Railroad Co., 6 Hurl. \& N. 211;
Wilson v. Railroad Co., 9 C. B. N. S. 632; Collard v. Railroad Co., 7 Hurl. \& N. 79. See, also, Great Western R. R. Co. v. Redmayne, L. R. 1 C. P 330 ; Lord v. Railroad Co., L. R. 2 C. P. 345 ; Smud v. Foard, 1 El. \& El. 602.

1. Passinger v. Thorburn, $34 \mathrm{~N}$. Y. 634, 90 Am. Dec. 753 and note; Van Wyck v. Allen, 69 N. Y. 61; Booth v. Mill Co., 60 N. Y. 487, 25 Am. Rep. 136; Swain v. Schieftelin, 
loss by reason of a breach of a contract, he shall, so far as money can do it, be placed in the same situation, with respect to damages, as if the contract had been performed. ${ }^{2}$

The vendor, having sold the articles with the knowledge that they were purchased for a particular purpose, should be held liable for such damages as naturally flow from the breach of his contract, and which he, or any reasonable man, might apprehend would follow the breach. Thus, where a purchaser buys coloring matter for his ice cream and uses it, whereby many persons who ate it were made sick, and upon analysis of this ingredient it was found to contain arsenic, and the purchaser thereupon destroyed the rest of the ice cream in which it had been used, he can recover of the vendor of the coloring matter the value of the goods destroyed and the damage occasioned by the loss of customers caused by the sale of the poisonous cream. ${ }^{3}$

So far as the plaintiff's property was injuriously affected or contaminated by the use of the coloring matter sold him by the vendor, the damages were attributed directly to the act complained of, and to that extent he must recover. ${ }^{4}$ An injured party is allowed to charge the other with loss on collateral contracts, on proving notice, which in the absence of such notice would not be considered within the contemplation of the parties. ${ }^{5}$

Some of the courts hold that a bare notice of special consequences which may result from the breach, unless under such circumstances as to imply that it formed the basis of the agree-

134 N. Y. 471,31 N. E. 1025 ; White v. Miller, 71 N. Y. 118, 27 Am. Rep. 13; White v. Miller, 78 N. Y. 393,34 Am. Rep. 544; Messmore v. Lead Co., 40 N. Y. 422; Hammond v. Bussey, 57 L. J. Q. B. 58; Hammer v. Schoenfelder, 47 Wis. 455, 2 N. 1129; Blagen v. Thompson, 23 Oreg. 239, 31 P. 647; Carnegie r. Holt, 99 Mich. 606, 58 N. W. 623 ; Fleming v. Beck, 48 Pa. St. 309 ; Illinois Cent. R. R. Co. v. Cobb, 64 Ill. 128.
2. Messmore v. Lead Co., $40 \mathrm{~N}$. Y. 422 .

3. Swain v. Schieffelin, 134 N. Y. 471,31 N. E. 1025, distinguishing Crain v. Petrie, 6 Hill (N. Y.), 522, 41 Am. Dec. 705.

4. Jeffrey v. Bigelow, 13 Wend. (N. Y.), 518, 28 Am. Dec. 476; Mullett v. Mason, L. R. 1 C. P. 559.

5. Hadley v. Baxendale, 9 Exch. 341 ; Hammer v. Schoenfelder, 47 Wis. 455, 2 N. 1129. 
ment, is not sufficient to make the vendor liable for damages arising out of special circumstances. ${ }^{6}$

\section{$\S 686$. Breach of contract for personal services - Duty of} laborer to protect himself.-The rule that one who has been damaged by a breach of a contract should do all that reasonably lies within his power to protect himself from loss, by seeking another contract of like character, the profits of which should be applied in mitigation of such damages, is correct as applied to some classes of cases, especially to contracts for personal service, or for the use of some special instrumentality either with or withont connection with such personal service.

Thus, in a contract for teaching a school, which was broken by a refusal to receive the services, the teacher was in duty bound to make reasonable exertion to obtain other like employment in the same vicinity, and therefore, if possible, to mitigate the damages. ${ }^{8}$ And so, if an actress be refused employment in her profession according to agreement, she must endeavor to secure such employment elsewhere to mitigate the damages. ${ }^{9}$

\section{$\S 687$. Contract not for the use of some special instrumen-} tality.-A contract, not for the use of some special instrumentality, or for personal services, does not come under the rule that the injured party must seek another contract of similar nature in order to mitigate damages. ${ }^{1}$ But in contracts of special instrumentality, the party injured must do all within his porver to mitigate his damages. Thus, in a case of a breach

6. Friend, etc. Lum. Co. v. Miller, 67 Cal. 464, 8 P. 40 ; Bridges v. Stickney, 38 Me. 361; Snell v. Cottingham, 72 Ill. 161; McKinnon v. McEwan, 48 Mich. 108, $11 \mathrm{~N}$. 828, 42 Am. Rep. 458 and note; Booth v. Mill Co., 60 N. Y. 487.

7. Sullivan v. MeMillan, 37 Fla. 134, 19 So. 340,53 Am. Rep. 239.
8. Gillis v. Space, 63 Barb. (N. Y.), 177; Benziger v. Miller, 50 Ala. 206.

9. Harvard v. Daly, 61 N. Y. 362, 19 Am. Rep. 285. See, also, Watson v. Brick Co., 3 Wash. 283, 28 P. 527 ; Crescent Manuf. Co. v. Manuf. Co., 100 Mo. 325,13 S. IV. 503.

1. Watson v. Brick Co., 3 Wash. 283, 28 P. 527; Wolf v. Studebaker, 
of a contract to furnish a cargo for a vessel, it is the duty of the master of the chartered vessel, on the failure or refusal of the charterer to furnish the cargo as agreed, to avail himself of all ordinary means and proper opportmities to obtain another cargo; and if he neglects to perform this duty, the owners cannot hold the charterer liable for the increased damages resulting from such neglect. ${ }^{2}$ So where the landlord failed to place the tenant in possession of the store according to agreement, it is the duty of the tenant to mitigate the damages by accepting another store in the same vicinity, and equally suited for his purposes, which the landlord tendered. ${ }^{3}$

And where the plaintiff, owner of a portable sawmill, agreed to remove it to the farm of the defendant and to saw a stated number of logs, to be furnished by the defendant, during a certain season, and the defendant, after furnishing a portion, broke his contract by refusing to furnish more of such logs, but during that time offered the plaintiff other employment of the same kind, so that his mill need not have been idle, this offer of other work of the same kind should go in mitigation of damages. ${ }^{4}$

But there are many cases where no legal obligation rests upon the plaintiff to enter upon the performance of other contracts for the benefit of the defendant. ${ }^{5}$

Ordinarily contracts of hire, and contract for the performance of some specified undertaking, cannot be governed by the same rule. In one case the party can earn no more than the wages, and if he gets that his loss will be nominal. In the other

65 Pa. St. 459; Crescent Manuf. Co. v. Manuf. Co., 100 Mo. $325,13 \mathrm{~S}$. IV. 503; Nelson v. Morse, 52 Wis. 240, 255, 9 N. 1; Cameron v. White, 74 Wis. 425,43 N. W. 155,5 L. R. A. 493 ; Sullivan v. McMillan, 37 Fla. 134, 19 So. 340,53 Am. St. Rep. 239.

2. Murrell v. Whiting, 32 Ala. 54. See, also, Shannon v. Com- stock, 21 Wend. (N. Y.), 457, 34 Am. Dec. 262 and note.

3. Hodges v. Fries, 34 Fla. 63, 15 So. 682.

4. Heavilon v. Kramer, 31 Ind. 241; Frazier v. Clark, 88 Ky. 260, 10 S. W. 806,11 S. W. 83.

5. Sullivan v. MeMillan, 37 Fla. 134, 19 So. 340, 53 Am. St. Rep. 239; Cameron v. White, 74 Wis. 425,43 N. W. 155,5 L. R. A. 493. 
case, the loss of the party is the loss of the henefit of the contract. The damages are fixed by the law of the contract the moment it is broken, and eannot be altered by collateral cireumstances independent of and totally disconnected from it, and from the party oceasioning it. Aud so the doctrine that one who has been injured by the breach of a contract must do all that is reasonably within his power to mitigate the damages caused thereby, does not prevail to the extent that one who is injured by a violation of a contract to do a specifie act not necessarily involving personal services, must seek and perform other contracts for the benefit of one who, by breaking faith with him, has caused the injury. ${ }^{6}$

$\S$ 688. Part performance. - When a party injured by the stoppage of a contract by the other party, elects to rescind it, then he cannot recover any damages for a breach of the contract, either for outlay or for loss of profits; he recovers the value of his services actually performed as upon a quantum meruit. There is then no question of losses or profits. ${ }^{1}$ But where he elects to sue for damages for the breach of the contract, his loss will consist of two distinct items or grounds of damage: 1. What he has already expended towards performance, and if it be a construction contract, less the value of materials on hand. 2. The profits that he would realize by performing the whole contract. The second item, profits, cannot always be recovered. They may be too remote and speculative in their character, and therefore incapable of that elcar and direct proof which the law requires. But when profits are the direct and immediate fruits of the contract, they are a part and parcel of the contract itself, entering into and constituting a portion of its very elements; something stipulated for, the right

6. Wolf v. Studebaker, $65 \mathrm{~Pa}$. St. 459; IVatson v. Brick Co., 3 Wash. 283, 28 P. 527; Sullivan v. MeMlilan, 37 Fla. 134, 19 So. 340 , $53 \mathrm{Am}$. St. Rep. 239 ; Crescent Manuf. Co. v. Manuf. Co., 100 Mo. 325, 13
S. IV. 503; Nelson v. Morse, 52 Wis. 240, $9 \mathrm{~N}$. 1: Cameron v. White, 74 Wis. 425,43 N. W. 155 , 5 L. R. A. 493.

1. United States v. Behan, 110 U. S. 338,4 S. Ct. 81 . 
to the enjoyment of which is just as elear and plain as to the fulfillment of any other stipulation. ${ }^{2}$

It does not lie in the mouth of the party, who has voluntarily and wrongfully put an end to the contract, to say that the party injured has not been damaged at least to the amount of what he has been induced fairly and in good faith to lay ont and expend, including his own services, after making allowance for the value of the material on hand, unless he can show that the expenses of the party injured has been extravagant and unneccssary for the purpose of carrying out the contract. ${ }^{3}$

$\S 689$. Appreciation in the value of land. - Contracts are often made in the purchase of land, whereby improvements are to be made that shall enhance the value of the land. In case of breach, the question comes up as to the damages of the purchaser. Thus, the damages for breach of contract to build a motor railway to connect with the business portion of a city, a tract of land which one of the parties has just purchased with a view of platting and selling it for suburban residences, is the difference between the value of the land on the day the road should have been completed, not less than the agreed purchase price, and what its value would have been on that day with the road completed and in operation. ${ }^{4}$ This appreciation in the value of the land, if any, is elearly within the legal if not the actual contemplation of the parties at the time the contract was made. So the loss of its increased value is the proximate and natural consequence of defendant's breach, and is a fair and close approximation of the actual pecuniary loss sustained by the plaintiff which the Jaw can furnish. ${ }^{5}$

2. Masterson v. Brooklyn, 7 Hill (N. Y.), 69, 42 Am. Dec. 38 and note.

3. United States v. Behan, 110 U. S. 338,4 S. Ct. 81 ; Planche v. Colburn, 5 Car. \& P. 58, 8 Bing. 14; Goodman v. Pocock, 15 Ad. \& El. 576; Hadley v. Baxendale, 9 Exch. 341; Fletcher v. Tayleur, 17 C. B. 21; Smud v.
Foard, 1 El. \& El. 602 ; Inchbald v. Coffee Co., 17 C. B., N. S. 733; Griffin v. Colver, 16 N. Y. 489, 69 Am. Dec. 718 and note; United States v. Speed, 8 Wall. (U. S.), 77, 2 Ct. Cl. 429.

4. Blagen v. Thompson, 23 Oreg. 239, 31 P. 647,18 L. R. A. 315.

5. Wilson v. Railway Co., $9 \mathrm{Ch}$. App. 279; Bronson v. Coffin, 108 
$\S 690$. Uncertain and contingent damages. - Where one party violates and repuliates his contract, the damages sustained by the injured party are nearly always involved in some uncertainty and eontingeney. They may he so uncertain, contingent and imaginary as to be ineapable of adequate proof, and then they camot be recovered beeane they eamut be proved. But when it is eertain that damages have been cansed by a breach of contract, and the only uncertainty is as to their amount, there is no valid reason for refusing on account of such uncertainty any damages whatever for the breach. A person violating his contract should not escape liability because the anount of the damages which he has eaused is uncertain. ${ }^{1}$

The rule that damages which are uncertain or contingent camnot be recovered, only applies to such damages as are not the certain result of the breach, and not to such as are the certain result but uncertain in amount. ${ }^{2}$ It may be difficult for the plaintiff to prove with exactness what his damages are, but such uncertainty does not prevent him from recovering such damages as he may be able to prove. ${ }^{3}$

$\S 69 \mathrm{I}$. Interest upon unliqidated damages.-Formerly the rule was not to allow intercst upon muliquidated damages. But now the rule is the same in regard to liquidated and unliquidated damages. So whenerer a judgment liquidates a claim, and fixes it as of a prior date, interest should follow from the date. $^{4}$

Interest is not the mere incident of the debt, attaching only

Mass. 175, 11 Am. Rep. 335; Houston Railroad Co. v. Mallor, 64 Tex. 607 ; Mobile Railroad Co. v. Gilmer, 85 Ala. 422, 5 So. 138; Louisville Railroad Co. v. Summer. 106 Ind. 55, 5 N. E. 404, 55 Am. Rep. 119; Watterson v. Railroad Co., 74 Pa. St. 208.

1. Wakeman v. Mfg. Co., $101 \mathrm{~N}$. Y. 209, 4 N. E. 264, 54 Am. Rep. 676 .
2. Blagen v. Thompson, 23 Oreg. 239, 21 P. 641, 18 L. R. A. 315.

3. O'Brien v. Society, 117 N. Y. 310,22 N. E. 954 ; Huse Ice Co. v. Heinze, 102 Mo. 245, $14 \mathrm{~S}$. W. 756.

4. Sullivan v. McMillan, 37 Fla. 134, 19 So. 340, 53 Am. St. Rep. 239 ; State v. Lott, 69 Ala. 147; Van Rensselaer v. Jewett, 2 N. Y. 135, 51 Am. Dec. 275 and note; 
to contracts, express or implied, for the payment of money, but it is compensation for the use or for the detention of money. Whenever it is ascertained that at a particular time money ought to have been paid, whether in satisfaction of a debt, or as compensation for a breach of duty, or for a failure to keep a contract, interest attaches. ${ }^{5}$

Interest is the compensation for the use or detention of money, and so where a verdict liquidates a claim and fixes it as at a prior date, interest must follow from that date. ${ }^{6}$

$\S 692$. Breach by telegraph company. - The general rule that a failure of a telegraph company to deliver a message whereby the sender is damaged, is limited to the amount paid for transmission, when the face of the telegram does not show its importance. ${ }^{1}$ In order to recorer more, the face of the telegram ought to contain something to put the company on its guard. $^{2}$ Thus, where the telegram shows on its face that it is important, the company is liable for its negligence in sending or delivering it, and if the party is injured by the loss in the price of property, the measure of damages is the difference between the price received and the actual market value of the property. ${ }^{3}$

\section{$\S$ 693. Breach by telegraph company-Mental suffering.-} It is the general rule that a mistake in sending a message whereby mental suffering or anguish is produced is no cause

Jacksonville, etc. R. R. Co. v. Mfg. Co., 27 Fla. 1, 157, 9 So. 661, 17 L. R. A. 33 and note; Sullivan v. McMillan, 37 Fla. 134, 19 So. 340 , 53 Am. St. Rep. 239; Schmidt v. Kailroad Co., $95 \mathrm{Ky} .289,2 \neq \mathrm{S} . \mathrm{W}$. 444, 26 S. IV. 547.

5. Brackett v. Edgerton, 14 Minn. 174, 100 Am. Dec. 211; Boyd v. Gilchrist, 15 Ala. 849; Whitworth v. Hart, 22 Ala. 343 ; Sellect v. French, 1 Conn. 32, $6 \mathrm{Am}$. Dec. 185 and note; Adams v. Bank, 36 N. Y. 255.
6. State v. Lott, 69 Ala. 147; Sullivan v. McMillan, 37 Fla. 134, 19 So. 340, 53 Am. St. Rep. 239.

1. Ferguson v. Tel. Co., 178 Pa.St. 377,35 A. 979,35 L. R. A. 554, 56 Am. St. Rep. 770; Telegraph Co. v. Wenger, $55 \mathrm{~Pa}$. St. 263, $93 \mathrm{Am}$. Dec. 751 .

2. Abeles v. Tel. Co., 37 Mo. App. 554 .

3. Reed v. Tel. Co., 135 Mo. (i61, 37 S. W. 904, 34 I. R. A. 492, 58 Am. St. Rep. 609. 
for damages against the company. Mental suffering alone, though resulting naturally and proximately from the breach of the contract by the telegraph company, is not a proper element of damages. ${ }^{1}$

However, other decisions hold a contrary view, and so where a telegram is sent telling of the critical sickness or death of a friend or relative, and asking the receiver to come, and the telegram is delayed or not properly transmitted, so that the party summoned fails to comply with the requisition, and is thereby greatly grieved and suffers mentally, the telegraph company is liable in damages for his anguish as its breach is the proximate cause of such suffering. ${ }^{2}$

1. Francis v. Tel. Co., 58 Minn. 252, 59 N. W. 1078,25 L. R. A. 406, 49 Am. St. Rep. 507; Morton v. Tel. Co., 53 Ohio St. 431,41 N. E. 689,32 L. R. A. 735,53 Am. St. Rep. 648; Summerfield v. Tel. Co., 87 Wis. 1, 57 N. IV. 973, 41 Am. St. Rep. 17 ; Russell v. Tel. Co., 3 Dak. 315, 19 N. W. 408, Butner v. Tel. Co., 2 Okl. 234, 37 P. 1087; Chapman v. Tel. Co., 88 Ga. 763, 15 S. E. 901,17 L. R. A. 430,30 Am. St. Rep. 183; Western Union Tel. Co. v. Rogers, 68 Miss. 748, 9 So. 823, 13 L. R. A. 859 and note, 24 Am. St. Rep. 300; West v. Tel. Lo., 39 Kan. 93, 17 P. 807, 7 Am. St. Rep. 530 and note; International Tel. Co. v. Sanders, 32 Fla. 434, 14 So. 148, 21 L. R. A. 810 ; Newman v. Tel. Co. 54 Mo. App. 434 ; Chase v Tel. Co., 44 Fed. Rep. 554, 10 L. R. A. 464; Crawson v. Tel. Co., 47 Fed. Rep. 544; Western Union Tel. Co. v. Wood, 57 Fed. Rep. 471,6 C. C. A. 432,13 U. S. App. 317,21 L. R. A. 706 ; Gahan v. Tel. Co., 59 Fed. Rep. 433.

2. Relle v. Tel. Co., 55 Tex. 308 , 40 Am. Rep. 805; Western Union
Tel. Co. v. Berringer, 84 Tex. 38, 19 S. IV. 336; Western Union Tel. Co. v. Wisdom, 85 Tex. 261, 20 S. W. 56,34 Am. St. Rep. 805; Western Union Tel. Co. v. Carter, 85 Tex. 580, 22 S. W. 961, 34 Am. St. Rep. 826; Wadsworth v. Tel. Co., 86 Tenn. 695, 8 S. W. 374, 6 Am. St. Rep. 864; Young v. ${ }^{m}$.. Co., 107 N. Car. 370,11 S. E. 1044, 9 L. R. A. 669 and note, 22 Am. St. Rep. 883 and note; Thompson v. Tel. Co., 107 N. Car. 294, 12 S. E. 427; Western Union Tel. Co. v. Cline, 8 Ind. App. 364, 35 N. E. 564; Chapman v. Tel. Co., $90 \mathrm{Ky}$. 265, 13 S. W. 880; Western Union Tel. Co. v. Henderson, 89 Ala. jl0, 7 So. 419, 18 Am. St. Rep. 148; Beasley v. Tel. Co., 39 Fed. Rep. 181; Mentzer v. Tel. Co., 93 Iowa, 752, 62 N. W. 1, 28 L. R. A. 72,57 Am. St. Rep. 294; Reese v. Tel. Co.. 123 Ind. 294,24 N. E. 163,7 L. R. A. 583 and note; Western Union Tel. Co. v. Piner, 1 Tex. Civ. App. 301, 21 S. IV. 315; Western Union Tel. Co. v. Evans, 1 Tex. Civ. App. 297, 21 S. W. 266 ; Stuart v. Tel. Co., 60 Tex. 580 , 18 S. W. 351,59 Am. Re623; Western Union Tel. Co. v. 
Therefore, when an express company does not properly deliver medicine to a party, which causes physical and mental suffering of the invalid, this is a proper cause of recovery of damages $;^{3}$ but the mental suffering of the husband of the invalid is too remote to be a basis for the recovery of damages. ${ }^{4}$

The variance of the courts cannot be reconciled. The class of cases where mental suffering is an element of damages are: 1. Mental pain arising from negligence resulting in physical injury; 2 , breach of contract of marriage; 3 , willful wrongs affecting the liberty, character, reputation, personal security or domestic relations of the injured party. So, if mental pain is not connected with any physical injury or willful wrong, the plaintiff cannot recover for it, for mental suffering as an independent cause of action, is too remote, speculative and uncertain. This is the weight of authority in telegraph cases. ${ }^{5}$ There is no way to measure mental anguish where a suit is brought independently of physical injuries; in such case it is too remote, speculative and uncertain. Even in cases of libel, malicious prosecution, and the like, in which punative damages may be added to compensate the mental anguish, the basis of damages for mental pain is the enormity of the willful offense, the nature and extent of which are established by evidence open to both sides. $^{6}$

A statute rendering telegraph companies liable for mental anguish caused by failure promptly to transmit and deliver a message is constitutional and does not deprive the eompany of

Levy, 59 Tex. 563, 46 Am. Rep. 278; Western Union Tel. Co. v. Adams, 75 Tex. 531, 6 L. R. A. 844, 12 S. W. 857, 16 Am. St. Rep. 920; Western Union Tel. Co. v. Kirkpatrick, 76 Tex. 217,13 S. W. 70, 18 Am. St. Rep. 37; Western Union Tel. Co. v. Rosentreter, 80 Tex. 401, 16 S. W. 25.

3. Pacific Express Co. v. Black, 8 Tex. Civ. App. 363, 27 S. W. 830.

4. Pacific Express Co. v. Black,
8 Tex. Civ. App. 363, 27 S. W. 830.

5. Connelly v. Tel. Co., 100 Va. 51, 40 S. E. 678,56 L. R. A. 663 and note and review, $93 \mathrm{Am}$. St. Rep. 919.

6. Western Union Tel. Co. v. Ferguson, 157 Ind. 64, 60 N. E. $674,1080,54$ I. R. A. 846 ; Ewing v. Railroad Co., $147 \mathrm{~Pa}$. St. 40, 23 A. 340,14 I. R. A. 666 and note, 30 Am. St. Rep. 709 and note. 
property without due process of law, or deny it the equal pror tection of the laws.

\section{$\S 694$. Contract to furnish special material. - A eontract for} the furnisling of a particular article, intended for a special purpose and not adapted to the general market, is not within the statute of frauds as the contract for the sale of goods. ${ }^{1}$ But the eases on this point are conflieting and cannot be reconeiled.

In England it is held that if the eontract be such that the subjeet-matter of the contract is a chattel to be afterwards delivered, then the cause of action is, goods sold and delivered, and the seller cannot sue for work and labor. ${ }^{2}$

In New York an agreement for the sale of a thing not in existence at the time, but which the contractor is to manufacture or to put into condition to be delivered, is not a contract of sale, and so not within the statute of frauds. ${ }^{3}$

The general rule is that a contract for the sale of articles in existence, or for such as the vendor in the ordinary eourse of his business manufactures or procures for the general market, whether on hand at the time or not, is a contract for the sale of goods, to which the statute of frands applies; but if the goods are to be manufactured espeeially for the purehaser, and upon his speeial order and not for the general market, the case is not within the statute. "Therefore, the test is, not the nonexistence of the article at the time of the contract, as in New York, nor whether the contract will result in the sale of a chattel, as in England, but whether the goods are such as the vendor, in the ordinary course of his business, manufactures or procures for the general market, or whether they are manufactured espeeially

7. Simmon v. Tel. Co., $63 \mathrm{~s}$. Car. 425,41 S. E. 521,57 L. R. A. 607.

1. Forsyth v. Mann, $68 \mathrm{Vt}$. 116, 34 A. 481,32 L. R. A 783; Goddard $v$. Binney, 115 Mass. 450, 15 An. Rep. 112; Mixer v. Howarth, 21 Pick. (Mass.) 205, $32 \mathrm{Am}$. Dec. 256.

2. Lee v. Griffin, 1 Best \& $\mathrm{S}$.
272. See, also, Clay v. Iates, 1 Hurl. \& N. 73.

3. Cook v. Willard, 65 N. Y. 352, 22 Am. Rep. 619.

4. Goddard v. Binney, 115 Mass. 450, 15 Am. Rep. 112; Forsyth v. Mann, $68 \mathrm{Vt} .116,34$ A. 481, $32 \mathrm{~L}$. R. A. 788. See, also, Pitkin v. Noyes, 48 N. H. 294, 2 Am. Rep. 218; Cason r. Cheeley, 6 Ga. 554. 
for the vendee and on his special order, and not for the general market, and for which they are neither intended nor adapted.

Under this general rule the personal services of the plaintiff in procuring material and superintending the construction of the special article may be included as part of the damages to be included in a breach of the contract, ${ }^{5}$ which is not void as a sale under the statute of frauds.

It is not necessary that personal skill and labor should be stipulated for in order to make a contract one for manufacture. It is sufficient if the work and labor requisite to such a contract are to be performed by the contractor or by his procurement and at his expense. The latter would be work and labor done by him, in the eye of the law, and could be declared for as such. ${ }^{6}$

Whether such parol contracts are within the statute of frands is of great importance in those States where the seventeenth section of that act is in operation. Thus the plaintiff agreed to build a buggy for the defendant, and to deliver it at a certain date. The defendant gave directions as to the style and finish, and it was built accordingly and marked with his monogram. It was destroyed by fire before delivery, and the plaintiff sued for the price. The court held that the carriage was not only built for the defendant, but in conformity, in some respects, with his directions, and at his request was marked with his initials, and that it was neither intended nor adapted for the general market, and so the statute did not apply and the defendant must pay for it. ${ }^{7}$ So parties contracted to furnish a monument within a certain time. Upon learning that such parties would not finish it, the plaintiff at once procured stock and had the monument cut. Owing to the circumstances that the work must be done in the winter, the monument cost more than it otherwise would. Under such circumstances the plaintiff could recover the difference between the contract price and

5. Forsyth v. Mann, 68 Vt. 116 , 34 A. 481,32 L. R. A. 788.

6. Bird v. Muhlinbrink, 1 Rich. I. (S. Car.) 119; Forsyth v. Mann,
68 Vt. 116,34 A. 481,32 L. R. A. 788.

7. Goddard v. Binney, 115 Mass. 450, 15 Am. Rep. 112. 
the actual cost, and for his personal services in procuring stock and superintending the construction as part of the damages. ${ }^{8}$

So damages may be recovered for the deprivation of intellectual enjoyment and for mental suffering resulting from the breach of the contract of a fashionable milliner to furnish the dresses for the trousseau of a bride of wealth and high social standing; because it must be taken into consideration not only the disappointment of the bride in not having the dresses in time for the wedding, and her mortification in going to her husband unprovided with a suitable trousseau, but also the fact that entertainments had been planned in her honor on her wedding tour and at her arrival at the home of her husband, which entertainments she had to forego for want of dresses. ${ }^{9}$

$\S 695$. Profits as damages-General rule.-It is held both in England and in the United States that the general rule is, subject to certain well-established qualifications, that anticipated profits prevented by the breach of a contract are not recoverable in the way of damages for such breach; but in the application of this principle the same uniformity in the decisions do rot exist. In some cases of almost exact analogy, in the facts, the adjudications in the different States are directly opposite. The grounds upon which the general rule of excluding profits, in estimating damages are: 1 . In the greater number of cases such expected profits are too dependent upon numerous, uncertain and changing contingencies to constitute a definite and trustworthy measure of actual damages. 2. Such loss of profits is ordinarily remote and not, as a matter of course, the direct and immediate result of the nonfulfillment of the contract. 3. Most frequently the engagement to pay such loss of profits, in case of defanlt in the performance, is not a part of the contract itself, nor can it be implied from its nature and terms. ${ }^{1}$

8. Forsyth v. Mann, 6s Vt. 116, 34 A. 481,32 L. R. A. 784.

9. Lewis v. Holmes, 109 La. Ann. 1030, 34 So. 66 .

1. Parish v. United States, 100 U. S. 500; Buckley v. United
States, 19 Wall. (U. S.) 37 ; Smith v. Conley, 1 How. (U. S.) 2S; The Amiable Nancy, 3 Wheat. (U. S.) 546; The Anna Naria, 2 Wheat. (U. S.) 327 ; The Schooner Lively, 1 Gall. C. C. 315 . 
$\S 696$. Profits which would have been realized.-The profits which wonld have been realized had the contract been performed, and which have been prevented by its breach, are included in the damages to be recovered in every case where such profits are not open to the objection of uncertainty or of remoteness, or where from the express or implied terms of the contract itself, or the special circumstances under which it was made, it may reasonably be presumed that they were within the intent and mutual understanding of both parties at the time it was entered into. ${ }^{1}$

Where a business is established so as to furnish a basis for the ascertaining of damages, damages are recoverable for loss of profits when the party has been prevented from carrying on his business, but not where the business has not been established. ${ }^{2}$ So damages from diminution of yield because of breach of contract to furnish fertilizers to assist in making a crop, is not too remote to sustain an action for the breach. ${ }^{3}$

In regard to sales, the general rule is that the purchaser is entitled to recover the difference between the contract price and the value of the article in the market at the time and place of delivery. ${ }^{4}$ The damages where the vendor knows that the purchaser has an existing contract for a re-sale at an advanced price, and that the purchaser is made to fulfill such contract, and the vendor agrees to supply the article to enable him to fulfill the same, because the profits which would accrue to the purchaser upon fulfilling the contract of re-sale, may justly be

1. United States v. Behan, 110 U. S. 338; Western Union Tel. Co. v. Hall, 124 U. S. 444,8 S. Ct. 577 ; Philadelphia, etc. R. R. Co. v. Howard, 13 How. (U. S.) 307 ; Arkansas, etc. Town Co. v. Lincoln, 56 Kan. 145, 42 P. 706; Blymyer Ice Mach. Co. v. McDonald, 48 La. Ann. 439, 19 So. 459; Kreamer v. Irwin, 46 Neb. 827,65 N. W. 885; Barrett $v$. Veneer Works, 110 Mich. 6,
67 N. W. 976 ; Lanahan v. Heaver, 79 Md. 413, 29 A. 1036, 19 Am. St. Rep. 180.

2. Chicago, etc. R. R. Co. v. Howison, 86 Ill. 215.

3. Herring v. Armwood, $130 \mathrm{~N}$. Car. 177,41 S. E. 96,57 L. R. A. 958.

4. Messmore v. Lead Co., $40 \mathrm{~N}$. Y. 427; Carpenter v. Bank, 119 Ill. 352,10 N. E. 18. 
said to have entered into the contemplation of the parties in making the contract. ${ }^{5}$

$\S 697$. Contingent profits not allowed.-Calculations as to prospective profits in other enterprises which the party would have engaged in, had his contract with defendant been fulfilled, are too remote to form the basis of damages occasioned by the breach of such contract. ${ }^{1}$ Damages which are contingent cannot be allowed. ${ }^{2}$ Thus, the plaintiff, who was an owner of a mill, sent a broken iron shaft to the office of the defendants, who were common carriers, to be conveyed by them to a manufacturer of such machinery, the broken shaft to serve as a model or pattern for the new one. The clerk of the defendants in their office was told that the mill was stopped, that the shaft must be delivered immediately and that a special entry should be made, if necessary to hasten its delivery. The delivery of the broken shaft to the manufacturer was delayed an unreasonable length of time, in consequence of which the plaintiff did not receive the new shaft for some days after the time it ought to have been received, and he was, therefore, unable to work his mill from want of the new shaft, thereby incurring loss of profits. It was held that such loss of profits could not be recovered as damages in an action against the defendants as common carriers. ${ }^{3}$

So in an action to recover the contract price for putting up mill machinery, anticipated profits of the defendant resulting from grinding wheat into flour and selling the same, had the

5. Hadley v. Baxendale, 9 Exch. 341; Cockburn v. Lumber Co., 54 Wis. 619,12 N. 49; Wetmore v. Pattison, 45 Mich. 430, 8 N. 67 ; Rahm v. Deig, 121 Ind. 283, $23 \mathrm{~N}$. E. 141 .

1. Fox v. Harding, 7 Cush. (Mass.) 516; Consumers' Pure Ice Co. v. Jenkins, 58 Ill. App. 519.

2. Paola Gas Co. v. Glass Co., 56 Kan. 614, 44 P. 621, 54 Am. St. Rep. 598; Brownell v. Chapman, 84 Iowa, 504, 51 N. W. 249, 35 Am.
St. Rep. 326; Jones v. Call, 96 N. Car. 337, 2 S. E. 647,60 Am. Rep. 416; New York, etc. Mining Co. $\mathbf{\text { v. }}$ Fraser, 130 U. S. 611,9 S. Ct. 665; Howard v. Manuf. Co., 139 U. S. 199, 11 S. Ct. 500; Pennypacker $\nabla$. Jones, 106 Pa. St. 237; Allis v. MicLean, 48 Mich. 428, 12 N. 640; Dixon-IVood Co. v. Glass Co., 169 Pa. St. 167, 32 A. 432.

3. Hadley v. Baxendale, 9 Exch. $341,354,356$. 
mill been completed at the date specified in the contract, cannot be recovered by way of damages for delay in putting it up." Likewise the plaintiff, who owned and operated a flour mill, entered into a contract with the defendants, by certain of the terms of which the defendants were to place in his mill, within a specified time, machinery of a certain capacity, to make flour of a high grade. The machines when furnished were found not to make a high grade of flour, and to be incapable of producing the stipulated number of barrels per day. In an action for damages by the plaintiff for breach of the contract, it was held that the loss of possible profits, which might have been made if the mill had run properly, was not a proper subject of damages, for the reason that the damages were too remote and speculative. ${ }^{5}$ So in an action for the seizure and detention of a steamboat by an attachment which was discharged, it was held that measure of damages was only the actual damage sustained by the seizure. ${ }^{6}$ And in an action for the price of a steamboat which was delayed by imperfect construction, the profits which might have been made if perfectly constructed are too remote. ${ }^{7}$ And in all cases where the profits are contingent, uncertain, and speculative, they camnot be estimated upon any certain basis, and are not therefore an element of damages. ${ }^{8}$

4. Howard v. Manuf. Co., 139 U. S. 199,11 S. Ct. 560 .

5. Pennypacker v. Jones, $106 \mathrm{~Pa}$. St. 237, 242.

6. Callaway Mining, etc. Co. v. Clark, 32 Mo. 305.

7. Blanchard v. Ely, 21 Wend. (N. Y.) 342, 34 Am. Dec. 250 and note.

8. Olmstead v. Burke, 25 Ill. 86 ; Winne v. Kelley, 34 Iowa, 339; Howe Mach. Co. v. Bryson, 44 Iowa, 159, 24 An. Rep. 735; Housten, etc. R. R. Co. v. Hill, 63 Tex. 381, 57 Am. Rep. 642; Bridges v. Lan- ham, 14 Neb. 369, 15 N. 704, 45 Am. Rep. 121; Willingham v. Hoovin, 74 Ga. 233, 58 Am. Rep. 435 ; Georgia Railroad v. Hayden, 71 Ga. 518; Freeman v. Clute, 3 Barb. (N. Y.) 424; Griffin v. Colver, 16 N. Y. 489, 69 Am. Dec. 718 and note; Wakeman v. Manuf. Co., $101 \mathrm{~N}$. Y. 205,4 N. E. 264, $54 \mathrm{Am}$. Rep. 676; Brown v. Smith, 12 Cush. (Mass.) 366; Boyd v. Brown, 17 Pick. (Mass.) 453; Smith v. Conley, 1 How. (U. S.) 28; Howard v. Manuf. Co., 139 U. S. 199, 11 s. Ct. 500 . 
$\S 698$. Resale by purchaser.-The general rule for awarding damages for a breach of a contract for the sale and delivery of personal property is the difference between the contract price and the market value at the time and place of delivery as fixed by the contract. ${ }^{1}$ And in an action for breach of contract of sale by the vendor, the vendee cannot recover for profits which he might have received by sale of such goods under a contract made after the contract of purchase. ${ }^{2}$

But the general rule has exceptions. Thus, where the vendor knows that the purchaser has an existing contract for the resale at an advanced price, and that the purchase is made to fulfill such contract, and the vendor agrees to supply the article to enable him to fulfill the same, those profits which would accrue to the purchaser upon fulfilling the contract of resale, may justly be said to have entered into the contemplation of the parties in making the contract, for which the vendor is liable upon breach of the sale. ${ }^{3}$

But profits of the resale by the vendor are not recoverable, unless the original vendor contracts with reference to the resale." And the vendor is bound, whether the price of the resale was communicated to him or not, unless the price was such at to yield an extraordinary and unusual profit, which could not be reasonably presumed to have been in contemplation by him at the time he made his contract; in such case he would not be bound beyond such sum as would yield a reasonable and fair

1. Merritt v. Wittich, 20 Fla. 27 ; Robinson v. Hyer, 35 Fla. 544, 17 So. 745 ; Daris v. Furniture Co., 41 IV. Va. 717,24 S. E. 630.

2. Penu v. Smith, 104 Ala. 445, 18 So. 38 .

3. Orr v. Commission Co., $97 \mathrm{Ga}$. 241, 22 S. E. 937 ; Sanderlin v. Willis, 94 Ga. 17l, 21 S. E. 291; Borries v. Hutchinson, 18 C. B., N. S. 445 ; Messmore v. Lead Co., 40 N. Y. 422; Booth v. Mill Co., 60 N.
Y. 487; Cockburn v. Ashland L. Co., 54 Wis. 619,12 N. W. 49 ; Guetzkow v. Andrews, 92 Wis. 214, 66 N. W. 119,52 L. R. A. 209 and note, 53 Am. St. Rep. 909; Robinson v. Hyer, 35 Fla. 544, 17 So. 745 .

4. Orr $r$. Commission Co., $97 \mathrm{Ga}$. 241,22 S. E. 937. See. also, EIbinger Actien-Gesellschaft $r$. Armstrong, L. R. 9 Q. B. 473; GrebertBorgnis v. Nugent, 15 Q. B. Div. 85. 
profit to his vendce, unless he was informed of the price to be received by his vendee. ${ }^{5}$

$\S$ 699. Building contracts.-Slight defects caused by inadvertence or unintentional omissions are not necessarily in the way of recovery of the contract price, less the amount by way of damages requisite to indemnify the owner for all expense of conforming the work to that for which he contracted. ${ }^{1}$ If the contract has been substantially performed in good faith, the price can be recovered less the necessary expense of conforming the work to the requirements of the contract. ${ }^{2}$

And where the plaintiff was prevented to complete the work by the defendant's default, the measure of damages is the difference in the price to be paid and the amount it would cost plaintiff to complete the contract. ${ }^{3}$

5. Guetzkow v. Andrews, 92 Wis. 214, 66 N. W. 119, 52 L. R. A. 209 and note, 53 Am. St. Rep. 909 .

1. Crouch v. Gutman, 134 N. Y. 45, 31 N. E. 271, 30 Am. St. Rep. 608 and note; Linch v. Lumber Co., 80 Tex. 23, 15 S. W. 208; Aetna Iron Works v. Kossuth Co., 79 Iowa, 40, 44 N. W. 215; Leeds v. Little, 42 Minn. 414, 44 N. W. 309 ; Moore v. Carter, $146 \mathrm{~Pa}$. St. 492, 23 A. 243; Gallaher v. Sharpless,
134 Pa. St. 134, 19 A. 491; Flaherty v. Minor, 123 N. Y. 382, 25 N. E. 418 .

2. Keeler v. Herr, 157 Ill. 57,41 N. E. 750 . See, also, Chamberlain v. Hibbard, 26 Oreg. 428, 38 P. 437 ; Sherman v. Connor, 88 Tex. 35,29 S. W. 1053.

3. Tennessee, etc. R. R. Co. $\mathbf{v}$. Danforth, 112 Ala. 80, 20 So. 502. See, also, Brandt v. Schurchmann, 60 Mo. App. 70. 


\section{ARTICLE II.}

\section{Composition with Creditors.}

SECtion 700. Composition Agreement.

701. Preference to Separate Creditor.

702. Composition with Part of the Creditors.

703. Adjustment and Compromise.

704. Conditional Sales-Validity of in Bankruptcy.

$\S 700$. Composition agreement. - A composition agreement is one made with a sufficient consideration, between an insolvent or embarrassed debtor and his creditors, whereby the latter, for the sake of immediate payment, agree to accept a dividend less than the whole amount of their claims, to be distributed pro rata in discharge and satisfaction of the whole. ${ }^{1}$ It is an exception to the rule that payment of part of a liquidated and due debt is not satisfaction for the whole. It is excepted because there is a consideration to each creditor for his agreement to accept less than his claim in full payment. It is an greement, not merely between the debtor and each creditor, but also between the several creditors. The engagement of each creditor to accept less than his claim is the consideration to each of the others for his like engagement. Each creditor signing has a right to assume that each one is to receive the benefit stipulated in the agreement; that it truly sets forth the terms of composition as to all the parties. ${ }^{2}$ And such a composition may be binding, even though resting in parol. ${ }^{3}$

1. Continental Nat. Bank v. McGeoch, 92 IVis. 286,66 ‥ IV. 606 .

2. Newell v. Higgins, 55 Minn. 82, 56 N. W. 577 ; Noyes v. Chapman Drake Co., 60 Minn. 88, 61 N. W. 901; Lathrop v. Knapp, 27 Wis. 225; Davenport v. Cong. Society, 33 Wis. 387 ; Mellen v. Goldsmith, 47 Wis. 573, 3 N. 592, 32
Am. Rep. 781; Continental Nat. Bank v. McGeoch, 92 Wis. 286, 66 N. W. 606.

3. Mellen v. Goldsmith, 47 Wis. 573, 3 N. 592, 32 Am. Rep. 781; Good v. Cheesman, 2 Barn. \& Ad. 328; Boyd v. Hind, 1 Hurl. \& N. 947. 
$\S 70$ r. Preference to separate creditor.-It is generally held that any separate agreement by which one of the creditors secures to himself benefits not conferred on the others, and which agreement is not disclosed to them before they sign the composition, is a fraud upon them. Such separate agreement and composition agreement also are void as to all parties. ${ }^{1}$

But another line of decisions holds that if a creditor signs a composition agreement under a secret agreement with the debtor, giving him a preference or some undue advantage over other creditors, this does not, as to such creditors, nullify the composition agreement. The two agreements are to be consideretd as separate and independent, and while the secret agreement is fraudulent and void, the composition agreement remains valid and enforceable. ${ }^{2}$

In England and in some of the States it is held that the fraud in the secret agreement with the creditor so vitiates the whole transaction of composition, as to disable him from recovering even the amount of the composition, and that the other creditors may declare the composition void. ${ }^{3}$

But another rule is that the secret and fraudulent agreement, only, is illegal and is inoperative to confer any rights or advantage upon the creditor. Such cases fall within the rule, which permits a severance of the illegal from the legal part of the covenant, and so nothing but the fraudulent contract is void, the composition agreement being valid. ${ }^{4}$

1. Newell v. Higgins, 55 Minn. $82,85,56$ N. IV. 577 ; Lee v. Sellers, 81 Pa. St. 473; Patterson v. Boehm, 4 Pa. St. 50 $\mathrm{T}$; Lawrence v. Clark, 36 N. I. 128; Fay v. Fay, 121 Mass. 561; Harvey v. Hunt, 119 Mass. 279; Atkinson v. Denby, 7 Hurl. \& N. 933; Continental Nat. Bank v. McGeoeh, 92 Wis. 286, 66 N. IV. 606 .

2. Hanover Nat. Bank v. Blake, 142 N. Y. 404,37 N. E. 519, 27 L. R. A. 33 and note, 40 Am. St. Rep. 607; Way v. Langley, 15 Ohio St.
392; Cleveland v. Richardson, 132 U. S. 318,10 S. Ct. 100.

3. Howden v. Haigh, 11 Ad. \& El. 1033; Mallalieu v. Hodgson, 16 Ad. \& El., N. S. 689 ; Knight v. Hunt, 5 Bing. 432; Leicester v. liose, 4 East, 372; Leake on Cont. 768: Chitty on Cont. 694; Wald's Polloek on Cont. 239. Compare Davison v. McGregor, 8 Mees. \& Wel. 703.

4. Hanover Nat. Bank v. Blake, 142 N. X. 404,32 N. E. 519, 27 L. R. A. 33 and note, 40 Am. St. Rep. 
Under the English doctrine where any secret preference has been given either by the debtor or by any person for him, either with or without his direction, if he ratifies it by claiming the benefit, the composition agreement itself also becomes void, and the creditors can then, without returning or offering to return the amount received, bring suit for the amount remaining unpaid. ${ }^{5}$

$\S 702$. Composition with part of the creditors. - While it is true that a debtor cannot, for want of consideration, make a binding composition with a single creditor of an undisputed and liquidated debt, yet it does not follow that such contract must be made with all his creditors. So any agreement entered into between a debtor and two or more of his creditors, or all of them, to take a composition for their debts, is binding upon those who make the agreement. ${ }^{6}$

$\S 703$. Adjustment and compromise. - An adjustment and compromise of a bona fide controversy as to matters which are fairly the subject of debate between the parties at the time of such compromise, each party acting with full knowledge of the facts, and no element of fraud or of serious or injurious mistake intervening, is valid. ${ }^{1}$

When a compromise has been fairly effected, its validity will be independent of the merits of the controversy on which it is founded, and it cannot be reopened for the purpose or with the effect of reviving the dispute which it was meant to determine. ${ }^{2}$

607. See, also, Pickering v. Railway Co., L. R. 3 C. P. 235, 250; United States v. Bradley, 10 Pet. (U. S.) 343,360 ; Mallan v. May, 11 Mees. \& Wel. 653.

5. Ex parte Milner, 15 Q. B. Div. 606; Bank v. Hoeber, 11 Mo. App. 475, s8 Mo. 37, 57 Am. Rep. 359 and note; Kullman $v$. Greenebaum, 92 Cal. 403, 28 P. 674, 27 Am. st. Rep. 150; Laird v. Campbell, 100 Pa. St. 159; Mygatt v. 'Tarbell, 78
Wis. 351,47 N. W. 618 ; Hefter v. Cahn, 73 Ill. 296; Cobb v. Tirren, 137 Mass. 143.

6. Continental Nat. Bank v. McGeoch, 92 Wis. 286, 66 N. W. 606; Bishop on Insol. Debtors, 484.

1. Van Tratt v. Wiese, 36 Wis. 439; Woodrufl v. Marshall, 72 Wis. 132, 39 N. W. 376 ; Hennessy v. Bacon, 137 U. S. 78,11 S. Ct. 17.

2. Kerehival v. Doty, 31 Wis. 476,487 . 
A compromise of a doubtful claim is a good consideration for a promise to pay money, and it is no answer to an action brought upon such promise to show that the claim was invalid. ${ }^{3}$

So the fact that the validity of a claim is questionable, as where money is borrowed to be used in an illegal attempt to corner the market of a certain product, constitutes a sufficicnt consideration for an accord and satisfaction or settlement by which the creditors receive less than the full amount of such claims. ${ }^{4}$

\section{$\S$ 704. Conditional sales-Validity of in bankruptcy.-The} bankruptcy act does not vest the trustee with any better right or title in the bankrupt or in his creditors at the time the trustee's title accrued. Under the act a lien, good at the time of going into bankruptcy as agaiust the debtor and as against all of his creditors, shall remain undisturbed. Therefore, where a conditional sale is valid, if the vendee goes into bankruptcy, ${ }^{5}$ this does not divest the title as to the vendor. In such case the trustee is not a subsequent purchaser in good faith. ${ }^{6}$

But in some States a conditional sale not recorded is void as against creditors. In such case undoubtedly the trustee will take a valid title as against the rendor and all other parties. The following language of the Federal court is significant: "Our view is not shaken by a different result in cases arising in States by whose laws conditional sales are void as against creditors."

3. Hennessy v. Bacon, 137 U. S. 78, 11 S. Ct. 17 ; Saxton v. MeNair, 71 Wis. 459,37 N. W. 439.

4. Continental Nat. Bank v. McGeoch, 92 Wis. 286, 66 N. W. 606.

5. HewitE v. Berlin Machine Works, 194 U. S. 296, 24 S. Ct. 690, 28 Nat. Cor. Rep. 609. See, also, In re $\mathrm{N}$. Y. Economical Printing
Co., 110 Fed. Rep. 514, 49 C. C. A. 133.

6. Low v. Welch, 139 Mass. 33, 29 N. E. 216.

7. Hewitt v. Berlin Machine Works, 194 U. S. 296,24 S. Ct. 690, 2s Nat. Cor. Rep. 609. 


\section{TABLE OF CASES.}

(References are to sections.)

Sec.

Sec.

Abbott v. Creal........22, 47

Adlard $v$. Booth......... 587

Abbott v. Draper..........4480

Adlin v. Greenleaf.........6 628

Abbott v. Inskip.......... 480

Abbott v. Smith........... 368

Abeles v. Telegraph Co..297, 692

Abell v. Munson.......... 81

Abrams v. Railroad Co..... 288

Abshire v. Corey.......... 507

Accident Ins. Co. v. Crandel.. 19

Acebat v. Levy........141, 152

Acers v. Curtis.......... 391

Acheson v. Miller....394, 437, 438

Ackley v. Palmenter.. 128, 131, 663

Acton v. Blundell......... 345

Adae v. Zangs........... 530

Adams v. Bank.......499, 691

Adams v. Beall......58, 60, 63

Adams v. Brennan......301, 317

Adams v. Clem............ 585

Adams v. Coulhard......... 409

Adams County v. Hunter..... 281

Adams v. Crosby.........4 475

Adams v. Crossly.....6640, 666

Adams v. Fite............ 67

Adams v. Gay.........192, 412

Adams v. Honness......... 100

Adams v. Kuehn....356, 357, 358

Adams v. Lavens......... 507

Adams v. New York........ 272

Adams v. Nichols......573, 586

Adams v. Stewart......... 200

Adamson v. Jarvis...164, 394, 437

Adderley v. Dixon......667, 669

Addison $v$. Cox........... 526

Addison v. Dawson........ 22

Addyston Pipe and Steel Co. v.

United States . . . 323, 324, 326

517,549

Aetna Iron Works v. Kossuth

Co. . . ............ 699

Aiken v. Blaisdell . 173, 177, 200, 409

Aiken v. Nogle..........133, 134

Aimstead v. Blythe........240

Ainslie v. Wilson.......... 441

Aiwon v. Stout........... 7

Akerly v. Vilas...........600

Akro v. Demond........... 417

Albany v. Abbott......... 225

Albany \& Northern R. R. Co.

v. Brownell .......... 541

Alderton v. Bucboz......... 13s

Aldine Manuf. Co. v. Barnard. 464

Aldine Press Co. v. Estes.... 623

Aldrich v. Aldrich.......... 434

Aldrich v. Ames........123, 129

Aldrich v. Bennett.......... 29

Aldrich v. Blackstone....... 188

Aldridge v. Bank......... 194

Alexander v. Comber....... 139

Alexander v. Gish........ 367

Alexander v. Haskins......14, 22

Alexander v. O'Donnell....... 173

Alexander v. Railway Co.... 295

Alexander v. Vane......... 434

Alexander v. Whipple...... 629

Alexander v. Wright....... 30

Alford v. Wilson......... 84

Alger v. Scott........... 526

Alger v. Scoville........... 124

Alger $\mathrm{v}$. Thacher.......310, 313

Allen v, Allen........... 562

Allen v. Baker.........476, 589

Allen v. Berrylitl........9, 21

Allen v. Compress Co......6 614

Allen v. Denning.......192, 205

Adkins v. Ins. Co........ 20 
Sec.

Allen v. Duffie.......... 190

American Oak Leather Co. v. Porter............ 85

Allen v. Flood.....335, 336, 342

Allen v. Ford...........464

Allen v. Gardiner.......... 187

Allen v. Hamond.......571, 572

Allen v. Hawks............ 196

Allen v. Jarvis........... 146

Allen v. Lardner.....41, 46, 53

Allen v. Pearce............ 204

Allen v. Poole......26, 27, 65

Allen v. Rescons........... 162

Allen v. Stenger.......... 502

Allen v. Thomas.......... 352

Alles v. Billings.......... 9

Allgeyer v. Louisiana....182, 278

310,549

American Mortg. Co. v. Wright

American Steel Co. v. Wire

Drawers Union ......... 336

American Steamship Co. v.

Young . . ........... 452

Ames v. Foster........... 123

Ames v. Gilman.......... 199

Ames v. Jackson.......... 113

Ames v. Kyle............ 187

Amesbury, etc. Manuf. Co. v.

Amesbury ............4496

Ames Iron Works v. Warren.. 398

Amey v. Cockey.......... 59

Amis v. Smith.......... 563

Allin v. Shadburne........ 375

Allis v. Billings.........6, 21

Allis v. McLean.........697

Allison v. Schmitz........ 235

Alorado v. Nordholt.......6 631

Alson v. Sharpless........ 85

Alston v. Boyd........... 8

Alston v. Richardson....... 450

Alsworth v. Cordtz........ 66

Alt v. Graff............ 67

Alt v. Lohnas............ 135

Alton v. Bank.......... 450

Alves v. Hodgson......... 415

Alves v. Schlesinger....... 520

Amble v. Whipple........638

Ambrose v. Kerrison....... 485

Amer. Free L. Co. v. Dykes. . 53

Amer. Mort. Co. v. Wright.. 27

American Bank v. Wall..... 506

American Base Ball Co. v.

Harper . . ...........6 677

American Box Machine Co. v.

Crossman ............667 667

American Freehold Land

Mortg. Co. v. Sewall...399, 420

American Freehold Land

Mortg. Co. v. Whaley..... 229

American Freehold, etc. Mortg.

Co. v. Jefferson ........ 417

American Life Ins. Co. v. Isett 17

Amonett v. Montague....... 355

Amont v. Christofferson..... 124

Ammondson v. Ryan. .227, 228, 230

Amson v. Dreher........... 145

Amy v. Dubuque.......... 241

Anderson v. Anderson.......567

Anderson v. Amstead....... 571

Anderson v. Harold......... 98

Anderson v. Haskell........ 595

Anderson v. Jett.......... 304

Anderson v. Martindale..... 380

Anderson v. May.........116, 135

Anderson v. Perkins......... 92

Anderson v. Smith......... 216

Anderson v. Spencer......... 129

Anderson v. United States.323, 324

Andexried v. Railroad Co.... 306

Anding v. Levy........... 416

Andre v. Bodman......... 125

Andrews v. Andrews....... 400

Andrews v. Bank.......... 464

Andrews v. Creditors....... 401

Andrews v. Herriot......... 408

Andrews v. Pond.......... 419

Andrews v. Portland....... 652

Andrews v. Torrey......... 243

Androscoggin Water Power Co.

v. Metcalf . . . . . . . . . 464

Angel v. McLellan. .45, 47, 49, 470

Anglesea v. Rugeley....... 576 
Sec.

Angier v. Webber......312, 319

Angus v. Robinson........ 377

Annas v. Railroad Co...28s, 295

Anthony v. Heman......... 365

Anthony v. Leftwich....... 102

Anthony v. Perciful........ 389

Antoni v. Grecnbow......... 556

Anvil Min. Co. v. Humble... 614

Appeal of Morehouse....... 178

Appel v. Waltman......... 278

Appleby v. Myers......572, 659

Appleton Bank v. TicGilvrey.. 450

Arbuckle v. Cawhan....... 517

Arbuckle v. Cowlan......... 283

Arbuckle v. Reaume........ . 412

Archard v. Horner.........6603

Archer v. Bogne.......... . 37

Archer v. James.......... 3

Ardress's Appeal......... 628

Arkansas, etc. R. R. Co. v.

Whitby . . . . . . . . 134

Arkansas, etc. Town Co. v.

Lincoln . . . . . .......696

Arkansas Valley Smelting Co.

v. Min. Co............ 519

Armendiaz v. Serna........ 415

Arnifield v. Nash.........603

Armitage v. Widoe......28, 60

Armstrong v. Best....397, 401, 408

Armstrong Co. v. Clarion Ca...394

Armstrong v. Express Co..2ss, 289

Armstrong v. Freeman...... 230

Armstrong $v$. Latimer...... 449

Armstrong v. Toler.....321, 414

Arnick v. Butler........... 268

Arnold v. Bournique....... 643

Arnold v. Clifford......... 164

Arnold $v$ Garst........... 79

Arnold v. Potter.........4 417

Arnold v. Richmond Iron

Works . . .........9, 23

Arnot v. Coal Co........305, 324

Arnot v. Pittston......... 317

Artcher v. Zeh........155, 156

Arthur v. Clark..........6.681
Sec.

Arthur v. Oakes........335, 677

Ashbury Railway, etc. Co. v.

Riche ...........301, 352

Asheraft $v$. DeArmand..... 22

Ascroft v. Butterworth..... 141

Asher v. 'exas........... 552

Ashley v. Ashley.......267, 485

Ashley v. Dixon........343, 346

Ashmead v. Reynolds....... 21

Ashton v. Dakin.......... 255

Askew v. Bank............ 406

Askey v. Williams.......43, 49

Aspdin v. Austin......603, 622

Association v. Herman...... 64

Astey v. Emery.......... 152

Astley v. Reynolds........452

Atcheson v. Mallon.......165, 324

Atchison, etc. R. R. Co. v. Eng-

lish . . .........134, 137

Atchison, etc. R. R. Co. v. Cock-

$\operatorname{ran} \ldots \ldots \ldots \ldots \ldots \ldots . . \ldots 5$

Atchison. etc. R. R. Co. v. Law-

ler .............. 288

Atherton v. Atherton....... 400

Atkins v. Banwell......... 431

Atkins v. Barnstable....... 473

Atkins v. Kansas........... 4

Atkins v. Owen........... 446

Atkinson v. Daniel......... 624

Atkinson v. Denby......171, 701

Atkinson v. Doherty........ 340

Atkinson v. Medford........ 13

Atkinson v. Ritchie........ 573

Atkinson v. Stewart........ $89 \%$

Atkinson v. Water Works Co.. 349

Atkinson $v$. Whitehead....... 584

Atkyns r. Kinnear......... 319

Atlintic Bank v. Bank...... 503

Atlanta, etc. R. R. Co. v.

Spear .........667, 676

Atlanta Nat Bank r. Burke... $42 \mathrm{~S}$

Atlanta Min. Co. r. Gwyer.... 228

Atlantic Cotton Mills v. Or-

chard Mills ............ 503

Atlantic Phosphate Co. v. Ely. 395

Atlas Nat. Bank v. Holm..... 321 


\begin{tabular}{|c|c|}
\hline Atlee v. Fink. . . . . . . 451 & Badger v. Badger..........626 \\
\hline Attrill v. Patterson........6 620 & Padger v. Phinney..27, 64, 69, 7 I \\
\hline Attorney Gen. v. Telephone Co. 307 & Badisehe Anilin Und Soda Fab- \\
\hline Attorney Gen. v. Tongue..... 551 & rik v. Schott.......... 3I 1 \\
\hline Atwater v. Hough......... 146 & Baehr v. Downey............ 585 \\
\hline Atwell v. Jenkins.......... 9 & Baggett v. Trulock........ 23I \\
\hline Atwell v. Milton......... 371 & Baggott v. Sawyer........ 165 \\
\hline Atwood r. Cobb......91, 92, 641 & Bagley v. Walker.......... 146 \\
\hline Atwood v. Norton......... 135 & Baglies v. Fettyplace....... 576 \\
\hline Atwood v. Small.........600 & Bagshaw v. Parker........ 15 \\
\hline Aughton v. Seppings........ 464 & Bagwell v. MeTighe........ 632 \\
\hline Augur v. Belting Co........ 515 & Bahm v. Deig........... 696 \\
\hline Augrusta Bank v. Augusta.... 509 & Bailey v. Bussing.431, 437, 438, 444 \\
\hline Augusta Sav. Bank v. Stellings 406 & Bailey v. De Cuspigny....576, 580 \\
\hline Auhert v. Maze.......... 176 & Bailey v. Gibbs.......... 457 \\
\hline Aultman v. Booth......... 114 & Bailey v. Harris.......... 177 \\
\hline Aultman v. Flinn......... 612 & Bailey v. Jackson......... 624 \\
\hline Austedt v. Sutter......... 258 & Bailey v. Marshall......... 128 \\
\hline $\begin{array}{r}\text { Austin } \quad \text { v. Charlestown Semi- } \\
\text { nary } \ldots \ldots \ldots \ldots \ldots \ldots 57,66\end{array}$ & 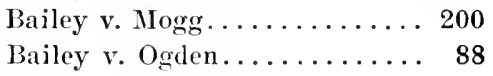 \\
\hline Austin v. Coal Co......... 492 & Bailey v. People............ \\
\hline Austin v. Foster......... 650 & Bailey v. Smith.......... 14 \\
\hline Austin v. Seligman......... 348 & Bain v. Clark............. \\
\hline Avery v. Bowden......... 594 & Bain v. Cline........... \\
\hline Ayer v. Telegraph Co...... 297 & Bain v. Railway \\
\hline Ayers v. Burns.........43, 49 & Bain v. Whitehouse........ \\
\hline Aymar v. Sheldon......... 115 & $\begin{array}{l}\text { Bainbridge v. Pickering..... } \\
\text { Bainter v. Fults........... } 595 \\
\end{array}$ \\
\hline Babcock v. Chase......... 352 & Bake v. Pope.......... 13 \\
\hline Babeock v. Fonddu Lac...... 449 & Baker v. Bueklin........ \\
\hline Brbenck v. Moore......... 619 & Baker v. Hodgson.......... \\
\hline Brbcock v. Railroad Co..... 290 & Baker v. Howell............ \\
\hline Babeock v. Terry.......... 164 & Baker v. Ins. Co........ \\
\hline Bach v. Owen........... 156 & Baker v. Jewell.......... \\
\hline Bach v. Smith.......... 205 & Baker v. Johnson.......... \\
\hline Bachelde v. Fiske......... 373 & Baker v. Kennett......... 58 \\
\hline Backhouse v. Sneed . . . . . . . 616 & Baker v. Lauterbach..112, 133, 479 \\
\hline Backus v. Spaulding. . . . . . 507 & Baker v. Lovett........... 2 \\
\hline Backworth v. Young........ 577 & Baker v. Massey.......... 45 \\
\hline Bacon v. Bacon .......... 501 & Baker v. State.......... 53 \\
\hline Bacon v. Bonham......... 520 & Baker v. Stone........... 6 \\
\hline Bacon v. Cobb......... 573 & Balch v. Patten.....446, 486, 48 \\
\hline Bacon v. Green. .595, 596, 599, 601 & Balderston v. Rubber Co..... 8 \\
\hline Baenn v. Jee. . . . . . . . . I78 & Balkey v. Parker.......... I \\
\hline Bacon v. McChrystal. ...... 109 & Baldwin v. Flagg........... \\
\hline Bacon v. Texas............ 531 & Thaldwin v. Fletcher.....667, \\
\hline
\end{tabular}


See. See.

Baldwin v. Golde......... 9 Jiank v. Express Co........ 2s9

Baldwin v. Gray....... 401 Bank v. Garlinghonse..... 232

Baldwin v. Hiers........ 152 Bank v. Gettinger......... 508

Baldwin v. Ifutehınson......498 Bank v. Gibson........240,417

Baldwin v. MeKay........ 148 Bank v. Giand Lodge....... 354

Baldwin $v$. Newark........ 560 Bank $v$ Hagner..........678

Baldwin v. losier........ 66 Bank v. Hirsch......513, 514

Baldwin v. Steamshup Co.... 497 Bank v. IIoeber........72, 701

Baldwin v. Telegraph Co.... 297 Bank v. Jones.......... 511

Baldwin $r$ Van Deusen...... 27 Bank $r$. Kimberlands... 524. 526

Baldwin $v$ Williams....... 144 Bank $v$. Lea........... 402

Baldy v. Stratton......... 274 Bank r. 1lann..........417

Balfour v. Davis......206, 417 Bank v. Mcclellan....... 227

Balkau r. Woodstock.......638 bank v. Metealf.......... 402

Ball v. Mannin......... 6 Bank r. Owens.....173, lit, 179

Ball $v$. Stover........... 80 Bank $v$ Pratt........... 232

Ballance $v$. Samuel........ $37 \mathrm{I}$ Bank r. Price........... 351

Ballantine $v$. Proudfoot..... 8 liank $r$ Webb......... 642

Ballard v. Brown.........263 bank r. Williams........401

Ballard v. Winter........ 402 Banking Asso. v. Bank...631, 632

Ballas $v$ Fogely.......... 352 Banking Co. v. Rantenberg.... 196

Baltimore Breweries Co. v. Banks v. Crossland........ 112

Callahan ........... 134 Banks $v$. Dewitt........ 555

Baltimore, ete. R. R. Co. $r$ Banks $r$ Goodfellow....... 8

Brydon . . . . . . 639, 645 Banks v. Flint..........228

Baltimore, ete. R. R. Co. Banks v. Manuf. Co....... 91

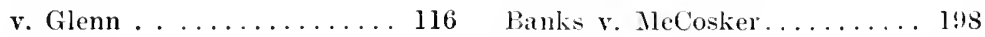

Baltimore, ete. R. R. Co. Banks v. Werts.......185, 192 v. Polly . . . . . . . 646

Baltimore, ete. R. R. Co. v. Scholes . . ........4 419

Baltimore, ete. li. R. Co.

v. School Dist.......... 582

Banchor v. Mansel.....409, 447

Bancroft v. Abbott........ 432

Baneroft $v$. Dumas.......... 205

Bang v. Windmill co....... 206

Bangor Bank v. Treat... 382, 386

Bangs $v$. Dunn............ 283

Bank v. Archer........... 124

Bank v. Benoist. . . . . . . . . 352

Bank r. Burton.......... 278

Bank v. Cook........208, 226

Bank v. Dearing.......... 232

Bank v. Donnally.........6.638

Bank v. Earle........... 397

Banorgee $v$. Henly. . . . . . . . 370

Barabather v. Lee......... . 382

Barber v. Fox........... 119

Barber s sphalt Paring Co. $v$

Denver . . ............. 359

Barber Asphalt Paring Co. v.

Botsford ............ 286

Barelay r. Pearson......270, 272

Barker v. Bank.......... 242

Barker v. Cory.......4\$7, 489

Barker v. Hibbard......... 43

Barker r. Hodgson........ 569

Barker v. Ins. Co......... 605

Barker r. Scudder......... 12S

Barker v. Staey.......... 402

Barker's Case......... 12

Barley v. Bussing. ........ 394

Barlow r. Ins. Co........ 454 
See.

Barnaby v. Barmaby........ 27

Barnard v. Backhaus....245, 254 255,257

Barnet v. Bank.......... 232

Barnett v. Denison......... 534

Barnett v. Kinney......... 406

Barnett v. Pratt.......352, 353

Barnett v. IVarren......445, 446

Barnes v. Barnes.......43, 49

Barnes v. Brown.......476, 683

Barnes v. Ins. Co.......... 352

Barnes v. Johnson........... . 445

Barnes v. McMullens........ 490

Barnes v. Perine........... 385

Barnes v. Shoemaker....... 478

Barnes v. Toye........49, 67

Barney v. Douglas......... 508

Barney v. Rutledge........ 27

Barnhard v. Lupping....... 183

Barnhardt v. Walls........ 114

Barnitz v. Beverly... .555, 566, 567

Barnum v. Childs......... 95

Barnum v. Frost.......72, 74

Barr v. Church........... 227

Barr v. Trades Council....334, 335

336,341

Barras v. Coal Co.......... 125

Barrett v. Dodge......... 399

Barrett v. Forney.......... 105

Barrett v. Geisinger........ 667

Barrett v. Goddard......... 593

Barrett v. Kelley.......... 398

Barrett v. McAllister........ 114

Barrett v. Veneer Works.... 696

Barrows v. Turner......... 402

Barry v. Assur. Co ....... 496

Barry v. Capen...........286

Barry v. Ransom........123, 129

Barry v. Ryan........... 442

Bartel v. Mathias..........6.627

Barter v. Whecler.......... 421

Barth v. Backus........... 406

Barthell v. Jensen......... 236

Bartlett v. Drake......... 71

Bartlett v. Mystic River Corp. 134

Bartlett v. Smith......... 255
Sec.

Bartlett v. Telegraph Co.... 297

Bartlett v. Viner......... 196

Bartholomew v. Jackson...... 457

Bartholomew v. Finnemore.... 71

Barton v. Bank........... 229

Barton v. Benson.......... 165

Barton v. Gray........... 133

Barton v. Muir........... 173

Barwick v. Read.......... 517

Bascom v. Zediker......396, 399

Bashford v. Pearson.........4480

Basket v. Moss.......279, 280

Bassett v. Hughes... .352, 353, 362

Bassett v. Percival......319, 448

Batchelder v. Fisk........ 388

Batchelor v. Kerkbride...... 646

Bateman v. Butler......... 128

Bateman v. Maddox........ 135

Bates v. Chesbro........... 154

Bates v. Moore............ 137

Bates v. Railroad Co........ 295

Bates v. Townley......... 431

Batsford v. Every........ 187

Batson v. King........... 123

Battenbury v. Vyse........646

Battersey's Case........164, 439

Batts v. Richards Lumber Co. . 515

Baum v. Birchall.........4 401

Baum v. Dubois.......... 99

Baum Iron Co. v. Burg...... 598

Baumgardner v. Taylor...... 186

Banrick v. Read.......... 283

Bauserman v. Blunt.......6 638

Bavington v. Clarke........ 30

Bawber v. Savage........ 87

Baxter Bank v. Talbot...... 115

Baxter v. Gray........... 465

Baxter v. Kitch.......... 110

Baxter v. Portsmonth.. 11, 471, 472

Baxter v. Telegraph Co...... 297

Bayles v. Railroad Co....... 325

Bayles v. Mallace......121, 663

Bayley v. Alexander........ 18

Bayley v. Greenleaf....... 508

Bayne v. United Stales..... 502

Beach v. Hotelikiss........ 377 
Sece. Sec.

Beach v. Mullen.....619, 640, (651 Beach v. Vandeburg.....430,457 Beal v. Chase.........312, 316 Beale v. Williamson . . . . . . . 402 Bean v. Bunker...........662 Bearce v. Barstow......... 233 Beard v. Beard........449, 452

Beard v. Horton...........441

Beard v. Linthieum......... 669

Beardsley v. Hotchkiss....... 58

Beardsley v. Morgner....... 521

Beardsley v. Root......... 446

Beasley v. Teleg. Co........ 693

Beaton v. Tarrant........ 336

Beattie v. Callanan......334, 335

Beatty v. Dufief......... 453

Beaty v. Grim........... 128

Beaumont v. Greathead...382, 683

Beaupre v. Noyes.......... 531

Beaupre v. Telegraph Co..... 297

Beavan v. McDonnell........ 9

Beavan v. Oxford......... 508

Beaver County v. Armstrong. 509

Becar v. Flues............ 135

Bechtel v. Cone........... 105

Beck v. Allison........... 668

Beck v. Railway Teamsters

Protect. Union . . . . 335, 336

Becker v. Hallgarten....... 510

Becker v. Holm............ 145

Becker v. Mason......... 69

Becker v. Northway........ 490

Becker v. Water TVorks Co.349, 350

Beckwell v. Christie....... 166

Beckwith v. Frisbie........ 452

Beckwith v. 'Talbat.......83, 85

Bedinger v. Wharton....64, 71

Bedow v. Tonkin........... 474

Beebe v. Johuson.......5568, 569

Beede v. Lumprey.......... 492

Beekman v. Fletcher........ 92

Beeler v. Bank............. 368

Beeler v. Bullett........... 66

Beeler v. Young......48, 50, 468

Beer Co. v. Massaclusetts.532, 547

Beeston v. Caller...........618
Begbie v. Phosphate Sewage Co. 161

Behrens v. Mckenzie.....14, 472

Behrensmeyer v. Kreitz....... 12

Bciteman's Appeal........ 193

Belford v. Woodward....278, 529

Belknap v. Bender......... 131

Bell v. Bell............... 400

Bell v. Boyd............ 393

Bell v. Campbell.......... 330

Bell v. Chaplain.......... 364

Bell v. Gardiner..........450

Bell v. Leggatt........... 276

Bell v. Lent.............. 234

Bell v. Mahin........... 185

Bell v. McVicker........283, 517

Bell v. Morrison.....384, 634, 638

Bell v. Packard.......401, 420

Bell v. Reynolds...........682

Bell v. State............. 271

Bellamy v. Debenham....... 85

Bellows v. Sowles.......119, 121

Bellows v. Stone......... 467

Beman v. Wessels.......... 185

Bemis v. Becker......... 179

Bemis v. Hoseley.......... 379

Benbow v. Soothsmith...... 125

Benedict v. Bachelder....... 597

Benedict v. Lynch........... 669

Bennett v. Asso.......... 417

Bennett v. Davis.......... 28

Bennett v. Hull......... 139

Bennett v. Judson. . . . . . . 503

Bensley v. Bigold.......176, 178

Benson v. Drake.......... 186

Benson v. Monroe.449, 452, 497, 501

Benson v. Remington....44, 470

Benson v. Paine......... 370

Beunson v. Savage......... 224

Bent v. Cobb..........87, 99

Bent v. Manning..........4468

Benton v. Pratt........344, 346

Bently v. Terry.......... 277

Benton v. Goodale......... 452

Benze v. Hiatt........... 361

Benziger v. Miller.........686

Berch v. Frolick.......... 15 
Sec.

Sec.

Berdsley v. Hotchkiss....... 66

Beresford v. Browning....... 372

Bergamini v. Bastian...... 319

Bergenthal v. Fribrantz.... 450

Bergman v. Cleveland....... 544

Bergman v. McGuire....... 375

Bergson v. Ins. Co....... 518

Berkhauser v. Schmitt...... 452

Berlin Machine Works v. Perry 312

Berly v. Taylor........... 489

Bermudez Asphalt Paving Co.

v. Critchfield ..........286

Bernard v. Taylor......245, 246

Bernhardt v. Walls........ 144

Berry v. Clary.......... 186

Berry v. Cooper............ 288

Berry v. Doremus........134, 137

Berry v. Thompson......... 234

Berthold v. Fox......... 561

Besch v. Ins. Co..........266

Besore v. Potter.......... 386

Bestor v. Hickey.......... 52

Bestor v. Wathen......... 302

Bethlehem v. Annis......... 519

Bethlehem Borough v. Ins. Co. 464

Betts v. Carroll............ 21

Betts v. Gibbins.... 164, 394, 437

438,439

Bettsworth v. St. Paul...... 588

Beveridge v. Livingston...... 531

Beverly v. Barnitz........ 566

Beverley's Case . . . . . . . . . 8

Bevier v. Covell............. 233

Bibb v. Allen............. 89

Bibber v. Simpson......... 200

Bice v. Building Asso.... 125, 127

Bicknell v. Bicknell.....46, 73

Bicgler v. Trust Co....... 263

Bigelow v. Benclict. .249, 254, 255

Bigelow v. Ins. Co....... 19, 20

Bigelow v. Pritchard....... 560

Billinguey v. Dean......... 229

Billings v. Ames........... 328

Billings v. Ins. Co....... 20

Billing's Appeal.......... 590

Brllington v. Cahill......... 134

Bingham v. Barley....55, 59, 64

Binney v. Annan..........673

Bird v. Mullinbrink.....146, 694

Bird v. Nunroe.......... 138

Birl v. Pope.............. 667

Bird v. Randall........... 370

Birkett v. Chatterton....... 203

Birkmyr v. Darnell.......... 96

Birmingham Lumber Co. v.

Brinson ............. 445

Birncy v. Telegraph Co...... 297

Bisbee v. McAllen......177, 197

Bishop v. Palmer......... 312

Bishop v. American Preserves

Co ................. 320

Bishop v. Palmer. 164, 204, 246, 313

Bishop v. Slocomb......... 508

Bissell v. Balcom......... 153

Bissell v. Kellogg......... 243

Bissig v. Britton.......96, 129

Bixby v. Church........... 124

Bixby v. Dunlap.......... 341

Bize v. Dickanson......... 87

Black v. Railroad Co.....615, 616

Black v. Transportation Co.... 288

Black v. Woodrow. ....... 579

Blackburn v. Hayes........ 210

Blackburn v. Smith........ 448

Blackburn v. Vigors........ 503

Blacklock v. Dobic......... 170

Blackstock v. Railroad Co.... 615

Blackstone v. Buttemon...... 622

Blackstone v. Ins. Co........ 20

Blackstone v. Miller........ 395

Blackwell v. IVebster....... 404

Blaen Avon Coal Co. v. Mc-

Culloh . ............ 492

Blagen v. Thompson.....689, 690

Blair v. Railroad Co....... 295

Blair v. Snodgrass......... 85

Blair v. Wait........... 428

Blair v. Williams......... 561

Blair Town Lat. Co. v. Walker 133

Blake v. Supervisors........ 27

Blake v. Voight.......... 134

Blake v. Williams.....4406, 407 
Sec.

Blakeley v. Blakeley......6, 9 Blakeney $v$. Goode......... 144 Blakeslee v. 1Iolt......473, 477 Blalock v. Phillips........ 464 Blanch v. Cochran........ 609 Blanchard v. Association..430, 432 Blanchard v. Ely......... 697 Blanchard v. Low......... 450 Blanchard v. Railroad Co.... 676 Blanchard v. Trim........ 81 Blanck v. Sadlier.......... 278 Bland v. Fleeman.........6 630 Blanding v. Sargent...8, 134, 137 Blaston v. Pye........... 262 Bleaden v. Charles........440 Bledsoe v. Irvin.......... 368 Blenkinsop v. Clayton....... 151 Blight v. Page........569, 573 Bliss v. Brainard...... 205, 408 Bliss v. Lawrence........283, 517 Bliss v. Thompson......440, 488 Bliss v. Railroad Co........ 8 Bliss Co. v. Gas Light Co... 654 Bliven v. Lydecker......... 228 Block v. Dorman......... 634 Blogen v. Thompson........ 685 Blood v. Goodrich......... 81 Blood v. Wilson. .473, 477, 651, 655 Bloom v. Hazzard......... 281 Bloom v. Richards....180, 181, 184 Bloomer v. Henderson....... 508 Bloomer v. MicInerney....... 226 Bloomer v. Nolan..46, 53, 63, 64 Blossom v. Barrett........4 461 Blount v. Hawkins......... 129 Bloxsome v. Williams.....180, 187 Blumenthal v. Anderson..... 578 Blymere v. Boistle........ 356 Blymer Ice Mach. Co. v. Mc.

Donald .............696

Blythe v. Railroad Co.....66 615

Board v. Blodgett.........628

Board v. Millword......... 228

Board v. Wagaman........201

Boardman v. Cutter........ 144

Boardman v. Spooner...... 85
Sec.

Board of Trade v. Kinsey Co.. 249

Boast v. Firth.......... 589

Bobbs-Merrill Co. v. Snellenburg .............. 330

Bobertson v. Robinson...... 279

Bodine v. Glading. . . . . . . . 668

Boehl $v$. Railroad Co........ 288

Boering v. Railroad Co...... 295

Bog Lead Mining Co. v. Montague ............. 148

Bohannon v. Jones......... 129

Bohanon v. Pope......352, 353

Boice v. Boice.......... 562

Bold v. State............ 181

Bolton v. Street.......... 115

Bolton v. Tomlin.......80, 100

Bona's Appeal............ 255

Bond v. Bond............. 8

Bonesteel v. Todd........ 370

Bonney v. Seely..........446

Bonsteel v. Vanderbilt....... 588

Boody v. MeKenney....27, 64, 65

Booge v. Railroad Co........603

Bool v. Mix............ 58

Boone County v. Jones....... 635

Booth v. Bank............ 179

Booth v. Clark.......... 406

Booth v. Illinois.......249, 254

Booth v. Mill Co...573, 685, 698

Booth v. Sweezy..........2 210

Boozer r. Trague.......... 105

Bordentown v. Wallace...... 33

Borradaile v. Hunter......17, 18

Borries v. Hutchinson.......698

Bormm v. Garland......... 598

Boscowitz v. Express Co..... 289

Boseley v. Taylor......... 391

Boston v. Farr........... 125

Boston Bank v. Chamberlin.. 65

Boston, etc. Co. v. Boston.... 449

Boston, ete. R. R. Co. v. County 537

Boston Ice Co. v. Potter. .339, 340

$457,478,519$

Boston Ins. Co. v. Railroad Co. 291

Bostwick v. Atkins........ 56

Bouchell v. Clary......... 43 
Sec.

Boucas v. Cooke.......... . 340

Boucher v. State Board...... 200

Boulder Valley, etc. Co. v. Farnham ............ 104

Boulton v. Jones....457, 478, 519

Bour v. Kimball.......... 623

Bourlier v. Macauley........ 343

Bourne v. Cabot........... 522

Boursot v. Savage........ 503

Boutwell v. Foster.......... 205

Bowdish v. Briggs.........660

Bowditch v. Ins. Co......175, 177

Bowdoin v. Hammond....... 216

Bowen v. Hoxie........... 423

Bowen v. Hall........341, 342

Bowen Nat. Bank v. Wilson.. 283

Bower v. Hadden.......... 524

Bowers v. Bowers.......... 400

Bowery Nat. Bank v. Mayor.. 646

Bowery Nat. Bank v. Wilson.. 283

Bowland v. Windley........ 624

Bowles v. Field.......... 401

Bowman v. Boyd..........456

Bowman v. Coffroth........ 284

Bowman v. Miller.......... 243

Bowman v. Neely.... 222, 224, 225

Bowman v. Railroad Co...... 548

Boxendale v. Railway Co.... 325

Boyce v. Anderson.........6617

Boyce v. Lake.........624, 627

Boyce v. Murphy.......... 122

Boyce v. Smith..........6, 8

Boyce v. Tabb......... 416

Boyd v. Brown............697

Boyd v. Gilchrist......... 691

Boyd v. Hanson........... 256

Boyd v. Hind.......... 700

Boyd v. Martin.......... 382

Boyd v. Paul............ 91

Boydell v. Drummond...... 85

Boyden v. Boyden......... 65

Boydson v. Goodrich....... 402

Boyer v. Berryman.....9, 21, 22

Boyer v. Bolender......... 437

Boyer v. Soules........... 129
Boyer v. Western Union Tel.

Co. . . .............. 337

Boyett v. Potter.......445, 491

Boykin v. Campell......... 519

Boyland v. Leonard........ 515

Boyland v. Railroad Co..... 293

Boynton v. Hubbard....... 500

Boynton v. Page.......184, 187

Boyse v. Adams.......... 267

Boyson v. Thorn.......... 343

Bozarth v. Dudley...473, 477, 640

Bozeman v. Browning.....26, 66

Brace v. Wehnert.........668 668

Bracegirdle v. Heald....134, 137

Brackett v. Blake......283, 515

Brackett v. Edgerton........691

Brackett v. Hoyt........... 197

Braceville Coal Co. v. People.2, 540

Bradburne v. Botfield....... 386

Bradford v. Chicago........ 571

Bradford Corporation v. Pickles 345

Bradford v. Manly.........6 612

Bradford v. McCormick..... 635

Bradlaugh v. Newdegate..... 164

Bradley v. Burwell......... 374

Bradley v. Fuller........... 345

Bradley v. Owsley......... 105

Bradley v. Pierson......... 341

Bradley v. Pratt........27, 34

Bradley v. Rea.........185, 192

Bradley v. Richardson....... 87

Bradley v. Riches.........5 503

Bradley v. Root..........526

Bradner v. Roffsell..........646

Bradshaw v. Beard......... 485

Bradshaw v. Branan.......6.605

Bradshaw v. Railroad Co..... 293

Bradshaw v. Van Winkle.... 70

Brady v. Brennan......... 490

Bragdon v. Perkins-Campbell

Co . . ............... 348

Brakefield v. Anderson........ 114

Braithwaite v. Aiken....486, 487

489,490

Braman v. Dowse.......... 353 
Sec.

Sec.

Brand v. Brand........4 419 Brimmer v. Rebman....... 549

Brand v. Williams.......445 Brine v. Ins. Co......555, 565

Brandon v. Brown......... 64 Brisbane v. Dacres..450, 452, 501

Brandt v. Schurchman.....699 Brisendine v. Martin....... 389

Brantley v. Wolf.......22, 64 Bristoe, etc. Co. v. Maggs.... 85

Braxton v. State........ 373 Bristow v. Lane.......352, 353

Brawner v. Franklin....... 64 Bristow v. Sequeville....... 415

Brazee v. Bryant......... 195 British, etc. Tel. Co. v. Bank. 503

Brechkill v. Randall.......538 British Wagon Co. v. Lea... 519

Breckinridge v. Crocker...85, 92 Britt v. Hays.......... 602

Breckinridge v. Ormsby..9, 57, 66 Brittian v. Rossiter..103, 108, 134

Breckinridge v. Taylor...... 391 Britton v. Royal Arcanum.... 269

Brecknock Company v. Pritch-

ard . ............. 573

Breed v. Judd.....41, 43, 62, 63

Breeze v. Telegraph Co...... 297

Brennan v. Titusville....... 552

Bresbane v. Adams.......... 165

Brewer v. Boston Theater.... 384

Brewer v. Dyer.....353, 356, 442

Brewer v. Griesheimer..... 515

Brewer v. Sparrow........ 487

Brewsen v. Engler.......... 287

Brewster v. Bates.........6 634

Brewster v. Kitchell....... 576

Brewster v. Sims........... 510

Brice v. Bannister......... 526

Brice v. King. ........... 352

Brice v. Wilson.......... 485

Brick Presbyterian Church $\mathbf{v}$.

New York . . ........ 576

Bride v. Clark........... 257

Bridge Co. v. Pomroy........ 351

Bridgeford v. Tuscumbia..... 284

Bridgen v. Parkes......... 485

Bridger v. Goldsmith........ 276

Bridges v. Lanhan........ 697

Bridges v. Stickney........685

Bridges v. Stephens.....275, 637

Briggs v. Boyd......... 497

Briggs v. McCabe.......... 27

Briggs v. Vanderbilt....... 588

Brigham v. Fayerweather..22, 23

Bright v. Coffman......... 427

Brighton v. Railroad Co..... 664

Brill v. Tuttle.......519, 524

Britton $v$. Turner.........474

Britton v. Water Works Co.. 349

Britz v. Muscatine........ 555

Broach v. Smith.......... 231

Broadhead v. Noyes........ 419

Broadsman v. Paige........ 391

Broadwell v. Getman.....88, 137

Broadwell v. Howard........ 513

Brockhausen v. Bowes....... 109

Brockway v. Frost........ 92

Brockway v. Express Co..... 410

Brodeck v. Farnum........ 375

Bronson v. Coffin......... 689

Bronson v. Ins. Co........ 367

Bronson v. Kimpton........ 278

Bronson v. Kinzie.......555, 556

$560,565,566$

Brownson v. Newbury...... 557

Bronson v. Rodes......... 529

Bronson Agri. \& B. Asso. v.

Ramsdell . . . . . . . . . 262

Brook v. Brook.......178, 400

Brook v. Hook........... 352

Brooklyn v. Railroad Co.... 614

Brooks v. Berryhill........ 498

Brooks v. Martin......... 321

Brooks v. Morgan......... 94

Brooks v. Stuart........ 387

Brookshire v. Brookshire.... 622

Brow v. Brightman........ 470

Brown v. Adair.......... 202

Brown v. Agnew......... 433

Brown r. Bank. .124, 233, 234, 275

$281,282,403$ 
See.

Sec.

Brown v. Bateman.........5 528

Brown v. Tuttle.......... 461

Brown v. Brown......... 6

Brown v. Browning......180, 412

Brown v. Buena Vista...... 625

Brown v. Buttle......... 460

Brown v. Cable Co......... 297

Brown v. Caldwell.......... 27

Brown v. Cambridge....... 379

Brown v. Chase........... 74

Brown v. Conger.......... 102

Brown v. Delafield.........634

Brown v. Dillahunts........ 576

Brown v. Dunean.177, 178, 196, 205

Brown v. Dunn.......... 519

Brown v. Foster......614, 639

Brown v. Harris.......595, 599

Brown v. Hodgson......431, 435

Brown v. Holbrook......... 461

Brown v. Houston......... 551

Brown v. Ins. Co.......353, 577

Brown v. Jodrell.......... 472

Brown v. Jones............ 399

Brown v. Kimball Co...... 158

Brown v. Kling.......... 314

Brown v. Mahusin......... 599

Brown v. Nlarsh........... 379

Brown v. Maryland........ 553

Brown v. McCune......... 67

Brown v. Mckee........... 382

Brown v. MeKinally....... 501

Brown v. Mitchell......... 5

Frown v. Mort. Co......... 208

Brown v. Mullin..........604

Brown v. Nat. Bank. . . . . . . 232

Brown v. Nealey......... 171

Brown v. OBBrien......... 352

Lirown v. Pollard.......102, 104

Brown v. Railroad Co.293, 4이, 482

Brown v. Richardson....... 15

Brown v. Road Co....... 450

Brown v. Rodes.........278

Brown v. Rounsavell....... 317

Brown v. Russell........... 198

Brown v. Smith............697

Brown v. Sutton.......... 105

Brown v. Tel. Co.......... 296

Brown v. United States...... 580

Brown v. Weiland......... 409

Brown v. Weleh........... 278

Brown v. Wheeloek......... 26

Brown v. Whipple......85, 97

Browne v. Bank........... 378

Browne v. United States..... 588

Brownell v. Chapman....... 697

Brownell v. Harsh........ 128

Brownell v. Weleh........ 111

Browning v. Carson.....369, 382

Browning v. Hamilton....... 148

Browning v. Morris........ 500

Browning v. Parker....... 100

Browning v. Reane........ 13

Brubaker v. Taylor........624

Bruce v. Flagg........... 387

Bruce v. Snow.......... 570

Bruce v. Warwick......... 66

Bruen v. Hone........... 427

Bruen v. Marquand......377, 381

Brummitt v. McGuire...... 450

Brundage v. Portchester..... 446

Bruner v. Nisbett......... 124

Bruinaguire v. Tillinglıast... 455

Bryan v. Booze........... 185

Bryan v. Lewis........... 255

Bryan v. Reynolds......284, 285

Bryan v. Spurgin......... 580

Bryan v. Watson.......... 190

Bryant v. Richardson....... 41

Bryson v. Home........... 449

Buehanan v. Hubbard...... 65

Buehanan v. Ins. Co....... 266

Buchanan v. Moran........ 132

Buchanan v. Sahlein........ 499

Buchegger v. Schultz....... 278

Buek v. Biddeford......... 191

Buekalew v. State........ 271

Buckey v. Buekey......... 7

Bucklen v. Hasterlik........ 678

Buckley v. Beardsley........ 93

Buckley v. IImmanson...... 198

Buckhardt v. Buckhardt..... 309

Buckinhamshire v. Drury.... 49 


\begin{tabular}{|c|c|}
\hline & \\
\hline $\begin{array}{l}\text { Buckman v Bergholtz........ } \\
\text { Buckman v. Nash........... }\end{array}$ & $\begin{array}{l}173 \\
142\end{array}$ \\
\hline Bucknall v. Story......455, & 456 \\
\hline Buckner v. Colcote......... & 626 \\
\hline Buckner v. Stewart......... & 392 \\
\hline Budd v. Hiler.........446, & 464 \\
\hline Budd v. New York. .296, 538, & 539 \\
\hline Buffalo v. OMalley........... & 450 \\
\hline $\begin{array}{l}\text { Buffalo, etc. Land Co. v. Belle- } \\
\text { vue, etc. Imp. Co......... }\end{array}$ & \\
\hline
\end{tabular}
road $\mathrm{Co} \ldots \ldots \ldots \ldots \ldots 576$

Bugbee v. Kendrickson...... 122

Building and Loan Asso. v. Logan . . ...........4 417

Bulger v. Ross........... 5

Bulkley v. United States..... 695

Bull v. Faulkner.......... 518

Bull v. Quincey.......... 440

Bullard v. Hascall.........445

Bullard v. Smith.......... 249

Bullman v. Fenwick....... 580

Bullock v. Dommit.......... 573

Bullock v. Turnpike Co..... 133

Bullowa v. Orga.......... 87

Bumgarden v. Leavite...... 674

Bumpass v. Webb......... 642

Bundy v. Hyde.......... 460

Bunn v. Guy.........316, 319

Bunn v. Prather.......... 573

Bunn v. Riker........245, 262

Bunneman v. Wagner........ 128

Burbridge v. Fockler........ 284

Burehard v. Dunbar........ 419

Burchfield v. Moore........ 448

Burdick v. People......173, 293

Burdett r. Williams........ 67

Burge v. Cedar, ete. Railroad

Co ............... 599

Burger v. Rice.......... 519

Burgess v. Pollock........ 8

Burghart v. Ilall......... 468

Burgoyne v. Ins. Co....... 373

Burk v. Railroad Co....... 288

Burke v. Allen..........9, 21

Burke v. Mayor..........642
Sec.

Burley v. Russell......... 67

Burlingame v. Burlingame.... 110

Burlington Mut. L. Asso. v.

Heirler . . . . . . . . 219

Burmudez Asphalt Co. v.

Critehfield ............ 284

Burn v. Carvalho......... 526

Burn v. Miller........... 666

Burney v. Ludling...284, 301, 302

Burnett v. Baxter......... 254

Burnett v. Crandall.....524, 526

Burnett v. Railroad Co......421

Burnett v. Telegraph Co..... 188

Burnham v. Kidwell....6, 9, 12 $14,21,25$

Burnherr $\dot{v}$. Rau........ 354

Burns v. Moore.........183, 185

Burns v. Munger.......... 614

Burns v. Railroad Co....395, 408

Burnside v. Merrick........ 380

Burphalter v. Farmer....... 126

Burr v. Beers........352, 353

Burr v. Boyer.......... 393

Burrill v. Crossman........ 580

Burroughs v. Lott......... 391

Burroughs v. Railroad Co.... 290

Bursinger v. Bank........ 267

Burt v. Meyer........... 249

Burt v. Union Cent. L. Ins.

Co ............... 545

Burtis v. Thompson....6604, 607

Burton v. Curyea......... 513

Burton v. Driggs.......486, 491

Burton v. Henry.......... 382

Burton v. Larkin....348, 351, 354

Burton v. Stevens......636, 637

Burton Coal Co. v. Cox....... 492

Burton Lumber Co. v. ITilder. 443

Buser v. Shepard......... 562

Bush v. Brown.......... 498

Bush v. Linthicum......5 I, 60

Bush v. Lisle........... 5

1.ush v. Moore........... 503

Bushby v. Wunday......... 258

Binshel v. Wheeler......... 152

Bushnell v. Bushnell.. .388, 390, 434 


\begin{abstract}
Sec.
Bushwell v. Bicknell....... 613 Butcher's' Union Co. v. Crescent

City Co ......271, 535, 547

Butler v. Butler..........609

Butler v. Chambers......... 542

Butler v. Foster.......... 129

Butler v. Lee........... 185, 192

Butler v. Horwitz... ...278, 529

Butler v. Palmer...........561

Butler v. Pennsylvanı...426, 530

Butler v. Sliehan......... 134

Butnor v. Teleg. Co........663 693

Butterfield v. Byron.....575, 659

Butterfield v. Merlin........ 622

Butters v. Glass......... 116

Button v. Russell.........652

Butts v. Broughton........ 237

Buxton v. Bedall........... 139

Buxton v. Lester........... 675

Byerlee v. Mendel.........474

Byrd v. Boyd...........605

Byrd v. Hughes...........451

Byxbie v. Wood......... 518
\end{abstract}

Cabot v. Park Co..........679

Cadavel v. Collins......497, 501

Cagger v. Lansing.......... 84

Cadman v. Markle......110,479

Cahill v. Bigelow.......113, 122

Cahill v. Hall.......457, 483

Cahill v. Heuser.......... 655

Cain v. Warford......... 7

Calahan v. Ward........... 125

Caldecatt v. Smythies....... 136

Calder v. Rutherford....371, 380

Caldwell v. Alton.......... 198

Caldwell v. Frazier.........669

Caldwell v. Signourney...... 634

Caldwell v. Wentworth....... 225

Calhoun v. Calhoun....... 576

Calhoun v. Phillips......... 183

Calkins v. Chandler......I21, 127

128,132

Call v. Hagger........... 559

Call v. Palmer...........211

Callahan v. Wood......... 460
Sec.

Callanan v. Chapin........ 84

Calland v. Loyd.......... 502

Callaway v. Mallett........ 293

Callaway Mining Co. v. Clark. 697

Catterill v. Stevens........ 156

Callis v. Bothamly........ 98

Callis v. Day.........27, 65

Callo v. Brouncker.........618

Calverley v. Worth........ 85

Cambioso v. Moffet......... 414

Camden, etc. R. R. Co. v. For-

syth . . . . . . . . . 290

Camerlin v. Palmer......47, 470

Cameron v. Clark......... 445

Cameron v. Durkheim....... 255

Cameron v. White........687

Cammack v. Lewis......266, 267

Camp v. Moreman........ 93

Camp v. Telegraph Co....... 297

Camp v. Randall.......... 243

Campbell v. Baxter........451

Camphell v. Coon......... 403

Camplell v. Clark......... 452

Campbell v. Crampton....... 397

Campbell v. Fleming.......6 600

Campbell v. Kuhn.......21, 25

Campbell v. Potter...667, 668, 671

Campbell v. Richardson...246, 262

Campbell v. Ridgeley....... 67

Campbell v. Segars......... 202

Campbell v. Stakes........ 69

Campbell v. Thomas........ 84

Ci mpbell v. Young........ 192

Campion v. Kille......241, 243

Canal Trustees v. Lynch..... 643

Canda v. Wick........... 654

C. \& C. Eleetric Motor Co. v.

Frisbie .............6 612

Candee v. Skinner......... 635

Candee v. Smith.......... 370

Candee v. Telegraph Co..... 297

Canfield v. Fairbanks....... 14

Cannan v. Bryee........164, 447

Cannell v. Smith......... 451

Cannon v. Brice........... 176

Cannon v. Handley........ 84 
Sec.

Cannon v. Olsburg......... 66

Cannon v. Ryan.......186, 192

Cannon v. Telegraph Co..... 297

Cantee v. Bennett.......... 398

Cantine v. Phillips........4 468

Canty v. Latterner.....524, 526

Cappell v. Hall.......... 280

Carberry v. Tannehill...667, 669

Card v. Hope............. 279

Cardell v. MeNell.......... 128

Cardigan v. Page......... 452

Carew v. Johnston........ 25

Carew v. Rutherford.....334, 341

452,497

Carey v. Freeholders.......487

Cargill v. Power.......... 561

Carib Prince.............4 421

Carleton v. Woods........... 204

Carlisle v. Hill.......... 212

Carlton v. Cummings........ 15

Carman v. Smick.......... 142

Carmichael v. Carmichael...667

Carnegie v. Holt.......... 685

Carnegie v. Morrison.....353, 356

357,403

Carney v. Carney.......... 105

Carney v. Mosher......... 136

Carney v. Newberry.....596, 597

Carow v. Kelly........... 237

Carpenter v. Atherton....278, 529

Carpenter v. Bank........6.698

Carpenter v. Carpenter..43, 64, 67

68, 468

Carpenter v. Davis........ 113

Carpenter v. Holcomb...... 606

Carpenter v. Kent.......... 427

Carpenter v. Pridgen........ 67

Carpenter v. Stevens........ 568

Carr v. Chapman.........6 626

Carr v. Clough.......... 57

Carr v. Drigs............624

Carr v. IIalliday......... $\mathbf{\Omega}$

Carr v. Hamilton......... 506

Carr v. Hilton........... 626

Carr v. Railway ('o....... 428

Carrall v. Railroad Co...... 514

Carralton v. Bazzett........ 198

Carrell v. Potter.......27, 51

Carren v. MeNulty.........614

Carrick v. Mincke......... 88

Carrier v. Sears........... 21

Carrington v. Roots.....100, 112

Carroll v. Welch.........474

Carson v. Cochran........ 449

Carter v. Alling.......... 312

Carter v. Beckwith....... 9

Carter v. Carter........... 386

Carter v. Nichols.......... 521

Carter v. Shorter......... 85

Carter White Lead Co. v. Kiv-

$\operatorname{lin} \ldots \ldots \ldots \ldots \ldots \ldots 134$

Carthage v. Gray.......589, 591

Carthrae v. Brown........ 382

Case v. Gerrish.......... 171

Case v. Dodge............ 401

Case v. Johnson.......... 173

Cashman v. Root......252, 253

Cason v. Cheely.....139, 146, 694

Cassady v. Clarke......... 590

Cassidy v. Cattle Co.......656

Cassitt v. Hobbs........... 92

Caster v. Aicles.......... 519

Castro v. Giel...........6631

Catawissa R. R. Co. v. Titus.. 382

Catlin v. Tohias....474, 477,478

Catling v. King......... 89

Cato v. Thompson.........681

Catskill v. Messenger....... 379

Catt v. Tourle........31i, 677

Caulkins v. Hellman.....145, 148

Cavanaugh v. Casselman..... 98

Cave v. Hastings......... 85

Center v. McQuestion........ 123

Central Build. \& Loan Asso.

v. Lampson . . ........ 219

Central Bridge Corp. v. Abbott 423

Central Land Co. v. Laidley.. 531

Central Line v. Lowe....... 615

Central Salt Co. v. Guthrie... 305

Central Shade Roller Co. r.

Crishman ...........317. 32:

Central S. R. Co. v. Cushman 317 
Sec.

Sec.

Central Trans. Co. v. Car

Chapins v. Mathol....... 237

Co ..............303, 330

Chapin's Will Case......... 8

Central Trust Co. v. Burton ............240,417

Central Trust Co. v. Railroad Co ................. 330

Central Union Tel. Co. v. Bradbury ............. 538

Central Union Tel. Co. v. State . . ........298, 538

Central Union Telephone Co. v. Swoveland ........... 298

Chace v. Chapin.......... 506

Chadwick v. Knox......... 287

Chafee v. Bank.......... 406

Chaffee v. Jones........... 388

Chafee v. Sprague..........674

Chafre v. Wilson.......... 237

Chamber'in v. McCallister... 603

Clamberlin v. Morgan...605, 611

Chambers v. Baldwin........ 343

Cluambers v. Goldwin........ 222

Chamberlain v. Barnes...... 321

Chamberlain v. Hibbard...... 699

Chamberlin v. Morgan....... 602

Chamberlin v. Scott........ 599

Ciamblee v. Baker.......... 474

Champion v. Ames..185, 272, 274

326,411

Champion v. Doty....... 126

Champion v. Hinkle....... 562

Champion v. Plummer...... 88

('hamplin v. larish........ 97

Champlin v. Rowley....474, 477

Cliancey v. May.......... 367

Chancey v. Powell........631

Chandler v. Simmons..22, 58, 64

Chandler v. Sanger........ 497

Chandler v. State......639, 655

Chaney v. Bryan......... 8

Chaney v. Smallwood....... 15

Chanter v. Jeese.......377, 382

Chapel v. Hicks..........666

Chapin v. Brown.......... 309

Chapin v. Shafer........58, 66

Chapin v. Longworth....... 519

Chaplin v. Rogers......... 151

Chapline v. Atkinson....... 96

Chapman v. Dalton........588

Chapman v. Hughes....30, 47, 468

Chapman v. Ins. Co........ 20

Chapman v. Railroad Co..... 537

Chapman v. Robertson....115, 241

Chapman v. Searle........ 593

Chapman v. Telegr. Co...... 693

Chappel v. Barkley......... 125

Chappel v. Brockway.....274, 314

Chapple v. Cooper..33, 40,43, 468

Chapsky v. Wood......... 277

Charles v. Hastedt......63, 70

Charles v. Hoskins......... 635

Charleston v. Benjamin..... 181

Charlestown v. Rogers.......540

Charlestown School Town v.

Hay . . ............ 587

Charles River Bridge v. War-

ren Bridge ........534, 535

Charnley v. Honig........660

Chase v. Barrett.......... 588

Chase v. Chapin.......... 358

Chase v. Lowell. . . . . . . . . . . 83

Chase v. Telegr. Co.........693

Chase v. Trafford......... 124

Chase v. Whitten......... 206

Chasemore v. Richards...... 345

Chatfield v. Wilson........ 345

Chavannah v. State....... 270

Cheale v. Kenward........ $\mathbf{6 7 5}$

Cheesman v. Wiggins....... 129

Cheever v. Schall......... 83

Chemical Co. v. Pegram..... 393

Chemical Naz. Bank v. Bank.. 445

Chenango Bridge Co. v. Bridge

Co. . . .............. 534

Cheney v. Cook........... 98

Cheney v. Iunlap.......... 237

Cheney v. Roodhouse....... 72

Cheny v. Cowan.......... 576

Cheorier v. Robert........ 632

Cherry v. Henning........ 82 
Sec.

Chesebrouglı v. Conover...284, 285

Chesapeake, ete. Co. v. Telegraph Co............ 307

Chesapeake \& Potomac Telephone Co. v. Tel. Co....... 538

Chesley v. King........... 345

Cheveront v. Textor....... 171

Chew v. Bank.........22, 23

Chewning v. Johnson....... 408

Chicago v. Allcock......... 224

Chicago v. Brownell........ 264

Chicago v. Railroad Co...... 538

Chicago v. Rumptf ......... 304

Chicago Attach. Co. v. Singer

Mach. Co . . .......102, 111

Chicago, ete. Coal Co. v. Liddell 131

Chicago, etc. R. R. Co. v. Abels 617

Chicago, etc. R. R. Co. v. Aekley 539

Chicago, etc. Asso. v. Hunt... 63

Chicago, etc. R. R. Co. v. Bell. 300

Chicago, ete. R. R. Co v. Chicago ............. 539

Chicago, etc. R. R. Co. v. Davis .........288, 291

Chicago, etc. R. R. Co. v. Dumser . . ........293, 294

Chicago, etc. R. R. Co. v. Hale . . . . . . . . . . . 682

Chicago, etc. R. R. Co. v.

Howison . . . ......... 696

Chicago, etc. R. R. Co. v. Iowa . . . . . . . . . 325, 539

Chicago, etc. R. R. Co. v. Miller ........... 300

Chicago, etc. R. R. Co. v. Minnesota . . . . . . .538, 539

Chieago, etc. R. R. Co. v. Mulford ........293, 294

Chicago, ete. R. R. Co. v.

People . ........... 306

Chicago, etc. R. R. Co. v. Sawyer ............ 580

Chicago, etc. R. R. Co. v.

Simon .............. 290

Chicago, etc. R. R. Co. v. Solan . . . . . . . . . . 549
Sec.

Chicago, ete. R. R. Co. v. Wabash, etc. R. R...... 324

Chicagro, ete. R. R. Co. v. Wallace ........... 288

Chicago, etc. R. R. Co. v. Wellman . ........... 539

Chicago Gas Light \& Coke Co.

v. Coke Co. .....301, 303, 301

Chicago Union Traction Co. v.

Chicago . ................. 305

Childs v. Dobbin......... 69

Childs v. Monins.......... 120

Childers r. Deane......... 208

Chillingworth v. Tinware Co... 402

Chipley v. Atkinson......... $341,342,344,347$

Chipman v. Morrill.....383, 436

Chippewa, etc. R. R Co v.

Railroad Co. .........284

Chism v. Schiffer......6643, 646

Christ v. Armour........... 604

Christian v. Ins. Co........ 427

Christie v. Railroad Co..... 325

Christie v. Sawyer........ 5:6

Christmas v. Russell....... 526

Christy v. Sullivan ....... 449

Chureh v. Brown.......... 94

Chureh v. Coke Co......... 444

Church v. Proctor......... 275

Churehill v. Holt......... 438

Churehward v. Queen....... 579

Churehward v. Reg........661

Citizen's Bank r. Grafllin.... 450

Citizen's Nat. Bank v. Donnell 232

City Bank v. Railroad Co.... 511

City Loan Asso. v. Gallagher. . 219

City Loan Co. v. Cheney...... 219

Civil Rights Cases......... 509

Claffin v. Kimball........ 5 26

Claflin v. Boorum........ 212

Claflin v. Godfrey......... 448

Claflin v. Mayer.......... 398

Clampet v. Jells.......... !n

Clancy v. Overman......... 580

Clancey v. Salt Manuf. Co.... 320

Clapp v. Pawtucket Inst..... 375 
Sec.

Clapp v. Webb........123, 128

Claremont Bank v. Wood..382, 386

Clark v. Allen............ 267

Clark v. Baker............ 448

Clark v. Burnham......... 144

Clark v. Cable........... 377

Clark v. Clark.........105, 400

Clark v. Crosby.......... 312

Clark v. Finlon........... 239

Clark v. Gilbert.......475, 589

Clark v. Goddard......... 27

Clark v. Howard.......... 354

Clark v. Hurd........... 157

Clark v. Iowa City......... 241

Clark v. James............ 128

Clark v. Jones............ 125

Clark v. Leslie.......48, 49, 469

Clark v. Lyon........... 352

Clark v. Marsiglia...579, 603, 608

Clark v. Mayor..........6 610

Clark v. McFarland......... 36I

Clark v. Needham.......... 321

Clark v. Parish.......... 371

Clark v. Pendleton......... 134

Clark v. Pinney........... 445

Clark v. Railroad Co....... 617

Clark v. Reyburn.........555

Clark v. School Dist....... 599

Clark v. Sisson........... 212

Clark v. Watson........... 646

Clark v. White.......... 171

Clarke v. Dutcher......... 449

Clarke v. Hawkins........ 506

Clarke v. Mariott.......... 151

Clarke v. Shee............ 502

Clarks v. Spence.......... 275

Clason v. Bailey........83, 98

Classey v. Ins. Co........ 267

Clawson v. Munson........ 229

Clay v. Powell.......... 317

Clay v. Severance......... 434

Clay v. Yates.......... 164, 694

Clayton v. Andrews......... 139

Clayton v. Blakey......... 111

Clayton v. Ellis..........567

Clayton v. Kynaston........ 377

Coc.

Clayton v. Somers........485

Cleary v. Sohier....572, 659, 665

Clearwater v. Meredith...... 384

Clegg v. Levy............ 415

Clemens v. Wilkinson........624

Clement v. Telegraph Co..... 297

Clements v. Railroad Co..... 300

Clement's Apeal.......... 129

Clendening v. Church...... 266

Clendening v. Wyatt....... 520

Cleveland v. Construction Co.. 4

Cleveland v. Richardson..... 701

Cleveland, etc. Railroad Co. v.

Closser . ............. 324

Clewes v. Jamison. . . . . . 249, 254

Clifford v. Brandon........ 342

Clifford v. Luhring......121, 123

125,132

Clifford v. Watts.......568, 571

Clift v. Schwabe......... 18

Clinan v. Cook............ 103

Clinton Bank $ヶ$ Hart....... 370

C:ippinger v. Hepbaugh...282, 284

Clodfelter v. Cox..........508

Close v. Phipps.......... 452

Clouch v. Moyer.......433, 441

C'lough v. Davis........... 185

Clough v. Goggins ......... 183

Clough v. Kyne.......... 402

Clowes r. Brooke.........468

Co.ll Creek M. Co. v. Moses.... 492

Coates v. Sangston........ 655

Coates v. Wilson.......... 39

Cobbv. Billings.......... 205

Cobb v. Charter.......... 497

Cobb v. Tirrell..........7 701

Cobbey v. Buchanan.40, 42, 50, 67

Cobleigh v. Pierce......... 171

Coburn v. Ware.......... 387

Cochran v. Ward...115, 116, 205

Cochran v. Railroad Co......661

Cockburn v. Ashland Co..696, 698

Cocke v. Montgomery....... 7

Cockle v. Flack...........210

Cockrell v. Thompson....... 249

Cocks v. Simmons......... 37 
See.

Cocks v. Varney......... 363

Code v. Carlton.......... 515

Coddingham v. Goddard...... 88

Codington v. Bispham...... 562

Coddington v. Goddard ..... 83

Codman v. Krell........... 398

Cody v. Railroad Co......... 292

Cody v. Quarterman........ 111

Coe v. Erral..........326, 395

Coffee v. TVilliams.......... 429

Coffin v. Landis . . . . . 620,622

Cogel v. Mickow.......... 558

Coghlan v. R. R. Co......399, 419

Cohen v. Cohen...........4 460

Cohen v. Envelop Co....... 320

Cohn v. Plumer.......... 473

Coit v. Stewart......... 490

Cole v. Cole............ 13

Cole v. Edwards........... 319

Cole v. Cunningham......258, 406

Cole v. Hutchinson......122, 125

Cole v. Kernon........... 515

Cole v. Malcom.......... 435

Cole v. Milmine........... 255

Cole v. Pennoyer.......27, 28

Cole v. Singerly .......... 134

Coles v. Trecothic......... 85

Colburn v. Patmore......... 164

Colburn v. Phillips........ 356

Colburn v. IVoodworth....... 605

Coleman v. Ballandi........ 558

Coleman v. Foster......... 509

Coleman v. Frazer......... 7

Coleman v. Hiler......... 354

Coleman v. Thurmond.......628

Coleman v. Whitney........352

Colgin v. Bank........... 232

Collar v. Patterson......... 460

Collard v. Railroad Co...683, 684

Collier v. Coates.......... 480

Collins v. Blantern......330, 500

Collins v. Loche........309, 322

Collins v. Price.......... 603

Collins v. Railroad Co...... 532

Colliins $v$. Stanfield......124, 125

Collins v. Sherman........ 535
Sec.

Collins . Townley......... 7

Collister v. Hayman........ 509

Collyer v. Collyer......... 460

Collyer v. Moulton..........608

Colman v. Jenkins........ 442

Colsell v. Buid...........624

Columbia College v. Thacher.. 672

Columbia County v. King..222, 224

Columbus, etc. R. R. Co. v.

Bridges . ..........6 616

Columbus, etc. R. R. Co. v.

Watson . ............676

Colwell v. Peden......... 497

Comes v. Lawson.......... 112

Combs v. Bateman......... 156

Combs v. Scott.......... 625

Commereial Bank v. Davidson. 420

Commercial Bank v. Jackson.. 403

Commercial F. Ins. Co. v.

Morris . ........... 129

Commercial Nat. Bank v. Gil-

lette . ............. 148

Commissioners v. Water Power

Co. . ............ 541

Commonwealth v. Alger..... 547

Commonwealth v. Evans..... 542

Commonwealth v. Farren.... 542

Commonwealth v. Gardner.... 551

Commonwealth v. Graham.... 29

Commonwealth v. Hamden.... 87

Commonwealth v. Hamilton

Mfg. Co..........4, 544

Commonwealth v. Harmel.... 551

Commonwealth v. Harrington. 274

Conmonwealth $r$. Has....... 181

Commonwealth v. Isenberg.... 2

Commonwealth v. Josselyn.... 189

Commonwealth v. Keary...... 173

Commonwealth v. Kendig..... 193

Commonwtalth v. Lane ..... 400

Commonwealth v. Nesbit ..... 181

Commonwealth r. Newhall ... 198

Commonwealth v. Ober ..... 551

Commonwealth v. Perry..2, 4, 540

Commonweath v. Railroad Co. 1ss

534, 541 
Sec.

Commonwealth v. Sampson. 188, 189

Commonwealth v. Sheriff.... 270

Commonwealth v. Simonds.... 264

Commonwealth v. Sisson..... 270

Commonwealth v. Specht..... 181

Commonwealth v. Thacher.... 271

Commionwealth v. Vrooman... 545

Commonwealth v. Waite..... 542

Commonwealth v. Wilson.... 173

Commonwealth v. Wright....270

Com. Nat. Bank v. Bureh.... 508

Comons v. Boyer.......... 180

Compton v. Martin........ 82

Comstock v. Hier......... 446

Comstock v. Norton........ 130

Concord v. Rumsey........ 13

Conkey v. Hart. . ........ 560

Conley v. Blalock......... 202

Conn v. Coburn.......34,48, 469

Conn v. MeCollough........ 351

Connecticut Ins. Co. v. Lathrop 19

Connecticut Life Ins. Co. v. Akens ............... 19

Connecticut Mut. I. Ins. Co. v. Groom ............... 19

Connelly v. Parsons........ 166

Connelly v. Telegr. Co...... 693

Connelly v. Union Sewer Pipe

Co .........2, 321, 341

Conner v. Baldwin......... 84

Conner v. Henderson........ 448

Conner v. New York........ 426

Conner v. Shew........... 485

Conners v. Holland......... 242

Conn. Mut. I. etc. Insurance

Co. v. Cushman....555, 556, 564

Connor v. Black....248, 249, 251

Conover v. Van Mater....... 239

Conrad v. Lane............ 67

Conroe v. Birdsall.......27, 61

Conrey v. Brandegee........ 622

Constable v. Steamship Co.... 288

Conservative Build. \& Loan Asso. v. Cady............ 219

Consumers Oil Co. v. Nunemaker . ............ 312
Consumers' Pure Ice Co. v. Jen-

kins . ............. 697

Continental Bank v. MeGeoch. 171

$700,701,702,703$

Conturier v. Hastie.....88, 128

571,572

Converse v. Brainerd......6 616

Conville v. Sheridan....... 427

Conway v. Cutting........ 526

Cook v. Bell............. 518

Cook v. Berrott.......... 352

Cook v. Bonitz.......427, 429

Cook v. Boston.......... 452

Cook v. Cook............ 400

Cook v. Cole............ 506

Cook v. Collingridge....... 15

Cook v. Husted...........4 425

Cook v. Jolmson.......... 316

Cook v. McCabe.......575, 659

Cook v. Millard........... 146

Cook v. Moffat........... 398

Cook v. Parker........... 9

Cook v. Pennsylvania....... 551

Cook v. Phillip........... 179

Cook v. Redman.......... 135

Cook v. Roche........... 402

Cook v. Shipman........... 284

Cook v. Todd............ 420

Cook v. Van Horn......... 406

Cook v. Willard..........694

Cooley v. Lobdell.......... 104

Cooley v. Wardens......... 548

Coombs v. Railroad Co....148, 152

Coombs v. Wilkes......... 88

Coon v. Spicer............ 234

Cooper v. Allport......... 43

Cooper v. Cooper.......461, 487

Cooper v. Elston.......... 139

Cooper v. Fynmore........ 508

Cooper v. Griffin..........200

Cooper v. Hornsby.......101, 113

Cooper v. Ins. Co......... 18

Cooper v. Nock............ 208

Cooper v. Rhodes.......... 26

Cooper v. Waldegrave....... 115

Cooper Manuf. Co. v. Ferguson 411 


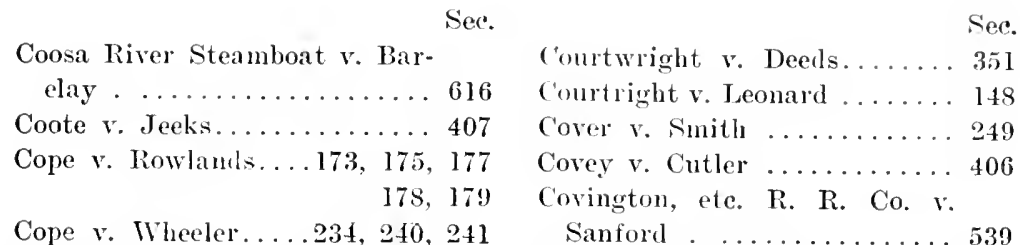

Coopeland v. Summers...... 355

Copenrath v. Kienly......12, 22

Coquillard v. Bearss........ 284

Corbet v. Littlefield........ 402

Corbett v. Gaslight Co....... 98

Corbett v. Watson.......... 139

Corbin v. Traey........... 673

Corcoran v. Bowers........ 212

Corcuran v. Coal Co....... 254

Cordes v. Miller......... 576

Corkins v. Collins.......... 127

Corliss v. Fleming......... 634

Corliss v. Walker Co........ 340

Cornell v. Electric Co....... 128

Corning v. Ludlum......... 243

Cornish v. Abington........ 428

Cornwall v. Gould......... 389

Corpe v. Overton.........38, 63

Corporation v. Minden....... 181

Cort v. Railway Co..579, 594, 606

Corwin v. IVallace......473,477

Costar v. Brush.......... 328

Coster v. Pruyn........... 362

Costigan v. Lunt........... 382

Costigan v. Railroad Co..602, 605

Cota v. Mishow.........650

Cotheal v. Blydenburgh...... 241

Cotterell v. Dutton......... 629

Cothran v. Ellis.246, 249, 251, 254

Cottrell v. Southwick........ 234

Cotten v. McKenzie........ 204

Cotton v. Unnor............ 8

Couch v. Kansas Lity . . . . . . 452

Couch v. Mills.........376, 377

Coughlin v. Knowles. 101, 102, 480

Council v. Burnett ........ 499

County v. Hinkley .....524, 526

County Court v. Griswold.... 540

Coupland v. Railroad Co.... 617

Courtwright v. Courtwright. . 470

Cowan v. Fairbrother...... 312

Cowan v. Milbourn ....274, 275

Cowes v. Jawson ........ 480

Cowles v. Brittian ....... 551

Cowdin v. Cottgetren........ 122

Cox v. Brewing Co........ 134

Cox v. Johnson .......... 26

Cox v. Mailatt ............ 563

Cox v. Valkert .......... 506

Cox v. MeGowan .......... 53

Cox v. Montgomery .......6 626

Cox v. Painter ........... 90

Cox v. United States....240, 420

Coxe v. Martin .......... 560

rochead v. Mullis ........ 26

Coyle v. Campbell ........ 200

Crabtree v. Nessersmith .... 594

Craddock v. Mortgage Co.... 330

Craft v. MeConoughy .250, 30.5, 320

Crafts v. Carr ......... 43

Crafts r. Sweeney ........ 375

Cragin v. Lamkin ......... 406

Cragin v. Railroad Co.....6 615

Craig r. Van Bebber......53, 58

Craig v. Williams ....... 402

Crain v. Petrie ...........685

Cram v. Cram ..........

Crampton v. Ballard ...... 352

Crampton v. Logan ........ 627

Crandall v. Payue ........ 354

Crandall v. Wellig ....... 667

Crandell v. White .....260, 261

Crane v. Alling .......378, 379

Crane v. Gough ......... 101

Crane v. Kildorf ......... 600

Crans r. Hunter ......... 352

Cranshay v. Collins ........ 15

Cranston v. Limlet ....... 437

Crapo v. Kelly......... 406

Crary v. Railroad Co....... 291 
Sec.

Crary v. Van Bebber........ 64

Craveu v. Bates ........... 240

Craven v. Freeman ......388, 436

Cravens v. Cotton Mills Co.... 384

Crawford v. Brooke ....... 515

Crawford v. Brown ........ 348

Crawford v. Edison ......121, 132

Crawford v. Edwards ....... 353

Crawford v. Johnson ....... 214

Crawford v. Kink ........ 128

Crawford v. Railroad Co..... 290

Crawford v. Russell....... 500

Crawford v. Siovell ......22, 23

Crawford v. Spencer....249, 251

254,259

Crawson v. Telegr. Co....... 693

Crayton v. Clark .........507

Creighton v. Sanders ....... 111

Crescent Manuf. Co. v. Manuf.

Co.......605, 623, 686, 687

Cressinger v. Welch ......56, 64

Cribbs v. Soule ........... 499

Crider v. Association ....... 222

Crim v. Post ............ 234

Crippen v. Heermance....... 235

Cripps v. Hartmall.......123, 129

Cripps v. Reade .......... 448

Crisfield v. State ........ 434

Criswell v. Whitney ....... 405

Critten v. Bank ......... 428

Crockett v. Scribner ........ 146

Croft v. Ins. Co.........80, 129

Cromwell v. County of Sac....

$\ldots \ldots \ldots \ldots \ldots 115,399,417$

Cronan v. Fox .......... 402

Cronin v. Olson .......... 211

Cronk v. Trumble .........667

Crookshank v. Burrell ....139, 146

Crosbie v. MeDonald ........ 106

Crosby v. Fitch ........583, 615

Crosby Hardware Co. v. Tester

$\ldots \ldots \ldots \ldots \ldots \ldots$ 145, 154

Crosman v. Lymı ......... 191

Cross v. Cheshire ......... 431

Cross v. O'Donnell ......... 145

Cross v. People ........... 270
Cross v. Richardson.. 121, 128, 271

C'ross v. Trusdale......... 365

Crotty v. Ins. Co......266, 267

Crouch v. Gutman ......... 699

Crowe v. Peters ......... 7

Crowell v. Curner ........ 353

Crowder v. Austin ......... 166

Croy v. Toney ............ 135

Crum v. Sawyer .......... 520

Cubbege v. Napier ......... 240

Cuddee v. Rutter ..........674

Cuff v. Penn ............. 648

Culbreath v. Culbreath .....4453

Cullen v. Sears ..........660

Culver v. Bigelow .......... 221

Culver v. Pullman ......... 208

Cumberiand Glass Manuf. Co.

v. Glass Bottle, etc. Asso.... 336

Cumberland R. R. Co. v. Baab. 302

Cumming v. Fisher ........ 441

Cumming v. Hackley ....... 446

Cummings v. Arnold ....... 81

Cummings v. Foss ......... 321

Cummings v. Powell...27, 57, 64

Cummings v. People ....... 371

Cummings v. Stone Co...... 320

Cummington v. Belchertown... 400

Cummins v. Wise ......... 213

Cundell v. Dawson ......178, 196

Cunningham v. Bank ...... 257

Cunningham v. Irwin .......468

Cunningham v. Monroe ...... 452

Cunningham v. Reardon ...... 468

Cunninghau v. Williauns .... 98

Curran v. Galen.334, 335, 336, 341

Current v. Fulton ......... 384

Currie v. Anderson .......151, 152

Currie v. Railroad Co....302, 661

Curry v. Plow Co....51, 52, 70

Curson v. Menteiro ........ 370

Curt v. Lassard .........677

Curtin v. Patton ....27, 67, 70

Curtis v. Aspinwall ....... 165

Curtis v. Brown ......... 128

Curtis v. Brownell ........ 7

Curtis v. Gokey ......... 316 
Sec. Sec.

Curtis v. Railroad Co....... 582 Curtis v. Sage .....82, 134, 137 Curtis v. IThitney ......556, 557 Cusack v. Robinson...148, 150, 152 Cusic v. Douglas .......... 558 Cutler v. Wright ......214, 387 Cutter v. Close........473,640 Cutting v. Railroad Co....... 684 Cutsinger v. Ballard ....... 105 Cutts v. Gordon .......... 375

Cutts v. Perkins ......... 519

Cuyler v. Cuyler ......... 376

Daeosta v. Davis .......115, 577

Da Costa v. Jones ......245, 262

Daggers v. Van Dyck ....... 625

Daggett v. Johuson ........6 614

Dahoney v. Dahoney ........ 193

Dalby v. Life Assur. Co..... 266

Dalby v. Pullen .........6.681

Dale v. Hamilton .......... 104

Dale v. Knepp............ 190

Daley v. Association ....... 227

Daley v. Ericsson .......371, 380

Daley v. Investment Co...217, 227

Dallman v. King ......... 473

Dalton v. Jones .......... 72

Dalton v. Murphy ......... 398

Daly v. Stetson ......... 519

Dana v. Bank ............ 428

Dane v. Kirkwall ........ 472

Danforth v. Laney ........ 102

Daniel v. Frazer .......... 138

Daniel v. Mitchel........... 571

Daniel v. Telegraph Co...... 297

Daniels v. Hatch ......... 379

Daniels v. Newton .....554, 604

Daniels v. Meinhard....524,526

Daniels v. Pratt ......... 269

Dannenhauer v. Browne ..... 483

Dant v. Head ...........134, 137

Danube, etc. Co. v. Senos.... 604

Darby v. Boocher .......48, 469

Darling v. Railroad Co...... 290

Darlinger v. Earle ......... 171

Darly v. Snith ......... 67 \%

Darraugh v. Blackfod ....53, 64

Darrell v. Tibbetts ........ 404

Darrow v. Family Fund Soc... 16

Dartmouth College v. Wood-

ward .........4426, 534

Darst v. Bates ........128, 237

Dashaway Asso. v Rogers.... 487

Dater v. Earl .......... 409

Dauchey v. Drake.......639, 666

Davenport v. Cong. Society... 700

Davenport v. Gentry ........ 519

Davies v. Davies ........311, 314

Davies v. Humphreys .....38s, 434

Davis v. Turton .......... 66

Davis v. Barger .......... 185

Davis v. Belford ...... 382, 383

Davis v. Booth ........323, 383

Davis v. Bronson....384, 408, 409

Davis v. Brown ......... 312

Davis v. Caldwell ......41, 50

Davis v. Chouteau......368, 377

Davis v. Clark .......... 634

Davis v. Coburn ........358, 519

Davis v. Coleman ......... 399

Davis v. Creamery Co....383, 385

Davis v. Cupp .......... 383

Davis v. Dudley .......27, 56

Davis v. Eastman ......... 151

Davis v. French......... 485

Davis v. Furniture Co....594, 698

Davis v. Gallagher ....... 429

Davis v. Garrett ......... 583

Davis v. Harper ........ 632

Davis v. Jones .......... 383

Davis v. Knoke ......... 383

Davis $v$. Lane .......... 15

Davis v. Light Co.........661

Davis v. Marlborough.....283, 517

Davis v. Murray ......... 383

Davis v. Phillips ........ 7

Davis v. Railroad Co...288, 291

410,421

Daris $v$. Randall ......... 232

Davis $v$. Reyner.......... 119

Daris r. Rowell .......... 138

Davis $v$ Rupe .......560, 561 
Sec.

Davis v. School Dist.......652

Daris v. Shafer .......... 383

Davis v. Sloman ......... 228

Davis v. Smith ......... 573

Davis v. State............. 538

Davi.s v. Statts .......... 96

Davis v. Talcott .........6.641

Daris v. Tarver .......... 14

Daris v. Van Buren ........ 374

Davis v. Water Co......... 349

Davidson v. Bohlman ...... 200

Davison v. Davison .....465, 467

Davidson v. MeGregor ...... 701

Davren v. White ........ 5

Dawes v. Howard ......47,470

Dawes v. Hubbard .........4 473

Dawes v. Peck ........... 152

Dawson v. Holmes ......... 64

Day v. Caton........... 458

Day v. Elmore ............ 94

Day v. Jeffords ......... 588

Day v. Lacasse ............ 84

Day v. McAllister ........ 192

J)ay v. Seely $\ldots \ldots \ldots \ldots \ldots \ldots$

Day v. Railroad Co........ 108

Dayton v. Fargo .......... 518

Dayton v. Moore .......227, 228

Dean v. Anderson ......... 107

Dean v. Dicker .......... 266

Dean v. Ins. Co........17, 18

Dean v. Newhall ......376, 378

Dean v. Walker ....362, 363, 365

Dearle v. Hall .......... 508

De Begins v. Armistead ..... 196

Le: Biel v. Thomson ........ 465

Decan v. Shipper ........ 512

Decell v. Lewenthal.41.44. 45. 50

Deering v. Winchelsea...... 434

De Francisco v. Barnum ..... 317

Defiance Water Co. v. Defiance 626

Deitz v. Sutcliffe .......... 464

De Gogorza v. Ins. Co....... 20

De La Grange v. Telegr. Co,.. 297

Delaney v. Anderson ........ 365

Delano v. Blake ......... 65
Delaware, etc. R. R. Co. v.

Stockyard Co......... 538

Delaware \& Atlantic Telephon

Co. v. Telegraph Co...... 296

De Leon v. Frevino......... 330

Delevan v. Wright ......... 105

Delier v. Agri. Society... . . . 262

Dellinger v. Foltz.......... 64

Delop v. Windsor ........ 402

Delz v. Winfree.......... 341

De Mary v. Bartenshaw ..... 251

De Meli v. De Meli ........ 632

Demeritt $v$. Bickford ...... 129

De Mesnil v. Dakin ........ 498

Demi v. Bassler ........... 136

Demorest $v$. IVillard ....... 518

Demoville v. Davidson County. 532

Denham v. Bryant ........ 473

Dering v. Railroad Co....... 583

Denison v. Crawford ........ 284

Denmead v. Coburn .........474

Dennett v. Dennett ......6, 9

Dennis v. Clark ......47, 470

Dennis v. Ins. Co......... 20

Dennis v. Moses .........1, 278

Denney v. Faulkner ........ 419

Denny v. Railroad Co........ 583

Denny v. Smith ........387, 634

Denny v. Williams ...... 147, 151

Dent v. West Virginia ...... 550

Dentler v. O'Brien ......... 66

Depau v. Humphreys ...... 115

Derby v. Johnson ......... 579

Dermott v. Jones .........

$\ldots \ldots 442,473,477,573,587,655$

Desha v. Robinson ........ 599

De Sobry v. De Laistre . . 274, 420

Dethlifs v. Tomsen ........ 316

Detrick v. Myatt ......... 37

Theutsch v. Bond ......... 93

Devaux v. Conolley ........ 448

Devaynes v. Noble ........ 428

Devine v. Edwards ......450, 640

Devlin v. New York..515, 518, 519

Devol v. McIntosh . . . . . . . 352 


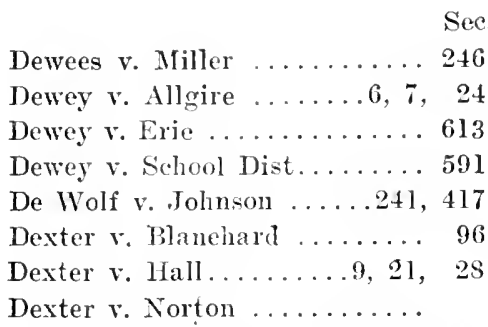
$.475,572,574,658,659$

Deyoe $\mathrm{v}$. Woodwortl ...... 280

Dial v. Wood ........... 35

Diamond Mateh Co. v. Roeber. . $304,312,314,318$

Diebold, etc. Lock Co. v. Barnes 454

Dier's Case .............. 309

Dietrich v. Railroad Co...... 293

Dick v. Ireland .........6621

Diekerman v. Day ... . . . . 212

Diekinson v. Conway ....... 352

Diekinson v. Dickinson ...... 140

Dickinson v. Edwards . . .417, 420

Dickson v. Dickson ....... 400

Dickson v. Frishee ......... 134

Dickson v. Thomas ........ 245

Dilk v. Keighley............ 44

Dill v. Bowen ........... 71

Dillon v. Allen ......178, 179, 196

Dillon v. Anderson .........

$$
602,605,610,611
$$

Dillon v. Burnham ......... 69

Dillon v. Russell ......... 393

Diman v. Railroad Co....... 600

Dingley v. Oler ........... 594

Dinsmore v. Neuesheimer.... 258

Dinsmore v. Webber ....... 66

Disbrough v. Bileman ........ 634

Disbrow v. Durand ......458, 460

Distilling and Cattle Feeding

Co. v. People ....... 320, 323

District v. Dauchy ........ 573

Ditmas v. Sackett ....... 211

Ditchman v. Worall ....... 26

Dix v. Cobb ........... 508

Dix v. Marcy ............ 108

Dixon v. Olmstead......... 500

Dixon v. Merritt ........27, 57
Siec.

Dixon v. Telegraph Co...... 297

Dixon County v. Beardshear.. 456

Dixon-Wood Co. v. Glass Co... 697

Doane v. Covell ........... 66

Doane v. Jockwood ........ 599

Dobbin v. Hewitt ........ 240

Dobson v. Winner .........4 450

Dock v. Boyd ............ 131

Doek Co. v. Kinzie ......... 113

Dodd v. Berthal .......... 32

Dodge v. Woolsey .........534

Doe v. Burnham ........175, 178

Doherr v. The Etona ........ 410

Doherty v. Doe ........... 80

Doherty v. Hill ........... 92

Doherty v. Shields .....446, 489

Dolan v. Green .......... 413

Dolan v. Rodgers .......657, 659

Doles v. Hilton ........... 26

Doll v. Noble ............ 614

Dolman v. Cook ........241, 243

Dolph v. Hand ....52, 55, 56, 59

Don v. Lippman . . . . . . 258, 419

Donald v. Homestead Asso.....114

Donnell v. Bennett ........ 317

Donellan v. Read .......82, 137

Dongan v. Blocker ........ 105

Donovan v. IVard ......... 56

Doolin v. Ward ........165, 167

Doolittle v. Dininny........ 79

Dorecher v. Continental Mills. 62

Dorenus v. Hennessey ....... $.335,341,342,344$

Dorsey v. Packwood ........ 98

Dougherty v. Bash ........ 125

Dougherty v. Chestmutt ..... 92

Dougherty v. Seymour ...... 274

Dougherty v. Whitehead ...... 458

Doughty v. Doughty . . . . . 15, 400

Douglas Ax Manuf. Co. v. Gard-

ner ..............6 612

Douglas County v. Keller .... 450

Douglas v. Kentucky.....273, 547

Donglass v. Chapin ....... 375

Douglass $v$. Howland.....94, 95

Douglass $v$. Spears ........ 98 
Dow v. Beidelman ......538, 539

Dow v. Clark ........... 356

Dow v. Haley ............ 200

Dow v. Updike ........... 229

Dow v. Warthen ........ 156

Dowell v. Cardwell ........ 526

Dowling v. McKenny ....110, 443

Down v. Halling ......... 505

Downer v. Chesbrough ...... 115

Downes v. Ross .......... 146

Downey v. Hinchman ....... 124

Downing v. Freeman ....... 444

Downing v. Ringer ....... 196

Downing v. Stone ......... 61

Downs v. Finnegan ......... $.464,486,489,490,492,493$

Downs v. Minchew ....... 200

Dows v. Glaspel .......251, 259

Dows v. Perrin .......... 512

Dows v. Sweet ........... 128

Dowse v. Coxe .......... 485

Doyle v. Dixon ........... 134

Doyle v. Ins. Co........... 545

Doyle v. Lynn .......... 190

Doyle v. Railroad Co....... 295

Doyle v. Trinity Church ..... 458

Drady v. Railroad Co...... 537

Drake v. Flewellen ........ 96

Drake v. Newton ......... 111

Drake v. Ramsey .....56, 59, 65

Drake v. Rice .......... 419

Drake v. Seaman ......... 94

Drake v. Wells ......... 509

Drake v. Whaley ......... 445

Drake v. White .......... 577

Draper v. Randolph ........ 442

Draughan v. Bunting. ....... 129

Dreeman v. Douglas ........ 274

Dresser v. Norwood......... 503

Drew v. Claggett ......482, 599

Drew v. Peer............. 509

Dreyer v. Goldy ........... 228

Drinkwater v. Jordan ....... 379

Driscoll v. Nichols ........ 485

Drovers Nat. Bank v. O'Hare. . 502
Drude v. Curtis ......... 57

Drury v. Defontaine ..... 180, 187

Drury v. Wolfe ........209, 225

Drury v. Young .......... 84

Dryfus v. Burnes ......... 216

Dry Goods Co. v. Harlin ..... 171

Dube v. Beauding ........ 64

Dublin, etc. Ry. Co. v. Black. 26

Ducett $v$. Wolf .......... 84

Duff v. Russell ...........677

Dufaur v. Assurance Co..... 18

Dugan v. Lewis ......... 417

Dulin v. McCaw .........4 401

Dulin v. Price ........... 109

Dunbar v. Johnson ........ 205

Dunbar v. Railroad Co....... 290

Duncan v. Baker ........ 474

Duncan v. Helm .......... 241

Duncan v. Humphries ....... 599

Duncan v. Jandon ......... 358

Duncan v. Railroad Co...... 295

Dunham v. Bent ......... 328

Dunham v. Branch ........ 379

Dunham v. Cudlipp ....... 230

Dunham v. Griswold .......427

Dunkin v. Hodge ......... 129

Dunlap v. Hand .......640, 651

Dunlap v. Lewis ......... 504

Dunlap v. Wiseman ........ 241

Dunn v. Bell ........... 249

Dunn v. People .......270, 271

Dunn v. Rothermel ....... 111

Dunn v. Sayles ...........622

Dunn v. Seymour ........ 364

Dunn v. West ........... 129

Dunsmore v. Lyle ......... 102

Dunton v. Brown ......... 27

Duquette v. Richar ........ 443

Duplex Saf. Boiler Co. v. Gar-

den ..........6614,639

Dupuy v. Wurtz .......... 632

Dural v. Myers .......... 669

Durand v. Curtis ......... 102

Durgin v. Dyer ........175, 178

Durgin v. Express Co........ 289 
Durfee v. O'Brien .......82, 137

Durham, etc. Improvement Co.

v. Guthrie ......97, 98, 109

Durham v. Hiatt ......... 133

Durkee v. Mott ...........6 603

Durner v. Huegin......... 315

Durnford v. Messiter ....340, 430

Durr v. Hervey ........... 513

Dutton v. Aurora .......... 208

Dutton v. Poole ........361, 364

Duvall v. Bank ............ 208

Duvall v. Myers ..........668

Duval v. Wellman ......275, 500

Dwight v. Badgley......... 256

Dwight v. Hamilton ....... 319

Dyer v. Jones .......... 477

Dykers v. Townsend......90, 142

Dykes v. Bottoms ........ 215

Eadie v. Slimmon.......... 499

Eagle v. Kohn .......... 257

Earl v. Bickford ......... 448

Earle v. Coburn ......... 457

Earle v. Reed .......27, 34, 49

Easp v. Tyler ............ 589

Eastabrook v. Ins. Co......19, 20

Easter v. White ........... 129

Eastern Bank v. Capron ..... 506

East Lewisburg L. \& Manuf.Co.

East Lewisburg L. \& Manuf.

Co. v. Marsh.......... 515

Eastman v. State ......... 200

Eastman v. Wright ........ 377

Easton v. Railroad Co...... 325

East River Bank v. Hoyt...... 216

East Tennessee, ete. R. R. Co. v.

Staub ...........134, 602

Eastwood v. Kenyon......123, 124

Eaton v. Eaton... 6, 9, 21, 22, 25

Eaton v. Hill.........66, 69

Eaton v. Kegan....197, 204, 540

Eaton v. Libbey.......... 350

Eaton v. MeIntire.......... 292

Eaton v. Water Works Co... 349

Eaton v. Whitaker......102, 135

Eaton v. Woolly.......... 640
Ebey v. Adams............ 520

Eckel v. Renne............ 267

Eckeurode v. Chemical Co.... 608

Eckman v. Railroad Co...... 300

Eckstein v. Downing........674

Eddy v. Capron............ 279

Eden v. Chaffee.......... 130

Eden v. People......... 180, 188

Edgall v. MeLaughlin....... 246

Edge v. Edge............ 8

Edgecomb v. Buckhout....... 474

Edgerly v. Shaw.......51, 52

Edgerton $v$. Hodge......... 155

Edison Phonograph Co. v. Pike 339

Edmunds v. Bruce........2237

Edmunds v. Mister........ 52

Edward, etc. Oil Co. v. Baker. . 664

Edwards v. Carter........52, 59

Edwards v. Clement........ 356

Edwards County v. Jennings.. 179

Edwards v. Hardware Manuf.

Co. . . .............. 449

Edwards v. Kearzey.....528, 555

$557,558,560$

Edwards v. Peterson......515, 518

Edwards v. Railroad Co..139, 146

Edwards v. West......... 577

Egbert v. Baker............ 406

Ege v. Koontz........... 449

Egeleshimer v. Van Antwerp.. 385

Eggleston v. Buck......... 371

Eggleston v. IVagnor........ 92

Ehrgatt v. Mayor......... 271

Eichelberger v. McCauley..... 146

Eidmon v. Martinez......... 395

Eisel v. Hayes.........312, 314

Eising v. Andrews......... 635

Elhert v. Gas Co........... 85

Elbinger-Actien-Gesellsehaft $r$.

Armstrong .......663, 698

Elder v. MeClaskey........ 631

Elder v. Selnumacher.......9, 22

Elder $v$. Thompson......... 368

Elder v. Warficld.......... 96

Elderton v. Emmons......... 603 
Sec. Siec.

Eldred v. Malloy.......... 246

Eldridge v. Rowe......... 474

Electric Light Co. v. Raihroad

Co ...............6\% 670

Eley v. Life Assur. Co....... 360

Elgie Cotton Cases......... 148

Elkhart County v. Crary.... 282

Ellenbogen v. Griffey........ 227

Eller v. Lacy. . . . . . . . . . . . 368

Ellerman v. Stock Yards

Co. ...........304, 312

Ellicott v. Turner.......... 82

Elliott v. Barrett........ 91

Elliott v. Caldwell...477, 640, 655

Elliott v. Horn........... 30

Elliot v. Ince............ 25

Elliott v. Railway Co....555, 642

Elliott v. Sugg........... 210

Ellis v. Alford........... 65

Ellis v. Bray............. 93

Ellis v. Cary....... 108, 467, 479

Ellis v. Deadman.......... 92

Ellis v. Ellis.............. 469

Ellis v. Hamlen..........473

Ellis v. Harrison. . . . . . . 352, 362

Ellis v. Murray........... 125

Ellis v. Railroad Co........ 92

Ellis v. Telegraph Co....... 297

Ellis v. Thompson..........6 641

Ellison v. Jackson.......... 121

Ellison v. Jackson Water Co.. 93

Elmore v. Kingscott......... 141

Elrod v. Myers.......... . . 45

Elston v. Jasper.........9, 10

Elwell v. Martin............ 34

Embrey v. Jemison. . 249, 251, 259

Emerson v. Aultman......... 94

Emerson v. Carpenter....... 66

Emerson v. Slater...121, 125, 132

Emery v. Bank..... . . . . . . 512

Emery v. Burbank......... 115

Emery v. Candle Co........ 320

Emery v. Clough........... . 398

Emery v. Darling.......... 667

Emery v. Emery........... 491
Emery v. Lawrence.......... . 515

Emery v. Ohio Co......... 313

Emery v. Smith.........82, 110

Emert v. Missouri........ 551

Emmons v. Elderton.....602, 605

Enders v. Enders......274, 277

Endres $v$. Bank........... 232

England v. Davidson....... 281

England v. Garner......... 27

England Trust Co. v. Abbott. . 674

Engle v. Chipman.......... 279

Englebert v. Troxell...40, 42, 43 $50,57,63,69$

English v. Smock.......... 208

Engster v. West.......... 573

Ennis v. Palace Car Co...622, 628

Epperly v. Bailey.......... 474

Epperson v. Nugent.......43, 49

Equitable, etc. Soc. v. Clements 404

Equitable, etc. Society v. Red-

ding ............... 404

Equitable Gas Light Co. v. Manuf. Co .........107, 108

Equitable Life Assur. Soc. v.

Frommbold ........... 420

Erdman v. Mitchell........ 336

Erie and Pacific Despatch Co.

v. Cecil . . . . . . . . . 325

Erie, etc. R. R. Co. v. Patrick . 383

Erie Railway v. Locomotive Co. 577

Erlanger v. Phosphate Co..... 626

Erman v. Lehman.......... 398

Ernst v. Crosby........... 274

Errington v. Aynesly.......668

Erskine v. Van Arsdale. . . . . 456

Erwin v. Nav. Co......... 384

Eslava v. Crampton........ 228

Espalla v. Wilson......... 114

Espasito v. Bowden......... 576

Espin v. Pemberton........ 503

Estate of Kessler.......... 108

Estate of Silver.......... 9

Essley v. Sloan........... 238

Estep v. Fenton..........655

Estevez v. Purdy............ 228 
See.

Etheridge v. Vernoy.....524, 526

Euds v. Williams......... (525)

Eureka v. Edwards......56, 71

European, ete. Mail Co. v.

Packet Co. . ......... 656

Eustis v. Bolles.......... 531

Evans v. Anderson........ 258

Evans v. Dravo........... 331

Evans v. Givens.......595, 599

Evans v. Jones. . . . . . . . . . 545

Eans v. Hughes.......... 449

Evans v. Miller.....105, 464, 490

Evans v. Montgomery....... . 560

Evans v. Morgan........... 70

Evans v. Railroad Co....617, 619

Evans v. Winona Lumber Co.. 111

Evansville v. Morris.....192, 193

Everhart v. Searle......... 451

Everingham v. Meighan..... 249

Eversen v. Carpenter....... 54

Evert v. Kleimenhagen...... 185

Ewell v. Daggs........332, 532

Ewing v. Litchfield......671, 676

Ewing v. Railroad Co........ 693

Ewins v. Gordon........... 98

Exall v. Partridge...430, 434, 435

Exchange Bank v. Rice.356 357, 359

Exchange Tel. Co. v. Gregory. . 341

Exeter Nat. Bank v. Orchard.. 234

Exley v. Berryhill.........234

Ex parte Andrews......... 181

Ex parte Apsey........... 504

Ex parte Christy......... 555

Ex parte Crammer......... 12

Ex parte Fellows.......... 199

Ex parte Hall........... 526

Ex parte Hayes.... . . . . . . 544

Ex parte Kuback.......... 4

Ex parte Lee............ 1

Ex parte Maclure......... 482

Ex parte Milner.........701

Ex parte Newman......... 181

Ex parte Parker......... 145

Ex parte Pye............ 358

Ex parte South.......... 526
Sec.

Wx parte Taylor........... 60

lex parte Unity, cte. Asso..... 70

Ex parte Jentzsch... . . . . . 188

Express Co. v. Caldwell....... 288

2S9, 296

Express Co. v. Jackson....... 016

Express Co. v. Moon......... 288

Express Co. v. Trego........618

Fagın v. Goggin........... 35

Fain v. Turner.....124, 127, 134

Fairfax v. Railroad Co..... 424

Fairly v. Wappoo Mills...... 198

Falliard v. Wallace.........614

Fanning v. Anderson.....387, 634

Fanning v. Dunhanı........ 216

Fareira v. Gabell......... 251

Farina v. Howe........... 152

Farley v. Parker.........9, 21

Farley v. Platt...........281

Farmer v. Arundel.......... 450

Farmers and Mech. Bank v.

Kingsley . . ......... 635

Farmers' Bank v. Transporta-

tion Co . ........289, 290

Farmers' Deposit N. Bank v.

Bank .............. 506

Farmers' Nat. Gold Bank v.

Stover . ........... 232

Farmington Academy v. Allen 458

Farnam v. Brooks.......... 7

Farnham v. Davis.......... 132

Farnham v. Railroad Co..... 288

Farnsworth v. Hemmer...... 451

Farquhar v. Morris......... 628

Farrell v. Farrell......... 470

Farrell v. Maxwell......... 96

Farson v. Louisville........ 278

Farwell v. Becker....388, 394, 438

Farwell v. Johnston........ 103

Farwell v. Lowther......... 98

Farwe

Faulknor v. Hyman.....25s, 406

Faw v. Roberdeau......... 633

Fawcett $v$. Cash........... 622 
Sec.

Fawcett v. Eberly.......... 281

Fawcett v. Woodbury County.. 281

Faxon v. Mansfield.........474

Fay v. Fay...........171, 701

Fay v. State............ 173

Fay v. Wheeler........... 140

Fear v. Bartlett........... 419

Fearing v. Glenn.........638

Fearnley v. De Mandenville.. 330

Feay v. Decamp........... 599

Fecel v. Gumault.......... 25

Feeney v. Howard.......... 107

Feleh v. Taylor........... 353

Feldew v. Besley.......... 573

Fender v. Kelly.........339, 348

Feldman v. Gamble.......... 204

Felt v. Smith...........664

Felton v. Dickinson........ 361

Fennell v. Ridder.......... 180

Fenno v. Sayre.......... 237

Fenton v. Clark.......474, 589

Ferguson v. Bank.......148, 513

Ferguson v. Bell.......56, 68

Ferguson v. Bobo....67, 69, 70

Ferguson v. Carrington...461, 464

Ferguson v. Clifford........ 402

Ferguson v. Railroad Co.... 27

Ferguson v. Telegr. Co....... 692

Ferrell v. Maxwell.......... 129

Ferris v. Water Co.....349, 350

Ferry v. Burchard........ 635

Fertilizing Co. v. Hyde

Park . . .........534, 547

Fetrow v. Wiseman........ 27

Fessenden v. Mussey........ 88

Fessenden v. Taft......... 395

Feurt v. Rowell............ 402

Fewings v. Tisdale......... 603

Fichter v. Frank.......... 254

Ficklin v. Shelly Taxing Dist. 552

Fıdelity, etc. Co. v. Lawlor.. 129

Fiedler v. Darrin............ 208

Field v. Brackett........ 659

Field v. Chipley........283, 517

Field v. Crawford......... 356

Field v. Herrick........ 66

Fleld v. Magaw.......... 526

Field v. Mayor........... 518

Field v. New York......515, 526

Field v. Runk........... 368

Fielder v. Starkin........6 612

Fildew v. Basley.......... 587

Files v. Railroad co........ 295

Fillienk v. Armstrong....... 618

Fillman v. Ryon.......... 455

Filson v. Himes.......... 279

Finch v. Barclay........... 197

Finch v. Finch...........470

Finch v. Mansfield......... 409

Finn v. Donahue........192, 195

Finney v. Apgar.......... 146

Finney v. Ins. Co.......... 404

Fireman's Ins. Co. v. Thompson 404

Fish v. Chapman.........6 615

Fish v. Stamping Co........ 483

Fishburn v. Chicago......... 304

Fisher v. Bernard......... 31

Fisher v. Bishop......... 499

Fisher v. Hopkins......... 373

Fisher v. Lackey......... 557

Fisher v. Lord.......205, 258, 409

Fisher v. Mowbray........ 27

Fisher v. Otis............ 115

Fisher v. Shattuck.........498

Fisk v. Reser............ 128

Fiske v. People.......... 4

First Nat. Bank v. Allen..... 428

First Nat. Bank v. Bank..... 427

First National Bank v. Chal-

mers ............... 128

First Nat. Bank v. Davis.... 226

First Nat. Bank v. Hendric.. 302

First Nat. Bank v. Kelly.... 511

First Nat. Bank v. Kingsley.. 186

First Nat. Bank v. Mann..... 214

First Nat. Bank v. Mayor.... 456

First Nat. Bank v. Mitchell.. 401

First Nat. Bank v. Packing

Co. ............251, 254

First Nat. Bank v. Railroad Co. 511 
Sec. Sec.

First Nat. Bank v. Rowley. . . 352 Fletcher v. Ingram. . . . . . . 149

First Nat. Bank v. Schmidt. 510 Fleteher v. Tayleur.......6688

First Nat. Bank v. Shaw...397 Flight v. Ballard......668, 669

401,512 Flinn v. Barber......... 480

First Nat. Bank v. Sowles. 159, 160 Flinn v. Railroad Co....... 288

First Nat. Bank v. WValker...406 Flint v. Cadenasso........ 352

First Presb. Church v. Bank. 597 Flint v. Pierce.......... 356

Fitch v. Constantine Hydraulic

Co.................. 509

Fitch v. Ins. Co......... 16

Fitch v. Jones............ 245

Fitch v. Remer..........2 241

Fitchburg Railroad Co. v.

Depot Co. ........... 541

Fitchburg R. R. Co. v. Gage. 325

Fitts v. Hall........... 67

Fitzgerald v. Allen......599, 621

Fitzgerald v. Baker......... 362

Fitzgerald v. Dressler....... 123

Fitzgerald v. Ins. Co . . . . 267

Fitzgerald v. Morrıssey... 121, 123

125,128

Fitzgerald v. Reed........9, 22

Fitzgerald v. Stewart....... 526

Fitzpatrick v. Woodruff..... 140

621,600

Flint v. Wood............ 600

Flood v. Allen............ 335

Flood v. Jackson. . . . . . . . . . 344

Florence R. R. ete. Co. v. Bank 232

Florida, etc. R. R. v. State... 302

Flower v. Railroad Co...... 26

Flynn v. Benefit Asso....... 363

Flynn v. Ins. Co.......... 363

Fonda v. VanHorne ........ 27

Folds v. Allardt........... 60

Foley v. Bushway........... 485

Foley v. Phelps........... 485

Follett v. Buyer.......... 507

Fonseca v. Steamboat Co.... 288

295,395

Fontaine v. Bush........114, 145

Foot v. Merrill. . . . . . . . . . . 492

Forbes v. Appleton......452, 501

Forbes v. Railroad Co....... 510

Force v. Haines........... 458

Ford v. Beech............ 376

Ford v. Cotesworth........ 573

Ford v. Ins. Co........... 404

Ford v. Milk Shippers Asso.. 320

Ford v. Tíley............. 594

Ford v. Ward...........4 458

Ford v. Williams........... 359

Fordyce v. Nelson.......... 524

Forest M. E. Church v. Donnell .............. 385

Forester v. Fuller.......... 11

Formby v. Proyer.......... 287

Forrester v. Flores......... 104

Forscht v. Green......... 502

Forsyth v. Mann.......... 694

Forsyth v. Wells..........4492

Forsyth v. Whaling........ 628 
Sec.

Forst v. Leonard. . . . . . . . . . 368

Fortesque v. Hannah.....466, 467 Forth v. Stanton......... 121

Fort Plain Bridge v. Smith... 535

Farward v. Pittard........ 581

Foshay v. Ferguson........4 498

Foss v. Cummins........250, 304

Foster v. Bartlett......... 496

Foster v. Blackstone....... 508

Foster v. Burton.......... 434

Foster v. Cockerell.......... 508

Foster v. Commissioners.... 544

Foster v. Fuller............ 485

Foster v. Green.......... 504

Foster v. Hooper.......... 371

Foster v. Kirby...........450

Foster v. Maginnis......... 105

Foster v. McO'Blennis........ 134

Foster v. Protective Asso..... 336

Foster v. Ropes............. 149

Foster v. Taylor.........196, 205

Foster v. Thurston.......... 205

Foster v. Water Co......... 349

Foster v. Wooten.......... 185

Fourth Nat. Bank v. Frank-

lyn . . ..........556, 565

Fowle v. Park........304, 312

Fowler v. Armour.......... 603

Fowler v. Burget.......... 100

Fowler v. Donovan......38s, 436

Fowler v. Ins. Co.......... 266

Fowler v. Trust Co..208, 211, 225

228, 229

Fowler v. Water Works Co... 349

Fowler Elevator Co. v. Cot-

trell ............85, 86

Fowler's Appeal............398

Fox v. Drewry........... 64

Fox v. Harding........684, 697

Fox v. Matthews.......... 116

Fox v. Tabel............. 596

Frances v. Barry.......... 92

Francis v. Telegr. Co......693

Frain v. Turner.......... 134

Frank v. Bank........... 428
Frank v. Bobbitt..........406

Frank v. Eltringham....... 88

Franchat v. Leach......594, 606

Franker v. Little......... 450

Franklin v. Long........... 139

Franklin v. Miller........ 595

Franklin Coal Co. v. McMillan 492

Franklin L. Ins. Co. v. Hazzard 267

Franklin Tel. Co. v. Harrison. . 672

Frary v. Rubber Co.........614

Fratt v. Clark........487, 489

Frazier v. Clark..........687

Frazier v. Fredericks....... 406

Frazier v. Massey.......... 27

Freden v. Richards........ 230

Frederick v. Railroad Co..292, 293

Frederick v. Williams.......6 631

Fred Miller Brewing Co. v. De

France ...........4 413

Fredericks v. Mayer.......6677

Freeman v. Bridger........ 39

Freeman v. Clute.........697

Freeman v. Cooke..........4 428

Freeman v. Foss........... 108

Freeman v. Freeman..15, 105, 106

Freeman v. Railroad Co...339, 348

Freeman's Appeal..........4401

Freese v. Brownell......399, 417

Freetl v. Burr........... 595

French v. Grindle........ 212

Freneh v. McAndrew.....27, 57

French v. Parker.......... 319

French v. Smith......... 425

French v. Townes.......... 571

Friend, etc. Lum. Co. v. Miller 685

Frierson v. Williams.......4 401

Frink v. Green.......... 379

Frisbie v. United States....1, 540

Frisby v. Parkhurst........ 667

Fritsch v. Heislem......... 185

Frolickstein v. Mobile....... 181

Frome v. Dawson.......... 104

Frorer v. People .....4, 515, 540

Frost v. Belmont.......... 284

Frost v. Gage........... 357 
Sec.

Sec.

Frost v. Knight.......594, 604

Gallious v. Pieree......... 278

Frost v. Tarr.......466, 627

Frost v. Vaught.......... 31

Frost v. Williams.......... 383

Frostburg Mining Co. v. Glass

Co ............... 152

Frothingham v. Morse...... 278

Fruitt v. Anderson. ....... 11

Fry v. Platt............ 91

Fuchs v. Fucks...........467

Fulford v. Keerl.......... 238

Fuller v. Abrahams........ 166

Fuller v. Brown.......475, 589

Fuller v. Dame........... 302

Fuller v. Davis........... 286

Fuller v. Dawe............ 274

Fuller v. Duren........4446, 486

Fuller v. Hope.........314, 316

Fuller v. Little............ 605

Fuller v. Mowry..........460

Fuller v. Relief Asso...... 300

Fuller v. Scott........... 128

Fullman v. Adams......... 123

Furbish v. Goodnow........ 130

Furlong v. Bartlett....... 60

Furman v. Van Sise.....47, 470

Fuqua v. Sholem........... 28

Furstenhein v. Railroad Co.. 294

Gabel v. Houston.......... 181

Gaffney v. Hayden......62,482

Gage v. Allen..........4 452

Gaines v. Hot Springs.......6 628

Gaines v. Miller........... 624

Gaither v. Clarke..209, 231, 237

Gaither v. Lindsey......... 200

Gaitskill v. ClienaeIt........ 339

Gale v. Harp........... 121

Gale v. Leckie............. 164

Gallagher v. Gallagher....... 103

Gallagher v. Nichols........656

Gallaher v. Sharpless....... 699

Galler v. Fett........... 492

Gallin v. Railway Co....... 295

Gallini v. Laborie.......... 203

Galton v. Emuss........... 165

Galveston, ete. R. R. Co. v.

Pfeuffer . ........... 302

Galvin v. Kenmeth........149, 151

Galway v. Railroad Co...... 625

Galway v. Shields.... 101, 102, 480

Gamewell Fire Alarm Tel. Co.

v. Crane . ........312, 313

Gammon v. Butler......... 504

Gandell v. Pontigney.......6603

Gantly v. Ewing........... 555

Gapen v. Gapen.........6668

Garber v. Armentrout....... 440

Garbracht v. Commonwealth.. 398

Gardels v. Kloke......... 97

Garden City Sand Co v. Miller 403

Gardner v. Gardner........ 80

Gardner v. Lane........... 568

Gardner v. Morse........... 165

Gardner v. Smith......524, 526

Gardner v. Tatum.......... 200

Garfield v. Huls.......... 640

Garfield v. Paris.......... 147

Garland v. Dover......47, 470

Garland v. Harrington....... 515

Garland v. Richeson........ 508

Garnett v. Handley........ . 364

Garnett v. Roper.......... 387

Garretét v. Burleson........600

Garrett v. Moss.......... 169

Garrett v. Taylor........341, 342

Garretson v. Joseph........ 449

Garrigan v. Knight......... 456

Garton v. Railway Co..... 325

Gartrell v. Stafford........ 98

Gartside v. Isherwood....... 7

Garvey v. Crouch.......... 128

Garvin v. Lenton........208, 233

Gary v. James........... 465

Gas Company v. San Franeisco . . . ......... 459

Gaskins v. Daris.......... 492

Gas Light Co. v. Colliday.... 307

Gas Light Co. v. Memphis... 459 
Gaslin v. Pinney.......... 145

Gassett v. Glazıer.......... 599

Gastenan v. Commonwealth.. 544

Gaston v. Drake........... 279

Gates v. Gaitlıer.......... 403

Gates v. Green............ 573

Gates v. MeKee............ 94

Gathings v. Williams....... 13

Gatlin v. Wilcox.......... 595

Gaul v. Willis............ 212

Gault v. Stormout......... 91

Gauthier v. Cole............ 412

Gautzert v. Hoge............ 363

Gavin v. Burton.......... 33

Gaw v. Bennett.......... 256

Gay v. Ballou........... 49

Gay v. Hassam.......... 637

Gay v. Ins. Co.......... 18

Gaylord v. Sorageii......409, 447

Gee v. Railroad Co.....6683, 684

Geer v. School Dist........ 382

Geipel v. Snith..........6 615

Geismer v. Railroad Co...... 615

Geist's Appeal.......... 521

Gelpeke v. Dubuque..224, 241, 531

Generaux v. Sibley......29, 48

Gennett v. Wuestner.....183, 192

Genoa v. Woodneff.........241

George v. East Tenn. C. Co... 317

George v. Hoskins. . . . . . . 129

George v. Security Co....... 211

Georgia Banking Co. v. Smith. 534

539

Georgia R. R. Co. v. Hayden.. 697

Gere v. Clark........371, 372

Gerhart v. Peck........... 99

German Sav. and L. Asso. v.

De Lashmutt . . . . . . . . 12

Gerz v. Demarra......... 460

Getty v. Binsse.......... 374

Gibben v. Maxwell........9, 14

Gibbons v. Bente....383, 384, 608

Gibbons v. Gouverneur....2152, 263

Gibbons v. Grinell.......383, 385

Gibbons v. Ogden......... 550
Sec.

Gibbs v. Blanchard......... 122

Gibbs v. Bryant.......434, 442

Gibbs v. Gas Co..246, 303, 305, 313

314,324

Gibbs v. Ins. Co.......... 404

Gibbs v Smith......165, 169, 324

Gibbs, etc. Manuf. Co. v.

Brucker ............ 185

Giblan v. Laborers' Union... . 335

Gibson v. Carnage..........614

Gibson v. Carruthers........ 519

Gibson v. Cook.......... 521

Gibson v. Holland.......... 116

Gibson v. Ins. Co........ I0I, 404

Gibson v. Jeyes........... 12

Gibson v. Pelkie......... 571

Gibson v. Soper..6, 21, 22, 23, 64

Gibson v. Stearnes.......... 233

Gibson v. Stevens.......513, 514

Gibson v. Trust Co........ 367

Gieske v. Anderson........ 367

Gifford v. Corrigan..352, 353, 362

Giles v. Edwards...448, 595, 599

Gill v. Bicknell........... 87

Gill v. Hewitt............ 87

Gill v. Vogler........474, 666

Gillenevatu v. Railroad Co.... 295

Gillenwaters v. Campbell..... 66

Gıllespie v. Bailey......56, 64

Gillespie Tool Co. v. Wilson..474

Gilles v. Tel. Co.......... 296

Gillett v. Maynard......108, 480

Gillette v. Hartford........456

Gillette v. Tucker.........6 628

Gilley v. Gilley.....30, 47, 470

Gilliland v. Phillips........4 416

Gillis v. Space.......... 686

Gillis v. Stinch fierd......... 531

Gillis v. Telegraph Co....... 297

Gillispie v. Nabors......... 37

Gillispie v. Railroad Co...... 582

Gilman v. Courtney.........645

Gilman v. Daught......... 312

Gilman v. Dwight......... 319 
Siec.

Gilman v. Hall.......477, 640

Gilman v. llill.........143, 149

Gilmore v. Bissell......... 225

Gilmore v. Courtney....... $\mathbf{6 4 3}$

Gilmore v. Lewes........... 281

Gilmore v. Wilbur.....446, 464

487,488

Gilmore v. Woodeock........ 461

Gilson v. Spear........67, 70

Gimbel v. Stalte..........561

Ginn v. Secnrity Co........ 228

Gipps Brewing Co. v. De France 205

Girard Storage Co. v. South-

ward Co............ 538

Gist v. Smith.......... 443

Gist v. Tel. Co.........408, 413

Gitchell v. Maney..........521

Glacius v. Black.473,639,640, 666

Giamorgan Coal Co. v. South

Wales Miners' Federation. . 335

Glanville v. Jennings........ 275

Glass Co. v. Binney......... 344

Glascock v. Hazell....... 446

Glasscock v. Hamilton..... . . 388

Glasscock v. Lyons......... 445

Gleason v. Burke...2208, 231, 235

Gleason v. Fitzgerald....... 130

Gleason v. Smith...6640,651, 666

Gleason v. United States..... 588

Glencoe Sand Co. v. Hudson...34l

343

Glendon Iron Co. v. Uhler.... 345

Glenn v. Jackson........... 585

Glenn v. Savage......... 457

Glenn v. Shannon......... 450

Gloss v. Hurlbert. 91, 102, 104, 105

Gloucester, etc. Co. v. Russia

Cement $\mathrm{Co}$. ........ 329

Glover v. Cheatham..... 184, 185

Glover v. Ott............. 41

Glyn v. Baker........... 503

Godcharles v. Wigeman. .2, 4, 540

Goddard v. Binney......146, 694

Goddard v. Danaha........ 104

Goddard v. Sawyer.....4403, 456
Sec.

Goulman v. Meixel......... 254

Goldman v. Oppenheim...... 165

Gold Mining Co. v. Bank.... 170

Goldsmith v. Bruning...275, 500

Gonzoles v. Chartier....... 133

Good v. Cheesman......... 700

Good v. Deland.......... 328

Goode v. Elliott....244, 245, 262

Goodlander Mill Co. v. Stand-

ard Oil Co........... 348

Goodman v. Griffiths......141, 464

Goodman v. Harvey........ 512

Goodman v. Henderson...... 312

Goodman v. Pocock......603, 688

Goodman v. Simonds....... 512

Goodman v. Winter....... 71

Goodnow v. Empire Lumber Co............55, 59

Goodnow v. Smith......... 376

Goodnow v. Stryker........ 632

Goodrich v. Association..... 219

Goodrich v. Reynolds........ 208

Goodrich v. Tenny......... 330

Goodsell v. Myers.......... 65

Goodspeed v. Fuller........ 448

Goodwin v. Bishop......... 216

Goodwin v. Cunnıngham..... 507

Goodwin v. Frances........ 85

Goodwin v. Gilbert...... .79, 353

Goodwin Gas Stove's Appeal.. 674

Goodyear v. Adams.......... 9

Gompers v. Rochester...... 322

Gompertz v. Denton.....448, 496

Gondon v. Railroad Co...... 642

Gordon v. Avery........... 91

Gordon v. Bank......... 393

Gordon v. Brewster........ 603

Gordon v. Little.......... 130

Gordon v. Potter......4 $\vec{i}, 470$

Gordon v. Rimmington.......58

Gordon v. Simonton....... 596

Gore v. Gibson........7, 9, 472

Gorham v. Dodge......102, 104

Gorman v. Railroad Co...... 530

Gornsey v. Rogers.......... 354 
Sec.

Goss v. Ellison........... 379

Goss v. Nugent.......... 81

Gottschalk v. Smith........ 445

Gotwaet v. Neal.......... 500

Gough v. Edelen.......... 149

Gough v. Findon......... 427

Gould v. Banking Co....... 105

Gould v. Gould.......... 377

Gould v. Murch......... 572

Gove v. Riddleford........667 667

Governor v. Art Union...... 271

Gowen v. Klous.......... 90

Grace v. Adams........... 288

Grace v. Denison.......... 93

Grace v. Hale.........44, 468

Grace v. Lynch........... 137

Gracone v. Wroughton...... 279

Graffty v. Rushville........ 551

Graft v. Loucks........... 107

Grafton v. Cummings...86, 88, 91

Graham v. Holloway.....48.2, 597

Graham v. Selover.........634

Graham v. Wickham....... 465

Grain v. Aldrich.521, 522, 524, 525

Grand United Order v. Merklin 231

Granger v. Granger........ 629

Granite State Provident Asso-

ciation v. Monk.......... 219

Grannis v. Quintain........ 653

Grans v. Hunter.......... 503

Grant v. Beard........... 355

Grant v. Ludlow........... 518

Grant v. MeGrath......185, 192

Grant v. Naylor.........159, 160

Grant v. Wolf.........122, 125

Grape Creek Coal Co. v. Spell$\operatorname{man} \ldots \ldots \ldots \ldots \ldots 68,676$

Gratoit v. Railway Co...... 198

Graves v. Johnson.......164, 398

409,415

Graves v. White.........482

Gray v. Bennett.......... 423

Gray v. Building Trades Coun-

cil . ............... 341

Gray v. Davis............ 151

Sec.

Gray v. Gas Light Co......438

Gray v. Garrison......... 518

Gray v. Green............ 594

Gray v. Hill............ 480

Gray v. Hook............ 279

Gray v. Iron Works........ 398

Gray v. Mathias........... 274

Gray v. Murray......475, 589

Gay v. Reynolds.......... 163

Gray v. Tel. Co........... 421

Gray v. Pearson.......... 367

Gray v. Van Blarcom........ 228

Great Western R. R. Co. v.

Redmayer . . .........684

Great Western Railway Co. v.

Sutton . ............ 325

Great Western Tel. Co. v. Purdy 638

Grebert v. Borgnis.........683 68

Grebert-Borgnis v. Nugent.... 698

Green v. Biddle........560, 566

Green v. Bulton........344, 346

Green v. Collins.......409, 447

Green v. Cresswell......123, 129

Green v. Gilbert......475, 589

Green v. Green........64, 71

Green v. Greentank.....68, 69

Green v. Hadfield......... 127

Green v. Iron Works........ 406

Green v. Moffet.........5 540

Green v. Railway Co.......676

Green v. Salmon.........485

Green v. Scranage ........ 499

Green v. Stobo......... 567

Green v. Van Buskirk...402, 407

Green v. Willing.......... 26

Greene v. Bartholomew..... 515

Greene v. Burton.......... 125

Greene v. Godfrey......... 195

Greene v. Greene.......... 5

Greene v. Latham........... 132

Greene v. Tyler.......... 237

Greenfield v. Monaghan...... 236

Greenfield School Dist. v. Bank 504

Greenhill v. Ins. Co........ 32

Greentree v. Rosenstock...... 508 
Sec.

Sec.

Greenwell v. Greenwell..... . 460

Grover v. Wakeman....... 170

Greenwood v. Butler....555, 566

Greenwood v. Curtis....... 408

Greenwood v. Freight Co.... 541

Greenwood v. Law.......... 144

Greenwood v. Stratner....... I35

Greesemer v. Ins. Co....... 420

Gregory v. Brunswick....341, 342

Gregory v. Ingwersen.......668

Gregory v. Lee........49, 57

Gregory v. Mighell....... 102

Gregory v. Spicker........ 312

Gregory v. Wendell. 245, 249, 255

Gregory v. Tilliams....... 360

Gressell v. Robinson........ 431

Greton v. Smith......... 480

Grew v. Produce Exchange... 249

Gribben v. Maxwell.....22, 25

Griesemer v. Ins. Co... . 396, 404

Griffin v. Clay County....... 281

Griffin v. Colver....683, 685, 697

Griftn v. Thomas......... 382

Griffith v. Schwendenman.... 27

Griffith v. Townley........ 453

Griffith v. Wells. . 178, 196, 197, 205

Griffiths v. Dudley......288, 299

Grim v. Iron Co......... 357

Grimes v. Hamilton County.. 83

Grimm v. Warner......... 319

Grimston v. Cunningham....677

Grindle v. Express Co...... 290

Grinnell v. Kiralfy........614

Grinnell v. Telegraph Co.... 297

Grissell v. Railroad Co..... 537

Griswold v. Butler......... 12

Griswold v. Railroad Co.:295, 519

Griswold v. Waddington.... 15

Griswood v. Bane.......255, 257

Groff v. Ramsey.......... 99

Grogan v. Express Co........ 288

Gross v. Coffey........... 222

Gross v. Davis........... 391

Gross v. Jordan.......... 116

Gross v. Mort. Co......... 532

Grover v. Duboís......... 87

Groynne v. Tel. Co........ 298

Grubb v. Sharkey......... 107

Grubb v. Wysor........... 508

Grubbs v. Harris.......... . 561

Grymer v. Sanders......596, 600

Gubbins v. Lautenschlager.... 653

Guetzkow v. Andrews........6 698

Guggenheimer v. Grieszler... 228

Guild v. Bank........... 232

Guild v. Conrad........96, 129

Guild v. Hull.......... 6

Guignon v. Trust Co....... 403

Gulf, etc. R. . Co. v. McGowan 295

Gulf, etc. R. R. Co. v. Morris. 304

Gulick v. Ward......... 167

Gullich v. Alford.......... 595

Gump v. Halberstadt....... 125

Gunnison v. Gregg........ 237

Gunn v. Barry.....548, 555, 562

Gunter v. Astor........... 344

Gunter v. Halsey.......... 104

Gunter v. Leckey.......... 173

Gurney v. Behrend......... 512

Gurney v. Womersley.......448

Gurwald v. Hahn......... 662

Gutlrie v. Anderson....... 97

Guthrie v. Morris........ 49

Gwathney v. Cason......... 87

Haacke v. Literary Club. . . . 192

Haas v. Railroad Co.......615

Hackett v. Hackett....... 485

Hackett v. King......... 498

Hadd v. Express Co......... 290

Hade v. MeVay......... 506

Hadley v. Baxendale..297, 683, 685

$688,696,697$

Hadley v. Clarke......... 576

Haebler v. Myers.........445

Hagadore v. Stronach....... 121

Hagar $v$. Reclamation Dist.... 278

Hageiin v. Wacks........ 80

Hagerty v. Nashua Lock Co.. 62

Hague v. Wheeler......... 345 


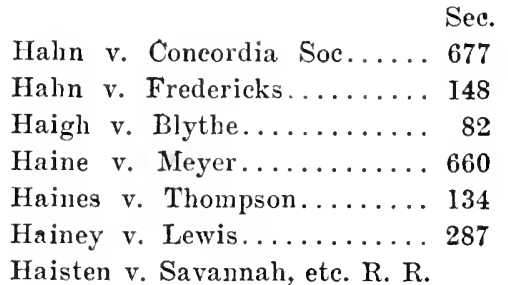

Co ................ 668

Halbrook v. Armstrong...... I37

Halderman v. Duncan....... 148

Haldeman v. Ins. Co........ 229

Haldeman v. Simonton....... 319

Hale v. Brown.......... 6

Hale v. Gerrish............ 51

Hale v. Hale. .86, 91, 104, 105, 467

Hale v. Navigation Co...421, 580

Hale v. Spaulding ........ 375

Hale v. Steam Nav. Co. ..... 420

Hales v. Freeman......... 431

Hall v. Alfred........... 132

Hall v. Bishop........... 199

Hall v. Buffalo........... 518

Hall v. Butterfield........ 62

Hall v. Cordell........115, 420

Hall v. Denckla . . . . . . . . . 625

Hall v. Finch.......... 460

Hall v. Gray............. 375

Hall v. Huntoon.......... 361

Hall v. Jones............. 51

Hall v. Lane............ 348

Hall v. Leigh . . . . . . . . . 382

Hall v. Mandlín............ 228

Hall v. Renfro...........6 615

Hall v. State............ 426

Hall v. Parker............ 193

Hall v. Potter........... 275

Hall v. Waחace........... 99

Hall v. Weir.........47, 470

Hall v. Wright..........476

Halleck v. Mixer.......... 464

Hallenback v Cockran...... 154

Hallett v. Novion.......175, 178

Halley v. Anness.......... 668

Halley v. Troester......... 21

Hallgarten v. Oldham...... 116
Sec.

Halliman v. Rogers......... 388

Halloway v. Talbot.....602, 605

Haltham v. Ryland........ 588

Hamill v. Hall............ 131

Familton v. Austin........ 189

Hamilton v. County Court.... 540

Hamilton v. Harvey........ 667

HamiIton v. Magill........683

Hamilton v. McPherson.602, 605

Hamilton v. Rogers........5 5I5

Hamilton Gas Light Co. v.

Hamilton City..........534

Hamlet v. Richardson......50 50I

Hamlyn v. Talisker Distillery

396,420

Hammer v. Schoenfelder..... 685

Hammersley v. De Biel......465

Hammond v. Bessey,....... 685

Hammons v. Slate........ 188

Hampden v. Walsh........244

Hampton v. France.......6632

Hampton v. Westcott...... 5

Hanchett v. Jordan......... 185

Hancock v. Hazzard........ 584

Hancock v. Merrick....... 470

Hancock v. Yaden......... 1, 2

Hand v. Pub. Co........... 186

Handforth v. Jackson....... 312

Handley v. Harris. . . . . . . . 402

Hands v. Slaney......40, 50, 468

Handy v. Brown........ 519

Handy v. Publishing Co...... 416

Haney v. Caldwelĩ.......... 619

Hanford v. Paine......... 406

Hanks v. Nagles.......... 274

Hanly v. Blackford......... 92

Hanly v. Kansas City, etc. R.

R. . . . . . . . . 182

Hann v. Dekater ........... 234

Hanna v. Andrews ....... 319

Hanna v. Ingram . . . . . . . 254

Hamuah v. Fife ......... 324

Hannibal v. 'l'elephone Co.... 198

Hanover Nat. Bank v. Blake.. 171

172,701 
See.

Hanover Nat. Bank v. Howell. . 401

Hansell v. Erickson........ 474

Hanser v. Sane.......... 460

Hanson v. Armitage ....... 1.i2

Hanson v. Marsh. . . . . . . . 139

Harbele v. O'Day ......... 121

Hapgood v. Houghton ...... 485

Hapgood v. Shaw ....... 4 4 4

Harbison v. Knoxville Iron Co. 2

Harboard v. Cooper ....... 518

Hardeman v. Donovan ...... 558

Harding v. Am. Glucose Co.... 323

Harding v. Cowing ......278, 529

Hardman v, Booth ........ 457

Hardy v. Bank ......... 428

Hardy Implement Co. v. Iron

Works .............. 519

Hargrave v. Adcock ......... 90

Hargraves v. Cooke ......... 93

Hargreaves v. Parsons.... 124, 129

Harland v. Lilienthal ....... 199

Harmer v. Cornelius ........6 618

Harmer v. Killing ........ 52

Harmon v. Reeve....138, 139, 141

Harmony v. Bingham ....... 665

Harner v. Dipple .......26, 27

Harp v. Osgood . ......... 129

Harper v. Ely ........... 224

Harper v. Fairley .........634

Harralson v. Barrett ..... 452

Harrell v. De Normandie..... 571

Harriman v. Harriman ...... 379

Harrington v. Crawford ..... 286

Harrington v. Dock Co....204, 274

Harrington v. Iron Works.... . $475,589,591$

Harrington v. Railroad Co.... 134

Harrington $r$ Rich......... 120

Harris v. Bradley ......513, 514

Harris v. Currier .........4460

Harris v. Frank .......114, 125

Harris v. Harper ......... 80

Harris v. Harris ......... 400

Harris v. Huntbach ........ 96

Harris v. Lee ........48, 469
Sec.

Ilarris v. McCormick ....... 362

Harris $v$. NcGoverns ....... 629

IIarris v. Roberts . . . . . . . 302

Harris v. Roof . . . . . . . . 284

Harris $v$. Ross .........58, 68

Harris v. Rumels.173, 175, 178, 199

Harris v. Sharpless . . . . . . 639

Harris v. Telegraph Co...... 297

Harris $\mathrm{v}$. Trickett ........ 664

Harris $\mathrm{v}$. Trall .......... 65

Harris v. White .......262, 265

Harris v. Wicks ........... 210

Harrisburg Lumber Co. v.

Washburn ............664 68

Harrison v. Bank ......... 508

Harrison v. Burnes .......... 62

Harrison v. Close .......... 379

Harrison v. Colton ......... 192

Harrison v. Fane ......... 41

Harrison v. Gibson ......... 626

Harrison v. Harrison ........ 103

Harrison v. Hicks ... . . . . . . . 430

Harrison v. Maynard ........ 339

Harrison v. Railroad Co...... 573

Harrison v. Sawtel ......123, 129

Harrison v. State ......... 200

Harrison v. Sterry .....406, 407

Harrison v. Willis ........ 530

Harrison Mach. IVorks v. Co-

quillard ............. 502

Harrod v. Myers......... 57

Harsfield v. Converse ...... 612

Harsinger v. Newman ....... 128

Hart v. Aldridge.......... 344

Hart v. Bush ........... 152

Hart v. Gregg ........... 520

Hart v. Hart .......... 614

Hart v. Kip ............ 632

Hart v. Machine Co........ 398

Hart v. Maney ..........443

Hart $r$. Prater ............ 41

Hart $v$. Raifroad Co........ 538

Hart $v$. Saftley .......... 152

Hart r. Telegraph Co....... 297

Hartford Fire Ins. Co v. Rail- 
Sec.

Sec.

road Co............ 332

Hartley v. Cummings ...... 317

Hartley v. Tapley ........ 515

Hartley v. Varmer ......122, 125

Hartley v. Wharton ....... 65

Hartman v. Ins. Co. ........ 16

Hartman v. Meighan .......666 666

Hartness v. Thompson...666, 387

Hartranft v. Ohlinger ...... 209

Harvey v. Briggs .......64, 68

Harvey v. Coffin .......... 660

Harvey v. Gibbons ......... 568

Harvey v. Hunt . . . . . 171, 701

Harvey v. Locomotive Works. 402

Harvey v. Merrill... 246, 249, 251

Harvester Co. v. Meinhardt. 344

Harwood v. Roberts . . . . . . . 368

Hasking v. Royston .....341, 342

Haskinson v. Eliot ....... 371

Haslack v. Mayers . . . . . . . 599

Hassard v. Rowe ........ 39

Hastings v. Dollarhide ...51, 66

Hastings v. Wiswall ....... 242

Hatch v. Douglas ..... 248, 252

Hatch v. Hatch ........... 52

Hatch v. Ins. Co......... 16

Hatch v. Oil Co............ I48

Hatcher v. Hall .......... 626

Hathaway v. Hagan ....... 206

Hathaway v. Moran .....179, 416

Hathaway v. The Brantford

City .............4 410

Hatsall v. Griffith ....... 377

Hattin v. Chase .. 650, 651, 652 $653,655,664$

Hatzfield v. Gulden ......284, 287

Haugh v. Blythe .......... 134

Haven v. Railroad Co...... 509

Havens v. Lathene ........ 584

Hawes v. Railroad Co....63, 64

Hawker v. Moore .......390, 392

Hawkes v. Phillips ......... 128

Hawkes v. Saunders ....... 485

Hawkins v. Asssociation .... 219

Hawkins v. Ball ........ 590

Hawkins v. Barney ........ 559

Hawley v. Beverley ........ 431

Hawley v. Bibb ........395, 408

Hawley v. Bristol ......515, 519

Hawley v. Harran . . . . . . 427

Hawley v. Kountze ........ 214

Hawley v. Mroody ....... 102, 480

Haworth v. Huling ........ 225

Haworth v. Montgomery .... 200

Hawralty v. Warren ........ 669

Hax v. Acme, etc. Plaster Co... 515

Haxton v. Bishop ........ 506

Hay v. Miller .......... 6

Hayden v. IVeldon......... 128

Haydock v. Coope ........ 170

Hayes v. Jackson ........93, 94

Hayes v. McConnell ........460

Hayes v. Parker ......67, 70

Hayes v. Railroad Co.203, 301, 306

Haynes v. Church ........ 575

Haynes v. Rudd ........... 500

Hay's v. Turner ......... 585

Hayward v. Bank ........6 626

Hayward v. Leonard ........

$473,47 \overline{7}, 640,666$

Hazar v. Reclamation Dist... 529

Hazard v. Ins. Co......450, 571

Hazard v. Irwin . . . . . . . 635

Hazel v. Railroad Co....410, 421

Hazelton v. Week ........ 492

Hazen v. Bearden ......... 126

Head v. Goodwin ......... 138

Head v. Railroad Co........ 293

Head v. Tattersall ....... 613

Healey v. Scofield ........ 430

Healy v. United States . . . . . 452

Heard v. James . . . . . . . . 492

Heard v. State ......... 188

llearn v. Cullin ........340, 430

Hearst v. Hite ......... 458

Heath v. Flannery ........ 653

Heatlı v. Heath .......... 134

Heaver v. Lanahan ........ 608

Heavilon v. Kramer ........ 687

Hecht v. Caughron ........ 352 


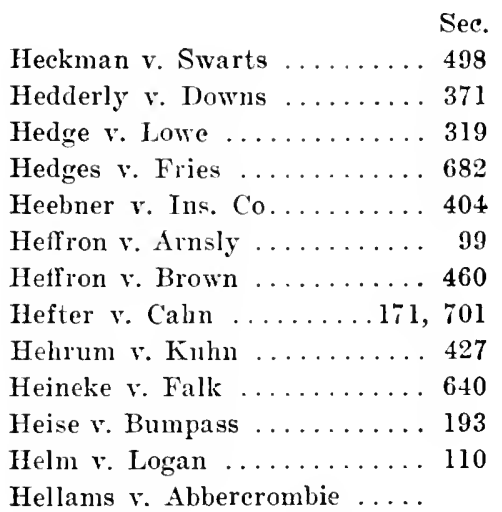
$180,184,187$

Heller v. Board of Trade ... . 383

Hellis v. Chapman ........ 474

Helpenstine $v$. Meredítl ..... 562

Henderson v. Beard ........ 99

Henderson v. Cummings .... . 352

Henderson v. Hammond ..... 368

Henderson v. Hicks . . . . . . 597

Henderson v. McDuffee ...... 391

Henderson v. McGregor ..... 14

Henderson v. McPike ...... 278

Henderson v. New York ..... 547

Henderson v. State ....... 530

Henderson v. Stevenson ..... 293

Henderson Build. \& Loan Asso.

v. Johnson ........... 219

Hendrick v. Lindsay . . . 352, 363

Hendricks v. Goodrich ...446, 598

Hendricks v. Railroad Co.... 299

Hendrickson v. Godsey ..... 234,

Henlin v. Hall ........... 149

Hennersdorf v. State ....... 189

Hennessy v. Bacon ....... 703

Henning v. Miller ....... 481

Hennington v. Georgia ...182, 549

Hennington v. State ....... 181

Henry v. Dietrich ......... 384

Henry v. Fine ......., 21, 22

Henry v. McAllister ....... 236

Henry v. Root ....27, 52, 65, 66

Henry v. Sanson ......... 233

Henry v. Township ....... 377
Sec.

Ifenry v. Wells........... 102

Hensel v. Association ....... 219

Hentz v. Jewell .......... 256

Herdic v. Young . . . . . . . . 492

Herckoff, ete. Lum. Co. v. Olmstead .............. 528

Herman v. Hodges ......... 107

Herman v. Jeuchner........ 129

Hermann v. Curiel......... 111

Herreshoff v. Boutineau ..312, 314

Herrick v. Belknap ........ 646

Herrick v. Newell ........ 109

Herring v. Amwood ........ 696

Herriter v. Porter ........ 521

Hersh v. Railroad Co....... 325

Hervey v. Krost .......... 567

Hess v. Culver .......... 157

Hetfield v. Down ........ 122

Hewes v. Bailey . . . . . . 377

Hewes v. Jordan . . . . . . . . 148

Hewitt v. Berlin .......... 704

Hewitt v. Dement ........ 216

Hewlett v. Nutt ........ 530

Heywood v. Tillson ........ 343

Hibbard v. Telegraph Co..... 297

Hibernia Nat. Bank v. Lacombe 419

Hibbert v. Aylatt ......... 105

Hibblewhite v. Mc.Morine ... 255

Hickam v. Hickam ....... 627

Hickman v. Eggman ....... 449

Hickman v. Haynes . . . . . 648

Hickman v. Pinkney ....... 640

Hickman v. Shimp .......6 613

Hicks v. Chapman ......12, 73

Hicks v. Cram .......... 368

Hicks v. Ins. Co. . . . . . . 404

Higgins $v$. Brown . . . . . . 499

Higgins $v$. Dewey . . . . . . . 583

Higgins $v$. Hallock . . . . . . 125

Higgins $v$. Murray . . . . . . 146

IIiggins $v$. Pitt . . . . . . 172

Higgins v. Senior ........ 90

Higgins $v$. Scott . . . . . . . 629

Higham v. Harris . . . . . . 598

Highley v. Bank ......... 232 
sec.

Hight v. Ripley ......... 139

Hightower v. Slayton ...... 517

Hill v. Anderson ........... 61

Hill v. Bank ........... 397

Hill v. Canfield .......... 492

Hill r. Davis . . . . . . . . 489

Hill v. Day ........... 7

Hill v. Dunham ........... 185

Hill v. Gomme .......... 277

Hill v. Jolnnson ............ 254

Hill v. Manuf. Co......... 681

Hill v. Meeker ........... 222

Hill v. Mortg. Co.......... 240

Hill v. Nelms ............ 56

Hill v. Paul ..........283, 517

Hill v. Spear......258, 295, $40 \mathrm{~s}$

409,447

Hill v. Swinney .......... 201

Hill v. Taylor ........... 237

Hill v. Umberger .........6 626

Hillary v. Walter ......... 624

Hillebert v. Porter ....... 562

Hiller v. Ellis .......... 217

Hills v. Elliott .......... 79

Hills v. Snell ..... $340,457,478$

Hillson v. Browne ......... 199

Hillyard v. Crabtree .......474

Hillyer v. Bennett......... 71

Hilton v. Eckerly......321, 341

Hilton v. Houghton ...... 185, 193

Hime v. KTasey ......... 595

Hinchman v. Lincoln . . . . . . 144

Hinckley v. Fowler .....363, 479

Hind v. Holship ......... 125

Hindmarek v. Hoffman ...... 502

Hindrey v. Williams ....... 575

Hinds v. Marmolejo . . . . . . 232

Hinney v. Baldwin ....... 402

Hinsdale v. Humphrey ..... 353

Hinson v. Lott............ 551

Hippes v. Griffin ......... 90

Hissam v. Pastish.667, 668, 669), 670

Hissong v. Railroad Co..... 299

Hitchenck v. Coker.......311, 316

Hitcheock v. Galveston ..... 459

Hitcheock v. Giddings ...... 571

Hoadley v. MeLaine ........ 648

Hoadley v. Transportation Co.

...............28 28, 509

Hoboken v. Gear ......426, 530

Hockett v. State .......307, 538

Hochster v. De La Tour...... $594,604,607$

Hoddesdon Gas Co. v. Haselwood 98

Hodgdon v. Davis ......... 208

Hodge v. Sloan ........312, 318

Hodges $r$. Fries .......... 687

Hodges v. Kowing......... 98

Hodges v. Manuf. Co....... 134

Hodgson v. Temple ...... I77, 409

Hofflin v. Moss ........... 276

Hoffman v. Bughlett ....... 487

Hoffman v. Felt .......... 102

Hoffman v. Gallaher ........614

Hogan v. Eașterday ........ 114

Hogg v. Ruffner .......... 214

Holbrook v. Armstrong ..... 82

Holbrook v. Burt ......... 593

Holbrook v. Clapp ........ 443

Holcomb v. Weaver ........451

Holcroft v. Barber ........ 622

Holden v. Alton ........301, 317.

Holden v. Brooks .......... 205

Holden v. Hardy .......2, 4, 544

Holden v. Upton .......... 175

Holden Steam Mill Co. v. Wes-

tervelt. . ...........444

Holladay v. Holladay ...... 237

Holladay v. Kennard ....... 582

Holladay v. Patterson ... . . . 302

Holland v. Dickerson ....... 561

Holland v. Taylor ......... 269

Holland v. Wilson .........4 479

Hollenback v. Restine ...... 337

Holley v. Anness .........6 $67 \mathrm{l}$

Hollingsworth v. Detroit. .224, $24 \mathrm{l}$

Holman v. Johnson... . I61, 177

$275,331,414,447$

IIolman v. State ......... 270

Holme v. Guffy ......... 568 
Sere.

Holmes v. Bank .......... 212

Holmes v. Blagg ......... 63

Holmes v. Halde .......... 200

Holmes v. Hunt . . . . . . . . 260

Holmes $v$ Knights ........ 129

Holmes $v$. Oil Co.......... $35 \mathrm{I}$

Holmes v. Rice........26, 66

Holmes v. Williams ........ 212

Holmes $v$. Williamson ...... 434

Holshue v. Norgan ........ 199

Holt v. Clarencieux ........ 66

Holt v. Green ..........196, 198

Holt v. Holt .......... 470

Holt v. Knowlton ......... 395

Holt v. Thomas .......4449, 455

Holtzapffell v. Baker ...... 573

Holyoke Co. v. Lyman ....... 541

Homan v. Steele ........... 385

Homan v. Stewart .........667

Home Ben. Assso. v. Sargent. 19, 20

Homer v. Thwing ......69, 70

Honaker v. Board ......... 286

Hood v. League .......... 483

Hood v. Railroad Co.....290, 294

Hooker v. Vandewater. 305, 321, 330

Hooksett v. Railroad Co.... 537

Hooper v. Edwards.......... 188

Hooper v. Payne........... 66

Hooper v. Van Husen....... 518

Hoover v. Buck. ........... 107

Hope v. Association........ 330

Hope v. Hope . .......286, 677

Hopkins v. Butte.........456

Hopkins v. Logan......... 98

Hopkins v. Hinkley ....... 57 I

Hopkins v. O'Kane......... 248

Hopkins v. Stefan........ 192

Hopkins v. Stove Co....... 341

Hopkins v. United States.323, 324

Hopkinson v. Forster....... 526

Horacek v. Keebler......... 184

Horkan v. Nesbit.......... 228

Hormby v. Clark.......... 334

Horn v. Bank........... 567

Horn v. Ins. Co.......... 16
Sec.

Horn v. Luddington........ 104

Horn v. Railroad Co....... 427

Horner v. Frazier........ 133, 137

Horner v. Graves. . . . . . . . . 313

Horner v. Webster.......... 460

Hornthal v. Burwell........ 402

Horstmeyer v. Conners.....30, 41

Horton v. Bauer.........6683

Horton v. MeCarty......87, 97

Horton v. Thurber......... 228

Horton v. Tramway Co...... 191

Hosack v. Rogers......... 376

Hosford v. Kanouse........ 357

Hosford v. Niehols.......... 243

Hosler v. Beard........... 14

Hosmer v. Railroad Co...... 295

Hosmer v. Wilson......609, 610

Hostetter v. Hallinger....... 357

Hotel Co. v. IVade........... 239

Houghtaling $v$ Ball........ 138

Houlton v. Dunn.......... 284

Houston v. Frazier........491

Houlton v. Manteuffel....5I, 55

Houlton v. Nichol.......... 284

House' v. Alexander....4 41, 43, 44

House v. Water Works...... 349

Houseman v. Water Co...... 366

Houser v. Lamont. . . . . . . . 113

Houser v. MeGinnas....431, 432

Houston v. Darling........ 375

Houston v. Merrifield....... 267

Houston, ete. R. R. Co. v. Harm 582

Houston, ete. R. R. Co. v.

Hill . . ...........697

Houston, ete. R. R. Co. v.

Snelling . ..........6.640

Houston R. R. Co. v. Mallory. . 689

IIovey v. Chase........6, 9

llovey v. Hobson. . 9, 21, 22, 23, 24

Hovey v. Pitcher....639, 640, 655

How v. Loring. . . . . . . . 124

Ifoward v. Benton........ 345

Howard v. Borden.......... 147

I [oward v. Bugbee. $555,562,565,566$

Howard v. Castle........ 166 


\begin{tabular}{|c|c|}
\hline $\begin{array}{r}\text { Sec. } \\
\text { Howard v. Daly....602, 604, 606, } \\
607,686\end{array}$ & 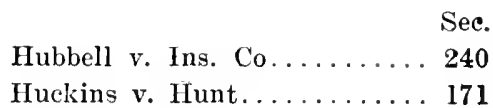 \\
\hline Howard v. Gobel.......... 483 & Hudson v. Geary.......... \\
\hline Howard v. Hunt. . . . . . . . 597 & Hudson Coal Co. v. Coal Co... \\
\hline Howard v. Manuf. Co....... 697 & Huegin v. Wisconsin....... \\
\hline Howard v. Roberts.......... 386 & Huff v. Nickerson.......... \\
\hline Howard v. Simpkins........ 41 & Huffman v. Houghlett....... \\
\hline Howard v. Stilliwell Co..... 297 & Huffman v. Starks.......... \\
\hline Howden v. Haigh....171, 172, 701 & Hughes $v$. Dougherty........ \\
\hline Howden v. Simpson........ 286 & Hughes v. Edwards......... \\
\hline Howe v. Clancey.......... 488 & Hughes v. Fisher.......... \\
\hline Howe v. Conduitt. ........ 594 & Hughes v. Fru \\
\hline Howe v. Hayward.......... 153 & Hughes v. Gri \\
\hline Howe v. Howe.......... 21 & Hughes v. Kli \\
\hline Howe v. Smitlı......... 153 & Hughes v. Pen \\
\hline Howe Mach. Co. v. Bryson... 697 & Hughes v. Stanley......... \\
\hline Howe Machine Co. v. Gage.551, 552 & erecht v. State........ \\
\hline $\begin{array}{l}\text { Howe Sew. Mach. Co. v. Ros- } \\
\text { enteel } \ldots \ldots \ldots \ldots \ldots \ldots \ldots 59\end{array}$ & $\begin{array}{l}\text { ston v. } \mathrm{Na} \\
\text { enin v. Bos }\end{array}$ \\
\hline Howell v. Church.......... . 385 & ard v. Mo \\
\hline Howell v. Coupland. . . . . . . 659 & Huling v. Drexell. ........ 22 \\
\hline Howell v. Field.......... 125 & ing v. Huling........... \\
\hline Howell v. Fountain. . . . . . 284 & Hull v. Louth............ \\
\hline $\begin{array}{l}\text { Howell v. Knickerbocker Ins. } \\
\text { Co. } \ldots \ldots \ldots \ldots \ldots \ldots \ldots 570\end{array}$ & $\begin{array}{l}\text { Hull v. Railroad Co } \ldots \ldots \ldots .288 \\
\text { Hull v. Ruggles . . . 270, 271, } 409\end{array}$ \\
\hline Howell v. Showell. . . . . . . 97 & Hulse v. Machine Co........ \\
\hline Howell v. Taylor............ & Hulst v. Ássociation....... 666 \\
\hline Howes v. Wireworks Co..... 660 & Humber v. Brisbane....... 9 \\
\hline Howlett v. Haswelı........ 68 & Humble v. Hunter.....457, 519 \\
\hline Howsmon v. Water $0.348,349,352$ & Humble's Case.......... 107 \\
\hline Hoxie v. Lincoln. ......... 62 & Humphrey v. Clark........ 21 \\
\hline Hoyt v. Casey........... 45 & Humphrey v. Douglass....... 6 \\
\hline Hoyt v. Holly . . . . . . . . . 319 & Hundley v. Louisviחe, etc. R. \\
\hline Hoyt v. Pawtucket Inst. . . . 208 & 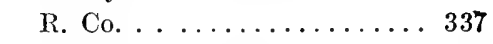 \\
\hline 226,228 & ford $\mathrm{v} . \mathrm{Mo}$ \\
\hline Hoyt v. Thompson...... & v. Hunkins......... \\
\hline Hubard v. Long. . . . . . . . . 158 & Hunnewell v. Duxbury...... \\
\hline oard v. Andrews........ 402 & Bridghan............ \\
\hline Hubbard $v$. Belden......475, 5s9 & Hunt v. Hecht............ \\
\hline nings...... 65 & Hunt v. Knickerbocker..... \\
\hline Hubbard v. Martin........ 452 & Hunt v. Lane............. \\
\hline Hubbard v. MeNaughton..... 170 & Hunt v. Rousmanier........ 45 \\
\hline Hubbard v. Miller......... & Hunt v. Silk........448, 59 \\
\hline Hubbard v. Railroad Co..... 293 & HunE v. Simonds.......... 34 \\
\hline Hubbell v. Flint. . . . . . . . 409 & IIunt v. Standart.......... \\
\hline
\end{tabular}


Sec.

Hunt v. Wier............ 25

Hunt v. Wyman..........613

Hunter v. Gardner........ 517

Hunter v. Giddings........ 359

Hunter v. Linn. . . . . . . . . 2229

Hunter v. Mills............ 105

Hunter v. Randall......... 158

Hunter v. Pfelffer...... 165, 324

Hunter v. Robertson........6 634

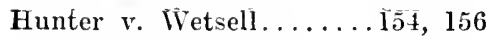

Huntington v. Knox......... 359

Huntington v. Railroad Co.... 603

Hunton v. Nichols......... 629

Hurley v. Brown.......... 92

Hurley v. Eddenfield....... 200

Hurley v. Lamoreaux. . . . . . 464

Hurson v. Gaum.......... 312

Hurry v. Mangles.......... 593

Hurt v. Ford............ 114

Husband v. Davis..... . . . . 382

Husband v. Husband....... 470

Huse Ice Co. v. Heinze...... 690

Hussey v. Horne-Payne...... 85

Hussey v. Jewett.......... 66

Hustis v. Pickands......196, 198

Hutchen v. Gibson......... 286

Hutchins v. Hewbard....... 276

Hutchins v. Webster. . . . . . . 664

Hutchinson v. Hutchinson.... 134

Hutchinson v. Weldin...... 275

Huth v. Carondelet, etc. Co... 56

Huttman v. Boulnois....... 622

Hutton v. Eyre...........431

Hutton v. Padgett......... 96

Huttley v. Simmons......335, 342

Hutzler v. Lord.......... 431

Hyatt v. Bank.....395, 398, 408

Hyatt v. Clark.......... 228

Hyde v. Goodnow.......... 399

Hyman v. Cain......... 49

Ide v. Stanton.........91, 141

Ihley v. Padgett......... 57

Iherd v. Beavens......667, 669

Illinois Cent. R. R. Co. v. Cobb 685

Illinois Cent. R. R. Co.

Ilinois Cent. R. R. Co. v. Read 295 Illinois Cent. R. R. Co. v. Har-

ris . . . . . . . . . . . 292

III. Cent. R. R. Co. v. Illinois. . 539

Illinois Land Co. v. Bonner.27, 66

Inchbald $v$. Coflee Co......6 688

Inchbald $v$. Western....... 609

Independence v. Ott....... 382

India Rubber Co. v. Koch.... 320

Indianapolis Chair Co. v. Wil$\operatorname{cox} \ldots \ldots \ldots \ldots \ldots \ldots .27$

Indianapolis, etc. R. R. Co. v. Ervin . . .......... 306

Indianapolis R. R. Co. v. Allen 288 Ingersoll v. Randall....... 197 Ingersoll v. Roe.......... 499

Ingles $v$. Usherwood........ 407

Ingraham v. Baldwin....9, 12, 25

Inhoff v. Witmer......... 12

In re Argus Co..........670

In re Baker............ 8

In re Breitung.......404, 405

In re Brooklyn.......534, 535

In re Considine.......... 544

In re Davison........... 36

In re Debs............ 336

In re Dugend........... 57

In re Eight-Hours Bîll....... 4

In re Eidenmuller.......... 57

In re Empress Eng. Co....... 360

In re Eyer............... 93

In re Frítz's Estate........ 520

In re Garcelon........274, 520

In re Gillespie........... 508

In re Gordner............6.627

In re Hearn........... 30

In re Hodson's Settlement...32, 52

In re Hong Wah.......... 1

In re House Bill........., 540

In re Hoyle........... 83

In re Hummel's Estate...... 118

In re Jacobs..........4, 271

In re Jager............. 198

In re Kessler's Estate...... 460

In re Keymer........... 198 
Sec.

Sec.

In re Kimball...........400

In re King............ 69

In re Macleay.......... 179

In re Maguire........... 544

In re Mechanics \& Farmers

Bank .............. 560

In re Molineux.......... 340

In re Morgan........... 4

In re Morrissey.......... 36

In re Negus............. 364

In re Penzansky.......... 57

In re Preston............. 2

In re Rahrer............ 554

In re Rogers............ 704

In re Rothehan, etc. Co...339, 360

In re Ryder............ 470

In re Saltykoff.......... 57

In re Schmidt's Estate......460

In re Snelling.......... 7

In re Stein............. 15

In re Ten-Hour Law........ 4

In re West............. 516

In re Worthington......... 283

In re Wyatt........... 508

Insurance Co. v. Bullene.... 521

Ins. Co. v. Colt........... 80

Insurance Co. v. Hull. . . . . . . 330

Insurance Co. v. Rodel....... 19

Insurance Co. v. Water Co. . . 348

349,350

International vuild. \& Loan Asso. v. Abbott.......... 219

International R. R. Co. y. Dawson ............... 302

International, etc. Railroad Co. v. Hinzie . . . . . . . ... 288

International Text Book Co. v. Weissinger . . ........ 515

Inter-Ocean Publishing Co. v. Associated Press ....... 322

Interstate Commerce Commission v. Baird.......... 326

Iowa City v. Johnson County. 452

Iron Works v. Warner...... 402

Iverson v. Shorter........ 561

Irvine v. Hanlin. . . . . . . . 449

Irvine v. Irvine. .26, 27, 56, 57, 331

Irvine $v$. Stone.......... 139

Irwin v. Curie.......... 176

Irwin v. Williar. .245, 249, 259, 305

Isaacs v. Davis........602, 605

Isaacs v. Hermann. . . . . . . . 464

Isle Royal Mine Co. v. Herlon. 492

Isler $r$ Baker.......... 15

Irenson v. Caldwell........ 128

Ivey v. Lelland........415, 420

Izard v. Izard.......... 466

Jabriskie v. Railroad Co..... 384

Jacobia v. Terry......... 74

Jacobs v. Credit-Lyonnais.... 420

Jacobs v. Pollard.......394, 438

Jacobson v. Le Grange....... 465

Jacobus v. Railroad Co....288, 295

Jackisch v. Hardtke....... 430

Jackson v. Benson........ 79

Jackson v. Burchin......57, 66

Jackson v. Covert......... 139

Jackson v. Fassitt........ 212

Jackson v. Green......... 403

Jackson v. Gumear........ 9

Jackson v. Hough.......... 445

Jackson Iron Co. v. Concentra-

tion Co. . ............ 354

Jackson v. Jackson. . . . . . . . 400

Jackson v. Lever. . . . . . . . . 672

Jackson v. May........228, 235

Jackson v. Morris........ 215

Jackson v. Mortg. Co........ 417

Jackson v. Murray..... 388, 434

Jackson v. Myers.......... 107

Jackson v. Seelye.......... 79

Jackson v. Stanfield.....113, 341

Jackson v. Stockbridge..... 351

Jackson v. Travis...208, 212, 230

Jackson v. Tupper......... 154

Jackson v. Walsh......... 541

Jacksonville, etc. Railway v.

Hooper . . . . . . 568, 569, 575 
Sec. Jacksonville, etc. R. R. Co. v.

Manuf Co. ...........6 691

Jacques v. Sax.........27, 69

Jacqninet v. Boutron....... 577

Jaffray v. King...........6 618

James v. Morgan . . . . . . . . . 568

James v. Muir............. 141

James v. Newton....521, 522, 523

524,526

James v. Shorter.......... 123

James v. State............. 264

Jameson v, Dimock......... 105

Jamison v. Wallace........ 254

Janin v. Brown........... 590

Jannin v. State........... 173

Jaques v. Golightly........ 176

Jaques v. Marquand........ 504

Jarboe v. Telegraph Co..... 297

Jared v. Vanvleet.......... 457

Jarrett v. Cope........... 220

Jefferson v. Asch......... 354

Jefferson Branch Bank v.

Shelly ............. 534

Jefferson v. Slagle.......... 132

Jefford v. Ringgold........ 66

Jeffrey v. Bigelow........ 655

Jeffreys v. Gurr.......... 435

Jelks v. Barrett........... 87

Jell v. Donglass........... 371

Jellett v. Rhode.......... 135

Jemison v. McDaniel...573, 580

Jemness v. School Dist.......201

Jenesen v. Jenesen......... 7

Jenkins v. Fowler.......... 345

Jenkins v. Frink.......165, 169

Jenkins v. Hogg. .......... 168

Jenkins v. Jenkins.......13, 61

Jenkins v, Lewis.... . . . . . 234

Jenkins v. Locke..........678

Jenkins v. Long . . . . . . . . . . . 623

Jenkins v. Sehool Dist....... 432

Jenkins v. Tucker......435, 485

Jenks v. School Dist....... 386

Jenness $\vee$. Wendell . . . . . . . . 143

Jennings v. Broughton...... 600
Sec.

Jennings $v$. Camp......... 666

Jennings v. Lyons. . . . . . . . . 589

Jennings v. Newman........ 485

Jennings v. Rundall......69, 70

Jermyn v. Molhtt.....515, 518

Jerome v. Bigelow.......... 163

Jerret v. Bartlett.......... 301

Jesserich v. Walrutl........484

Jeter v. Fellows........... 402

Jewett Pub. Co. v. Butler.... 164

Jewett v. Railroad Co....... 302

Jex v. Mayor............ 456

Jock v. Mckee............ 110

John Hancock L. Ins. Co. v.

Moore .............. 19

Johns v. Bailey............ 193

Johns v. State............ 181

Johnson v. Brook. . . . . . .84, 674

Johnson v. Brown.......... 181

Johnson v. Buek.......... 85

Johnson v. Church........ 83

Johnson v. Cuttle.......... 151

Johnson v. De Peyster...... 640

Johnson v. Dodgson....... 83

Johnson v. Foster......... 363

Johnson v. Gawtry.........4401

Johnson v. Harvey.........444

Johnson v. Hodgson........ 196

Johnson v. Hubbell.....465, 466,

467,667

Johnson v. Hudson......... 177

Jolinson v. Hulings..177, 196, 198

Johnson v. Hunt.......... 275

Johnson v. Ins. Co...63, 70, 348

404,488

Johnson v. Jennings. . . . . . . 448

Jolinson v. Johnson........ 448

Johnson v. Kaune.......... 249

Johnson v. Krassin........4480

Johnson v. Lines.......41, 67

Johnson v. MeGregor........ 261

Johnson v. Pace.......515, 517

Johnson v. Packet Co...430,431

Johnson v. P'eople.......... 188

Johnson v. Pie.......... 70 
Sec.

Johnson v. Railroad Co..288, 299 300,325

Johnson v. Rockwell......... 66

Johnson v. Russell......... 246

Johnson v. Stark County..... 224

Johnson v. Steffen.........673

Johnson v. Stone.......... 9

Johnson v. Terry.......... 277

Johnson v. Torpy.......394, 437

Johnson v. University...... 644

Johnson v. Wadsworth....94, 95

Johnson v. Watson......82, 137

Johnson v. Welch......... 359

Johnson v. Willis.......... 195

Johnston v. Browne.......5 514

Johnston v. Jones......... 84

Johnston v. McConnell....178, 202

Johnston v. Mining Co...625, 626

Johnston v. Trask.......... 140

Johnstone v. Willing....... 594

Jolly v. Walker.......... 121

Jones v. Ashburnham....... 119

Jones v. Bacon.........96, 129

Jones v. Baird...........4 488

Jones v. Bank........151, 152

Jones v. Blocker.......341, 342

Jones v. Call. ........... 697

Jones v. Caswell........... 167

Jones v. Dow...........89, 98

Jones v. Evans............ 21

Jonas v. Fields........... 114

Jones v. Fulcord......... 165

Jones v. Hoar...461, 486, 487, 488

Jones v. Jones. . . . . . . . 605, 628

Jones v. Judd......475, 576, 589

659,660

Jones v. Martin.......466, 667

Jones v. Noy............ 15

Jones v. Orchard.......... 129

Jones v. Parker...........668

Jones v. Pouch........... 134

Jones v. Railroad Co........ 288

Jones v. Randall.......... 245

Jones v. Reynolds.......... 144

Jones v. Swith........196, 458
Sec.

Jones v. Stanley........... 341

Jones v. Taylor........... 402

Jones v. Thomas.......... 352

Jones v. Trust Co......... 396

Jones v. Tye.........91, 92

Jones v. United States...569, 586

Jones v. Wilson. . . . . .432, 457

Jones v. Yates............ 162

Jordan v. Coffield......43, 50

Jordan v. Dayton......... 200

Jordan v. Humphrey....... 228

Jordan v. Miller........... 134

Joseph v. Machine Co....... 483

Joseph v. Smith.......... 128

Joslin v. Car Spring Co..352, 353

Joslyn v. Parlin.......... 519

Joy v. St. Lonis. . . . . . 668, 676

Judah v. Mieure.......... 392

Judd v. Harrington . . . . . 320, 323

Judefind $v$. State......180, 181

Judge v. Stone........... 25

Judson v. Bessemer........ 278

Judson v. Corcoran......... 508

Judy v. Gilbert. . . . . . . . . 105

Julliard v. Greenman....278, 529

Justh v. Bank............ 504

Justice v. Elwert. . . . . . . . . 660

Justice v. Lange......... 98

Kahn v. Walton.......249, 257

Kamena v. Huelbig......... 508

Kanaga v. Taylor......... 402

Kanapolis Land Co. v. Morgan 647

Kane v. Bloodgood.........630

Kane v. Clough........... 515

Kansas City v. O'Connell. .349, 366 Kansas City, etc. R. R. Co. v.

Conlee ............ 133

Kansas City, etc. R. R. Co. v.

McCoy ............. 284

Kansas Pac. R. R. Co. v.

Peavey .............299

Karcher v. Green........27, 35

Kassie v. Congregation...... 518

Kates v. Woodson......... 9 
Siec.

Sec.

Katzmyer v. Ennis........ 125

Kenard v. Cass........... 509

Kauffman v. Cooper........ 352

Kendall v. Gaxnead....... 137

Kaufman v. Hamm. . 184, 185, 187

Kaum v. Kaltwasser....... 365

Keagy v. Tront.......... 208

Keane v. Boyeott.......... 66

Kearley v. Thomson........ 275

Kearney v. Taylor......... 169

Kearney Milling and Elevator

Co. v. Railroad Co....... 510

Kearson v. Pearson........573

Keat v. Allen.......... 275

Kendall v. Kendall........ 460

Kendall v. Lawrence.....27, 66

Kendall v. May........... 11

Kendriek v. Baker......... 53

Kendrick v. Niesz. . . . 26, 52, 65

Kendricky v. Jervis. . . . . . . 508

Kennard v. Whitson........ 465

Kennedy v. Brown......... 205

Kennedy v. Cochrane....... 173

Kennedy v. Eblen......... 99

Keeble v. Hickeringill....... 341

Keedy v. Long.........603, 618

Kennedy v. Green.......... 626

Kennedy v. Poor......... 645

Keeler v. Clifford.........653 Kennemore v. Kennemore.... 105

Keeler v. Herr...........699

Keenan v. Stimpson........ 402

Keene v. Sage........... 357

Keesling v. Frazier........ 129

Kegan v. Malone..........460

Keichen v. Lee........... 27

Keifer v. Summers......... 430

Keil v. Healey............. 9

Keiser v. State..........4 425

Keith v. Herschberg Co..... 317

Keith v. Optical Co........ 312

Keller v. Boatman......... 389

Keller v. Hewitt.........201

Keller v. Railroad Co........ 290

Kelley v. Lewis.......... 208

Kelley v. Sclrupp. . . . . . . . . . 132

Kelleyville Coal Co. v. Harrier 1

2, 341

Kellogg v. Clark......... 82

Kellogg v. Larkin......... 313

hellogg v. Miller..........4 417

Kelly v. Bradford......473,477

kelly v. Davis.......30, 47, 470

Kelly v. Solari........450,451

Kelsey v. Crother........6678

Kemble v. Kean.........677

Kemmitt v. Adamson........ 228

Kémp v. Fender........ 388, 434

Kemp $v$. Vigne.......... 266

Kempe v. Bader..........6 632

Kenner v. Bitely.........661

Kenney v. Queen..........642

Kenney v. Railroad Co..288, 295

Kemneway v. Trelevan....... 96

kent v. Kent........133, 134

Kenworth v. Stevens........6 610

Kenworthy v. Schofield...... 138

Kenyon v. Stewart........559

Kerchival v. Doty.......... 703

Kerkhof v. Atlas Paper Co... 154

Kern v. Kern........... 13

herr v. Benefit Asso...... 16

herr v. Lucas........... 454

Kerr v. Lunsford........ 7

hershaw v. Kershaw....... 520

Kerwin v. Ins. Co......... 25

Kestler v. Hereth.......... 629

Ketchum v. Catlı........ 5 il

Kettle v. Harvey,......... 666

Keyes v. Maynard......... 127

Key v. Davis.........23, 25

Keys v. Harwood......... 482

Keyser v. Rice.......... 258

lidd v. Pearson.....182, 326, 411

Kidder v. Hunt.......... 480

Kidder v. Vandersloot....... 227

Kidney v. Persons......446, 488

Kiehne v. Wessell......... 10

Kiene v. Shaetling......... 134

Kehlholz v. Woltf ......... 239 
Sec.

Kihlbery v. United States.642, 645

Kilbee v. Myrick.......... 25

Kilbourn v. Sunderland......6 626

Kilcrease v. Johnson........ 399

Kiley v. Telegraph Co....... 297

Kilgore v. Jordan....64, 67, 69

Kilgore v. Rich........43, 4૪

Killbride v. Moss......... 121

Kilner v. O'Brien.......... 234

Kimball v. Comstock........ 158

Kimball v. Cunningham...... 448

Kimball v. Morton.........674

Kimball v. Noyes........... 362

Kimball v. Railroad Co.....66 617

Kimball v. Vroman..........6 613

Kimberly v. Jennıngs....... 677

Kimble v. Cummins......... 434

Kincaid v. Hocker.......388, 436

Kincaid v. Kincaid.....5 1, 103

Kine v. Turner.......... 321

King v. Birdbrooke........ 619

King v. Brown... 108, 110, 479, 480

King v. Bushnell.......80, 113

King v. Cummings........ 7

King v. Doolittle........ 571

King v. Fleming.......... 185

King v. Hoar.........368, 370

King v. Inhabitants........ 619

King v. King........... 474

King v. Missouri......... 555

King v. Steiren.......602, 605

King v. Summit.......... 96

King v. Toney...........6 619

King v. Welcome.........480

King v. Whitnash........ 180

King v. Woodbridge........ 684

Kinghorne v. 'Telegraph Co.. 297

Kingman v. Perkins......68, 508

Kingsbury v. Burrill....... 524

Kingsbury v. Earle........ 365

Kingsbury v. Kirwan.245, 249, 255

Kingsbury v. Powers....... 72

Kingsley v. Balcome........ 123

Kingston Bank v. Ettinger.. 450

Kinney v. Com........... 400
Sec.

Kinney v. MeDermott....... 195

Kinney v. Railroad Co...... 288

295,300

Kinsman v. Parkhurst...... 328

Kinyon v. Kinyon........ 5:0

Kinyon v. Young.......... 104

Kirby v. Johnson.......... 149

Kirck v. Merry...........281

Kirkland v. Lowe.........406

Kirkham v. Morter........ 122

Kirkland v. Randen........ 246

Kirkpatrick v. Bonsall..... 249

254,255

Kirkpatrick v. Smitn...... 237

Kiser v. Halladay.......... 483

Kitchen v. Lee............ 60

Kitzinger v. Sanborn....569, 573

Klapp v. Kleckner......... 386

Kleckley v. Leyden.....175, 178

Klinck v. Price........243, 408

Knapp v. Hyde.......... 499

Kneitle v. Newcomb........ 276

Knevals v. Blauvelt......... 518

Knickerbocker Ins. Co. v.

Peters ............18, 20

Knight v. Bean........ 589

Knight v. Hunt.......171, 701

Knight v. Knight........6627

Knight v. Mann......... 148

Knight v. McKinney........624

Knight v. Packer.......... 170

Knight v. Railroad Co...290, 294

Knights v. Naeru......... 269

Knights Templar Indem. Co.

v. Berry ............ 404

Knights Templars Asso. v.

Greene . . ............4404

Knorr v. Bates........... 368

Knott v. Railroad Co....... 332

Knowlman v. Bluett........ 134

Kinowlton v. Cooley........ 52l

Knowlton v. Dorety........ 205

Knowlton v. Moore........ 395

Knox v. Flack............ 28

Knox v. Haug.......... 12 
See.

Knoxville Iron Co. v. Harbison. ¿ lamb v. Harris........... 600

Koch v. Williams......110,480

Lamb $v$. Nice........... 360

Koehler v. Buht.........6.614

Kohn v. The Renaisance..... 415

Koontz v. Bank.......... 450

Lamb r. Tucker........128, 353

Lambert v. Heath......... 448

Lamborn v. Commissioners.... 449

Liansburg v. Dist. Col...... 270

Koontz v. Franklin ........5 530

Koplitz v. Gustavus........ 111

Korn v. Browne........... 528

Kountz v. Price.......... 192

Kozel v. Dearlove.......... 99

Kramer v. Irwin.........669

Krebs v. Rosenstein........ 336

Kreger v. Leppel.......474,484

Kreith v. Myer........... 91

Kribben v. Hayeraft....... 287

Krohn v. Bantz........... 98

Krohn v. Williamson......6 674

Krutz v. Stewart........ 122

Kuhns v. Gates........156, 192

Kuhn's Estate........... 520

Kullman v. Greenbaum...... 171

172,701

Kullman v. Simmes........ 252

Kupfert v. Association.......220

Kurner v. O'Neil.......... 398

Ky. L. \& C. Ins. Co. v. Hamil-

ton ..................... 266

Lachman v. Block. ......... 395

Lacy v. Kinaston......... 376

Lacy v. Osbaldiston........618

Lacy v. Pixler....56, 59, 69, 70

Ladd v. Rogers........... 192

La Dow v. Bank........... 232

La Fayette M. Corpo. v. Magoon 385

Laflin v. Howe............ 448

Laidlou v. Hatch......... 122

Laird v. Campbell......... 701

Laird v. Hodges.......... 419

Lake v. Tyson........... 429

Lakeman v. Pollard.....475, 591

Lamar v. Micou........240,.420

La Mar v. Weidman......... 198

Lamb v. Bralaski......... 474

Lamb v. Crafts........139, 146

Lamoile County Nat. Bank v.

Bingham ........... 237

Lamore $v$. Frisbie....... 194, 195

Lampert v. Gas Light Co. . . . . 351

Lampson v. Hobart........ 121

Lanahan v. Heaver.........696

Laneaster Bank v. Wood.... 12

Lancaster Co. Bank v. Moore. 22

Lance v. Pearee........122, 125

Land and Loan Co. v. Bonner. 26

Land Co. v. Pitt.......... 351

Landis v. Saxton .......... 228

Landworlen $v$. Wheeler ..... 383

Lane v. Crossman ........671

Lane v. Shackford ........ 137

Lang v. Railroad Co........ 616

Langdon v. Clayson ........ 56

Langdon v. People ......... 12

Langdon v. Richardson ..... 125

Lange $v$. Werk .......... 313

Langevin v. St. Paul....... 452

Langfort v. Tiler .......153, 156

Langforth v. Gentry ....... 629

Langhlin v. Harvey........ 278

Langworthy v. Little . . . . . 402

Lannan v. Smith .....515, 522

Lansden v. MeCarthy ...... 519

Lantry v. Parks .......... 474

Lanz v. MeLaughlin........ 102

Laphan v. Osborne ....... 479

Lapping v. Dutfy ........ 5:6

Lapsley v. Brashear ....... 561

Largerfelt $v$. Mchie ........ so

Larned v. Andrews ........ 177

Larsen $v$. Jensen ......... 126

Laroussini v. Werlein ......6671 
Sec.

La Rue v. Gilkyson ......11, 472

La Rue v. Groezinger ....... 518

Larson v. Chase ......... 485

Larzion v. Piochi ........ 521

Lash v. Parlin .......... 91

Lasher v. Gardner .......... 99

Latham v. De Loeselle ...... 419

Lathrop v. Knapp......335, 700

Latt v. Booth .......... 44

Laubenheimer v. Mann ...... 313

Langhran v. Smith ........ 111

Lavell v. Frost . . . . . . . 12t

Law v. Grant ........... 352

Law v. Hodgson ....178, 196, 205

Law $v$. Mills . . ......... 406

Lawing v. Rentles ......573, 587

Lawrence v. Bank ......... 450

Lawrence v. Clark ......171, 701

Lawrence v. Cook ......... 134

Lawrence v. Fox.339, 348, 353, 354

Lawrence $v$. Lawrence . . . . 107

Lawrence $v$. McArter ....... 28

Lawrence v. Railroad Co..... 290

Lawrence $v$. Robilıson ....... 15

Lawrence v. Taylor ....... 482

Lawrence $r$. United States ... 339

Lawrenson v. Butler ....... 669

Lawson v. Lawson .........445

Lawton v. Bleten.......... 249

Lawton v. Steele ......... 1

Lea v. Cassan ........... 330

Lea v. Hopkins . . . . . . . . 186

Leach v. Marsh ........ 471

Leacox v. Griffith .......57, 61

Leahy v. Dugdale ......... 519

Learn v. Upstill .......... 121

Lease v. Railroad Co...... 300

Leatherberry v. Odell .......618

Leather Cloth Co. v. Lorsont. . 309

314,318

Leather Co. v. Hieronimous. . 648

Leather Manuf. Co. v. Morgan. 428

Leavans v. Bank ......... 229

Leavitt v. Dover . . . . . . . 665

Leavitt v. Files ......... 22
Sec.

Leavitt v. Stern .......... 112

Ledbetter v. Walker ....... 99

Leddy v. Barney........... 375

Lee v. Abdy ........... 405

Lee $v$. Core............ 675

Lee v. Cherry .......... 83

Lee v. Griffin .......... 694

l.ee v. Hawks .......... 81

Lee $r$ Hills . .........91, 134

Lee v. Kirby ............672

Lee v. Lee .............. . 465

Lee $v$. Mahoney ......... 85

Lee $v$. Mekioy .......... 632

Lee $v$. Merritt . . . . . . . . . 446

Lee v. Sellens ........171, 701

L.ee County v. Abrahams .... 530

Leeds v. Little .....655, 666, 699

Leep v. Railroad Co.....1, 2, 541

Lee's Appeal ............ 467

Lees v. Whiteomb ........ 98

Leffingwell v. Warren ...... 533

Lefils v. Sugg .......... 41

Legat v. Clark .......... 12

Leligh Valley R. R. Co. v.

Woodring .....515, 517, 518

Lehman v. Field ......... 413

Lehman v. Schmidt ........464

Leicester v. Rose ......... 701

Leightmens v. Kadetska .... 193

Leisy v. Hardin . . . $411,548,552$

Leith v. llwin .......... 2:2

Leloup v. Mobile........ 552

Lemmon v. Beeman ......26, 64

Lemmon v. Box ........121, 125

Lemonius v. Mayer .....413, 416

Lento v. Clarke .......... 92

Leonard v. Leonara ........ 12

Leonard v. Patton ......... 229

Leonard v. Pool ........... 173

Leonard v. Stott.......... 41

Leonard v. Vredenberg ...125, 127

Leonard v. Williams ....... 222

Leonardson v. Hutin ...... 667

Leopold v. Salkey ........ 578

Le Peinteo v. Railroad Co... 684 


\begin{abstract}
Siec.
Lerch $v$, Gallup .........96, 1:99

Lerned r. Johns ........... s

Lemed v. Wammenacher ..... \$3

Leroux $r$, linwn. 100,101, 115, 118

Le Roy v. lieard . . . . . . . . 41 ?

Le Sage r. Coussmaker ...... 445

Leslie r. Lorillard. . . 303, 304,
\end{abstract}

$31 \pm, 318$

Lesserrich r. Pettit . . . . 12t, 125

Lessley v. Phipps.......... 560

Lester v. Buel ......249, 251, 254

Lester v. Heidt............ 9l

Lester v. Iloward ......... 17:

Lester $r$ Jewct .........

Lett $r$ Morris ............520

Levisee r. Railroad Co. . . . . . 402

Levistone v. Landreaux ..... . . .

Lery v. Herbert. . . . . . . . . 606

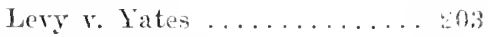

Leryeau v. Clements........ 340

Lewis $v$ Asbuckle ........ 8

Lewis v. Brehme .......... si

Lewis v. Bright .......... It,

Lewis $v$. Coal Co.......... 313

Lewis $v$. Hadley ... . . . . . 4 4.

Lewis $v$. Holmes .......... 694

L.ewis r. Land Co....... 348, 351

Lewis $v$. Lewis .......... 432

Lewis $v$. Littlefield ......... 69

Lewis v. Maddocks ......... 466

Lewis $r$. Railroad Co....642, 645

Lewis $v$. Reichey $\ldots . . . . .91$

Lewis $v$. Sawyer . . . . . . . 357

Lewis v. Weleh..176, 178, 197, 205

Lewis $v$. Wood ............ 88

Lewis Invest. Co. v. Boyd . . . . 222

Lhoneux v. Corporation ..... 404

Libbey $\vee$ Downey ......... Its

Libby v. Robinson ......... 446

Libhart v. Irood ......... 619

Lieense 'Tax Cases ......... 547

Liekbariow v. Mason ...... 510

Liddell $v$. Wiswall......... 391

Lidderdale v. Montrose ....... 283

Life Asso. v. Waller . . . . . . 19
Sees.

limhtlorly v. Smith ........ 515

Jigonier v. Aekrman ...... 458

Lilly r. llays ........... 360

Jilly v. Tobbein ......... 367

Lilly v. IIagoned .......12, 517

Lme Co. v. Giren ... . . . . . 35:

Lime Rock lank v. Plimpton. . 50 t

Lincoln v. Buckmaster...9, 2.2, 472

Lineoln v. Kinzey .......... 128

Lincoln v. Preserving (o..... 88

Linder v. Carpenter ....... 30.

Lindley $r$ Simpson ........ 130

Ijindsay v. 11 ill .......... 420

Lindsey v. Boone County...... $450^{\circ}$

Lindsey $v$. Lindsey ........ 7

Lindsley v. Railload Co...238, 6,17

Line $v$. Velson ........... 379

Liness v. Hesing ........27!, 280

Lingeman v. Shirk . . . . . . . 92

Linnenian v. Moross ....... 354

Lupp v. Hout ........... 105

Little v. Bowers ........... $\$ .56$

Little $v$. Dawson .......... 465

Little v. Dongherty ........ 85

Little v. Gibbs ........... 430

Little v. Poole ......... 19;, 205

little v. Portland ......521, 522

523,026

Little r. Thurston ......... 595

Littlefield v. Littletield ...... 634

Little Miama R. K. Co. v. Ste-

vens . . . . . . . . . . . 299

Littler v. Snively . . . . . . . . 627

Livermore v. Crane ........ 364

Liverpool v. Wright . . . . . s3, 517

Liverpool, ete. Asso. v. Fai:"

hurst . ............ 70

Liverpool Marine Crealit Co. $r$.

Hunter . ........... 258

Iiverpool Steam Co. v. Ins. Co. 240 $288,420,421$

Livingston v. Page........ 280

Livingstone $v$. Tremper . . . . 375

Lloyd r. Brewster .........660

Lloyd v. Giubert....... . 240, 420 
Sec.

Sec.

Lloyd v. Malone ......... 165

Lorillard v. Clyde ......354, 658

Lloyd v. Scott . . . . . . . . 233

Lorillard v. Palmer ........ 569

Lobdell v. Lobdell ......... 106

Loser v. Board .......... 283

Lobdell v. Mason .......... 99

Lound v. Grimwade......... 164

Locke v. Sinith . . . . . . . 49

Lockett v. Usiy ......... 560

Louisiana v. New Orleans ... 555

Louisiana v. Pilsbury ...... 533

Lockman v. Woorl ......... 67

Lockwood v. Barnes ....... 82

Lockwood v. Mitchell ....... 241

Lockwood v. Thorne . . . . 427, 429

Lockwood v. Wilson ....... 120

Lodge v. Dicas ........... 368

Loeb v. Peters ........... 510

Logan v. Gardner ......... 27

Logan v. Musie .......... 255

Logan v. Trayser ......... 434

Logan v. Wallis .......... 464

Logan v. Weinholt . . . . . . . 466

Log Cabin Permanent Build.

Asso. v. Gross .......... 238

Lohman v. State ......... 270

Lombard v. Gregory ........ 208

Lomen v. Crossman ......... 474

Lomerson v. Johnston ........ 499

London Guaranty and Accident

Co. v. Horn ........335, 337

Long v. Fox ........... 25

Long v. Girdwood ........ 406

Long v. Hartwell ......... 99

Long $v$. Miller ........... 85

Long v. Railroad Co.....330, 582

Long v. State ........... 271

Long v. Towl ............ 304

Longfellow v. Moore ....... 648

Longley v. Griggs . . . . . 390, 434

Longshore Printing Co, v. How-

ell .............334, 335

Loomis v. Ins. Co......... 266

Loomis v. Spencer ......... 14

Lord v. Dall ..............266

Lord v. Davis ........... 130

Lord v. Railroad Co........ 684

Lord v. Thomas ........578, 608

Lord v. Wheeler .......572, 575

Loren v. 1lillhouse .....639, 655

Louisville, ete. R. R. Co. v.

Barkhouse .......... 512

Louisville, etc. R. R. Co. v. Boudenschatz . ..6667, 668, 669 676,677

Louisville, etc. R. R. Co. v. Commonwealth . ........ 188

Louisville, etc. R. R. Co. v. Dies . . . . . . . . . . 288

Louisville, ete. R. R. Co. v. Faylor ............. 295

Louisville, ete. R. R. Co. v. Flanagan . .......... 325

Lonisville, etc. R. R. Co. v. Ofiutt . ........... 134

Louisville, etc. R. R. Co. v. Orr 299 Louisville, etc. R. R. Co. v. Philyaw . ........... 102 Louisville, ete. R. R. Co. v.

Sumner . ........302, 689 Louisville Gas Co. v. Citizens

Gas Co.................303 Love v. Harvey ........245, 246 Love $v$. Welch .........98, 704 Love $v$. Wells .......... 183

Lovelock v. Franklyn ......607

Lovejoy v. Howe ......... 352

Lovejoy v. Whipple .....185, 193

Lovridge v. Cooper......... 508

Low v. Prichard ......... 213

Low v. Rees Printing Co..... 4

Lowe v. Griflith ......... 44

Lowe $v$. Harris . . . . . . . . . 92

Lowell v. Railroad Co....... 394

Lowndes v. Anderson ...... 505

Lowery v. Cate .......... 68

Lowry v. Dillman ......249, 251

Lozear v. Shiclds ......... 7

Lubbock v. Tribe .......... 442 
Siec.

Lucas v. Gadwin ......473, 477

Lucas v. Harper .......... 246

Lucas v. Parsons .......... s

Luce $v$. Duitz............ 669

Lucke v. Clothing Cutters.... 336

341,342

Luckens v. Hazlett ... . . . . 234

Ludlow r. Tan liensselaer ... 415

Lufkin Rule Co. v. Fringeli. . 312

Lull v. Korf............. 645

Lully v. Morgan ............ 257

Luni v. McEwen ... . . . . . . . 974

Luman v. Hitchens ........ 1

Lumley v. Gre .....334, 341, 342

Lumley v. Ravenscroft. . .665, 669

Lumley v. Wagner .........6677

Iundy $v$. Railroad Co........ 294

Iyle v. Shinnebarger ...... 450

Lyman v. Raihroad Co...... 537

Lyman v. Townshend ....... 274

Lynch $v . \operatorname{Bog} y \ldots \ldots \ldots \ldots \ldots .457$

Lynch v. Doran .......... 7

Lynch v. Lumber Co. . . . . . 699

Lynchberg Nat. Bank v. Scott. 212

Lynd v. MeGregor ......... 64

Lynde v. Lynde .......... 274

Lyng v. Michigan .........552

Lynn v. Railroad Co........646

Lyon v. Annable .......... 440

Lyon v. Culbertson . .245, 249, 255

Lyon v. King ............. 134

Lyon v. Mitchell .......... 286

Lyon v. Strong . . . . . . . . . 183

Lyons v. Hodgen ......... 257

Lyons v. Wikins . . .334, 335, 336

Lythgoe v. Vernon ......... $\$ 87$

Lytle v. Bowden .......... 443

Macaluley v. Turney ........336

MacGreal r. Taylor ......28, 69

Mackay v. Telegraph Co..... 297

Mackey v. Smith .......... 125

Mackler v. Tiailroad Co...... 64:2

Maclary r. Turner ........ I 45

Macombier v. Dane ........ 283
Maddison v. Alilevon .... 101, 104

108,138

Madklox v. Rowe .........667

Maddox $v$. Simmon ........ 7

Naeder v. Norton ........6.6?6

Magee v. Billingsly ......... 150

Magee $v$. Welsh .......... 46

Magoflin $v$. Muhllow ....... 488

Magoun v. Bank ......... 19s

Magnon v. Clay .......... 124

Maguire r. Dinsmore ....... 295

Mahoney v. Evans ......... 41

Mahood v. Teazle ......... 274

Mahoon v. Greenfield ... .4487, 488

Maio $v$. Tea Co...........667 67

Makall v. Ratehford ....... 336

Makin v. Watkinson ........ 659

Malbon v. Birney ..........655

Malcom v. Fullerton ...... 427

Male v. Roberts .......... 401

Mallalieu v. Hodgson .......7 701

Mallen r. May ........316, 701

Mallen $r$. Wenham ......515, 516

Mallory v. Gillett. 123, 127, 128, 129

Malone v. Ice Co....... 124, 484

Malone v. Railroald Co...... 293

Maloney $r$. Dewey ......... 12

Maloney v. Echart ........ 230

Maloney r. Nelson ......... 129

Mancy v. Hart .......... 483

Mandel v. Butler .........6612

Manderille v. Harman ...... 319

Mandlebaum v. Gregorich ... 177

Mandon v. Ins. Co......... 404

Mandville v. Welch ........ 521

Mamhattan Life Insur. Co. v.

Broughton ........17, 19 Manistee Iron llork Co. v.

Lumber Co.............661

Manly r. Howlett ......... 106

Mann v. Betterley ......... 7

Mann v. Bhanchaid ........ 158

Manning v. Johnson .......27, 69

Mamning $v$ Pipper.........667

Mansfield $v$. Gordon ....... $66^{\circ}$ 


\begin{tabular}{|c|c|}
\hline \\
\hline Mansfield v. Lynch & 453 \\
\hline Tanstick v. Ranege. & 341 \\
\hline Manton v. Ray ........... & 675 \\
\hline Mantz v. Maguire .......... & 90 \\
\hline $\begin{array}{l}\text { Manufacturing Co. } \therefore \text { Ames } \\
\text { burg } \ldots \ldots \ldots \ldots \ldots \ldots \ldots\end{array}$ & \\
\hline Ianufacturer's Bank v. Barmes & 428 \\
\hline anufacturing Co. v. Barber.. & 383 \\
\hline
\end{tabular}

Longley . ............ 336

Marble Co. v. Ripley ....6657, 668 $672,677,678$

Marchand v. Association..... 463 Marey v. Marey .........2, 137

Marden v. Chimplin ....... 83

Marey v. Crawford . . . . . . 129

Marie v. Garrison .......... 169

Mariner v. Collius ......... 460

Marino v. Lahmaier ........ 203

Market Co. v. New Orleans... 573

Marlin Fire Arms Co. v. Shields 340

Marlow v. Pittsfield ...... 469

Marr v. Ray ........... III

Marserve v. Anderson ....... 270

Marsh v. Hyde...83, 139, 150, 151

Marsh v. McPherson ....609, 6Il

Marsh v. Railroat Co........ 302

Marsh v. Russell .......... 322

Marshall v. Lym ......... 81

Marshall v. Marsluall ......7, I78

Marshall v. Meech ........5 520

Marshall v. Quinn .......... 283

Marshall v. Railroad Co..2so, 2St

286,424

Marshall v. Rice ......... 218

Masterson v. Brooklyn ...... (6s8

Marston v. Bigelow ........ $3 t j l$

Marston v. Marston ....... 425

Martin v. Goldstein........ 180

Martin v. Hunt ......... 592

Martin v. Johnson ...396, 210, 241

Martin v. NeFall ......... 341

Martin v. Murphy ......312, 314

Martin v. Patterson ........ 105

Martin v. Peet .......339, 348
See.

Martin v. Potter ......... 508

Martin v. Quinn ..........4430

Martin v. Railroad Co...... 300

Martin v. Schoenberger .....666

Martin v. Stubbins ....... 267

Martin r. Thayer ........ 5

Martin v. Wilson .......395, 638

Martin v. Wright.........466

Martus v. llouck ......475, 640

Martyn v. Amold ......... 124

Marvin Safe Co. v. Norton.... 402

Maryland v. Railroad Co.... 529

Maslin v. Hiett ........375, 387

Mason v. Eldred .......... 370

Mason v. Hale ........... 557

Mason v. Hall .......... 352

Mason v. Lake . . . . . . . 399

Mason v. Loud . .......... 237

Mason v. Pierce ........... 238

Mason v. Prendergast ...... 502

Mason $v$. Thompson ........ 585

Mason v. Waite ......491, 495

Mason v. Wright...29, 44, 60, 468

Masonic Asso. v. Jones ...... 404

Masonic Mut. Ben. Soe. v. Burk-

hart . ............. 269

Massachusetts Gen. Hospital v.

Asso. Co.............. 541

Massachusetts Gen. Hospital v.

Fairbanks . ........... 11

Massey $r$. Wallace ........ 274

Massie v. Hiatt .......... 37

Mastin v. Halley ......... 668

Materue v. Horwitz ....... 163

Matherson v. Davis ....... 32

Mathews v. People ........ 341

Mathews v. Railroad Co..... 537

Matt v. Clark ........... 508

Matthews v. Associated Press. 312

Natthews $v$. Coe ......210, $₫ 28$

Matthews r. L'oytress ...... 512

Mathew's $v$. Seaver ........ 128

Matthews v. Wason......... 243

Matthieson v. McMahon...14, 472

Maurer v. Midway ........ 368 
Maurine v. Fogclbeyer ...... 126

Manser v. Davis ..........600

Maxfield v. Schwartz ...... 352

Maxfield $r$. West ......... 104

Maxim Nordenfelt Guns and

Ammunition Co. v. Nordenfelt 311

Maxton v. Green ........249, 255

Maxwell v. Gerard ........ 585

Maxwell $v$. Griswold ....... 452

Maxwell v. Railroad Co...... 288

Maxwell r. Swigart ....... 200

May v. Bank ........... 406

May v. Campbell .......... 212

May v. Flint . . . . . . . . 2.8

May v. Wanamacher ...... 406

May v. Williams........96, 1.99

Maybury v. Berkery ....... 429

Mayer v. Stone Cutters..... 336

Maynard v. Railroad Co..... 295

Mayo v. Assurance Soc...... 398

Mayor v. Bowman ........ 501

Mayor v. Colgate .......... 129

Mayor v. Hughes ......... 430

Mayor v. Lefferman .....449, 455

Mayor v. Linck ............ 181

Mayor v. New York ........450

MeAfferty v. Hall .........4 474

McAllester v. Haden ....... 262

McAllister v. Hotfman ..... 502

McAllister v. Smith ....... 418

McAllister v. Sprague ....... 379

McAndrew v. Telegrapli Co. . . 297

MeArthur $v$. Luce ......... $\$ 50$

McAuley v. Carter ........ $6 ! 3$

MeAuliff v. Parker .....62!), 63 I

MeBlain v. Cross .......... \$ 8

MeBratney v. Chandler ...... 284

MeBrazer v. Cohn ......... o7

MeCabe v. Blymyre ........ 402

Mc.Cabe v. Gray .......... 507

McCabe $v$. Raney .........6.6. 635

MleCagg v. Woodman ........ 506

MeCall v. California ....... 1:2

McCall v. Capehart........ 163

MeCall v. Hampton . . . . . . 5 520
Mc.Call v. Parker .......... 33

Mr.Candless v. Steel Co...274, 281

NeCarthy v. Nash ........ 145

McCarty v. Curter .......39, 46

MeCarty v. Murray ......... 66

McCarty v. Woodstock Iron Co. 57

MeCaull v. Graham ....... 677

McCawley v. Railroad Co..2ss, 2!5

MeCay r. Raitroad Co...... 806

MeClain v. Davis ......2l, 24

MeClary r. Railroad Co...... 483

MeClay v. Hedges .......... 474

MeClellan v. Bank ........ 377

MeClellan v. Sanford ..80, \$2, 134

McClintie v. Wise ........508

McClintock v. Laing ........ 107

McClure v. Briggs ........ $\mathbf{6 3 9}$

McClure v. Otrich ........ 114

McClure v. Raben ........ 520

McClure v. Railroad Co...... 302

MeCollough Iron Co. v. Carpenter .............6 619

MeConahey v. Grifly ........ 134

McConuel v. Delaware ...... 488

McConnell v. Brillhart ...... 88

MeConnell v. Kitchens ...175, 178

$196,198,202$

McCord v. Williams ........ 319

McCormick v. Danville ...... 612

MeCormick v. Littler ......10, 11

$12, \quad 22$

Michosh v. Crow .......... 340

MeCoy v. Hoffiman ......... 38

McCracken v. Hayward . . 528, 555

$565, \quad 566$

MeCracken v. San Francisco.. 3.2

450

MeCraith r. Bank ........ 1:3

MeCraney $v$ Alden ......... 234

McCrary v. Ruddick ........ 458

MeCrea v. Purmont ....... 98

NlcCrellis v. Burtlett .....11, 472

AleCullough v. Virginia . .560, 565

MeCurry v. Gibson ........ 200 
Sec. Sec.

McDaniel v. Parks ......602, 605

MeDònald v. Aufdengarter ... 234

McDonald v. Beer ......... 234

MeDonald $v$. Lyneh ........ 450

MeDonald v. Magruder . . .390, 434

MeDonald $v$ MeCallon ...... $6 i 7$

McDonald v. Morton ........ 12

MeDonald r. Railroad Co..643, 645

MeDonald v. Youngbluth .... 107

MrcDowell v. Laev ......352, 362

MeDuffee r. Railroad Co..306, 325

McEacherman v. Railroad Co. . 290

AcElmoyle $v$. Cohen ........638

MeElpatrick $v$. Hicks ....... 233

MIcElroy v. Buck ........85, 91

MeElroy $v$. Lewis ......... 15

McElroy v. Ludlum. . . . . . . 103, 134

MeElroy v. Seery .......88, 97

MeElroy ${ }^{\circ}$ Case .........

MeFarland v. Bank ........ 233

MeFadden v. Railroad Co..... $28 s$

McGahey v. Virginia ....... 528

MeGarry v. Nicklin ......240, 418

McGatrick v. Wasson ....... 188

McGavock v. Whitford ...... 72

MeGilvery v. Moorhead ...... 377

MeGinnis v. Commonwealth... 10

MeGinnis v. Fernandes ...... 112

MeGinnis v. Loring . . . . . . 388

McGovern v. Hern ........ 88

MeGovern v. Ins. Co....225, 2.26

McGowen v. West ........ 114

McGratîn v. Merwun ....... 18y

MlcGregor v. Balch ........ 368

MeGregor v. Garduer . . . . . . 022

McGregor v. MeGregor ...... 134

McGregor v. Railroad Co..... 497

McGuire v. Campbell ...... 206

MeHose r. Fulmer ........ 682

McIlquhan v. Taylor ....... 577

Mclntyre v. Parks ......398, 409

415,447

MeIntyre v. Yates ......... 229

Melianey v. Cooper ......26, 67

McKay v. Carrington ....... 596

Mckiay v. Railroad Co...... 293

Mckee v. Jones .......... 412

Mckee v. Judd ........... 518

Mckeegan v. O'Neil .......467

MeKenna v. Merry ....41, 43, 50

Mickenney v. Harvie ....... 480

McKemon v. McEwan....... 685

McKenzie v. Bank ......... 128

MeKenzie $v$. Harrell ........ 95

McKenzie v. Linen Co....... 428

MeKibben v. Ellingsen ...... 406

McKinnell v. Robiuson ......447

McKinnes v. Estes ......... 185

Mckinney v. Whiting ....... 158

MeKissick v. MeKissick ..... 416

MeLain v. Davis ......... 14

MeLane v. Creditors ....... 398

McLaren v. Clark ......... 231

McLaren v. McMartin ...... 634

MeLaughlin v. Austin ...... 127

MeLaughlin v. Piatt ....... 148

MeLendon v. Frost . . ..... 122

Mcleran v. Benton .......6631

McMaster v. Vermon ....... 370

Mc.lichael v. Carlyle ......6 628

Mc.Millan v. Mallay ....... 477

MeNillan v. Railroad Co..... 290

Mc.Millan v. Sprague ...... 560

McMinn v. Phipps ........ 165

Mc.Mullin v. Hoffman ...... 321

Mc.Jullen v. Rafferty .......634

McMullen v. Winfield, ete. Asso. 635

MeNeil v. Hill .......... 513

MeNichol v. U. S. ete. Asso.... 404

MeQueen v. Bank ........ 445

McQueen v. Fox .........485

MeTague v. Association ..... 596

MeWhinne v. Martin . . . . . 105

Meacham v. Dow ......... 279

Neacham v. Ins. Co.......18, 20

Mead v. Phoenix Ins. Co..... 63

Meaker v. Fiero ........... 216

Mechanic's Bank v. Levy ..... 502

Mechanics Build. Asso. v. Whitacre . ............6 632 
See.

Medbury v. Watrous .....38, 482

Mederas $v$. Hill .......569, 573

Medway v. Needham ....178, 400

Meech v. Lee ............ 49?

Meflin v. Milton .......... 133

Meguire v. Corwine .....279, 280

Mehlhop v. Rae ......... 60

Meincke v. Falk ......... 146

Melchert $v$. Telegraph Co.... 245

Melchoir v. McCarty ....192, 205

Melins v. Duncan ......... 449

Mellen v. Whipple ...353, 356, 359

Meller v. Goldsmith ....... 700

Mellet v. Bateman .......6 635

Mellon v. Dawson ......... 92

Melone v. Keener .......... 128

Melville v. DeVWolf ........660

Memphis v. United States .... 555

Memphis, etc. Railroad Co. v.

Neighbors . ........... 596

Memplis Nat. Bank v. Sneed.. 14

Menkins v. Lightner ...... 8

Mentone v. Athawes .......575

Mentz v. Newmiller ......83, 87

Mentzer v. Telegr. Co......693

Mercer v. Kelso ......... 7

Mercer County v. Hubbard .... 224

Merchants' Bank v. Rawls.445, 511

Merchants' Bank v. Spalding. . 398

415

Merchants' Desp. Co. v. Smith. .580

Merchants', etc. Bank v. Doshiell . ............660

Merchants', ete. Ins. Co. v. MeLain . .............. 599

Merchants' Fire Ins. Co v. Grant . ............ 65

Merchants' Nat. Bank v. Bank. 450

Meredith v. Crawford ...... 62

Meredith v. Meigh ........ 152

Meridian Water Co. v. Schulhorr . ............. 274

Meriwether v. Smith ....... $1: 2$

Meroney $v$. Association ...220, 419

Merriam v. Cumningham.41, 44, 47
Merriam v. Hassam See.

Nerriam v. Lumber Co..... 364

Merriam v. Stearns ..... 183, 192

Merrill v. Bell .......... 570

Merrill v. Downs ......... 193

Merrill v. Grem ......... 852

Merrill v. MeIntire ........ 177

Merriman v. Chapman ...... 612

Merriman v. MeNamus ..... 132

Merritt v. Earle .......187, 615

Merritt v. Gmaer ........ $\theta$

Merritt v. Ins. Co......... 20

Nerritt v. Robinson ....... 597

Merritt v. Wittich ........ 698

Merryweather v. Nixan... 394, 434 439

Mersey, etc. Co. v. Naylor ... 594

Mervine v. Sailer ......... 278

Merwin v. Austin ........ 506

Merwin v. Chicago ........ 517

Merz Capsule Co. v. Capsule

Co.......... 320, 323, 329

Messenger $v$. Railroad Co.... 306

Messmore v. Cunnington ..... 91

Messmore v. Lead Co....682, 685 696,698

Metcalf v. Kincaid .....515, 518

Metcalf $v$. Waterman ......6 638

Methven v. Heat \& Power Co.. 508

Metson $v$. Roath ........ 52

Mette v. Feltgen ........ 57

Meux v. Bell ........... 508

Mexican International Banking

Co. v. Lichtenstein ....272, 330

Meyer $v$. Estes .......312, 368

Meyer $v$ Graffin .......... 125

Mleyer v. Lowell ........... 352

Neyer v. Nuscatine ........ 208

Meyer v. Richards ........ 398

Meyer v. State .......... 244

Michael v. Albright ........ $39 \mathrm{l}$

Michaelis v. Wolf ....... ‘ 43

Michaels v. Railroad Co..... 583

Michigan Central R. R. Co. v.

Curtis . ........... 583 
Michigan Mut. Ben. Asso. v.
Rolfe . .............. 269
Michigan Mut. L. Ins. Co. v. Nangle ...........19, 20 Middleboro v. Rochester ..... 13

Middleburg College v. Chandler 43 Middletown Bank v. Jerome... 212 Mighell v. Dougherty ....... 146 Miles v. Alford Estate Co..82, 137 Miles v. Lingerman ........ 61

Miles v. McIlwaith ........ $\$ 28$

Miles v. Stevens ......... 571

Miles v. Thorn .......... 284

Milks v. Rich ......... 128

Millard v. Baldwin . . . . 3564, 363

Mill Dam Foundry r. Hovey . . .660

Miller v. Ammon .......173, 175

Miller v. Ball ........... 105

Miller v. Bledsoe ........ 521

Miller v. Campbell ........ 405

Miller v. Cook ............ 94

Miller v. Craig . . . . . . 7

Miller v. Eldredge ......l10, 479

Miller v. Fenton .......394, 437

Miller v. Gittings . . . . . . . . 258

Miller v. Goddard ......47t, 602

Miller v. Ins. Co.......200, 274

Miller v. Lorentz .......... 103

Miller v. Phillips ......477, 640

Miller v. Post ......175, 178, 197

Niller v. Race ........504, 512

Miller v. Railroad Co....224, 541

Miller v. Sims ..........60 60

Miller v. Smith ......... 41

Miller v. State ........... $5+1$

Miller v. Tilfany . . . 3966, 417, 420

Miller v. Wilson .....101. 115, 403

Miller v. Woodward ........ 5i2

Miller's Appeal..........4 460

Millett v. People ......... 4

Milligan v. Pollard ........ 14

Milliken v. Pratt ......395, 397

$401,403,420$

Mills v. Brown .......... 1:9

Mills v. Graham ........ 69
Sec.

Mills v. McDaniels ....... 449

Mills v. Mills ............ 284

Mills v. Williams ...187, 240, 241

Mills v. U. S. Printing Co.336, 341

Milne v. Field .......... 646

Milne v. Huber ......... 416

Milne v. Moreton ......... 406

Milnes v. Duncan ......... 501

Milne's Appeal ........... 629

Milroy v. Iron Co......... 521

Miltimore v. Railroad Co.... 582

Milwaukee, etc. R. R. Co. v.

Smitl . ........... 398

Minard v. Mead ........... 89

Miner v. Bradley ......448, 599

Mineral Point Railroad v. Bar-

ron ............... 419

Minich v. Huff .......... 129

Mining Co. v. Fraser . . . . . 697

Minneapolis, ete. Manuf. Co. v.

Manuf. Co............6641

Mimneapolis Harvest Works v.

Kaessner .............2 216

Minnesota v. Barber........ 549

Minnesota Lumber Co. v. Coal

Co. ................ 254

Minock v. Shortridge ...... 27

Mintern v. Laru . . . . . . . . 534

Mirebach v. Bank ........ 14

Miskey's Appeal .......... 25

Misner v. Knapp ......... 262

Mississippi, etc. R. R. Co. v.

Green ............ 576

Mississippi Logging Co. v. Robson $\ldots \ldots \ldots \ldots \ldots \ldots \ldots, 573$

Missouri, ete. R. R. Co. v. Fagan . . . . . . . . 617

Missouri, ete. R. Li. Co. v. Ha-

ber . ............. 549

Missouri Pae. R. R. Co. v. Iney 288

Missouri Valley J. lns. Co. v.

Sturges ............. 267

Mlitchell v. Bank .........4401

Mlitchell v. Lapage . . . . . 340, 457

Nitchell v. Lyman ......208, 226 
Sine.

Mitchell v. Reyuolds ....... 311

Mitchell v. Kingman ........ 9 9

Mitchell v. S.eott .......... 205

Mitchell r. Smith ......... 196

Mitchell v. Vance .......... 281

Mittenlal v. Mascagni ...396, 420

Mix v. Ins. Co........... 230

Mixer v. Howarth ......146, 694

Mobile v. Watson .......... 555

Mobile, etc. R. R. Co. v. Felrath 491

Mobile, ete. R. R. Co. v. Gilmer 689

Mobile, etc. R. R. Co. v. Hop-

kins . ............. 29.

Mobile, etc. R. R. Co. v. People 302

Modisett v. Johnson ........667 667

Mogul Steamship Co. v. Mc-

Gregor . ..........335, 341

Mohr v. Miesen .......... 249

Mohr v. Tulip .......... 12

Moley v. Brine .......... 60

Mollyneaux v. Wittenberg .... 316

Molton v. Camroux .....22, 25

Monaghan v. Ins. C'o....... 66

Monaghan v. School Dist...... 470

Monroe v. The lowa ....... 410

Monson v. Bragdon ........6 678

Monson v. Williams ........ 444

Montague v. Flocton ......6 677

Montague v. Garrett ....137, 479

Montague v. Lowry . . . . . . . . 3:4

Montgomery v. Edwards... 100, 114

Montgomery v. wright ..... 402

Monumental Asso. v. Herman.. 67

Moody v. Leverich .......... 6i) 3

Moody v. Longfellow ....... 492

Mooiy v. Walker ......... 446

Moody v. Wright .......... 518

Mooney v. Hon Co........ 4h

Moore v. Appleton ....... 437

Moore v. Bruner .......... 391

Moore v. Carter ...........699

Moore v. Chenault ........ 97

Moore v. Chureh .......... 406

Moore v. Eddowes ......... 450

Moore $r$ Garwood .......... 4.ts
Moore v. Hershey ........14, 24

Moore v. Holcombe ........ 508

Moore v. House .......... 363

Moore v. Mlahaska County.... 281

Moore v. Nartin ......... 561

Moore v. Murdock ........184, 187

Hoore v. Nat. Bank .....357, 5 18

Moore v. Rogers ......... 597

Moore v. Shields ..........445

Moore v. Taylor ........8, 99

Moore, ete. Hardware Co. v.

Hardware Co.......... 316

Moores v. Bricklayers' Uniou.. 335

$3+1$

Moorhouse v. Colvin ....... tt6

Moot v. Association ........647

Moran v. Dunphy ........ 337

More v. Bennett .......313, 221

More v. Clymer ....180, 184, 185

Moreau v. Dumagene . . . . . 6:0

Moreau v. Edwards ......... 319

Moreliead v. Wotlyus ....... 111

Moreland v. Davidson ...... 458

Morford v. White ........ 464

Morgan v. Bailey ........... 183

Morgan v. Battle ......... 105

Morgan v. Hetler ......65 I, 655

Morgan v. Palmer ........ 452

Morgan's Steamshup Co. v.

Board . ........... 547

Morienthal v. Mosier ...... 634

Morier v. Morgan ........ 443

Morin v. Martz ........... 98 .

Morley v. Attenberough . . . . 448

Morley v. Railroad Co.533, 556,563

Morrill v. Aden .......... 65

Morrill r. Mackman ....... 111

Morrill v. Noges .......515, 518

Morrill v. State ......... 5.5

Morris v. Assurance Co...... 16

Morris .. Burcett . . . . . . . 423

Morris v. Cleasby ......... 87

Morris $r$. Colman ......... 317

Morris $v$. Fox .......... 669

Morris $v$. Hale ........... 330 
See.

Morris v. Manuf. Co....... 312

Morris v. Mayor ......... 456

Morris v. Osterhout ....... 125

Morris $v$. Wilbaux ........ 399

Morris Canal v. Van Vorst ... 379

Morris Run Coal Co. v. Coal

Co.......... 321, 324, 331

Morrison v. Baker ........ 122

Morrison v. Davis ......583, 616

Morrison v. Dingley ....... 148

Morrison v. Herrick ....... 105

Morrison v. Markham ...... 231

Morrison v. Poyntz ......... 391

Morrissey v. Broomal ......6.621

Morrissey v. Kinsey ......125, 132

Moritz v. Larsen ......... 474

Morrow v. Campbell ....... 580

Morrow v. Higgins ........ 99

Morrow v. Robinson ........624

Morrow v. Starke ....... 377

Morse v. Bellows ......... 377

Morse v. Brackett ........448

Morse v. Ely .........62, 64

Morse v. Gould .......558, 560

Morse v. Machine Co....... 316

Morse v. West ........... 198

Morse v. Wheeler ......... 52

Morse Machine Co. v. Morse.. 318

328,329

Mortmer v. Capper ........ 672

Morton v. Dean .......... 92

Morton v. Naylor ........ 526

Morton v. Tibbett ......148, 151

Morton v. Stewart .......28, 49

Morton v. 'I'elegr. Co....... 693

Mory v. Michael .......... 358

Mosely v. Baker .......... 584

Mosely v. Fullerton ........ 392

Mosely v. Vanhooser ........ 185

Moses v. Arnold .......... 488

Moses v. Association ....... 237

Moses v. Lawrence Co. Bank. 96

Moses v. Maepherlan ...... 501

Moses v. Stone .......... 482

Mosher v. Railroad Co....... 294
Sec.

Moslin v. Railroad Co....... 288

Moss v. Culver ........... 102

Motley v. Ins. Co......... 353

Mott v. Rowland.240, 241, 396, 399

Mott v. Water Co......349, 350

Moulding v. Prussing ....... $9 \mathrm{I}$

Moule v. Garrett .......... 440

Moulton v. Harris ........ 105

Moulton v. MeEwen .....473, 651

$652,655,66 \mathrm{~b}$

Moulton v. Railroad Co..... 617

Mount v. Waite ........... 500

Mountstephen v. Lakeman .... 635

Mournin v. Trainer ........ 105

Mowry v. Bishop .......... 208

Moyer v. Cantieny ........ 287

Moyer v. Shoemaker .......446

Mozell v. Burnett......... 570

Mozings v. Ross..........6 634

Mudge v. Oliver....340, 457, 478

Mudgett v. Clay......... 105

Mugler v. Kansas......... 546

Muir v. Schenck........... 508

Muldoon v. Railroad Co...... 295

Mulhall v. Quinn......515, 518

Mullalieu v. Hodgson....... 171

Mullen v. Reed........... 404

Muller v. Riviere........... 128

Mullett v. Mason......... 685

Mulligan v. Railroad Co..... 290

Mullin v. Bloomer........ 597

Luumford v. Canty......258, 402

Mumford v. Tolan........ 229

Mun v. Commission Co...... 212

Munday v. Kaufman........ 29

Mundorff v. Kilbourn.......466

Mundy v. Joliffe......... 105

Munn v. Illinois.......307, 532

538,539

Munro v. Butt.......473, 477

Munsell v. Temple........ 519

Munsey v. Butterfield....... 319

Murdfeldt v. Railroad Co.... 672

Murdock v. Finney........ 508

Murdock v. Jones.......... 646 
Sere.

Murdock v. Railroad Co..... 293

Murdock v. Walker......331, 336

Murkley v. Whitney........ 103

Murphy v. Bank......... 380

Murply v. Reed........... 267

Murphy r. San Luis Obispo.. 278

Mmphy v. State......... 530

Murphy v. Weil........... 368

Murray v. Bond.......... 198

Miurray v. Flavell......... 360

Murray v. Lardner........ 512

Murray v. Lylburn......... 508

Murray v. Marshall........ 585

Murray v. Wakefield........ 286

Murrell v. Whiting.......6.687

Muser v. Express Co........ 289

Musselman $v$. Stover....... 91

Mustard v. Wohlford.....26, 27 $61,64,69,71$

Mutual Ben. L. Ins, Co. v.

Davies .............. 20

Mutual Ins. Co. v. Cohen.... 401

$$
404,420
$$

Mutual L. Ins. Co. v. Allen... . 267

Mutual L. Ins. Co. v. Hunt.14, 22

Mutual Life Ins. Co. v. New

York .............456

Mutual Life Ins. Co. v. Terry 19

Mutual L. Ins. Co. v. Walden. . 19

Mutual Sav. Inst. v. Enslin... 449

Muzzy v. Shattuck........ 584

Meyer v. Estes...........649

Myer v. Cole........... 485

Myers v. Bank......... 428

Myers v. Gross..........667

Myers v. linabe........... 22

Myers v. Munson.......... 85

Myers v, Sanders......... 61

Myers v. Smith.......... 435

Mygatt v. Tarbell........7 701

Mynard v. Rarlroad Co..... 288

Myrick v. Dame.......37ז, 381

Nace v. Boyer............ 14

Nash v. Jewett.......... 67
Sec.

Nash v. Page........... 538

Nash v. Skinner.......... 368

Nasli v. Town............ 599

Nashrille Trust Co. v. Bank. . 506

Natches Build. \& Loan Asso.

v. Shields . . . . . . . . . 219

Nat. Cordage Co. v. Sims.... 87

National Bank v. Bruhn..... 232

National Bank v. Danforth... 229

National Bank v. Fink...283, 517

National Bank v. Matthews.. 175

National Bank v. Mloore...... 14

National Bank v. Morris.... 402

National Bank v. Tappan.... 428

National Bank v. Whitney.... 175

National Ben. Co. v. Hospital

Co ............312, 314

National B. \& L. Asso. v. Brahan .............4 417

National Exchange Bank v. McLoon.....52^, 522, 524, 526

Nat. Fire Ins. Co. v. Rowe... 80

National Harrow Co. v. Quick 320

National Lead Co. v. Paint Store . . .......... 323

National Mut. Build. \& L.

Asso. v. Ashworth.....417, 419

National News 'l'el. Co. v.

Western Union Tel. Co.... 339

National Protection Asso. v.

Cummins .............. 335

National Security Bank v.

Cushman .............. 503

National Trust Co. v. Gleason 446

495

National Union v. Marlow.... 404

Neal v. Berry.......... 51

Neal v. Hines........... 312

Neal v. Saunilerson........615

Neate v. Harding......... 487

Nebraska Tel. Co. v. State.... 298

Necker v. llarvey........ 348

Necker v. Koehn.......... 53

Needles r. Burk.......... 452

Needles v. Needles.......... 518 
Sec.

Sec.

Neff $v$. Landis............ 69

Neff v. Wooding.......... 427

Neil v. Bank............ 417

Nelson v. Boynton......123, 125

$12 \tau, 132$

Nelson v. Imp. Co......... 480

Nelson v. Moose......... 687

Nelion v. Plimpton, etc. Co... 606

Nelson v. State........... 188

Nerot v. Wallace.......... 568

Nesbit r. Works.......... 125

Nester v. Brewing Co.320, 321, 331

Neuman v. Schroeder........ 124

Neustadt v. Hall........... 281

New Albany, ete. Co. v. Lewis. 423

New Albany, etc. R. R. Co. v.

Micornick . . ......... 302

Newark Sar. Inst. v. Forman. . 560

Newbery v. Wall......... 83

New Brunswick Steamboat Co.

v. Tiers . . .........6 616

Newburgh, etc. Turnpike Co.

v. Welter............554

Newbury v. Armstrong....... 96

Newby v. Hill........... 508

Newcomb v. Clark........89, 94

Newcomb v. Ins. Co........ 474

Newcomb v. Raynor......... 375

Neweome v. Davenport....... 456

Newell v. Bank........208, 232

Newell v. Higgins...171, 700, 701

Newell v. Meyendorf....... 312

New England, etc. Co. v. Spitler................ 12

New England, etc. Co. v. Worsted Co. ..........97, 148

New England Express Co. v. Railroad Co. ......... 306

New England Mortg. Co. v. Baxley . . ........... 228

New England Mortg. Co. v. Gay . . .........228, 239

New England Mortg. Co. v. Mclaugblin . . ......399, 420 Newhall v. Railroad Co...... 510 Newhall v. Wyatt......... 504 New Hampshire F. Ins. Co. v. Noyes ............ 46

New Home L. Asso. v. Hagler. 19 New Jersey Steam Nav. Co. v.

Bank . . ............4 410

Newman $v$. Kershaw.....240, 241

Newman v. Morris......... 139

Nerman v. Nellis....80, 100, 103

Newman v. Reagan.......6618

Newman v. Sherifl......... 398

Newman v. Supervisors...... 456

Newman v. Telegr. Co.......693

Newport v. Saunders........ 423

New Orleans, etc. R. R. Co. v.

Turean .........457, 483

New Orleans Gas Co. v. Louisville Light Co....303, 547, 550 New Orleans Water Works Co.

v. Sugar Refining Co...... 53I

New South Water Co. v.

1.ythes ............676

Newton v. Bronson......... 100

Newton v. Ins. Co.......... 17

Newton Manuf. Co. v. White.. 464

Newton v. Pence........... 391

Newton v. Rowse.......... 588

New York Cent. R. R. v. Lockwood . . .....288, 295, 587

New York and Erie R. R. Co.

v. Winter . . . ........ 292

New York, elc. Ins. Co. v.

Aitkins ...........4 419

New York, eic. R. R. Co. v.

Bennett . . ........... 293

New York, etc. R. R. Co. v.

New York . . . . . . . . . . 549

New York, etc. R. R. Co. v.

Winans ............ 303

New York ex rel. Pennsylvania

R. R. Co. v. Knight...... 182

New York, etc. Tel. Co. v. Dry-

burg . . . ........... 297

New York Life Ins. Co. v.

Rosenheim .......... 266 
See. See.

Niagara Fire Ins. Co. v. Torman v. Phillips........ 152

Greene ............ 134 Xorris v. Railroad Co.....615

Nibbe $v$. Brauhn.......... 66t Norris v. School Dist...640, 666

Nibert r. Baghurst. . 104, 183, 192 Norris r. Sowles.......... 402

Niblo $v$. Biusse.......... 659 North $r$. Forest .......... 144

Nicewander $v$. Niccwander.... 5 North $v$ Mendel........85, 91

Nicholas $v$. Kershear....... 7 North $v$. Nichols......... 442

Nicholas v. Railroad Co.....28s North v. Wakefield........ 3/8

Nichols v. Allen.......... 128 Northern Pac. R. R. ('o. v.

Nichols v. Johnson........ ss Adams ............ 295

Nichols v. Fearson........212 Northern Pae. R. R. Co. v.

Nichols $v$ Mantyn........618 Pausen ............ 292

Nichols v. Marsland........ 580

Nichols v. Nowling......394, 437

Nichols v. Raulroad Co...... 295

Nichols v. Vinson......... 483

Nicholson v. Bower........ 152

Nicholson $v$. Railroad Co.... 3.25

Nicholson v. Spencer.....tl, 50

Nicholson v. Wilborn...... 4 I

Nickerson v. Howard....... 519

Nickerson v. Hydraulic Co... 349

Nickerson v. Spindell...... 483

Nickles v. Asso........... 240

Niell v. Morley........25, 47:

Niemeyer v. Wright........ 178

Nightingale v. Withington... 27

47,470

Niland v. Murphy......... 80

Nimick v. Ins. Co.......... 18

Niver v. Best.......... 274

Noble v. Adams............ 593

Noble v. James............6 640

Noel v. Karper........... 8

Noland v. Whitney.........643

Nolte v. Libbert.......66, 355

Noreross v. Noreross........ 585

Norden v. Jones. .464, 487, 489, 490

Nordenfelt v. Maxim Nordenfelt Guns and Anmunition

Co. ................ 314

Nordholt $r$. Nordholt....... 30

Nordyke v. Kehlor........ 568

Norfolk, etc. R. R. Co. v. Marshall ............. 582

Northern Securities Co, v.

United States .......... 324

Northern Trust Co. v. Markell firt

Northhampton v. Elwell..... 363

Northrop v. Graves......... 453

Northrup v. Phillips....... 330

Northwestern Ins. Co. v.

Blankenship ......... 22

Northwestern Mnt. L. Ins. Co.

v. Hazelett ......... 20

Norton v. Blinn.......321, 330

Norton v. Faucher.........665

Norton v. Highleyman...... 452

Norton v. Marden ........ 450

Norton v. Paxton.......... 5

Norwegian Plow Co. v. Haw-

thorn ............. 156

Norwood v. Faulkner........ 210

Noyes v. Chapman Drake Co.. 700

Noyes v. Humphreys....... 121

Noyes $v$. Loring. . . . . . . . . 464

Noyes v. Spaulding........ 25

Nugent $v$. Snith.......... 615

Nugent v. Teachout........479

Nugent v. Wolfe........96, 129

Nunez v. Morgan.......... 114

Nye v. Grand Lodge.....267, 268

Oakdale Manuf. Co. v. Garst. . 312

314,322

Oakes v. Water Co........ 304

Uakley v. Aspinwall........ 370

Oakley v. Morton......... 570 
Sec.

Oates v. Buckwith........631

Olmsted v. Hotailing....... 503

Oates v. Hudson.......... 497

Obear v. Bank............ 638

Omaha Consolidated Vinegar

Co. v. Burns...........6 655

O'Brien v. Goslin......... 55

O'Brien v. Greenbaum....... 172

O Brien v. O'Brien......... 627

O'Brien v. Prietenbach...... 274

O'Brien v. Society......... 690

Omaha, ete. Co. v. Tabor..... 492

Omaha Loan and 'Trust Co. v.

Hanson . . .......... 206

Omohundro v. Omohundro.... 641

O'Neal v. Board.......... 357

O'Brien v. Vail.......... 585

0 Neal v. King..........644

O'Brien v. Young.......... 563

O'Neil v. Behanna......... 336

O'Bryan v. Fitzgerald....... 205

O'Conley v. Natches........ 445

$0^{\circ}$ Connell v. Lewiston...... 191

$0^{*}$ Conner v. State......... 200

O'Connor v. Tyrrell.......6671

O Dea v. Winona.........655

O'Dell v. Rogers........... 59

Oden v. Elliott......... 430

Odom v. Mortg. Co........ 417

Odom v. Riddick.......... 24

O'Donnell v. Leaman........ 97

O'Donnell v. Sweeney..... 178, 202

O'Fallon v. Boismenn...... 445

Offutt v. Flagg........... 402

Ogden v. Fossick.......... 677

Ogden v. Gibbons......... 534

Ogden v. Maxwell........ 452

Ogden v. Peters........... 170

Ogden v. Sanders.......... 555

O'Grady v. O'Grady........ 108

Ogsbury v. Ogsbury........ 106

Ohio v. Frank............ 224

Ohio Ins. Co. v. Ross....... 508

O'Kelly v. Williams........ 555

Ord Colony R. K. Co. v. Evans 98

Olive v. Olive........... 446

Ohver v. Gilmore......... 312

Oliver v. Hunting......... 92

Uliver v. Ins. Co.......... 98

Oliver v. MeClellan........ 69

Oliver v. Shoemaker.......221

Olmstead v. Beale......474, 666

Olmstead v. Burke........6 697

Olmstead r. neyes......... 267

U'Neil v. Cram........... 91

O'Neil v. Iron Co........ 300

O'Neil v. Mining Co....... 146

O'Neill v. Sinclair.......... 198

Ontario Salt Co. v. Salt Co.... 322

Oppenheim v. Waterbury.... 91

Oppenheimer v. Express Co.. 289

Orange County Bank v. Brown 289

Oreutt v. Nelson.340, 409, 457, 478

Urgan v. Stewart........ 81

O'Regan v. Cunard, etc. Co.. 410

Oregon Steam Nav. Co. v.

Winsor . . ......303, 308, 309 $310,312,313,316$

Orendorff v. Express Co..... 288

Ormerod v. Dearman.....284, 286

O'Rourke v. O'Rourke....... 412

Orr v. Commission Co....... 698

Orr v. Ins. Co.......... 345

Orr v. Meek........... 200

Ortloff v. Klitzke......... 145

Ortt v. Railroad Co........ 290

Osborn v. Guy's Hospital. .... 465

Osborn v. Plelps........88, 91

Osborne v. Baker.......87, 94

Osborne v. Bank.......... 240

Usborne v. Ins. Co......... . 404

Usborne v. Kimball........ 137

Osborne v. Lawrence........6.64l

Usborne v. Williams........ 330

Oscanyan v. Arms Co...282, 284

285,408

Osgood v. Bender......254, 398

Osgood v. Groning......569, 573 
Sec.

Sec.

O'Shea v. Lead Co.......171, 172

Oshkosh Water Works Co. v.

Oshkosh . . .......560, 565

Osier v. Hobbs............ 425

O'Sullivan v. Overton...... 87

Othemway v. Zekind........ 198

Utis v. Gregory.......... 403

Otis v. Railroad Co........ 300

Otis Steel Co. v. Local Union.. 336

Otto v. Doty............ 8

Otto v. Durege............. 212

Outhouse v. Allen......... 463

Overton v. Banister........ 67

Owen v. Long.........27, 52

Owen v. Partridge........ 340

Owens v. Railroad Co...... 300

Oxendale v. Wetherell......4 478

Oxford v. Columbia........6.628

Oxley v. Tryon.......... 27

Pacific Express Co. v. Black.. 693

Pacific Express Co. v. Wallace. 288

Pacific Factor Co. v. Adler... . 320

Pacific Guano Co. v. Mullen.. 202

Pacific R. R. Co. v. Seeley.... 302

Packard v. Taylor......... 582

Packer v. Benton........... 125

Packer v. Steward......... 81

Paddock v. Stout...........664

Padmore v. Gunning....... 466

Paducalı Lum. Co. v. Water Co. 349

Pangburn v. Westlake...... 173

Pat. Railhoad Co. v. Bray ...... 293

Paine v. Lester........... 406

Paine v. Hutchinson....... 672

Paine v. McGinchey........ 464

Paine $r$ Mellor..........672

Palm $\vee$ Railroad Co........ 473

Palmer v. Bates.......2s3, 517

Palmer v. Breen.......... 64l

Palmer v. liailroatd Co....... 617

Palmer v. State......... 542

Palmer v. Stebbins......... 303

Palmer's Case . ........ 119

Paola Gas Co. v. Glass Co... 697

Paradine v. Jane.......... 573

Parcell v. McComber........ 474

Paris v. Strong.......... 134

Parish v. United States..... 695

Parish v. Webster......... 330

Parish v. Wilson........... 119

Park v. Druggists' Asso..... 324

Parker v. Bricklayers' Union. . 335

Parker v. Cousins......... 208

Parker v. Parker......... 84

Parker v. Platt......640, 651

Parker v. Railway Co...452, 497

Parker v. Steed.......... 477

Parker v. Syracuse......... 524

Parker v. Taintor......... 4S0

Parkhurst v. Van Cortland.... 86

Parmalee v. Wilks......... 188

Parmelee v. Adolph........ 597

Parmelee v. Lawrence....... 378

Paquin v. State Board....... 200

Parr v. Brady.......... 402

Parsell v. Stryker......466, 667

Parsons v. Babcock........ 234

Parsons v. Hill.......... 66

Parsons v. Loucks.......... 146

Parsons v. Monteath.......6.615

Partee v. Silliman.......398, 419

Parton v. Crolts......... 98

l'ass v. Grenada County..... 452

Pass v. Security Co......... 228

Passaic Print Works v. Dry

Goods Co. ........... 315

Passenger v. Thorburn......685

Passmore v. Telegraph Co.... 297

Patchin v. Cromack...... $0, \quad 27$

late v. Wright......... 192

l'aterson $v$. Paterson....... $46 \overline{5}$

Pateshall v. Tranter........ 012

Patuote v. Sinders......... 4,4

Patrick v. Railroad Co...597, 621

Pattce v. Greely....183, 195, 196

Patten v. Hicks......

Palmer $v$ Stephens........ 89 l'atterson $r$ Birdsall....... 235 
Patterson r. Boehm.....171, 701

Patterson v. Caldwin....... 520

Patterson v. Kentucky...... 547

Patterson v. Lawrence....... 67

Patterson v. Lippineott...... 66

Patterson v. Manuf. Co.....621

Patterson v. Martz........ 825

Patterson's Appeal.........635

Pattison v. Judd.........640

Paul v. Grimm..........445

Paul v. Smith.......... 44

Pawelski v. Hargreave...... 146

Pawlet v. Sandgate........ 444

Pawley v. Turnbull.........646

Paxton v. Newton.....668, 677

Payne v. Mayor.......... 515

Payne v. Newcomb.......... 228

Payne v. Railroad Co....... 343

Payne v. Western, ete. Co... 315

Peabody v. Kendall........ 7

Peabody v. Norfolk......318, 677

Peabody v. Railroad Co...... 293

Peabody v. Speyers......... 255

Peacock v. Bunder.......53, 54

Peacock v. Cummings...... 602

Peacock v. Rhodes......... 512

Pearce v. Brooks.161, 164, 274, 409

Pearce v. Foot.....249, 251, 253

Pearce v. Rice........... 249

Pearl v. McDowell. .11, 12, 22, 471

Pearsall v. Kingsland....... 237

Pearson v. Carlton......... 37

Pearson v. Cox........... 9

Pearson v. Distilling Co.... 411

Pearson v. Skelton........ 437

Pease v. Herst........... 377

Peck v. Briggs........... 447

Peek v. Burr............... 203

Peck v. Ellis............. . 437

Peck v. Mayo........... 241

Peck v. Randall.......... 629

Peck v. Stanfield.......... 105

l'eck v. Vandemark........ 9I

Peebles v. Gay............. 388

Peele v. Northcote.......... 87
Peet v. Hatcher........... 413

Peevey v. Haughton........ 85

Peik v. Railroad Co..288, 295, 539

Pelletier v. Courture....... 60

Peltz v. Eichele.......... 312

Pemberton Build. L. Asso. v.

Adams ........67, 70

Pembroke v. Thorpe........668

Pence v. Langdon......... 597

Pendenhaur v. Ins. Co....... 20

Penfold v. Ins. Co....... 20

Peninsular, etc. Co. v. Shand.. 240

Penn v. Bornman..... 173, 176, 178

Penn v. Bowman.......... 196

Penn v. Smith........... 698

Pennell v. Deffell......... 502

Penngar v. State.......178, 400

Penniman's Case......... 557

Pennsylvania Co. v. Fairehild. 421

Pennsylvania Railroad Co. v. Comnell ............... 294

Pennsylvania Railroad Co. v. Henderson . . . . . . . . 288

l'ennsylvania R. R. Co. v. Lenhart. . . . . . . . . . . . . 292

Pennsylvania R. R. Co. v. Miller . . .......... 541

Penn Mut. L. Ins. Co. v. Trust Co. . . ..........404, 420

Pennypacker v. Jones.......697

Penrose v. Canal Co........ 560

Pensacola, ete. R. . Co. v. Braxton ............... 450

Peonage Cases............ 17t

People v. Adams.......... 272

People v. Arendt......... 200

People v. Armstrong....... 542

People v. Barondess........ 347

People v. Bartlett......... 568

People v. Booth........... 254

P'eople v. Budd........... 538

People v. Bullalo Fish Co.... 549

People v. Buttling......... 188

People v. Campbell......... 528

People v. Cipperly......... 542 
Ser. Siec.

People v. Coler.........2, 4, 549

reople v. Comptroller.......4 426

Pcople v. Dayton........... 283

People v. Dscker.......... 270

People v. Eastern......... 567

People v. Fallon........... 263

People v. Folks........... I

People v. Foundry Co........ 321

People v. Gas Light and Coke

Co ..............307, 535

People v. Gas 'Trust Co. . . 320, 323

People v. Gillson........4, 271

People v. Girard.......542, 543

People v. Gordon........... 629

People v. Grout........... 4

People v. Guthrie......... 538

People v. Havnor............ 188

People v. Hawkins. . . . . . . . 549

People v. Holden........... 351

People v. Hughes......... 347

People v. Ingersoll......... 129

People v. Ins. Co. . . . . . . . . 570

People v. Live Stoek Exchange 301

People v. Manning.......475, 589

People v. Milk Exeliange. .320, 323

People v. Moores...30, 33, 35, 470

People v. Mullin.......... 30

People v. Omaha.......... 517

People v. Orange County Con-

struetion $\mathrm{Co} \ldots \ldots \ldots \ldots, 4$

People v. Otis . . . . . . . . 540

People v. Platt...........6632

People . Railroad Co........ 302

People v. Russell........... 55 I

People v. Sheldon......320, 323

People v. Speir........... 445

People v. Sugar Retining Co.. 323

People v. Supervisors...... 667

People v. Trust Co......... 304

People v. Warden.......... 173

People v. WVest. . . . . . . . . . . 542

People v. White.........629

People v. Wilzig......... 336

People's Bank v. Jaekson.215, 237
People's Gas Light and Coke

Co. v. Chicago.......... 535

People's Puxe Iee Co. v. 'Trumbull ............... I35

Peoria Co. v. Gordon....... 629

Pepper v. Plibadelphia......666

Peree v. Hallett. ..........5530

Pereaux v. Simon.......... 80

Perin v. Parker...........441

Perlman v. Satorius......... 398

Perkins v. Barstow.........6 634

Perkins v. Butler County..515, 519

Perkins v. Catlin......... 128

Parkins v. Clay........... 137

Perkins v. Cummings........ 164

Perkins v. Hadsell......... 98

Perkins v. Hart.......... 428

Perkins v. Hasbrouck....... 460

Perkins v. Littlefield . . . . . . . 124

Perkins v. Pendleton. . 335, 337, 341

Perkins v. Railroad Co...... 295

Perkins v. Watkins....... 196

Perrault v. Gauthier........ 334

Perrin v. Canal Co........ 534

Perrin v. Wilson.......41, 45

Perry v. Ins. Co........... 404

Perry v. Pearson........6, 8

Person v. Chase.......27, 66

Pervear v. Commonwealth... 547

Peter v. Westborough....... 134

Peters v. Davenport......279, 283

Peters v. Davis........... 380

Peters v. Fleming......39. 50, 468

Peters v. Grim........218, 252

Peters v. Johnson.......... 364

Peters v. Opie........... 606

Peters v. Railroad Co...... 497

Peters v. Ryland......... 303

Peterson v. Cluristensen....... 274

Peterson v. Gurren........ 249

Peterson v. Laik........... 58

Peterson v. Neazer....... 474

Petrie v. Berry......... 377

Petrie v. Williams......... 58

Petrow v. Wiseman........ 51 


\begin{tabular}{|c|c|c|}
\hline \multicolumn{3}{|c|}{ Peugh v. Porter......... $\begin{array}{r}\text { Sec. } \\
524\end{array}$} \\
\hline Pevey v. & . Jones............. & 445 \\
\hline Pew v. B & Bank............... & 462 \\
\hline Peyser v & v. Mayer............ & 499 \\
\hline Pey & v. Conniff ...... & 125 \\
\hline Pfeming & ger v. Kokesch....... & 634 \\
\hline Phadenh & haur v. Ins. Co..... & 19 \\
\hline Phelps v & v. Holderness........ & 259 \\
\hline Phelps v & v. Montgomery....... & \\
\hline
\end{tabular}

Phelps v. Nowlin......... 345

Phelps v. Rowe.......... 131

Phelps v. Stillings......... 91

Phelps v. Worcester...44, 46, 72 75,468

Philadelphia, ete R. R. Co. v.

Anderson ............ 583

Philadelphia v. Kelly...... 216

Philadelphia Ball Club v.

Lajoie . . . . . . . . . . 677

Philadelphia, etc. K. R. Co. v.

Howard ............696

Philadelphia, ete. R. R. Co. v.

Lehman . . . . . . . . . 188

Phila. IV. and B. Railroad Co.

v. Rice ............ 293

Philadelphia, ete. R. R. Co. v.

Tow Boat Co........... 188

Philadelphia's Appeal.521, 523, 526

Philbrook v. Belknap....... 480

Philip v. Gallant......... 640

Phillimore v. Barry....... 89

Phillip v. Howell.........6 622

Phillips v. Adams.......... 91

Phillips v. Banking Co...... 292

Phillips v. Belden........ 427

Phillips v. Bislolli........ 151

Phillips v. Clagett........ 381

Phillips v. Edsall......521, 524

Phillips v. Green.......65, 71

Phillips v. Imms.......... 188

Phillips v. Ins. Co........ 19

Phillips v. Lloyd.......4.2, 46

Phillips v. Morrison.......661

Phillips v. Oemulgee Mills.... 156
Sec.

Phillips v. Ogle.......... 237

Phillips v. Roberts......... 228

Phillips v. Stevens........ 573

Phillips v. Swank.......... 92

Phillips v. Thompson....... 104

Philpot v. Bingham........ 28

Phipot v. Briant......... 119

Philpotts v. Evans......... 604

Phinney v. Baldwin. .224, 258, 408

Phinney v. Phinney........ 562

Phippen v. Stickney..165, 168, 169

Phoenix Bank v. Risley...... 428

Phoenix Ins. Co. v. 'Transp. Co. 410

Physio-Nled. College v. Wilkin-

son ............... 14

Piatt v. Oliver......... 167

Pickard v. Car Co......... 303

Pickenny v. Railroad Co..204, 701

Pickering v. Cease.....249, 255

Pickering v. Gunning...... 43

Pickering v. Railway Co..... 508

Pickersgill v. Lahens........ 374

Hier v. George.......... 518

Pierce v. Cenultry........ 485

Pierce v. Chamberlain....... 15

Pierce v. Listate.......... 102

Pierce v. Fuller.......303, 312

Pierce v. Ins. Co......... 20

Pierce v. Paine.....82, 110, 137

Pierce v. Railroad Co...536, 537

Pierce v. IVoodward........ 316

Pieronnet v. Lull......... 254

Pierrepont v. Bırnard.......648

Pike v. Brown.......... 353

Pike v. King..........183, 195

Pike v. Warren.......... 634

Pilkington v. Scott....... 317

Pinches v. Chureh...473, 475, 477

$6 \_0,666$

Pinkstone v. Taliaferro...... 389

Pioneer baving, etc. Co. v. Can-

non .............4 417

Piper v. Foster.......... 137

l'iper v. Hoards..........6.631

Pipp v. Reynolds........ 356 
Sec.

See.

Pit v. Cholmondeley....... 499

Pitcher v. Lowe.......... 85

Pitkin r. Noyes........146, 694

Pitt v. Gentle........... 385

Pittsburg Carbon Co. v. Me-

Millin . . ......... 320

Pittsburg, ete. R. R. Co. v.

Cillwell . . . . . . . . 295

Pittsburg, ete. R. R. Co. v. 1lallowel! . . .......6.615

Pittsurg, ete. R. R. Co. v.

Hogen . . . .........6 615

Pittshurg, etc. Railroad Co. v.

Moore .............. $28 s$

Pittrburg, ete. R. R. Co. v.

Russ . . ............ 292

Pixler v. Xichols......... 474

Pixley v. Boynton......... 2.55

Place v. Langworthy....... 170

Plaisted v. Palmer........ 192

Planche v. Colburn.....482, 688

Plant v. Wood........... 336

Planters Bank v. Sharp.... 560

Plaster v. Plaster........ 470

Plate v. Durst.......... 460

Platt $v$. brand........... 594

Platt v. Colvin......... 367

Pleasants v. hoss.........642

Pledger v. Garrison........ 82

Plimpton v. Goodell........ 329

Plumley v. Massachusetts... 550

Plummer v. Buckman....480, 599

Podmole v. Guaning.......667 667

Polen v. Palmer.......208, 226

Pollard v. Photograph Co.... 340

Pollock v. Accident Asso.... . . 20

Polson v. Stewart...101, 397, 403

Poneher v. Railroad Co..... 295

Pond v. Williams......... 379

Pool v. Allen .......... 432

Pool v. Boston............ 281

Poole v. Ileggins......... 330

Pooler v. Christman....... 7 .

Poor v. Woodward........ 599

lope v. IIanke....25l, 254, 257

258,413

Pope v. Linn.......... 192

Pope v. Manuf. Co........ 64l

Pope v. Malshill. ........ 231.

Pope r. Xickersun......... 420

Pope r. Terle llatute, etc. Co.. 404

Popp v. Swanke........84, 114

Pordage v. Cole........153, 579

Portarlington v. Soully..... 2.58

Porter v. Banking Co...... 237

rorter v. Bille......... 119

Porter v. Day......262, 263, 265

Porter v. Gurman.......... 313

Porter v. Water Co........667

Porter v. Moods........6 640

Port Clinton, ete. R. R. Co. v.

Railroad Co . .......668, 676

Port Jervis v. Bank........448

Post v. Bank........... 403

Postal Telegrapl Co. v. Adams 552

Postal Telegraph Co. v.

Charlestown ......... 552

Postal Tel. Co. v. Lathrop..... 297

Potter v. Carpenter........ 457

Potter v. Jacobs.......... 105

Potter v. Jones........... 5

Potter v. McCaz.......... 368

Poulton v. Lattimore....... 612

Poussard v. Spiers........ 589

Powler River Live stock Co.

v. Lamb . . . . . . 133, 145

l'owell v. Commonwealth. .5 $4 * 2,543$

Powell v. Graham........ 485

l'owell v. Iloward.........651

Powell v. Hunt........... 237

Powell v. Kees...........464

l'owell v. Ko h'er......... 633

Powell v. Pensylvania...542, 550

l'owell v. Powell......... 13

f'owell v. Railroad Co......617

Powell v. Sinith......... 493

Powell v. St. Croix County. ... 456

Powell v. Supervisors...... 449 
Powell v. Waters........... 212

Power v. Athen.......... 534

Power v. Rankin.......... 128

Powers v. Skinner......284, 286

Powers v. Stout.......... 319

Powers v. Tilley........... 492

Pownal v. Ferrand.....434, 435

Pracht v. Daniels.......... 443

Prather v. Harlan......... 193

Pratt v. Adans.......... 240

Pratt v. Butcher........... 99

Pratt v. Huggins. . . . . . . . . 629

Pratt v. Humphrey.....118, 124

Pratt v. Miller......... 146

Pratt v. Philbrook.........660

Pratt v. Railroad Co....288, 537

Pray v. Burbank.......... 178

Pray v. Mitchell.......... 144

Preachers' Aid Soc. v. England 358

Prebble v. Baldwin......... 124

Prentice v. Steele......... 405

Prentiss v. Ledyard. . . . . . . 619

Presbyterian Church v. Paint

Co.................655

Prescott v. Locke........... 146

Prescott v. Norris......... 67

Preston v. Boston...452, 455, 456 496,499

Preston v. Smith........... 254

Price v. Barker........... 378

Price v. Berrington......22, 25

Price v. Campbell......... 233

Price v. Easton............. 360

Price v. Estill........... 452

Price v. Furnam....62, 64, 71

Price v. Hartshorn.......... 580

Price v. Haynes............ 170

Price v. Hewett.......... 70

Price v. Jennings.......... 66

Price v. Lien.............. 102

Price v. Mayor........... 668

Price v. Mckay............ 92

Price v. People........... 321

Price v. Pepper........... 572
Price v. Railroad Co......382, 383

Price v. Sanders....30, 40, 41, 42

$44,47,48,468,469$

Priestley v. Railroad Co.... 683

l'rime v. Koehler.......... 128

Primley v. Shirk.......... 214

Primrose v. Telegraph Co.296, 297

Prince v. Kuhler.........663

Princeton, ete. 'Turnpike Co. v.

Gulick ............. 442

Printing, etc. Registering Co.

v. Sampson ....1, 274, 3:34, 329

Pritchard v. Martin....6602, 605

Pritchard v. Norton.....116, 240 $406,419,420$

Pritchet v. Badger.........6620

Proctor v. Sears......... 54

Proprietors v. Taylor.......4 423

Proprietors v. Wheeley...... 534

Prospect Park, etc. R. R. Co.

v. Railroad Co......672, 676

Prouty v. Edgar..........30, 69

Prouty v. Wiley........... 59

Providence Bank v. Billings.. 534

Providence County Bank v.

Benson . . . . . . . . . 508

Provident Institution v. Massa-

chusetts .......... 533

Pruitt v. Pruitt......... 355

Public Schools v. Heath..... 526

P'ublishing Co. v. Smyth..... 339

Puchet v. Alexander....176, 200

Puckett v. Bates.......... 121

Puckett v. Reed.......513,514

Pugh v. Barnes........... 352

Pugh v. Jenkins. . . . . . . . . . 244

Pugh v. Stringfield........ 377

Pulfer v. Little.......... . . 602

Pullman Car Co. v. Pennsyl-

vania .............. 552

Purcell v. Daly..... . . . . . 509

Puterbaugh v. Farrell....... 239

l'utnam v. Field.......... 357

Putnam v. Hill.......... 66 
sec.

Sec.

Putnam v. Putnam......... 178

Railroad Co. v. Mundy..... 29:

Putnam v. Ritchie.......39, 46

Railroad Co. v. Navigation. . . 293

Putnam Machine Co. v. Cann.. 124

Putney v. Farnham........ 353

Pyle v. Cravens............ 28

Railroad Co. v. Perkins..643, 644

Railroad Co. v. Price.......642

643,645

Pyne v. Wood..........41, 44

Quarles v. State......... 186

Queen City Furniture Co. v.

Crawford ............ 463

Quick v. Corliss.......636, 637

Quick v. Stuyvesant........588

Qnimby v. Railroad Co....... 295

Quincy v. Tilton..........593

Quinn v. Champagne....... 92

Quinn v. Latham......334, 335

Raabe v. Squire......6662, 663

Radeliff v. Poundstone... . . 122

Raesner v. Hermann... . . . . 299

Rafferty v. Lougee.......... 97

Ragan v. Aiken.......... 325

Raggan v. Green.......... 14

Ragio v. State........... 540

Railroad Co. v. Bartram..... 293

Railroad Co. v. Bishop...288, 295

Railroad Co. v. Central Lum.

Co. . . . . . . . . . 643, 645

Railroad Co. v. Curran..288, 295

Railroad Co. v. Derny....... 295

Railroad Co. v. Fitzgerald.... 293

Railroad Co. v. Fix.........29!3

Railroad Co. v. Henderson.... 295

Railroad Co. v. Henry........ 644

Railroad Co. v. Hopkins..£88, 365

Railroad Co. v. Howard....... 610

Railroad Co. v. Husen.... .547, 549

Railroad Co. v. Hutchins.... 492

Railroad Co. v. Maine....... 541

Railroad Co. v. March.642, 643, 645

Railroad Co. v. Martino....... 293

Railroad Co, v. McClelland... 537

Railroad Co. v. McClure.... 531

Railroad Co. v. MeConnell.... 173

Railroad Co. v. Mieehe...... 295

Railroad Co. v. Lialroad Co.. 538

Railroad (๖o. v. Reed......... 582

Railroad Co. v. Leveses...... 616

Railroad Co. v. Sayers....... . 288

Railroad Co. v. Smith.......664

Railroad Co. v. Spangler.... 299

Railroad Co. v. Stevens... 288, 295

Railroad Co. v. Stockton..... 351

Railroad Co. v. Tygard...... 351

Railroad Co. v. Vanatta..... 293

Railroad Co. v. Wynn........ 288

Raisin v. Clark..........4 451

Rake v. Pope............ \$2

Rallman v. Express Co. ...... 288

Ralston v. Wood........359, 390

Ramey v. Capps........... 192

Ramsay v. Clark......... 212

Ramsdell v. Edgarton....... 171

Ramsey v. People.........2, 540

Rand v. Mather............ 204

Rand v. Webber.......... 448

Randall v. Brigham........ 533

Randall v. Latham.........668

Randall v. Rich......... 441

Randall v. Sweet......... 48

Randall v. Turner.......... 82

Randle v. State.......... 270

Random v. Tobey.........6637

Ranken v. Alfaro.......... 526

Rankin v. Collins......... 392

Rann v. Hughes........... 119

Rannells v. Gerner......... 12

Ranney v. Higby.......... 150

Ransome v. Railway Co...... 325

Rappleye v. Seeder Co...... 519

Rather v. Bank.......... 177

Rau v. Boyle............ 287

lianb v. Van Horn. . . . . . . . . 322

Rauft v. Reimers.......... 319

Raus v. Yates.......... 371 
See.

See.

Rawson v. Clirk.........665 665

Rawson v. Copland......... 353

Rawson v. Railro d Co....... 293

Rawstorne v. Gaudeil......381

Rawstone v. P،rr......... 374

liay v. Cattell............ 193

Ray v. Haines........... 62

Ray v. Maekin........... 165

Ray v. Thompson.........6 613

Ray v. Tubbs............ 34

Raymond v. Bearnard...... 598

Raymond v. Leavitt.....250, 321

Raymond v. Lowe......... 486

Raymond v. Vaughn....... 1.5

Raynor v. Drew........... 133

Rea v. Bishop.......... 23

Rea v. Somerset .......... 584

Read v. Bank........... 560

Read v. Brewer..........4401

head v. Legard........11, 468

Read v. Nash............ 124

Read v. Railroad Co........ $58:$

Read v. Spaulding........ 583

Reade v. Lamb........100, 11:?

Reader v. Kingham......... 123

Reading v. Wilson...72, 73, 74

Ready v. Huebner.......... 237

Reagan v. Trust Co........ 539

Reando v. Misp'ay........11, 12

Reardon v. Searcy.........561

Reave v. Boyeott ......... 20

Rebman v. Land Water Co... 479

Reeht v. Kelly......... 51.5

Red Bank Mut. Build. \& Loan

Asso. v. Patterson.......... 219

Redden v. Baker.......... 10

Redelsheimer v. Miller...... 365

Redford v. Clarke........ 630

Redheffer v. Leathe........ 519

Redington v. Roberts....... 149

Redpath v. Telegraph Co.... 297

Reed v. Gallagher.........640

Reed v. Golden........... 595

Reed v. Lane............. 27

Reed v. MeConnell........4481

Reed v. Nash........... 122

Reed v. Tel. Co....421, 692, 693

Reeder v. Sayre........... 136

Rees v. Berrington........ 393

Reeve v. Assoc ation........ 219

Reeves v. Butcher......... 192

Refining Co. v. Michahon..... 9

Reg v. Aspinall......... 162

lieg v. Hudson. . . . . . . . . 162

Regan v. l3aldwill.........50 $\mathbf{I}$

Regan v. Steamship Co..... 395

Reger v. O'Neal........... 215

Reggann $v$ Green.......... 22

Rehill v. MeTague.....427, 429

Reichenbach v. Sage.....657, 661

Reid v. Friendly Society of

Operative Stonemasons .... 335

Reid v. Kenworthy......... 83

Reid v. Scituate......... 473

Reid v. Wilson.......... 368

Reiff v. Bakken.......... 243

Reinhard v. Columbus....... 129

Relle v. Teleg. Co......... 693

Relleick v. Sandford........ 15I

Renihan v. Wright........ 485

Rentch v. Long.......... 146

Repetti v. Maisak......90, 92

Republic Iron, etc. Co. v. State 2

liesetter v. Waterman....96, 124

Reuss v. Picksley.......... 98

Reus Glass Factory v. Reed.. 457

Revell v. Hussey.......... 672

Rex v. Berenger........162, 163

liex v. Brotherton......... 180

Rexford v. Smith.........6 617

Reybold v. Parker........ 633

Reynall v. Sprye......... 330

Reynolds v. Bank.......... 175

Reynolds v. Everett....... 347

Reynolds v. Kirk......... 83

Reynolds v. MeCnrry.....663, 64

Lieynolds v. Padgett....488, 489

Rieynolds v. Sweetser....47, 476

Lhea v. White .......... 330

Bheel v. Hicks............ 454 


\begin{tabular}{|c|c|}
\hline hoads v. Association....... 220 & Ricks v. Yates........... 60 \\
\hline hodes v. Iowa............ 182 & Ridgeway v. Darwin....... \\
\hline hodes v. Neal. ............ 286 & Rirlgeway v. Ingram......... \\
\hline hodes Furniture Co. v. & Ridgway v. Ridgway........ \\
\hline Weedon ............... 135 & Ridgeway r. II \\
\hline iicards v. Ricards......... 195 & Ridgway v. English......... \\
\hline ice $r$. Boyer..41, 57, 58, 69, io & Riggan $v$ Green........ \\
\hline ice v. Gist............ 246 & Riggs v. Tract Soc........ S, \\
\hline ice v. Inskeep............ 373 & Riley v. Burroughs...... \\
\hline ice v. Manly.........344, 346 & Riley ง. Carier..........9, 2 \\
\hline ice v. Shute.........368, 3 & Riles v. lns. Co.......... \\
\hline ichards v. Allen.......... 108 & Riley v. Jorian.......... 20 \\
\hline ards r. Bank......... 241 & Riley v. Mallory......:s, 5s, \\
\hline$\ldots \ldots \ldots 6$ & $\ldots \ldots \ldots \ldots 27$ \\
\hline ichards v. Heather...368, 3̈1. 380 & $\cdots \cdots \cdots+40$ \\
\hline ards v. Seating Co...... 313 & $n \ldots \ldots 22$ \\
\hline$\ldots \ldots \ldots 508$ & 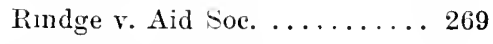 \\
\hline ool...... 498 & 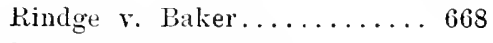 \\
\hline$\ldots \ldots \ldots 198$ & $w \ldots \ldots \ldots$ \\
\hline ichardson v. Buhl......320,323 & d Co...... 30 \\
\hline ardson v. Cheneyworth... 683 & $\ldots \ldots \ldots \ldots 44$ \\
\hline rdson v. Cook......... 560 & $\ldots \ldots \ldots 60$ \\
\hline ichard on v. Denver....... 456 & $\ldots \ldots \ldots 524,52$ \\
\hline an...... 200 & $\ldots \ldots \ldots 37$ \\
\hline$\therefore \ldots 372,374$ & 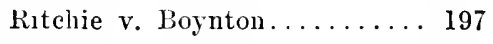 \\
\hline n....497, 498 & $\ldots \ldots 1,4,34$ \\
\hline n...... 98 & $\ldots \ldots \ldots 27$ \\
\hline ichardson r. Horn......... 600 & legraph Co.. 29 \\
\hline ardson v. Horton....... 374 & 1се Co.....16, \\
\hline ardson v. Pate........ 5 & $\ldots \ldots \ldots \ldots 26$ \\
\hline ardson v. Pierce........ 134 & $\ldots \ldots \ldots 646$, \\
\hline ns....... 122 & $11 \ldots \ldots 555,5$ \\
\hline ntree..... 293 & $1 \ldots \ldots \ldots 52$ \\
\hline ardson v. Shaw....... 572 & ins v. Cutler........... \\
\hline ichardson v. Strong..49,471, 484 & Robbins v. Eaton.......27, \\
\hline ichardson v. Williams, .... 432 & $r \ldots \ldots \ldots 46$ \\
\hline nd v. Moor & elly Taxing Dist 55 \\
\hline ichmond v. Toothaker...... 368 & $e \ldots \ldots \ldots 10$ \\
\hline $\begin{array}{l}\text { Richmond, etc. R. R. Co. v. } \\
\text { Jones . . . . . . . . . . } 299\end{array}$ & $\begin{array}{l}\text { Roberson v. Box Co } \ldots \ldots \ldots \ldots \\
\text { lioberts v. Adams . . . . . . . } 34\end{array}$ \\
\hline $\begin{array}{l}\text { Richmond, ete. R. R. Cu. v. } \\
\text { Tobacco Co } \ldots \ldots \ldots \ldots \ldots 5\end{array}$ & $\begin{array}{l}\text { Roberts v. Barnes.......184, } 18 \\
\text { Roberts v. Carter......... } 50\end{array}$ \\
\hline Richter v. Pappenhausen.... $3{ }^{7} 4$ & Roberts v. Cocke.......... 55 \\
\hline icketts v. Jolliff.......22, 23 & \\
\hline - & berts $r$. \\
\hline
\end{tabular}


Roberts v. Rock Bottom Co.... 134

Roberts v. Wiggin.......... 71

Robertson v. Deatherage..388, 436

Robertson v. Frank........ 497

Robertson v. Lockie........ 15

Robertson v. Railroad Co.... 295

Robertson v. Smith......... 370

Robertson v. Van Cleave.... 564

Robinson v. Barrows....... 416

Robinson v. Bland......396, 420

Robinson v. Coulter........ 26

Robinson v. Davison..475, 589, 659

Robinson v. Eastman....... 460

Robinson v. Green...... 164, 204

Robinon v. Harman........ 683

Robison v. Hornbaker....... 92

Robinson v. Hyer......682, 698

Robinson v. Mandell....... 466

Robinson v. Maxcey........ 389

Robinson v. Queen......... 397

Robinson v. Raynor......481, 589

Robiuson v. Smith.......212, 387

Robinson v. Texas Pine Land

Asso .............. 315

Robinson v. Weeks.....26, 27, 43

48,62

Robinson v. Welly.......... 440

Robson v. Calze.......... 503

Robson v. Drummond...457, 519

Robstelli v. Railroad Co..... 292

Rockford, etc. R. R. Co. v. Sage 463

Rock Island v. Mercer County. 129

Rockwell v. Bank......... 232

Rockwell v. Hubbell......... 558

Rodeeker v. Littauer........ 212

Rodemacher v. Railroad Co.... 537

Rodgers v. Maw........... 464

Rodgers v. Raulroad Co.....583

Rodick v. Gandell......... 526

Roe v. Kiser............ 206

Roebling Sons Co. v. Fence Co. 594

Roehl v. Haumesser......... 99

Rochm v. Horst........... 594

Logers v. Allen........... 555

Rogers v. Blackwell....9, 22, 24
Sec.

Rogers v. Buckingham...... 228

Rogers v. Gosnell... . . . . . . 362

Rogers v. Greenbush . . . . . . 456

Rogers v. Hardware Co...... 128

Rogers v. Hillhouse. . . . . . . 629

Rogers v. Palmer.......... 503

Rogers v. Sanders.......... 625

Rogers v. Steamboat Co..... 295

Rogers v. Union stone Co.356, 357

Rogers v. Van Nortwick..625, 626

hogers v. Walsh..........571

Rogers v. Weaver.........4453

Rolland v. Hart......... 503

Roller v. Ott........312, 317

Rollins v. Marsh.......73, 74

Rollins' Invest. Co. v. George. 674

Rome, etc. R. R. Co. v. Sullivan 290

Romero v. Newman........ 588

Rondeau v. Wyatt......... 139

Roodes v. Suithurst. . . . . . 629

Roodhouse v. Roodhouse..... 37

Root v. Railroad Co.....290, 325

Roper v. Johnson........... 604

Rose v. Munford........... 217

Rose v. Park Bank... . . . . . . 399

Rose v. Railroad Co..288, 293, 295

Rose v. Savory... . . . . . . . 427

Rose v. Truax............. 284

Rose v. Wallenburg........ 96

Rosenblatt v. 'Townsley...... 192

Ross v. Allen............ 92

Ross v. Milne........... 36I

Ross v. Railroad Co........ 536

Ross v. Scott. . . . . . . . . . 492

Ross v. Welch........... 151

Rossiter v. Miller......... 89

Rothschild v. Mack........ 506

Rothwell v. Dean..........665

liottman v. Fix............ 122

Roundtree v. Baker.....402, 413

Roundy v. Thatcher........ 62

Rousillon v. Rousillon....309, 311

314,408

liow v. Dawson........... 526

Rowan v. Hyatt......... 352 
Sier.

Rowland v. Bull.......... 216
Rowley v. Stodrlard......377, 379

Roxbury v. Railroad Co..... 541

Roycroft v. Tayntor........ 344

Rucker v. Cammejer........ 87

Rucker v. Harrington....... 81

Ruckman v. Bergholz........ 175

Rudolf $\mathrm{v}$. Winters........... 255

Ruggles r. Illinois.......... 539

Ruggles v. People......... 538

Ruhe v. Buck............ 419

Rumsey v. Berry....249, 251, 255

Rundlett $\vee$. Weber......... 205

Runnells v. Bosquet.....55 5, 518

Ruple v. Bindley.......515,518

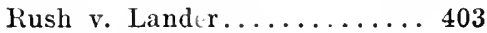

Rushing Reduction Co. v. Hil-

liard ............. 128

Rusk v. Fenton.......... 22

Russell v. Allen........... 567

Kussell v. Bell........... . 464

Russell v. Burton............ 284

Russell v. Clarke......... 159

Russell v. Jackson... . . . . . . 503

Kussell v. Murdock.......... 192

Russell v. Telegr. Co....... 693

Rutherford v. McIvor.......450

Rutland R. R. Co. v. Railroad

Co ............... 531

Rutledge v. Price County.... 456

Ryalls v. Moody.........664

Kyan v. Clanton.......... 402

Ryan v. Dayton........... 474

Ryan v. Douglass County.... 519

Ryan v. Growney......... $6 \vec{t}$

Ryan v. Lynch........... 460

Ryan v. Potwin........... 173

Ryan v. School Dist.......201

Ryan v. Smith.......... 44

Kyan v. United States....... 85

Ryde v. Curtis.......... 96

Ryder v. Wombwell.......40, 41

Kydon v. Walcott......... 599

Rylands v. Fletcher........5 584

Ryno v. Darby........... 192
Sabin Sec.

Sabin v. National Union...... 20

Sife Co. v. Ward.......... 351

Safety Deposit L. Ins. Co. v.

Smith . . .......... 425

Safford v. Wyckoff........ 505

Sage v. Wilcox............ 79

Sager v. Railroad Co........ 2SS

Said r. Stromberg.......180, 412

Sale r. Lambert........... S9

Salentine v. Ins. Co........ 20

Salesbury v. Herchenroder... 583

Salinas v. Bennett......27, 60

Salladin v. Mitchell....... 506

Salmon Falls Manuf. Co. $v$.

Goddard............ S5, S6, 89

Salt Co. v. Guthrie... . . . 320, 321

Salt Marsh v. Bank......... 212

Salter v. Howard........... 344

Sampson v. Shaw.......... 255

Sampson v. Townshend...... 274

Samson v. Freedman....... 427

Samuel v. Marshall......... 8

Samuel v. Thomas......... 485

Samuels v. Oliver......... 250

San Antonia, etc. Co. v. Wilson 2

Samborn v. Flagler......89, 90

Sanborn v. Goodhue........ 425

Sanborn v. Merrill.......... 129

Sanborn v. Sanborn........ 97

Sanderlin v. Willis.........698

Sanders v. Filly.......... 363

Sanders v. Gillespie........ 123

Sanders v. Johnson......... 187

Sanders v. Rodway......... 677

Sanders v. Stuart......... 297

Sanderson $v$. Rating Co....668

Sandford v. Kane.......... 228

Sandford v. Railroad Co.... 306

San Diego Gas Co. v. Frame.. 305

San Diego Water Works v.

Flume . . . . . . . . . 322

Sandren r. Railroad Co...... 464

sands v. Potter........... 10

Sandwich Manuf. Co. v. Herriott .............. 368 
Sec.

Schmidt v. Thomas ....... 145

Sanger v. Rothchild........ 269 Santa Clara, etc. Co. v. Hayes 320 Sapp v. Cobb............. 213 Sapsford v. Fletcher........441

Sargent v. Butts.......... 192

Sarles v. Sharlow.......... 133

Sartwell v. Horton......... 497

Satterlee v. Mattnewson..... 532

Saterlee v. United States.... 665

Saul v. Creditors......... 401

Saunders v. Saunders. . . . . . 363

Saurdsfeger v. State....... 356

Sarage v. Gregg. . . . . . . . . 524

Savage v. Lee............ 113

Savage v. Lichlyter........ 51

Saville v. Welch........... 446

Savings Bank v. Burnes..... 330

Savings Bank v. Ward....... 348

Sawyer v. Bank........... 462

Sawyer v. Davis........... 538

Sawyer v. Lufkin. .11, 12, 471, 472

Sawyer v. Smith........175, 204

Sawyer v. Ware.......139, 146

Saxe v. Womack ......... 214

Saxton v. MIeNair........ 703

Sayles v. Wellman ........ 192

Sayward v. Gardner ........ 91

Scales v. State .....181, 248, 249

$252,255,256$

Scanlon v. Cable .......9, 14, 22

Scarth v. Ins. Co......... 19, 20

Sceva v. True ........... 11

Schafer v. Bank......... 128

Schafler v. Lovsette........ 27

Schaps v. Lehner .......... 22

Scheffer v. Ins. Co.... 17, 19, 20

Scheible v. Klein.......474, 660

Schilling v. Black ......... 386

schilling v. Mullen ........ 508

Schlee v. Guckenkeimer . . . . 254

Schloss v. Hewlett ......283, 577

Schmertz v. Dwyer ........ 398

Schmidt v. Glade ......... 365

Schmidt v. Ittman ........ 29

Schnidt v. Pailroad Co......691

Schmitheiner v. Eiseman .... 67

Schmoling v. Thomlinson .... 339

340,457

Schneider v. Schiffman ...... 128

Schneider v. Turner . . . . . . . 254

Schnell v. Chicago ........ 67

schofield v. Gaskill ........ 388

Schofield v. Railroad Co..... 306

scholefield r. Templer ...... 503

School Dist. v. Dauchy....580, 5S7

School Trustees v. Bennett.573, 587

Schoonorer v. Vachou ...479, 627

Schreiner v. Orr . . . . . . . . . 249

Schroeder v. Loeber ....... 109

Schroeder v. Wanzor ........ 106

Schrweppel v. Corning ...... 500

Schucy v. Schaefer ........ 106

Schufl v. Rawson ......... 21

Schuler v. Israel ......... 506

Schultz v. Culbertson ....... 499

Schultz v. Ins. Co......... 19

Schultz v. Johnson ........ 519

Schumacher v. Eiley ......... 398

schuster v. Railroad Co...... 365

Schuyler v. Curtis ........ 340

Schwab v. Pierro .......... 108

Schwab v. ligigy .......... 185

Schwartz v. Saunders ....... 659

Schwenk v. Wyckoff ...... 283

Schwenk v. Wycks ....... 517

Śchwinger v. Hickok ....... 448

Scioto Brick Co. v. Pond .... 571

Scofleld v. Gaskill ......... 436

Scotland County v. Ewing .... 452

Scotland County v. Hill .... . 399

Scott v. Brown ........65, 163

Scott v. Buchanan ....27, 32, 55

S'cott v. Gilmore ... . . . . . . . 204

Scott v. Godwin .......... 377

Sicott v. Pertce ........... 417

sicott v. Porter ........... 37

Ścott v. Saflord .......... 222

Scott v. White .......... 128

Scoville v. Canfield ........4 419 
Sec.

Scranton v. Stewart ....... 26

Seribner v. Collar ......... 45I

Seruggs v. Driver ......... 571

Seruggs v. Mort. Co......... 208

Seudder v. Bank ...116, 124, 240

$395,419,420$

Scully v. Kirkpatrick.475, 589, 659

Scully v. Scully .......458, 460

Seamons v. Knapp Co...... 404

Searcy v. Hunter . . . . 57, 61, 66

Searles v. Galbraith ......8, 10

Searles v. Pipkin ........ 11

Sears v. Smith .......... 135

Sears v. Starbird ......... 433

Seary v. Drake ........... 106

Seattle v. Libcrman ........ 523

Seaver v. Phelps ...9, 14, 22, 471

Seaver v. Young ..........6 635

Second Nat. Bank v. Grand

Lodge . ..........354, 356

Secret Service Co. v. Manuf. Co. 668

673

Seddon v. Rosenbaum ..... 134, 137

Sedgwick v. Stanton .....276, 284

Seeman v. Inman ......... 87

Segeson v. Leaky.......... 25

Seibert v. Lewis . . . . . . . . . 555

Seigman v. Hoffaeker ...363, 364

Selby v. Jackson .......25, 472

Selby v. Railroad Co.......617

Selby $v$. Selby ........... 97

Seldon v. Preston ........ 580

Sellers v. Botsford ........ 237

Selliot v. French .........691

Semmes v. Ins. Co........ 576

Semmes v. Worthington ...... 114

Seneca Nation v. Christy .... 531

Senescal v. Bolton ........ 373

Sennett v. Shehan ......... 480

Sergeant v. Stryker ....... 445

Seton v. Slade ........... 600

Severance v. Kimball ....... 498

Sewell r. Eaton .......... 149

Sewell v. Sewell ......... 67

Sewing Machine Co. v. Barnard 22
Sec.

Sext v. Geise ........... 132

Seymour v. Delancey ...... 667

Shaaber v. Bushong ........ 131

Shackell v. Rosier ......... 164

Shafer v. Riley ......... 508

Shatler v. Mining Co.1, 2, 515, 541

Shafher $v$. State ......... 31

Shakespeare v. Markham .... 466

Shane v. Simith ......... 481

Shankel v. Moffat ........ 274

Shanion v. Comstock ....... 687

Shapley v. Abbott ........ 276

Sharp v. Carroll ........ 156

sharp v. Robertson ....... 66

Slıarp v. Robinson ......... 27

Shaver v. McCarthy ....... 5

Shaver v. Railroad Co....... 300

Shaw $v$. Berry ......... 585

Shaw v. Clark ....249, 257, 413

Shaw v. Graves ......... 457

Shaw v. Ins. Co.......... 594

Shaw v. Lumber Co........ 145

Shaw v. Railroad Co....... 512

Shaw v. Pratt .......... 379

Shaw v. Shaw .......... 480

Shaw v. Spencer ......... 358

Slaw v. 'T'ompson ......... 11

Shaw v. Woodcock .......... 100

shed v. Pierce ........... 376

Shed v. Prince .......... 379

Sheehy v. Nandeville ....... 370

Sheehy v. Shinn ......248, 253

Sheer v. Wright .........659

Sheffield, etc. R. R. Co. v. Gor-

don ................6 643

Sheldon v. Hactun ........ 240

Sheldon v. Railroad Co...... 293

sheldon v. Willians ....... 393

Shepard v. Gals Llight Co.303, 307

Shepardson v. Cary ....... 513

Sherbourne v. Sllaw ....... 88

sher burne v. Fuller ......... 108

Sherburne v. Hartland ..... $\quad 29$

Sherman v. Barnird ....... 571

Sherman v. Blackman ...... 212 


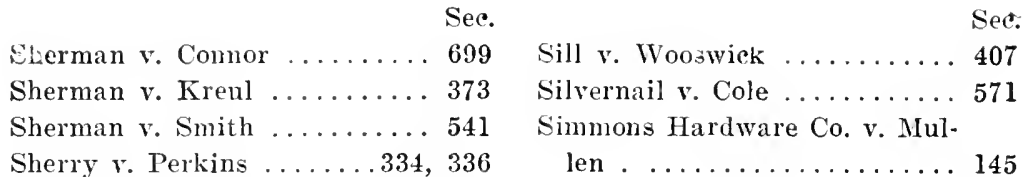

Sherwood v. Archer ........ 234

Sherwood $v$. Stone ......87, 128

Shields v. Land Co......... 532

Shields v. Ohio ......... 541

Shirk v. Shultz .....58, 60, 64

Shirley v. Shirley ........ 98

Shipley v. Bumn ....26, 57, 58

Shipley v. State ......... 188

Shipman v. Bank ........4 428

Shipton v. Casson ........ 478

Shivers v. Newton ........ 542

Shober, etc. Co. v. Kertney.... 309

Shoe Co. v. Saxey ........ 336

Shoemaker v. Benedict ...384, 634

Shook v. Vanmeter ......... 128

Short $v$. Blount .......... 124

Short v. Stone .......... 607

Shorter v. Smith ........ 535

Shoulters v. Allen .......14, 22

Shoup v. Wills ......... $453^{\circ}$

Showalter v. MicDonell ...... 80

Shrainka v. Schoringhausen... 322

Shrock v. Cowl .......... 66

Shropshire v. Burms ....... 27

Shubrick v. Adams ........ 624

Slunfelt v. Shufelt ........ 237

Shuler v. Millsap ........ 476

Shumate v. Farlow .....134, 137

Shulz v. Johnson ...475, 589, 590

Shurman v. Thompson ...... 204

Shurtleff v. Millard ........ 43

Shute v. Dorr ........... 480

Sickles v. Flanagan ........ 230

Sickles v. United States...... 591

Siedenbender v. Charles ...... 178

Siefel v. Ins. Co.......... 482

Siegel v. Drumm .......... 229

Siegel v. Eaton.......573, 665

Siegrist $v$. Arnat ........ 295

Siemens v. Siemens ........ 93

siler v. Gray ........589, 590
Simmons v. Telegr. Co......693

Simon $v$. Brown .......... 348

Simons v. Almy .......... 74

Simonton v. Bacon .......7, 22

Simpson v. Bank ........ 560

Simpson v. Bloss .......... 162

Simpson v. Brown......351, 352

Simpson v. Castle ......... 567

simpson v. Harris ........ 128

Simpson v. Nance ......... 129

Simpson v. Nicholls ........ 192

simpson v. Robert . . . . . . 129

Simpson v. Vaughn ........ 374

Sims v. Bond .........359, 360

sims v. Clark ........... 382

Sims v. Everhardt . . .56, 67, 68

Sims v. Hutchins ... 101, 102, 480

Sims v. MeEwan ........ 100

Sims v. Mchure ......... 472

Sims v. Landray......... 87

Sinclair v. Talmadge ...6640, 653

Singer Mach. Co. v. Lamb. .65, 66

Singerly v. Thayer ....... 639

Singleton v. Hill ........ 85

Singstack v. Harding . . . . 138

Sinking Fund Cases .....306, 541

Sinnott v. Colombet ....... 201

Skillin v. Merrill ......... 435

Skinner v. Garnett ....... 2

Skinner v. Maxwell ......27, 53

Skinner v. Plaisted ........ 26

Skimner v. Santa Rosa ..... 278

skipper v. Stokes......... 518

Skudder v. Bank .......390, 401

Slacum v. Pomery ......... 24l

Slade v. Arnold .......... 183

Slater v. Foster .........662 662

Slatter v. Meek .........80, 100

slaughter House Cases....... 4

slayton v. Barry ........ 57 singer $v$. MeCormick ...... 619 
Sec.

Sleeper $\vee$ Railroad Co....... 293 Sleigh v. Sleigh .......430, 431

Slingersby's Case ........ 377

Sloan v. Williams ........ 519

Slocum v. Assurance Co..... $\$ 10$

Sloo v. Pool ............ 392

Simall v. Atwood ........ 367

Small v. Jones . . . . . . . 165, 169

Simalley v. Greene .... . . 133, I34 $137,309,319$

Smallwood v. Sheppards ..... I11

Smart v. Cason ........... 129

Smart v. Sanders .........622

Smeed v. Foard ....683, 681, 688

Smith v. Alabama ......... 550

Smith v. Alkire .......... 579

Smith v. Arnold .......... 197

Smith v. Baker ........464, 487

Smith v. Bank ... . . . . . . . 128

Smith v. Bean ........... 195

Smith v. Benefit Soc........ 16

Smith v. Black .......... 370

Smith v. Bouck ........... 144

Smith v. Bradley .......... 79

Smith v. Brady ....477, 478, 639 $640,655,666$

Simith v. Brenman .......... 145

Smith v. Bromley ......172, 500

Smith v. Brown .......... 312

Smith v. Bruning ......275, 500

Smith v. Case ........... 192

Smith v. Chapman ........ 373

Smith v. Church .......... 473

Smith v. Clark .......... 166

Smith v. Clay ........... 626

Smith v. Coal Co........... 590

Smith v. Condry......6695, 697

Smith v. Coon ............6 634

Smith v. Cross ......... 230

Smith v. Cufl ............. 171

Smith v. Delaney . . . . . . . 129

Smith v. Evans ......... 71

Smith v. Express Co........ 290

Sinith v. Finch ........... 128

Smith v. Franklin ........ 371
Sec.

Sinith v. Gray ........... 53

Suith v. Greenlee . . . . . . 165, 168

Sinitlı v. Gugerty ......... 655

Simith v. Hayward ......... 603

S'mitl v. Hollister ......... 235

Sinith v. Humphrey . . . . . . . 274

Smith r. Hyde .......... 96

S'mith v. Ingram ......4401, 403

Smith v. Johnson .......... 460

Smith v. Jones .........83, 521

Smitlı v. Mason .....389, 390, 391

392,393

Simitl v. Marvin ........... 210

Simith v. Mawhood ......175, 196

Smith v. Mayo ......665, 66, 124

Simith v. McLean .......... 402

Sinith v. Meeting House ..... 473

Simith v. Miller ........... 368

Smith v. Milligan .......... 460

Smith v. Mitchell ........170

Smith r. Morris .......... 660

Smith v. Morrison ..........559

Smith v. Neale .........82, 98

Smith r. Northrup .......94, 95

Smith v. O'Dommell ........ 608

Smith v. Packard ......... 559

Smith v. Parsons ...216, 240, 241

396,420

Smith v. Philbrook ....... 75

Smith v. Railroad Co.183, 616, 684

Smith v. Rowley .......... 500

Smith v. Sayward ......... 123

Smith v. School Dist........ 473

Smith v. Shell ............ 91

Smith v. Sheltering Arms..647, 655

Smith v. Silvers . . . . . . . . 229

Smith v. Smith . . . . 103, 105, 142 $402,425,470,508$

Smith v. Sparrow ........ 187

Smith v. Stone........... 377

Smith v. Tiden .......... 571

Smith v. Trust Co......... 642

Smith v. Ulman .......... 169

Smith v. Watson ......... 188

Smith v. Wheeler ......... 609 
See.

Sec.

Smith v. Whitaker ........ 402

South v. Strawbridge ....... 82

Smith v. White .......... 274

Southcombe v. Bishop ....... 625

Smith v. Wilcox ....... 186, 194

Southern Build. \& Loan Asso.

v. Harris ........... 219

Smith v. Will ............ 8

Smith v. Woodin ......... 479

Smith's Appeal ......99, 312, 322

Smock v. Smock ......... 137

Southern Express Co. v. Glenn 615

Southern Express Co. v. Hunnicutt . . . . . . . . . . 289

Smoot's Case ........... 594

Smythe v. Allen .......... 233

Smyth v. Ames .......... 539

Smyth v. Munroe ........ 276

Simyth v. Ward ......... 640

Sneed v. Bradley .......... 1!4

Sneider v. Heidelberger ..... 558

Snelden v. Harmes ........ 521

Snell v. Brown ...........646

Snell v. Cottingham .....664, 685

Snell v. Dwight .......... 321

Snell v. Harris ........... 64

Snell v. Ins. Co........... 4.52

Snell v. Ives ............ 365

Snelson v. State .......449, 452

Snider v. Yates .......... 402

Snow v. Warner ........... 151

Snowden v. Dulavey ....... 9

Snyder v. Kirtley .......3s8, 436

Snyder v. Willey .......... 275

Soames v. Spencer ........ 90

Sobey v. Brisbee ......... 135

Solan v. Railroad Co........ 292

Solinger v. Earle ......... 172

Solly v. Forbes ........376, 378

Soloman v. Dreschier ...... 205

Somerby v. Buntin ........ 144

Somer's v. MeLaughlin ...... 150

Somers v. Pumphrey ......6, 22

Somes v. Beaver ......... 11

Somes v. Brewer .......... 21

Sondhein v. Gilbert ....395, 413

soper v. Gabe ...........6.6.8

Sortnell v. Hughes..........4 409

Sottomayor v. De Barras..... 400

Sunch v. Strawbridge..98, 134, 137

Soule v. Albee ........... $1 \geq 9$

Southern Express Co. v. Palmer 352

Southern Pacific R. R. Co. v.

United States ..........401

South Royalton Bank v. Bank. 345

South Seituate v: Hanover.430, 432

South Wayles R. R. Co. v.

Wythe ............677

Southwick v. Bank ........ 504

Spain v. Hamilton ......508, 515

Spalding v. Ewing ......284, 285

Spalding v. Oakes ....... 437

Spalding v. Rosa ...475, 589, 658

Sparman v. Keim...26, 43, 58, 66

Spaulding v. Ludlow ....... 357

Spear v. Bank ........96, 124

Spear v. Bach ........... 151

Spears v. Hartley .........6 629

Spencer v. Ayrault ........ 208

Spencer v. Cone ........... 140

spencer v. Parry ......... 442

Spencer v. Trafford ........ 458

Spengler v. Snapp ........ 237

Sperry v. Fanning ....... 75

Spetz v. Railroad Co....... 300

Spicer v. Earl ........... 62

Spickler v. Marsh ........613

Sipies v. Bank .......... 399

Spiller v. Skating Rink .... 360

Spoftord v. Railroad Co..... 325

Spoor v. Newell ......... 486

Spotswood v. Barrow ....... 275

Sprague v. Cochran ........ 103

sprague v. Haines ........ 110

Sprague v. Warren ........ 256

spratt v. Spratt ........ 5

Spring v. Haskell ......... 684

Spring v. lieed ......... 228 
Sec

Springfield v. Jacobs ....... 198

Springfield Bank v. Merrick... 178

205

Springs v. Railroad Co....... 288

Spring Valley Water Works v.

Schottler ..........538, 541

Squire v. Hydliff.......43, 162

Squire v. Tellier ......... 1

Staat v. Evans .........446

Stack v. Cavanaugh ...61, 65, 67

68,70

Stack v. Sperry .......... 216

Stackpole v. Symonds ...... 185

Staey v. Kemp ........... 194

Stafford v. Devereaux ...... 460

Stafford v. Roof ........ 58

Stamper v. Temple ........ 281

Stauberry v. Smythe...... 526

Standard Cotton Oil Co. v.

Adoue ............... 313

Standard Mill Co. v. Flower. . 249

Standard Oil Co. v. Murry.... 348

Standard Tube v. Inter Union. 336

Stanford v. McGill ......... 594

Stanhilber v. Ins. Co....... 404

Stansell v. Trust Co........ 228

Stanton v. Allen......... 305

Stanton v. Singleton ...... 668

Stanton v. Wilson ........4468

Stark v. Olson ...........4 403

Stark v. Parker .......... 474

Stark v. Raney .......... 129

Starns v. Dillingham ...... 488

Star Publishing Co. v. Associated Press ............ 322

Starr Cash Car Co. v. Reinhardt . ...........4 490

Startup v. Macdonald ...661, 645

St. Andrew v. Manut. Co..... 507

st. George v. Biddeford ..... 13

St. John v. Ins. Co........ $26 \pi$

st. Joseph's Academy v. Augus-

tine . ...............

St. Joseph, etc. R. R. Co. v.

Palmer .......28s, 290, 291
St. Joseph, etc. R. R. Co. v.

Ryan . .............. 302

St. Louis Agricultural, etc.

Asso. v. Delano .......... 180

st. Louis, etc. Railroad Co. v.

Clark . ............. 113

St. Louis, etc. R. R. Co. v.

Dorman ...........6 617

St. Louis, etc. R. R. Co. v.

Gill ............5 539

St. Louis, ete. R. R. Co. v.

Mathews . ........... 302

St. Louis, etc. R. R. Co. v.

Nelson ............. 295

St. Louis, etc. R. R. Co. v.

Paul ............... 2

St. Louis v. Gas Light Co.... 303

st. Louis Life Ins. Co. v.Graves 18

St. Louis Nat. Bank v. Gay... 507

St. Patrick's Church v. Abst.. 458

State v. Addington ......5 5 2, 5₫3

State v. Ambs ............ 181

State v. Bain ..........6 640

State v. Baum ........... 181

State v. Bernheim ........ 173

State v. Bladen County ..... 584

State v. Board .......... 530

State v. Boneil ..........270

State v. Bonham ......... 200

State v. Bott .......... 181

State v. Broadbelt ........ I

State v. Brown, etc. Co.....1, 2

State v. Bryant .......... 270

State v. Buchanan .......4, 544

State v. Bunce .......... 26

State v. Cadigan .......... $1 \subseteq 8$

State v. Campbell......... 542

State v. Chandler ........ 386

State v. Clark ........... 270

State v. Clover .......... 277

State v. Coal and Coke Co.1, 2, 534

540

State v. Collier ........... 282

State v. Cone ............ 31

State $v$. Considine ....... 544 


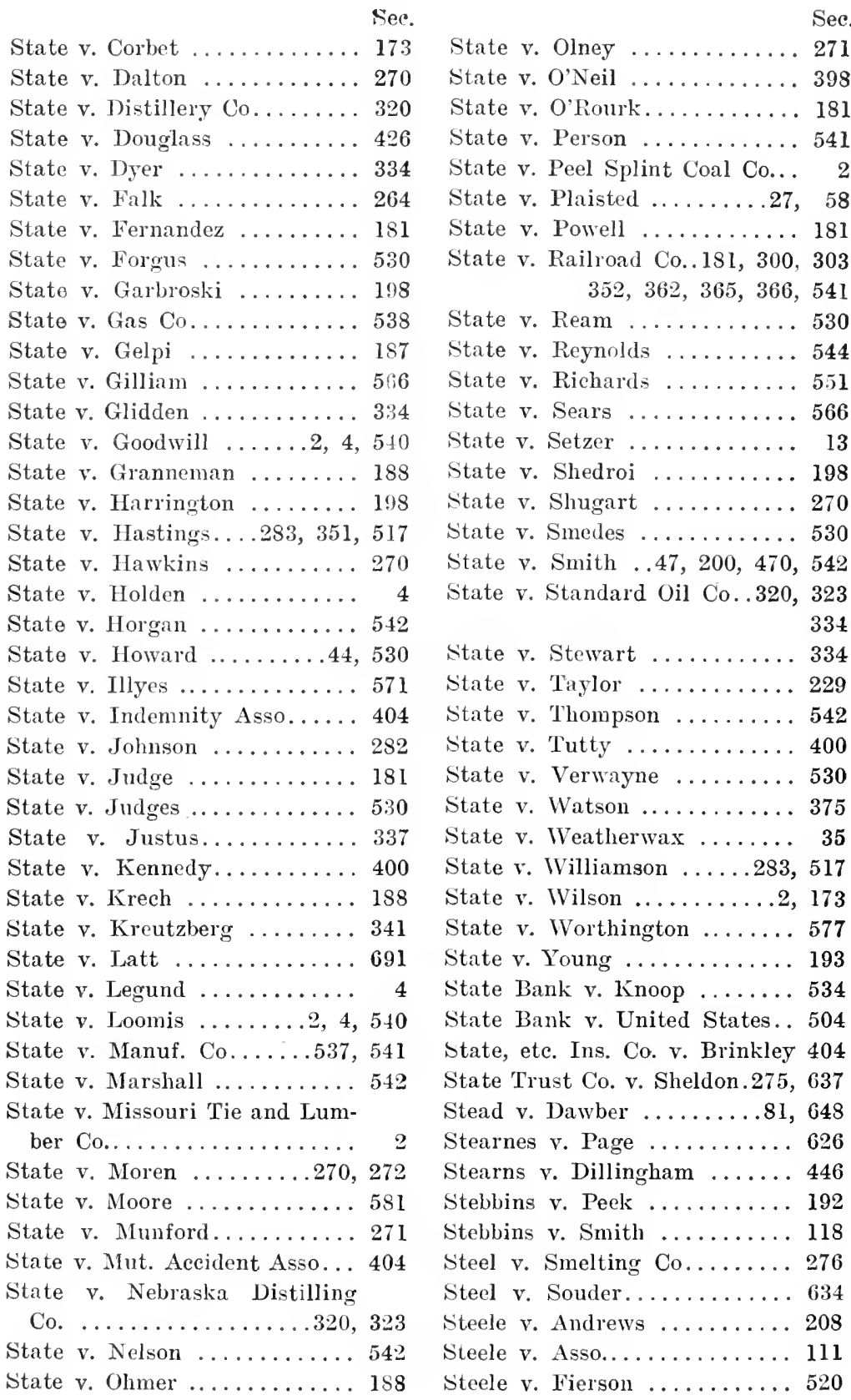


Sec.

Steele v. Railroad Co....... 530

Steele v. Williams ........ 452

Steene v. Ayleswortl ... . 352, 364

Steere r. 'Trebileock ........ 185

Stees v. Lconard ......... 573

Steffes v. Lemke ......... 382

Stein v. Bienville Co....... 534

Stein r. Swenson ....... 228, 237

Steiner v. Clisby. 486, 48s, 491, 494

Stephens r. Bank......... 2:32

Stephens r. Board......... 504

Stephens r. Olson ......211, 230

Stepliens v. hailroad Co..... 274

Stephenson v. Osborne ...... 550

Stern v. Dermis ......... 576

Sterens r. Benning ........ 519

Stevens r. Catlin ......... 371

Stereus v. Cincin. Enquirer Co 270

Sterens v. Goodsell ........4 453

Stevens v. Hay ............ 129

Stevens v. Lce .........110, 479

Sterens r. Warren ........ 266

Stevens v. Webb ........ 577

Stevenson v. Ewing ... . . . . . 198

Stevenson v. Gray ......... 400

Sterenson v. Kyle .........517

Steward v. Conner ......... 44.5

Stewart v. Ahrenfeldt . . . . . . 427

Stewart v. Davis .......188, 190

Stewart v. Flint ......... 7

Stewart v. Ins. Co......513, 514

Stewart v. Jerome ........ 128

Stewart v. Lispenard ....... 7

Stewart v. Loring ......475, 585

Stewart v. Mallon ......... 320

Stewart v. McQuade ........ 664

Stewart v. Petree .......... 222

Stewart v. Railroad Co...... 325

Stewart v. Schall .......... 249

Stewart $v$. Stewart .....106, 449

Stewartson v. Lathrop ...... 198

Sticker v. Overpeck......... 666

Stickney v. Moore ......222, 224

Stiger v. Burt ........... 238

Stiles v. MeClellan ........ 98
Sec.

Sitillwell, ete. Co. v. Phelps ... 666

Stix v. Matthews .......395, 408

Stocker v. Brockelbich ..... 677

stockett v. Watkins ....... 489

Sitorkiner $v$. Hunt ......... 560

Stocks v. Dobson .......... 508

Stoddard v. Martin ....... 246

Sitodhard v. Lee .......... 473

Stokes v. Niw Tork ....... 540

Sitokes $v$. Stokes .........668

Stondenmeier v. Williamson... 120

Stone v. Browning ......14], 147

148,149

Stone v. Dennison .....34, 80, 482

Ftone v. Dickinson ........ 375

Sitone v. Graves ........... 188

Situme v. Lidderdale ......2s3, 517

Stone v. Mississippi ......273, 532

546,547

Stone v. Porter .......... $3 \$ 99$

Stone v. Railroad Co.203, 538, 539

Stone v. State .......... 87

Stone v. Stone ........... 48l

Stone v. Todd ........... 460

Stone v. Trust Co.......... 539

stone v. Walker ........... 122

Stone v. Wilbur .......... 7

Stone v. Wisconsin ........ 539

Storer v. Gordon ......... 615

Storer v. Railway Co......676

Stormont v. Assurance Co.... 18

Story v. Soloman . . 245, 249, 255

Storz v. Finkelstein........ 205

stout v. Ennis ........... 279

Stouthall v. Farish ........ 208

Stover v. Duren ........... 624

Stowell v. Drake .......... 371

Stowell v. Robinson ........ 81

Stowers v. Hollis .... 30, 33, 134

Straight v. Wright . . .93, 94, 96

Strathman v. Gorla ... . . . . . 284

Straus v. Wessel ......... 512

Strauss v. Meertief .......6611

strawbery Point Bank v. Lee. 399

Stray v. Russell ........... 448 
Sec.

Sec.

Streatfield v. Halliday . . .382, 286

Street v. Blay .......4496, 612

Street v. Varney Electrical Supply Co.............. 4

Streeter v. Life and Accident

Soc. . .............. 20

Strickland v. Burns........ 445

Strickland v. Hamlin ...... 124

Strickland v. Turner ...... 572

Stringfield v. Heiskell ...... 519

Strobridge Litho. Co. v. Crane 677

Strohn v. Railroad Co...... 582

Strong v. Bird .......... 360

Strong v. Foote ......... 43

Strother v. Butler ......... 464

Strubbles v. Railroad Co.... 492

Struthers v. Drexel . . . . . . 209

Stuart v. Baker ......... (it

Stuart v. Marvel ......... 64l

Stuart v. Sears . . . . . . . 454

Stuart v. Railway Co....... 672

Stuart v. Telegr. Co.........6 $6 ! 3$

Stublins v. Mlitehell....389, 390

Studholme v'Mandell....... 577

Studley v. Borth.......... 125

Studwell v. Shapter.....67, cis

Stull's Estate..................

Sturdivant v. Bank....... 417

Sturgis v. Bank.......... 130

Sturges v. Crowninshield 557

559,561

Stuht v. Sweesy.......... 105

Sturt v. Mellieh..........633

Sturtevant v. Armsby Co... 406

Stutz v. Dickey.......... 136

Sucession of Cassidy....... 403

Suecession of Gaines....... 26

Succession of Jackson....473, 620

Suceession of Larendon...... 403

Succession of Latchford...208, 219

Succession of Voorhies...... 634

Sugarman v. State....... 581

Suggett v. Cason......... 82

Sugworth v. Lellel........ 612

Suit v. Woodhall......409, 503

Sullivan v. Association...... 219

Sullivan v. Flynn........22, 23

Sullivan v. McMillan.686, 687, 691

Sullivan v. Sullivan..115, 395, 398

Summerfield v. Teleg. Co.... 693

Summers v. Clark......... 435

Sumners v. Huston........ 508

Sumner v. Jones........... 192

Sumner v. Powell.......372, 374

Sumner v. Williams........ 485

Supreme Commandery v. Ains-

worth ...........16, 19

Superior Con. Land Co. v. Bick-

ford ................ 385

Supervisor's v. Briggs....... 452

Supervisors v. Galbraith..... 399

Suppiger v. Ins. Co......... 20

Susong v. Vaiden......... 374

Sussex Peerage Case....... 178

Sutherland v. Briggs....... 98

Sutherland v. Carter....... 122

Sutherland v. Reeve.......508

Sutton v. Head............ 312

Sutton v. Warner........ 400

Suydam v. Clark.......... 571

Swain v. Burnett........ 84

Swain $v$. Lindsey.........628

Swain v. Schiefrelin........685

Swan v. Nesmith.......87, 128

Swan v. West........... 568

Swank v. Hufnagle........ 403

Swann v. Buck.......... 530

Swam v. Scott........... 331

Swann v. Swann. 180, 274, 322, 412

Swanzey v. Moore......80, 474

Swart v. Gale.......... 448

Swartout v. Railroad Co.... 302

Swayne v. Riddle...209, 214, 215

Swearington v. Dairy Co.... 630

Sweatland v. Telegraph Co.... 297

Swedish-Am. Nat. Bank v.

Bank . . . .......... 407

Sweeney v. Hunter......... 540

Sweeney v. Ins. Co........ 260

Sweency v. Mcleod......... 284 
See.

Sec.

Sweeney v. United States....6 642 Taylor v. Mygatt.......... 118

643,645 Taylor v. Palmer........ 519

Sweet v. Lumber Co........ 134

Sweigart $v$ Berk......... 377

Swift v. Beers............ 635

Swift v. Bennett.....33, 48, 49

Swift v. Poughkeepsie.......456

Swift Co. v. United States.... 452

Swigart v. People.......... 264

Swing v. Munson......... 404

Switzer v. Skiles........... 169

Sykes v. Bank.....524, 525, 527

Sykes v. Beaden.......... 330

Sykes v. Dixon........98, 344

Sylvester v. Swain......... 212

Syracuse Water Co. v. Syracuse 534

Taff Vale Railroad Co. v. The Amalgamated Society of

Railway Servants . . ...334, 335

Taft v. Adams............ 426

Taft v. Sergeant......... 66

'lalbott v. Trans. Co......... 421

Tank v. Rohweder.......... 460

'Tapham v. Portland........ 503

'l'arbell v. Railroad Co........ 288

Tarlton v. McGawley....... 342

'I'ate v. Development Co...... 679

Tatum v. Kelly............ 205

Tawney v. Levy............ 8

Taylor v. Allen........... 92

'I'aylor v. Beck........... 655

'l'aylor v. Blanchard......... 318

'laylor v. Boardman....... 407

Taylor v. Bowers........... 275

'Taylor v. Caldwell...572, 589, 657

'I'aylor v. Chester.......161, 409

'Taylor v. Gas and Coke Co.... 175

'laylor v. Hare........... 448

'l'aylor v. Higgins......... 441

'laylor v. Hill............ 29

'aylor v. Jaques........... 499

Taylor v. Lyneh.......515, 522

'laylor v. Marcum.......... 655

Taylor v. Mitehell......... 667

'l'aylor v. Pratt........... 93

'laylor v. Railroad Co....... 288

Taylor v. Read............ 109

'Taylor v. Salmon......... 367

Taylor v. Savage......... 388

'laylor v. Sharp........397, 420

'l'aylor v. Stockwell.....55s, 560

'laylor v. Taylor........357, 373

'l'aylor v. IVilliams........4 477

'Taylor v. Wood.......... 466

T'aylor v. Young........... 185

'leegarder v. Lewis......... 445

'leeters v. Lamborn......... 125

Telegraph Co. v. Adams....... 693

'l'elegraph Co. v. Berringer.... 693

Telegraph Co. v. Carter.....6693

T'elegraph Co. v. Cline.......6 693

'l'elegraph Co. v. Evans....... 693

'Ielegraph Co. v. Griswold.... 297

'lelegraph Co. v. Henderson.. 693

'l'elegraph Co. v. Kirkpatrick.. 693

'lelegraph Co. v. Levy....... 693

¿elegraph Co. v. Piner....... 693

'Telegraph Co. v. Rogers....... 693

''elegraph Co. v. Rosentreter.. 693

'Ielegraph Co. v. Saunders.... 693

'Telegraph Co. v. 'l'exas....... 296

'Lelegraph Co. v. Wenger...... 692

'Jelegraph Co. v. Wisdom...... 693

'l'elegraph Co. v. Wood...... 693

'l'elford v. Albro.......... 612

'Telford v. Garrels...208, 22s, 229

'Tegler v. Shipman........ 398

'l'emperton v. Russell....334, 342

Templeman v. Biddle....... 136

'Templeton v. Bascom....... 121

Templeton v. Russell....... 341

'l'enant v. 'lenant.......... 399

'l'en Eyck v. Manning.... .667, 668

'l'ennessee r. Sneed...... 556, 540

'l'ennessee, etc. R. R. Co. v.

Danforth . . ..........6 699

'lenney v. Evans.......... 72 
Terrell v. Wentworth...... 55

Territt v. Bartlett......177, 205 408, 409

'I'erry v. Auderson.......... 528

Terry v. Eagle Lock Co....... 330 'l'ery v. Munger.......487, 489 T'exas, et,e R. R. Co. r. Railroad Co. . ........... 330

Texas Standard Oil r. Adone.. 321

Thaeher v. Pray..........504

Thacker v. Hardy.......245, 257 'Inallheimer v. Brinckerhoff... 518 Thames v. Jones.......... 36 \% 'Thateher v. Morris......... 408 Thayer v. Allison.........6.621.

'Thayer v. Burchard........ 615 Thayer v. Daniels......... 508 'I'hayer v. Kelley......... 515 'I'hayer v. Juce.......... 85 Thayer v. Star Mining Co.... 225 'I'he Amiable Nancy........ 695 The Anma Maria........... 695 'I'hebald v. Burleign........ 660 'The Bradford City.......... 420 The Elvira Harbeck........ 424 'The Guildhall ..........4 410 The Hadji . . . . . . . . . . . 410 'The Harriman . . . . .568, 569, 573 'The Juliana ........... 3 'The Majestic . . ......293, 295 The Schooner Lively........ 695 'I he Tornado ........... 572 'l'hibodeau v. Hildreth....... 677 Thiebaud v. Furniture Co..97, 678 'Third Nat. Bank v. Harrison. . 257 'Third Nat. Bank v. Steele.... 408 'Tholen v. Duffy............ 208 'l'homan v. Dodge.......... 128 'I'homas v. Armstrong........ 134 'l'homas v. Bartow ......... 600 'I'homas v. Caulkett........ 163 Thomas v. Cohen.......... 515 'Thomas v. Cook........123, 129 Thomas v. Flevry.....643, 646 'Thomas v. Hatch.......110, 619
Thomas v. Hawkes......205, 427

Thomas v. Hunter.......... 186

'Thomas v. Jones. . . . . . . . . . 229

Thomas v. Joslin.......... 99

Thomas $v$. Knowles......... 659

'Thomas r. Lee County...... 509

'Thomas v. Miles........... 312

'Thomas r. Murray......... 210

Thomas v. People......... 271

'lhomas v. Poor............661

Thomas v. Pullis.......... 56

Thomas v. Railroad Co...301, 303 $304,305,330,410,683$

'Thomas r. Sypert.........630

Thomas v. Trustees......... 98

Thomas Fruit Co. v. Start... 650

Thomasson v. Townsend..... 229

'Tompkins v. Dudley ......... 665

'Lhompson v. Alger......... 154

'L'hompson v. Blanehard... .79, 93

'l'hompson v. Bowman....... 384

Thompson v. Davies........ 167

Thompson v. Ellenz........ 406

'Thompson v. Gould........ 571

'l'hompson v. Hamilton....... 66

'l'hompson v. Howard....... 487

'Lhompson v. Ketcham.......4401

'Thompson v. Lay........... 54

'l'hompson v. Leach.....9, 23, 471

'Thompson v. Lee County.... 509

'Thompson v. Lock.......... 378

'hompson v. Marshall...... 62

Thompson v. Parkex....... 355

'Thompson v. Peck......... 498

'Lhompson v. Read........632

'I'hompson v. Richards...... 384

'Ihompson v. Simpson....... 526

Thompson v. Smith........631

'Ihompson v. Strickland...26, 55 'l'hompson v. Taylor....... 401 'thompson v. Telegr. Co..... 693 'lhompson v. Thompson...... 445 I'hompson v. Trustees....... 584 Ihompson v. Van Veehten.... 237 'thompson v. Wood........6 603 
Sec.

Thomson v. Poor...........648 Thormachlen v. Kaeppel...59. 70 Thorn v. San Francisco..... 561 'Thornborow v. Whiteacre... 568 Thornburg r. Masten....... 93 'Thornett r. Haines......165, 496 Thornlill v. Evans......... 222 'thornton v. Dean......... 420 'Thornton v. Kelly........s, 89 'Thornton $r$. Rosenfield...... 406 Thornton v. Sherratt...... 317 'Lhornton v. Wynn........ 140 'L norp r. Bateman........ 460 'Ihorpe v. Railroad Co...534, 536 Thousand Island Park Asso.

v. Tucker............. 320

'Ihrift $v$. Payne........... 474

Ihurston $v$. Blanchard...... 57

Thurston v. Mills......... 446

Thurston v. Percival....... 443

Tibbetts v. George......... 526

Tibbetts v. Gerrish....... 52

Tice v. Freeman......... 85

Tiedman v. Knox........... 512

Tierman v. Jackson........ 521

Tietz v. Tietz........... 442

Tighe v. Morrison.......123, 124

Tilden v. Blair........240, 408

Tilden v. Johnson.......... 492

Tilford v. Roberts......... 156

Iilley v. Damon........... 498

Tillinghast v. Lumber Co... 419

Tillock v. Webb........... 191

Tillotson v. Pritchard....... 403

Tillotsson v. Nye......... 222

Tilton v. Tilton.......... 102

Tiluen v. Blair........... 395

Timberlake $v$. Thayer........ 474

Timothy v. Wright....... 287

Timson v. Ramsbottom...... 508

Tingle v. Fisher......... 508

'Tinkler v. Swaynie......... 100

Tinsley v. Harkins......... 229

'I'isdale v. Harris. . . . . . . . 144

Tison v. Howard.......... 512
Sec.

'Titman v. Titman......... 470

Tobey v. Wood........... 1,60

'Todd v. Clapp........... 60

Todd $v$. Railroad Co......... 295

'lodd $v$. Taft............ 674

Tode v. Gross..........30t, 318

'loledo, ete, R. R. Co. v. Chew. 464

'loledo, ete. Co. v. Jacksonville 271

'Lledo, ete. Co. v. Penn Co.341, 677

'Ioledo, ete. R. R. Co. v. Tapp. 424

Tolson v. Garner.......... 21

T'om v. Goodrich.......... 370

tomblin v. Callen......... 249

'lombs v. Alexander........6 620

'lomlinson v. Gill......... 360

'Tomlinson v. Jessup....... 541

Tooke v. Newman.......... 239

lool Co. v. Norris... .279, 280, 282

284,285

Topeka Water Supply Co. v.

Root .................. 10

Torpy v. Johnson.......394, 437

'Touche v. Warehousing Co... 360

louissaint v. Martinant..... 434

435,442

Tourret v. Cripps......... 97

Touteng v. Hubbard........ 569

'Iowers v. Barnett......140, 448

Towers v. Moore.......... 374

Towers v. Osborne......... 139

Towle v. Dresser.....27, 58, 66

'lowle v. Larrabee.......... 183

'lowle v. Leavitt. .......... 165

'Towne v. Wiley......... 69

'lownsend v. Hargraves....S4, 100

138,150

Townsend v. Hurst........ 595

'Lownsend v. Kennedy.....83, 85

lownsend v. Mead......... 634

'lownsend v. Railroad Co.... 293

'lownsend v. Riley......... 241

'lownsend v. Rockham....... 354

Townsend v. Vanderwerker.... 104

105,667

'1 racy $\therefore$ Roberts.......... 75 
Sec.

See.

Tracy v. Talmage......176, 409

$414,447,500$

Trist v. Child...274, 280, 284, 285

$286,305,526$

Tracy v. State.......... 551

Tracy v. Waters.......... 518

'I'rader v. Jarvis.........30, 6:5

Traders Bank v. Alsop...... 257

'Traders' Nat. Bank v. Wood-

lawn Manuf. Co......... 230

Tradesman's Bank v. Merritt.. 502

'I'rafton v. United States..... 370

'Trainer v. Trumbull......45, 49

Trammell v. Craddock....... 103

'I'ransportation Co. v. Corn-

forth . . . . . . . . . . 288

Transportation Co. v. Downie. . 582

Transportation Co. v. Thielbar 293

'L rapnall v. Bank ........ 27

Travellers' Ins. Co. v. MeKon-

key .............. 19

'Traver v. Halsted.......... 594

Treadway v. Riley......... 411

Treadway v. Veasej........ 53

Treadwell v. Herndon........ 120

Treasurer v. Mining Co...... 674

'l'reat v. Hiles............ 133

Treat v. Stanton.......... 364

Trebilcock v. Wilson....278, 529

'Treford v. Holmes.......... 119

Trenton Ins. Co. v. Johnson. . 246

Irenton Potteries Co. v. Oli-

phant .......309, 312, 314

Trevor v. Wood........... 85

'Trewinian v. Howell....... 485

Trible v. Nichors.......... 234

'Irieder v. Bank........... 193

'Trigg v. Read........... 449

'Trimble v. Thorson. . . . . . . . 234

Trimbo v. Trimbo......... 7

'l'rimley v. Vignier......... 399

Trimmer v. Thumpson....373, 576

'L'ripp v. Armutage......... 575

'Iripp v. Bishop........... 98

'Lripp v. Brownell........ 5ะl

Trovinger v. McBurney...... 274

'Troy v. Bland.......... 450

Troy Conference Aeademy v.

Nelson ............. 385

Trudeau v. Poutre........ 130

'l'rue v. Ranney.......... 400

True v. Telegraph Co....... 297

Trueman v. Loder.......... 90

Trueman v. Hurst......... 427

'Truman v. Fenton.........624

Trumbull v. Nicholson....... 622

'I'rundler v. Riley.......... 281

Trustees v. Wheeler........ 508

Tucker v. Moreland...21, 28, 64

'lucker v. Mowrey.......... 195

'Iucker v. IVest.......... 192

'Tuckerman v. Newhall....375, 381

'Tuder v. Perkins.......... 508

'Iufts v. Plymouth, etc. Co... 83

'I'ugman v. Chicago......... 198

Iunison v. Bradford....... 105

Tunison v. Chamblin....27, 57, 65

'I'upper v. Cadwell....39, 42, 46

'l'urk v. Ridge........... 352

'I urner v. Esselman......... 387

'Turner v. Frisby....30, 33, 40,468

Turner v. Gaither....41, 43, 52

'lurner v. Hubbell.......... 122

Turner v. Mason.......... 619

'I'urner v. Rusk.........21, 25

'Iurner v. 'Telegraph Co..... 297

'Iutt v. Ide............ 452

Tuttle v. Armstead........ $43 \mathrm{~b}$

'Iuttle v. Block........... 528

'luttle v. Burgett.......595, 597

'I'uitle v. Campbell.......446, 458

T'uttle v. Cooper.....369, 375, 387

'I'uttle v. Strout........... 558

'I weddle v. Atkinson. .339, 360, 361

Tweeddale v. Tweeddale..... 339

Twin Lick Oil Co. v. Marbury 625

'fyler v. Carlisle......... 447 
Sec.

Tyler v. Gallop........29, 56

'I'yler v. Telegraph Co....... 297

Tyler v. Wadingson........ 185

'Iyson v. Rickard... ....209, 233

Uberoth v. Bank......... 15

Udall v. Metcalf.......... 272

Udell v. Atherton........ 503

Underhill v. Ins. Co....... 629

Underwood v. Mort. Co...... 240

Underwood v. Scott....... 200

Underwood v. Wolf........ 612

Ungericht v. State......... 188

Uhler v. Applegate........ 185

Ullmann v. Barnard....... 151

Ulrich v. Reinaehl......... 268

Ungley v. Ungley......... 102

Union Bank v. Coster....... 94

Union Central Life Ins. Co. v.

Woods .............4 405

Union El. R. R. Co. v. Nixon.. 284

Union, etc. R. R. Co. v. Dodge

County ............ 456

Union Nat. Bank v. Bank.... . 237

Union Nat. Bank v. Chapman 396

401

Union Pac. R. R. Co. v. Bank ...........515, 518

Union Pac. R. R. Co. v. De Busk ........... 537

union Pac. R. R. Co. v. Railroad Co . ...672, 676, 680

Union Pac. R. K. Co. v. Rainey . . ............ 288

Union Pac. R. R. Co. v. Ruef ............... 336

Union Pacific R. R. Co. v. United States . ........ 325

Union State Bank v. Railroad Co . . ...............290

Union Strawboard Co. v. Bonfield ............... 314

United States v. Behan...... 473 688, 696
Sec.

United States v. Bradley.... 701

United States v. Bainbridge.. 30

United States v. Coal Co..... 628

United States v. Coal Dealers'

Asso ............310, 326

United States v. Craig. ...... 422

United States v. C'rosby...... 403

United States v. Dashiell.... 584

United States v. Dewitt..547, 548

United States v. Edgar...... 422

United States v. Fox....... 403

United States v. Freight Asso. 274 $320,323,324,326,557$

United States v. Gibbon...... 36

United States v. Kane....... 336

United States v. heeler..... 584

United States v. Joint Traffic

Asso . . . .........324, 326

United States v. Knight Co... 323

326

United States v. MeDaniel... 620

United States v. Northern Se-

curities Co . .......324, 326

United States v. Olney...... 271

United States v. Piek.......656

United States v. Pipe and Steel

Co ................ 310,326

United States v. Prescott.... 584

United States v. Price...372, 374

United States v. Speed....... 688

United States Express Co v.

Backman ............ 306

United States sxpress Co. v. Rush . . . . ........290

United States, etc. Investment Co. v. Harris.......... 70

United States Invest. Co, v.

Windmill Co ......... 403

United States Mortgr. Co. $v$.

sperry . . .......224, 240

United States Sav. \& Loan

Asso. v. Scott....219, 396, 399

United States Tel. Co. v. Gil-

dersleve . . .......... 297 


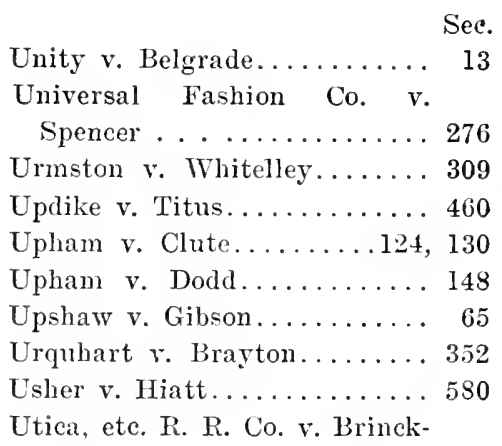
erhoff ............ 98

Vahlberg v. Keaton........ 208

Vail v. Railroad Co......... 580

Vail v. Van Doren.......217, 227

Valentine v. Canali......... 63

Valentine v. Lunt.......... 9

Vallett v. Parker........... 257

Valley Railroad Co. v. Iron Co. 449

Valpey v. Rea.........21, 25

Valton v. Ins. Co.......... 267

Van Alst v. Hunter......... 7

Van Baumbach v. Bade...... 566

Van Buren v. Diggs........ 640

Vanbuskirk v. Ins. Co...... 508

Vance v. Hair............634

Vance v. Vance.........528, 560

Vandenburgh v. Spooner.... 88

Vanderback v. Rochester..449, 452

Van Doren v. Everett........ 136

Van Doren v. Robinson...... 669

Van Doren v. Tjader......... 128

Van Dusen v. Sweet......... 9

Van Dyne v. Vreeland....... 277

Van Hoffman v. Quincy......555

Vanhorn v. Des Moines...... 350

Van Horn v. Haun......... 11

Van Horn v. Van Horn....... 341

Van Hoven v. Irish.......... 192

Van Kensen v. Parmelee..384, 634

Van Marter v. McMillan...... 229

Vanmeter v. Spurrier........ 202

Vannoy v. Patton.......... 205

Van Patton v. Beals......... 22
Sec.

Van Rensselaer v. Hayes.... 560

Van Rensselaer v. Jewett .... 69 69

Van Santen v. Oil Co........ 440

Van Sehaick v. Railroad Co... 362

Van Schoonhoven v. Curley... 555

Van Tratt v. IViese........ 703

Van Valkenburg v. Torrey.... 262

Van Valkenburgh v. Watson... 47

Van Voorhis v. Brintnal..178, 400

Van Wagener v. Gas Light Co. 506

I an Wych v. Allen.........685

Van Wyck v. Watters....... 228

Varney v. Bradford.........479

Vassault v. Edwards........ 98

Vasse v. Smith......68, 69, 70

Vaughn v. Dorr.......... 27

Vauglin v. Railroad Co...... 288

Vaughn v. Smith......... 86

Vaught v. Rider.......... 234

Vawter v. Griffin.......... 144

Veal v. Fortson........... 66

Veazie v. Williams......... 165

Vegelahn v. Guntner.....334, 336

Vehne v. Pinkham......... 62

Vernon v. Vawdey.........4 429

Vesey v. Ackington......... 239

Vent v. Osgood......27, 62, 482

Vickerss v. Railroad Co..... 300

Vickery v. Dickson........ 234

Vickery v. Welch......... 318

Vicksburg, etc. R. R. Co. v. Ragsdale ............683 68

Victor v. Stroock........145, 150

Victor Talking Mach. Co. v.

The Fair . . . . ....... 339

Vidal v. Girard.......... 274

Vidal v. Thompson......... 115

Vincent v. Germond........ 151

Vincent v. Railroad Co...... 306

Violett v. Patton.......... 93

Violett v. Powell......... 89

Virginia Development Co. v.

Iron Co. . . ......... 541

Vliet v. Camp........... 241 
Sec.

Vocke v. Peters........134, 274

Voglesang v. Null........ 27

Voight v. Raby.........6 626

Voight v. Wright......... 549

Von Hoflman v. Quincy...... 5 528

Voorhees v. Combs......... 442

Voorhies r. Society........ 404

Voorhis v. Child.......... 373

Voorhis v. Staed.......... 213

Vores v. Harshbayer......... 14

Vose v. Grant.........394, 437

Vought v. Williams........ 645

Vrooman v. McKaig....... 445

Vrooman v. Turner..348, 351, 354

Wabash R. R. Co. v. Hannahan 336

Wabasl, etc. R. R. Co. v. llli-

nois ............. 538

Wabaunsee County v. Walker. 456

Wade v. Haycock.......640, 651

Wadleigh v. Sutton.........666

Wadsworth v. Sherman..... 12

Wadsworth v. Telegr. Co.... 693

Wailing v. Toll.......... 45

Wain v. Walters.......... 93

Wainright v. Water Works Co. 349

Waite v. Leggett.........450

Wait v. Maxwell........9, 12

Waite v. Paud............ 250

Wait v. Wait............ 131

Wake v. Harrop.......... 160

Wakefield v. Martin........ 508

Wakeman v. Grover........ 170

Wakeman v. Manuf. Co..690, 697

Walberton v. Davis......... 129

Walcott v. Heath......... 255

Wald v. Railroad Co....424, 580

582,583

Waldron v. Evans.......... 427

Wales v. Stetson.......534, 541

Walker v. Barney......... 107

Walker v. Brown.......... 442

Walker v. Coleman........ 488

Walker v. Conant.......4445,450

Walker v. Cronin.......341, 342
Walker v Davis ...... See.

Walker $r$ Denison......... 622

Walker v. Duncan.......... 464

Walker v. Emerson.........624

Walker v. Fitts.......57s, 660

Walker v. Gregory......... 274

Walker v. Hill........122, 132

Walker v. Irwin......... 125

Walker v. Johnson.......... 249

Walker v. Larkin.......... 498

Walker v. Mattraw......... 319

Walker v. Maxwell......3i l, 380

Walker v. MeCnlloch.....37\%, 379

Walker v. Nussey......... 153

Walker v. Railroad Co....... 134

Walker v. Richards........ 126

Walker v. Rostron........ 360

Walker v. Shackelford...... 479

Walker v. Supple......... 144

Walker v. Tucker...568, 572, 659

Walker v. Tyrrel.........6 620

Walker v. Whitehead....... 555

Wall v. Equitable Soc...... 404

Wallace v. Chair Co....... 515

Wallace v. Eldridge.....278, 529

Wallace v. Kelsall......... 382

Wallace v. Latham......... 56

Wallace v. Lawyer......... 517

Wallace v. Lewis.......... 55

Wallace v. Long.........108, 667

Wallace v. Morss.......... 69

Wallace v. Railroad Co...... 537

Wallace v. Rappleye........ 274

Wallace v. Sanders.......... 582

Wallace v. Schaub......458, 460

Wallace v. Wortham........ 125

Walling v. Michigan.... 547,549

Wallis v. Bardwell....42, 46, 73

Wallis v. Carpenter........ 382

Wallis v. Randall......... 384

Wallis v. Warren......... 606

Walmsley v. Cooper....... 377

Walpole v. Oxford......... 466

Walrath $v$. Champion Mining

Company ............ 338 
Walrath v. Ingles......... $\begin{array}{r}\text { Sec. } \\ 155\end{array}$

Walsh v. Mayor..........6638

Walsh v. Powers.......... 66

Walsh v. Young.......... 71

Walter v. Foutz......... 216

Walters v. Whitlock....... 406

Walton v. Gaines.........32, 66

Walton v. Hollis......... 580

Walton v. Waterhouse...... 573

Walworth v. Harris....... 402

Walworth v. Holt......... 367

Wampler v. Shissler........ 386

Wamn v. MeNulty........ 370

Wann v. Telegraph Co...... 297

Waples v. Jones.......... 242

Ward v. Anderson.......51, 53

Ward v. Bandon........... 242

Ward v. Byrne.......... 311

Ward v. Doncombe......... 508

Ward v. Johnson........... 370

Ward v Laverty.......... 59

Ward v. Morrison.......... 508

Ward v. Vance........... 572

Ward v. Vosburgh........ 413

Ware v. Cartledge......... 27

Ware v. Manning.......427, 429

Ware v. Stephenson........ 121

Warehouse Co. v. Duke...... 597

Warfield v. Booth.......312, 316

Waring v. Cunlitf. . . . . . . . 222

Waring v. Mason........90, 612

Waring v. Railroad Co..... 669

Warner v. Bank.......... 399

Warner v. Grace.......... 281

Warner v. Jefrìay......... 407

Warner v. Hale.......... 111

Warner v. Railway Co...... 137

Warner v. Willoughby....... 128

Warnock v. Davis......... 267

Warren v. Bank.515, 521, 524, 526

Warren v. Conings........ 521

Warren v. Richmond....... 595

Warren v. Seanlon......... 248

Warren v. Stoddart.....640, 651

Warren v. Tyler.......... 599
Sec.

Warren v. Wheeler........641

Warren Deposit Bank v. Rob-

inson .............. 217

Washburn v. Cutler....... 493

Washburn v. Dasch.....137, 313

Washington v. Jolinson......6 613

Washington Ice Co. v. Webster 97

Wason v. Railroad Co...... 560

Waterman v. Meigs.......139, 141

Waters v. Riley.......... 374

Waters v. Stevenson........ 492

Watertown Thermometer Co.

v. Pool .............. 318

Watkins v. Baird.......497, 498

IVatkins v. Glenn.......555, 566

Watkins v. Sands......... 131

Watson v. Brick Co.....686, 687

Watson v. Cresap......... 448

Watson v. Lane........... 417

Watson v. Ledoux. . 425, 458, 483

Watson v. McLarin........ 94

Watson v. Murray........ 286

Watson v. Perrigo.......... 131

Watson v. Railroad Co...... 56l

Watson v. Sherman....... 99

Watson v. Stever.......... 488

IVatson v. Watson......... 7

Watson v. Wellington....... 526

Watt v. Cranberry Co.....86, 88

Watte v. Wiekersham...... 256

Watterson v. Railroad Co..302, 689

Watts v. Camors.......240, 420

Watts v. Creswell........ 70

Watts v. Van Ness.......183, 192

Waugh v. Morris.......... 164

Waughop v. Bartlett....... 634

Way v. Cutting..........448

Way v. Langley........... 701

Way v. Raihoad Co........ 292

Waymeer v. Jetmore........ 13

Waymell v. Reed..........4 414

Waymire v. Waymire...... 105

Wayne County v. Randall.449, 452

Wayne County Savings l3ank r. Low . . .....240, 395, 408 
Waywell r. Reid.......... 409
Weatherford, ete. R. R. Co. v.

Wood . . . . . . . . . I34

Weatherly v. Smith........ 229

Weaver v. Carpenter........ 28

Wearer r. Jones..........26, 27

Weaver v. Shyrock........ 374

Webb v. Lumber Co........ 122

Webb v. NcCauley.......... 283

Webb v. Railroad Co....... 144

Webber v. Ilowe..........4 413

Webber v. Virginia......... 551

Weber v. kerkendall....... 455

Weber v. Squire.........683

Webster v. Brown.......... 91

Webster v. Davis.........632

Webster v. Enfield......... 595

Webster v. Fleming........ 362

Webster v. Le Compte....s 0,100

Webster v. Maehine Co...... 399

Webster v. Munger.......398, 409

Webster v. Rees........... 555

Webster v. Seminary....... 541

Webster v. Wade......602, 605

Weed v. Black........... 284

Weed v. Ins. Co......17, 18, 20

Weed v. Jewett........... 515

Viecd v. Page............ 150

Weed v. Walker.........4455

Weeks v. Hunt........... 507

Weeks v. Merrow.......47, 470

Weeks v. O'Brien.........6643

IVeeks v. Robie........... 599

Weems v. Mortg. Co......... 228

Weil $v$. Golken...............398

Weil v. Willard.........91, 92

Weingartner v. Probst.......667

Weintz v. Hafner.......... 595

Weir's Will............ 8

Weis v. Denlin.......... 575

Weisser r. Denison.....427,428

Welch v. Bank..........428

Welch v. Bunce.......... 58

Welch v. Dirling......... 109

Weleh v. Marvin......... 122
Sec.

Weleh v. Mayer.......... 521

Wellaner v. Fellows......... 478

Weller v. Golle............ 366

Weller v. State........542, 543

Wellis v. Jevy..........6 632

Wells v. Brown.......... 128

Wells v. Calnan......572, 575

Wells v. Cook........... 494

Wells v. Evans........... 377

Wells v. Foster.......283, 517

Wells v. Hartford Manilla Co. 594

Wells v. Miller..........3s8, 436

Wells v. Monihan.......... 114

Wells v. People........179, 201

Wells $v$. Prince........... 158

Wells v. Raibroad Co....... 295

Wells v. Stradling........ 105

Wells v. Vansickle......... 399

Welsh v. Bank......427, 428

Weltmer v. Bishop........ 164

Welty v. Jaeobs...........667

Welton v. Missouri........ 551

Wenestine v. Freyer......... 398

Wenham v. State........4, 544

Wentworth v. Woolside...... 186

Werner r. Humphreys....... 590

Werner's Appea1.......... 43

Wessel $v$. Land Co.......... 449

West v. Blackway........6. 650

West v. Camden...........274

Ilest v. Greggs........39, 42

West v. Holmes.......... 246

West v. OHarra......... 122

West v. Penny........... 27

West v. Russell.......... 8 8

West v. Telegr. Co........6693

W'est v. Wright.......249, 256

Westcott v. Hunckley....... 483

Westerfield v. Bried........237

Westerfield v. Jackson....... 9

Western v. Shirp........ 442

Western Dist. Warehouse Co.

v. Hobson .......... 312

Western, ete. Railroad Co. $v$.

Cotton Mills . . . ........4 421 
Sec.

Western, etc. R. R. Co. v. Strong . . . . . . . . . 299

Western Transportation Co. v. Newhall ............. 289

Western Union Tel. Co. v. Cook .............. 297

Western Union 'lel. Co. v. Blanchard ............ 297

Western Union Tel. Co. v. Call Pub. Co........... 296 Western Union 'Tel. Co. v. Carew .............. 297

Western Union Tel. Co. v. Crall ................ 297

Western Union Tel. Co. v. Crawford ............ 297

Western Union Tel. Co. v. Fenton .............. 297

Western Union Tel. Co. v. Ferguson ...........693

Western Union Tel. Co. v. Griffin ............... 188

Western Union Tel. Co. v. Hall . . . . . ......297, 696

Western Union Tel. Co. v. Howell ............. 297

Western Union Tel. Co. v. James ................ 549

Western Union Tel. Co. v. Linn . . . . . . . . . . . 297

Western Union Tel. Co. v. Littlejohn . . ......... 248

Western Union Tel. Co. v. Lyon . . . . . . . . . . . 297

Western Union Tel. Co. v. Meek ............... 297

Western Union 'Tel. Co. v. Railroad Co. . ........ 308 Western Union T'el. Co. v. Stevenson ........... 297

Western Union Tel. Co. v. Telegraph Co. ........304, 308 Western Union Tel. Co. v. Wilson .........188, 297

Western Union Tel. Co. v. Yopst ............. 188 Western U. R. R. Co. v. Bishop 299 Western Wooden Ware Asso.

v. Starkey .......... 312

Westfall v. Parsons......... 124

Westlake v. Adams.......... 448

Weestmoreland v. Porter..... 96

Westropp v. Solomon....... 448

West Virginia Trans. Co. v.

Pipe Line Co........304, 324

West Virginia Trans. Co. v.

standard Oil Co......... 304

Wetherbee v. Potter........ 101

Wetherell v. Langston....... 377

Wethwell v. Jones.......... 177

Wetmore v. Pattison....... 696

Wettingham's Case ...... 66

Weyburn v. White........ 259

Whalen v. Sullivan....... 83

Whaley v. Hinchman....... 85

Whaley v. Mort. Co....211, 228

Whaley v. Peak......... 425

Wharton v. Mackenzie...... 41

Wheadon v. Olds......427, 450

Wheat v. Rice........... 354

Wheatly v. Baugh........ 345

Wheaton v. East.......... 65

Wheaton v. Hibbard....... 500

Wheelan v. Clock Co...... 575

Wheelden v. Lyford........ 186

Wheeler v. Collier......... 166

Wheeler v. Frankenthal..... 111

112,135

Wheeler v. Jackson.....528, 638

Wheeler v. Reynolds........ 103

Wheeler v. Russell.......196, 205

Wheeler v. Spencer......... 246

Wheeler v. Stewart........ 356

Wheeler v. Walton........ 519

Wheeler v. Wheeler........ 275

Wheelock v. Lee.......... 243

Whelan v. Sullivan........ 92

Whelen v. Boyd..........6 645 
See.
Whelpdale's Case........ 368
Whipple v. Dow........ 470
Whipple v. Fowler....... 403
Whipple v. Parker....108, 110
137,479

Whicheote v. Lyle......... 27

Whitaker v. Sandifer....... 603

Whitaker v. Security Co..396, 399

Whiteomb v. Gilman....... 188

Whitcomb v. Joslyn....66, 68

White v. Allen.......... 590

White v. Bank........... 330

White v. Barber........249, 413

White $v$. Breen.......... 92

White v. Buss........176, 461

White v. Cook...........280

White v. Core.......... 83

White v. Farley......... 7

White v. Gardner......... 15

White v. Hart.......... 560

White v. Henry........29, 47

White v. Hermann......... 92

White v. Holland......... 135

White v. Ins. Co........ 18

White v. Jones........... 457

White v. Joyce.........72, 73

White v. Knapp.......... 140

White v. Levy............ 135

White v. Mann........... 588

White v. Miller.........6 685

White v. Oliver..473, 477, 651, 652

White v. Palmer......... 12

White v. Prentiss......... 508

White v. Rintoul.......127, 663

Whitesides v. Hunt. .249, 251, 255

Whitford Chemical Co. v. Hard-

way ............... 677

Whiting v. Ohlert........ 135

Whiting v. Sullivan....... 457

Whitlock v. Doolittle...... 634

Whitmarsh v. Hall......... 62

Whitmore v. Montgomery. 183, 184

Whitney v. Cowan......... 526

Whitney v. Dutch......... 65

II hitney v. Port Huron...... 456
Sec.

Whitney v. Spencer........ 568

Whitney v. Stearns........ 94

Whitney v. Stayton........ 312

Whitney v. Whitney.......4 408

Whitstine v. Wilson.......467

Whitstone v. Sliaw........ 433

Whittemore v. Cope........ 37

Whittemore v. Gibbs......... 144

Whittemore v. Wentworth... 125

Whittingham v. Hill....... 44

Whitwarth v. Adams........ 212

Whitworth v. Hart.........691

Wibert v. Railroad Co....... 615

Wick China Co. v. Brown.... 336

Wick v. Dawson........... 419

Wicker v. Hoppoch...... 169, 364

Wickham v. Wickham..... 87

Wieland v. Kobick......67, 68

Wier v. Batdorf.......... 84

Wiggin v. Bush......... 171

Wiggin v. Cumings........ 377

Wiggins v. Burkham....... 428

Wiggins Ferry Co. v. Railroad

Co. . . ............ 308

Wigglesworth v. Dallison... 136

Wightman v. Wightman..... 400

Wilbaux v. Live Stock Co.368, 382

Wilbur v. How.......... 167

Wilbur v. Wilbur......356, 361

Wileox v. Fitzhugh........ 12

Wileox v. Howell......... 276

Wilcox, etc. Co. v. Green..... 116

Wileoxson v. Andrews....... 281

Wild v. Williams......... 377

Wilder v. Collier......... 500

Wilder v. Pigot........... 32

IIilder v. Weakley.......14, 472

Vilder's Succession........ 401

Wildes v. Dudlow.....96, 123, 129

Wildey v. Collier.......284, 286

Wiley v. Starbuck........ 232

Wilhelm v. Fagan........ 83

Wilhelm v. Hardman....... 43

Wilhelm v. Voss.......... 132

Wilkie v. Womble......... 109 
Wilkinson v. Heavenrich..... $\begin{array}{r}\text { Sec. } \\ 98\end{array}$ Wilkinson $v$. Lindo......377, 381 Wilkinson v. Towsley...... 240 Wilkinson v. Verity........ 604 Wilkinson v. Wilkinson...145, 491 Wilks v. Rich.........663 Willard v. Bosshard....... 125 Willard v. Ford..........668 Willard v. Sperry......... 521 Willes v. Greenlill......... 508

Willett v. People......... 540

Willet v. Willet.........488

Willetts v. Waite........406 Willey v. Paulk........... 635

Williams v. Association...... 220

Williams v. Bacon.......83, 90

Williams v. Bagley........ 330

Williams v. Bank......... 568

Williams v. Banks......... 212

Williams v. Bemis.....480, 482

Williams v. Bradley....... 373

Williams v. Brown........ 27

Williams v. Burgess........ 140

IVilliams v. Butler........ 355

Williams v. Byrnes........ 88

Williams v. Clseney........ 196

Williams v. Davis.......... 118

Williams v. Flowers........ 229

Williams v. Fitzhugh....... 241

Williams v. Gitchell........ 624

Williaume v. Gorges........ 627

Williams v. Grant.......... 583

Williams v. Hance......... 221

Williams v. Harrison.....27, 468

Williams v. Hastings....... 189

Williams v. Hitchings....... 378

Williams v. Jones.......... 629

Williams v. Knight........ 32

Williams v. Ladew......... 491

Williams v. Lake.......... 88

Williams v. Leper.......... 128

Willians v. Mershon........ 99

Williams v. Montgomery.....6 670

Williams v. Moore........ 27

Williams v. Morris......86, 91
Sec.

Williams v. Oates........ 178

Williams v. Paul......... 192

Williams v. Rich.......... 229

Williams v. Robinson.....91, 98

Williams v. Schmidt...... 640

IVilliams v. Smith........ 85

Williams v. Tiedemann...... 255

Williams v. Vanderbilt...... 588

Williams v. Webb........ 521

Williams v. Wentworth...11, 471

Williams v. Williams....... 485

Williamson v. Railroad Co.... 302 $642,643,645$

Willingham v. Hooven...... 697

Willis v. Cutter.......... 125

IVillis v. Hammond........ 83

Willis v. Jernegon........ 7

Willis v. Railroad Co...... 288

Willis v. Twombley........ 27

Willis v. Webster.........661

Willoughby v. Irish......384, 634

Wills v. Bank........... 131

Wills v. Ross........... 122

Willson v. McCormick....... 368

Willworth v. Leonard....... 12

Wilson v. Barker.........450

Wilson v. Branch.......... 64

Wilson v. Carson.......... 402

Wilson v. Duncan......... 37

Wilson v. For'ce........... 464

Wilson v. Fuller......... 80

Wilson v. Harvey.......... 234

IVilson v. Hentges......... 128

Wilson v. Hunter......... 90

Wilson v. Irish.......... 600

Wilson v. Mcllillan.......4 470

Wilson v. Milligan........ 192

Wilson v. Mills Co......... 115

Wilson v. Picknick Co....... 665

Wilson v. Porter.......... 66

Wilson v. Railroad Co...28s, 293 $424,668,676,683,68 t, 689$

Wilson v. Ray.......... 137

Wilson v. Voss........... 130

Wilson v. Wallace........ 377 
Sec.

Sec.

Wilson r. IVilson.........460

Womack v. Smith.....674, 675

Wilson v. Winter.......... 185

Wonsettler v. Lee.......I10, 479

Wilton v. Tazwell......... 434

Wimard v. Lincoln......... 399

Winchell v. Hicks..........634

Winchell v. Carey......... 192

WinchelI $v$. Noyes.......... 464

Winchester v. Howard..... 457

Winchester v. Thayer....... 66

Winchester Electric Light Co.

v. Veal . .........173, 330

Wood v. Armstrong........ 196

Wood v. Brady...........551

Wood r. Carpenter..625, 626,630

Wood v. Corcoran......... 130

Wood v. lisk............. 374

IVood v. Ins. Co.......... 404

Wood v. Leadbetter......... 509

Wood v. Losey............ 44

Wood v. Mayor........... 490

Windhand v. Deeds.........460

Windmuller v. Pope......... 594

Winfield v. Dodge......... 192

Wingo v. Brown.......... 444

Winkle v. Ketcham......... 61

Winn v. Investment Co..... 353

Winne v. Keeley.......... 697

Winona, etc. R. R. Co. v. Blake 539

Winslow v. Anderson........ 30

Winsor v. Savage....430, 431, 432

Winston v. Beeson......... 270

Winston v. Dalby......... 376

Winter v. Hite........... 120

Winters v. Cherry......... 137

Wirebach v. Bank......... 24

Wiseman v. Thompson.......665

Wiser v. Lockwood......... I3

Witherall v. Jones.......... 196

Witherby v. Mann.......... 389

Witlers v. Richardson......668

Wittkowski v. Harris....240, 241

Wolcott v. Frissell........ I

Wolcott v. Heath........ 598

Wolf v. Burk.......101, I15, 403

Wolf v. Dietzsch.......598, 599

Wolf v. Dozer............ I35

Wolf v. Express Co....... 583

Wolf v. Gerr............ 474

Wolf $v$. Shannon......... 402

Wolf v. Studebaker........6687

Wolfe v. Howes........475, 589

Wolfe v. Luyster.......... 168

Wolff v. Kappel............ 87

Wolff v. New Orleans........ 560

Wood v. MeCann........... 284

Wood v. Moriarity......352, 357

Wood v. Sheldon........... 448

Wood v. Partridge......... 508

Woodford v. Hamilton........ 205

Woodford v. Levenworth..... 432

Woodland v. Newhall....... 356

Wood Reap.\& Mow. Mach. Co.

v. Smith . . . . . 614, 639

Woodruff v. Berry........ 305

Woodruff v. Hill........258, 399

Woodrutf v. Hinman........ 204

Woodruff v. Marshall........ 703

Woodruff v. Mississippi..278, 5:9

Woodruff v. Parham........ 551

Woodruff v. Wentworth... 164, 204

Woods v. Armstrong. 178, 197, 202

Woods v. McGee......... 148

Woods v. Russell.......... 575

Woodstock Iron Co. v. Exten-

sion Co......I63, 284, 285, 302

305,324

Woodward v. Brooks....... 406

Woodward v. Fuller.... 640,666

Woodward v. Newhall....... 369

Wooley v. Batte.......... 437

Wooliver v. Ins. Co........ 185

Woolsey v. Jones........... 210

IVooster v. Sage........... 140

Wooten v. Hinkle......... 165

Wooten r. Miller...........301

Wooten $v$. Wilcox......... 128

Worcester v. Eaton........ 57

Worden r. Sharp........ 137 
Sec.

Work v. Welsh........... 680

Workman v. Campbell....... 284

Worley v. Hineman......... 403

Worley v. Lyon.......... 399

Worley v. Sipe........... 133

Wornock v. Loar........... 46

Worrall v. Munn........... 99

Wright v. Augusta........ 349

Wright v. Barnes..........6 612

Wright v. Bolling.........4 416

Wright v. Crabbs......... 330

Wright v. Dickenson........ 448

Wright v. Eisle.......... 339

Wright v. Ellison........ 524

Wright v. Gardner......173, 330

Wright v. Haskell......... 595

Wright v. Johnson......... 632

Wright v. Jones........... 113

Wright v. Post.......... 377

Wright v. Pucket......... 103

Wright v. Rindskott ........ 286

Wright v. Terry.......348, 352

Wright v. Tinsley..........667

Wright's Appeal . ........4 467

Wunch v. Shankland....... 335

Wycoff v. Mickle......... 87

Wycoff v. Meyers..........646

Wyman v. Adams.......... 66

Wyman v. Goodrich........ 128

Wynne v. Raikes......... 124

Wynne v. Wright......... 551

Wynne v. Wynne......... 532

Yale v. Wheelock......... 369

Yanger v. Skinner.....12, 22, 25

Yates v. Boen........... 9

Yates v. Foot............ 382

Yates v. Lyon........... 60

Yates v. Milwaukee........ 540

Yates v. Robertson.......199, 284
Sec.

Yeates v. Groves.......... 526

Yeatman v. Cullen......... 258

Yellow Stone Kit v. State.270, 271

Yenni v. MeNamee........ 513

Yerger v. Raines.......... 418

Yerkes v. Salonan......... 255

Yerrinton v. Green......475, 592

Yick Wo v. Hopkins........ 547

Yoeman v. Mueller......121, 132

Yonoski v. State......... 188

loung v. Clark.......... 39l

Young v. Commonwealth...... 270

Young v. Drake.......... 135

Young v. French.......... 121

Young v. Glendemning....... 106

Young v. Hail........... 170

Young v. Hicks........... 34l

Young v. Hill............ 222

Young v. Jones............ 515

Young v. Lambert.......... 513

Young v. Lyons........... 391

Young v. Overbraugh....... 106

Young v. Railroad Co..64, 294, 337

Young v. Stevens......14, 22, 599

Young v. Telegr. Co........693

Younge v. College......... 485

Young Lock Nut Co. v. Manuf.

Co .......667, 668, 671

Zabriskie v. Smith....... 518

Zachry v. Nolan.......... 111

Zaleski v. Clark.......614, 639

Zanesville v. Gaslight Co.534, 538

Zang Brewing Co. v. Bernhein 445

Zillmer v. Kreutzberg...... 175

Zoebisch v. Rauch......... 55

Zouch v. Parsons.......27, 28

Zuck v. Culp...........6 628

Zuck v. MeClure.......594, 608 


\section{INDIX.}

(References are to the seetions.)

\section{ACCEPTANCE-}

Sec.

oral, of order in existence not within the statute of frauds... 124

of bill of exchange in existence by parol is valid......... 124

what is-when question for jury.................. 47

goods delivered subject to examination................ 148

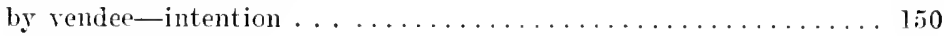

acts which amount to........................ 151

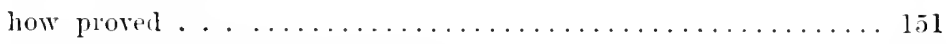

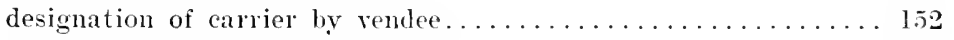

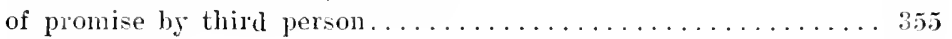

as to minors . . . . . . . . . . . . .

of voluntary act of another-effect............... 47

voluntary acceptance of benefits-implied contract......... 4.5s

of contract partly performed................... 477

orders given by one and filled by another-effect.......... 1 is

of theater ticket with conditions.................. 509

when necessary in rescission of contract, to make it ellcetive... 594

of work-partial payment as evidence of ............. 652

of labor on building........................664

ACCOMMIODATION INDORSER-

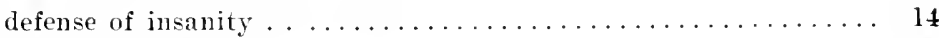

may avoid his indorsement, when ............... 24

ACCOUNT STATED-

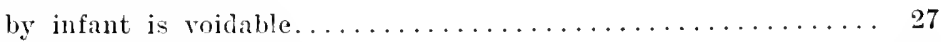

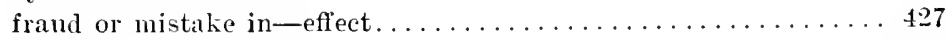

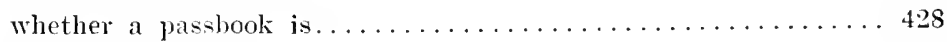

burden of proof . ........................ 429

ACKNOWLEDGMENT-

when defective-how arred..................... 532

ACTIONS-See Revedies.

by indorser against lunatic on note................. 14

to dissolve partnership-insane partner.............. 15

by infant, as an aftirmance of contraet............. 65

can be sustained against infant for fraud.............. 69

by infant to aroid contract....................... 71

no action shall be brought-statute of frauds-neaning...... 100 


\section{INDEX.}

ACTIONS- (continued)

Sec.

statute of frauds affects remedy ................. 100

as to voidable and void contracts.................. 101

to recover back money lost in gaming................... 259

constitutionality of statute to recover back money lost at gaming 260

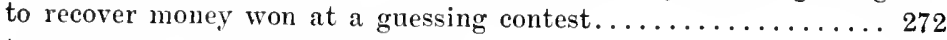

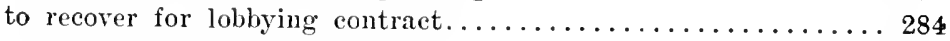

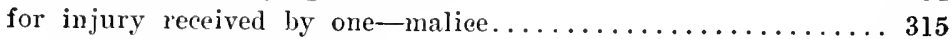

to enforce illegal contract.................... 330

legality at the time of enforcement............... 332

against parties in combination not a corporation......... 334

for injury from combination of workmen............. 334

for malicious interference between master and servant...... 341

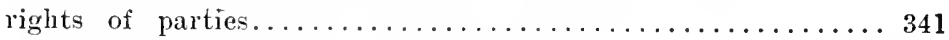

for malicions interference in any contract............ 342

by master for interference with his servant............ 344

doing an act legal within itself ................... 345

fraudulent representations of third party............. 346

for servant to sustain action against third party, le must be dis-

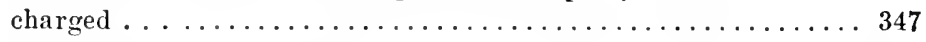

when third party can maintain-contract for his benefit...... 348

against water companies........................ 349

on contract for benefit of third person............. 355-357

brought by next of kin, for promise made for the benefit of his

father ........................................ 361

who may bring action on simple contracts............ 364

how brought against many promisors............... 367

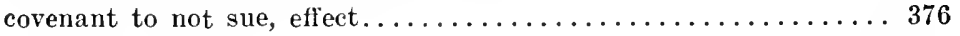

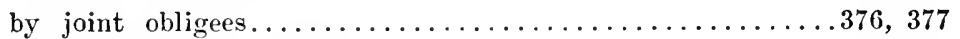

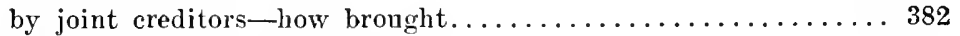

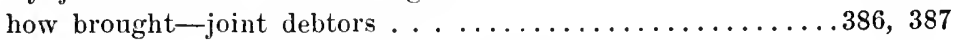

when surety can bring against co-surety............. 391

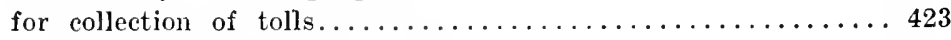

to recover forged check-negligence of depositor........... 428

to recover back money paid on a void contract........... 443

on implied contracts......................... 444

for money had and received-when property is received......446

in illegal contracts......................... 447

no consideration in contract-recovering back money paid......448

where vendor partially fails to deliver.............. 448

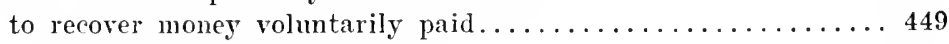

under mistake of fact-effect................... 450

to recover back commission wrongfully paid the agent....... 451

to recover back taxes illegally paid................ 452

to recover money illegally paid for taxes and assessments...... 456

waiving tort-suing in assumpsit.................... 464

to enforce oral agreement to bequeath or devise property..... 466 
to recover for part performance................473,474

to recover for part performance of vois contract. . . . . . . . 479

under no obligation-part performance...............480

to recover expenses of funeral. .................. 485

to recovery for part performance of roid contract. . . . . . . 479

for tort-election of actions...................487

doctrine that the property taken must be sold...........488

to recover money paid under duress..............496, 497

payment of husband's debt by wife-duress.............499

to recover money paid in compounding felony............ 500

to recover back money voluntarily paid............. 501

cannot be split up........................... 521

reduction of time to bring-effect................ 528

limitations are part of the contract.............. 528

changing procedure-effect on the contract............ 56

when may be brought for rescission of contract.........594

when notice of rescission of contract.............. 597

to recover back consideration-contract rescinded......... 599

to recover money back on a sealed contract-assumpsit.......601

for constructive services . . .................... 603

for services to be performed .................... . 604

for damages for rescinding contract for work on personalty.... 608

for damages for affixing machine to real estate-rescission of contract ............................ 609

when statute of limitations runs................628

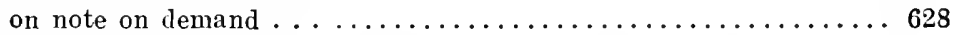

time to bring against debtor absent from State-statute of limi-

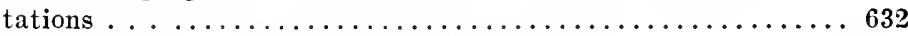

by creditor out of State-statute of limitations.........663 statutes controlling the limitations for bringing suit are valid.. 636

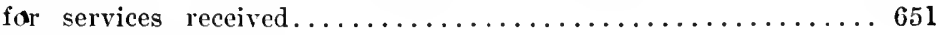
ACTIONS EX DELICTO-

infant is liable for.......................... 69

ACT OF GOD-

preventing fulfillment of contract to marry-effect........476

may excuse performance of contract............... 580

as to common carriers....................5s2, 583

where law imposes a duty..................... 584

failure of consideration by act of God .............. 586

intervention of the act of God................. 588

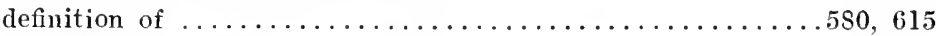

that will excuse a common carrier to deliver goods.........6 616

ACTORS-

speeific performance of contract................677 
breach of contract by manager-duty of actress to seek other en-

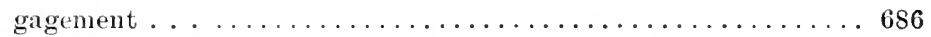

ADMINISTRATOR-See ExEcutons and Administrators.

when liable for debts...................... 485

ADVERSE POSSESSION-

of land-taking trees and stone-right of real owner...... 493

AFFIRMANCE-

of insane person's contracts................... 21

necessity of ratifying contract made by minor........... 51

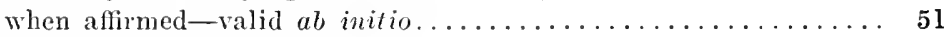

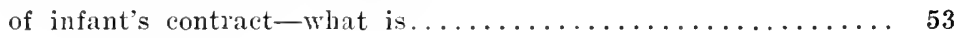

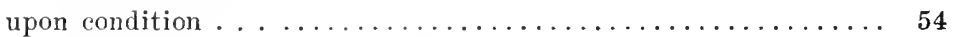

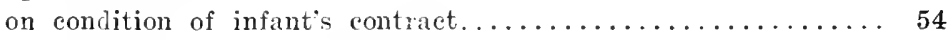

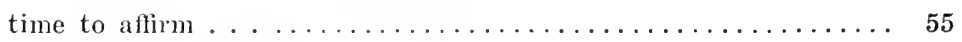

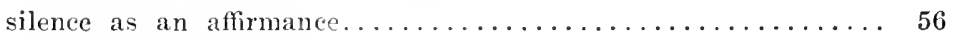

how are infants' contracts afỉmed................ 65

of guardian's contract, by ward ................ 75

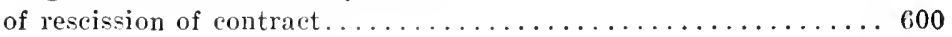

by silence, of rescission....................600

AFFREIGHTIENT-

interstate contracts of ...................... 421

\section{AGENCI-}

signing for principal-must have authority........... 99

power to sell land-not authorized to make deed ......... 99

sale of principal's goo's-parol warranty is part of consideration 140

when third party can be interested in contract-rights of . . . . 348

AGREEMENTS-

contracts made in violation of statutes............. 173

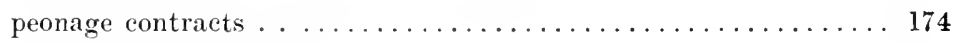

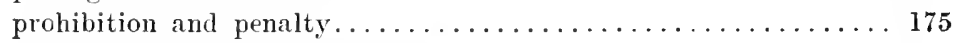

malum prohibitum and malum in se............... 176

penalty imposed for administrative purposes.......... 177

acts impliedly prohibited..................... 178

what cannot be done by direct means.............. 179

AGREEMENT NOT TO BE PERFORMED WITHIN A YEAR-See

Frauds, Statute of.

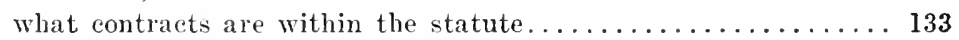

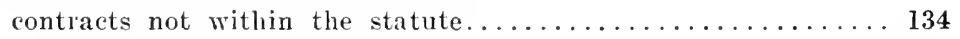

one year from the making thereof................. 135

parol lease of land for a year....................... 136

part performance within a year-performance on one side.... 137

AGREEMENTS, STATUTE OF FRAUDS-SEVENTEENTH SECTION-

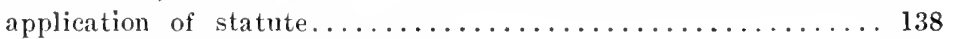

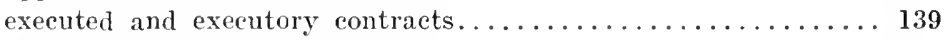

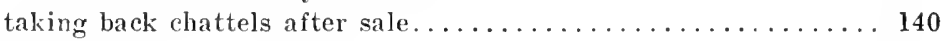

price .......................... 141 


\section{INDEX.}

AGREEMENTS-(continued $)$ Sec.

amount of sale . . . . . . . . . . . . . . . . . . . . 142

sale of several articles........................ 143

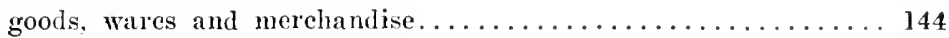

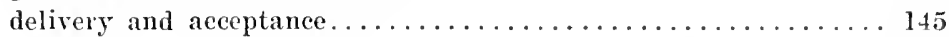

contracts for work and labor.................... 146

what is an acceptance-when question for jury.......... 147

goods delivered subject to eximination-acceptance......... 148

intention . . ........................... 149

property in possession of third party................ 150

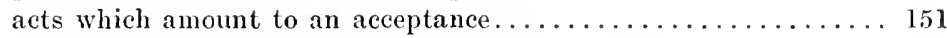

designation of earrier by vendee-delivery of goods......... 152

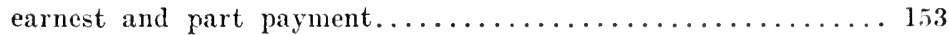

when part payment must be made................. 154

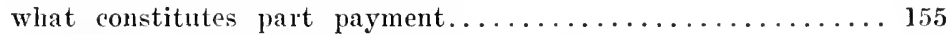

in what property, part payment may be made........... 156

ALIEN-

labor acts . . .......................... 422

object of alien labor acts................... 422

ALTERATION-

of written contract, under the statute of frauds.......... 81

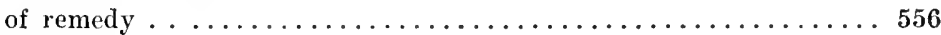

ANCESTOR-

death of-ruming of the statute of limitations...........631

APPEAL BOND-

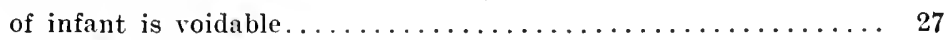

APPOINTMENT-

to public office is not a contract................426

APPRENTICE-

cannot be assigned over by master................519

ARBITER-

condition in contract for .....................642

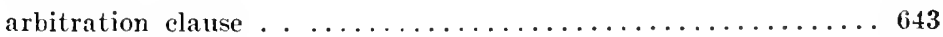

decision of, must be pertinent..................644

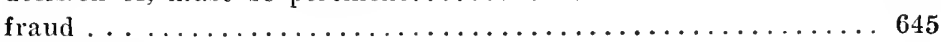

ARBITRATION-

provision in contract for arbiter as to performance.........642

clause of . ............................. 643

the arbiter's decision must be pertinent..............644

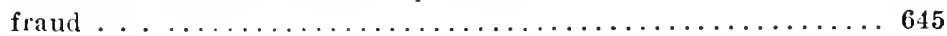

ARCHITECT-

publishing his plans-right of property in.......... 339

assignment of future wages-controlled by statnte........ 515

assigmment of wages forbidden by statute-effect........ 515

as arbiter in building contracts..................... 643

ARREST-

of servant-effeet of on contract with master.......... 578 
ARTIST-

contract with-cannot be assigned............... 519

agreeing to paint picture-death of-effect on contract...... 589

specific performance of contract...................677

ASSESSMENTS-

payment of-illegality of when payment is voluntary.......456

ASSIGNMENTS-See Assignor ANd AssigneE.

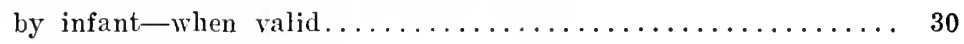

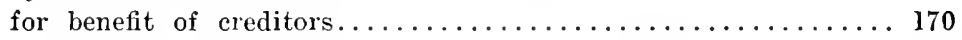

of insurance policy, valid in its inception-effect......... 267

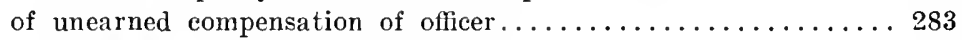

of contract-stranger has no right in...................... 348

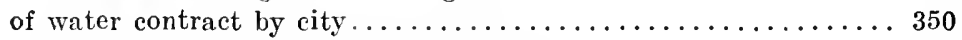

of judgment-is legal title transferred............... 395

of policy of insurance-what law governs............ 405

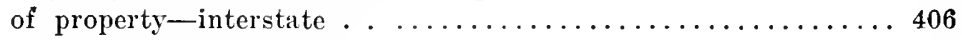

voluntary for benefit of creditors............... 506

set-off against assignment..................... 507

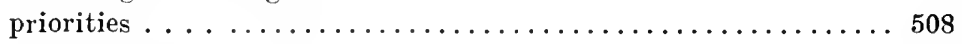

coupons-theater tickets . . .................. 509

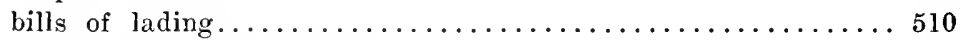

drawing drafts by consignor................... 511

bills of lading-negotiability ................. 512

warehouse receipts . . ................... 513

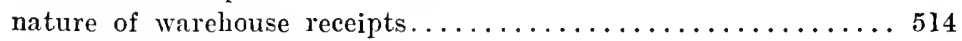

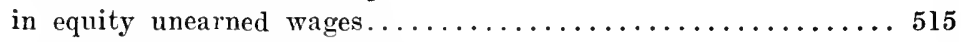

effect of assignor's discharge in bankruptey........... 516

unearned salary of public officer................. 517

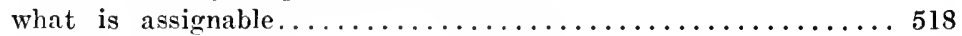

of personal trusts involving personal skill............. 519

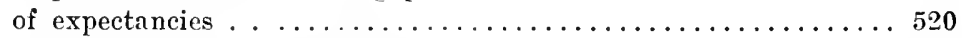

partial assignments at law......................... 521

partial assignments with consent of debtor........... 522

partial assignment-city as debtor............... 523

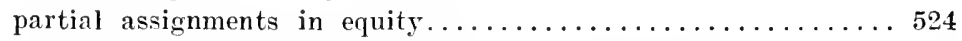

difference between an equitable and legal assignment....... 525

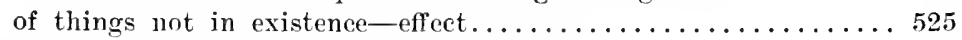

when partial assignment will be sustained........... 526

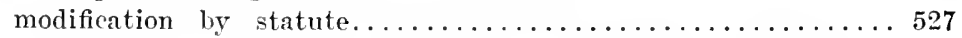

of claim to be collected in another State-statute controlling is

valid ............................. 540

ASSIGNOR AND ASSIGNEE-See AsSIGNMENTS.

assignor of promissory note-guaranty of payment need not be

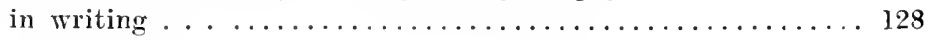

receipt of property out of which to pay debt of another-must

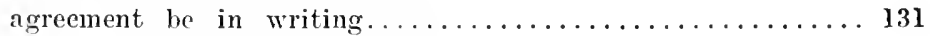

assignment for benefit of creditors................ 170 


\section{INDEX.}

ASSIGNOR AND ASSIGNEE-(continucd) Sec.

taking insurance policy valid in its inception........... 267

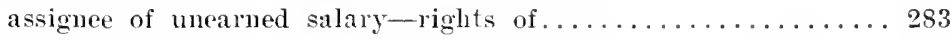

assignce of the property of a combination-notice of fraud.... 321

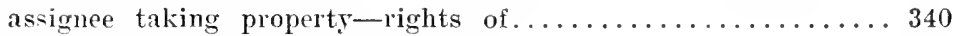

when there is no privity of contract................. 340

assignee taking property to pay assignor's debts......... 352

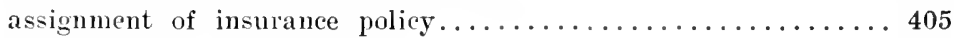

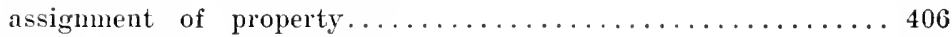

rights of assignee in voluntary................... 506

rights of assignee of stolen bill of lading............. 512

rights of assignee of unearned wages............... 515

ASSOCIATED PRESS-

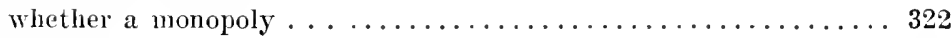

ASSUMPSIT-

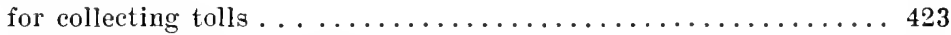

will not lie for voluntary payment................. 430

creditor accepting voluntary parment-debt extinguished..... 430

when it lies for money paid by another...........431, 432

lies for saving of another's property .............. 435

does not lie on a sealed instrument................ 442

does not lie for express promise of record............. 442

when not implied .......................... 457

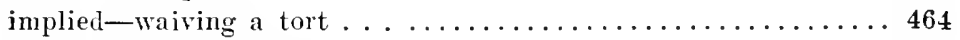

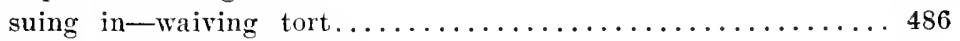

when tort may be waivel $\ldots \ldots \ldots \ldots \ldots \ldots \ldots \ldots \ldots \ldots \ldots \ldots 487$

doctrine that the property must be sold..............488

implied assumpsit lies for trees and stone converted......... 492

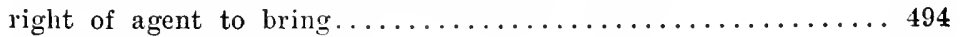

to recover money paid under a sealed contract...........6 601

ATTORNEY-

appointment of, by minor to confess judgment is void....... 2s

fees-when infant must pay.................... 43

procuring legislation-validity . . . . . . . . . . . . . 285

fees of, in pension cases may be limited by Congress........ 540

when statute of limitations runs against payment of retainer...628

ATTORNEI'S FEES-

when payable by borrower-whether usurious........... 229

AUC'ION-

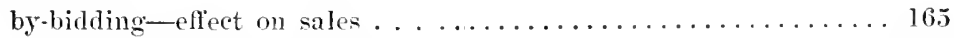

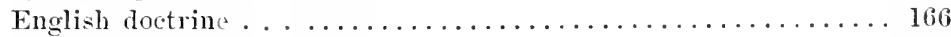

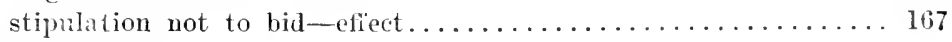

AUCTIONEEL-

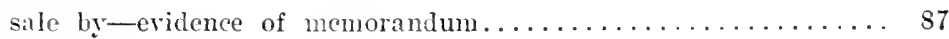

AUTHOR-

agreement to write a book- ceath of-effect on contract...... 589

contract to write-services . . . . . . . . . . . . . . 677 
INDEX.

AVOIDANCE- Sec.

of insane person's contracts.................. 21

of sale by insane person ..................... 22

of contract-return of consideration by insane person....... 23

of contract by infant-a privilege, not a disability-they are

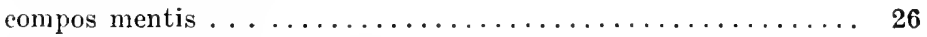

of marriege contract - non-age.................. 31

of infant's contract in shopping................. 38

of infant's contracts ...................... 57

as to personal contracts of infant................. 58

of personal contraet by infant, when .............. 58

of sale of real estate-when.................... 58

what is a reasonable time to avoid................ 59

of infant's contract for service.................. 62

of infants benefieial contracts................. 63

return of consideration by infant................. 64

how is infant's contract avoided................. 65

who may avoid infant's contract.................. 66

of infant's contracts camnot be by a stranger ........... 66

ean be made by privies in blood................... 66

cannot be by privies in estate.................. 66

when avoided by infant's administrator .............. 66

by infant of contract by action................ 71

BAGGAGE-

implied contract to send on same train with passenger......4 424

BAIL-See Barlment; BalleE.

indemnity of, by prineipal-illegal ................ 129

indemnity by third person is legal ................. 129

depositing money for security .................. 129

BAILEE-See BAILMENT.

liability of infant, as..................... 68

when railroad company is as to baggage shipped-liability ....424

of materials-loss-liability ................. 575

BAILMENT-Sec BaIleE.

responsibility-of infant.................... 68

of an article to be repaired-performance............. 575

BANKRUPTCY-

of partner, effect on partnership................. 15

of infant-discharge of debts................. 57

discharge of laborer-elfect on assigned wages for the future. .515, 516

diseharge of insolvent-efrect on judgment.............578

discharge of principal-eflect on surety's liability .........635

effect of conditional sale..................... 704

BANKS-

depositor in-pass-book written up................428

when may recover back overpayment................ 450 
BANK'S COMMISSION-See ComMISSION. See.

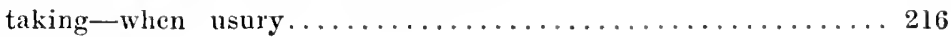

BARBERS-

when may work on Sunday.................. 188

BARGAIN AND SALE-

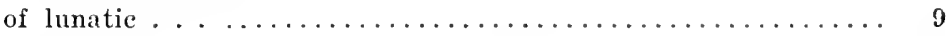

deed of insane person-equal to a feoffment............. 21

BAR-MAIDS-

regulation of occupation by legislature............. 544

BENEFI'T ASSOClATION-

servant receiving benefits from-limiting master's liability. . . . 300

BENEVULENT ASSOCIATIONS-

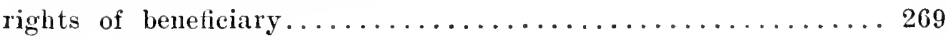

to whom benefit must be paid................... 269

\section{BEQUEST-}

oral agreement to bequeath. . . . . . . . . . . . . . 465

\section{BETTING-}

on horse races-whether gambling..................... 263

BILLS AND NOTES-

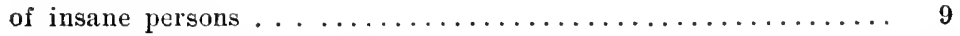

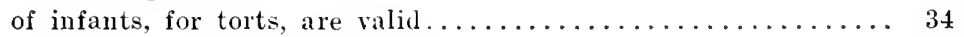

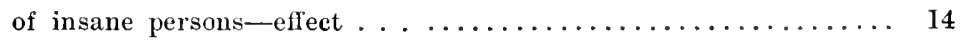

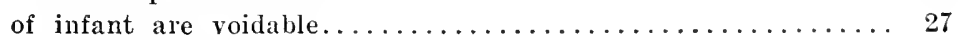

of minor are voidable-but warrant of attorney is void....... 28

of emancipated minor are voidable................ 29

holder of infant's note must demand payment of him to hold

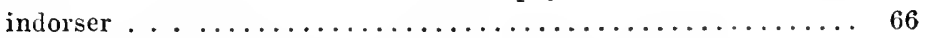

holder of-guaranteeing its collection by parol is liable...... 128

confession of judgment on note does not make the contract to

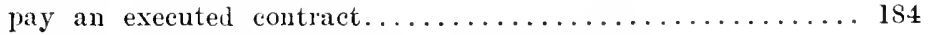

execnted on Sunday-delivered on Monday-effect.......... 185

note made on Sunday-void-in the hands of an innocent third

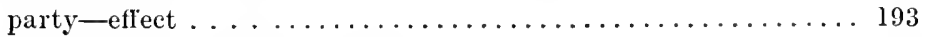

note dated on Sundas-delivered on secular day-effect...... 194

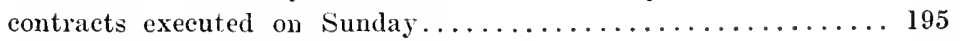

discount of accommodation paper-when usury.......... 212

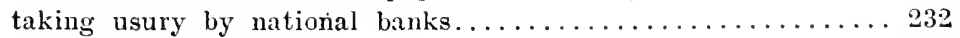

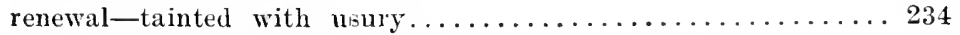

rights of innocent holder of note given for gambling contract... 257

rights of innocent holder of note given for gambling contract in

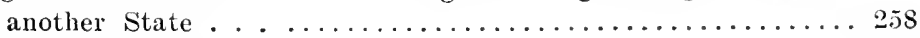

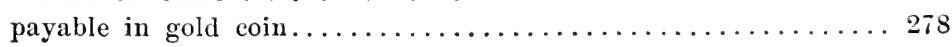

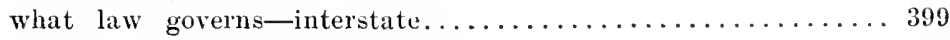

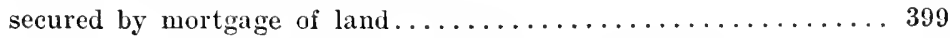

made to pay option contracts-payable in another State...... 413

given for liquor-another State law................ 413 
BILLS AND NOTES-(continucd) Sec.

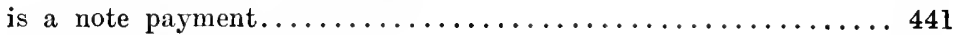

payment by bond-effect....................441

selling forged paper-recovering back money paid......... 448

given to compound a felony-illegal............... 500

holder of stolen note with notice................. 502

in the hands of an innocent holder-subject of larceny....... 504

given for antecedent debts..................... 504

in the hands of an innocent holder-stolen from owner........ 505

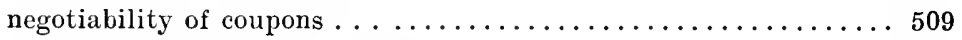

negotiability of bills of lading ................ 512

payable on demand-as to statute of limitations..........6628

note secured by mortgage-running of statute of limitations.... 629

part payment by one joint debtor-as to the statute of limitations 634

BILLS OF EXCHANGE-

in existence -verbal acceptance is valid.............. 124

to be drawn in the future are within the statute, as to acceptance 124

BILLS OF LADING-

stipulation exempting common carrier from liability-notice... 290

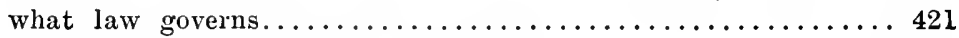

as to assignment of rights of assignee.............. 510,511

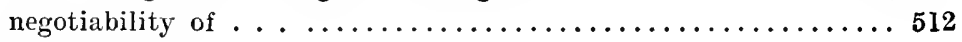

BLACKLISTING-

by employer-of union laborers................. 337

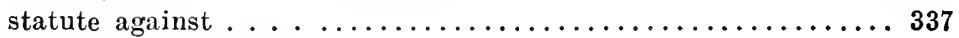

BOARD OF EDUCATION-

contracting to employ only union labor-validity.......... 301

compelling contractors to employ only union laborers-legality.. 317

BOARD OF TRADE-

dealing in futures-when void.................... 248

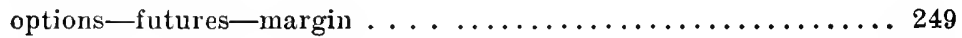

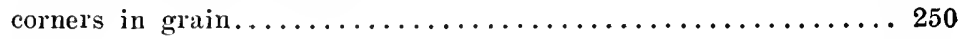

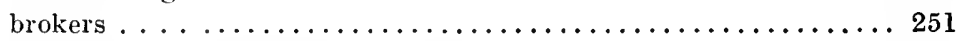

designation of transaction by diflerent name........... 252

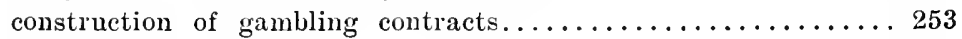

intent-deal in futures . . . . . . . . . . . . . . . . 254

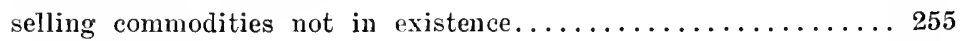

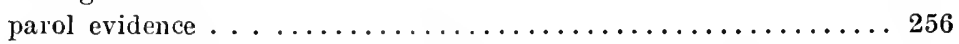

rights of innocent holder of note given on option contract..... 257

BONDS-

of infants with a penalty are voidable............... 27

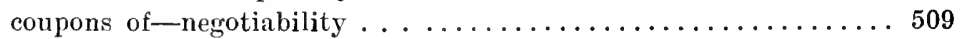

BOOK ACCOUNTS-

as evidence to place liability.................. 126

BOOKMAKING-

difference fiom pool selling-betting on horse races......... 264 
BONUS-

for making a loan-when usury.................. 216 BOUNDARIES-

settlement of by infant is voidable............... 27

BOYCOTT-

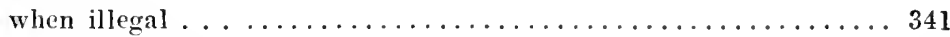

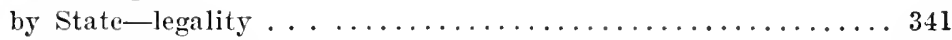

rules controlling . . ........................... 34

BREACH-See Breacil and Discharge.

of contract-anticipatory, effect............... 594

of contract-giving party right to rescind ............ 595

of building contract-what is . . . . . . . . . . . . . 662

BREACH AND DISCHARGE-See BREACII.

object in awarding damages for breach of contract........6682

rule for estimating damages...................6. 683

damages as to common carrier..................664

ale of property for special purpose...............665

for personal services-duty of laborer to protect himself.......686

contract not for the use of some special instrumentality.......687

part performance .......................6688

appreciation in the value of land .................689

uncertain and contingent damages...............6. 690

interest upon unliquidated damages...............661

breach by telegraph companies.................. 692

breach by telegraph company-mental suffering..........693

contract to furnish special material.................694

profits as damages-general rule..................695

profits which would have been made...............696

contingent profits not allowed..................697

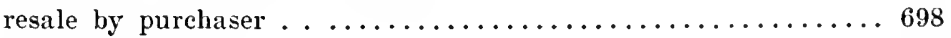

building contracts $\ldots \ldots \ldots \ldots \ldots \ldots \ldots \ldots \ldots \ldots \ldots \ldots .69$.

\section{BRIBE-}

contracts to bride-invalid ..................... 274

BROKERS-

sale by-evidence of memorandum................ 87

acting without license-effect $\ldots \ldots \ldots \ldots \ldots \ldots \ldots \ldots \ldots \ldots . \ldots \ldots$

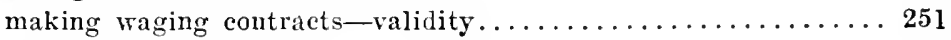

of marriage contracts............................ 275

BUCKET SHOP-

dealing in commodities-contracts are illegal........... 162

BUILDERS-See BUILdINg Contracts.

must perform their contracts in substantial performance...... 640

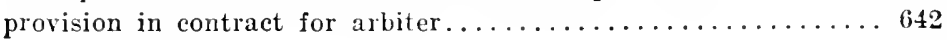

arbitration clause ..........................643

the arbiter's decision must be pertinent..............644

fraud of arbiter ............................. 645 
BUILDERS-(continued) Sec.

dispensing with the production of the architect'c certificate....646

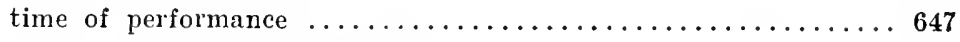

waiver of time of performance................648

BUILDING AND LOAN ASSOCIATIONS-

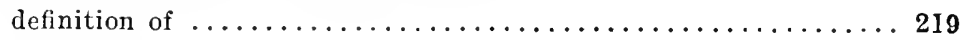

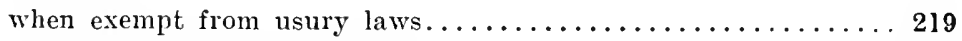

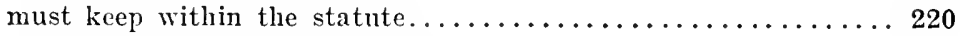

when transactions are usurious................... 219, 220

BUILDING CONTRACTS-See BUILdERS.

owner preventing performance.................660

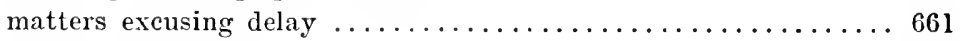

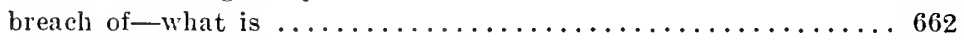

owner of building promising to pay seller of materials-effect...663

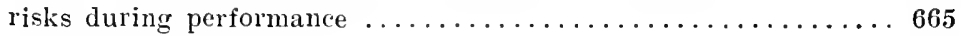

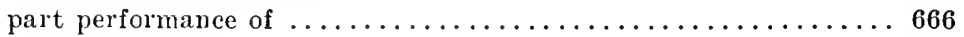

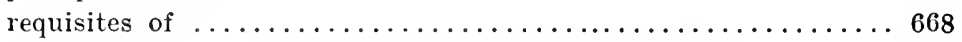

when will a court of equity decree specific performance......668

slight defects-damages $\ldots \ldots \ldots \ldots \ldots \ldots \ldots \ldots \ldots \ldots \ldots \ldots 96$

BURDEN OF PROOF-

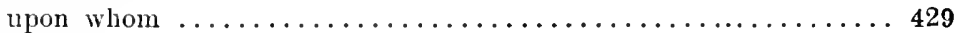

BURIAL-

of the dead-implied contract to pay expenses........... 485

BY-BIDDING-

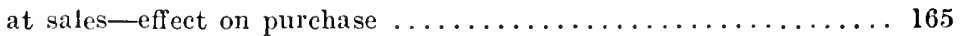

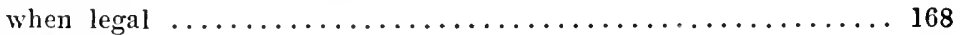

BY-LAWS-

control payment to beneficiary in benefit association........ 269

CAPACITY TO CONTRACT-

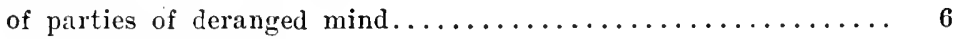

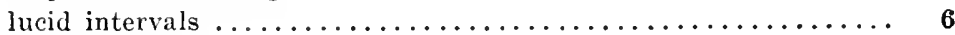

CAPACITY TO MARRY-

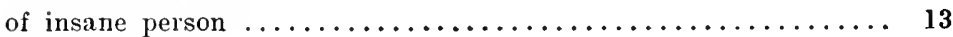

CERTIFICATE-

must be taken out by teacher, to draw his salary.......... 201

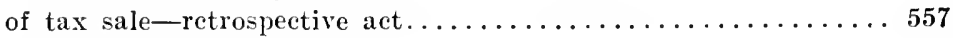

of architect-effect ...........................646

CESTUI QUE TRUST-

when he may sue..................................... 364

when suit must be brought in the name of the trustee....... 364

CHANCERY-

filing a bill in, takes the contract out of the statute of frauds... 85

CHARTERS-See Francinses.

reservation in ............................... 2

when may be introdnced as evidence as to a valid sale of chattels. .256

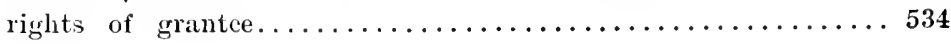




\section{INDEX.}

CHARTERS- $($ continued $)$ Sec.

exclusive franchise . . . . . . . . . . . . . . . . . . . . 535

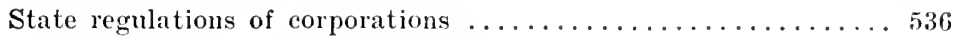

subsequent acts regulating railroad companies........... 537

establishing maximum rates .................. 538

legislature must not destroy a business by establishing maximum

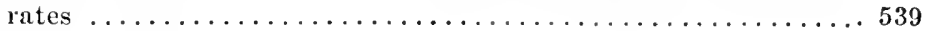

private contracts .......................... 540

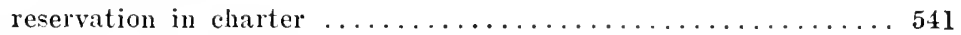

CHATTEL MORTGAGES-

lien follows the property.................... 402

danger clause camot be changed by subsequent act........ 562

CHATTELS-

wrongfully obtained-rights of true owner........... 505

CHECKS-

verification of pass-book by clerk-duty of principal........ 428

how considered in the hands of an innocent holder......... 505

CHILD LABOR LAW-See INFANTS.

violation-employment of minors $\ldots \ldots \ldots \ldots \ldots \ldots \ldots \ldots \ldots 203$

CHOSES IN ACTION-

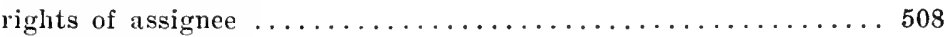

when assigned-action brought in assignee's name........ 527

CITIES-

liability for negligence of water company.............. 349

assignment by city of water contract............... 350

CIVIL RIGHTS CASES-

ticket to public entertainment-rights of vendee of ticket-Ameri-

can doctrine .............................. 509

COAL STRIKE COMMISSION-

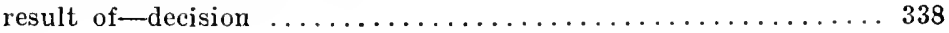

COIN-

gold clause in contracts-effect................. 529

COLLATERAL PROMISE-

comes under the statute of frauds................. 121

COMBINATIONS-See Industrial Combinations.

of quasi-corporations to stifle competition.............. 305

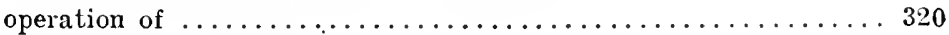

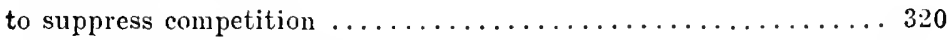

in restraint of trade, general or partial............... 321

may be legal when not a monopoly .................. 322

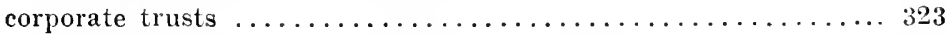

trusts formed in Ohio and in New York-legality........... 324

Standard Oil Company--authority to do business.......... 324

Sugar Refining Co. of New York-right to do business......... 324

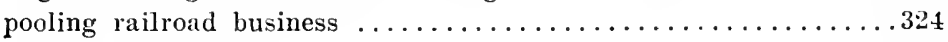

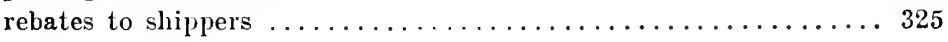




\section{INDEX.}

COMBINATIONS-(continued)

monopoly in interstate and international trade . . . . . . . . 326

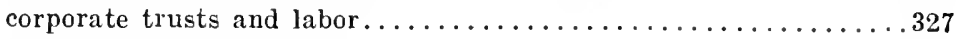

trades unions are lawful ..................... 334

of laborers for self-protection $\ldots \ldots \ldots \ldots \ldots \ldots \ldots \ldots \ldots \ldots \ldots$

COMMISSION-See CoMmission AND Drscount.

collection by nonlicensed broker.................... 198

taking interest and commissions. ..... .............. 198

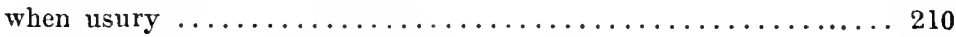

to agent for loaning principal's money-usury........... 211

COMMISSION AND DISCOUNT-See DIscounT; Commrssron.

when taken-amounting to usury ................. 228

agent taking commission ..................... 228

COMMON CARRIERS-

designation of, by vendee-delivery............... 152

through tickets-when interstate commerce............ 182

a physician does not come under the rules of ............ 200

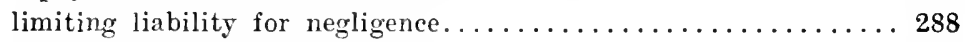

limiting liability for carelessness................. 288

limiting liability beyond their own lines............. 290

limiting liability as to losses not from their own negligence.... 291

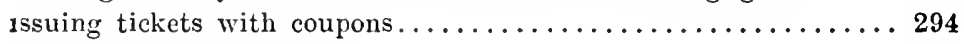

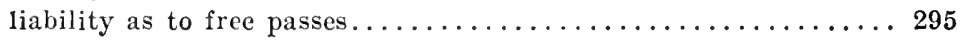

whether telegraph companies are................. 296

limiting liability for their own negligence............. 299

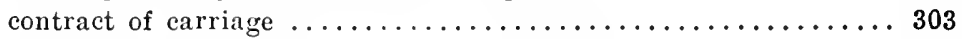

buying a competing line to suppress competition........... 304

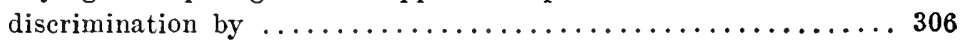

rights to regulate the carriage of goods and passengers....... 320

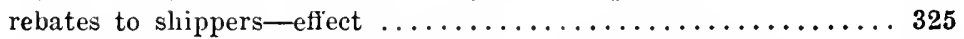

stipulation exempting from negligence-interstate commerce.... 410

interstate contracts of affreightment................421

limitation of contract...................... 421

implied contract to send baggage on same train with passenger.. 424

regulation of, by the State............536, 537, 538, 539

in interstate and foreign commerce-regulation of......... 550

excused by act of God or public enemy.............. 582

when liable for act of God ................... 583

duty to deliver goods......................615

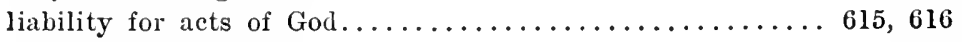

shipment of live stock.................... 617

breach of contract to deliver goods-damages............684

COMPOSITION AGREEMENT-See INSOLvENCY.

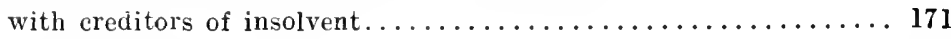

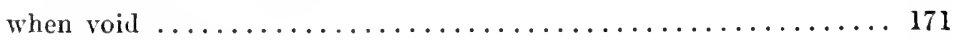

secret preferences $\ldots \ldots \ldots \ldots \ldots \ldots \ldots \ldots \ldots \ldots \ldots \ldots \ldots \ldots \ldots \ldots$ 
COMPOSITION AGREEMENT-(continued) Sec.

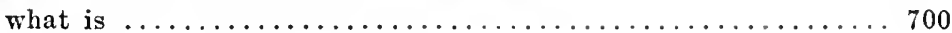

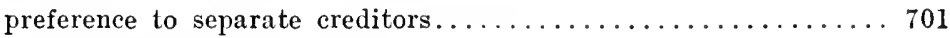

with part of the creditors ...................... 702

adjustment and compromise ..................... 703

conditional sale-validity of, in bankruptey........... 704

COMPOUNDING-

of felony-duress ......................... 500

COMPOUND INTEREST-See INTEREST.

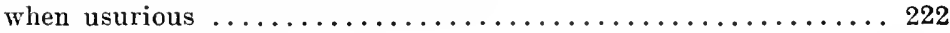

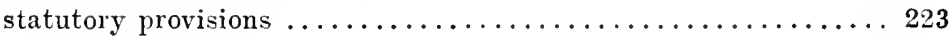

compounding of interest-usury ................ 226

COMPROMISE-

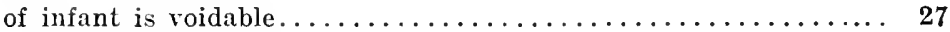

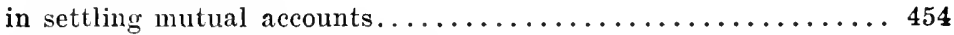

with creditors-insolvent debtor $\ldots \ldots \ldots \ldots \ldots \ldots \ldots \ldots \ldots \ldots$

CONDITIONAL SALES-

validity of in bankruptey...................... 704

CONDITIONS-

precedent-performance of contract............... 570

matters excusing nonperformance of contract............656

implied as to contingent impossibility of performance.........657

implied conditions of contracts..................658

when implied, as to contracts..................659

contracts subject to performance.................68 68

CONDUCTOR-

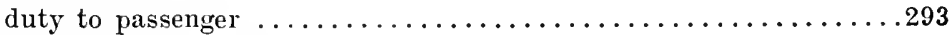

CONFLICT OF LAWS-

lex loci celebrationis governs the interpretation of contract..... 115

as to the statute of frauds.......................... 116

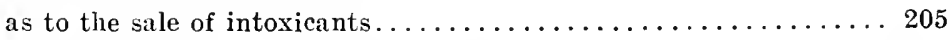

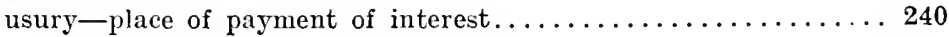

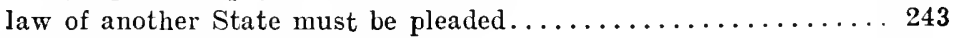

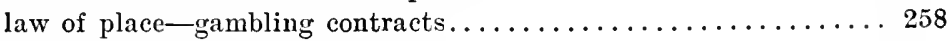

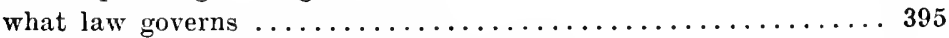

rule of construction of laws and contracts............ 533

what law governs-suits against which the statute of limitations

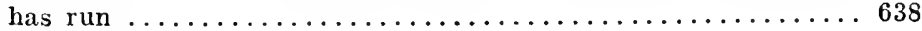

CONSERVATOR-

of insane person-contracts $\ldots \ldots \ldots \ldots \ldots \ldots \ldots \ldots \ldots \ldots \ldots$

CONSIDERATION-

return of-avoidance of contract by insane person.......... 23

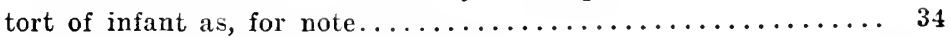

return of - when infant avoids contract..............6. 63,64

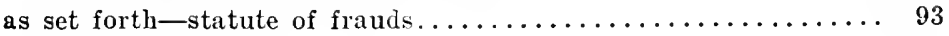

"for value received" $\ldots \ldots \ldots \ldots \ldots \ldots \ldots \ldots \ldots \ldots \ldots \ldots, 94$ 


\section{INDEX.}

seal imports a consideration.................... 95

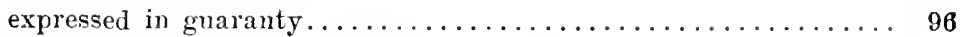

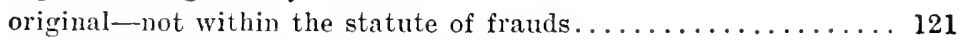

to bind third person under the statute of frauds........... 122

to support contract to pay debt of another............. 128

substituting one debt for another-whether within the statute of

frauds ................................ 130

of agreement of composition....................... 17

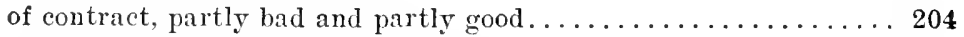

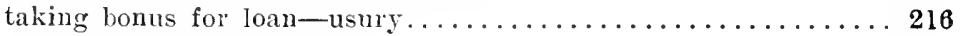

of note-innocent bolder ...................... 257

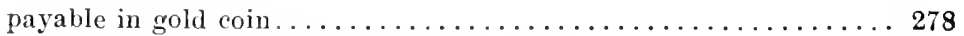

free passes-collateral consideration besides............ 295

to pay railroad company a sum for locating station......... 302

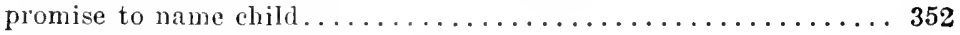

must be more than a mere promise................ 354

whether third party can sue on contract made in his favor...... 356

party buying business-to pay debts-liability........... 358

want of-recovering back money paid............... 448

failure of-party causing-rights of .............. 448

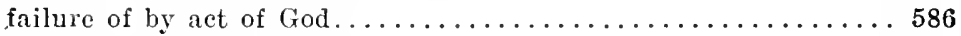

failure of-recovering back $\ldots \ldots \ldots \ldots \ldots \ldots \ldots \ldots \ldots \ldots \ldots \ldots \ldots 5$

recovering back after rescission of contract............ 599

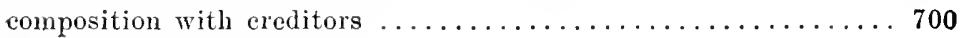

CONSIGNOR AND CONSIGNEE-

"consignor drawing on consignee-rights of parties.........511

CONSPIRACY-

to raise price of stock-illeral contracts-............ 163

to stifle competition at auction sales-effect........... 165

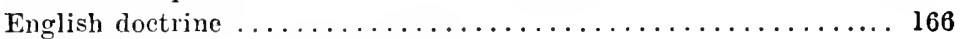

CONSTRUCTION-See INTERPRETATION.

CONTRACT'S-

of insane persons $\ldots \ldots \ldots \ldots \ldots \ldots \ldots \ldots \ldots \ldots \ldots \ldots \ldots, \boldsymbol{9}$

of lunatics, after inquisition found $\ldots \ldots \ldots \ldots \ldots \ldots \ldots \ldots \ldots \ldots$

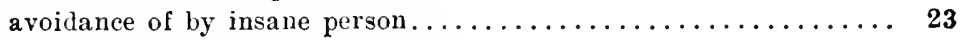

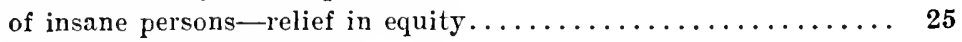

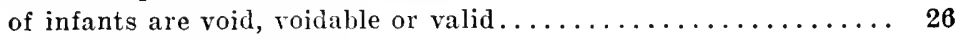

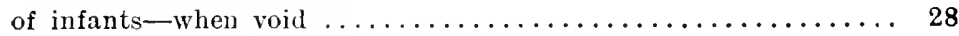

of infants-when valid......................... 30

of infants required by law are valid................. 35

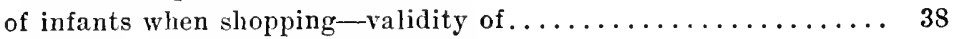

of infant for necessaries are valid . . . . . . . . . . . . 39

of infant for repairs on his real estate, voidable............ 42

of infants-necessity of ratification............... 51

when ratified valid ab initio....................... 51 
CONTRACTS-(continued) Sec.

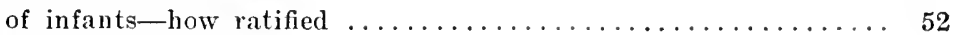

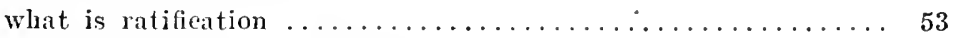

of infants what is a ratifieation.................... 53

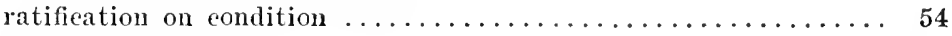

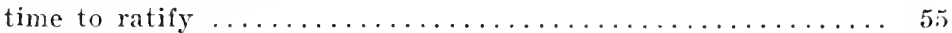

silence as a ratifieation...................... 56

of infants-avoidance of $\ldots \ldots \ldots \ldots \ldots \ldots \ldots \ldots \ldots \ldots \ldots \ldots \ldots$

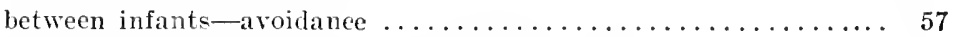

as to personalty - when may be avoided by infant......... 58

as to realty, by infant, when avoided................ 58

of partnerslip by infant-his liability............... 60

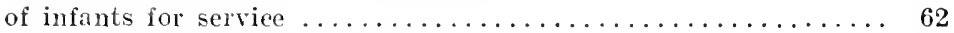

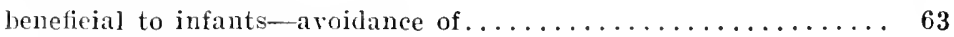

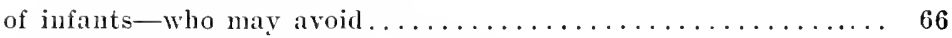

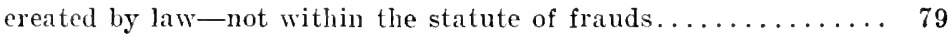

exeeuted, not within the statute of frauds............. 80

executed on one side, not within the statute of frauds........ 82

what law governs ............................... 115

of indemnity-whether within the statute of frauds........ 129

abandoning work-owner of work agreeing to pay workmen

wh ther within the statute of frauds.............. 132

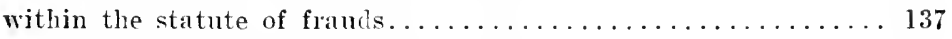

not within the statute of frauds, as to time............ 138

application of the 17 th section of the statute of frauds....... 138

exeented and executory, governed by the statute of frauls..... 139

of work and labor-when within the statute of frauds........ 146

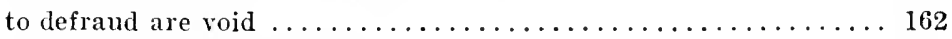

to buy stoek at a fietitious premium-effect............. 163

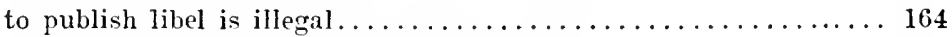

to prevent competition at sales, are illegal............. 165

not to bid at auction sales-effect................. 167

made in violation of law. . . . . . . . . . . . . . . . . 173

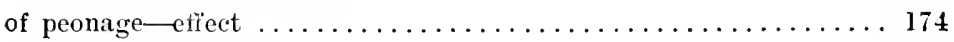

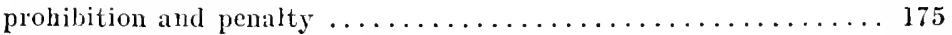

malum in se-illegal . .......................... 176

malum prohibitum-validity . ............... 170

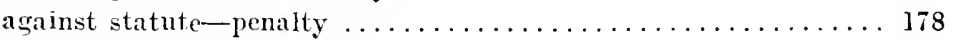

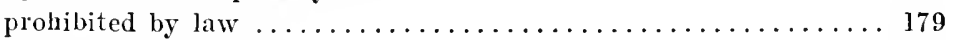

made on Sunday at common law.................. 180

Sunday contraets-English laws .................. 180

to be performed within and without the statute-when interstate

commerce . . .................... 18.

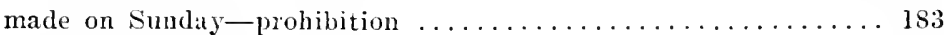

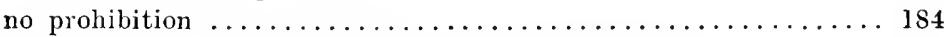

negotiated on Sunday-completed on Monday-etiect......... I85 


\section{INDEX.}

CONTRACTS- (continucd) Sec.

within the prohibition of Sunday contracts............ 186

void-made on Sunday-ratification ................ 192

made on Sunday - rights of innocent third parties........... 193

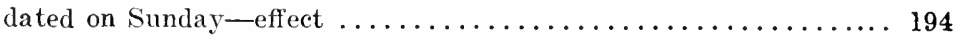

made on Sunday-executed and executory.............. 195

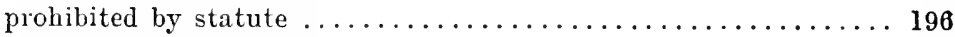

of sale of prohibited articles.................... 202

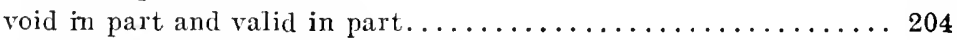

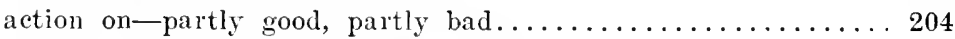

hiring or renting of securities, when usury............ 218

having an independent existence - not usury............. 235

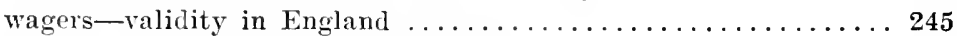

wagers-validity in the United States............... 246

statutory provisions as to wagering contracts.......... 247

on option-futures-margins $\ldots \ldots \ldots \ldots \ldots \ldots \ldots \ldots \ldots \ldots \ldots 249$

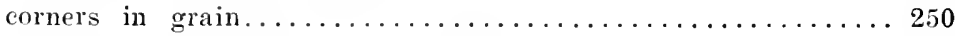

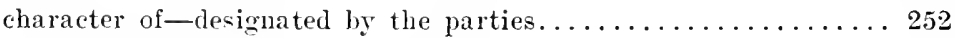

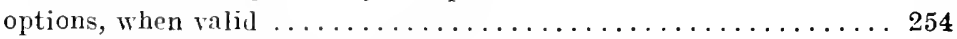

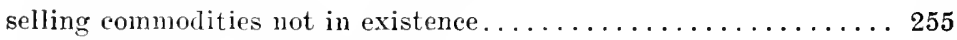

as controlled by public policy...................... 274

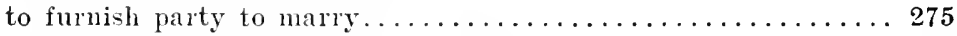

stipulation that false representation shall not avoid........276

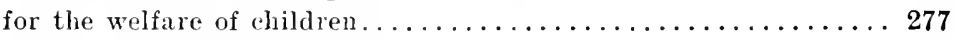

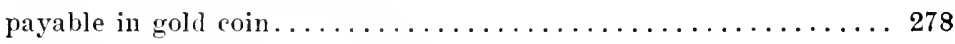

influencing appointment to office. . . . . . . . . . . . . 280

by newspaper to advance the interest of a candidate........ 280

compensation to officer by private person............. 281

to control the regular administration of justice.......... 282

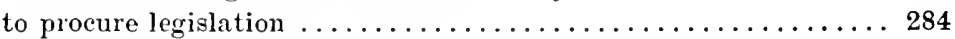

to use improper influence-illegal................... 286

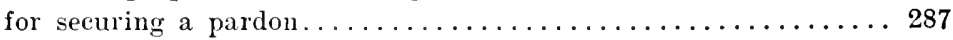

special contract of railroad company to haul circus cars.......288

express contract by express company limiting its liability...... 289

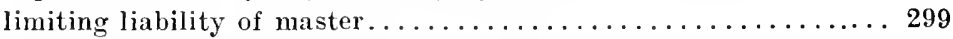

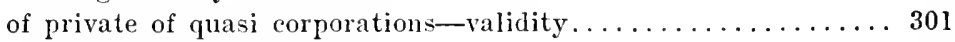

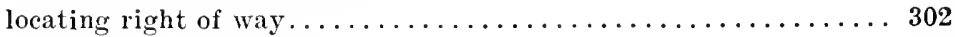

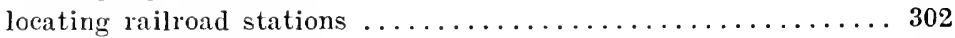

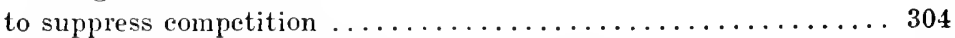

made by corporations giving exclusive privileges.......... 308

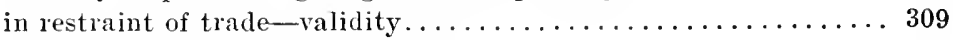

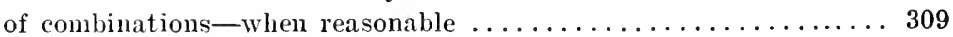

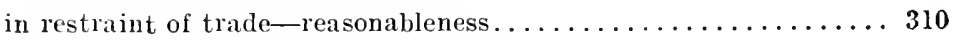

in restraint of trade-English doctrine................. 311

American doctrine in restraint of trade............... 312

construction of in retraint of trade.................. 316 
CONTRACTS-(continued) Sec.

dealing with exclusive persons.................. 316

sale of secret process. . . . . . . . . . . . . . . . 316

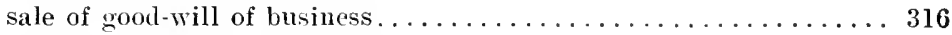

of monopoly in restraint of trade.................. 320

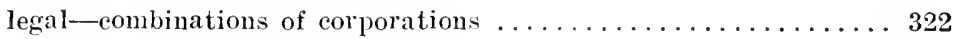

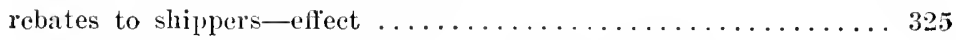

combinations to restrict the right to contract-legality . . . . . 334

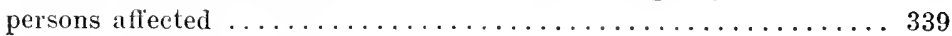

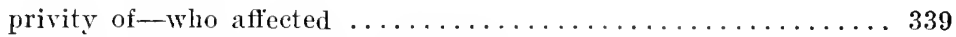

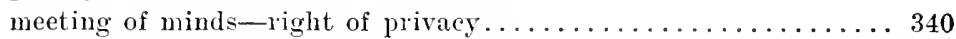

where there is no privity of parties................. 340

as to boycotts .............................. 341

duty not to interfere........................ 342

privity of party-stranger's rights................ 348

for the benefit of third parties. . . . . . . . . . . . . 352

assumption of mortgage debt-right of mortgagee to sue...... 353

must be something more than a mere promise............. 354

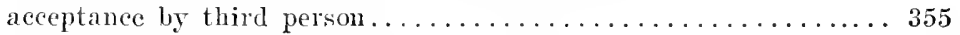

for the benefit of third persons-modification of the rule......356

exceptions to the modified rule................. 357

party to the consideration-trust................ 358

promise as to agent. . . . . . . . . . . . . . . . . . . . . 359

English doctrine . . . . . . . . . . . . . . . . . 360

next-of-kin-right to sue ........................ 361

covemants .......................... 362

covenants-another rule $\ldots \ldots \ldots \ldots \ldots \ldots \ldots \ldots \ldots \ldots \ldots$

who may bring suit on simple contract.............. 364

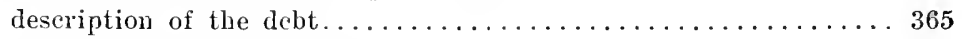

agreement to save harmless. ................. 366

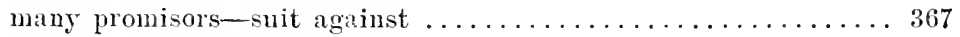

oral merged in special-effect.................. 370

when several ............................. 382

joint subseribers $\ldots \ldots \ldots \ldots \ldots \ldots \ldots \ldots \ldots \ldots \ldots \ldots \ldots \ldots \ldots \ldots$

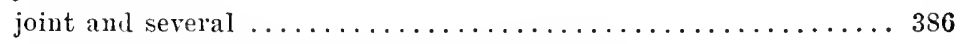

release of several and joint promisors by law . . . . . . . . . 387

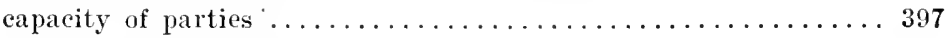

validity-how determined ..................... 408

as to the payment of interest-law of another State........447

agreement as to what law shall govern............... 420

impairing the obligation of-dismissal of public office........426

no implied contract between parties making an express contract. . 442

when void, are a nullity...................... 443

difference between express and implied.................444

implied-when receiving money which belongs to another . . . . . 445

a party may contract with whom he pleases in express contract. . 457 
CONTRACTS- (continued) Sec.

when private camnot be regulated by the legislature.........540

law enters into when made..................... 555

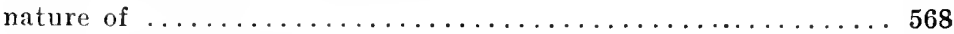

subsequently arising-performance $\ldots \ldots \ldots \ldots \ldots \ldots \ldots \ldots$

in commercial transactions . . . . . . . . . . . . . . 574

bailment of artiele to be repitired . . . . . . . . . . . . . 575

executory contracts can only be rescinded............. 593

CONTRACTUAL RELATIONS-

persons aflected ........................... 339

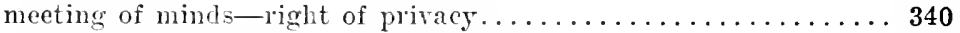

master and servant-interference of third parties-boycott..... 341

duty not to interfere in any contract............... 342

restricting the rule to servast................... 343

when the period of emplofment is not certain. . . . . . . . . 344

doing an act which is legal within itself.............. 345

fraudulent representations ................... 346

to sustain an action the diseharge must take place. . . . . . . 347

as to priorities of the parties...................... 348

water companies-rights of third parties............... 349

assignment of city contract. . . . . . . . . . . . . . 350

no priorities of parties or of consideration ............ 351

CONTRIBUTION-

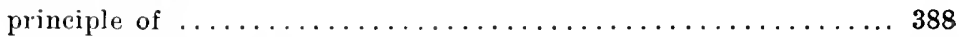

when surety may clain. ..................... 388

payment by surety-in what property . . . . . . . . . . . 389

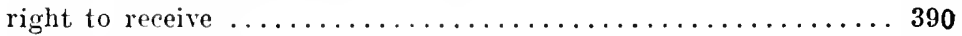

by joint wrongdoers ...................... 394

in cases of indemnity ........................ 394

among sureties .......................... 434

right to have $\ldots \ldots \ldots \ldots \ldots \ldots \ldots \ldots \ldots \ldots \ldots \ldots \ldots \ldots \ldots$

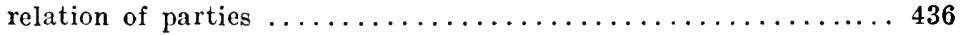

among wrongdoers $\ldots \ldots \ldots \ldots \ldots \ldots \ldots \ldots \ldots \ldots \ldots \ldots \ldots \ldots$

among wrongdoers-exceptions to general rule...........438

CONVERSION-

of property-waiving tort $\ldots \ldots \ldots \ldots \ldots \ldots \ldots \ldots \ldots \ldots$ 48, 489

CONVEYANCES-

of Iand- specific performance ..................667

of land-failure of-liquidated damages..............671

CORNERS-

in grain, on board of trade-validity . . . . . . . . . . . 250

combination of parties to advance price of grain. . . . . . . 250

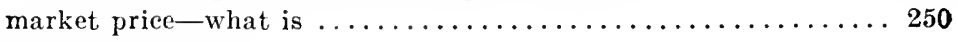

CORPORATE TRUSTS-

industrial and commercial combinations.............. 323

pooling railroad business $\ldots \ldots \ldots \ldots \ldots \ldots \ldots \ldots \ldots \ldots \ldots \ldots$ 
CORPORATE TRUSTS-(continued)

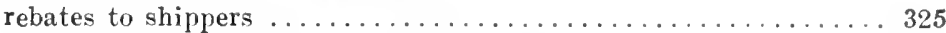

monopoly in interstate and international trade........... 326

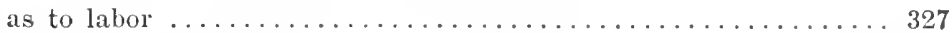

antagonism to labor ....................... 327

sugar trust agreement, for protection of corporations against labor 327

OORPORATIONS-

private contract of quasi corporation................. 301

locating right of way and stations of railroads........... 302

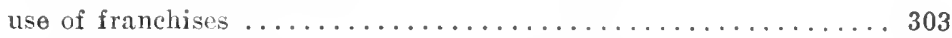

combination of quasi colporations to stifle competition........ 305

telegraph and telephone companies must not discriminate......307

giving exclusive privileges ..................... 308

right to create a monopoly....................... 320

restraint of trade-general or partial................ 321

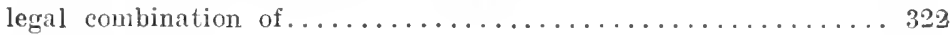

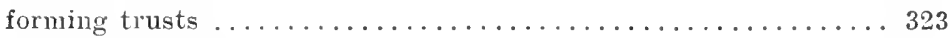

pooling of railroad business..................... 324

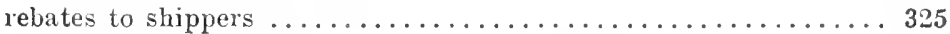

monopoly in interstate and international trade............ 326

corporate trusts and labor.................... 327

what law governs interstate contracts................ 395

member of-paying corporate debt.................442

making voluntary payment-effect ..................448

must fulfil implied contracts......................459

liability to promoters ......................463

having money misappropriated by treasurer-rights of ....... 503

collection of debts in a State where they have no situs.......552

as grantee from state......................... 534

when exchusive franchises are given................. 535

exclusive franchises ....................... 535

regulated by the State ....................... 536

State regulation of $\ldots \ldots \ldots \ldots \ldots \ldots \ldots \ldots \ldots \ldots \ldots \ldots$

subsequent acts regulating railroad companies............ 537

State establishing maximum rates................. 538

legislature must not destroy a business by establishing maximum

rates ............................... 539

private contracts . . . . . . . . . . . . . . . . . . 540

reservation in charter....................... 541

as to the running of the statute of limitations............630

enforcing contracts against . . . . . . . . . . . . . . 668

COPYRIGHT-

publisher trying to ereate an infringement by reservation...... 330

COUNTER-CLAIM-

setting $u p-$ waiver of tort....................490 


\section{INDEX.}

COUPONS- Seo.

given as interest notes-drawing interest-not usury ........222

interest coupons-not usurious ................. 224

when negotiable .........................509

COUPON TICKETS-

of carriers-rights of connecting lines............... 294

COVENANTS-

of infant to carry money are voidable.............. 27

for use and occupation are valid.................. 111

limited as to space-restraint of trade-English doctrine..... 311

as to limitation of time and space................ 312

test of reasonableness as to restraint of trade............ 313

the latest statement as to reasonableness in the restraint of trade. 314

to benefit a third person ..................... 362

another rule $\ldots \ldots \ldots \ldots \ldots \ldots \ldots \ldots \ldots \ldots \ldots \ldots \ldots \ldots \ldots \ldots$

to save harmless-who can bring suit.............. 366

not to sue-effect $\ldots \ldots \ldots \ldots \ldots \ldots \ldots \ldots \ldots \ldots \ldots \ldots \ldots$

when pleadable $\ldots \ldots \ldots \ldots \ldots \ldots \ldots \ldots \ldots \ldots \ldots \ldots \ldots \ldots \ldots$

or debt will lie for action on sealed instrument..........442

part performance of void contract................479

of warranty of assignment of expectancies.............520

excused by act of law ...................... $57 \theta$

COVERTUPE-

disability of, concurring with the privilege of infancy-when deed

may be affirmed ......................... 32

\section{CRIMES-}

committed by the beneficiary in life insurance-effect........545

\section{DAMAGES-}

for property destroyed-promise to pay by third person must be in

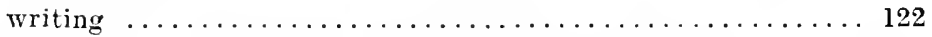

measure of, for trees and stone taken from another's land . . . . . 492 recoverable for rescission of contract...............610 object in awarding $\ldots \ldots \ldots \ldots \ldots \ldots \ldots \ldots \ldots \ldots \ldots \ldots \ldots$

rule for estimating for breach . . . . . . . . . . . . . . . . 683

common carrier's breach ......................684

sale of property for special purposes-breach of contract...... 685

breach of contract for personal services................686

contract not for the use of some special instrumentality .....687

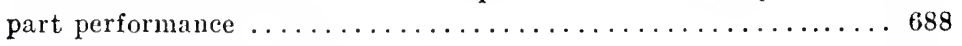

appreciation in the value of land $\ldots \ldots \ldots \ldots \ldots \ldots \ldots \ldots \ldots \ldots$

contracts and contingent damages.................690

interest upon unliquidated.....................691

breach by telegraph conıany ................... 692

breach by telegraph company-mental suflering...........693

contract to furnish special material-breach of . . . . . . . . 694

profits as damages-general rule.................. 695 


\section{INDEX.}

DAMAX्रES-(continued) Sec.

profits which would have been realized ..............696

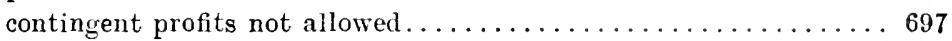

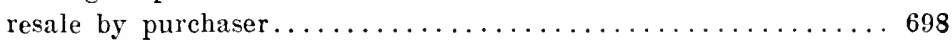

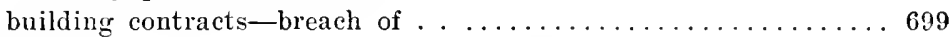

DATE-

of contract made on Sunday-dated on Monday-effect........ 185

validity of contract-delivery $\ldots \ldots \ldots \ldots \ldots \ldots \ldots \ldots \ldots \ldots 185$

note dated on Sunday-executed on another day-eriect........ 194

antedating note-interest payable in advance, when usury..... 217

DEATH-

of ancestor-rumning of the statute of limitations.........631

DEBT.

or covenant will lie for action on sealed instrument........ 442

DEBTOR AND CREDITOR-

a creditor cannot disaffirm an infant debtor's sale......... 66

collateral promise to pay debt of debtor-within the statute of

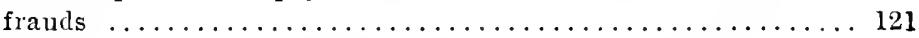

liability of person to pay debt of another-five essentials...... 122

to whom promise to pay debt of another must be made....... 123

promise to pay debt of another promisor benefited ......... 125

release of original debtor-novation-whether within the statute

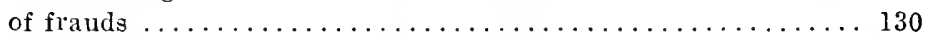

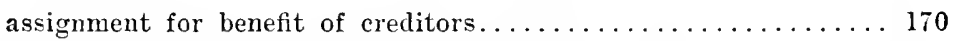

secret preferences in insolvency-particeps criminis........ 172

liniting amount of debt in the insurance policy.......... 268

fraud in account stated-effect................. 427

depositor in bank-relation to bank.............4 428

third roluntarily paying creditor who accepts payment-effect.. 430

voluntary payment of another ................... 430

when law creates an agreement to pay the debts of another... 431

payment of debt of another-obligation.............. 431

payment of debt of another-no assumpsit is raised........ 432

absence of debtor from State-ruming of the statute of limita-

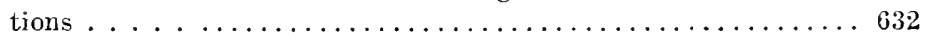

absence of the creditor from the State-running of the statute of

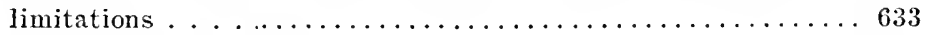

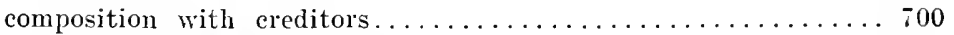

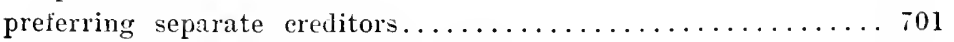

composition with part of the ereditors $\ldots \ldots \ldots \ldots \ldots \ldots \ldots, 702$

DECEIT-

of infant-liability of $\ldots \ldots \ldots \ldots \ldots \ldots \ldots \ldots \ldots \ldots, 68$

DECREE-

not binding on infant in ventre sa mere............... 
of lunatic, feoffment ..................... 9

of insane person, how ratified $\ldots \ldots \ldots \ldots \ldots \ldots \ldots \ldots \ldots \ldots 21$

of iusane person-affirmance or avoidance of .......... 21

of insane man cannot be set aside by a stranger.......... 25

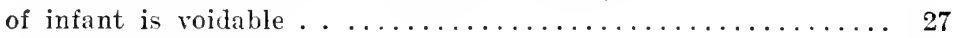

of trust by infant-how ratified................. 53

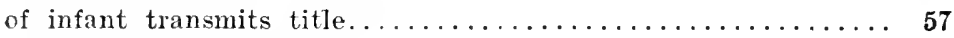

of minor-how aroided .................... 57

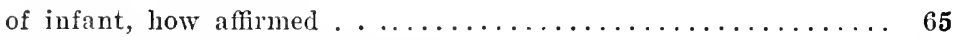

when decreed-part performance................ 107

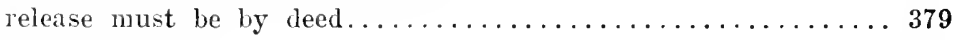

what law governs ........................ 403

DEFALCATION-

money misapplied-riglits of third persons...........503

DEFENSE-

oral sale of land set aside.................... 112

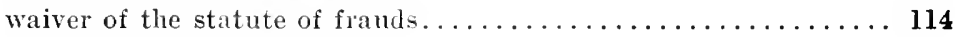

DEFINITION-

of necessaries for infant.................... 40

DEL CREDERE-

definition of $\ldots \ldots \ldots \ldots \ldots \ldots \ldots \ldots \ldots \ldots \ldots \ldots \ldots$

DELIVERY-See Delivery and Acceptance.

of note or memorandum of contracts in writing......... 84

of possession, coupled with making valuable improvements, or the

payment of the purchase price, is part performance....... 102

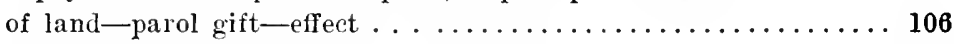

of property in possession of third party.................. 150

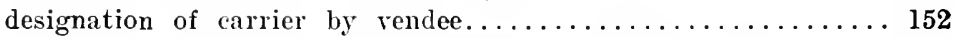

of instrument nade on Sunday, delivery on Monday-effect.... 185

of note dated on Sunday, on secular day-effect........... 194

of insurance policy, completes contract............. 404

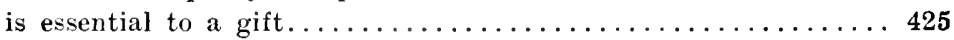

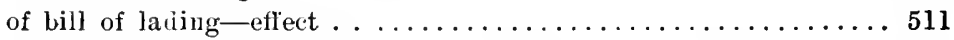

of warehouse receipt-effect on the property represented..... 513

contract to deliver gold coin...................5 529

by vendor-executed sale cannot be rescinded.......... 593

DELIVERY AND ACCEPTANCE-See DELIVERX.

of goods-within the statute of frauds............. 145

may not be at the same time.................. 145

DE LUNATICO INQUIRENDO-

writ of-contract of lunatic.................... 12

DEPOSITARY-

holding stolen money with notice............... 502 
in bank-duty to examine pass-book. . . . . . . . . . . . 428

over-paid-recovering back money................ 450

\section{DESCRIPTION-}

of parties, in memorandum of sale................ 88

of subject-matter in memorandum under statute of frauds....91, 92

of the debt-benefit of third person.................. 365

DEVISE-

parol promise to devise - within the statute of frauds....... 108

oral agreement to devise property................465

oral agreement-enforeed in equity ................ 466

agreement to devise to a certain person-effect...........667

DISAFFIRMANCE-See AroIDANCE.

DisCHARGE-See Breach and Discharge.

of laborer in bankruptey-cffect on future wages assigned. ..515, 516

DiscounT-See Commission; Conimission and Discount.

on accommodation paper-usury................ 212

accommodation paper in hands of innocent party-usury...... 212

DISCRIMINATIONS-

suppression of competition.......................... 304

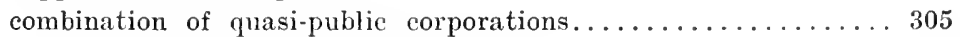

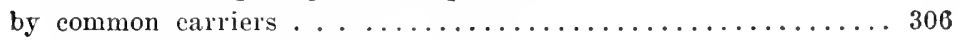

by telegraph and telephone companies.............. 307

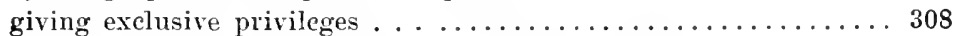

in favor of agriculture products-restraint of trade......... 321

by railroads-rebates to shippers................ 325

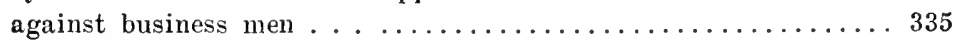

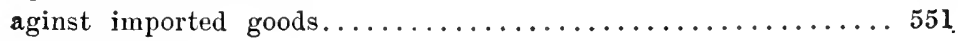

DISSOLUTION-

of partnership by bankrnptey, death or lunacy of partner..... 15

of partnership-rights of partners..............431, 433

DISTRESS-

of goods-released by third party................. 435

for rent-when may be abolished.................. 560

DIVORCE-

is a proceeding in quasi in rem....................400

liability of father for necessaries of children...........470

DOCTOR-See PHYSICIAN.

DOMICIL -

of party seeking divorce...................... 400

of owner of personalty governs.................. 407

of debtor-absence from State-running of the statute of limi-

tations . . ...........................632

DRAFTS-

drawn by consignor-rights of parties.............5 511

third party taking bill of lading.................. 511 


\section{INDEX.}

DURESS- Sec.

payment under-effect ..................... 452

payment under......................... 455

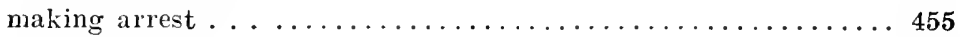

money obtained under-recovery . ................496

of goods-right of injured party................ 497

by imprisonment-legel or illegal................. 498

threats of imprisomment ..................... 499

EARNEST AND PART PAYMENT-

distinguished under the statute of frauds.............153

when part payment must be made................. 154

what constitutes part payment.................. 155

in what property part payment can be made............ 156

EDUCATION-

as a necessary for infant..................... 41

whether a necessary to infant...................43

EIGHT-HOUR LAW-

is it class legislation $\ldots \ldots \ldots \ldots \ldots \ldots \ldots \ldots \ldots \ldots \ldots$

under the police power..................... 4

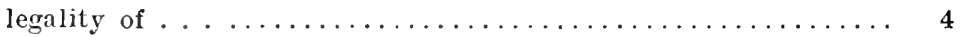

ELECTION-

waiving tort and suing in assumpsit...............487

doctrine that the property must be sold..............488

bets on election-rights of stakeholder .............502

EMANCIPATION-

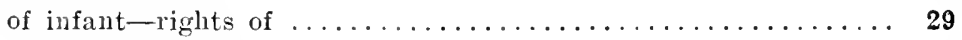

illegality of cannot be set up by strangers.............. 29

of infant by marriage ..................... 29

of child by father-effect.....................470

EMPLOYER AND EMPLOYE-

under the truck system ...................... 2

putting child to do prohibited labor-effect............ 203

unfair firms, listed by unions ................... 335

picketing by employe....................... 336

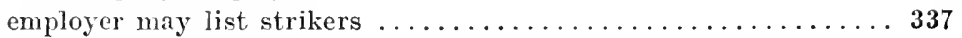

boycotts by employe ......................... 341

malicious interference between, by third party . . . . . . . . 343

when the period is not certain-malicious interference.......344

employer agreeing to protect employe from strikers. . . . . . . . 348

employe recovering for extra services................462

effect of contract of employe not to marry .............474

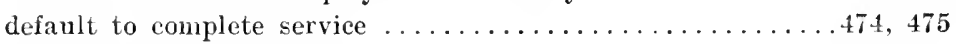

substantial performance of contract-effect $\ldots \ldots \ldots \ldots \ldots \ldots \ldots 7$

right of employe to assign nuearned wages.............515

partial indebtedness cannot be assigned ...............521 


\section{INDEX.}

EMPLOYER AND EMPLOYE-(continued)

effect of statute compelling employers to give reason for discharge

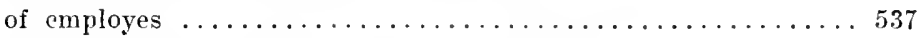

regulating hours of work of women and minors.......... 544

death of employer-effect on contract.............. 592

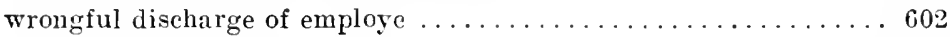

constructive service ........................6. 603

service to be performed in the future...............604

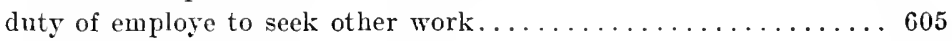

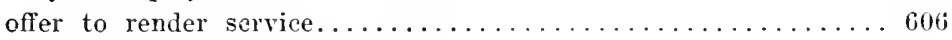

mode of rescission by employer ..................... 607

enploying another to work on personalty .............668

entploying another to affix machine to realty............609

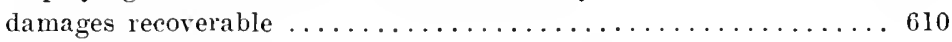

after notice of rescission-duty of the employe..........6. 611

contract of hiring-employe guarantees satisfaction.........614

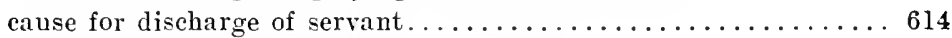

hiring contracts-implication of discharge ............. 618

reservation of wages payable at certain intervals..........619

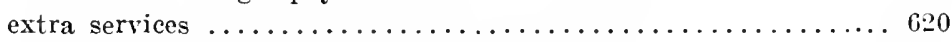

contract of hiring-as to statute of limitations . . . . . . . 628

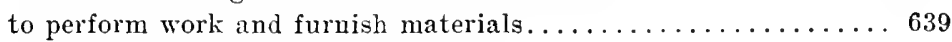

substantial performance-good faith $\ldots \ldots \ldots \ldots \ldots \ldots \ldots \ldots \ldots \ldots$

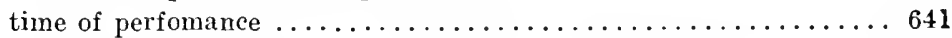

meaning of satisfaction in doing work as to the employer......653

EMPLOYMENT BUREAU-

run by the State-boycott illegal.................. 341

ENGINEER-

as arbiter in building contracts................... 643

fraud of-as arbiter-effect $\ldots \ldots \ldots \ldots \ldots \ldots \ldots \ldots \ldots 66 \ldots \ldots 6$

ENLISTMENT-

of infant in the army, when valid.................. 36

ENTRANCE FEE-

to enter horse racing contest, whether gambling......... 263

ESTOPPEL-

of infant by his deceit, misrepresentation as to age......... 67

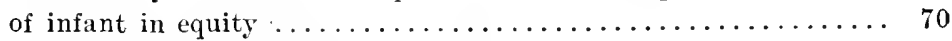

fraud in contract-cannot be set up............... 276

EVIDENCE-

parol evidence cannot vary written contract............ sl

to take the contract out of the statute of frauds.......... 86

to identify parties to memorandum................ 89

parol, to apply the description to the parties in memorandum... S9

to identify agent or principal................... 90

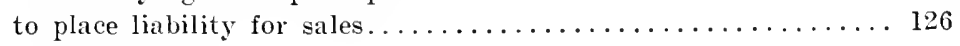

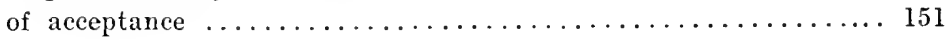


EVIDENCE-(continued) Sec.

parol evidence cannot vary representations in writing........ 160

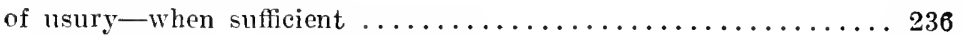

of usury-burden of proof of usury................ 239

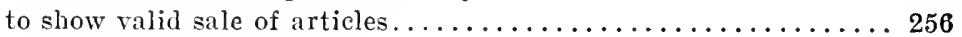

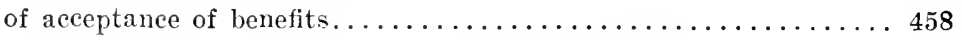

partial payment as evidence of acceptance of work........6652

Exchange-See Premiums and Excmange.

of property by insane person-mental capacity........... 21

of property by infant is voidable.................. 27

EXCURSION TICKET-

limiting liability of common carrier............... 291

EXECUTION AND LEVY-

by ereditor on joint debtors................... 370

EXECUTIONS-

selling property under limiting amonnt..............565

EXECUTOR AND ADMINISTRATOR-See ADMINISTRAToR.

contracts under the statute of frauds..............117, 118

forbearance-statute of frauds .................. 119

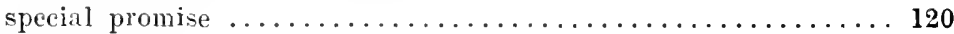

EXEMIPTIONS-

of married debtor cannot be waived............... 515

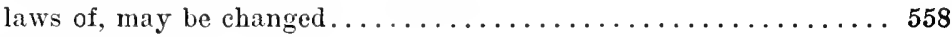

EXPECTANCIES-

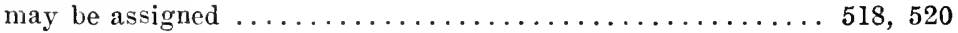

mere possibility cannot be assigned............... 518

EXPENSES-

taking legal rate of interest and adding expenses—when usury... 227

EXPRESS COMPANIES-

liability as to their own negligence. ................ 289

notice regulating amount of money carried............. 289

failure to deliver goods-mental suffering as damages.......693

FEES-See Atrorney's Fees; Entrance Fees.

established by ordinance cannot be excessive........... 198

of attorney-paying by borrower-whether usury...........229

FELONY-

compounding of-duress .................... 500

money stolen and paid on debts cannot be reclaimed by true owner 504

FEME SOLE-

contracts of, for services-not to marry.............. 474

FEOFFMENT-

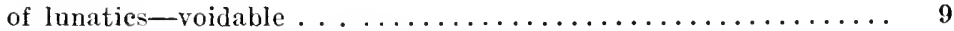

deed of insane person equivalent to................. 21

FERTILIZERS-

selling without a license-effect.................. 202 
of executor to collect-nust it be in writing............ 119

to collect deht-usurious agreement................ 206

\section{FORECLOSURE-}

of mortgage-paying attorney's fees-whether usury . . . . . . . 229

interest on debt-how computed....................242

interest must not be compounded................... 242

of real estate mortgage-what law governs.............. 403

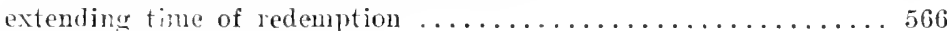

FOREIGN TASURANCE-

policy-what law governs ..................... 404

FORGERY-

of check-cxamination of pass-book by clerk who made the for-

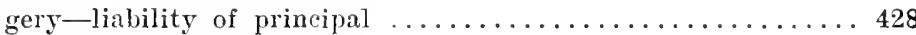

FOURTEENTH AMENDMENT-

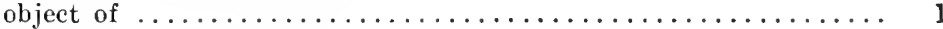

FRANCHISES-See CharTERs.

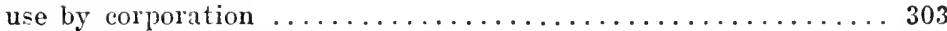

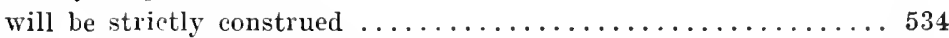

must be created by express grant................. 534

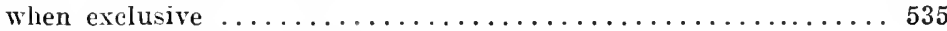

FRAUDS-See Frauds, Statute of.

of infant in contracting-effect................. 57

of infant, as to age, liability of $\ldots \ldots \ldots \ldots \ldots \ldots \ldots \ldots \ldots 67,68$

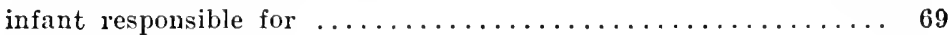

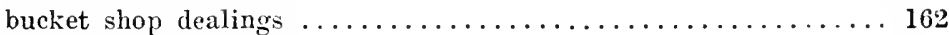

in assignments for benefit of creditors................ 170

composition agreements with creditors $\ldots \ldots \ldots \ldots \ldots \ldots \ldots \ldots 17$

in secret preferences of assignor-insolvency........... 172

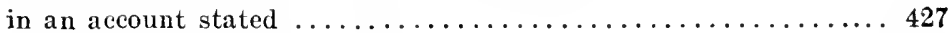

in writing up pass-book-eflect.................. 428

in an account stated-effect ....................429

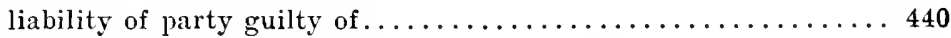

money fraudulently obtained-implied contract........... 440

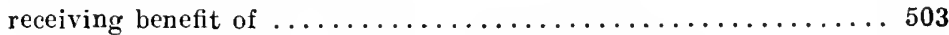

receiving stolen money to pay debts-rights of owner........504

of principal-liability of surety-statute of limitations........635

the arbiter must act in good faith for his decision to be bind-

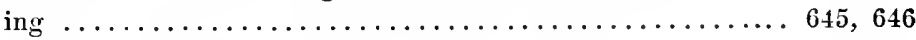

in composition agreement with creditors-effect........... 701

FRAUDS, STATUTE OF-

waiving of contract by parol-English doctrine as to labor..... 648 waiving written contract to work by parol-American doctrine... 648

contract to furnish special material................ 694

FREE PASSES-

of common carriers-liability on ................... 295 
FUNERAL EXPENSES- Sec.

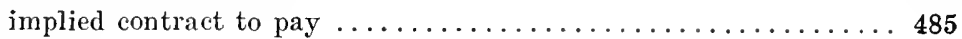

FUTURES-

dealing in - when valid .................... 248

intent-deal in futures ..................... 254

when sale of - when valid .................... 413

not gaming contracts ...................... 413

GAMBLING CONTRACTS-

law of the place-gambling contracts............... 258

recovering back money lost . . . . . . . . . . . . . . . . . 259

constitutionality of statute to recover back money lost in wagering

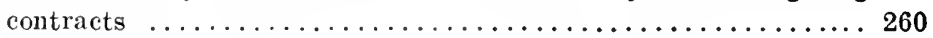

action to recover back money lost in gambling contract.......261

offering a reward or premium ................... 262

entrance fee-competitious at horse racing............. 263

bookmaking and pool selling ................... 264

difference between wager and premium or award.......... 265

GAMING-

note given for-another State law.................. 413

a future delivery of commodity ..................4 413

rights of stakeholder....................... 502

GARNISHMENT-

of wages already assigned.................... 515

GIFT ENTERPRISES-

giving trading stamps is not.........................

GIFTS-

of infant are voidable $\ldots \ldots \ldots \ldots \ldots \ldots \ldots \ldots \ldots \ldots \ldots \ldots$

executed by infant-avoidance................... 66

parol-not taken out of the statute of frauds............ 102

parol-of real estate-when enforceable............... 106

gratuitous distribution of property is not a lottery .........271

effect of statute regulating .................... 271

no implied contract to revoke.................. 425

GOLD COIN-

as consideration of contract................... 278

GOODW1LL-

of business-sale of-restraint of trade.............. 319

sale of physician's practice..................... 319

sale of school-rights of vendor.................. 319

GOODS, WARES, AND MERCHANDISE-

what included $\ldots \ldots \ldots \ldots \ldots \ldots \ldots \ldots \ldots \ldots \ldots \ldots \ldots \ldots$

GRACE-

days of-what law governs-interstate................ 399

GRAIN DEALERS-

combination to suppress competition............... 320 
GUARANTOR-

Sec.

when the consideration is original-eflect-paying debt of another 123

\section{GUARANTY-}

expressing consideration .......................... 96

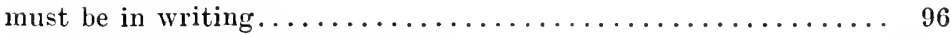

of note before and after delivery................... 96

employe guaranteeing satisfaction................... 614

GUARDIAN-

of insane persons-restoration of reason-effect as to contracts.. 10

furnishing necessaries to lunatic $\ldots \ldots \ldots \ldots \ldots \ldots \ldots \ldots \ldots, 11$

and ward tenants in common-method of partition.......... 37

right to contract for ward...................... 72,73

title to ward's property........................ 74

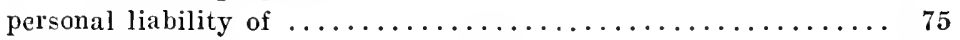

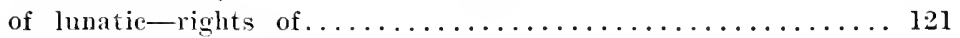

GUARDIAN AD LITEM-

for infant in partition............................ 37

GUESSING CONTEST-

winner cannot recover money won.................. 272

HEIRS-

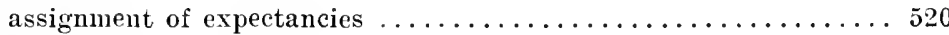

HOMESTEAD-

exemption of-what law governs................... 558

HORSE RACING-

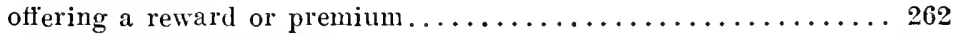

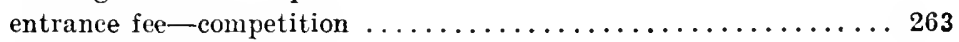

HOTELKEEPER-

contract with-cannot be assigned................. 519

HUSBAND AND WIFE-

services-implied contract $\ldots \ldots \ldots \ldots \ldots \ldots \ldots \ldots \ldots 456,460,461$

implied agreement to furnish wife necessaries.. ......... 468

wife aiding her husband-tort................. 495

ILLEGAL CONTRACTS-See CONTRACTS.

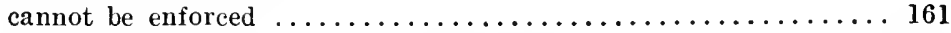

agreements to defraud others-bucket shops............ 162

agreement to buy shares of stock at fictitious premium....... 163

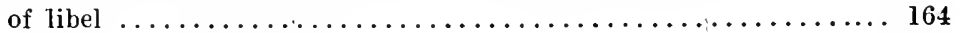

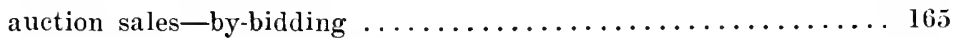

auction sales-English doctrine $\ldots \ldots \ldots \ldots \ldots \ldots \ldots \ldots \ldots \ldots \ldots$

stipulation not to bid at auction sales................ 167

by-bidding-when legal $\ldots \ldots \ldots \ldots \ldots \ldots \ldots \ldots \ldots \ldots \ldots \ldots . \ldots \ldots$

the purchase of property on joint account............... 169

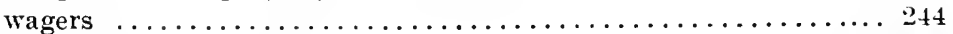

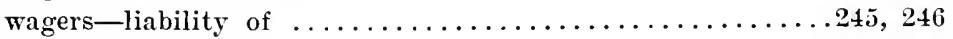

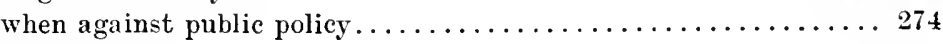

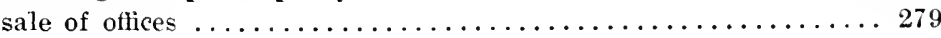




\section{INDEX.}

ILLEGAL CONTRACTS-(continued) Sec.

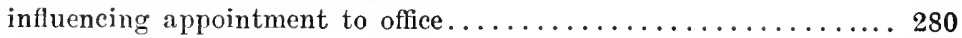

compensation in office by private person............. 281

controlling the regular administration of justice.......... 282

assignment of unearned compensation................283

contracts to promote legislation-lobbying contracts......... 284

compensation for professional services in office........... 285

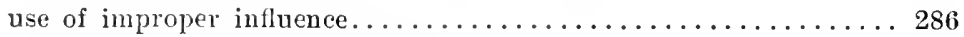

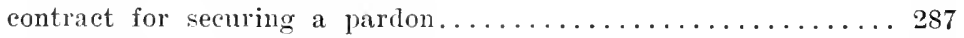

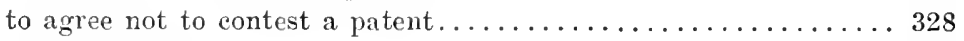

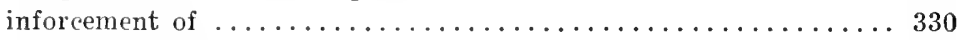

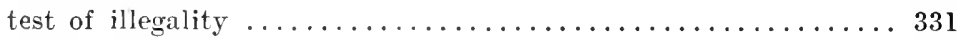

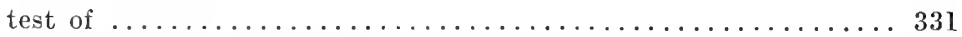

legality of time of enforcement................. 332

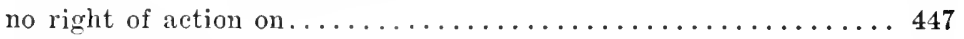

loaning money ........................ 447

ILLEGITIMATES-

parent bound to upport as if legitimate............. 33

IMPAIRMENT OF OBLIGATION OF CONTRACTS-

reduction of periods of limitations................ 528

gold clause in contracts . ................... 529

salaries of public officers . ..................... 530

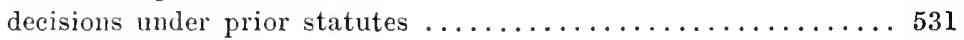

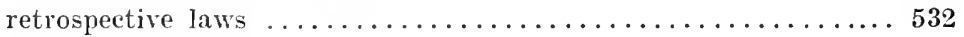

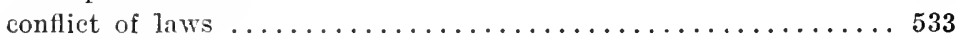

IMPLIED CONTRACT-

of common carrier in transporting goods beyond its own line.... 290

as to photographer's rights over photograph............ 340

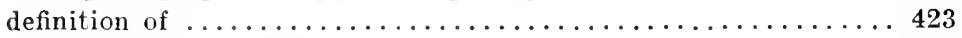

as to tolls .............................. 423

of railway to send baggage on same train with passenger.....4 424

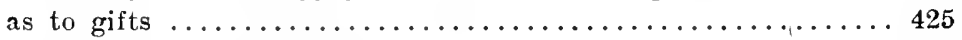

impairing the obligation of contract............... 426

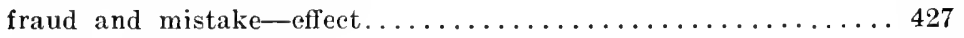

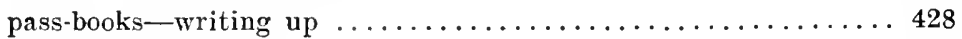

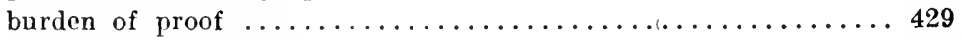

distinguished from express $\ldots \ldots \ldots \ldots \ldots \ldots \ldots \ldots \ldots \ldots \ldots 44$

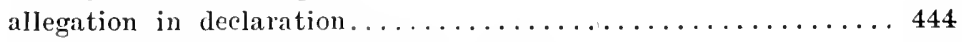

receiving money which belongs to another............. 445

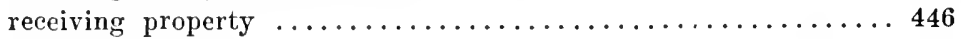

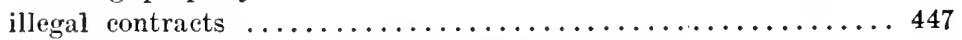

want of consideration-recovering back money paid.........448

voluntary payment with knowledge of the facts..........449

payment under mistake of fact................. 450

agent of both seller and purchaser-payment of commission..... 45l

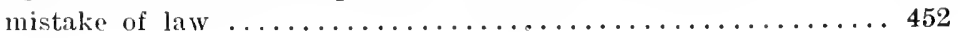




\section{INDEX.}

IMPLIED CONTRACT-(eontinued) See.

mistake of law in equity ..................... 453

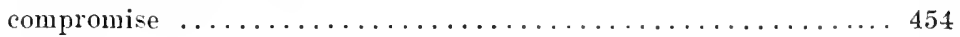

duress ............................... 455

payment of taxes and assessments................. 456

voluntary benefits conferred ................... 457

voluntary acceptance of bencfits. . . . . . . . . . . . . . 458

municipal corporations .....................459

family relations-benefits received ................ 460

services of a supposed wife..................... 461

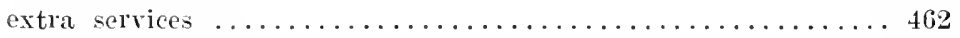

corporation's liability to its promoters............... 463

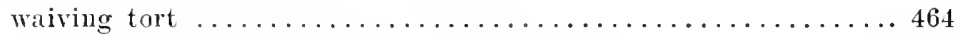

oral agreement to bequeath or devise property ............465

enforcement in equity and in law ..................466

parol contracts ......................... 467

necessaries for wife $\ldots \ldots \ldots \ldots \ldots \ldots \ldots \ldots \ldots \ldots \ldots \ldots \ldots$

necessaries for minor-money furnished by another. . . . . . . 469

father liable for necessarues for minor children . . . . . . . . . . 470

necessaries for insane person.....................47

liability of insane person's estate.................. 472

part performance-quantum meruit................ 473

wilful default-wages $\ldots \ldots \ldots \ldots \ldots \ldots \ldots \ldots \ldots \ldots \ldots \ldots \ldots \ldots \ldots$

default not wilful-personal scrvices...............4 475

promise to marry ..................... 476

substantial performance ................... 477

order given by one and filled by another.............. 478

part performance under a roid contract...............479

under no obligation to perform-part performance..........448

failure to pay in a manner agreed to ................ 481

part performance-rescission of contract............. 482

work and labor .......................... 483

physician's services ....................... 484

burial of the dead ....................... 485

waiving the tort and suing on the implied contract.........486

when waiver may be made...................... 487

doctrine that the property must be sold-tort. . . . . . . . . . . 488

doctrine that the property need not be converted into money-tort. 489

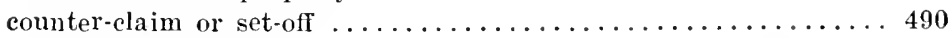

privity of contract $\ldots \ldots \ldots \ldots \ldots \ldots \ldots \ldots \ldots \ldots \ldots \ldots \ldots \ldots$

implied assumpsit lies for trees and stones severed and converted. . 492

when wrongdrer has aarerse possession of land ........... 493

right of agent of injured party to sue in assumpsit. . . . . . . 494

several tort-feasors ....................... 495

duress .............................. 496

duress of goods $\ldots \ldots \ldots \ldots \ldots \ldots \ldots \ldots \ldots \ldots \ldots \ldots \ldots$ 


\section{INDEX.}

IMPLIED CONTRACT-(continued) Sec,

imprisonment . . ....................... 498

threats of imprisonment.................... 499

compounding felony ....................... 500

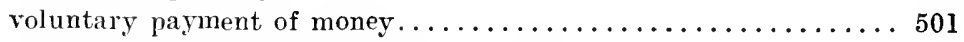

as to third parties with notice................... 502

receiving benefits of fraud-agency............... 503

money received in payment of debts................ 504

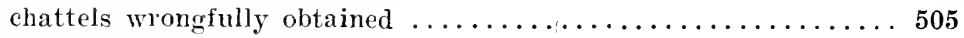

IMPOSSIBLE CONTRACTS-

impossible of fulfillment $\ldots \ldots \ldots \ldots \ldots \ldots \ldots \ldots \ldots \ldots \ldots .568$

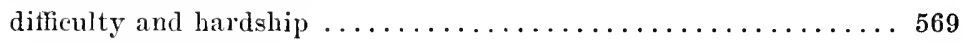

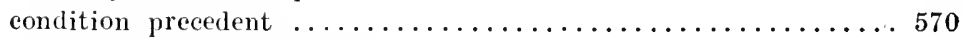

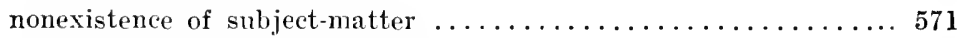

subject-matter ceasing to exist................. 572

impossibility of performing a contract subsequently arising....573

in commercial transactions $\ldots \ldots \ldots \ldots \ldots \ldots \ldots \ldots \ldots \ldots \ldots \ldots \ldots$

bailment of an article to be repaired.............. 575

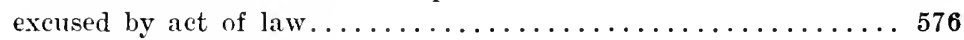

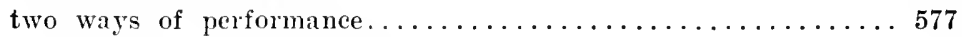

judgments and other judicial processes.............. 578

promisee preventing performance................. 579

implied condition as to contingent impossibility of performance. . 657

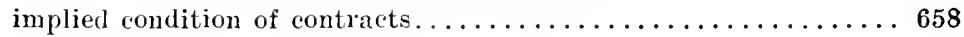

what implied conditions attach to a contract............669

IMPRISONMENT-

payment of money to prevent................. 498

money voluntarily paid $\ldots \ldots \ldots \ldots \ldots \ldots \ldots \ldots \ldots \ldots \ldots \ldots 498$

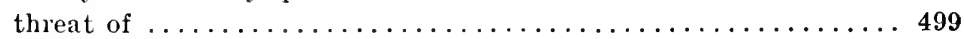

IMPROVEMENTS-

and possession as part performance.............. 105

IMPULSIVE INSANITY-

suicide of insane person................... 17

INDEMNITOR AND INDEMNITEE-
must the agreement to indemnify be in writing. $\ldots \ldots \ldots \ldots 129$

INDEMNITY-

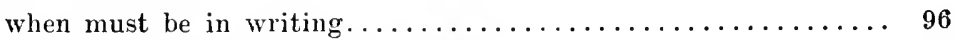

whether within the statute of frauds................ 129

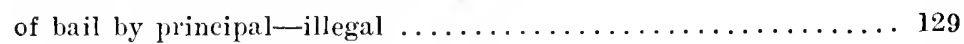

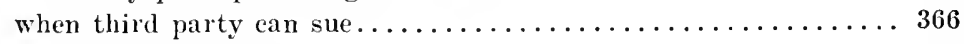

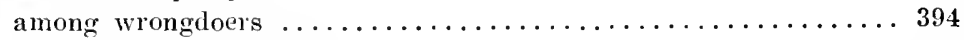

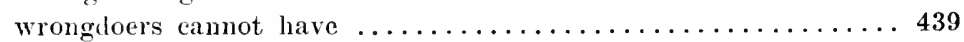

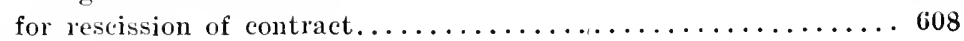

INDORSEMENT-

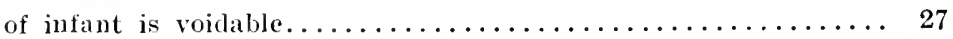

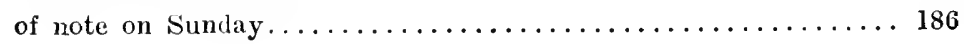


INDUSTRIAL COMBINATIONS- Sec.

monopoly-contracts in restraint of trade............. 320

restraint of trade-general or partial. ............... 321

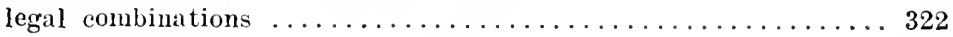

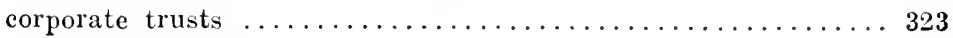

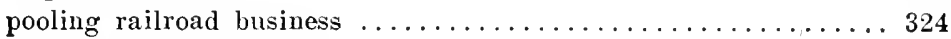

rebate to shippers................................... 325

monopoly in interstate and international trade........... 326

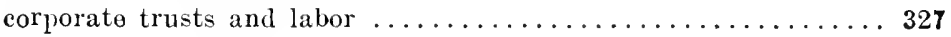

INFAN'L'-.-

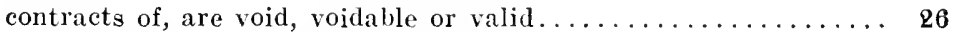

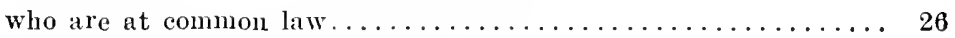

majority reached by, in difierent States............. 26

privilege of, given for their protection............... 26

contracts of-distinction between voidable and void........ 27

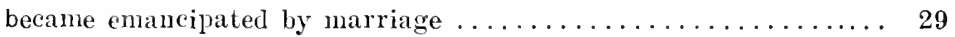

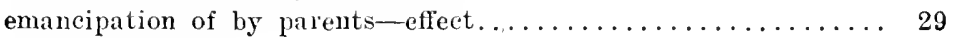

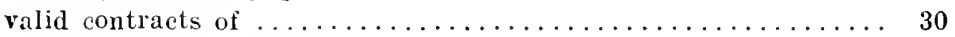

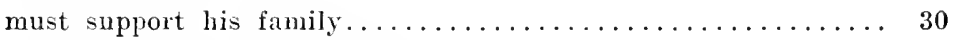

may assign his property-when................. 30

may make a valid contract to support his bastard child....... 33

notes for torts of, are valid.................... 34

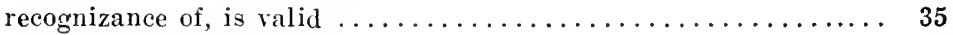

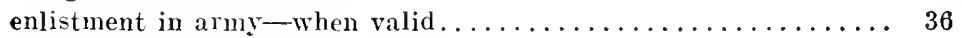

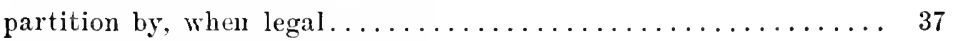

validity of shopping contracts..................... 38

wife of-her necessaries are also his................ 40

repairs on real estate, not a necessary............... 42

going into business-necessaries ................. 44

living at home with his father-necessaries........... 45

cardinal tenets as to what are necessaries for infant........ 46

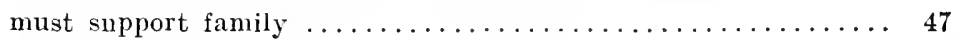

payable of their debts by another-effect.............. 49

method of ratifying contracts................. 52

ratification of contract on condition............... 54

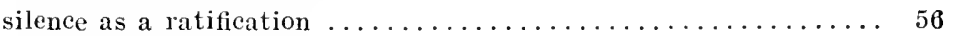

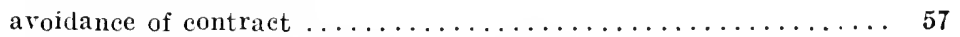

when contracts for personalty may be a voided.......... 58

selling land-entering thereon and taking rents and profits....57, 58

what is a reasonable time to avoid a contract............ 59

how are partnership contracts avoided.............. 60

bona fide purchaser from-title transferred.............. 61

contracts of service-disafirmance............... 62

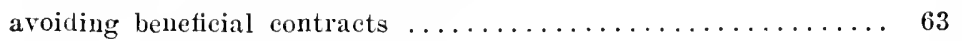

return of consideration by infant..............

how can they affirm or disafirm their contracts........... 64 


\section{INDEX.}

INFANTS- (continucd)

Sec.

who may avoid infant's contracts.................. 66

estoppel for deceit........................ 67

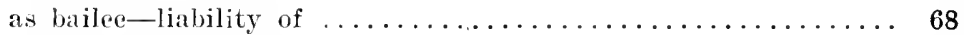

for acts $e x$ delicto ........................ 69

prohibited work-validity of laws................. 203

contracts for their welfare................... 277

promise by third party-acceptance................. 355

narried husband must furnish necessaries for his wife.......468

necessaries for .........................469

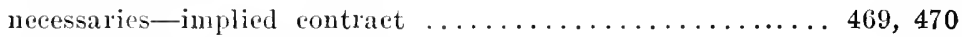

regulation of hours of labor.................... 544

right to specific performance...................669

INJUNCTION-

against unlawful interference in the business of others....... 335

INNKEEPERS-

loss of goods by act of God ................... 585

loss of goods by act of public enemy ................ 585

contract of clerk to forward letters and baggage of guest...... 585

IN PARI DELICTO-

effect on contracts ..................... 176

note to compound a felony-illegal.................500

INQUISITION OF LUNACY-

when found-contracts of lunatic................ 12

INSANE DELUSIONS-

of parties-power to contract.................. 8

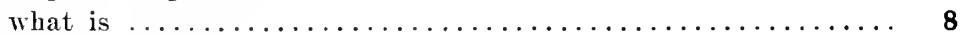

INSANE PERSONS-

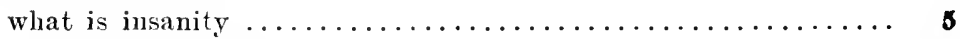

void, voidable and valid contracts of ............... 9

restoration of reasons-contracts................. I0

third party furnishing necessaries................. 11

contracts for necessaries $\ldots \ldots \ldots \ldots \ldots \ldots \ldots \ldots \ldots \ldots \ldots$

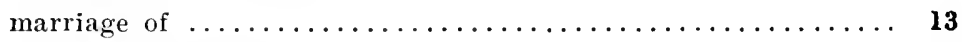

validity of their notes $\ldots \ldots \ldots \ldots \ldots \ldots \ldots \ldots \ldots \ldots \ldots \ldots \ldots$

can he be adjudged a bankrupt.................. 15

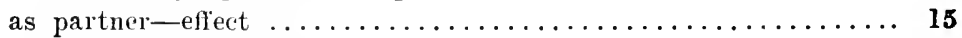

taking out life insurance..................... 16

affirmance and avoidance of contracts............... 21

bona fide purchaser from. ...................... 22

avoiding sale to bona fide vendee................... 22

contracts of -relief in equity .................. 25

liable for necessaries $\ldots \ldots \ldots \ldots \ldots \ldots \ldots \ldots \ldots \ldots \ldots \ldots \ldots$

liability of his estate for necessaries...............472

INSANITY-See INSANE PERSONS. 
INSOLVENCY-Sce Composition Agreements. Sec.

assignment for benefit of ereditors-effect............ 170

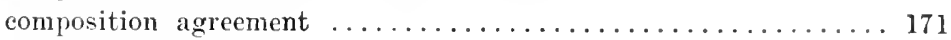

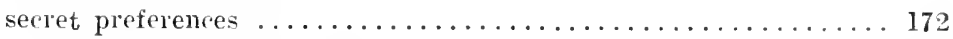

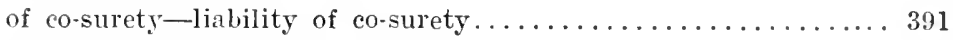

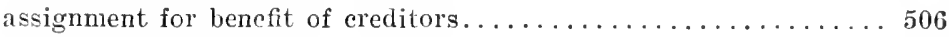

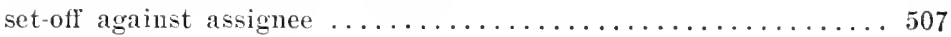

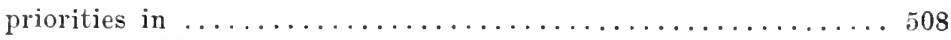

of rendee on conditional sale-effect on the vendor's rights.... 704

INSPECTION LAWS-

inspection of chattels for sale according to law-failure to inspect 202

INSTALLAENTS-

parment of interest-how made................ 242

by the month or week-to draw suit of clothes-validity...... 272

failure to pay-breach of contract.................662

IN STATU QUO-

avoiding insane person's contract-placing in statu quo...... 22

American and English doctrine................... 22

avoidance of insane person's contract-placing in statu quo.... 25

INSURANCE-See INSURANCE Contracts.

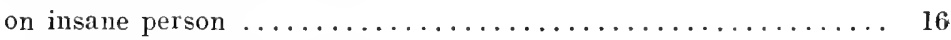

contract of infant-voidable $\ldots \ldots \ldots \ldots \ldots \ldots \ldots \ldots \ldots \ldots, 46$

oral contract for-not within the statute of frauds.......... 80

policy dater and delivered on Monday-insured examined on Sun-

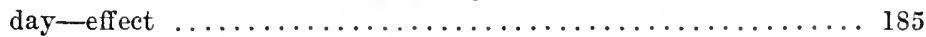

contracts-what law governs ................... 404

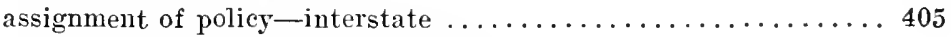

when money paid for, may be assigned.............. 518

regulation of, under police power................. 545

INSURANCE CONTRACTS-See IxsuraNCE.

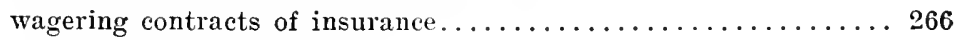

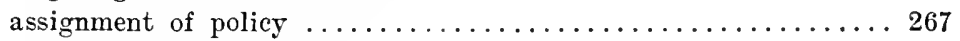

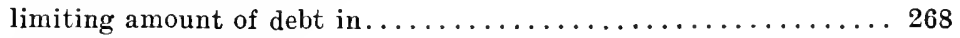

benevolent associations $\ldots \ldots \ldots \ldots \ldots \ldots \ldots \ldots \ldots \ldots \ldots$

INTENTION-

as to completion of sale.................... 149

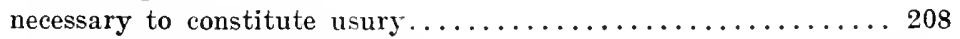

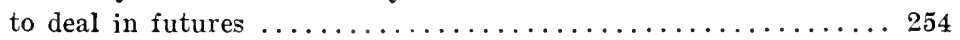

as controlling in interstate contracts............... 396

as to smuggling-contracts $\ldots \ldots \ldots \ldots \ldots \ldots \ldots \ldots \ldots \ldots \ldots . \ldots \ldots$

as to what place shall govern the rate of interest-law of another

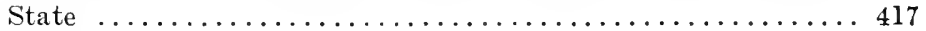

INTEREST-

agreement to pay by infant is voidable............... 27

when taking above legal rate-usury per se........... 208

on loans above legal rate-usury................. 210 


\section{INDEX.}

INTEREST-(continued)

Sec.

taking more than the legal rate-accommodation paper-usury . . 212

taking personal property as interest when usury........... 213

payment of quarterly or semi-annually is not usury.......... 216

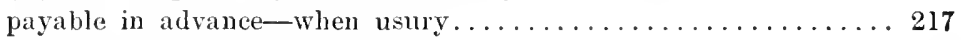

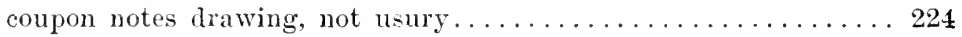

recovering back usurious interest. . . . . . . . . . . . . 225

computation of interest-compounding-when usury........226

taxes and expenses-taking legal rate besides-usury . . . . . . 227

commission and discount-usury ................. 228

mistake in taking too great amount-eflect-nsury......... 233

on renewal notes and mortgages, when usury............ 234

place of payment-usury-conflict of laws............ 240

payment of may be controlled by contract.............. 241

computation at stated periods-as to usury ............. 242

payment on mortgage debt-how eomputed............. 242

when does the lex loci solutionis control payment of . . . . . . . 399

usurions-amother state law ................... 417

changing rate of, on judgment................. 563

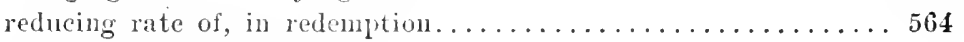

upon unliquidated damages..................6. 691

INTERAAL REVENUE-

license fees imposed on attorneys-failure to take out license. . . 199

INTERNATIONAL COMMERCE-

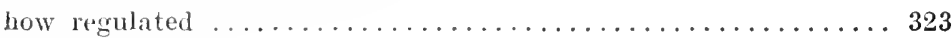

INTERPRETATION-

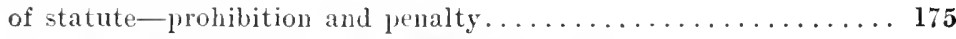

malum prohibitum and malum in sc-statutes............ 176

of Sunday contracts-constitutionality of ............. 181

of eontracts made on Sunday................... 183

no prohibition of sunday contracts................ 184

of law prohibiting barbers to work on sunday........... 188

what are works of necessity to be performed on Sunday....... 188

when telegrams are work of necessity ................ 188

ratification of void contract..................... 192

of contracts prohibiting contracts............... 196

of ordinance-establishing an exorbitant fee for doing business... 198

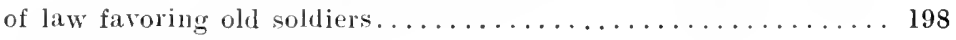

of laws imposing license fee.................... 199

of license law imposed on physicians................. 200

right of physician to refuse to call upon patient........... 200

a law requiring teacher to take out certificate to teach.......201

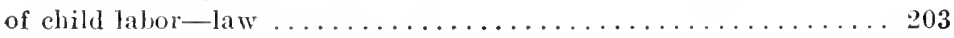

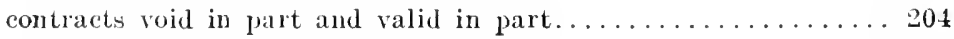

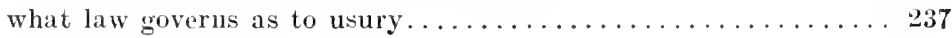

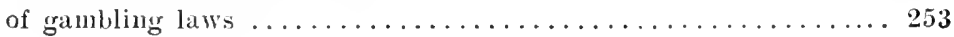


INTERPRETATION-(continued) Sec.

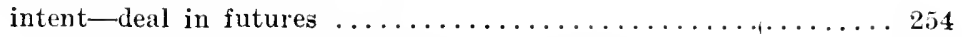

a statute to recover back money lost in gaming........... 260

a statute prohibiting the giving of trading stamps......... 270

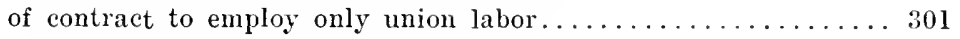

of contracts in restraint of trade.................. 315

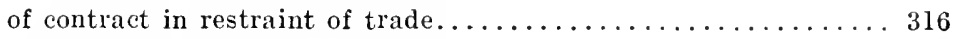

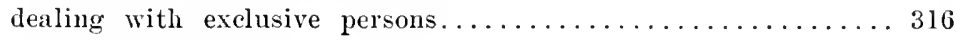

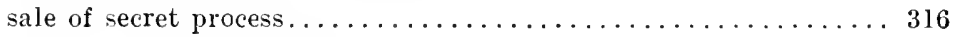

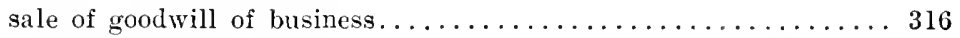

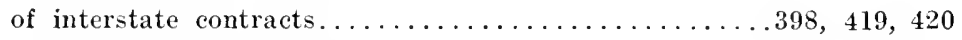

courts' decisions-a uthority of. ................. 531

jurisdiction of U. S. Supreme Court................ 531

of contracts-conflict of laws................... 533

controlling efiect of State court decisions in other jurisdictions. . 533

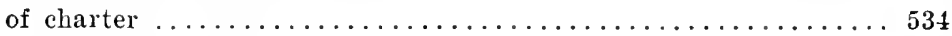

of private contracts ...................... 540

of police power of State................... 547

INTERSTATE COMMERCE-

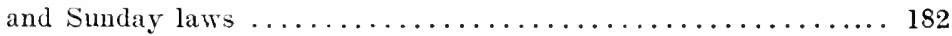

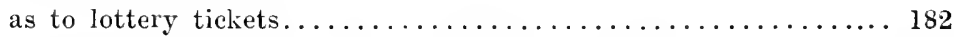

sending lottery tickets from one State to another......... 272

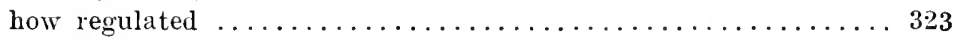

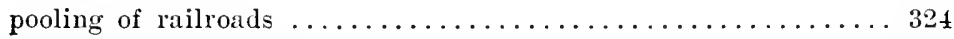

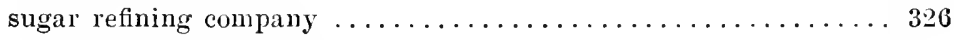

is under Federal law............................. 411

sending lottery tickets into another State............. 411

State must not interfere in controlling common carriers...... 539

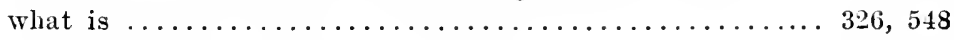

conflicting with the State police power.............. 548

right of Congress to delegate its powers.............. 548

State statute interfering with . . . . . . . . . . . . . . 549

law providing for the purchase of certain dressed stone....... 549

INTERSTATE CONTRACTS-See CONELICT OF LAWS.

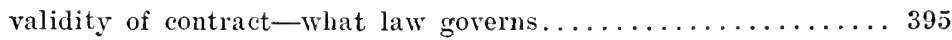

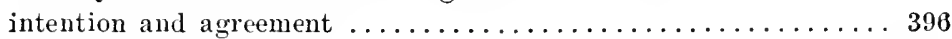

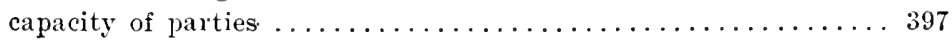

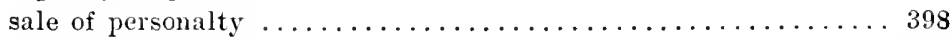

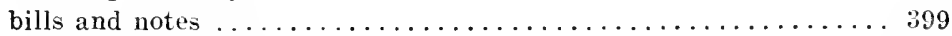

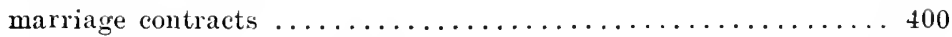

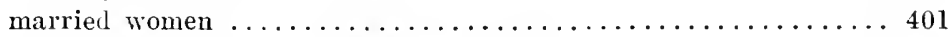

chattel mortgage lien follows the property ............ 402

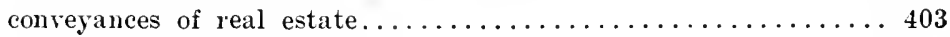

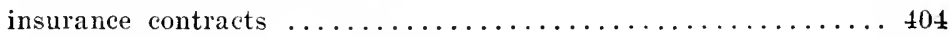

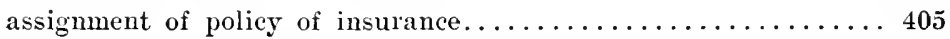

assignment of property........................ 406 
INTERSTATE CONTRACTS-(continued) Sec.

as to the situs of personal property .............. 407

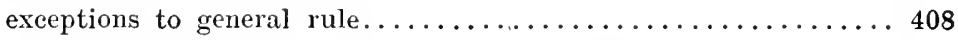

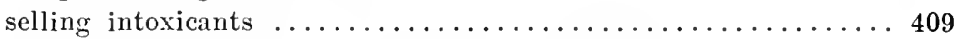

carriers—stipulations exempting from negligence......... 410

interstate commeree ........................411

Sunday contracts ........................ 412

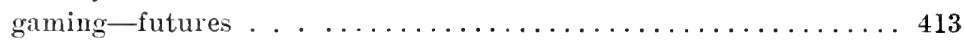

smuggling contracts ...................... 414

enforcing revenue laws of another country ............ 415

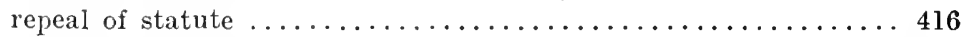

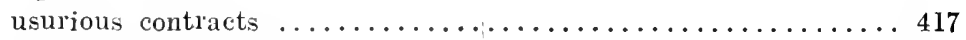

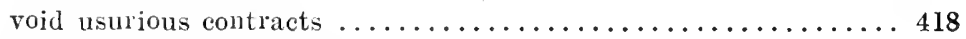

INTERSTATE MONOPOLIES-

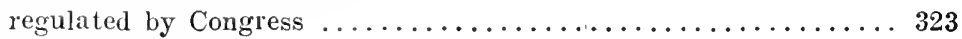

INTIMLDATION-

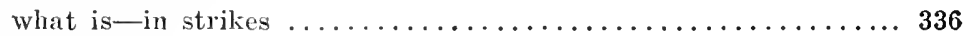

INTOXICANTS-

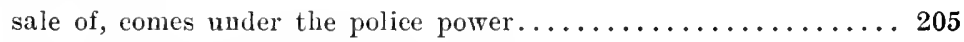

sale of, in prohibited State.................... 409

sale and manufacture of-when under the Federal law.......4 411

note given for-another State law................. 413

manufacture and sale of -when a nuisance........... 546

soliciting trade in different States-State law regulating...... 549

statute incorporating imported-effect .............. 554

INVOLUNTARY ASSIGNMENT-See INSOLVENCY.

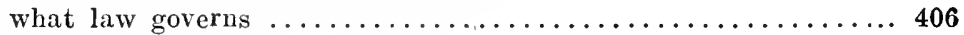

JOINT AND SEVERAL CONTRACTS-

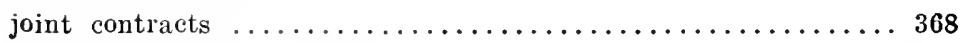

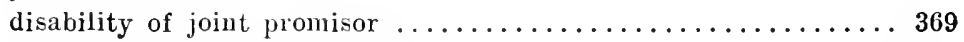

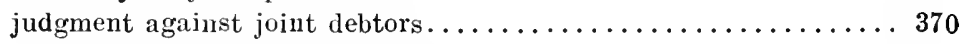

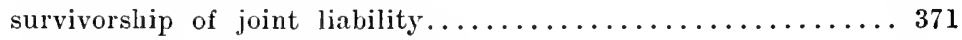

in equity-survivorship of liability ............... 372

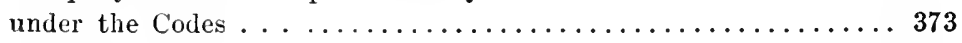

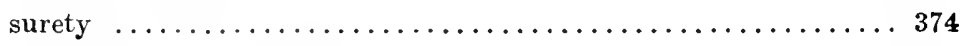

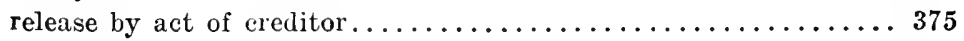

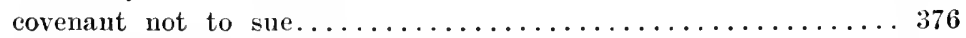

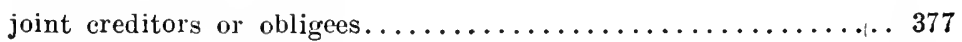

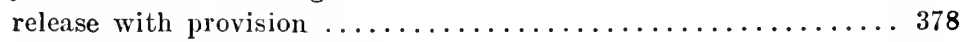

release should be under seal. ................... 379

survivorship of joint creditors................... 380

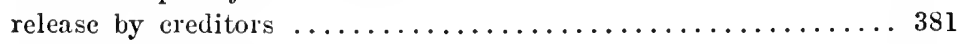

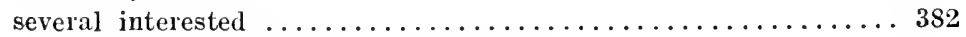

subseription to establish business enterprise............ 383

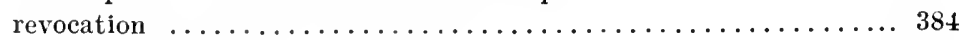

validity of subscription contracts................ 385 
JOINT AND SEVERAL CONTRACTS-(continued) Sec.

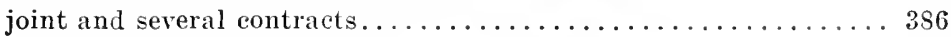

release of joint and several promisors by law........... 387

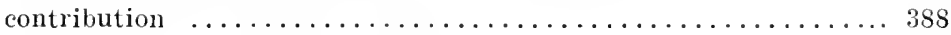

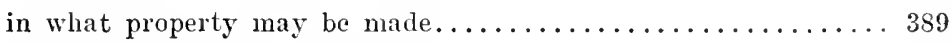

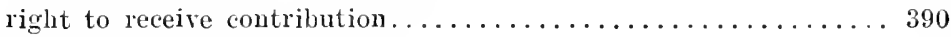

JOINT AND SEVERAL CREDITORS-

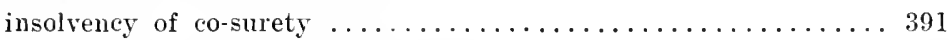

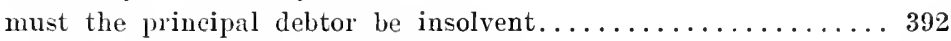

surety discharged by act of promisee............... 393

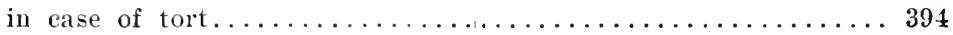

JOINT CONTRACTS--

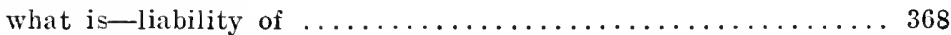

JOINT CREDITORS-See JoINT OBLIGEES.

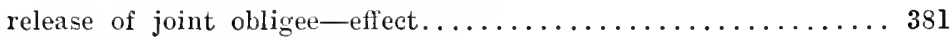

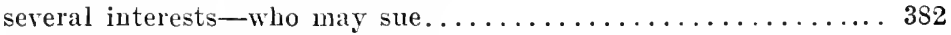

JOINT DEBTORS-See Jonx Obligors.

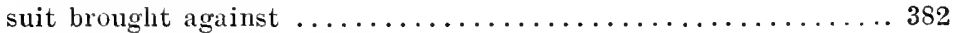

subscribe to establish business ..................... 383

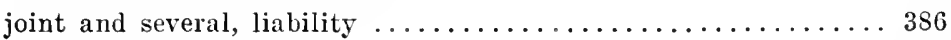

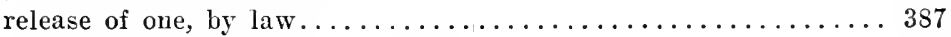

running of the statute of limitations.................634

JOINT OBLIGEE-See Jonnt Promsons.

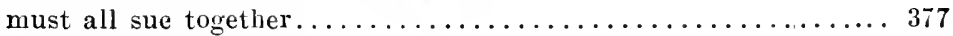

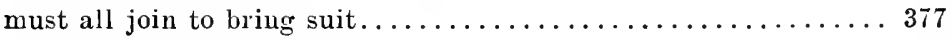

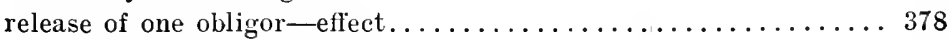

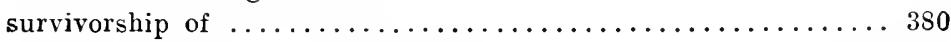

release of-should be under seal............... 379, 380

JOINT PROMISOR-

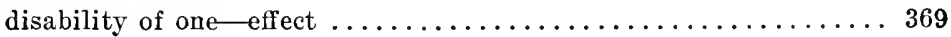

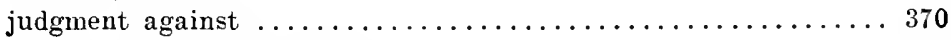

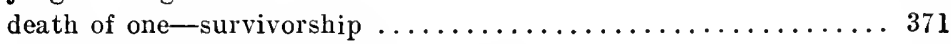

survivorship of joint liability in equity.............. 372

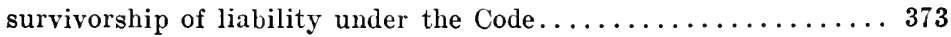

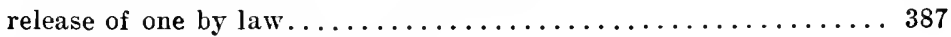

death of one-survival of contract................ 592

JOINT TORT-FEASORS-

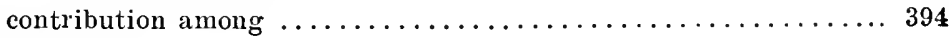

JUDGMENT-

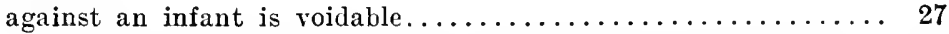

confession of, agreement to enter is only an executed contract.... 184

against joint debtors-plaintiff's rights............. 370

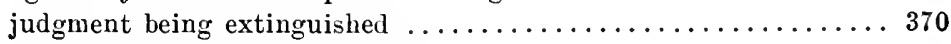

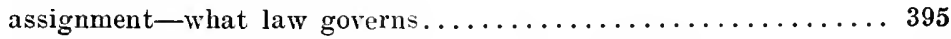

of State-when reviewable by the U. S. Supreme Court....... 531

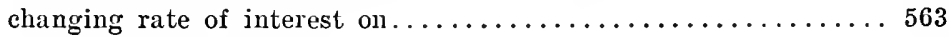

discharged by act of law........................ 578 
LACHES- Sec.

right to open an account stated................. 429

in equity - statute of limitations.................625

gross laches not considered in equity...............626

LANDLORD AND TENANT-See LESSOR AND LEsseE.

lease executed by infant cannot be aroided by the lessee..... 66

giving tenant motice to quit, on Sunday-effect......... 186

breach by landlord-mitigation of damages...........687

LAWYERS-

license to follow their practice-intermal reronue license..... 199

unlicensed-right to recover fees................. 199

LEASE-

by parol-for one year-when within the statute of frausls. . 135, I36

LEASE AND RELTASE-

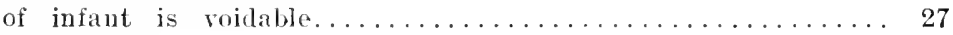

LEGISLATURE-

power to amend charter...................... 2

LESSOR AND LIESSEL-See LANDLORD AND TENANT.

voluntary payment of rent ly tenant-recovering back........ 501

when lessor may assign rent to accrue.............. 518

abolishing by legislature of distress for rent-elleet....... 560

destruction of building before occupancy by lessee-liability of

$\operatorname{lessor} \ldots \ldots \ldots \ldots \ldots \ldots \ldots \ldots \ldots \ldots \ldots \ldots \ldots$

notice by lessor to rescind lease................. 597

when recision of contract cannot be made............. 597

LETTERŚ-

as written proof of contract.................. 85

LEX DOMICILLII-

as to the sale of personalty .................... 398

as governing mariage contracts.................. 400

as to married women....................... 401

as surety-what law governs...................... 401

governs involuntary assigmment . . . . . . . . . . . . 406

LEX FORI-

gives the remedy . . . . . . . . . . . . . . 115, 406, 419

governs as to the time of bringing of suits.............. (i3s

LEX LOCI CELEBRA'TIONIS-

when governs the waiver of the statute of frands......... 101

oral contract for sale of land not void............... lol

governs interpretation of contract................ 115

as to insurance policy . . . . . . . . . . . . . . . 40.4

control stipulation against negligenec of carrier. . . . . . . 410

governs bill of affreightment..................421

LEX I,OCT CONSIDERATIONIS-

where parties contract . .................... 413

governing contract-usury ..................417 
LEX LOCI CONTRACTUS- Sec.

when it governs ....................... 116

as to the sale of personal property ................ 398

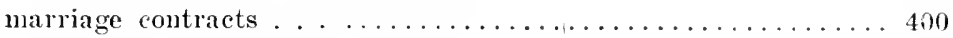

as to married woman's contracts.................401

as to validity of chattel mortgage lien................ 402

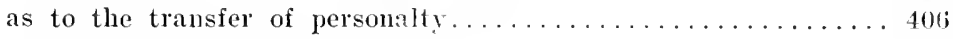

in the interpretation of contract..................419

when the court will apply..................... 420

LEX LOCI SOLUTIONIS-

governs the performance of contract.............. 11 j

as to payment of a note....................

for the payment of insurance................... 404

LEX REI SITAE-

as to sale of personal property ................. 398

LIBEL-

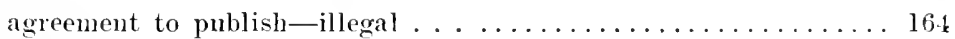

LICENSE-

to enter land-no trespass.................... 112

to sell intoxicants-effect .....................

to peddlers-old soldiers..................... 19s

to practice law-failure to take ont internal revenue license... 199

is a theater ticket a license or contract............... 509

required of person selling goods................. 552

\section{LIEN}

of chattel mortgage-follows the property............4 402

created to hold proporty of corporations............... 54 i

on real estate-changing of $\ldots \ldots \ldots \ldots \ldots \ldots \ldots \ldots \ldots \ldots \ldots$

specific cannot be changed.................... 562

of mortgage statute of limitations................629

for materials furnished on building................660

on goods by vendor-in conditional sales-insolvency of vendee. 704

LIFE INSURANCE-

on insane persou, no suicide clause in policy........... 16

snicide by impulsive insanity of insured-eflect on insurance... 17

insured knowledge of right and wrong-English and American

doctrine .............................. 18

self-destruction of insured-responsibility of insured......18, 19

insured "die by suicide, sane or insane" ............. 20

\section{LIMITATIONS-}

reduction of periods of ..................... 528

of the time to bring action................. 559

LIMITATIONS, STATUTE OF-

at law .............................

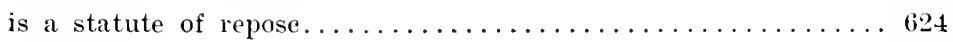

in equity .......................... 
LIMITATIONS, STATUTE OF-(continued) Sec.

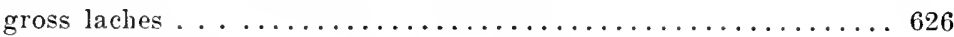

rebuttal of presumption - continuing contract........... 627

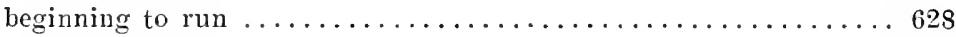

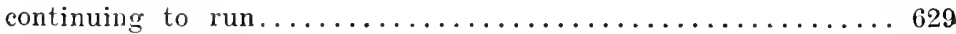

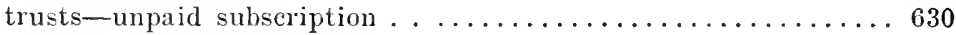

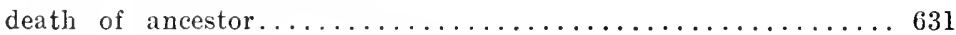

absence of debtor from the State.................6. 632

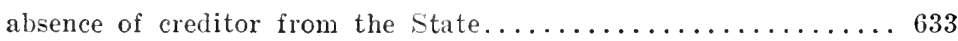

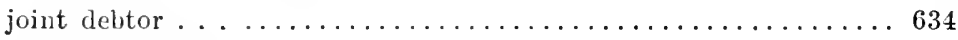

surety's liability . . . . . . . . . . . . . . . . . . 635

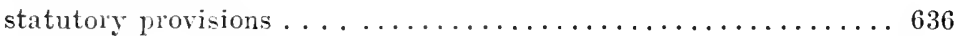

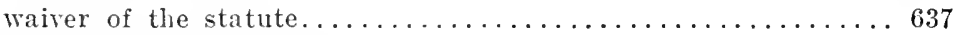

what law governs . . . . . . . . . . . . . . . . . 638

LOANING AND BORROWING-See LOANS.

taking interest-when usury..................... 209

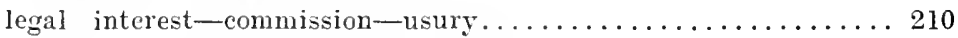

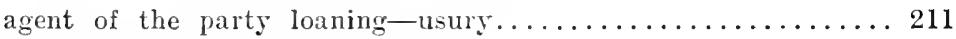

taking a bonus for loan-usury ................. 216

LOANS-See LOANING AND BorrowiNg.

made on Sunday-recovery of money................ 195

usurious contracts-laws of another State............. 417

agreement whether the interest of the lex loci celebrationis shall

control ............................. 417

when illegal-action to recover................ 447

LOBBYING CONTRACTS-

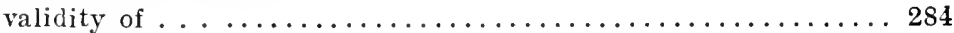

LOTTERIES-

definition-trading stamps . . . . . . . . . . . . . 270

gratuitous distribution of property by lot or chance........ 271

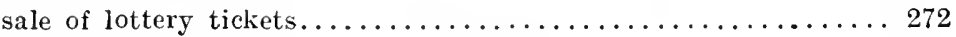

lottery company chartered by the State............... 273

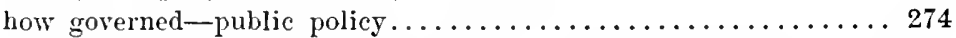

sending tickets into another State is interstate commerce.....4 411

incorporation of, by State-revocation of charter......... 547

LO'I'IERY COMPANIES-SEe LOTTERY TICKETS.

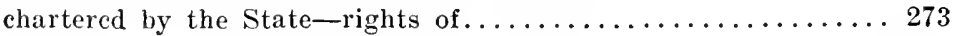

charter a mere license to enjoy the franchise........... 273

rights of the legislature over....................... 273

LOTIERY TICKETS-See TICKETS.

regulating purchase of $\ldots \ldots \ldots \ldots \ldots \ldots \ldots \ldots \ldots \ldots \ldots \ldots, 1$

may be subject to interstate commerce............. 182

LUCID INTERVALS-

of insane persons-power to contract............... 6

LUnatics-See Insane Person. 
MALICE- Sec.

alone, not sufficient to base an action.............. 342

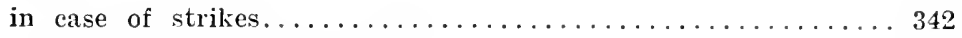

doing an act legal within itself. . . . . . . . . . . . . 345

making false representations . . . . . . . . . . . . 346

MANUFAC'TURERS-

trying to control retail trade................... 315

may legally manufacture and sell to one person only ....... 317

combining for mutual benefit................... 322

receiving a bonus for locating plant............... 351

MARGINS-

bucket shop dealings........................ 162

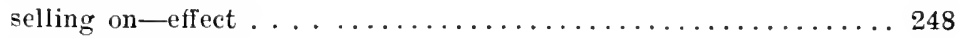

MARKET PRICE-

of grain-what is . . . . . . . . . . . . . . . . . 250

MARRIAGE-

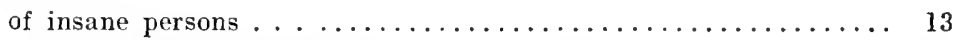

void $a b$ initio docs not need a decree of court to annul....... 13

by infant-when valid contract.................. 31

of minor emancipates lim, with or without parent's consent.... 29

governed by the lex loci....................... 400

leaving State to evade law, effect................ 400

creates a marital status....................... 400

not naturally unlawful in another state-effect...........408

employment-servant agreeing not to marry-effect.......4 474

promise to marry-breach of ................. 476

promise to marry a certain person-marrying another........607

MARRIAGE BROKERAGE-

legality of contracts $\ldots \ldots \ldots \ldots \ldots \ldots \ldots \ldots \ldots \ldots \ldots \ldots$

MARRIED WOMAN-

can affirm contract as provided by law, as to real estate...... 32

may affirm a covenant entered into when a feme sole......... 32

interstate contracts-effect .................. 396

capacity to contract-what law governs............... 401

work and labor of a supposed wife-recovery for . . . . . . . . 461

MASTER AND SERVANT-See Employer and EMploye.

when infant can recover for services............... 62

limiting master's liability to servant................ 299

limiting master's liability to servant-servants receiving from as-

sociation . . ........................... 300

interference of third parties-boycott.............. 341

malicious interference-effect-is it restricted to master and

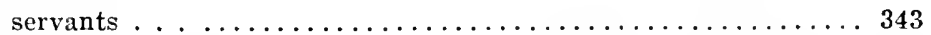

period of employment of servant not determined-interference.. 344 servant discharged by false representations of third party-action 347 master cannot assign over his apprentice.............. 519 


\section{INDEX.}

MASTER AND SERVANT-(continued) Sec.

wrongful discharge of employe..................602

contstructive service ......................603

services to be performed in the future................604

duty of employe to seek other work..............6. 605

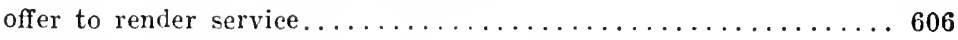

mode of rescission of contract by employer............667

employing another to work on personalty............668

employing another to affix to real estate a machine.........669

damages recoverable . . . . . . . . . . . . . . . . . 610

after notice of rescission-duty of employe..........6. 611

MaTrimonial BUREAU-See Marriage Brokerage.

MAXIMUM RATES-

effect of State establishing maximum rates of charges of cor-

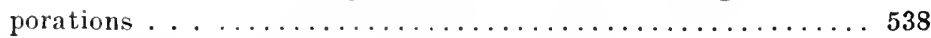

must not destroy a business by the establishment of . . . . . . 539

MECHANIC'S LIEN-

does not apply to infant's property................ 46

MEMORANDUM UNDER STATUTE OF FRAUDS-

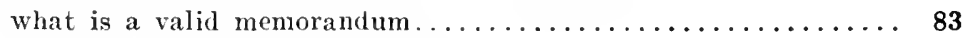

delivery of note or memorandum................. 84

letters, telegrams and other papers................ 85

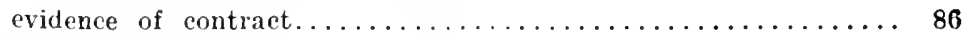

sale by auctioneer or broker-sufficiency of memorandum..... 87

description of parties $\ldots \ldots \ldots \ldots \ldots \ldots \ldots \ldots \ldots \ldots \ldots . \ldots \ldots$

evidence to identify parties................... 89

parol evidence to identify agent or principal........... 90

terms of memorandum....................... 9 I

description of subject-matter................. 92

consideration ............................... 93

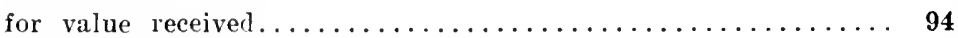

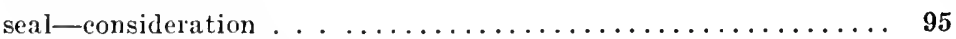

guaranty-consideration $\ldots \ldots \ldots \ldots \ldots \ldots \ldots \ldots \ldots \ldots \ldots . \ldots \ldots$

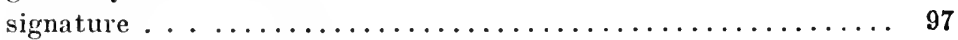

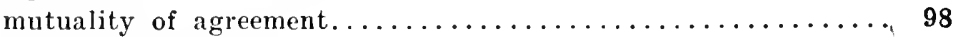

signature by agent.................... 9

MENTAL SUFFERING-

as a matter for damages for breach of contract.........693

statutory provisions-valid ...................6. 693

MERGER-See Pooling.

MESSAGES-

of telegraph companies-limiting liability for mistakes in send-

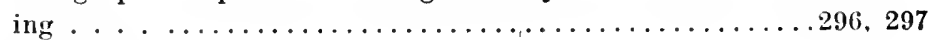

MILEAGE-BOOK-

is a contract between the railroad and passenger........... 292

MINORS-See INFANTS. 
MISREPRESENTATIONS- Sec.

of infant as to age-effect....................67, 68

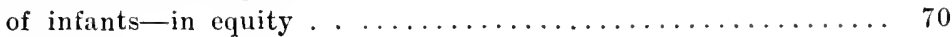

MISTAKE-

in an account stated - effect.................. 427

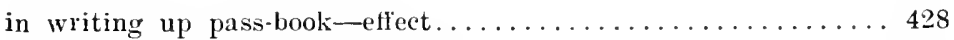

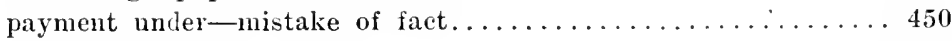

of law in payment-effect........................ 45 2

of law in equity............................. 453

of fact in compromise........................ 454

MONOPOLIES-

contracts in restraint of trade.................... 320

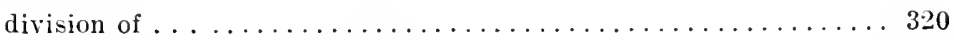

combinations of manufacturers for their own welfare....... 322

in international and interstate trade................... 326

by common carriers-regulation by State........... 538

MORTGAGE-

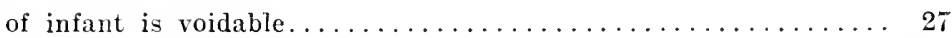

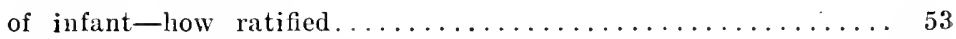

interest on debt-how computed on foreclosure........... 242

assumption of debt-rights of mortgagee to sue.......... 353

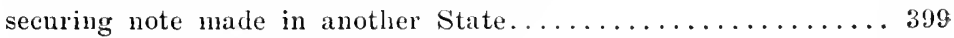

foreclosure-what law governs................. 403

interest on secured note-whether usurious............ 417

MORTGAGEE-

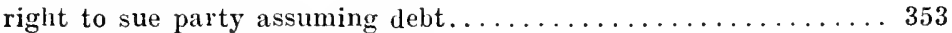

MORTGAGOR AND MORTGAGEE-

changing time of redemption................. 561

resale of mortgaged property when bought by the mortgagor.... 567

MUNICIPAL CORPORATIONS-

liability on implicd contracts................. 459

MUNICIPALITY-

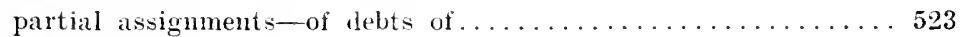

MUTUALITY-

in contract under the statute of frauds.............. 98

signed by party to be charged.................. 98

NATIONAL BANKS-

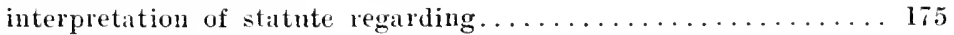

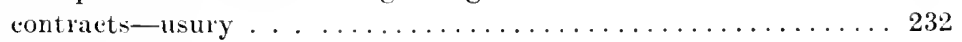

NECESSARIES-

insane person s contract for ..................... 11

contract for by infant is valid................... 39

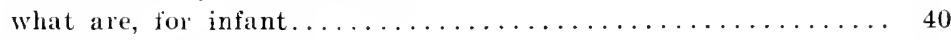

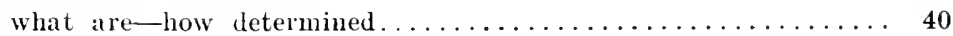

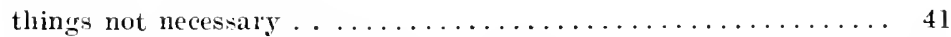

what things are not necessaries for infant............. \& 


\section{INDEX.}

NECESSARIES- (continued) Sec.

what things are necessaries for infant.............. 43

of infant living with father................... 45

payment for by another-effect................. 48

value of articles furnished to infant................49

what are, is a mixed question of law and fact. . . . . . . . 50

for wife and children-lusband and father bound..........457

for wife-implied contract. . . . . . . . . . . . . . 468,

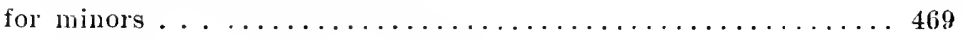

for insane persons-implied contract.............. 471

\section{NECESSITY-}

work of-made on Sunday.................... 188

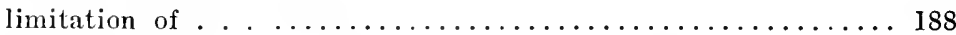

ruming passenger and freight trains may be carried on ....... I88

NEG. TTIVE-

of photograjh-to whom does it belong.............. 340

NEGLIGENCE--

limiting liability-common carriers............... 288

limiting liability-express companies............... 289

liability linited as to losses not from its own negligence..... 290

limitation of liability of common carier by notice on ticket. . . 292

tickets as a contract. . ..................... 293

coupon tickets-rights of connecting lines............. 294

free passes . . . . . . . . . . . . . . . . . . . 295

of telegraple company in sending message............ 297

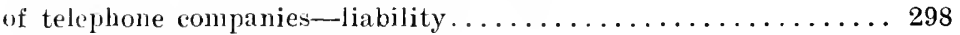

limiting liability of master.................... 299

third party injured-whether privity of contract..........348

stipulation exemption interstate carriers-effect.......... 4I0

of depositor to examine pass-book................ 428

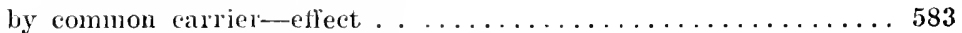

NEGOTIABLE PAPER-Siee BILLS and Notes.

NEIV PROMISE-

positive and exact by infant to affirm deed $\ldots \ldots \ldots \ldots \ldots \ldots$

NEWSPAPERS-

publisher of, trying to control adrertising-wheth.r any remedy. . 315

NEXT OF KIN-

suine for promise madr for the benefit of his father....... 361

NON-AGE-

of parties who marry-effect................... 31

NON COMPOS MEN'TIS-

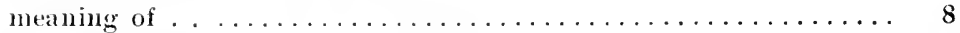

of acconlodation indorser-defense................ 14

NON-PLLIFUMANCH-

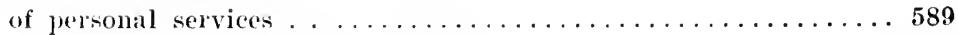

where porsonal skill is not required . . . . . . . . . . . 590 
NON-PERFORMANCE-(continued) Sec.

on account of sickness......................... 591

death of employer........................... 592

NORTHERN SECURITIES COMPANY-

merger of railroads-legality $\ldots \ldots \ldots \ldots \ldots \ldots \ldots \ldots \ldots \ldots .324$

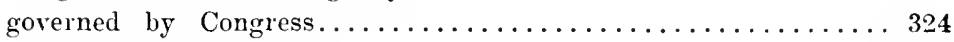

interstate traffic-regulation of ................ 324

NOTICE-

by express company on its receipts as to liability ......... 289

in bill of lading-brought to attention of shipper-legality. . . . . 290

on back of ticket limiting railroad's liability-low served...... 293

in telegraph blank-when sender of message is charged with notice 297

of goods furnished by one not contracted with-acceptance..... 478

of roluntary payment of money as to third party.......... 502

of holder of money that it was stolen................ 502

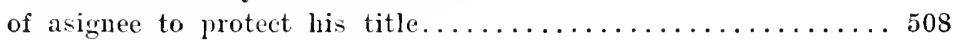

of condition in theater ticket.................. 509

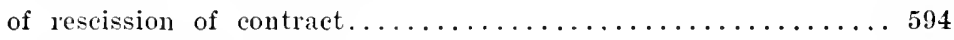

to rescind-vhen served on the opposite party............ 597

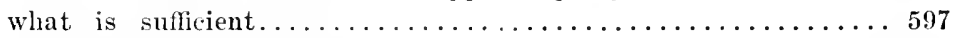

bringing suit may be notice...................... 597

of rescinding contract for services in future-rights of employe. 604

of rescission of contract-duty of employe............. 611

given to agent of rescission.......................

to terminate contract-reservation...............62, 623

to vendor-sale for special purpose-damages............685

NOVATION-

release of debtor-whether within the statute of frauds...... 130

NUISANCES-

when property may be destroyed $\ldots \ldots \ldots \ldots \ldots \ldots \ldots \ldots \ldots . \ldots 46$

OBLIGOR AND OBLIGEE-

rights of assignee of bond..................... 508

OCCUPATIONS-

laws for protection of women and minors are valid......... 544

when State may regulate.................... 544

OLD AGE-

as incapacity to contract.................. 7

OLEOMARGARINE-

prohibiting matnufacture and sale of $\ldots \ldots \ldots \ldots \ldots \ldots \ldots \ldots, 542$

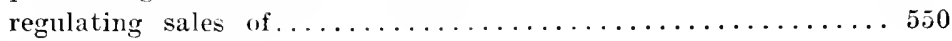

OPERA TROUPE-

failure of manager to perform contract............. 5s9

OPTIONS-

on contracts-validity . . .................... 249

when a wager, void.............................. 249

right oi innocent holder of note given for option transaction.... 257 


\section{INDEX.}

OPTIONS-(continued) Sec.

in futuers-law of another State................. 413

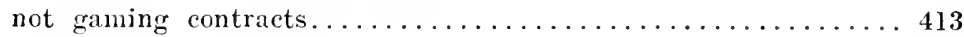

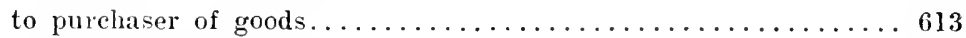

contracts-specific performance of . . . . . . . . . . . 669

ORAL AGREEMENT-See Parol Contract.

to bequeath or devise-legality .................. 465

when performance ....................... 465

ORDINANCE-

establishing an exorbitant fee for doing business.......... 198

ORDINARY CALLING-

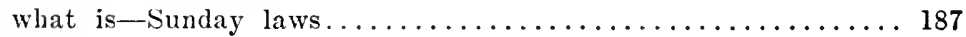

PACKAGE-

registered letter sent by common carrier-lost-liability of rail-

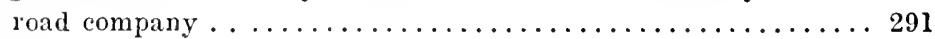

PARDON-

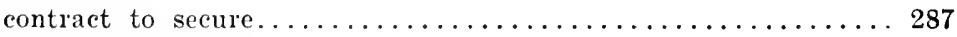

PAROL CONTRACT-See Oral Agreement.

to convey land-when enforced.................467

PARTIAL ASSIGNMENTS-

at law-effect . . . . . . . . . . . . . . . . . . . 521

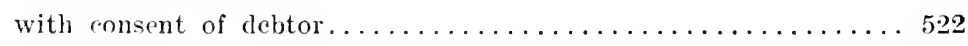

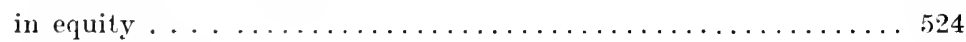

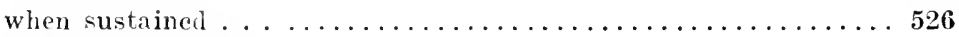

PARTICEPS CRIMINIS-

delotor and ereditor-secret preferences in insolvency....... 172

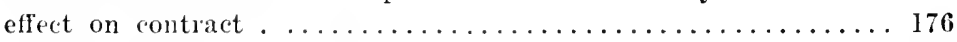

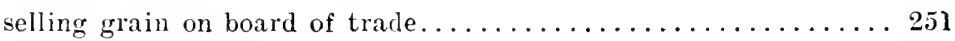

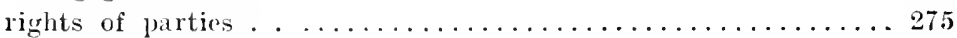

when parties are not in pari dclicto-relief............500

PAR'TIES-

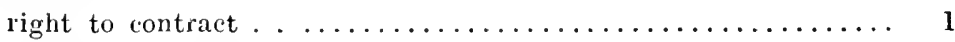

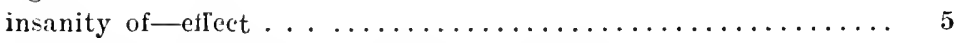

having insane delusions-power to contract........... $s$

description of, in memorandun................. 88

who must $\operatorname{sign}$ memorandum. . . . . . . . . . . . . 88

signed by party to be charged under the statute of frauds...... 98

who may plead the statute of frauds................ 113

paying debt of another-to whom must the promise be made... 123

when they may unite to buy on joint account........... 169

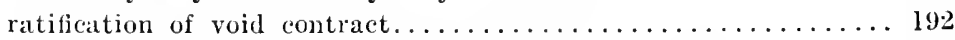

Sunday note-in the hands of an innocent third party....... 193

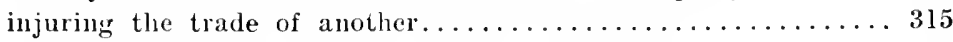

in pari delicto-enforcement of illegal contract.......... 330

rights of relatives to photographs of the dead............ 340

duty not to interfere in any contract............. 342 
who are-to a contract...................... 339

taking news from ticker-who has the right............ 339

when third persons may become a party to a contract........ 352

assumption of mortgage debt-right of mortgagee to sue...... 353

must be something more than a mere promise........... 354

acceptance by third party .................... 355

contract for the benefit of third persons-modification of general

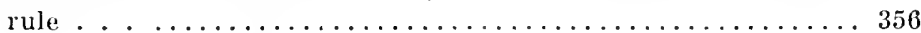

exceptions to the modified rule................ 357

party to the consideration-trust................ 358

promise as agent ...................... 359

English doctrine....................... 360

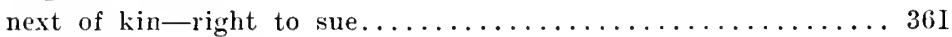

covenants ........................... 362

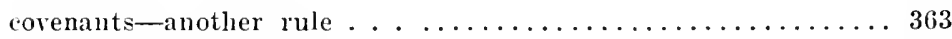

who may bring suit on simple contract............... 364

description of the debts..................... 365

agreement to save harmless................... 366

many promisors-suit against................. 367

capacity to contract-interstate................. 397

members of the same family-services among............ 460

in pari delieto-relief of .................... 500

PARTITION-

of infant-when jegal $\ldots \ldots \ldots \ldots \ldots \ldots \ldots \ldots \ldots \ldots \ldots \ldots \ldots$

PARTNER-See PARTNership.

giving his individual note as payment of firm's debt-effect..... 370

when one partner can sue another after dissolution..........433

PARTNERSHIP-See PARTner.

insanity of partner-as to dissolution of $\ldots \ldots \ldots \ldots \ldots \ldots \ldots$

of infants are voidable..................... 27

contract of infants-time to avoid................ 60

compelled to pay debt of partner-rights of $\ldots \ldots \ldots \ldots \ldots \ldots \ldots 1$

of partners after dissolution...................4433

one party to a sale acting through a partnership..........649

PART I'AYALNT-See Earnest and Part Payant.

distinguished from earnest money............... 153

when must part payment be made................. 154

what constitutes part payment.................. 155

in what property must part payment be made........... 156

tender-statute of frauds-must be of some value......... 156

\section{PART PERFORMANCE-}

takes contract ont of the statute of frauds, when ......... 81

at law-under the statute of frauds................102

marriage, coupled with possession of land, is part performance.. 102

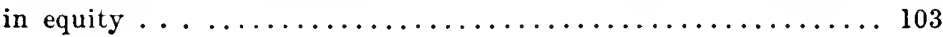




\section{INDEX.}

PART PERFORMANCE-(continued) Sec.

what is . . . . . . . . . . . . . . 104

by taking possession and making permanent improvements..... 105

by personal service and conveyance of personal property...... 108

services rendered or benefits received.................. 110

of contract to convey land.................... 467

of contract to furnish labor or material-quantum meruit.... 473

taking care of party-recovery................. 474

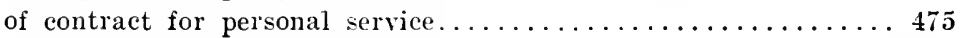

of void contract-recovery................... 479

under no obligations to perform-part performance-recovery.. 480

failure to pay in the manner agreed to.............. 481

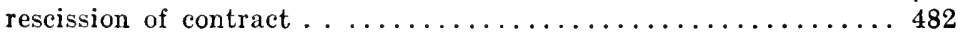

PASS-BOOK-

whether an account stated...................... 428

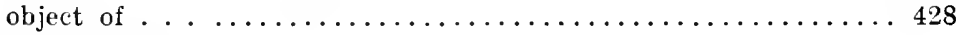

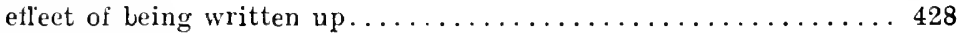

PATENTEE-

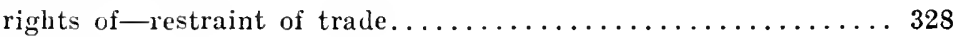

when under police power.................. 547

PATENTS-

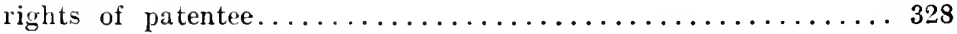

owners of ditlerent patents in single article-restraint of trade. . 329

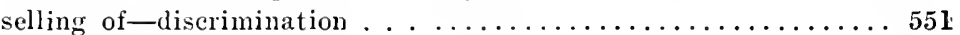

sale of-specific performance of contract............6673

PAYMENT-

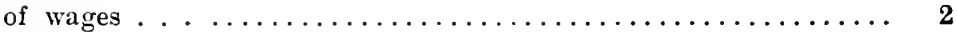

of infant's debt by another-eflect.................. 48

of consideration alone does not take sale ont of the statute of

frauds ............................... 102

of purchase-money as part performance.............. 104

of money and labor-part performance............... 108

of consideration-oral agreement to convey real estate-recovery

back purchase money....................... 109

of debt guaranteed-as to the statute of frauds.......... 127

of liquidated debt-exception as to part payment.......... 171

secret preferances by insolvent-eflect on assignment........ 172

of money on sunday-etreet..................... 195

of interest quarterly or semi-annually is not usury......... 216

of interest, may be controlled by contract............ 241

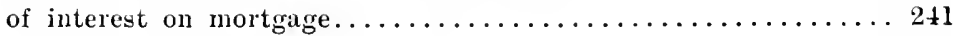

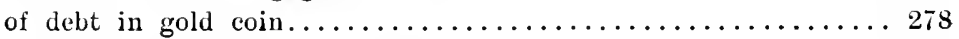

voluntary payment of another's debt-rights of the parties.... 340

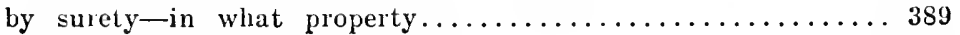

of insurance loss............................. 404

of forged check by bank-liability................ 428 
PAYMENT-(continucd) Sec.

of the debts of another-eflect.................. 430

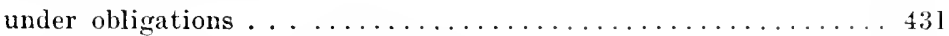

voluntary payment raises no assumpsit............. 439

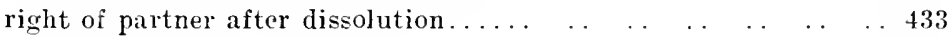

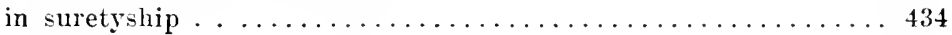

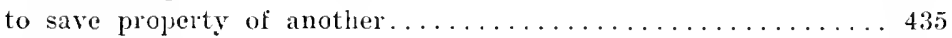

contribution ........................... 436

contribution among wrongdoers................. 437

contributions anong wrongdoers-exceptions to the general rule.. 438

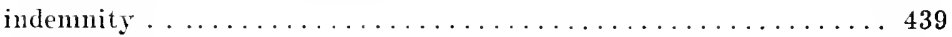

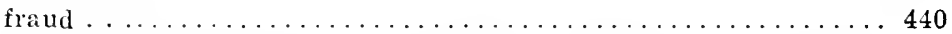

before party can collect for payment of another's debts-he must

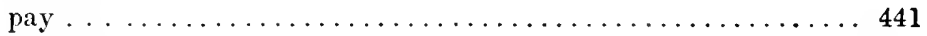

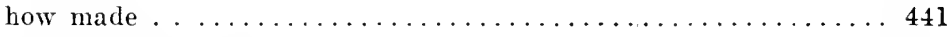

of express contracts....................... 442

of roid contracts........................ 413

of money on void contract-effect.................. 443

difference between express and implied contracts........... 444

action for money-not property.................. $4 \frac{16}{46}$

when voluntary-effect...................... 449

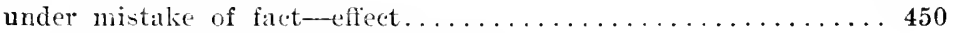

of commission by both seller and buyer.............. 451

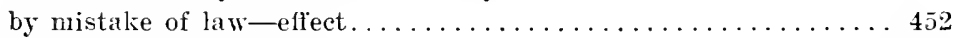

under duress . . . . . . . . . . . . . . . . . . . . . . 452

what will make it voluntary . . . . . . . . . . . . 452

of settlement by compromise-mistake.............. 454

under duress-efiect . . . . . . . . . . . . . . . . . . . . 455

of taxes and assessments..................... 456

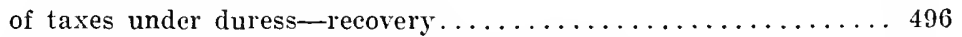

voluntary payment of money-recovering back........... 501

voluntary payment of money-notice to third partics....... 502

of debts with stolen money-rights of true owner.......... 504

as to statute of limitations..................... 624

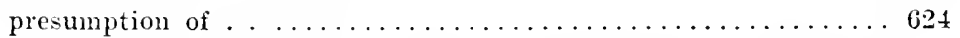

of debts of corporation-unpaid subseription stock-statute of

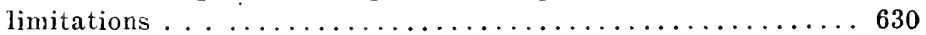

part payment by one joint debtor-statute of limitations......664

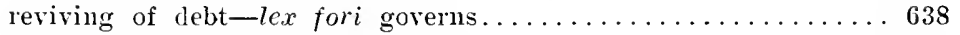

when payable on contract work..................647

partial payment as evidence of aceeptance of work........652

by composition with creditors................. 700

PEDDLERS-

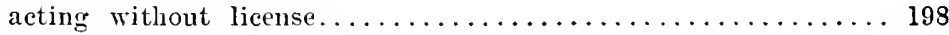

cannot be favored by the legislature, because they are old soldiers 198 


\section{INDEX.}

PENALTY- Sec.

implies a prohibition. .................... 173

and prohibition by statute................... 175

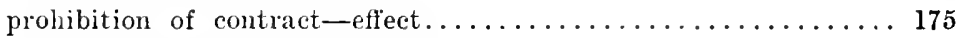

imposed for administrative purposes ............... 177

acts impliedly prohibited..................... 178

for selling articles without inspection. .............. 202

PENSIONS-

fees in collecting of, may be limited by Congress. . . . . . . . . 540

PEONAGE-

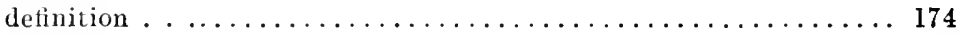

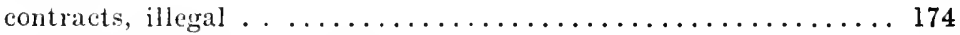

act of Congress-construction ................ I74

PERForiJANCE-See Specific Performance; Part Performance.

substantial performance of contract-effect............477

one party stancing ready to perform-his rights. . . . . . . . 480

failure to pay as agreed to.....................481

of work and labor........................ 481

action for part performance...................481

diflicuity and had diship will not excuse................ 569

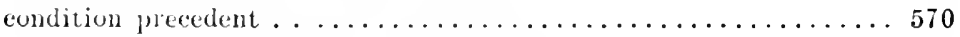

non-existence of subject-matter of contract............571

subject-matter of contract ceasing to exist............ 572

imposibility of performing a contract arising subsequently.... 573

in commencial transatetions..................... 574

bailnent of an article to be repaired............... 575

excused by act of law.......................... 576

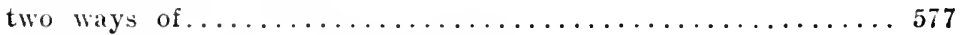

judgnuent aud other judicial processes................ 578

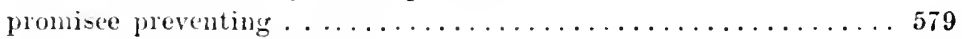

when excused by act of God .................... 580

when exclised by public eneny-act of God-applieation to

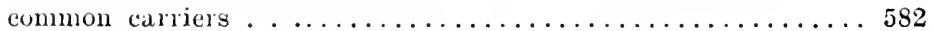

common carriers, when liable by loss by act of God......... 583

where law imposes a duty...................... 585

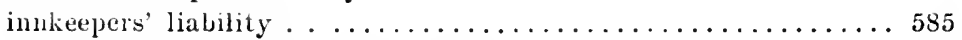

failure of consideration by act of God .............. 586

destruetion by fire....................... 587

intervention by the act of $\operatorname{God} \ldots \ldots \ldots \ldots \ldots \ldots \ldots \ldots \ldots$

tender of-when not necessary..................606

to perform work and furnish materials . . . . . . . . . . . 639

snbstantial performance-good faith $\ldots \ldots \ldots \ldots \ldots \ldots \ldots \ldots$

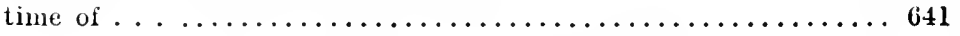

condition in contract for arbiter as to performance.........

arbitration clause in contract...................643

the arbiter's decision must be pertinent..............644 
PERFORMANCE-(continued) Sec.

fraud in . . . . . . . . . . . . . . . . . . 645

dispensing with the production of the architect's certificate....646

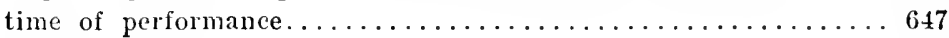

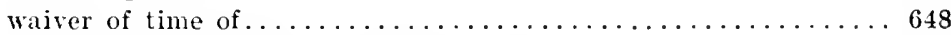

one party acting through a partnership.............. 649

work must be performed in a workmanship manner.........6650

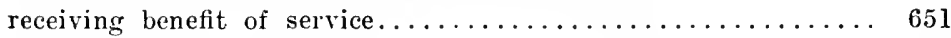

partial payment as evidence of acceptance of work.......6652

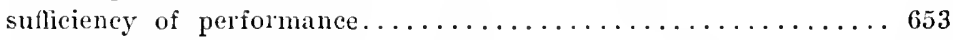

manufacturing articles according to sample-delivery........654

substantial performance .......................655

matters excusing non-performance................. 656

implied condition as to contingent impossibility of performance.. 657

implied condition of contracts. . .

why implied conditions attach to conracts............ 659

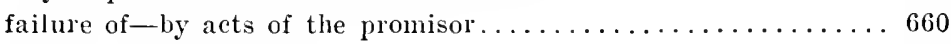

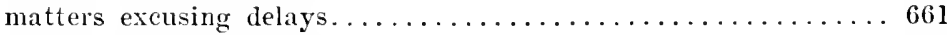

what constitutes breach.....................662

owner of building promising to see seller of materials paid.... 663

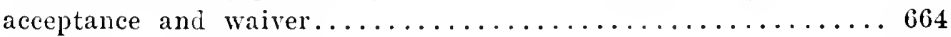

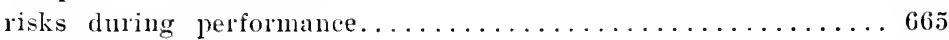

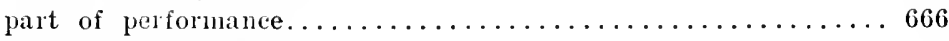

PERSONAL PROPERTY-

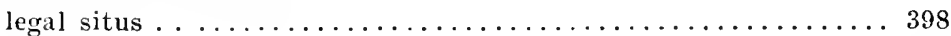

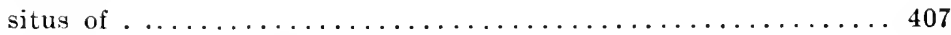

as to domicile of owner..................... 407

PERSONAL SERVICES-

nature of-performance . . . . . . . . . . . . . . . 589

when skill is not required-as to performance........... 590

sickness-effect on contract.................... 591

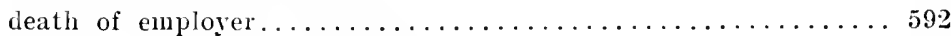

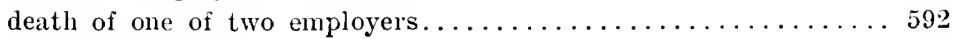

PHOTOGRAPHS-

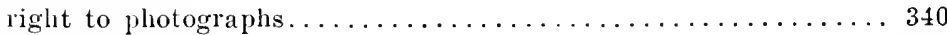

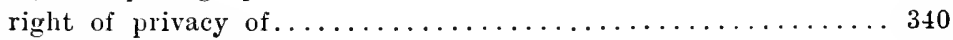

PHYSICLANS-

curing by telepathic methods-libel by newspaper......... 164

laws requiring license-failure to take out-etlect......... 200

not a conmon carrier-need not attend patients unless so disposed 200

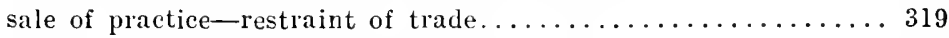

services rendered in case of emergency-implied contract......444

regulation of practice of by State................ 550

action against-as to the statute of limitations...........6. 628

PICLETING-

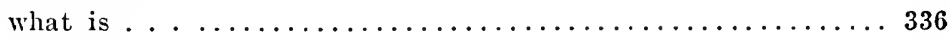

intimidating non-union men..................... 336 


\section{INDEX.}

PLEADINGS- Sec.

when the statute of frauds can be pleaded............. 112

who may plead the statute of frauds................ 113

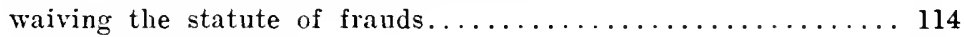

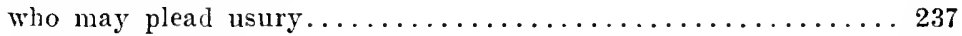

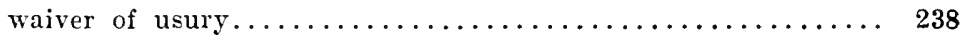

law of another State-must be pleaded as to usury........ 243

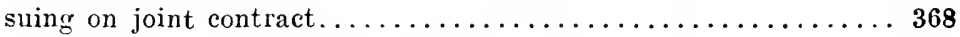

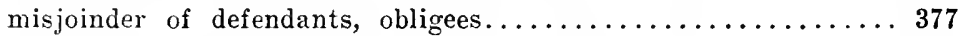

allegation in declaration to recover on implied contract....... 444

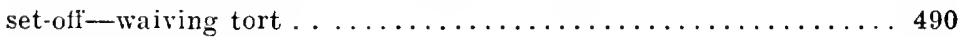

under the Code................................ 527

POLICE POWER-

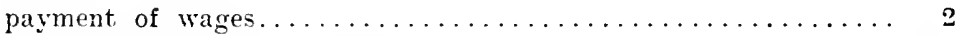

controls the sale of intoxicants.................. 205

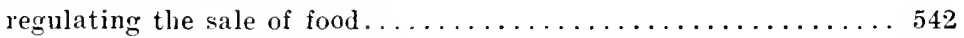

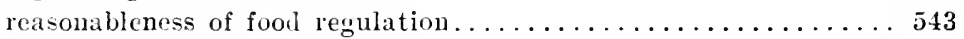

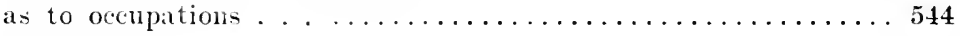

insurance . . . . . . . . . . . . . . . . .

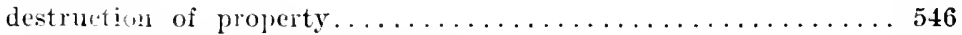

controlled by Federal Constitution................ 547

interstate commerce . . ................... 548

State statute interfering with interstate commerce......... 549

surrender of the police power................. 550

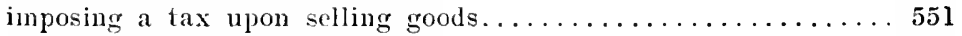

tax upon interstate commerce................... 552

when is an imported commodity incorporated with the general

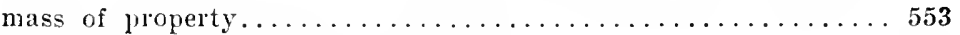

statute incorporating imported goods.............. 554

\section{POLICY-}

of life insurance-no suicide clause................ 16

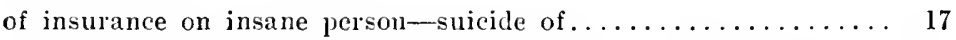

of insurance-suicide clause-self-destruction-American doctrine 19

of insurance-clanse inserterl, "dic by suicide, sane or insane"-

meaning . . ............................. 20

of insurance-what law governs................ 404

assignment of-interstate .................... 405

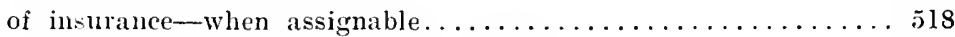

af insurance-after loss-may be assigned............ 526

of life insurance-insured committing a crime-effect........ 545

POOJING-

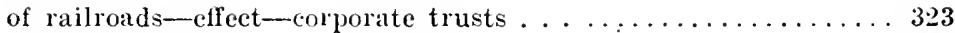

railroad business . . . . . . . . . . . . . . . . . . . . 324

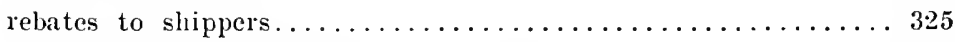

monopoly in interstate and international trade........... 326

corporate trusts and labor..................... 327 


\section{INDEX.}

POOL SELLING-

Sec.

whether legal

POSSESSION-

alone, of land, as to part performance.............. 102

of land as part performance.................. 105

POIVER OF ATTORNEY-

to assign public officer's salary................ 517

PREFERENCES-

by insolvent when assigning. ................. 171

secret preferences by assignors-effect............. 172

PREMIUU-

given at horse racing-whether gambling.............. 262

buying stock at a ficttitious price-when fraudulcnt........ 163

difference as to wager....................... 265

PREMIUN AND EXCHANGE-

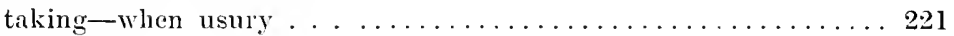

PRICE-

essential element-within the statute of frauds.......... 141

of goods paid on Monday, sale executed on Sunday........... 185

taking lower price for cash than when credit is given-usury... 214

in purchase price of land-cash sale or on credit-usury..... 215

lowering price by merchant-informing retailers-as to malice.. 315

of book reserved by publisher-when sale is made......... 339

recovery of - sale prohibited..................... 409

in smuggling contracts-collection of . . . . . . . . . . . 414

working on personalty-rescission of contract-right to recover. . 608

PRINCIPAL AND AGENT- See AgENCY.

verbal guarantee of solvency of purchaser by agent-not within

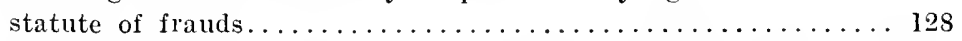

executed contract by agent for principal-principal's rights..... 195

agent taking commission for loaning principal's money-usury... 211

agent soliciting passenger traffic-when interstate commerce... 182

railroad through tickets-state and interstate service........ 1s 2

agent taking commission for loaning money-when usury...... 228

principal may charge for extra expense............... 228

promising as agent-benefit of third party.......... 359

agent acting for both principals................. 451

agent receiving commission from seller and buyer-effect......451

right of agent to bring assumpsit for his injured principal. . . . 494

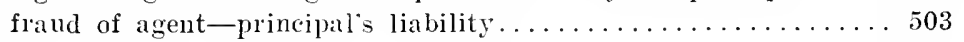

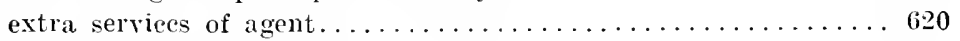

no limitation as to the time of hiring. . . . . . . . . . 622

PRINCIPAL AND SURETY-

joint obligation-death of one-effect.............. 374

release by act of creditor................... 375

must principal be insolvent before surety can bring action for con- 
PRINCIPAL AND SURETY-(continued) Sec.

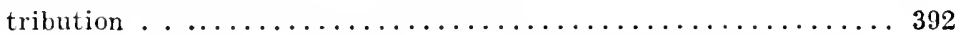

liability for fraud of principal-as to statute of limitations run-

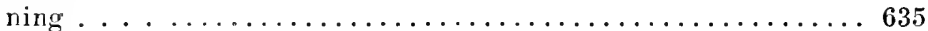

\section{PRIORITY-}

of chattel mortgage lien...................... 402

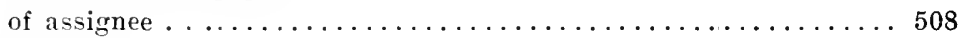

PRIVACY-

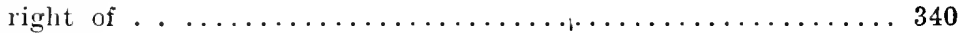

PRIVITI-

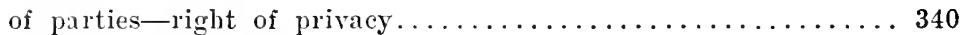

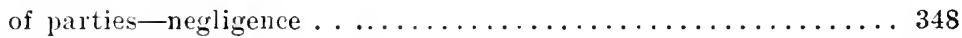

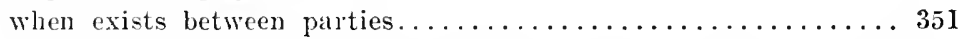

of estate-receiving money belonging to another-implied contract 445

selling land with no title.......................445

when there is none between parties................ 457

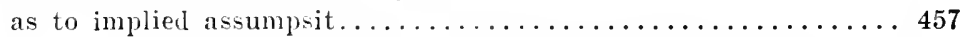

of contract-waiving tort and suing on the implied contract... 491

PROFESSIONAL SERTICES-

as attorney to procure legislation.................. 285

PROFITS-

sales at anction-conspiracy among buyers-division of profits.. 165 as a matter in estimating damages for breach of contract.687, 688, 689 as damages-general rule...................... 695

which would have been made.................. 696

contingent not allowed...................... 697

resale by purchaser . . . . . . . . . . . . . . . . . . 698

PRONHSE-

to pay debt of another-to whom made............. 123

to pay debt of another-when within the statute of frauds...... 124

to pay for goods sold to another-original consideration...... 125

PRONISEE-

preventing performance of contract-effect on promisor......579

PRONISE WITHIN STATUTE OF FRAUDS-

to bind third parties for the debt of another............ 122

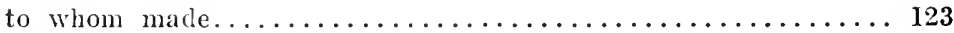

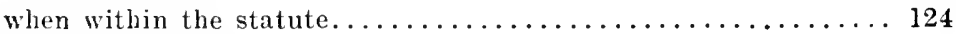

when original . . ............................. 125

evidence to place liability...................... 126

to pay debt on behalf of promisor.................. 127

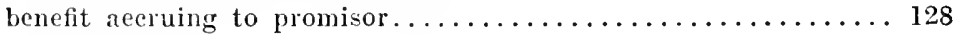

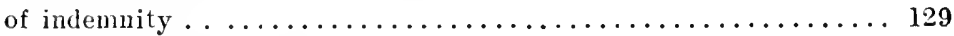

release of original debtor-novation................. 130

receipt of property out of which to pay the debt.......... 131

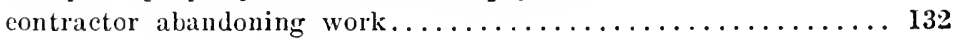




\section{INDEX.}

PROMISOR- Sec.

to pay debt on his own behalf................. 127

promise accruing to him-not within the statute of frauds..... 128

where there are many-how suit shall be brought against...... 367

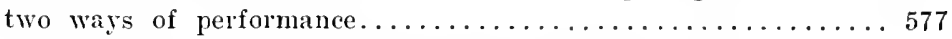

destruction by fire of building is no discharge of contract..... 587

intervention of the act of God-effect on contract..........588

failure of performance by acts of .................660

PROMOTERS-

riglit to collect pay from the corporation after organized......4 463

PROOF-

burden of-for discharged employee seeking other work......665

burden of - selling by sample................... 612

PUBLIC ENEMY -

excusing performance of contract by acts of $\ldots \ldots \ldots \ldots \ldots \ldots 51$

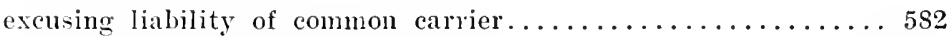

where law imposes a duty.................... 584

PUBLIC OFFICE-

dismissing oflicer-impairment of obligation of contract......426

PUBLIC OFFICER-

assignment of unearned salary................. 517

PUBLIC POLICY-

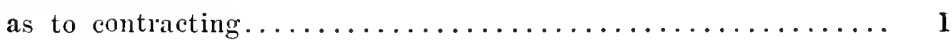

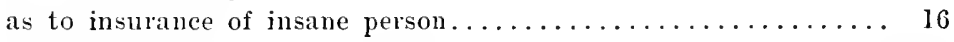

how determined . . . . . . . . . . . . .

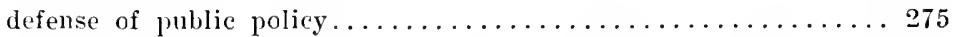

stipulation that representation shall not avoid the contract.... 276

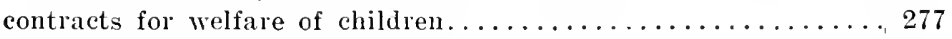

contract payable in gold coin........................ 278

PUBLISHERS-

trying to control the business of advertising in newspapers.... 315

selling his books-what rights can be exercised........... 339

contract with author is not assignable............ 519

PUFFERS-See AUCTION; BY BiddiNg.

QUANTUM MERUIT-

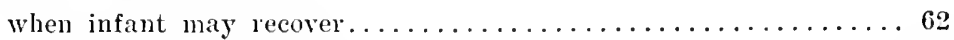

for services in pait performance................. 110

when recovery can be had $\ldots \ldots \ldots \ldots \ldots \ldots \ldots \ldots \ldots \ldots \ldots . \ldots 43$

recovery on personal services.................. $4 \pi 5$

recovery for part performance of void contract........., 479

one party rescinding contract.................. 482

when party may recover on-non-performance of contract......551

when discharged employe may recover on ............60

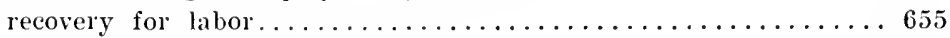

for breach of contract for work................ 6 ss 


\section{INDEX.}

QUARANTINE- Sec.

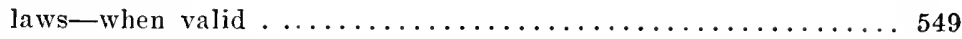

excluding cattle and meats.................. 549

RAILROADS-See Common Carriers.

when not common carriers-special contract............ 288

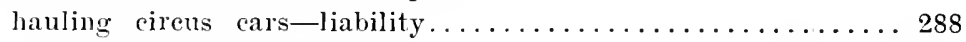

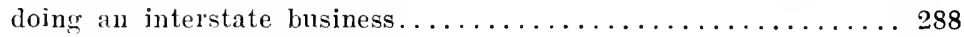

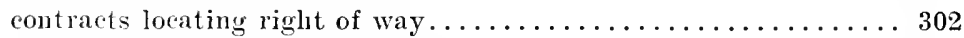

contracts locating stations and depots........................ 302

giving telegraph company exclusive privilege to sct poles...... 308

must not create a monopoly in the carriage of passengers and

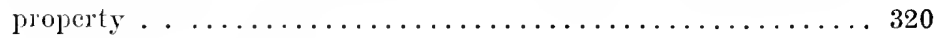

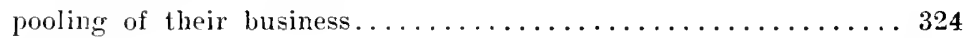

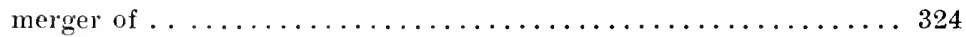

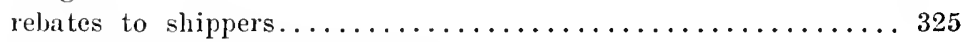

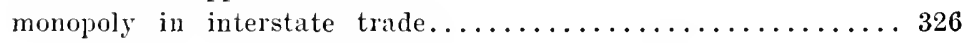

may establish reasonable rates among themselves for self-pro-

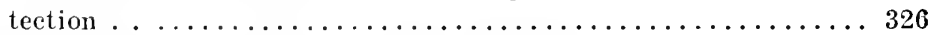

giving employees reason for their discharge............ 537

when compelled to make changes in roadbed........... 541

RATIFICATION-See AfFirmance.

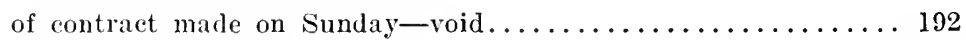

in part of contract............................ 598

REAL ESTATE-

sale of-what law governs.................... 403

REBATES-

to shippers by railroad companies................ 325

RECOGNI\%ANCE-

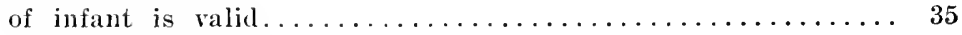

RECOUPMENT-

when allowed as to work...................650, 651

when not waived by acceptance of work............. 664

REDEMPTION-

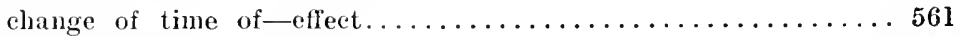

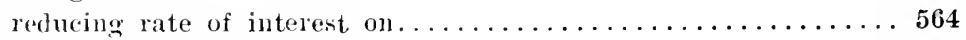

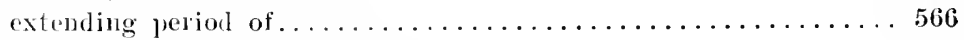

resale when bought by mortgagor for less than the debt...... 567

REGLLATIONS-

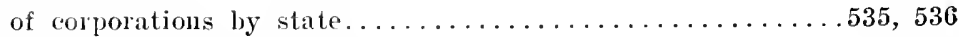

charters of corporations are contracts............. 530

subequent acts regulating railroad companies.......... 537

the sale of food............................... 542

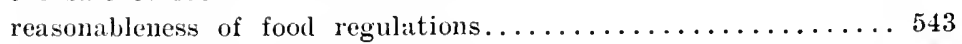

by states-excluding food products................ 549

of telegraph company by state.................. 549

of common carriers.......................... 550 
RELEASE- $\quad$ Sec.

of lien on property-promisor to pay debt........... 127

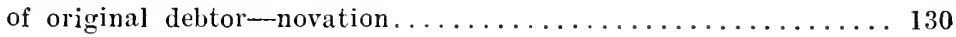

of surety by act of creditor.................... 375

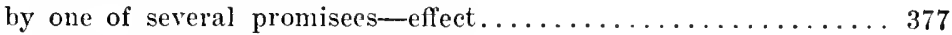

of one joint obligee with conditions................... 378

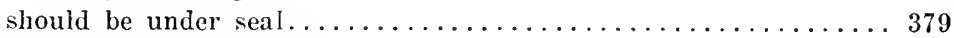

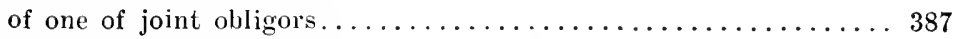

REMEDIES UNDER STATUTE OF FRAUDS-

no action to be brought......................... 100

roid and voidable contracts.................. 101

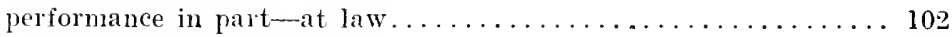

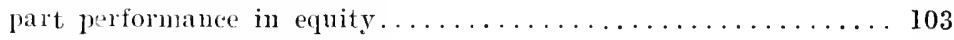

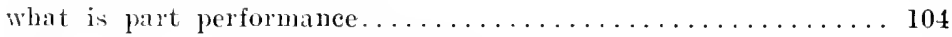

possession of land and improvements.................. 105

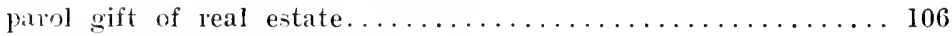

specific performance of agreement............... 107

fertonal service and conveyance of personal property ....... 108

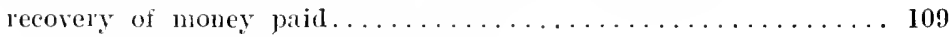

service rendered or benefits received................. 110

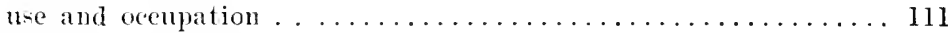

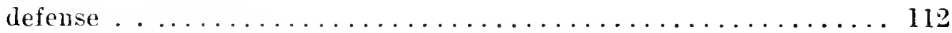

who may take advantage of the statute of frauds......... 113

waiver of statute in action for breach of contract.......... 114

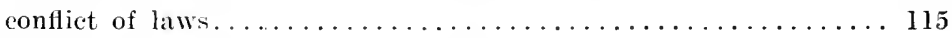

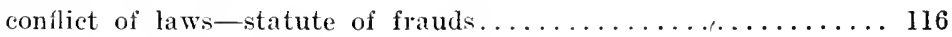

REMEDY-

statute of frands concerns the remedy only........... 113

to enforce prohibited contract.................. 184

to collect money loaned on Sunday, against the statıte....... 195

of unlicensed brokers to collect commission for sale......... 198

peddling without a license-camnot collect for services........ 198

on contract partly bad and partly valia................ 204

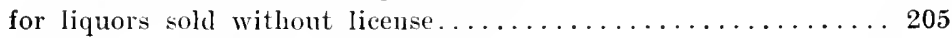

pleading usury laws of another state............... 243

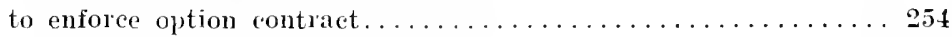

to recover back money lost at gaming................. 259

to enforce illegal contract...................... 330

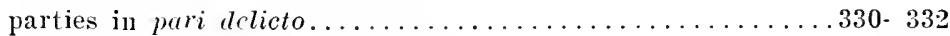

test of the liability of trades unions................ 335

to enforce revellue contraets of another country..........415

interpretation of interstate contract................ 419

agreement as to what law should govern............... 420

common carriers-contract of aflreightment............. 421

alien labor aets......................... 422

impairment of-laws enter into the contract when made....... 555 
REMEDY-(continued) Sec.

altering the remedy $\ldots \ldots \ldots \ldots \ldots \ldots \ldots \ldots \ldots \ldots \ldots \ldots \ldots$

retrospective acts . . . . . . . . . . . . . . . 557

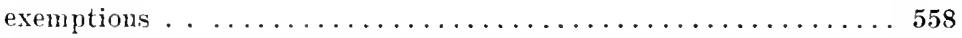

limitations . . . . . . . . . . .

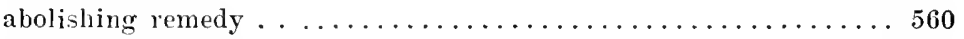

redemption from sales of real estate.............. 561

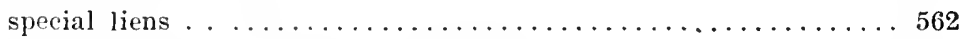

changing rate of interest on judgment............. 563

reducing rate of interest in redemption.............. 564

change of procedure........................ 565

extending the period of redemption................. 566

resale when bought by the mortgagee for less than the debt.... 567

the statute of limitations aflects only the remedy..........629

when law furnishes no complete remedy-specific performance...667

specific performance-mutuality . . . . . . . . . . . 669

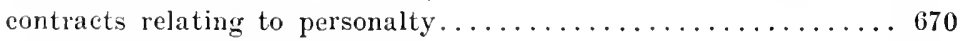

at law-specific performances........................

change in the condition of one party ...............

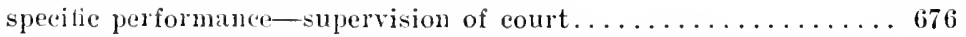

contracts involving the exercise of skill, personal labor and culti-

vated judgment. . ....................... 677

\section{RENTS-}

voluntarily paid-recovering back............... 501

future rents may be assigned.................. 518

REPAIRS-

on real estate of infant, not a necessary ............ 42

REPLAL-

of statute-eflect on contracts................. 416

of statute in another state-contract made there-effect......416

REPLEVIN-

of goods delivered on Sunday ..................... 195

of property delivered by agent on Sunday-action by principal. 195

REPRESENTATIONS-

as to credit under the statute of frauds-statutory provisions... 157

when the statute of frands applies............... 158

sulliciency of writing under the statute of frauds-as to credit,

parol evidence-representation as to credit............ 160

stipulation that false representation shal not avoid a contract. 276

when false-injury to third party .................. 346

taking as true-pass-book-eflect . . . . . . . . . . . 428

RESALE-

lnying goods to resell-breach by vendor-damages........ 698

RESCISSION-

of contract for benefit of third person.............. 355

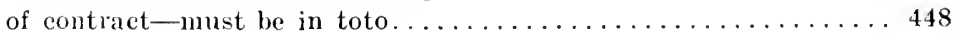




\section{INDEX.}

RESCISSION-(continued) See.

action for ................................ 448

of contract-part performance................. 482

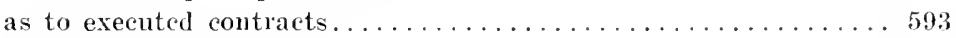

notice and acceptance of ................... 594

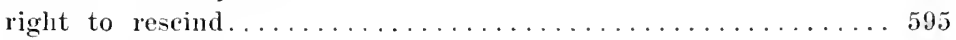

time to rescind. . . . . . . . . . . . . . . . . . 596

notice to rescind........................ 597

rescission in patrt......................... 598

recovering back consideration paid................. 599

sealed contracts-to recover money paid ................600

of contract-as to damages....................68s

of contraet-damages ......................6690

contingent damages for breach....................690

RESCISSION, CONIDITION SUBSEQUENT-

selling by sample..........................612

option to purchaser......................613

contract of hiring, employe guarantees satisfaction. . . . . . 614

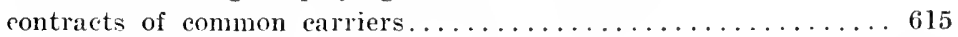

act of God that will excuse a common carrier...........6616

shipment of live stock. . . . . . . . . . . . . 617

hiring contracts-implication of discharge............618

reservation of wages payable at certain intervals.........619

extra services . . . . . . . . . . . . . . . . . 620

reservation of right to terminate................. 621

no limitation as to term of hiring...............622

notice of termination-reservation ...............623

RESERVATION-

in charter of corporation-effect................ 54l

of wages-payable at certain intervals ..............619

of right to terminate contract.................6.

notice of termination of contract.................623

RESTRAINT OF TRADE-

by establishing an excessive fee for doing business.......... 198

by corporations in a public business......................

contracts of . .......................... 30 !

unreasonable restraint . . ................... 310

English doctrine as to limitation to time and space-leasonable-

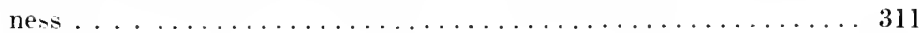

American doctrine as to limitation of time and space....... 312

test of reasonableness..................... 313

the latest statement of the test of reasonableness......... 314

Illinois vule is abbitrary ................... 314

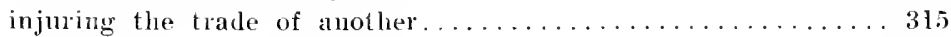

interpretation of contract....................

dealing with exclusive persons.................. 316 
RESTRAINT OF TRADE-(continued) Sec.

sale of secret process........................ 316

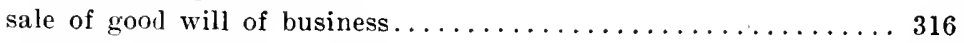

rights of patentee....................... 328

owners of different patents in single article............. 329

RETROSPECTIVE LAWS-

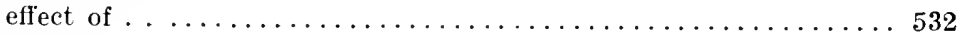

REVENUES-

enforcing revenue law of another country............ 415

REVOCATION-

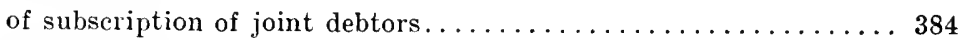

as to gifts........................... 425

RIGHT TO CONTRACT-

right of State over....................... 1

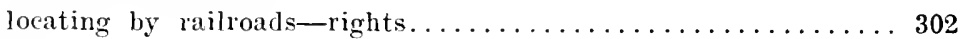

RISKS-

during performance of building contracts............ 665

SALARI-

teacher cannot collect if he has no certificate to teach...... 201

assignment of unearned-effect................. 283

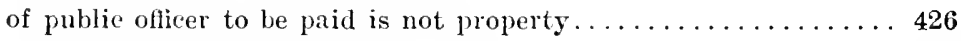

recovering for extra services................... 462

one partuer may engage for a salary ............... 483

assignment of unearned salary by public officer.......... 517

of public officers-ean be controlled by the legislature.......530

of sehool teacher-if school house burns, goes on with no abate-

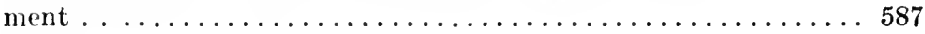

of school teacher-elosing of school..............589

SALES-

by insane vendor to bona fide purchaser-validity of . . . . . 22

by infant of land-ratification of sale.............. 53

requisites of memorandum of . . . . . . . . . . . . . . 88

promise of one to become responsible for goods sold to another. . . 122

credit given to the receiver of the goods. . . . . . . . . . . 122

of goods-to be paid by a third party-when within the statute

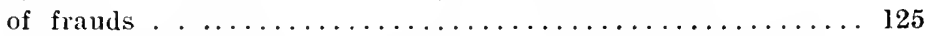

of claim-gualranteeing its collection-not within the statute of

frands . . . . . . . . . . . . . . . . . 127

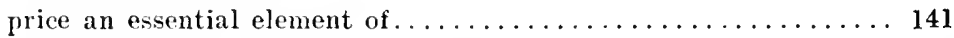

amount of, minder statute of frauds................ 142

of several artieles-amount--how determined $\ldots \ldots \ldots \ldots \ldots \ldots$

of goods, wares and merehandise.................. 144

earnest money under the statute of frauds.............. 153

when must part payment be made............... 154

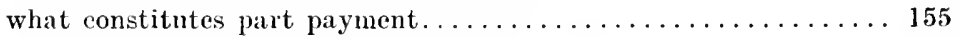

in what property part payment may be made........... 156 


\section{INDEX.}

SALES-(continued)

Sec.

by-bidding-effect on purchase.................... 165

at auction-by-bidding-when 1 gal . . ............. 167

agreement to purchase property on joint account-at auction... 169

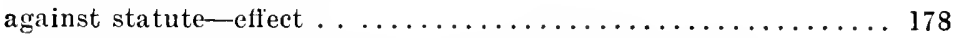

of goods on Sunday-delivered on a secular day-effect........ 185

goods delivered on Sunday-price paid on Monday-effect...... 185

when within the Sunday laws.................. 187

vessel not sealed-effect..................... 197

by broker having no license-collection of commission........ 198

of articles withont inspection according to law-effect....... 202

of intoxicants without license.................... 205

of property-taking commission for care of property-not usury. . 210

of property - taking lower price for cash than when sold on credit

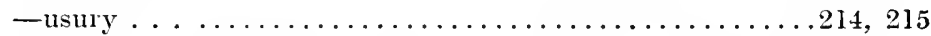

of securities-tainted with usury-in the hands of innocent pur-

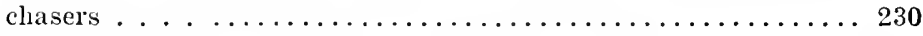

absolute sale with agreement to repurchase-usury......... 231

for furture delivery . . . . . . . . . . . . . . . . . . . 248

with option-margins . . . . . . . . . . . . . . . . . . 249

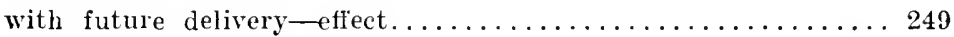

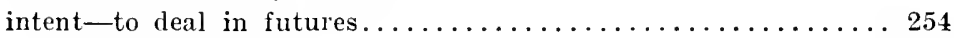

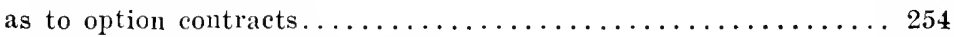

of commodities not in existence................... 255

of lottery tickets-when illegal.................. 272

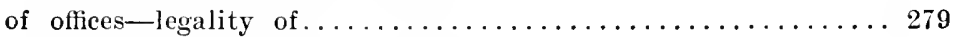

of secret processes-restraint of trade................ 318

of good will of business-restraint of trade........... 318

of books-publisher wishing to control............... 339

of photographs without owner's consent............... 340

of articles-third party injured by vendor's negligence........ 348

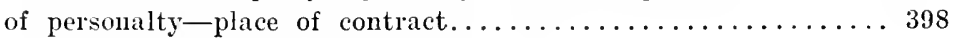

vendor reserving title-what law governs............. 402

of real property-what law gorerns............... 403

interstate laws . . . . . . . . . . . . . . . . . . 408

of merchandise to be delivered in another State..........4408

interstate-controlled by Congress................. 411

of goods on Sunday-law of another State.............. 412

for snuggling purposes.................... 414

selling land with no title-right of purchaser........... 445

delivery of part of the chattels sold-remedy of purchaser......448

of theater tickets-rights of purchaser.............. 509

of property under execution-limiting amount........... 565

when executed cannot be rescinded................ 593

purchaser advancing money-consideration fails-effect on con-

tract .............................. 595 
SALES-(continued) Sec.

by sample-rescission of sale.................612

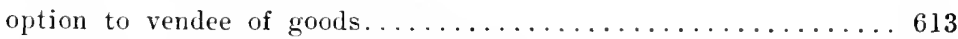

of patent rights-specifie performance.............673

of personalty-specific performance...............674

of chattels having a special value-specific performance......675

of property for special purposes_breach of, damages........665

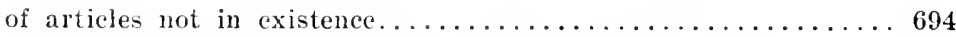

vendor knowing of the vendee's profits-breach-damages.....665

to purchaser to resell-breach of-damages............6. 698

SAMPLES-

manufacturing of articles according to..............654

SCALPING CONTRACTS-

in sale of tickets-illegal...................... 173

SCALPING TICKLTS-See TICKETS.

SCHOOL TEACHERS-

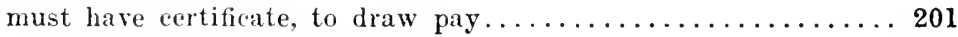

assignment of uncarned salary................... 515

agreeing to instruct a student-intervention of act of God..... 586

buruing of school house-salary ................ 587

closing of school by board of health-salary continues........ 589

breach of contract by school board-duty of, to seek other em-

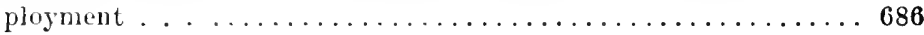

SEAL-

imports a consideration.................... 95

release of obligor, should be under seal............. 379

sealed contract-how interpreted................. 419

contract sealed-part performance of void agreement-recovery . 479

contract under seal-suing to recover money back.........601

SEDUC'IIUN-

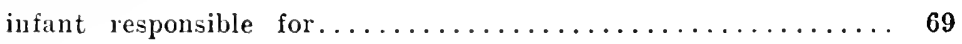

SEIS1N-

livery of, by lunatic-effect................ 9

SET-OFF -

waiver of tort-suing in assumpsit...............490

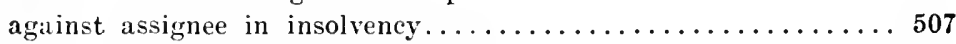

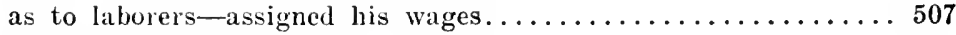

by owner of building-against contractor..............640

SHIIPERS-

rebates to, by railroad companies................. 323

SHOPIING-

by infant-validity of contracts................ 38

SICKNESS-

when it will excuse performance of contract..........589, 592 
of telegram-under the statute of frauds............. 85

of auctioneer or broker to sale-when sufficient......... 87

to memorandum-party to be charged.............. 88

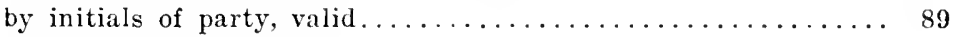

under statute of frauds...................... 97

when must be at the end of the writing.............. 97

signing by both parties, under the statute of frauds........ 98

by agent under the statute of frauds ................ 99

agent must have authority to $\operatorname{sign} \ldots \ldots \ldots \ldots \ldots \ldots \ldots$

as "administrator" or "executor"-personal liability ....... 120

SINGERS-

specific performance of contract..............677

\section{SITUS-}

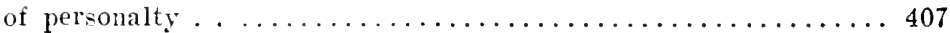

legal and actual....................... 407

SLOT MACHINES-

use of-whether gambling.................... 244

SMELTING CONIPANT-

contracts with-cannot be assigned................519

SMILGGLING-

contracts-ralidity of ..................... 414

SOBRIQUET-

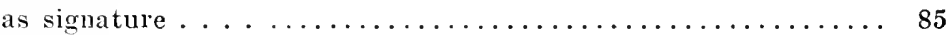

SOLDIERS-

cannot be favored as against other citizens............ 198

SPECIAL CONTRACTS-

part performance-recovery . . . . . . . . . . . . . . 473,474

wilful default to furnish services-effect............. 474

default not wilful....................... 475

SPECIAL PROMISE-

of administrator or executor-when required to be in writing... 120

SPECIFIC PERFORMANCE-See Performaxce.

part perfornance-when enforced................. 107

of oral agreement to devise................... 466

when enforced-contracts to devise...............667

requisites of contract-building contracts............668

mutuality of obligations and remedy ..............669

contracts as to personal property................670

when there is an adequate remedy at law .............67

change of conditions of one of the parties.............672

sale of patent rights.....................673

sale of personalty........................ 674

sales of chattels having a special value................675

supervision of the court-continuous acts.............6676 
contracts involving the exercise of skill, personal labor and cul-

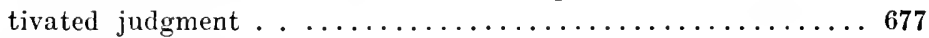

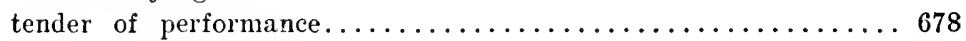

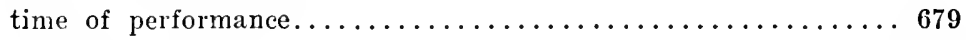

contracts subject to conditions................ $\$ 80$

part performance . . ....................681

SPIRITUAL MANIFESTATIONS-

as evidence of sanity........................ 8

STAKEHOLDER-

right to pay over money..................... 502

STATIONS-

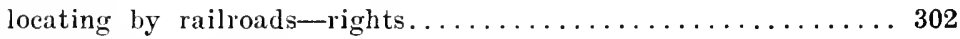

STATUTE OF FRAUDS-

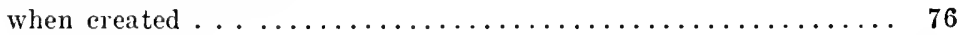

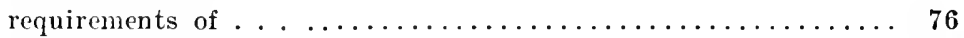

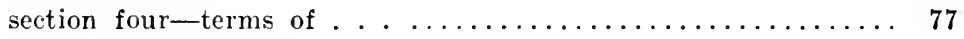

section seventeen-terms of $\ldots \ldots \ldots \ldots \ldots \ldots \ldots \ldots \ldots \ldots \ldots \ldots$

as to contracts created by law.................... 79

as to executed contract............................ 80

modification of written contract within.............. 81

contract executed on one side.................... 82

STOCK EXCHANGE--See BoArd of Trade.

STOCKHOLDERS-

of bauk-liability for future debts................ 54I

running of the statute of limitations...............6. 630

STOCKS-

shares of, bought at fictitious prices-effect.......... 163

purchase of, on board of trade-when valid........... 252

STOPPAGE IN TRANSITU-

assignment of bill of lading-effect................ 510

STREET CARS-

failure to run-by act of God................. 588

STRIKERS-

right of, to persuade non-union men to leave employment...... 336

boycott by State............................. 341

STRIKES-

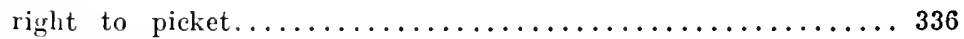

SUBJECT-MAT'TER-

description of, in memorandum-under statute of frauds...... 92

of contract non-existing- performance of contract........ 571

ceasing to exist . ......................... 572

SUBSCRIPTION-

to pay debt of church-made on Sunday-work of charity.... 190

conditional subscription to stock................ 302

by parties to establish business................. 383 
SUBSCRIPTION- (continued) Sec.

revocation of-joint debtors.........................

to establish business-liability................. 384

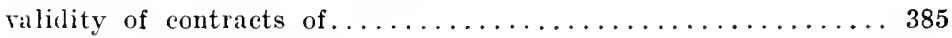

validity of-joint debtors................... 385

to corporation stock-running of the statute of limitations.....630

SUCCESS1ON-

interstate-taxation . . .................. 395

SUICIDE-

of insanc person-collecting life insurance............ 16

by impulsive insanity of injured-effect on policy......... 17

of insured-knowledge of right and wrong-English and Anerican

doctrine . . . . . . . . . . . . . . . . . . . . 18, 19

of insured "sane or insane" .................. 20

SUNDAY CONTRACTS-

contracts made outside of State................ 412

SUNDAY LAWS-

contracts made on Sunday at common law-effect......... 180

constitutionality of Sunday law................. 181

as to interstate commerce..................... 182

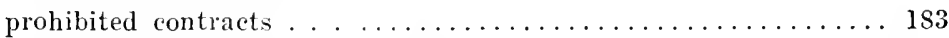

contracts not prohibited by statute................ 184

negotiation on Sunday-contract completed on Monday....... 185

contracts within the statute................... 186

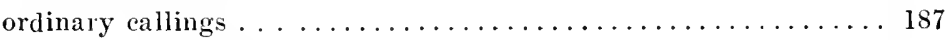

works of necessity........................ 188

working on Sunday to prevent loss on week day .......... 189

works of charity ......................... 190

traveling on Sunday ........................ 191

ratification of Sunday contracts................. 192

third persons ......................... 193

as to thild persons-contracts dated on Sunday ........... 194

contracts executed on Sunday................... 195

SURETY-See Prixcipal and Surety.

when surety may claim contribution............... 388

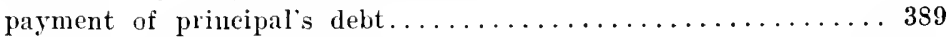

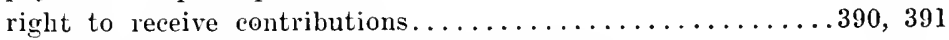

when action can be brought against co-surety ............ 391

action by-must the principal be insolvent............. 392

discharged by act of promisee.................... 393

married women as........................ 401

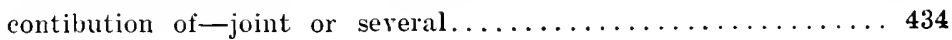

SURETYSHIP-

infant's contract of, is voidable ................ 27

inforcement of contribution................... 434 


\section{INDEX.}

SURVIVORSHIP-

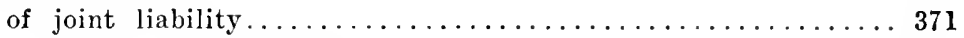

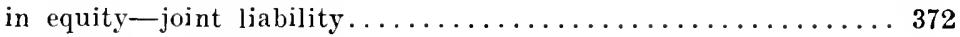

of interest-joint obligees..................... 380

TAXATION-

lex fori-action in assignee's name............... 406

TAXES-

legal interest and taxes taken-usury ............. 227

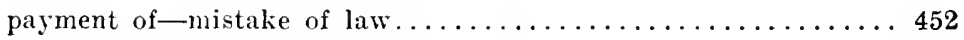

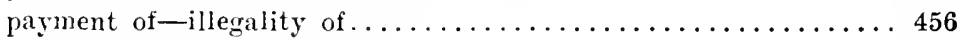

when payment is voluntajy ..................... 456

paid under duress-recovery.................. 496

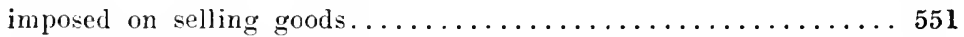

upon interstate commerce.................. 552

when is the imported property incorporated with the general mass

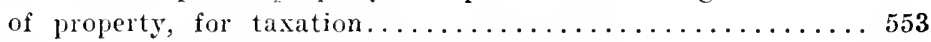

statute incorporating imported goorls-validity.......... 554

statute which is retrospeetive................. 557

TEACHERS-See School Teachers.

TELEGRANS-

as memorandum to charge the sender.............. 85

when may be sent on Sunday-necessity ............. 188

TELEGRAPH COMPANIES-

must serve all customers alike.................. 296

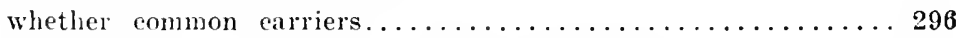

limiting liability in sending message-validity of . . . . . 297

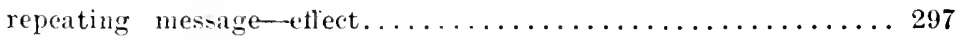

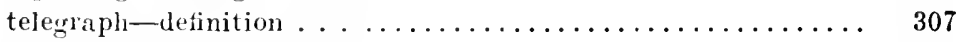

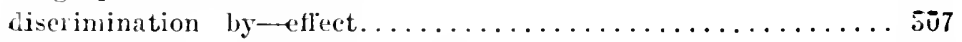

agreeing to an impossible contract................ 568

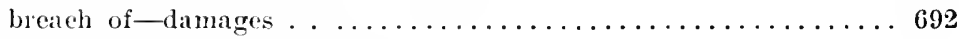

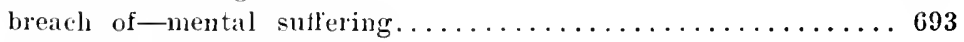

TELEPHONE COMPANHES-

whether common carriers................... 296

rights in transmitting message for mistake............. 298

must not diseriminate............................ 307

TENANTS IN COMHON-

guardian and ward-partition-method ............. 37

TENDER-

of performance - when necessary.................. 678

TENURE-

of public office-legislature may control............ 420

TERMS-

of memorandum required by the statute of frauds......... 91 
THEATER TICKET- Sec.

whether a mere license..................... 509

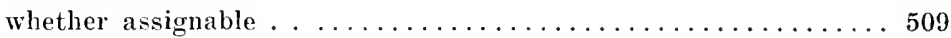

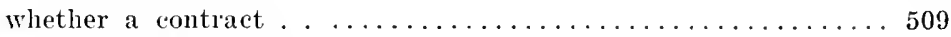

THEATRICAL MANAGER-

rights of-tickets to public entertainments............509

THEFTS-

stolen money in the hands of a third party with notice...... 502

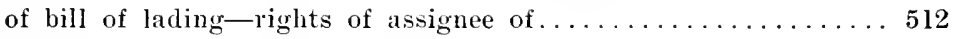

THREATS-

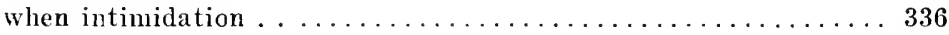

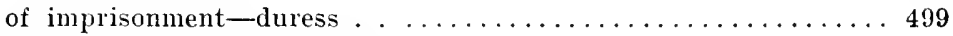

TICKERS-See Board of Trade.

right to use information of $\ldots \ldots \ldots \ldots \ldots \ldots \ldots \ldots \ldots \ldots \ldots$

TICKETS-

prohibition of sales except by lawfully authorized agents...... 173

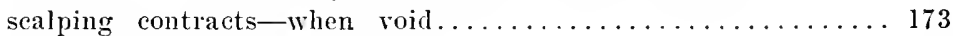

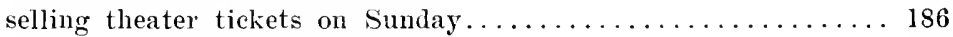

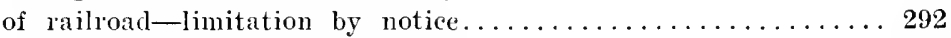

non-transferable-when assigned . . . . . . . . . . . . 292

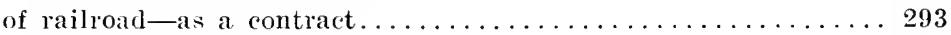

limitations on . . . . . . . . . . . . . . . . . . . 293

railroad tickets with coupons................... 294

TIME-

to ratify infant's contract..................... 55

what is a reasonable time to avoid an infant's contract....... 59

one year from the making of a contract-when within the statute

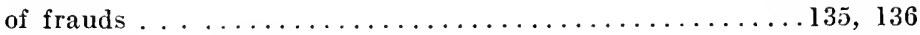

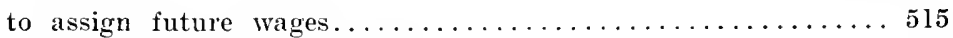

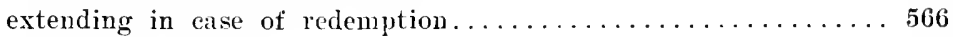

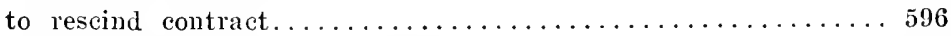

what is reasonable, to return chattels bought on option.......613

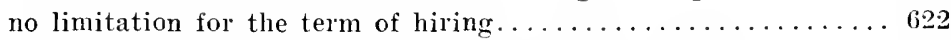

as between principal and agent-as to term of hiring........622

continuing contracts-when statute of limitations begins to run. . 627

running of the statute of limitations............... 629

parties under disabilities-running of the statute of limitations. . 629

of performance of contract...................... 641

of payment of debt payable on demand............... 641

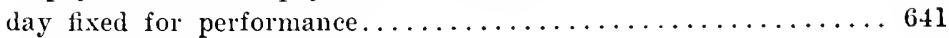

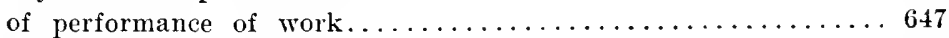

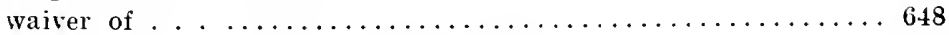

of performance-specific performance.................. 679

TIME AND SPACE-

limitations of in contracts in restraint of trade...309, 310, 311, 312

$313,314,315$ 


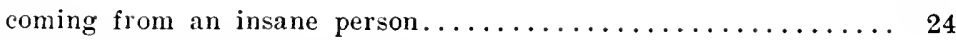

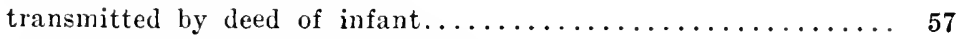

guardian's title to ward's property................. 74

of real estate by verbal agreement................. 103

TOLLS-

implied contract to pay.................... 423

action to collect-assumpsit.................. 423

TORT-FEASORS-

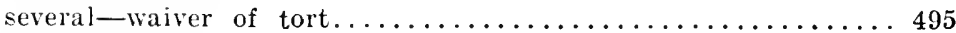

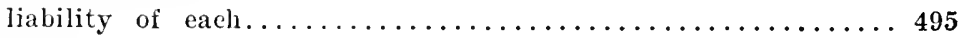

TORTS-

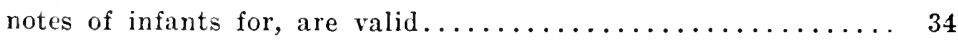

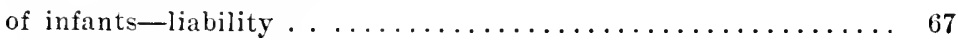

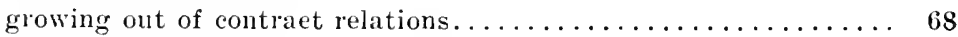

infants liable for . . ....................... 69

promise to pay-within the statute of frauds........... 122

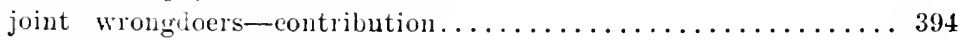

waiver of-suing in assumpsit.................464, 486

when waiver may be made.................. 487

TRADE AND PROFESSIONS-

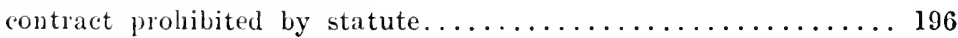

sealing of weights and measures.................. 197

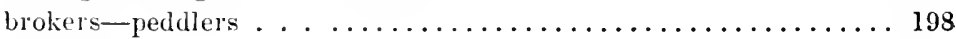

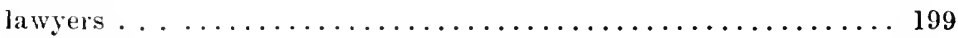

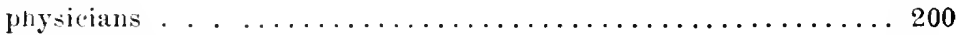

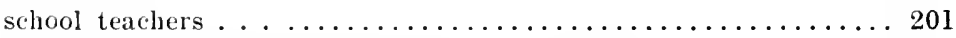

articles of commerce-sales without inspection.......... 202

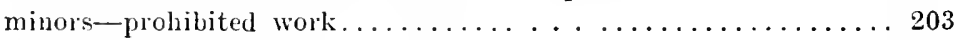

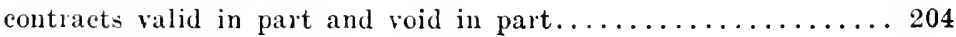

sale of intoxicants without license................. 205

TRADES UNIONS-

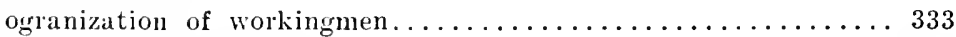

are lawful combinations...................... 334

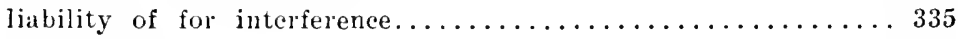

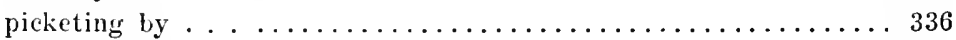

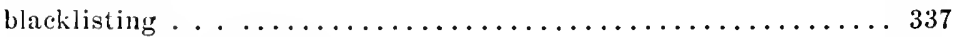

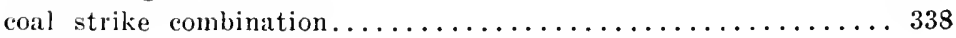

TRADING STAMPS-

issuing-whether gambling . . . . . . . . . . . . . 270

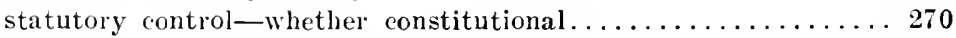

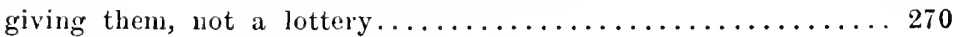

TRUCK STORES-See TRUCK SYSTEM.

TRUCK SYSTEM-

regulating payment of wages................... 2

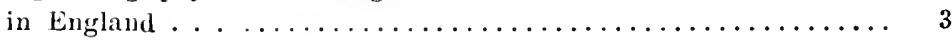




\section{INDEX.}

TRUST DEED-

Sec.

executed on Sunday-delivered on Monday-as to validity...... 185

\section{TRUSTS-}

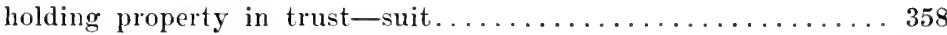

personal trust cannot be assigned................. 519

running of the statute of limitations................6630

enforcement of a contract to devise...............667

TURNPIKE-

collection of tolls due....................... 423

assumpsit may be brought for collection of tolls due........423

UNFAIR TRADERS-

listing by trades unions....................... 335

UNION ASSOCIATIONS-

board of education compelling contractor to employ union laborers 317

organized to protect the members.................... 327

UNION LABOR-

stipulation that only union labor shall be employed-effect.... 301

UNITED STATES SUPREME COURT-

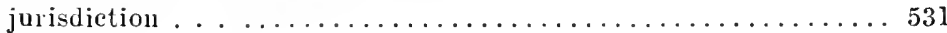

USE AND OCCUPATION-

of land-covenants valid ........................ 111

USURIOUS CONTRACTS-

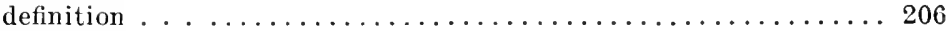

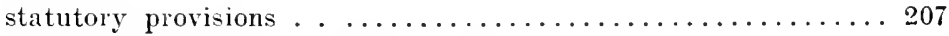

intent is essential to constitute usury................ 20s

lending and borrowing money $\ldots \ldots \ldots \ldots \ldots \ldots \ldots \ldots \ldots \ldots \ldots$

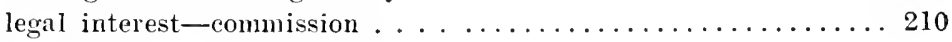

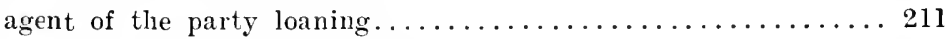

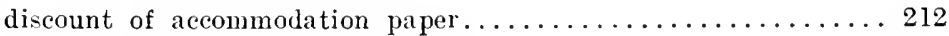

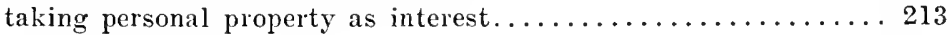

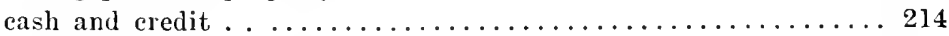

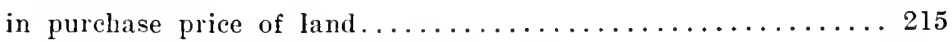

bonus for consideration for making the loan............. 216

antedating a note-interest payable in advance............ 217

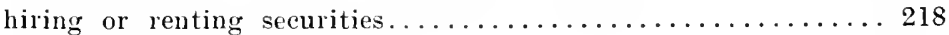

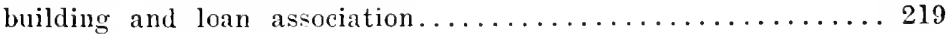

building association must keep within the statute......... 220

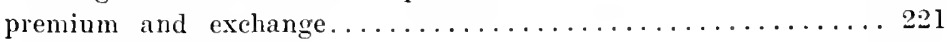

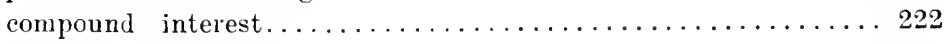

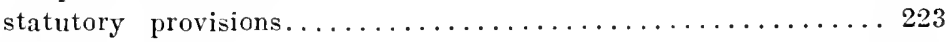

interest coupons . . ........................ $2 \mathbf{2 4}$

recovering back usury.........................25

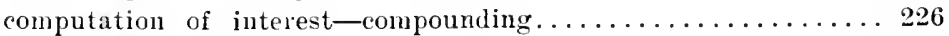

taxes and exchange..............................27

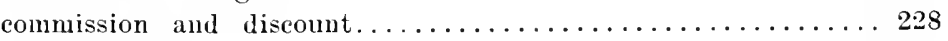

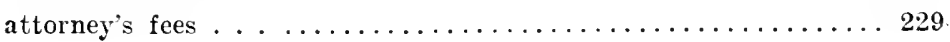


USURIOUS CONTRACTS-(continued) Sec.

sale of security-innocent purchaser............... 230

absolute sale with agreement to repurchase............. 231

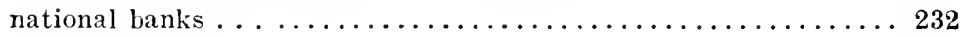

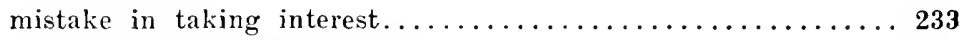

renewal notes and mortgages.................... 234

contract having an independent existence............ 235

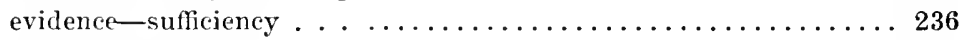

who may plead usury..................... 237

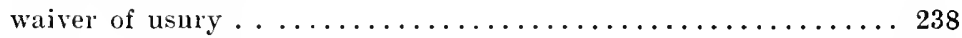

burden of proof ......................... 239

place of payment of interest-contlict of laws ...........240

payment may be controlled by contract................ 241

conputing interest at stated times................. 242

the law of another State must be pleaded..............243

USURY-See Usurious Con'Tracts.

definition ......................... 206

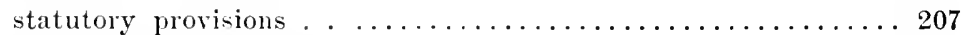

taking personal property as interest...............213

making different prices for cash or on credit........... 214

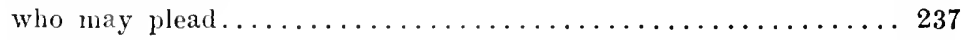

wairer of .......................... 238

burden of proof to establish . . . . . . . . . . . . . 239

usurious contracts-law of another state.............417

intention of parties....................... 417

does the lex loci solutionis govern on judgment...........4 417

making contract void-ralidity in other States.......... 418

as to retrospective laws.................... 532

VALUE RECEIVED-

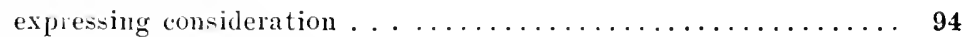

VENDOR AND VENDEE-

insane vendor selling to bona fide purchaser-validity of sale... 22

bona fide purchaser of the grantee of a lunatic-validity...... 24

shopping by infant-validity of contract............. 38

bona fide purchaser from infant-title transferred.........661

oral sale of land-purchase money paid-recovering back...... 109

taking back chattels after sale-when within the statute of

frauds ........................... 140

performance of contract by vendor-effect............. 148

soliciting business from another.................. 304

selling business-restraint of trade..309, 310,311,312, 313, 314, 315

sale of good-will-restraint of trade............... 319

sale of physician's practice.................... 319

when third party is injured by negligence of vendor . . . . . . 348

sclling for smuggling purposes...................4 44

receiving goods from one not the original vendor-effect.....478 
VENDOR AND VENDEE-(continucd) Sec.

receiving part of the goods........................... 48

selling property in contravention of the law-recovery......44 481

sale of theater ticket-rights of venclee............. 509

rights of assignee of bill of lading. . . . . . . . . . . . 510

sale-impossibility to deliver-effect.............. 574

rights to return goods by vendee - sale by sample..........612

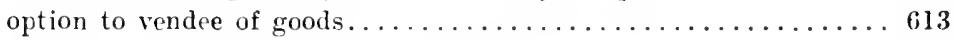

owner of building promising to pay seller of building materials... 663

specific performance of part of contract............ 681

selling articles for special purposes-breach of-damages......685

sale of articles not in existence..................694

buying goods to resell-breach by vendor-damages........698

WAGERS-

definition . . . . . . . . . . . . . . . . . . . . 244

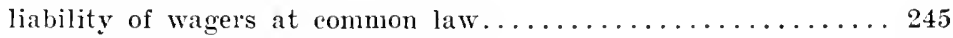

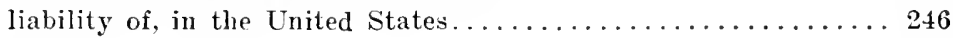

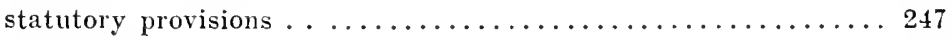

in insurance . . . . . . . . . . . . . . . . . . . . 266

assignment of policy-valid in its inception-effect......... 267

WAGES-

execution of party for crime-whether court will review...... 545

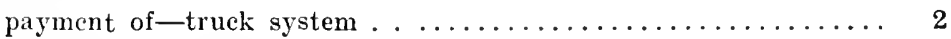

payment monthly . . . . . . . . . . . . . .

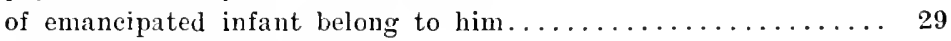

father may pay to children.................... 470

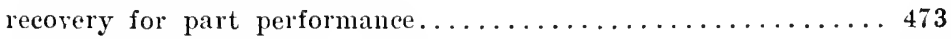

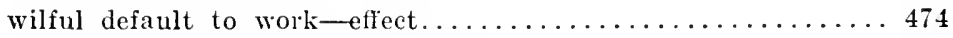

what plaintiff must show to recover............... 474

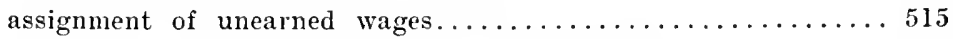

compelling corporations to pay employes weekly.......... 541

right to sue for, after discharge................. 602

for constructive services...................6 603

WAlVER-

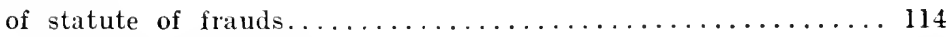

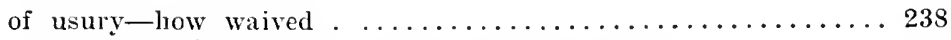

of the statute of limitations-when against public policy.....2 275

of right to hold master liable for injury to servant......... 300

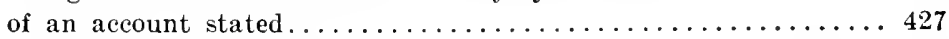

of tort-suing in assumpsit.............464, 486, 489, 489

doctrine that the property must be sold ............. 488

doctrine that the property need not be sold............ 489

of tort by agent-bringing assumpsit............... 494

no waiver of exemptions of married man............. 515

of buildiing contract by accepting building........... 579

the statute of limitations may be waived.............6637 
WAIVER-(continued) Sec.

of time of performance of work................648

by owner of building by acceptance...............664

of condition of contract.................... 680

WARD-

and guardian tenants in common-method of partition...... 37

right of guardian..................... 72,73

WAREHOUSE RECEIPTS-

whether negotiable . .................... 513

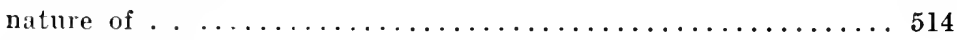

WAREHOUSES-

kept by indivicuals-establishing of maximum rates by State... 538

WARRANT-

of minor to confess judgment is void.............. 28

WARRAN'TY-

on Sunday-sale of goods when valid...............412

sales by samples...........................612

WATER COMPANIES-

rights of third persons...................... 349

as to statutory provisions..................... 349

assignment of contract by city ................. 350

WEIGHTS AND MEASURES-

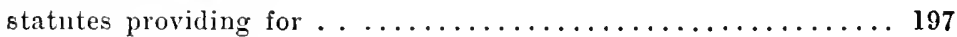

WORK AND LABOR-

as part payment in parol agreement to convey land-effect.... 110

contracts of -when within the statute of frauds.......... 146

chattels in existence and goods to be manufactured-when within

the statute of frauds...................... 146

on Sunday-what included .................... 187

of necessity . ....................... 188

on Sunday to prevent loss on week day-effect. . . . . . . . 189

works of charity on Sunday .................... 190

traveling on Sunday . ....................... 191

minor doing prohibited labor................... 203

organization of laborers for self-protection. ... . . . . . . 327

organization of trades unions................... 333

trades unions are lawful...................... 334

discrimination by laborer's against employers............ 335

blacklisting of laborers . . . . . . . . . . . . . . 337

statute prohibiting blacklisting ............... 337

coal strike commission condemns boycotts............. 338

laborers using unlawful means in strikes to persuade........ 338

malicious interference between master and servant........ 343

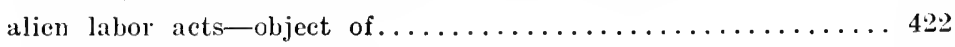

gratuitous-implied contract . .................458

to nembers of same family ....................458 
WORK AND LABOR-(continued) Sec.

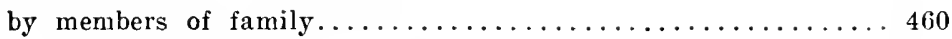

of a supposed wife-recovery for.................. 461

recovering for extra services.................. 462

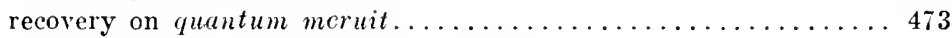

wilful default to work-effect on wages.............. 474

default not wilful-recovery for part performance..........475

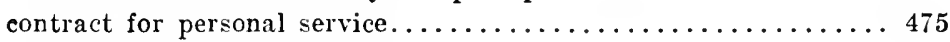

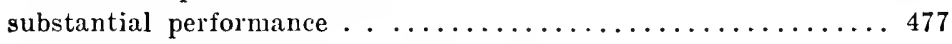

recovery for services under void contract............... 479

failure to pay as agreed to.................... 481

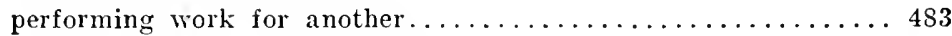

in case of flood or conflagration.................. 483

physician in emergency . . ................. 484

burial of the dead-implied contract.............. 485

set-otl by laborer, who has assigned his wages............ 507

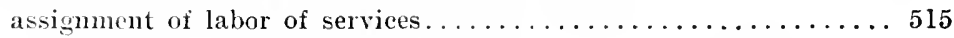

contracts for personal skill or services camnot be assigned..... 519

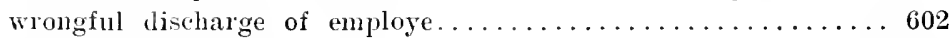

constructive service . . .....................603

services to be performed in the future..............64

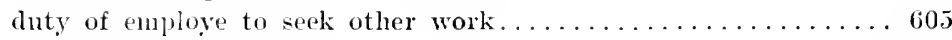

offer to render service.......................6606

mode of rescission by employer..................667

employing another to work on personalty.............608

employing another to affix machine to realty...........6 609

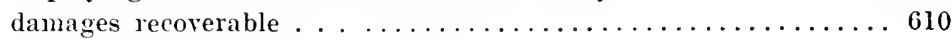

after rotice of rescission-duty of employe............611

continuing contract to work-effect of statute of limitations....6627

performance of-furnishing materials..............639

substantial performance-good faith ...............640

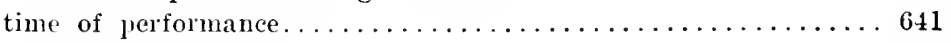

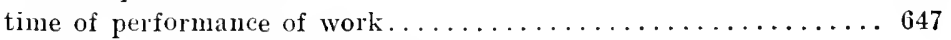

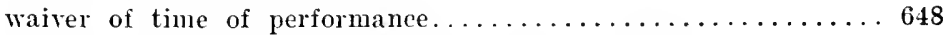

labor must be performed in a workmauship manner........650

receiving benefits of work-liability...............65l

partial payment as evidence of acceptance of work.........652

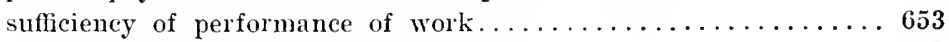

manufacturing articles according to order............. 654

substantial performance . . . . . . . . . . . . . . . 655

matters excusing non-performance................. 656

implied condition as to contingent impossibility of performance.. 657

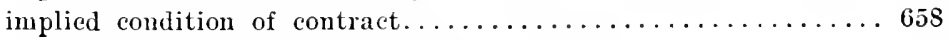

when implied conditions attach to a contract..........659

what constitutes a breach of building contract...........662

risks during performance of building contract............665 


\section{INDEX.}

WORK AND LABOR-(continued) Sec.

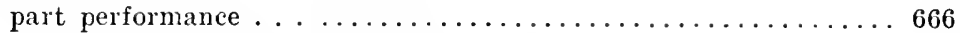

specific performance of labor contracts.............668

specific performance of contract to labor............676

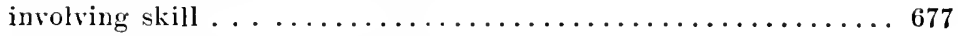

cannot be specifically performed.................6. 677

breach of contract-laborer must protect himself-duty to seek

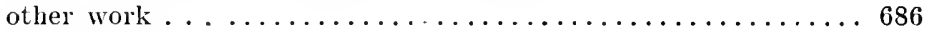

for the use of some special instrumentality...........667

breach of contract by, not furnishing $\operatorname{logs} \ldots \ldots \ldots \ldots \ldots \ldots 687$

labor or a sale-personal skill..................694

WRONGDOERS-

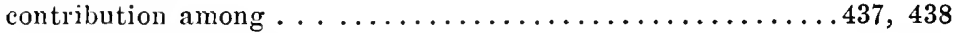

when one party is innocent-contribution............. 438

cannot have indemnity...................... 439

having adverse possession of land-taking stone and trees-

(Total number of pages 952.) 






UC SOUTHERN REGIONAL LIBRARY FACILITY

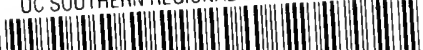

AA 0008567117 
